Ricardo Henrique Dias

\title{
ANÁLISE NUMÉRICA DE PAVIMENTOS DE EDIFÍCIOS EM LAJES NERVURADAS
}

Dissertação apresentada à Escola de Engenharia de São Carlos da Universidade de São Paulo, como parte dos requisitos para obtenção do título de Mestre em Engenharia de Estruturas.

Orientador: Prof. Associado João Batista de Paiva

São Carlos

2003 

Este trabalho dedico à minha mãe, Elza, exemplo de luta e perseverança. 



\section{AGRADECIMENTOS}

Agradeço ao professor orientador João Batista de Paiva, pela amizade e compreensão; pelos valiosos esclarecimentos, e pelo direcionamento indispensável ao desenvolvimento do trabalho.

Ao professor José Samuel Giongo, pelas trocas de idéias, correções e sugestões, e pela amizade.

Ao CNPq, pela bolsa de estudo nos anos iniciais do mestrado.

Aos amigos da pós-graduação: Clayton de Castro, Humberto Correia Lima, Fernando Menezes Filho, Ricardo Carrazedo, Andrei Merlin, Gustavo Tristão, André Branco e em especial ao Rodrigo Delalibera, pelo apoio dado durante o desenvolvimento deste trabalho.

Aos funcionários do Departamento de Engenharia de Estruturas, em especial à Rosi Rodrigues e à Maria Nadir Minatel.

Aos meus pais José e Elza, irmãos Alessandra e Rodrigo, e à minha querida Ligia, pela compreensão nesses anos, e pelos incentivos nos momentos difíceis. Aos meus tios Júlio e Lurdes, e a minha avó Augusta, pelo apoio durante o curso de graduação.

Aos Engenheiros e Professores Antonio Carlos Peralta, Jorge Silka Pereira e Rogério Gomes de Carvalho, pelas oportunidades e contribuições dadas ao meu desenvolvimento profissional, que também se refletiram neste trabalho.

A todos que de alguma maneira contribuíram para que este trabalho fosse desenvolvido.

E a Deus, acima de tudo, minha gratidão infinita. 



\section{RESUMO}

DIAS, R. H. (2003). Análise numérica de pavimentos de edifícios em lajes nervuradas.

Dissertação (Mestrado) - Escola de Engenharia de São Carlos, Universidade de São Paulo, São Carlos, 2003.

Este trabalho verifica, por meio de análises numérico-paramétricas de lajes nervuradas, o quanto a desconsideração (ou a consideração de maneira simplificada) da excentricidade existente entre os eixos das nervuras e o plano médio da capa influencia nos resultados de deslocamentos e esforços atuantes nas peças que compõem estes sistemas. Foram apresentados os conceitos teóricos relativos à cada modelo de cálculo permitido pelas normas técnicas, e foram realizadas análises considerando variações nos seguintes parâmetros: relação entre a altura da capa e a altura total da laje nervurada; relação entre a distância entre os eixos das nervuras e a distância entre os pontos de apoio, e espaçamento entre os eixos das nervuras. Os diferentes modelos mecânicos foram analisados utilizando o Método dos Elementos Finitos, por meio do programa computacional ANSYS 5.5, considerando-se um comportamento elástico-linear para o material concreto armado. Foram relacionados aspectos importantes a serem observados na escolha do modelo adequado, de acordo com os parâmetros analisados, para serem aplicados nos escritórios de cálculo. Verificou-se a necessidade da consideração da excentricidade, seja por modelo realista, ou por modelos simplificados, para a obtenção de resultados numéricos mais próximos do comportamento da estrutura real.

Palavras-chave: lajes nervuradas elásticas; enrijecedores excêntricos; Método dos Elementos Finitos; Concreto Armado - estruturas. 



\begin{abstract}
DIAS, R. H. (2003). Numerical analysis of building floors in ribbed slabs. Dissertação (Mestrado) - Escola de Engenharia de São Carlos, Universidade de São Paulo, São Carlos, 2003.

This work verifies, through parametric-numerical analysis of slabs stiffened with ribs, how much the disregard (or regard in a simplified way) of the existent eccentricity between the axis of the ribs and the medium plan of the plate influences on the results of displacements and acting efforts over the parts wich make the system. The theorical concepts related to each model of calculation allowed through technical codes have been presented, and, analysis have been made considering variations in the following parameters: relation between plate height and total height of the waffle slab; relation of distance between the axis of the ribs and the distance between the supporting points, and the gap between the axis of the ribs. Different mechanical models have been analysed using the Finite Element Analysis, through the computer program ANSYS 5.5, considering an elastic-linear behaviour for the reinforced concrete material. Important aspects have been disclosed and should be carefully looked into for an adequate model choice, according to the analysed parameters to be applied in the design's offices. The need for eccentricity consideration has been verified, be it by using a realistic model or by simplified models, for close numerical results gathering of the real structural behaviour.
\end{abstract}

Keywords: Stiffened elastic slabs; eccentric stiffeners; Finite Element Analysis; Reinforced concrete - structures. 



\section{SUMÁRIO}

RESUMO

ABSTRACT

CAPÍTULO 1 - APRESENTAÇÃO DO TRABALHO

1.1 INTRODUÇÃO AO CAPÍTULO 1

1.2 OBJETIVOS

1.3 TÉCNICAS E MÉTODOS EMPREGADOS

CAPÍTULO 2 - A ANÁLISE DE LAJES NERVURADAS UTILIZANDO PROCESSOS SIMPLIFICADOS

2.2 ANÁLISE ESTRUTURAL DE LAJES NERVURADAS CONVENCIONAIS E SEM VIGAS POR ANALOGIA DE PLACA

2.2.2 $\mathrm{O}$ conceito de espessura equivalente

2.2.2.1 Definição da largura colaborante da seção "T"

2.2.3 Os parâmetros elásticos do concreto armado na Teoria da Placa Ortótropa Equivalente 
2.3 ANÁLISE ESTRUTURAL DE LAJES NERVURADAS CONVENCIONAIS E SEM VIGAS POR ANALOGIA DE GRELHA 43

2.3.1 O funcionamento estrutural das grelhas 45

2.3.2 O processo de Analogia de Grelha aplicado às lajes nervuradas 45

2.3.2.1 As propriedades geométricas das barras da grelha 46

2.3.2.2 Os parâmetros elásticos do concreto na Analogia de Grelha 47

2.3.2.3 Carregamento da grelha 49

2.3.2.4 Consideração da vinculação dos pilares nos modelos de Analogia de Grelha $\quad 50$

2.3.3 Processos e métodos de análise de grelhas 52

2.4 ANÁLISE ESTRUTURAL DE LAJES NERVURADAS SEM VIGAS POR MÉTODOS

ELÁSTICOS DE PÓRTICOS VIRTUAIS 53

2.4.1 O Método dos Pórticos Múltiplos para o cálculo dos esforços 58

2.4.1.1 Características geométricas dos elementos do Pórtico Múltiplo 59

2.4.1.2 Os parâmetros elásticos do concreto armado no Processo de Pórticos Múltiplos $\quad 60$

$\begin{array}{ll}\text { 2.4.1.3 Combinações de tramos carregados e descarregados } & 60\end{array}$

2.4.1.4 Determinação dos esforços nos Pórticos Múltiplos 61

2.4.1.5 Distribuição dos esforços calculados segundo o Método de Pórticos Múltiplos do projeto de revisão da NBR6118/2000 62

2.4.2 O Método dos Pórticos Equivalentes para o cálculo dos esforços 62

2.4.2.1 O pilar equivalente $\quad 66$

2.4.2.2 A rigidez da laje nervurada no modelo de Pórticos Equivalentes 69

$\begin{array}{ll}\text { 2.4.2.3 Combinações de tramos carregados e descarregados } & 73\end{array}$

2.4.2.4 Os parâmetros elásticos do concreto armado no Método dos Pórticos Equivalentes 75

2.4.2.5 Determinação dos esforços nos Pórticos Equivalentes 75

2.4.2.6 Distribuição dos momentos fletores entre as faixas de laje 77

2.4.3 O Método dos Pórticos Virtuais para o cálculo dos deslocamentos elásticos $\quad 78$

CAPÍTULO 3 - A ANÁLISE DE LAJES NERVURADAS CONSIDERANDO A EXCENTRICIDADE NERVURAS-CAPA DE FORMA MAIS REALISTA 85

3.1 INTRODUÇÃO AO CAPÍTULO $3 \quad 85$ 
3.3 A CONSIDERAÇÃO DA EXCENTRICIDADE DE FORMA MAIS REALISTA NESTE TRABALHO

CAPÍTULO 4 - OS MODELOS MECÂNICOS EM MEF APLICADOS À ANÁLISE ESTRUTURAL DE LAJES NERVURADAS

4.1 INTRODUÇÃO AO CAPÍTULO 4

4.2 OS ELEMENTOS FINITOS UTILIZADOS NAS ANÁLISES NUMÉRICAS

4.3 OS MODELOS MECÂNICOS APLICADOS NESTE TRABALHO

4.4 VERIFICAÇÃO DA VALIDADE DOS MODELOS EM MEF APLICADOS NESTE TRABALHO

4.5 COMENTÁRIOS SOBRE OS RESULTADOS DAS MODELAGENS DOS EXEMPLOS DA BIBLIOGRAFIA

\section{CAPÍTULO 5 - EXPERIMENTAÇÃO NUMÉRICO-PARAMÉTRICA DE LAJES} NERVURADAS

5.2 DESCRIÇÃO DAS EXPERIMENTAÇÕES NUMÉRICO-PARAMÉTRICAS

5.2.1 Variação da relação altura total da capa $\left(h_{f}\right)$ pela altura total da laje $(h)$, mantendo os outros fatores de análise fixos

5.2.2 Variação da relação espaçamento entre os eixos das nervuras $\left(a_{1}\right)$ pela distância entre os apoios (1), mantendo os outros fatores de análise fixos

5.2.3 Variação do espaçamento entre os eixos das nervuras, com distância entre os pontos de apoio ajustada a um número fixo de nervuras por lado

5.3.1Resultados apresentados nas modelagens das lajes com variação da relação $h_{f} / h$

5.3.3 Resultados apresentados nas modelagens das lajes com variação do espaçamento entre os eixos das nervuras 



\section{CAPÍTULO 1 - APRESENTAÇÃO DO TRABALHO}

\subsection{INTRODUÇÃO AO CAPÍTULO 1}

A análise estrutural de pavimentos de edifícios por meio de métodos numéricos constitui-se, atualmente, em rotina nos escritórios de projeto. O cálculo e detalhamento com o auxílio de softwares é praticamente imprescindível, devido principalmente ao ritmo imposto pelos contratantes do projeto estrutural e a necessidade de avaliar as diversas possibilidades de sistemas procurando, dessa forma, a de melhor viabilidade econômica.

Ao tratar-se de pavimentos de edifícios, estudos já foram feitos buscando identificar a solução estrutural que gere maior economia global.

Nos edifícios de vários pisos as lajes são responsáveis por elevada parcela do consumo de concreto. Utilizando-se lajes maciças nos pavimentos esta parcela chega usualmente a quase dois terços do volume total da estrutura. Assim, mostraram a necessidade do estudo dos critérios de escolha dos tipos de lajes a serem empregados nos edifícios de vários pisos tendo em vista a obtenção de soluções técnicas e economicamente otimizadas.

BOCCHI JÚNIOR (1995) indicou que essa necessidade de racionalização na construção civil com a minimização dos custos e prazos vem fazendo das lajes nervuradas uma opção cada vez mais difundida.

Em uma análise de custos ALBUQUERQUE (1998) mostrou que um pavimento em laje nervurada convencional (juntamente com vigas) utilizando caixotes de polipropileno foi o mais econômico dentre as diversas alternativas estudadas, apresentando uma redução de $15,15 \%$ no custo total da estrutura. 
A empresa ATEX do Brasil, produtora de caixotes de polipropileno, fez um estudo comparativo de consumo de materiais através da análise de cinco lajes simplesmente apoiadas, nervuradas e maciças de espessura equivalente em inércia à flexão, utilizando como processo de cálculo a Teoria de Placa para ambos os sistemas, através de tabelas. Concluiu que, em média, a utilização das lajes nervuradas como solução resulta em uma economia de $28,8 \%$ no consumo de concreto e $38,4 \%$ no consumo de aço, em comparação com a laje maciça.

Além do critério economia, outros que pesam na escolha das lajes nervuradas como solução estrutural para pisos de pavimentos são a liberdade arquitetônica (já que permitem grandes vãos) e a simplificação na execução da obra, em termos de formas e escoramentos, quando aplicado em sistemas sem vigas, de acordo com a Figura 1.1, onde vê-se a simplificação na execução de formas.

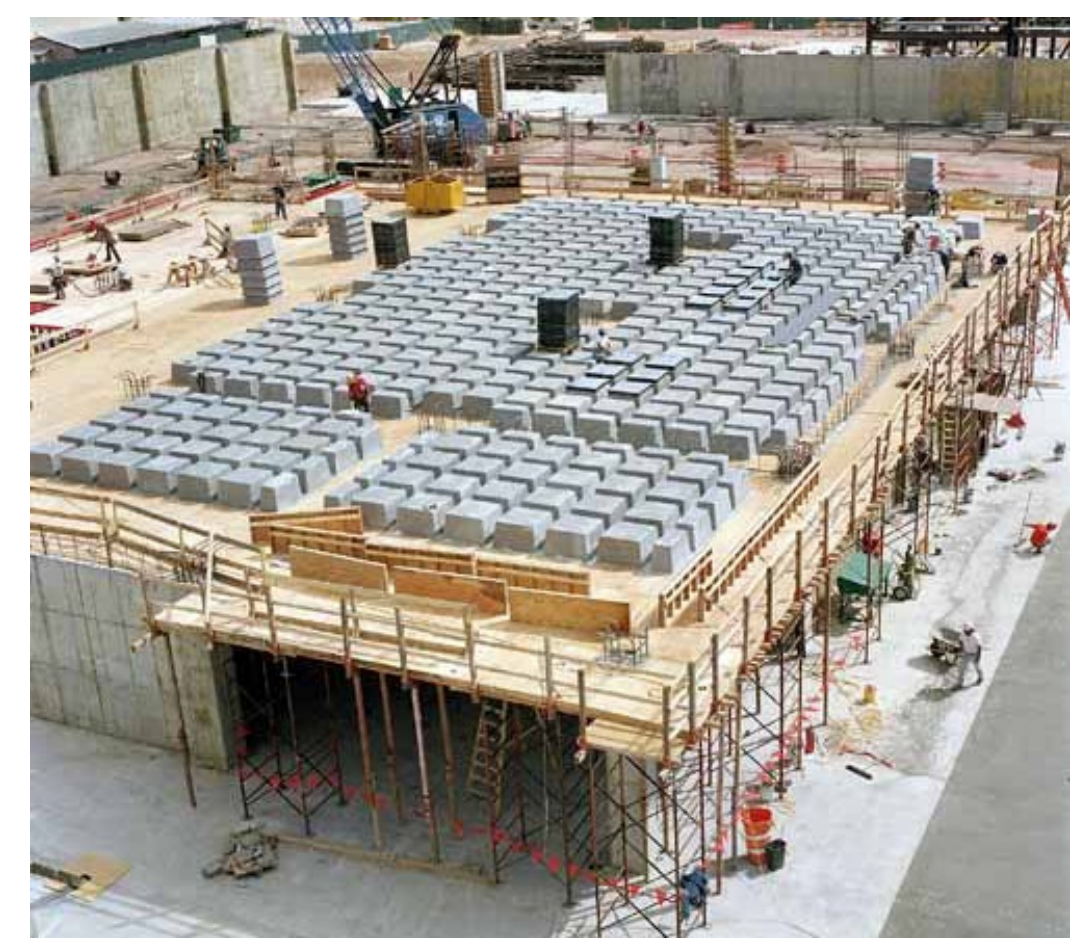

FIGURA 1.1: Simplificação na execução de formas com o uso de lajes nervuradas

As lajes nervuradas tiveram origem em 1854, conforme LIMA et al. [200?], quando um fabricante inglês de gesso e cimento chamado William Boutland Wilkinson obteve a patente, na Inglaterra, de um sistema que já demonstrava o domínio dos princípios básicos de funcionamento do concreto armado ao dispor barras de aço nas regiões tracionadas das vigas. Wilkinson percebeu que a rigidez da laje podia ser aumentada por meio da inserção de vazios utilizando-se moldes de gesso regularmente espaçados e 
separados por nervuras, aonde barras de aço eram colocados na sua porção inferior no meio do vão e subiam para a parte superior da viga nas proximidades dos apoios. A laje possuía um vão de aproximadamente $4 \mathrm{~m}$ em cada direção e uma malha de barras de aço era colocada na parte inferior da camada de concreto de $4 \mathrm{~cm}$ de espessura que cobria as nervuras, conforme a Figura 1.2. É interessante verificar que Joseph Monier (1823-1906) é considerado inventor do concreto armado, a partir de sua patente obtida em 1867, mas é certo que já em 1850 várias pessoas, em diferentes partes do mundo, construíam peças em concreto armado, inclusive o próprio Monier.

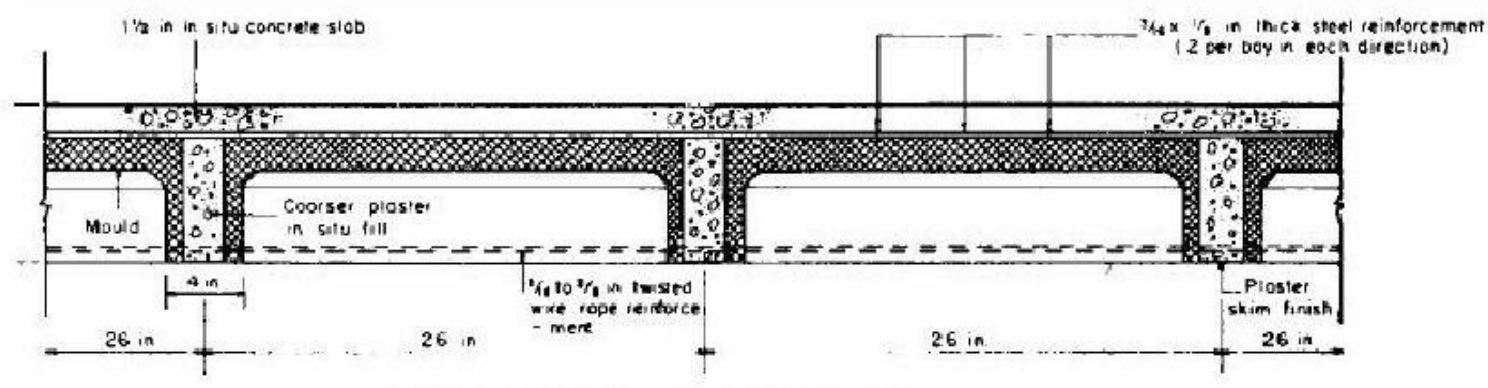

OETAILS OF HOLLOW PLASTER BLOCK FLOOR

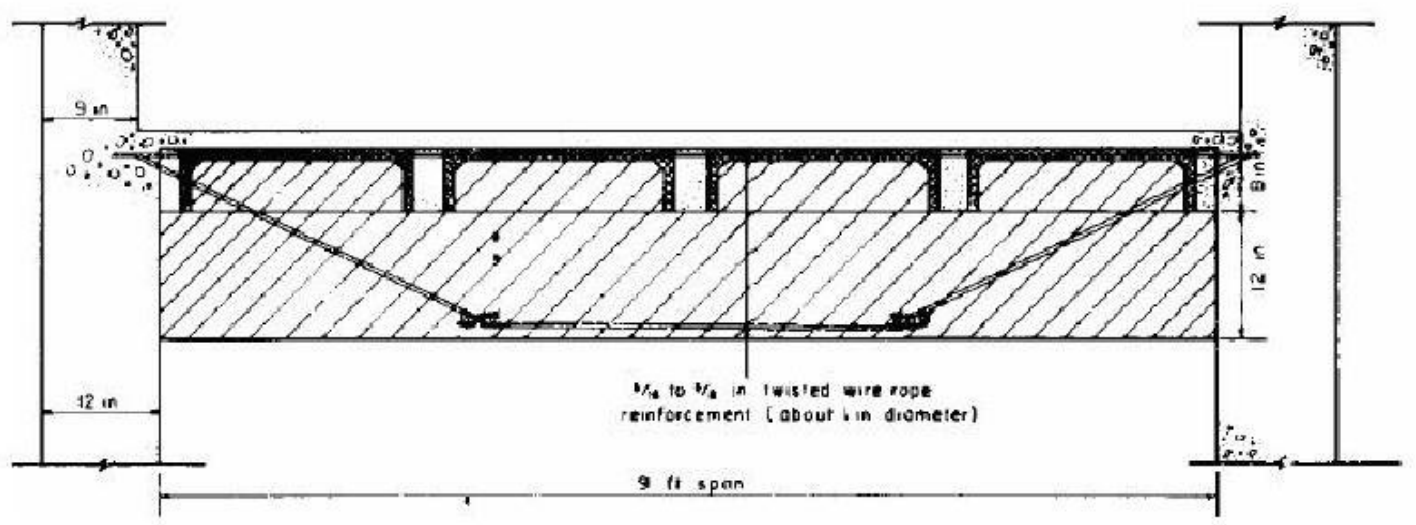

FIGURA 1.2: Laje nervurada patenteada por Wilkinson, na Inglaterra, em 1854

[LIMA et al. [200?]]

O sistema nervurado, conforme citado em FRANCA \& FUSCO (1997), é uma evolução natural das lajes maciças, pois resultam da eliminação da maior parte do concreto abaixo da linha neutra, o que permite o aumento econômico da espessura total das lajes pela criação de vazios em um padrão rítmico de arranjo ou com a utilização de material inerte, que não colabora com a resistência da laje. Com isso tem-se um alívio do peso próprio da estrutura e um aproveitamento mais eficiente dos materiais, aço e concreto, já que 
a mesa de concreto resiste aos esforços de compressão e a armadura os de tração, sendo que a nervura de concreto faz a ligação mesa-alma.

Segundo o projeto de revisão da Norma Brasileira Registrada NBR 6118/2000 - Projeto de Estruturas de Concreto, "lajes nervuradas são as moldadas no local ou com nervuras pré-moldadas, cuja zona de tração é constituída por nervuras entre as quais pode ser colocado material inerte". Neste trabalho serão tratadas apenas as lajes nervuradas moldadas no local, em concreto armado.

Usualmente, para as lajes nervuradas, têm-se painéis apoiados em vigas mais rígidas que as nervuras, num sistema chamado de convencional. Contudo, podem também serem utilizadas nos pisos de lajes sem vigas.

Pelo uso cada vez mais crescente destes sistemas de lajes nervuradas, convencionais ou sem vigas, vê-se a necessidade de um claro entendimento das diversas possibilidades de análise estrutural, comparando os processos simplificados com os mais especializados em busca de resultados mais próximos da realidade.

Assim, com a alta capacidade de processamento atualmente disponível pelos computadores começa a ser viável a consideração de fatores usualmente negligenciados nas análises, buscando os resultados mais próximos possíveis do comportamento real dessas estruturas.

Um dos fatores usualmente desconsiderados nas análises numéricas, ou considerados de forma simplificada, nos escritórios de cálculo estrutural, é a excentricidade existente entre os eixos das nervuras e o plano médio da placa. O problema desta interação placa-viga, que já aparece nos pavimentos convencionais de concreto armado (sistemas laje maciça apoiadas em vigas) é ainda mais importante nos sistemas de lajes nervuradas devido ao grande número de nervuras que participam na rigidez global da estrutura e que, dessa forma, não devem ter sua contribuição subestimada pela desconsideração das excentricidades.

\subsection{OBJETIVOS}

Visando contribuir para o aprimoramento da análise estrutural de lajes nervuradas este trabalho tem como objetivos principais:

- apresentar uma revisão bibliográfica relativa a cada solução estrutural aproximada permitida à análise de lajes nervuradas convencionais e sem vigas pelas normas 
técnicas, descrevendo as características fundamentais dos processos, bem como as vantagens e desvantagens frente a soluções mais realistas;

- apresentar um estudo numérico amplo sobre a interação placa-viga no cálculo estrutural de lajes nervuradas, aplicando o Método dos Elementos Finitos, considerando como fator principal de análise a excentricidade existente entre o eixo da nervura e o plano médio da placa e sua influência nos deslocamentos e esforços. O estudo numérico avaliará principalmente a influência das variáveis número de nervuras por lado, espaçamento entre as nervuras e altura das nervuras em relação à altura da placa;

- apresentar uma comparação entre os resultados de esforços e deslocamentos apresentados pelas teorias de cálculo simplificadas (Teoria da Placa Ortótropa Equivalente e Teoria de Grelha) e modelos mais realistas (com elementos finitos que consideram a excentricidade na formulação), buscando determinar o quanto as simplificações influenciam na análise estrutural das lajes nervuradas.

\subsection{TÉCNICAS E MÉTODOS EMPREGADOS}

Os modelos de cálculo adotados à análise de lajes nervuradas serão aplicados a exemplos numéricos de lajes enrijecidas por nervuras e resolvidos por meio do Método dos Elementos Finitos, utilizando-se o software ANSYS 5.5.

O Método dos Elementos Finitos, ou MEF, constitui-se no método numérico mais utilizado na análise estrutural, visto que é capaz de ser aplicado aos diversos tipos de estruturas, apresentando resultados bastante satisfatórios. Além disso, o uso de um software comercial na análise ressalta a condição de que os resultados obtidos neste trabalho podem ser obtidos também pelos projetistas de estruturas, já que existem no mercado diversos programas computacionais comerciais que disponibilizam a opção da consideração da excentricidade da viga em relação à placa, objetivo primordial deste trabalho.

Os elementos finitos utilizados serão elementos de viga bidimensional, elementos de viga tridimensional aplicados de forma concêntrica e excêntrica em relação ao plano das placas e finalmente elementos de casca tridimensional.

Em todos os modelos aplicados neste trabalho são válidas as seguintes condições:

- os materiais das lajes nervuradas são elásticos, homogêneos e isótropos;

- as deformações transversais por cisalhamento são negligenciadas; 
- a análise é de primeira ordem geométrica, ou seja, desconsideram-se grandes deslocamentos;

- todos os carregamentos são aplicados ortogonalmente ao plano médio da placa;

- os enrijecedores são prismáticos e têm pelo menos uma simetria de seção transversal.

\subsection{SÍNTESE DOS CAPÍTULOS}

Este trabalho foi dividido em seis capítulos conforme comentários:

Neste Capítulo 1 apresenta-se uma introdução ao tema por meio de uma visão geral dos assuntos tratados neste trabalho, os motivos de interesse, os objetivos a serem atingidos e os métodos e técnicas empregados.

No Capítulo 2 procuram-se detalhar os métodos simplificados de análise de lajes nervuradas permitidas pelas normas, descrevendo as características essenciais dos processos e métodos, bem como as vantagens e desvantagens frente a soluções mais realistas.

No Capítulo 3 apresentam-se as formas de consideração da excentricidade nos modelos em Método dos Elementos Finitos aplicados neste trabalho, descrevendo-se também experimentações numéricas anteriores encontradas na revisão bibliográfica que apresentam resultados comparativos entre modelos simplificados e modelos realistas.

No Capítulo 4 descrevem-se as características dos modelos mecânicos em Método dos Elementos Finitos adotados à análise das lajes nervuradas deste trabalho. São apresentadas as características dos elementos finitos utilizados e procede-se a uma verificação da validade dos modelos através da aplicação dos mesmos à exemplos anteriormente resolvidos em diversos artigos encontrados na bibliografia.

No Capítulo 5 apresenta-se a experimentação numérica visando avaliar a influência das variáveis número de nervuras por lado, espaçamento entre as nervuras e altura das nervuras em relação à altura da placa nos resultados de deslocamentos e esforços, aplicando-se os modelos adotados neste trabalho. Os resultados são comparados e os erros avaliados.

No Capítulo 6 discutem-se as conclusões e considerações finais. Além disso, faz-se sugestões para a continuação do trabalho e aprofundamento dos tópicos de análise envolvidos. 


\section{CAPÍTULO 2 - A ANÁLISE DE LAJES NERVURADAS UTILIZANDO PROCESSOS SIMPLIFICADOS}

\subsection{INTRODUÇÃO AO CAPÍTULO 2}

A análise estrutural de lajes nervuradas por processos simplificados é, até os dias de hoje, muito difundida nos escritórios de cálculo. Os modelos adotados podem ser resolvidos através de softwares facilmente disponíveis: análise de grelha, análise de pórtico plano e tabelas de cálculo de lajes maciças.

Contudo, o comportamento desta estrutura não é bem definido quando da consideração das simplificações.

Como mostrado em BOCCHI JÚNIOR (1995) as lajes nervuradas apresentam um comportamento elástico intermediário entre placa e grelha. Assim, as normas técnicas permitem que, além do cálculo dos esforços solicitantes e deslocamentos segundo a teoria das placas, pode-se fazê-lo segundo a teoria das grelhas. Contudo o autor indica, em um estudo comparativo entre os resultados obtidos para esforços solicitantes e deslocamentos empregando-se a teoria das placas, por meio de tabelas [PINHEIRO (1993)], e teoria das grelhas, por meio do programa GPLAN3 [CORRÊA \& RAMALHO (1987)], que nem sempre os valores obtidos pelos dois processos são compatíveis. Para uma laje quadrada de 6,48 m de lado, com distância entre nervuras a $<50 \mathrm{~cm}$, obteve discrepâncias entre os valores de momentos fletores da nervura de até $18 \%$ entre os dois processos.

A análise estrutural das lajes nervuradas por processos simplificados, a fim de obter-se tanto os deslocamentos quanto os esforços solicitantes, pode ser realizada por meio de modelagem destas como estruturas bidimensionais, planas, elásticas, considerando a excentricidade entre mesa e nervura de forma implícita, das seguintes maneiras: 
- Analogia de Placa ou Teoria da Placa Ortótropa Equivalente: consideração da inércia da seção "T" para a obtenção de uma espessura equivalente de laje maciça, constante, para lajes nervuradas convencionais e sem vigas;

- Analogia de grelha: consideração da inércia da seção "T", onde mesa e alma trabalham juntas num sistema linear de grelha, para lajes nervuradas convencionais e sem vigas;

- Processo dos Pórticos Múltiplos proposto pela NB1/1978: consideração da espessura equivalente para o cálculo da laje nervurada em modelo de pórtico plano considerando a interação laje-pilar, para lajes nervuradas sem vigas, com capitéis ou ábacos junto aos pilares;

- Processo dos Pórticos Equivalentes proposto pelo Código American Concrete Institute ACI-318: consideração ou da espessura equivalente, ou das seções reais para o cálculo da laje nervurada como modelo de pórtico plano mais refinado, substituindo o pilar por um pilar equivalente, aplicável a lajes nervuradas sem vigas com capitéis ou ábacos junto aos pilares.

\subsection{ANÁLISE ESTRUTURAL DE LAJES NERVURADAS CONVENCIONAIS E SEM VIGAS POR ANALOGIA DE PLACA}

Um dos métodos mais populares de análise de lajes nervuradas sob flexão é conhecido como Teoria da Placa Ortótropa Equivalente, ou Analogia de Placa, originalmente desenvolvido apenas para um material elástico ideal (logo, tratando-se de concreto armado, vemos a sua validade apenas na fase elástica do concreto).

A filosofia do método é converter a placa enrijecida por nervuras em uma placa maciça, de espessura constante, equivalente em comportamento à laje nervurada. Assim, a flexão geral do sistema de placa enrijecida por nervuras é computada utilizando-se algum método convencional e os resultados são superposições daqueles obtidos da flexão local dos enrijecedores e painéis de laje.

De acordo com KENNEDY \& EL-SEBAKHY (1982) as constantes elásticas de uma estrutura ortótropa equivalente podem ser tomadas como semelhantes àquelas que geram o comportamento à flexão e à torção de uma laje nervurada justificando, assim, o uso da teoria. Concluíram que a Teoria da Placa Ortótropa aplicada sob a resolução de Séries de Fourier pode ser utilizada com confiança para estimar o comportamento elástico de lajes nervuradas. 
DEB \& BOOTON (1987) indicaram que a substituição da laje nervurada por uma laje maciça equivalente, apesar de menos preciso do que um modelo em que o sistema de placa enrijecida por nervuras é tratado como elementos de placas e vigas interagindo adequadamente pode ser preferível, especialmente em uma análise não-linear física, em termos de economia de processamento computacional, bem como na simplicidade de entrada de dados. Concluíram que as formulações ortótropas podem ser consideradas precisas na estimativa de deslocamentos e tensões para uma placa enrijecida submetida a carregamento uniformemente distribuído, podendo a máxima tensão no enrijecedor ser esperada como $20 \%$ a favor da segurança quando os enrijecedores são pouco espaçados.

Também conforme AJDUKIEWICZ \& STAROSOLSKI $^{1}$ apud BARBIRATO (1997) os métodos baseados na analogia de placas proporcionam resultados satisfatórios no que refere-se ao comportamento da estrutura.

DEB et al. (1991) indicaram que uma premissa comum nas teorias de placa ortótropa aplicadas a placas com enrijecedores ortogonais é assumir a ausência de torção nos enrijecedores, o que pode ocasionar resultados errôneos quando os enrijecedores não estiverem razoavelmente próximos. Também demonstraram que a Teoria da Placa Ortótropa Equivalente não é válida para a análise de laje submetida a carregamento concentrado, verificando-se uma grande superestimativa das tensões nos enrijecedores quando da aplicação da teoria, reafirmando o que foi observado por CLARKSON ${ }^{2}$ apud DEB et al. (1991).

De acordo com MUKHOPADHYAY (1992) e PALANI et al. (1992) este modelo não consegue evoluir para uma solução satisfatória do problema. A mesma opinião é compartilhada em SHEIKH \& MUKHOPADHYAY (1992).

BEDAIR (1997) acrescenta que aparecem dificuldades se os enrijecedores não são idênticos nas duas direções ou não igualmente espaçados, o que faz com que a espessura resultante não seja uniforme, ou haja a necessidade de mudança das dimensões em planta da laje.

ABDUL-WAHAB \& KHALIL (2000) verificaram, experimentalmente, que o comportamento de uma laje nervurada em modelo reduzido foi significativamente diferente do comportamento da respectiva laje maciça equivalente. Verificaram que a laje

1 AJDUKIEWICZ, A.B.; STAROSOLSKI, W. (1990). Reinforced - concrete slab-column structures. Amsterdam, Elsevier.

${ }^{2}$ CLARKSON, J. (1962). The behaviour of deck stiffening under concentrated loads. Trans. R. Inst. Naval Arch. 140,57-65. 
maciça equivalente rompeu-se com uma carga $60 \%$ menor que a carga de ruptura da laje nervurada correspondente.

Neste trabalho, visando utilizar o processo, em adição às condições básicas na formulação da equação diferencial de uma placa ortótropa (ou preferencialmente isótropa, se as nervuras forem idênticas em forma e espaçamento nas duas direções ortogonais), as condições seguintes devem ser adotadas e/ou verificadas:

a) o número de nervuras deve ser grande o suficiente, cinco ou mais por lado, conforme ABDUL-WAHAB \& KHALIL (2000), para que a estrutura real possa ser substituída por uma idealizada e com propriedades contínuas. Outros autores apresentaram parâmetros mais específicos em relação ao número de nervuras: HOPPMANN et al. (1956) compararam entre resultados teóricos (pela Teoria da Placa Ortótropa) e experimentais nos deslocamentos e deformações, encontrando os resultados mais próximos entre eles na relação $a_{1} / l=0,071$, sendo $a_{1}=$ espaçamento entre os centros dos enrijecedores e $1=$ dimensão do lado analisado da laje, de acordo com a Figura 2.1; DEB et al. (1991) encontraram diferenças de 5 a $10 \%$ nos deslocamentos e tensões na placa, a favor da segurança, utilizando uma relação $a_{1} / 1=0,067$ para placa submetida a carga uniformemente distribuída. Dessa forma, há indícios de que a relação em torno destes valores é a mais adequada. Neste trabalho esta investigação será complementada;

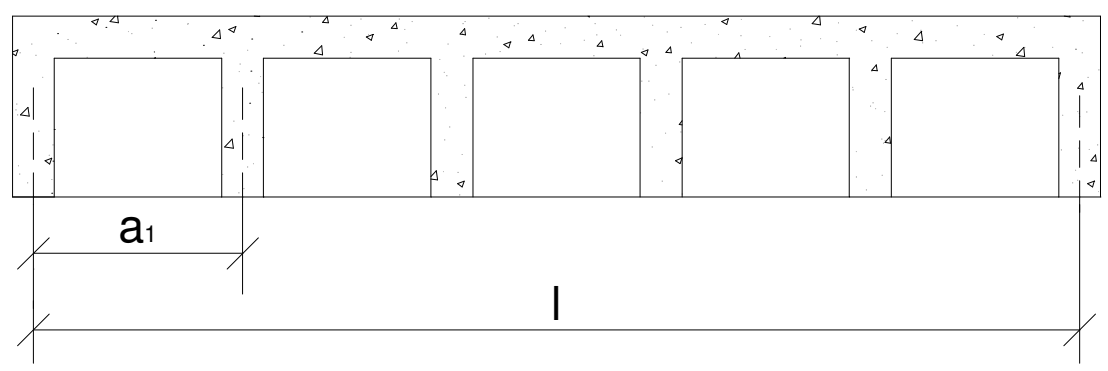

FIGURA 2.1: Espaçamento entre as nervuras

b) o plano neutro em qualquer das duas direções ortogonais coincide com o centro de gravidade da seção total na correspondente direção.

SAPOUNTZAKIS \& KATSIKADELIS (2000) acrescentaram que para o uso da Teoria da Placa Ortótropa Equivalente é necessário que a relação entre a rigidez do enrijecedor e a rigidez da placa (ou laje) não seja tão grande, o que caracterizaria uma predominância da ação das vigas.

Conforme a Norma Brasileira de Concreto Armado, mesmo considerando as lajes nervuradas como elementos estruturais complexos, estas podem ser calculadas como 
elementos de placa dando-lhes assim o mesmo tratamento das lajes maciças, observando-se para isso algumas condições, enumeradas a seguir:

a) Segundo a NB1/1978 - Projeto e Execução de Estruturas de Concreto Armado, tem-se:

- a distância livre entre nervuras não deve ultrapassar 100 cm;

- a espessura das nervuras não deve se inferior a 4 cm e da mesa não deve ser menor que $4 \mathrm{~cm}$, nem que 1/15 da distância livre entre nervuras, garantindo-se dessa forma a exeqüabilidade adequada de sua concretagem e o eventual alojamento de tubulações de distribuição de energia elétrica;

- o apoio das lajes deve ser feito ao longo de uma nervura;

- nas lajes armadas numa só direção são necessárias nervuras transversais sempre que haja ações concentradas a distribuir ou quando o vão teórico for superior a $4 \mathrm{~m}$, exigindo-se duas nervuras no mínimo se o vão ultrapassar $6 \mathrm{~m}$. De acordo com FIORIN (1998), as nervuras transversais devem possuir praticamente a mesma altura das longitudinais, e apresentar a mesma seção transversal de armadura inferior destas, enquanto na parte superior deve-se colocar pelo menos $40 \%$ da armadura inferior;

- em nervuras com espessura inferior a $8 \mathrm{~cm}$ não é permitido colocar armadura de compressão na face oposta à mesa;

Além destas prescrições contidas no item 6.1.1.3, tem-se outras da NB1/1978 para tratar-se a laje nervurada como placa:

- a resistência da mesa à flexão deverá ser verificada como laje apoiada nas bordas sempre que a distância livre entre nervuras superar $50 \mathrm{~cm}$ ou houver carga concentrada no painel entre nervuras;

- as nervuras serão verificadas ao cisalhamento como vigas se a distância livre entre nervuras ultrapassar $50 \mathrm{~cm}$, e como laje em caso contrário;

- nas lajes armadas em uma só direção deve-se colocar uma armadura de distribuição, na mesa de compressão, de $0,9 \mathrm{~cm}^{2} / \mathrm{m}$ ou $1 / 5$ da armadura principal;

- os estribos, quando necessários, não devem ter espaçamento maior que 20 $\mathrm{cm}$, nem diâmetro maior que $1 / 8$ da largura das nervuras.

b) Segundo o projeto de revisão da NBR6118/2000, tem-se:

- a espessura da mesa, quando não houver tubulações horizontais embutidas, deve ser maior ou igual a $1 / 15$ da distância entre nervuras, e não menor que $3 \mathrm{~cm}$; o valor mínimo absoluto deve ser de $4 \mathrm{~cm}$ quando existirem tubulações embutidas de diâmetro máximo de 12,5 mm; 
- a espessura das nervuras não deve ser inferior a $5 \mathrm{~cm}$;

- não é permitido o uso de armadura de compressão em nervuras de espessura inferior a $8 \mathrm{~cm}$;

- para lajes com espaçamento entre eixos de nervuras menor ou igual a 60 cm devem ser dispensadas a verificação da flexão da mesa e para a verificação do cisalhamento da região das nervuras permite-se a consideração dos critérios de laje;

- para lajes com espaçamento entre eixos de nervuras entre $60 \mathrm{~cm}$ e $110 \mathrm{~cm}$ exige-se a verificação da flexão da mesa e as nervuras serão verificadas ao cisalhamento como vigas;

- para lajes nervuradas com espaçamento entre eixos de nervuras maior que $110 \mathrm{~cm}$ a mesa deve ser projetada como laje maciça, apoiada na grelha de vigas, respeitandose os seus limites mínimos de espessura.

Além das condições contidas no item 13.1.4.2, o projeto de revisão da NBR6118/2000 indica que, havendo necessidade de estribos, estes não devem ter espaçamento superior a $20 \mathrm{~cm}$.

De acordo com o EUROCODE (1992) uma laje nervurada pode ser tratada como laje maciça quando:

- as nervuras possuírem rigidez suficiente à torção;

- a distância entre as nervuras não ultrapassar $150 \mathrm{~cm}$;

- a espessura da mesa for maior ou igual a $5 \mathrm{~cm}$ ou $4 \mathrm{~cm}$ (quando existir bloco de fechamento permanente entre as nervuras), ou maior de 1/10 da distância livre entre nervuras.

\subsubsection{A Teoria Clássica das Placas Delgadas Isótropas e Ortótropas}

A resolução de um elemento de placa de espessura constante submetido a níveis baixos de tensões perpendiculares ao plano médio, delgado e sofrendo pequenos deslocamentos, segundo o método clássico da elasticidade, é feita através da integração da equação diferencial de equilíbrio de Lagrange, proposta em 1816, que possibilita o cálculo dos esforços solicitantes e dos deslocamentos para um ponto qualquer no interior da placa isótropa, mostrada na Eq. 2.1:

$$
\frac{\partial^{4} w}{\partial^{4} x}+2 \frac{\partial^{4} w}{\partial x^{2} \partial y^{2}}+\frac{\partial^{4} w}{\partial^{4} y}=\frac{(g+q)}{D}
$$


sendo:

$\mathrm{D}=\frac{\mathrm{E} \cdot \mathrm{h}^{3}}{12 \cdot\left(1-v^{2}\right)}=$ rigidez da placa à flexão

E: módulo de deformação longitudinal do material;

h: altura da laje;

v: coeficiente de Poisson do material;

$(\mathrm{g}+\mathrm{q})$ : ação aplicada perpendicularmente ao plano da placa, no ponto considerado, no interior da placa;

w: deslocamento medido perpendicularmente ao plano da laje.

$\mathrm{x}, \mathrm{y}$ : eixo de coordenadas ortogonais para o plano médio da placa.

O sistema de coordenadas do elemento de placa é dado na Figura 2.2.

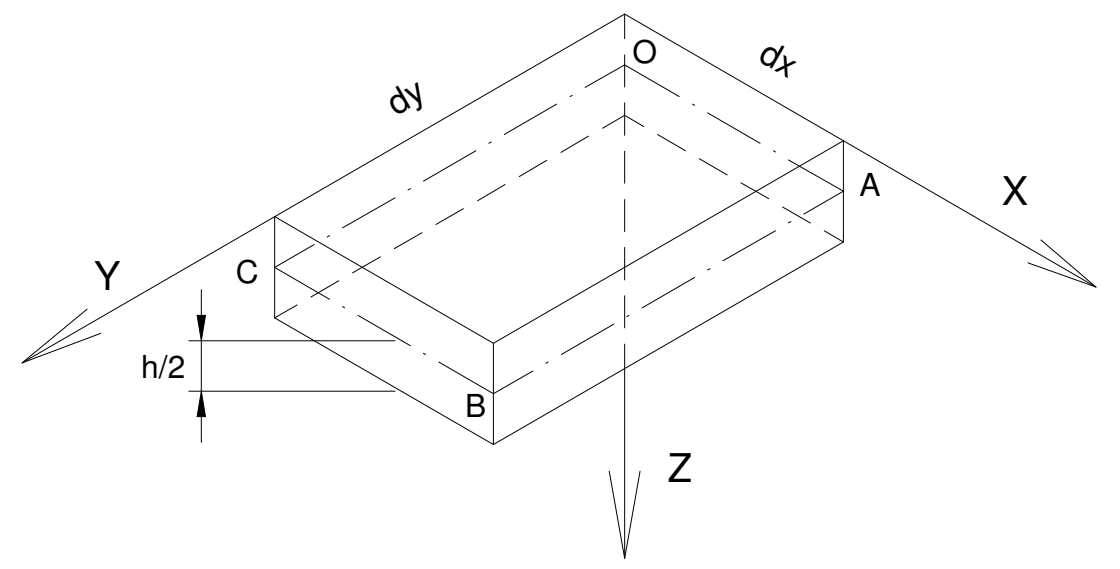

FIGURA 2.2: Sistema de coordenadas de um elemento de placa

Para que o problema seja resolvido é necessário que se aplique às bordas as condições de contorno conforme o tipo de vinculação, sendo os clássicos:

a) nas bordas simplesmente apoiadas, perpendiculares ao eixo Ox, tem-se que os deslocamentos w serão nulos e, se não houver momentos prescritos, mx também será nulo $\therefore$

$$
\mathrm{w}=0 \text { e } \frac{\partial^{2} \mathrm{w}}{\partial \mathrm{x}^{2}}+v \cdot \frac{\partial^{2} \mathrm{w}}{\partial \mathrm{y}^{2}}=0
$$

b) nas bordas perfeitamente engastadas, perpendiculares ao eixo Ox, tem-se que os deslocamentos w serão nulos e o giro $\theta x$, não sendo prescrito, deverá ser nulo ao longo dessa borda $\therefore$

$$
\mathrm{w}=0 \text { e } \frac{\partial \mathrm{w}}{\partial x}=\theta \mathrm{x}=0
$$


c) nas bordas livres, perpendiculares ao eixo Ox, as reações de apoio rx e os momentos fletores mx ao longo desse apoio deverão ser nulos $\therefore$

$$
\begin{aligned}
& \frac{\partial^{3} w}{\partial x^{3}}+(2-v) \cdot \frac{\partial^{3} w}{\partial x \partial y^{2}}=0 \\
& \frac{\partial^{2} w}{\partial x^{2}}+v \cdot \frac{\partial^{2} w}{\partial y^{2}}=0
\end{aligned}
$$

As equações para as bordas perpendiculares ao eixo Oy são as mesmas das demonstradas, alterando-se apenas as variáveis x e y.

Após a integração da equação diferencial tem-se o deslocamento ortogonal ao plano em qualquer ponto da placa. Conhecidos os deslocamentos podem ser obtidos os momentos, esforços cortantes e reações, através de combinações apropriadas de derivadas da função de deslocamento. As tensões podem ser determinadas a partir dos momentos e esforços cortantes.

A espessura constante pedida na teoria, para as lajes nervuradas, é obtida através do cálculo da chamada "espessura equivalente", que será posteriomente apresentado.

Para uma placa maciça equivalente ortótropa, no caso em que a forma ou o espaçamento entre as nervuras forem diferentes nas duas direções ortogonais, dada uma distribuição de carga e para conhecidas condições de contorno, os deslocamentos, momentos e cortantes são determinados pela integração da equação diferencial seguinte, de acordo com TIMOSHENKO \& WOINOWSKY-KRIEGER (1959):

$$
D_{x} \cdot \frac{\partial^{4} w}{\partial^{4} x}+2 . H \cdot \frac{\partial^{4} w}{\partial x^{2} \partial y^{2}}+D_{y} \cdot \frac{\partial^{4} w}{\partial^{4} y}=P(x, y)
$$

onde:

$D_{\mathrm{x}}$ e $\mathrm{D}_{\mathrm{y}}=$ rigidezes à flexão nas duas direções ortogonais;

2.H = rigidez total à torção, soma das rigidezes à torção nas direções x e y, ou seja, $D_{x y}$ e $D_{y x}$, e as rigidezes acopladas $D_{1}$ e $D_{2}$, que representam a contribuição da flexão para a torção da placa.

Assim, tem-se:

2.H $=\left(\mathrm{D}_{\mathrm{xy}}+\mathrm{D}_{\mathrm{yx}}+\mathrm{D}_{1}+\mathrm{D}_{2}\right)$

onde:

$\mathrm{D}_{\mathrm{xy}}$ e $\mathrm{D}_{\mathrm{yx}}=$ rigidezes à torção nas direções $\mathrm{x}$ e y, sendo:

$\mathrm{D}_{\mathrm{xy}}=\mathrm{D}_{\mathrm{yx}}=\frac{\mathrm{G}^{\mathrm{h}} \mathrm{h}^{3}}{12}$

$D_{1}$ e $D_{2}=$ contribuição da flexão na torção da placa enrijecida, sendo: 


$$
\mathrm{D}_{1}=\mathrm{D}_{2}=v \cdot \frac{\mathrm{E}_{\mathrm{cs}} \cdot \mathrm{h}^{3}}{12 .\left(1-v^{2}\right)}
$$

O termo de rigidez 2.H, segundo BARES \& MASSONNET (1968), pode também ser escrito na forma:

$$
2 . \mathrm{H}=2 \cdot \alpha \cdot \sqrt{\mathrm{D}_{\mathrm{x}} \cdot \mathrm{D}_{\mathrm{y}}}
$$

onde:

$$
\alpha=\frac{\mathrm{D}_{\mathrm{xy}}+\mathrm{D}_{\mathrm{yx}}+\mathrm{D}_{1}+\mathrm{D}_{2}}{2 \cdot \sqrt{\mathrm{D}_{\mathrm{x}} \cdot \mathrm{D}_{\mathrm{y}}}}
$$

O valor de $\alpha$ tem um valor limite superior igual a 1 para uma placa verdadeiramente isótropa, onde $H=D_{x}=D_{y}$ e um limite inferior igual a 0 para uma grelha com os elementos desprovidos de rigidez à torção, ou seja, nesse caso $\mathrm{H}=0$.

Entretanto, para o caso de um enrijecedor torcional, geralmente aplicados em pisos de pontes flexíveis, por exemplo, tem-se $\mathrm{H}^{2}>\left(\mathrm{D}_{\mathrm{x}}\right.$. $\left.\mathrm{D}_{\mathrm{y}}\right)$, e conseqüentemente $\alpha>1$.

Para aplicações práticas, de acordo com BARES \& MASSONET (1968), tem-se:

$$
\begin{aligned}
& D_{x}=\frac{E \cdot I_{s x}}{S_{x}} \\
& D_{y}=\frac{E \cdot I_{s y}}{S_{y}}
\end{aligned}
$$

onde:

$\mathrm{I}_{\mathrm{sx}}$ e $\mathrm{I}_{\mathrm{sy}}=$ momentos de inércia nas seções das nervuras com respeito aos eixos neutros nas direções x e y, respectivamente;

$S_{\mathrm{x}}$ e $\mathrm{S}_{\mathrm{y}}=$ espaçamento das nervuras.

\subsubsection{O conceito de espessura equivalente}

$\mathrm{Em} \mathrm{JI}^{3}$ et al. apud BARBIRATO (1997) vê-se que a determinação da laje maciça de rigidez equivalente à laje nervurada baseia-se no conceito de "espessura equivalente".

${ }^{3}$ JI, X.; CHEN, S. et al. (1985). Deflection of waffle slabs under gravity and in-plane loads. In: SABNIS, G., ed. Deflections of concrete structures. Detroit, ACI. P.283-295. (ACI SP-66). 
O processo consiste em considerar a espessura equivalente como a espessura de uma placa uniforme que tenha o mesmo comportamento à flexão que uma laje nervurada, de acordo com a Figura 2.3.
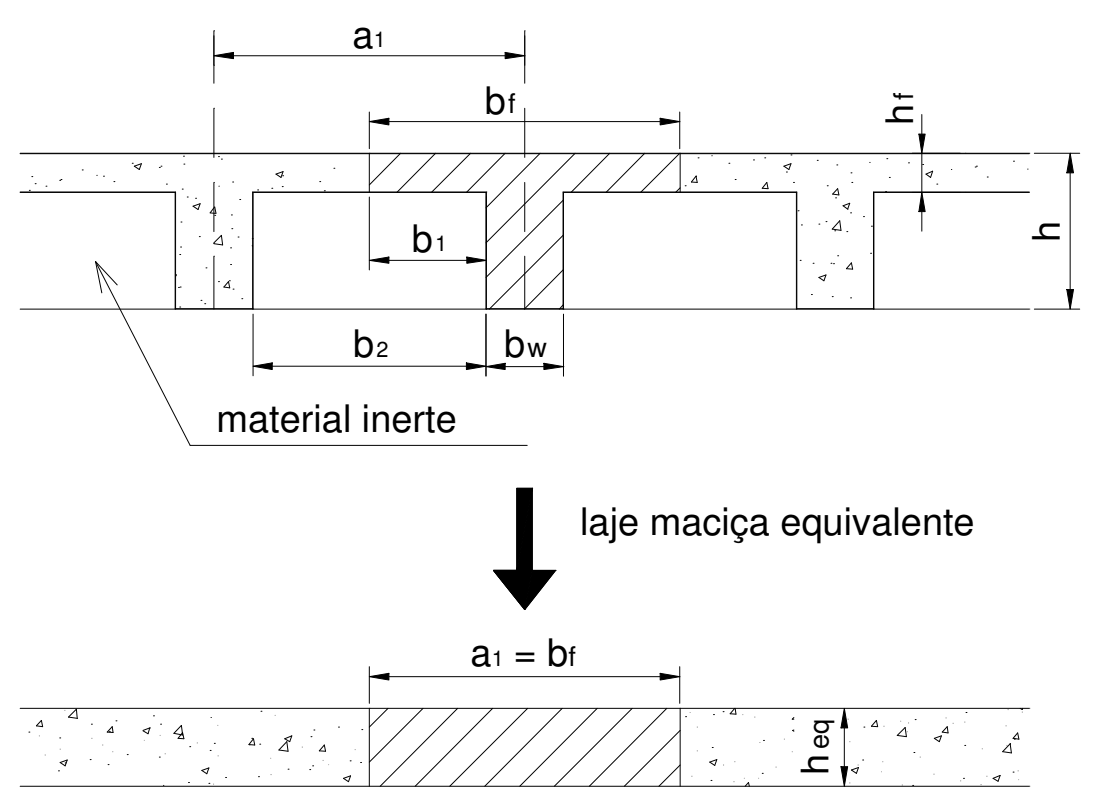

FIGURA 2.3: Processo de espessura equivalente maciça para uma laje nervurada isótropa

A espessura equivalente da laje pode ser calculada considerando a equivalência do momento de inércia à flexão, pela fórmula:

$$
\mathrm{h}_{\mathrm{eq}}=\left(\frac{12 . \mathrm{I}}{\mathrm{a}_{1}}\right)^{1 / 3}
$$

sendo:

$\mathrm{h}_{\mathrm{eq}}$ : espessura da laje maciça equivalente;

$\mathrm{a}_{1}$ : distância entre eixos de nervuras;

I: momento de inércia à flexão da seção transversal "T", sem a consideração da fissuração, e em relação ao eixo baricêntrico horizontal.

Além desse processo, diferentes espessuras equivalentes podem também ser obtidas utilizando equivalência em momento de fissuração ou em módulo de resistência.

$\mathrm{Na}$ análise estrutural deve-se sempre atentar para os valores de peso próprio da laje nervurada, que não são os mesmos apresentados pela laje maciça de espessura equivalente em inércia à flexão.

A laje equivalente é considerada isótropa se as nervuras forem igualmente espaçadas nas duas direções, e ortótropa em caso contrário. 
Em um estudo das características dos deslocamentos de lajes nervuradas de concreto armado $\mathrm{JI}^{3}$ et al. apud ABDUL-WAHAB \& KHALIL (2000) testaram uma laje nervurada em modelo reduzido, em concreto armado, sob carga transversal e compararam os resultados da rigidez no campo elástico não-fissurado (estádio I) com aqueles obtidos pelo Método dos Elementos Finitos e pelo conceito de espessura equivalente. Concluíram que o Método da Espessura Equivalente conduz a uma superestimativa da rigidez à torção e a uma subestimativa dos deslocamentos. Para compensar este fato sugeriram que a espessura equivalente fosse reduzida em aproximadamente $20 \%$. Agindo todo o carregamento de serviço, estando o concreto no campo elástico fissurado (estádio II), sugeriram que a rigidez efetiva fosse estimada como $40 \%$ da rigidez inicial, ou seja, daquela estando o concreto no campo elástico não-fissurado (estádio I).

ABDUL-WAHAB \& KHALIL (2000), em testes realizados com modelos de laje nervurada, confirmaram a melhora de resultados com a redução da espessura em $20 \%$ para o concreto no campo elástico. Concluíram, entretanto, que estimativas melhores da rigidez no campo elástico fissurado do concreto, quando da atuação da carga total, são obtidas assumindo-se uma redução de $25 \%$ da rigidez inicial.

Neste trabalho haverá modelos (para lajes nervuradas de concreto armado) utilizando a espessura da laje maciça equivalente sem qualquer redução na espessura, e os resultados apresentados por estes serão comparados com os modelos utilizando as considerações de ABDUL-WAHAB \& KHALIL (2000), reduzindo-se 20\% da espessura da laje maciça equivalente, nas análises elásticas consideradas.

\subsubsection{Definição da largura colaborante da seção " $T$ "}

Para o cálculo do momento de inércia do elemento de barra de seção integral "T" torna -se necessário definir a largura colaborante da mesa de concreto. Na laje nervurada deve ser considerada a seção "T" pelo fato de que a mesa tem a função de solidarizar as nervuras, compatibilizando assim os deslocamentos. Dessa forma a mesa participa da rigidez da laje, em composição com a nervura.

De acordo com a teoria elementar de vigas (assumindo que as seções planas permanecem planas depois da flexão da viga) a tensão normal $\sigma_{\mathrm{x}}$ para um ponto com coordenadas $(\mathrm{y}, \mathrm{z})$ é dada pela Eq. 2.16, no qual implica uma tensão constante na direção y. 


$$
\sigma_{\mathrm{x}}=\frac{\mathrm{M}_{\mathrm{y}}}{\mathrm{I}_{\mathrm{y}}} \cdot \mathrm{z}
$$

sendo:

$\mathrm{M}_{\mathrm{y}}=$ momento fletor atuante na viga;

$\mathrm{I}_{\mathrm{y}}=$ momento de inércia à flexão da viga;

$\mathrm{z}=$ distância da fibra ao centro de gravidade da seção homogênea.

Conforme LEONHARDT \& MÖNNIG (1978) surge, ao longo da junção da laje com a viga, uma força cortante $\mathrm{V}$ desconhecida que atua cisalhando no plano e que solicita a laje como chapa, conforme a Figura 2.4.

A partir das tensões introduzidas pela força cortante $\mathrm{V}$ é que determina-se a largura colaborante (ou largura efetiva).

Assim, no caso de seções de viga "T" (ou associação de viga e largura colaborante de laje), os deslocamentos longitudinais nas partes da mesa distantes da nervura (na direção y) defasam daqueles próximos à nervura devido à ação da transmissão da tensão de cisalhamento no plano da placa para o enrijecedor (atuação da força cortante V). Esta defasagem resulta na distribuição não-uniforme de tensões axiais ou longitudinais, de acordo com a Figura 2.5.

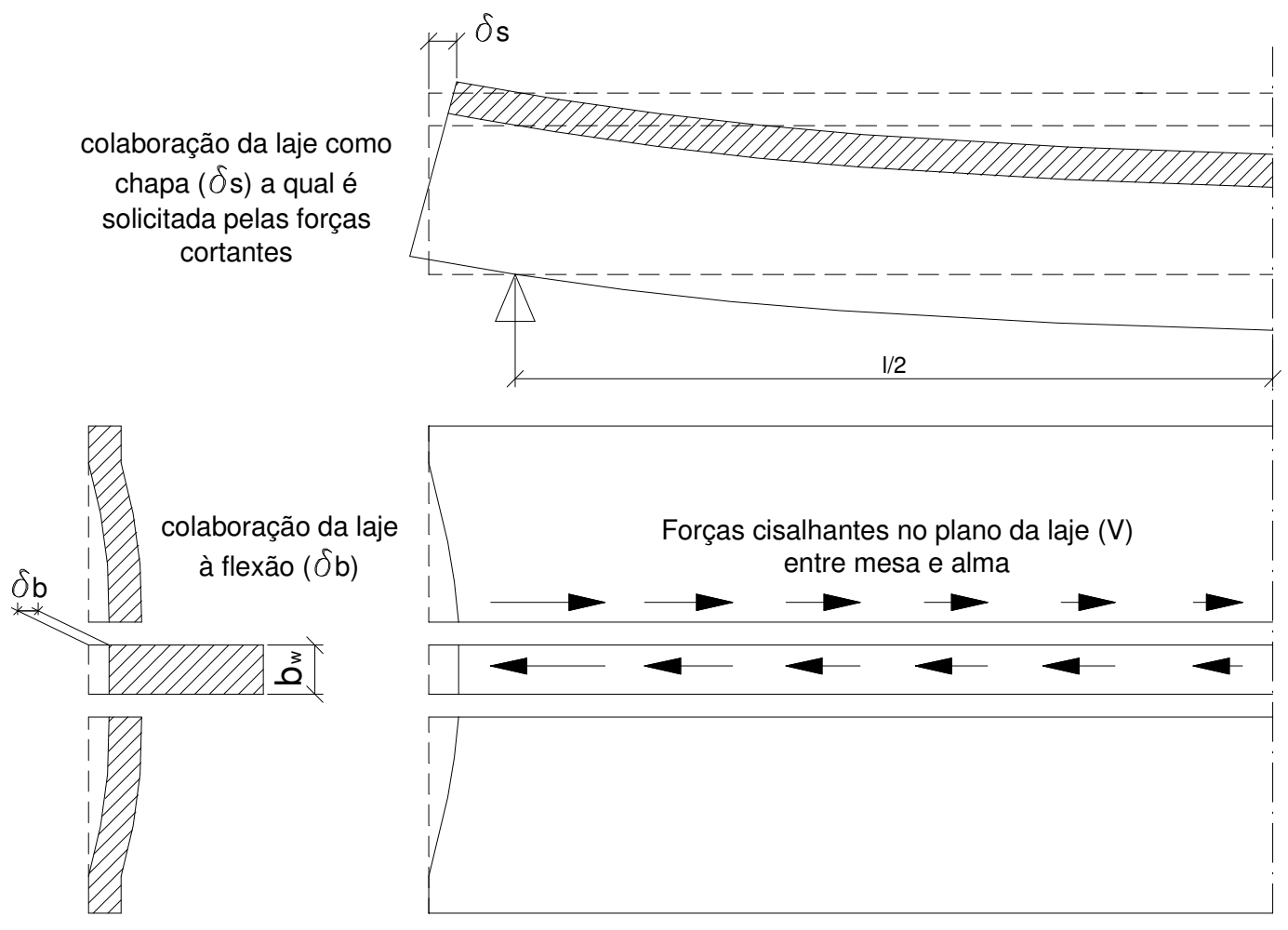

FIGURA 2.4: Colaboração da laje em uma viga "T"

[LEONHARDT \& MÖNNIG (1978)] 


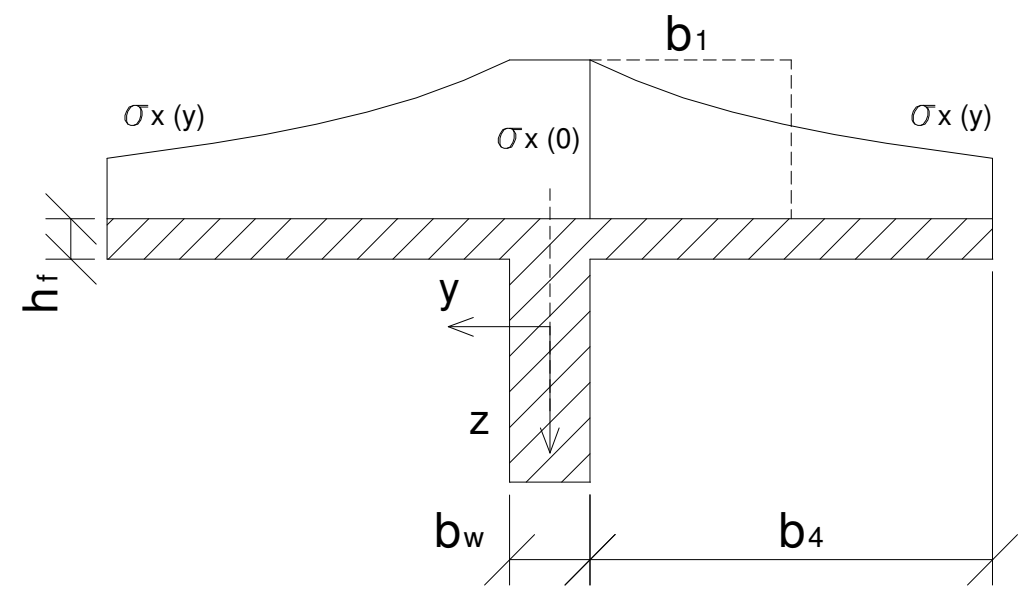

FIGURA 2.5: Distribuição de tensão $\sigma_{\mathrm{x}}$ na mesa de uma viga "T"

[TENCHEV (1995)]

Este fenônemo é chamado de defasagem de cisalhamento (ou "shear lag"). Se a largura da mesa é grande a Eq. 2.16 irá subestimar significativamente a tensão na interseção nervura-mesa. Entretanto, é ainda possível obter um valor correto para a máxima tensão usando uma largura efetiva de mesa $b_{1}$, da seguinte forma:

$$
\mathrm{b}_{1}=\frac{1}{\sigma_{\mathrm{x}(0)}} \int_{0}^{\mathrm{b}_{4}} \sigma_{\mathrm{x}(\mathrm{y})} \cdot \mathrm{d}_{\mathrm{y}}
$$

A Eq. 2.17 é de uso pouco prático se $\sigma_{\mathrm{x}}$ é desconhecida e, pela dificuldade de aplicação, não será utilizada neste trabalho.

Uma formulação alternativa é dada por:

$\mathrm{b}_{1}=\lambda \cdot \mathrm{b}_{4}$

sendo:

$\mathrm{b}_{1}=$ largura efetiva;

$\mathrm{b}_{4}=$ largura construída da mesa;

$\lambda=$ coeficiente de defasagem de cisalhamento (ou "shear lag").

O problema da consideração da largura colaborante tem sido estudado por diversos pesquisadores, visando-se determinar os valores adequados para $\lambda$.

TENCHEV (1995) efetuou um estudo paramétrico da distribuição de tensões em vigas ortótropas considerando diversas condições de contorno e seções transversais, além do caso de placas finas enrijecidas por nervuras, o que é o caso de lajes nervuradas. Utilizou no Método dos Elementos Finitos um modelo bidimensional e estabeleceu uma fórmula empírica para o coeficiente de "shear lag" $\lambda$ utilizado no cálculo da largura efetiva colaborante da seção "T". 
WANG \& RAMMERSTOFER (1996) apresentaram um processo empregando o Método de Faixas Finitas para a previsão da largura colaborante em placas enrijecidas sujeitas à flexão, onde interpolaram o comportamento da estrutura na direção longitudinal por funções harmônicas e na direção transversal por funções polinomiais, assumindo na resolução a Teoria Clássica das Placas. Encontraram resultados satisfatórios com a teoria proposta. Afirmaram que, para carregamento concentrado, a idealização das nervuras por um modelo de viga resulta em erros relativamente grandes, sendo necessário que se aplique na análise da placa enrijecida submetida a esse carregamento um modelo de placa bidimensional para o enrijecedor.

A largura colaborante da mesa pode ser determinada também seguindo as normas técnicas brasileiras, com a nomenclatura de acordo com a Figura 2.6 sendo, sem dúvida, o método mais utilizado nos escritórios brasileiros de cálculo estrutural:

a) segundo a NB1/1978, que pede:

$\mathrm{b}_{1} \leq\left\{\begin{array}{l}0,10 \cdot \mathrm{a} \\ 8 . \mathrm{h}_{\mathrm{f}} \\ 0,5 \cdot \mathrm{b}_{2}\end{array}\right.$

$b_{f}=2 \cdot b_{1}+b_{w}$

onde:

$\mathrm{a}=1$ para tramo simplesmente apoiado;

$\mathrm{a}=0,75.1$ para tramo com momento fletor numa só extremidade;

$\mathrm{a}=0,60.1$ para tramo com momento nas duas extremidades;

$\mathrm{a}=2.1$ para tramo em balanço;

1: comprimento do tramo;

$\mathrm{b}_{2}$ : distância livre entre as nervuras;

$\mathrm{b}_{1}$ : aba da seção "T".

b) segundo o projeto de revisão da NBR6118/2000, que pede:

$\mathrm{b}_{1} \leq\left\{\begin{array}{l}0,10 \cdot \mathrm{a} \\ 0,5 \cdot \mathrm{b}_{2}\end{array}\right.$

$b_{\mathrm{f}}=2 \cdot \mathrm{b}_{1}+\mathrm{b}_{\mathrm{w}} \leq 0,10 \cdot \mathrm{a}+\mathrm{b}_{\mathrm{w}}$

onde:

$\mathrm{a}=1$ para tramo simplesmente apoiado;

$\mathrm{a}=0,75.1$ para tramo com momento fletor numa só extremidade;

$\mathrm{a}=0,60.1$ para tramo com momento nas duas extremidades; 
$\mathrm{a}=2.1$ para tramo em balanço;

l: comprimento do tramo;

$\mathrm{b}_{2}$ : distância livre entre as nervuras;

$b_{1}$ : aba da seção "T".

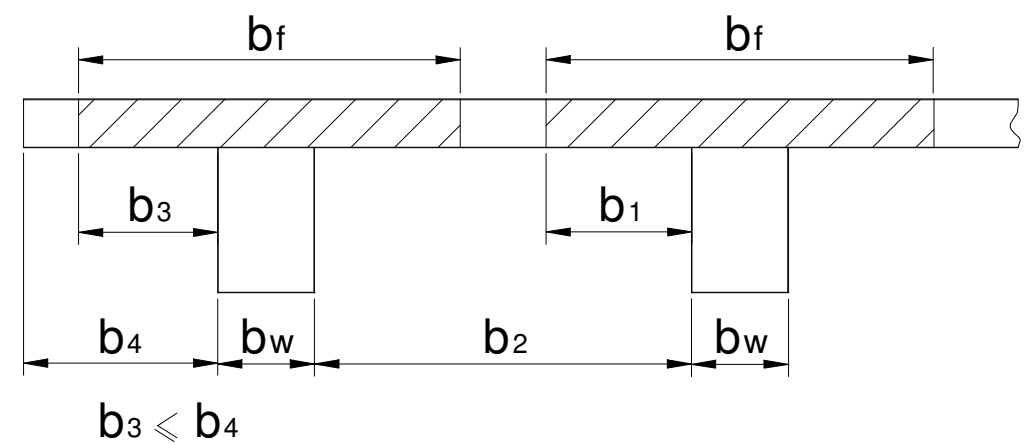

FIGURA 2.6: Nomenclaturas para a determinação da largura da mesa colaborante segundo a NBR6118

Neste trabalho serão aplicados apenas modelos utilizando as considerações do projeto de revisão da NBR6118/2000 para o cálculo da largura colaborante. Na maioria dos casos aplica-se a consideração $b_{1}=0,5 . b_{2}$.

Conforme LEONHARDT \& MÖNNIG (1978), pelo desenvolvimento das trajetórias de compressão na laje, pode-se verificar que próximo a um apoio extremo a largura colaborante da laje é menor que para o meio do vão. Assim, a mesma depende do afastamento do apoio. Contudo, para as experimentações numéricas deste trabalho será considerada uma largura colaborante única para toda a extensão da nervura. O projeto de revisão da NBR6118/2000 permite o cálculo de uma largura colaborante única para todas as seções de uma viga contínua desde que ela seja calculada a partir do trecho de momentos positivos onde resulte mínima.

Logo, tendo a largura colaborante $b_{f}$ pelo processo citado, o momento de inércia da seção integral em relação ao centro de gravidade da peça pode ser determinado dividindo-se a seção transversal em retângulos.

Dessa forma, separando a mesa de concreto da nervura a fim de ter-se duas seções retangulares conforme a Figura 2.7, tem-se: 


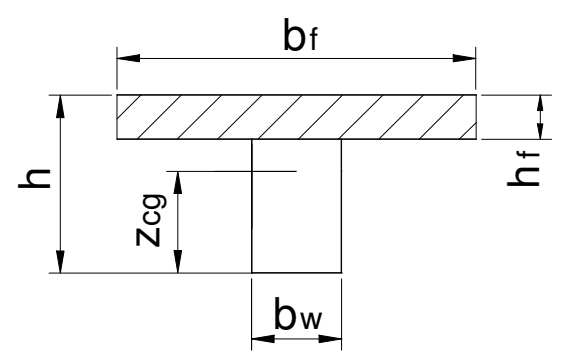

FIGURA 2.7: Divisão da seção transversal “T”' em seções retangulares

$$
I_{y}=\frac{b_{f} \cdot h_{f}^{3}}{12}+b_{f} \cdot h_{f} \cdot\left(h-h_{f}-z_{c g}+\frac{h_{f}}{2}\right)^{2}+\frac{b_{w} \cdot\left(h-h_{f}\right)^{3}}{12}+b_{w} \cdot\left(h-h_{f}\right) \cdot\left(z_{c g}-\frac{h-h_{f}}{2}\right)^{2}
$$

onde:

$\mathrm{I}_{\mathrm{y}}=$ momento de inércia à flexão da seção transversal "T";

$\mathrm{z}_{\mathrm{cg}}=$ ordenada do centróide da seção 'T", medido a partir da face inferior da

nervura, dada por:

$$
\mathrm{z}_{\mathrm{cg}}=\frac{\frac{\mathrm{b}_{\mathrm{w}} \cdot\left(\mathrm{h}-\mathrm{h}_{\mathrm{f}}\right)^{2}}{2}+\left(\frac{\mathrm{h}_{\mathrm{f}}}{2}+\mathrm{h}-\mathrm{h}_{\mathrm{f}}\right) \mathrm{b}_{\mathrm{f}} \cdot \mathrm{h}_{\mathrm{f}}}{\mathrm{b}_{\mathrm{f}} \cdot \mathrm{h}_{\mathrm{f}}+\mathrm{b}_{\mathrm{w}} \cdot\left(\mathrm{h}-\mathrm{h}_{\mathrm{f}}\right)}
$$

Agora, tendo o momento de inércia, pode-se calcular a espessura equivalente da laje e, com ela, os esforços e deslocamentos por processo simplificado.

\subsubsection{Os parâmetros elásticos do concreto na Teoria da Placa Ortótropa Equivalente}

\section{a) Módulo de deformação longitudinal do concreto}

Conforme a norma NB1/1978, tem-se que as análises elásticas devem ser feitas utilizando-se:

$\mathrm{E}_{\mathrm{cs}}=0,9 . \mathrm{E}_{\mathrm{c}}[\mathrm{MPa}]$

sendo:

$\mathrm{E}_{\mathrm{c}}=6600 \cdot\left(\mathrm{f}_{\mathrm{ck}}+3,5\right)^{1 / 2}[\mathrm{MPa}]$

$\mathrm{E}_{\mathrm{cs}}$ : módulo de elasticidade secante do concreto;

$\mathrm{E}_{\mathrm{c}}$ : módulo de elasticidade tangente do concreto;

$\mathrm{f}_{\mathrm{ck}}$ : resistência característica do concreto à compressão. 
Segundo o projeto de revisão da NBR6118/2000 o módulo de elasticidade a ser utilizado nas análises elásticas de projeto, especialmente para a determinação de esforços solicitantes e verificação de estados limites de serviço, deve ser o módulo secante, dado por:

$\mathrm{E}_{\mathrm{cs}}=0,85 . \mathrm{E}_{\mathrm{c}} \quad[\mathrm{MPa}]$

sendo:

$\mathrm{E}_{\mathrm{c}}=5600 .\left(\mathrm{f}_{\mathrm{ck}}\right)^{1 / 2} \quad[\mathrm{MPa}]$

$\mathrm{E}_{\mathrm{cs}}$ : módulo de elasticidade secante do concreto;

$\mathrm{E}_{\mathrm{c}}$ : módulo de elasticidade tangente do concreto;

$\mathrm{f}_{\mathrm{ck}}$ : resistência característica do concreto à compressão.

A consideração de apenas $85 \%$ do módulo de elasticidade tangente do concreto é uma forma de compensar os efeitos da deformação lenta nas peças de concreto.

Assim, neste trabalho será aplicado o módulo de elasticidade secante proposto pelo projeto de revisão da NBR6118/2000, sem reduções, quando da análise das lajes nervuradas pela Teoria da Placa Ortótropa Equivalente nos modelos sem redução da espessura da laje maciça equivalente e naquele com as reduções propostas por ABDULWAHAB \& KHALIL (2000).

Estes pesquisadores apresentaram processo alternativo na determinação da rigidez da laje sólida equivalente e que envolve com mais precisão o comportamento do concreto armado e de seus estados elástico não-fissurado (estádio I) e elástico fissurado (estádio II), aplicando-se à laje nervurada um módulo de elasticidade longitudinal chamado de "módulo efetivo". O processo e suas formulações são apresentados abaixo, contudo não foram utilizados neste trabalho devido à necessidade da verificação da linha neutra em cada nervura em um processamento inicial, bem como o cálculo das áreas de armadura durante a análise, o que foge dos objetivos do trabalho.

O processo criado baseia-se no conceito de "disco elementar" inicialmente proposto para placas perfuradas. Para placas e lajes com disposição quadrada de buracos sujeitas a um uniforme campo de tensão assumiram que uma distorção uniforme ocorria e, dessa forma, apenas uma única célula (ou buraco) precisava ser considerada na formulação que relacionava o módulo de elasticidade do concreto e o respectivo módulo efetivo do concreto. Comparando o comportamento de um disco elementar com um disco sem buraco, chegaram ao módulo de elasticidade efetivo, $\mathrm{E}_{\mathrm{e}}$, dado pela expressão:

$$
\mathrm{R}=\frac{\mathrm{E}_{\mathrm{e}}}{\mathrm{E}_{\mathrm{cs}}}=\frac{(1-v) \cdot(1-\nabla)}{(1+v)-v \cdot(1-\nabla)}
$$

onde, de acordo com a Figura 2.8, tem-se: 


$$
\nabla=0,785 .\left(\frac{\mathrm{a}_{1}-\mathrm{b}_{\mathrm{w}}}{\mathrm{a}_{1}}\right)
$$

Assumiram então que a placa nervurada podia ser considerada formada por uma série de discos elementares conectados, cada disco tendo a forma de uma placa circular com um buraco no centro, de acordo com a Figura 2.8.

A solução para a laje nervurada foi obtida pelos autores para os campos elástico não-fissurado do concreto (estádio I) e elástico fissurado (estádio II), demonstrados na Figura 2.9. A presença de armadura no concreto foi considerada pelos autores na formulação, já que contribuem no enrijecimento da laje.

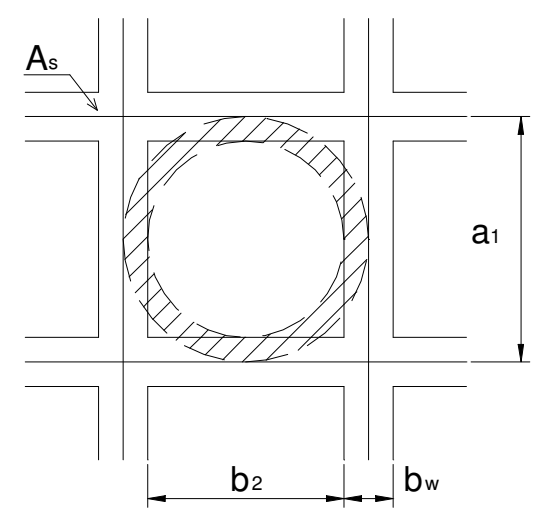

FIGURA 2.8: Célula quadrada da laje nervurada e Disco Elementar Equivalente

[ABDUL-WAHAB \& KHALIL (2000)]
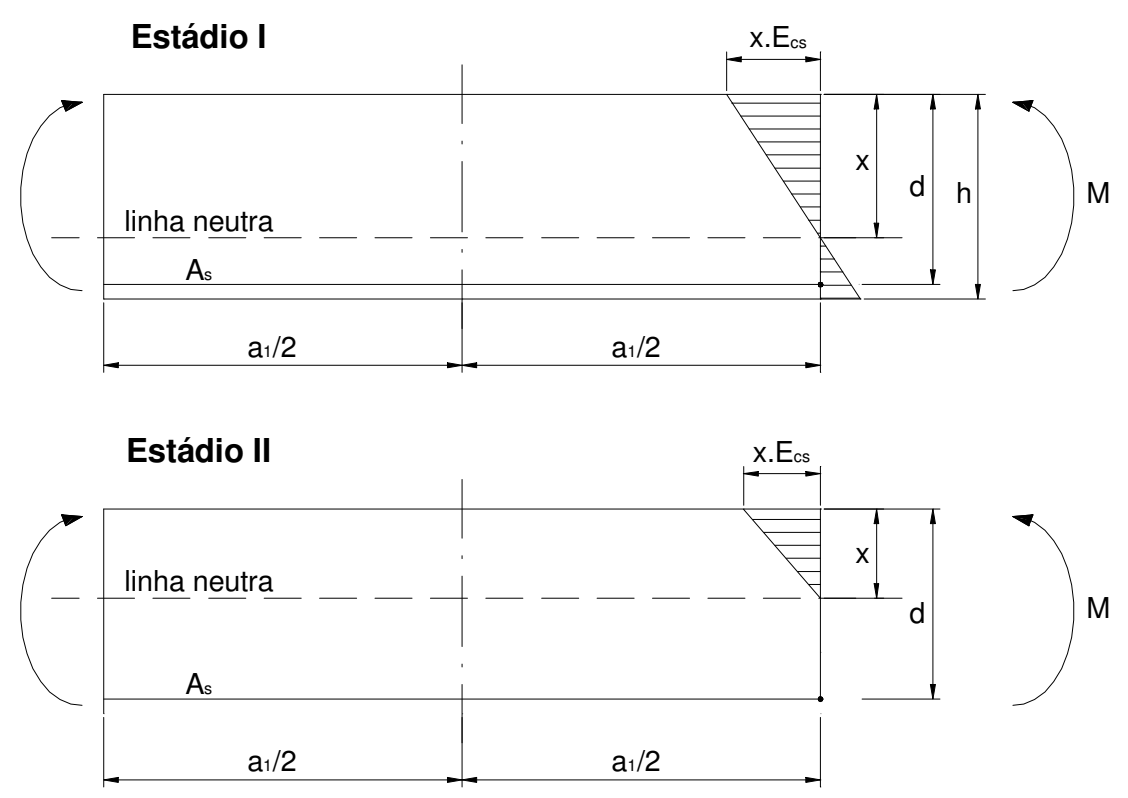

FIGURA 2.9: Discos Elementares Equivalentes submetidos à flexão nos estádios I e II

[ABDUL-WAHAB \& KHALIL (2000)] 
As formulações para cada estádio, determinadas pelos autores do artigo, são apresentadas abaixo.

\section{- Campo elástico não-fissurado do concreto}

Para um disco elementar de concreto armado submetido a um momento fletor uniforme radial no campo elástico não-fissurado (ou estádio I), de acordo com a Figura 2.9, assumiram que ocorre uma distorção uniforme. A altura da linha neutra " $\mathrm{x}$ " $\mathrm{n}$ a seção transformada é dada por:

$$
\mathrm{x}=\frac{\mathrm{h}^{2}+\mathrm{K}}{2 \cdot \mathrm{h}+\mathrm{K}}
$$

onde:

$$
\mathrm{K}=\frac{2 \cdot \mathrm{A}_{\mathrm{s}} \cdot \mathrm{m} \cdot(1-v)}{\mathrm{a}_{1} \cdot \mathrm{R}}
$$

sendo:

$\mathrm{A}_{\mathrm{s}}=$ área da armadura de tração;

$\mathrm{m}=$ coeficiente modular $=\mathrm{E}_{\mathrm{s}} / \mathrm{E}_{\mathrm{cs}}$;

$\mathrm{R}=\mathrm{E}_{\mathrm{e}} / \mathrm{E}_{\mathrm{cs}}$

$\mathrm{E}_{\mathrm{e}}=$ módulo de elasticidade efetivo do concreto.

Das considerações das forças internas, calcula-se o braço de alavanca do momento, $1_{\mathrm{a}}$, dado por:

$$
1_{a}=\frac{2 \cdot(h-x)^{3}+3 \cdot K \cdot(d-x)^{2}}{3 \cdot(h-x)^{2}+3 \cdot K \cdot(d-x)}+\frac{2}{3} \cdot x
$$

$\mathrm{O}$ módulo de elasticidade efetivo ' $\mathrm{E}_{\text {et }}$ " é obtido através do equacionamento da relação entre a rotação do contorno externo do disco elementar de concreto armado com aquela de um disco sólido homogêneo com a mesma espessura h. Assim, tem-se:

$$
\frac{\mathrm{E}_{\mathrm{et}}}{\mathrm{E}_{\mathrm{e}}}=\frac{6 \cdot \mathrm{x}^{2} \cdot \mathrm{l}_{\mathrm{a}}}{\mathrm{h}^{3}}
$$

onde:

$\mathrm{E}_{\mathrm{e}}=\mathrm{R} \cdot \mathrm{E}_{\mathrm{cs}}$

\section{- Campo elástico fissurado do concreto}

Após o aparecimento da primeira fissura assumiram que a resistência do concreto submetido à tração podia ser negligenciado, conforme Figura 2.9. A altura da linha neutra é determinada por:

$$
\mathrm{x}=\frac{1}{2} \cdot[-\mathrm{K}+\sqrt{\mathrm{K} \cdot(\mathrm{K}+4 . \mathrm{d})}]
$$


Como antes, através do equacionamento da relação entre a rotação do contorno externo para um disco sólido equivalente com aquela obtida pelo disco elementar de concreto armado, o módulo de elasticidade efetivo ' $E_{\text {et }}$ "para uma laje maciça de concreto armado no campo elástico fissurado (estádio II) é dado por:

$$
\frac{E_{e t}}{E_{e}}=\frac{6 \cdot x^{2} \cdot\left(d-\frac{x}{3}\right)}{12 \cdot\left(1-v^{2}\right)}
$$

onde:

$\mathrm{E}_{\mathrm{e}}=$ R. $\mathrm{E}_{\mathrm{cs}}$

\section{b) Módulo de deformação transversal do concreto}

De acordo com a NB1/1978, tem-se que o módulo de deformação transversal do concreto é obtido admitindo-se o coeficiente de Poisson $v=0,20$, resultando:

$\mathrm{G}_{\mathrm{c}}=0,4 \cdot \mathrm{E}_{\mathrm{cs}}=2376 \cdot\left(\mathrm{f}_{\mathrm{ck}}+3,5\right)^{1 / 2}[\mathrm{MPa}]$

onde:

$\mathrm{G}_{\mathrm{c}}$ : módulo de elasticidade transversal do concreto.

No projeto de revisão da NBR 6118/2000 tem-se que o módulo de deformação transversal do concreto também é calculado adotando $v=0,20$, resultando:

$\mathrm{G}_{\mathrm{c}}=0,4 \cdot \mathrm{E}_{\mathrm{cs}}=1904 .\left(\mathrm{f}_{\mathrm{ck}}\right)^{1 / 2}[\mathrm{MPa}]$

onde:

$\mathrm{G}_{\mathrm{c}}$ : módulo de elasticidade transversal do concreto.

Apesar da orientação da norma muitos autores recomendam valores menores para o módulo de deformação transversal.

LEONHARDT \& MÖNNIG (1978) sugeriram dividir o módulo de deformação transversal do concreto por 100, já que as microfissuras no concreto, que existem mesmo a peça estando no Estádio I, já reduzem a sua rigidez à torção.

TAKEYA (1985) sugeriu adotar $\mathrm{G}_{\mathrm{c}}=0,15 . \mathrm{E}_{\mathrm{cs}}$.

Propôs esta redução, porém, em modelos de grelha que simulavam lajes lisas, argumentando que essa redução em pisos de concreto armado é interessante por levar em conta a fissuração de maneira geral. Aqui essa redução será testada para verificar os efeitos no comportamento do modelo em laje maciça com espessura equivalente.

Assim, nos modelos de Teoria da Placa Ortótropa Equivalente serão aplicados o módulo de elasticidade transversal sugerido por TAKEYA (1985), nos modelos sem redução da espessura da laje equivalente. Com isso haverá um aumento nos momentos fletores atuantes na placa, e conseqüentemente uma diminuição nos momentos volventes. 
Nos modelos com espessura reduzida conforme ABDUL-WAHAB \& KHALIL (2000) será considerado o valor de $\mathrm{G}_{\mathrm{c}}$ integral.

\subsubsection{Simulação dos pilares nos modelos de Teoria da Placa Ortótropa Equivalente}

De acordo com CORRÊA (1991) a vinculação dos pilares no plano do pavimento de edifícios pode ser considerada de forma simplificada através da colocação de um nó no centro do apoio, impedindo-se aí os graus de liberdade ou então associando ao mesmo vínculos deformáveis através da consideração do pilar de forma tridimensional, processo que será utilizado nas modelagens deste trabalho, de acordo com a Figura 2.10. Os pilares, quando da análise de pavimentos intermediários, serão lançados com a altura duplicada e considerados engastados na base fornecendo, dessa forma, um adequado coeficiente de mola, explicitado posteriormente.

Na modelagem da laje nervurada pela Teoria de Placa é necessário, pelos fundamentos do Método dos Elementos Finitos, que as placas em torno do nó do pilar concorram para ele. Assim, em algumas geometrias, um ajuste por meio de elementos finitos triangulares poderá sempre ser efetuado, conforme a Figura 2.10 .

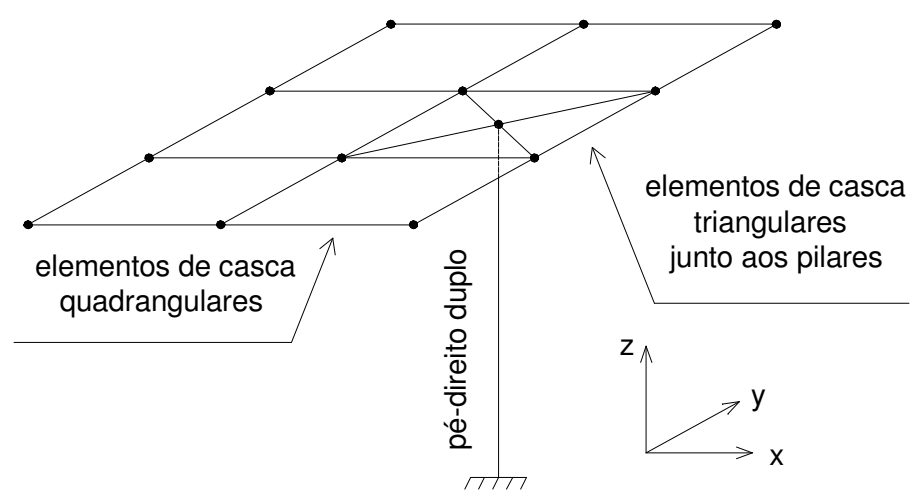

FIGURA 2.10: Ajuste dos elementos de placa junto aos pilares

Ainda de acordo com CORRÊA (1991) quando o pilar tiver grande dimensão em planta será simulado por meio de três nós: um no centro do pilar, do qual sairá a barra segundo o eixo z com a seção geométrica real do pilar e com a altura duplicada; e mais dois nós, cada um próximo às faces do pilar. Interligando os nós serão lançados 
elementos finitos de viga tridimensional, no plano $\mathrm{x}-\mathrm{y}$, de rigidez infinita, que pode ser verificado na Figura 2.11.

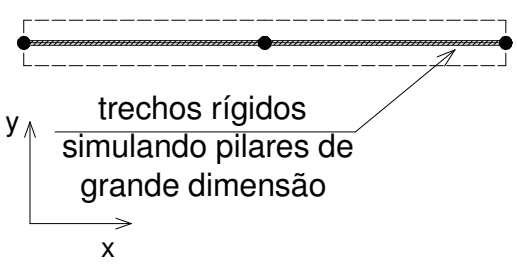

FIGURA 2.11: Trecho rígido para pilares de grande dimensão em planta

\subsubsection{Processos e métodos de cálculo aplicando a Teoria da Placa Ortótropa Equivalente}

Determinada a espessura equivalente, a laje nervurada pode ser calculada como se fosse uma placa em uma análise elástica.

A integração da equação diferencial de equilíbrio das placas delgadas apresentada anteriormente, para as lajes retangulares pode ser feita de várias formas:

a) tabelas montadas por Czerny e Bares onde utilizaram o processo de Diferenças Finitas o que, como mostrado em SILVANY (1995), no caso de placas com formas não-regulares, com aberturas e distribuição de ações complexas, não são de aplicação prática;

b) aplicação direta dos métodos numéricos como o Processo das Diferenças Finitas, Método dos Elementos Finitos ou Método dos Elementos de Contorno, utilizando softwares como auxílio.

Neste trabalho será aplicado o Método dos Elementos Finitos através do software ANSYS 5.5, onde as placas serão discretizadas por elementos de casca plana e os pilares simulados por elementos de barra tridimensionais.

Após calculados os momentos e os esforços cortantes por faixa de um metro, na laje maciça equivalente, nas duas direções, esses valores devem ser multiplicados pelo valor da largura colaborante $b_{\mathrm{f}}$, verificando-se em seguida o cisalhamento e a flexão, tanto na mesa quanto nas nervuras, ao tratar-se do dimensionamento. 


\subsection{ANÁLISE ESTRUTURAL DE LAJES NERVURADAS CONVENCIONAIS E SEM VIGAS POR ANALOGIA DE GRELHA}

A complexidade e as limitações dos métodos clássicos da elasticidade aplicados na Teoria de Placas fizeram pesquisadores buscarem outros métodos para a determinação de esforços e deslocamentos em lajes maciças.

Segunto o Código ACI-435 (1989) Marsh, em 1904, substituiu uma laje maciça uniformemente carregada por uma malha de vigas que se cruzavam. Contudo, em sua modelagem, negligenciou os momentos torçores da placa, gerando assim um erro de $25 \%$ nos momentos fletores para uma placa simplesmente apoiada.

Posteriormente a teoria foi modificada por Marcus numa tentativa de levar em conta os momentos torçores desprezados por Marsh. Dessa forma, introduziu fatores de modificação no cálculo dos momentos fletores e deslocamentos, relacionando condições de vinculação e características geométricas.

Em 1952 foi apresentado por Ewell, Okubo e Abrams um método denominado "Método de Analogia de Grelha". Nesse processo desenvolvido a influência do momento torçor pôde ser considerada de maneira direta e imediata. A placa maciça foi inicialmente dividida em faixas nas direções ortogonais escolhidas e, posteriormente, substituídas por vigas equivalentes, com as mesmas propriedades de flexão e torção. Nestas, foram calculados os esforços e deslocamentos, fazendo-se a compatibilização de momentos torçores e fletores por nós, ou pontos de cruzamento das vigas da grelha, conforme Figura 2.12 .

A placa maciça e a grelha devem ser tais que, quando submetermos as duas estruturas ao mesmo carregamento elas se deformarão de maneira idêntica, e os esforços em qualquer barra da grelha serão iguais às resultantes das tensões na seção transversal da posição da laje que a barra representa.

Indicou que o processo foi utilizado pioneiramente em computador por Lightfoot e Sawko, em 1959. A facilidade computacional do processo dá-se principalmente porque a técnica trabalha com elementos lineares, ou elementos de barra, onde a resolução da estrutura resulta em um problema simples de análise matricial: o problema de grelhas. Dessa forma, o alto grau de hiperestaticidade e deslocabilidade das grelhas não é um empecilho para a análise quando do uso de computadores.

Algumas diferenças de comportamento físico entre placas maciças e grelhas existem, contudo, e são enumeradas abaixo: 
- o equilíbrio da laje dá-se com a igualdade entre os momentos torçores atuantes nas duas direções; na grelha equivalente não há princípio físico ou matemático para que isso ocorra;

- o momento fletor da laje, em qualquer direção, depende tanto da curvatura naquela direção quanto da curvatura na direção ortogonal; no elemento de barra o momento fletor é somente proporcional à própria barra.

BARBOZA (1992) mostra, contudo, comparando-se os resultados obtidos com a analogia de grelha e com o método dos elementos finitos, que a analogia oferece resultados satisfatórios para lajes maciças. Assim, espera-se resultados ainda melhores ao analisar-se lajes nervuradas por este processo devido à maior semelhança geométrica entre ambos - estrutura real e modelo mecânico, em um modelo tridimensional.

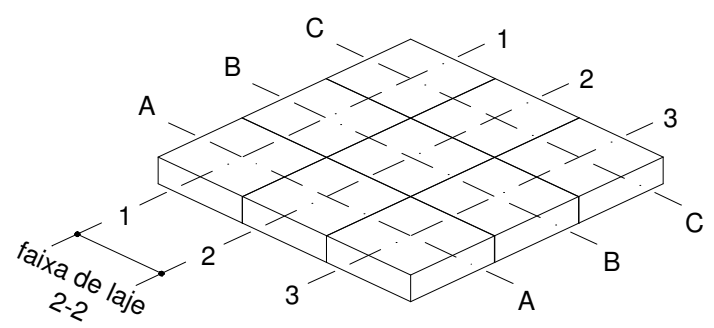

(a) divisão da placa em faixas

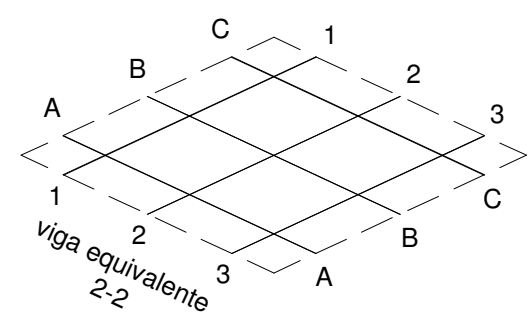

(b) substituição das faixas pelas vigas

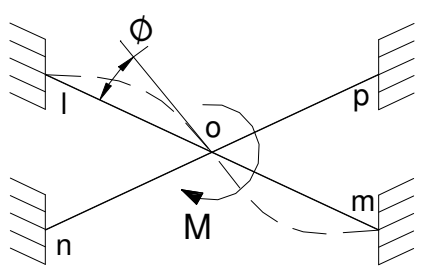

(c) deslocamento devido ao momento no plano I-o-m

FIGURA 2.12: Analogia de grelha aplicada à lajes maciças

[ACI-318-89]

Mas, de acordo com SHEIKH \& MUKHOPADHYAY (1992), a modelagem de placas enrijecidas através de sistemas de grelhas têm fracassado na evolução de uma solução genérica satisfatória. 


\subsubsection{O funcionamento estrutural das grelhas}

A grelha, quando tratada como estrutura plana, recebe ações solicitantes perpendicularmente ao seu plano. Na análise desses elementos estão envolvidos três esforços internos, de acordo com a Figura 2.13: o esforço cortante normal ao plano da grelha, o momento fletor normal ao eixo da barra e o momento torçor axial à barra. Com isso, têm-se então três deformações, conjugadas aos esforços internos.

Ao determinar-se os esforços solicitantes e deslocamentos de uma laje nervurada segundo a teoria das grelhas a estrutura como um todo deve resistir às ações, já que as vigas não são tratadas de forma independente.

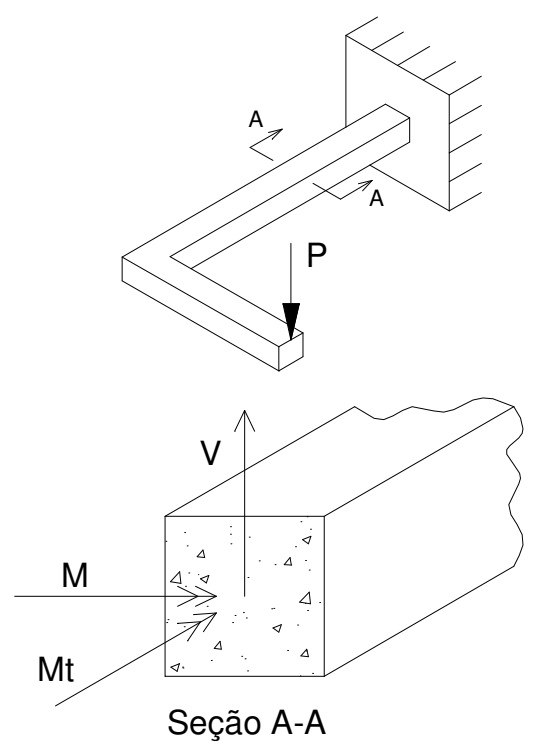

FIGURA 2.13: Esforços solicitantes na barra de uma grelha plana

Assim, para que o cálculo seja econômico, é preciso considerar que a transferência das ações ocorra no plano da estrutura o que, com eficiência, só ocorre se as nervuras tiverem rigidezes semelhantes. Dessa forma, se as nervuras de uma direção forem mais rígidas que as da outra direção elas absorverão maiores parcelas de esforços solicitantes e a transmissão dos mesmos ocorrerá apenas em uma direção, o que foge da teoria econômica das grelhas.

\subsubsection{O processo de Analogia de Grelha aplicado à lajes nervuradas}


Para a aplicação do processo às lajes nervuradas torna-se evidente que as mesmas já são um conjunto de vigas e, assim, tem-se a própria malha equivalente, onde as barras terão seção transversal "T" devido a mesa de concreto. Serão então concentradas nas vigas as rigidezes à torção e à flexão da placa.

De acordo com TANAKA \& BERCIN (1998) implicitamente considera-se a excentricidade existente entre o eixo da nervura e o plano médio da placa através das translações de eixos no cálculo das inércias das seções transversais compostas. Nesta aproximação, segundo os pesquisadores, a dificuldade está na determinação da 'largura colaborante", aquela hipotética representação da placa na viga, o mesmo problema encontrado para o cálculo da espessura da laje maciça equivalente em comportamento à uma laje nervurada demonstrado anteriormente.

Para que se tenha um modelo de grelha que expresse tanto o comportamento da estrutura (laje nervurada) quanto do material (concreto armado) algumas considerações também devem ser feitas na concepção da grelha quanto às propriedades geométricas da seção e parâmetros do concreto.

\subsubsection{As propriedades geométricas das barras da grelha}

\section{a) Momento de Inércia à flexão das barras da grelha}

Para a determinação dos esforços, considerando a seção integral de concreto em um cálculo elástico, as nervuras da laje devem ser consideradas como seções 'T", com largura colaborante da laje, e a inércia a flexão das mesmas será calculada como já demonstrado anteriormente, ou seja, neste trabalho haverá modelos utilizando as considerações do projeto de revisão da NBR6118/2000.

\section{b) Momento de Inércia à torção das barras da grelha}

As torções que ocorrem na maioria das grelhas são esforços advindos da compatibilidade de deformações haja visto que, à medida que se reduz a rigidez à torção da barra de grelha, os momentos de torção também são reduzidos até que, para um limite teórico de rigidez nula à torção, tem-se também momentos de torção nulos. Dessa forma, geralmente, nos pisos de edifícios em grelha surgem esforços de torção meramente oriundos da compatibilidade das deformações. Verifica-se também ser possível a ocorrência de uma situação em que há equilíbrio com torção nula, no caso de baixa rigidez à torção ou no caso de tolerar-se plastificações, conforme SUSSEKIND (1985). 
A norma brasileira NBR 6118/1978 permite desprezar os momentos de torção de compatibilidade para o cálculo das peças no Estado Limite Último já que aí tem-se a barra fissurada e, dessa forma, a mesma tem inércia à torção muito reduzida.

Do item 14.5.7.2 do projeto de revisão da NBR 6118/2000 vê-se que, de maneira aproximada, pode-se reduzir a rigidez à torção das vigas (exceto em peças curtas) por fissuração utilizando-se $15 \%$ da rigidez elástica.

Já SUSSEKIND (1985) recomendou considerar como inércia à torção, para elementos de concreto fissurados, $20 \%$ da inércia $I_{t}$ da seção homogênea, constituindo-se num valor tolerável para a consideração da inércia à torção de compatibilidade.

Ambas as recomendações conduzem a valores reduzidos de torção, e são satisfatórias.

SUSSEKIND (1985) e LEONHARDT \& MÖNNIG (1978) apresentaram o momento de inércia à torção da seção bruta para seções compostas por retângulos, de acordo com a teoria da elasticidade, para elementos retangulares onde $\mathrm{h}>\mathrm{b}$, calculado pela seguinte expressão:

$$
\mathrm{I}_{\mathrm{t}}=\frac{1}{3} \cdot \sum_{\mathrm{i}=1}^{\mathrm{n}}\left(\mathrm{b}_{\mathrm{i}}{ }^{3} \cdot \mathrm{h}_{\mathrm{i}}\right)
$$

onde:

$b_{i}$ : menor dimensão da porção i da seção transversal;

$\mathrm{h}_{\mathrm{i}}$ : maior dimensão da porção i da seção transversal.

LEONHARDT \& MÖNNIG (1978) apresentaram também uma tabela com valores mais específicos de inércia à torção para seções retangulares de acordo com a relação entre as dimensões da seção transversal.

Neste trabalho a inércia à torção das peças serão calculadas de acordo com LEONHARDT \& MÖNNIG (1978), na Eq. 2.38, contudo utilizando apenas 15\% dessa inércia bruta, de acordo com o projeto de revisão da NBR6118/2000, supondo-se a fissuração das peças (mesmo na análise elástica, já que este é um recurso satisfatório para simular o comportamento do material concreto armado também em serviço).

\subsubsection{Os parâmetros elásticos do concreto armado na Analogia de Grelha}

\section{a) Módulo de deformação longitudinal do concreto}

Segundo o projeto de revisão da NBR 6118/2000: 
$\mathrm{E}_{\mathrm{cs}}=0,85 \cdot \mathrm{E}_{\mathrm{c}} \quad[\mathrm{MPa}]$

sendo:

$\mathrm{E}_{\mathrm{c}}=5600 .\left(\mathrm{f}_{\mathrm{ck}}\right)^{1 / 2} \quad[\mathrm{MPa}]$

$\mathrm{E}_{\mathrm{cs}}$ : módulo de elasticidade secante do concreto;

$\mathrm{E}_{\mathrm{c}}$ : módulo de elasticidade tangente do concreto;

$\mathrm{f}_{\mathrm{ck}}$ : resistência característica do concreto à compressão.

$\mathrm{O}$ valor do módulo de elasticidade secante do concreto pode ainda ser reduzido para se considerar os efeitos da fissuração, como foi aplicado em BOCCHI JÚNIOR (1995), que considerou apenas 70\% do valor do módulo em suas análises.

TAKEYA (1985) indicou que a redução do módulo de elasticidade é interessante, porém complexo de quantificar, já que parte da laje pode trabalhar no Estádio I e parte no Estádio II, além de ocorrer o efeito da retração e da deformação lenta do concreto.

Neste trabalho, nos modelos de Analogia de Grelha, serão aplicados o módulo de elasticidade secante proposto pelo projeto de revisão da NBR6118/2000, sem reduções.

\section{b) Módulo de deformação transversal do concreto}

De acordo com projeto de revisão da NBR6118/2000:

$\mathrm{G}_{\mathrm{c}}=0,4 \cdot \mathrm{E}_{\mathrm{cs}}=1904 .\left(\mathrm{f}_{\mathrm{ck}}\right)^{1 / 2} \quad[\mathrm{MPa}]$

onde:

$\mathrm{G}_{\mathrm{c}}$ : módulo de elasticidade transversal do concreto.

Apesar da orientação da norma muitos autores recomendam valores menores para o módulo de deformação transversal.

TAKEYA (1985) sugeriu adotar $\mathrm{G}_{\mathrm{c}}=0,15 . \mathrm{E}_{\mathrm{cs}}$.

Já BOCCHI JÚNIOR (1995) indicou que, já levando em conta a diminuição da inércia à torção da peça, a diminuição do módulo de deformação transversal devido a fissuração não torna-se necessário.

Contudo, nos modelos de Analogia de Grelha deste trabalho serão aplicados o módulo de elasticidade transversal sugerido por TAKEYA (1985), para simular melhor o material concreto armado, mesmo nas análises elásticas. 


\subsubsection{Carregamento da grelha}

Todo o carregamento da grelha pode ser aplicado diretamente nos nós da estrutura através do processo de área de influência, conforme a Figura 2.14:

$\mathrm{Q}_{\mathrm{i}}=(\mathrm{g}+\mathrm{q}) \cdot \mathrm{A}_{\mathrm{i}}$

sendo:

$\mathrm{Q}_{\mathrm{i}}$ : carga nodal aplicada à grelha no nó;

$(\mathrm{g}+\mathrm{q})$ : carga total atuante na laje;

$\mathrm{A}_{\mathrm{i}}$ : área de influência do nó i.

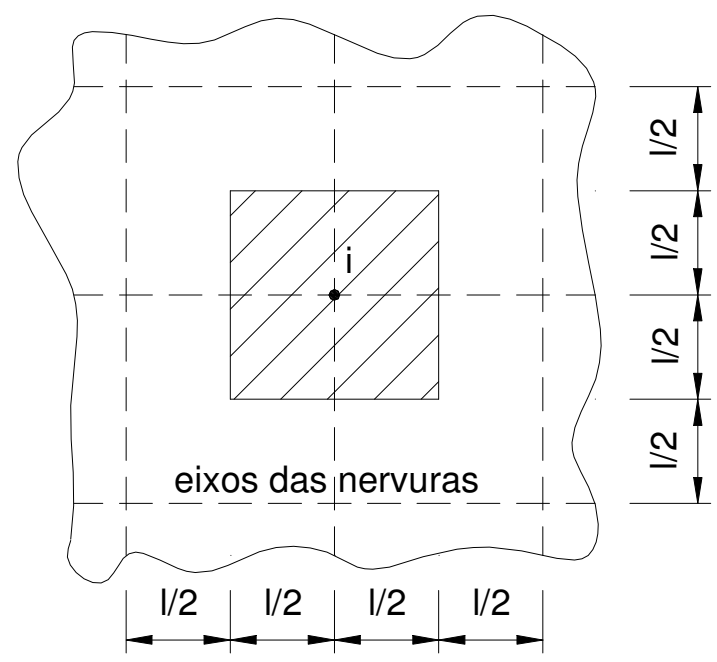

FIGURA 2.14: Área de influência para o cálculo de carga nodal em grelhas

Porém, é interessante considerar todas as ações atuantes na laje nervurada como uniformemente distribuídas ao longo das barras da grelha, conforme Figura 2.15, o que representa melhor a forma dos diagramas de momentos fletores das nervuras. 


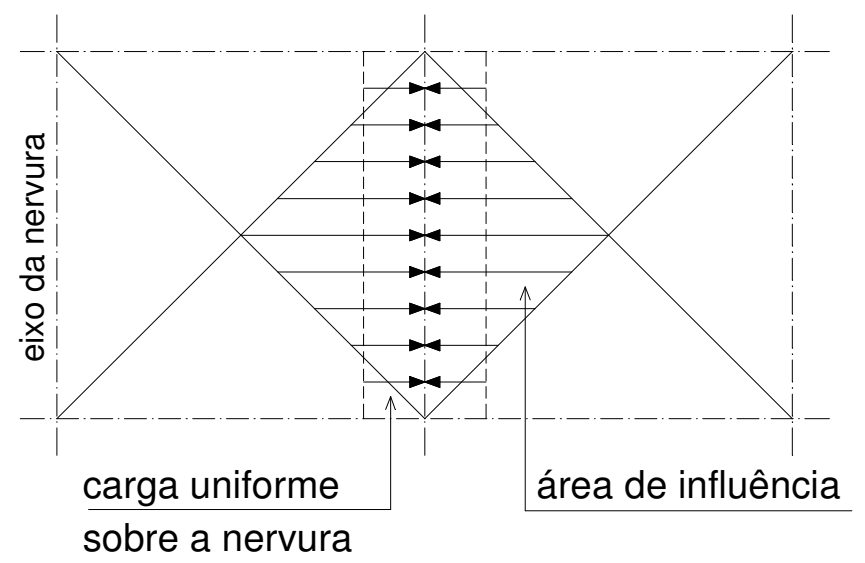

FIGURA 2.15: Carga uniformemente distribuída sobre as nervuras

Assim, pode-se imaginar a laje nervurada como constituída de várias lajes menores apoiadas nas nervuras, onde as ações serão distribuídas como reações de apoio às nervuras.

Neste trabalho as cargas distribuídas uniformemente sobre a laje nervurada, nos modelos de grelha, serão lançadas uniformemente distribuídas ao longo das nervuras.

\subsubsection{Consideração da vinculação dos pilares nos modelos de Analogia de Grelha}

Quando um modelo de grelha plana é processado por meio de softwares apropriados para tal sistema é possível considerar a influência das rigidezes dos pilares por meio da introdução de constantes de mola aos nós dos apoios da grelha equivalente, conforme Figura 2.16.

\section{a) rigidez do pilar às deformações axiais:}

A grandeza da deformação na direção axial do pilar é pequena e, conseqüentemente, pouco significativa, podendo ser desprezada nas análises do pavimento. Assim, pode ser considerada uma área elevada de seção transversal nos pilares nas análises. 


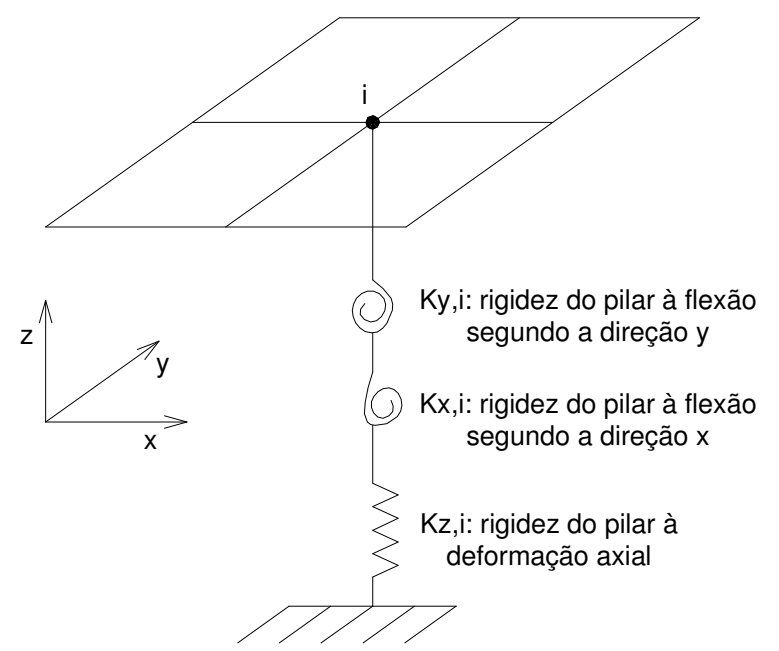

FIGURA 2.16: Representação das constantes de mola aplicadas ao apoio de uma grelha

\section{b) rigidez do pilar à flexão:}

As rigidezes do pilar devem ser avaliadas tanto na direção x quanto na direção y, e são incorporadas no nó contido na barra da grelha, na direção correspondente, respectivamente obtendo-se $\mathrm{K}_{\mathrm{x}}$ e $\mathrm{K}_{\mathrm{y}}$, quando o software para análise de grelha permitir a introdução automática das constantes de mola no nó vinculado.

Neste trabalho, quando da consideração dos pilares, os mesmos serão lançados de forma mais realista, associando-se à grelha barras referentes aos pilares formando um conjunto tridimensional, já que o sistema será analisado através de barras tridimensionais no ANSYS 5.5. Os pilares serão lançados com a altura duplicada e considerados engastados na base, de acordo com a Figura 2.17 fornecendo, dessa forma, um adequado coeficiente de mola de valor:

$$
\mathrm{K}=\left(2 . \mathrm{E}_{\mathrm{cs}} \cdot \mathrm{I}\right) / \mathrm{l}
$$

sendo:

$\mathrm{K}$ : constante de mola do pilar;

$\mathrm{E}_{\mathrm{cs}}$ : módulo de elasticidade secante longitudinal do concreto;

I: momento de inércia à flexão da seção no eixo considerado;

1: altura do pé-direito. 


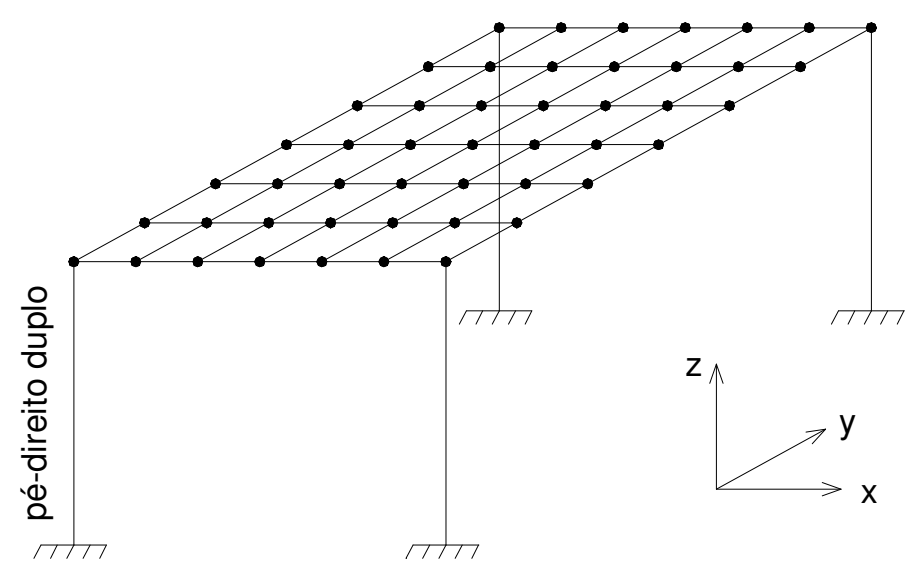

FIGURA 2.17: Consideração dos pilares nos modelos de grelha deste trabalho

De acordo com CORRÊA (1991) os pilares de grande dimensão serão modelados utilizando-se três nós no plano XY do pavimento em grelha, criando-se dessa forma dois trechos rígidos no mesmo plano (ou barras de alta inércia à flexão) modelados pelo elemento de barra tridimensional disponível no ANSYS 5.5. Ligando o nó central ao nó da base do pilar será utilizado novamente o elemento de barra tridimensional, contudo tendo as características reais do pilar, ao longo do seu eixo, de acordo com a Figura 2.18.

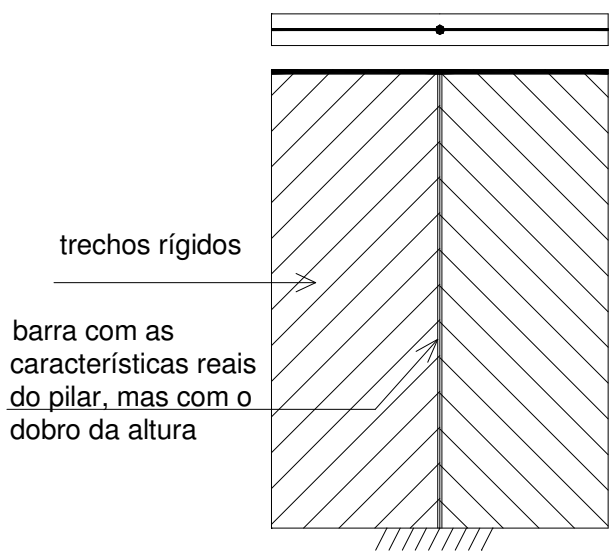

FIGURA 2.18: Características da modelagem dos pilares de grande dimensão

\subsubsection{Processos e métodos de análise de grelhas}

Tendo as características geométricas e parâmetros do concreto a análise da grelha plana, sem os pilares no modelo, pode ser feita por diversos métodos e processos. 
Um dos processos mais utilizados é a Análise Matricial, que pode ser encontrada em diversos programas computacionais de grelha plana.

Neste trabalho, contudo, será aplicado o Método dos Elementos Finitos, pelo ANSYS 5.5, onde as nervuras serão discretizadas por elementos finitos de viga tridimensional, assim como os pilares. Na verdade será um modelo onde a laje nervurada é simulada por barras, como uma grelha, mas em conjunto com os pilares, o que confere ao modelo características de pórtico tridimensional.

\subsection{ANÁLISE ESTRUTURAL DE LAJES NERVURADAS SEM VIGAS POR MÉTODOS ELÁSTICOS DE PÓRTICOS VIRTUAIS}

Além dos sistemas convencionais de piso de lajes nervuradas, ou seja, aqueles com a existência de vigas mais rígidas no conjunto, tem-se também sistema especial, sem vigas.

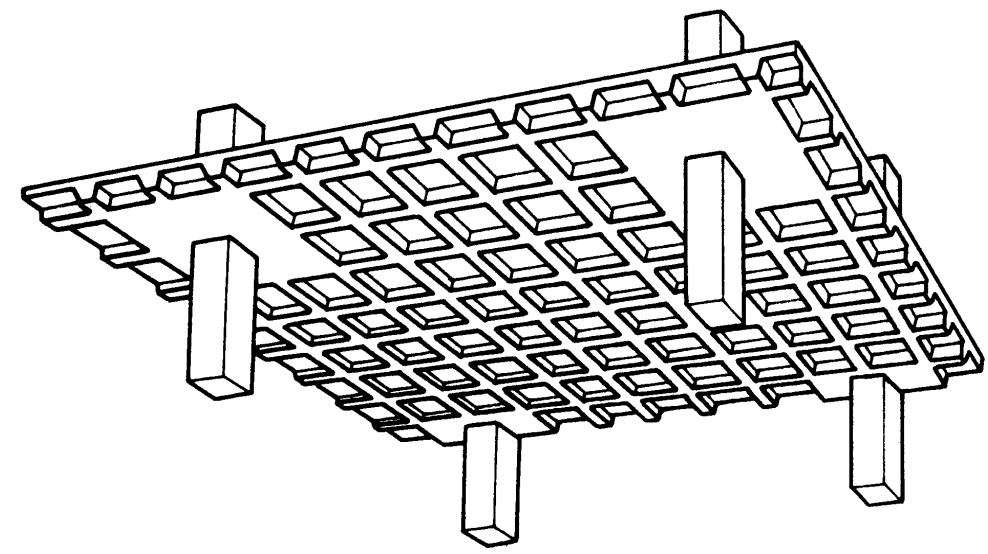

FIGURA 2.19: Laje nervurada sem vigas

[NAWY (1995)]

Em algumas lajes desse sistema podem ser colocadas vigas de borda com a função de diminuir os momentos fletores nas lajes e deslocamentos, constituindo-se num apoio de contorno, absorvendo também a torção e a punção alí geradas. Outra vantagem da utilização das vigas nas bordas do pavimento é a formação de pórticos para resistir às ações laterais, quando conectadas a pilares. 
Esse tipo de sistema estrutural apresenta grande versatilidade quanto ao projeto arquitetônico, já que a inexistência de vigas permite uma maior liberdade na disposição de cômodos no pavimento.

Como nas lajes sem vigas tem-se o apoio diretamente no pilar é necessário que neste sistema com pavimento em laje nervurada a região em torno dos pilares seja maciça, tendo capitéis (engrossamento dos pilares) ou ábacos (engrossamento de lajes maciças ou, neste caso, lajes maciças de espessura constante embutidas na laje nervurada). Dessa forma, as regiões maciças terão dupla finalidade: absorver os momentos negativos que surgem no entorno dos pilares internos e resistir ao efeito de puncionamento que ocorre nessa regiões, junto aos pilares.

A punção, que deve ser verificada nas lajes lisas nervuradas, é o fenômeno de perfuração devido às altas tensões de cisalhamento, provocadas por forças concentradas ou agindo em áreas pequenas.

A verificação da punção, em várias normas, é baseada no método da superfície de controle, ou seja, consiste no cálculo de uma tensão nominal de cisalhamento na superfície a verificar. Tendo esse valor e o da resistência do concreto pode-se fazer a verificação. Este é, por exemplo, o processo utilizado no projeto de revisão da NBR6118/2000 que considera como superfícies críticas as seguintes, de acordo com a Figura 2.20:

a) perímetro $C$, do pilar ou da carga concentrada, onde verifica-se a tensão de compressão diagonal do concreto;

b) perímetro C', afastado 2.d do pilar ou da carga concentrada, sendo d a altura útil da laje na região considerada, verificando-se a capacidade de ligação a punção associada à resistência à tração diagonal;

c) perímetro C", utilizado quando é necessário colocar armadura transversal, afastado 2.d da última armadura transversal, sendo d a altura útil da laje no trecho considerado. 


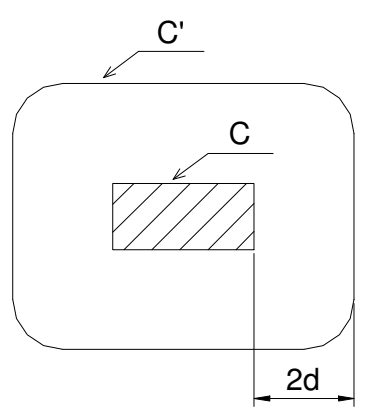

(a) maciço sem armadura transversal

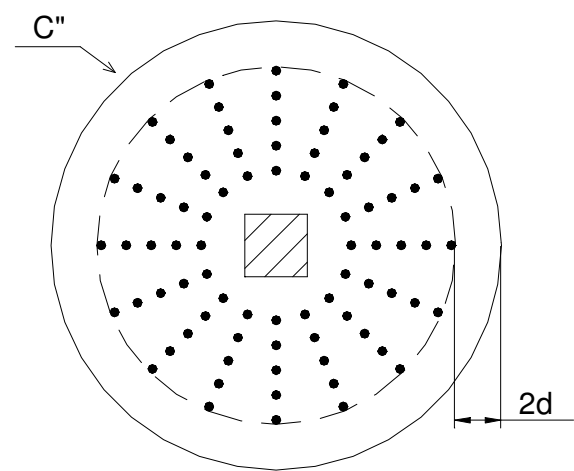

(b) maciço com armadura transversal

FIGURA 2.20: Perímetros de controle da punção segundo o projeto de revisão da

NBR6118/2000

Como pode-se observar, caso o concreto não resista ao efeito de puncionamento torna-se necessário distribuir armaduras de punção radialmente ao pilar, podendo as barras estarem inclinadas para atravessar a zona tracionada ortogonalmente em relação às tensões de tração.

A ruptura por puncionamento dá-se segundo uma superfície troncopiramoidal com inclinação de 30 a 35 graus, sendo brusca e sem aviso prévio, conforme a Figura 2.21:

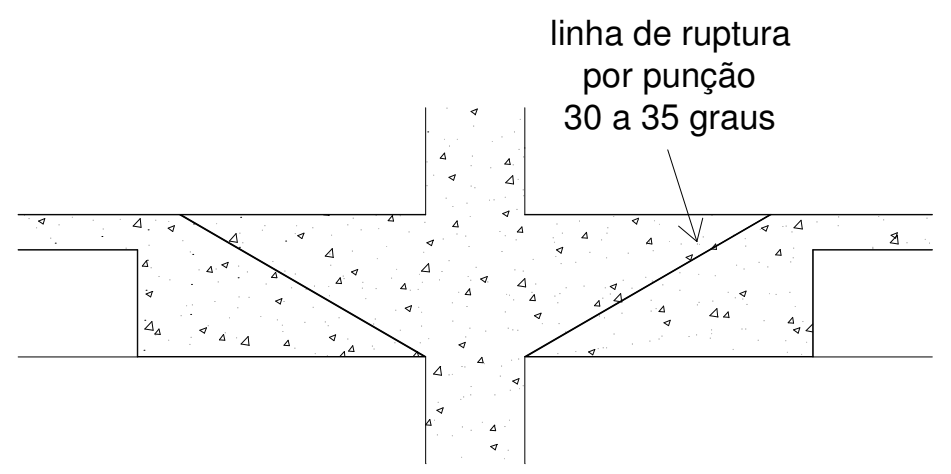

FIGURA 2.21: Ruptura por Punção

Verifica-se, assim, que a região maciça em torno dos pilares, nos sistemas sem vigas, deve abranger em planta a região de altas concentrações de força cisalhante.

TESORO (1991) afirmou que os pavimentos em lajes nervuradas sem vigas devem ser analisados da maneira mais realista possível em conjunto com os pilares. Assim, 
complementou que pouco serve empregar métodos que resolvem perfeitamente a laje se estes não contemplarem adequadamente o cálculo dos pilares.

Quanto aos processos de determinação dos esforços solicitantes e deslocamentos o projeto de revisão da NBR6118/2000 afirma que o cálculo de lajes lisas (ou lajes sem vigas apoiadas diretamente sobre pilares) deve ser realizado mediante emprego de procedimento numérico adequado, citando: método das diferenças finitas, método dos elementos finitos ou método dos elementos de contorno. Como mostrado em ALBUQUERQUE (1998), a existência de softwares que possibilitam a análise estrutural pelos métodos dos elementos finitos e a sua confiabilidade fizeram com que o mesmo fosse o mais difundido para o cálculo das lajes lisas.

Em casos particulares, quando os pilares estiverem dispostos em filas ortogonais de maneira regular e com vãos pouco diferentes o projeto de revisão da NBR6118/2000 permite o cálculo dos esforços por processo elástico aproximado que consiste em adotar, em cada direção ortogonal, pórticos múltiplos num processo de análise bidimensional. Pede, porém, que se assim for procedida a análise sejam então estudadas cuidadosamente as ligações das lajes com os pilares, com especial atenção nos casos de assimetria de forma e de carregamento, devendo ser obrigatória a consideração dos momentos de ligação entre laje e pilares extremos.

Um método mais refinado de cálculo do que o dos Pórticos Múltiplos é apresentado pelo código ACI-318 (1989) e denominado de Método dos Pórticos Equivalentes, que também pede apoios praticamente alinhados.

Para a aplicação de todos os métodos de pórtico há um consenso nas normas técnicas que a tolerância de desvio para a consideração de pilares alinhados é de no máximo $10 \%$ do valor do vão.

Contudo, de acordo com TESORO (1991), os métodos que idealizam pórticos virtuais no pavimento, mais precisamente o Método dos Pórticos Equivalentes, com pequenos ajustes, podem ser aplicados em estruturas com pilares desalinhados em até $30 \%$ do vão, de acordo com a Figura 2.22.

Com essa consideração, uma vez determinados os esforços trabalhando com o vão oblíquo, a análise da armadura negativa sobre os apoios é a mesma daquela para pórticos perfeitamente alinhados. O problema é a determinação da armadura positiva das nervuras já que não se distingue com precisão onde localizam-se as faixas de pórtico classificadas como faixas sobre os apoios (que contém os pilares) e faixas centrais. Este problema, segundo o autor, pode ser contornado pela distribuição uniforme dos momentos positivos nas nervuras, sem distinção de faixas. 


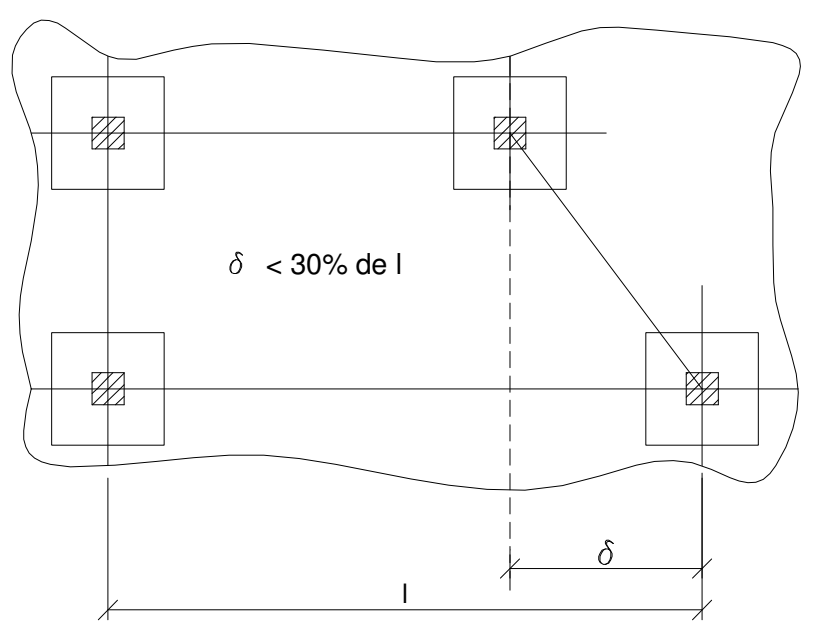

FIGURA 2.22: Desvio máximo de alinhamento entre os pilares para a aplicação do Método dos Pórticos Equivalentes

[TESORO (1991)]

Além disso, TESORO (1991) indicou que havendo muita disparidade entre os valores dos vãos de pórticos, de acordo com a Figura 2.23, idealiza-se um apoio fictício que permite a diminuição real da flexão do vão maior do pórtico.

Nessas condições determina-se uma armadura de flexão negativa a partir de um momento em torno de $\mathrm{Pl}^{2} / 30$ a $\mathrm{Pl}^{2} / 40$, ou simplesmente colocando uma armadura negativa semelhante a obtida para as nervuras das faixas centrais dos pórticos adjacentes.

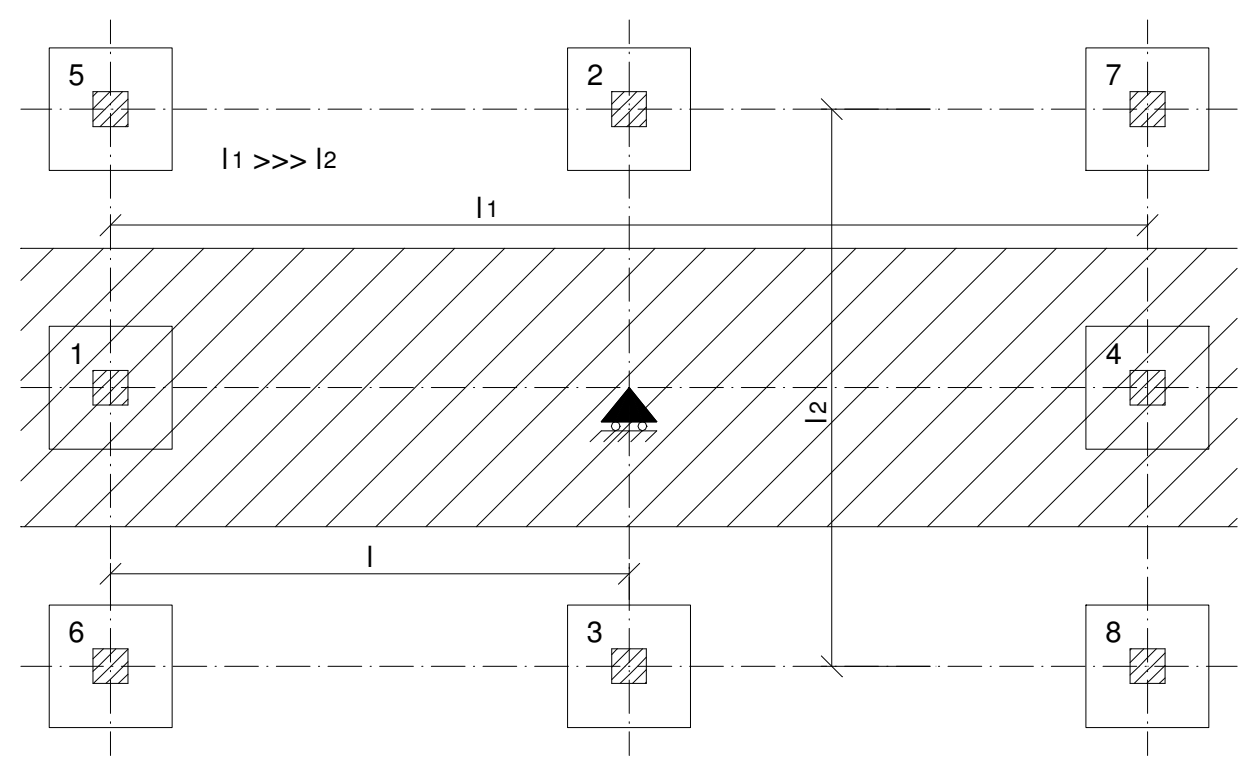

FIGURA 2.23: Artifício para o cálculo de pórticos virtuais cruzados com vãos muito diferentes [TESORO (1991)] 
Existem também outros processos de Pórticos Virtuais, conforme CANO \& KLINGNER (1988), como o Método de Pórtico Equivalente Extendido criado por Vanderbilt em 1981 a partir do processo utilizado pelo ACI-318 (1989) e que pode ser utilizado nas formas de coluna equivalente extendida e laje equivalente extendida. Uma das principais vantagens desse processo é que pode ser utilizado para casos envolvendo apenas carregamentos laterais.

\subsubsection{O Método dos Pórticos Múltiplos para o cálculo dos esforços}

Conforme mostrado em GUARDA (1995) é um método baseado em estudo realizado por Marcus, em 1924, e que consiste em representar uma estrutura de piso (lajes, pilares e vigas, se existirem) através de uma série de pórticos tomados nas duas direções ortogonais à borda da laje.

De acordo com a NB1/1978 os pórticos para o cálculo dos momentos fletores devem ser obtidos através da divisão do pavimento em duas séries ortogonais de pórticos. Os mesmos são obtidos traçando-se retas pelos centros dos pilares alinhados, dividindo o piso em faixas de largura '1" iguais aos vãos teóricos dos painéis, segundo a direção perpendicular à que se estiver calculando os momentos, conforme com a Figura 2.24.

Cada viga do pórtico de laje nervurada será uma faixa de largura ' '” e altura de laje maciça equivalente $h_{\text {eq }}$, conforme mostrado anteriormente na Eq. 2.15, dos respectivos painéis.

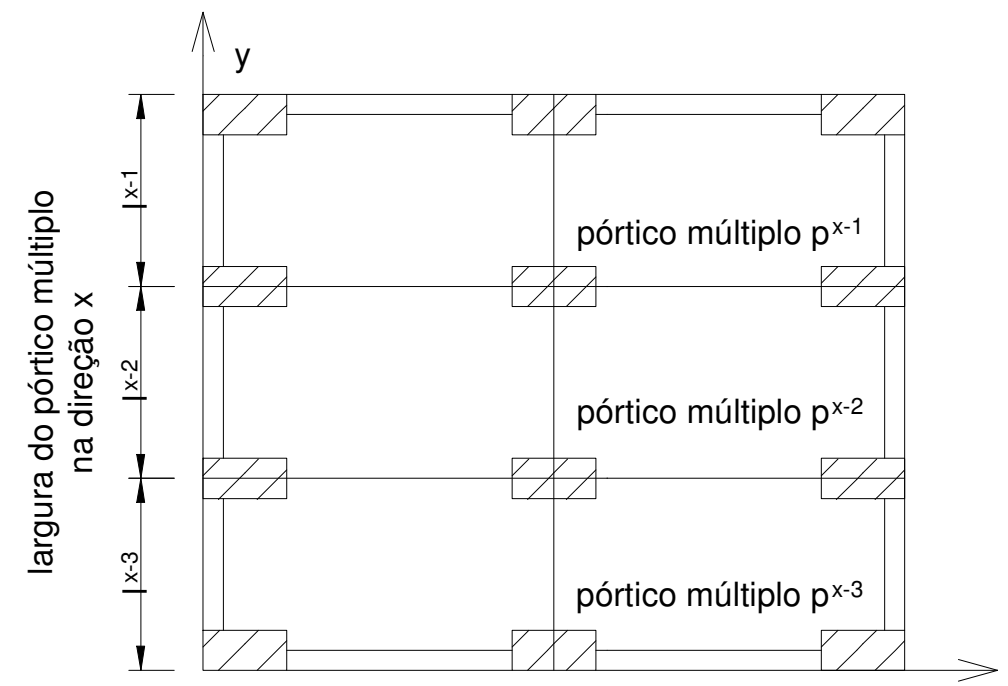

FIGURA 2.24: Definição dos Pórticos Múltiplos 


\subsubsection{Características geométricas dos elementos do Pórtico Múltiplo}

As características geométricas das faixas de vigas dos pórticos múltiplos para lajes maciças (e aí incluí-se a laje maciça com espessura equivalente em inércia à laje nervurada) podem ser obtidas por:

a) Área da seção transversal das faixas de vigas:

$\mathrm{A}_{\mathrm{i}}=\mathrm{l}_{\mathrm{i}} \cdot \mathrm{h}_{\mathrm{eq}}$

onde:

$l_{i}$ : largura da faixa de laje genérica $\mathrm{i}$.

b) Momento de inércia das faixas de vigas:

$\mathrm{I}_{\mathrm{i}}=\left(\mathrm{l}_{\mathrm{i}} \cdot \mathrm{h}_{\mathrm{eq}}{ }^{3}\right) / 12$

onde:

$1_{\mathrm{i}}$ : largura da faixa de laje genérica $\mathrm{i}$.

As retas que delimitam o pórtico dividem os pilares ao meio; portanto, as características geométricas do pilar j do pórtico genérico i serão dadas por:

c) Área da seção transversal do pilar do pórtico:

$\mathrm{A}_{\mathrm{j}, \mathrm{i}}=\left(\mathrm{A}_{\mathrm{j}, \mathrm{i}}+\mathrm{A}_{\mathrm{j}, \mathrm{i}+1}\right) / 2$

onde:

$\mathrm{A}_{\mathrm{j}, \mathrm{i}}$ : área do pilar do pórtico genérico i;

$\mathrm{A}_{\mathrm{j}, \mathrm{i}+1}$ : área do pilar do pórtico genérico i+1.

d) Momento de inércia à flexão do pilar do pórtico:

$\mathrm{I}_{\mathrm{j}, \mathrm{i}}=\left(\mathrm{I}_{\mathrm{j}, \mathrm{i}}+\mathrm{I}_{\mathrm{j}, \mathrm{i}+1}\right) / 2$

onde:

$\mathrm{I}_{\mathrm{j}, \mathrm{i}}$ : inércia à flexão do pilar do pórtico genérico i;

$\mathrm{I}_{\mathrm{j}, \mathrm{i}+1}$ : inércia à flexão do pilar do pórtico genérico i+1. 


\subsubsection{Os parâmetros elásticos do concreto armado no Método de Pórticos Múltiplos}

\section{a) Módulo de deformação longitudinal do concreto}

Segundo o projeto de revisão da NBR6118/2000:

$\mathrm{E}_{\mathrm{cs}}=0,85 . \mathrm{E}_{\mathrm{c}} \quad[\mathrm{MPa}]$

sendo:

$\mathrm{E}_{\mathrm{c}}=5600 .\left(\mathrm{f}_{\mathrm{ck}}\right)^{1 / 2}[\mathrm{MPa}]$

$\mathrm{E}_{\mathrm{cs}}$ : módulo de elasticidade secante do concreto;

$\mathrm{E}_{\mathrm{c}}$ : módulo de elasticidade tangente do concreto;

$\mathrm{f}_{\mathrm{ck}}$ : resistência característica do concreto à compressão.

\section{b) Módulo de deformação transversal do concreto}

No projeto de revisão da NBR 6118/2000 tem-se que o módulo de deformação transversal do concreto também é calculado adotando $v=0,20$, resultando:

$\mathrm{G}_{\mathrm{c}}=0,4 \cdot \mathrm{E}_{\mathrm{cs}}=1904 .\left(\mathrm{f}_{\mathrm{ck}}\right)^{1 / 2} \quad[\mathrm{MPa}]$

onde:

$\mathrm{G}_{\mathrm{c}}$ : módulo de elasticidade transversal do concreto.

TAKEYA (1985) sugere adotar $\mathrm{G}_{\mathrm{c}}=0,15 . \mathrm{E}_{\mathrm{cs}}$.

\subsubsection{Combinações de tramos carregados e descarregados}

Para satisfazer as condições de equilíbrio cada pórtico múltiplo deve ser calculado com o carregamento total atuante na laje, ou seja, sempre que em uma placa possa ser produzida uma deformação e giro em uma direção sem a necessidade geométrica de produzir flexões nas demais direções, como é o caso do pórtico múltiplo, este deve ser calculado com a totalidade da carga. [MACGREGOR (1988)]

O carregamento simultâneo de todos os tramos do pórtico não produzem, necessariamente, os máximos momentos negativos e positivos.

Assim, para o cálculo no Estado Limite Último é interessante analisar os pórticos com os carregamentos acidentais alternados, como mostrado a seguir, se a soma das cargas acidentais ultrapassar $75 \%$ da carga permanente: 
a) carga permanente em todos os vãos e $75 \%$ da carga acidental em vãos alternados para se determinar os momentos positivos atuantes no meio dos vãos;

b) carga permanente em todos os vãos e $75 \%$ da carga acidental em vãos adjacentes para se determinar os momentos negativos atuantes nos vãos.

\subsubsection{Determinação dos esforços nos Pórticos Múltiplos}

A determinação dos esforços nos pórticos múltiplos, após a sua definição, pode ser feita por:

a) cálculo manual, utilizando o métodos dos esforços ou dos deslocamentos para o cálculo hiperestático;

b) com o auxílio de programas computacionais que resolvem pórticos planos e que utilizam qualquer um dos processos numéricos disponíveis, como o ANSYS 5.5.

O esquema estrutural utilizado, quando tratando-se de um piso intermediário, pode definir um pórtico perfeitamente engastado nos lances inferiores e quase engastado nos lances superiores (apresentado apenas pequenas rotações), conforme Figura 2.25.

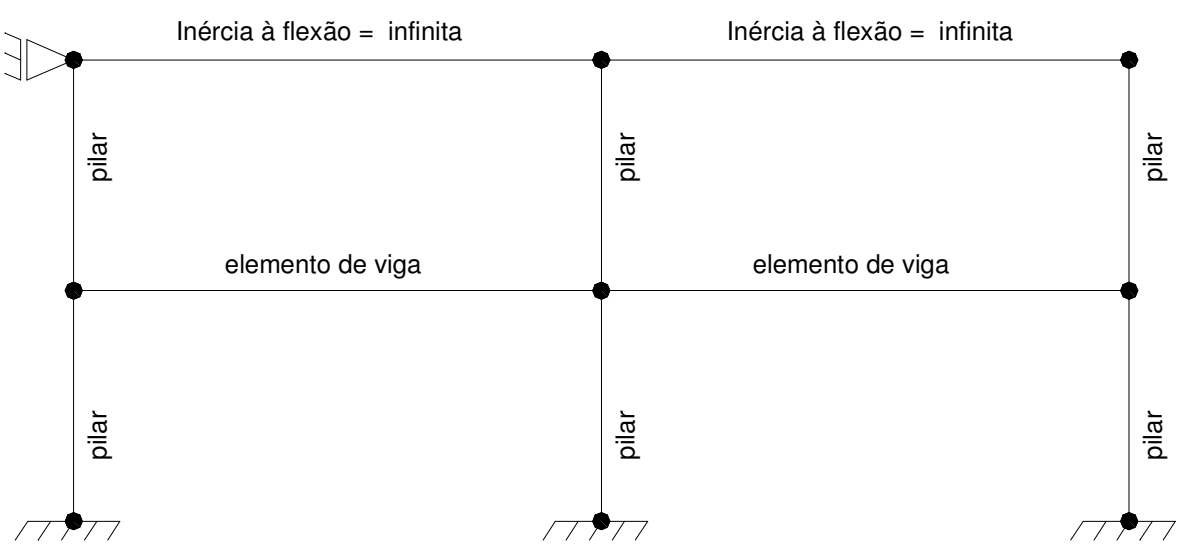

FIGURA 2.25: Modelo de Pórtico Múltiplo Plano 


\subsubsection{Distribuição dos esforços calculados segundo o Método de Pórticos} Múltiplos do projeto de revisão da NBR6118/2000

O projeto de revisão da NBR6118/2000 indica que após calculados os esforços para o pórtico estes devem ser distribuídos, para cada direção considerada, da seguinte forma:

a) $45 \%$ dos momentos positivos para as duas faixas internas;

b) $27,5 \%$ dos momentos positivos para cada uma das faixas externas;

c) $25 \%$ dos momentos negativos para as duas faixas internas;

c) $37,5 \%$ dos momentos negativos para cada uma das faixas externas.

Tem-se as faixas de distribuição conforme a Figura 2.26:

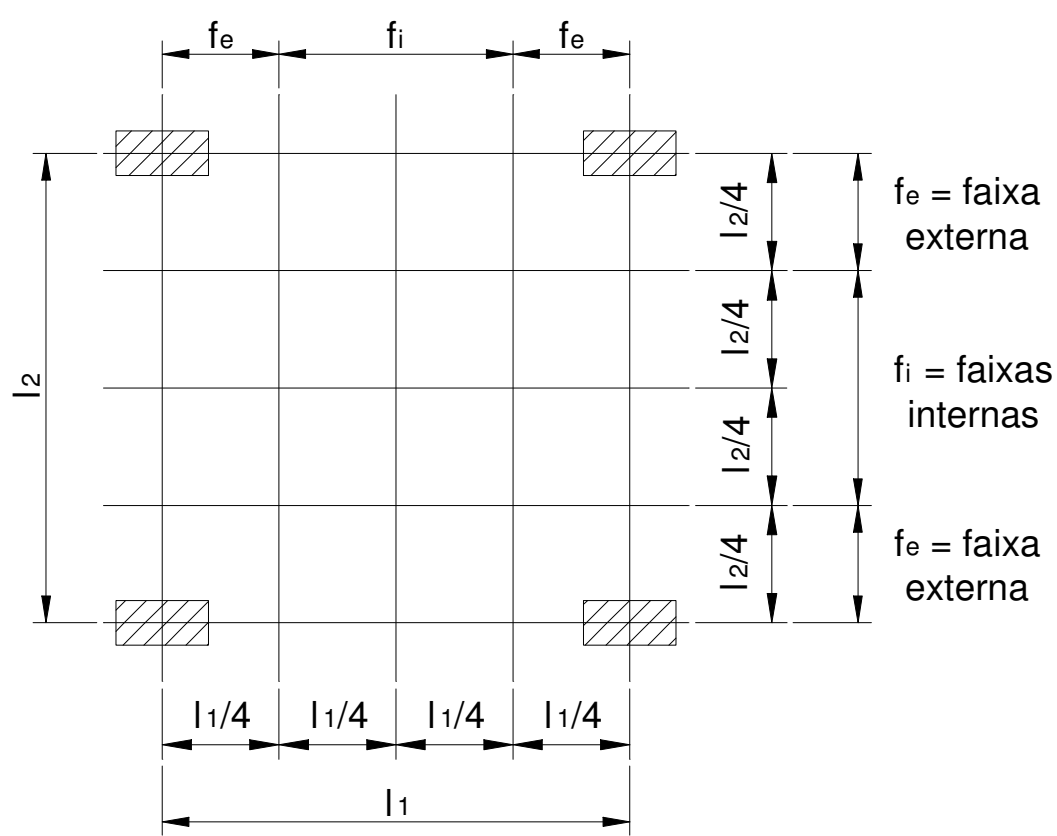

FIGURA 2.26: Faixas de distribuição de esforços no pórtico múltiplo conforme o projeto de revisão da NBR 6118/2000

\subsubsection{O Método dos Pórticos Equivalentes para o cálculo dos esforços}

Propostas para a análise de placas lisas maciças através de pórticos datam dos anos 30, na Alemanha e Estados Unidos, segundo o ACI-435 (1989). Em 1948, Peabody 
apresentou em detalhes um método para a análise de pórticos equivalentes. Posteriormente uma forma mais refinada de análise foi intensivamente testada pela Universidade de Illinois, Estados Unidos, nos anos 60.

Como mostrado em SILVANY (1996) este trabalho serviu de base para que em 1971 fosse incluído no código do ACI o processo dos pórticos equivalentes para a determinação dos momentos em lajes.

O processo é um modelo estrutural alternativo ao processo de pórticos múltiplos.

Conforme NAWY (1995) o método dos pórticos equivalentes apresenta alguns pontos interessantes no cálculo de placas:

a) variações no momento de inércia ao longo dos eixos dos pórticos podem ser consideradas, como por exemplo o efeito dos capitéis;

b) efeitos de carregamento lateral podem ser analisados, fazendo-se para isso alterações adequadas nas rigidezes visando considerar o efeito das fissurações;

c) o processo é de fácil implementação computacional.

O método dos pórticos equivalentes consiste em supor que o pavimento está dividido, em cada uma das direções, em uma série de pórticos formados por um conjunto de colunas e barras horizontais cujas inércias serão iguais às da região da laje limitadas pela metade da distância entre duas linhas de pilares, conforme a Figura 2.27.

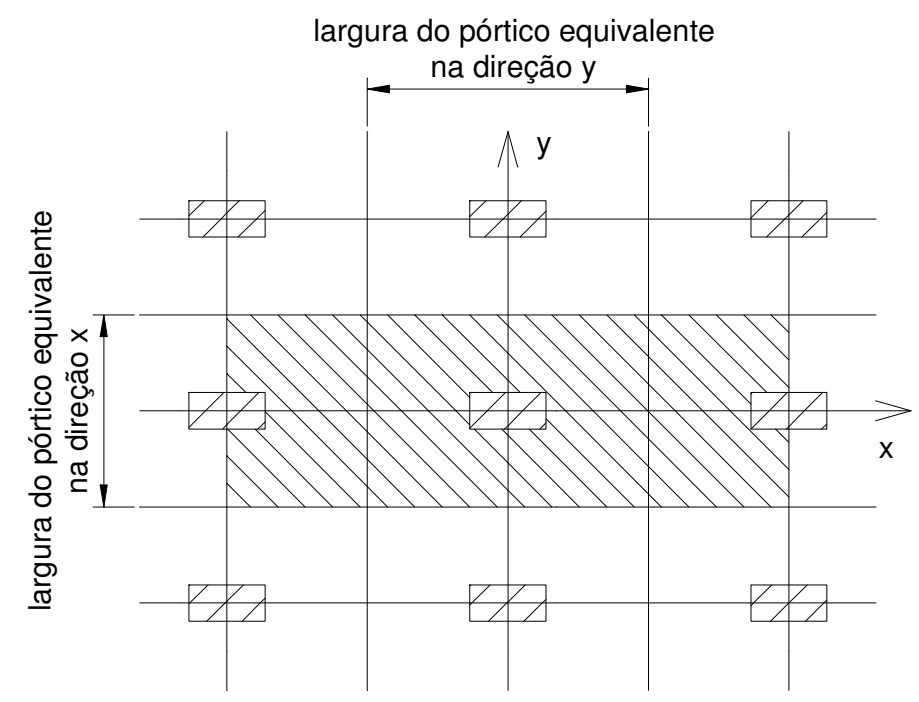

FIGURA 2.27: Largura dos pórticos equivalentes

[ACI-318 (1989)] 
IKEDA et al. (2000) indicaram que o modelo analítico para a análise de pórticos planos utilizados pelo ACI-318 (1989) baseia-se em uma estrutura tridimensional proposta por Wang, em 1985, e mostrada na Figura 2.28.

Neste modelo tridimensional tem-se:

a) elementos de viga $\mathrm{ABC}$ e GHK que, na eventual falta das vigas entre os pilares, representam parte da laje atuando como viga, limitada pela largura dos pilares;

b) elementos de pilar DA, AG, EB, BH, FC e CK;

c) peças de torção representadas pelos elementos AA', BB' e CC', de comprimento igual à largura da faixa do pórtico equivalente;

d) elementos de laje, que na verdade são vigas com momento de inércia iguais a de toda a seção transversal na largura do pórtico equivalente, mas localizadas na posição A'B'C', sendo então retirada toda a inércia dos elementos de vigas da linha ABC, permitindo a atuação dos elementos de torção.

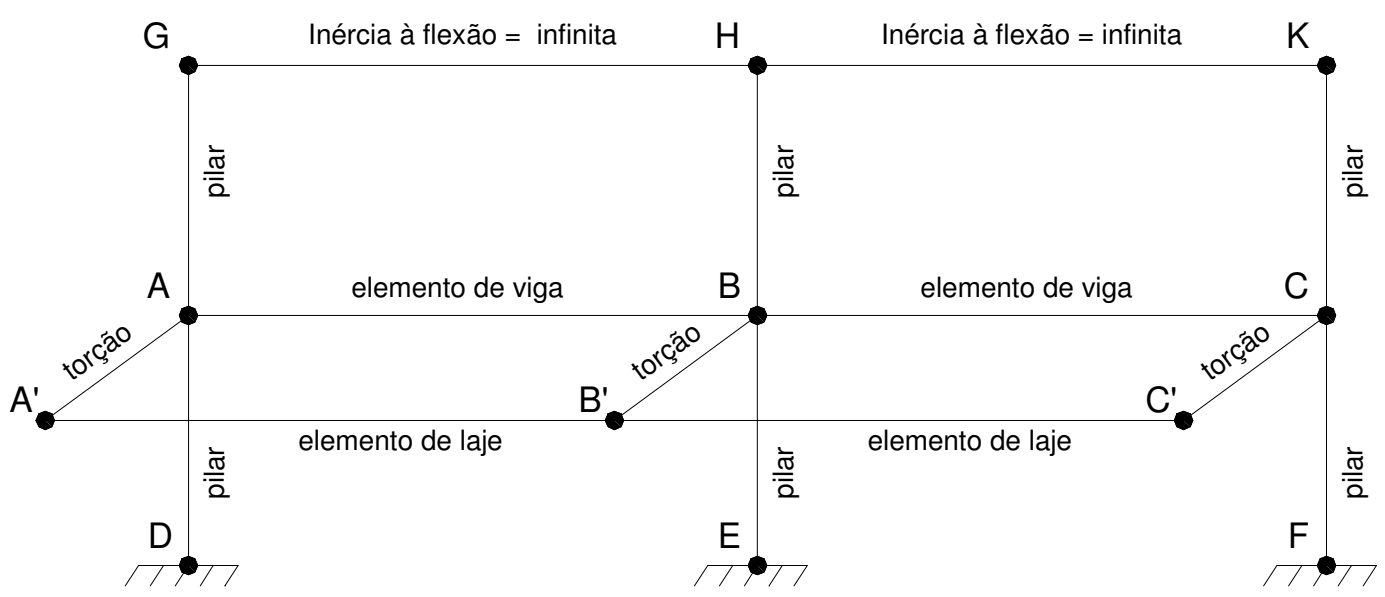

FIGURA 2.28: Modelo analítico tridimensional do Pórtico Equivalente

[IKEDA et al. (2000)]

Com o intuito de substituir o modelo tridimensional por um modelo em pórtico plano CORLEY \& JIRSA (1970) desenvolveram o conceito de pilar equivalente, ou seja, um pilar que já engloba no plano as rigidezes à torção das ligações viga-pilar.

Dessa forma, segundo o ACI-318 (1989), o método dos Pórticos Equivalentes substitui o sistema tridimensional de lajes por uma série de pórticos bidimensionais. 
Assim, neste modelo os pórticos planos equivalentes são compostos por três

partes:

a) faixas horizontais de laje;

b) pilares ou outros elementos verticais de apoio, considerados acima e abaixo da laje;

c) elementos da estrutura que possibilitam a transferência de momentos entre os elementos verticais e os horizontais, ou seja, elementos submetidos à torção (daí a vantagem de se aplicar, às bordas, vigas maciças rígidas à torção facilitando, dessa forma, a transferência de momentos fletores aos pilares).

Na Figura 2.29 é apresentada uma ilustração esquemática dos elementos componentes do pórtico equivalente.

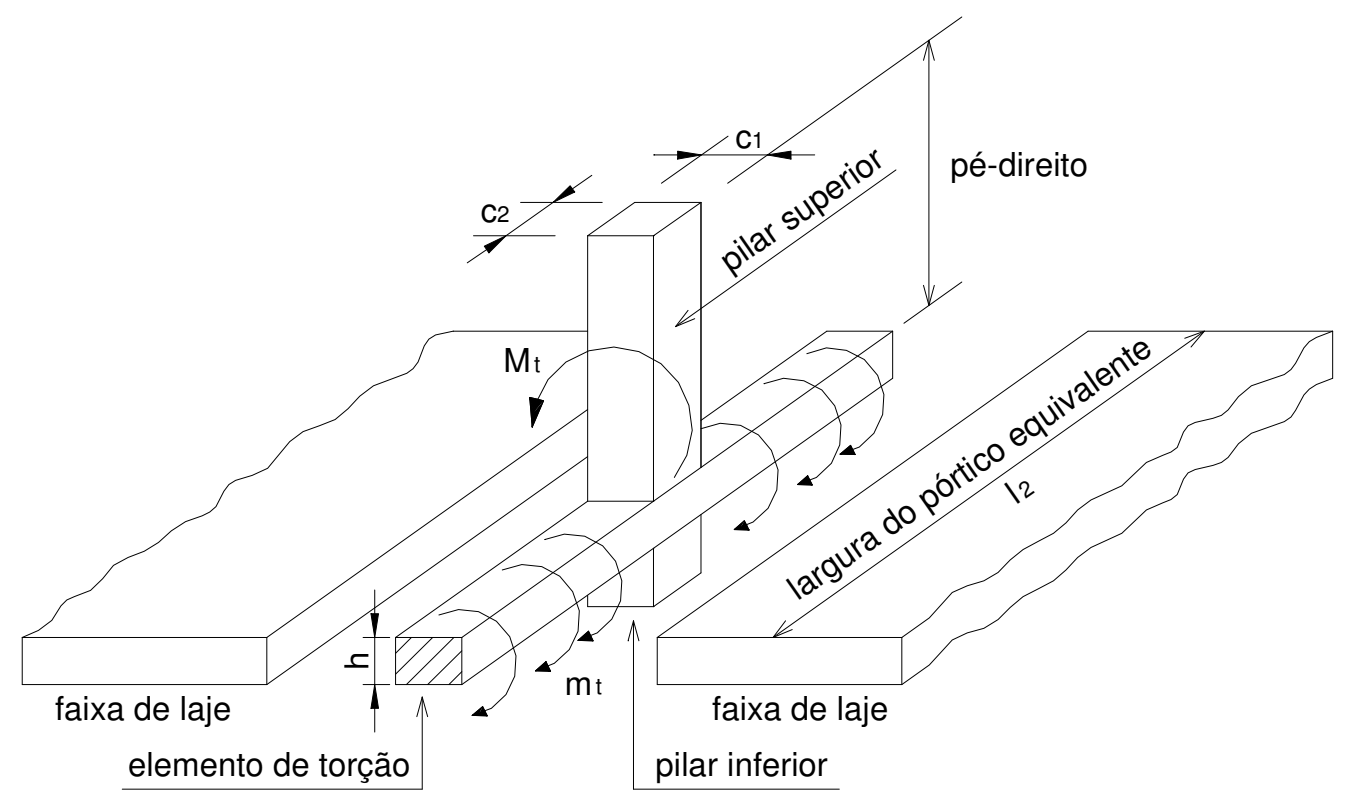

FIGURA 2.29: Elementos componentes do Pórtico Equivalente

As faixas de laje são necessárias para suportar os carregamentos transversais ao plano da placa. A coluna oferece resistência ao torque $\mathrm{M}_{\mathrm{t}}$ equivalente ao momento torçor de intensidade $\mathrm{m}_{\mathrm{t}}$. A borda exterior da faixa de laje rotaciona mais que a seção central da faixa devido a deformação rotacional. Para a consideração destas rotações e deformações o pilar e a laje, no nó de encontro dos dois, serão substituídos por uma coluna equivalente.

As faixas de laje nos painéis são também subdivididas para a distribuição dos esforços calculados através do pórtico equivalente.

De acordo com o código ACI-318 (1989) tem-se as faixas de distribuição conforme a Figura 2.30. 
Sob o ponto de vista dos projetistas, de acordo com CANO \& KLINGNER (1988), o Método dos Pórticos Equivalentes do ACI-318 (1989) apresenta também algumas desvantagens:

a) a necessidade do cálculo de rigidezes $K_{t}, K_{s}$ e $K_{e c}$ que mesmo quando feitos computacionamente consomem tempo;

b) as equações podem ser aplicadas corretamente para os casos de carregamentos laterais apenas se a rigidez da laje (que será simulada por elementos de viga) for reduzida devido a efeitos de fissuração;

c) o método é estritamente aplicável a subestruturas de um pavimento apenas.

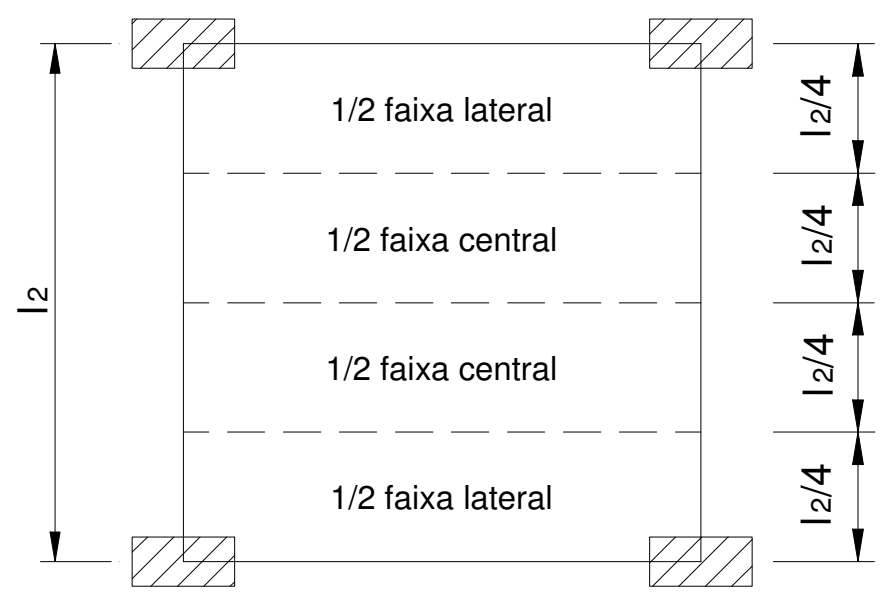

FIGURA 2.30: Identificação das meias faixas centrais e laterais de um painel no Método dos Pórticos Equivalentes, conforme ACI-318 (1989)

\subsubsection{O pilar equivalente}

A coluna equivalente, elemento que substitui a laje e pilar na região de encontro dos mesmos, tem a sua flexibilidade igual à soma das flexibilidades dos elementos separados, ou seja, dos pilares acima e abaixo da faixa de laje e dos elementos de torção, segundo o ACI-318 (1989):

$$
\frac{1}{\mathrm{~K}_{\mathrm{ec}}}=\frac{1}{\sum \mathrm{K}_{\mathrm{c}}}+\frac{1}{\sum \mathrm{K}_{\mathrm{t}}}
$$

onde: 
$\mathrm{K}_{\mathrm{ec}}$ : rigidez à flexão da coluna equivalente, em momento por rotação unitária;

$\Sigma \mathrm{K}_{\mathrm{c}}$ : soma das rigidezes dos pilares acima e abaixo do nó, em momento por rotação unitária;

$\Sigma \mathrm{K}_{\mathrm{t}}$ : soma das rigidezes à torção dos elementos submetidos à torção, em momento por rotação unitária; é definido para pórticos internos e externos: se interno, somam-se os dois lados do pilar e se externo considera-se somente um lado do pilar.

A consideração do pilar equivalente modifica a rigidez do pilar real considerando a flexibilidade torcional da ligação laje-pilar reduzindo, dessa forma, sua eficácia na transmissão de momentos.

Uma expressão para o cálculo de $\mathrm{K}_{\mathrm{c}}$ representando um pilar engastado nos lances superior e inferior, é dado em NAWY (1995) como sendo:

$$
\sum \mathrm{K}_{\mathrm{c}}=\frac{4 . \mathrm{E}_{\mathrm{cs}} \cdot \mathrm{I}_{\mathrm{pi}}}{\mathrm{l}_{\mathrm{i}}-2 \cdot \mathrm{h}_{\mathrm{eq}}}+\frac{4 \cdot \mathrm{E}_{\mathrm{cs}} \cdot \mathrm{I}_{\mathrm{ps}}}{1_{\mathrm{s}}-2 \cdot \mathrm{h}_{\mathrm{eq}}}
$$

onde:

$\mathrm{I}_{\mathrm{p} i}$ : momento de inércia à flexão do pilar inferior à laje;

$\mathrm{I}_{\mathrm{ps}}$ : momento de inércia à flexão do pilar superior à laje;

$1_{i}$ : pé-direito inferior à laje;

$1_{\mathrm{s}}$ : pé-direito superior à laje;

$\mathrm{h}_{\mathrm{eq}}$ : espessura da laje maciça equivalente.

O elemento que sofre a ação da torção na coluna equivalente, conforme a

Figura 2.31, pode ser assumido como tendo uma seção transversal constante por todo o seu comprimento formado por:

a) uma porção da laje tendo uma largura igual a do pilar na direção do vão em que os momentos são determinados;

b) havendo viga na borda, para regiões monolíticas, o elemento submetido a torção será constituído pela viga mais uma porção da laje maciça, cuja largura é igual a projeção da viga, abaixo ou acima, a maior, a partir da face da mesma, não sendo maior que quatro vezes a altura da laje naquela região.

A rigidez a torção do elemento de placa na linha da coluna é dada, segundo o ACI-318 (1989), por:

$$
\mathrm{K}_{\mathrm{t}}=\sum \frac{9 \cdot \mathrm{E}_{\mathrm{cs}} \cdot \mathrm{C}}{1_{2} \cdot\left(1-\frac{\mathrm{c}_{2}}{\mathrm{l}_{2}}\right)^{3}}
$$

onde: 
$\mathrm{E}_{\mathrm{cs}}$ : módulo de deformação secante longitudinal do concreto da laje;

$1_{2}$ : largura da faixa do pórtico equivalente, medida de centro a centro entre

dois apoios;

$\mathrm{c}_{2}$ : largura da coluna retangular ou da coluna equivalente retangular, transversal à direção de atuação dos momentos;

C: seção transversal constante para definir as propriedades de torção, dadas pela divisão da seção transversal em retângulos, resultando:

$$
C=\sum\left(1-0,63 \cdot \frac{x}{y}\right) \frac{x^{3} y}{3}
$$

onde:

x: menor dimensão da parcela retangular considerada na junção da laje com a coluna;

y: maior dimensão da parcela retangular considerada na junção da laje com a coluna.

Esquematicamente tem-se a Figura 2.32 que representa a divisão da seção transversal dos elementos submetidos à torção.

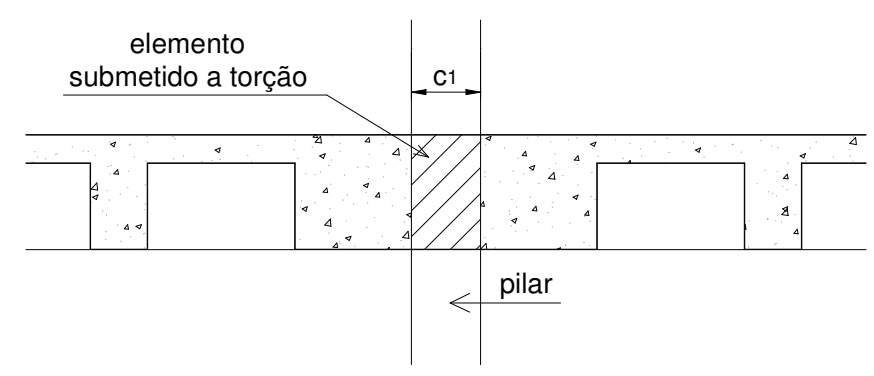

(a) elemento submetido à torção para pilar interno

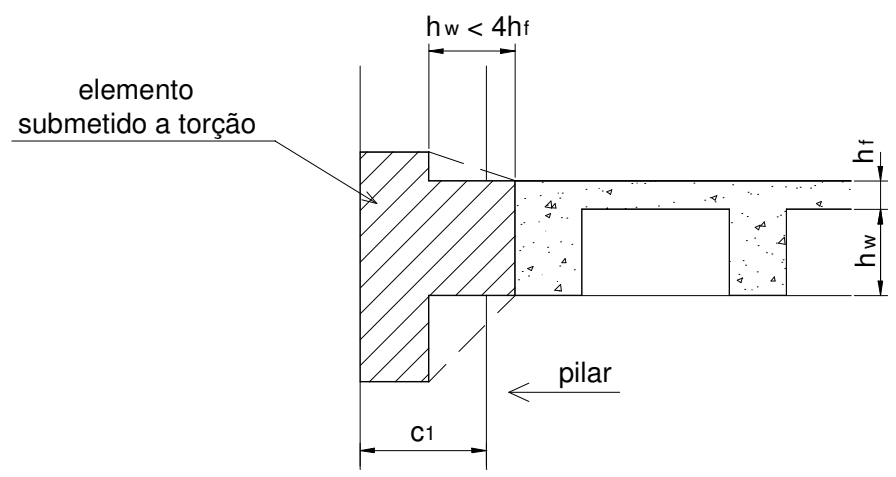

(b) elemento submetido à torção para pilar externo e com viga de borda

FIGURA 2.31: Elementos submetidos à torção no Método dos Pórticos Equivalentes, segundo o ACI-318 (1989) 
A partir das rigidezes calculadas para o pilar equivalente a inércia à flexão do mesmo pode então ser obtida pela relação:

$$
\mathrm{I}_{\mathrm{eq}}=\mathrm{I}_{\text {PILAR }} \times \mathrm{K}_{\mathrm{ec}} / \mathrm{K}_{\mathrm{c}}
$$
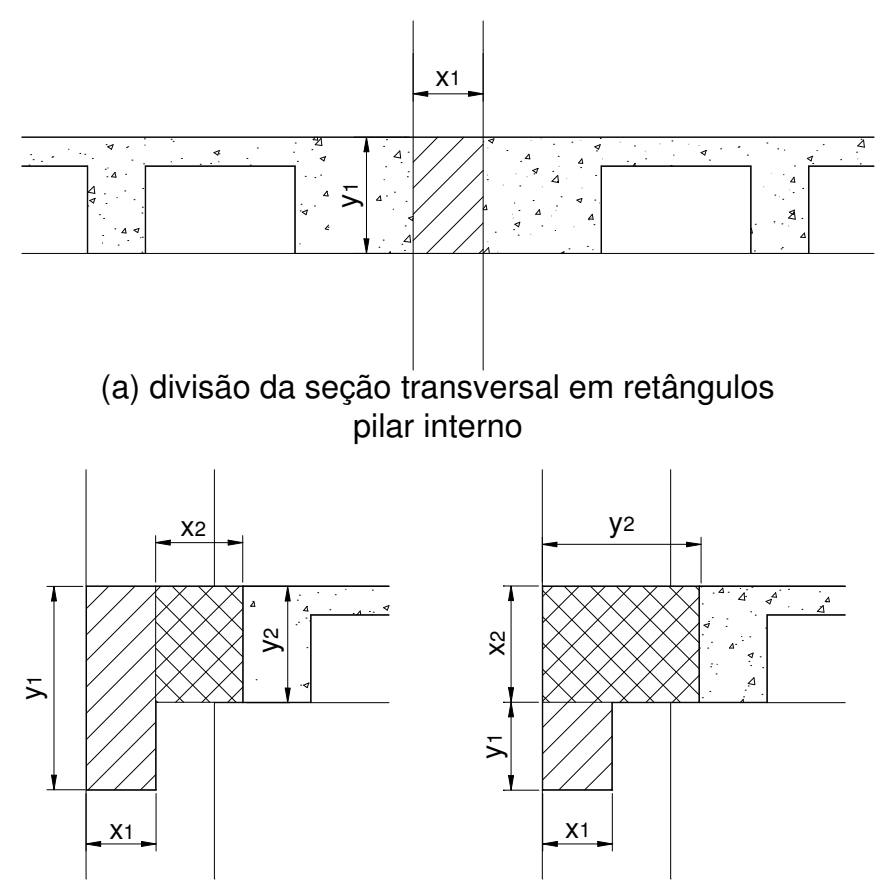

(b) divisão da seção transversal em retângulos pilar externo e viga de borda

FIGURA 2.32: Divisão da seção transversal do elemento submetido à torção no Método dos Pórticos Equivalentes, segundo o ACI-318 (1989)

\subsubsection{A rigidez da laje nervurada no modelo de Pórticos Equivalentes}

Analisando as lajes nervuradas por meio do processo de pórticos equivalentes (e também pelo processo de pórticos múltiplos anteriormente apresentado) torna-se necessário atribuir aos elementos idealizados as rigidezes reais ou, se isto não for possível, rigidezes equivalentes que conduzam a resultados razoáveis.

A dificuldade está, então, em determinar-se a inércia real do elemento de pórtico que representa a placa com sua geometria variável devido à presença de regiões maciças e regiões nervuradas.

TESORO (1991) indicou processo para consideração da inércia da laje nervurada considerando os pormenores existentes. 
Uma alternativa viável, porém não a mais precisa, é transformar a região nervurada em uma laje maciça com espessura equivalente em inércia à flexão da laje com enrijecedores. Como o processo de Pórticos Múltiplos da NB1/1978 já é muito simplificado neste indica-se considerar o pavimento substituído pela laje maciça equivalente, como pôde ser verificado anteriormente.

\section{a) A rigidez da laje maciça equivalente}

A rigidez da placa maciça equivalente é dada por:

$$
\sum \mathrm{K}_{\mathrm{s}}=\frac{4 \cdot \mathrm{E}_{\mathrm{cs}} \cdot \mathrm{I}_{\mathrm{s}}}{1_{\mathrm{ne}}-\mathrm{c}_{1} / 2}+\frac{4 \cdot \mathrm{E}_{\mathrm{cs}} \cdot \mathrm{I}_{\mathrm{s}}}{1_{\mathrm{nd}}-\mathrm{c}_{1} / 2}=\mathrm{K}_{\mathrm{se}}+\mathrm{K}_{\mathrm{sd}}
$$

onde:

$\Sigma \mathrm{K}_{\mathrm{s}}$ : rigidez à flexão da faixa da placa, em momento por rotação unitária;

$\mathrm{E}_{\mathrm{cs}}$ : módulo de deformação longitudinal secante do concreto da laje;

$\mathrm{I}_{\mathrm{s}}$ : momento de inércia referindo-se ao eixo central da seção transversal da laje maciça o que, para lajes nervuradas, pode ser dada pela inércia dada laje maciça equivalente;

$1_{\text {ne: }}$ comprimento na direção de atuação dos momentos, à esquerda do pilar, até o centro do mesmo;

$1_{\text {nd: }}$ comprimento na direção de atuação dos momentos, à direita do pilar, até o centro do mesmo;

$\mathrm{c}_{1}$ : largura da coluna retangular ou da coluna retangular equivalente, na direção de atuação dos momentos.

O momento de inércia à flexão nas faixas de laje (ou vigas do pórtico bidimensional) da face de apoio até a linha central de apoio será tomada como sendo igual a inércia da faixa de laje-viga com espessura equivalente que faz fronteira na face do apoio dividida pelo fator $\left(1-c_{2} / l_{2}\right)^{2}$, onde $c_{2}$ e $l_{2}$ são medidas na direção transversal à direção para os quais as armaduras estão sendo dimensionadas, de acordo com a Figura 2.29 anteriormente apresentada. Deve-se ressaltar que o ACI-318 (1989) considera como apoios os pilares, paredes, capitéis e ábacos. Segundo CORLEY \& JIRSA (1970) a divisão da inércia por este fator tem duas funções: aumentar a rigidez da viga equivalente a um nível consistente àquele determinado por uma análise tridimensional e verificado em muitos testes e, ao mesmo tempo, cobrir a condição onde a laje é suportada por pilares largos. Nesse último caso se a laje for suportada por uma parede de concreto armado tem-se aproximadamente $c_{2} / l_{2}=1$, e a inércia da laje-viga dentro do pilar torna-se enorme. Deve-se 
atentar ao fato que a elevada inércia só ocorre se a laje for construída monoliticamente com o pilar.

\section{b) A rigidez da laje nervurada considerada de forma realista}

Ao tentar-se utilizar uma inércia mais próxima da inércia real da laje nervurada sem vigas algumas considerações devem ser verificadas, de acordo com TESORO (1991):

a) a adoção das inércias diferenciadas para as regiões maciças e regiões nervuradas reflete melhor o mecanismo transmissor das flexões da placa para os pilares neste tipo de estrutura;

b) a presença das nervuras transversais, com certeza, oferecem rigidez adicional à rigidez longitudinal do elemento, contudo é muito difícil avaliar sua colaboração no método dos pórticos equivalentes.

O modelo apresentado pelo autor, contudo, baseia-se em operar com uma inércia constante da faixa de laje nervurada que compõe o pórtico, obtendo a mesma através da soma das inércias do ábaco (ou capitel) com a das nervuras contidas na faixa correspondente do pórtico virtual. Assim, de acordo com a Figura 2.33, TESORO (1991) utiliza para todo o pórtico a inércia $\mathrm{I}_{1}$, que passa pela região maciça.

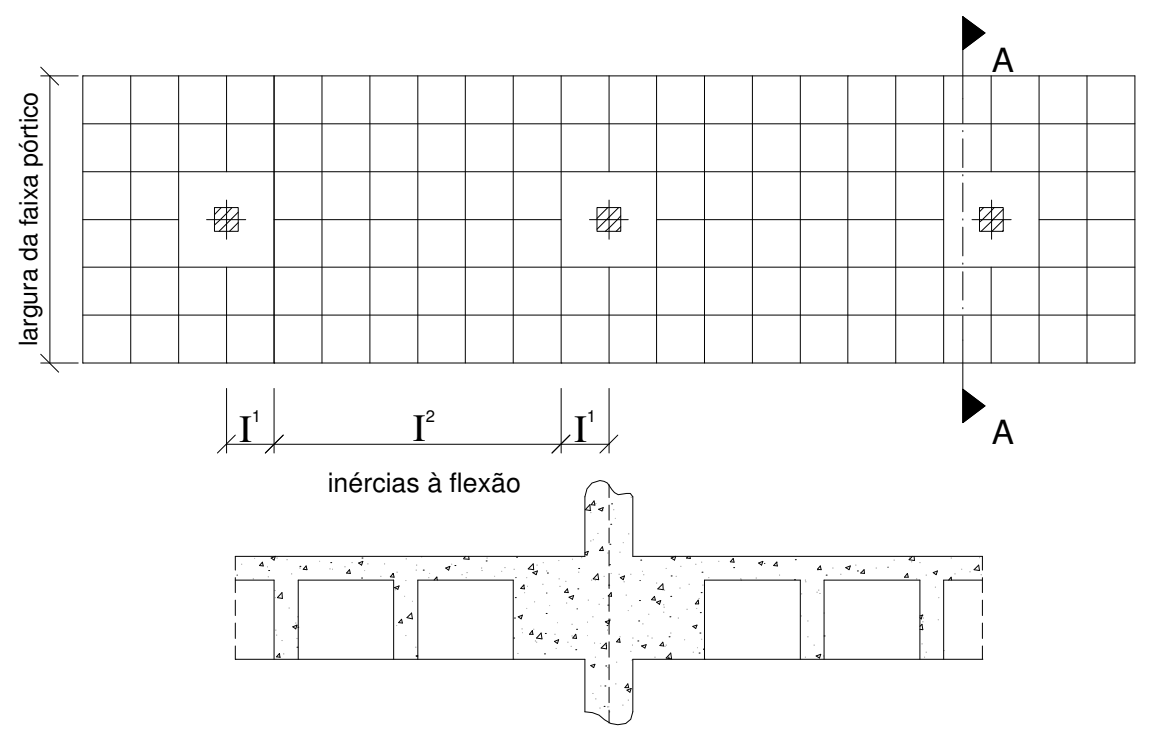

Corte A-A: secão para o cálculo da inércia à flexão $I^{1}$

FIGURA 2.33: Seção transversal da faixa laje do pórtico virtual

[TESORO (1991)] 
A inércia da faixa que passa pela região de laje nervurada que contém o ábaco, de acordo com a Figura 2.34, pode ser calculada de acordo com TESORO (1991), onde a Figura 2.32 apresenta a nomenclatura utilizada para o cálculo das inércias.
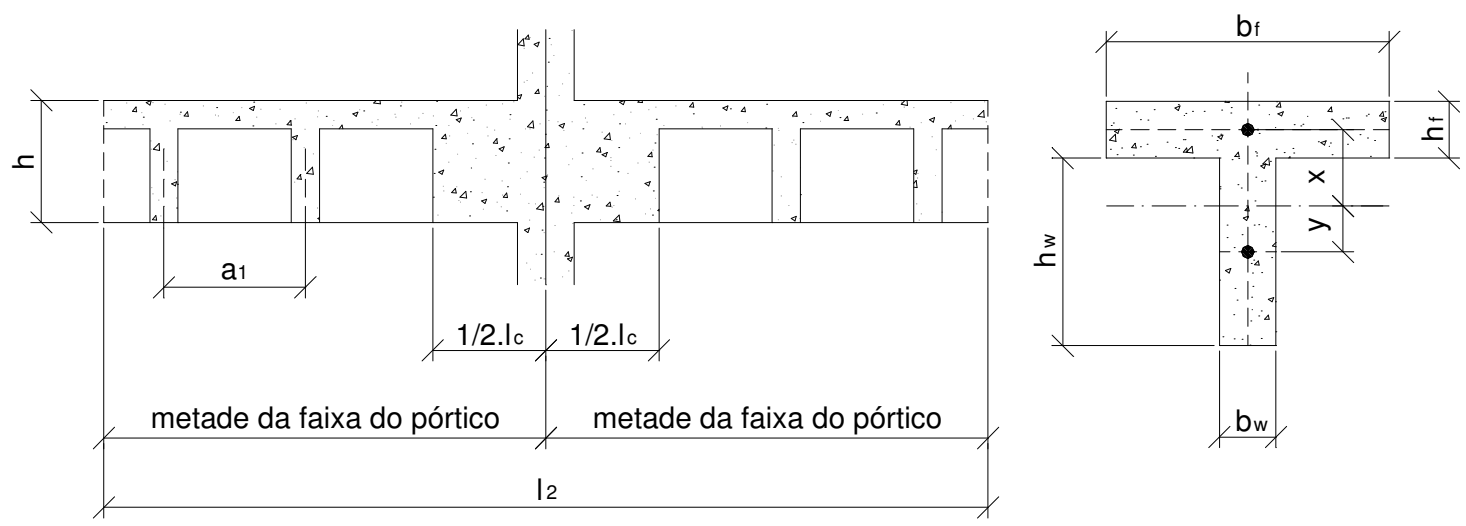

Figura 2.34: Seção considerada para o cálculo da inércia da placa do Pórtico Virtual

[TESORO (1991)]

O mesmo pesquisador adotou eixos de inércia distintos para a mesa e para a alma por considerar que o caráter de seção única é discutível. Dessa maneira, a determinação do eixo principal de inércia da nervura é feita através dos valores de x e y, como abaixo:

$$
\begin{aligned}
& x=\frac{b_{w} \cdot h_{w} \cdot\left(h_{w}+h_{f}\right)}{2 \cdot\left(b_{w} \cdot h_{w}+b_{f} \cdot h_{f}\right)} \\
& y=\frac{h_{w}+h_{f}}{2}-x
\end{aligned}
$$

Fixado o eixo, a inércia à flexão de uma nervura com seção transversal em forma de "T" pode ser calculada como:

$$
I_{n}=\frac{b_{w} \cdot h_{w}^{3}}{12}+b_{w} \cdot h_{w} \cdot y^{2}+\frac{b_{f} \cdot h_{f}^{3}}{12}+b_{f} \cdot h_{f} \cdot x^{2}
$$

A inércia à flexão do ábaco (ou capitel) pode ser determinada diretamente da equação:

$$
I_{a}=\frac{1_{c} \cdot h^{3}}{12}
$$

O número de nervuras que formam cada faixa de laje nem sempre constituise em número exato e quase sempre as almas das nervuras extremas é compartilhada pelas faixas virtuais adjacentes. Assim, a fim de determinar-se a inércia $I_{1}$, pode operar-se matematicamente com as nervuras fracionadas, ou então empregar a fórmula que determina o número de nervuras por faixa, de forma não necessariamente exata: 
$\mathrm{n}=$ parte inteira de $\left(\frac{\mathrm{l}_{2}}{\mathrm{a}_{1}}\right)+1$

sendo:

$\mathrm{n}=$ número de nervuras por faixa de laje

Somando as inércias à flexão do ábaco (ou capitel) com as inércias à flexão das nervuras fora do mesmo, obtém-se a inércia à flexão da faixa do pórtico virtual.

$$
\mathrm{I}_{1}=\mathrm{I}_{\mathrm{a}}+\mathrm{n}^{*} \cdot \mathrm{I}_{\mathrm{n}}
$$

sendo:

$\mathrm{n}^{*}=$ número de nervuras da faixa do pórtico que cortam transversalmente o ábaco.

Nas faixas que não contém regiões maciças o processo é semelhante, excetuando-se a soma de $\mathrm{I}_{\mathrm{a}}$ (inércia à flexão da região maciça).

O momento de inércia à flexão nas faixas de laje (ou vigas do pórtico bidimensional) da face de apoio até a linha central de apoio pode então ser tomada como sendo igual a inércia da faixa de laje-viga considerada de forma realista que faz fronteira na face do apoio dividida pelo fator $\left(1-c_{2} / l_{2}\right)^{2}$, onde $c_{2}$ e $l_{2}$ são medidas na direção transversal à direção para os quais as armaduras estão sendo dimensionadas, de acordo com a Figura 2.29 anteriormente apresentada.

\subsubsection{Combinações de tramos carregados e descarregados}

Como já visto, o carregamento simultâneo de todos os tramos do pórtico não produzem, necessariamente, os máximos momentos negativos e positivos.

Assim, para o cálculo no Estado Limite Último é interessante analisar os pórticos com os carregamentos acidentais alternados, como mostrado a seguir, se a soma das cargas acidentais ultrapassar 75\% da carga permanente, de acordo com GUARDA (1995).

a) carga permanente em todos os vãos e $75 \%$ da carga acidental em vãos alternados, de acordo com a Figura 2.35, para se determinar os momentos positivos atuantes no meio dos vãos; 


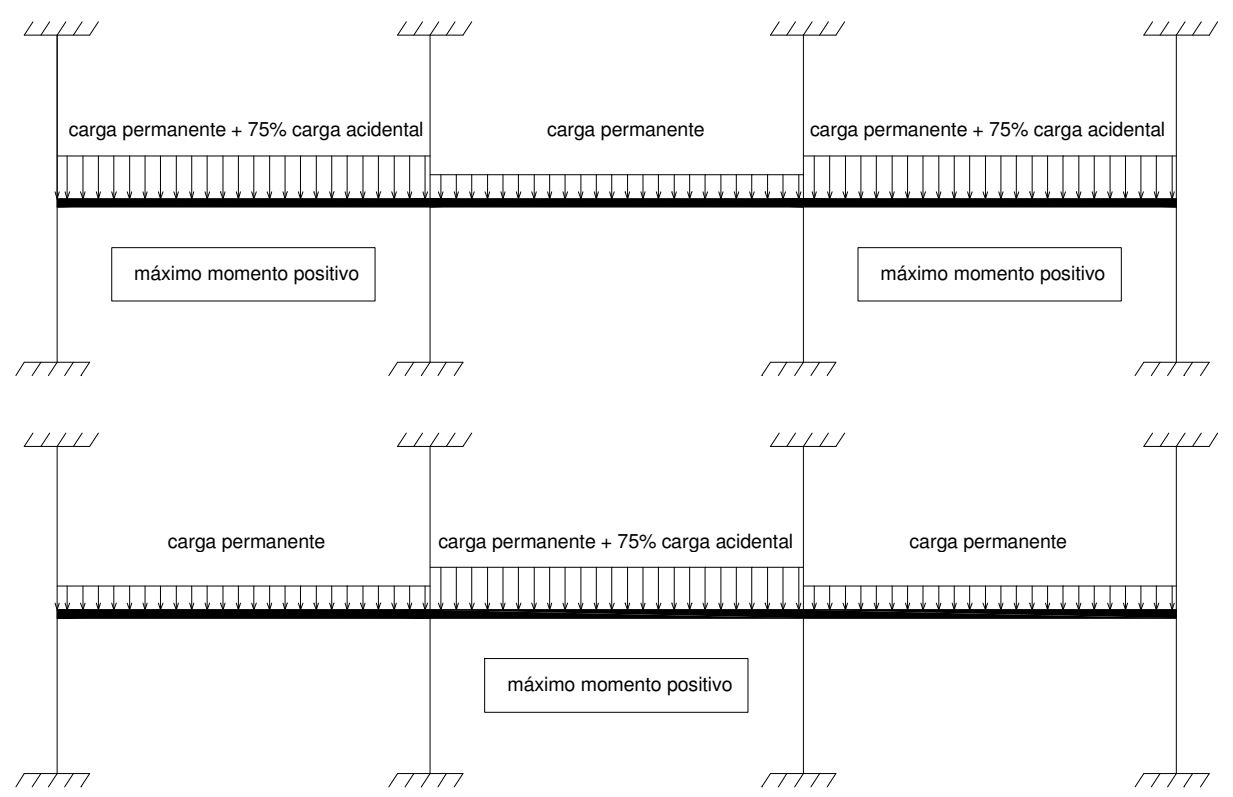

FIGURA 2.35: Determinação dos máximos momentos positivos em Pórticos Virtuais

[GUARDA (1995)]

b) carga permanente em todos os vãos e $75 \%$ da carga acidental em vãos adjacentes, de acordo com a Figura 2.36, para se determinar os momentos negativos atuantes nos vãos.

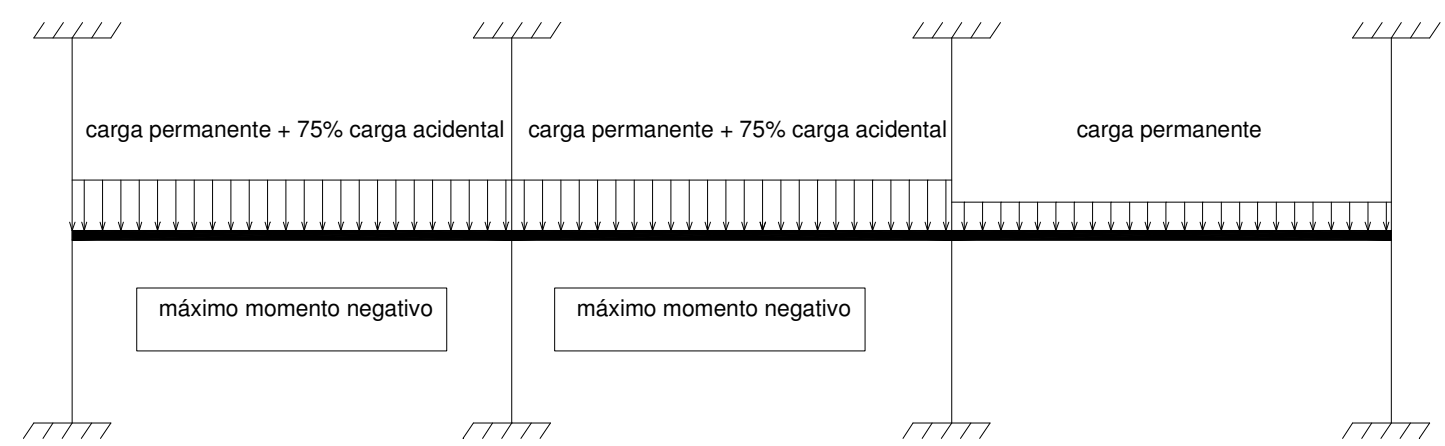

FIGURA 2.36: Determinação dos máximos momentos negativos em Pórticos Virtuais

[GUARDA (1995)]

De acordo com NAWY (1995) outra forma de verificar as condições máximas de esforços é a alternância de tramos carregados e descarregados da totalidade da carga acidental, verificando-se as inúmeras possibilidades de combinações e os resultados de esforços apresentados. 


\subsubsection{Os parâmetros elásticos do concreto armado no Método dos Pórticos Equivalentes}

a) Módulo de deformação longitudinal do concreto

Segundo o projeto de revisão da NBR6118/2000:

$\mathrm{E}_{\mathrm{cs}}=0,85 . \mathrm{E}_{\mathrm{c}} \quad[\mathrm{MPa}]$

sendo:

$\mathrm{E}_{\mathrm{c}}=5600 .\left(\mathrm{f}_{\mathrm{ck}}\right)^{1 / 2} \quad[\mathrm{MPa}]$

$\mathrm{E}_{\mathrm{cs}}$ : módulo de elasticidade secante do concreto;

$\mathrm{E}_{\mathrm{c}}$ : módulo de elasticidade tangente do concreto;

$\mathrm{f}_{\mathrm{ck}}$ : resistência característica do concreto à compressão.

\section{b) Módulo de deformação transversal do concreto}

No projeto de revisão da NBR 6118/2000 tem-se que o módulo de deformação transversal do concreto também é calculado adotando $v=0,20$, resultando:

$\mathrm{G}_{\mathrm{c}}=0,4 \cdot \mathrm{E}_{\mathrm{cs}}=1904 \cdot\left(\mathrm{f}_{\mathrm{ck}}\right)^{1 / 2} \quad[\mathrm{MPa}]$

onde:

$\mathrm{G}_{\mathrm{c}}$ : módulo de elasticidade transversal do concreto.

TAKEYA (1985) sugere adotar $\mathrm{G}_{\mathrm{c}}=0,15 \cdot \mathrm{E}_{\mathrm{cs}}$.

\subsubsection{Determinação dos esforços nos Pórticos Equivalentes}

Tendo sido determinadas as rigidezes da coluna equivalente e das faixas de laje a análise dos pórticos equivalentes pode ser realizada por qualquer método, como exemplo o Processo de Cross, que considera uma distribuição de momentos a partir das rigidezes dos elementos de barra concorrentes aos nós aplicando-se um determinado coeficiente de transmissão de momentos para se fazer o equilíbrio, conforme SUSSEKIND (1978).

Além do processo de transmissão de momentos para o cálculo hiperestático os pórticos podem ser calculados através de programas computacionais desenvolvidos para a análise de pórticos planos e que utilizam qualquer processo numérico, aplicando-se aí as rigidezes calculadas, como o ANSYS 5.5. 
O esquema estrutural utilizado pode ser aquele apresentado por IKEDA et al. (2000), de acordo com a Figura 2.37. Esse modelo de pórtico equivalente plano é uma estrutura dividida em uma malha de elementos de barra bidimensionais ligados a nós, tanto na laje-viga (ou faixa de laje) quanto nos pilares, podendo ser colocadas barras de inércia diferentes. Assim, a laje-viga é dividida em 05 partes para cada vão. O primeiro nó da lajeviga é colocado no eixo do pilar, o segundo na face do pilar, o terceiro na extremidade do capitel ou ábaco. A inércia para cada faixa de apoio (faixas dentro dos pilares e faixas dos ábacos), como anteriormente discutido, é resultado da inércia da faixa de laje-viga que faz fronteira com a face de cada elemento de apoio dividida pelo fator $\left(1-c_{2} / l_{2}\right)^{2}$. Para os pilares os dois primeiros nós correspondem ao eixo da laje-viga inferior e topo da mesma. O último nó de cada pilar é colocado no eixo da laje a ser calculada e a estrutura possui restrições apenas nos nós extremos dos pilares.

As peças torcionais são consideradas implicitamente através da redução da inércia dos pilares através dos coeficientes calculados posteriormente.

A inércia dos pilares na região entre a face superior da laje de piso e a meia altura da mesma deve ser considerada infinita. $\mathrm{O}$ mesmo serve para a região limitada entre a face inferior e o eixo da laje, de acordo com a Figura 2.37.

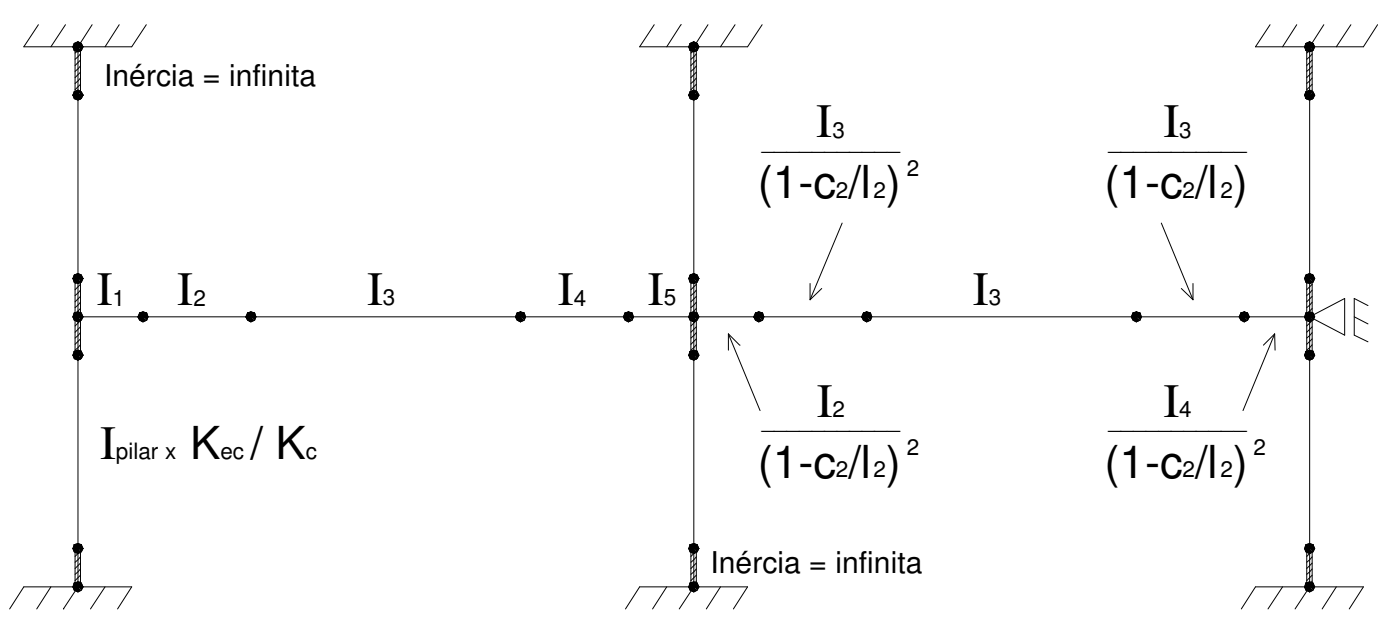

FIGURA 2.37: Modelo de Pórtico Equivalente Plano

[IKEDA et al. (2000)] 


\subsubsection{Distribuição dos momentos fletores entre as faixas de laje}

Calculados os momentos fletores que atuam nas faixas de laje através de algum processo que resolva o pórtico plano os momentos devem ser distribuídos às faixas.

A distribuição dos momentos do pórtico equivalente entre as faixas de laje dos painéis vai depender da relação entre os vãos teóricos da laje e seguirá a Tabela 2.1: Fatores de Multiplicação dos Momentos para Distribuição entre as Faixas.

Se a relação entre o maior vão teórico "a" e o menor "b" for menor ou igual a 4/3, então os momentos serão distribuídos de acordo com a Tabela 2.1, caso 01 .

Se a relação a/b for maior que $4 / 3$ devem ser então analisadas as seguintes situações:

a) se os momentos estiverem sendo calculados na direção do lado menor a distribuição dos momentos será feita também de acordo com a Tabela 2.1, caso 01;

b) se os momentos estiverem sendo calculados na direção do lado maior a distribuição de momentos será conforme a Tabela 2.1, caso 02 .

TABELA 2.1: Fatores de Multiplicação dos Momentos para Distribuição entre as Faixas

\begin{tabular}{|c|c|c|c|c|c|}
\hline \multirow[t]{2}{*}{ Faixa } & \multirow[t]{2}{*}{ Caso } & \multicolumn{2}{|c|}{ Painéis internos } & \multicolumn{2}{|c|}{$\begin{array}{l}\text { Painéis externos } \\
\text { (momentos negativos } \\
\text { sobre o apoio } \\
\text { externo) }\end{array}$} \\
\hline & & $\begin{array}{c}\text { Momentos } \\
\text { negativos }\end{array}$ & $\begin{array}{c}\text { Momentos } \\
\text { positivos }\end{array}$ & Caso A & Caso B \\
\hline \multirow{2}{*}{ Faixa lateral } & Caso 01 & 0,76 & 0,60 & 0,80 & 0,60 \\
\hline & Caso 02 & 0,66 & 0,50 & 0,73 & 0,50 \\
\hline \multirow{2}{*}{ Faixa central $^{* *}$} & Caso 01 & 0,24 & 0,40 & 0,20 & 0,40 \\
\hline & Caso 02 & 0,34 & 0,50 & 0,27 & 0,50 \\
\hline
\end{tabular}

* Os demais momentos devem ser distribuídos como nos painéis internos

** Neste caso, faixa central se refere às duas meias faixas centrais de cada pórtico múltiplo cabendo, portanto, a cada uma a metade dos seus valores obtidos com o uso da tabela.

Assim, para a Tabela 2.1 valem as seguintes observações:

a) CASO 01: situações onde $a / b \leq 4 / 3$ ou $a / b>4 / 3$ se os momentos estiverem sendo calculados agindo na direção do lado menor; 
b) CASO 02: situações onde $\mathrm{a} / \mathrm{b}>4 / 3$ e os momentos estiverem sendo calculados agindo na direção do lado maior;

c) CASO A: placa apoiada na borda sobre os pilares;

d) CASO B: placa apoiada na borda sobre parede de concreto armado ou sobre vigas com altura maior ou igual a três vezes a espessura da placa.

TESORO (1991) apresentou uma distribuição de esforços mais específica, de acordo com a posição da faixa de laje equivalente na planta do pavimento e que independe da geometria do vão, podendo ser visualizado na Figura 2.38.

\begin{tabular}{|c|ccccc||c||}
\hline & Faixa apoio & $80-90 \%$ & $60 \%$ & $76 \%$ & $60 \%$ & $76 \%$ \\
\hline
\end{tabular}

Figura 2.38: Porcentagens de distribuição de momentos de acordo com a posição da faixa dentro do pavimento no Método dos Pórticos Equivalentes

[TESORO (1991)]

\subsubsection{O Método dos Pórticos Virtuais para o cálculo dos deslocamentos elásticos}

Apesar do projeto de revisão da NBR 6118/2000 nada citar sobre a possibilidade do cálculo dos deslocamentos das lajes sem vigas através do Processo de Pórticos Múltiplos ou qualquer outro método de pórticos bidimensionais tem-se a possibilidade do cálculo por tal processo, segundo a bibliografia pesquisada. 
TESORO (1991) afirmou que o cálculo do deslocamento ortogonal ao plano da placa em sistemas estruturais reticulados como a laje nervurada sem vigas é um problema complexo por todos os fatores que intervém no mesmo: os próprios do material, concreto armado, e os específicos do sistema estrutural.

De acordo com o ACI-435 (1989) pode ser aplicado um método desenvolvido pela Universidade de Illinois, Estados Unidos, para o cálculo dos deslocamentos de lajes através da consideração de pórticos equivalentes.

Por esse processo as faixas de laje não são consideradas apoiadas diretamente nos pilares, mas em faixas limitadas por linhas de inflexão locadas aproximadamente a 0,20.1 das linhas de centro de apoios, sendo $1=$ distância entre eixos de pilares, como mostrado na Figura 2.39.

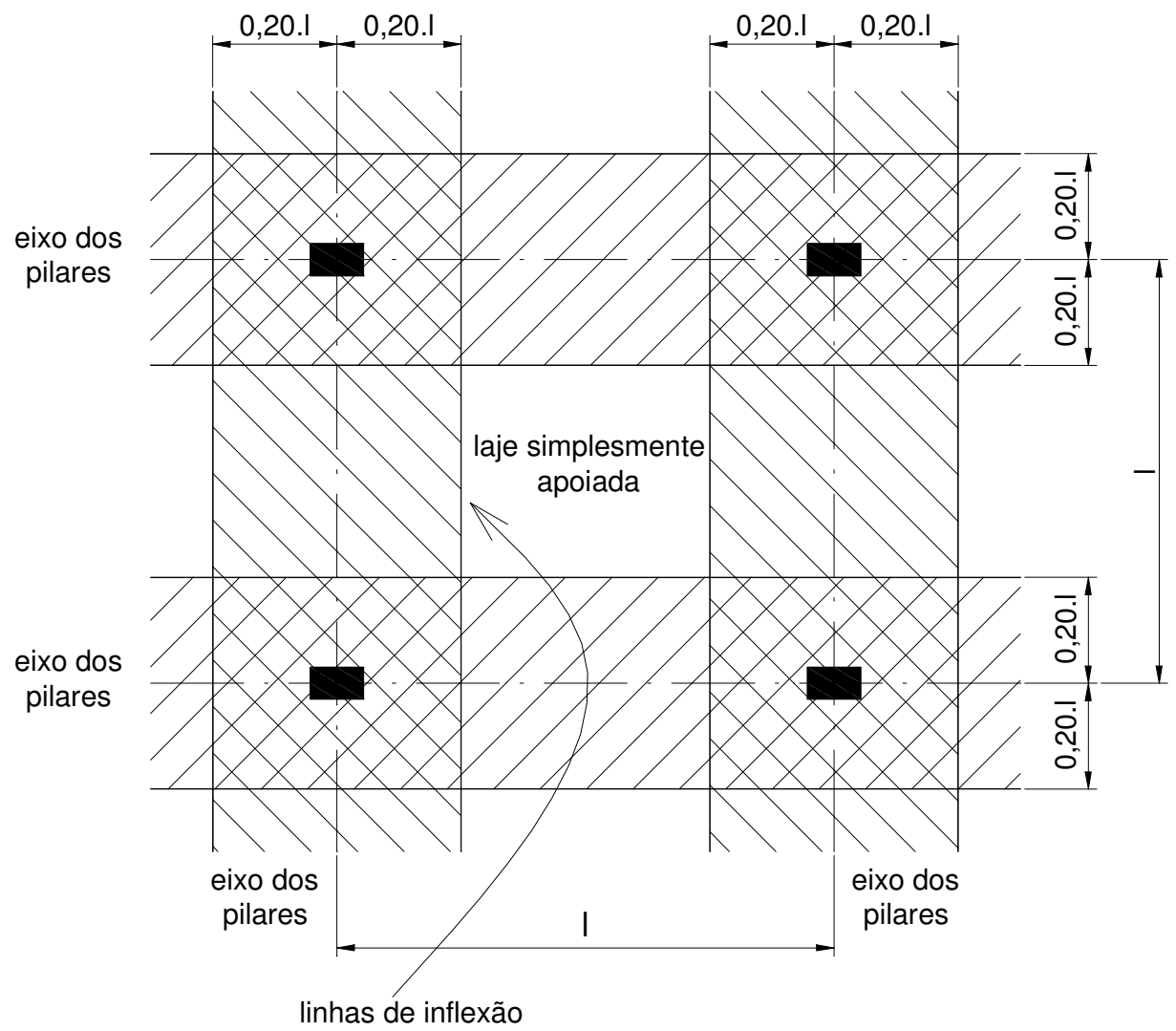

FIGURA 2.39: Pórticos equivalentes para o cálculo dos deslocamentos segundo o ACI-435 (1989)

De acordo com NAWY (1995) a faixa limitada pelas linhas de inflexão podem ser consideradas dentro desses limites locados a 0,25.1. 
A porção da placa no centro do painel limitada aproximadamente pelas linhas de inflexão pode ser analisada como uma laje simplesmente apoiada, com esforços solicitantes nas duas direções.

As faixas de laje limitadas pelas linhas de inflexão são analisadas como vigas, agindo o efeito dos momentos solicitantes. $\mathrm{O}$ carregamento assumido para a análise das vigas é igual a soma do carregamento diretamente aplicado mais as reações de apoio da porção central da laje, aplicadas nas linhas de inflexão.

Neste processo de cálculo aproximado dos deslocamentos a deformação de um painel terá a contribuição das duas direções ortogonais, $\mathrm{x}$ e y.

Inicialmente, o deslocamento angular devido ao momento na direção x é computado.

A seguir o deslocamento devido ao momento na direção y é encontrado. $\mathrm{O}$ deslocamento da linha central da faixa pode ser obtido pela soma do deslocamento no centro do vão da faixa de apoio na direção do seu eixo ( $\delta a)$, cujo funcionamento é o de uma viga; do deslocamento da linha de inflexão $(\delta b)$ e da da laje simplesmente apoiada $(\delta c)$, ambas na direção ortogonal ao primeiro deslocamento, de acordo com a Figura 2.40.

linha da laje descarregada

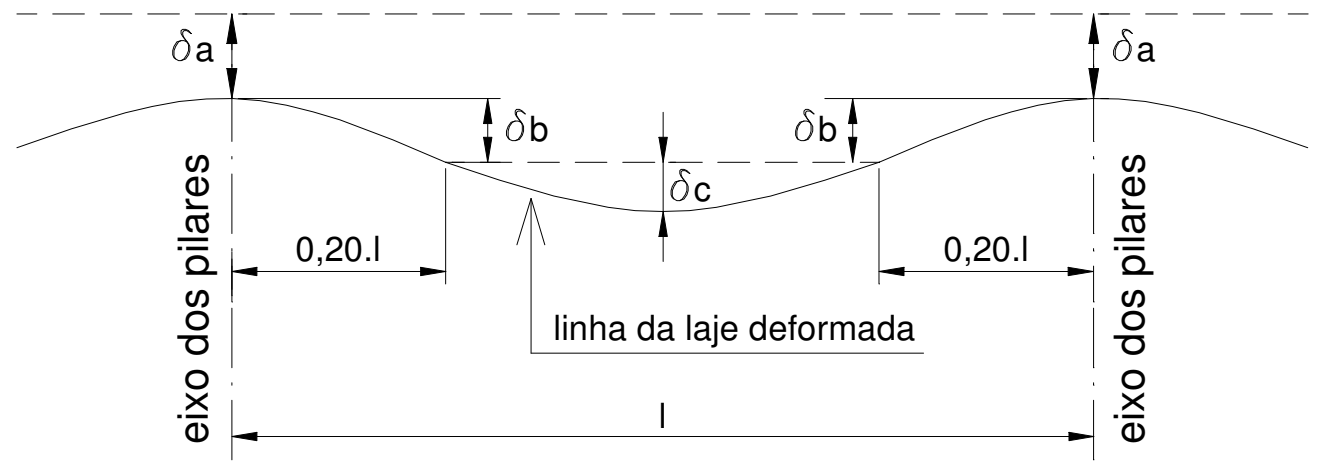

FIGURA 2.40: Parcelas de contribuição ao deslocamento no centro da placa segundo o ACI435 (1989) para o Método dos Pórticos Equivalentes

O deslocamento no ponto central para o painel analisado é dado então pela soma dessas três componentes, implícitas no processo apresentado a seguir:

a) calcula-se o deslocamento básico no ponto central do painel, considerando-o simplesmente apoiado nas bordas, para os eixos x e y, dada por:

$$
\delta^{\prime}=\frac{\mathrm{w} \cdot \mathrm{I}^{4}}{384 \cdot \mathrm{E}_{\mathrm{cs}} \cdot \mathrm{I}_{\mathrm{cs}}}
$$

onde: 
w: carregamento uniformemente distribuído na laje;

1: lado paralelo a direção de cálculo da flecha;

$\mathrm{E}_{\mathrm{cs}}$ : módulo de deformação longitudinal secante do concreto da laje;

$\mathrm{I}_{\mathrm{cs}}$ : momento de inércia da faixa de laje do pórtico equivalente.

Com isso, pode-se separar as parcelas de deslocamento $\delta_{\mathrm{c}}$ da faixa de apoio e $\delta_{\mathrm{s}}$ da faixa central de laje, dadas por:

$$
\begin{aligned}
& \delta_{\mathrm{c}}=\delta^{\prime} \cdot \frac{\mathrm{M}_{\text {apoio }}}{\mathrm{M}_{\text {pórtico }}} \cdot \frac{\mathrm{E}_{\mathrm{cs}} \cdot \mathrm{I}_{\mathrm{cs}}}{\mathrm{E}_{\mathrm{cs}} \cdot \mathrm{I}_{\mathrm{c}}} \\
& \delta_{\mathrm{s}}=\delta^{\prime} \cdot \frac{\mathrm{M}_{\text {laje }}}{\mathrm{M}_{\text {pórtico }}} \cdot \frac{\mathrm{E}_{\mathrm{cs}} \cdot \mathrm{I}_{\mathrm{cs}}}{\mathrm{E}_{\mathrm{cs}} \cdot \mathrm{I}_{\mathrm{s}}}
\end{aligned}
$$

onde:

$\mathrm{I}_{\mathrm{cs}}$ : momento de inércia da faixa de laje do pórtico equivalente;

$\mathrm{I}_{\mathrm{c}}$ : momento de inércia da faixa de apoio;

$\mathrm{I}_{\mathrm{s}}$ : momento de inércia da faixa central de laje.

NAWY (1995) indicou que essas parcelas de momento também podem ser encontradas através do uso de coeficientes de fatoração dos momentos, usuais nos cálculos difundidos nos Estados Unidos e aceitos pelo Código ACI.

b) calcula-se o deslocamento central devido a rotação do ponto de apoio esquerdo, $\delta{ }^{\prime \prime}{ }_{\theta 1}$, considerando o ponto de apoio direito fixo:

$$
\begin{aligned}
& \delta^{\prime \prime} \theta_{1}=\frac{1}{8} \theta_{1} \\
& \theta_{1}=\frac{\mathrm{M}_{\text {pórtico , apoio esquerdo }}}{\mathrm{K}_{\mathrm{ec}}}
\end{aligned}
$$

onde:

$\mathrm{K}_{\mathrm{ec}}$ : rigidez à flexão da coluna equivalente, em momento por rotação unitária.

c) calcula-se o deslocamento central devido a rotação do ponto de apoio direito, $\delta{ }^{\prime \prime}$, considerando o ponto de apoio esquerdo fixo:

$$
\begin{aligned}
& \delta^{\prime \prime} \theta_{\mathrm{r}}=\frac{1}{8} \theta_{\mathrm{r}} \\
& \theta_{\mathrm{r}}=\frac{\mathrm{M}_{\text {pórtico, apoio direito }}}{\mathrm{K}_{\mathrm{ec}}}
\end{aligned}
$$

onde: 
$\mathrm{K}_{\mathrm{ec}}$ : rigidez à flexão da coluna equivalente, em momento por rotação

unitária.

Dessa forma faz-se o cálculo para as duas direções, x e y, o deslocamento para a faixa central interna da laje e para as faixas de apoio externas:

$$
\begin{aligned}
& \delta_{\mathrm{cx}} \text { ou } \delta_{\mathrm{cy}}=\delta_{\mathrm{c}}+\delta^{\prime \prime} \theta_{1}+\delta^{\prime \prime} \theta_{\mathrm{r}} \\
& \delta_{\mathrm{sx}} \text { ou } \delta_{\mathrm{sy}}=\delta_{\mathrm{s}}+\delta^{\prime \prime}{ }_{\theta_{1}}+\delta^{\prime \prime} \theta_{\mathrm{r}}
\end{aligned}
$$

onde:

$\delta_{c x}$ e $\delta_{c y}$ : deslocamentos totais da faixa de apoio nas direções x e y, respectivamente;

$\delta_{\mathrm{sx}}$ e $\delta_{\mathrm{sy}}$ : deslocamentos totais da faixa de laje central nas direções x e y, respectivamente.

O deslocamento total, então, é dado por:

$\Delta=\delta_{\mathrm{cy}}+\delta_{\mathrm{sx}}=\delta_{\mathrm{cx}}+\delta_{\mathrm{sy}}$

onde:

$\Delta$ : deslocamento total no ponto central da laje.

Quando a igualdade não for conseguida o deslocamento aproximado é a média dos dois resultados acima.

De acordo com o ACI-435 (1989) o método, em geral, apresenta bons resultados. Na maioria das vezes, porém, subestima os valores dos deslocamentos elásticos.

Processo semelhante é mostrado em TESORO (1991), desenvolvido por Scanlon \& Murray, a partir do esquema mostrado na Figura 2.41.

Considerando as faixas do método dos pórticos equivalentes obtém-se cargas fictícias $\mathrm{q}_{1}$ e $\mathrm{q}_{2}$ que hipoteticamente atuariam nas faixas sobre os apoios e centrais, respectivamente, correspondentes aos momentos fletores agindo nas mesmas, através das equações:

$$
\begin{aligned}
& \frac{0,76 .\left(M_{\text {apoio direito }}+M_{\text {apoio esquerdo }}\right)}{2}+0,60 \cdot M_{\text {vão }}=\frac{q_{1} \cdot 1^{2}}{8} \\
& \frac{0,24 .\left(M_{\text {apoio direito }}+M_{\text {apoio esquerdo }}\right)}{2}+0,40 . M_{\text {vão }}=\frac{q_{2} \cdot 1^{2}}{8}
\end{aligned}
$$




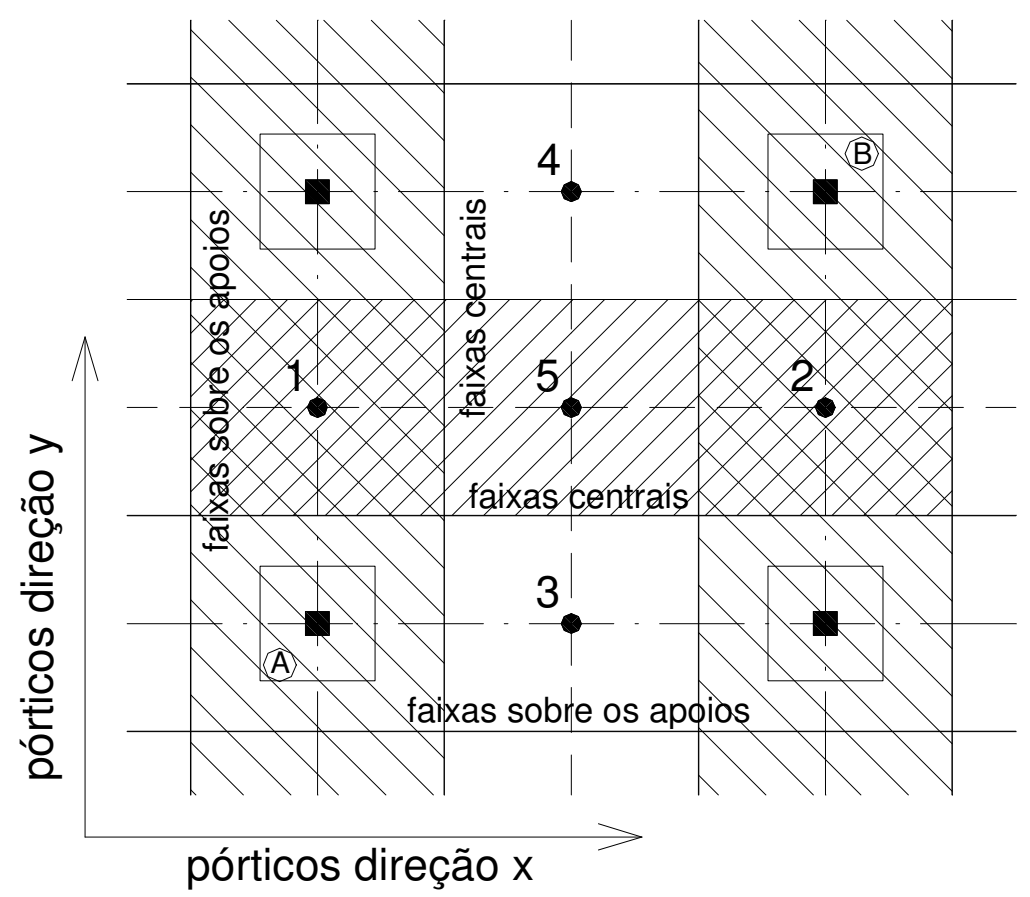

Figura 2.41: Esquema de faixas de Scanlon \& Murray para o cálculo de flechas no Método dos Pórticos Equivalentes [TESORO (1991)]

Considera-se como inércia das faixas sobre os apoios a metade da inércia à flexão proposta por TESORO (1991) para a análise do pórtico, e para as faixas centrais a inércia devida exclusivamente às nervuras, já que não há regiões maciças de concreto.

As flechas instantâneas nos pontos 1,2, 3 e 4, que seriam as flechas que seriam obtidas nas vigas de um piso convencional, podem ser calculadas pela equação abaixo:

$$
\mathrm{f}=\frac{5 \cdot \mathrm{q}_{1} \cdot 1^{4}}{384 . \mathrm{E}_{\mathrm{cs}} \cdot \frac{\mathrm{I}_{1}}{2}}-\frac{0,76 .\left(\mathrm{M}_{\text {apoio direito }}+\mathrm{M}_{\text {apoio esquerdo }}\right) \cdot \mathrm{I}^{2}}{16 \cdot \mathrm{E}_{\mathrm{cs}} \cdot \frac{\mathrm{I}_{1}}{2}}
$$

sendo:

$\mathrm{f}=$ flecha nos pontos $1,2,3$ ou 4 ;

$\mathrm{I}_{1}=$ inércia à flexão da região nervurada, calculada de acordo com TESORO (1991), apresentada na Figura 2.34.

Um primeiro deslocamento parcial no ponto 5 é obtido entre os pontos 1 e 2 , com uma fórmula semelhante à anterior, mas operando com $\mathrm{q}_{2}$ e a inércia das nervuras $\mathrm{I}_{2}$ segundo ora à direção x, e ora à direção $\mathrm{y}$.

$$
\mathrm{f}_{\mathrm{x}}, \mathrm{f}_{\mathrm{y}}=\frac{5 \cdot \mathrm{q}_{2} \cdot \mathrm{l}^{4}}{384 \cdot \text { E. } \mathrm{I}_{2}}-\frac{0,24 .\left(\mathrm{M}_{\text {apoio direito }}+\mathrm{M}_{\text {apoio esquerdo }}\right) \cdot \mathrm{l}^{2}}{16 . \mathrm{E}_{2}}
$$


A flecha instantânea no ponto 5 pode ser estimada como:

$$
\begin{aligned}
& \left\{\begin{array}{l}
\mathrm{f}_{5}^{1}=\frac{\mathrm{f}_{1}+\mathrm{f}_{2}}{2}+\mathrm{f}_{\mathrm{x}} \\
\mathrm{f}_{5}^{2}=\frac{\mathrm{f}_{3}+\mathrm{f}_{4}}{2}+\mathrm{f}_{\mathrm{y}}
\end{array}\right\} \\
& \mathrm{f}_{5}=\frac{\mathrm{f}_{5}^{1}+\mathrm{f}_{5}^{2}}{2}
\end{aligned}
$$

Segundo TESORO (1991), para se ter uma idéia da flecha diferida no tempo, de modo rápido, bastaria multiplicar a flecha instantânea encontrada por dois e então compará-la com os valores permitidos pelas normas técnicas considerando como vão de análise a distância entre os pontos fixos, ou seja, a linha ligando os pilares no sentido A-B, de acordo com a Figura 2.41 anterior. 


\section{CAPÍTULO 3 - A ANÁLISE DAS LAJES NERVURADAS CONSIDERANDO A EXCENTRICIDADE NERVURAS-CAPA DE FORMA MAIS REALISTA}

\subsection{INTRODUÇÃO AO CAPÍTULO 3}

Além dos processos de análise de lajes nervuradas que tratam o sistema de forma simplificada e que podem ser resolvidos por softwares de pórticos planos, grelha bidimensional e outros, tem-se a possibilidade da aplicação do Método dos Elementos Finitos e, dessa forma, utilizar elementos que permitam considerar de forma mais realista a excentricidade existente entre o eixo das vigas e o plano das placas.

Diversos trabalhos já foram escritos sobre a interação placa-viga e suas aplicações à análise de pavimentos, incluindo-se aí pavimentos em laje nervurada. Em muitos deles a influência das excentricidades nos deslocamentos e esforços é o fator essencial de análise.

Apresenta-se neste capítulo uma revisão bibliográfica demonstrando a preocupação de pesquisadores acerca do comportamento estrutural das lajes nervuradas, e de processos de cálculo adequados.

Demonstram-se também as formas de consideração da excentricidade utilizando-se elementos de viga tridimensionais e elementos de casca. 


\subsection{REVISÃO BIBLIOGRÁFICA}

A complexidade de análise do comportamento estrutural de sistemas em lajes nervuradas tem levado alguns pesquisadores a realizar estudos experimentais. Contudo, informações sobre a resistência e comportamento elástico dessas estruturas ainda são bastante limitadas, existindo poucos ensaios em modelos de grande escala.

CORLEY \& MAGURA (1971) efetuaram ensaios de carga até à ruína em uma laje nervurada composta de vários painéis, piso de cobertura do edifício 'Rathskeller Building” no Pavilhão da Bélgica em 1964 -1965, exibido na Feira Mundial de Nova Iorque. Carregamentos uniformes foram aplicados a painéis internos e painéis ao longo do contorno da laje com a finalidade de investigar a resistência ao cisalhamento dos painéis, a resistência das ligações laje-pilar e o efeito de forças axiais na resistência à flexão. Segundo os pesquisadores o comportamento da estrutura esteve de acordo com as teorias de projeto existentes. Os deslocamentos medidos tiveram boa concordância com aqueles calculados por meio de análise pelo Método dos Pórticos Equivalentes, o qual concluíram ser um método confiável na previsão dos deslocamentos no centro de painéis, apesar de trabalhoso.

KENNEDY \& EL-SEBAKHY (1982) estudaram a capacidade de carga de pontes de laje nervurada armada e protendida de forma retangular e com nervuras esconsas, sob carga de trabalho (análise em serviço) e carga de ruptura. Os resultados experimentais de ensaios em dois modelos ortótropos em concreto armado na escala 1/8 com duas bordas apoiadas e duas livres, ambas paralelas, foram comparados com resultados de análises elásticas e de carga última. As relações entre carga e deslocamentos e entre carga e deformações foram apresentadas. Os resultados teóricos e experimentais mostraram boa concordância até a carga de fissuração, como esperado, começando a divergir a partir da microfissuração do concreto. Notaram que, sob carga pontual, há uma excelente distribuição transversal de carga, já que as deformações medidas nas nervuras transversais foram significantes. Nos dois modelos as fissuras foram normais às nervuras longitudinais e geradas predominantemente por flexão. Concluíram que a Teoria Clássica da Placa Ortótropa Equivalente aplicada sob a resolução de Séries de Fourier pode ser usada com confiança para estimar o comportamento elástico de pontes em lajes nervuradas.

AJDUKIEWICZ \& KLISZCZEWICZ (1986) apresentaram resultados obtidos em ensaios de modelos de lajes enrijecidas por nervuras e sem vigas rígidas em grande escala (1/3), com balanços ao longo de dois lados adjacentes, suportadas por 12 colunas aplicadas em capitéis maciços. Indicaram que nenhum experimento ou investigação analítica tem satisfatoriamente confirmado os resultados das aproximações permitidas pelas 
normas técnicas para análise destas estruturas, como a transformação em uma laje maciça equivalente em inércia. Verificaram que a diferença já é significativa para painéis internos e aumenta para os painéis externos de uma laje, e quanto menor o número de vãos em alguma direção, maior a diferença na distribuição das forças internas entre as lajes maciças e as nervuradas. Daí a importância de um estudo numérico visando encontrar uma relação de $\mathrm{a}_{1} / \mathrm{l}$, sendo $\mathrm{a}_{1}=$ espaçamento entre os enrijecedores e 1 = comprimento do lado, que garanta o uso da Teoria da Placa Ortótropa Equivalente no cálculo de lajes nervuradas.

KLEIN \& SELISTRE (1997) apresentaram o comportamento experimental de uma laje nervurada executada em modelo reduzido, na escala 1/7,5 e em microconcreto armado, construída de forma semelhante a um protótipo empregado em edifícios. Mediram deslocamentos ortogonais ao plano da placa e determinaram momentos fletores em determinadas seções transversais. Compararam os resultados experimentais com resultados numéricos através de diversas modelagens: MEF, Análise de Grelha e Pórticos Equivalentes. Concluíram que a consideração da resistência à torção tem importante influência no cálculo dos deslocamentos e que nenhum dos métodos de cálculo usados para a determinação dos deslocamentos foram adequados, já que as análises numéricas foram elásticas, não acompanhando o comportamento do concreto fissurado. A correção nos deslocamentos proposta pelo Comité Euro-Internacional du Béton, CEB, buscando um comportamento de não-linearidade física, resultou em deslocamentos maiores que os experimentais em pontos de menor área de aço no modelo. Verificaram também que a laje nervurada apresentou um comportamento linear físico na zona do microconcreto comprimido e não-linear nas zonas de maior tração.

CARRIJO \& PAIVA (1997) apresentaram um estudo numérico e experimental da interação placa-viga, ensaiando uma placa de acrílico com capa de espessura $0,88 \mathrm{~cm}$ e dimensões $90 \mathrm{~cm}$ x $90 \mathrm{~cm}$ em planta, enrijecida por vigas de seção transversal de $0,82 \mathrm{~cm} \times 4 \mathrm{~cm}$. Nas análises numéricas foram utilizados os seguintes modelos: tridimensional, utilizando elementos de casca e modelo composto de placas e vigas considerando-se ou não a excentricidade da viga em relação à placa. Afirmaram que a melhor forma de modelar um pavimento em lajes nervuradas é considerar a estrutura como tridimensional formada por lâminas trabalhando em flexão e tensão, e utilizar elementos finitos de casca. Segundo os pesquisadores, devido ao caráter não-prático desse modelo, foram desenvolvidas algumas formulações para a consideração das excentricidades. Mesmo assim, devido ao fato de que o deslocamento axial das vigas está relacionado aos deslocamentos do plano médio da placa, esta última precisa ser modelada com o elemento de casca. Contudo, essa modelagem ainda não garante a compatibilidade de deformações na 
ligação placa-viga, sempre existindo algum erro de modelagem. Concluíram que a excentricidade das vigas em relação à placa de pavimentos leva a um enrijecimento da estrutura como um todo e que essa consideração conduz à resultados bem próximos dos obtidos na análise tridimensional.

ABDUL-WAHAB \& KHALIL (2000) apresentaram os resultados de um estudo experimental de 6 modelos de lajes nervuradas quadradas, simplesmente apoiadas e em grande escala (1/4), variando-se o espaçamento e a altura das nervuras. No estudo foram avaliadas as rigidezes na fase elástica não-fissurada (estádio I) e fase elástica fissurada (estádio II) do concreto, além da validade do conceito de Espessura Equivalente, através de ensaios comparativos entre duas lajes nervuradas e de duas lajes maciças correspondentes com espessura equivalente.

Concluíram que a Teoria da Placa Ortótropa Equivalente apresenta estimativas satisfatórias do comportamento das lajes, contudo envolve um procedimento trabalhoso na determinação da rigidez à torção. Demonstraram que o Método da Espessura Equivalente modificado para ser aplicado nas fases elástica fissurada e não-fissurada do concreto fornece valores moderadamente maiores para as rigidezes do que aqueles obtidos na análise experimental. Assim, propuseram um método aproximado e simplificado baseado no "Módulo de Elasticidade Efetivo", o qual forneceu r igidezes seguras e razoavelmente próximas dos resultados experimentais para o material concreto armado.

Além de ensaios experimentais, encontram-se na literatura artigos que descrevem estudos teóricos da interação placa-viga, aplicando-se diversos processos numéricos para a análise, e considerando hipóteses das mais variadas. A seguir apresentamse aquelas que consideram a análise elástica e de primeira ordem geométrica, hipóteses também adotadas neste trabalho.

ROSSOW \& IBRAHIMKHALIL (1978) apresentaram um processo denominado Método da Restrição para a análise estática, utilizando o MEF, de lajes enrijecidas por nervuras excêntricas e concêntricas. O Método da Restrição aplicado a elementos finitos consiste no desenvolvimento de uma hierarquia de elementos em um programa único que apresenta convergência com respeito tanto ao decréscimo do tamanho do elemento quanto ao acréscimo da ordem da função polinomial aproximadora. O usuário do método pode especificar a ordem do polinômio a ser utilizado nas funções aproximadoras dos deslocamentos. O campo de deslocamentos do enrijecedor é expresso em termos dos deslocamentos do plano médio da placa e, superpondo-se a energia de deformação da placa e das nervuras tem-se a matriz de rigidez da estrutura composta. 
Os pesquisadores analisaram duas lajes nervuradas sob carga estática transversal com enrijecedores ora excêntricos, ora concêntricos. Encontraram diferenças elevadas entre os valores de deslocamento ortogonal ao plano das placas máximo pelas duas considerações, a maior para as nervuras concêntricas: 233,28\% para laje quadrada com um enrijecedor, sob carga uniformemente distribuída e $173 \%$ para laje retangular com dois enrijecedores, sob cargas distribuída e pontual. Em todas as análises a consideração do enrijecedor excêntrico aumentou a rigidez do sistema.

MILLER (1980) indicou que a função de forma linear usual para aproximar o deslocamento axial em uma viga discretizada por elementos finitos usados em enrijecedores excêntricos levava a uma inconsistência, gerando erros nos valores dos deslocamentos das placas. $\mathrm{O}$ autor contornou este problema introduzindo um grau-deliberdade adicional para esses elementos criando, assim, um novo elemento de viga para modelar enrijecedores excêntricos onde os deslocamentos nodais foram considerados como "variáveis escravas" enquanto os deslocamentos da placa tornaram -se as "variáveis mestres", permitindo o uso de um polinômio quadrático para a função de forma do deslocamento axial.

De acordo com o pesquisador as nervuras das placas produzem resistência tanto axial quanto à flexão na deformação. O erro é uma conseqüência da incompatibilidade entre o campo de deslocamento axial do elemento de viga quando o eixo central é excêntrico em relação ao plano médio da placa.

Na opinião do pesquisador não há dificuldades em incorporar estes graus-deliberdade adicionais em problemas onde a contribuição dos enrijecedores excêntricos é significativa.

KANOK-NUKULCHAI \& GILANI (1981) investigaram o comportamento de uma laje nervurada submetida a um carregamento transversal ao plano da placa por meio de uma série de análises tridimensionais envolvendo o conceito de "macroelemento", ou seja, a consideração de cada célula de laje nervurada como um elemento finito com determinado modo de deformação.

Apresentaram também um estudo do comportamento de uma laje enrijecida no que diz respeito à contribuição dos componentes individuais na rigidez total da estrutura. Em geral, a resposta de uma laje nervurada submetida a carregamentos transversais é resultado de uma participação mútua de três componentes estruturais distintos:
a) grelha das vigas;
b) flexão da placa;
c) efeito de membrana da placa. 
Para entender a ação integrada desses componentes estruturais analisaram numericamente uma laje nervurada por um modelo tridimensional em MEF submetida a carga uniformemente distribuída. A análise foi dividida em três partes:

a) análise apenas da grelha de vigas;

b) elementos no estado plano de tensão foram adicionados no nível da placa fornecendo, assim, uma percepção da interação viga-membrana e do mecanismo de rigidez adicional conferida;

c) finalmente, a rigidez à flexão da placa foi superposta ao elemento em estado plano de tensão para uma completa compatibilização do modelo tridimensional.

Verificaram que há um aumento considerável na rigidez total da estrutura com a adição do efeito de membrana da placa à grelha de vigas. Atribuíram isso a grande rigidez no plano da placa que impede que as fibras do topo de cada viga movimentem-se livremente no plano horizontal, limitando dessa forma a flexão e a torção da grelha de vigas tridimensionais. A inclusão da resistência à flexão da placa apenas fornece um acoplamento local entre os graus de liberdade da placa e das vigas. $\mathrm{O}$ aumento da rigidez total da estrutura devido a este efeito é de caráter, segundo os pesquisadores, simbólico.

PENG-CHENG et al. (1987) apresentaram um método semi-analítico usando funções 'B-Spline" para analisar o comportamento estático de placas enrijecidas. Forneceram resultados numéricos de deslocamentos e momentos fletores na capa de uma placa quadrada enrijecida por duas nervuras ortogonais e com contornos fixos sujeita a uma carga uniformemente distribuída, e compararam-los com resultados experimentais de uma placa concêntrica.

DEB \& BOOTON (1987) apresentaram modelos em MEF baseados na teoria de Distorção por Cisalhamento de Mindlin (que leva em conta a consideração da deformação transversal) para a análise de lajes enrijecidas excentricamente sujeitas a cargas transversais. De acordo com os pesquisadores, a análise em MEF de placas com enrijecedores pode ser feita adequadamente por dois modelos:

a) um modelo geral em que o sistema de placa enrijecida pode ser discretizada como placas e vigas;

b) um método restrito onde os enrijecedores são pouco espaçados e a laje enrijecida pode ser substituída por uma placa equivalente isótropa ou ortótropa com espessura constante.

O primeiro método mencionado fornece, obviamente, resultados mais precisos. Entretanto, de acordo com os autores, o segundo pode algumas vezes ser preferível, 
especialmente em uma análise não-linear física, em termos de economia de tempo de processamento computacional, bem como na simplicidade da entrada de dados.

HARIK \& SALAMOUN (1988) aplicaram o Método Analítico de Faixas à placas retangulares enrijecidas por nervuras. Idealizaram a placa como um sistema de faixas de laje e segmentos de viga rigidamente conectados e o comportamento do sistema foi encontrado impondo-se à fronteira condições de continuidade nas soluções de forma dos elementos individuais: faixas de laje e segmentos de vigas. A desvantagem do processo é que o mesmo considera a nervura sempre concêntrica ao plano médio da placa, já que assume-se que a viga e a placa, na região de encontro dos mesmos, fundem-se em uma linha infinitesimal contidas no mesmo plano cartesiano.

DEB et al. (1990) aplicaram uma formulação ortótropa à análise de placas com nervuras excêntricas baseada na Teoria de Placa de Reissner-Mindlin, comparando os resultados com aqueles obtidos de um modelo discreto de placa-viga. Devido a décima ordem das equações governantes nesta formulação, que as tornaram praticamente impossíveis de serem utilizadas em soluções analíticas, os autores aplicaram o Método dos Elementos Finitos.

Concluíram que o parâmetro de excentricidade $h_{w} / h_{f}$ utilizado nas formulações, onde $h_{w}=$ altura do enrijecedor $e h_{f}=$ espessura da placa, tem um efeito significativo nos resultados. Observaram que com o aumento da relação da excentricidade a flecha w diminui, como esperado. Concluíram também que para baixos níveis de carga as tensões não parecem variar muito com a relação de excentricidade $h_{w} / h_{f}$. Entretanto, para altas cargas, as diferenças nas tensões são bastante notáveis para diferentes valores de $h_{w} / h_{f}$, com tensões mostrando acréscimos com o aumento dos valores da relação, ou seja, com o aumento da excentricidade. Neste trabalho será investigada a influência da relação altura do enrijecedor por altura da placa nos resultados de análise dos diversos modelos mecânicos propostos.

PALANI et al. (1992) propuseram dois elementos finitos isoparamétricos (elementos com formas arbitrárias que utilizam a mesmas funções de interpolação para representar a geometria do elemento e os deslocamentos no seu domínio) para a análise estática de placas e cascas com enrijecedores excêntricos.

No artigo foram feitos estudos numéricos para a análise de placas com nervuras excêntricas e concêntricas para validar os elementos finitos propostos. Apresentou o deslocamento ortogonal ao plano da placa ao longo da linha do centro da mesma, e verifica-se grande diferença entre os resultados da análise excêntrica e concêntrica. 
MUKHOPADHYAY (1992) apresentou a aplicação de um método semianalítico desenvolvido inicialmente para lajes maciças à análise de placas enrijecidas retangulares em várias condições de contorno e carregamento, possuindo variados tipos e números de enrijecedores, considerando-os concêntricos e excêntricos. Segundo o autor, a contribuição da nervura excêntrica à placa ocasiona deslocamentos axiais e flexão no plano médio da placa resultando em três equações diferenciais acopladas, que no trabalho foram resolvidas por processo semi-analítico.

No Método em Diferenças Finitas proposto a excentricidade dos enrijecedores geraram três equações diferenciais parciais acopladas envolvendo deslocamentos em três direções ortogonais: u, v e w, que foram assumidos para satisfazer as condições de contorno ao longo de dois lados opostos. Essas funções foram então substituídas dentro das equações diferenciais relevantes que indicavam a exata localização do enrijecedor. Fazendo-se adequada transformação, as equações resultantes foram reduzidas a equações diferenciais ordinárias com coeficientes constantes, resolvidas pela Técnica das Diferenças Finitas.

$\mathrm{O}$ artigo apresentou exemplos, entre eles uma placa quadrada simplesmente apoiada tendo uma única nervura no centro. A análise foi feita considerando a nervura excêntrica e concêntrica e a diferença entre o deslocamento central em ambos os modelos foi de 239,66\%, com maior deslocamento considerando as nervuras concêntricas. A análise do enrijecedor excêntrico também foi feita de dois modos: incluindo e ignorando os deslocamentos segundo o plano da placa. Assim, o deslocamento central diminuiu quando o deslocamento no plano foi ignorado, o que era esperado, já que a rigidez da placa aumenta quando as deformações axiais são ignoradas. A diferença encontrada entre os dois modos foi de $159,03 \%$.

SHEIKH \& MUKHOPADHYAY (1992) apresentaram um Método de Faixas Finitas "Spline" extendido à análise de placas com enrijecedores. Segundo os pesquisadores, o Método de Faixas Finitas apresenta muitas desvantagens, entre elas a aplicação, com facilidade, apenas a lajes de forma regular sem aberturas ou vãos contínuos. Isto porque o método utiliza uma função de viga característica que deve ser continuamente diferenciável, não admitindo dessa forma placas com cargas concentradas, variações de espessura ou outras descontinuidades. No processo apresentado pelos pesquisadores algumas desvantagens do método semi-analítico de Faixas Finitas foram superados, já que utilizou-se uma função cúbica 'B -Spline”, fornecendo também continuidade $C_{2}$. Diz-se que uma função tem continuidade $\mathrm{C}_{2}$ quando suas derivadas até a segunda ordem são contínuas, ou seja, quando existe continuidade até a derivada de segunda ordem do deslocamento. 
Nas análises numéricas os autores demonstraram a importância da consideração da excentricidade no cálculo de placas enrijecidas, gerando assim menores valores de flechas nas estruturas do que se as nervuras forem consideradas concêntricas, e diferenças nos valores de momentos fletores na capa.

NAVARRA (1995) analisou painéis de placas enrijecidas por vigas através do Método dos Elementos Finitos. Considerando o efeito da excentricidade da viga sua própria flexão produzirá deslocamentos do plano médio da placa o que obriga, segundo o autor, a utilizar uma formulação geral de elementos de lâmina plana e de elementos de viga tridimensional, como os elementos de lâmina plana de Reissner-Mindlin e de vigas de Timoshenko, por exemplo.

Admitindo que as vigas giram solidariamente com a laje os movimentos do centro de gravidade das seções das vigas expressam-se em função dos movimentos dos nós do plano médio da laje.

Assim, a laje pode ser modelada com elementos de placa associados a elementos de vigas podendo ser considerados três graus de liberdade: w, $\theta_{\mathrm{x}}$ e $\theta_{\mathrm{y}}$, correspondentes as rigidezes a flexão e à torção. $\mathrm{O}$ autor apresentou um estudo comparativo de uma laje nervurada de ponte calculada pelos seguintes modelos:

a) elementos de lâmina plana de 4 nós para discretizar tanto a placa quanto as vigas;

b) elementos de lâmina plana de 4 nós rigidamente conectados a elementos de viga tridimensionais de Timoshenko, considerando assim a excentricidade;

c) elementos de placa de 4 nós rigidamente conectados a elementos de viga de Timoshenko de dois nós, com largura colaborante de laje, incluindo os efeitos de torção, lançados de forma concêntrica no pavimento.

No exemplo analisado, em termos de tensões, verificou que os resultados mais simplificados gerados pelo modelo c) não erraram mais que $20 \%$ dos obtidos com os outros modelos. O pesquisador concluiu que são válidas as hipóteses de placa rigidamente conectada a vigas sem a consideração da excentricidade, contudo utilizando para as vigas inércias referentes à seção com largura colaborante de laje (ou seção 'T"), de acordo com a Figura 3.1. 


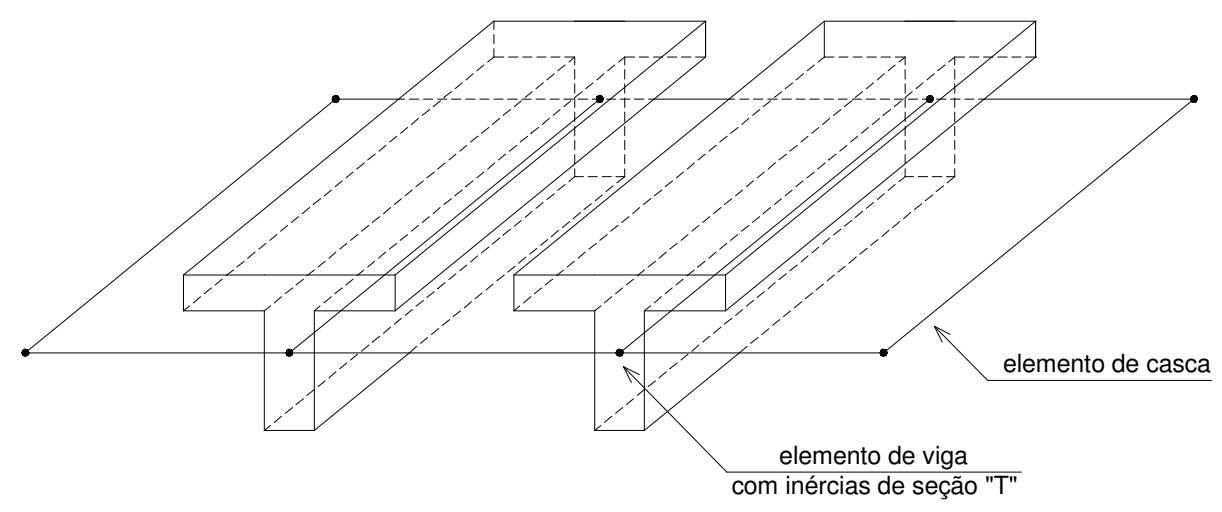

FIGURA 3.1: Modelo apresentado por NAVARRA (1995)

BEDAIR (1997) apresentou uma metodologia para a análise de placas multienrijecidas submetidas a carregamento transversal. Considerou a estrutura como a união de placas e vigas rigidamente conectadas em suas junções. Assim, a energia de deformação para a estrutura foi derivada em termos de generalizadas funções de deslocamentos agindo fora e no plano da placa. Tratando os coeficientes destas funções como variáveis de projeto a Programação Seqüencial Quadrática (SQP) foi então utilizada para determinar a magnitude destes coeficientes que minimizam o potencial total do sistema.

$\mathrm{O}$ artigo oferece exemplos com laje enrijecida, entre eles:

- exemplo 1: placa quadrada simplesmente apoiada tendo uma nervura ao longo do eixo central considerado ora excêntrico, ora concêntrico. A configuração deste painel também foi usada para ilustrar a eficiência da lajes enrijecidas sob carga transversal e comparar a análise discreta com o Método da Placa Ortótropa. Mostrou a diferença na deformada dos dois modelos: para a placa com espessura constante o deslocamento transversal ao plano da placa máximo localizou-se no centro enquanto que na análise discreta o máximo deslocamento não deu-se no centro. A razão foi que, ao longo da linha central, a rigidez à flexão da placa foi melhorada pela rigidez à flexão do enrijecedor. Na verdade tal análise exemplificou que a Teoria da Placa Ortótropa Equivalente só deve ser aplicada a lajes nervuradas com um número suficiente de enrijecedores por lado, variável que será pesquisada neste trabalho.

A diferença entre as análises concêntrica e excêntrica foi de $265,83 \%$ para o maior deslocamento. Assim, o deslocamento aumentou quando considerou-se a nervura simétrica em relação ao plano médio da placa. $\mathrm{O}$ aumento da inércia no caso excêntrico é resultado de uma maior energia de deformação do sistema e daí a um menor deslocamento;

- exemplo 2: placa retangular simplesmente apoiada, com nervuras ortogonais, submetida a cargas distribuída e concentrada. A diferença entre os valores de 
deslocamentos ortogonais ao plano da placa máximos nas análises concêntrica e excêntrica foi de $200 \%$.

TANAKA \& BERCIN (1998) apresentaram uma formulação do Método dos Elementos de Contorno aplicada à análise estática e flexão de placas enrijecidas por vigas de arbitrária seção transversal aberta, modelando as estruturas como placas e vigas rigidamente conectadas ao longo da junção.

Afirmaram que o caso mais geral de modelagem, que cabe em qualquer análise, é aquele em que a placa e o enrijecedor são analisados separadamente, aplicando-se condições de equilíbrio e continuidade ao longo da linha de união entre a placa e a viga.

$\mathrm{O}$ artigo apresentou exemplos, entre eles uma placa conectada a um enrijecedor retangular e simplesmente apoiada. A estrutura foi analisada considerando as nervuras nas configurações excêntrica e concêntrica e a diferença entre os dois modelos foi de $233,72 \%$ nos resultados de deslocamentos ortogonais ao plano da placa.

SIDDIQI \& KUKRETI (1998) apresentaram uma solução pelo Método da Quadratura Diferencial para a análise de flexão de placas enrijecidas sujeitas a cargas uniformemente distribuídas transversais. Consideraram as forças no plano da placa para levar em conta a rigidez axial da placa e a interação entre as vigas e a placa devido à excentricidade, além das rigidezes à torção e ao cisalhamento das vigas. Dois exemplos, um com uma nervura central excêntrica e outro com dois enrijecedores centrais perpendiculares foram analisados e comparados com resultados disponíveis na literatura.

De acordo com os autores quando as nervuras são poucas e bem espaçadas a estrutura age como painéis de placa apoiadas em vigas. As vigas e segmentos de placa podem ser consideradas separadamente, mas apropriada interação deve ser feita entre os dois componentes para que a carga seja resistida coletivamente. Uma forma para que isso seja feito é buscar as soluções independentes de painéis de placa e vigas sujeitas a forças de interação inicialmente desconhecidas entre os dois componentes estruturais. O efeito da torção e do cisalhamento transversal das vigas para a placa são geralmente negligenciados nestes métodos. Além disso, geralmente são apresentadas fórmulas enormes para qualquer cálculo do projeto. Na visão dos pesquisadores o MEF requer grande esforço computacional. Indicaram que a análise de placas enrijecidas torna-se mais complicada quando os enrijecedores são localizados com alguma excentricidade em relação ao plano médio da placa, o que é o caso das lajes nervuradas, e pelo o qual as forças no plano (ou forças axiais) dos segmentos de placa tornam-se significativos por afetar o comportamento total do sistema. 
ASSAN (1999) indicou que, para simplificar a modelagem numérica de placa ligada excentricamente à viga, a análise pode ser feita supondo que o eixo baricêntrico da viga coincide com o lado do plano médio da placa desprezando-se a excentricidade que existe entre os dois. $\mathrm{O}$ erro contido nessa aproximação é tanto maior quanto maior for a excentricidade, como já verificado.

Segundo o pesquisador, uma maneira de contornar este problema é admitir que haja uma barra de rigidez infinita unindo os nós dos elementos de viga aos elementos de placa contidos em planos diferentes, de acordo com a Figura 3.2. Essa barra infinitamente rígida permite que a excentricidade entre os dois nós seja considerada ao se escrever componentes dos deslocamentos de um nó em função das componentes dos deslocamentos nas mesmas direções, no outro nó. Este processo é aplicado quando existe a possibilidade da consideração de "hós mestres" e "nós escravos", ou "offsets rígidos", pelo próprio programa computacional utilizado na análise, já que se modelado de forma manual, ligando-se realmente os nós por uma barra rígida, torna-se operação muito trabalhosa, para a maioria dos problemas.

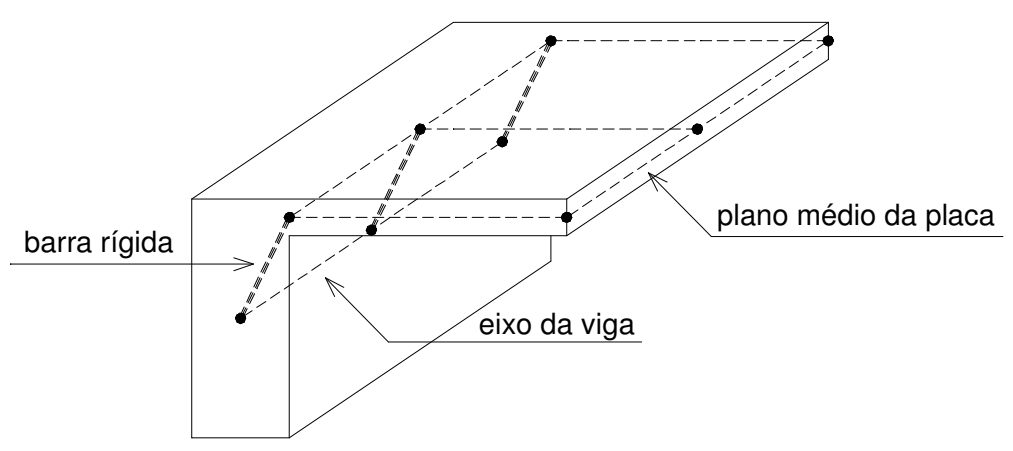

FIGURA 3.2: Consideração da excentricidade mesa-alma através de barra rígida

[ASSAN (1999)]

TANAKA et al. (2000) propuseram uma formulação básica dentro do Método dos Elementos de Contorno para o problema de flexão estática de placas elásticas com enrijecedores onde as forças interativas e os momentos entre a placa e o enrijecedor foram tratados como cargas inicialmente desconhecidas, porém assumindo-as como distribuídas linearmente. $\mathrm{Na}$ implementação numérica estas forças foram aproximadas por uma família de funções interpoladoras.

O método proposto neste artigo pertence a categoria que modela a placa e as nervuras separadamente considerando condições de conectividade, assumindo uma linha de 
contato entre a placa e a nervura. Muitos dos métodos de análise, segundo os autores, empregam a Teoria de Timoshenko, onde a força de cisalhamento equivalente e o momento fletor da placa são considerados como uma força distribuída na linha e um momento na nervura, respectivamente. Eles são expressos em termos do deslocamento na placa e assim aparece na formulação derivadas de quarta-ordem, o que constitui numa desvantagem da teoria.

SAPOUNTZAKIS \& KATSIKADELIS (2000) apresentaram uma solução à análise de placas reforçadas por vigas por meio de um modelo que levava em conta forças agindo no plano da placa e deformações na placa, além de forças axiais e deformações das vigas. As nervuras foram isoladas da placa, seccionadas na face inferior das mesma; assumiram-se forças para a interface capazes de gerar deslocamentos laterais na placa, deformações no plano da placa, deslocamentos laterais nas vigas e deformações axiais nas vigas fornecendo, dessa forma, continuidade ao sistema. Os pesquisadores utilizaram o Método da Equação Análoga (AEM) para a resolução de vigas associadas a placas considerando-as não-linearmente acopladas, encontrando os valores das forças de cisalhamento na interface.

\subsection{A CONSIDERAÇÃO DA EXCENTRICIDADE DE FORMA MAIS REALISTA NESTE TRABALHO}

Pelos artigos apresentados verifica-se que em muitas formulações e análises da interação placa-viga um fator relevante é a consideração da excentricidade que existe entre o eixo longitudinal da nervura e o plano médio da laje, conforme Figura 3.3 .

Contudo, na prática de projetos estruturais, nos escritórios de cálculo, o que se vê é a negligência desta excentricidade, de acordo com a Figura 3.4, ou a sua consideração de forma implícita e simplificada (considerações de seções "T") mesmo dispondo -se de softwares de análise de estruturas em MEF que aceitam a consideração da excentricidade do enrijecedor em relação à placa, seja através de elementos finitos apropriados ou recursos do tipo “mestre -escravo", dependendo apenas do usuário a sua consideração ou não.

Pelos resultados numéricos apresentados pelos pesquisadores revisados na bibliografia a total desconsideração da excentricidade leva à uma subestimada rigidez do pavimento, já que a inércia à flexão dos elementos de barra que representam as nervuras são erroneamente referenciadas, sem nenhuma translação ao plano médio dos elementos de laje. 
Neste trabalho as modelagens mais realistas em Métodos dos Elementos Finitos aplicará a excentricidade de duas maneiras.

A mais simplificada delas consiste em discretizar a placa em elementos finitos de casca tridimensional e modelar as nervuras utilizando um elemento de viga tridimensional que permite a criação de "offsets" rígidos para definir a localização do centróide da seção em relação à localização do nó do elemento. Assim, o elemento linear é lançado no próprio plano dos elementos de casca e, internamente, aceita a excentricidade, de acordo com o Figura 3.5. A excentricidade em relação à placa pode ser encontrada tomandose a nervura até a face inferior da placa ou até a face superior, conforme Figura 3.3.

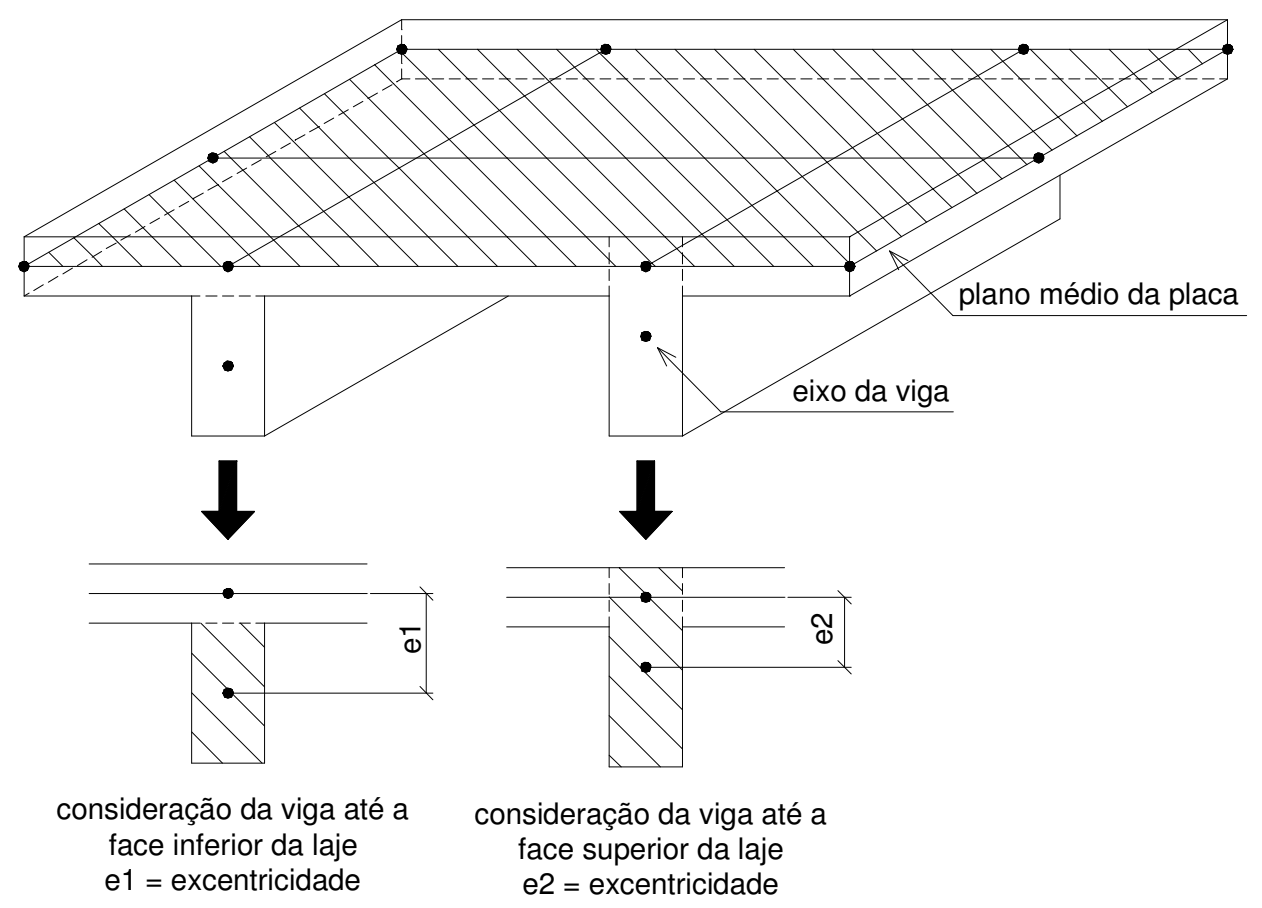

FIGURA 3.3: Consideração da excentricidade entre mesa e alma por meio de elemento finito de viga excêntrica

A forma mais precisa de considerar a excentricidade, contudo, de acordo com CARRIJO \& PAIVA (1997), é uma modelagem em que tanto a placa quanto as nervuras são discretizadas por elemento finito de casca tridimensional e, dessa forma, tem-se naturalmente o comportamento gerado pela excentricidade entre as peças, de acordo com a Figura 3.6. Assim, nenhuma simplificação é feita quanto ao comportamento da seção depois de fletida, como a manutenção da seção plana (ou Hipótese de Bernoulli). 


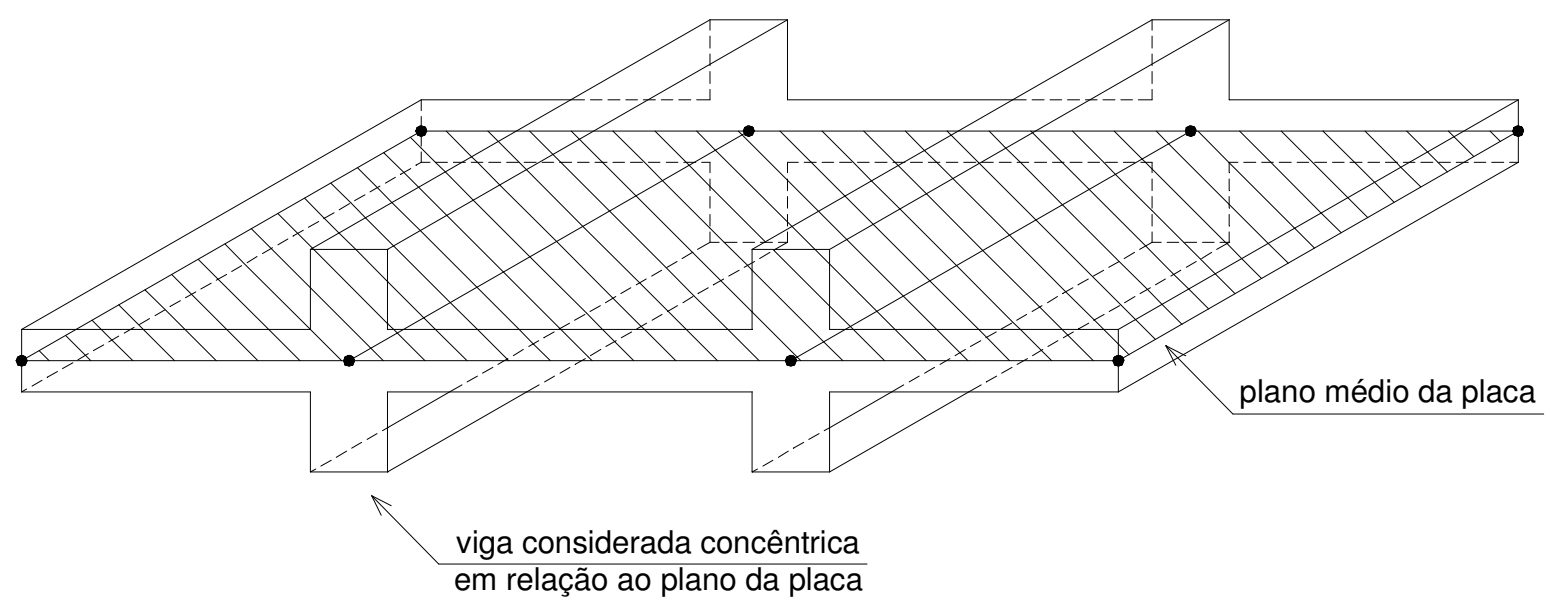

FIGURA 3.4: Negligência da excentricidade entre alma e mesa

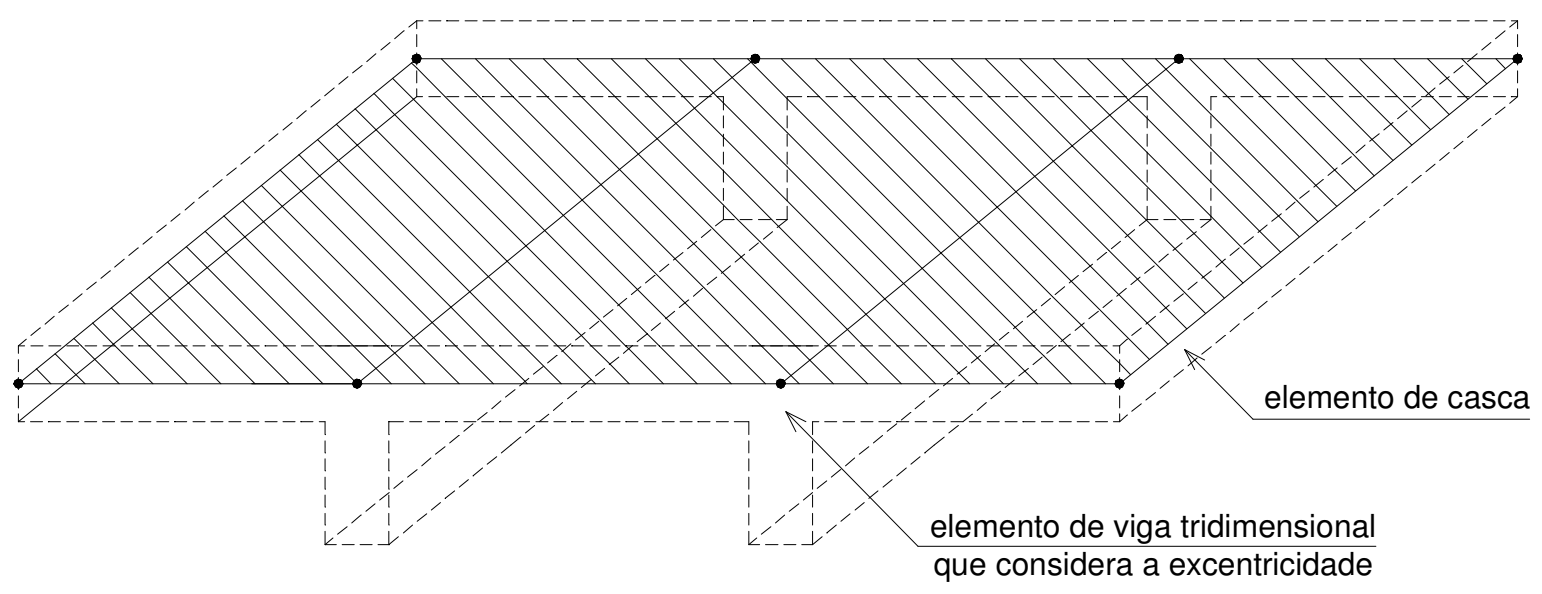

FIGURA 3.5: Elemento finito de viga tridimensional que considera a excentricidade

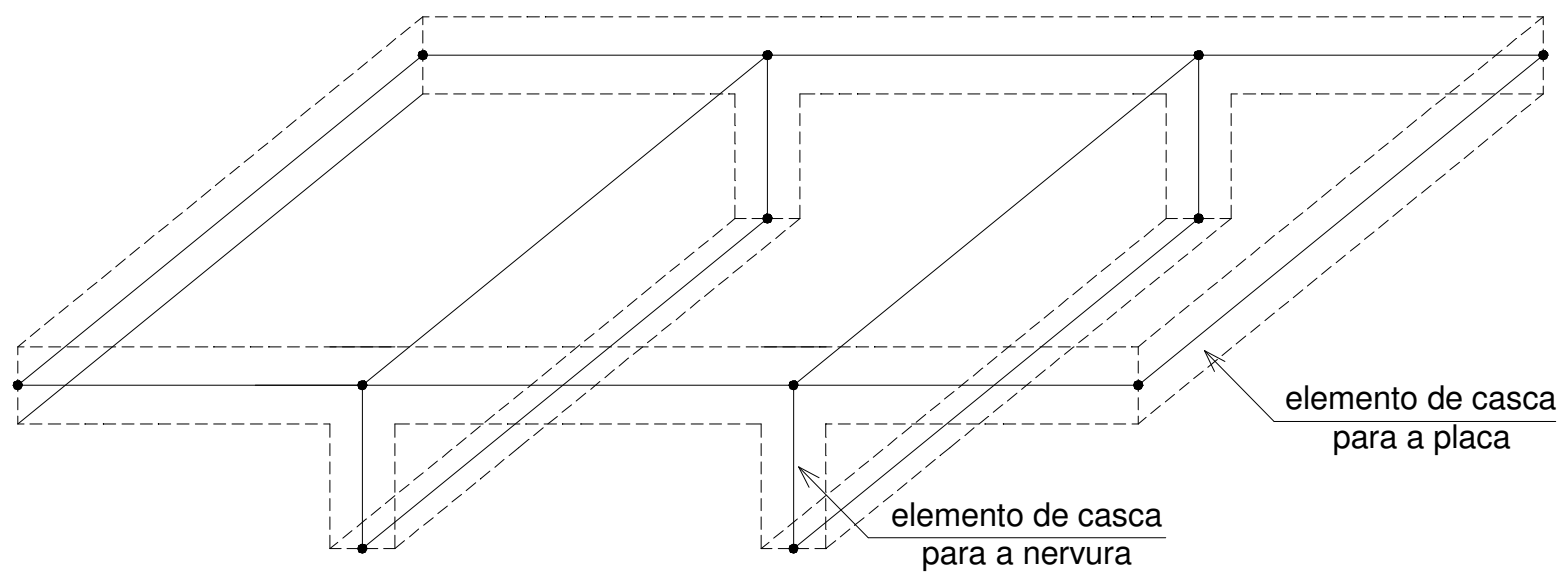

FIGURA 3.6: Elementos de casca tridimensional para a placa e para as nervuras, em modelo realista 



\section{CAPÍTULO 4 - OS MODELOS MECÂNICOS EM MEF APLICADOS À ANALISE ESTRUTURAL DE LAJES NERVURADAS}

\subsection{INTRODUÇÃO AO CAPÍTULO 4}

Toda a estrutura de pavimentos objeto de análise é, como apresentado em CORRÊA (1991), uma versão idealizada da estrutura real que pode ser denominada de modelo mecânico e que contém diversas aproximações: arranjo estrutural, idealização dos materiais, das ações, de vínculos e condições de contorno e, enfim, do comportamento dos componentes estruturais.

SAVASSI (2000) indicou que as simplificações na estrutura não podem ser drásticas, já que pretende-se obter respostas do modelo que sejam as mais próximas possíveis da estrutura real.

Além da aproximação da estrutura real por um modelo mecânico surge a necessidade de utilização de ferramentas numéricas de análise do modelo, já que a complexidade de uma análise analítica para os sistemas de pavimentos de edifícios inviabiliza o seu uso. Essa etapa constitui-se em um segundo nível de aproximação.

Existem diversos métodos numéricos passíveis de serem usados na análise estrutural: Método de Rayleigh-Ritz, Método das Diferenças Finitas, Método dos Resíduos Ponderados, Método dos Elementos Finitos, Método dos Elementos de Contorno, entre outros.

O de maior aplicação na atualidade, sem dúvida, é o Método dos Elementos Finitos. Existem diversos softwares disponíveis para a sua utilização. Com estes programas os deslocamentos, reações, forças internas e momentos podem ser encontrados para diversas configurações de carregamento e lajes de arbitrária geometria, interconectadas com vigas ou 
sistemas em pórtico. CORRÊA (1991) indicou, contudo, que para a aplicação do método não basta dispor de uma biblioteca de elementos abrangente, riqueza de recursos e instruções claras de operação de um software. É imprescindível a compreensão das características do método, atentando-se para as diferentes possibilidades e ocorrências de erros.

Os erros usuais introduzidos na análise numérica por MEF devem ser minimizados principalmente por meio da escolha correta dos elementos finitos, de acordo com o comportamento esperado do modelo mecânico, da divisão adequada do modelo e da aplicação correta das condições de contorno do sistema.

O MEF surgiu como um novo meio de resolver problemas de elasticidade, superando outros métodos numéricos anteriormente utilizados. Uma das principais críticas, porém, da aplicação do MEF à análise estrutural de pavimentos é a necessidade de intensa discretização para obter bons resultados, tornando-se caros para grandes estruturas. CANO \& KLINGNER (1988), MUKHOPADHYAY (1992), BEDAIR (1997) e SIDDIQI \& KUKRETI (1998) compartilham desta opinião.

No MEF a estrutura é dividida em partes denominadas elementos finitos. Admitem-se conhecidas as formas das funções incógnitas destes elementos, ou seja, o comportamento dos mesmos. Essa divisão é denominada rede de elementos finitos, onde a malha pode ser aumentada ou diminuída variando o tamanho dos elementos. Os pontos de intersecção das linhas da rede são chamados de nós.

A formulação mais importante do MEF é aquela em que o campo de deslocamentos é descrito por funções aproximadoras, em que aplicando-se o princípio de mínima energia potencial para o funcional resultante da soma dos funcionais de cada elemento encontra-se os valores dos parâmetros nodais (deslocamentos).

O software para modelagem em elementos finitos utilizado neste trabalho, nas análises numéricas, é o ANSYS 5.5.

O programa dispõe de elementos adequados à análise tanto para os modelos simplificados bidimensionais (Teoria da Placa Ortótropa, Analogia de Grelha, Pórticos Múltiplos e Pórticos Equivalentes) quanto para modelos mais refinados de análise, que levam em consideração a discretização de todo o pavimento em peças específicas, interconectadas e tridimensionais.

O fator de relevância nas análises efetuadas neste trabalho, como já demonstrado, é a consideração da excentricidade existente entre a alma da nervura e a mesa que na maioria das vezes é desconsiderada nas análises, ou considerada de forma simplificada. 
Dessa maneira, apresenta-se um resumo de todos os modelos de análise numérica para lajes nervuradas utilizados neste trabalho com os respectivos elementos finitos disponíveis no ANSYS 5.5 que levam em conta ou não a excentricidade entre o eixo longitudinal da nervura e o plano médio da placa.

Os modelos são também validados, através da aplicação dos mesmos na resolução de problemas de placas enrijecidas disponíveis na literatura.

Cabe ressaltar que todas as análises serão feitas considerando o material concreto armado como elástico-linear. É evidente que uma análise não-linear física oferece grandes vantagens ao calculista de estruturas por demonstrar resultados mais realistas acerca dos efeitos de perda de rigidez dos elementos estruturais devido a fissuração e escoamento das armaduras longitudinais tracionadas, permitindo ao projetista promover uma uniformização de esforços no pavimento por meio da eliminação de picos de momentos fletores. Assim, aplicando-se esse procedimento neste trabalho também teria-se valores mais refinados de deslocamentos e esforços. Contudo, pela proposta deste trabalho de quantificar parâmetros e relações de variáveis que exprimam a influência da consideração da excentricidade entre as peças nos resultados dos modelos permitidos de análise, dos simplificados aos sofisticados, acredita-se que a análise elástico-linear constitui-se em um passo inicial imprescindível a futuras complementações e aprofundamentos. Apenas algumas considerações acerca do comportamento do material, entretanto, são feitas neste sentido: diminuições do módulo de elasticidade transversal e da inércia à torção das peças.

\subsection{OS ELEMENTOS FINITOS UTILIZADOS NAS ANÁLISES NUMÉRICAS}

Os elementos finitos disponíveis no software ANSYS 5.5 para a utilização nas análises são apresentados a seguir:

\section{a) Elemento finito de barra elástica bidimensional BEAM3}

É um elemento uniaxial com capacidade de trabalhar à tração, compressão e flexão. Tem três graus de liberdade para cada nó: translações nodais nas direções x e y, além de rotação em torno do eixo cartesiano nodal z.

A geometria do elemento é apresentada na Figura 4.1. 


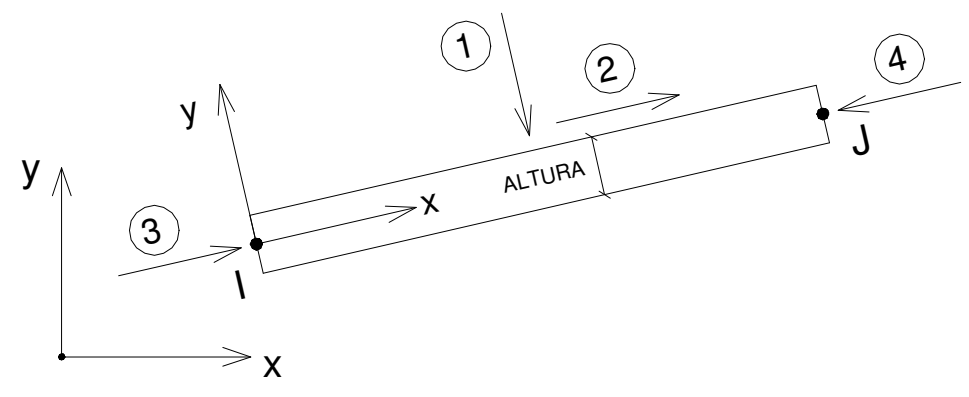

FIGURA 4.1: Geometria do elemento BEAM3

[ANSYS 5.5 Reference Manual (1994)]

Os resultados apresentados após o processamento podem ser de duas maneiras:

- deslocamentos nodais, e todas as soluções nodais associadas;

- esforços nos elementos, como os apresentados na Figura 4.2 abaixo.

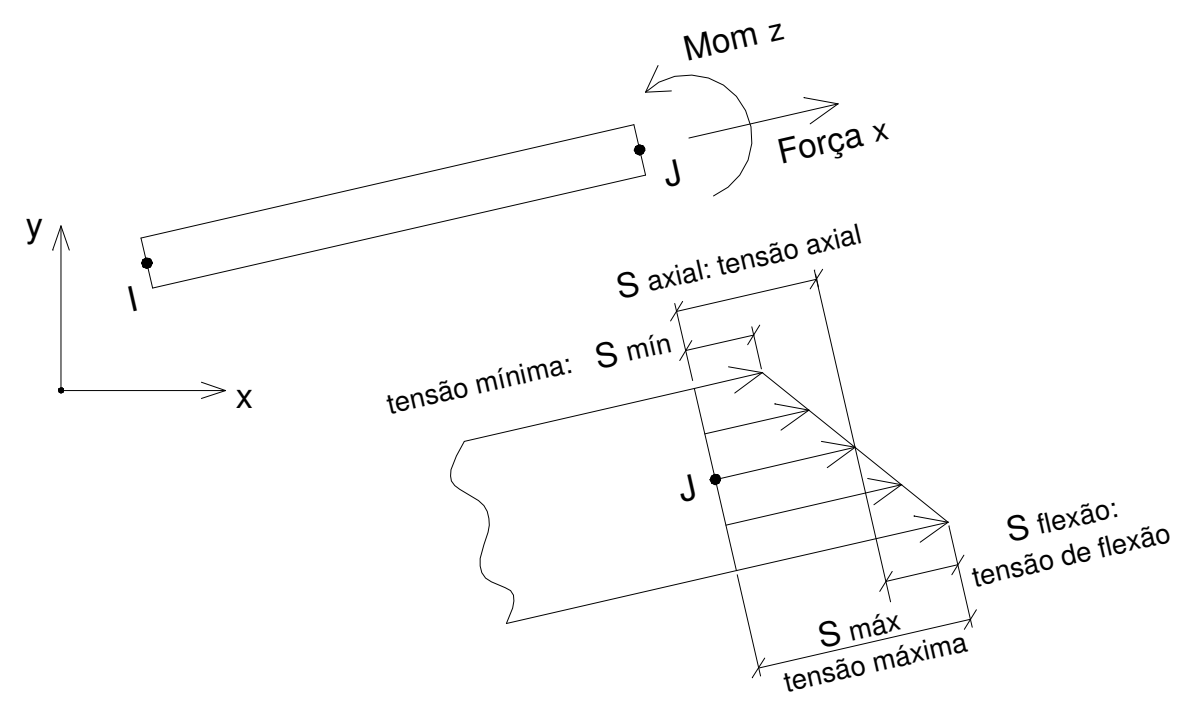

FIGURA 4.2: Exemplos de esforços no elemento BEAM3

[ANSYS 5.5 Reference Manual (1994)]

As funções aproximadoras dos deslocamentos u e v são apresentadas abaixo, com os índices referindo-se à Figura 4.3.

$$
\begin{aligned}
& \mathrm{u}=\frac{1}{2} \cdot\left[\mathrm{u}_{\mathrm{I}} \cdot(1-\mathrm{s})+\mathrm{u}_{\mathrm{J}} \cdot(1+\mathrm{s})\right] \\
& \mathrm{v}=\frac{1}{2} \cdot\left[\mathrm{v}_{\mathrm{I}} \cdot\left(1-\frac{\mathrm{s}}{2} \cdot\left(3-\mathrm{s}^{2}\right)\right)+\mathrm{v}_{\mathrm{J}} \cdot\left(1+\frac{\mathrm{s}}{2} \cdot\left(3-\mathrm{s}^{2}\right)\right)\right]+\frac{\mathrm{L}}{8} \cdot\left[\theta_{\mathrm{Z}, \mathrm{I}} \cdot\left(1-\mathrm{s}^{2}\right)(1-\mathrm{s})+\theta_{\mathrm{z}, \mathrm{J}} \cdot\left(1-\mathrm{s}^{2}\right) \cdot(1+\mathrm{s})\right]
\end{aligned}
$$




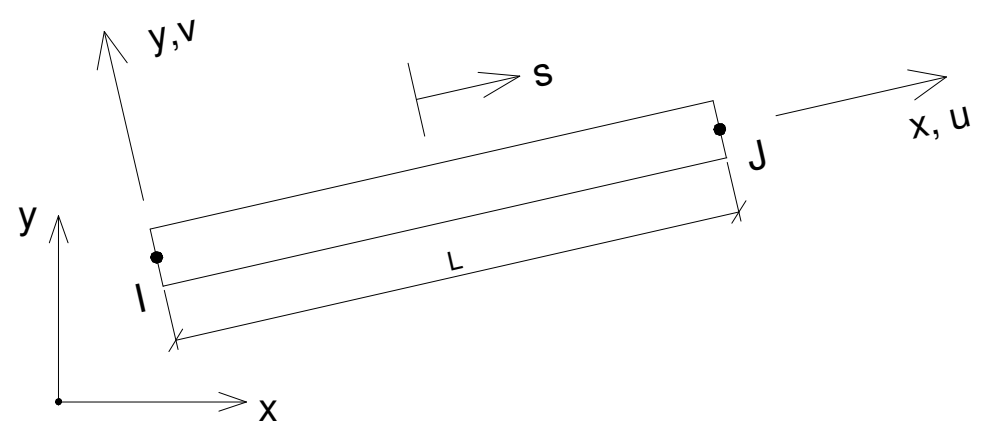

FIGURA 4.3: Parâmetros das funções aproximadoras de deslocamentos do elemento

BEAM3 [ANSYS 5.5 Reference Manual (1994)]

\section{b) Elemento finito de barra elástica tridimensional BEAM4}

É um elemento uniaxial com capacidade de trabalhar à tração, compressão, torção e flexão. Tem seis graus de liberdade para cada nó: translações nodais nas direções x, y e z, além de rotações em torno dos eixos cartesianos.

A geometria do elemento é apresentada na Figura 4.4.

Os resultados apresentados após o processamento podem ser de duas maneiras:

- deslocamentos nodais, e todas as soluções nodais associadas;

- esforços nos elementos, como os mostrados na Figura 4.5.

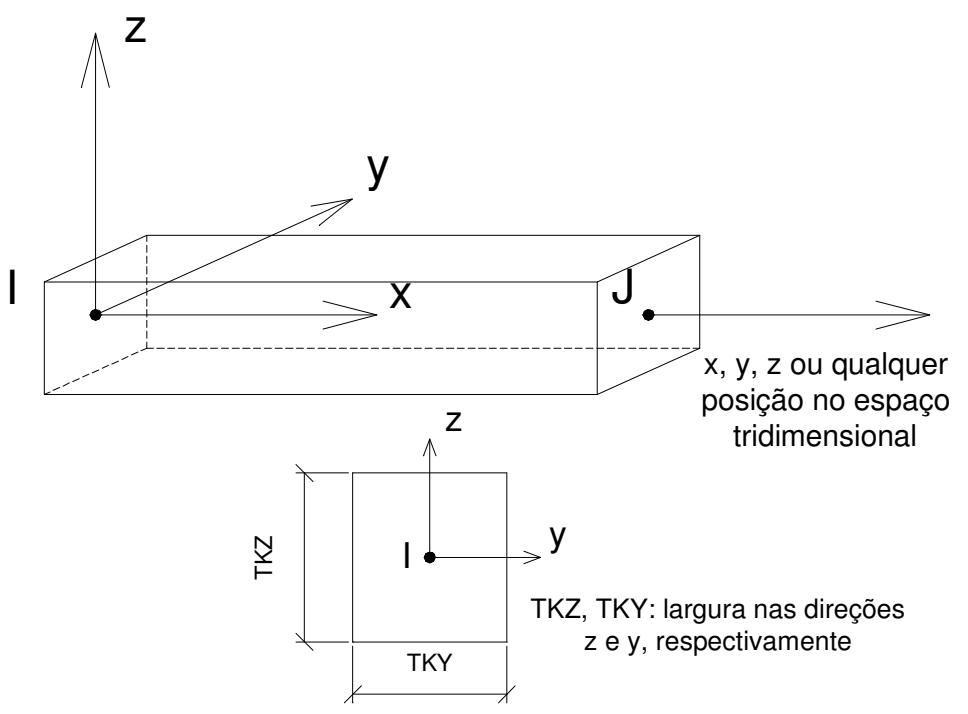

FIGURA 4.4: Geometria do elemento BEAM4

[ANSYS 5.5 Reference Manual (1994)] 
As funções aproximadoras dos deslocamentos $\mathrm{u}, \mathrm{v}$, w e $\theta_{\mathrm{x}}$ são apresentadas abaixo, com os índices referindo-se à Figura 4.6.

$$
\begin{aligned}
& \mathrm{u}=\frac{1}{2} \cdot\left[\mathrm{u}_{\mathrm{I}} \cdot(1-\mathrm{s})+\mathrm{u}_{\mathrm{J}} \cdot(1+\mathrm{s})\right] \\
& \mathrm{v}=\frac{1}{2} \cdot\left[\mathrm{v}_{\mathrm{I}} \cdot\left(1-\frac{\mathrm{s}}{2} \cdot\left(3-\mathrm{s}^{2}\right)\right)+\mathrm{v}_{\mathrm{J}} \cdot\left(1+\frac{\mathrm{s}}{2} \cdot\left(3-\mathrm{s}^{2}\right)\right)\right]+\frac{\mathrm{L}}{8} \cdot\left[\theta_{\mathrm{z}, \mathrm{I}} \cdot\left(1-\mathrm{s}^{2}\right)(1-\mathrm{s})-\theta_{\mathrm{z}, \mathrm{J}} \cdot\left(1-\mathrm{s}^{2}\right) \cdot(1+\mathrm{s})\right] \\
& \mathrm{w}=\frac{1}{2} \cdot\left[\mathrm{w}_{\mathrm{I}} \cdot\left(1-\frac{\mathrm{s}}{2} \cdot\left(3-\mathrm{s}^{2}\right)\right)+\mathrm{w}_{\mathrm{J}} \cdot\left(1+\frac{\mathrm{s}}{2} \cdot\left(3-\mathrm{s}^{2}\right)\right)\right]-\frac{\mathrm{L}}{8} \cdot\left[\theta_{\mathrm{y}, \mathrm{I}} \cdot\left(1-\mathrm{s}^{2}\right) \cdot(1-\mathrm{s})-\theta_{\mathrm{y}, \mathrm{J}} \cdot\left(1-\mathrm{s}^{2}\right) \cdot(1+\mathrm{s})\right] \\
& \theta_{\mathrm{x}}=\frac{1}{2} \cdot\left[\theta_{\mathrm{x}, \mathrm{I}} \cdot(1-\mathrm{s})+\theta_{\mathrm{X}, \mathrm{J}} \cdot(1+\mathrm{s})\right]
\end{aligned}
$$
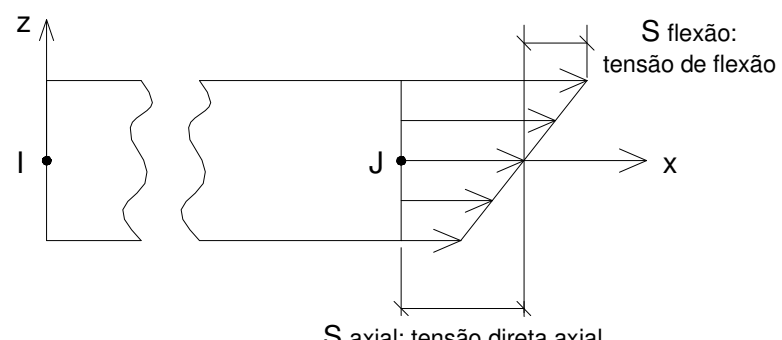

S axial: tensão direta axial
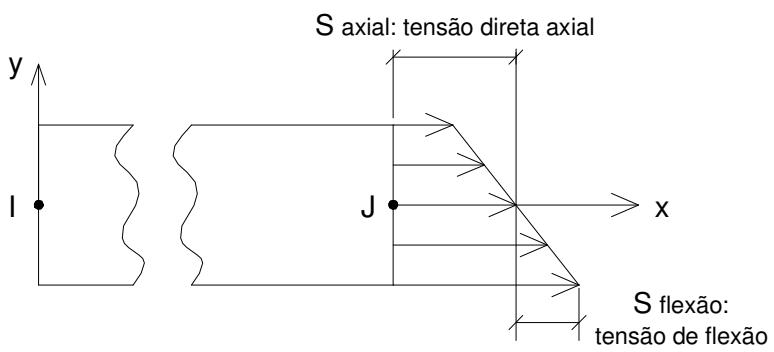

FIGURA 4.5: Exemplos de tensões nos elementos BEAM4

[ANSYS 5.5 Reference Manual (1994)]

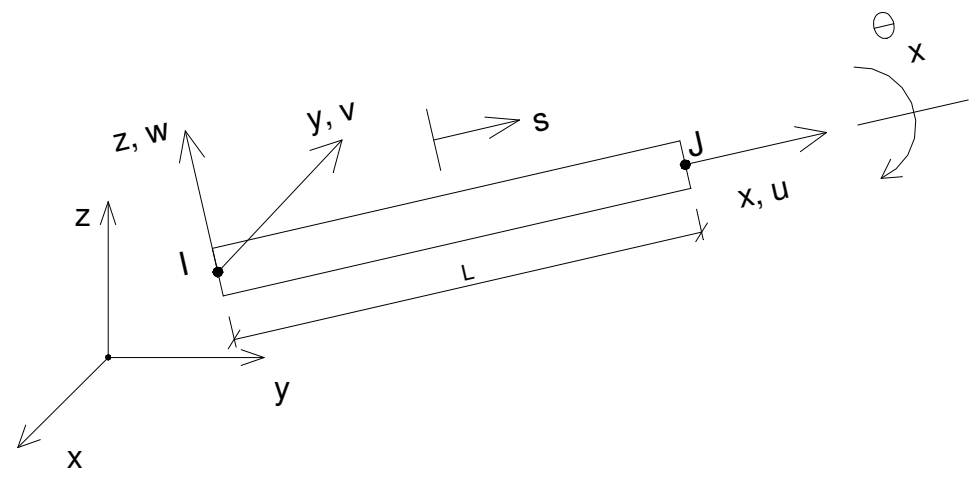

FIGURA 4.6: Parâmetros das funções aproximadoras de deslocamentos do elemento BEAM4 [ANSYS 5.5 Reference Manual (1994)] 


\section{c) Elemento finito de barra elástica tridimensional BEAM44:}

É um elemento uniaxial com capacidade de trabalhar à tração, compressão, torção e flexão. Tem seis graus de liberdade para cada nó: translações nodais nas direções $\mathrm{x}$, y e z, além de rotações em torno dos eixos cartesianos. Permite a consideração de diferentes geometrias não-simétricas para cada nó, além da possibilidade de considerar excentricidades.

A geometria do elemento é apresentada na Figura 4.7.

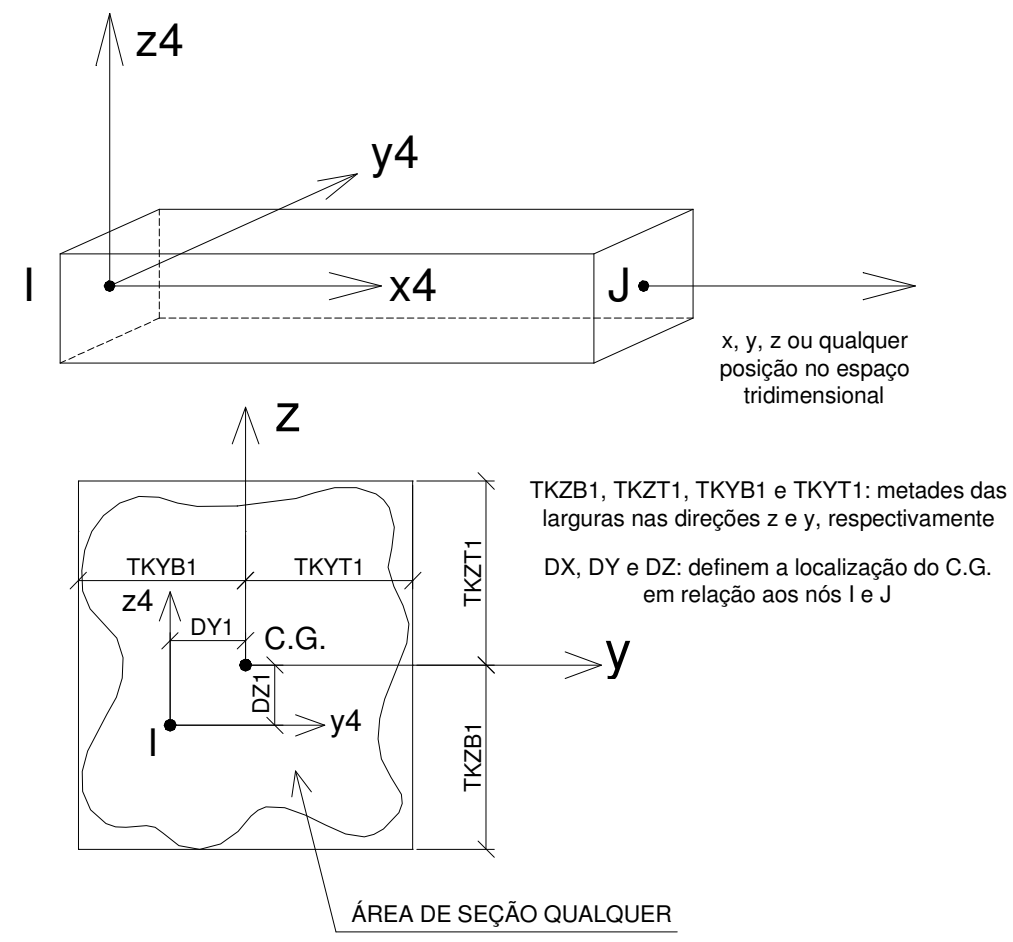

FIGURA 4.7: Geometria do elemento BEAM44

[ANSYS 5.5 Reference Manual (1994)]

Os resultados apresentados após o processamento podem ser de duas maneiras:

- deslocamentos nodais, e todas as soluções nodais associadas;

- esforços nos elementos.

As funções aproximadoras dos deslocamentos $\mathrm{u}, \mathrm{v}$, w e $\theta_{\mathrm{x}}$ são as mesmas utilizadas no elemento finito BEAM4, novamente apresentadas abaixo, com os índices referindo-se à Figura 4.8.

$$
\begin{aligned}
& \mathrm{u}=\frac{1}{2} \cdot\left[\mathrm{u}_{\mathrm{I}} \cdot(1-\mathrm{s})+\mathrm{u}_{\mathrm{J}} \cdot(1+\mathrm{s})\right] \\
& \mathrm{v}=\frac{1}{2} \cdot\left[\mathrm{v}_{\mathrm{I}} \cdot\left(1-\frac{\mathrm{s}}{2} \cdot\left(3-\mathrm{s}^{2}\right)\right)+\mathrm{v}_{\mathrm{J}} \cdot\left(1+\frac{\mathrm{s}}{2} \cdot\left(3-\mathrm{s}^{2}\right)\right)\right]+\frac{\mathrm{L}}{8} \cdot\left[\theta_{\mathrm{z}, \mathrm{I}} \cdot\left(1-\mathrm{s}^{2}\right) \cdot(1-\mathrm{s})-\theta_{\mathrm{z}, \mathrm{J}} \cdot\left(1-\mathrm{s}^{2}\right) \cdot(1+\mathrm{s})\right]
\end{aligned}
$$




$$
\begin{aligned}
& \mathrm{w}=\frac{1}{2} \cdot\left[\mathrm{w}_{\mathrm{I}} \cdot\left(1-\frac{\mathrm{s}}{2} \cdot\left(3-\mathrm{s}^{2}\right)\right)+\mathrm{w}_{\mathrm{J}} \cdot\left(1+\frac{\mathrm{s}}{2} \cdot\left(3-\mathrm{s}^{2}\right)\right)\right]-\frac{\mathrm{L}}{8} \cdot\left[\theta_{\mathrm{y}, \mathrm{I}} \cdot\left(1-\mathrm{s}^{2}\right) \cdot(1-\mathrm{s})-\theta_{\mathrm{y}, \mathrm{J}} \cdot\left(1-\mathrm{s}^{2}\right) \cdot(1+\mathrm{s})\right] \\
& \theta_{\mathrm{x}}=\frac{1}{2} \cdot\left[\theta_{\mathrm{x}, \mathrm{I}} \cdot(1-\mathrm{s})+\theta_{\mathrm{x}, \mathrm{J}} \cdot(1+\mathrm{s})\right]
\end{aligned}
$$

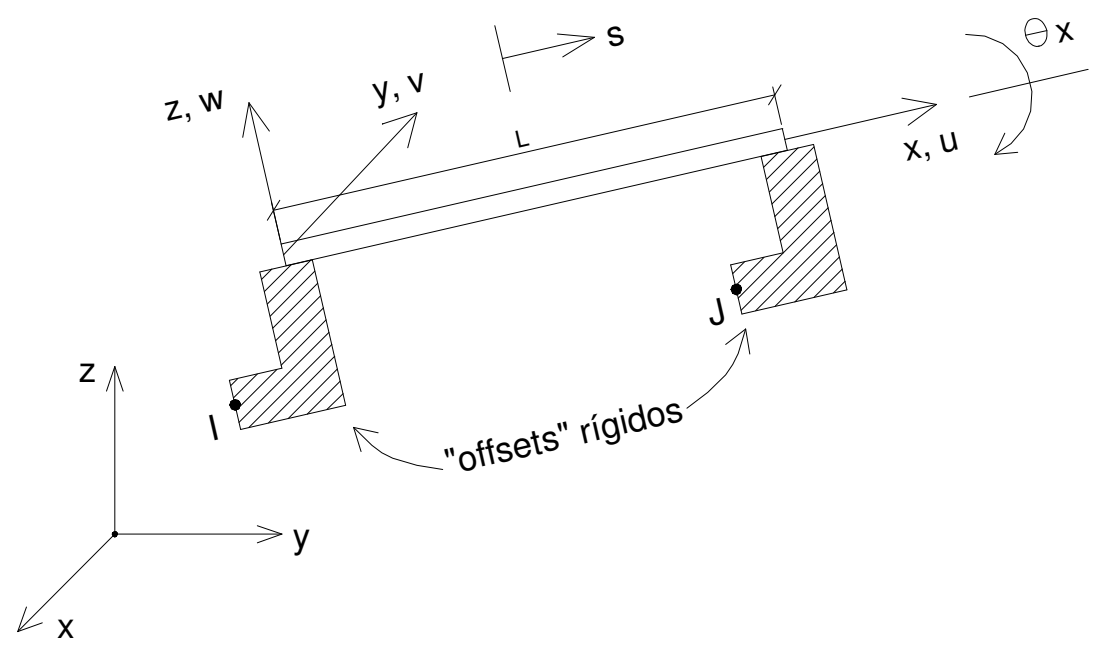

FIGURA 4.8: Parâmetros das funções aproximadoras de deslocamentos do elemento finito BEAM44 [ANSYS 5.5 Reference Manual (1994)]

A matriz de rigidez do elemento finito BEAM44 é a mesma do elemento BEAM4, exceto que é utilizada área média para o elemento, já que a área do elemento pode ser diferente nos nós I e J. Também os três momentos de inércia são valores médios. Ambas as características são definidas abaixo.

$$
\begin{aligned}
& \mathrm{A}_{\text {média }}=\frac{1}{3} \cdot\left[\mathrm{A}_{\mathrm{I}}+\sqrt{\mathrm{A}_{\mathrm{I}}+\mathrm{A}_{\mathrm{J}}}+\mathrm{A}_{\mathrm{J}}\right] \\
& \mathrm{I}_{\text {média }}=\frac{1}{5} \cdot\left[\mathrm{I}_{\mathrm{I}}+\sqrt[4]{\mathrm{I}_{\mathrm{I}}^{3} \cdot \mathrm{I}_{\mathrm{J}}}+\sqrt{\mathrm{I}_{\mathrm{I}} \cdot \mathrm{I}_{\mathrm{J}}}+\sqrt[4]{\mathrm{I}_{\mathrm{J}}^{3} \cdot \mathrm{I}_{\mathrm{I}}+\mathrm{I}_{\mathrm{J}}}\right]
\end{aligned}
$$

\section{d) Elemento finito de casca elástica SHELL63}

É um elemento finito de casca elástica com resistência à flexão e de membrana que permite a consideração de carregamentos no plano do elemento e transversalmente ao mesmo. Tem seis graus de liberdade para cada nó: translações nodais nas direções x, y e z, além de rotações em torno dos eixos cartesianos.

Pode apresentar formato quadrangular ou triangular, de acordo com a Figura 4.9 e é indicado para ser aplicado a cascas não-curvas. 


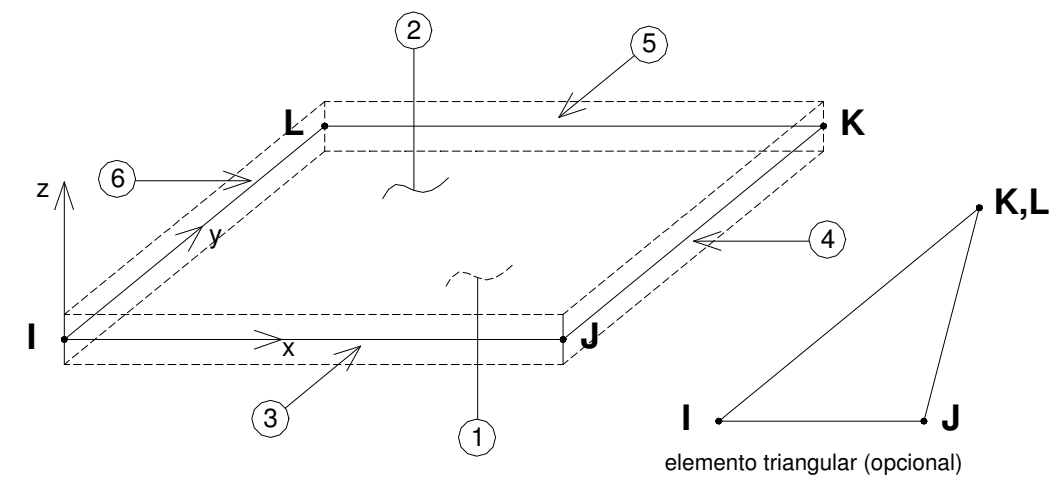

Figura 4.9: Elemento SHELL63

[ANSYS 5.5 Reference Manual (1994)]

Os resultados apresentados após o processamento podem ser de duas maneiras:

- deslocamentos nodais, e todas as soluções nodais associadas;

- esforços nos elementos, entre eles momentos fletores por unidade de comprimento, em torno dos eixos cartesianos $\mathrm{x}$ e $\mathrm{y}$, aqui denominados $\mathrm{M}_{\mathrm{y}}$ e $\mathrm{M}_{\mathrm{x}}$, respectivamente; momentos torçores $\mathrm{M}_{\mathrm{xy}} \mathrm{e}$ tensões nas direções paralelas aos eixos cartesianos, de acordo com a Figura 4.10.

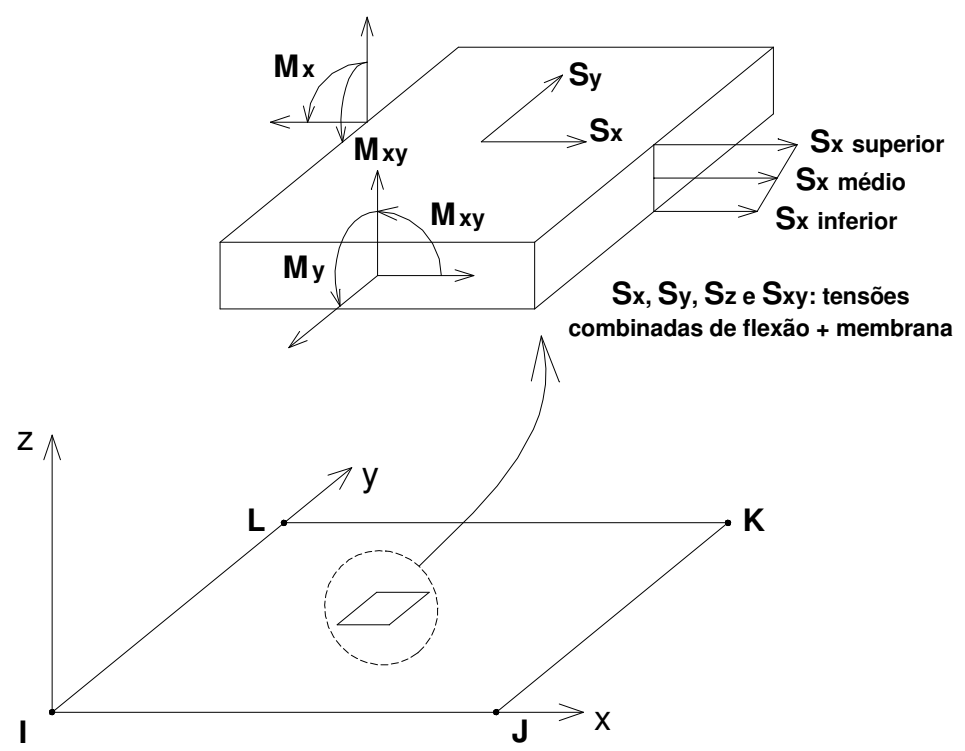

FIGURA 4.10: Exemplos de esforços nos elementos SHELL63

[ANSYS 5.5 Reference Manual (1994)] 
O efeito de membrana do elemento é considerado através das funções aproximadoras dos deslocamentos u e v, apresentadas abaixo, com os índices referindo-se à Figura 4.11, utilizando-se seis pontos de integração dentro do elemento, ou seja, deixando-se ativo o recurso de incluir mais dois pontos extras, garantindo assim uma convergência mais rápida com menor discretização:

$$
\begin{aligned}
& \left.\mathrm{u}=\frac{1}{4} \cdot \mathrm{u}_{\mathrm{I}} \cdot(1-\mathrm{s}) \cdot(1-\mathrm{t})+\mathrm{u}_{\mathrm{J}} \cdot(1+\mathrm{s}) \cdot(1-\mathrm{t})+\mathrm{u}_{\mathrm{K}} \cdot(1+\mathrm{s}) \cdot(1+\mathrm{t})+\mathrm{u}_{\mathrm{L}} \cdot(1-\mathrm{s}) \cdot(1+\mathrm{t})+\mathrm{u}_{1} \cdot\left(1-\mathrm{s}^{2}\right)+\mathrm{u}_{2} \cdot\left(1-\mathrm{t}^{2}\right)\right] \\
& \mathrm{v}=\frac{1}{4} \cdot\left[\mathrm{v}_{\mathrm{I}} \cdot(1-\mathrm{s}) \cdot(1-\mathrm{t})+\mathrm{v}_{\mathrm{J}} \cdot(1+\mathrm{s}) \cdot(1-\mathrm{t})+\mathrm{v}_{\mathrm{K}} \cdot(1+\mathrm{s}) \cdot(1+\mathrm{t})+\mathrm{v}_{\mathrm{L}} \cdot(1-\mathrm{s}) \cdot(1+\mathrm{t})+\mathrm{v}_{1} \cdot\left(1-\mathrm{s}^{2}\right)+\mathrm{v}_{2} \cdot\left(1-\mathrm{t}^{2}\right)\right]
\end{aligned}
$$

O efeito da flexão é considerado através da subdivisão do elemento quadrilateral em quatro subtriângulos, onde cada um destes utilizam as funções de forma do elemento finito DKT (Discrete Kirchhoff Triangle), que segundo BATOZ et al. (1980) é adequado para a análise de flexão de placas delgadas.

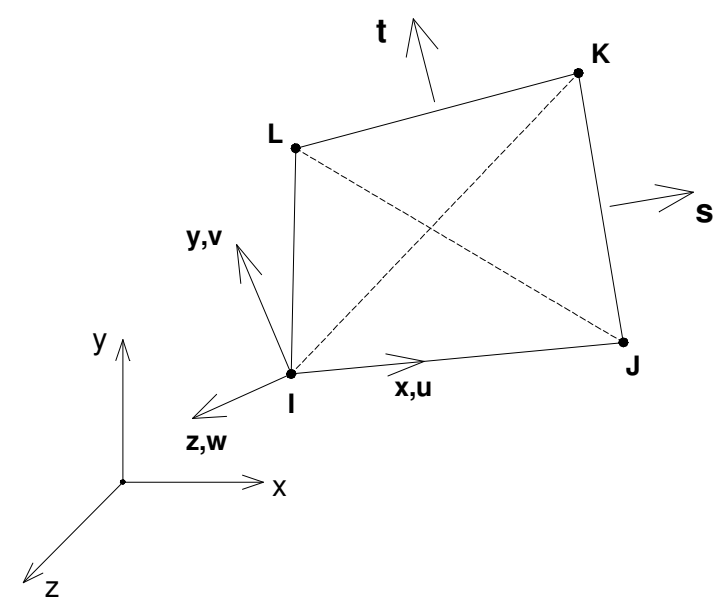

FIGURA 4.11: Parâmetros das funções aproximadoras dos deslocamentos do elemento

SHELL63

O elemento finito DKT possui três graus de liberdade por nó, sendo uma translação segundo o eixo global cartesiano z e duas rotações em torno dos eixos cartesianos y e z, que formam o plano em que está contido o elemento, de acordo com a Figura 4.12. 


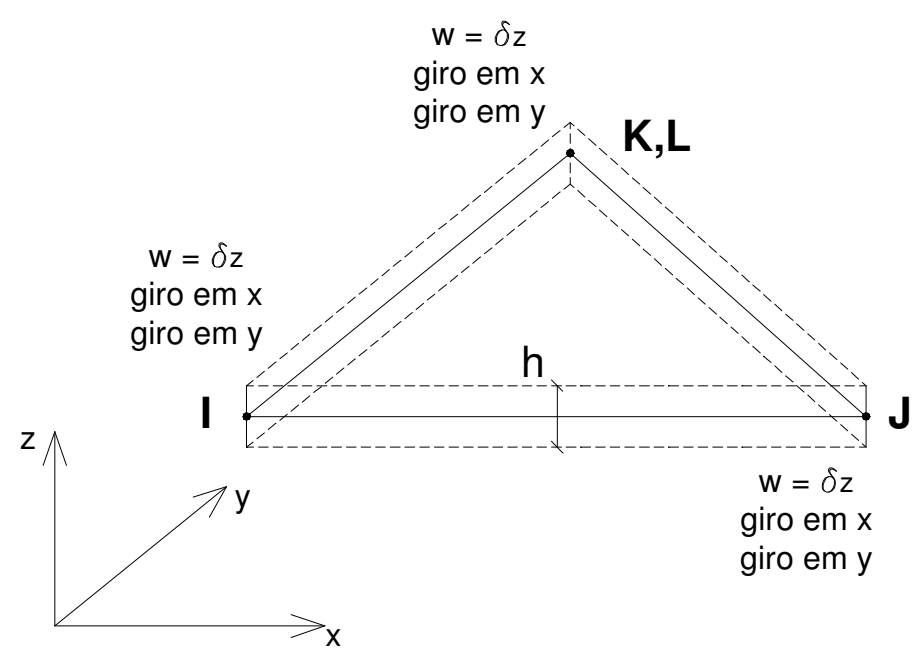

FIGURA 4.12: Graus de liberdade do elemento finito DKT

Na Teoria de Kirchhoff a parcela da energia de deformação relativa ao esforço cortante é desprezível quando comparada à energia de deformação por flexão. Sendo assim, a hipótese clássica de Kirchhoff onde: "uma reta normal ao plano médio indeformado da placa, mantém-se normal à superfície média após a deformação"é imposta discretamente ao longo dos lados do elemento, discretamente nos seus pontos nodais, e dessa forma a energia de deformação relativa ao esforço cortante é finalmente desprezada.

É importante ressaltar que placa delgada é definida como a placa que tem a relação entre sua espessura (h) e seu menor vão (l) compreendido entre 1/5 e 1/100.

\subsection{OS MODELOS MECÂNICOS APLICADOS NESTE TRABALHO}

Um aspecto desconsiderado nas análises deste trabalho, mas que torna-se necessário quando tem-se um problema prático de engenharia, onde um pavimento é definido por vazios que necessitam de ajustes próximos à borda, criando regiões maciças anexas as vigas, é a consideração das vigas não mais com seção retangular, e sim com inércias referentes a seção composta viga e região maciça, conforme Figura 4.13: 


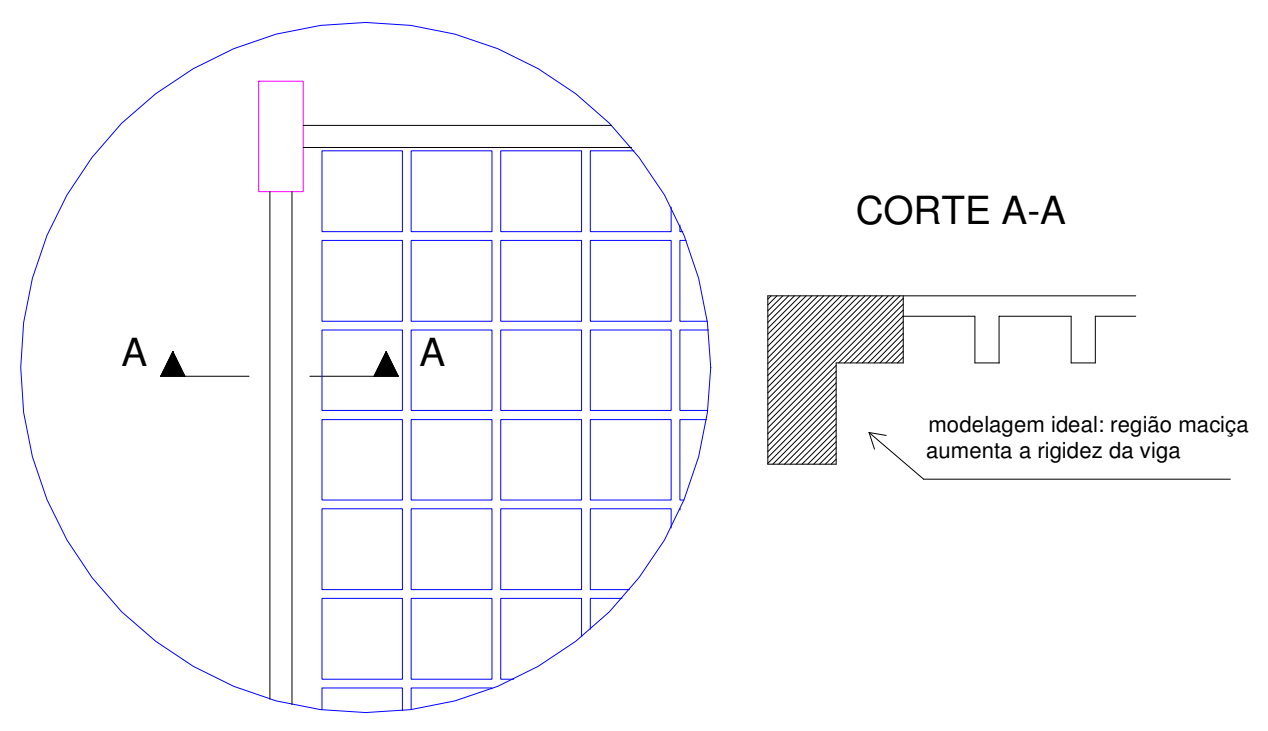

FIGURA 4.13: Modelagem ideal das regiões maciças junto às vigas quando necessário ajustes na distribuição de nervuras

Apresentam-se a seguir as descrições dos modelos em MEF utilizados e/ou identificados neste trabalho e as considerações envolvidas em cada um deles.

a) Modelo 01: nervuras discretizadas pelo elemento de viga elástica BEAM4 considerando seção retangular, com seis graus de liberdade, concêntrico ao plano médio da placa; laje discretizada pelo elemento de casca SHELL63, elemento plano com seis graus de liberdade trabalhando à flexão e tensão. Também aplica-se o elemento BEAM44 de forma concêntrica para testar sua validade nessa condição, denominando este modelo complementar como Modelo 01-A. O Modelo 01 é apresentado esquematicamente na Figura 4.14 .

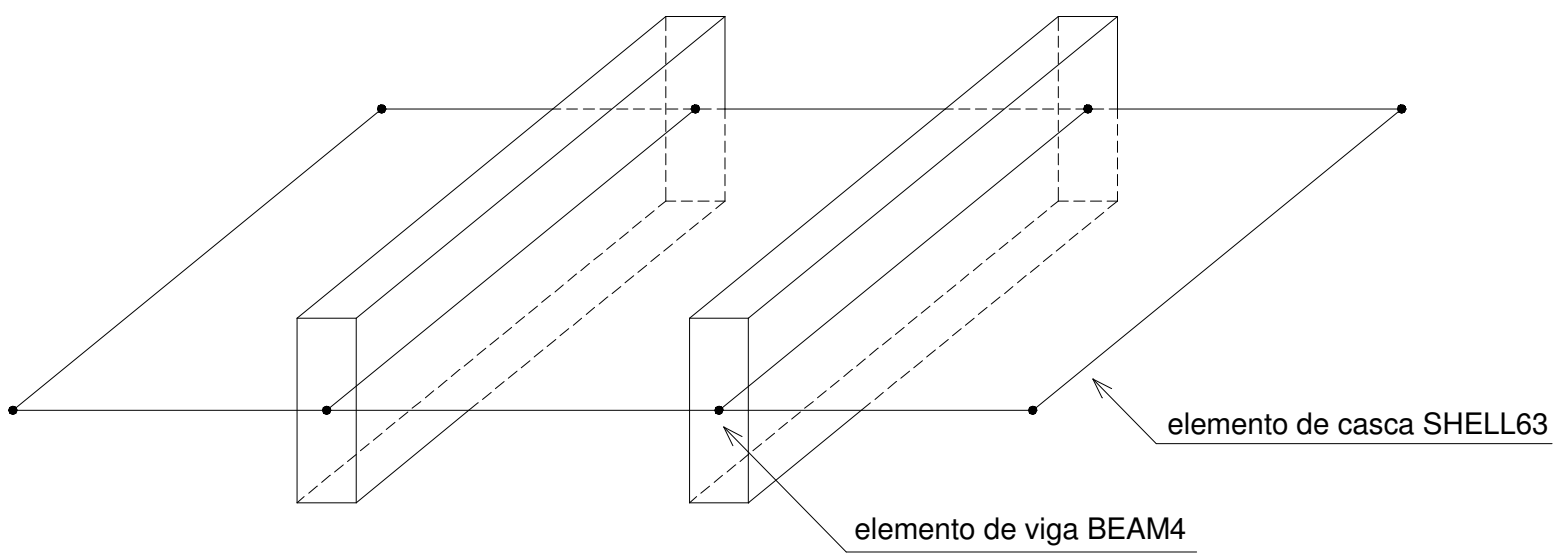

FIGURA 4.14: Representação esquemática do Modelo 01 
b) Modelo 02: nervuras discretizadas pelo elemento de viga elástica BEAM44 considerando seção retangular, com seis graus de liberdade, aplicando a excentricidade existente entre a nervura e o plano médio da placa, tomando a altura da viga até a face superior da placa; laje discretizada pelo elemento de casca SHELL63, elemento plano com seis graus de liberdade trabalhando à flexão e tensão. O Modelo 02 é apresentado esquematicamente na Figura 4.15.

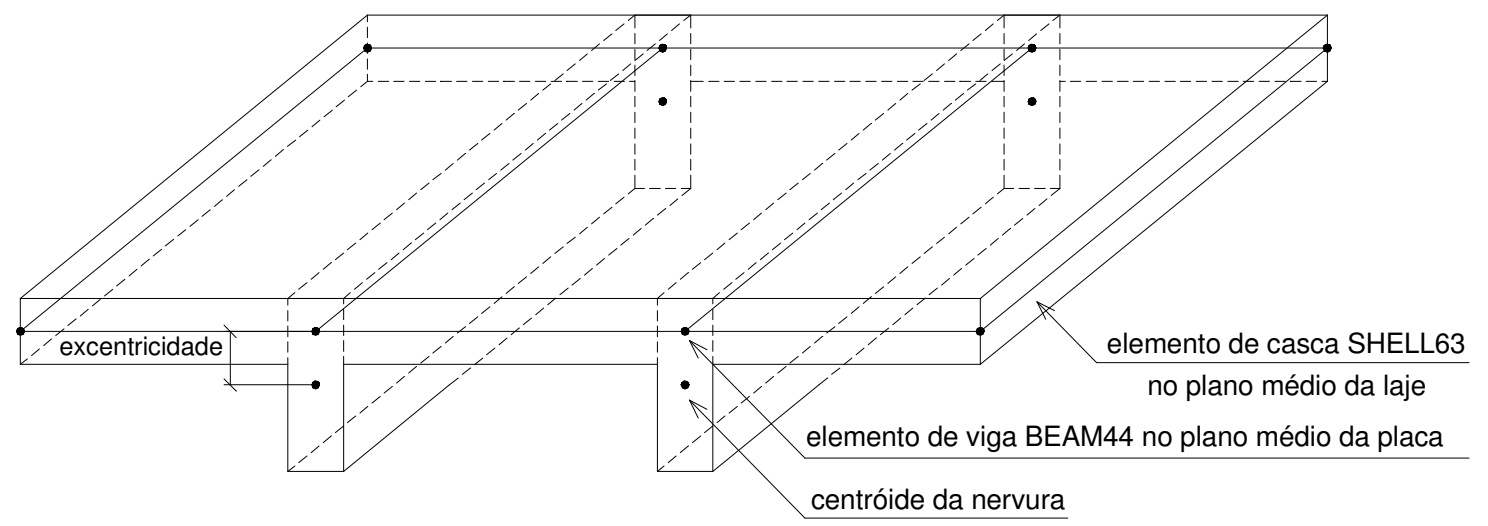

FIGURA 4.15: Representação esquemática do Modelo 02

c) Modelo 03: nervuras discretizadas pelo elemento de viga elástica BEAM44 considerando seção retangular, com seis graus de liberdade, aplicando a excentricidade existente entre a nervura e o plano médio da placa, tomando a altura da viga até a face inferior da placa; laje discretizada pelo elemento de casca SHELL63, elemento plano com seis graus de liberdade trabalhando à flexão e tensão. O Modelo 03 é apresentado esquematicamente na Figura 4.16.

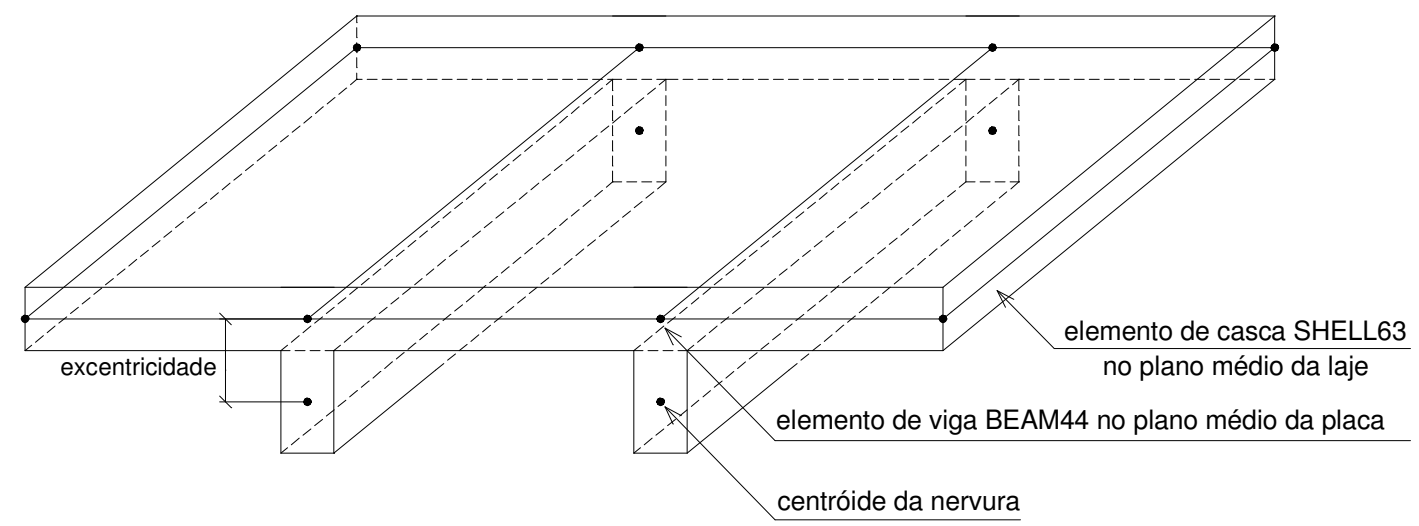

FIGURA 4.16: Representação esquemática do Modelo 03 
d) Modelo 04: nervuras e lajes discretizadas pelo elemento de casca SHELL63, elemento plano com seis graus de liberdade, trabalhando à flexão e tensão, em um modelo tridimensional. Havendo lajes de espessura diferentes os elementos de casca serão lançados no mesmo plano (plano médio da laje de menor espessura). O Modelo 04 é apresentado esquematicamente na Figura 4.17.

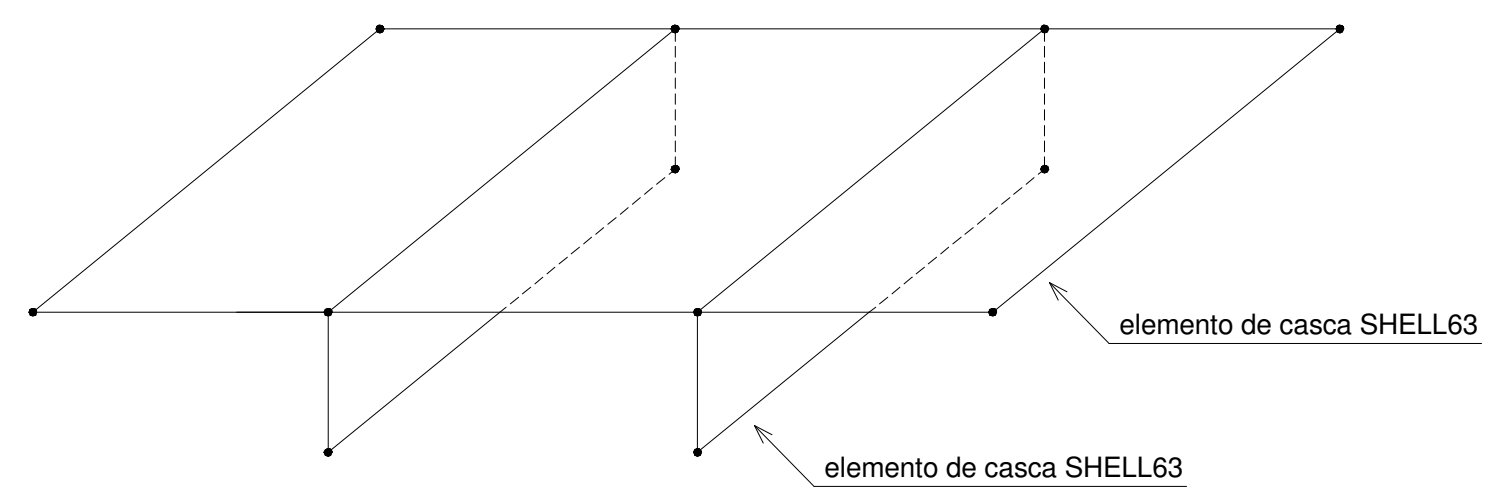

FIGURA 4.17: Representação esquemática do Modelo 04

e) Modelo 05: nervuras discretizadas pelo elemento BEAM4 com seção transversal tipo "T", considerando a colaboração da laje na rigidez das vigas de acordo com o projeto de revisão da NBR6118/2000, aplicado de forma concêntrica ao plano médio da placa de acordo com NAVARRA (1995); laje discretizada pelo elemento de casca SHELL63, elemento plano com seis graus de liberdade trabalhando à flexão e tensão. O Modelo 05 é apresentado esquematicamente na Figura 4.18.

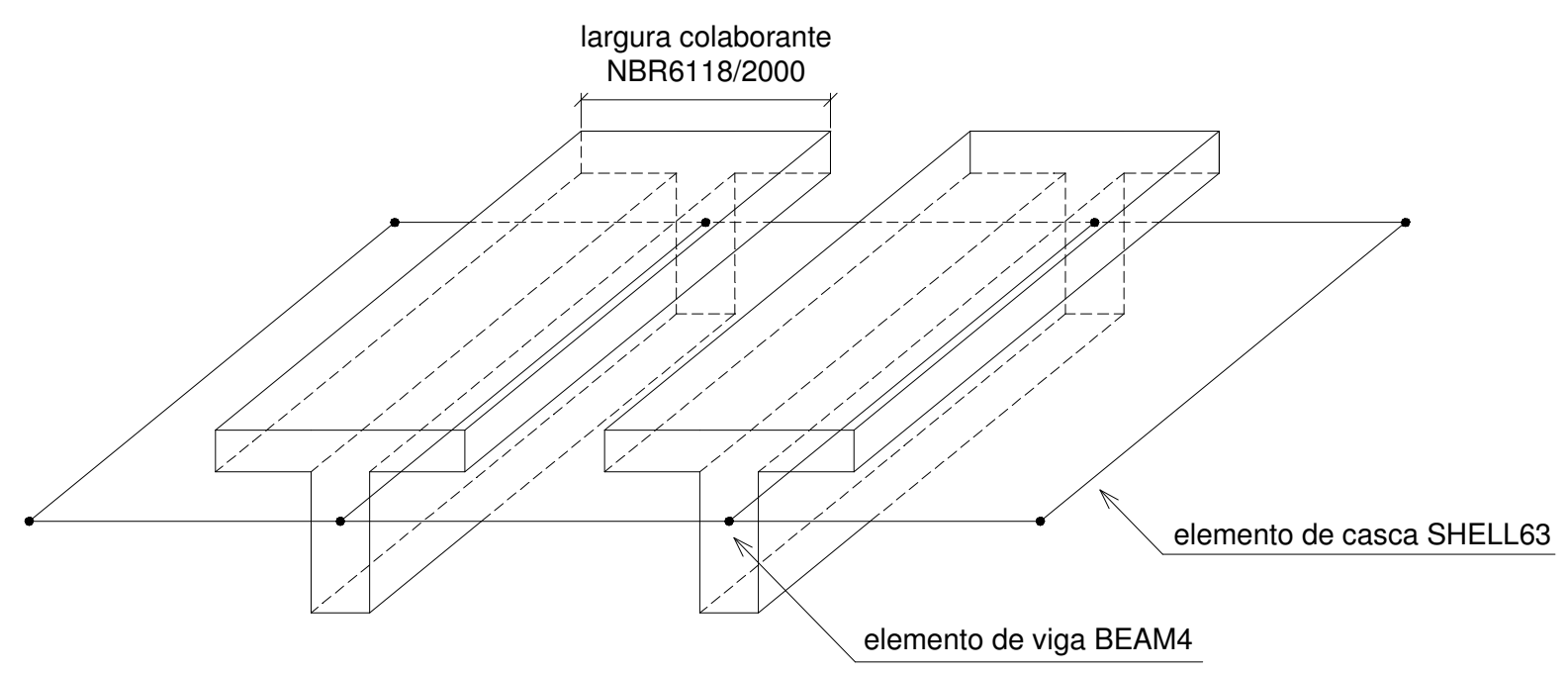

FIGURA 4.18: Representação esquemática do Modelo 05 
f) Modelo 06: modelo de grelha onde o pavimento em laje nervurada convencional (placa e enrijecedores) é representado pela grelha das nervuras, sendo estas discretizadas pelo elemento BEAM4 com seção transversal tipo 'T", considerando a colaboração da laje na rigidez das vigas, de acordo com o projeto de revisão da NBR6118/2000. O Modelo 06 é apresentado esquematicamente na Figura 4.19.

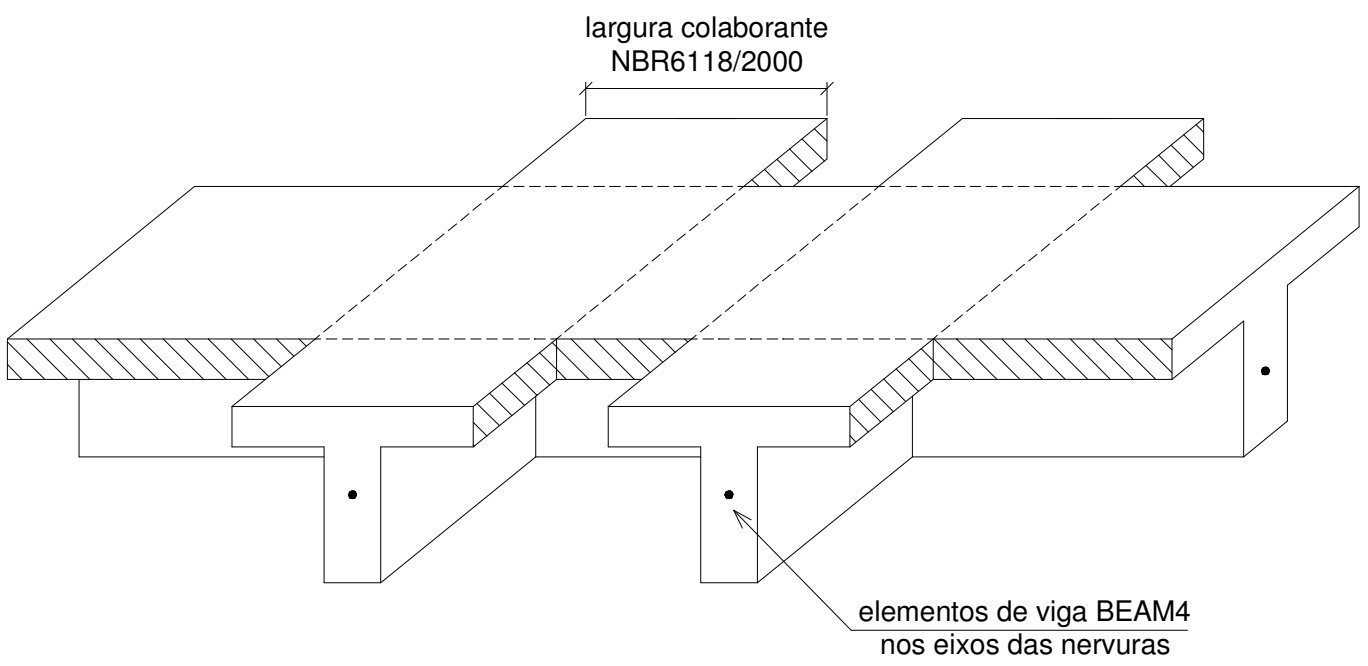

FIGURA 4.19: Representação esquemática do Modelo 06

g) Modelo 07: modelo de laje maciça equivalente utilizando os conceitos da Teoria da Placa Ortótropa Equivalente, onde a laje nervurada é transformada em uma laje maciça com espessura constante equivalente em inércia à flexão. Para o cálculo da laje maciça de espessura equivalente em inércia utilizou-se a largura colaborante definida pelo projeto de revisão da NBR6118/2000. Assim, a laje maciça equivalente é discretizada pelo elemento de casca SHELL63, elemento plano com seis graus de liberdade trabalhando à flexão e tensão. Havendo capitéis ou ábacos, no caso de lajes nervuradas sem vigas, estes serão modelados também pelo elemento SHELL63, contudo mantendo a altura da seção de acordo com sua geometria original. É importante lembrar que neste modelo também é considerada a redução do módulo de deformação transversal do material, se este for concreto armado. O Modelo 07 é apresentado esquematicamente na Figura 4.20. 


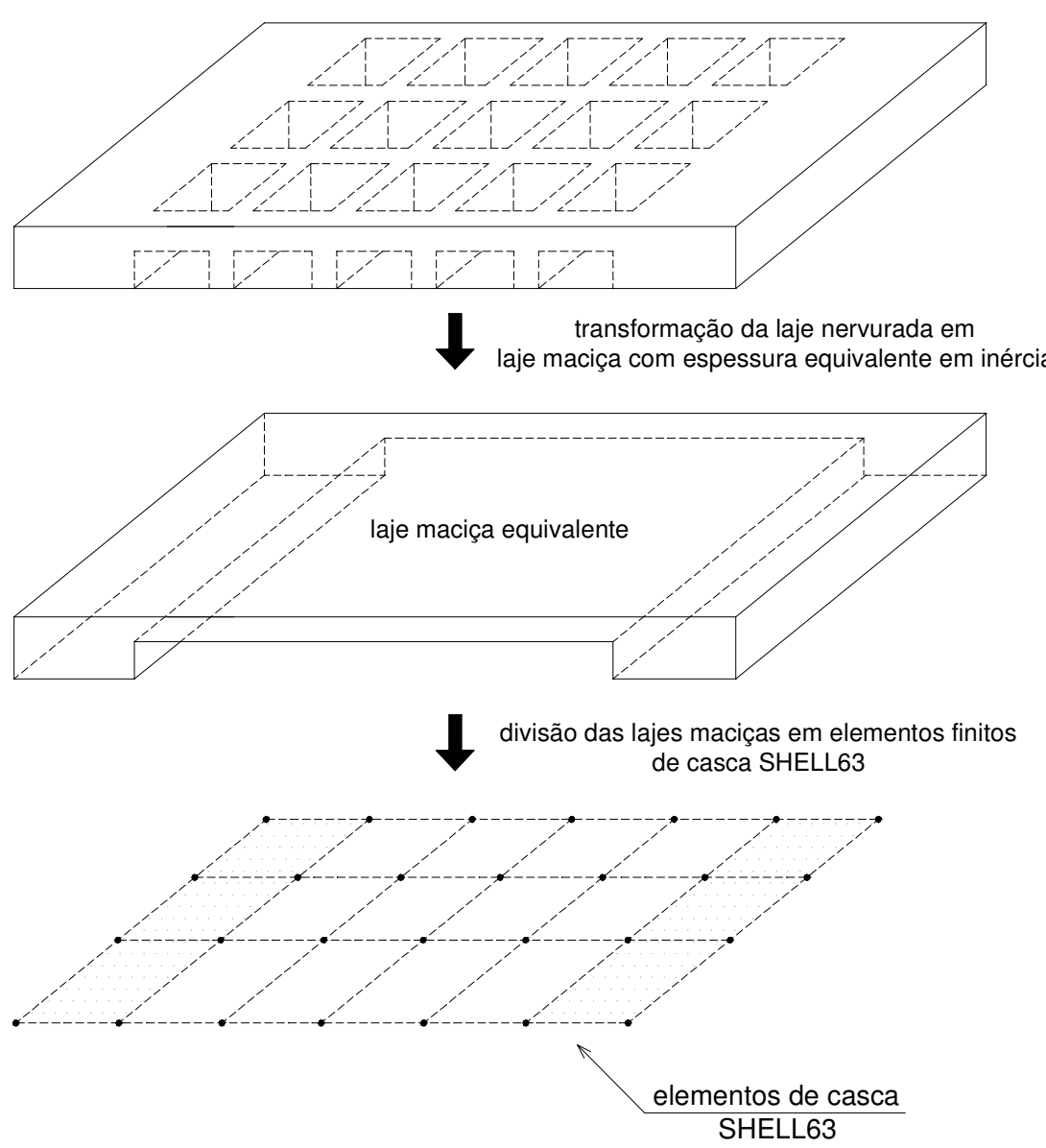

FIGURA 4.20: Representação esquemática do Modelo 07

h) Modelo 08: modelo de laje maciça equivalente utilizando os conceitos da Teoria da Placa Ortótropa Equivalente, onde a laje nervurada é transformada em uma laje maciça com espessura constante equivalente em inércia. Para o cálculo da laje maciça de espessura equivalente em inércia utilizou-se a largura colaborante definida pelo projeto de revisão da NBR6118/2000. Aplicou-se a diminuição de 20\% da espessura equivalente proposta por ABDUL-WAHAB \& KHALIL (2000). Assim, a laje maciça equivalente é discretizada pelo elemento de casca SHELL63, elemento plano com seis graus de liberdade trabalhando à flexão e tensão. Havendo capitéis ou ábacos, no caso de lajes nervuradas sem vigas, estes serão modelados também pelo elemento SHELL63, contudo mantendo a altura da seção de acordo com sua geometria original. Para este modelo de laje maciça equivalente não deve ser aplicada a redução do módulo de deformação transversal. A representação esquemática é similar àquela apresentada na Figura 4.20.

i) Modelo 09: modelo de grelha onde o pavimento em laje nervurada sem vigas é representado pela grelha das nervuras e grelha dos capitéis. Assim, as nervuras 
podem ser discretizadas pelo elemento BEAM4 com seção transversal tipo "T", considerando a colaboração da laje na rigidez das vigas de acordo com o projeto de revisão da NBR6118/2000. Os capitéis podem ser modelados também pelo elemento BEAM4 tendo suas características calculadas de acordo com o tamanho das faixas correspondentes. É interessante aumentar o número de barras de grelha nos capitéis, buscando enrijecer o sistema, já que, conforme verificado em OLIVEIRA et al. (1998), a simulação dos capitéis por barras de grelha reduz a rigidez do pavimento. O Modelo 09 é apresentado esquematicamente na Figura 4.21.
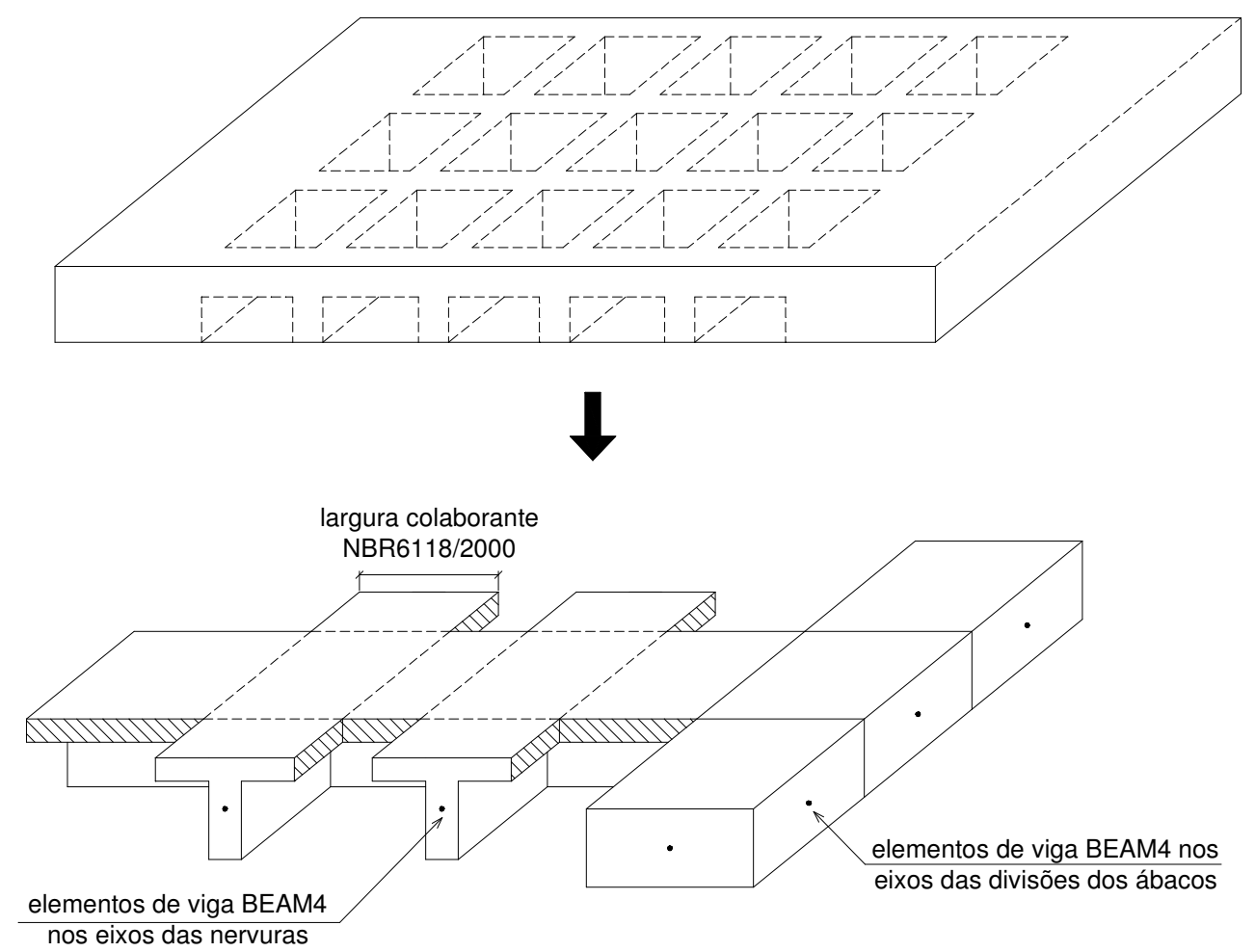

FIGURA 4.21: Representação esquemática do Modelo 09

j) Modelo 10: modelo de grelha onde o pavimento em laje nervurada sem vigas é representado pela grelha das nervuras associado a placa dos capitéis. Assim, as nervuras podem ser discretizadas pelo elemento BEAM4 com seção transversal tipo "T", considerando a colaboração da laje na rigidez das vigas de acordo com a NBR6118/2000. Os capitéis podem ser modelados pelo elemento SHELL63, mantendo a altura da seção de acordo com sua geometria original. O Modelo 10 é apresentado esquematicamente na Figura 4.22 . 

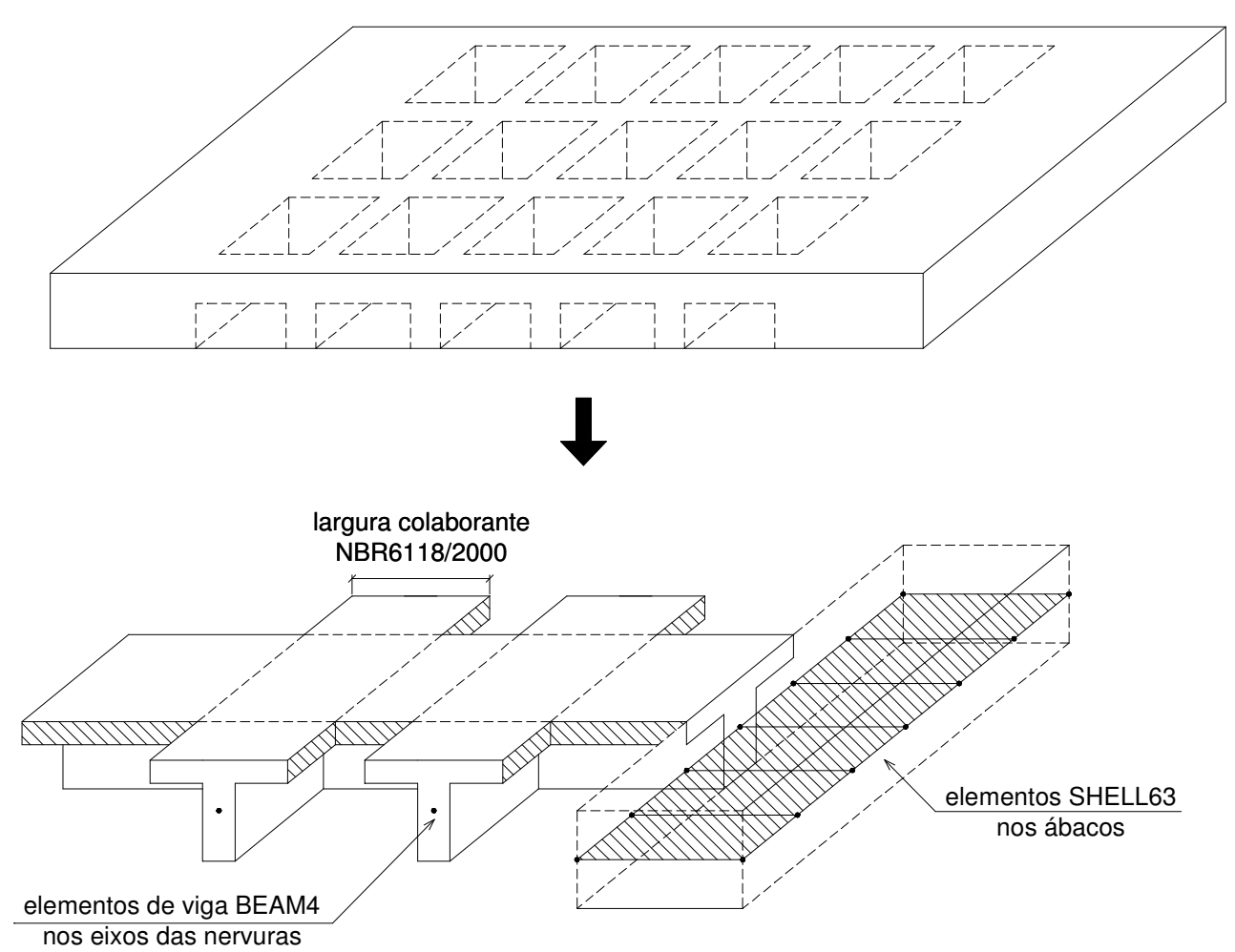

FIGURA 4.22: Representação esquemática do Modelo 10

k) Modelo 11: modelo de pórtico plano utilizando os conceitos do Método dos Pórticos Múltiplos da NBR6118/2000 onde o pavimento em laje nervurada sem vigas é representado por pórticos virtuais. As faixas de laje nervurada podem ser substituídas pela laje maciça com espessura equivalente em inércia, sendo a largura colaborante da seção " $\mathrm{T}$ " calculada de acordo com o projeto de revisão da NBR6118/2000. Os elementos lineares podem ser discretizados pelo elemento BEAM3, elemento de viga elástica bidimensional com três graus de liberdade (dois deslocamentos segundo os eixos cartesianos do plano e uma rotação em torno do eixo perpendicular ao plano) com as características de inércia e geometria advindas do método simplificado utilizado. O Modelo 11 é apresentado esquematicamente na Figura 4.23. 


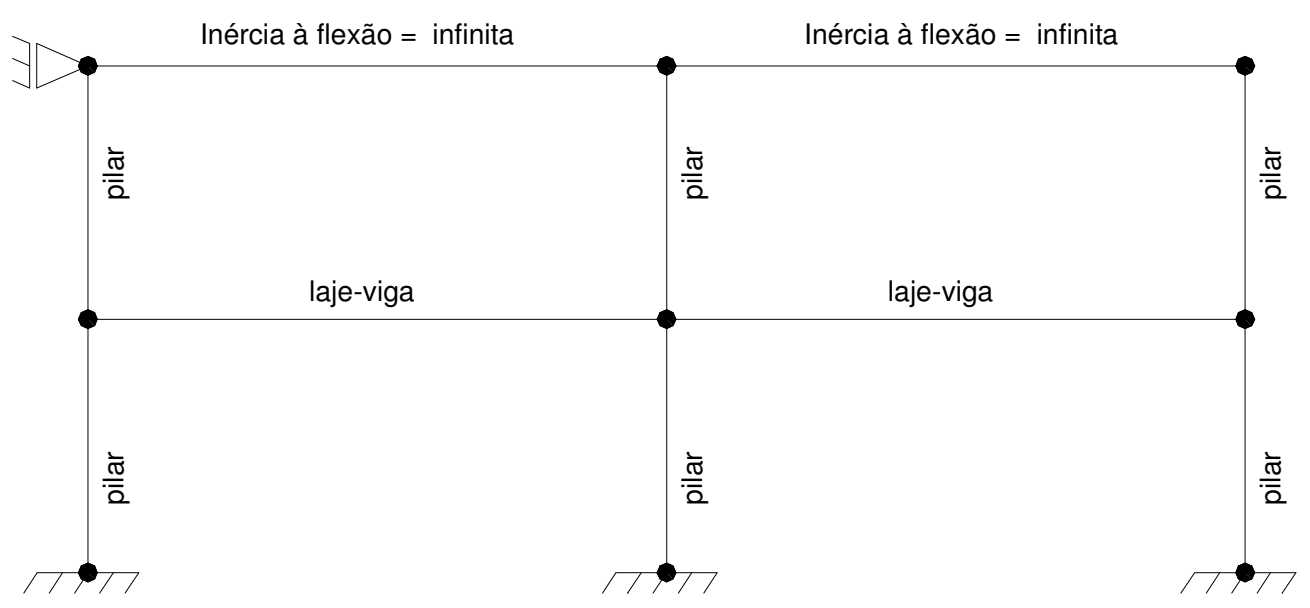

FIGURA 4.23: Representação esquemática do Modelo 11

l) Modelo 12: modelo de pórtico plano utilizando os conceitos do Método dos Pórticos Equivalentes do ACI-318 (1989) onde o pavimento em laje nervurada sem vigas é representado por pórticos virtuais. Os elementos lineares podem ser discretizados pelo elemento BEAM3, elemento de viga elástica bidimensional com três graus de liberdade (dois deslocamentos segundo os eixos cartesianos do plano e uma rotação em torno do eixo perpendicular ao plano) com as características de inércia e geometria advindas do método simplificado utilizado, onde a laje nervurada é substituída por uma laje maciça de espessura equivalente em inércia considerando a largura colaborante da seção "T" de acordo com o projeto de revisão da NBR6118/2000. O Modelo 12 é apresentado esquematicamente na Figura 4.24.

m) Modelo 13: modelo de pórtico plano utilizando os conceitos do Método dos Pórticos Equivalentes onde o pavimento em laje nervurada sem vigas é representado por pórticos virtuais. Os elementos lineares podem ser discretizados pelo elemento BEAM3, elemento de viga elástica bidimensional com três graus de liberdade (dois deslocamentos segundo os eixos cartesianos do plano e uma rotação em torno do eixo perpendicular ao plano) com as características de inércia e geometria advindas das considerações de TESORO (1991), que busca representar a inércia da laje nervurada de forma mais realista. O Modelo 13 é apresentado esquematicamente na Figura 4.25. 


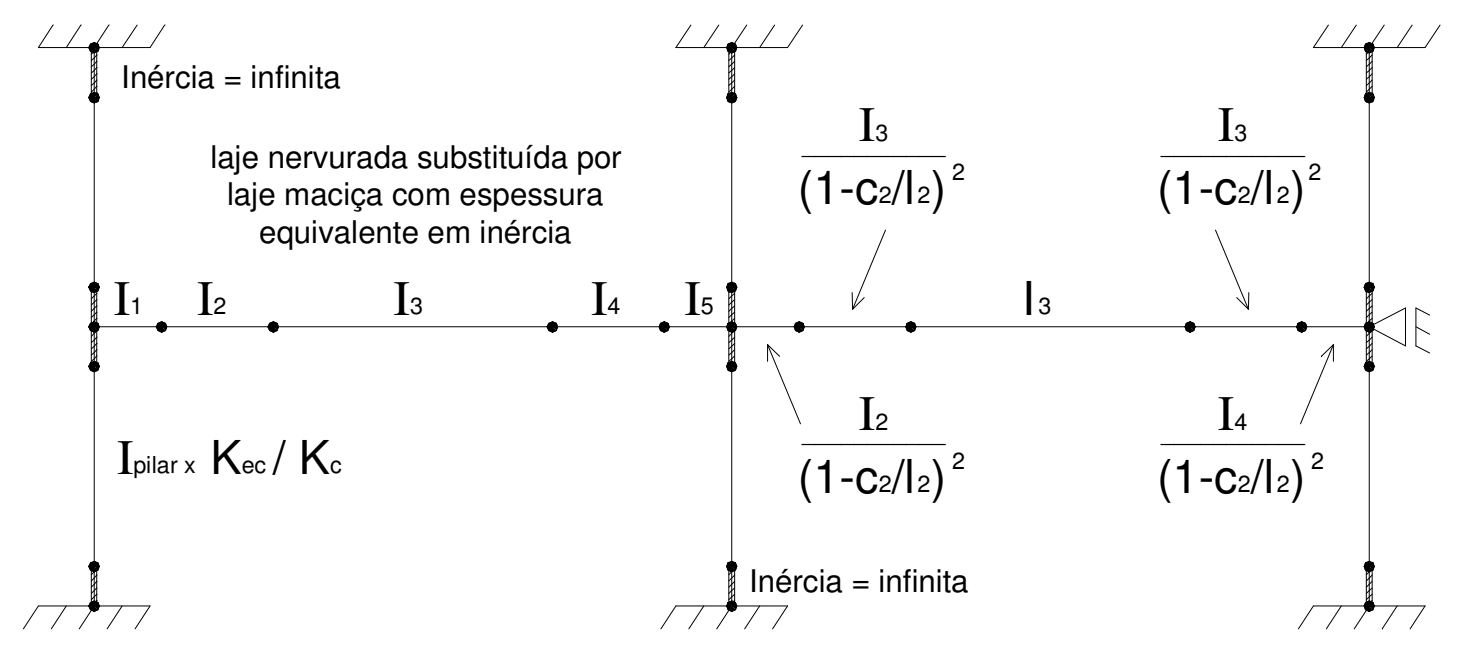

FIGURA 4.24: Representação esquemática do Modelo 12

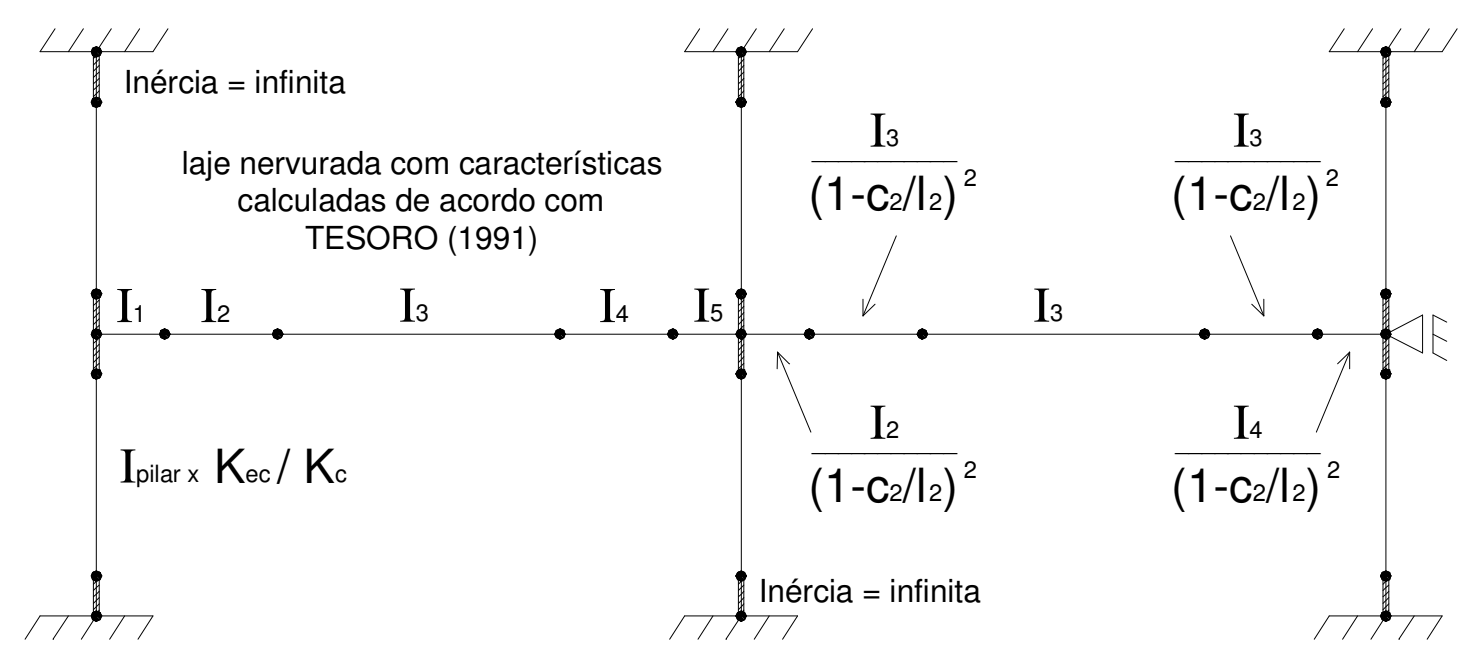

FIGURA 4.25: Representação esquemática do Modelo 13 


\subsection{VERIFICAÇÃO DA VALIDADE DOS MODELOS EM MEF APLICADOS NESTE TRABALHO}

Com o intuito de verificar a validade dos modelos em MEF que serão aplicados neste trabalho, para a análise da interação placa-viga, alguns exemplos numéricos foram efetuados utilizando o software ANSYS 5.5 e os resultados obtidos comparados com resultados disponíveis na literatura. Ressalta-se que não foram aplicados os modelos de pórticos múltiplos e equivalentes, denominados neste trabalho Modelos 11 a 13, já que não foram encontrados artigos experimentais sobre o assunto com dados completamente disponíveis para comparação. Os parâmetros de análise são os deslocamentos transversais aos planos das placas, considerando os materiais elásticos (ou, quando em concreto armado, o deslocamento na fase elástica) e momentos fletores na capa das lajes.

\section{a) Lajes maciças apoiadas em vigas elásticas no contorno, conforme TIMOSHENKO \& WOINOWSKY-KRIEGER (1959)}

A partir de dois problemas resolvidos analiticamente por TIMOSHENKO \& WOINOWSKY-KRIEGER (1959) foram analisadas duas lajes a fim de verificar os resultados apresentados pelo elemento finito de viga tridimensional BEAM44 disponível pelo software ANSYS 5.5, que aceita a consideração da excentricidade da viga em relação ao plano médio da placa. Os resultados apresentados com a utilização deste elemento são comparados com os obtidos utilizando-se o elemento de viga tridimensional BEAM4, considerado sempre concêntrico ao plano médio da placa. A laje, em todos os modelos, foi discretizada com elementos de casca SHELL63, considerando dessa forma os efeitos de membrana e de flexão.

Assim, tem-se:

a.1) Placa quadrada com dois lados opostos simplesmente apoiados e os outros dois suportados elasticamente

Foram considerados os seguintes dados de entrada:

- carga uniformemente distribuída: $\mathrm{q}=0,0005 \mathrm{kN} / \mathrm{cm}^{2}$;

- módulo de elasticidade do concreto: $\mathrm{E}=2128,74 \mathrm{kN} / \mathrm{cm}^{2}$;

- coeficiente de Poisson: $v=0,30$;

- espessura da laje maciça de concreto: $\mathrm{h}=10 \mathrm{~cm}$; 
- vigas de suporte com as dimensões $10 \mathrm{~cm}$ x $50 \mathrm{~cm}$, desprezando-se a inércia à torção.

A geometria do problema pode ser verificado na Figura 4.26.

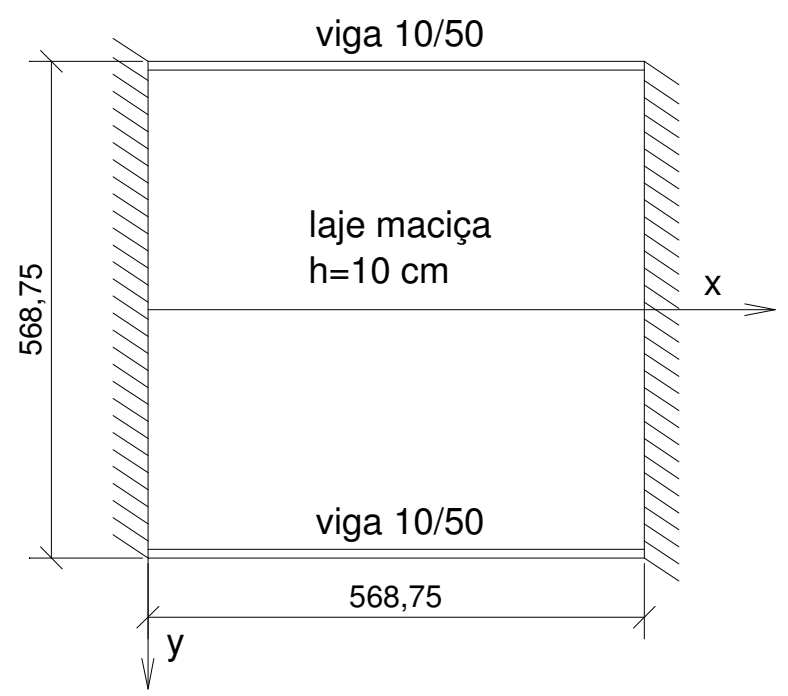

FIGURA 4.26: Laje simplesmente apoiada em dois lados, e com outras duas vigas opostas, $\mathrm{em} \mathrm{cm}$

Foram analisados os Modelos 01 a 04. O Modelo 02 considera a excentricidade entre a nervura e a placa, tomando a altura da viga até a face superior da laje, de acordo com a Figura 4.27.

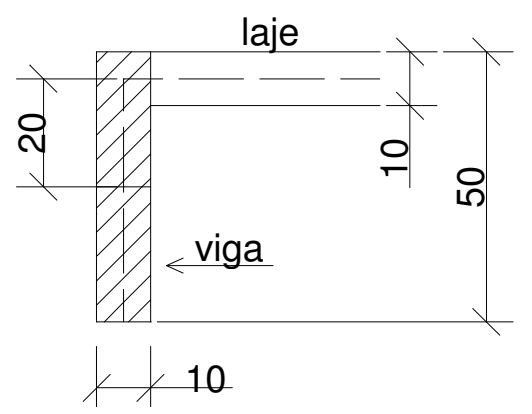

FIGURA 4.27: Excentricidade da viga até a face superior da laje, em $\mathrm{cm}$

O Modelo 03 considera a excentricidade entre a nervura e a placa, tomando a altura da viga até a face inferior da laje, de acordo com a Figura 4.28. 


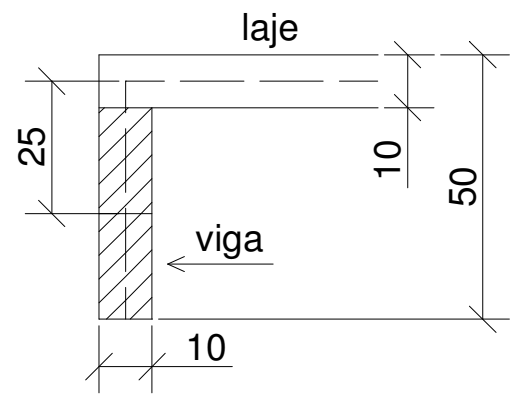

FIGURA 4.28: Excentricidade da viga até a face inferior da laje, em $\mathrm{cm}$

Os resultados encontrados são apresentados na Tabela 4.1 juntamente com os calculados analiticamente a partir de TIMOSHENKO \& WOINOWSKY-KRIEGER (1959), tratados aqui como resultados Analíticos, e que não consideram a excentricidade entre os elementos.

TABELA 4.1: Resultados obtidos nas modelagens

\begin{tabular}{c|c|c|c}
\hline \hline Modelo & $\begin{array}{c}\text { w máximo } \\
(\mathbf{e m ~ c m})\end{array}$ & $\begin{array}{c}\mathbf{M}_{\mathbf{x}} \text { máximo } \\
(\mathbf{e m} \text { kN.cm/cm) }\end{array}$ & $\begin{array}{c}\mathbf{M}_{\mathbf{y}} \mathbf{m a ́ x i m o} \\
(\mathbf{e m} \text { kN.cm/cm) }\end{array}$ \\
\hline \hline Modelo 01 & 1,42 & 9,3282 & 7,2141 \\
\hline Modelo 01-A & 1,42 & 9,3282 & 7,2141 \\
\hline Modelo 02 & 1,24 & 8,4227 & 7,4561 \\
\hline Modelo 03 & 1,32 & 8,7985 & 7,1790 \\
\hline Modelo 04 & 1,17 & 7,9600 & 7,1000 \\
\hline Analítico & 1,42 & 9,2353 & 6,7768 \\
\hline \hline
\end{tabular}

Analisando-se os resultados da Tabela 4.1, verificou-se que:

- os modelos concêntricos apresentaram o mesmo deslocamento transversal ao plano da placa máximo de TIMOSHENKO \& WOINOWSKY-KRIEGER (1959), e os excêntricos apresentaram deslocamentos ortogonais ao plano da placa menores, com a maior diferença sendo $21 \%$ para o Modelo 04;

- entre os modelos concêntricos e o resultado dito Analítico os momentos fletores máximos apresentaram diferença máxima de $6 \%$.

a.2) placa quadrada com os quatro lados apoiados em vigas elásticas, e cantos simplesmente apoiados

Foram considerados os seguintes dados de entrada:

- carga uniformemente distribuída: $\mathrm{q}=0,0005 \mathrm{kN} / \mathrm{cm}^{2}$;

- módulo de elasticidade do concreto: $\mathrm{E}=2128,74 \mathrm{kN} / \mathrm{cm}^{2}$;

- coeficiente de Poisson: $v=0,25$;

- espessura da laje maciça de concreto: $\mathrm{h}=10 \mathrm{~cm}$; 
- vigas de suporte com as dimensões $10 \mathrm{~cm}$ x $50 \mathrm{~cm}$, desprezando-se a inércia à torção.

A geometria do problema pode ser verificado na Figura 4.29.

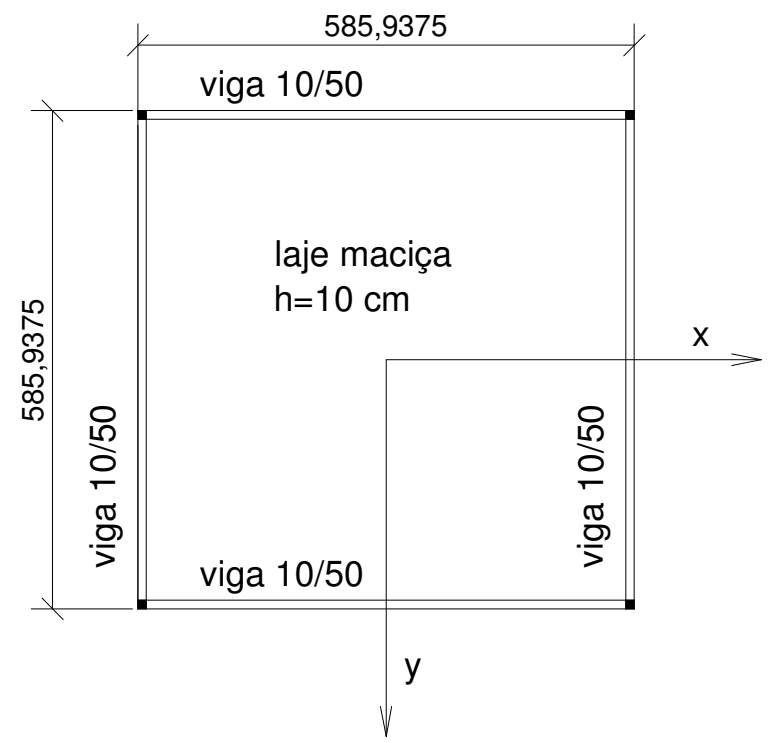

FIGURA 4.29: Laje apoiada em vigas nos quatro lados, em $\mathrm{cm}$

Foram analisados os mesmos modelos em MEF do exemplo anterior. A Tabela 4.2 apresenta os resultados obtidos.

TABELA 4.2: Resultados obtidos nas modelagens

\begin{tabular}{c|c|c}
\hline \hline Modelo & $\begin{array}{c}\text { W no centro da laje } \\
(\mathbf{e m} \mathbf{~ c m})\end{array}$ & $\begin{array}{c}\mathbf{M}_{\mathbf{x}}=\mathbf{M}_{\mathbf{y}} \mathbf{n o ~ c e n t r o} \\
(\mathbf{e m} \mathbf{~ k N . c m} / \mathbf{c m})\end{array}$ \\
\hline \hline Modelo 01 & 2,078 & 9,184 \\
\hline Modelo 01-A & 2,078 & 9,184 \\
\hline Modelo 02 & 1,686 & 8,311 \\
\hline Modelo 03 & 1,593 & 8,297 \\
\hline Modelo 04 & 1,472 & 7,596 \\
\hline Analítico & 2,081 & 9,253 \\
\hline \hline
\end{tabular}

Analisando-se os resultados da Tabela 4.2 verificou-se que:

- os modelos concêntricos apresentaram deslocamento transversal ao plano da placa máximo $0,14 \%$ menor que o resultado apresentado por TIMOSHENKO \& WOINOWSKY-KRIEGER (1959), e diferença de 0,75\% nos momentos fletores no centro da placa; 
- os modelos excêntricos apresentaram maior rigidez, sendo a maior diferença entre os deslocamentos ortogonais ao plano da placa máximos de $41 \%$ para o Modelo 04 em relação ao modelo chamado de Analítico.

\section{b) Lajes maciças apoiadas em vigas elásticas no contorno, conforme experimento de ALLEN \& SEVERN (1961)}

ALLEN \& SEVERN (1961) apresentaram soluções em série para lajes retangulares de espessura constante simplesmente apoiadas em duas vigas idênticas e em lados opostos, unidas à laje e submetidas a carregamentos aplicados na laje e nas vigas.

Determinaram as constantes das soluções em série através de apropriadas condições de simetria, de apoio simples em dois lados e com a compatibilidade de deformação nas junções laje-viga. Consideraram, na formulação, a resistência à torção das vigas.

Verificaram a formulação através de resultados experimentais de seis lajes construídas com Araldite sob estas condições. Neste trabalho fez-se a análise numérica em Método dos Elementos Finitos nos Modelos 01 a 05. Os Modelos 01, 02, 03 e 05 resultaram em 60 elementos finitos de barra tridimensional e 900 elementos finitos de casca. O modelo 04 resultou em 1200 elementos finitos de casca.

Foram considerados os seguintes dados de entrada para a resolução do problema:

- módulo de elasticidade do material compósito: $\mathrm{E}=302,48365 \mathrm{kN} / \mathrm{cm}^{2}$;

- coeficiente de Poisson: $v=0,35$;

Os carregamentos aplicados na lajes, apresentados na Tabela 4.3, agem da seguinte forma:

a) cargas pontuais aplicadas no centro das vigas, $\mathrm{W}$;

b) carregamento uniformemente distribuído sobre a laje, q, associado a carregamento distribuído ao longo das vigas, p.

TABELA 4.3: Carregamentos das lajes

\begin{tabular}{|c|c|c|c|}
\hline Laje & $\overline{\mathrm{W}(\mathrm{em} \mathrm{kN})}$ & $\bar{Q}\left(\mathrm{em} \mathrm{kN} / \mathrm{cm}^{2}\right)$ & $P(\mathrm{em} \mathrm{kN} / \mathrm{cm})$ \\
\hline Laje $01-\mathrm{C} 1$ & 0,17723 & - & - \\
\hline Laje $01-\mathrm{C} 2$ & - & 0,000691 & 0,000315 \\
\hline Laje $02-\mathrm{C} 1$ & 0,17723 & - & - \\
\hline Laje $02-\mathrm{C} 2$ & - & 0,000722 & 0,000315 \\
\hline Laje $03-\mathrm{C} 1$ & 0,17723 & - & - \\
\hline Laje $03-\mathrm{C} 2$ & - & 0,000722 & 0,000315 \\
\hline
\end{tabular}


As características geométricas das lajes ensaiadas podem ser verificadas na Figura 4.30 e Tabela 4.4. Os lados ortogonais às vigas são simplesmente apoiados.

TABELA 4.4: Características geométricas das lajes ensaiadas

\begin{tabular}{c|c|c|c|c|c}
\hline \hline Laje & $\mathbf{a}(\mathbf{c m})$ & $\mathbf{b}_{\mathbf{w}}(\mathbf{c m})$ & $\mathbf{h}(\mathbf{c m})$ & $\mathbf{l}(\mathbf{c m})$ & $\mathbf{h}_{\mathbf{f}}(\mathbf{c m})$ \\
\hline \hline Laje 01 & 13,858 & 0,452 & 1,910 & 13,000 & 0,445 \\
\hline Laje 02 & 13,858 & 0,452 & 1,524 & 13,000 & 0,445 \\
\hline Laje 03 & 13,858 & 0,452 & 1,910 & 13,000 & 0,318 \\
\hline \hline
\end{tabular}

Os resultados dos deslocamentos no vão central das vigas, nas análises numéricas, são apresentados na Tabela 4.5. Os mesmos são comparados com os resultados experimentais e numéricos fornecidos por ALLEN \& SEVERN (1961), respectivamente chamados de ensaio e numérico.

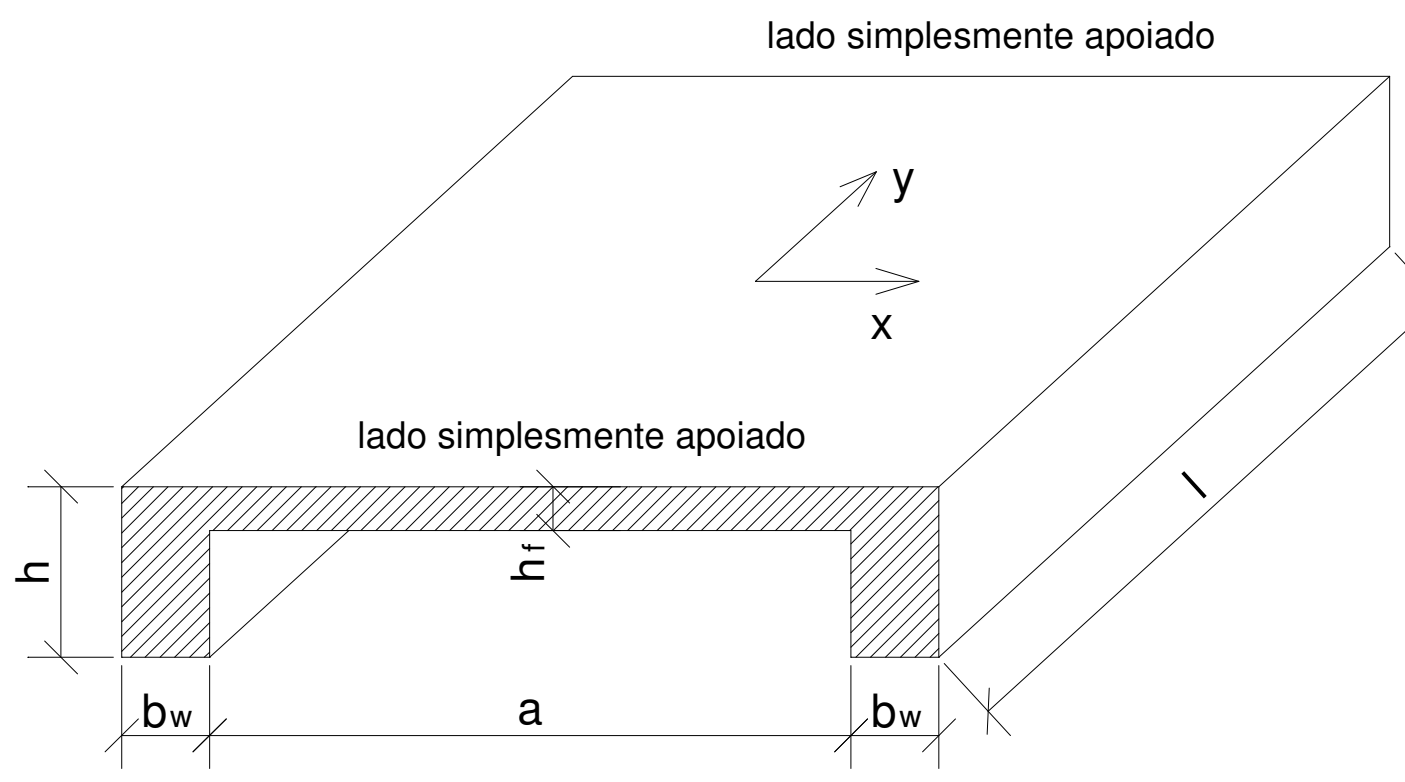

FIGURA 4.30: Geometria das lajes em Araldite ensaiadas

[ALLEN \& SEVERN (1961)]

TABELA 4.5: Deslocamentos no vão central das vigas (em cm)

\begin{tabular}{c|c|c|c|c|c|c|c}
\hline \hline Laje & Ensaio & Numérico & Modelo 01 & Modelo 02 & Modelo 03 & Modelo 04 & Modelo 05 \\
\hline L1-C1 & 0,0533 & 0,0507 & 0,0886 & 0,0521 & 0,0567 & 0,0545 & 0,0535 \\
\hline L1-C2 & - & 0,0086 & 0,0161 & 0,0094 & 0,0102 & 0,0095 & 0,0100 \\
\hline L2-C1 & 0,0711 & 0,0776 & 0,1561 & 0,0975 & 0,1058 & 0,0988 & 0,0971 \\
\hline L2-C2 & - & 0,0166 & 0,0245 & 0,0154 & 0,0164 & 0,0181 & 0,0160 \\
\hline L3-C1 & 0,0584 & 0,0526 & 0,0959 & 0,0552 & 0,0604 & 0,0577 & 0,0580 \\
\hline L3-C2 & - & 0,0096 & 0,0192 & 0,0110 & 0,0119 & 0,0105 & 0,0118 \\
\hline \hline
\end{tabular}


Analisando-se os resultados apresentados na Tabela 4.5 verificou-se que:

- para a laje L1-C1 o Modelo 04 apresentou o deslocamento no vão central das vigas diferindo apenas 2,25\% do resultado do ensaio. Os Modelos de viga excêntrica 02 e 03 apresentaram resultados discrepantes em 2,30\% e 6,38\%, respectivamente. O modelo, contudo, que ofereceu resultado de deslocamento mais próximo do experimental foi o Modelo 05, diferindo apenas 0,38\%. O modelo concêntrico subestimou a rigidez apresentando deslocamento $66,23 \%$ maior que o experimental;

- para a laje L1-C2 os Modelos 02 e 04 apresentaram o mesmo resultado, diferindo de 9,88\% do resultado numérico de ALLEN \& SEVERN (1961);

- a laje L2-C1 modelada neste trabalho apresentou grandes diferenças nos resultados em relação à laje ensaiada, de 37\% no mínimo para os modelos excêntricos;

- para a laje L2-C2 os Modelos numéricos 03 e 05 apresentaram resultados muito próximos daqueles obtidos pelo modelo numérico de ALLEN \& SEVERN (1961), diferindo no máximo $3,75 \%$;

- para a laje L3-C1 o Modelo 04 apresentou o deslocamento no vão central das vigas diferindo apenas $1,21 \%$ do resultado experimental. Os modelos de viga excêntrica 02 e 03 apresentaram resultados discrepantes em 5,8\% e 3,42\%, respectivamente. O modelo, contudo, que ofereceu resultado de deslocamento mais próximo do experimental foi o Modelo 05, diferindo apenas 0,69\%. O modelo concêntrico apresentou deslocamento $64,21 \%$ maior que o experimental.

\section{c) Análise de placa simplesmente apoiada enrijecida por duas nervuras paralelas dispostas no maior lado, conforme CHEUNG et al. (1994)}

CHEUNG et al. (1994) apresentaram solução através da associação do Método dos Elementos de Contorno (para as lajes) e Método das Faixas Finitas (para as vigas) para a análise de lajes retangulares ou esconsas acopladas a vigas, muito utilizadas em pontes.

Como exemplo numérico tem-se uma ponte de laje sobre vigas simplesmente apoiada nos lados transversais às vigas e submetida a uma carga de pneu (carga pontual distribuída sobre uma pequena área) no centro da laje, de acordo com a Figura 4.31 .

Foram considerados os seguintes dados de entrada para a resolução do problema:

- carga pontual aplicada no centro da laje, de valor $\mathrm{p}=110,363 \mathrm{kN}$; 
- módulo de elasticidade: $\mathrm{E}=2500 \mathrm{kN} / \mathrm{cm}^{2}$;

- coeficiente de Poisson: $v=0,15$;

Foram analisados os mesmos modelos em MEF do exemplo anterior.

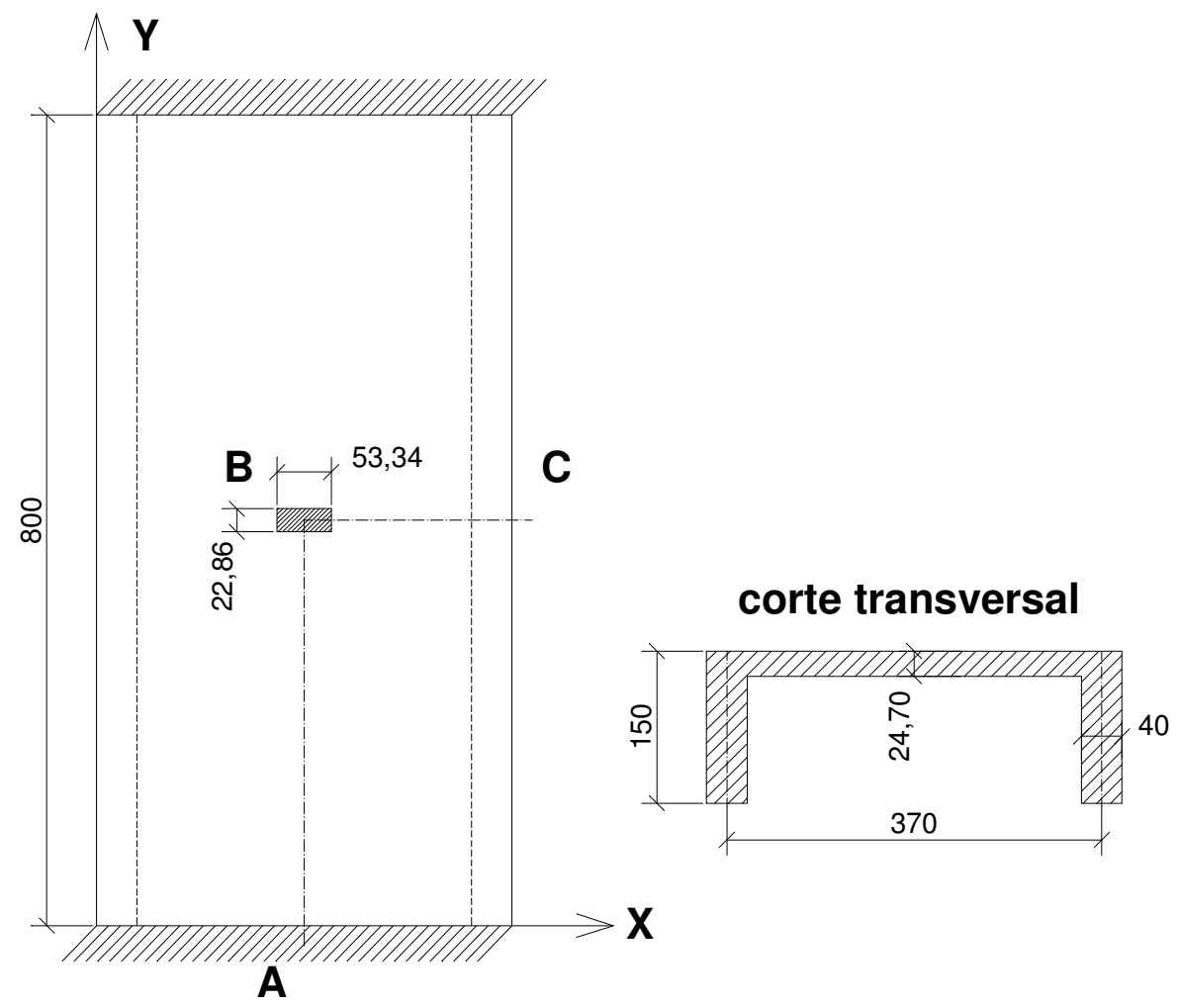

FIGURA 4.31: Geometria da laje analisada, em cm [CHEUNG et al. (1994)]

Os resultados de deslocamentos no centro da laje são apresentados na Tabela 4.6 abaixo, comparando-se os valores encontrados pelos modelos numéricos deste trabalho.

TABELA 4.6: Deslocamentos no centro da laje $(\mathrm{em} \mathrm{cm})$

\begin{tabular}{c|c}
\hline \hline Modelo numérico & Deslocamento transversal (em cm) \\
\hline \hline Modelo 01 & 0,06815 \\
\hline Modelo 02 & 0,06308 \\
\hline Modelo 03 & 0,05987 \\
\hline Modelo 04 & 0,06306 \\
\hline Modelo 05 & 0,06002 \\
\hline \hline
\end{tabular}

Por meio da análise da Tabela 4.6 pode-se verificar que os resultados dos modelos excêntricos ficaram muito próximos, com diferença máxima de 5,36\%, sendo o 
Modelo 03 o mais rígido e o Modelo 02 o mais flexível. Considerando as vigas concêntricas obtém-se uma diferença máxima entre os modelos de 13,83\%.

Os resultados de momentos fletores são comparados entre os modelos deste trabalho, ao longo das linhas A-B-C, e apresentados nas Tabelas 4.7 e 4.8, e as respectivas Figuras 4.32 e 4.33 . Os mesmos são comparados com os resultados numéricos fornecidos por CHEUNG et al. (1994).

TABELA 4.7: Momentos fletores $\mathrm{M}_{\mathrm{x}}$ ao longo da linha A-B-C (em kN.cm/cm)

\begin{tabular}{|c|c|c|c|c|c|c|c|c|c|}
\hline \multicolumn{10}{|c|}{ Momentos fletores $M_{x}(\mathrm{em}$ kN.cm/cm) } \\
\hline \multirow{2}{*}{ Modelo } & \multirow{2}{*}{$\begin{array}{c}\mathbf{A} \\
0 \mathrm{~cm} \\
\end{array}$} & \multirow[b]{2}{*}{$100 \mathrm{~cm}$} & \multirow[b]{2}{*}{$200 \mathrm{~cm}$} & \multirow[b]{2}{*}{$250 \mathrm{~cm}$} & \multirow[b]{2}{*}{$300 \mathrm{~cm}$} & \multirow{2}{*}{$\begin{array}{c}\text { B } \\
400 \mathrm{~cm} \\
\end{array}$} & \multirow[b]{2}{*}{$450 \mathrm{~cm}$} & \multirow[b]{2}{*}{$500 \mathrm{~cm}$} & \multirow{2}{*}{$\begin{array}{c}\text { C } \\
585 \mathrm{~cm} \\
\end{array}$} \\
\hline & & & & & & & & & \\
\hline 01 & 0,15 & 1,45 & 4,15 & 5,93 & 9,98 & 27,45 & 11,10 & 4,01 & $-11,12$ \\
\hline 02 & 0,16 & 1,55 & 4,34 & 7,29 & 10,23 & 27,72 & 11,38 & 4,29 & $-10,92$ \\
\hline 03 & 0,14 & 1,83 & 4,92 & 7,00 & 11,85 & 27,38 & 10,10 & 4,37 & $-11,51$ \\
\hline 04 & 0,15 & 1,45 & 4,17 & 7,08 & 10,00 & 27,44 & 11,10 & 4,24 & $-10,74$ \\
\hline 05 & 0,14 & 1,86 & 4,97 & 7,05 & 11,91 & 27,45 & 11,10 & 4,02 & $-11,12$ \\
\hline Cheung & 0 & 2,00 & 4,50 & 7,00 & 11,00 & 27,00 & 10,00 & 2,50 & $-12,00$ \\
\hline
\end{tabular}

TABELA 4.8: Momentos fletores $\mathrm{M}_{\mathrm{y}}$ ao longo da linha A-B-C (em kN.cm/cm)

\begin{tabular}{|c|c|c|c|c|c|c|c|c|c|}
\hline \multicolumn{10}{|c|}{ Momentos fletores $M_{y}(\mathrm{em}$ kN.cm/cm) } \\
\hline \multirow{2}{*}{ Modelo } & $\mathbf{A}$ & & & & & B & & & C \\
\hline & $0 \mathrm{~cm}$ & $100 \mathrm{~cm}$ & $200 \mathrm{~cm}$ & $250 \mathrm{~cm}$ & $300 \mathrm{~cm}$ & $400 \mathrm{~cm}$ & $450 \mathrm{~cm}$ & $500 \mathrm{~cm}$ & $585 \mathrm{~cm}$ \\
\hline 01 & $-0,03$ & $-0,34$ & $-0,71$ & $-0,55$ & 0,98 & 22,88 & 13,69 & 7,87 & $-0,39$ \\
\hline 02 & $-0,03$ & $-0,35$ & $-0,79$ & $-0,43$ & 0,80 & 22,63 & 13,44 & 7,61 & $-0,70$ \\
\hline 03 & $-0,04$ & $-0,53$ & $-0,93$ & $-0,60$ & 1,80 & 22,41 & 14,39 & 5,23 & $-0,87$ \\
\hline 04 & $-0,04$ & $-0,44$ & $-0,94$ & $-0,53$ & 0,76 & 22,72 & 13,54 & 6,68 & $-0,49$ \\
\hline 05 & $-0,05$ & $-0,43$ & $-0,68$ & $-0,28$ & 2,20 & 22,88 & 13,69 & 7,87 & $-0,39$ \\
\hline Cheung & 0 & $-0,50$ & $-0,75$ & $-0,50$ & 0,75 & 24,50 & 14,00 & 6,00 & $-0,20$ \\
\hline
\end{tabular}

Analisando-se as tabelas e gráficos de momentos fletores verifica-se que os resultados encontrados por todos os modelos de análise denotam o mesmo comportamento, porém ocorrendo pontos com valores discrepantes. A influência dessa discrepância no dimensionamento será analisada com maior profundidade na etapa posterior do trabalho. 


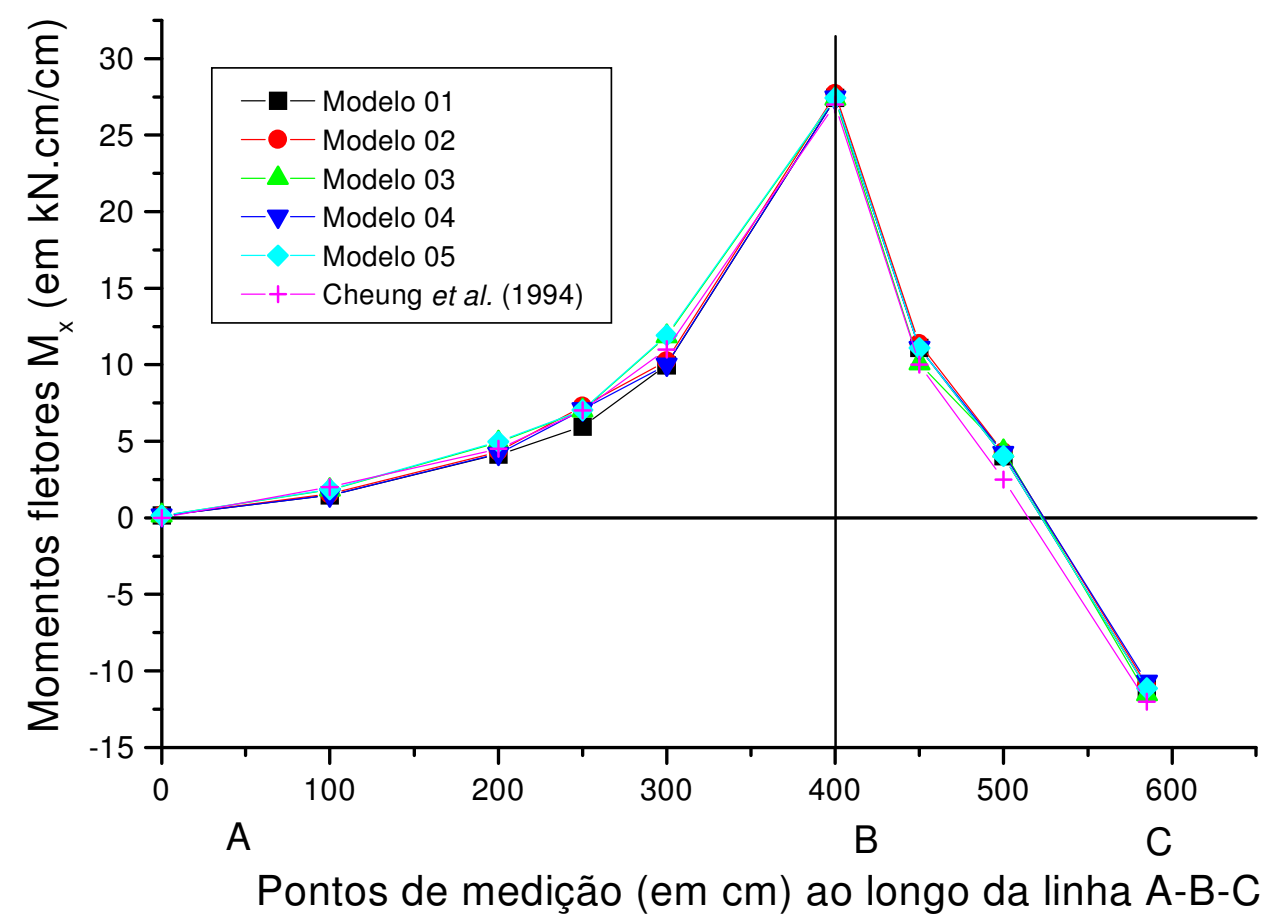

FIGURA 4.32: Momentos fletores $\mathrm{M}_{\mathrm{x}}$ ao longo da linha A-B-C, em $\mathrm{kN} . \mathrm{cm} / \mathrm{cm}$, na laje proposta por CHEUNG et al. (1994)

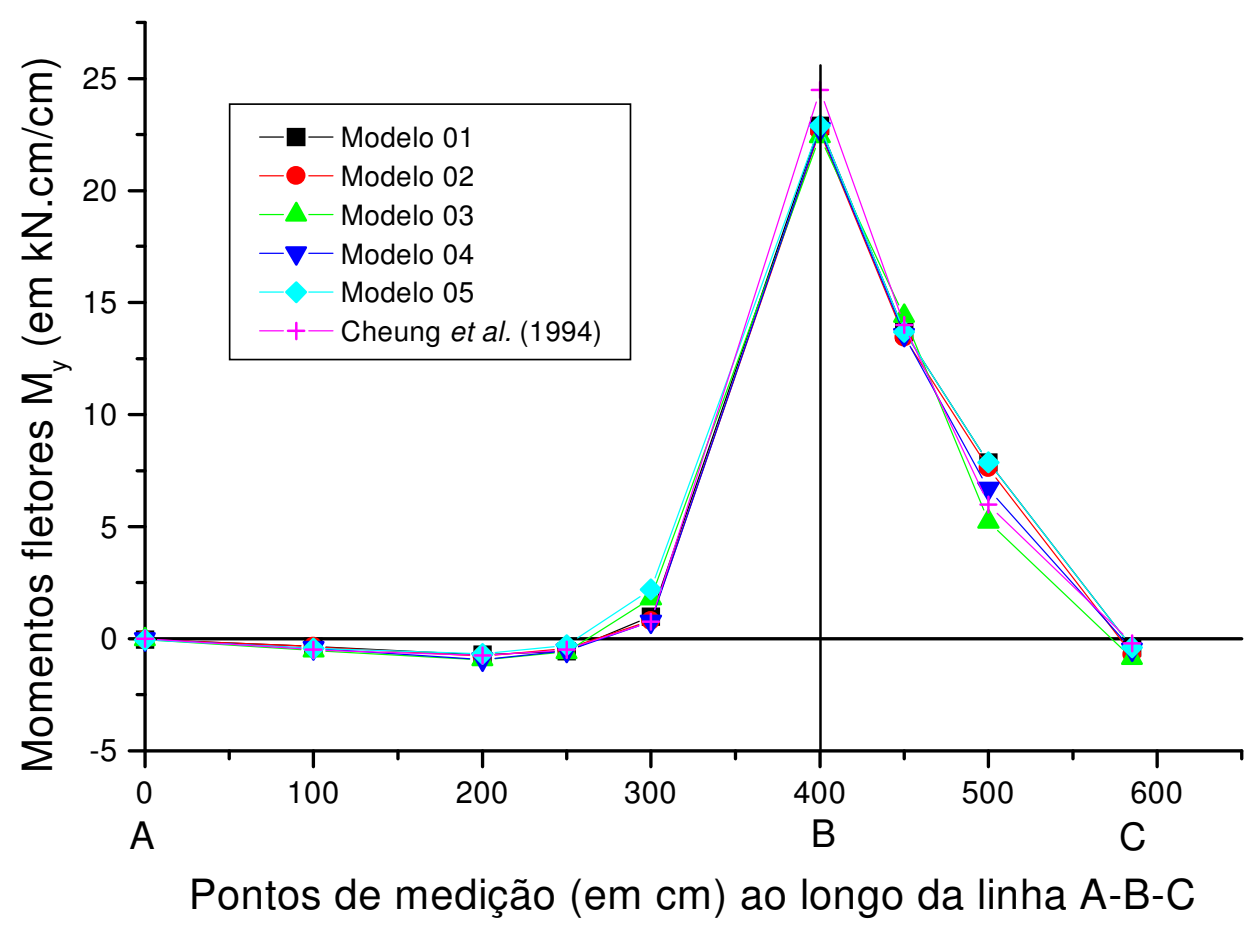

FIGURA 4.33: Momentos fletores $\mathrm{M}_{\mathrm{Y}}$ ao longo da linha A-B-C, em $\mathrm{kN} . \mathrm{cm} / \mathrm{cm}$, na laje proposta por CHEUNG et al. (1994) 
d) Análise de placa enrijecida por duas nervuras ortogonais conforme PENGCHENG et al. (1987)

PENG-CHENG et al. (1987) efetuaram análise numérica utilizando funções "B -Spline" em placa enrijecida submetida a carregamento uniformemente distribuído e engastada nos contornos.

Considerou-se os seguintes dados de entrada para a resolução do problema:

- carga uniformemente distribuída: $\mathrm{q}=0,005 \mathrm{kN} / \mathrm{cm}^{2}$;

- módulo de elasticidade: $\mathrm{E}=21160 \mathrm{kN} / \mathrm{cm}^{2}$;

- coeficiente de Poisson: $v=0,30$;

- espessura da placa: $\mathrm{h}=0,2817 \mathrm{~cm}$;

- inércia à flexão das nervuras: $\mathrm{I}=0,00596 \mathrm{~cm}^{4}$;

- inércia à torção das nervuras: $\mathrm{I}_{\mathrm{t}}=0$;

A geometria do problema pode ser verificado na Figura 4.34.

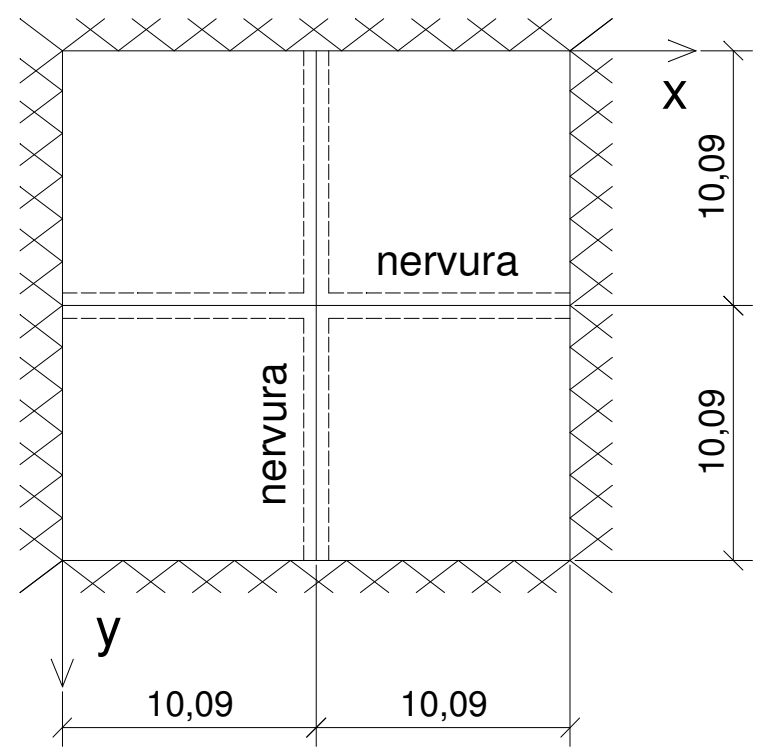

FIGURA 4.34: Geometria da placa enrijecida por nervuras concêntricas, em cm [PENG-CHENG et al. (1987)]

Na análise numérica foi usado o Modelo 01, ou seja, modelo concêntrico, único cábivel na análise.

As Tabelas 4.9 a 4.11 apresentam os resultados obtidos comparando-os com os resultados experimentais e numéricos encontrados por PENG-CHENG et al. (1987).

Pode-se verificar, a partir das tabelas de resultados, que o modelo concêntrico aplicado neste trabalho forneceu resultados de deslocamentos idênticos aos 
resultados numéricos de PENG-CHENG et. al. (1987), aproximando-se do experimental concêntrico. Quanto aos momentos fletores os resultados do Modelo 01 deste trabalho ficaram mais próximos dos experimentais do que o numérico apresentado pelos autores do artigo original.

TABELA 4.9: Deslocamentos na placa enrijecida, em mm

\begin{tabular}{c|c|c|c|c}
\hline \hline \multirow{2}{*}{ Ponto na laje } & \multicolumn{4}{|c}{ Deslocamento transversal } \\
\cline { 2 - 5 } & Experimental & Numérico & Modelo 01 & Modelo 01-A \\
\hline \hline 0 & 0 & 0 & 0 & 0 \\
\hline $1 / 8.1$ & 0,049000 & 0,040695 & 0,04070 & 0,04070 \\
\hline $1 / 4.1$ & 0,117000 & 0,112957 & 0,11302 & 0,11302 \\
\hline $3 / 8.1$ & 0,169000 & 0,168990 & 0,16912 & 0,16912 \\
\hline $1 / 2.1$ & 0,185000 & 0,189010 & 0,18916 & 0,18916 \\
\hline \hline
\end{tabular}

TABELA 4.10: Momentos fletores na laje, em kN.cm/cm x $10^{-2}$

\begin{tabular}{c|c|c|c|c}
\hline \hline \multirow{2}{*}{ Ponto na laje } & \multicolumn{4}{|c}{ Momentos Fletores na laje } \\
\cline { 2 - 5 } & \multirow{2}{*}{ Experimental } & Numérico & Modelo 01 & \multirow{2}{*}{ Modelo 01-A } \\
\hline \hline 0 & $-7,9270$ & $-7,4520$ & $-8,0004$ & $-8,0004$ \\
\hline $1 / 8.1$ & - & $-1,6686$ & $-1,8942$ & $-1,8942$ \\
\hline $1 / 4.1$ & - & 1,7812 & 1,4890 & 1,4890 \\
\hline $3 / 8.1$ & - & 3,2989 & 3,3034 & 3,3034 \\
\hline $1 / 2.1$ & 3,379 & 3,6089 & 3,4083 & 3,4083 \\
\hline \hline
\end{tabular}

TABELA 4.11: Momentos fletores nas vigas, em kN.cm x 10-2

\begin{tabular}{c|c|c|c|c}
\hline \hline \multirow{2}{*}{ Ponto na laje } & \multicolumn{4}{|c}{ Momentos Fletores nas vigas } \\
\cline { 2 - 5 } & Experimental & Numérico & Modelo 01 & Modelo 01-A \\
\hline \hline 0 & $-23,080$ & $-21,700$ & $-22,149$ & $-22,149$ \\
\hline $1 / 8.1$ & $-4,919$ & $-5,003$ & $-5,584$ & $-5,584$ \\
\hline $1 / 4.1$ & 3,973 & 4,116 & 3,685 & 3,685 \\
\hline $3 / 8.1$ & 6,950 & 7,645 & 7,394 & 7,394 \\
\hline $1 / 2.1$ & 7,568 & 8,084 & 8,007 & 8,007 \\
\hline \hline
\end{tabular}


e) Placas enrijecidas por nervuras conforme McBEAN ${ }^{4}$ e CHANG ${ }^{5}$ apud ROSSOW \& IBRAHIMKHALIL (1978), ROSSOW \& IBRAHIMKHALIL (1978), PALANI et al. (1991), BEDAIR (1997), TANAKA \& BERCIN (1998) $e$ SIDDIQI \& KUKRETI (1998)

ROSSOW \& IBRAHIMKHALIL (1978) aplicaram o Método da Restrição para a análise estática em elementos finitos de lajes enrijecidas com nervuras excêntricas e concêntricas. Nestes, o campo de deslocamentos nos enrijecedores são expressos em termos dos deslocamentos do plano médio da placa. Analisaram numericamente duas lajes enrijecidas sob carregamento transversal estático inicialmente estudadas por $\mathrm{McBEAN}^{4} \mathrm{e}$ $\mathrm{CHANG}^{5}$ : uma laje quadrada contendo uma nervura e outra retangular enrijecida por duas nervuras ortogonais, no centro da placa.

PALANI et al. (1991) propuseram dois modelos em elementos finitos isoparamétricos para a análise estática e dinâmica de lajes enrijecidas por nervuras e testaram os mesmos nas duas lajes enrijecidas descritas anteriormente.

O artigo apresentado por BEDAIR (1997) mostra uma metodologia em Programação Quadrática Seqüencial para a análise de placas multi-enrijecidas submetida a carregamento transversal, analisando as duas lajes.

TANAKA \& BERCIN (1998) aplicaram o Método dos Elementos de Contorno à flexão estática de placas enrijecidas por nervuras para analisar as mesmas placas.

O artigo apresentado por SIDDIQI \& KUKRETI (1998) aplica o Método da Quadratura Diferencial para a resolução do mesmo problema.

Os exemplos são agora analisados com os modelos concêntricos e excêntricos utilizando o ANSYS 5.5.

\section{e.1) Placa quadrada simplesmente apoiada enrijecida por uma nervura}

A geometria da placa analisada é mostrada na Figura 4.35.

Foram considerados os seguintes dados de entrada para a resolução do problema:

- carga uniformemente distribuída: $\mathrm{q}=0,000689 \mathrm{kN} / \mathrm{cm}^{2}$;

- módulo de elasticidade: $\mathrm{E}=11713 \mathrm{kN} / \mathrm{cm}^{2}$;

\footnotetext{
${ }^{4}$ McBEAN, R. P. (1968). Analysis of stiffened plates by the finite element method. Ph.D. Thesis presented to Stanford University (1968).

${ }^{5}$ CHANG, S. P. (1973). Analysis of eccentrically stiffened plates. Ph.D. Thesis presented to the University of Missouri, Columbia, Mo.
} 
- coeficiente de Poisson: $v=0,30$;

$\mathrm{Na}$ análise numérica foram utilizadas as modelagens 01 a 05.

Os resultados de deslocamentos no ponto central da laje, obtidos pelas análises numéricas, são apresentados na Tabela 4.12 e comparados com resultados numéricos disponíveis na literatura.

CORTE A-A
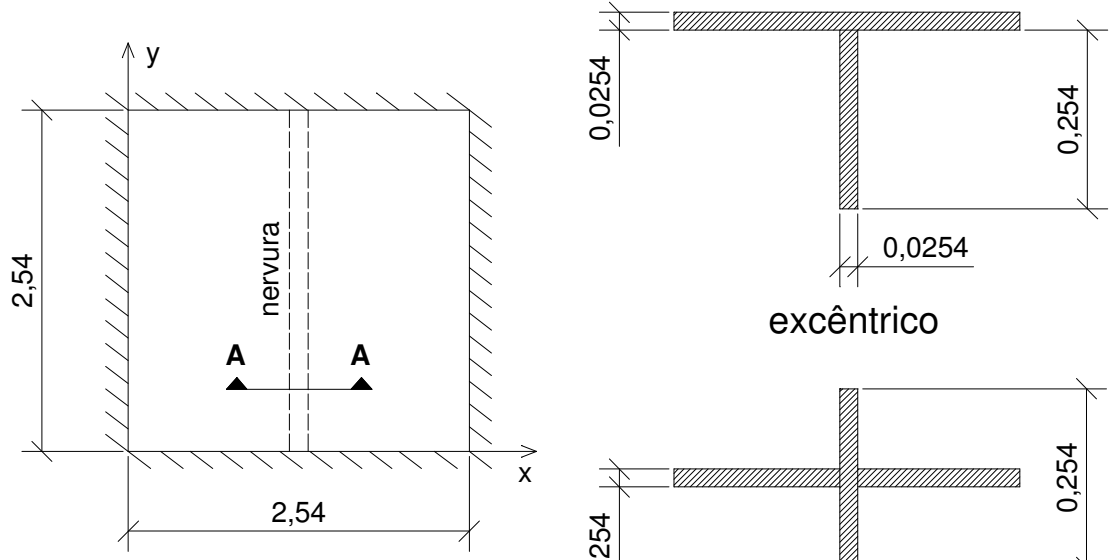

excêntrico

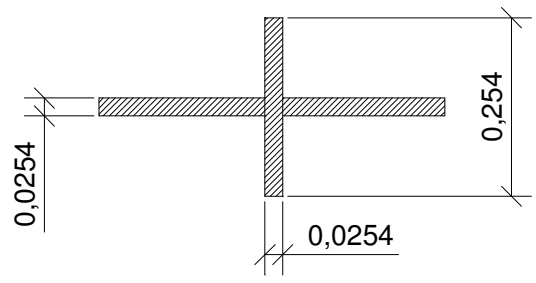

concêntrico

FIGURA 4.35: Geometria da placa enrijecida, em cm, inicialmente estudada por McBEAN ${ }^{4}$ apud ROSSOW \& IBRAHIMKHALIL (1978)

TABELA 4.12: Deslocamentos do centro da placa, em $\mathrm{cm}$

\begin{tabular}{c|c|c}
\hline \hline Análise numérica & Excêntrico & Concêntrico \\
\hline \hline McBEAN $^{4}$ apud ROSSOW \& IBRAHIMKHALIL (1978) & 0,0003472 & 0,0011575 \\
\hline ROSSOW \& IBRAHIMKHALIL (1978) $^{\text {N }}$ & 0,0003472 & 0,0011572 \\
\hline NASTRAN por ROSSOW \& IBRAHIMKHALIL & 0,0003607 & - \\
\hline BEDAIR (1997) & 0,0003048 & 0,0011151 \\
\hline TANAKA \& BERCIN (1998) & 0,0003140 & 0,0011470 \\
\hline Modelo 01 & - & 0,0011562 \\
\hline Modelo 02 & 0,0003342 & - \\
\hline Modelo 03 & 0,0003357 & - \\
\hline Modelo 04 & 0,0003660 & 0,0011804 \\
\hline Modelo 05 & 0,0003780 & - \\
\hline
\end{tabular}

Analisando-se a Tabela 4.12 verificou-se que:

- há discrepância de valores de deslocamentos no centro da placa entre os modelos numéricos excêntricos deste trabalho no máximo 13\%, com o Modelo 05 apresentando o maior deslocamento; 
- os Modelos 02 e 03 apresentaram valores praticamente iguais de deslocamento máximo;

- os modelos excêntricos deste trabalho apresentaram resultados razoavelmente próximos daqueles obtidos pelos modelos numéricos de pesquisas anteriores. É interessante notar que o modelo em MEF aplicado por ROSSOW \& IBRAHIMKHALIL (1978) com o uso do software NASTRAN aproximou-se do modelo de casca deste trabalho, ou seja, o Modelo 04, com erro de apenas 1,47\%;

- os modelos concêntricos apresentaram diferença máxima de 5,90\% entre o Modelo 04 e BEDAIR (1997);

- a maior diferença entre os modelos excêntricos e concêntricos deste exemplo, no deslocamento máximo, foi de $253,20 \%$.

A Tabela 4.13 apresenta os valores de deslocamentos ortogonais ao plano da placa ao longo do eixo central da nervura, de acordo com os resultados dos modelos numéricos. A Figura 4.36 apresenta o gráfico comparativo desses deslocamentos.

TABELA 4.13: Deslocamentos ortogonais ao plano da placa ao longo do eixo da nervura, $\mathrm{em} \mathrm{cm} \mathrm{x} 10^{-4}$

\begin{tabular}{c|c|c|c|c|c|c}
\hline \hline \multirow{2}{*}{ Ponto } & \multirow{2}{*}{ Modelo 01 } & \multirow{2}{*}{ Modelo 02 } & \multirow{2}{*}{ Modelo 03 } & \multicolumn{2}{|c|}{ Modelo 04 } & \multirow{2}{*}{ Modelo 05 } \\
\cline { 5 - 6 } & & & Excêntrico & Concêntrico & \\
\hline \hline 0 & 0 & 0 & 0 & 0 & 0 & 0 \\
\hline 0,254 & 3,615 & 1,055 & 1,060 & 1,162 & 3,700 & 1,181 \\
\hline 0,508 & 6,851 & 1,996 & 2,006 & 2,192 & 7,005 & 2,239 \\
\hline 0,762 & 9,391 & 2,730 & 2,744 & 2,992 & 9,595 & 3,071 \\
\hline 1,016 & 11,008 & 3,192 & 3,207 & 3,494 & 11,240 & 3,601 \\
\hline 1,270 & 11,562 & 3,342 & 3,358 & 3,657 & 11,804 & 3,782 \\
\hline \hline
\end{tabular}

Analisando-se a Tabela 4.13 verificou-se que:

- os modelos concêntricos apresentaram resultados próximos de deslocamentos ortogonais ao plano da placa ao longo da nervura, diferindo no máximo $2,10 \%$ no ponto de maior deslocamento;

- os modelos excêntricos apresentaram discrepância máxima de 13,20\% no deslocamento máximo ao longo da nervura, sendo o Modelo 05 o mais flexível. 


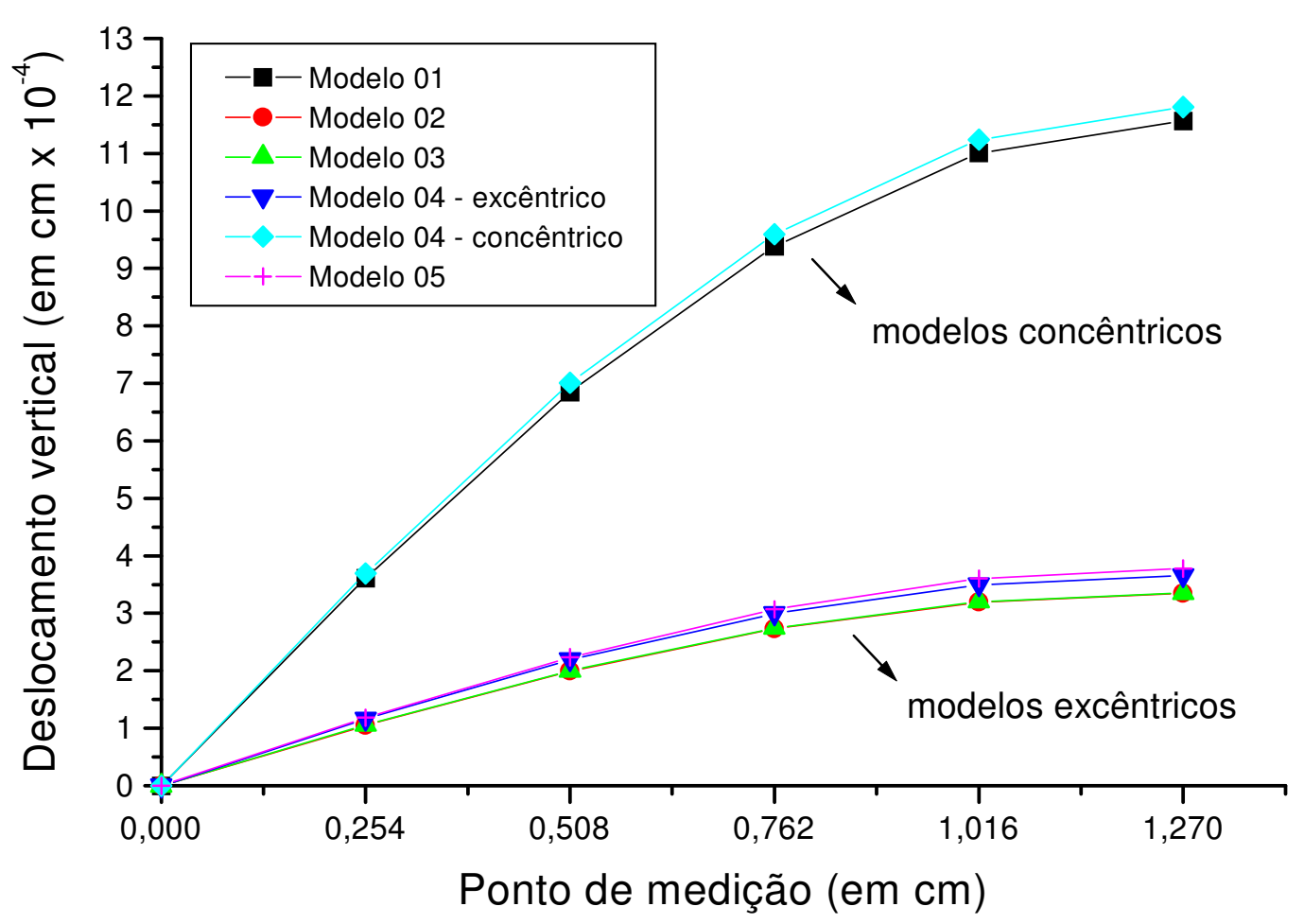

FIGURA 4.36: Deslocamentos ortogonais ao plano da placa ao longo do eixo da nervura, em $\mathrm{cm} \times 10^{-4}$, na placa proposta por McBEAN ${ }^{4}$ apud ROSSOW \& IBRAHIMKHALIL (1978)

A Tabela 4.14 apresenta os valores de deslocamentos ortogonais ao plano da placa na linha central e ortogonal ao eixo da nervura, de acordo com os resultados numéricos. A Figura 4.37 apresenta o gráfico comparativo desses deslocamentos.

TABELA 4.14: Deslocamentos ortogonais ao plano da placa ao longo da linha central ortogonal ao eixo da nervura, em $\mathrm{cm} \times 10^{-4}$

\begin{tabular}{c|c|c|c|c|c|c}
\hline \hline \multirow{2}{*}{ Ponto } & \multirow{2}{*}{ Modelo 01 } & \multirow{2}{*}{ Modelo 02 } & \multirow{2}{*}{ Modelo 03 } & \multicolumn{2}{|c|}{ Modelo 04 } & \multirow{2}{*}{ Modelo 05 } \\
\cline { 5 - 7 } & & & Excêntrico & Concêntrico & \\
\hline \hline 0 & 0 & 0 & 0 & 0 & 0 & 0 \\
\hline 0,254 & 6,641 & 4,429 & 4,434 & 4,516 & 6,707 & 4,549 \\
\hline 0,508 & 11,215 & 6,889 & 6,897 & 7,057 & 11,344 & 7,122 \\
\hline 0,762 & 12,950 & 6,742 & 6,754 & 6,982 & 13,134 & 7,076 \\
\hline 1,016 & 12,416 & 4,787 & 4,802 & 5,081 & 12,642 & 5,197 \\
\hline 1,270 & 11,562 & 3,342 & 3,358 & 3,657 & 11,804 & 3,782 \\
\hline \hline
\end{tabular}




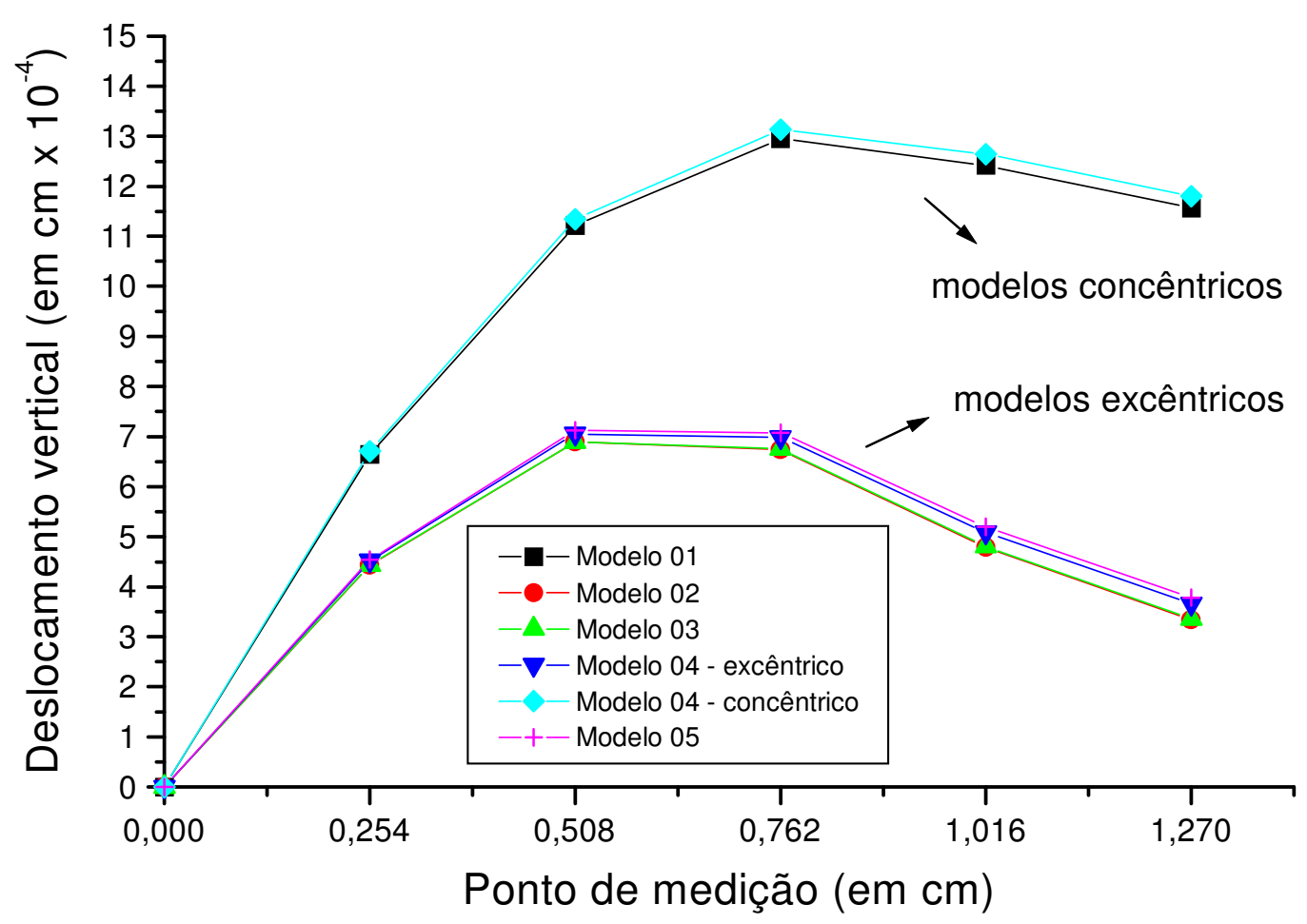

FIGURA 4.37: Deslocamentos ortogonais ao plano da placa ao longo da linha central ortogonal ao eixo da nervura, em $\mathrm{cm} \mathrm{x} 10^{-4}$, na placa proposta por $\mathrm{McBEAN}^{4}$ apud ROSSOW \& IBRAHIMKHALIL (1978)

Analisando-se a Tabela 4.14 verificou-se que:

- os Modelos excêntricos 02 e 03 apresentaram resultados próximos de deslocamentos ortogonais ao plano da placa na linha central ortogonal à nervura, diferindo no máximo $0,48 \%$ no ponto de maior deslocamento;

- os Modelos excêntricos 04 e 05 diferiram no máximo de 3,42\%, sendo o Modelo 05 o mais flexível.

e.2) Placa retangular simplesmente apoiada, com dois enrijecedores ortogonais de alturas diferentes

A placa, cuja geometria é mostrada na Figura 4.38, está submetida ora a carga distribuída ora a carga concentrada.

Assim, consideraram-se os seguintes dados de entrada:

- carga uniformemente distribuída: $\mathrm{q}=0,00689 \mathrm{kN} / \mathrm{cm}^{2}$;

- carga pontual concentrada aplicada no centro da placa: $\mathrm{p}=4,45 \mathrm{kN}$;

- módulo de elasticidade: $\mathrm{E}=20670 \mathrm{kN} / \mathrm{cm}^{2}$;

- coeficiente de Poisson: $v=0,30$. 
$\mathrm{Na}$ análise numérica foram utilizadas as mesmas modelagens do exemplo anterior.

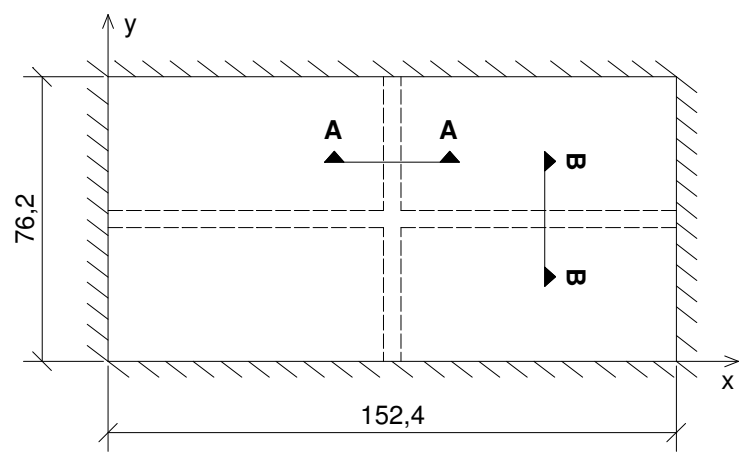

CORTE A-A

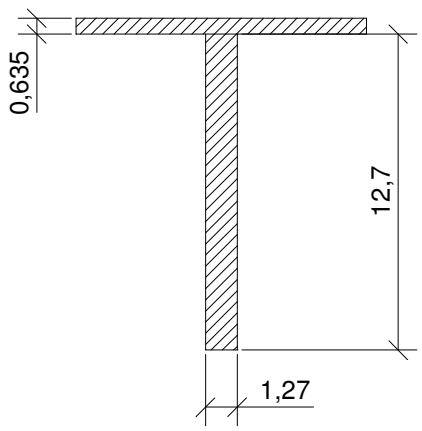

CORTE B-B

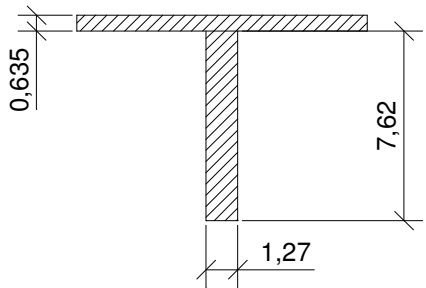

FIGURA 4.38: Geometria da placa ortogonalmente enrijecida, em $\mathrm{cm}$, inicialmente proposta por $\mathrm{CHANG}^{5}$ apud ROSSOW \& IBRAHIMKHALIL (1978)

As Tabelas 4.15 e 4.16 apresentam os resultados de deslocamentos ortogonais ao plano da placa máximos no ponto central da laje encontrados pela análise numérica dos modelos, obtidos respectivamente pelo carregamento uniformemente distribuído e pelo carregamento pontual, comparando-os com resultados encontrados na bibliografia.

TABELA 4.15: Deslocamentos do centro da placa, sob carga uniforme, em $\mathrm{cm}$

\begin{tabular}{c|c|c}
\hline \hline Análise numérica & Excêntrico & Concêntrico \\
\hline \hline CHANG $^{5}$ apud ROSSOW \& IBRAHIMKHALIL (1978) & 0,02285 & 0,06116 \\
\hline ROSSOW \& IBRAHIMKHALIL (1978) & 0,02248 & 0,06122 \\
\hline NASTRAN por ROSSOW \& IBRAHIMKHALIL & 0,02213 & - \\
\hline STRUDL por ROSSOW \& IBRAHIMKHALIL & - & 0,06126 \\
\hline BEDAIR (1997) & 0,02032 & 0,06096 \\
\hline Modelo 01 & - & 0,06108 \\
\hline Modelo 02 & 0,02090 & - \\
\hline Modelo 03 & 0,02120 & - \\
\hline Modelo 04 & 0,02551 & 0,06121 \\
\hline Modelo 05 & 0,02649 & - \\
\hline \hline
\end{tabular}


De acordo com a Tabela 4.15 pode-se verificar, em relação ao deslocamento no centro da placa sob carga distribuída, que:

- os Modelos excêntricos 02 e 03, devido à maior semelhança de considerações em comparação com os modelos numéricos de outros autores, apresentaram os resultados mais próximos destes;

- os Modelos excêntricos 04 e 05 comportaram-se novamente com maior flexibilidade, sendo o Modelo 05 o mais flexível;

- todos os modelos numéricos concêntricos apresentaram resultados muito próximos, diferindo no máximo $0,49 \%$;

- a maior diferença entre os deslocamentos excêntricos e concêntricos deste exemplo foi de $192,87 \%$.

TABELA 4.16: Deslocamentos do centro da placa, sob carregamento pontual aplicado no centro da laje, em cm

\begin{tabular}{c|c|c}
\hline \hline Análise numérica & Excêntrico & Concêntrico \\
\hline \hline CHANG $^{5}$ apud ROSSOW \& IBRAHIMKHALIL (1978) & 0,003165 & 0,008799 \\
\hline ROSSOW \& IBRAHIMKHALIL (1978) & 0,003226 & 0,008788 \\
\hline NASTRAN por ROSSOW \& IBRAHIMKHALIL & 0,003150 & - \\
\hline STRUDL por ROSSOW \& IBRAHIMKHALIL & - & 0,008796 \\
\hline BEDAIR (1997) & 0,002845 & 0,008534 \\
\hline Modelo 01 & - & 0,008807 \\
\hline Modelo 02 & 0,002950 & - \\
\hline Modelo 03 & 0,002987 & - \\
\hline Modelo 04 & 0,003778 & 0,008939 \\
\hline Modelo 05 & 0,003801 & - \\
\hline \hline
\end{tabular}

De acordo com a Tabela 4.16 pode-se verificar, em relação ao deslocamento transversal ao plano da placa no centro da placa submetida a carregamento concentrado pontual, que:

- entre os modelos numéricos excêntricos deste trabalho houve um desvio máximo de 28,80\%, sendo o Modelo 05 o mais flexível e o Modelo 02 o mais rígido;

- entre os modelos excêntricos com maiores semelhanças de formulação e hipóteses (modelos de outros autores e Modelo 02 e 03) a maior diferença foi de 13,40\%;

- todos os modelos numéricos concêntricos apresentaram resultados muito próximos, diferindo no máximo 4,75\%;

- a maior diferença entre os modelos excêntricos e concêntricos deste exemplo foi de $203,02 \%$. 
As Tabelas 4.17 e 4.18 apresentam os valores de deslocamentos ortogonais ao plano da placa ao longo do eixo central da maior nervura, de acordo com os resultados dos modelos numéricos, respectivamente para carregamento uniformemente distribuído e carregamento concentrado. As Figuras 4.39 e 4.40 comparam os resultados desses deslocamentos.

TABELA 4.17: Deslocamentos ortogonais ao plano da placa ao longo do eixo da maior nervura, em $\mathrm{cm} \times 10^{-2}$, para carregamento uniformemente distribuído

\begin{tabular}{c|c|c|c|c|c|c}
\hline \hline \multirow{2}{*}{ Ponto } & \multirow{2}{*}{ Modelo 01 } & \multirow{2}{*}{ Modelo 02 } & \multirow{2}{*}{ Modelo 03 } & \multicolumn{2}{|c|}{ Modelo 04 } & \multirow{2}{*}{ Modelo 05 } \\
\cline { 5 - 7 } & & & & Excêntrico & Concêntrico & \\
\hline \hline 0 & 0 & 0 & 0 & 0 & 0 & 0 \\
\hline 15,24 & 5,610 & 1,837 & 1,871 & 2,194 & 5,394 & 1,943 \\
\hline 30,48 & 8,990 & 3,025 & 3,085 & 3,619 & 8,691 & 3,188 \\
\hline 45,72 & 9,318 & 3,196 & 3,262 & 3,884 & 9,133 & 3,463 \\
\hline 60,96 & 7,503 & 2,592 & 2,643 & 3,224 & 7,509 & 3,029 \\
\hline 76,20 & 6,108 & 2,090 & 2,120 & 2,551 & 6,121 & 2,649 \\
\hline \hline
\end{tabular}

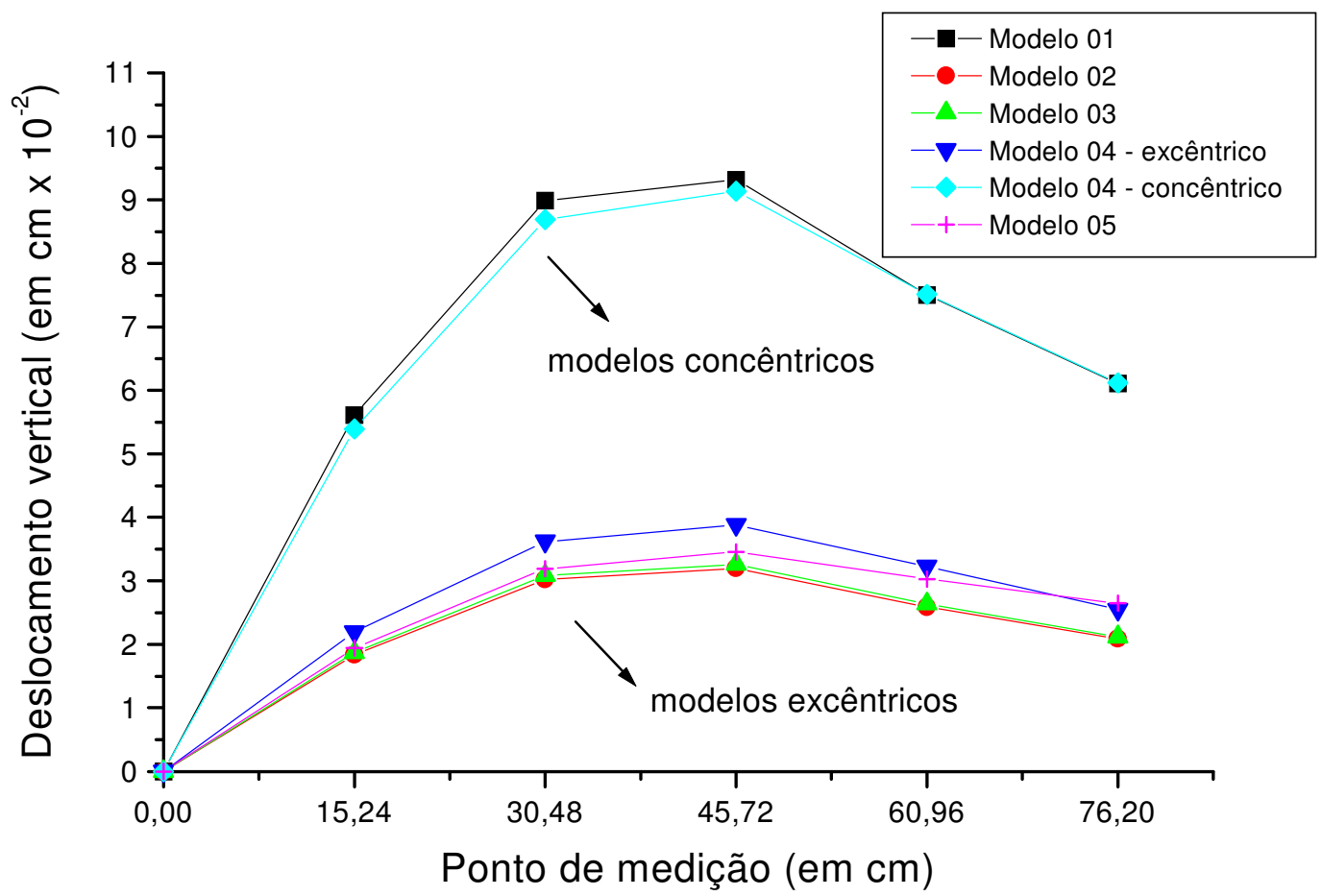

FIGURA 4.39: Deslocamentos ortogonais ao plano da placa ao longo da maior nervura, em $\mathrm{cm} \times 10^{-2}$, para carregamento uniformemente distribuído, na placa proposta por $\mathrm{CHANG}^{5}$ apud ROSSOW \& IBRAHIMKHALIL (1978) 
TABELA 4.18: Deslocamentos ortogonais ao plano da placa ao longo do eixo da maior nervura, em $\mathrm{cm} \times 10^{-3}$, para carregamento concentrado

\begin{tabular}{c|c|c|c|c|c|c}
\hline \hline \multirow{2}{*}{ Ponto } & \multirow{2}{*}{ Modelo 01 } & \multirow{2}{*}{ Modelo 02 } & \multirow{2}{*}{ Modelo 03 } & \multicolumn{2}{|c|}{ Modelo 04 } & \multirow{2}{*}{ Modelo 05 } \\
\cline { 5 - 7 } & & & Excêntrico & Concêntrico & \\
\hline \hline 0 & 0 & 0 & 0 & 0 & 0 & 0 \\
\hline 15,24 & 2,561 & 0,902 & 0,918 & 1,100 & 2,575 & 1,119 \\
\hline 30,48 & 4,932 & 1,734 & 1,764 & 2,120 & 4,960 & 2,150 \\
\hline 45,72 & 6,915 & 2,400 & 2,439 & 2,951 & 6,959 & 3,002 \\
\hline 60,96 & 8,289 & 2,818 & 2,859 & 3,495 & 8,355 & 3,584 \\
\hline 76,20 & 8,807 & 2,950 & 2,987 & 3,778 & 8,939 & 3,801 \\
\hline \hline
\end{tabular}

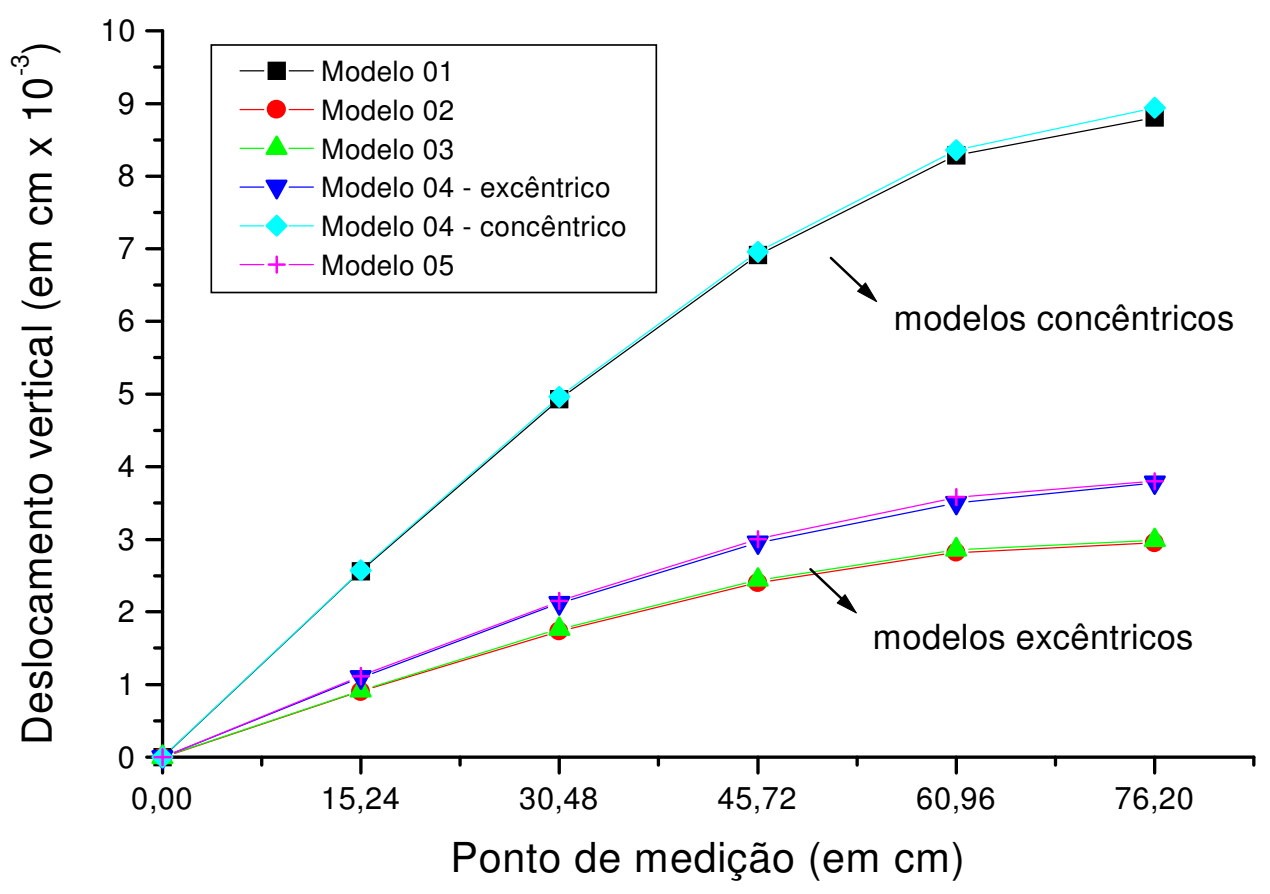

FIGURA 4.40: Deslocamentos ortogonais ao plano da placa ao longo da maior nervura, em $\mathrm{cm} \times 10^{-3}$, para carregamento concentrado, na placa proposta por $\mathrm{CHANG}^{5}$ apud ROSSOW \& IBRAHIMKHALIL (1978)

As Tabelas 4.19 e 4.20 apresentam os valores de deslocamentos ortogonais ao plano da placa ao longo do eixo central da menor nervura, de acordo com os resultados dos modelos numéricos, respectivamente para carregamento uniformemente distribuído e carregamento concentrado. As Figuras 4.41 e 4.42 comparam os resultados desses deslocamentos. 
TABELA 4.19: Deslocamentos ortogonais ao plano da placa ao longo do eixo da menor nervura, em $\mathrm{cm} \mathrm{x} 10^{-2}$, para carregamento uniformemente distribuído

\begin{tabular}{c|c|c|c|c|c|c}
\hline \hline \multirow{2}{*}{ Ponto } & \multirow{2}{*}{ Modelo 01 } & \multirow{2}{*}{ Modelo 02 } & \multirow{2}{*}{ Modelo 03 } & \multicolumn{2}{|c|}{ Modelo 04 } & \multirow{2}{*}{ Modelo 05 } \\
\cline { 5 - 6 } & & & & Excêntrico & Concêntrico & \\
\hline \hline 0 & 0 & 0 & 0 & 0 & 0 & 0 \\
\hline 7,62 & 1,853 & 0,634 & 0,642 & 0,752 & 1,838 & 0,803 \\
\hline 15,24 & 3,534 & 1,210 & 1,226 & 1,432 & 3,504 & 1,532 \\
\hline 22,86 & 4,889 & 1,676 & 1,698 & 1,985 & 4,852 & 2,120 \\
\hline 30,48 & 5,785 & 1,985 & 2,014 & 2,367 & 5,760 & 2,509 \\
\hline 38,10 & 6,108 & 2,090 & 2,120 & 2,551 & 6,121 & 2,649 \\
\hline \hline
\end{tabular}

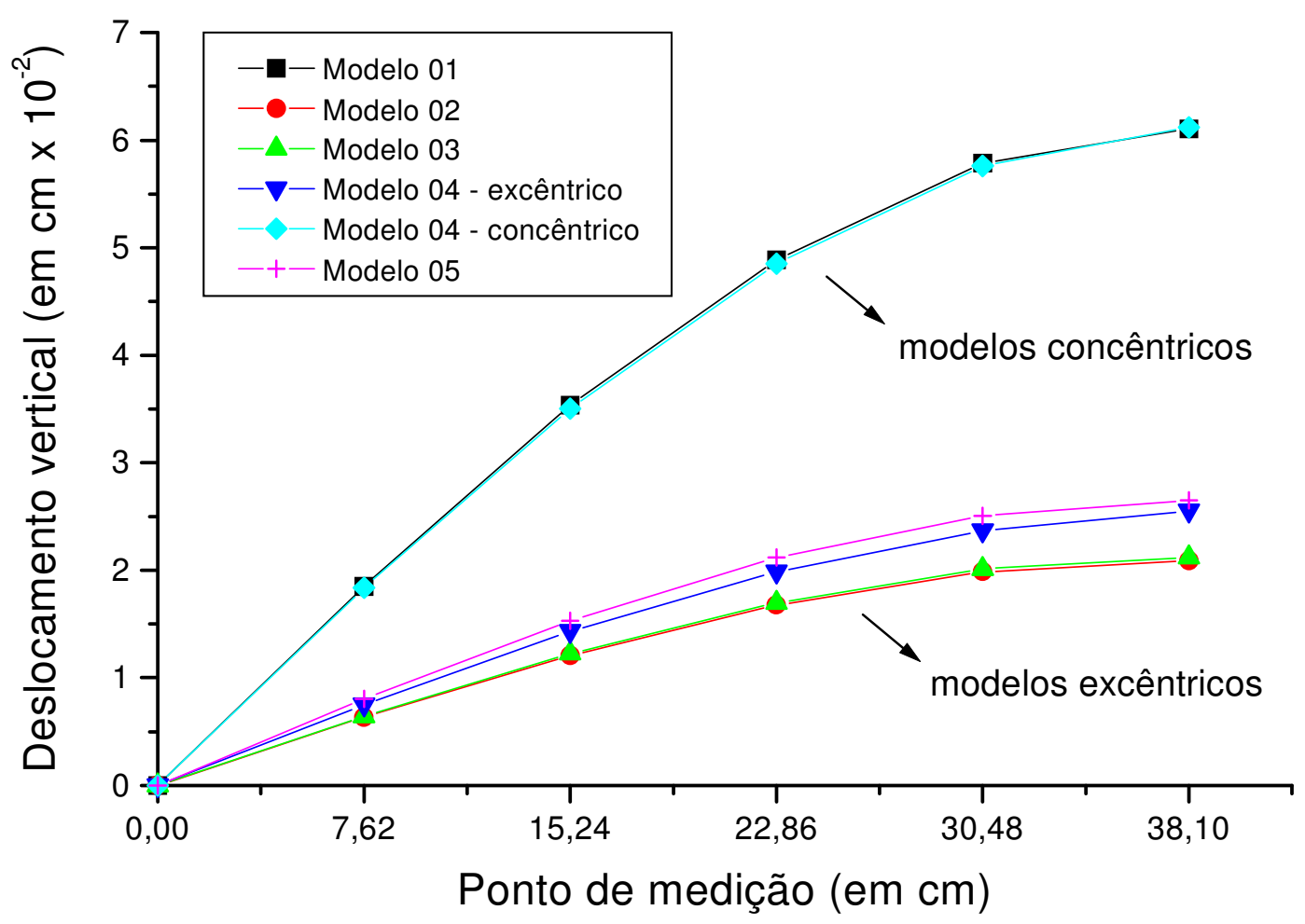

FIGURA 4.41: Deslocamentos ortogonais ao plano da placa ao longo da menor nervura, em $\mathrm{cm} \times 10^{-2}$, para carregamento uniformemente distribuído, na placa proposta por $\mathrm{CHANG}^{5}$ apud ROSSOW \& IBRAHIMKHALIL (1978) 
TABELA 4.20: Deslocamentos transversais ao plano da placa ao longo do eixo da menor nervura, em $\mathrm{cm} \mathrm{x} 10^{-3}$, para carregamento concentrado

\begin{tabular}{c|c|c|c|c|c|c}
\hline \hline \multirow{2}{*}{ Ponto } & \multirow{2}{*}{ Modelo 01 } & \multirow{2}{*}{ Modelo 02 } & \multirow{2}{*}{ Modelo 03 } & \multicolumn{2}{|c|}{ Modelo 04 } & \multirow{2}{*}{ Modelo 05 } \\
\cline { 5 - 7 } & & & & Excêntrico & Concêntrico & \\
\hline \hline 0 & 0 & 0 & 0 & 0 & 0 & 0 \\
\hline 7,62 & 2,607 & 0,869 & 0,879 & 1,015 & 2,565 & 1,125 \\
\hline 15,24 & 5,002 & 1,671 & 1,689 & 1,961 & 4,935 & 2,159 \\
\hline 22,86 & 6,975 & 2,336 & 2,363 & 2,769 & 6,913 & 3,010 \\
\hline 30,48 & 8,314 & 2,790 & 2,824 & 3,364 & 8,304 & 3,588 \\
\hline 38,10 & 8,807 & 2,950 & 2,987 & 3,778 & 8,939 & 3,801 \\
\hline \hline
\end{tabular}

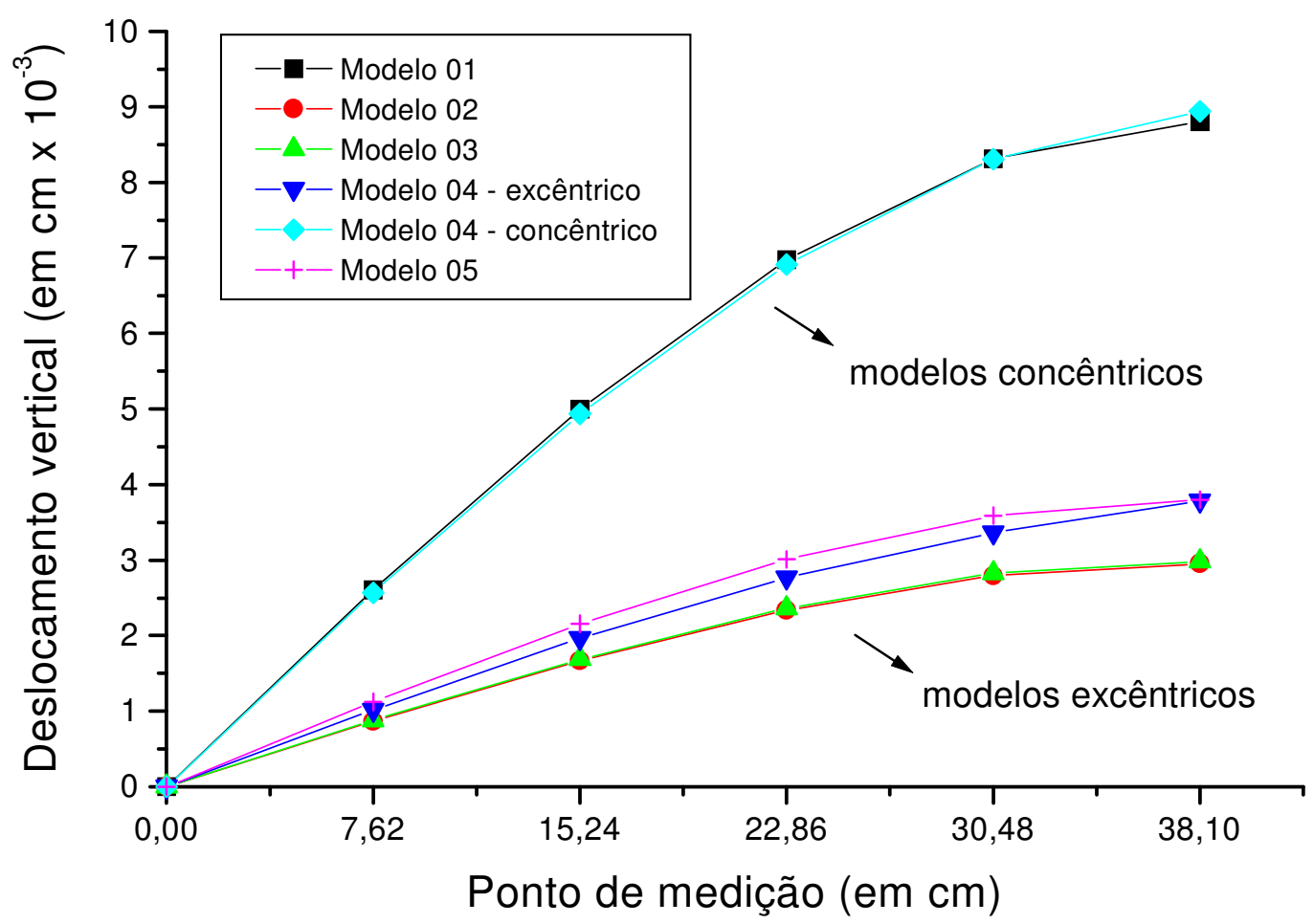

FIGURA 4.42: Deslocamentos ortogonais ao plano da placa ao longo da menor nervura, em $\mathrm{cm} \times 10^{-3}$, para carregamento concentrado, na placa proposta por $\mathrm{CHANG}^{5}$ apud ROSSOW \& IBRAHIMKHALIL (1978) 


\section{f) Placas enrijecidas por nervura analisadas experimental e numericamente por SAPOUNTZAKIS \& KATSIKADELIS (2000)}

SAPOUNTZAKIS \& KATSIKADELIS (2000) aplicaram o Método da Equação Análoga (AEM) para a solução de sistemas de laje enrijecidas por vigas levando em conta efeitos geralmente negligenciados: deslocamentos laterais e deformação no plano das placas, assim como deslocamentos laterais e deformações axiais nas vigas.

$\mathrm{O}$ artigo apresentou dois exemplos de laje enrijecida, descritos a seguir:

f.1 ) Lajes 01: lajes retangulares enrijecidas por uma nervura central de largura igual a $100 \mathrm{~cm}$, ao longo do maior lado, simplesmente apoiadas ao longo dos lados menores e livre nos outros dois, com geometrias demonstradas na Figura 4.43.
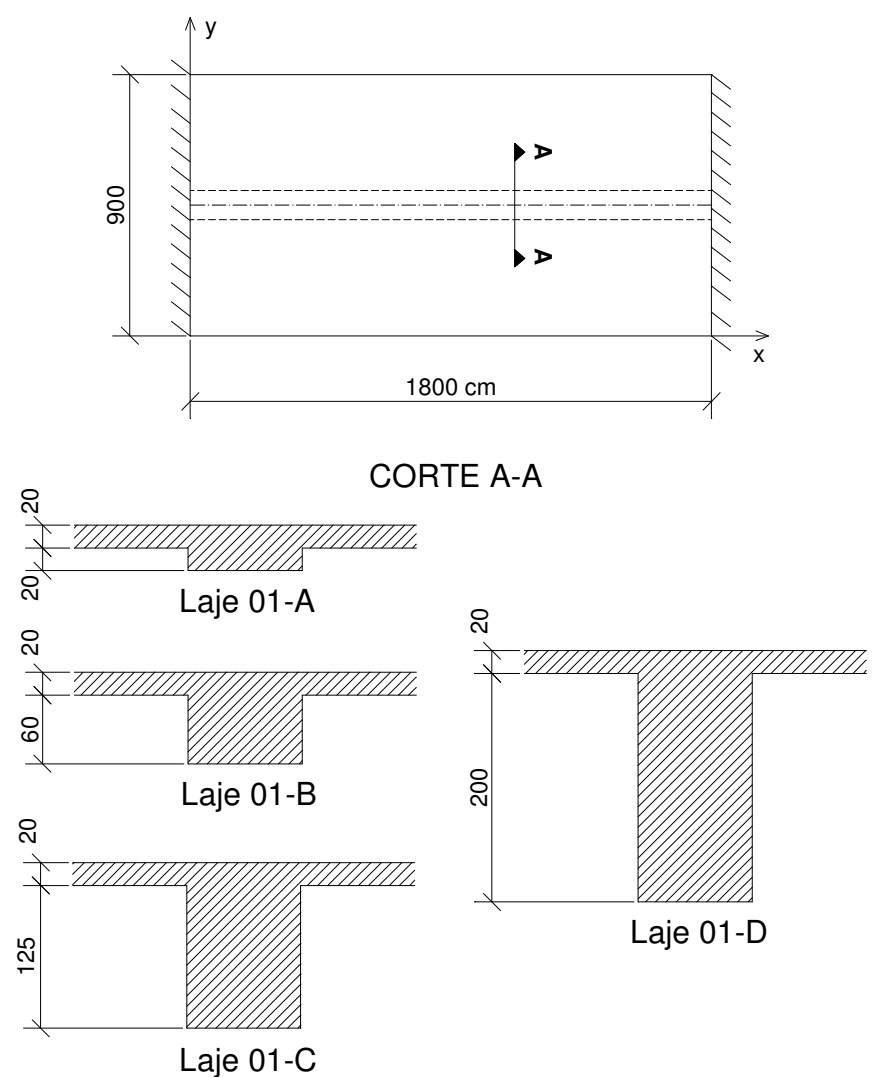

FIGURA 4.43: Geometria das lajes L1 $(\mathrm{em} \mathrm{cm})$

[SAPOUNTZAKIS \& KATSIKADELIS (2000)]

f.2) Lajes 02: lajes retangulares enrijecidas por uma nervura central com largura igual a $100 \mathrm{~cm}$, ao longo do maior lado, simplesmente apoiadas ao longo de todos os lados, com geometrias demonstradas na Figura 4.44. 


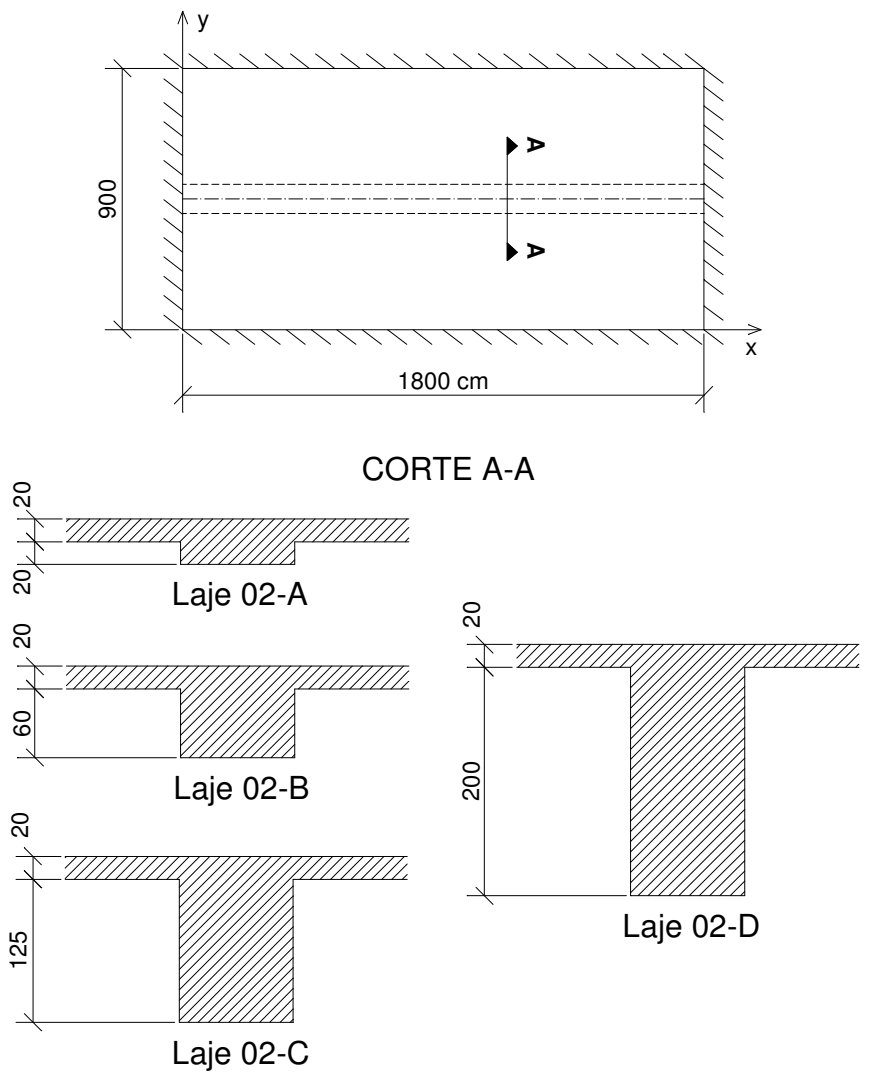

FIGURA 4.44: Geometria das lajes L2 (em cm) [SAPOUNTZAKIS \& KATSIKADELIS (2000)]

Foram considerados os seguintes dados de entrada:

- carga uniformemente distribuída: $\mathrm{q}=0,001 \mathrm{kN} / \mathrm{cm}^{2}$;

- módulo de elasticidade: $\mathrm{E}=3000 \mathrm{kN} / \mathrm{cm}^{2}$;

- coeficiente de Poisson: $v=0,154$.

$\mathrm{Na}$ análise numérica foram aplicados os modelos 01 a 05.

Comparam-se na tabela 4.21 os resultados obtidos para o deslocamento máximo na nervura, segundo cada modelo analisado, com aqueles apresentados por SAPOUNTZAKIS \& KATSIKADELIS (2000) utilizando-se o método AEM, ou método da Equação Análoga, e os citados no artigo, SOFISTIK $^{6}$ e CUBUS $^{7}$ apud SAPOUNTZAKIS \& KATSIKADELIS (2000).

${ }^{6}$ SOFSTIK GmbH (1995). Software für Statik und Konstruktion Gesellschaft mit beschränkter Haftun., Ringstr. 29a, D-8042, Oberschleißheim.

${ }^{7}$ CUBUS AG, Software (1995). Cedrus-3 User's References Manual. Zürich, Switzerland, version 1.56 , June. 
TABELA 4.21: Deslocamentos ortogonais ao plano da placa máximos obtidos na nervura, $\mathrm{em} \mathrm{cm}$

\begin{tabular}{c|c|c|c|c|c|c|c|c}
\hline \hline \multirow{2}{*}{ Laje } & \multicolumn{10}{c}{ Modelo de análise } \\
& AEM & Sofistik $^{\mathbf{6}}$ & Cubus $^{7}$ & $\mathbf{0 1}$ & $\mathbf{0 2}$ & $\mathbf{0 3}$ & $\mathbf{0 4}$ & $\mathbf{0 5}$ \\
\hline \hline $01-\mathrm{A}$ & 6,65 & 13,85 & 32,13 & 60,58 & 28,25 & 29,95 & 29,93 & 24,96 \\
\hline $01-\mathrm{B}$ & 0,77 & 2,75 & 4,88 & 16,98 & 5,96 & 4,57 & 4,70 & 4,80 \\
\hline $01-\mathrm{C}$ & 0,12 & 0,51 & 0,78 & 2,42 & 0,77 & 0,81 & 0,85 & 0,91 \\
\hline $01-\mathrm{D}$ & 0,03 & 0,16 & 0,24 & 0,61 & 0,24 & 0,25 & 0,27 & 0,28 \\
\hline $02-\mathrm{A}$ & 1,95 & 1,18 & 3,05 & 3,23 & 2,98 & 3,00 & 3,00 & 2,93 \\
\hline 02-B & 0,42 & 0,79 & 1,65 & 2,70 & 1,80 & 1,52 & 1,62 & 1,64 \\
\hline 02-C & 0,07 & 0,27 & 0,42 & 1,07 & 0,38 & 0,40 & 0,46 & 0,49 \\
\hline 02-D & 0,02 & 0,09 & 0,12 & 0,34 & 0,13 & 0,13 & 0,16 & 0,17 \\
\hline \hline
\end{tabular}

Analisando-se a Tabela 4.21, verifica-se que os resultados apresentados pelos modelos excêntricos deste trabalho aproximam-se bastante daqueles mostrados por CUBUS $^{7}$ apud SAPOUNTZAKIS \& KATSIKADELIS (2000), e afastam-se daqueles obtidos por SAPOUNTZAKIS \& KATSIKADELIS (2000). A grande diferença deve-se à consideração do deslocamento lateral do enrijecedor considerada pelos autores na formulação, e há não negligência de forças e deformações no plano do elemento. Conforme os autores, o método AEM é ideal para o cálculo de estruturas de placas enrijecidas préfabricadas ou constituídas por compósitos, visando encontrar o cisalhamento no plano.

Apresentam-se a seguir as Tabelas 4.22 a 4.29 e as Figuras 4.45 a 4.52 com os resultados de deslocamentos ao longo da nervura para cada laje analisada, conforme cada modelo numérico.

TABELA 4.22 : Deslocamentos máximos obtidos ao longo da nervura da laje 01-A, em cm

\begin{tabular}{c|c|c|c|c}
\hline \hline \multirow{2}{*}{ Modelo } & \multicolumn{4}{c}{ LAJE 01-A } \\
\cline { 2 - 5 } & $\mathbf{0}$ & $\mathbf{3 0 0}$ & $\mathbf{6 0 0}$ & $\mathbf{9 0 0}$ \\
\hline \hline 01 & 0 & 30,65 & 52,64 & 60,58 \\
\hline 02 & 0 & 14,21 & 24,51 & 28,25 \\
\hline 03 & 0 & 15,06 & 25,99 & 29,95 \\
\hline 04 & 0 & 15,17 & 26,01 & 29,93 \\
\hline 05 & 0 & 12,61 & 21,69 & 24,96 \\
\hline \hline
\end{tabular}




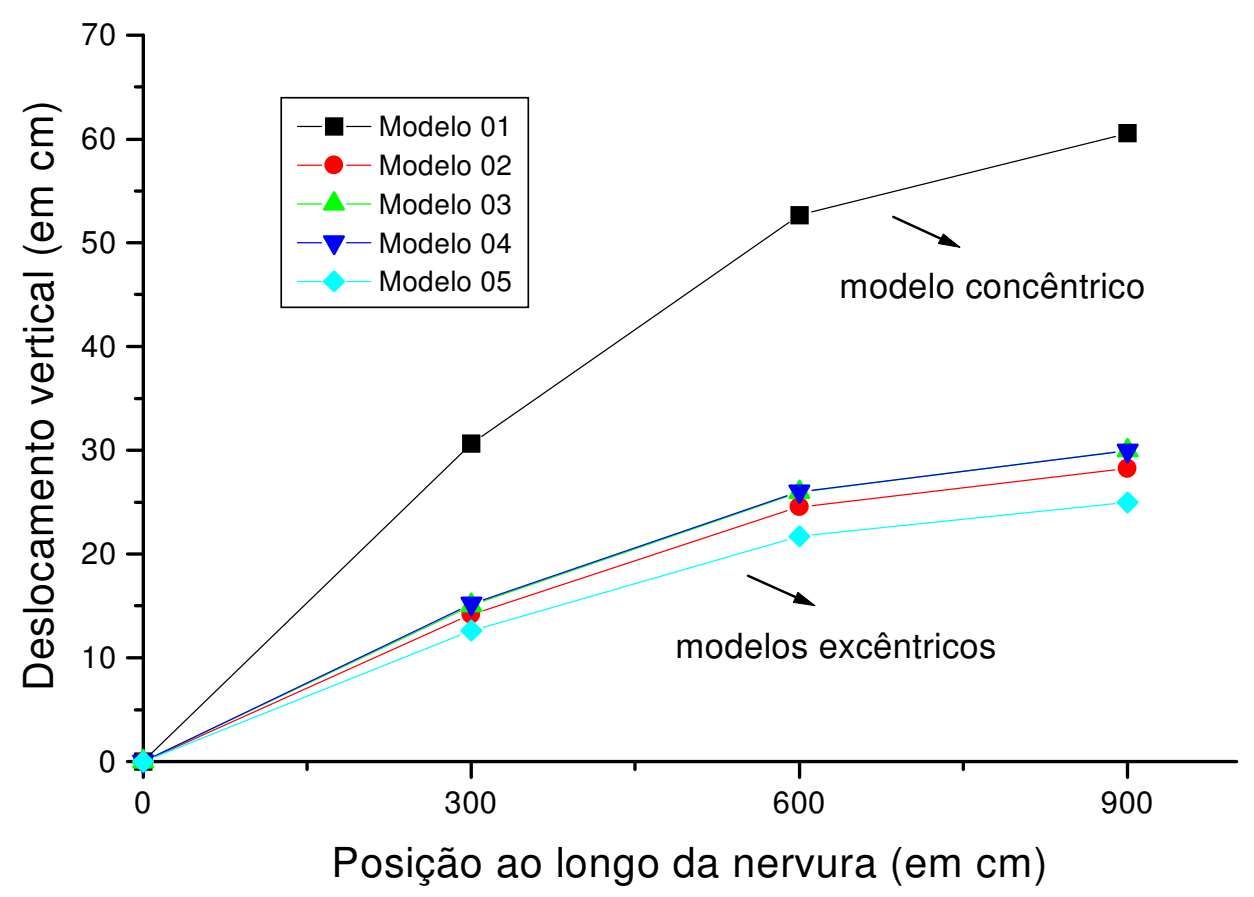

FIGURA 4.45: Deslocamentos máximos ortogonais ao plano da placa obtidos ao longo da nervura da laje 01-A proposta por SAPOUNTZAKIS \& KATSIKADELIS (2000)

Analisando-se a Tabela 4.22, verificou-se que:

- a maior diferença percentual entre os modelos excêntricos e concêntrico foi de 142,70\% entre os Modelos 01 e 05;

- os modelos excêntricos apresentaram diferença máxima de $20 \%$.

TABELA 4.23 : Deslocamentos máximos obtidos ao longo da nervura da laje 01-B, em cm

\begin{tabular}{c|c|c|c|c}
\hline \hline \multicolumn{5}{c}{ LAJE 01-B } \\
\hline \multirow{2}{*}{ Modelo } & \multicolumn{4}{c}{ Posição ao longo da nervura (em cm) } \\
\cline { 2 - 5 } & $\mathbf{0}$ & $\mathbf{3 0 0}$ & $\mathbf{6 0 0}$ & $\mathbf{9 0 0}$ \\
\hline \hline 01 & 0 & 8,58 & 14,75 & 16,98 \\
\hline 02 & 0 & 2,98 & 5,16 & 5,96 \\
\hline 03 & 0 & 2,27 & 3,95 & 4,57 \\
\hline 04 & 0 & 2,39 & 4,09 & 4,70 \\
\hline 05 & 0 & 2,42 & 4,17 & 4,80 \\
\hline \hline
\end{tabular}




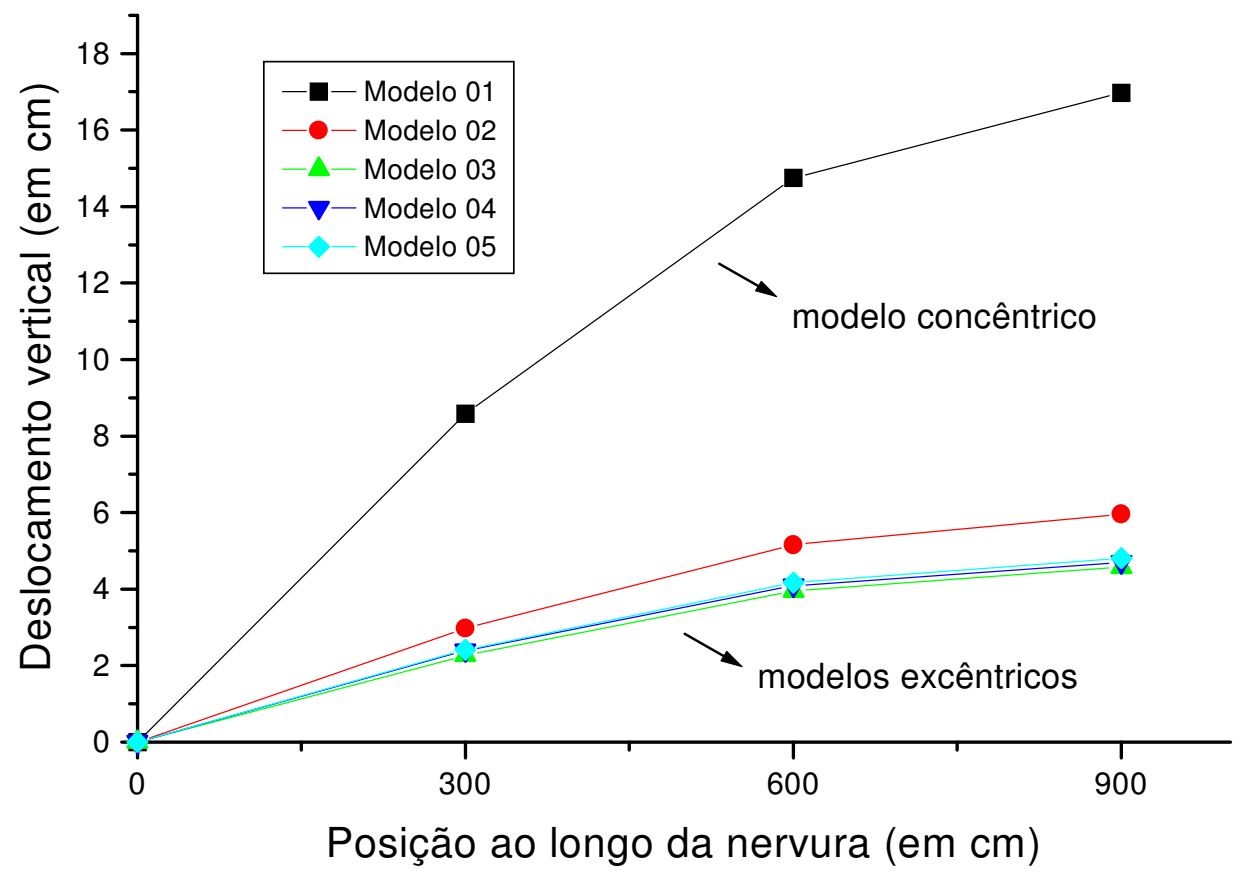

FIGURA 4.46: Deslocamentos máximos ortogonais ao plano da placa obtidos ao longo da nervura da laje 01-B proposta por SAPOUNTZAKIS \& KATSIKADELIS (2000)

Analisando-se a Tabela 4.23, verificou-se que:

- a maior diferença percentual entre os modelos excêntricos e concêntrico foi de 271,55\% entre os Modelos 01 e 03;

- os modelos excêntricos apresentaram diferença máxima de 30,42 \%;

- os Modelos 03 a 05 apresentaram resultados de deslocamentos transversais muito próximos.

TABELA 4.24: Deslocamentos máximos obtidos ao longo da nervura da laje 01-C, em cm

\begin{tabular}{c|c|c|c|c}
\hline \hline \multicolumn{5}{c}{ LAJE 01-C } \\
\hline \multirow{2}{*}{ Modelo } & \multicolumn{5}{c}{ Posição ao longo da nervura (em cm) } \\
\cline { 2 - 5 } & $\mathbf{0}$ & $\mathbf{3 0 0}$ & $\mathbf{6 0 0}$ & $\mathbf{9 0 0}$ \\
\hline \hline 01 & 0 & 1,22 & 2,10 & 2,42 \\
\hline 02 & 0 & 0,38 & 0,67 & 0,77 \\
\hline 03 & 0 & 0,40 & 0,70 & 0,81 \\
\hline 04 & 0 & 0,43 & 0,74 & 0,85 \\
\hline 05 & 0 & 0,46 & 0,79 & 0,91 \\
\hline \hline
\end{tabular}




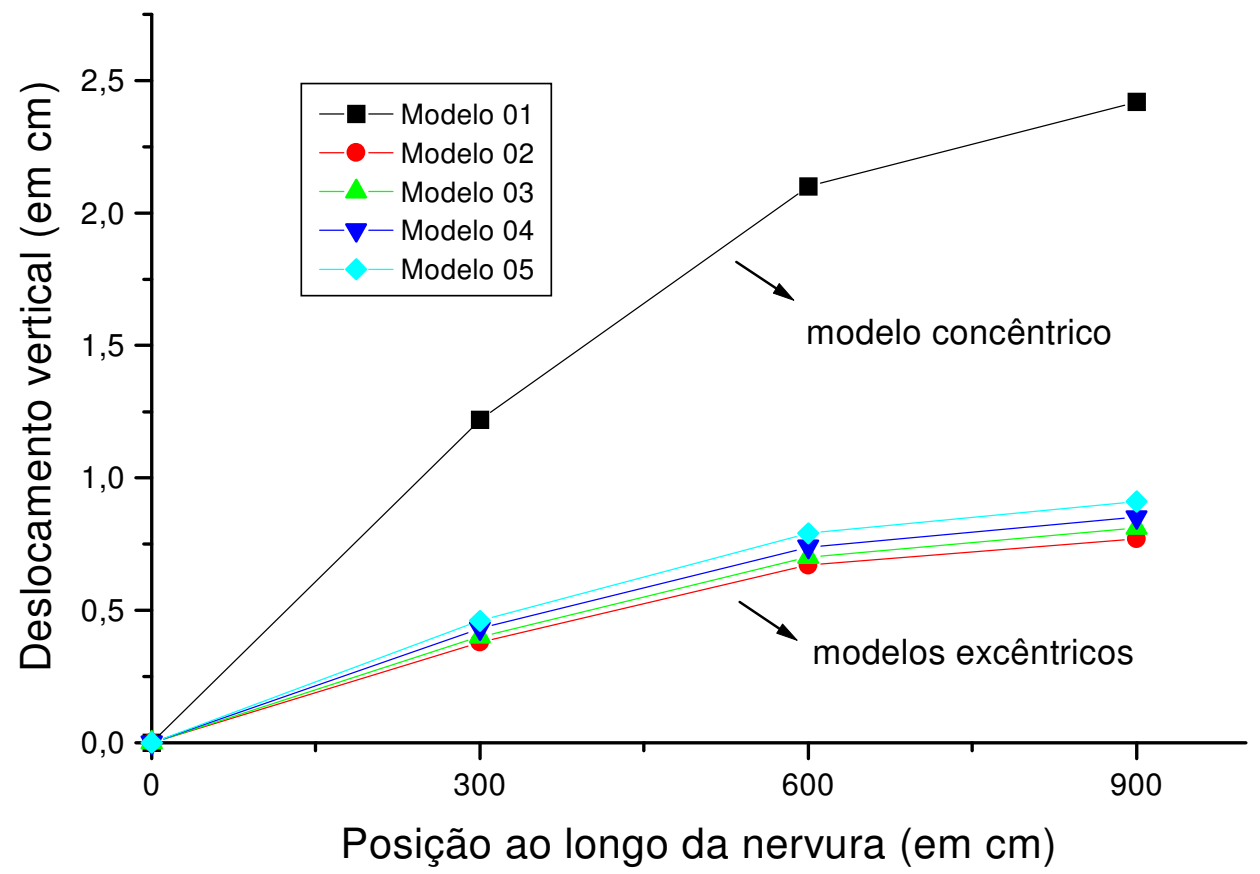

FIGURA 4.47: Deslocamentos máximos ortogonais ao plano da placa obtidos ao longo da nervura da laje 01-C proposta por SAPOUNTZAKIS \& KATSIKADELIS (2000)

Analisando-se a Tabela 4.24, verificou-se que:

- a maior diferença percentual entre os modelos excêntricos e concêntrico foi de 214,29\% entre os Modelos 01 e 02;

- os modelos excêntricos apresentaram diferença máxima de 18,18\%.

TABELA 4.25: Deslocamentos máximos obtidos ao longo da nervura da laje 01-D, em $\mathrm{cm}$

\begin{tabular}{c|c|c|c|c}
\hline \hline \multirow{2}{*}{ Modelo } & \multicolumn{5}{c}{ LAJE 01-D } \\
\cline { 2 - 5 } & $\mathbf{0}$ & $\mathbf{3 0 0}$ & $\mathbf{6 0 0}$ & $\mathbf{9 0 0}$ \\
\hline \hline 01 & 0 & 0,31 & 0,53 & 0,61 \\
\hline 02 & 0 & 0,12 & 0,20 & 0,24 \\
\hline 03 & 0 & 0,12 & 0,22 & 0,25 \\
\hline 04 & 0 & 0,14 & 0,24 & 0,27 \\
\hline 05 & 0 & 0,14 & 0,25 & 0,28 \\
\hline \hline
\end{tabular}




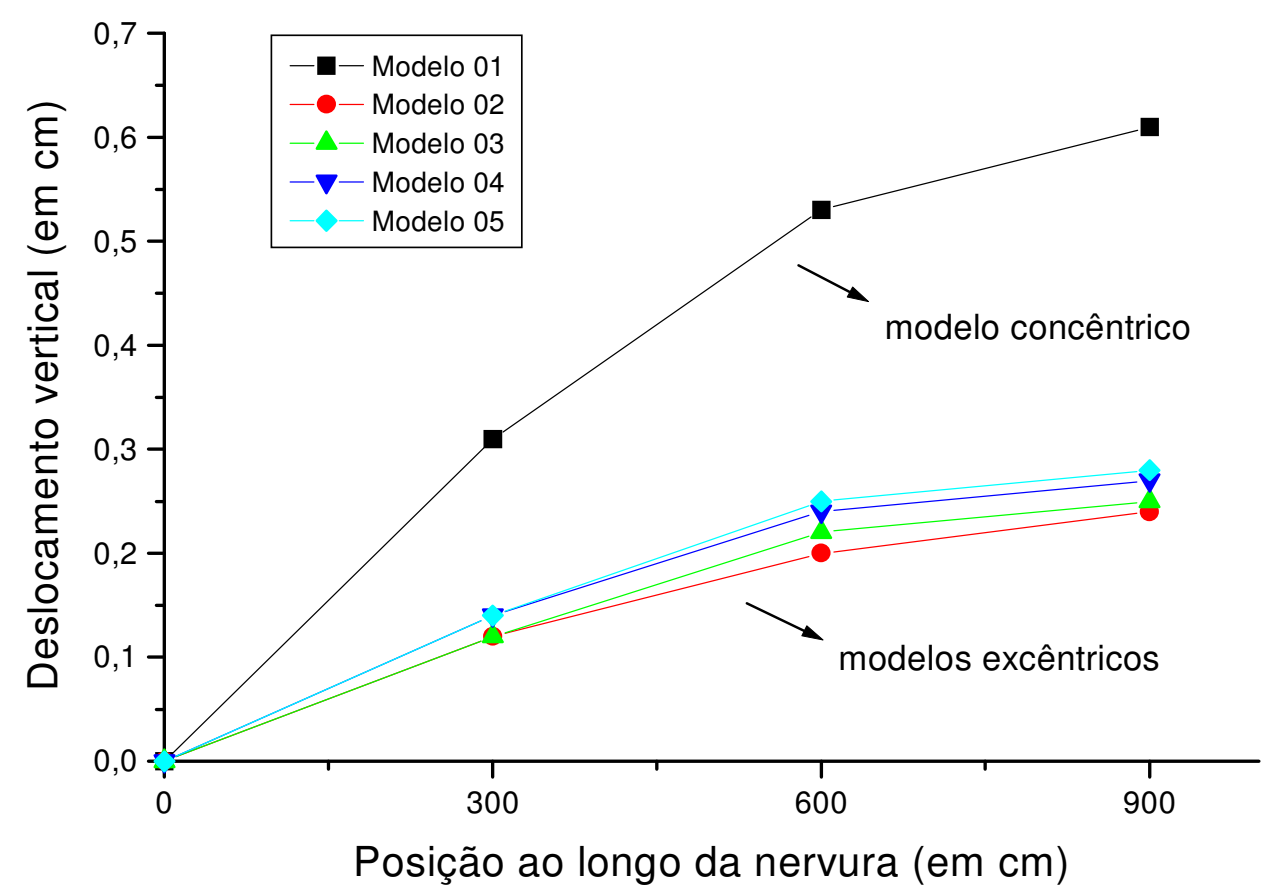

FIGURA 4.48: Deslocamentos máximos ortogonais ao plano da placa obtidos ao longo da nervura da laje 01-D proposta por SAPOUNTZAKIS \& KATSIKADELIS (2000)

Analisando-se a Tabela 4.25, verificou-se que:

- a maior diferença percentual entre os modelos excêntricos e concêntrico foi de $154,17 \%$ entre os Modelos 01 e 02;

- os modelos excêntricos apresentaram diferença máxima de 16,67\%.

TABELA 4.26: Deslocamentos máximos obtidos ao longo da nervura da laje 02-A, em $\mathrm{cm}$

\begin{tabular}{c|c|c|c|c}
\hline \hline \multicolumn{5}{c}{ LAJE 02-A } \\
\hline \multirow{2}{*}{ Modelo } & \multicolumn{5}{c}{ Posição ao longo da nervura (em cm) } \\
\cline { 2 - 5 } & $\mathbf{0}$ & $\mathbf{3 0 0}$ & $\mathbf{6 0 0}$ & $\mathbf{9 0 0}$ \\
\hline \hline 01 & 0 & 1,83 & 2,90 & 3,23 \\
\hline 02 & 0 & 1,58 & 2,62 & 2,98 \\
\hline 03 & 0 & 1,60 & 2,65 & 3,00 \\
\hline 04 & 0 & 1,62 & 2,66 & 3,00 \\
\hline 05 & 0 & 1,55 & 2,58 & 2,93 \\
\hline \hline
\end{tabular}




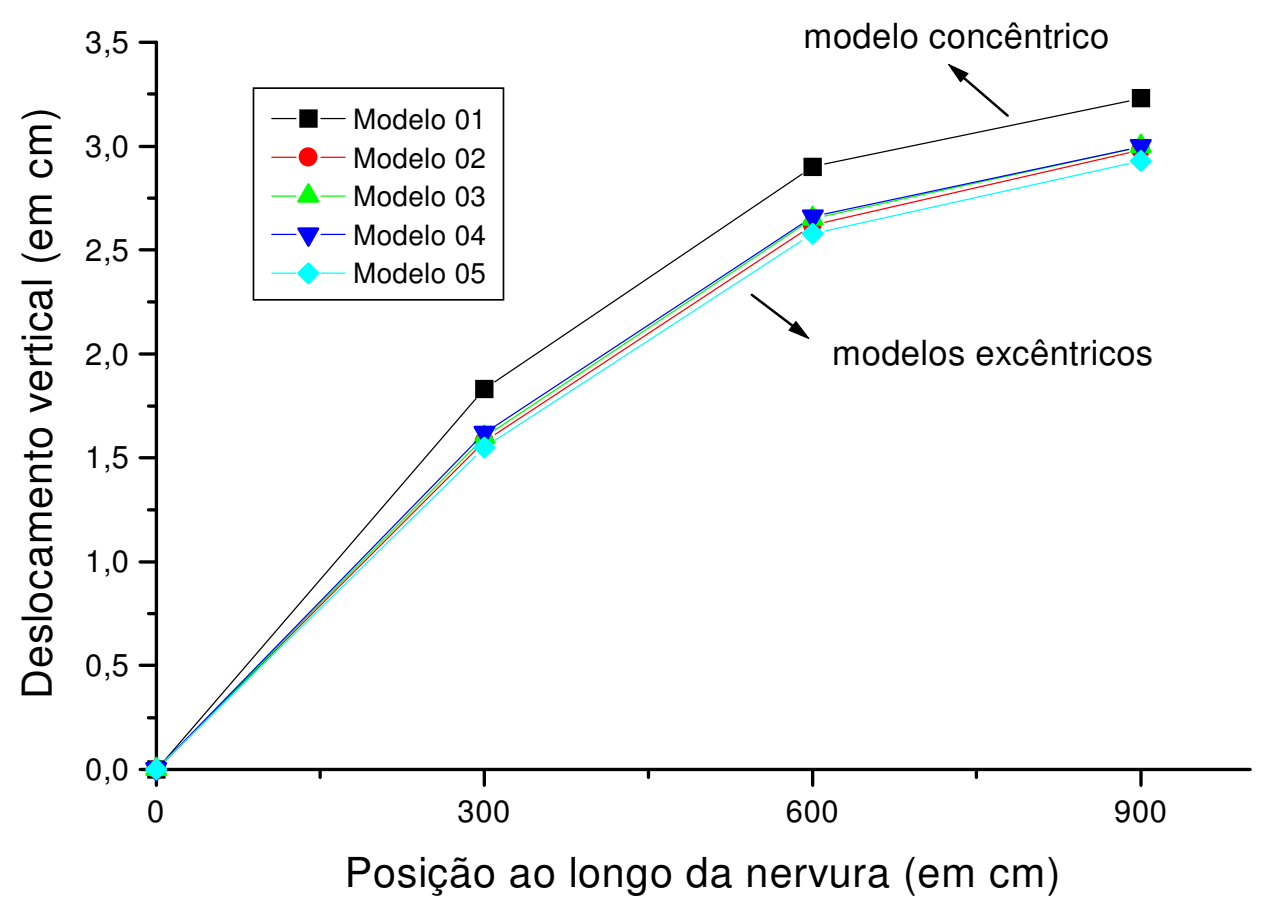

FIGURA 4.49: Deslocamentos máximos ortogonais ao plano da placa obtidos ao longo da nervura da laje 02-A proposta por SAPOUNTZAKIS \& KATSIKADELIS (2000)

Analisando-se a Tabela 4.26, verificou-se que:

- a maior diferença percentual entre os modelos excêntricos e concêntrico foi de 10,24\% entre os Modelos 01 e 05;

- os modelos excêntricos apresentaram diferença máxima de 2,39\%.

TABELA 4.27: Deslocamentos máximos obtidos ao longo da nervura da laje 02-B, em $\mathrm{cm}$

\begin{tabular}{c|c|c|c|c}
\hline \hline \multicolumn{5}{c}{ LAJE 02-B } \\
\hline \multirow{2}{*}{ Modelo } & \multicolumn{4}{c}{ Posição ao longo da nervura (em cm) } \\
\cline { 2 - 5 } & $\mathbf{0}$ & $\mathbf{3 0 0}$ & $\mathbf{6 0 0}$ & $\mathbf{9 0 0}$ \\
\hline \hline 01 & 0 & 1,41 & 2,37 & 2,70 \\
\hline 02 & 0 & 0,90 & 1,56 & 1,80 \\
\hline 03 & 0 & 0,75 & 1,31 & 1,52 \\
\hline 04 & 0 & 0,83 & 1,41 & 1,62 \\
\hline 05 & 0 & 0,84 & 1,43 & 1,64 \\
\hline \hline
\end{tabular}




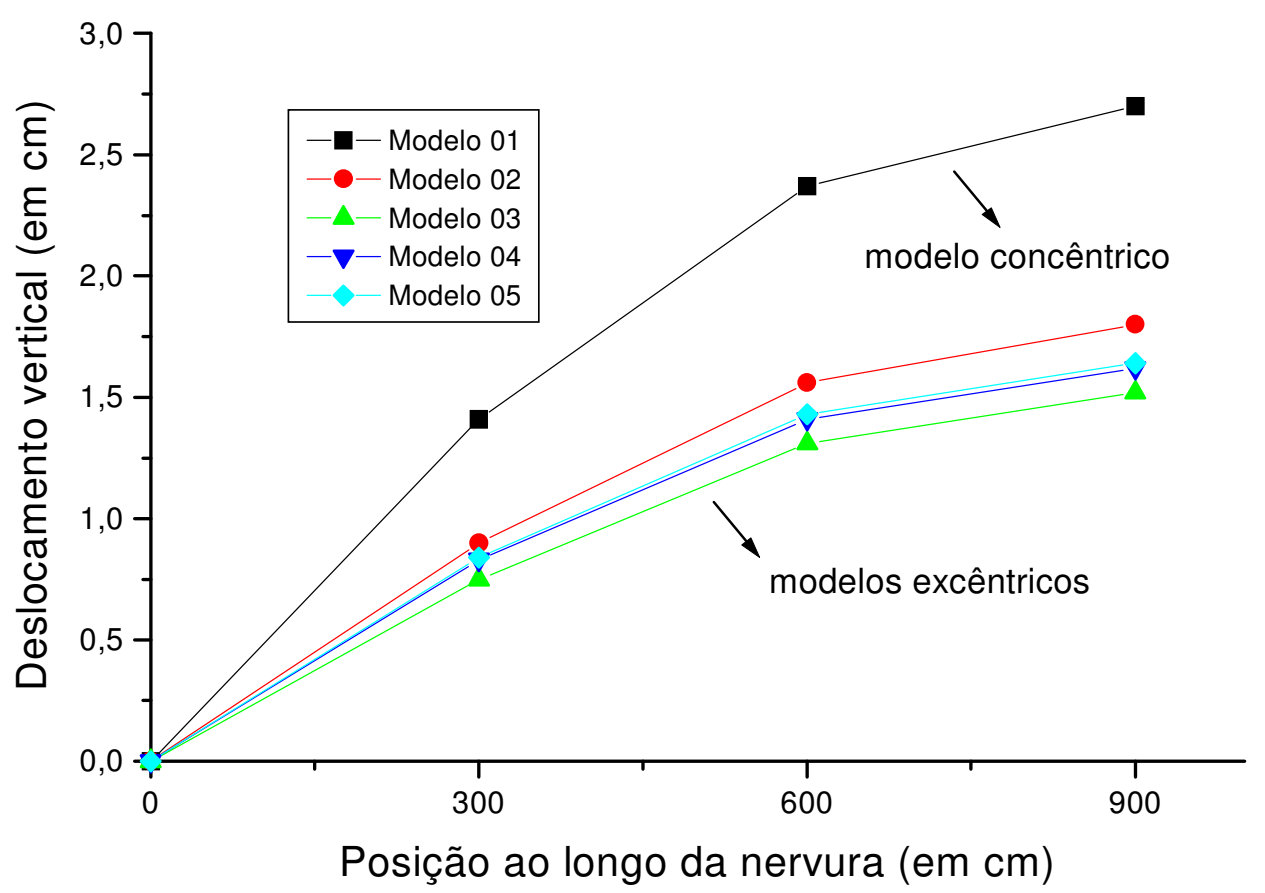

FIGURA 4.50: Deslocamentos máximos ortogonais ao plano da placa obtidos ao longo da nervura da laje 02-B proposta por SAPOUNTZAKIS \& KATSIKADELIS (2000)

Analisando-se a Tabela 4.27, verificou-se que:

- a maior diferença percentual entre os modelos excêntricos e concêntrico foi de 77,63\% entre os Modelos 01 e 03;

- os modelos excêntricos apresentaram diferença máxima de 18,42\%.

TABELA 4.28 : Deslocamentos máximos obtidos ao longo da nervura da laje 02-C, em cm

\begin{tabular}{c|c|c|c|c}
\hline \hline \multicolumn{5}{c}{ LAJE 02-C } \\
\hline \multirow{2}{*}{ Modelo } & $\mathbf{5}$ Posição ao longo da nervura (em cm) \\
\cline { 2 - 5 } & $\mathbf{0}$ & $\mathbf{3 0 0}$ & $\mathbf{6 0 0}$ & $\mathbf{9 0 0}$ \\
\hline \hline 01 & 0 & 0,54 & 0,93 & 1,07 \\
\hline 02 & 0 & 0,18 & 0,33 & 0,38 \\
\hline 03 & 0 & 0,19 & 0,34 & 0,40 \\
\hline 04 & 0 & 0,24 & 0,40 & 0,46 \\
\hline 05 & 0 & 0,25 & 0,42 & 0,49 \\
\hline \hline
\end{tabular}




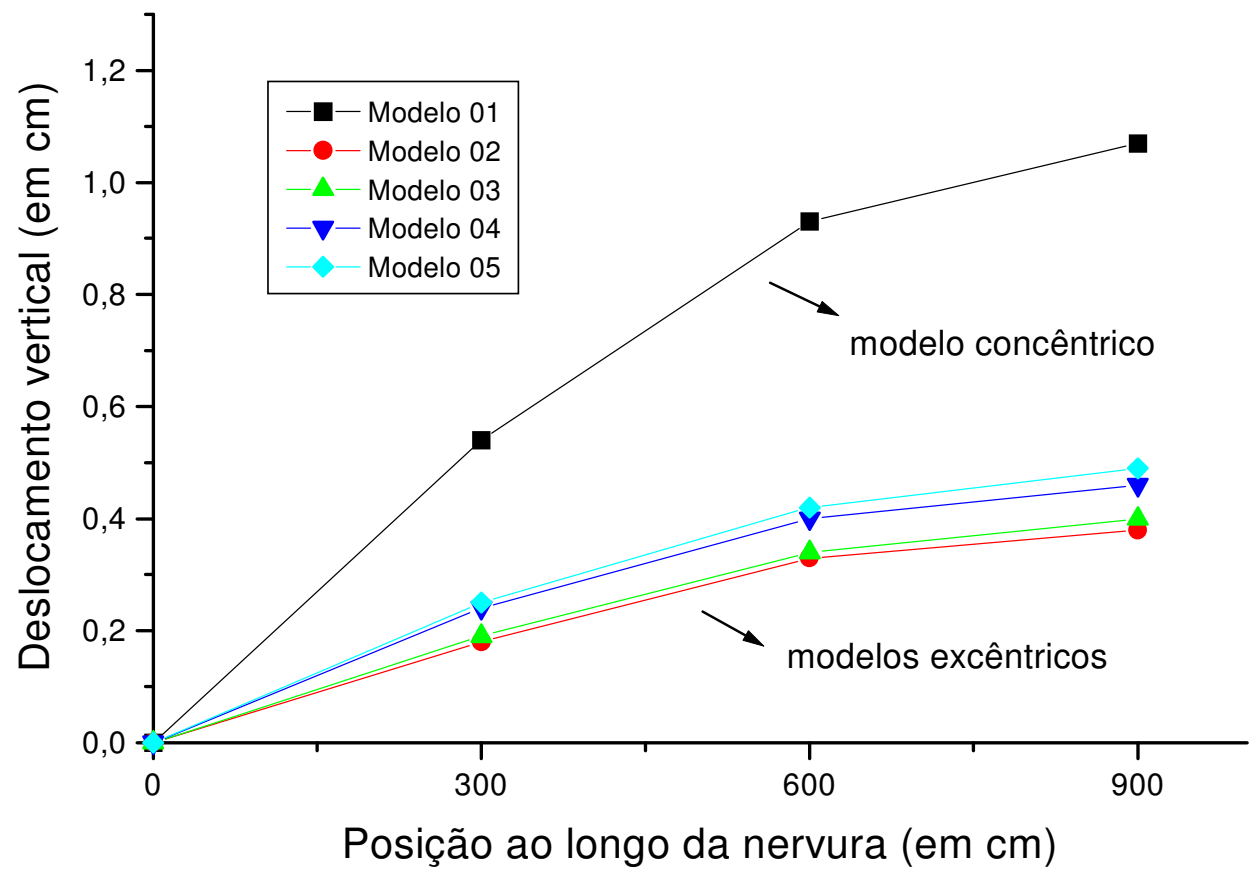

FIGURA 4.51: Deslocamentos máximos ortogonais ao plano da placa obtidos ao longo da nervura da laje 02-C proposta por SAPOUNTZAKIS \& KATSIKADELIS (2000)

Analisando-se a Tabela 4.28, verificou-se que:

- a maior diferença percentual entre os modelos excêntricos e concêntrico foi de 181,58 \% entre os Modelos 01 e 02;

- os modelos excêntricos apresentaram diferença máxima de 28,95\%.

TABELA 4.29: Deslocamentos máximos obtidos ao longo da nervura da laje 02-D, em $\mathrm{cm}$

\begin{tabular}{c|c|c|c|c}
\hline \hline \multirow{2}{*}{ Modelo } & \multicolumn{5}{c}{ LAJE 02-D } \\
\cline { 2 - 5 } & $\mathbf{0}$ & $\mathbf{3 0 0}$ & $\mathbf{6 0 0}$ & $\mathbf{9 0 0}$ \\
\hline \hline 01 & 0 & 0,17 & 0,30 & 0,34 \\
\hline 02 & 0 & 0,06 & 0,11 & 0,13 \\
\hline 03 & 0 & 0,06 & 0,11 & 0,13 \\
\hline 04 & 0 & 0,08 & 0,14 & 0,16 \\
\hline 05 & 0 & 0,09 & 0,15 & 0,17 \\
\hline \hline
\end{tabular}




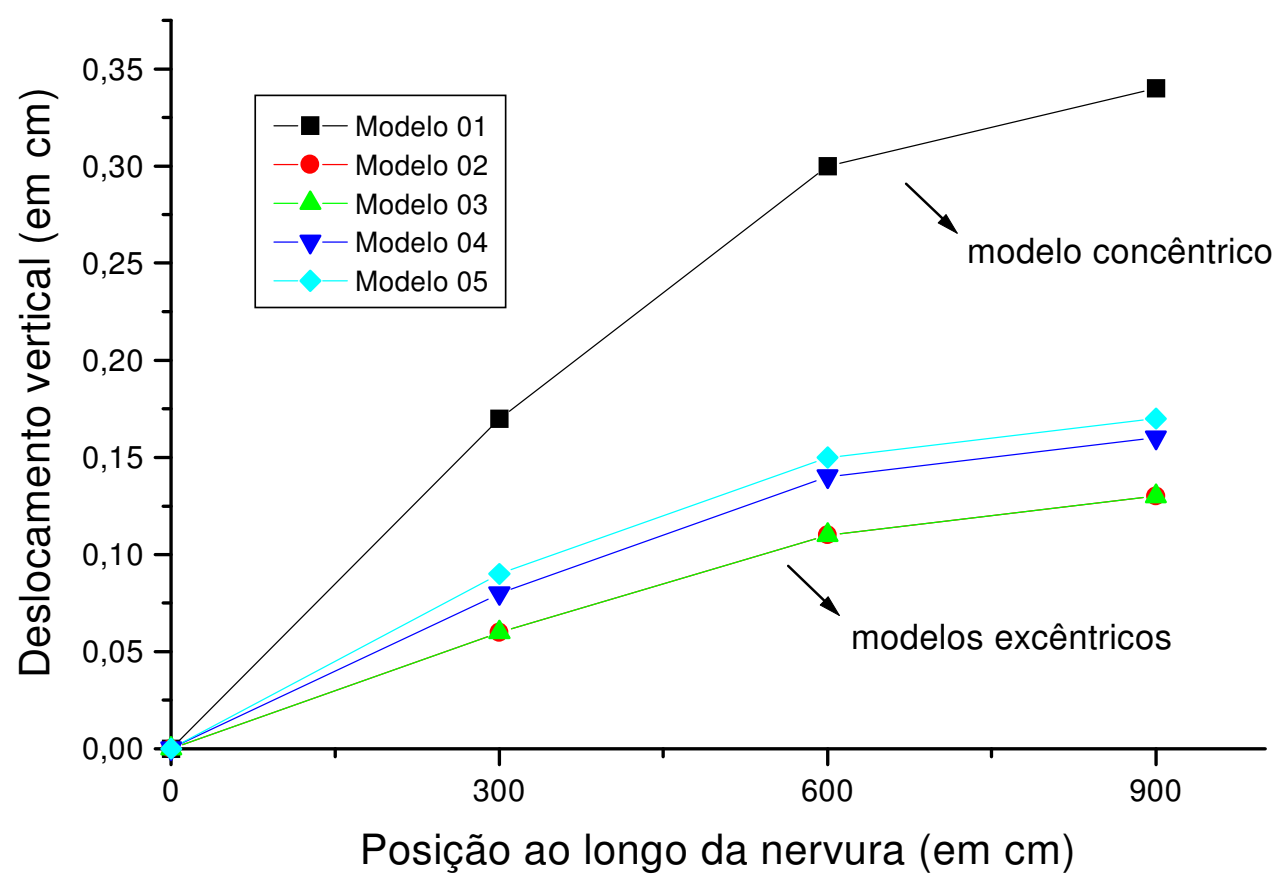

FIGURA 4.52: Deslocamentos máximos ortogonais ao plano da placa obtidos ao longo da nervura da laje 02-D proposta por SAPOUNTZAKIS \& KATSIKADELIS (2000)

Analisando-se a Tabela 4.29, verificou-se que:

- a maior diferença percentual entre os modelos excêntricos e concêntrico foi de 161,54\% entre os Modelos 01 e 02/03;

- os modelos excêntricos apresentaram diferença máxima de 30,77\%.

Visando encontrar alguma relação entre as diferenças percentuais de resultados de deslocamentos apresentados por modelos excêntricos e concêntricos conforme a relação $h=$ altura total da laje $e h_{f}=$ altura da capa da laje nervurada, foram montadas as Tabelas 4.30 e 4.31, apresentadas abaixo.

TABELA 4.30 : Diferenças percentuais entre resultados de deslocamentos ortogonais ao plano da placa dos modelos de análise numérica aplicados à Laje L1, conforme relação $\mathrm{h} / \mathrm{h}_{\mathrm{f}}$

\section{LAJES L1}

\begin{tabular}{c|c|c}
\hline Relação $\mathbf{h} / \mathbf{h}_{\mathbf{f}}$ & $\begin{array}{c}\text { Diferença percentual entre } \\
\text { os modelos excêntricos e } \\
\text { concêntrico }\end{array}$ & $\begin{array}{c}\text { Diferença percentual entre } \\
\text { os modelos excêntricos }\end{array}$ \\
\hline 2,00 & $142,70 \%$ & $20,00 \%$ \\
\hline 4,00 & $271,55 \%$ & $30,42 \%$ \\
\hline 7,25 & $214,29 \%$ & $18,18 \%$ \\
\hline 11,00 & $154,17 \%$ & $16,67 \%$ \\
\hline \hline
\end{tabular}


TABELA 4.31 : Diferenças percentuais entre resultados de deslocamentos ortogonais ao plano da placa dos modelos de análise numérica aplicados à Laje L2, conforme relação $\mathrm{h} / \mathrm{h}_{\mathrm{f}}$

\section{LAJES L2}

\begin{tabular}{c|c|c}
\hline Relação $\mathbf{h} / \mathbf{h}_{\mathbf{f}}$ & $\begin{array}{c}\text { Diferença percentual entre } \\
\text { os modelos excêntricos e } \\
\text { concêntrico }\end{array}$ & $\begin{array}{c}\text { Diferença percentual } \\
\text { entre os modelos } \\
\text { excêntricos }\end{array}$ \\
\hline \hline 2,00 & $10,24 \%$ & $22,39 \%$ \\
\hline 4,00 & $77,63 \%$ & $18,42 \%$ \\
\hline 7,25 & $181,58 \%$ & $28,95 \%$ \\
\hline 11,00 & $161,54 \%$ & $30,77 \%$ \\
\hline \hline
\end{tabular}

Analisando-se as Tabelas 4.30 e 4.31 verifica-se que, com os resultados apresentados, parece não haver uma ordem entre a diferença percentual dos resultados de modelos excêntricos e concêntricos e a relação altura total por altura da placa, uma relação onde quanto maior a excentricidade entre a nervura e a capa, menor a diferença percentual entre os modelos excêntricos e concêntrico. Esta sentença não deve, agora, ser tomada como uma afirmação ou conclusão, devendo ser pesquisada de maneira mais aprofundada e verificada neste trabalho com um maior número de resultados, visto também que este exemplo possui apenas uma nervura central, o que não gera o sistema de laje nervurada.

\section{g) Placa enrijecida por duas nervuras, engastada, conforme SHEIKH \& MUKHOPADHYAY (1992)}

O artigo apresentado por SHEIKH \& MUKHOPADHYAY (1992) analisa numericamente placas com enrijecedores através de função chamada 'B -Spline”, dentro do Método 'Spline Finite Strip". Os autores apresentaram os resultados de esforços em placa enrijecida por duas nervuras, engastada em um dos menores lados e submetida a um carregamento concentrado na ponta do balanço, em uma das nervuras, de acordo com a Figura 4.53. 


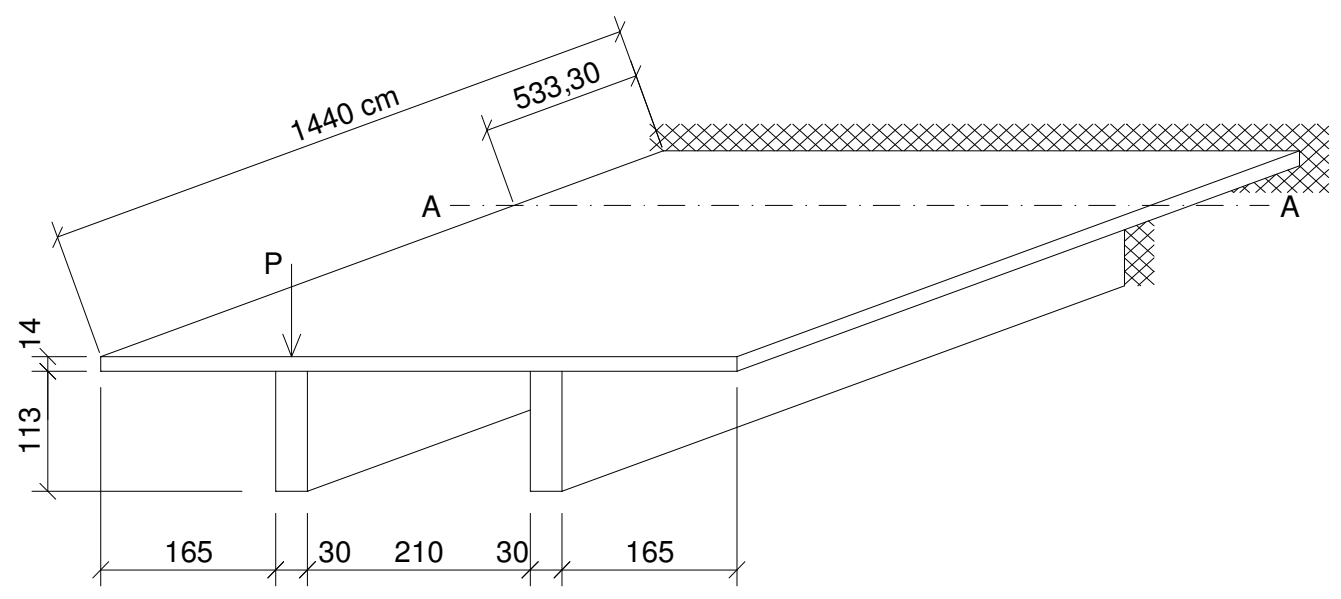

FIGURA 4.53: Geometria da laje analisada, em $\mathrm{cm}$

[SHEIKH \& MUKHOPADHYAY (1992)]

Foram considerados os seguintes dados de entrada:

- carga pontual concentrada aplicada na borda livre de uma das nervuras: $\mathrm{p}=$

$10 \mathrm{kN}$

- módulo de elasticidade: $\mathrm{E}=2100 \mathrm{kN} / \mathrm{cm}^{2}$;

- coeficiente de Poisson: $v=0,15$;

A Tabela 4.32 apresenta os resultados de deslocamentos transversais ao plano da placa máximos, no canto esquerdo em balanço, segundo os modelos analisados.

TABELA 4.32: Deslocamento transversal ao plano da placa máximo $(\mathrm{em} \mathrm{cm})$ conforme os modelos

\begin{tabular}{c|c}
\hline \hline Modelo & Deslocamento transversal máximo (cm) \\
\hline \hline Modelo 01 & 0,857 \\
\hline Modelo 02 & 0,346 \\
\hline Modelo 03 & 0,361 \\
\hline Modelo 04 & 0,349 \\
\hline Modelo 05 & 0,364 \\
\hline \hline
\end{tabular}

Analisando-se a Tabela 4.32 verifica-se que a diferença percentual máxima entre os deslocamentos transversais obtidos pelos modelos excêntricos e concêntrico foi de $147,69 \%$. 


\section{h) Placa enrijecida por nervuras, em acrílico, conforme CARRIJO \& PAIVA (1997)}

A partir dos resultados obtidos por CARRIJO \& PAIVA (1997) para uma placa de acrílico enrijecida por nervuras ortogonais fez-se a análise dos mesmos modelos numéricos efetuados pelos autores do artigo, agora utilizando-se o software de elementos finitos ANSYS 5.5, comparando-os também com os resultados experimentais e demais modelos propostos neste trabalho.

Nas análises numéricas efetuadas pelos autores foram utilizados os seguintes modelos: modelo tridimensional utilizando elementos de casca plana e também modelos compostos de placas e vigas considerando-se ou não a excentricidade da viga em relação à placa.

A geometria do modelo reduzido pode ser verificada na Figura 4.54. Este foi apoiado nos quatro cantos e submetido a um carregamento uniformemente distribuído.

Foram considerados os seguintes dados de entrada para a resolução numérica do problema:

- carga uniformemente distribuída: $\mathrm{q}=0,000096 \mathrm{kN} / \mathrm{cm}^{2}$;

- módulo de elasticidade do acrílico: $\mathrm{E}=250 \mathrm{kN} / \mathrm{cm}^{2}$;

- coeficiente de Poisson do acrílico: $v=0,36$.

$\mathrm{Na}$ análise numérica foram usados os Modelos 01 a 07. Com o intuito de verificar os resultados dos modelos a laje foi também discretizada por elementos sólidos de oito nós, com seis graus de liberdade por nó: três translações segundo dos eixos cartesianos do espaço tridimensional, e as três rotações associadas. O elemento sólido com essas características disponível no ANSYS 5.5 é o SOLID73. Cabe ressaltar que a modelagem da estrutura por elementos sólidos é extremamente trabalhosa e gera grande esforço computacional, sendo praticamente inviável a sua aplicação no dia-a-dia dos escritórios de projeto e cálculo estrutural. Assim, o uso desse modelo serviu apenas para verificar os resultados apresentados pelos outros modelos apresentados neste trabalho. 


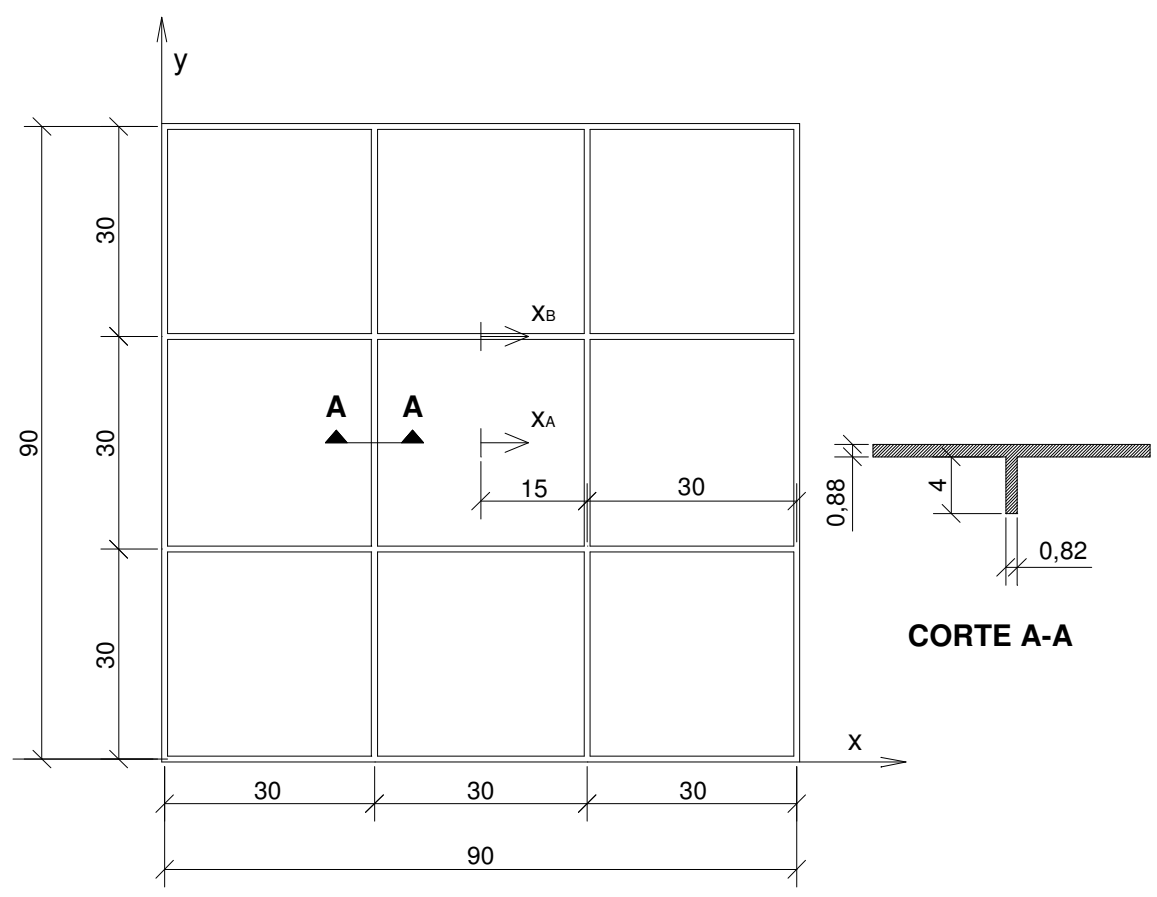

FIGURA 4.54: Geometria do modelo estudado, em $\mathrm{cm}$

[CARRIJO \& PAIVA (1997)]

Os pontos de medição da análise experimental podem ser verificados na Figura 4.55 .

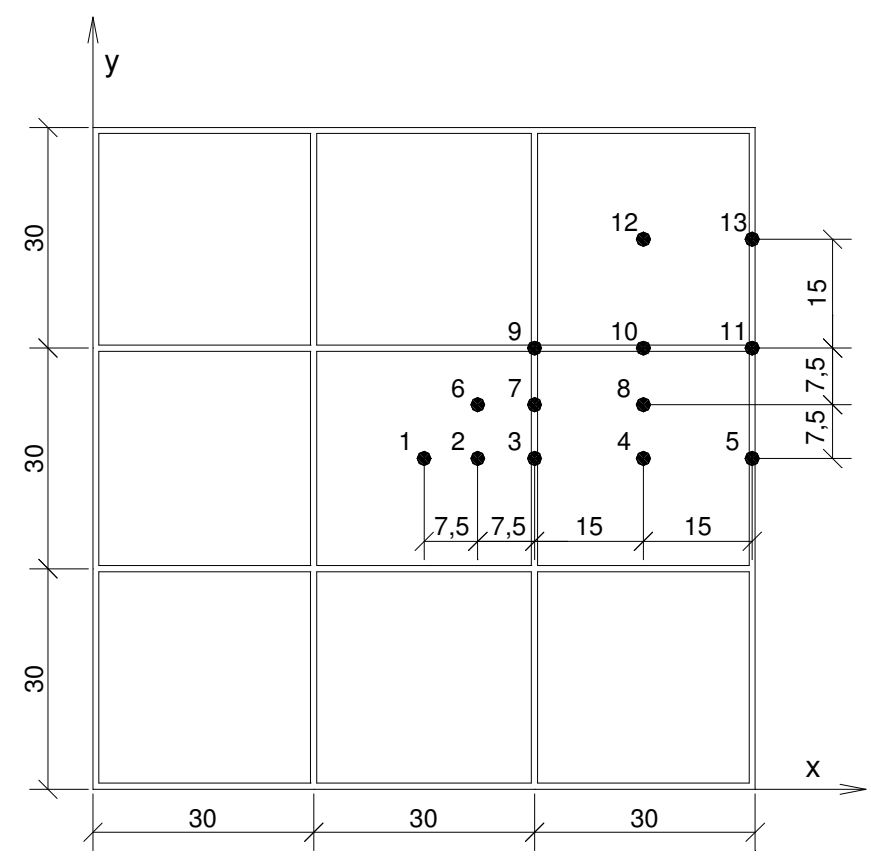

FIGURA 4.55: Pontos de instrumentação [CARRIJO \& PAIVA (1997)] 
A Tabela 4.33 abaixo apresenta os valores dos deslocamentos transversais obtidos experimentalmente e numericamente nos pontos de medição. A Figura 4.56 plota os deslocamentos obtidos para os pontos 01 a 05 da Figura 4.55 acima.

TABELA 4.33: Deslocamentos transversais (em mm) obtidos experimentalmente e numericamente na placa

\begin{tabular}{c|c|c|c|c|c|c|c|c|c}
\hline \hline \multirow{2}{*}{ Ponto } & \multirow{2}{*}{ Ensaio } & \multicolumn{10}{|c}{ Modelos de cálculo } \\
\cline { 3 - 10 } & & $\mathbf{0 1}$ & $\mathbf{0 2}$ & $\mathbf{0 3}$ & $\mathbf{0 4}$ & $\mathbf{0 5}$ & $\mathbf{0 6}$ & $\mathbf{0 7}$ & Sólido \\
\hline \hline 01 & 6,22 & 14,98 & 6,25 & 6,30 & 6,48 & 6,40 & - & 7,71 & 6,85 \\
\hline 02 & 6,13 & 14,75 & 6,13 & 6,19 & 6,29 & 6,25 & - & 7,58 & 6,78 \\
\hline 03 & 5,86 & 14,13 & 5,87 & 5,93 & 6,08 & 6,04 & 6,21 & 7,37 & 6,52 \\
\hline 04 & 4,80 & 12,05 & 5,14 & 5,19 & 5,37 & 5,33 & - & 6,50 & 5,77 \\
\hline 05 & 3,15 & 8,99 & 3,96 & 4,01 & 4,21 & 4,18 & 4,35 & 5,52 & 4,71 \\
\hline 06 & 6,11 & 14,61 & 6,08 & 6,14 & 6,16 & 6,13 & - & 7,45 & 6,71 \\
\hline 07 & 5,87 & 13,91 & 5,79 & 5,85 & 5,96 & 5,92 & 6,10 & 7,23 & 6,46 \\
\hline 08 & 4,67 & 11,77 & 5,01 & 5,06 & 5,18 & 5,15 & - & 6,32 & 5,66 \\
\hline 09 & 5,72 & 13,29 & 5,57 & 5,63 & 5,76 & 5,72 & 5,89 & 6,99 & 6,22 \\
\hline 10 & 4,54 & 11,01 & 4,68 & 4,73 & 4,90 & 4,86 & 5,01 & 5,99 & 5,29 \\
\hline 11 & 3,77 & 7,83 & 3,44 & 3,49 & 3,68 & 3,64 & 3,78 & 4,81 & 4,16 \\
\hline 12 & 3,72 & 8,33 & 3,66 & 3,70 & 3,80 & 3,77 & - & 4,62 & 4,05 \\
\hline 13 & 2,60 & 4,51 & 1,95 & 1,98 & 2,12 & 2,10 & 2,57 & 2,83 & 2,46 \\
\hline \hline
\end{tabular}

Analisando-se a Tabela 4.33 pode-se verificar que:

- o modelo concêntrico de análise superestimou os deslocamentos na placa, já que subestimou a rigidez gerada pela excentricidade das nervuras; em relação ao resultado do maior deslocamento do ensaio de CARRIJO \& PAIVA (1997) o modelo concêntrico apresentou um erro de 140,84\%;

- os Modelos excêntricos 02 a 05 comportaram-se aproximadamente iguais, com a maior diferença para o ponto de maior deslocamento de $3,68 \%$, sendo o mais rígido o Modelo 02 e o mais flexível o Modelo 05;

- o Modelo 06, ou modelo de grelha, apresentou-se mais flexível que os modelos excêntricos 02 a 05 , como esperado; verificou-se também que o mesmo não permite a análise de deslocamentos nos pontos fora das linhas das nervuras;

- o Modelo 07, ou modelo de laje maciça com espessura equivalente nãoreduzida, comportou-se com maior flexibilidade dentre todos os modelos excêntricos. Isso contrariou uma premissa difundida que afirma que o modelo é mais rígido que a laje nervurada real. A razão para este fato ter ocorrido é o pouco número de nervuras por lado gerando, dessa forma, uma elevada relação $a_{1} / 1=0,333$. ABDUL-WAHAB \& KHALIL (2000) consideram o modelo aplicável a lajes com cinco ou mais nervuras por lado; 
HOPPMANN et al. (1956) e DEB et al. (1991) consideram adequada uma relação a $1 /$ em torno de 0,070 .

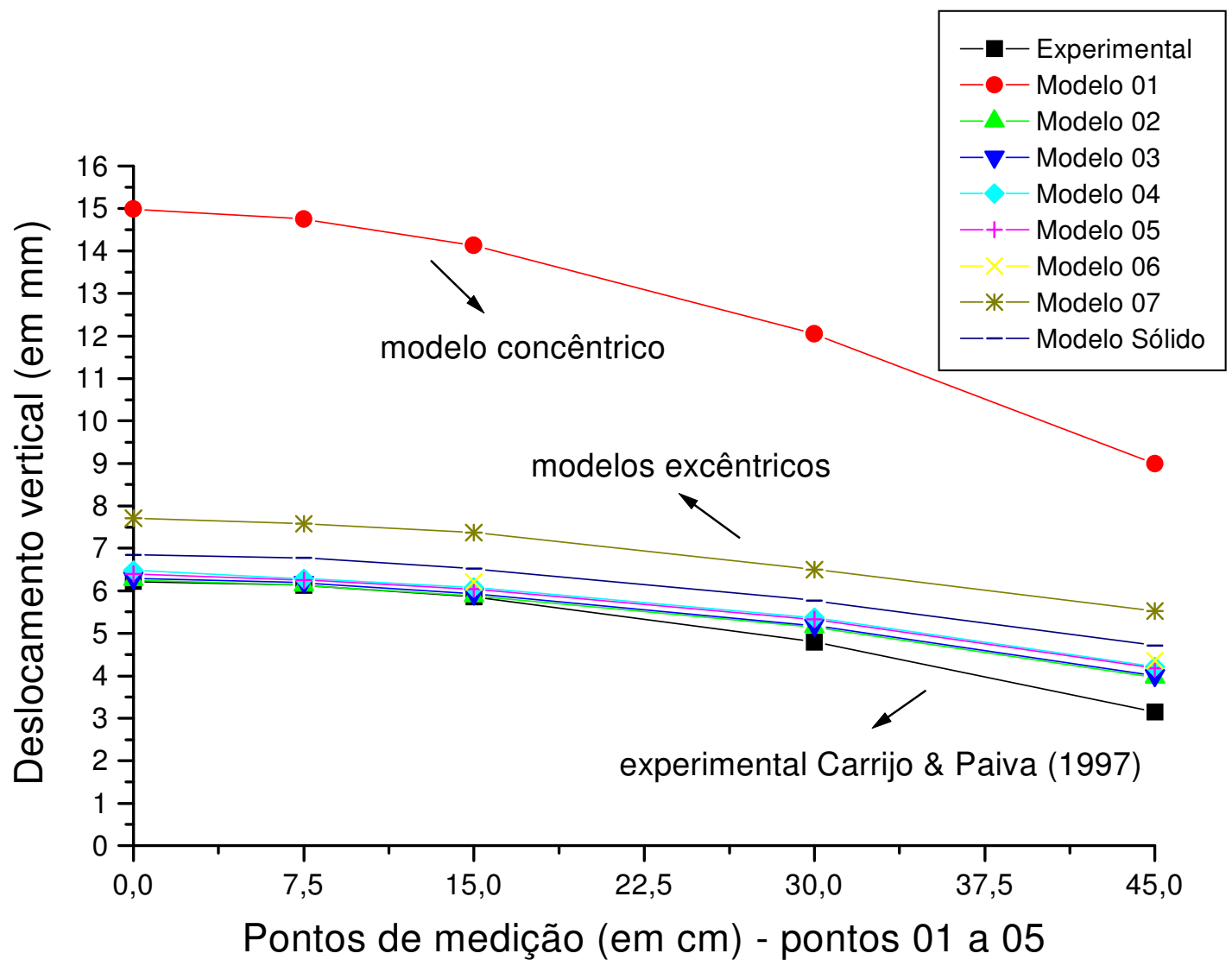

FIGURA 4.56: Deslocamentos transversais (em $\mathrm{mm}$ ) nos pontos 01 a 05 da placa proposta por CARRIJO \& PAIVA (1997)

A Tabela 4.34 abaixo apresenta os valores de deslocamentos transversais obtidos ao longo da nervura do corte A-A da Figura 4.54, de y $=0$ até o centro da placa enrijecida, ou seja, $y=45 \mathrm{~cm}$.

A Figura 4.57 representa os deslocamentos obtidos ao longo da nervura, por meio das modelagens numéricas deste trabalho, de acordo com a Tabela 4.34. 
TABELA 4.34: Deslocamentos transversais (em mm) obtidos numericamente ao longo da nervura do corte A-A

\begin{tabular}{c|c|c|c|c|c|c|c}
\hline \hline \multirow{2}{*}{$\begin{array}{c}\text { Ponto y } \\
(\mathbf{e m ~ c m})\end{array}$} & \multicolumn{7}{|c}{ Modelo de cálculo } \\
\cline { 2 - 8 } & $\mathbf{0 1}$ & $\mathbf{0 2}$ & $\mathbf{0 3}$ & $\mathbf{0 4}$ & $\mathbf{0 5}$ & $\mathbf{0 6}$ & $\mathbf{0 7}$ \\
\hline 0 & 7,83 & 3,59 & 3,63 & 3,68 & 3,64 & 3,78 & 4,81 \\
\hline 6 & 9,16 & 4,09 & 4,13 & 4,19 & 4,15 & 4,30 & 5,27 \\
\hline 12 & 10,42 & 4,56 & 4,61 & 4,67 & 4,63 & 4,78 & 5,75 \\
\hline 18 & 11,56 & 4,99 & 5,03 & 5,10 & 5,07 & 5,22 & 6,23 \\
\hline 24 & 12,52 & 5,35 & 5,39 & 5,46 & 5,43 & 5,59 & 6,65 \\
\hline 30 & 13,29 & 5,63 & 5,68 & 5,76 & 5,72 & 5,89 & 6,99 \\
\hline 36 & 13,82 & 5,83 & 5,88 & 5,95 & 5,92 & 6,09 & 7,23 \\
\hline 42 & 14,09 & 5,93 & 5,98 & 6,07 & 6,03 & 6,19 & 7,35 \\
\hline 45 & 14,09 & 5,93 & 5,98 & 6,07 & 6,03 & 6,19 & 7,35 \\
\hline \hline
\end{tabular}

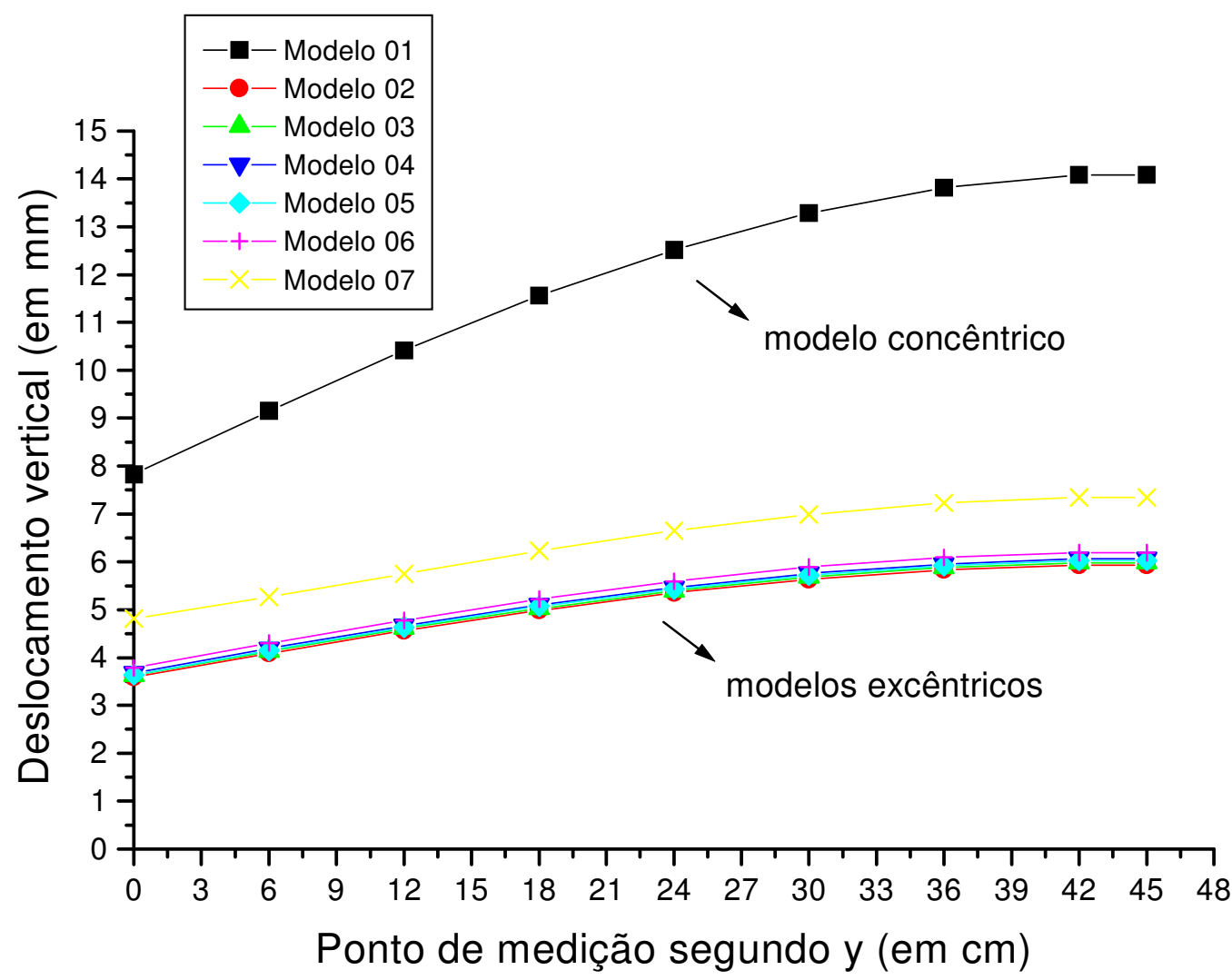

FIGURA 4.57: Deslocamentos transversais (em mm) obtidos numericamente ao longo da nervura da placa proposta por CARRIJO \& PAIVA (1997)

Analisando-se a Tabela 4.34, que mostra os deslocamentos transversais obtidos numericamente ao longo da nervura A-A, verificou-se que:

- o maior deslocamento obtido no modelo concêntrico, 14,09 mm, é 137,61\% maior que o menor deslocamento máximo obtido pelos modelos excêntricos, 5,93 mm, encontrado no Modelo 02; 
- os resultados apresentados pelos Modelos excêntricos 02 a 06 estão muito próximos, diferindo no máximo $4,38 \%$ no ponto de maior deslocamento.

A fim de comparar os resultados numéricos encontrados através das modelagens pelo ANSYS 5.5 confrontam-se na Tabela 4.35 os resultados dos modelos numéricos similares àqueles efetuados por CARRIJO \& PAIVA (1997), descritos a seguir:

- Modelo TRID: similar ao Modelo 04, onde o pavimento foi modelado como estrutura tridimensional formado por elementos planos trabalhando à flexão e tensão, ou seja, elementos de casca plana com seis parâmetros nodais (u, v, w, $\theta_{\mathrm{x}}, \theta_{\mathrm{y}}$ e $\theta_{\mathrm{z}}$ );

- Modelo GRIL1: similar ao Modelo 01, onde o pavimento foi modelado como uma placa associada a elementos de vigas sem considerar a excentricidade; contudo, os elementos finitos utilizados pelos autores possuem apenas cinco parâmetros nodais $(\mathrm{u}, \mathrm{v}$, w, $\theta_{\mathrm{x}}$ e $\theta_{\mathrm{y}}$ ), enquanto os elementos utilizados pelo ANSYS 5.5 possuem seis parâmetros nodais $\left(\mathrm{u}, \mathrm{v}, \mathrm{w}, \theta_{\mathrm{x}}, \theta_{\mathrm{y}}\right.$ e $\left.\theta_{\mathrm{z}}\right)$;

- Modelo GRIL2-V1: similar ao Modelo 03, divergindo apenas no número de graus de liberdade dos elementos finitos, da mesma forma que o Modelo GRIL1;

- Modelo GRIL2-V2: similar ao Modelo 02, divergindo apenas no número de graus de liberdade dos elementos finitos, da mesma forma que o Modelo GRIL1.

Pela análise da Tabela 4.35 verificou-se que os modelos aplicados neste trabalho similares aos modelos efetuados por CARRIJO \& PAIVA (1997) comportaram-se de forma semelhante, apresentando resultados próximos, diferindo no máximo 5\% no ponto de maior deslocamento da placa enrijecida. 
TABELA 4.35: Comparação entre os deslocamentos transversais (em mm) obtidos numericamente por CARRIJO \& PAIVA (1997) e pelos modelos no ANSYS 5.5

\begin{tabular}{c|c|c|c|c|c|c|c|c}
\hline \hline \multirow{2}{*}{ Ponto } & \multicolumn{7}{|c}{ Modelos } \\
\cline { 2 - 9 } & $\mathbf{0 1}$ & GRIL1 & $\mathbf{0 2}$ & GRIL2-V1 & $\mathbf{0 3}$ & GRIL2-V2 & $\mathbf{0 4}$ & TRID \\
\hline \hline 01 & 14,98 & 14,26 & 6,25 & 6,02 & 6,30 & 6,00 & 6,48 & 6,24 \\
\hline 02 & 14,75 & 14,04 & 6,13 & 5,92 & 6,19 & 5,90 & 6,29 & 6,14 \\
\hline 03 & 14,13 & 13,42 & 5,87 & 5,66 & 5,93 & 5,63 & 6,08 & 5,89 \\
\hline 04 & 12,05 & 11,43 & 5,14 & 4,90 & 5,19 & 4,90 & 5,37 & 5,19 \\
\hline 05 & 8,99 & 8,53 & 3,96 & 3,81 & 4,01 & 3,71 & 4,21 & 4,09 \\
\hline 06 & 14,61 & 13,82 & 6,08 & 5,83 & 6,14 & 5,80 & 6,16 & 6,05 \\
\hline 07 & 13,91 & 13,21 & 5,79 & 5,58 & 5,85 & 5,54 & 5,96 & 5,80 \\
\hline 08 & 11,77 & 11,17 & 5,01 & 4,83 & 5,06 & 4,77 & 5,18 & 5,08 \\
\hline 09 & 13,29 & 12,60 & 5,57 & 5,35 & 5,63 & 5,30 & 5,76 & 5,57 \\
\hline 10 & 11,01 & 10,42 & 4,68 & 4,50 & 4,73 & 4,44 & 4,90 & 4,73 \\
\hline 11 & 7,83 & 7,40 & 3,44 & 3,31 & 3,49 & 3,22 & 3,68 & 3,56 \\
\hline 12 & 8,33 & 7,87 & 3,66 & 3,47 & 3,70 & 3,41 & 3,80 & 3,67 \\
\hline 13 & 4,51 & 4,26 & 1,95 & 1,90 & 1,98 & 1,85 & 2,12 & 2,05 \\
\hline \hline
\end{tabular}

Apresentam-se também os resultados de momentos fletores obtidos numericamente ao longo do centro da placa, segundo à linha iniciada pela coordenada $\mathrm{x}_{\mathrm{A}}$ da Figura 4.54, nos pontos 01 a 05 da experimentação. Nas Tabelas 4.36 e 4.37 comparam-se os resultados obtidos pelos modelos de cálculo com aqueles apresentados por CARRIJO \& PAIVA (1997), obtidos experimentalmente usando o Método das Diferenças Finitas. As Figuras 4.58 e 4.59 exprimem os resultados das tabelas.

TABELA 4.36: Comparação entre momentos fletores $M_{x}$ ao longo de $x_{A}$ $\left(\mathrm{em} \mathrm{kN.cm/cm} \mathrm{x} 10^{-3}\right)$ da placa proposta por CARRIJO \& PAIVA (1997)

\begin{tabular}{c|c|c|c|c|c|c|c}
\hline \hline \multirow{2}{*}{$\begin{array}{c}\text { Ponto } \mathbf{x}_{\mathbf{A}} \\
(\mathbf{e m ~ c m})\end{array}$} & \multicolumn{7}{|c}{ Modelo } \\
\cline { 2 - 8 } & Ensaio & $\mathbf{0 1}$ & $\mathbf{0 2}$ & $\mathbf{0 3}$ & $\mathbf{0 4}$ & $\mathbf{0 5}$ & $\mathbf{0 7}^{\text {* }}$ \\
\hline 0,0 & 7,00 & 17,86 & 7,60 & 7,62 & 7,69 & 7,81 & - \\
\hline 7,5 & 6,25 & 16,01 & 6,85 & 6,88 & 6,97 & 7,11 & - \\
\hline 15,0 & 4,50 & 11,73 & 2,47 & 2,51 & 2,66 & 2,44 & - \\
\hline 30,0 & 7,00 & 13,10 & 6,36 & 6,40 & 6,49 & 6,50 & - \\
\hline 45,0 & 0,50 & 6,55 & 1,36 & 1,33 & 1,32 & 1,93 & - \\
\hline \hline
\end{tabular}

"Pode-se verificar que o Modelo 07, neste caso, não permite obter o momento que ocorre na capa da laje nervurada, visto que os momentos obtidos no modelo devem ser distribuídos somente às nervuras, por meio de área de influência de cada uma delas. O Modelo 06 também não consta, visto que o mesmo não permite obter valores de momentos na capa da laje, já que é um modelo de grelha. 


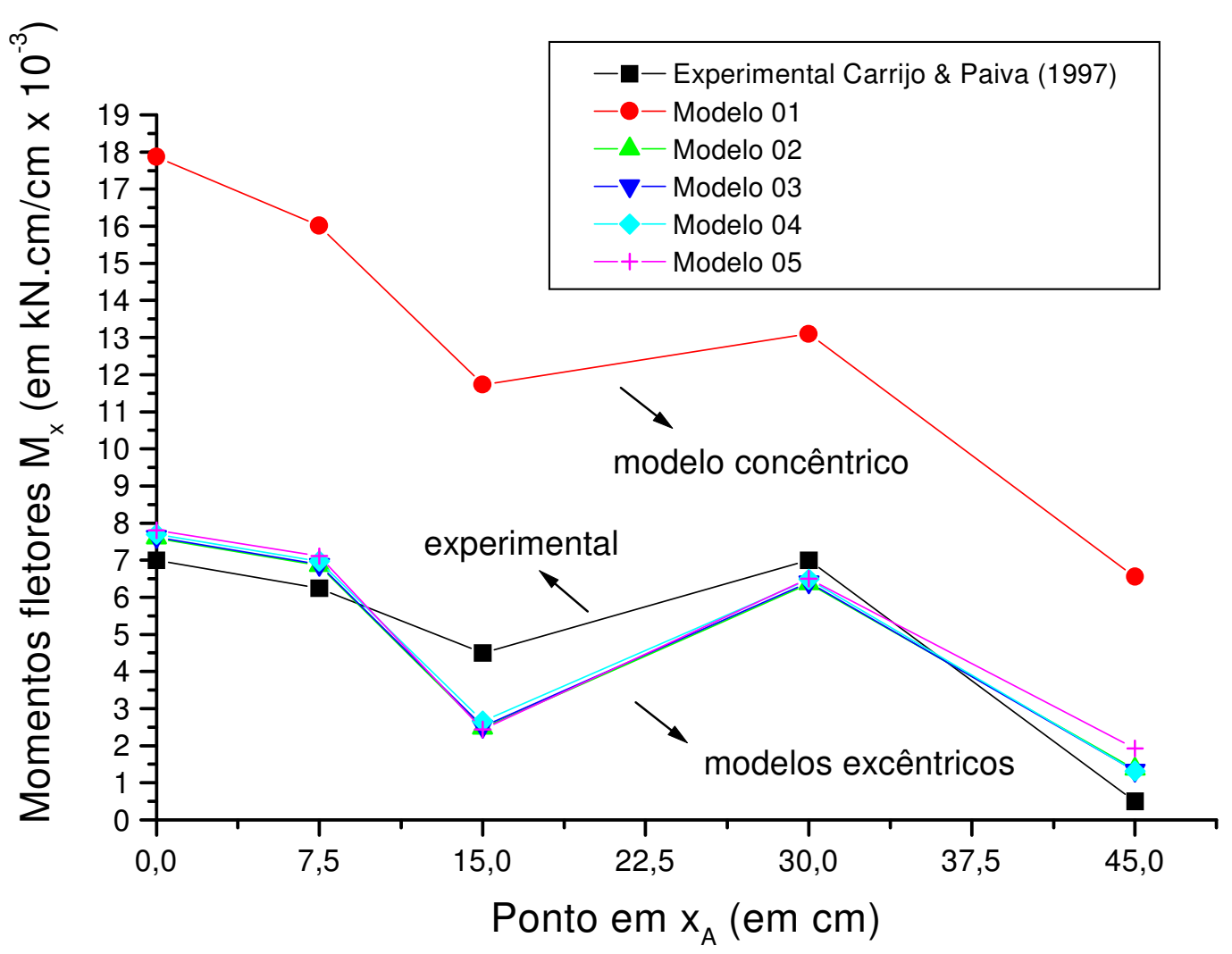

FIGURA 4.58: Comparação entre momentos fletores $\mathrm{M}_{\mathrm{x}}$ ao longo de $\mathrm{x}_{\mathrm{A}}$ $\left(\mathrm{em} \mathrm{kN.cm} / \mathrm{cm}^{-10^{-3}}\right.$ ) na placa proposta por CARRIJO \& PAIVA (1997)

TABELA 4.37: Comparação entre os momentos fletores $\mathrm{M}_{\mathrm{y}}$ ao longo de $\mathrm{x}_{\mathrm{A}}$ $\left(\mathrm{em} \mathrm{kN.cm} / \mathrm{cm} \mathrm{x} 10^{-3}\right)$

\begin{tabular}{c|c|c|c|c|c|c|c}
\hline \hline \multirow{2}{*}{$\begin{array}{c}\text { Ponto } \mathbf{x}_{\mathbf{A}} \\
(\mathbf{e m} \mathbf{~ c m})\end{array}$} & \multicolumn{7}{|c}{ Modelo } \\
\hline \hline 0,0 & Ensaio & $\mathbf{0 1}$ & $\mathbf{0 2}$ & $\mathbf{0 3}$ & $\mathbf{0 4}$ & $\mathbf{0 5}$ & $\mathbf{0 7}^{*}$ \\
\hline 7,5 & 4,85 & 17,86 & 7,50 & 7,53 & 7,69 & 7,81 & - \\
\hline 15,0 & 1,25 & 16,82 & 6,29 & 6,98 & 7,19 & 7,29 & - \\
\hline 30,0 & 9,00 & 18,18 & 4,90 & 4,94 & 5,23 & 5,09 & - \\
\hline 45,0 & 4,88 & 17,11 & 8,56 & 8,61 & 8,81 & 8,89 & - \\
\hline \hline
\end{tabular}

"Pode-se verificar que o Modelo 07, neste caso, não permite obter o momento que ocorre na capa da laje nervurada, visto que os momentos obtidos no modelo devem ser distribuídos somente às nervuras, por meio de área de influência de cada uma delas. O Modelo 06 também não consta, visto que o mesmo não permite obter valores de momentos na capa da laje, já que é um modelo de grelha. 


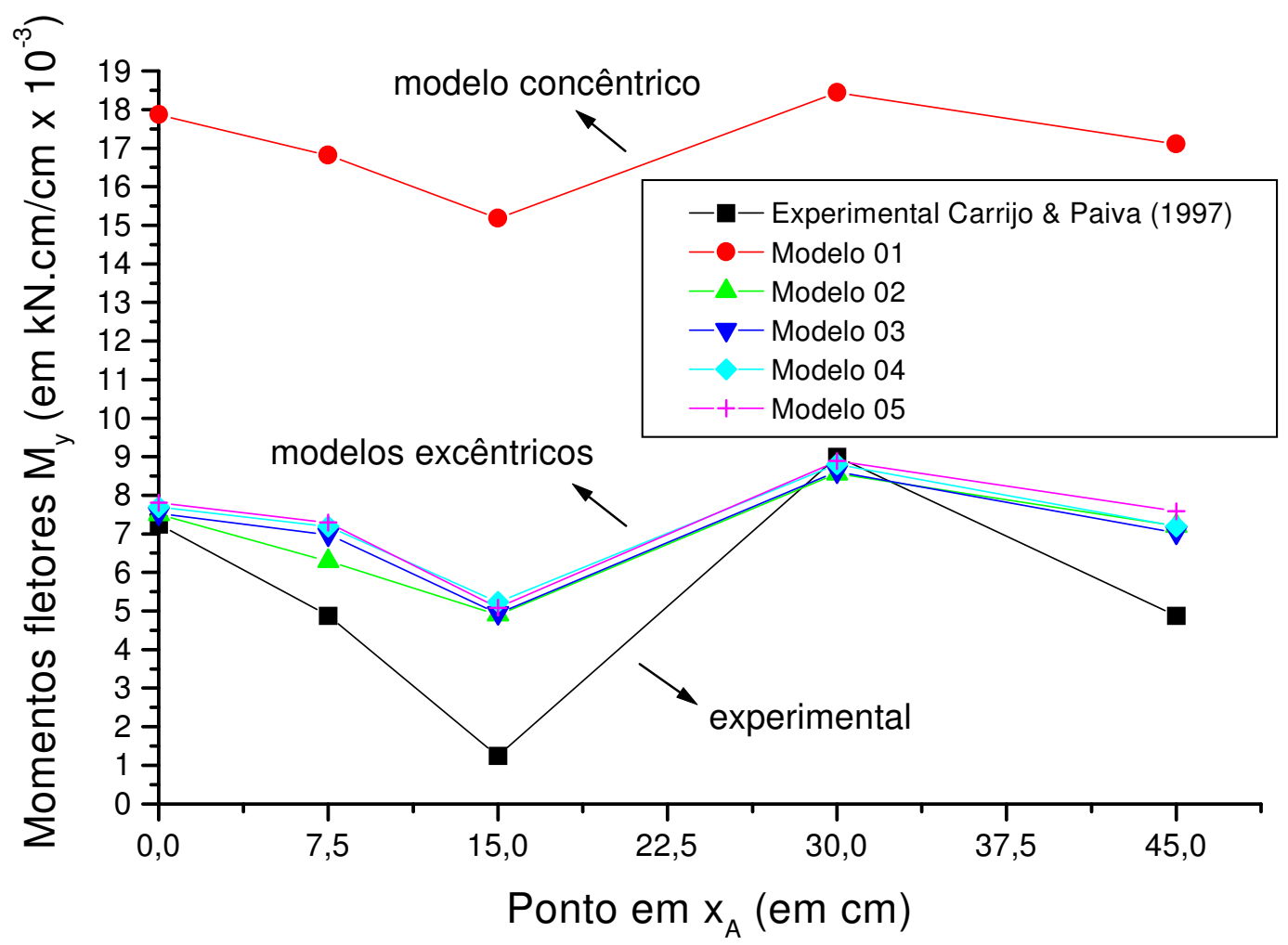

FIGURA 4.59: Comparação entre momentos fletores $\mathrm{M}_{\mathrm{y}}$ ao longo de $\mathrm{x}_{\mathrm{A}}$ $\left(\mathrm{em} \mathrm{kN} . \mathrm{cm} / \mathrm{cm} \times 10^{-3}\right)$ da placa ensaida por CARRIJO \& PAIVA (1997)

Apresentam-se os resultados de momentos fletores obtidos numericamente ao longo da nervura indicada na Figura 4.54, segundo à linha iniciada pela coordenada $\mathrm{x}_{\mathrm{B}}$. Nas Tabelas 4.38 e 4.39 comparam-se os resultados obtidos pelos modelos de cálculo com aqueles apresentados por CARRIJO \& PAIVA (1997), obtidos experimentalmente usando o Método das Diferenças Finitas.

Apresentam-se nas Figuras 4.60 e 4.61 os gráficos comparativos entre os valores de momentos fletores obtidos na capa da laje ao longo da linha iniciada em $\mathrm{x}_{\mathrm{B}}$, de acordo com as Tabelas 4.38 e 4.39. Verifica-se, através das Figuras, que os melhores resultados numéricos são aqueles apresentados pelos modelos excêntricos. Na próxima etapa do trabalho será verificada o quanto a diferença entre os resultados de momentos fletores nas nervuras pode influenciar no dimensionamento das seções de nervuras, em lajes nervuradas de concreto armado. 
TABELA 4.38: Comparação entre os momentos fletores $M_{x}$ ao longo de $x_{B}$ $\left(\mathrm{em} \mathrm{kN.cm} / \mathrm{cm} \times 10^{-3}\right)$ da placa ensaida por CARRIJO \& PAIVA (1997)

\begin{tabular}{c|c|c|c|c|c|c|c}
\hline \hline \multirow{2}{*}{$\begin{array}{c}\text { Ponto } \mathbf{x}_{\mathbf{B}} \\
(\mathbf{e m} \mathbf{~ c m})\end{array}$} & \multicolumn{7}{|c}{ Modelo } \\
\hline \hline 0,0 & Ensaio & $\mathbf{0 1}$ & $\mathbf{0 2}$ & $\mathbf{0 3}$ & $\mathbf{0 4}$ & $\mathbf{0 5}$ & $\mathbf{0 7}^{*}$ \\
\hline 7,5 & 4,60 & 15,18 & 5,08 & 5,11 & 5,24 & 5,09 & - \\
\hline 15,0 & 6,25 & 15,08 & 5,15 & 5,19 & 5,28 & 5,20 & - \\
\hline 30,0 & 2,50 & 14,00 & 5,00 & 5,01 & 4,98 & 5,14 & - \\
\hline 45,0 & - & 7,079 & 3,70 & 3,64 & 3,91 & 3,73 & - \\
\hline \hline
\end{tabular}

"Pode-se verificar que o Modelo 07, neste caso, não permite obter o momento que ocorre na capa da laje nervurada, visto que os momentos obtidos no modelo devem ser distribuídos somente às nervuras, por meio de área de influência de cada uma delas. O Modelo 06 também não consta, visto que o mesmo não permite obter valores de momentos na capa da laje.

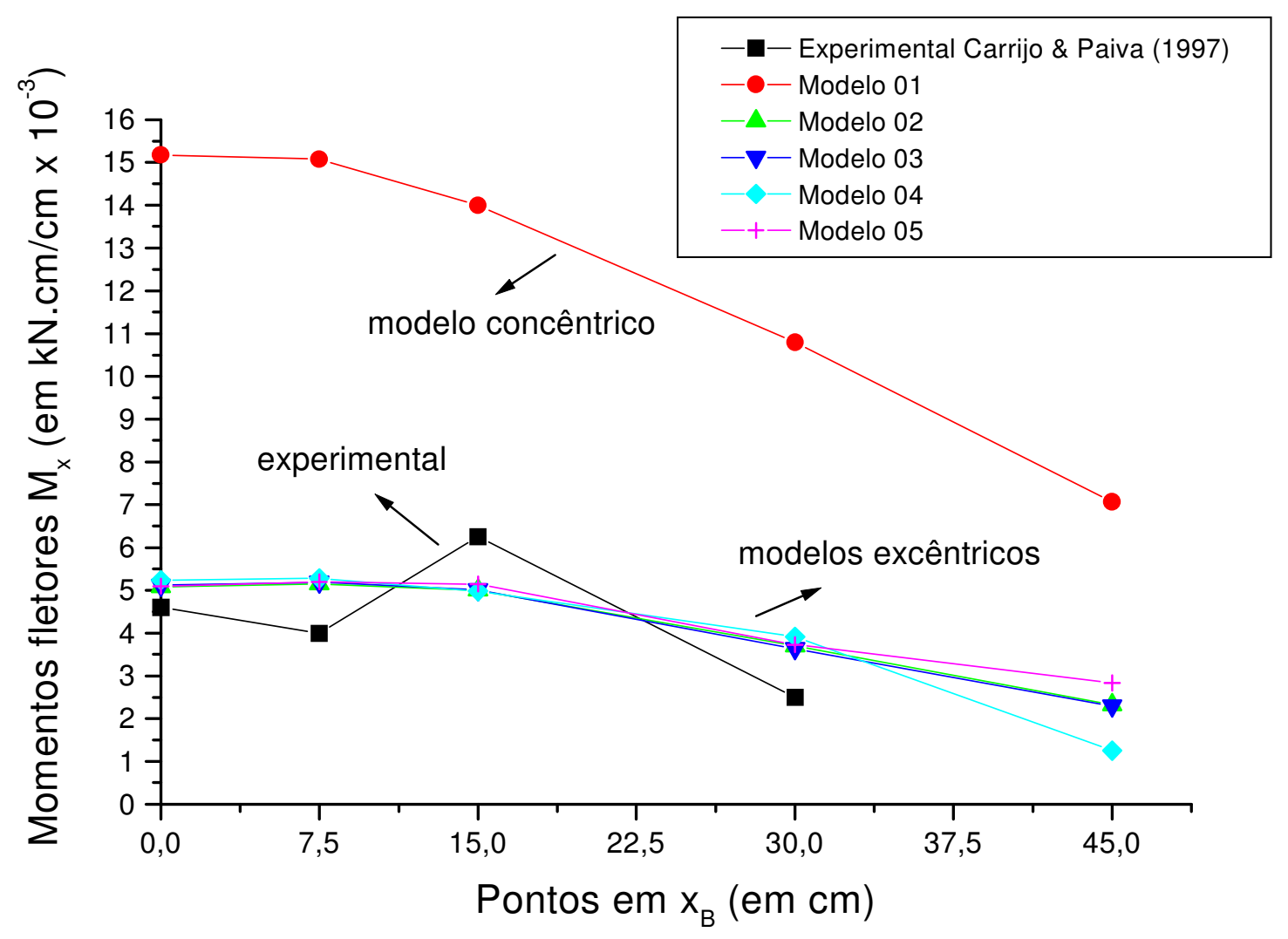

FIGURA 4.60: Comparação entre momentos fletores $M_{x}$ ao longo de $x_{B}$ (em kN.cm/cm x 10 $0^{-3}$ ) da placa ensaiada por CARRIJO \& PAIVA (1997) 
TABELA 4.39: Comparação entre os momentos fletores $\mathrm{M}_{\mathrm{y}}$ ao longo de $\mathrm{x}_{\mathrm{B}}$

$\left(\mathrm{em} \mathrm{kN.cm} / \mathrm{cm} \times 10^{-3}\right.$ ) da placa proposta por CARRIJO \& PAIVA (1997)

\begin{tabular}{c|c|c|c|c|c|c|c}
\hline \hline \multirow{2}{*}{$\begin{array}{c}\text { Ponto } \mathbf{x}_{\mathbf{B}} \\
(\mathbf{e m ~ c m})\end{array}$} & \multicolumn{7}{|c}{ Modelo } \\
\cline { 2 - 8 } & Ensaio & $\mathbf{0 1}$ & $\mathbf{0 2}$ & $\mathbf{0 3}$ & $\mathbf{0 4}$ & $\mathbf{0 5}$ & $\mathbf{0 7}^{\text {* }}$ \\
\hline 0,0 & 1,25 & 11,72 & 2,45 & 2,49 & 2,66 & 2,43 & - \\
\hline 7,5 & 5,38 & 12,26 & 2,58 & 3,11 & 3,29 & 3,11 & - \\
\hline 15,0 & 6,00 & 13,99 & 4,85 & 4,87 & 4,98 & 5,14 & - \\
\hline 30,0 & 4,50 & 13,24 & 3,48 & 3,57 & 3,94 & 3,70 & - \\
\hline 45,0 & 6,63 & 16,21 & 6,97 & 7,16 & 7,06 & 7,05 & - \\
\hline \hline
\end{tabular}

"Pode-se verificar que o Modelo 07, neste caso, não permite obter o momento que ocorre na capa da laje nervurada, visto que os momentos obtidos no modelo devem ser distribuídos somente às nervuras, por meio de área de influência de cada uma delas. O Modelo 06 também não consta, visto que o mesmo não permite obter valores de momentos na capa da laje.

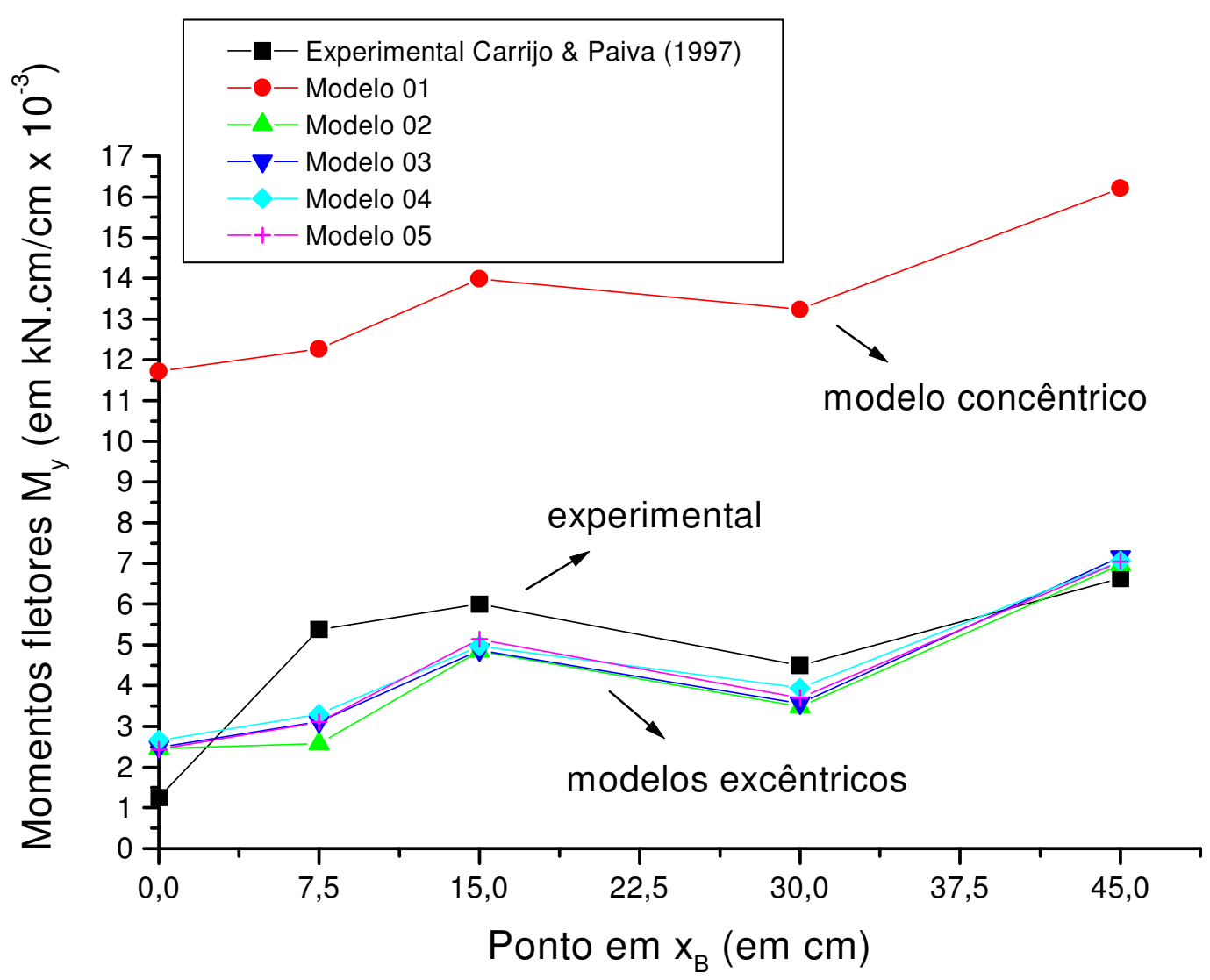

FIGURA 4.61: Comparação entre momentos fletores $\mathrm{M}_{\mathrm{y}}$ ao longo de $\mathrm{x}_{\mathrm{B}}$

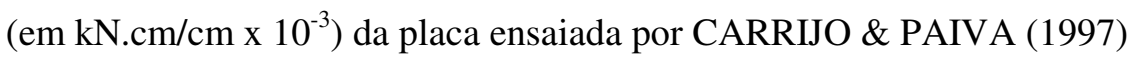




\section{i) Placa enrijecida por nervuras ortogonais, conforme KANOK-NUKULCHAI \& GILANI (1981)}

KANOK-NUKULCHAI \& GILANI (1981) efetuaram análise numérica através do MEF utilizando o conceito de "macroelemento" para modelar cada célula da laje nervurada e aplicaram à uma laje nervurada simplesmente apoiada ao longo dos quatro lados.

Neste trabalho foram efetuadas análises utilizando o ANSYS 5.5 visando verificar os modelos numéricos aqui estudados.

Foram considerados os seguintes dados de entrada:

- carga uniformemente distribuída: $\mathrm{q}=0,006895 \mathrm{kN} / \mathrm{cm}^{2}$;

- módulo de elasticidade: $\mathrm{E}=6895 \mathrm{kN} / \mathrm{cm}^{2}$;

- coeficiente de Poisson: $v=0,15$;

- espessura da placa: $\mathrm{h}=7,62 \mathrm{~cm}$;

A geometria do problema pode ser verificado na Figura 4.62.

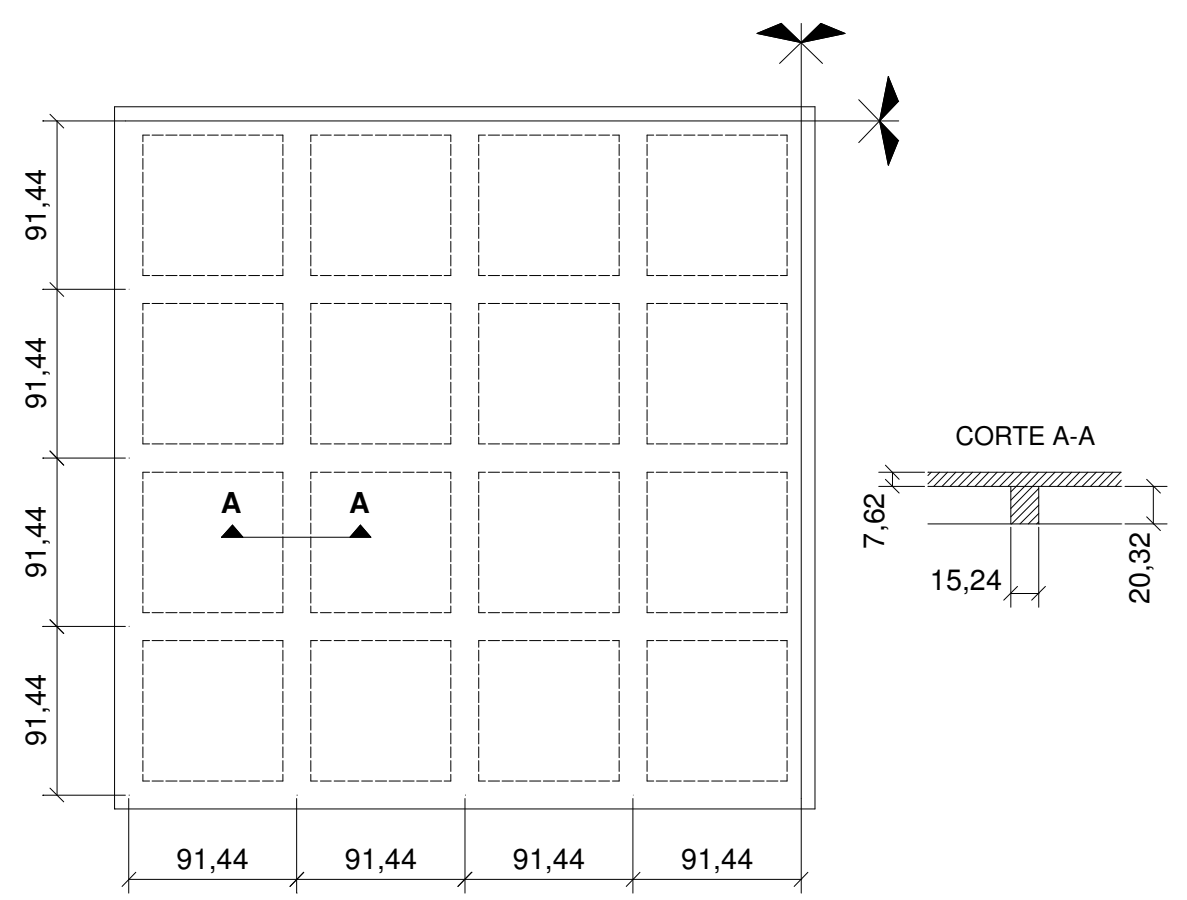

FIGURA 4.62: Geometria da laje nervurada, em cm, conforme KANOK-NUKULCHAI \& GILANI (1981)

Na análise numérica foram usados os Modelos 01 a 07. 
A Tabela 4.40 apresenta os resultados de deslocamentos nos pontos de medição da laje enrijecida, apresentados na Figura 4.63, de acordo com os modelos numéricos analisados. As Figuras 4.64 e 4.65 exprimem estes deslocamentos.

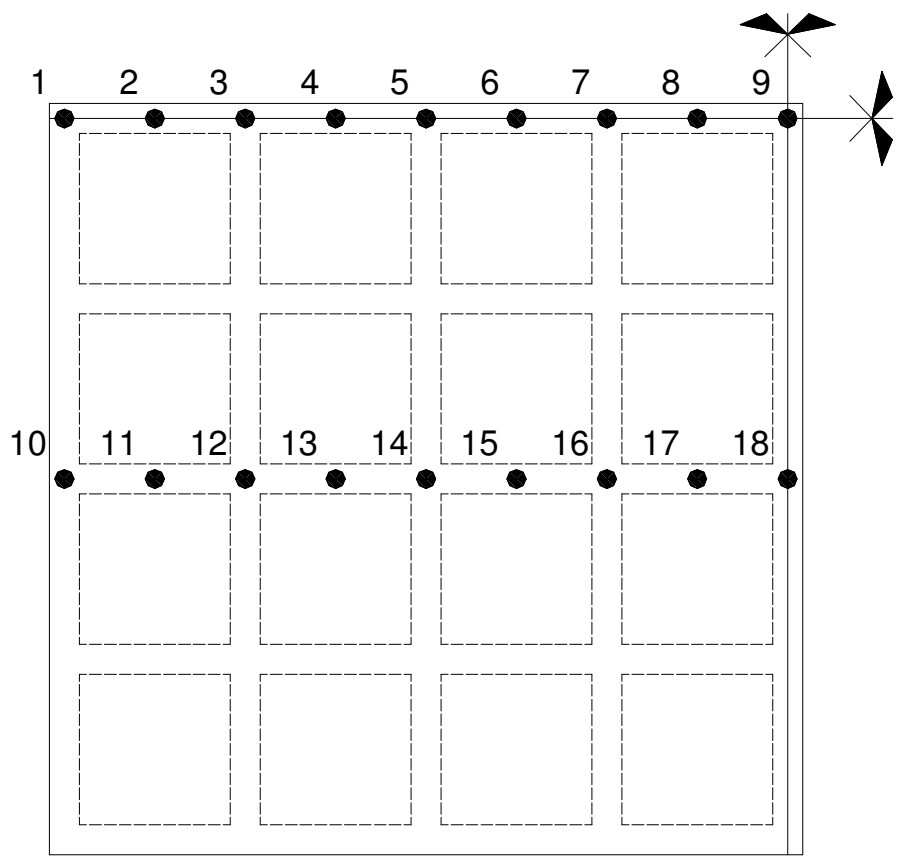

FIGURA 4.63: Pontos de medição dos deslocamentos ortogonais ao plano da placa

[KANOK-NUKULCHAI \& GILANI (1981)]

TABELA 4.40: Deslocamentos transversais $(\mathrm{em} \mathrm{cm}$ ) obtidos numericamente

\begin{tabular}{c|c|c|c|c|c|c|c|c}
\hline \hline \multirow{2}{*}{ Ponto } & \multicolumn{8}{|c}{ Modelos Numéricos } \\
\cline { 2 - 9 } & $\mathbf{0 1}$ & $\mathbf{0 1 - A}$ & $\mathbf{0 2}$ & $\mathbf{0 3}$ & $\mathbf{0 4}$ & $\mathbf{0 5}$ & $\mathbf{0 6}$ & $\mathbf{0 7}$ \\
\hline \hline 01 & 0 & 0 & 0 & 0 & 0,0005 & 0 & 0 & 0 \\
\hline 02 & 1,71 & 1,71 & 0,55 & 0,59 & 0,53 & 0,57 & 0,61 & 0,38 \\
\hline 03 & 3,35 & 3,35 & 1,07 & 1,15 & 1,03 & 1,11 & 1,20 & 0,74 \\
\hline 04 & 4,84 & 4,84 & 1,54 & 1,65 & 1,49 & 1,60 & 1,73 & 1,07 \\
\hline 05 & 6,12 & 6,12 & 1,95 & 2,09 & 1,88 & 2,02 & 2,19 & 1,35 \\
\hline 06 & 7,15 & 7,15 & 2,28 & 2,44 & 2,20 & 2,36 & 2,56 & 1,57 \\
\hline 07 & 7,90 & 7,90 & 2,52 & 2,70 & 2,43 & 2,61 & 2,84 & 1,73 \\
\hline 08 & 8,36 & 8,36 & 2,66 & 2,85 & 2,56 & 2,76 & 3,00 & 1,83 \\
\hline $\mathbf{0 9}$ & $\mathbf{8 , 5 1}$ & $\mathbf{8 , 5 1}$ & $\mathbf{2 , 7 1}$ & $\mathbf{2 , 9 0}$ & $\mathbf{2 , 6 1}$ & $\mathbf{2 , 8 1}$ & $\mathbf{3 , 0 6}$ & $\mathbf{1 , 8 6}$ \\
\hline 10 & 0 & 0 & 0 & 0 & 0,0005 & 0 & 0 & 0 \\
\hline 11 & 1,24 & 1,24 & 0,40 & 0,43 & 0,38 & 0,41 & 0,44 & 0,28 \\
\hline 12 & 2,42 & 2,42 & 0,77 & 0,83 & 0,75 & 0,80 & 0,87 & 0,54 \\
\hline 13 & 3,49 & 3,49 & 1,11 & 1,19 & 1,08 & 1,15 & 1,25 & 0,78 \\
\hline 14 & 4,41 & 4,41 & 1,40 & 1,51 & 1,36 & 1,45 & 1,58 & 0,98 \\
\hline 15 & 5,14 & 5,14 & 1,64 & 1,76 & 1,58 & 1,70 & 1,84 & 1,14 \\
\hline 16 & 5,68 & 5,68 & 1,81 & 1,94 & 1,75 & 1,87 & 2,03 & 1,25 \\
\hline 17 & 6,01 & 6,01 & 1,91 & 2,05 & 1,85 & 1,98 & 2,15 & 1,32 \\
\hline 18 & 6,12 & 6,12 & 1,95 & 2,09 & 1,88 & 2,02 & 2,19 & 1,35 \\
\hline \hline
\end{tabular}


Analisando-se a Tabela 4.40 pode-se verificar que:

- a consideração das nervuras concêntricas aos elementos de placa subestimaram a rigidez do sistema apresentando, dessa forma, deslocamento transversal ao plano da laje máximo da ordem de $216 \%$ maior que aquele apresentado por KANOKNUKULCHAI \& GILANI (1981), que foi de 2,70 cm, encontrado através de análise tridimensional;

- o Modelo 07, ou modelo de laje maciça equivalente sem redução de espessura, como já verificado na literatura, comportou-se com rigidez maior que os demais modelos excêntricos (simplificados e realistas). A laje possui 05 nervuras por lado, mas uma elevada relação $a_{1} / l=0,25$ o que, segundo a bibliografia pesquisada, é muito elevada para que o método seja aplicado com confiança e segurança de resultados;

- o Modelo 06, ou modelo de grelha, foi o modelo mais flexível dentre os modelos excêntricos, como esperado;

- os resultados dos Modelos excêntricos 02 a 05 estiveram muito próximos daquele obtido por KANOK-NUKULCHAI \& GILANI (1981), apresentando diferença máxima de 7,41\% no maior deslocamento transversal ao plano da placa enrijecida, verificado no ponto 09 da Figura 4.62.

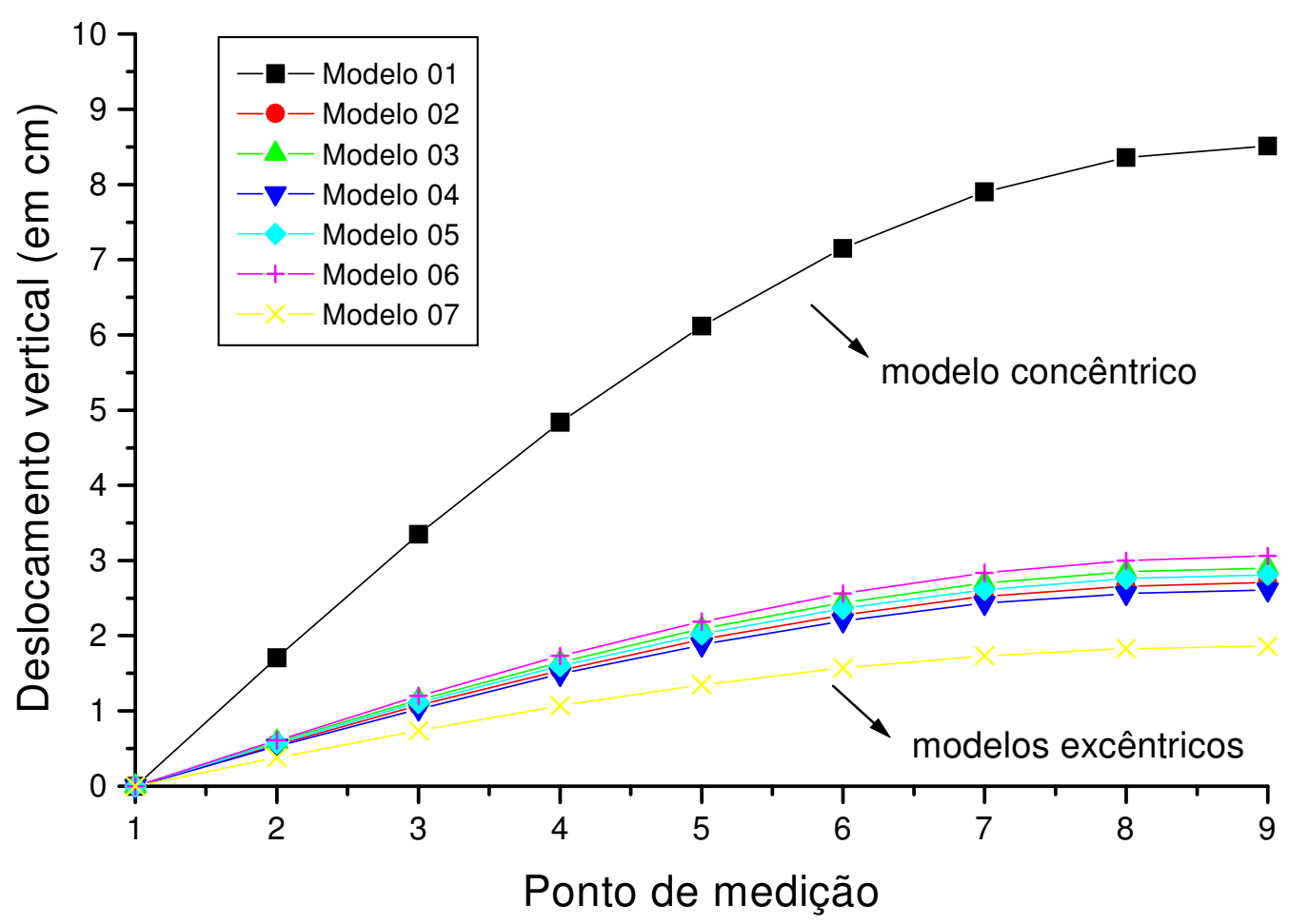

FIGURA 4.64: Deslocamentos numéricos transversais ao plano da placa $(\mathrm{em} \mathrm{cm})$ - pontos 01 a 09 da laje proposta por KANOK-NUKULCHAI \& GILANI (1981) 


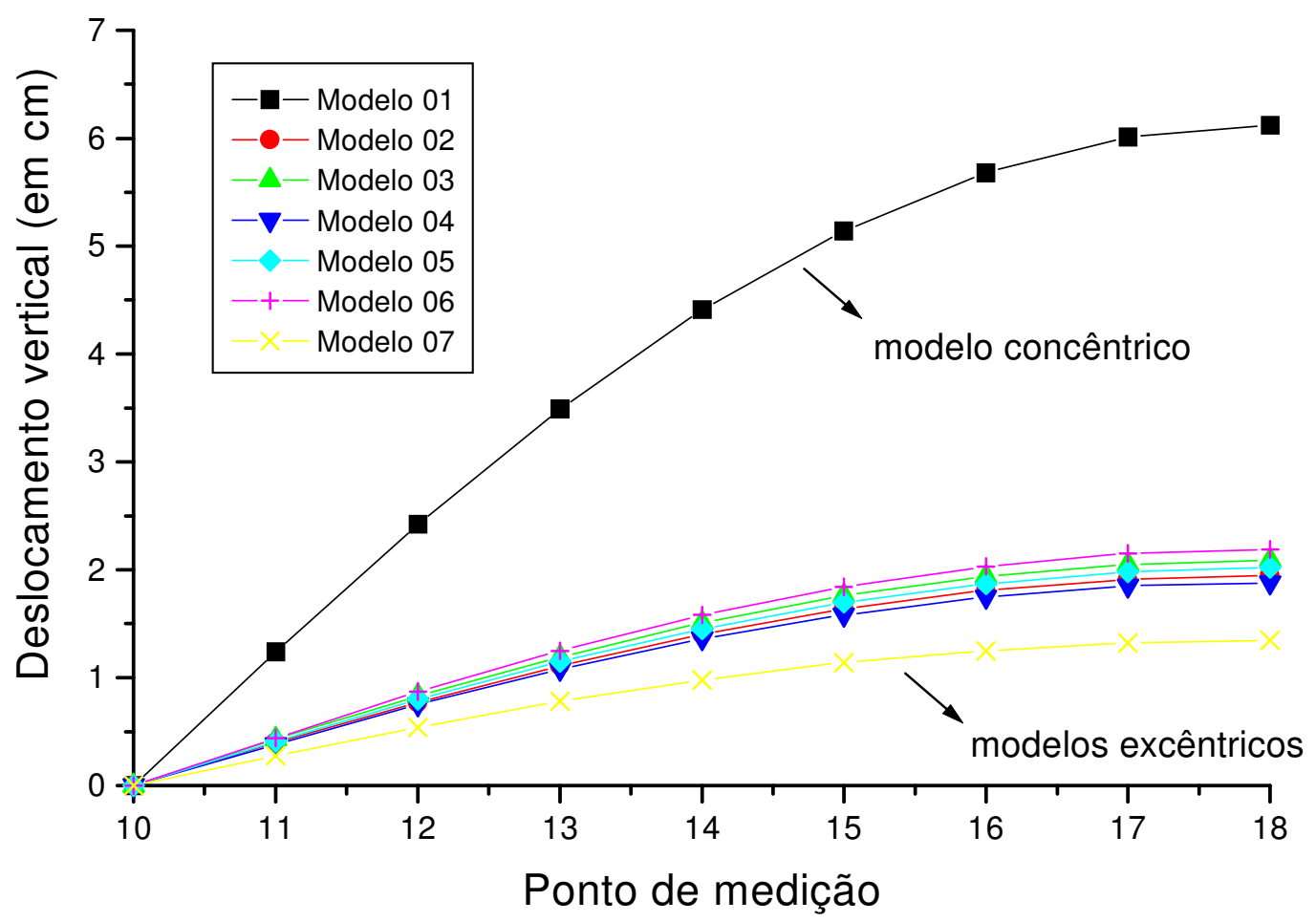

FIGURA 4.65: Deslocamentos numéricos transversais ao plano da placa $(\mathrm{em} \mathrm{cm})$ - pontos 10 a 18 da placa proposta por KANOK-NUKULCHAI \& GILANI (1981)

Apresentam-se os momentos fletores obtidos na capa ao longo da nervura no centro da placa, segundo à linha do ponto 01 ao ponto 09 da Figura 4.63, nas Tabelas $4.41 \mathrm{e}$ 4.42 .

TABELA 4.41: Comparação entre os momentos fletores $\mathrm{M}_{\mathrm{x}}$ na capa da laje abaixo da nervura delimitada pelos pontos 01 a $09(\mathrm{em} \mathrm{kN} . \mathrm{cm} / \mathrm{cm})$ da placa proposta por KANOK-

NUKULCHAI \& GILANI (1981)

\begin{tabular}{c|c|c|c|c|c|c|c}
\hline \hline \multirow{2}{*}{ Ponto } & \multicolumn{7}{|c}{ Modelo } \\
\cline { 2 - 8 } & $\mathbf{0 1}$ & $\mathbf{0 2}$ & $\mathbf{0 3}$ & $\mathbf{0 4}$ & $\mathbf{0 5}$ & $\mathbf{0 6}$ & $\mathbf{0 7}$ \\
\hline \hline 01 & $-4,95$ & $-0,36$ & 0,40 & 1,05 & 0,35 & - & - \\
\hline 02 & 10,25 & 0,65 & 1,50 & 1,31 & 1,28 & - & - \\
\hline 03 & 21,13 & 5,08 & 5,82 & 4,29 & 5,66 & - & - \\
\hline 04 & 29,04 & 8,48 & 9,85 & 8,91 & 9,35 & - & - \\
\hline 05 & 35,16 & 10,43 & 11,84 & 10,63 & 11,35 & - & - \\
\hline 06 & 39,22 & 11,43 & 9,85 & 11,98 & 12,79 & - & - \\
\hline 07 & 42,09 & 12,47 & 11,84 & 12,63 & 13,76 & - & - \\
\hline 08 & 43,57 & 12,71 & 13,29 & 13,29 & 14,35 & - & - \\
\hline 09 & 44,14 & 13,07 & 14,15 & 13,20 & 14,50 & - & - \\
\hline \hline
\end{tabular}


TABELA 4.42: Comparação entre os momentos fletores $\mathrm{M}_{\mathrm{y}}$ na capa da laje abaixo da nervura delimitada pelos pontos 01 a $09(\mathrm{em} \mathrm{kN} . \mathrm{cm} / \mathrm{cm})$ da placa proposta por KANOK-

NUKULCHAI \& GILANI (1981)

\begin{tabular}{c|c|c|c|c|c|c|c}
\hline \hline \multirow{2}{*}{ Ponto } & \multicolumn{7}{|c}{ Modelo } \\
\cline { 2 - 8 } & $\mathbf{0 1}$ & $\mathbf{0 2}$ & $\mathbf{0 3}$ & $\mathbf{0 4}$ & $\mathbf{0 5}$ & $\mathbf{0 6}$ & $\mathbf{0 7}$ \\
\hline \hline 01 & 0,78 & $-1,61$ & $-1,53$ & $-4,22$ & $-0,87$ & - & - \\
\hline 02 & 7,69 & 3,08 & 3,69 & 3,32 & 3,51 & - & - \\
\hline 03 & 17,24 & 6,29 & 7,12 & 7,17 & 6,74 & - & - \\
\hline 04 & 24,30 & 5,57 & 7,18 & 6,30 & 6,82 & - & - \\
\hline 05 & 31,74 & 9,29 & 10,60 & 9,37 & 10,34 & - & - \\
\hline 06 & 36,48 & 8,96 & 11,33 & 10,05 & 10,90 & - & - \\
\hline 07 & 40,98 & 12,01 & 13,74 & 12,22 & 13,43 & - & - \\
\hline 08 & 42,83 & 10,72 & 13,48 & 12,00 & 13,05 & - & - \\
\hline 09 & 44,14 & 12,92 & 14,80 & 13,19 & 14,50 & - & - \\
\hline \hline
\end{tabular}

Pode-se verificar que o Modelo 07, neste caso, não permite obter o momento que ocorre na capa da laje nervurada, visto que os momentos obtidos no modelo devem ser distribuídos somente às nervuras, por meio de área de influência de cada uma delas. O Modelo 06 também não consta, visto que o mesmo não permite obter valores de momentos na capa da laje.

Apresentam-se nas Figuras 4.66 e 4.67 os gráficos comparativos entre os valores de momentos fletores obtidos na capa da laje nervurada ao longo da linha delimitada pelos pontos 01 a 09 , de acordo com as Tabelas 4.41 e 4.42 .

Analisando-se as tabelas e os gráficos de momentos fletores na capa da laje nervurada ao longo da linha delimitada pelos pontos 01 a 09 verifica-se a discrepância entre os resultados do modelo concêntrico em relação aos modelos excêntricos. Os resultados de momentos fletores segundo os modelos excêntricos apresentam-se com o mesmo comportamento, e com valores próximos. 


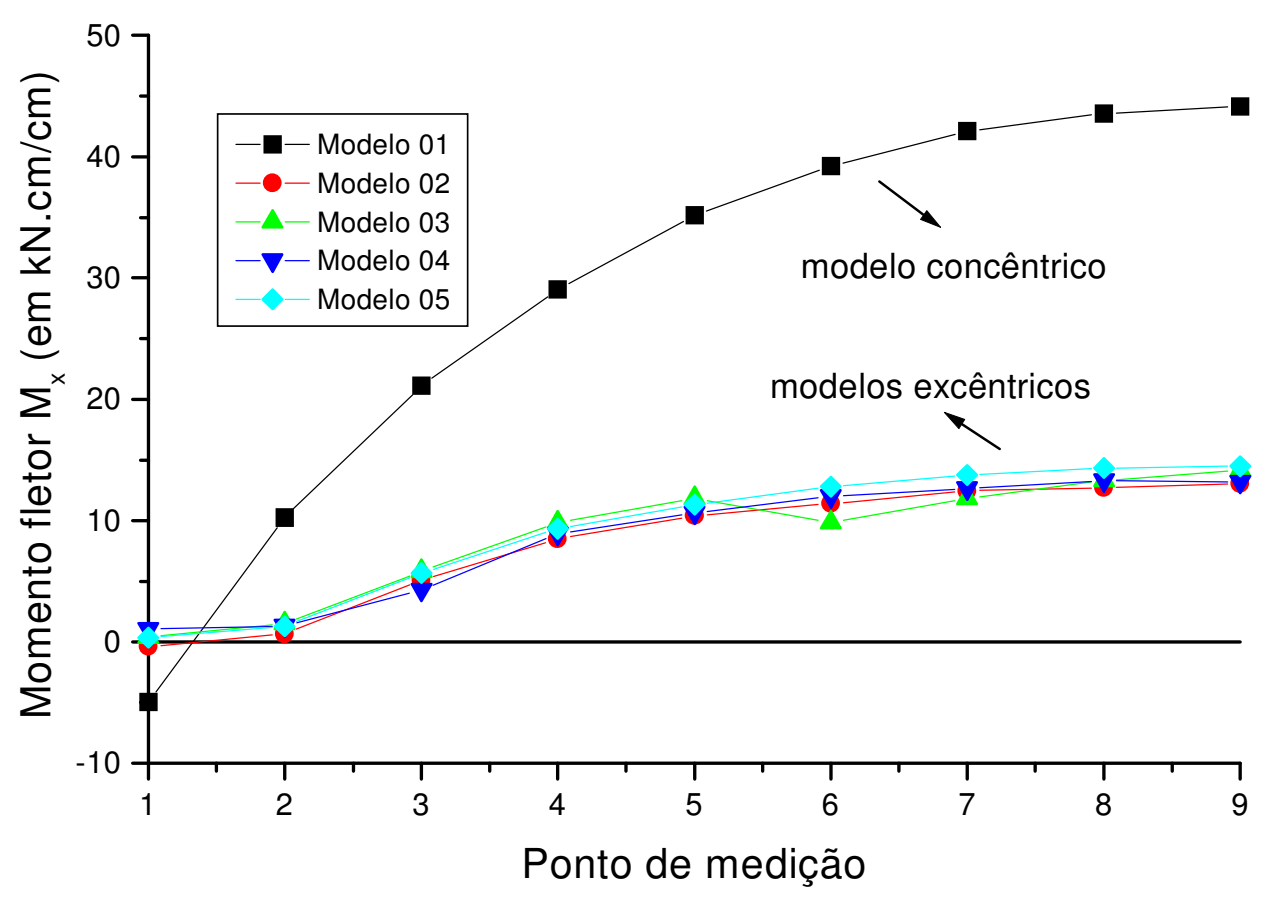

FIGURA 4.66: Comparação entre momentos fletores $M_{x}$ na capa abaixo da nervura delimitada pelos pontos 01 a $09(\mathrm{em} \mathrm{kN} . \mathrm{cm} / \mathrm{cm})$ da placa proposta por KANOK-

NUKULCHAI \& GILANI (1981)

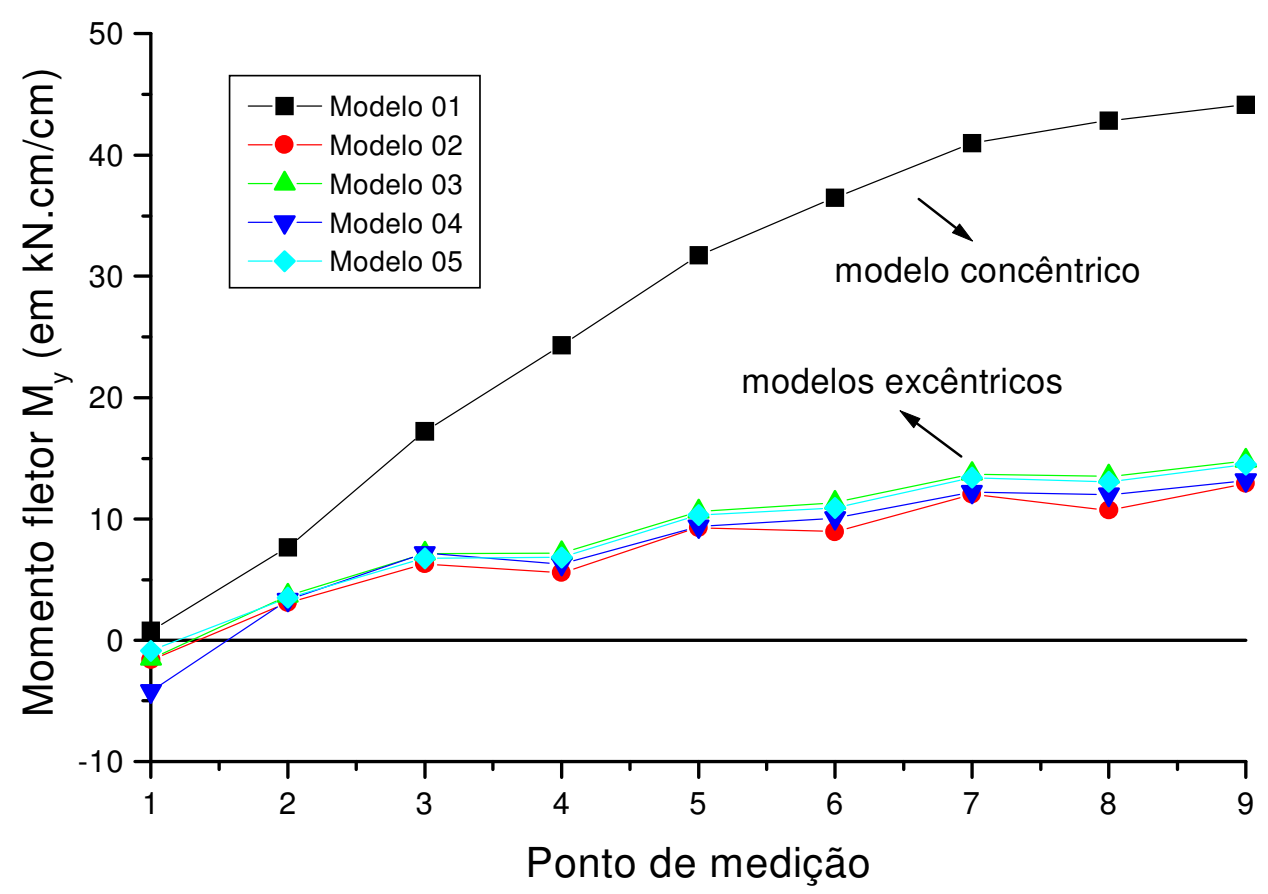

FIGURA 4.67: Comparação entre momentos fletores $M_{y}$ na capa abaixo da nervura delimitada pelos pontos 01 a $09(\mathrm{em} \mathrm{kN} . \mathrm{cm} / \mathrm{cm})$ da placa proposta por KANOK- 


\section{j) Lajes nervuradas em concreto armado ensaidas por ABDUL-WAHAB \& KHALIL (2000)}

ABDUL-WAHAB \& KHALIL (2000) ensaiaram 06 modelos de lajes nervuradas em concreto armado, em escala 1/4, variando-se o espaçamento e a altura das nervuras. Ensaiaram também 02 modelos de lajes maciças com espessura equivalente à duas lajes nervuradas anteriormente ensaiadas visando verificar a validade da Teoria da Placa Ortótropa e os efeitos da flexão e torção. Apresentam o comportamento estrutural obtido e, além de outros resultados, os deslocamentos na laje.

A geometria básica do problema pode ser verificado na Figura 4.68. As lajes eram simplesmente apoiadas ao longo dos lados, permitindo-se rotações livres perpendiculares ao plano da placa.

A Tabela 4.43 apresenta as características geométricas particulares de cada modelo ensaiado por ABDUL-WAHAB \& KHALIL (2000).

TABELA 4.43: Características geométricas das lajes ensaiadas por ABDUL-WAHAB \& KHALIL (2000)

\begin{tabular}{c|c|c|c|c|c|c|c}
\hline \hline Laje & Vazios & $\mathbf{a}_{\mathbf{1}}(\mathbf{c m})$ & $\mathbf{h}_{\mathbf{f}}(\mathbf{c m})$ & $\mathbf{b}_{\mathbf{w}}(\mathbf{c m})$ & $\mathbf{h} \mathbf{( c m )}$ & $\mathbf{h} / \mathbf{h}_{\mathbf{f}}$ & $\mathbf{a}_{\mathbf{1}} / \mathbf{l}$ \\
\hline \hline S1 & 11 X 11 & 13,6 & 2,0 & 5,2 & 9,5 & 4,75 & 0,0907 \\
\hline S2 & $9 \times 9$ & 16,7 & 2,0 & 5,2 & 9,5 & 4,75 & 0,1113 \\
\hline S3 & 7 X 7 & 21,4 & 2,0 & 5,2 & 9,5 & 4,75 & 0,1427 \\
\hline S4 & $5 \times$ 5 & 30,0 & 2,0 & 5,2 & 9,5 & 4,75 & 0,2000 \\
\hline S5 & 9 X 9 & 16,7 & 2,0 & 5,2 & 12,5 & 6,25 & 0,1113 \\
\hline S6 & 9 X 9 & 16,7 & 2,0 & 4,7 & 6,5 & 3,25 & 0,1113 \\
\hline S7 & Maciça & - & - & - & 7,5 & 1,00 & - \\
\hline S8 & Maciça & - & - & - & 9,5 & 1,00 & - \\
\hline \hline
\end{tabular}

A laje maciça $\mathrm{S} 7$, com espessura de 7,5 cm, é a laje maciça com espessura equivalente em inércia à laje S2, determinada pelos autores ABDUL-WAHAB \& KHALIL (2000).

A laje maciça S8 é uma laje com as mesmas características da laje S2, ou seja, com a mesma espessura total e a mesma quantidade de armadura 

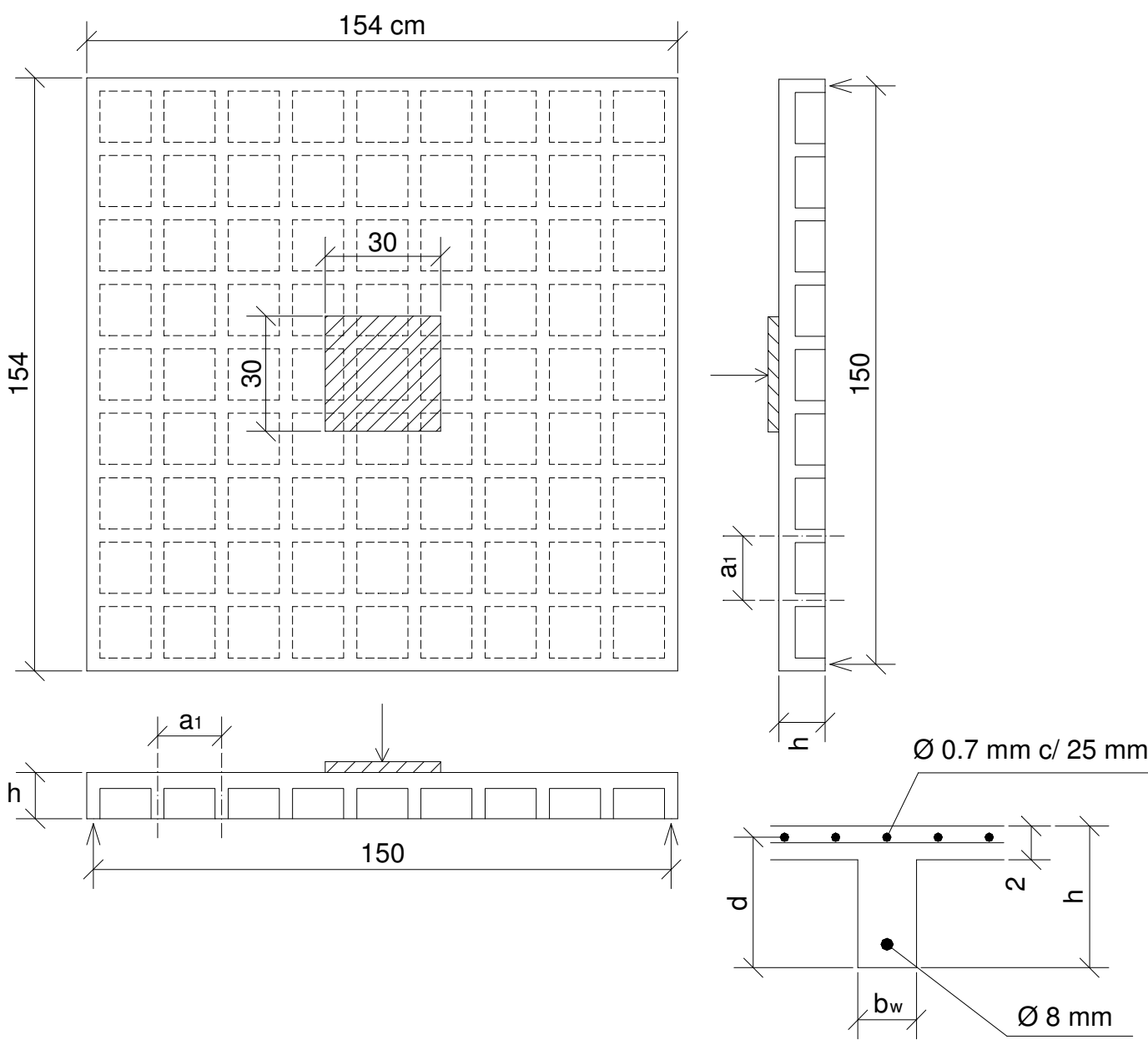

FIGURA 4.68: Geometria básica das lajes nervuradas ensaiadas, em $\mathrm{cm}$

[ABDUL-WAHAB \& KHALIL (2000)]

Neste trabalho foram efetuadas análises utilizando o ANSYS 5.5, segundo os Modelos 01 a 08.

Consideraram-se os seguintes dados de entrada para a resolução numérica:

- carga concentrada aplicada no centro da laje, sobre uma placa de 30 x 30 $\mathrm{cm}$, em incrementos de $5 \mathrm{kN}$, até a carga última de cada laje, que podem ser verificadas na Tabela 4.43;

- módulo de elasticidade: calculado para cada laje em particular, de acordo com a resistência característica à compressão apresentada pelos corpos cilíndricos referentes a cada laje, de acordo com o projeto de revisão da NBR 6118/2000, apresentados na Tabela 4.43;

- coeficiente de Poisson: $v=0,20$ (adotado de acordo com o projeto de revisão da NBR-6118/2000). 
Apresenta-se a Tabela 4.44, que além da resistência à compressão, mostra as cargas de fissuração e últimas encontradas no ensaio efetuado por ABDUL-WAHAB \& KHALIL (2000).

TABELA 4.44: Características das lajes ensaiadas por ABDUL-WAHAB \& KHALIL

(2000)

\begin{tabular}{c|c|c|c|c|c}
\hline \hline Laje & $\mathbf{f}_{\mathbf{c k}}(\mathbf{M P a})$ & $\mathbf{E}_{\mathbf{c s}}\left(\mathbf{k N} / \mathbf{c m}^{\mathbf{2}}\right)$ & $\mathbf{G}_{\mathbf{c}}\left(\mathbf{k N} / \mathbf{c m}^{\mathbf{2}}\right)^{*}$ & $\mathbf{P}_{\text {fissuracão }}(\mathbf{k N})$ & $\mathbf{P}_{\text {última }}(\mathbf{k N})$ \\
\hline \hline S1 & 31,3 & 2663,05 & 399,46 & 30 & 105 \\
\hline S2 & 32,0 & 2692,66 & 403,90 & 20 & 81 \\
\hline S3 & 31,4 & 2667,30 & 400,10 & 20 & 65 \\
\hline S4 & 28,9 & 2558,92 & 383,84 & 20 & 48 \\
\hline S5 & 29,9 & 2602,81 & 390,42 & 40 & 120 \\
\hline S6 & 29,1 & 2567,75 & 385,16 & 20 & 48 \\
\hline S7 & 36,0 & 2856,00 & 428,40 & 30 & 65 \\
\hline S8 & 28,5 & 2541,15 & 381,17 & 50 & 100 \\
\hline \hline
\end{tabular}

Módulo de elasticidade transversal reduzido a $15 \%$ do valor calculado da Teoria da

Elasticidade; apenas o Modelo 08 é processado com o valor integral do módulo.

A seguir são apresentadas as Tabelas 4.45 a 4.50 de resultados de deslocamentos máximos nas lajes, segundo cada modelo numérico, assim como os Gráficos 4.69 a 4.74 correspondentes. Junto a cada laje relata-se aspectos verificados nas análises.

Analisando-se a Tabela 4.45 e Figura 4.69 verifica-se que:

- os modelos que apresentam melhores resultados de deslocamentos na fase elástica da laje em concreto armado são os Modelos 04 e 07, que apresentam resultados muito próximos entre eles para essa laje;

- o Modelo 08, modelo de laje maciça equivalente com redução de espessura para a consideração do material concreto armado, apresentou resultados distantes do modelo 04, o que não ocorreu com o Modelo 07, modelo de laje maciça equivalente com redução do módulo de elasticidade transversal do concreto;

- a maior diferença percentual entre os modelos excêntricos e concêntrico foi de $326,81 \%$, e entre os modelos excêntricos foi de $52,76 \%$. 
TABELA 4.45: Deslocamentos máximos ortogonais ao plano da Laje S1, em mm, proposta por ABDUL-WAHAB \& KHALIL (2000)

\begin{tabular}{c|c|c|c|c|c|c|c|c|c}
\hline \hline \multicolumn{10}{c}{ LAJE S1 } \\
\hline $\begin{array}{c}\text { Carga } \\
(\mathbf{k N})\end{array}$ & \multirow{2}{*}{ Ensaio } & \multicolumn{10}{c}{ Modelos numéricos de análise } \\
\cline { 3 - 10 } & & $\mathbf{0 1}$ & $\mathbf{0 2}$ & $\mathbf{0 3}$ & $\mathbf{0 4}$ & $\mathbf{0 5}$ & $\mathbf{0 6}$ & $\mathbf{0 7}$ & $\mathbf{0 8}$ \\
\hline \hline 0 & 0 & 0 & 0 & 0 & 0 & 0 & 0 & 0 & 0 \\
\hline 10 & 0,10 & 1,25 & 0,34 & 0,37 & 0,30 & 0,45 & 0,43 & 0,29 & 0,44 \\
\hline 20 & 0,30 & 2,51 & 0,69 & 0,73 & 0,59 & 0,90 & 0,87 & 0,59 & 0,87 \\
\hline 30 & 0,60 & 3,76 & 1,03 & 1,10 & 0,89 & 1,35 & 1,30 & 0,88 & 1,31 \\
\hline 40 & 1,40 & 5,01 & 1,37 & 1,46 & 1,18 & 1,79 & 1,74 & 1,18 & 1,75 \\
\hline 50 & 2,20 & 6,27 & 1,71 & 1,83 & 1,48 & 2,24 & 2,17 & 1,47 & 2,19 \\
\hline 60 & 3,00 & 7,52 & 2,06 & 2,19 & 1,77 & 2,69 & 2,61 & 1,77 & 2,62 \\
\hline 70 & 4,20 & 8,77 & 2,40 & 2,56 & 2,07 & 3,14 & 3,04 & 2,06 & 3,06 \\
\hline 80 & 5,50 & 10,03 & 2,74 & 2,92 & 2,36 & 3,59 & 3,48 & 2,35 & 3,50 \\
\hline \hline
\end{tabular}

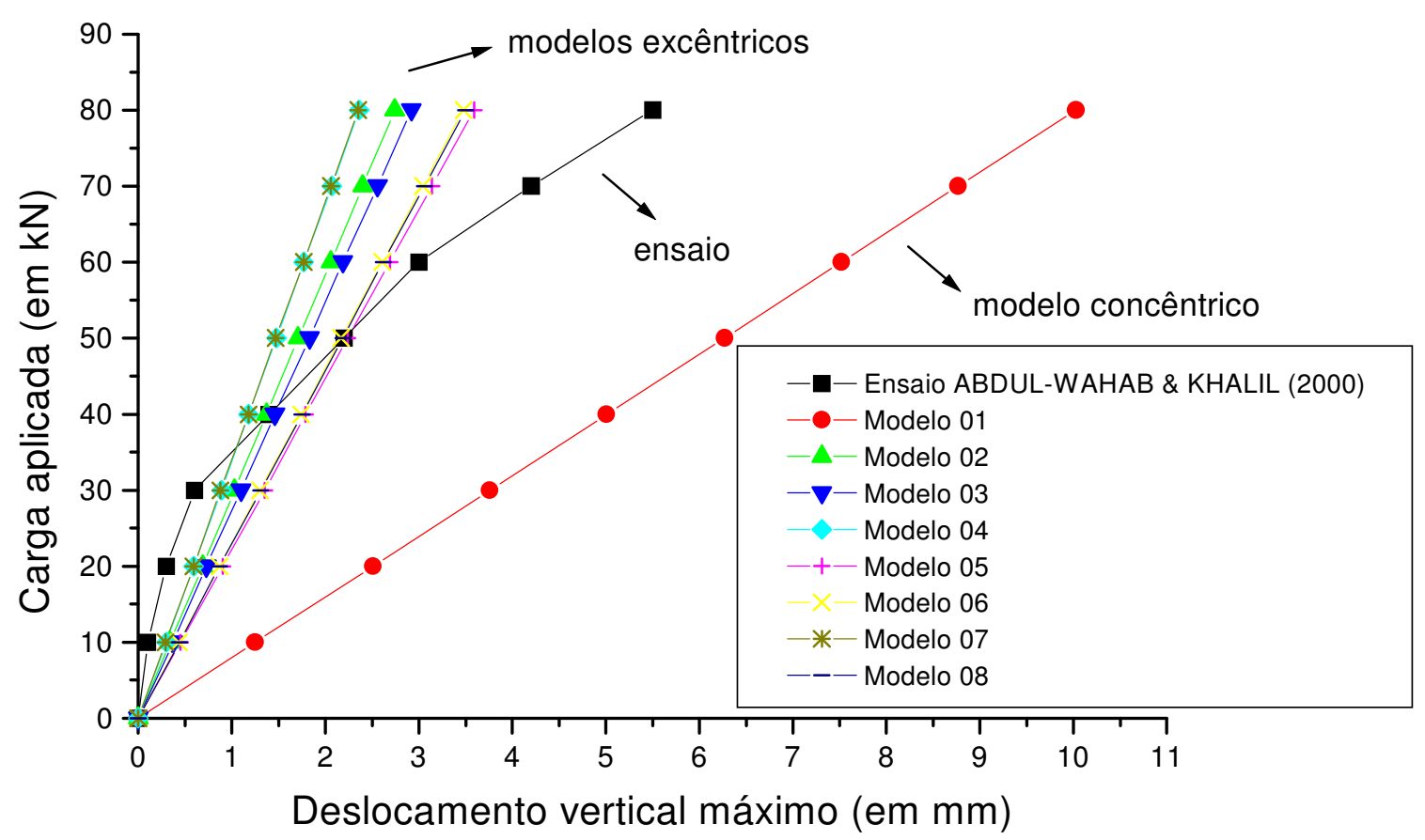

FIGURA 4.69: Deslocamentos transversais máximos (em $\mathrm{mm}$ ) obtidos numericamente na Laje S1 de ABDUL-WAHAB \& KHALIL (2000)

Analisando-se a Tabela 4.46 e Figura 4.70 verifica-se que:

- a maior diferença entre modelos excêntricos e concêntrico foi de 344,53\%;

- os Modelos 04 e 07 apresentaram os melhores resultados de deslocamentos na fase elástica do concreto, e maior diferença entre modelos excêntricos foi de 47,08\%. 
TABELA 4.46: Deslocamentos máximos ortogonais ao plano da Laje S2, em mm, proposta por ABDUL-WAHAB \& KHALIL (2000)

\begin{tabular}{c|c|c|c|c|c|c|c|c|c}
\hline \hline \multicolumn{10}{c}{ MAJE S2 } \\
\hline $\begin{array}{c}\text { Carga } \\
(\mathbf{k N})\end{array}$ & \multirow{2}{*}{ Ensaio } & \multicolumn{10}{c}{ Modelos numéricos de análise } \\
\cline { 3 - 10 } & & $\mathbf{0 1}$ & $\mathbf{0 2}$ & $\mathbf{0 3}$ & $\mathbf{0 4}$ & $\mathbf{0 5}$ & $\mathbf{0 6}$ & $\mathbf{0 7}$ & $\mathbf{0 8}$ \\
\hline \hline 0 & 0 & 0 & 0 & 0 & 0 & 0 & 0 & 0 & 0 \\
\hline 10 & 0,30 & 1,52 & 0,42 & 0,44 & 0,36 & 0,52 & 0,48 & 0,34 & 0,50 \\
\hline 20 & 0,60 & 3,04 & 0,83 & 0,88 & 0,71 & 1,04 & 0,97 & 0,69 & 1,00 \\
\hline 30 & 1,40 & 4,57 & 1,25 & 1,32 & 1,07 & 1,56 & 1,45 & 1,03 & 1,51 \\
\hline 40 & 2,40 & 6,09 & 1,67 & 1,76 & 1,43 & 2,08 & 1,94 & 1,37 & 2,02 \\
\hline 50 & 3,30 & 7,61 & 2,08 & 2,20 & 1,78 & 2,60 & 2,42 & 1,71 & 2,52 \\
\hline 60 & 4,50 & 9,13 & 2,50 & 2,64 & 2,14 & 3,12 & 2,90 & 2,06 & 3,03 \\
\hline 70 & 7,00 & 10,66 & 2,91 & 3,08 & 2,50 & 3,64 & 3,39 & 2,40 & 3,53 \\
\hline 80 & 8,20 & 12,18 & 3,33 & 3,52 & 2,85 & 4,16 & 3,87 & 2,74 & 4,03 \\
\hline \hline
\end{tabular}

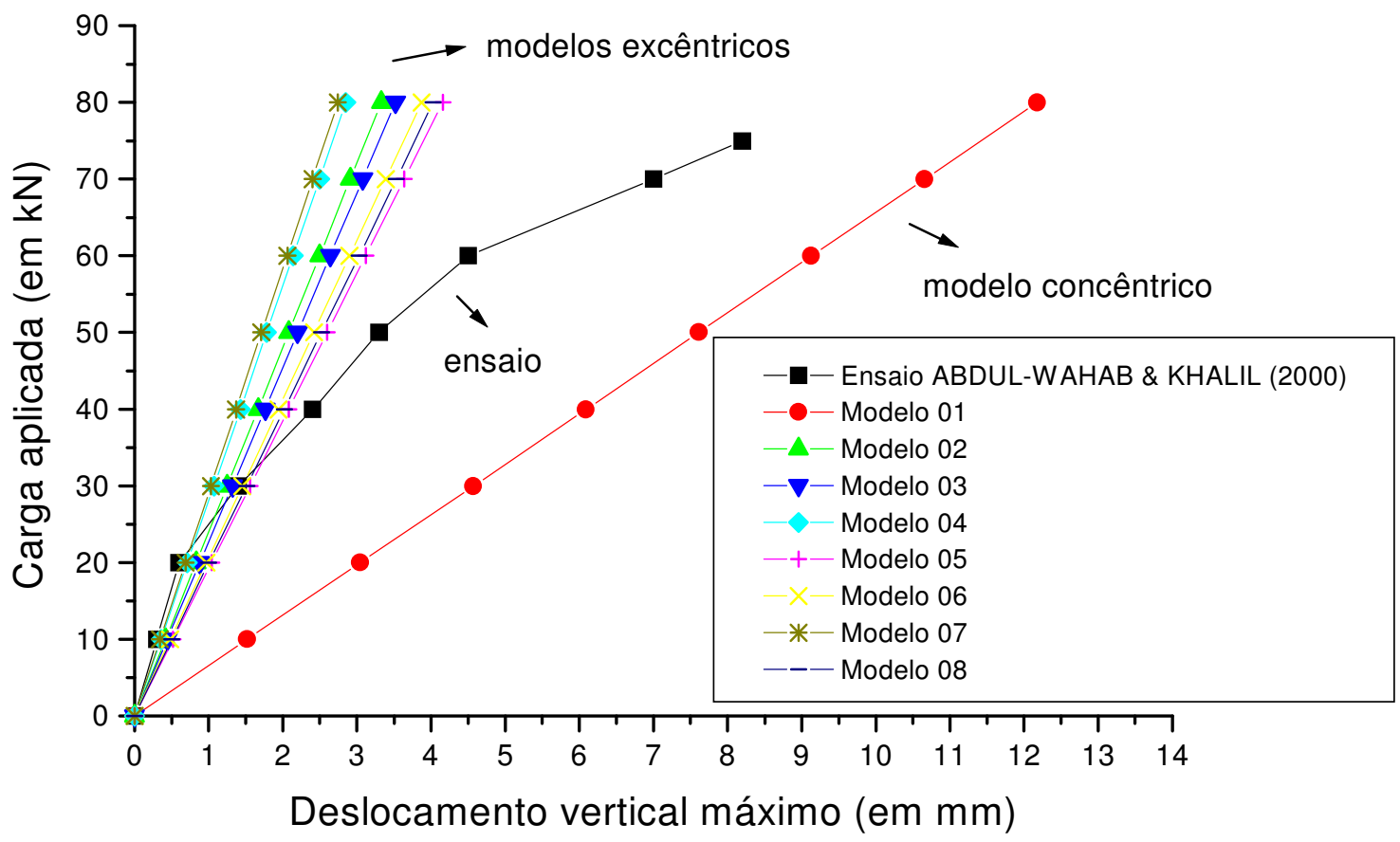

FIGURA 4.70: Deslocamentos transversais máximos (em $\mathrm{mm}$ ) obtidos numericamente na Laje S2 de ABDUL-WAHAB \& KHALIL (2000) 
TABELA 4.47: Deslocamentos máximos ortogonais ao plano da Laje S3, em mm, proposta por ABDUL-WAHAB \& KHALIL (2000)

\begin{tabular}{c|c|c|c|c|c|c|c|c|c}
\hline \hline \multicolumn{10}{c}{ LAJE S3 } \\
\hline $\begin{array}{c}\text { Carga } \\
(\mathbf{k N})\end{array}$ & \multirow{2}{*}{ Ensaio } & \multicolumn{10}{c}{ Modelos numéricos de análise } \\
\cline { 3 - 11 } & & $\mathbf{0 1}$ & $\mathbf{0 2}$ & $\mathbf{0 3}$ & $\mathbf{0 4}$ & $\mathbf{0 5}$ & $\mathbf{0 6}$ & $\mathbf{0 7}$ & $\mathbf{0 8}$ \\
\hline \hline 0 & 0 & 0 & 0 & 0 & 0 & 0 & 0 & 0 & 0 \\
\hline 10 & 0,30 & 1,89 & 0,51 & 0,54 & 0,43 & 0,61 & 0,55 & 0,38 & 0,56 \\
\hline 20 & 1,00 & 3,78 & 1,02 & 1,07 & 0,86 & 1,22 & 1,10 & 0,76 & 1,12 \\
\hline 30 & 2,40 & 5,67 & 1,54 & 1,61 & 1,30 & 1,83 & 1,65 & 1,15 & 1,69 \\
\hline 40 & 3,80 & 7,56 & 2,05 & 2,14 & 1,73 & 2,44 & 2,19 & 1,53 & 2,25 \\
\hline 50 & 5,40 & 9,45 & 2,56 & 2,68 & 2,16 & 3,05 & 2,74 & 1,91 & 2,81 \\
\hline 60 & 10,50 & 11,33 & 3,07 & 3,21 & 2,59 & 3,66 & 3,29 & 2,29 & 3,37 \\
\hline \hline
\end{tabular}

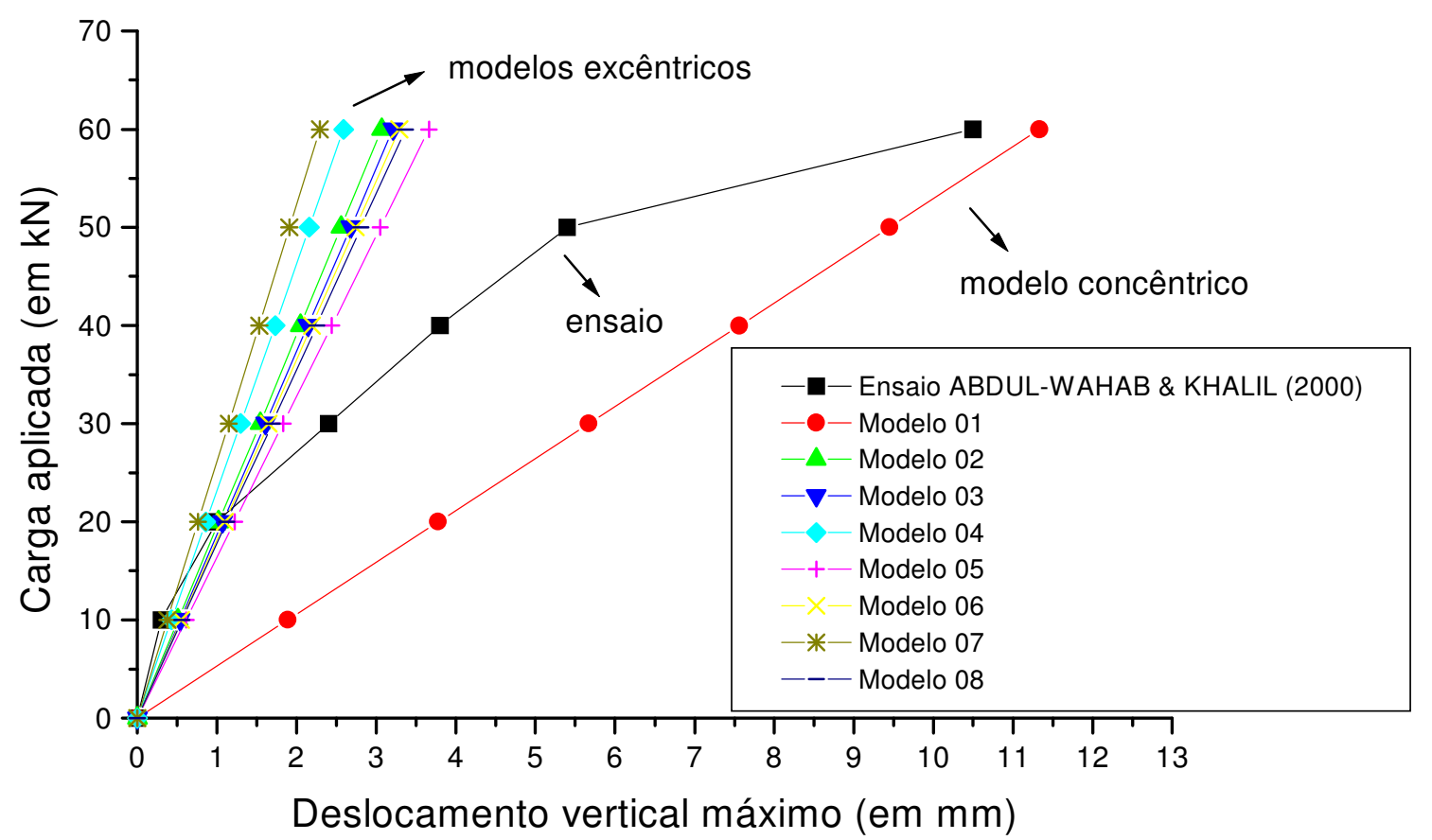

FIGURA 4.71: Deslocamentos transversais máximos (em $\mathrm{mm}$ ) obtidos numericamente na Laje S3 de ABDUL-WAHAB \& KHALIL (2000)

Analisando-se a Tabela 4.47 e Figura 4.71 verifica-se que:

- a maior diferença entre os modelos excêntricos e concêntrico foi de $394,76 \%$;

- os Modelos 04 e 07 apresentaram os melhores resultados de deslocamentos na fase elástica do concreto, e maior diferença entre modelos excêntricos foi de 59,83\%. 
TABELA 4.48: Deslocamentos máximos ortogonais ao plano da Laje S4, em mm, proposta por ABDUL-WAHAB \& KHALIL (2000)

\begin{tabular}{c|c|c|c|c|c|c|c|c|c}
\hline \hline \multicolumn{10}{c}{ LAJE S4 } \\
\hline $\begin{array}{c}\text { Carga } \\
(\mathbf{k N})\end{array}$ & \multirow{2}{*}{ Ensaio } & \multicolumn{10}{c}{ Modelos numéricos de análise } \\
\cline { 3 - 10 } & $\mathbf{0 1}$ & $\mathbf{0 2}$ & $\mathbf{0 3}$ & $\mathbf{0 4}$ & $\mathbf{0 5}$ & $\mathbf{0 6}$ & $\mathbf{0 7}$ & $\mathbf{0 8}$ \\
\hline \hline 0 & 0 & 0 & 0 & 0 & 0 & 0 & 0 & 0 & 0 \\
\hline 10 & 0,50 & 2,62 & 0,72 & 0,75 & 0,59 & 0,82 & 0,67 & 0,49 & 0,73 \\
\hline 20 & 1,70 & 5,24 & 1,45 & 1,50 & 1,18 & 1,63 & 1,33 & 0,99 & 1,45 \\
\hline 30 & 3,30 & 7,86 & 2,17 & 2,25 & 1,78 & 2,45 & 2,00 & 1,48 & 2,18 \\
\hline 40 & 6,20 & 10,48 & 2,89 & 3,00 & 2,37 & 3,26 & 2,67 & 1,98 & 2,90 \\
\hline 50 & 10,00 & 13,11 & 3,61 & 3,74 & 2,96 & 4,08 & 3,34 & 2,47 & 3,63 \\
\hline \hline
\end{tabular}

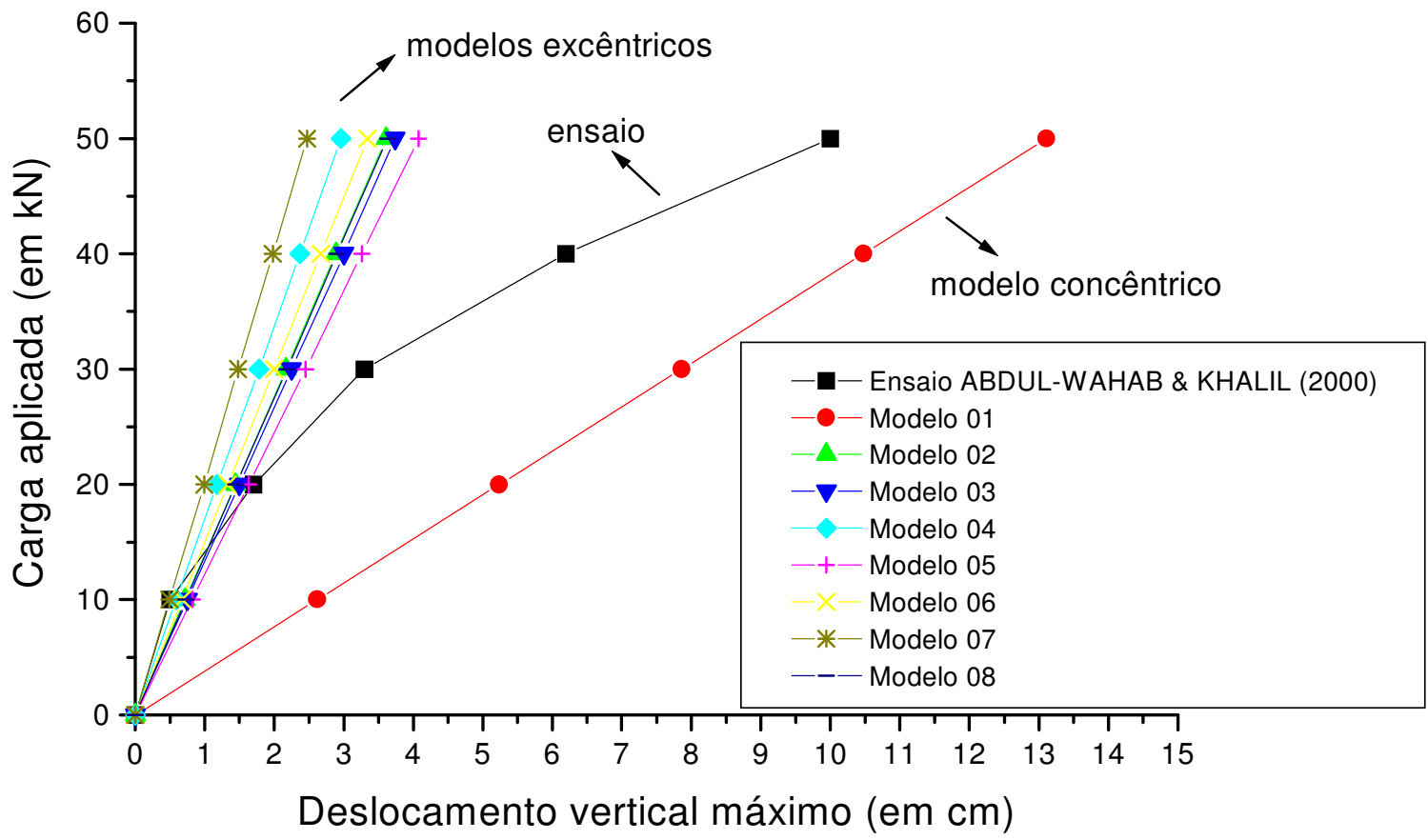

FIGURA 4.72: Deslocamentos transversais máximos (em mm) obtidos numericamente na Laje S4 de ABDUL-WAHAB \& KHALIL (2000)

Analisando-se a Tabela 4.48 e Figura 4.72 verifica-se que:

- a maior diferença entre os modelos excêntricos e concêntrico foi de 430,77\%;

- os Modelos 04 e 07 apresentaram os melhores resultados de deslocamentos na fase elástica do concreto, e maior diferença entre modelos excêntricos foi de 51,42\%. 
TABELA 4.49: Deslocamentos máximos ortogonais ao plano da Laje S5, em mm, proposta por ABDUL-WAHAB \& KHALIL (2000)

\begin{tabular}{c|c|c|c|c|c|c|c|c|c}
\hline \hline \multicolumn{10}{c}{ LAJE S5 } \\
\hline $\begin{array}{c}\text { Carga } \\
(\mathbf{k N})\end{array}$ & \multirow{2}{*}{ Ensaio } & \multicolumn{10}{c}{ Modelos numéricos de análise } \\
\cline { 3 - 10 } & & $\mathbf{0 1}$ & $\mathbf{0 2}$ & $\mathbf{0 3}$ & $\mathbf{0 4}$ & $\mathbf{0 5}$ & $\mathbf{0 6}$ & $\mathbf{0 7}$ & $\mathbf{0 8}$ \\
\hline \hline 0 & 0 & 0 & 0 & 0 & 0 & 0 & 0 & 0 & 0 \\
\hline 10 & 0,20 & 0,63 & 0,20 & 0,21 & 0,20 & 0,27 & 0,23 & 0,16 & 0,23 \\
\hline 20 & 0,30 & 1,26 & 0,40 & 0,42 & 0,40 & 0,53 & 0,46 & 0,32 & 0,47 \\
\hline 30 & 0,55 & 1,90 & 0,60 & 0,63 & 0,60 & 0,80 & 0,68 & 0,48 & 0,70 \\
\hline 40 & 0,70 & 2,53 & 0,80 & 0,85 & 0,80 & 1,06 & 0,91 & 0,64 & 0,93 \\
\hline 50 & 1,20 & 3,16 & 1,00 & 1,06 & 1,00 & 1,33 & 1,14 & 0,79 & 1,16 \\
\hline 60 & 1,70 & 3,79 & 1,20 & 1,27 & 1,20 & 1,59 & 1,37 & 0,95 & 1,40 \\
\hline 70 & 2,20 & 4,42 & 1,40 & 1,48 & 1,40 & 1,86 & 1,60 & 1,11 & 1,63 \\
\hline 80 & 2,80 & 5,06 & 1,60 & 1,69 & 1,60 & 2,13 & 1,83 & 1,27 & 1,86 \\
\hline 90 & 3,90 & 5,69 & 1,80 & 1,90 & 1,80 & 2,39 & 2,05 & 1,43 & 2,10 \\
\hline 100 & 5,30 & 6,32 & 2,00 & 2,11 & 2,00 & 2,66 & 2,28 & 1,59 & 2,33 \\
\hline 110 & 8,00 & 6,95 & 2,20 & 2,33 & 2,20 & 2,92 & 2,51 & 1,75 & 2,56 \\
\hline \hline
\end{tabular}

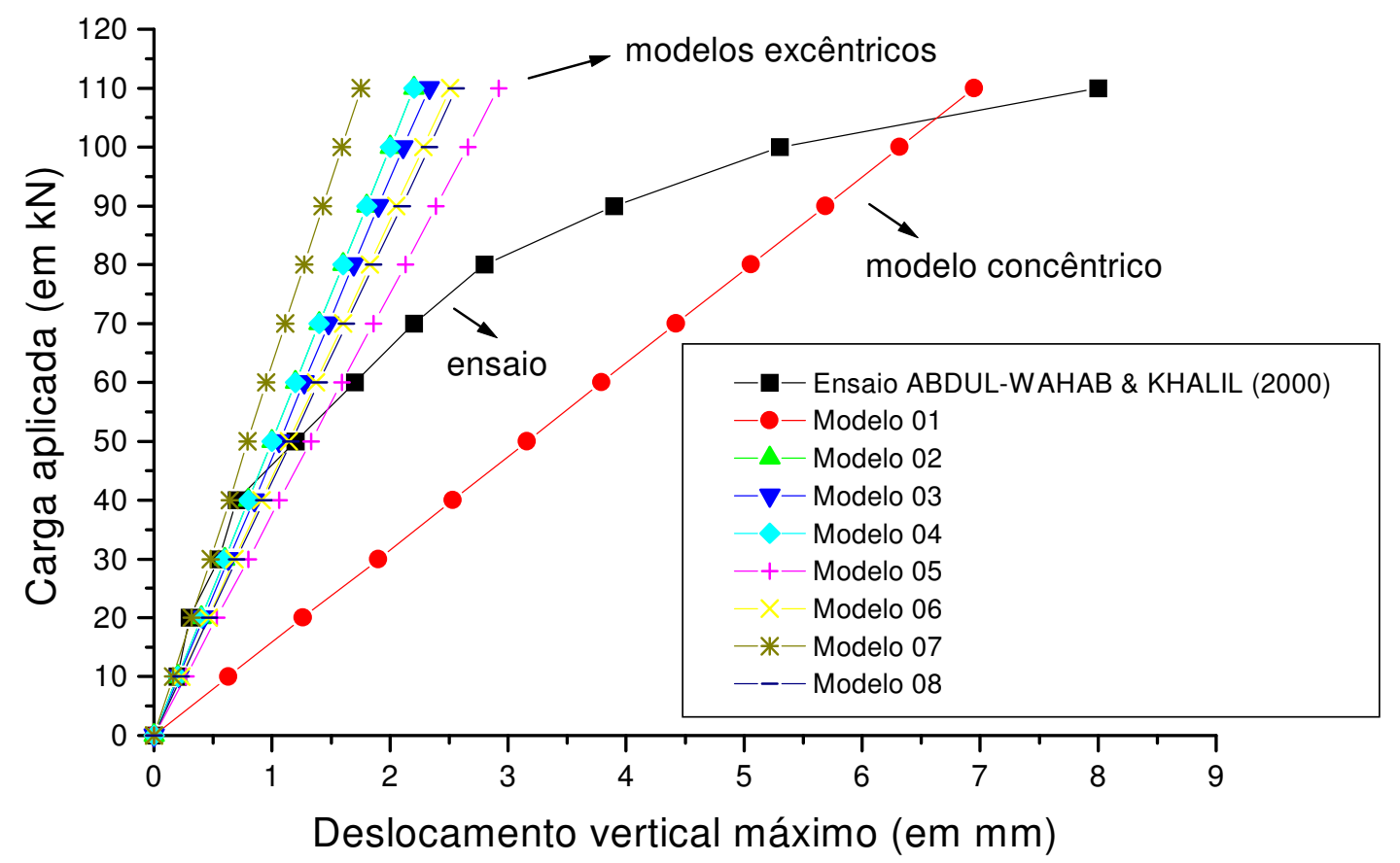

FIGURA 4.73: Deslocamentos transversais máximos (em $\mathrm{mm}$ ) obtidos numericamente na Laje S5 de ABDUL-WAHAB \& KHALIL (2000)

Analisando-se a Tabela 4.49 e Figura 4.73 verifica-se que:

- todos os modelos excêntricos apresentaram resultados muito próximos de deslocamentos na fase elástica quando comparados aos resultados apresentados no ensaio;

- a maior diferença entre os resultados excêntricos e concêntricos foi de $297,14 \%$; 
- a maior diferença entre os modelos excêntricos foi de $66,86 \%$.

TABELA 4.50: Deslocamentos máximos ortogonais ao plano da Laje S6, em mm, proposta por ABDUL-WAHAB \& KHALIL (2000)

\begin{tabular}{|c|c|c|c|c|c|c|c|c|c|}
\hline \multicolumn{10}{|c|}{ LAJE S6 } \\
\hline \multirow{2}{*}{$\begin{array}{c}\text { Carga } \\
(\mathbf{k N}) \\
\end{array}$} & \multirow{2}{*}{ Ensaio } & \multicolumn{8}{|c|}{ Modelos numéricos de análise } \\
\hline & & 01 & 02 & $\mathbf{0 3}$ & 04 & $\mathbf{0 5}$ & 06 & 07 & 08 \\
\hline 0 & 0 & 0 & 0 & 0 & 0 & 0 & 0 & 0 & 0 \\
\hline 10 & 0,80 & 5,93 & 1,41 & 1,48 & 1,05 & 1,60 & 1,64 & 1,14 & 1,66 \\
\hline 20 & 2,65 & 11,86 & 2,82 & 2,95 & 2,10 & 3,21 & 3,29 & 2,28 & 3,32 \\
\hline 30 & 5,55 & 17,80 & 4,23 & 4,43 & 3,15 & 4,79 & 4,93 & 3,43 & 4,97 \\
\hline 40 & 9,55 & 23,76 & 5,64 & 5,90 & 4,20 & 6,39 & 6,58 & 4,57 & 6,63 \\
\hline
\end{tabular}

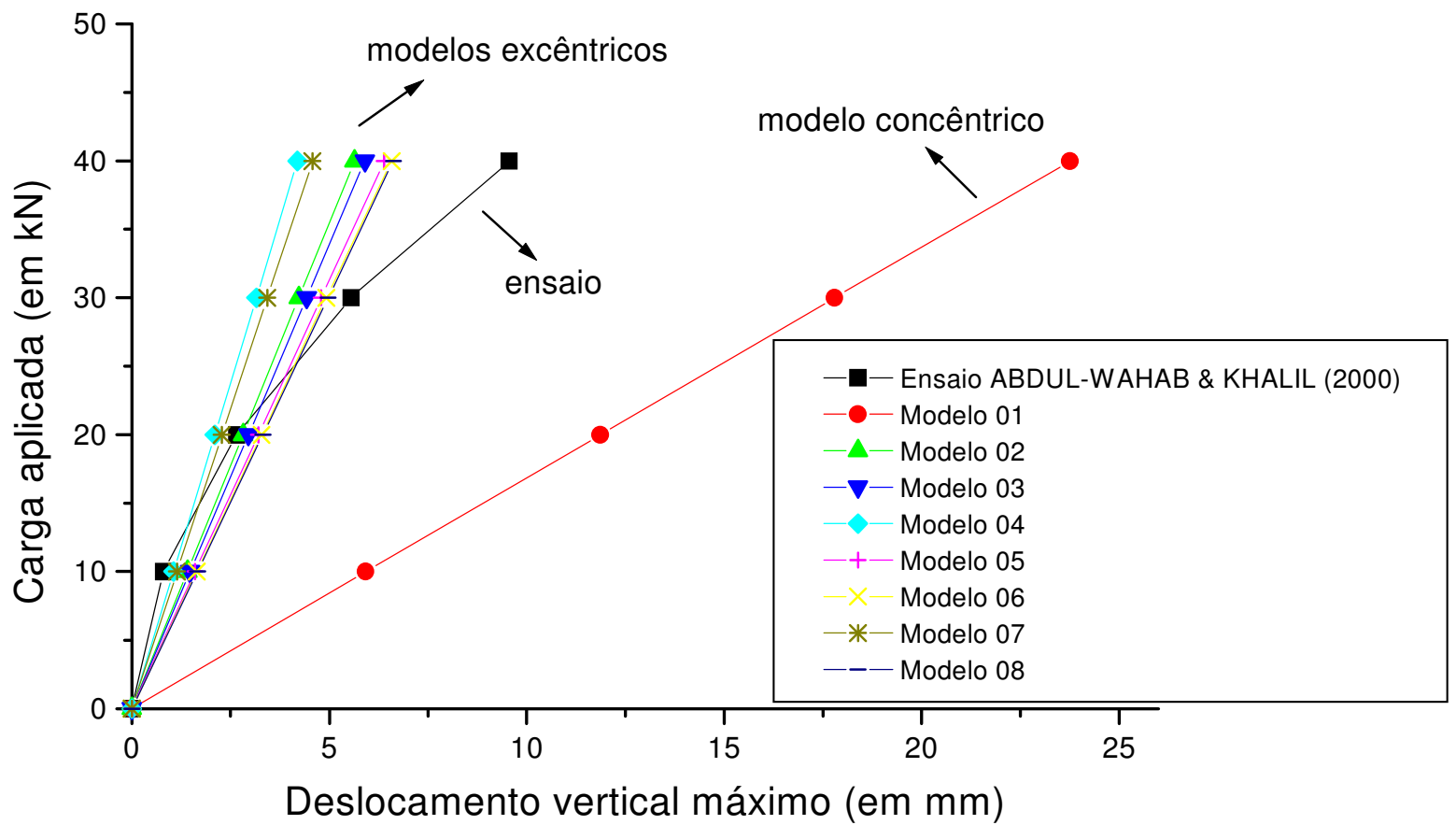

FIGURA 4.74: Deslocamentos transversais máximos (em $\mathrm{mm}$ ) obtidos numericamente na Laje S6 de ABDUL-WAHAB \& KHALIL (2000)

Analisando-se a Tabela 4.50 e a Figura 4.74, verifica-se que:

- os Modelos excêntricos 04 e 07 são os que mais se aproximam dos resultados de deslocamentos máximos na fase elástica da laje S6 ensaiada;

- o modelo concêntrico afasta-se totalmente do resultado experimental, apresentando uma diferença percentual de 465,71 \% comparado ao Modelo excêntrico 04.

De uma maneira geral, para todas as lajes ensaiadas, vê-se que melhores resultados seriam obtidos nas análises numéricas, na fase elástica do concreto, se fosse 
levado em conta um enrijecimento da capa (aumento do módulo de elasticidade da membrana) devido a presença de armaduras no modelo ensaiado. Assim, os deslocamentos numéricos na fase elástica tornariam-se menores, e aproximariam-se ainda mais dos resultados dos ensaios. Isso não foi aqui aplicado devido ao caráter de se verificar as respostas de modelos usualmente aplicados nos escritórios de cálculo, ou seja, em análises puramente elásticas e sem incrementos de rigidezes devido a presença de armaduras nas seções.

Apresentam-se a seguir as Figuras 4.75 a 4.78, comparativos entre os resultados obtidos pelas análises através dos Modelos 04 (modelo de casca para placa e nervuras) e Modelo 07 (modelo onde a laje nervurada é substituída por placa maciça equivalente), para as lajes com a mesma altura de nervura, com variação do espaçamento entre as nervuras.

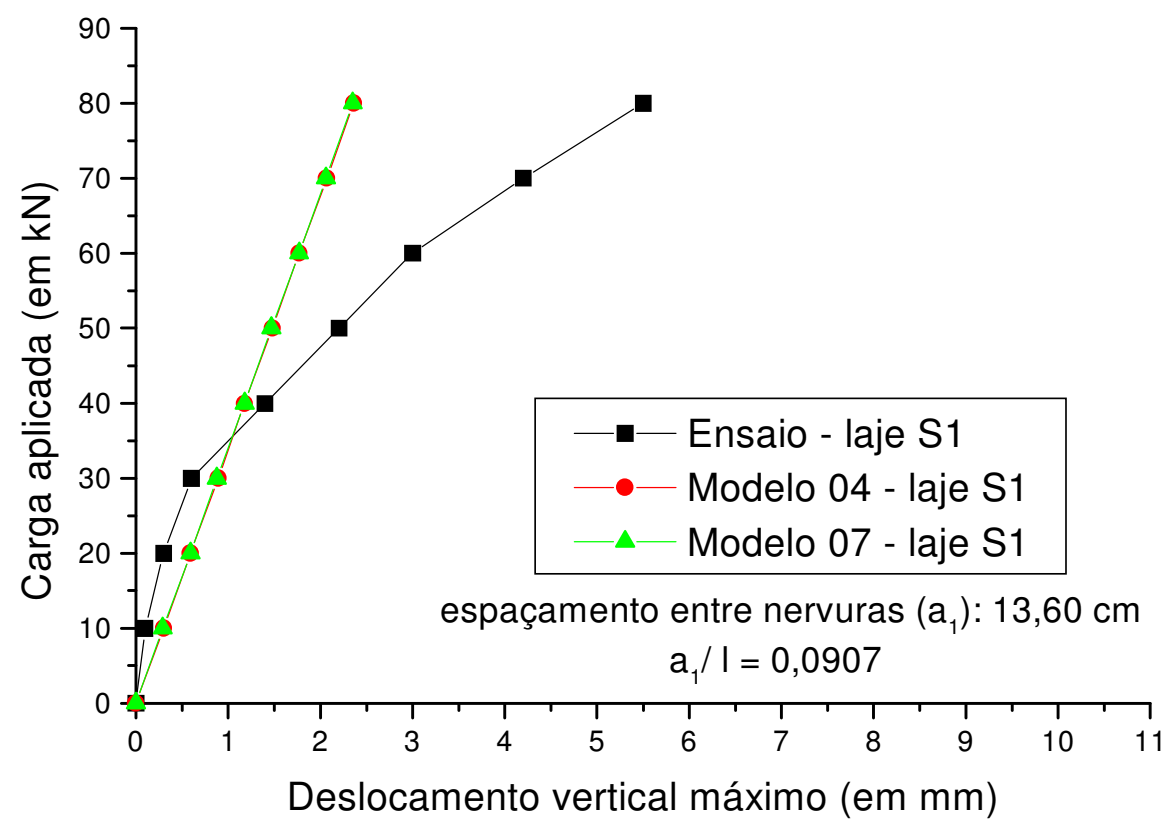

FIGURA 4.75: Deslocamentos transversais máximos (em mm) nos Modelos 04 e 07 na laje S1 proposta por ABDUL-WAHAB \& KHALIL (2000) 


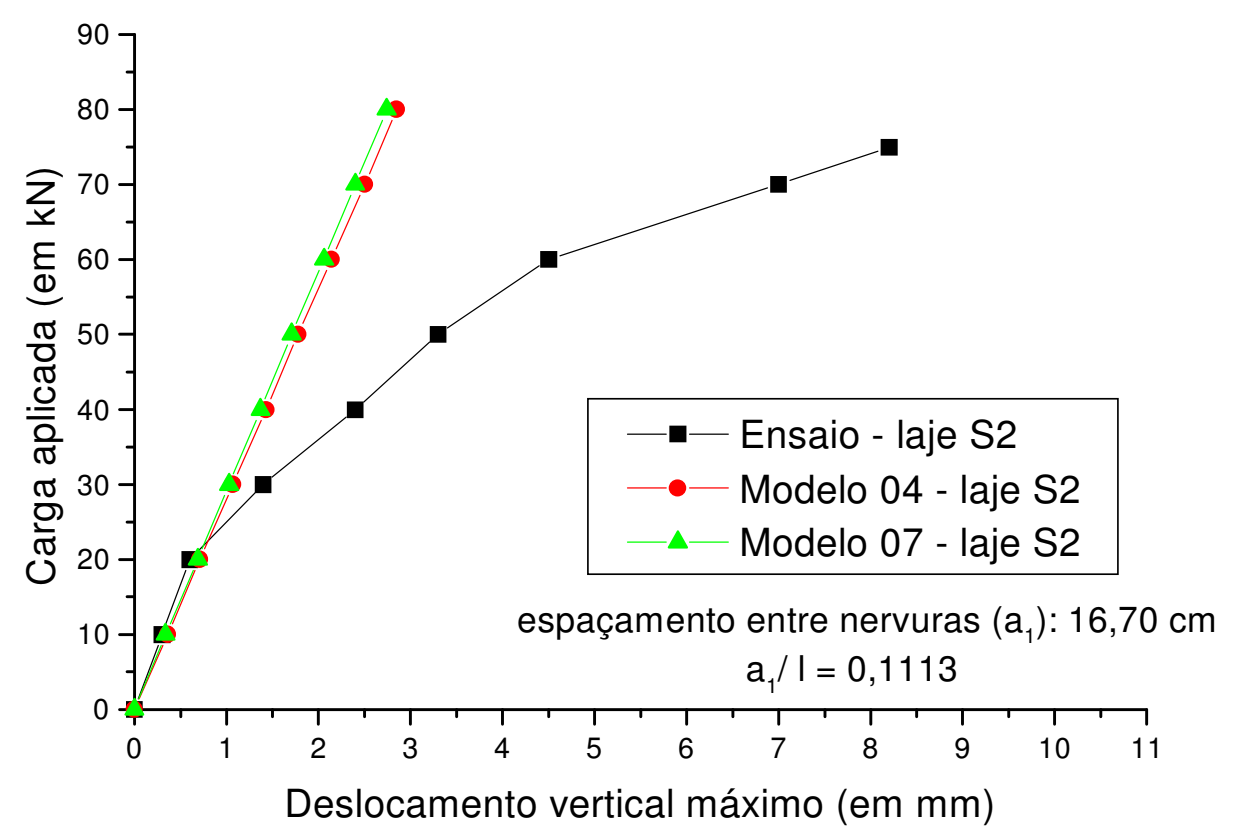

FIGURA 4.76: Deslocamentos transversais máximos (em mm) nos Modelos 04 e 07 na laje S2 proposta por ABDUL-WAHAB \& KHALIL (2000)

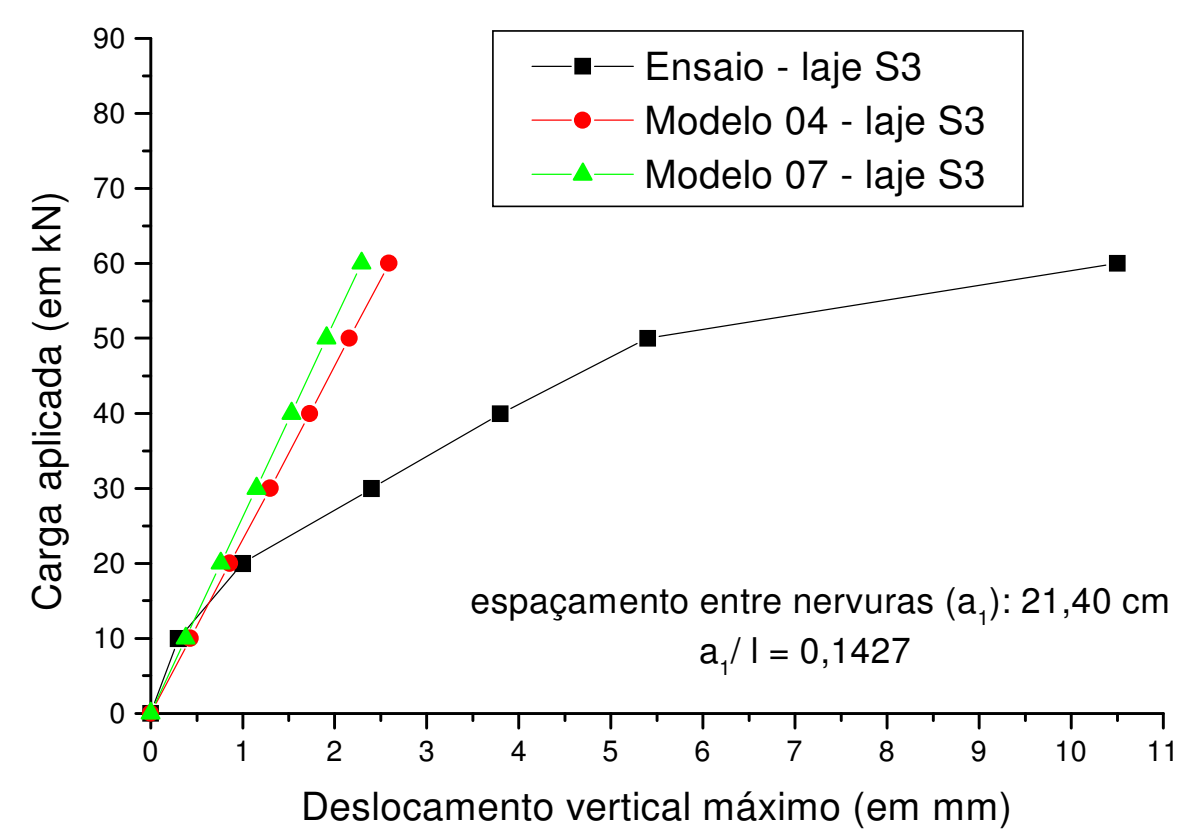

FIGURA 4.77: Deslocamentos transversais máximos (em mm) nos Modelos 04 e 07 na laje S3 proposta por ABDUL-WAHAB \& KHALIL (2000) 


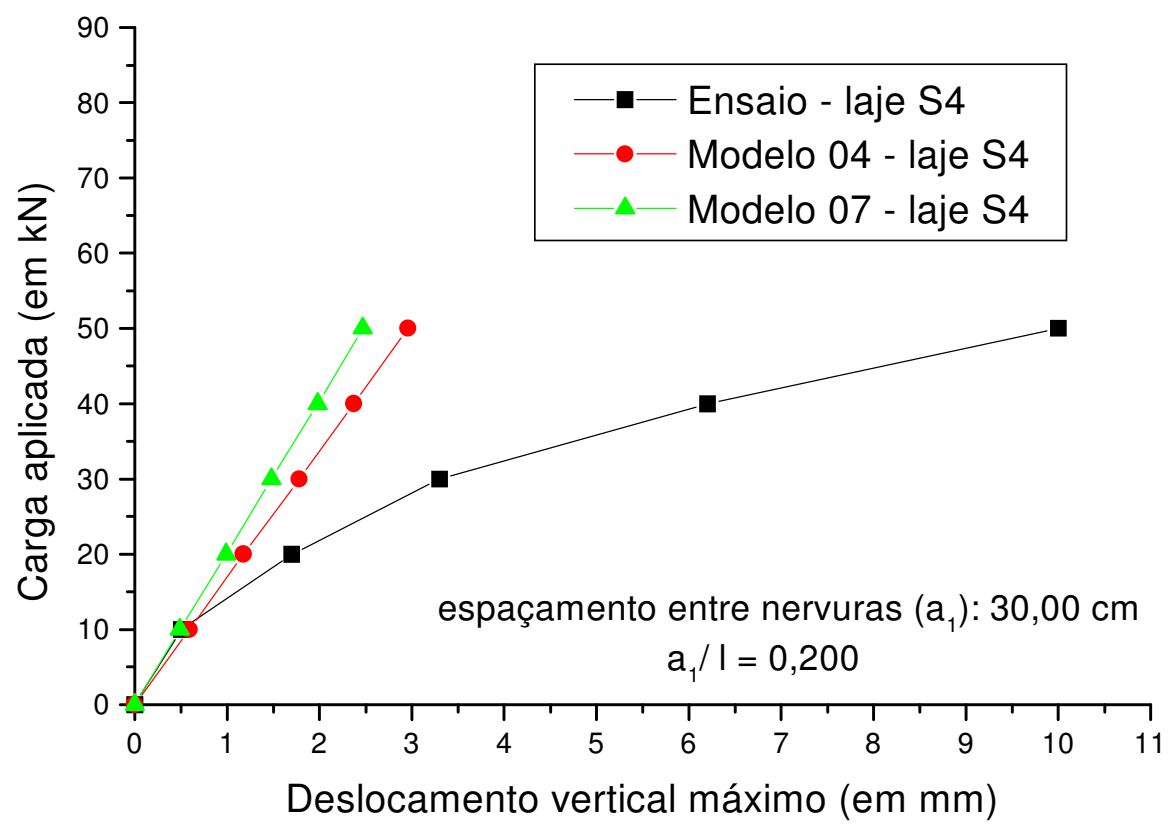

FIGURA 4.78: Deslocamentos transversais máximos (em mm) nos Modelos 04 e 07 na laje S4 proposta por ABDUL-WAHAB \& KHALIL (2000)

A Tabela 4.51 ordena as diferenças percentuais entre os Modelos 04 e 07 de acordo com a relação $a_{1} / l$.

TABELA 4.51: Diferenças percentuais entre os Modelos 04 e 07, ordenados conforme a relação $a_{1} / l$, para lajes nervuradas com a mesma altura do enrijecedor e capa

\begin{tabular}{c|c}
\hline \hline Relação a $\mathbf{l} \mathbf{l}$ & Diferença percentual entre os Modelos 04 e 07 \\
\hline \hline 0,0907 & $0,426 \%$ \\
\hline 0,1113 & $4,015 \%$ \\
\hline 0,1427 & $13,100 \%$ \\
\hline 0,2000 & $19,838 \%$ \\
\hline \hline
\end{tabular}

Analisando-se a Tabela 4.50 verifica-se e os Gráficos 4.75 a 4.78 que os melhores resultados apresentados pelo modelo de laje maciça equivalente ocorrem para baixas relações de espaçamento das nervuras por vão da laje, ou seja, $a_{1} / l$. A relação $a_{1} / l=$ 0,0907 apresentou diferença de $0,426 \%$ entre os modelos, o que pode ser considerada uma ótima correlação. Este tópico, então, merece análise aprofundada neste trabalho, visando verificar a relação ideal apresentada por HOPPMANN et al. (1956) e DEB et al. (1991), ou seja, $a_{1} / 1$ em torno de 0,070 . 


\section{k) Laje nervurada em concreto armado ensaiada por KLEIN \& SELISTRE (1997)}

KLEIN \& SELISTRE (1997) ensaiaram uma laje nervurada executada em modelo reduzido, conforme Figuras 4.79 e 4.80, na escala 1/7,5 em microconcreto armado, construída de forma semelhante a um protótipo empregado em edifícios. Apresentaram resultados do comportamento estrutural, como o máximo deslocamento transversal ao plano da laje do pavimento.

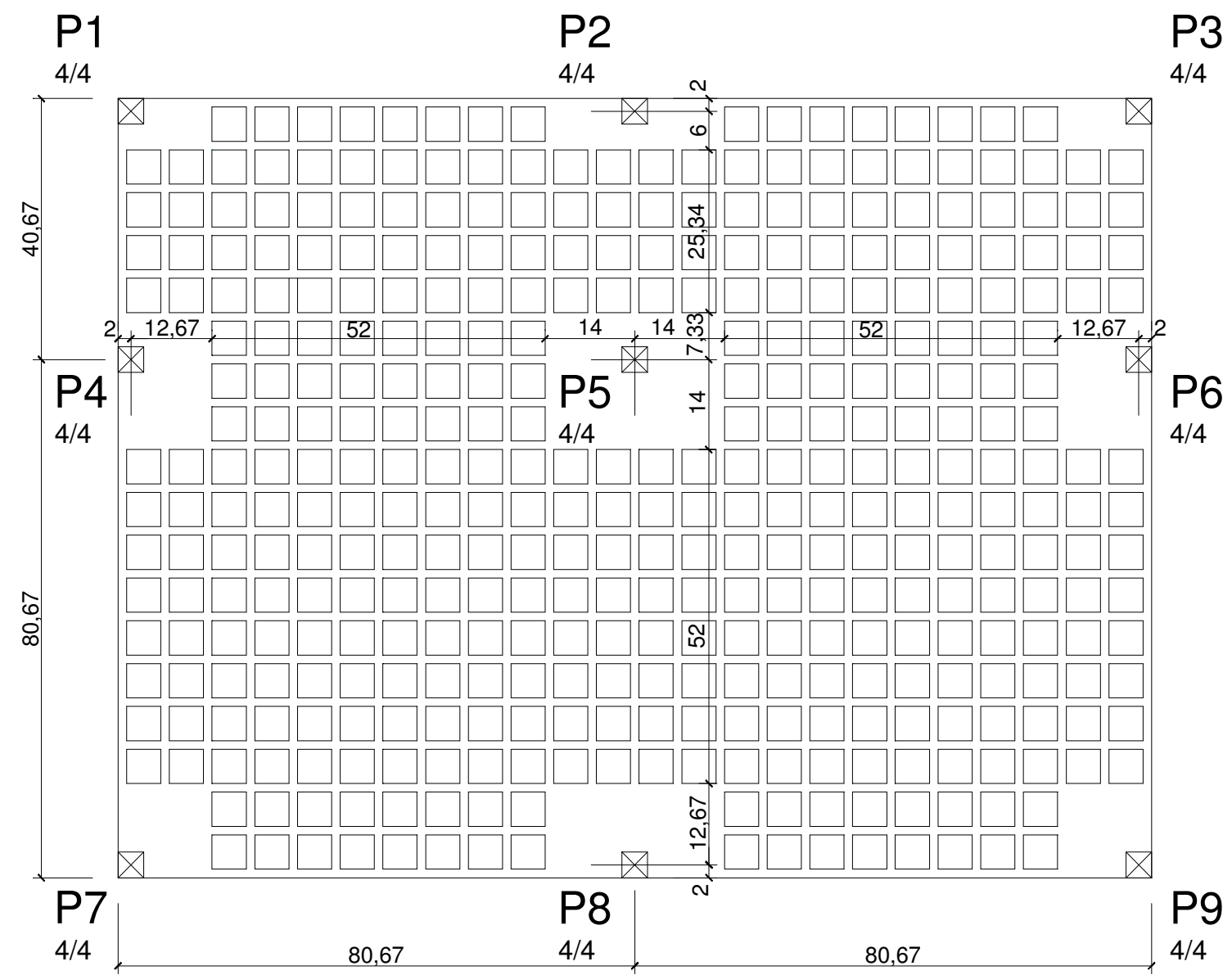

FIGURA 4.79: Geometria da laje nervurada, em cm [KLEIN \& SELISTRE (1997)]

Foram considerados os seguintes dados de entrada:

- carga uniformemente distribuída, em etapas, de acordo com a Tabela 4.52;

- módulo de elasticidade: $\mathrm{E}_{\mathrm{c}}=3640 \mathrm{kN} / \mathrm{cm}^{2}$, de acordo com KLEIN \&

SELISTRE (1997);

- coeficiente de Poisson: $v=0,20$; 
- os nós referentes aos pilares, de acordo com o modelo experimental, são considerados indeslocáveis e as rotações impedidas segundo os planos normais à laje.

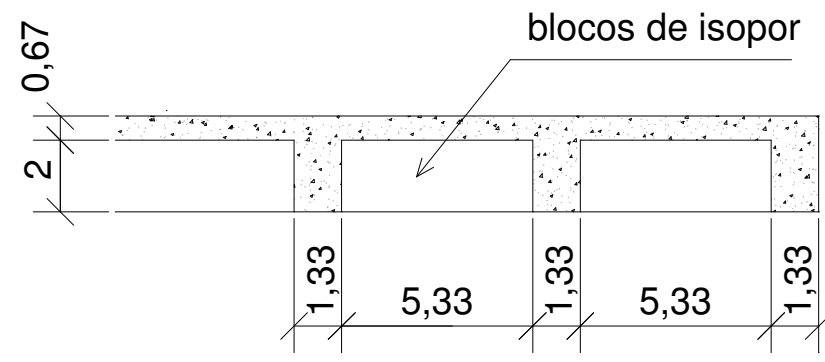

FIGURA 4.80: Corte da laje nervurada, em cm [KLEIN \& SELISTRE (1997)]

TABELA 4.52: Etapas de carregamento das análises numéricas

\begin{tabular}{c|c}
\hline \hline Etapa de carregamento & Carga aplicada $(\mathbf{g}+\mathbf{q}) \mathbf{~ e m ~} \mathbf{k N} / \mathbf{c m}^{2}$ \\
\hline \hline 0 & 0 \\
\hline 1 & 0,000250 \\
\hline 2 & 0,000375 \\
\hline 3 & 0,000500 \\
\hline 5 & 0,000625 \\
\hline \hline
\end{tabular}

A Figura 4.81 apresenta os pontos de medição utilizados no modelo experimental, por meio da disposição de extensômetros elétricos e relógios comparadores.

$\mathrm{Na}$ análise numérica foram utilizadas os Modelos 01, 02, 04, 05, 07 a 10.

Apresentam-se a seguir os resultados de deslocamentos transversais ao plano da placa máximos obtidos por meio das modelagens numéricas aplicadas neste exemplo, na Tabela 4.53.

TABELA 4.53: Deslocamentos máximos transversais ao plano da placa na laje, em mm, na seção transversal relativa ao deflectômetro 4 da instrumentação, na placa de KLEIN \&

SELISTRE (1997)

\begin{tabular}{c|c|c|c|c|c|c|c|c}
\hline \hline \multirow{2}{*}{ Carga } & \multirow{2}{*}{ Ensaio } & \multicolumn{8}{|c}{ Modelos numéricos de análise } \\
\cline { 3 - 9 } & & $\mathbf{0 1}$ & $\mathbf{0 2}$ & $\mathbf{0 5}$ & $\mathbf{0 7}$ & $\mathbf{0 8}$ & $\mathbf{0 9}$ & $\mathbf{1 0}$ \\
\hline \hline 0 & 0 & 0 & 0 & 0 & 0 & 0 & 0 & 0 \\
\hline 1 & 0,50 & 0,77 & 0,49 & 0,34 & 0,34 & 0,46 & 0,33 & 0,34 \\
\hline 2 & 0,80 & 1,16 & 0,73 & 0,51 & 0,51 & 0,70 & 0,49 & 0,51 \\
\hline 3 & 1,22 & 1,55 & 0,98 & 0,68 & 0,68 & 0,93 & 0,65 & 0,69 \\
\hline 4 & 1,75 & 1,94 & 1,22 & 0,85 & 0,84 & 1,16 & 0,82 & 0,86 \\
\hline 5 & 2,57 & 2,32 & 1,46 & 1,02 & 1,01 & 1,39 & 0,98 & 1,03 \\
\hline \hline
\end{tabular}




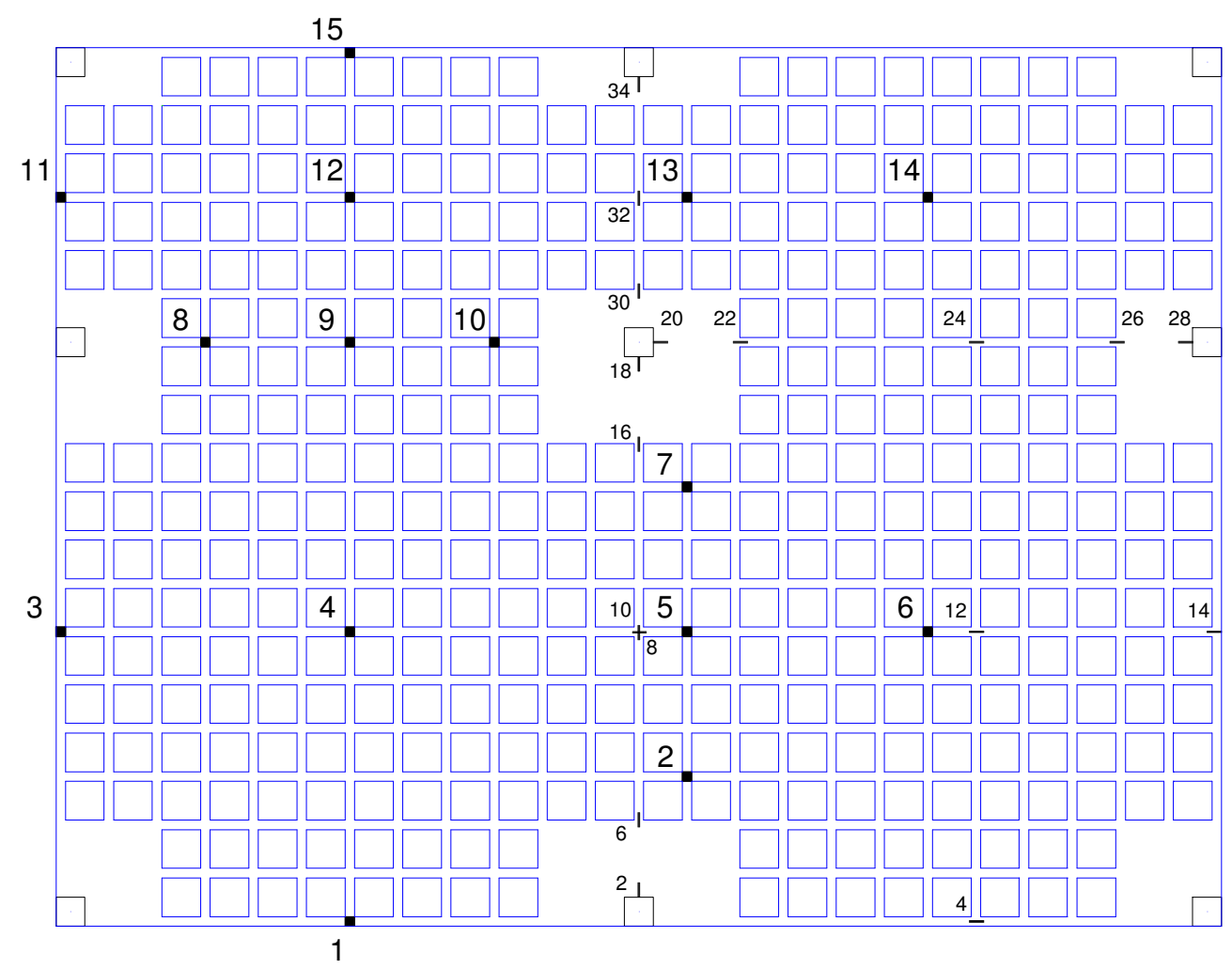

\section{Legenda:}

- deflectômetros

$\|$ extensômetros

FIGURA 4.81: Disposição dos extensômetros elétricos e relógios comparadores

[KLEIN \& SELISTRE (1997)]

Analisando-se os resultados apresentados na Tabela 4.53 verifica-se que, para baixos valores de carregamentos, havendo o comportamento elástico do concreto armado, os melhores resultados são apresentados pelos modelos excêntricos, visto que o concêntrico apresenta resultados maiores de deslocamentos.

A medida que o carregamento é aumentado, a laje ensaiada fissurou e passou a dar uma resposta não-linear física, o que nas modelagens elásticas não aconteceram. Dessa maneira, para o carregamento 5, o Modelo concêntrico 01 acabou ficando mais próximo do resultado do ensaio, visto que é um modelo elástico muito menos rígido que aqueles que consideram as nervuras excêntricas. Isso mostra que o ideal é que fosse aplicada a nãolinearidade física aos modelos, quando da análise das estruturas nos escritórios de cálculo. Não é intuito deste trabalho implementar análises desta maneira, contudo verifica-se a necessidade de continuação desta pesquisa incluindo este fator. 


\subsection{COMENTÁRIOS SOBRE OS RESULTADOS DAS MODELAGENS DOS EXEMPLOS DA BIBLIOGRAFIA}

Pela análise dos exemplos apresentados, e daqueles já processados utilizando-se as modelagens 01 a 10, pode-se fazer algumas considerações:

- a análise dos deslocamentos apresentados na fase elástica demonstrou que a total desconsideração da excentricidade leva a um comportamento excessivamente flexível da estrutura, o que não corresponde ao comportamento real; além disso, o momentos fletores na capa da laje encontrados na modelagem concêntrica são excessivamente maiores do que os resultados experimentais e daqueles apresentados por modelos excêntricos;

- todo os modelos excêntricos, simplificados ou realistas, apresentaram, de uma maneira geral, comportamentos muito próximos de deslocamentos na fase elástica e momentos fletores na capa; contudo o Modelo 04 (modelo de casca tridimensional), por ser um modelo com muito mais elementos finitos, muito mais refinado, e que aproximou-se muito bem de resultados experimentais de deslocamentos, como pode ser verificado nas modelagens comparativas com resultados de ensaios experimentais de CARRIJO \& PAIVA (1997) e ABDUL-WAHAB \& KHALIL (2000), será então utilizado na fase seguinte como modelo balizador dos resultados frente ao possível resultado do comportamento da estrutura real;

- dos modelos que substituem a laje nervurada por uma laje maciça equivalente, melhores resultados de deslocamentos foram até agora obtidos naquele que mantém a espessura equivalente calculada em função da inércia à flexão e diminui o módulo de elasticidade transversal; além disso, resultados numéricos mais próximos de experimentais para este modelo foram encontrados, para o exemplo de ABDUL-WAHAB \& KHALIL (2000), com a relação $a_{1} / 1=0,0907$, sendo $a_{1}=$ distância entre os eixos das nervuras e 1 = comprimento do lado que contém as nervuras. Este fator será melhor investigado na fase seguinte do trabalho, em uma análise mais ampla, buscando confirmar a relação ideal em torno de $a_{1} / l=0,07$ encontrada por HOPPMANN et al. (1956) e DEB et al. (1991);

- para estruturas em concreto armado melhores resultados seriam obtidos, na fase elástica do material, se levássemos em conta um incremento da rigidez devido a presença de armadura. Isto não ocorre nos escritórios de cálculo, pois o mesmo é feito em modelos elásticos e inicialmente com as propriedades de elasticidade oferecidas na NBR6118 para o material concreto armado, sem contudo iniciar as análises com as armaduras já especificadas para as seções, de forma discreta. Além disso, prevendo-se o comportamento 
não-linear do material para elevados níveis de carregamentos, os modelos ideais deveriam levar em conta esse comportamento, fato também ainda não aplicado de maneira rotineira nos escritórios de projeto. 


\section{CAPÍTULO 5 - EXPERIMENTAÇÃO NUMÉRICO- PARAMÉTRICA DE LAJES NERVURADAS}

\subsection{INTRODUÇÃO AO CAPÍTULO 5}

Dentro do objetivo amplo de verificar a validade dos resultados de modelos simplificados frente a resultados de modelos que considerem a excentricidade entre nervuras e capa em lajes nervuradas de maneira mais realista, a experimentação numérico-paramétrica consiste na comparação dos resultados encontrados no processamento destes modelos, conforme promovem-se variações em aspectos geométricos constituintes das lajes nervuradas, gerando as seguintes séries de processamentos em pavimentos de lajes nervuradas com vigas rígidas no contorno:

a) variação da altura da capa em relação a altura total da laje, ou seja, variação de $h_{f} / h$, com todos os outros fatores de análise fixos (espaçamento entre os eixos das nervuras e número de nervuras por lado);

b) variação do número de nervuras por lado, mantendo-se fixo o espaçamento entre os eixos das nervuras e as dimensões das mesmas, o que resulta também em diferentes relações entre o espaçamento entre os eixos das nervuras e a distância entre apoios fixos $\left(\mathrm{a}_{1} / \mathrm{l}\right)$;

d) variação do espaçamento entre os eixos das nervuras, com distância entre pontos de apoio (pilares) ajustada a um número fixo de nervuras por lado, mantendo-se também a altura da capa e nervura em todos os modelos. 


\subsection{DESCRIÇÃO DAS EXPERIMENTAÇÕES NUMÉRICO- PARAMÉTRICAS}

Todos as lajes foram processadas utilizando o software ANSYS 5.5, segundo os modelos 01 a 08 mostrados anteriormente no Capítulo 4. Os modelos 09 e 10 foram aplicados somente no capítulo anterior, onde comparam-se os resultados destes com resultados encontrados por outros pesquisadores. Os modelos 11 a 13, ou seja, modelos de Pórticos Planos Múltiplos e Equivalentes, não foram experimentados neste trabalho. Abaixo tem-se a descrição e os resultados encontrados em cada série de processamentos.

\subsubsection{Variação da relação altura total da capa $\left(h_{f}\right)$ pela altura total da laje $(h)$, mantendo os outros fatores de análise fixos}

Visando verificar se a relação entre a altura da capa e altura da nervura $\left(h_{f} / h\right)$ influencia na comparação entre resultados de modelos mais simplificados e modelos mais realistas na consideração da excentricidade, fez-se a experimentação numérica mantendo-se a altura da capa como um valor fixo de $h_{f}=5 \mathrm{~cm}$, e variando-se a altura total da laje, pela variação da altura do enrijecedor. Para esta experimentação criou-se um pavimento padrão composto de um pano de laje nervurada apoiada em quatro vigas rígidas no contorno, e em cada canto um pilar, com distância fixa entre pontos de apoio de $600 \mathrm{~cm}$, espaçamento entre os eixos das nervuras mantido em $60 \mathrm{~cm}$ e, consequentemente, um número de nervuras por lado igual a 9 nervuras.

Assim, para esta laje tem-se, para cada modelo numérico (modelos 01 a 08), os seguintes valores de altura total de laje nervurada:

$15 \mathrm{~cm} \quad 20 \mathrm{~cm} \quad 25 \mathrm{~cm} \quad 30 \mathrm{~cm} \quad 35 \mathrm{~cm} \quad 40 \mathrm{~cm} \quad 45 \mathrm{~cm} \quad 50 \mathrm{~cm}$

Dessa maneira, cada altura total de laje levou a 8 modelos, resultando nesta experimentação um total de 64 modelos processados. Considerou-se apenas um valor de carga uniformemente distribuída no pavimento, já que são análises elásticas.

Abaixo tem-se a tabela de correspondência entre a altura total da laje nervurada e a relação $h_{f} / h$ : 
TABELA 5.1: Correspondência entre a altura total da laje nervurada e a relação $h_{f} / h$

\begin{tabular}{|c|c|}
\hline \multicolumn{2}{|c|}{ CORRESPONDÊNCIA ENTRE A ALTURA TOTAL DA LAJE E A RELAÇÃO $h_{f} / 1$} \\
\hline Altura total da laje (em cm) & Relação $h_{f} / h$ \\
\hline 15 & 0,333 \\
\hline 20 & 0,250 \\
\hline 25 & 0,200 \\
\hline 30 & 0,167 \\
\hline 35 & 0,143 \\
\hline 40 & 0,125 \\
\hline 45 & 0,111 \\
\hline 50 & 0,100 \\
\hline
\end{tabular}

Apresenta-se a seguir, na Figura 5.1, a forma estrutural da laje experimentada:

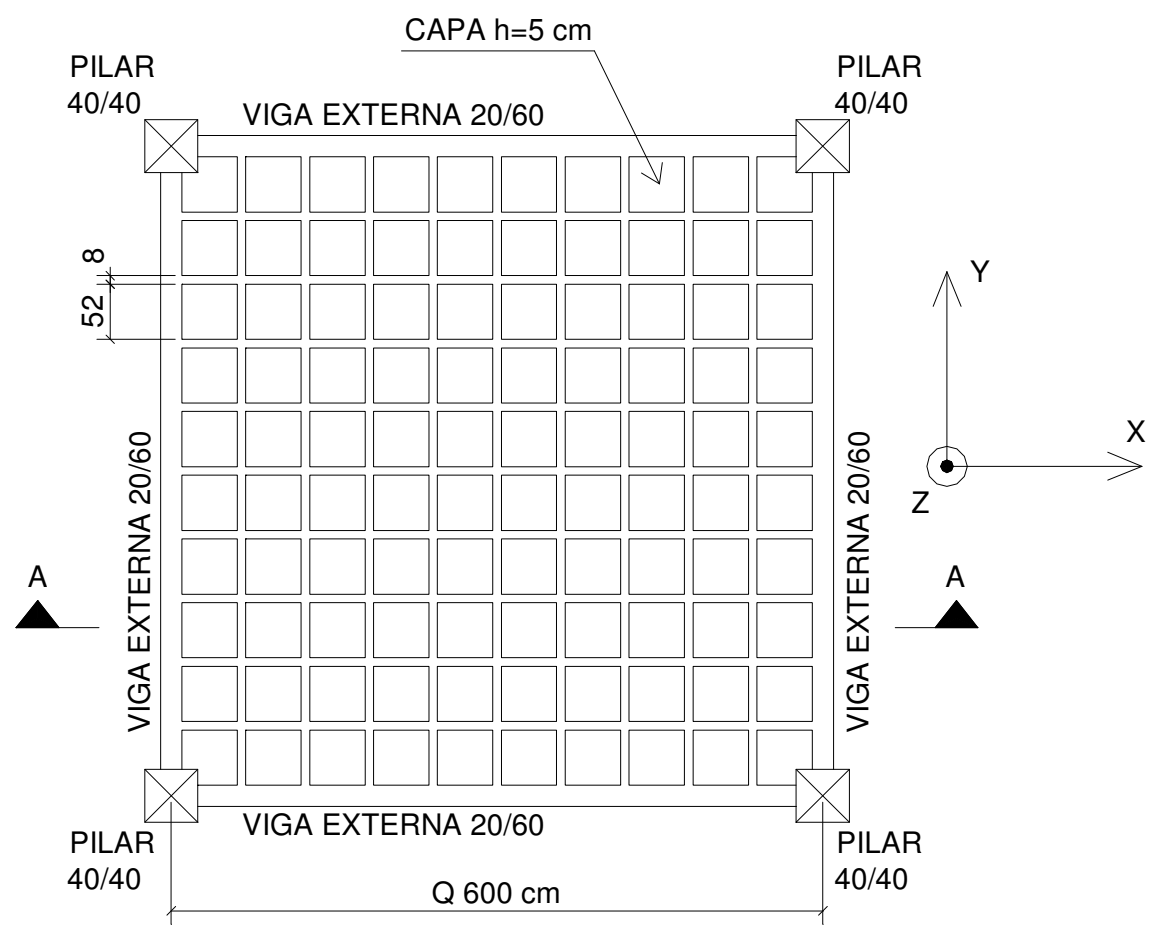

เ

CORTE A-A

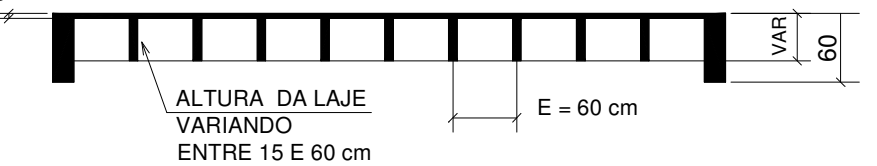

FIGURA 5.1: Forma estrutural básica dos modelos com variação da altura total da laje em relação a altura da capa

Os carregamentos aplicados nas lajes são mostrados na Tabela 5.2. 
TABELA 5.2: Carregamentos aplicados nas lajes nervuradas - Lajes com variação da altura da nervura

\begin{tabular}{|c|c|}
\hline \multicolumn{2}{|c|}{ CARRREGAMENTO APLICADO NAS LAJES NERVURADAS } \\
\hline MODELOS & DESCRIÇÃO DO CARREGAMENTO \\
\hline 01 A 08 ( EXCETO 06) & $\begin{array}{l}\text { Carregamento uniformemente aplicado sobre a capa de } \mathrm{q}=-0,00075 \\
\mathrm{kN} / \mathrm{cm}^{2}\end{array}$ \\
\hline 06 & $\begin{array}{l}\text { Carregamento linearmente distribuído aplicado sobre os elementos de vigas } \\
\text { que simulam as nervuras e vigas, obtido pela parcela do carregamento } \\
\text { aplicado sobre a capa de } q=-0,00075 \text { atuante em cada nervura, por traçado } \\
\text { de linhas de ruptura da capa delimitada pelas nervuras. }\end{array}$ \\
\hline
\end{tabular}

As características do material concreto armado considerado nas análises elásticas com $\mathrm{f}_{\mathrm{ck}}=25 \mathrm{MPa}$ são apresentados na Tabela 5.3.

As características geométricas dos elementos finitos utilizados para simular cada elemento estrutural são apresentadas nas Tabelas 5.4 a 5.9. As nomenclaturas R e T apresentadas pelos elementos de viga significam seção retangular e seção T, e os momentos de inércia estão representados na Figura 5.2.

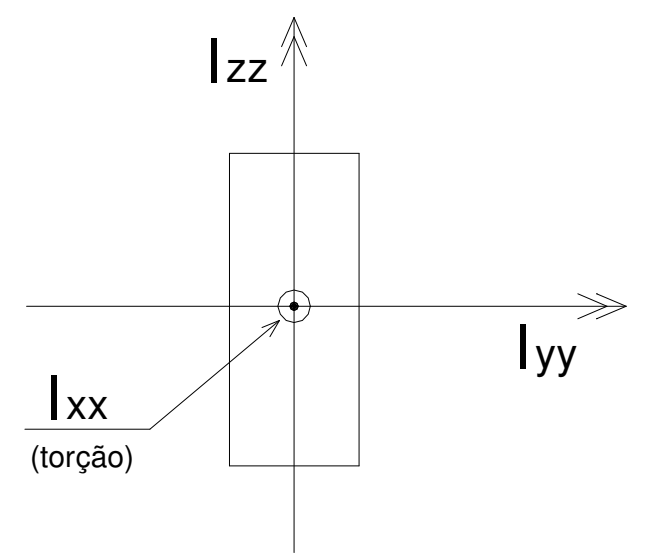

FIGURA 5.2: Nomenclatura dos momentos de inércia das seções de viga

TABELA 5.3: Propriedades do Concreto Armado utilizado nas modelagens numéricas - Lajes com variação da altura da nervura

\begin{tabular}{c|c|c|c}
\hline \hline \multicolumn{4}{c}{ CARACTERÍSTICAS DO MATERIAL } \\
\hline \multirow{2}{*}{ MODELO } & \multicolumn{2}{c}{ PROPRIEDADES DO CONCRETO ARMADO } \\
\cline { 2 - 4 } & $\mathbf{E}_{\mathrm{cs}}\left(\mathbf{k N / \mathbf { c m } ^ { 2 } )}\right.$ & Coeficiente de Poisson & $\mathbf{G}_{\mathbf{c}}\left(\mathbf{k N} / \mathbf{c m}^{\mathbf{2}}\right)$ \\
\hline \hline 01 A 07 & 2380 & 0,20 & 357 \\
\hline 08 & 2380 & 0,20 & 952 \\
\hline \hline
\end{tabular}


TABELA 5.4: Características dos pilares nos modelos - Lajes com variação da relação hf/h

\begin{tabular}{|c|c|c|c|c|c|c|c|c|}
\hline & & & & 01 AO 08 & & & & \\
\hline $\begin{array}{l}\text { Altura } \\
\text { Laje }\end{array}$ & Pilar & $\begin{array}{c}\text { hy } \\
(\mathbf{c m})\end{array}$ & hz $(\mathbf{c m})$ & $A\left(\mathrm{~cm}^{2}\right)$ & $\begin{array}{c}\mathbf{I z z} \\
\left(\mathrm{cm}^{4}\right)\end{array}$ & $\begin{array}{c}\text { Iyy } \\
\left(\mathrm{cm}^{4}\right)\end{array}$ & $\begin{array}{c}\mathbf{I x x} \\
\left(\mathrm{cm}^{4}\right)\end{array}$ & $\begin{array}{c}\text { Excent. } \\
\text { (cm) }\end{array}$ \\
\hline 15 A 50 & R 40/40 & 40 & 40 & 1600 & 213333,33 & 213333,33 & 42666,67 & 0,0 \\
\hline
\end{tabular}

TABELA 5.5: Características das vigas de contorno para os modelos 01 a 08 (exceto modelo 04) - Lajes com variação da relação $\mathrm{hf} / \mathrm{h}$

\begin{tabular}{|c|c|c|c|c|c|c|c|c|}
\hline \multicolumn{9}{|c|}{$\begin{array}{l}\text { CARACTERÍSTICAS DAS VIGAS DE CONTORNO SIMULADAS PELO ELEMENTO BEAM44 } \\
\text { CONSIDERADO ATÉ O TOPO DA CAPA - SEÇÃO RETANGULAR - MODELOS 01 AO } 08 \\
\text { (EXCETO MODELO 04) }\end{array}$} \\
\hline $\begin{array}{c}\text { Altura } \\
\text { Laje }\end{array}$ & Vigas & $\begin{array}{c}\text { hy } \\
\text { (cm) }\end{array}$ & $\begin{array}{c}\text { hz } \\
(\mathbf{c m})\end{array}$ & $\begin{array}{c}\mathbf{A} \\
\left(\mathbf{c m}^{2}\right)\end{array}$ & $\begin{array}{c}\mathbf{I z z} \\
\left(\mathrm{cm}^{4}\right)\end{array}$ & $\begin{array}{c}\text { Iyy } \\
\left(\mathrm{cm}^{4}\right)\end{array}$ & $\begin{array}{c}\mathbf{I x x} \\
\left(\mathrm{cm}^{4}\right)\end{array}$ & $\begin{array}{l}\text { Excent. } \\
\text { (cm) }\end{array}$ \\
\hline $15 \mathrm{~A} 50$ & R 20/60 & 20 & 260 & 1220 & 40000 & 360000 & 8000 & 27,50 \\
\hline
\end{tabular}

TABELA 5.6: Características das vigas de contorno para o modelo 04 - Lajes com variação da relação $h f / h$

\begin{tabular}{c|c|c}
\hline \multicolumn{3}{c}{ CARACTERÍSTICAS DAS VIGAS DE CONTORNO SIMULADAS PELO ELEMENTO SHELL63 - } \\
MODELO 04
\end{tabular}


TABELA 5.7: Características das nervuras para os modelos 01, 02, 03, 05 e 06 - Lajes com variação da relação $\mathrm{hf} / \mathrm{h}$

\begin{tabular}{|c|c|c|c|c|c|c|c|c|}
\hline \multicolumn{9}{|c|}{$\begin{array}{c}\text { CARACTERÍSTICAS DAS NERVURAS SIMULADAS POR ELEMENTOS BEAM44 } \\
\text { (EXCENTRICOS) E BEAM4 (CONCENTRICOS) }\end{array}$} \\
\hline $\begin{array}{c}\text { Altura } \\
\text { Laje }\end{array}$ & Nervura & $\begin{array}{c}\text { hy } \\
(\mathrm{cm})\end{array}$ & $\begin{array}{c}\text { hz } \\
(\mathbf{c m})\end{array}$ & $\begin{array}{c}\mathrm{A} \\
\left(\mathrm{cm}^{2}\right)\end{array}$ & $\begin{array}{c}\mathbf{I z z} \\
\left(\mathrm{cm}^{4}\right)\end{array}$ & $\begin{array}{c}\text { Iyy } \\
\left(\mathrm{cm}^{4}\right)\end{array}$ & $\begin{array}{c}\mathbf{I x x} \\
\left(\mathrm{cm}^{4}\right)\end{array}$ & $\begin{array}{c}\text { Excent. } \\
\text { (cm) }\end{array}$ \\
\hline \multicolumn{9}{|c|}{ MODELO 01} \\
\hline 15 & R 8/15 & 8 & 15 & 120 & 640,00 & 2250,00 & 128,00 & 0,0 \\
\hline 20 & $\mathrm{R} 8 / 20$ & 8 & 20 & 160 & 853,33 & 5333,33 & 170,67 & 0,0 \\
\hline 25 & $\mathrm{R} 8 / 25$ & 8 & 25 & 200 & 1066,67 & 10416,67 & 213,33 & 0,0 \\
\hline 30 & $\mathrm{R} 8 / 30$ & 8 & 30 & 240 & 1280,00 & 18000,00 & 256,00 & 0,0 \\
\hline 35 & $\mathrm{R} 8 / 35$ & 8 & 35 & 280 & 1493,33 & 28583,33 & 298,67 & 0,0 \\
\hline 40 & $\mathrm{R} 8 / 40$ & 8 & 40 & 320 & 1706,67 & 42666,67 & 341,33 & 0,0 \\
\hline 45 & $\mathrm{R} 8 / 45$ & 8 & 45 & 360 & 1920,00 & 60750,00 & 384,00 & 0,0 \\
\hline 50 & $\mathrm{R} 8 / 50$ & 8 & 50 & 400 & 2133,33 & 83333,33 & 426,67 & 0,0 \\
\hline \multicolumn{9}{|c|}{ MODELO 02} \\
\hline 15 & R 8/15 & 8 & 15 & 120 & 640,00 & 2250,00 & 128,00 & 5,0 \\
\hline 20 & $\mathrm{R} 8 / 20$ & 8 & 20 & 160 & 853,33 & 5333,33 & 170,67 & 7,5 \\
\hline 25 & R 8/25 & 8 & 25 & 200 & 1066,67 & 10416,67 & 213,33 & 10,0 \\
\hline 30 & $\mathrm{R} 8 / 30$ & 8 & 30 & 240 & 1280,00 & 18000,00 & 256,00 & 12,5 \\
\hline 35 & $\mathrm{R} 8 / 35$ & 8 & 35 & 280 & 1493,33 & 28583,33 & 298,67 & 15,0 \\
\hline 40 & $\mathrm{R} 8 / 40$ & 8 & 40 & 320 & 1706,67 & 42666,67 & 341,33 & 17,5 \\
\hline 45 & $\mathrm{R} 8 / 45$ & 8 & 45 & 360 & 1920,00 & 60750,00 & 384,00 & 20,0 \\
\hline 50 & $\mathrm{R} 8 / 50$ & 8 & 50 & 400 & 2133,33 & 83333,33 & 426,67 & 22,5 \\
\hline \multicolumn{9}{|c|}{ MODELO 03} \\
\hline 15 & R 8/10 & 8 & 10 & 80 & 426,67 & $\begin{array}{ll}666,67 \\
\end{array}$ & 85,33 & 7,5 \\
\hline 20 & $\mathrm{R} 8 / 15$ & 8 & 15 & 120 & 640,00 & 2250,00 & 128,00 & 10,0 \\
\hline 25 & $\mathrm{R} 8 / 20$ & 8 & 20 & 160 & 853,33 & 5333,33 & 170,67 & 12,5 \\
\hline 30 & $\mathrm{R} 8 / 25$ & 8 & 25 & 200 & 1066,67 & 10416,67 & 213,33 & 15,0 \\
\hline 35 & $\mathrm{R} 8 / 30$ & 8 & 30 & 240 & 1280,00 & 18000,00 & 256,00 & 17,5 \\
\hline 40 & $\mathrm{R} 8 / 35$ & 8 & 35 & 280 & 1493,33 & 28583,33 & 298,67 & 20,0 \\
\hline 45 & $\mathrm{R} 8 / 40$ & 8 & 40 & 320 & 1706,67 & 42666,67 & 341,33 & 22,5 \\
\hline 50 & R 8/45 & 8 & 45 & 360 & 1920,00 & 60750,00 & 384,00 & 25,0 \\
\hline \multicolumn{9}{|c|}{ MODELO 05} \\
\hline 15 & T 8/15/60 & 8 & 15 & 380 & 90427 & 4844 & 203 & 0,0 \\
\hline 20 & T 8/20/60 & 8 & 20 & 420 & 90640 & 11446 & 246 & 0,0 \\
\hline 25 & T 8/25/60 & 8 & 25 & 460 & 90853 & 22263 & 288 & 0,0 \\
\hline 30 & T 8/30/60 & 8 & 30 & 500 & 91067 & 38042 & 331 & 0,0 \\
\hline 35 & $\mathrm{~T} 8 / 35 / 60$ & 8 & 35 & 540 & 91280 & 59458 & 374 & 0,0 \\
\hline 40 & T 8/40/60 & 8 & 40 & 580 & 91493 & 87139 & 416 & 0,0 \\
\hline 45 & T 8/45/60 & 8 & 45 & 620 & 91707 & 121679 & 459 & 0,0 \\
\hline 50 & T 8/50/60 & 8 & 50 & 660 & 91920 & 163648 & 502 & 0,0 \\
\hline \multicolumn{9}{|c|}{ MODELO 06} \\
\hline 15 & T 8/15/60 & 8 & 15 & 380 & 90427 & 4844 & 203 & 0,0 \\
\hline 20 & T 8/20/60 & 8 & 20 & 420 & 90640 & 11446 & 246 & 0,0 \\
\hline 25 & T 8/25/60 & 8 & 25 & 460 & 90853 & 22263 & 288 & 0,0 \\
\hline 30 & $\mathrm{~T} \mathrm{8/30/60}$ & 8 & 30 & 500 & 91067 & 38042 & 331 & 0,0 \\
\hline 35 & $\mathrm{~T} 8 / 35 / 60$ & 8 & 35 & 540 & 91280 & 59458 & 374 & 0,0 \\
\hline 40 & $\mathrm{~T} 8 / 40 / 60$ & 8 & 40 & 580 & 91493 & 87139 & 416 & 0,0 \\
\hline 45 & $\mathrm{~T} 8 / 45 / 60$ & 8 & 45 & 620 & 91707 & 121679 & 459 & 0,0 \\
\hline 50 & T 8/50/60 & 8 & 50 & 660 & 91920 & 163648 & 502 & 0,0 \\
\hline
\end{tabular}


TABELA 5.8: Características das nervuras para os modelos 04, 07 e 08 - Lajes com variação da relação hf/h

\begin{tabular}{|c|c|c|}
\hline \multicolumn{3}{|c|}{$\begin{array}{l}\text { CARACTERÍSTICAS DAS NERVURAS SIMULADAS POR ELEMENTOS SHELL63 - MODELOS } \\
\text { 04, } 07 \text { E } 08\end{array}$} \\
\hline Altura Laje & Nervura & h (cm) \\
\hline \multicolumn{3}{|c|}{ MODELO 04} \\
\hline 15 & CASCA 8/12,5 & 8,000 \\
\hline 20 & CASCA 8/17,5 & 8,000 \\
\hline 25 & CASCA 8/22,5 & 8,000 \\
\hline 30 & CASCA 8/27,5 & 8,000 \\
\hline 35 & CASCA 8/32,5 & 8,000 \\
\hline 40 & CASCA 8/37,5 & 8,000 \\
\hline 45 & CASCA 8/42,5 & 8,000 \\
\hline 50 & CASCA 8/47,5 & 8,000 \\
\hline \multicolumn{3}{|c|}{ MODELO 07} \\
\hline 15 & LAJE MACIÇA EQUIVAL. & 9,895 \\
\hline 20 & LAJE MACIÇA EQUIVAL. & 13,179 \\
\hline 25 & LAJE MACIÇA EQUIVAL. & 16,451 \\
\hline 30 & LAJE MACIÇA EQUIVAL. & 19,668 \\
\hline 35 & LAJE MACIÇA EQUIVAL. & 22,825 \\
\hline 40 & LAJE MACIÇA EQUIVAL. & 25,927 \\
\hline 45 & LAJE MACIÇA EQUIVAL. & 28,979 \\
\hline 50 & LAJE MACIÇA EQUIVAL. & 31,987 \\
\hline \multicolumn{3}{|c|}{ MODELO 08} \\
\hline 15 & "LAJE MACIÇA EQUIVAL. & 7,916 \\
\hline 20 & LAJE MACIÇA EQUIVAL. & 10,543 \\
\hline 25 & LAJE MACIÇA EQUIVAL. & 13,161 \\
\hline 30 & LAJE MACIÇA EQUIVAL. & 15,735 \\
\hline 35 & LAJE MACIÇA EQUIVAL. & 18,260 \\
\hline 40 & LAJE MACIÇA EQUIVAL. & 20,741 \\
\hline 45 & LAJE MACIÇA EQUIVAL. & 23,183 \\
\hline 50 & LAJE MACIÇA EQUIVAL. & 25,590 \\
\hline
\end{tabular}

TABELA 5.9: Características da capa - Lajes com variação da relação hf/h

\begin{tabular}{c|c|c}
\hline \multicolumn{3}{c}{ CARACTERÍSTICAS DA CAPA SIMULADA POR ELEMENTOS SHELL63 - LAJES COM } \\
ALTURA TOTAL DE $\mathbf{1 5} \mathbf{A 0} \mathbf{~ c m}$ \\
\hline Modelo & Nervura & $\mathbf{h} \mathbf{( \mathbf { c m } )}$ \\
\hline 01 & CASCA & 5,0 \\
\hline 02 & CASCA & 5,0 \\
\hline 03 & CASCA & 5,0 \\
\hline 04 & CASCA & 5,0 \\
\hline 05 & CASCA & 5,0 \\
\hline \hline
\end{tabular}

O número de elementos finitos utilizados em cada modelo analisado é demonstrado abaixo. 
TABELA 5.10: Número de elementos finitos em cada modelo analisado, para lajes com variação de $h_{f} / h$

\begin{tabular}{|c|c|c|c|c|c|c|c|c|c|}
\hline \multirow{2}{*}{$\begin{array}{l}\text { Altura } \\
\text { da laje }\end{array}$} & \multirow{2}{*}{ Elementos } & \multicolumn{8}{|c|}{ Modelos numéricos de análise } \\
\hline & & 01 & 02 & 03 & 04 & 05 & 06 & 07 & 08 \\
\hline \multirow{3}{*}{$\begin{array}{c}\mathrm{h}=15 \\
\mathrm{~cm}\end{array}$} & BEAM4 & 724 & 4 & 4 & 56 & 724 & 724 & 4 & 4 \\
\hline & BEAM44 & 160 & 880 & 880 & 0 & 160 & 160 & 160 & 160 \\
\hline & SHELL63 & 1600 & 1600 & 1600 & 6560 & 1600 & 0 & 1600 & 1600 \\
\hline \multirow{3}{*}{$\begin{array}{c}\mathrm{h}=20 \\
\mathrm{~cm}\end{array}$} & BEAM4 & 724 & 4 & 4 & 56 & 724 & 724 & 4 & 4 \\
\hline & BEAM44 & 160 & 880 & 880 & 0 & 160 & 160 & 160 & 160 \\
\hline & SHELL63 & 1600 & 1600 & 1600 & 7280 & 1600 & 0 & 1600 & 1600 \\
\hline \multirow{3}{*}{$\begin{array}{c}\mathrm{h}=25 \\
\mathrm{~cm}\end{array}$} & BEAM4 & 724 & 4 & 4 & 56 & 724 & 724 & 4 & 4 \\
\hline & BEAM44 & 160 & 880 & 880 & 0 & 160 & 160 & 160 & 160 \\
\hline & SHELL63 & 1600 & 1600 & 1600 & 8000 & 1600 & 0 & 1600 & 1600 \\
\hline \multirow{3}{*}{$\begin{array}{c}\mathrm{h}=30 \\
\mathrm{~cm}\end{array}$} & BEAM4 & 724 & 4 & 4 & 56 & 724 & 724 & 4 & 4 \\
\hline & BEAM44 & 160 & 880 & 880 & 0 & 160 & 160 & 160 & 160 \\
\hline & SHELL63 & 1600 & 1600 & 1600 & 8720 & 1600 & 0 & 1600 & 1600 \\
\hline \multirow{3}{*}{$\begin{array}{c}\mathrm{h}=35 \\
\mathrm{~cm}\end{array}$} & BEAM4 & 724 & 4 & 4 & 56 & 724 & 724 & 4 & 4 \\
\hline & BEAM44 & 160 & 880 & 880 & 0 & 160 & 160 & 160 & 160 \\
\hline & SHELL63 & 1600 & 1600 & 1600 & 9440 & 1600 & 0 & 1600 & 1600 \\
\hline \multirow{3}{*}{$\begin{array}{c}\mathrm{h}=40 \\
\mathrm{~cm}\end{array}$} & BEAM4 & 724 & 4 & 4 & 56 & 724 & 724 & 4 & 4 \\
\hline & BEAM44 & 160 & 880 & 880 & 0 & 160 & 160 & 160 & 160 \\
\hline & SHELL63 & 1600 & 1600 & 1600 & 10160 & 1600 & 0 & 1600 & 1600 \\
\hline \multirow{3}{*}{$\begin{array}{c}\mathrm{h}=45 \\
\mathrm{~cm}\end{array}$} & BEAM4 & 724 & 4 & 4 & 56 & 724 & 724 & 4 & 4 \\
\hline & BEAM44 & 160 & 880 & 880 & 0 & 160 & 160 & 160 & 160 \\
\hline & SHELL63 & 1600 & 1600 & 1600 & 10880 & 1600 & 0 & 1600 & 1600 \\
\hline \multirow{3}{*}{$\begin{array}{c}\mathrm{h}=50 \\
\mathrm{~cm}\end{array}$} & BEAM4 & 724 & 4 & 4 & 56 & 724 & 724 & 4 & 4 \\
\hline & BEAM44 & 160 & 880 & 880 & 0 & 160 & 160 & 160 & 160 \\
\hline & SHELL63 & 1600 & 1600 & 1600 & 11600 & 1600 & 0 & 1600 & 1600 \\
\hline
\end{tabular}

Os pontos de medição de deslocamentos e esforços, nos modelos numéricos, são apresentados abaixo na Figura 5.3: 


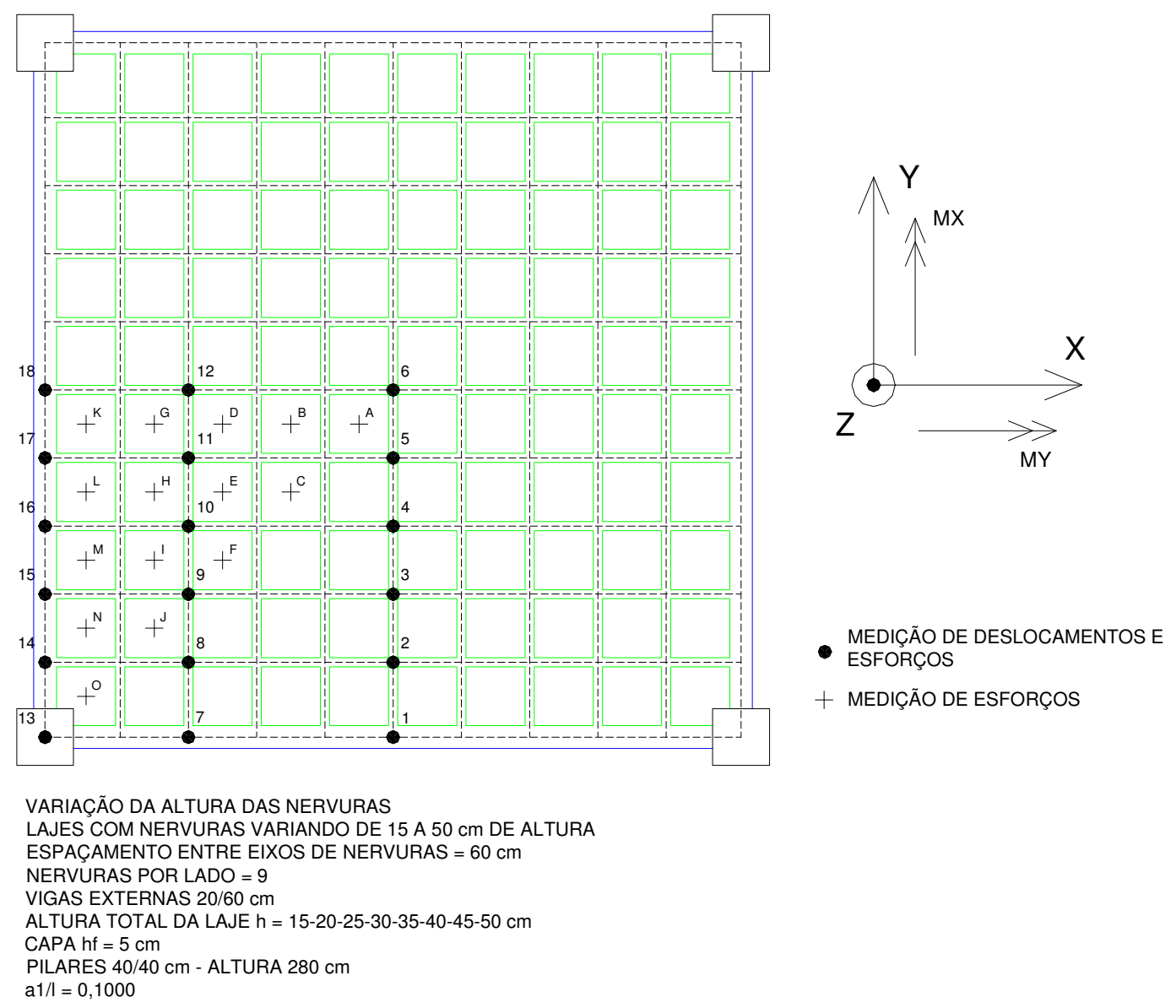

FIGURA 5.3: Pontos de medição de deslocamentos e esforços - Modelos com variação da altura total da laje

\subsubsection{Variação da relação espaçamento entre os eixos das nervuras $\left(a_{1}\right)$ pela distância entre os apoios (l), mantendo os outros fatores de análise fixos}

Para esta experimentação criou-se um pavimento padrão composto de um pano de laje nervurada apoiada em quatro vigas rígidas no contorno, e em cada canto um pilar. Fixou-se como espaçamento entre os eixos das nervuras o valor de $60 \mathrm{~cm}$. A altura da capa foi considerada como $h_{f}=5 \mathrm{~cm}$ e a altura total da laje como h $=20 \mathrm{~cm}$. Dessa maneira, variou-se o número de nervuras, considerando os seguintes valores de número de nervuras por lado:

$\begin{array}{lllllllllll}5 & 6 & 7 & 8 & 9 & 10 & 11 & 12 & 13 & 14 & 15\end{array}$


Nesta experimentação é verificado o comportamento de modelos simplificados frente a modelos mais realistas conforme a relação entre o espaçamento entre os eixos das nervuras $\left(a_{1}\right)$ e a medida entre apoios fixos (l). Tem-se, então, a seguinte correspondência:

TABELA 5.11: Correspondência entre o número de nervuras por lado e a relação $a_{1} / 1$

\begin{tabular}{c|c}
\hline \hline \multicolumn{2}{c}{ CORRESPONDÊNCIA ENTRE NÚMERO DE NERVURAS POR LADO E A RELAÇ̃̃o $\mathbf{a}_{\mathbf{1}} / \mathbf{l}$} \\
\hline Número de nervuras por lado & Relação $\mathbf{a}_{\mathbf{1}} / \mathbf{l}$ \\
\hline \hline 5 & 0,1667 \\
\hline 6 & 0,1429 \\
\hline 7 & 0,1250 \\
\hline 8 & 0,1111 \\
\hline 9 & 0,1000 \\
\hline 10 & 0,0910 \\
\hline 11 & 0,0833 \\
\hline 12 & 0,0769 \\
\hline 13 & 0,0714 \\
\hline 14 & 0,0667 \\
\hline \hline
\end{tabular}

Cada laje foi processada segundo os modelos 01 a 08, resultando nesta experimentação um total de 88 modelos processados. Considerou-se apenas um valor de carga uniformemente distribuída no pavimento, já que são análises elásticas.

Apresenta-se a seguir, na Figura 5.4, a forma estrutural básica da laje experimentada.

As características do material concreto armado considerado nas análises elásticas com $\mathrm{f}_{\mathrm{ck}}=25 \mathrm{MPa}$ são apresentadas na Tabela 5.12:

TABELA 5.12: Propriedades do Concreto Armado utilizado nas modelagens numéricas - Lajes com variação do número de nervuras por lado

\begin{tabular}{c|c|c|c}
\hline \hline \multicolumn{4}{c}{ CARACTERÍSTICAS DO MATERIAL } \\
\hline \multirow{2}{*}{ MODELO } & \multicolumn{2}{|c}{ PROPRIEDADES DO CONCRETO ARMADO } \\
\cline { 2 - 4 } & $\mathbf{E}_{\mathrm{cs}}\left(\mathbf{k N / \mathbf { c m } ^ { 2 } )}\right.$ & Coeficiente de Poisson & $\mathbf{G}_{\mathbf{c}}\left(\mathbf{k N / \mathbf { c m } ^ { 2 } )}\right.$ \\
\hline \hline 01 A 07 & 2380 & 0,20 & 357 \\
\hline 08 & 2380 & 0,20 & 952 \\
\hline \hline
\end{tabular}




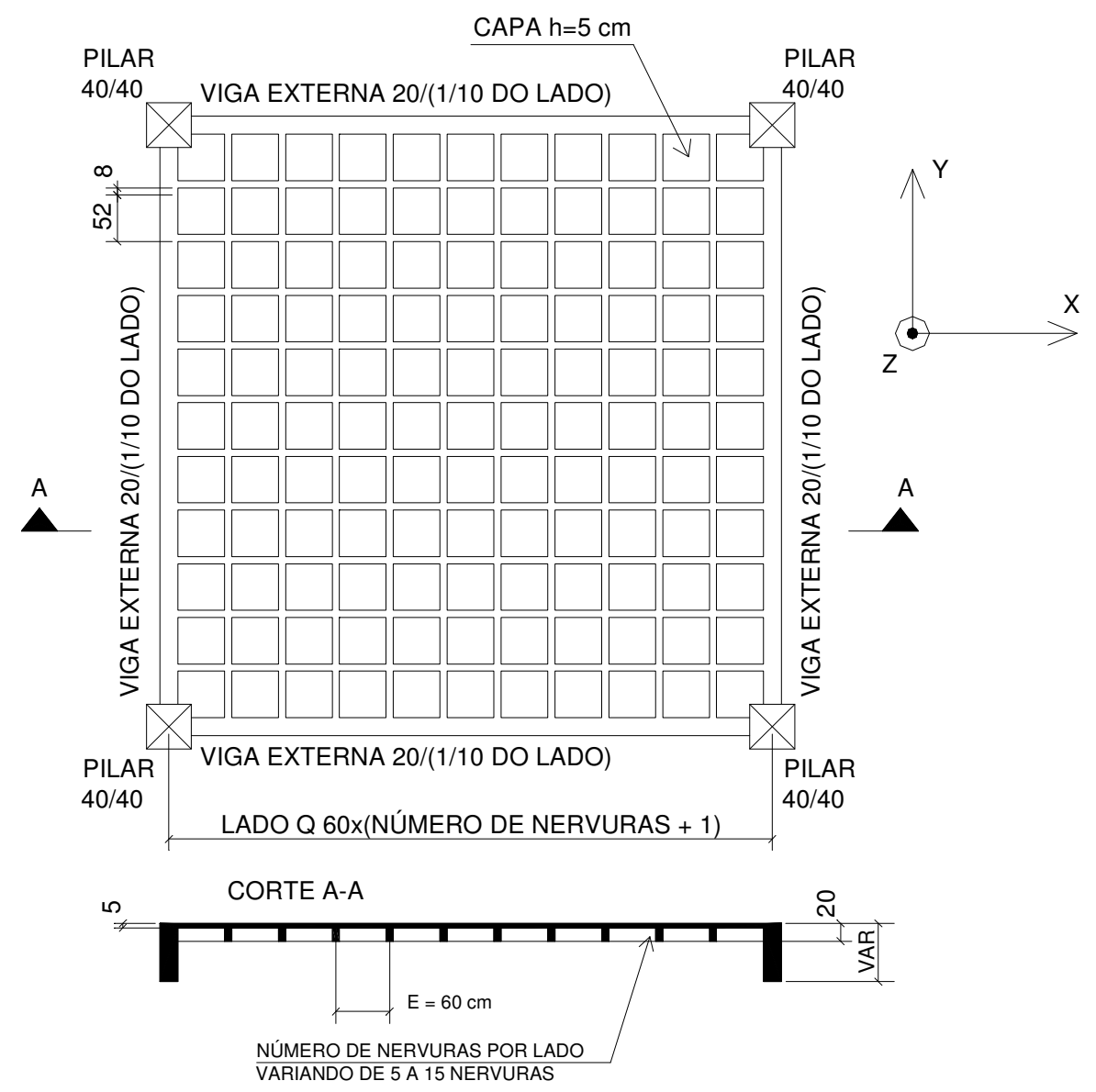

FIGURA 5.4: Forma estrutural básica dos modelos com variação do número de nervuras por lado

Os carregamentos aplicados aos modelos são mostrados na Tabela 5.13.

TABELA 5.13: Carregamentos aplicados nas lajes nervuradas - Lajes com variação do número de nervuras por lado

\begin{tabular}{|c|c|}
\hline \multicolumn{2}{|c|}{ CARRREGAMENTO APLICADO NAS LAJES NERVURADAS } \\
\hline MODELOS & \begin{tabular}{|c|} 
DESCRIÇÃO DO CARREGAMENTO \\
\end{tabular} \\
\hline 01 A 08 ( EXCETO 06) & $\begin{array}{l}\text { Carregamento uniformemente aplicado sobre a capa de } \mathrm{q}=-0,00075 \\
\mathrm{kN} / \mathrm{cm}^{2}\end{array}$ \\
\hline 06 & $\begin{array}{l}\text { Carregamento linearmente distribuído aplicado sobre os elementos de vigas } \\
\text { que simulam as nervuras e vigas, obtido pela parcela do carregamento } \\
\text { aplicado sobre a capa de } \mathrm{q}=-0,00075 \text { atuante em cada nervura, por traçado } \\
\text { de linhas de ruptura da capa delimitada pelas nervuras. }\end{array}$ \\
\hline
\end{tabular}


As características geométricas dos elementos finitos utilizados para simular cada elemento estrutural são apresentadas nas Tabelas 5.14 a 5.19. As nomenclaturas R e T apresentadas pelos elementos de viga significam seção retangular e seção $\mathrm{T}$.

TABELA 5.14: Características dos pilares nos modelos - Lajes com variação do número de nervuras por lado

\begin{tabular}{|c|c|c|c|c|c|c|c|c|}
\hline \multicolumn{9}{|c|}{$\begin{array}{l}\text { CARACTERÍSTICAS DOS PILARES - ELEMENTO BEAM4 - SEÇÃO RETANGULAR - MODELOS } \\
01 \text { AO 08 }\end{array}$} \\
\hline Nerv/lado & Pilar & $\begin{array}{c}\text { hy } \\
(\mathbf{c m})\end{array}$ & hz (cm) & $\mathrm{A}\left(\mathrm{cm}^{2}\right)$ & $\begin{array}{c}\mathbf{I z z} \\
\left(\mathrm{cm}^{4}\right)\end{array}$ & $\begin{array}{l}\text { Iyy } \\
\left(\mathrm{cm}^{4}\right)\end{array}$ & \begin{tabular}{|c|}
$\mathbf{I x x}$ \\
$\left(\mathrm{cm}^{4}\right)$
\end{tabular} & $\begin{array}{c}\text { Excent. } \\
\text { (cm) }\end{array}$ \\
\hline 5 A 15 & R 40/40 & 440 & 40 & 18000 & 213333,33 & 213333,33 & \begin{tabular}{|l|l}
42666,67 \\
\end{tabular} & 0,0 \\
\hline
\end{tabular}

TABELA 5.15: Características das vigas de contorno para os modelos 01 a 08 (exceto modelo 04) - Lajes com variação do número de nervuras por lado

\begin{tabular}{|c|c|c|c|c|c|c|c|c|}
\hline \multicolumn{9}{|c|}{$\begin{array}{l}\text { CARACTERÍSTICAS DAS VIGAS DE CONTORNO SIMULADAS PELO ELEMENTO BEAM44 } \\
\text { CONSIDERADO ATÉ O TOPO DA CAPA - SEÇÃO RETANGULAR - MODELOS } 01 \text { AO } 08 \\
\text { (EXCETO MODELO 04) }\end{array}$} \\
\hline Nerv/lado & Vigas & $\begin{array}{c}\text { hy } \\
(\mathrm{cm})\end{array}$ & $\begin{array}{c}\text { hz } \\
(\mathbf{c m})\end{array}$ & $\begin{array}{c}\mathbf{A} \\
\left(\mathrm{cm}^{2}\right)\end{array}$ & $\begin{array}{c}\mathbf{I z z} \\
\left(\mathrm{cm}^{4}\right)\end{array}$ & $\begin{array}{c}\text { Iyy } \\
\left(\mathbf{c m}^{4}\right)\end{array}$ & $\begin{array}{c}\mathbf{I x x} \\
\left(\mathrm{cm}^{4}\right)\end{array}$ & $\begin{array}{c}\text { Excent } \\
(\mathbf{c m})\end{array}$ \\
\hline 5 & R 20/36 & 20 & 36 & 720 & 24000 & 777760 & 48800 & 15,5 \\
\hline 6 & R 20/42 & 20 & 42 & 840 & 28000 & 123480 & 5600 & 18,5 \\
\hline 7 & R 20/48 & 20 & 48 & 960 & 32000 & 184320 & 6400 & 21,5 \\
\hline 8 & R 20/54 & 20 & 54 & 1080 & 36000 & 262440 & 7200 & 24,5 \\
\hline 9 & R 20/60 & 20 & 60 & 1200 & 40000 & 360000 & 8000 & 24,5 \\
\hline 10 & R 20/66 & 20 & 66 & 1320 & 44000 & 479160 & 8800 & 27,5 \\
\hline 11 & R 20/72 & 20 & 72 & 1440 & 48000 & 622080 & 9600 & 33,5 \\
\hline 12 & R 20/78 & 20 & 78 & 1560 & 52000 & 790920 & 10400 & 36,5 \\
\hline 13 & R 20/84 & 20 & 84 & 1680 & 56000 & 987840 & 11200 & 39,5 \\
\hline 14 & R 20/90 & 20 & 90 & 1800 & 60000 & 1215000 & 12000 & 42,5 \\
\hline 15 & R 20/96 & 20 & 96 & 1920 & 64000 & 1474560 & 12800 & 45,5 \\
\hline
\end{tabular}

TABELA 5.16: Características das vigas de contorno para o modelo 04 - Lajes com variação do número de nervuras por lado

\begin{tabular}{c|c|c}
\hline \multicolumn{3}{c}{ CARACTERÍSTICAS DAS VIGAS DE CONTORNO SIMULADAS PELO ELEMENTO SHELL63 - } \\
MODELO 04
\end{tabular}


TABELA 5.17: Características das nervuras para os modelos 01, 02, 03, 05 e 06 - Lajes com variação do número de nervuras por lado

CARACTERÍSTICAS DAS NERVURAS SIMULADAS POR ELEMENTOS BEAM44 (EXCÊNTRICOS) E BEAM4 (CONCÊNTRICOS) - LAJES COM NÚMERO DE NERVURAS POR LADO DE 05 A 15

\begin{tabular}{c|c|c|c|c|c|c|c|c}
\hline Modelo & Nervura & $\begin{array}{c}\text { hy } \\
(\mathbf{c m})\end{array}$ & $\begin{array}{c}\mathbf{h z} \\
(\mathbf{c m})\end{array}$ & $\begin{array}{c}\mathbf{A} \\
\left(\mathbf{c m}^{\mathbf{2}}\right)\end{array}$ & $\begin{array}{c}\mathbf{I z z} \\
\left(\mathbf{c m}^{\mathbf{4}}\right)\end{array}$ & $\begin{array}{c}\mathbf{I y y} \\
\left(\mathbf{c m}^{\mathbf{4}}\right)\end{array}$ & $\begin{array}{c}\mathbf{I x x} \\
\left(\mathbf{c m}^{\mathbf{4}}\right)\end{array}$ & $\begin{array}{c}\text { Excent. } \\
(\mathbf{c m})\end{array}$ \\
\hline \hline 01 & $\mathrm{R} 8 / 20$ & 8 & 20 & 160 & 853,33 & 5333,33 & 170,67 & 0,0 \\
\hline 02 & $\mathrm{R} 8 / 20$ & 8 & 20 & 160 & 853,33 & 5333,33 & 170,67 & 7,5 \\
\hline 03 & $\mathrm{R} 8 / 15$ & 8 & 15 & 120 & 640,00 & 2250,00 & 128,00 & 10,0 \\
\hline 05 & $\mathrm{~T} 8 \mathrm{X} 20 \mathrm{X} 60$ & 8 & 20 & 420 & 90640 & 11446 & 246 & 0,0 \\
\hline 06 & $\mathrm{~T} 8 \mathrm{X} 20 \mathrm{X} 60$ & 8 & 20 & 420 & 90640 & 11446 & 246 & 0,0 \\
\hline \hline
\end{tabular}

TABELA 5.18: Características das nervuras para os modelos 04, 07 e 08 - Lajes com variação do número de nervuras por lado

\begin{tabular}{c|c|c}
\hline \hline \multicolumn{3}{c}{ CARACTERÍSTICAS DAS NERVURAS SIMULADAS POR ELEMENTOS SHELL63 - LAJES } \\
COM NÚMERO DE NERVURAS POR LADO DE 05 A 15 \\
\hline Modelo & Nervura & h (cm) \\
\hline \hline 04 & CASCA 8/17,5 & 8,000 \\
\hline 07 & LAJE MACIÇA EQUIVAL. & 13,179 \\
\hline 08 & LAJE MACIÇA EQUIVAL. & 10,543 \\
\hline \hline
\end{tabular}

TABELA 5.19: Características da capa - Lajes com variação do número de nervuras por lado

\begin{tabular}{|c|c|c|}
\hline \multicolumn{3}{|c|}{$\begin{array}{l}\text { CARACTERÍSTICAS DA CAPA SIMULADA POR ELEMENTOS SHELL63 - LAJES COM } \\
\text { NÚMERO DE NERVURAS POR LADO DE } 05 \text { A } 15\end{array}$} \\
\hline Modelo & Nervura & $\mathbf{h}(\mathbf{c m})$ \\
\hline 01 & CASCA & 5,0 \\
\hline 02 & CASCA & 5,0 \\
\hline 03 & CASCA & 5,0 \\
\hline 04 & CASCA & 5,0 \\
\hline 05 & CASCA & 5,0 \\
\hline
\end{tabular}

O número de elementos finitos utilizados em cada modelo analisado é demonstrado abaixo. 
TABELA 5.20: Número de elementos finitos em cada modelo analisado, para lajes com variação de $a_{1} / 1$

\begin{tabular}{|c|c|c|c|c|c|c|c|c|c|}
\hline \multirow{2}{*}{ Nerv/lado } & \multirow{2}{*}{ Elementos } & \multicolumn{8}{|c|}{ Modelos numéricos de análise } \\
\hline & & 01 & 02 & 03 & 04 & 05 & 06 & 07 & 08 \\
\hline \multirow{3}{*}{5} & BEAM4 & 244 & 4 & 4 & 36 & 244 & 244 & 4 & 4 \\
\hline & BEAM44 & 96 & 336 & 336 & 0 & 96 & 96 & 96 & 96 \\
\hline & SHELL63 & 576 & 576 & 576 & 2544 & 576 & 0 & 576 & 576 \\
\hline \multirow{3}{*}{6} & BEAM4 & 340 & 44 & 44 & 440 & 340 & 340 & 44 & 4 \\
\hline & BEAM44 & 112 & 448 & 448 & 0 & 112 & 112 & 112 & 112 \\
\hline & SHELL63 & 784 & 784 & 784 & 3472 & 784 & 0 & 784 & 784 \\
\hline \multirow{3}{*}{7} & BEAM4 & 452 & 4 & 4 & 44 & 452 & 452 & 4 & 4 \\
\hline & BEAM44 & 128 & 576 & 576 & 0 & 128 & 128 & 128 & 128 \\
\hline & SHELL63 & 1024 & 1024 & 1024 & 4544 & 1024 & 0 & 1024 & 1024 \\
\hline \multirow{3}{*}{8} & BEAM4 & 580 & 4 & 4 & 52 & 580 & 580 & 4 & 4 \\
\hline & BEAM44 & 144 & 720 & 720 & 0 & 144 & 144 & 144 & 144 \\
\hline & SHELL63 & 1296 & 1296 & 1296 & 5904 & 1296 & 0 & 1296 & 1296 \\
\hline \multirow{3}{*}{9} & BEAM4 & 724 & 44 & 4 & 56 & 724 & 724 & 4 & 44 \\
\hline & BEAM44 & 160 & 880 & 880 & 0 & 160 & 160 & 160 & 160 \\
\hline & SHELL63 & 1600 & 1600 & 1600 & 7280 & 1600 & 0 & 1600 & 1600 \\
\hline \multirow{3}{*}{10} & BEAM4 & 884 & 4 & 4 & 60 & 884 & 884 & 4 & 44 \\
\hline & BEAM44 & 176 & 1056 & 1056 & 0 & 176 & 176 & 176 & 176 \\
\hline & SHELL63 & 1936 & 1936 & 1936 & 8800 & 1936 & 0 & 1936 & 1936 \\
\hline \multirow{3}{*}{11} & BEAM4 & 1060 & 44 & 4 & 6 64 & 1060 & 1060 & 4 & 4 \\
\hline & BEAM44 & 192 & 1248 & 1248 & 0 & 192 & 192 & 192 & 192 \\
\hline & SHELL63 & 2304 & 2304 & 2304 & 10464 & 2304 & 0 & 2304 & 2304 \\
\hline \multirow{3}{*}{12} & BEAM4 & 1252 & 4 & 4 & 68 & 1252 & 1252 & 4 & 4 \\
\hline & BEAM44 & 208 & 1456 & 1456 & 0 & 208 & 208 & 208 & 208 \\
\hline & SHELL63 & 2704 & 2704 & 2704 & 12272 & 2704 & 0 & 2704 & 2704 \\
\hline \multirow{3}{*}{13} & BEAM4 & 14660 & 44 & 4 & 7 & 14460 & 14460 & 44 & 44 \\
\hline & BEAM44 & 224 & 1680 & 1680 & 0 & 224 & 224 & 224 & 224 \\
\hline & SHELL63 & 3136 & 3136 & 3136 & 14448 & 3136 & 0 & 3136 & 3136 \\
\hline \multirow{3}{*}{14} & BEAM4 & 1684 & 4 & 4 & 80 & 1648 & 1648 & 4 & 4 \\
\hline & BEAM44 & 240 & 1920 & 1920 & 0 & 240 & 240 & 240 & 240 \\
\hline & SHELL63 & 3600 & 3600 & 3600 & 16560 & 360 & 0 & 360 & 360 \\
\hline \multirow{3}{*}{15} & BEAM4 & 1924 & 4 & 4 & 84 & 1924 & 1924 & 4 & 4 \\
\hline & BEAM44 & 256 & 2176 & 2176 & 0 & 256 & 256 & 256 & 256 \\
\hline & SHELL63 & 4096 & 4096 & 4096 & 18816 & 4096 & 0 & 4096 & 4096 \\
\hline
\end{tabular}

Os pontos de medição de deslocamentos e esforços, nos modelos numéricos, são apresentados abaixo nas Figuras 5.5 a 5.15: 


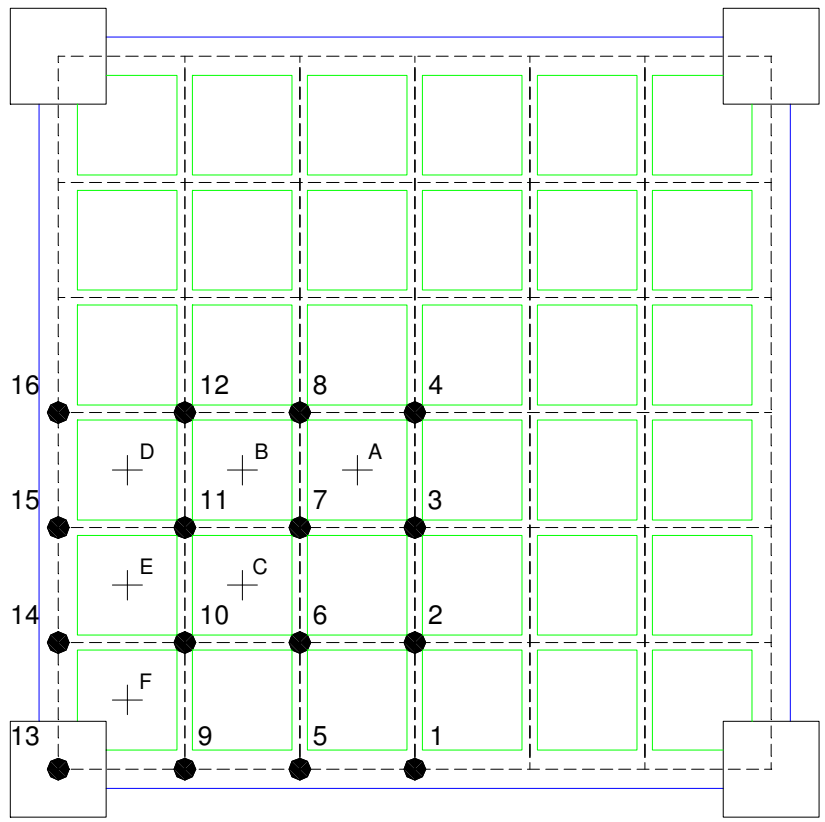

VARIAÇÃO DO NÚMERO DE NERVURAS POR LADO LAJE $\mathrm{N}=5$ NERVURAS POR LADO ESPAÇAMENTO ENTRE EIXOS DE NERVURAS $=60 \mathrm{~cm}$ VIGAS EXTERNAS $20 / 36 \mathrm{~cm}$

ALTURA TOTAL DA LAJE $\mathrm{h}=20 \mathrm{~cm}$

CAPA hf $=5 \mathrm{~cm}$

PILARES $40 / 40 \mathrm{~cm}$ - ALTURA $280 \mathrm{~cm}$ $\mathrm{a} 1 / \mathrm{I}=0,1667$

FIGURA 5.5: Pontos de medição de deslocamentos e esforços - Modelos com número de nervuras por lado $\mathrm{N}=5$

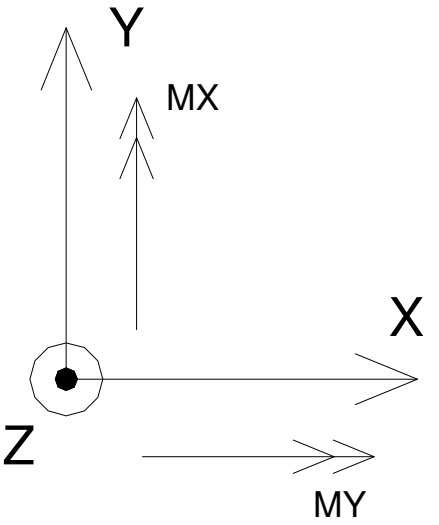

MEDIÇÃO DE DESLOCAMENTOS E ESFORÇOS

+ MEDIÇÃO DE ESFORÇOS 


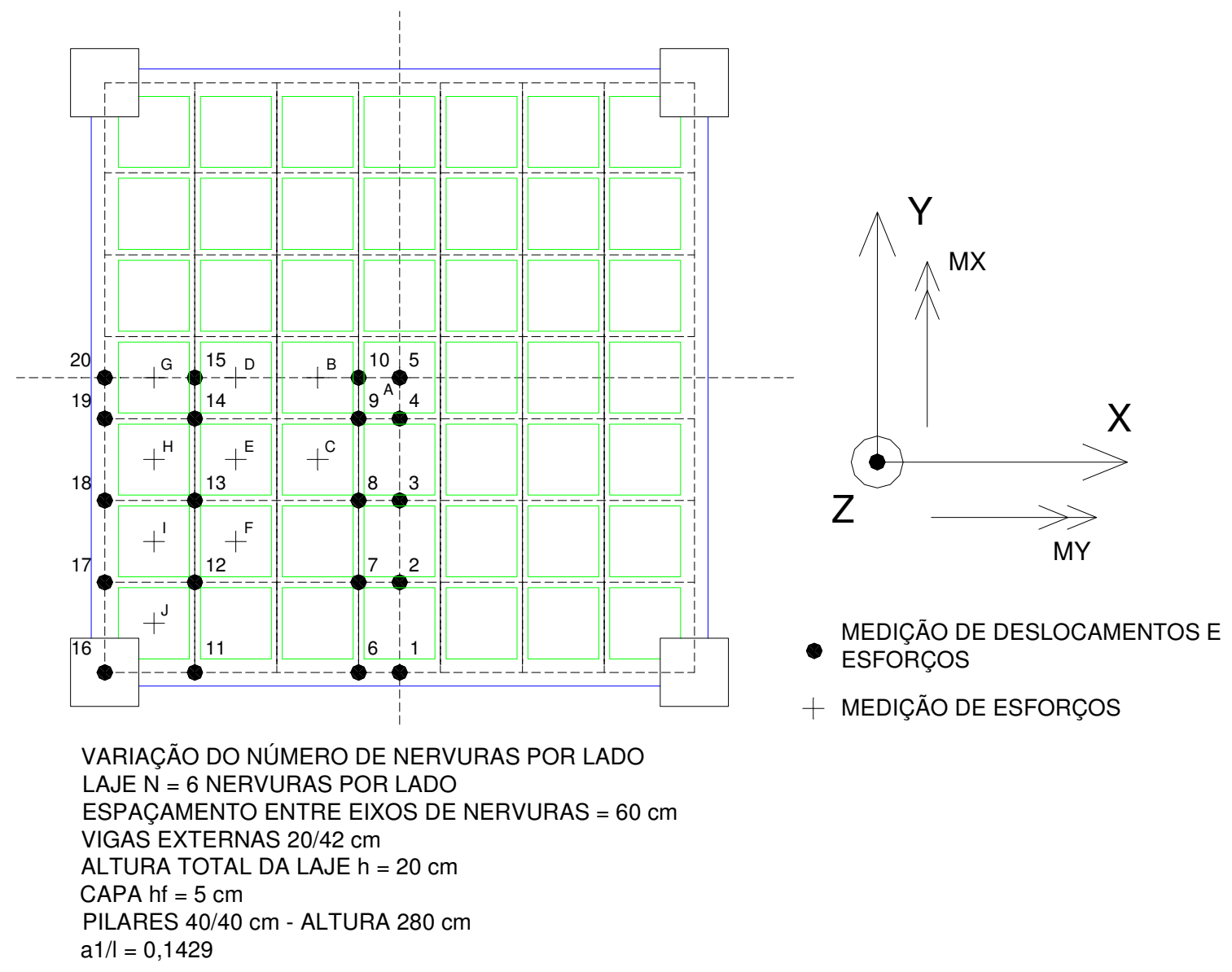

FIGURA 5.6: Pontos de medição de deslocamentos e esforços - Modelos com número de nervuras por lado $\mathrm{N}=6$ 

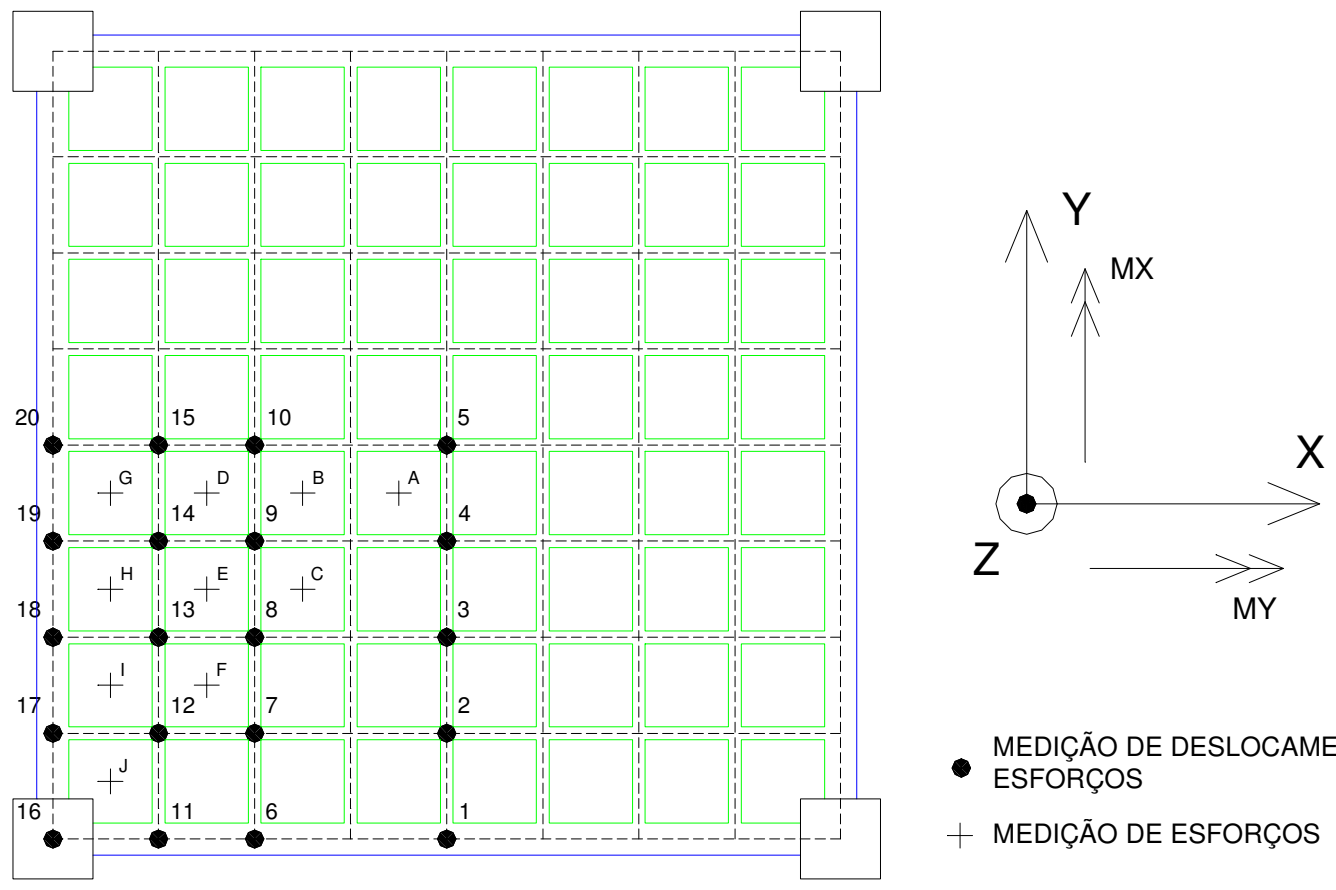

VARIAÇÃO DO NÚMERO DE NERVURAS POR LADO

LAJE $\mathrm{N}=7$ NERVURAS POR LADO

ESPAÇAMENTO ENTRE EIXOS DE NERVURAS $=60 \mathrm{~cm}$

VIGAS EXTERNAS $20 / 48 \mathrm{~cm}$

ALTURA TOTAL DA LAJE $\mathrm{h}=20 \mathrm{~cm}$

CAPA hf $=5 \mathrm{~cm}$

PILARES $40 / 40 \mathrm{~cm}$ - ALTURA $280 \mathrm{~cm}$

a1/l $=0,1250$

FIGURA 5.7: Pontos de medição de deslocamentos e esforços - Modelos com número de nervuras por lado $\mathrm{N}=7$ 


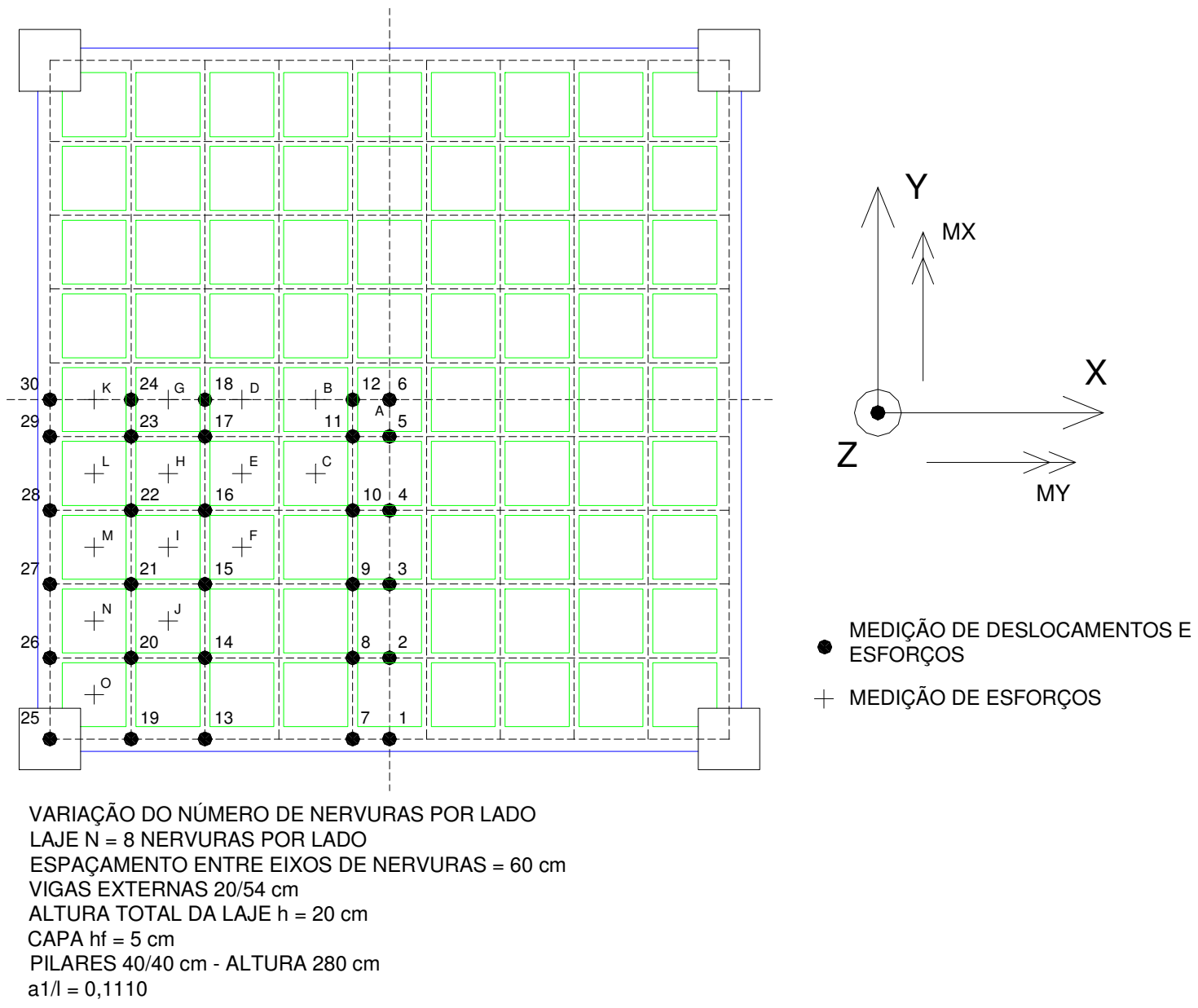

FIGURA 5.8: Pontos de medição de deslocamentos e esforços - Modelos com número de nervuras por lado $\mathrm{N}=8$ 


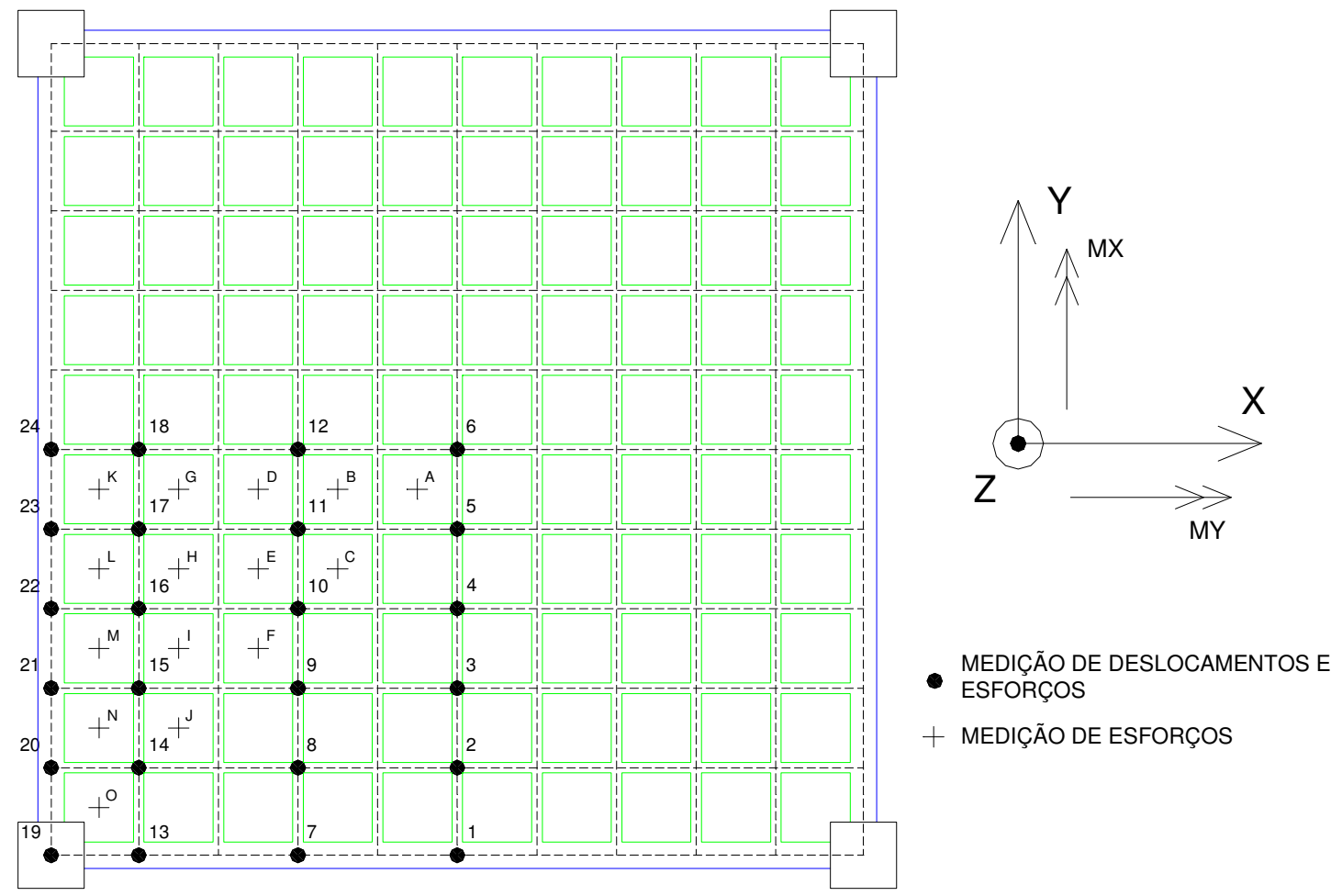

VARIAÇÃO DO NÚMERO DE NERVURAS POR LADO

LAJE $\mathrm{N}=9$ NERVURAS POR LADO

ESPAÇAMENTO ENTRE EIXOS DE NERVURAS $=60 \mathrm{~cm}$

VIGAS EXTERNAS $20 / 60 \mathrm{~cm}$

ALTURA TOTAL DA LAJE $\mathrm{h}=20 \mathrm{~cm}$

CAPA hf $=5 \mathrm{~cm}$

PILARES $40 / 40 \mathrm{~cm}$ - ALTURA $280 \mathrm{~cm}$

$\mathrm{a} 1 / \mathrm{l}=0,1000$

FIGURA 5.9: Pontos de medição de deslocamentos e esforços - Modelos com número de nervuras por lado $\mathrm{N}=9$ 


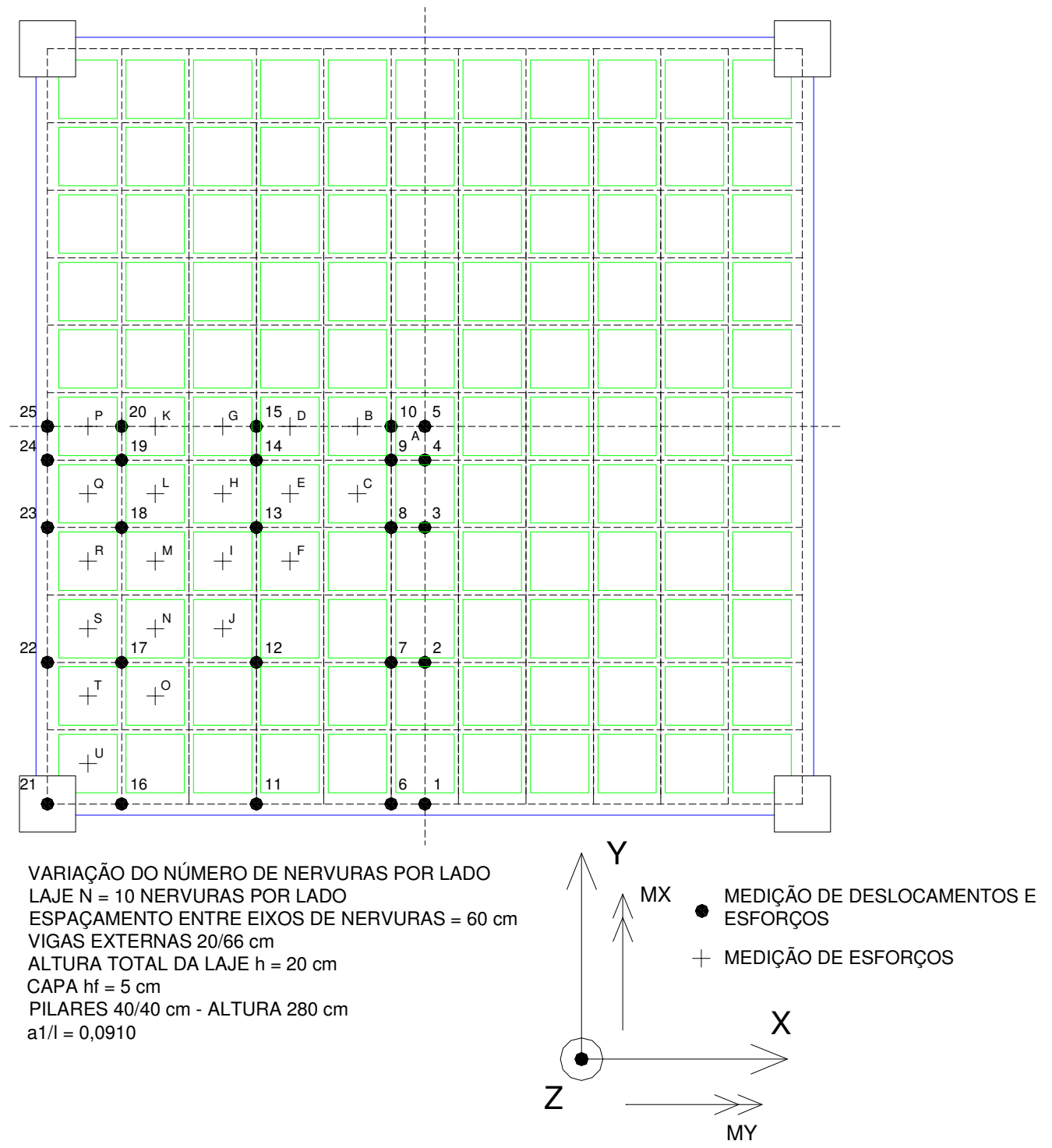

FIGURA 5.10: Pontos de medição de deslocamentos e esforços - Modelos com número de nervuras por lado $\mathrm{N}=10$ 


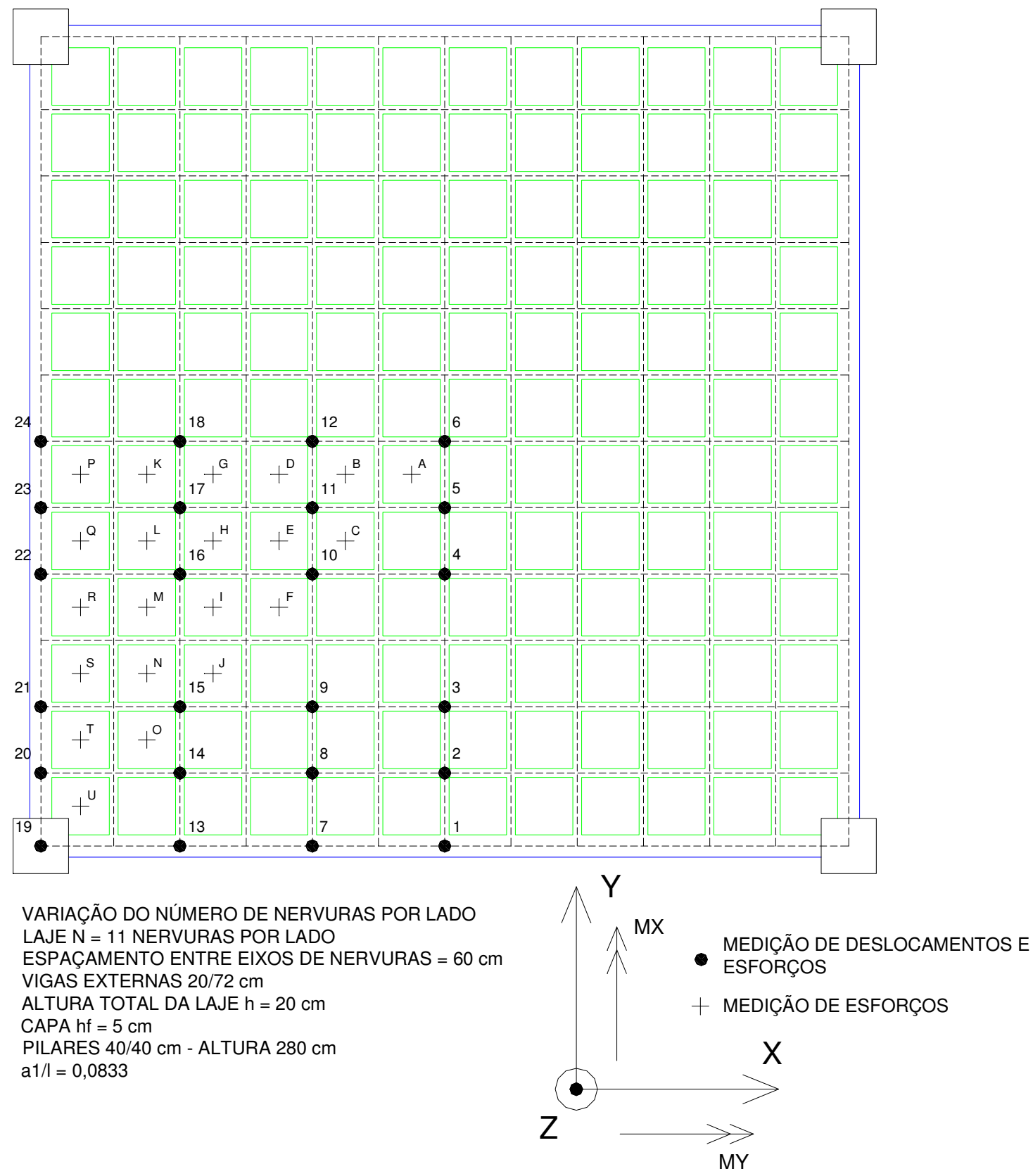

FIGURA 5.11: Pontos de medição de deslocamentos e esforços - Modelos com número de nervuras por lado $\mathrm{N}=11$ 


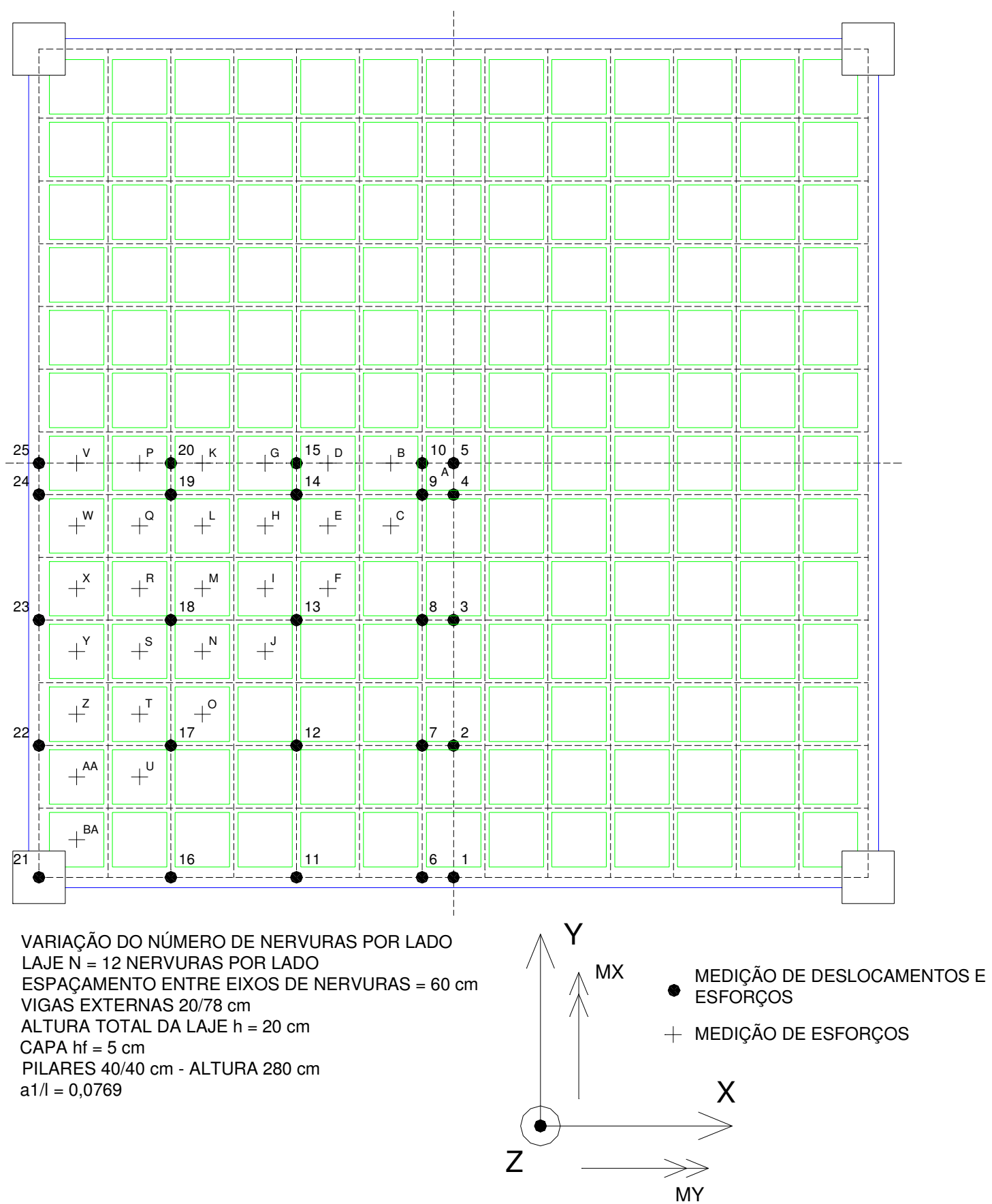

FIGURA 5.12: Pontos de medição de deslocamentos e esforços - Modelos com número de nervuras por lado $\mathrm{N}=12$ 


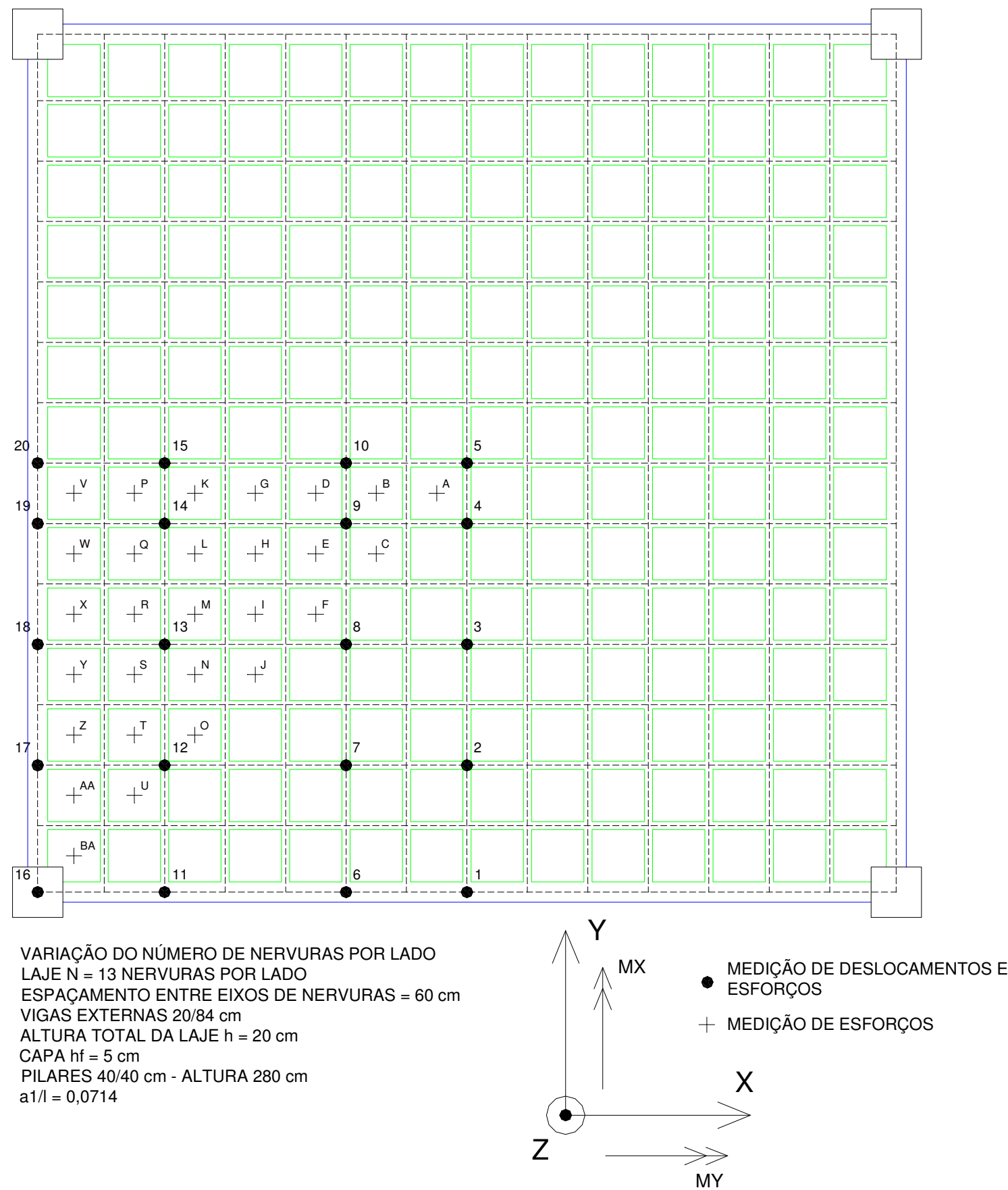

FIGURA 5.13: Pontos de medição de deslocamentos e esforços - Modelos com número de nervuras por lado $\mathrm{N}=13$ 


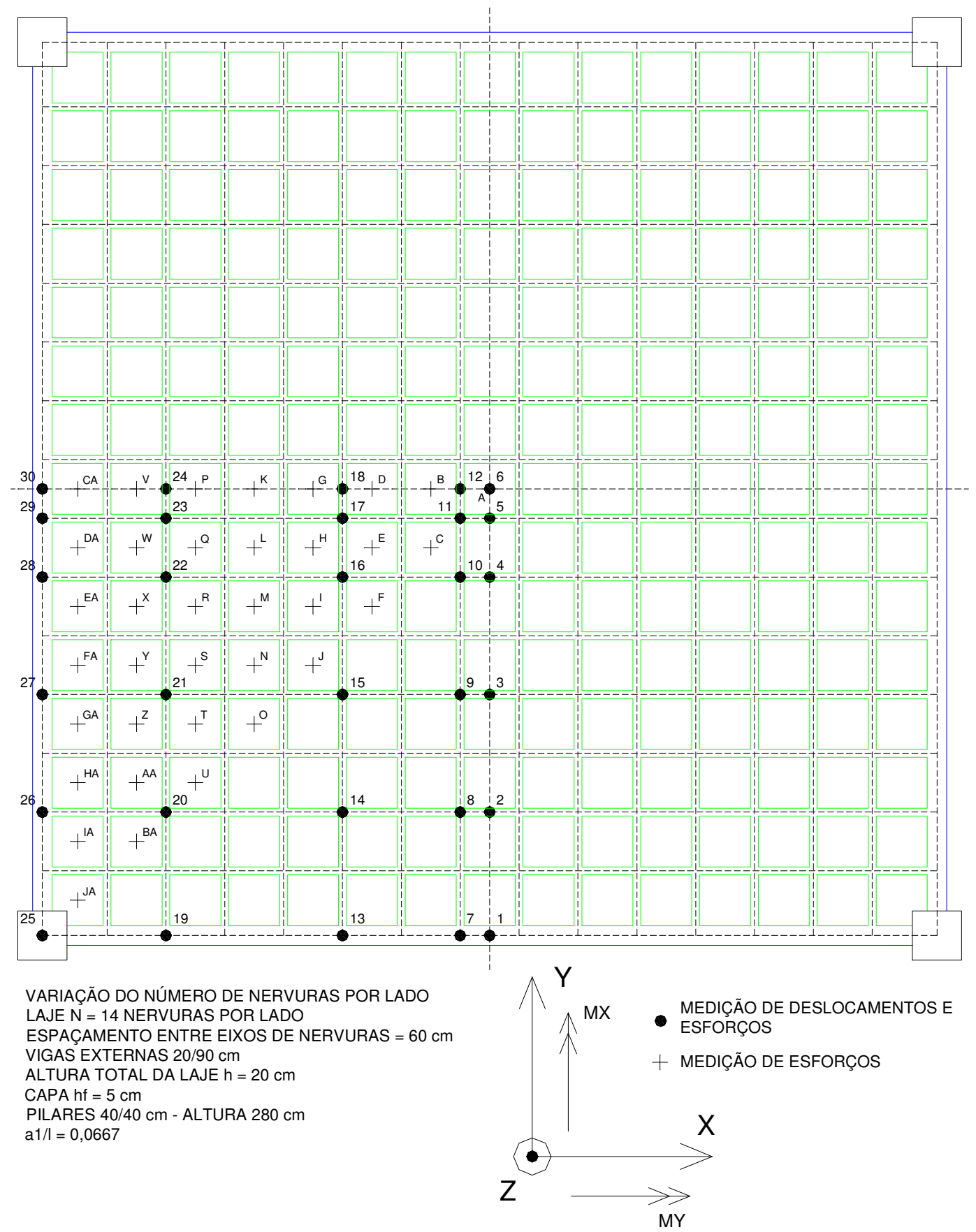

FIGURA 5.14: Pontos de medição de deslocamentos e esforços - Modelos com número de nervuras por lado $\mathrm{N}=14$ 


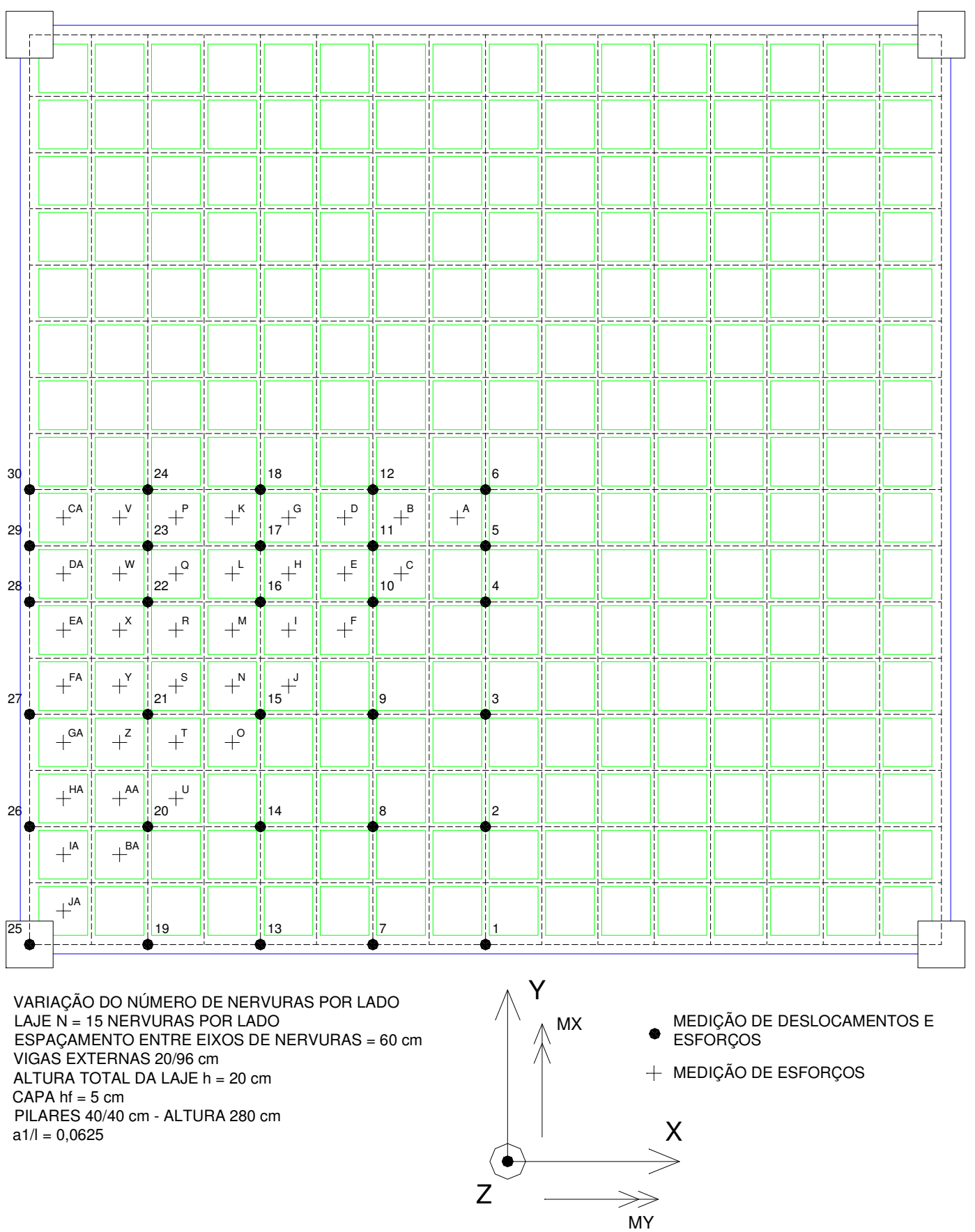

FIGURA 5.15: Pontos de medição de deslocamentos e esforços - Modelos com número de nervuras por lado $\mathrm{N}=15$ 


\subsubsection{Variação do espaçamento entre os eixos das nervuras, com distância entre pontos de apoio ajustada a um número fixo de nervuras por lado}

Para esta experimentação criou-se um pavimento padrão composto de um pano de laje nervurada apoiada em quatro vigas rígidas no contorno, e em cada canto um pilar. A altura da capa foi considerada como $h_{\mathrm{f}}=5 \mathrm{~cm}$ e a altura total da laje como h=20 cm. Fixou-se também o número de nervuras por lado $\mathrm{N}=10$, ajustando-se a distância entre pontos de apoio fixo para obter os seguintes espaçamentos entre nervuras:

$$
40 \mathrm{~cm} \quad 50 \mathrm{~cm} \quad 60 \mathrm{~cm} \quad 70 \mathrm{~cm} \quad 80 \mathrm{~cm} \quad 90 \mathrm{~cm}
$$

Como cada espaçamento fixo gera um total de 08 modelos (modelos numéricos 01 a 08, apresentados no Capítulo 4), tem-se nesta experimentação 48 modelos processados, considerando apenas uma valor de carga uniformemente distribuída.

Apresenta-se, na Figura 5.16, a forma estrutural da laje experimentada:

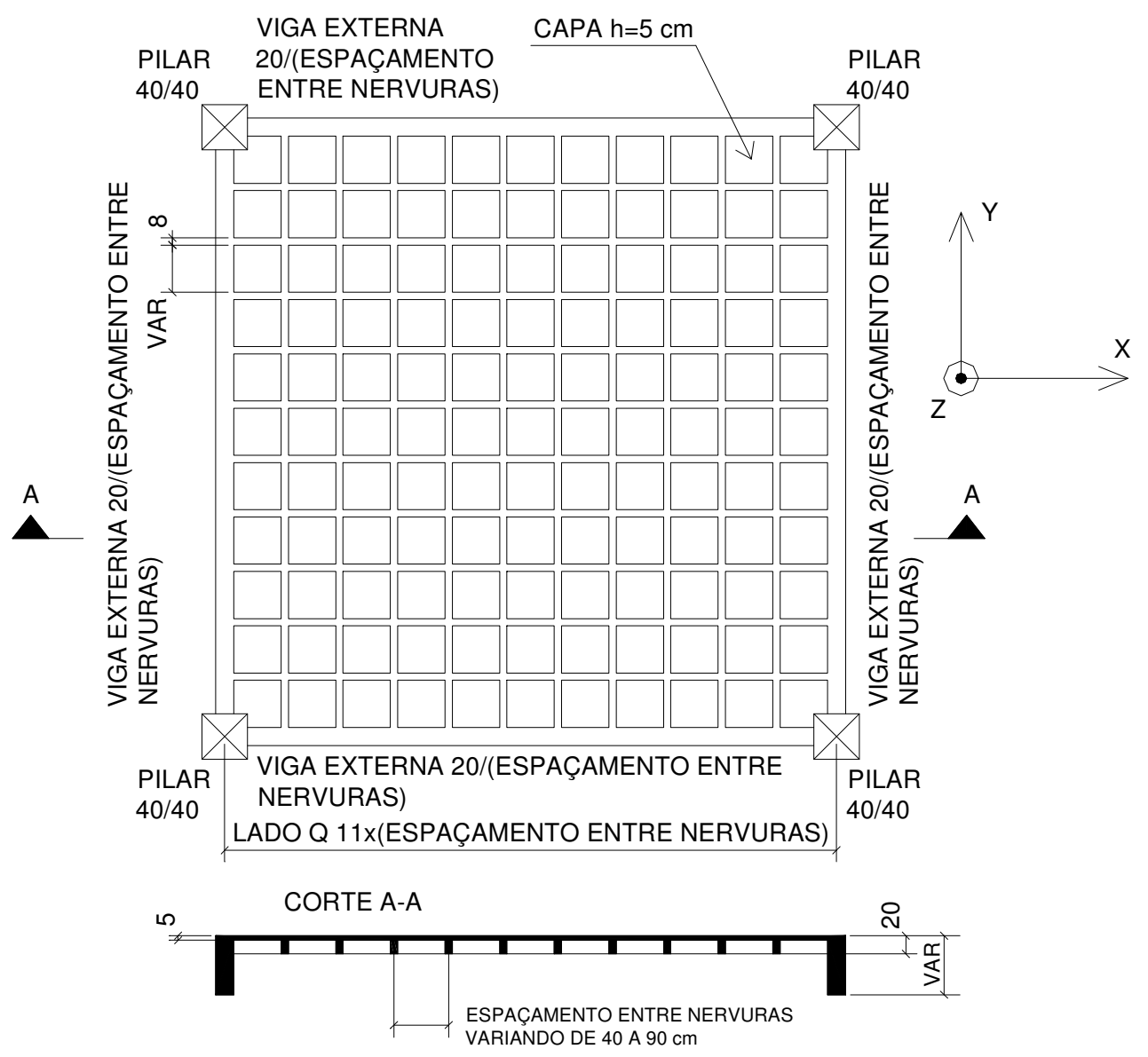

FIGURA 5.16: Forma estrutural dos modelos com variação do número de nervuras por lado 
As características do material concreto armado considerado nas análises elásticas com $\mathrm{f}_{\mathrm{ck}}=25 \mathrm{MPa}$ são apresentadas na Tabela 5.21:

TABELA 5.21: Propriedades do Concreto Armado utilizado nas modelagens numéricas - Lajes com variação do espaçamento entre nervuras

\begin{tabular}{|c|c|c|c|}
\hline \multicolumn{4}{|c|}{ CARACTERÍSTICAS DO MATERIAL } \\
\hline \multirow{2}{*}{ MODELO } & \multicolumn{3}{|c|}{ PROPRIEDADES DO CONCRETO ARMADO } \\
\hline & $\mathrm{E}_{\mathrm{cs}}\left(\mathrm{kN} / \mathrm{cm}^{2}\right)$ & Coeficiente de Poisson & $\mathrm{G}_{\mathrm{c}}\left(\mathrm{kN} / \mathrm{cm}^{2}\right)$ \\
\hline $01 \mathrm{~A} 07$ & 2380 & 0,20 & 357 \\
\hline 08 & 2380 & 0,20 & 952 \\
\hline
\end{tabular}

Os carregamentos aplicados aos modelos são mostrados na Tabela 5.22.

TABELA 5.22: Carregamentos aplicados nas lajes nervuradas - Lajes com variação do espaçamento entre nervuras

\begin{tabular}{c|c}
\hline \hline \multicolumn{2}{c}{ CARRREGAMENTO APLICADO NAS LAJES NERVURADAS } \\
\hline MODELOS & DESCRIÇÃO DO CARREGAMENTO \\
\hline \hline 01 A 08 ( EXCETO 06) & Carregamento uniformemente aplicado sobre a capa de q = -0,00075 \\
$\mathrm{kN} / \mathrm{cm}^{2}$
\end{tabular}

As características geométricas dos elementos finitos utilizados para simular cada elemento estrutural são apresentadas nas Tabelas 5.23 a 5.28. As nomenclaturas R e T apresentadas pelos elementos de viga significam seção retangular e seção $\mathrm{T}$.

TABELA 5.23: Características dos pilares nos modelos - Lajes com variação do espaçamento entre os eixos das nervuras

\begin{tabular}{|c|c|c|c|c|c|c|c|c|}
\hline \multicolumn{9}{|c|}{$\begin{array}{l}\text { CARACTERÍSTICAS DOS PILARES - ELEMENTO BEAM4 - SEÇÃO RETANGULAR - MODELOS } \\
\text { 01 AO } 08\end{array}$} \\
\hline $\begin{array}{l}\text { Espaçam. } \\
\text { Nervuras } \\
\end{array}$ & Pilar & $\begin{array}{c}\text { hy } \\
(\mathrm{cm})\end{array}$ & $\mathbf{h z}(\mathbf{c m})$ & $\mathrm{A}\left(\mathrm{cm}^{2}\right)$ & $\begin{array}{c}\text { Izz } \\
\left(\mathbf{c m}^{4}\right) \\
\end{array}$ & $\begin{array}{c}\mathbf{I y y} \\
\left(\mathrm{cm}^{4}\right) \\
\end{array}$ & $\begin{array}{c}\mathbf{I x x} \\
\left(\mathrm{cm}^{\mathbf{4}}\right) \\
\end{array}$ & $\begin{array}{c}\text { Excent. } \\
(\mathrm{cm})\end{array}$ \\
\hline 40 A 90 & R 40/40 & 40 & 40 & 1600 & 213333,33 & 213333,33 & 42666,67 & 0,0 \\
\hline
\end{tabular}


TABELA 5.24: Características das vigas de contorno para os modelos 01 a 08 (exceto modelo 04) - Lajes com variação do espaçamento entre os eixos das nervuras

\begin{tabular}{|c|c|c|c|c|c|c|c|c|}
\hline \multicolumn{9}{|c|}{$\begin{array}{l}\text { CARACTERÍSTICAS DAS VIGAS DE CONTORNO SIMULADAS PELO ELEMENTO BEAM44 } \\
\text { CONSIDERADO ATÉ O TOPO DA CAPA - SEÇÃO RETANGULAR - MODELOS } 01 \text { AO } 08 \\
\text { (EXCETO MODELO 04) }\end{array}$} \\
\hline $\begin{array}{l}\text { Espaçam. } \\
\text { Nervuras }\end{array}$ & Vigas & $\begin{array}{c}\text { hy } \\
\text { (cm) }\end{array}$ & $\begin{array}{c}\text { hz } \\
(\mathbf{c m})\end{array}$ & $\begin{array}{c}\mathrm{A} \\
\left(\mathrm{cm}^{2}\right)\end{array}$ & $\operatorname{Izz}\left(\mathrm{cm}^{4}\right)$ & Iyy $\left(\mathrm{cm}^{4}\right)$ & $\begin{array}{c}\mathbf{I x x} \\
\left(\mathbf{c m}^{4}\right)\end{array}$ & $\begin{array}{c}\text { Excent. } \\
(\mathbf{c m})\end{array}$ \\
\hline 40 & R 20/40 & 20 & 40 & 800 & 26666,67 & 106666,67 & 5333,33 & 17,5 \\
\hline 50 & R 20/50 & 20 & 50 & 1000 & 33333,33 & 208333,33 & 6666,67 & 22,5 \\
\hline 60 & R 20/60 & 20 & 60 & 1200 & 40000,00 & 360000,00 & 8000,00 & 27,5 \\
\hline 70 & R 20/70 & 20 & 70 & 1400 & 46666,67 & 571666,67 & 9333,33 & 32,5 \\
\hline 80 & R 20/80 & 20 & 80 & 1600 & 53333,33 & 853333,33 & 10666,67 & 37,5 \\
\hline 90 & R 20/90 & 20 & 90 & 1800 & 60000,00 & 1215000,00 & 12000,00 & 42,5 \\
\hline
\end{tabular}

TABELA 5.25: Características das vigas de contorno para o modelo 04 - Lajes com variação do espaçamento entre os eixos das nervuras

\begin{tabular}{c|c|c}
\hline \multicolumn{3}{c}{ CARACTERÍSTICAS DAS VIGAS DE CONTORNO SIMULADAS PELO ELEMENTO SHELL63 - } \\
MODELO 04
\end{tabular}

TABELA 5.26: Características das nervuras para os modelos 01, 02, 03, 05 e 06 - Lajes com variação do espaçamento entre os eixos das nervuras

\begin{tabular}{|c|c|c|c|c|c|c|c|c|}
\hline \multicolumn{9}{|c|}{$\begin{array}{c}\text { CARACTERÍSTICAS DAS NERVURAS SIMULADAS POR ELEMENTOS BEAM44 } \\
\text { (EXCÊNTRICOS) E BEAM4 (CONCÊNTRICOS) }\end{array}$} \\
\hline $\begin{array}{c}\text { Espaçam. } \\
\text { Nervura }\end{array}$ & Nervura & $\begin{array}{l}\text { hy } \\
(\mathrm{cm})\end{array}$ & $\begin{array}{c}\text { hz } \\
(\mathrm{cm})\end{array}$ & $\underset{\left(\mathbf{c m}^{2}\right)}{\mathrm{A}}$ & $\begin{array}{c}\mathbf{I z z} \\
\left(\mathrm{cm}^{4}\right)\end{array}$ & $\begin{array}{c}\text { Iyy } \\
\left(\mathrm{cm}^{4}\right)\end{array}$ & $\begin{array}{c}\mathbf{I x x} \\
\left(\mathrm{cm}^{4}\right)\end{array}$ & $\begin{array}{c}\text { Excent. } \\
\text { (cm) }\end{array}$ \\
\hline \multicolumn{9}{|c|}{ MODELO 01} \\
\hline 40 A 90 & R 8/20 & 8 & 20 & 160 & 853,33 & 5333,33 & $\begin{array}{ll}170,67 \\
\end{array}$ & 0,0 \\
\hline \multicolumn{9}{|c|}{ MODELO 02} \\
\hline 40 A 90 & R 8/20 & 8 & 20 & 160 & 853,33 & 5333,33 & 170,67 & 7,5 \\
\hline \multicolumn{9}{|c|}{$\begin{array}{l}\text { MODELO } 03 \\
\end{array}$} \\
\hline $40 \mathrm{~A} 90$ & R8/15 & 8 & 15 & 120 & 640,00 & 2250,00 & 128,00 & $\overline{10,0}$ \\
\hline \multicolumn{9}{|c|}{ MODELO 05} \\
\hline 40 & T T 8/20/40 & 8 & 20 & 320 & 27307 & 10167 & 207 & 0,0 \\
\hline 50 & T 8/20/50 & 8 & 20 & 370 & 52723 & 10879 & 226 & 0,0 \\
\hline 60 & T 8/20/60 & 8 & 20 & 420 & 90640 & 11446 & 246 & 0,0 \\
\hline 70 & T 8/20/70 & 8 & 20 & 470 & 143557 & 11915 & 266 & 0,0 \\
\hline 80 & T $8 / 20 / 80$ & 8 & 20 & 520 & 213973 & 12314 & 286 & 0,0 \\
\hline 90 & T 8/20/90 & 8 & 20 & 570 & 304390 & 12661 & 306 & 0,0 \\
\hline \multicolumn{9}{|c|}{ MODELO 06} \\
\hline 40 & T T 8/20/40 & 8 & 20 & 320 & 27307 & 10167 & 207 & 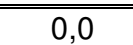 \\
\hline 50 & T 8/20/50 & 8 & 20 & 370 & 52723 & 10879 & 226 & 0,0 \\
\hline 60 & T 8/20/60 & 8 & 20 & 420 & 90640 & 11446 & 246 & 0,0 \\
\hline 70 & T 8/20/70 & 8 & 20 & 470 & 143557 & 11915 & 266 & 0,0 \\
\hline 80 & T 8/20/80 & 8 & 20 & 520 & 213973 & 12314 & 286 & 0,0 \\
\hline 90 & T 8/20/90 & 8 & 20 & 570 & 304390 & 12661 & 306 & 0,0 \\
\hline
\end{tabular}


TABELA 5.27: Características das nervuras para os modelos 04, 07 e 08 - Lajes com variação do espaçamento entre os eixos das nervuras

\begin{tabular}{|c|c|c|}
\hline \multicolumn{3}{|c|}{$\begin{array}{l}\text { CARACTERÍSTICAS DAS NERVURAS SIMULADAS POR ELEMENTOS SHELL63 - MODELOS } \\
\text { 04, } 07 \text { E } 08\end{array}$} \\
\hline Espaçamento Nervuras & Nervura & h (cm) \\
\hline \multicolumn{3}{|c|}{ MODELO 04} \\
\hline 40 A 90 & CASCA 8/17,5 & 8,000 \\
\hline \multicolumn{3}{|c|}{ MODELO 07} \\
\hline 40 & LAJE MACIÇA EQUIVAL. & 14,502 \\
\hline 50 & LAJE MACIÇA EQUIVAL. & 13,770 \\
\hline 60 & LAJE MACIÇA EQUIVAL. & 13,179 \\
\hline 70 & LAJE MACIÇA EQUIVAL. & 12,688 \\
\hline 80 & LAJE MACIÇA EQUIVAL. & 12,270 \\
\hline 90 & LAJE MACIÇA EQUIVAL. & 11,907 \\
\hline \multicolumn{3}{|c|}{ MODELO 08} \\
\hline 40 & LAJE MACIÇA EQUIVAL. & 11,602 \\
\hline 50 & LAJE MACIÇA EQUIVAL. & 11,016 \\
\hline 60 & LAJE MACIÇA EQUIVAL. & 10,543 \\
\hline 70 & LAJE MACIÇA EQUIVAL. & 10,150 \\
\hline 80 & LAJE MACIÇA EQUIVAL. & 9,816 \\
\hline 90 & LAJE MACIÇA EQUIVAL. & 9,526 \\
\hline
\end{tabular}

TABELA 5.28: Características da capa - Lajes com variação do espaçamento entre os eixos das nervuras

\begin{tabular}{c|c|c}
\hline \hline \multicolumn{2}{c}{ CARACTERÍSTICAS DA CAPA SIMULADA POR ELEMENTOS SHELL63 - LAJES COM } \\
ESPAÇAMENTO ENTRE NERVURAS DE $40 \mathrm{~A} \mathrm{90} \mathrm{cm}$ \\
\hline Modelo & Nervura & $\mathbf{h}(\mathbf{c m})$ \\
\hline 01 & CASCA & 5,0 \\
\hline 02 & CASCA & 5,0 \\
\hline 03 & CASCA & 5,0 \\
\hline 04 & CASCA & 5,0 \\
\hline 05 & CASCA & 5,0 \\
\hline \hline
\end{tabular}

O número de elementos finitos utilizados em cada modelo analisado é demonstrado abaixo. 
TABELA 5.29: Número de elementos finitos em cada modelo analisado, para lajes com variação do espaçamento entre os eixos das nervuras

\begin{tabular}{|c|c|c|c|c|c|c|c|c|c|}
\hline \multirow{2}{*}{ Espaçam. } & \multirow{2}{*}{ Elementos } & \multicolumn{8}{|c|}{ Modelos numéricos de análise } \\
\hline & & 01 & 02 & $\mathbf{0 3}$ & 04 & 05 & 06 & 07 & 08 \\
\hline \multirow{3}{*}{$40 \mathrm{~cm}$} & BEAM4 & 884 & 884 & 4 & 40 & 884 & 884 & 4 & 4 \\
\hline & BEAM44 & 176 & 176 & 1056 & 0 & 176 & 176 & 176 & 176 \\
\hline & SHELL63 & 1936 & 1936 & 1936 & 7920 & 1936 & 0 & 1936 & 1936 \\
\hline \multirow{3}{*}{$50 \mathrm{~cm}$} & BEAM4 & 884 & 884 & 4 & 48 & 884 & 884 & 4 & 4 \\
\hline & BEAM44 & 176 & 176 & 1056 & 0 & 176 & 176 & 176 & 176 \\
\hline & SHELL63 & 1936 & 1936 & 1936 & 8272 & 1936 & 0 & 1936 & 1936 \\
\hline \multirow{3}{*}{$60 \mathrm{~cm}$} & BEAM4 & 884 & 884 & 4 & 56 & 884 & 884 & 4 & 4 \\
\hline & BEAM44 & 176 & 176 & 1056 & 0 & 176 & 176 & 176 & 176 \\
\hline & SHELL63 & 1936 & 1936 & 1936 & 8624 & 1936 & 0 & 1936 & 1936 \\
\hline \multirow{3}{*}{$70 \mathrm{~cm}$} & BEAM4 & 884 & 884 & 4 & 64 & 884 & 884 & 4 & 4 \\
\hline & BEAM44 & 176 & 176 & 1056 & 0 & 176 & 176 & 176 & 176 \\
\hline & SHELL63 & 1936 & 1936 & 1936 & 8976 & 1936 & 0 & 1936 & 1936 \\
\hline \multirow{3}{*}{$80 \mathrm{~cm}$} & BEAM4 & 884 & 884 & 4 & 72 & 884 & 884 & 4 & 4 \\
\hline & BEAM44 & 176 & 176 & 1056 & 0 & 176 & 176 & 176 & 176 \\
\hline & SHELL63 & 1936 & 1936 & 1936 & 9328 & 1936 & 0 & 1936 & 1936 \\
\hline \multirow{3}{*}{$90 \mathrm{~cm}$} & BEAM4 & 884 & 884 & 4 & 80 & 884 & 884 & 4 & 4 \\
\hline & BEAM44 & 176 & 176 & 1056 & 0 & 176 & 176 & 176 & 176 \\
\hline & SHELL63 & 1936 & 1936 & 1936 & 9680 & 1936 & 0 & 1936 & 1936 \\
\hline
\end{tabular}

Os pontos de medição de deslocamentos e esforços, nos modelos numéricos, são apresentados abaixo na Figura 5.17: 


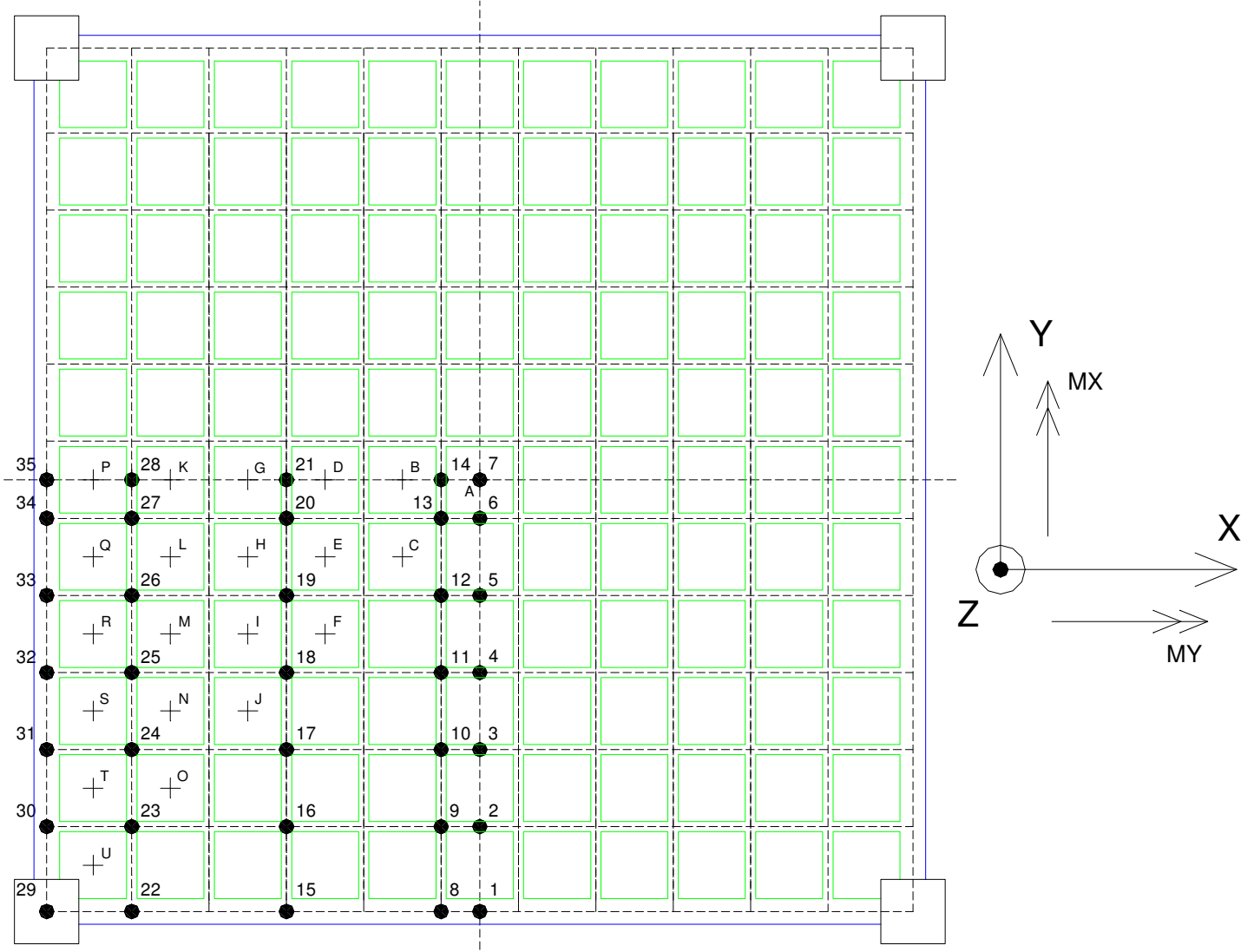

VARIAÇÃO DO ESPAÇAMENTO ENTRE EIXOS DE NERVURAS LAJES COM ESPACAMENTOS DE 40-50-60-70-80-90 cm NERVURAS POR LADO $=10$

VIGAS EXTERNAS 20/40 - 20/50 - 20/60 - 20/70 - 20/80 -20/90 cm (CONFORME ESPAÇAMENTO ENTRE NERVURAS) ALTURA TOTAL DA LAJE $\mathrm{h}=20 \mathrm{~cm}$ CAPA $h f=5 \mathrm{~cm}$

PILARES $40 / 40 \mathrm{~cm}$ - ALTURA $280 \mathrm{~cm}$ $\mathrm{a} 1 / \mathrm{I}=0,0910$

FIGURA 5.17: Pontos de medição de deslocamentos e esforços - Modelos com variação do espaçamento entre os eixos das nervuras

\subsection{RESULTADOS DAS EXPERIMENTAÇÕES NUMÉRICAS}

Após o processamento das lajes, em todos os modelos numéricos, fez-se a medição de deslocamentos e esforços, em vários pontos, apresentados nas Figuras anteriores.

A medição dos deslocamentos ortogonais ao plano da placa (UZ) é feita diretamente no ponto medido, utilizando ferramenta de pós-processamento do ANSYS 5.5 (chamada de "QUERY RESULTS"), em todos os modelos numéricos. O deslocamento UZ é considerado negativo quando as lajes deslocam-se do plano inicial para baixo, no sentido contrário ao eixo global z dos modelos. 
A medição dos esforços nas nervuras e vigas de contorno, nos modelos que simulam as mesmas por elementos de vigas BEAM4 e BEAM44, é feita pela leitura do esforço encontrado pela ferramenta "LINE-ELEMENT RESULT", sendo necessário entrar com códigos numéricos específicos que indicam, por exemplo, o momento fletor no nó inicial e no nó final dos elementos. Fez-se, então, medições de momentos fletores, cortantes e esforços normais em pontos das nervuras e vigas indicados nas figuras apresentadas anteriormente no item 5.2. Momento fletor positivo é aquele que traciona as fibras inferiores dos elementos de viga. Esforço Normal positivo traciona as fibras da seção transversal.

No Modelo 04, que simula as nervuras e vigas por elementos de casca SHELL63, a determinação dos mesmos esforços (momentos fletores, cortantes e esforços normais) é feita por meio de integrações de tensões, ao longo dos nós situados no ponto de análise dispostos segundo a altura da nervura. O ANSYS 5.5 disponibiliza ferramenta para as integrações, denominada de "PATH OPERATIONS". A Figura 5.18 demonstra o detalhe da criação de uma "PATH" ao longo da altura de uma nervura, com 05 pontos nodais para a integração, valor mínimo adotado neste trabalho para a determinação dos esforços nas nervuras e vigas simuladas pelo elemento de casca. Após a criação das "PATHS" correspondentes a cada ponto medido, para a integração, é necessário isolar, dos elementos estruturais que concorrem para o mesmo nó, apenas aqueles locados na direção da tensão utilizada para a integração, conforme Figura 5.19.

As integrações necessárias à determinação dos esforços são feitas utilizando os resultados das tensões nodais dos pontos da "PATH" exatamente na metade da espessura do elemento de casca, haja visto que utilizando-se tensões das faces extremas do elemento SHELL63 serão também incluídas tensões oriundas de flexões laterais do elemento, sensíveis principalmente nos elementos próximos aos extremos da laje (elementos que sofrem os maiores deslocamentos laterais), conforme Figura 5.20. As tensões devidas a estes deslocamentos e deformações laterais não são medidas nas análises.

Abaixo apresentam-se as integrações necessárias à determinação dos esforços:

\section{a) Momentos Fletores:}

Sendo:

M1 = Momento fletor na nervura simulada pelo SHELL63 em torno do nó inicial inferior que define a "PATH", em kN.cm;

M2 = Momento fletor gerado pela resultante da força normal que atua ao longo da "PATH", em torno do nó inicial inferior que define a "PATH", em kN.cm; 
$\mathrm{M}=$ Momento fletor na nervura simulada pelo SHELL63 em torno do centro de gravidade da seção, em kN.cm;

$\mathrm{b}=$ largura da nervura, ou seja, espessura da casca que a simula, em cm;

$\mathrm{s}=$ altura da nervura, ou seja, comprimento da "PATH", em cm;

$\mathrm{SY}=$ Tensões Nodais na direção do eixo $\mathrm{Y}, \mathrm{em} \mathrm{kN} / \mathrm{cm}^{2}$, nos nós ao longo da "PATH";

INT = Integral ao longo do comprimento da "PATH".

Tem-se:

M1 = b. [INT(SY.s.ds) $]$

M2 $=[($ b.s $) / 2] \cdot[$ INT(SY.ds) $]$

$\mathrm{M}=\mathrm{M1}$ - M2

\section{b) Forças Cortantes:}

Sendo:

$\mathrm{Vz}=$ Força Cortante na "PATH", em kN;

$\mathrm{b}=$ largura da nervura, ou seja, espessura da casca que a simula, em cm;

$\mathrm{s}=$ altura da nervura, ou seja, comprimento da "PATH", em cm;

$S Y Z=$ Tensões Nodais na direção do eixo $Z$ pelos elementos estruturais contidos na direção $\mathrm{Y}, \mathrm{em} \mathrm{kN} / \mathrm{cm}^{2}$;

INT = Integral ao longo do comprimento da "PATH".

Tem-se:

$\mathrm{Vz}=\mathbf{b}$.[INT(SYZ.ds) $]$

\section{c) Forças Normais:}

Sendo:

$\mathrm{N}=$ Força Normal na direção do eixo Y, na "PATH", em kN;

$\mathrm{b}=$ largura da nervura, ou seja, espessura da casca que a simula, em $\mathrm{cm}$;

$\mathrm{SY}=$ Tensões Nodais na direção do eixo $\mathrm{Y}, \mathrm{em} \mathrm{kN} / \mathrm{cm}^{2}$, nos nós ao longo da

"PATH";

INT = Integral ao longo do comprimento da "PATH".

Tem-se:

N = b.[INT(SY.ds)] 


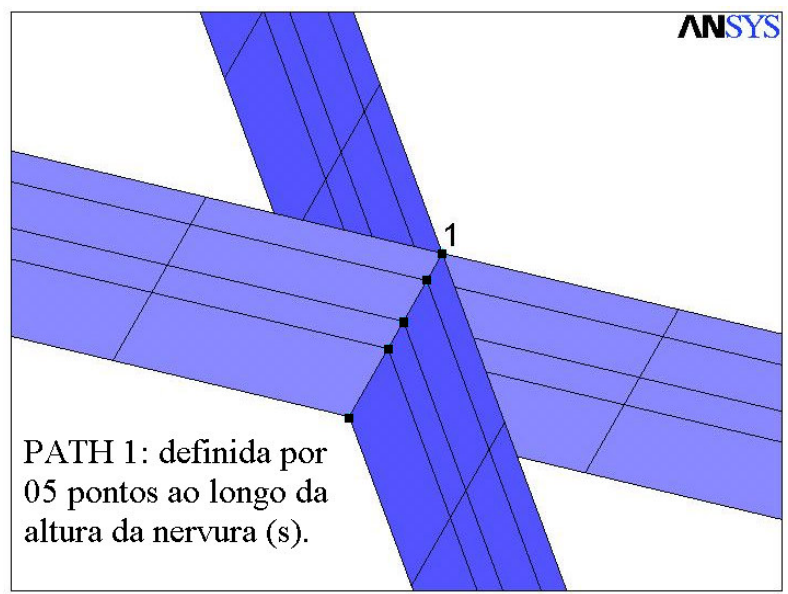

FIGURA 5.18: Detalhe da criação de uma "PATH" para a integração de tensões

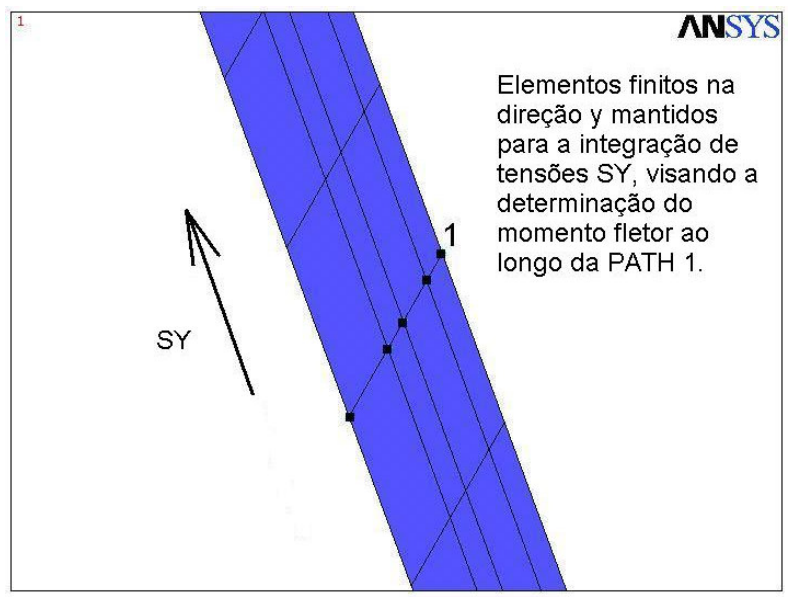

FIGURA 5.19: Elementos estruturais que contribuem para a "PATH" na direção correspondente à tensão que vai ser integrada

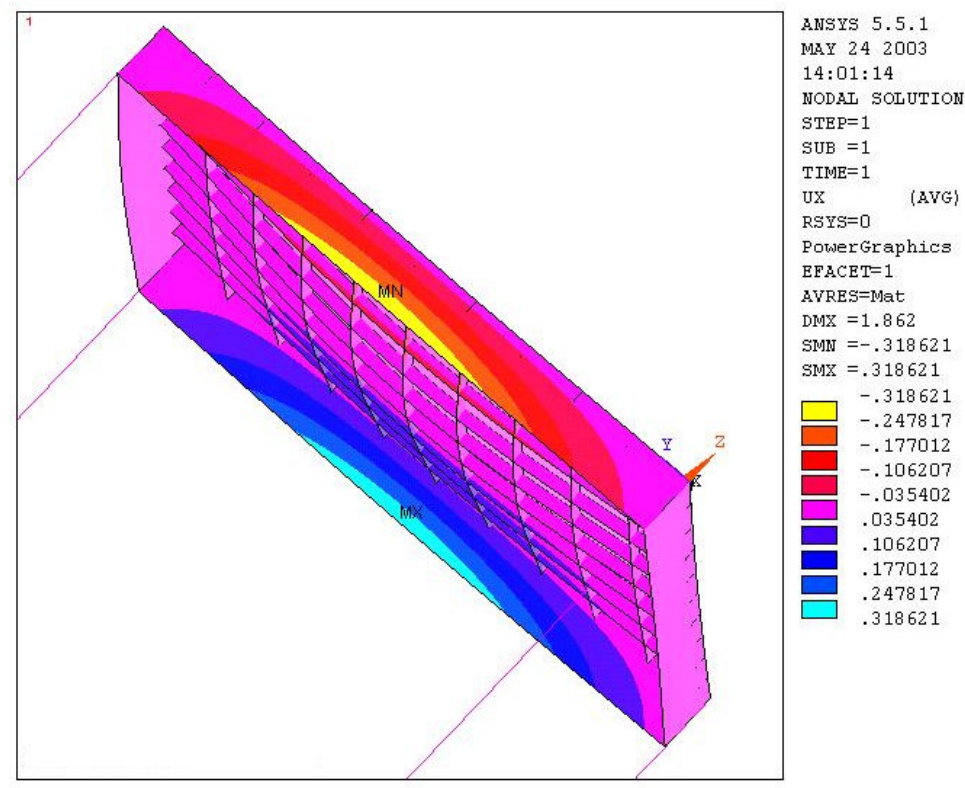

FIGURA 5.20: Deslocamentos laterais, na direção X, que geram flexão lateral 
Para as lajes nervuradas simuladas nos Modelos 07 e 08, ou Modelos de Laje Maciça Equivalente, determinou-se para as nervuras apenas os Momentos Fletores, fazendo o processo usual em escritórios de cálculo: mediu-se o momento fletor atuante no elemento, em $\mathrm{kN} . \mathrm{cm} / \mathrm{cm}$, exatamente no ponto onde previu-se a medição, conforme figuras apresentadas no item 5.2 anterior, multiplicando-o posteriormente pela largura colaborante da nervura, ou seja, pelo espaçamento entre os eixos das nervuras, determinando assim um Momento Fletor na nervura com unidade kN.cm.

Os Momentos Fletores atuantes nos pontos centrais entre as nervuras, ou seja, na capa, são medidos no elemento mais próximo aos nós indicados nas figuras do item 5.2 anterior como pontos de medição de esforços para a capa, utilizando recurso do ANSYS 5.5 que disponibiliza relatórios de esforços: ferramenta "LIST RESULTS" - "ELEMENT TABLE RESULTS". Momento fletor positivo é aquele que traciona as fibras inferiores do elemento de casca que simula a capa.

Compondo-se os momentos fletores e os esforços normais para as nervuras e vigas tem-se as tensões normais máximas, nas fibras superiores e inferiores extremas dos elementos, desconsiderando-se tensões oriundas de flexões laterais. Tensão Normal positiva é aquela que traciona as fibras da seção transversal dos elementos de viga, e momento fletor positivo é aquele que traciona as fibras inferiores. A composição é feita da seguinte maneira:

$$
\sigma \mathbf{y}_{\text {sup ou inf }}= \pm\left(\mathbf{M}_{\mathbf{y}} / \mathbf{I}_{\mathbf{y y}}\right) \cdot\left(\mathbf{z}_{\text {sup ou }} \mathbf{z}_{\text {inf }}\right)+\mathbf{N} / \mathbf{A}
$$

sendo:

$\sigma y_{\text {sup ou inf }}=$ Tensão Normal à seção transversal da viga, desconsiderando flexões laterais nos elementos, nas fibras superiores ou inferiores, em $\mathrm{kN} / \mathrm{cm}^{2}$;

$\mathrm{M}_{\mathrm{y}}=$ momento fletor atuante no elemento (de viga, de casca que simula o enrijecedor ou de casca que simula a nervura no modelo de laje maciça equivalente), em kN.cm, positivo ou negativo;

$\mathrm{I}_{\mathrm{yy}}=$ momento de inércia à flexão do elemento, $\mathrm{em} \mathrm{cm}^{4}$;

$\mathrm{Z}_{\text {sup }}=$ distância da fibra superior extrema ao centro de gravidade da seção homogênea, em cm;

$\mathrm{Z}_{\text {inf }}=$ distância da fibra inferior extrema ao centro de gravidade da seção homogênea, em cm;

$\mathrm{N}$ = esforço normal, em $\mathrm{kN}$, positivo ou negativo;

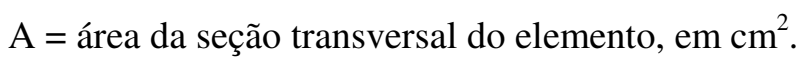

Escolhe-se entre o sinal positivo ou negativo apresentado na equação em função do $\mathrm{z}$ : $\mathrm{z}_{\text {sup }}$ é considerado negativo. 


\subsubsection{Resultados apresentados nas modelagens das lajes com variação da relação $\boldsymbol{h}_{f} / \boldsymbol{h}$}

As tabelas de resultados serão apresentadas na seguinte ordem:

a) Tabelas de Deslocamentos Ortogonais ao Plano da Placa, em cm, para as lajes com altura das nervuras variando de 15 a $50 \mathrm{~cm}$;

b) Tabelas de Momentos Fletores nas Nervuras e Vigas, em kN.cm;

c) Tabelas de Esforços Normais nas Nervuras e Vigas, em kN;

d) Tabelas de Tensões Normais nas Fibras Superiores Extremas das Nervuras e Vigas, em $\mathrm{kN} / \mathrm{cm}^{2}$;

e) Tabelas de Tensões Normais nas Fibras Inferiores Extremas das Nervuras e Vigas, em $\mathrm{kN} / \mathrm{cm}^{2}$;

f) Tabelas de Esforços Cortantes nas Nervuras e Vigas, em kN;

g) Tabelas de Momentos Fletores MY na capa, em kN.cm/cm;

h) Tabelas de Momentos Fletores MX na capa, em kN.cm/cm;

i) Tabelas de Esforços Normais e Momentos Fletores no topo dos Pilares, em $\mathrm{kN}$ e kN.cm, respectivamente.

Gráficos relevantes são também montados, para mostrar com mais clareza o comportamento das lajes, e as respostas de deslocamentos e esforços.

Também apresentam-se comentários sobre os resultados encontrados, nesta série de processamentos, tomando-se sempre como valores de referências os resultados apresentados pelo Modelo 04, considerado aqui como o que apresenta melhores resultados numéricos frente ao comportamento real dos pavimentos em lajes nervuradas, conforme revisão da bibliografia e ensaios realizados. 


\subsubsection{Deslocamentos ortogonais ao plano da placa}

TABELA 5.30: Deslocamentos ortogonais ao plano da placa, em $\mathrm{cm}$, na laje com altura total $\mathrm{h}=15 \mathrm{~cm}$

LAJE COM RELAÇÃO hf/h = 0,333

DESLOCAMENTOS ORTOGONAIS AO PLANO DA PLACA (cm)

\begin{tabular}{c|c|c|c|c|c|c|c|c}
\hline \multirow{2}{*}{ Ponto } & \multicolumn{7}{|c}{ Modelos numéricos de análise } \\
\cline { 2 - 8 } & $\mathbf{0 1}$ & $\mathbf{0 2}$ & $\mathbf{0 3}$ & $\mathbf{0 4}$ & $\mathbf{0 5}$ & $\mathbf{0 6}$ & $\mathbf{0 7}$ & $\mathbf{0 8}$ \\
\hline \hline $\mathbf{1}$ & $-0,1194$ & $-0,1339$ & $-0,1386$ & $\mathbf{- 0 , 1 6 8 7}$ & $-0,0850$ & $-0,0798$ & $-0,1155$ & $-0,1233$ \\
\hline $\mathbf{2}$ & $-1,1550$ & $-0,8780$ & $-0,9134$ & $\mathbf{- 0 , 6 0 3 5}$ & $-0,4477$ & $-0,5178$ & $-0,7448$ & $-0,8895$ \\
\hline $\mathbf{3}$ & $-2,1540$ & $-1,5670$ & $-1,6290$ & $\mathbf{- 1 , 0 8 4 0}$ & $-0,8531$ & $-1,0030$ & $-1,3170$ & $-1,6352$ \\
\hline $\mathbf{4}$ & $-2,9690$ & $-2,1150$ & $-2,1980$ & $\mathbf{- 1 , 4 9 5 0}$ & $-1,2040$ & $-1,4210$ & $-1,7691$ & $-2,2403$ \\
\hline $\mathbf{5}$ & $-3,4960$ & $-2,4660$ & $-2,5620$ & $\mathbf{- 1 , 7 6 7 0}$ & $-1,4370$ & $-1,7000$ & $-2,0576$ & $-2,6299$ \\
\hline $\mathbf{6}$ & $-3,6790$ & $-2,5870$ & $-2,6870$ & $\mathbf{- 1 , 8 6 2 0}$ & $-1,5180$ & $-1,7970$ & $-2,1566$ & $-2,7639$ \\
\hline \hline $\mathbf{7}$ & $-0,0730$ & $-0,0806$ & $-0,0830$ & $\mathbf{- 0 , 0 9 9 7}$ & $-0,0550$ & $-0,0515$ & $-0,0702$ & $-0,0750$ \\
\hline $\mathbf{8}$ & $-0,6153$ & $-0,4857$ & $-0,5057$ & $\mathbf{- 0 , 3 4 8 6}$ & $-0,2651$ & $-0,3055$ & $-0,4156$ & $-0,4939$ \\
\hline $\mathbf{9}$ & $-1,2020$ & $-0,9045$ & $-0,9418$ & $\mathbf{- 0 , 6 2 9 6}$ & $-0,4925$ & $-0,5764$ & $-0,7679$ & $-0,9408$ \\
\hline $\mathbf{1 0}$ & $-1,7050$ & $-1,2560$ & $-1,3070$ & $\mathbf{- 0 , 8 7 0 3}$ & $-0,6842$ & $-0,8033$ & $-1,0604$ & $-1,3136$ \\
\hline $\mathbf{1 1}$ & $-2,0380$ & $-1,4870$ & $-1,5460$ & $\mathbf{- 1 , 0 2 9 0}$ & $-0,8096$ & $-0,9514$ & $-1,2511$ & $-1,5565$ \\
\hline $\mathbf{1 2}$ & $-2,1540$ & $-1,5670$ & $-1,6290$ & $\mathbf{- 1 , 0 8 4 0}$ & $-0,8531$ & $-1,0030$ & $-1,3171$ & $-1,6405$ \\
\hline \hline $\mathbf{1 3}$ & $-0,0099$ & $-0,0099$ & $-0,0099$ & $\mathbf{- 0 , 0 0 8 9}$ & $-0,0099$ & $-0,0099$ & $-0,0099$ & $-0,0099$ \\
\hline $\mathbf{1 4}$ & $-0,0423$ & $-0,0459$ & $-0,0470$ & $-\mathbf{0 , 0 5 5 0}$ & $-0,0340$ & $-0,0316$ & $-0,0405$ & $-0,0430$ \\
\hline $\mathbf{1 5}$ & $-0,0731$ & $-0,0806$ & $-0,0830$ & $\mathbf{- 0 , 0 9 9 3}$ & $-0,0551$ & $-0,0515$ & $-0,0702$ & $-0,0750$ \\
\hline $\mathbf{1 6}$ & $-0,0978$ & $-0,1090$ & $-0,1126$ & $\mathbf{- 0 , 1 3 5 8}$ & $-0,0712$ & $-0,0668$ & $-0,0944$ & $-0,1009$ \\
\hline $\mathbf{1 7}$ & $-0,1139$ & $-0,1276$ & $-0,1319$ & $\mathbf{- 0 , 1 5 9 7}$ & $-0,0814$ & $-0,0765$ & $-0,1101$ & $-0,1178$ \\
\hline $\mathbf{1 8}$ & $-0,1194$ & $-0,1340$ & $-0,1386$ & $\mathbf{- 0 , 1 6 8 1}$ & $-0,0849$ & $-0,0798$ & $-0,1155$ & $-0,1236$ \\
\hline \hline
\end{tabular}

TABELA 5.31: Deslocamentos ortogonais ao plano da placa, em $\mathrm{cm}$, na laje com altura total $\mathrm{h}=20 \mathrm{~cm}$

\begin{tabular}{|c|c|c|c|c|c|c|c|c|}
\hline \multicolumn{9}{|c|}{$\begin{array}{c}\text { LAJE COM RELAÇÃO hf/h }=0,250 \\
\text { DESLOCAMENTOS ORTOGONAIS AO PLANO DA PLACA }(\mathrm{cm})\end{array}$} \\
\hline \multirow{2}{*}{ Ponto } & \multicolumn{8}{|c|}{ Modelos numéricos de análise } \\
\hline & 01 & 02 & 03 & 04 & 05 & 06 & 07 & 08 \\
\hline 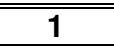 & $-0,1148$ & $-0,1307$ & $-0,1339$ & $-0,1596$ & $-0,0876$ & $-0,0879$ & $-0,1058$ & $-0,1133$ \\
\hline 2 & $-0,7722$ & $-0,5243$ & $-0,5397$ & $-0,4425$ & $-0,3318$ & $-0,3632$ & $-0,4130$ & $-0,5273$ \\
\hline 3 & $-1,3774$ & $-0,8777$ & $-0,9035$ & $-0,7195$ & $-0,5767$ & $-0,6366$ & $-0,6868$ & $-0,9062$ \\
\hline 4 & $-1,8582$ & $-1,1541$ & $-1,1880$ & $-0,9450$ & $-0,7794$ & $-0,8618$ & $-0,9003$ & $-1,2053$ \\
\hline 5 & $-2,1660$ & $-1,3290$ & $-1,3684$ & $-1,0910$ & $-0,9115$ & $-1,0083$ & $-1,0355$ & $-1,3955$ \\
\hline 6 & $-2,2718$ & $-1,3895$ & $-1,4301$ & $-1,1410$ & $-0,9572$ & $-1,0590$ & $-1,0820$ & $-1,4606$ \\
\hline$\overline{77}$ & $-0,0702$ & $-0,0783$ & $-0,0801$ & $-0,0946$ & $-0,0559$ & $-0,0554$ & $-0,0647$ & $-0,0692$ \\
\hline 8 & $-0,4282$ & $-0,3082$ & $-0,3172$ & $-0,2674$ & $-0,2040$ & $-0,2230$ & $-0,2458$ & $-0,3078$ \\
\hline 9 & $-0,7953$ & $-0,5331$ & $-0,5491$ & $-0,4442$ & $-0,3514$ & $-0,3874$ & $-0,4213$ & $-0,5455$ \\
\hline 10 & $-1,1040$ & $-0,7174$ & $-0,7387$ & $-0,5910$ & $-0,4719$ & $-0,5209$ & $-0,5638$ & $-0,7390$ \\
\hline 11 & $-1,3069$ & $-0,8367$ & $-0,8613$ & $-0,6865$ & $-0,5499$ & $-0,6069$ & $-0,6554$ & $-0,8635$ \\
\hline 12 & $-1,3774$ & $-0,8777$ & $-0,9035$ & $-0,7195$ & $-0,5767$ & $-0,6366$ & $-0,6868$ & $-0,9062$ \\
\hline 13 & $-0,0099$ & $-0,0099$ & $-0,0099$ & $-0,0093$ & $-0,0099$ & $-0,0099$ & $-0,0099$ & $-0,0099$ \\
\hline 14 & $-0,0408$ & $-0,0446$ & $-0,0454$ & $-0,0526$ & $-0,0341$ & $-0,0333$ & $-0,0378$ & $-0,0402$ \\
\hline 15 & $-0,0702$ & $-0,0783$ & $-0,0801$ & $-0,0946$ & $-0,0559$ & $-0,0554$ & $-0,0647$ & $-0,0691$ \\
\hline 16 & $-0,0940$ & $-0,1061$ & $-0,1086$ & $-0,1291$ & $-0,0729$ & $-0,0729$ & $-0,0866$ & $-0,0927$ \\
\hline 17 & $-0,1094$ & $-0,1243$ & $-0,1274$ & $-0,1517$ & $-0,0838$ & $-0,0841$ & $-0,1009$ & $-0,1080$ \\
\hline 18 & $-0,1148$ & $-0,1307$ & $-0,1339$ & $-0,1596$ & $-0,0876$ & $-0,0879$ & $-0,1058$ & $-0,1133$ \\
\hline
\end{tabular}


TABELA 5.32: Deslocamentos ortogonais ao plano da placa, em $\mathrm{cm}$, na laje com altura total $\mathrm{h}=25 \mathrm{~cm}$

\begin{tabular}{|c|c|c|c|c|c|c|c|c|}
\hline \multicolumn{9}{|c|}{$\begin{array}{c}\text { LAJE COM RELAÇÃO hf/h }=0,200 \\
\text { DESLOCAMENTOS ORTOGONAIS AO PLANO DA PLACA }(\mathrm{cm})\end{array}$} \\
\hline \multirow{2}{*}{ Ponto } & \multicolumn{8}{|c|}{ Modelos numéricos de análise } \\
\hline & 01 & 02 & 03 & 04 & 05 & 06 & 07 & 08 \\
\hline 1 & $-0,1122$ & $-0,1278$ & $-0,1303$ & $-0,1513$ & $-0,0901$ & $-0,0944$ & $-0,0991$ & $-0,1062$ \\
\hline 2 & $-0,5283$ & $-0,3490$ & $-0,3578$ & $-0,3376$ & $-0,2545$ & $-0,2704$ & $-0,2666$ & $-0,3464$ \\
\hline 3 & $-0,9035$ & $-0,5461$ & $-0,5605$ & $-0,5106$ & $-0,4108$ & $-0,4369$ & $-0,4157$ & $-0,5618$ \\
\hline 4 & $-1,1979$ & $-0,6995$ & $-0,7181$ & $-0,6480$ & $-0,5370$ & $-0,5710$ & $-0,5315$ & $-0,7300$ \\
\hline 5 & $-1,3851$ & $-0,7964$ & $-0,8177$ & $-0,7358$ & $-0,6180$ & $-0,6573$ & $-0,6047$ & $-0,8363$ \\
\hline 6 & $-1,4493$ & $-0,8296$ & $-0,8518$ & $-0,7659$ & $-0,6462$ & $-0,6869$ & $-0,6297$ & $-0,8726$ \\
\hline 7 & $-0,0684$ & $-0,0764$ & $-0,0777$ & $-0,0897$ & $-0,0567$ & $-0,0585$ & $-0,0607$ & $-0,0651$ \\
\hline 8 & $-0,3057$ & $-0,2164$ & $-0,2217$ & $-0,2118$ & $-0,1615$ & $-0,1715$ & $-0,1672$ & $-0,2120$ \\
\hline 9 & $-0,5401$ & $-0,3485$ & $-0,3576$ & $-0,3305$ & $-0,2614$ & $-0,2782$ & $-0,2672$ & $-0,3527$ \\
\hline 10 & $-0,7338$ & $-0,4548$ & $-0,4668$ & $-0,4270$ & $-0,3416$ & $-0,3635$ & $-0,3472$ & $-0,4654$ \\
\hline 11 & $-0,8599$ & $-0,5228$ & $-0,5366$ & $-0,4892$ & $-0,3931$ & $-0,4181$ & $-0,3982$ & $-0,5373$ \\
\hline 12 & $-0,9035$ & $-0,5461$ & $-0,5605$ & $-0,5106$ & $-0,4108$ & $-0,4369$ & $-0,4157$ & $-0,5618$ \\
\hline 13 & $-0,0099$ & $-0,0099$ & $-0,0099$ & $-0,0099$ & $-0,0099$ & $-0,0099$ & $-0,0099$ & $-0,0099$ \\
\hline 14 & $-0,0398$ & $-0,0435$ & $-0,0442$ & $-0,0501$ & $-0,0342$ & $-0,0348$ & $-0,0358$ & $-0,0381$ \\
\hline 15 & $-0,0684$ & $-0,0764$ & $-0,0777$ & $-0,0897$ & $-0,0567$ & $-0,0585$ & $-0,0607$ & $-0,0651$ \\
\hline 16 & $-0,0917$ & $-0,1036$ & $-0,1056$ & $-0,1224$ & $-0,0746$ & $-0,0777$ & $-0,0811$ & $-0,0870$ \\
\hline 17 & $-0,1069$ & $-0,1215$ & $-0,1239$ & $-0,1438$ & $-0,0861$ & $-0,0901$ & $-0,0944$ & $-0,1013$ \\
\hline 18 & $-0,1122$ & $-0,1278$ & $-0,1303$ & $-0,1513$ & $-0,0901$ & $-0,0944$ & $-0,0991$ & $-0,1062$ \\
\hline
\end{tabular}

TABELA 5.33: Deslocamentos ortogonais ao plano da placa, em $\mathrm{cm}$, na laje com altura total $\mathrm{h}=30 \mathrm{~cm}$

LAJE COM RELAÇÃ̃O hf/h = 0,167

DESLOCAMENTOS ORTOGONAIS AO PLANO DA PLACA (cm)

\begin{tabular}{|c|c|c|c|c|c|c|c|c|}
\hline \multirow{2}{*}{ Ponto } & \multicolumn{8}{|c|}{ Modelos numéricos de análise } \\
\hline & 01 & 02 & $\mathbf{0 3}$ & 04 & 05 & 06 & 07 & 08 \\
\hline 1 & $-0,1106$ & $-0,1252$ & $-0,1273$ & $-0,1445$ & $-0,0917$ & $-0,0984$ & $-0,0936$ & $-0,1008$ \\
\hline 2 & $-0,3799$ & $-0,2587$ & $-0,2647$ & $-0,2689$ & $-0,2030$ & $-0,2131$ & $-0,1942$ & $-0,2515$ \\
\hline 3 & $-0,6206$ & $-0,3774$ & $-0,3870$ & $-0,3818$ & $-0,3062$ & $-0,3193$ & $-0,2840$ & $-0,3859$ \\
\hline 4 & $-0,8084$ & $-0,4698$ & $-0,4821$ & $-0,4705$ & $-0,3883$ & $-0,4039$ & $-0,3539$ & $-0,4904$ \\
\hline 5 & $-0,9274$ & $-0,5281$ & $-0,5421$ & $-0,5267$ & $-0,4409$ & $-0,4580$ & $-0,3981$ & $-0,5563$ \\
\hline 6 & $-0,9682$ & $-0,5480$ & $-0,5626$ & $-0,5460$ & $-0,4590$ & $-0,4766$ & $-0,4132$ & $-0,5788$ \\
\hline 7 & $-0,0672$ & $-0,0748$ & $\begin{array}{l}-0,0760 \\
\end{array}$ & $-0,0858$ & $\begin{array}{l}-0,0571 \\
\end{array}$ & $-0,0604$ & $-0,0576$ & $\begin{array}{l}-0,0620 \\
\end{array}$ \\
\hline 8 & $-0,2288$ & $-0,1670$ & $-0,1708$ & $-0,1741$ & $-0,1324$ & $-0,1390$ & $-0,1266$ & $-0,1599$ \\
\hline 9 & $-0,3841$ & $-0,2521$ & $-0,2582$ & $-0,2575$ & $-0,2025$ & $-0,2119$ & $-0,1903$ & $-0,2515$ \\
\hline 10 & $-0,5107$ & $-0,3197$ & $-0,3277$ & $-0,3243$ & $-0,2583$ & $-0,2697$ & $-0,2409$ & $-0,3241$ \\
\hline 11 & $-0,5924$ & $-0,3627$ & $-0,3719$ & $-0,3671$ & $-0,2939$ & $-0,3066$ & $-0,2730$ & $-0,3702$ \\
\hline 12 & $-0,6206$ & $-0,3774$ & $-0,3870$ & $-0,3818$ & $-0,3062$ & $-0,3193$ & $-0,2840$ & $-0,3859$ \\
\hline 13 & $-0,0099$ & $-0,0099$ & $-0,0099$ & $-0,0099$ & $-0,0099$ & $-0,0099$ & $-0,0099$ & $-0,0099$ \\
\hline 14 & $-0,0390$ & $-0,0426$ & $-0,0432$ & $-0,0480$ & $-0,0343$ & $-0,0357$ & $-0,0343$ & $-0,0366$ \\
\hline 15 & $-0,0672$ & $-0,0748$ & $-0,0760$ & $-0,0858$ & $-0,0571$ & $-0,0604$ & $-0,0576$ & $-0,0620$ \\
\hline 16 & $-0,0902$ & $-0,1015$ & $-0,1031$ & $-0,1169$ & $-0,0756$ & $-0,0806$ & $-0,0767$ & $-0,0827$ \\
\hline 17 & $-0,1054$ & $-0,1191$ & $-0,1211$ & $-0,1374$ & $-0,0875$ & $-0,0938$ & $-0,0892$ & $-0,0961$ \\
\hline 18 & $-0,1106$ & $-0,1252$ & $-0,1273$ & $-0,1445$ & $-0,0917$ & $-0,0984$ & $-0,0936$ & $-0,1008$ \\
\hline
\end{tabular}


TABELA 5.34: Deslocamentos ortogonais ao plano da placa, em $\mathrm{cm}$, na laje com altura total $\mathrm{h}=35 \mathrm{~cm}$

\begin{tabular}{|c|c|c|c|c|c|c|c|c|}
\hline \multicolumn{9}{|c|}{$\begin{array}{c}\text { LAJE COM RELAÇÃO hf/h }=0,143 \\
\text { DESLOCAMENTOS ORTOGONAIS AO PLANO DA PLACA }(\mathrm{cm})\end{array}$} \\
\hline \multirow{2}{*}{ Ponto } & \multicolumn{8}{|c|}{ Modelos numéricos de análise } \\
\hline & 01 & $\mathbf{0 2}$ & $\mathbf{0 3}$ & 04 & 05 & 06 & 07 & 08 \\
\hline 1 & $-0,1094$ & $-0,1228$ & $-0,1246$ & $-0,1390$ & $-0,0923$ & $-0,1002$ & $-0,0887$ & $-0,0962$ \\
\hline 2 & $-0,2890$ & $-0,2081$ & $-0,2126$ & $-0,2239$ & $-0,1688$ & $-0,1769$ & $-0,1538$ & $-0,1973$ \\
\hline 3 & $-0,4489$ & $-0,2842$ & $-0,2912$ & $-0,3003$ & $-0,2388$ & $-0,2472$ & $-0,2121$ & $-0,2875$ \\
\hline 4 & $-0,5735$ & $-0,3434$ & $-0,3524$ & $-0,3601$ & $-0,2943$ & $-0,3029$ & $-0,2578$ & $-0,3577$ \\
\hline 5 & $-0,6523$ & $-0,3808$ & $-0,3910$ & $-0,3979$ & $-0,3296$ & $-0,3384$ & $-0,2866$ & $-0,4019$ \\
\hline 6 & $-0,6792$ & $-0,3936$ & $-0,4042$ & $-0,4108$ & $-0,3418$ & $-0,3506$ & $-0,2965$ & $-0,4170$ \\
\hline 7 & $-0,0663$ & $-0,0734$ & $-0,0744$ & $-0,0827$ & $-0,0572$ & $-0,0613$ & $-0,0549$ & $-0,0594$ \\
\hline 8 & $-0,1803$ & $-0,1385$ & $-0,1414$ & $-0,1487$ & $-0,1128$ & $-0,1183$ & $-0,1031$ & $-0,1292$ \\
\hline 9 & $-0,2876$ & $-0,1976$ & $-0,2022$ & $-0,2100$ & $-0,1638$ & $-0,1705$ & $-0,1474$ & $-0,1936$ \\
\hline 10 & $-0,3742$ & $-0,2444$ & $-0,2503$ & $-0,2587$ & $-0,2042$ & $-0,2118$ & $-0,1823$ & $-0,2444$ \\
\hline 11 & $-0,4298$ & $-0,2740$ & $-0,2808$ & $-0,2897$ & $-0,2300$ & $-0,2381$ & $-0,2046$ & $-0,2765$ \\
\hline 12 & $-0,4489$ & $-0,2842$ & $-0,2912$ & $-0,3003$ & $-0,2388$ & $-0,2472$ & $-0,2121$ & $-0,2875$ \\
\hline 13 & $-0,0099$ & $-0,0099$ & $-0,0099$ & $-0,0092$ & $-0,0099$ & $-0,0099$ & $-0,0099$ & $-0,0099$ \\
\hline 14 & $-0,0385$ & $-0,0419$ & $-0,0424$ & $-0,0464$ & $-0,0342$ & $-0,0361$ & $-0,0329$ & $-0,0352$ \\
\hline 15 & $-0,0663$ & $-0,0734$ & $-0,0744$ & $-0,0827$ & $-0,0572$ & $-0,0613$ & $-0,0549$ & $-0,0594$ \\
\hline 16 & $-0,0891$ & $-0,0996$ & $-0,1010$ & $-0,1126$ & $-0,0759$ & $-0,0820$ & $-0,0729$ & $-0,0790$ \\
\hline 17 & $-0,1042$ & $-0,1168$ & $-0,1185$ & $-0,1322$ & $-0,0880$ & $-0,0955$ & $-0,0846$ & $-0,0918$ \\
\hline 18 & $-0,1094$ & $-0,1228$ & $-0,1246$ & $-0,1390$ & $-0,0923$ & $-0,1002$ & $-0,0887$ & $-0,0962$ \\
\hline
\end{tabular}

TABELA 5.35: Deslocamentos ortogonais ao plano da placa, em $\mathrm{cm}$, na laje com altura total $\mathrm{h}=40 \mathrm{~cm}$

\begin{tabular}{|c|c|c|c|c|c|c|c|c|}
\hline \multicolumn{9}{|c|}{$\begin{array}{c}\text { LAJE COM RELAÇÃO hf } / \mathrm{h}=0,125 \\
\text { DESLOCAMENTOS ORTOGONAIS AO PLANO DA PLACA }(\mathrm{cm})\end{array}$} \\
\hline \multirow{2}{*}{ Ponto } & \multicolumn{8}{|c|}{ Modelos numéricos de análise } \\
\hline & 01 & 02 & $\mathbf{0 3}$ & 04 & 05 & 06 & 07 & 08 \\
\hline$\overline{11}$ & 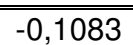 & 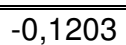 & $\overline{-0,1219}$ & $\overline{-0,1342}$ & 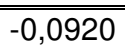 & 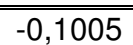 & $\overline{-0,0840}$ & 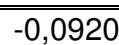 \\
\hline 2 & $-0,2316$ & $-0,1772$ & $-0,1809$ & $-0,1937$ & $-0,1457$ & $-0,1531$ & $-0,1286$ & $-0,1636$ \\
\hline 3 & $-0,3413$ & $-0,2282$ & $-0,2337$ & $-0,2471$ & $-0,1944$ & $-0,2011$ & $-0,1688$ & $-0,2277$ \\
\hline 4 & $-0,4267$ & $-0,2681$ & $-0,2750$ & $-0,2888$ & $-0,2329$ & $-0,2390$ & $-0,2003$ & $-0,2777$ \\
\hline 5 & $-0,4807$ & $-0,2933$ & $-0,3012$ & $-0,3152$ & $-0,2574$ & $-0,2632$ & $-0,2204$ & $-0,3092$ \\
\hline 6 & $-0,4992$ & $-0,3019$ & $-0,3101$ & $-0,3242$ & $-0,2658$ & $-0,2716$ & $-0,2272$ & $-0,3200$ \\
\hline 7 & $-0,0655$ & $-0,0721$ & $-0,0730$ & $-0,0801$ & $-0,0569$ & $-0,0615$ & $-0,0523$ & $0-0,0570$ \\
\hline 8 & $-0,1488$ & $-0,1206$ & $-0,1229$ & $-0,1313$ & $-0,0993$ & $-0,1044$ & $-0,0881$ & $-0,1095$ \\
\hline 9 & $-0,2262$ & $-0,1644$ & $-0,1680$ & $-0,1782$ & $-0,1379$ & $-0,1436$ & $-0,1208$ & $-0,1576$ \\
\hline 10 & $-0,2881$ & $-0,1989$ & $-0,2035$ & $-0,2154$ & $-0,1684$ & $-0,1746$ & $-0,1467$ & $-0,1955$ \\
\hline 11 & $-0,3277$ & $-0,2207$ & $-0,2260$ & $-0,2390$ & $-0,1878$ & $-0,1943$ & $-0,1631$ & $-0,2195$ \\
\hline 12 & $-0,3413$ & $-0,2282$ & $-0,2337$ & $-0,2471$ & $-0,1944$ & $-0,2011$ & $-0,1688$ & $-0,2277$ \\
\hline 13 & $-0,0099$ & $-0,0099$ & $-0,0099$ & $-0,0091$ & - $-0,0099$ & $-0,0099$ & $-0,0099$ & $-0,0099$ \\
\hline 14 & $-0,0381$ & $-0,0413$ & $-0,0417$ & $-0,0451$ & $-0,0340$ & $-0,0361$ & $-0,0316$ & $-0,0340$ \\
\hline 15 & $-0,0655$ & $-0,0721$ & $-0,0730$ & $-0,0801$ & $-0,0569$ & $-0,0615$ & $-0,0523$ & $-0,0570$ \\
\hline 16 & $-0,0882$ & $-0,0977$ & $-0,0989$ & $-0,1089$ & $-0,0757$ & $-0,0823$ & $-0,0692$ & $-0,0756$ \\
\hline 17 & $-0,1031$ & $-0,1144$ & $-0,1160$ & $-0,1277$ & $-0,0878$ & $-0,0958$ & $-0,0802$ & $-0,0878$ \\
\hline 18 & $-0,1083$ & $-0,1203$ & $-0,1219$ & $-0,1342$ & $-0,0920$ & $-0,1005$ & $-0,0840$ & $-0,0920$ \\
\hline
\end{tabular}


TABELA 5.36: Deslocamentos ortogonais ao plano da placa, em $\mathrm{cm}$, na laje com altura total $\mathrm{h}=45 \mathrm{~cm}$

\begin{tabular}{|c|c|c|c|c|c|c|c|c|}
\hline \multicolumn{9}{|c|}{$\begin{array}{c}\text { LAJE COM RELAÇÃO hf/h }=0,111 \\
\text { DESLOCAMENTOS ORTOGONAIS AO PLANO DA PLACA }(\mathrm{cm})\end{array}$} \\
\hline \multirow{2}{*}{ Ponto } & \multicolumn{8}{|c|}{ Modelos numéricos de análise } \\
\hline & 01 & 02 & 03 & 04 & 05 & 06 & 07 & 08 \\
\hline 1 & $-0,1070$ & $-0,1175$ & $-0,1189$ & $-0,1298$ & $-0,0912$ & $-0,0998$ & $-0,0795$ & $-0,0879$ \\
\hline 2 & $-0,1939$ & $-0,1568$ & $-0,1598$ & $-0,1724$ & $-0,1295$ & $-0,1367$ & $-0,1113$ & $-0,1409$ \\
\hline 3 & $-0,2712$ & $-0,1922$ & $-0,1966$ & $-0,2108$ & $-0,1641$ & $-0,1702$ & $-0,1403$ & $-0,1886$ \\
\hline 4 & $-0,3314$ & $-0,2199$ & $-0,2255$ & $-0,2408$ & $-0,1915$ & $-0,1967$ & $-0,1631$ & $-0,2258$ \\
\hline 5 & $-0,3695$ & $-0,2375$ & $-0,2438$ & $-0,2598$ & $-0,2089$ & $-0,2137$ & $-0,1777$ & $-0,2494$ \\
\hline 6 & $-0,3825$ & $-0,2436$ & $-0,2501$ & $-0,2663$ & $-0,2149$ & $-0,2195$ & $-0,1827$ & $-0,2574$ \\
\hline 7 & $-0,0647$ & $-0,0707$ & $-0,0715$ & $-0,0778$ & $-0,0564$ & $-0,0612$ & $-0,0498$ & $-0,0547$ \\
\hline 8 & $-0,1277$ & $-0,1085$ & $-0,1105$ & $-0,1188$ & $-0,0898$ & $-0,0948$ & $-0,0776$ & $-0,0960$ \\
\hline 9 & $-0,1856$ & $-0,1425$ & $-0,1455$ & $-0,1561$ & $-0,1200$ & $-0,1253$ & $-0,1030$ & $-0,1336$ \\
\hline 10 & $-0,2317$ & $-0,1693$ & $-0,1731$ & $-0,1856$ & $-0,1438$ & $-0,1495$ & $-0,1231$ & $-0,1633$ \\
\hline 11 & $-0,2611$ & $-0,1863$ & $-0,1906$ & $-0,2043$ & $-0,1589$ & $-0,1649$ & $-0,1359$ & $-0,1821$ \\
\hline 12 & $-0,2712$ & $-0,1922$ & $-0,1966$ & $-0,2108$ & $-0,1641$ & $-0,1702$ & $-0,1403$ & $-0,1886$ \\
\hline 13 & $-0,0099$ & $-0,0099$ & $-0,0099$ & $-0,0091$ & $-0,0099$ & $-0,0099$ & $-0,0099$ & $-0,0099$ \\
\hline 14 & $-0,0376$ & $-0,0406$ & $-0,0410$ & $-0,0440$ & $-0,0337$ & $-0,0360$ & $-0,0304$ & $-0,0329$ \\
\hline 15 & $-0,0647$ & $-0,0707$ & $-0,0715$ & $-0,0778$ & $-0,0564$ & $-0,0612$ & $-0,0498$ & $-0,0547$ \\
\hline 16 & $-0,0871$ & $-0,0956$ & $-0,0967$ & $-0,1055$ & $-0,0750$ & $-0,0818$ & $-0,0657$ & $-0,0724$ \\
\hline 17 & $-0,1019$ & $-0,1118$ & $-0,1132$ & $-0,1235$ & $-0,0870$ & $-0,0952$ & $-0,0759$ & $-0,0839$ \\
\hline 18 & $-0,1070$ & $-0,1175$ & $-0,1189$ & $-0,1298$ & $-0,0912$ & $-0,0998$ & $-0,0795$ & $-0,0879$ \\
\hline
\end{tabular}

TABELA 5.37: Deslocamentos ortogonais ao plano da placa, em $\mathrm{cm}$, na laje com altura total $\mathrm{h}=50 \mathrm{~cm}$

LAJE COM RELAÇÃ̃O hf/h = 0,100

DESLOCAMENTOS ORTOGONAIS AO PLANO DA PLACA (cm)

\begin{tabular}{c|c|c|c|c|c|c|c|c}
\hline \multirow{2}{*}{ Ponto } & \multicolumn{7}{c}{ Modelos numéricos de análise } \\
\cline { 2 - 8 } & $\mathbf{0 1}$ & $\mathbf{0 2}$ & $\mathbf{0 3}$ & $\mathbf{0 4}$ & $\mathbf{0 5}$ & $\mathbf{0 6}$ & $\mathbf{0 7}$ & $\mathbf{0 8}$ \\
\hline \hline $\mathbf{1}$ & $-0,1056$ & $-0,1143$ & $-0,1157$ & $\mathbf{- 0 , 1 2 5 5}$ & $-0,0899$ & $-0,0983$ & $-0,0751$ & $-0,0838$ \\
\hline $\mathbf{2}$ & $-0,1681$ & $-0,1421$ & $-0,1447$ & $\mathbf{- 0 , 1 5 6 6}$ & $-0,1176$ & $-0,1246$ & $-0,0986$ & $-0,1245$ \\
\hline $\mathbf{3}$ & $-0,2238$ & $-0,1673$ & $-0,1710$ & $\mathbf{- 0 , 1 8 4 8}$ & $-0,1427$ & $-0,1485$ & $-0,1202$ & $-0,1613$ \\
\hline $\mathbf{4}$ & $-0,2672$ & $-0,1871$ & $-0,1917$ & $\mathbf{- 0 , 2 0 6 9}$ & $-0,1625$ & $-0,1674$ & $-0,1374$ & $-0,1901$ \\
\hline $\mathbf{5}$ & $-0,2947$ & $-0,1998$ & $-0,2050$ & $\mathbf{- 0 , 2 2 1 0}$ & $-0,1751$ & $-0,1796$ & $-0,1484$ & $-0,2084$ \\
\hline $\mathbf{6}$ & $-0,3041$ & $-0,2041$ & $-0,2095$ & $\mathbf{- 0 , 2 2 5 8}$ & $-0,1795$ & $-0,1837$ & $-0,1521$ & $-0,2146$ \\
\hline \hline $\mathbf{7}$ & $-0,0639$ & $-0,0692$ & $-0,0699$ & $\mathbf{- 0 , 0 7 5 6}$ & $-0,0557$ & $-0,0605$ & $-0,0474$ & $-0,0524$ \\
\hline $\mathbf{8}$ & $-0,1130$ & $-0,0997$ & $-0,1014$ & $\mathbf{- 0 , 1 0 9 4}$ & $-0,0827$ & $-0,0876$ & $-0,0697$ & $-0,0860$ \\
\hline $\mathbf{9}$ & $-0,1578$ & $-0,1271$ & $-0,1297$ & $\mathbf{- 0 , 1 4 0 0}$ & $-0,1070$ & $-0,1122$ & $-0,0901$ & $-0,1166$ \\
\hline $\mathbf{1 0}$ & $-0,1933$ & $-0,1488$ & $-0,1519$ & $\mathbf{- 0 , 1 6 4 1}$ & $-0,1262$ & $-0,1317$ & $-0,1063$ & $-0,1407$ \\
\hline $\mathbf{1 1}$ & $-0,2160$ & $-0,1625$ & $-0,1661$ & $\mathbf{- 0 , 1 7 9 5}$ & $-0,1385$ & $-0,1442$ & $-0,1167$ & $-0,1560$ \\
\hline $\mathbf{1 2}$ & $-0,2238$ & $-0,1673$ & $-0,1710$ & $\mathbf{- 0 , 1 8 4 8}$ & $-0,1427$ & $-0,1485$ & $-0,1202$ & $-0,1613$ \\
\hline \hline $\mathbf{1 3}$ & $-0,0099$ & $-0,0099$ & $-0,0099$ & $\mathbf{- 0 , 0 0 9 0}$ & $-0,0099$ & $-0,0099$ & $-0,0099$ & $-0,0099$ \\
\hline $\mathbf{1 4}$ & $-0,0372$ & $-0,0398$ & $-0,0402$ & $\mathbf{- 0 , 0 4 3 0}$ & $-0,0333$ & $-0,0357$ & $-0,0291$ & $-0,0317$ \\
\hline $\mathbf{1 5}$ & $-0,0639$ & $-0,0692$ & $-0,0699$ & $-\mathbf{0 , 0 7 5 6}$ & $-0,0557$ & $-0,0605$ & $-0,0474$ & $-0,0524$ \\
\hline $\mathbf{1 6}$ & $-0,0860$ & $-0,0932$ & $-0,0943$ & $\mathbf{- 0 , 1 0 2 2}$ & $-0,0740$ & $-0,0807$ & $-0,0622$ & $-0,0692$ \\
\hline $\mathbf{1 7}$ & $-0,1005$ & $-0,1089$ & $-0,1102$ & $\mathbf{- 0 , 1 1 9 5}$ & $-0,0858$ & $-0,0938$ & $-0,0718$ & $-0,0801$ \\
\hline $\mathbf{1 8}$ & $-0,1056$ & $-0,1143$ & $-0,1157$ & $\mathbf{- 0 , 1 2 5 4}$ & $-0,0899$ & $-0,0983$ & $-0,0751$ & $-0,0838$ \\
\hline \hline
\end{tabular}

Abaixo tem-se os gráficos de deslocamentos ortogonais ao plano da placa para a nervura central das lajes processadas nesta série. 


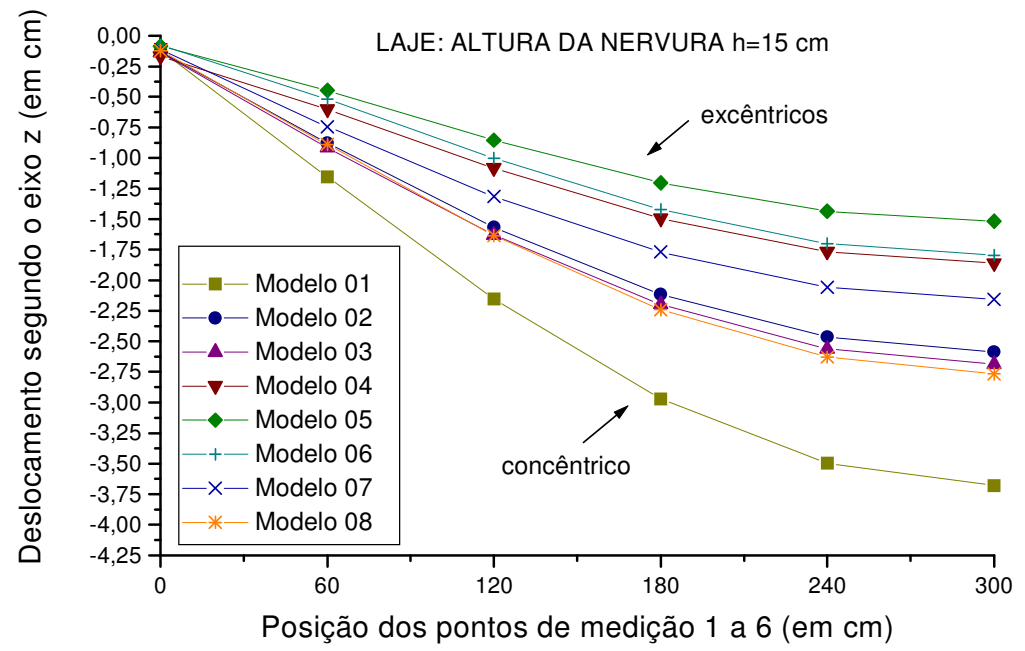

FIGURA 5.21: Deslocamentos em z $(\mathrm{cm})$, na nervura central, na laje com $\mathrm{hf} / \mathrm{h}=0,333$

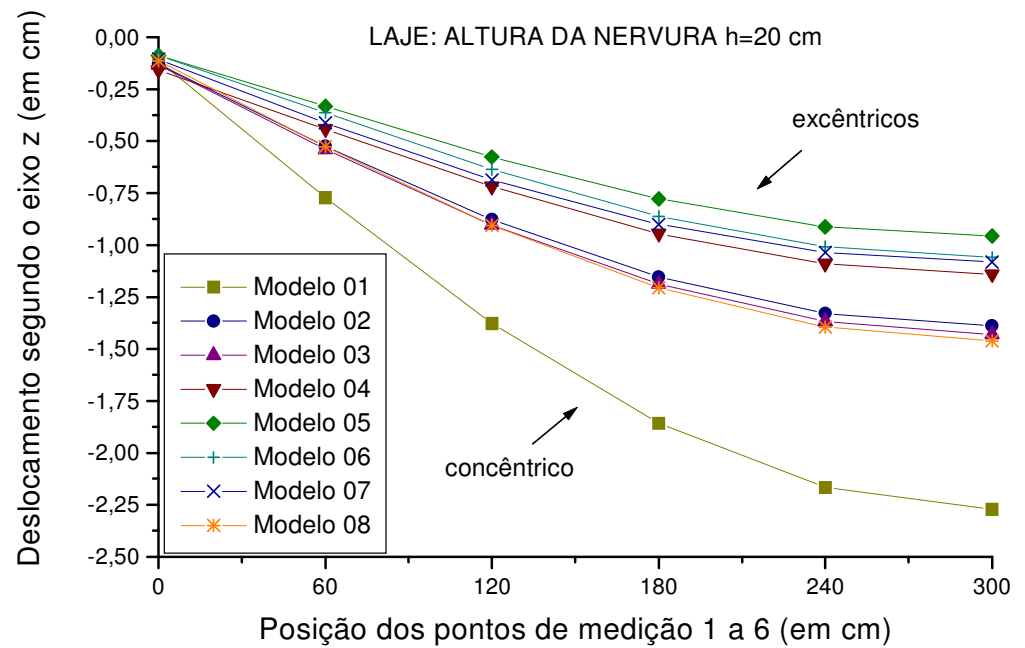

FIGURA 5.22: Deslocamentos em $\mathrm{z}(\mathrm{cm})$, na nervura central, na laje com $\mathrm{hf} / \mathrm{h}=0,250$

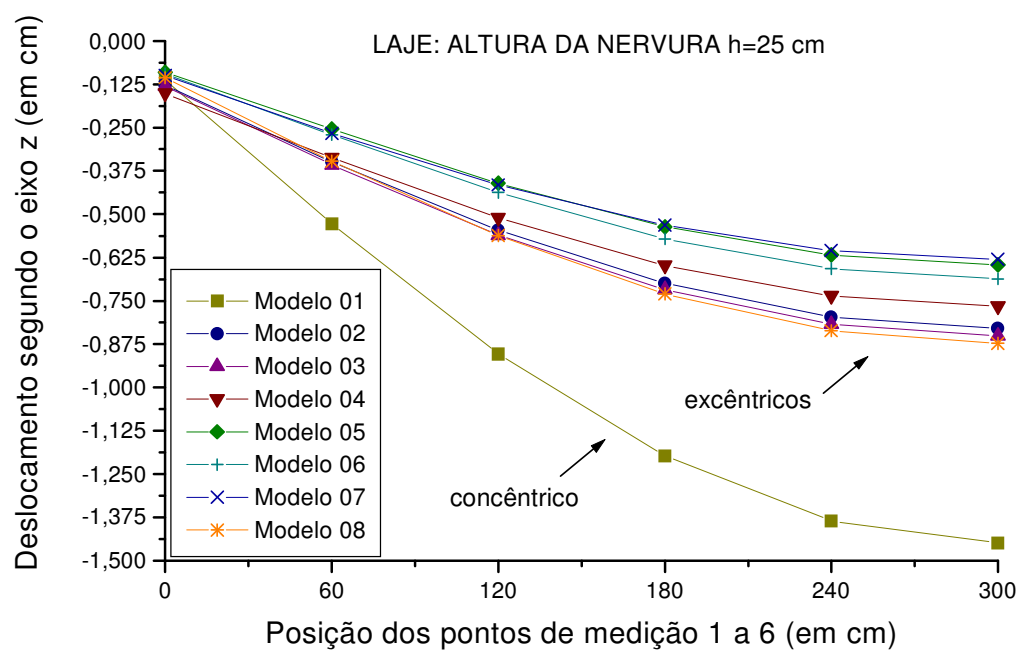

FIGURA 5.23: Deslocamentos em z (cm), na nervura central, na laje com $\mathrm{hf} / \mathrm{h}=0,200$ 


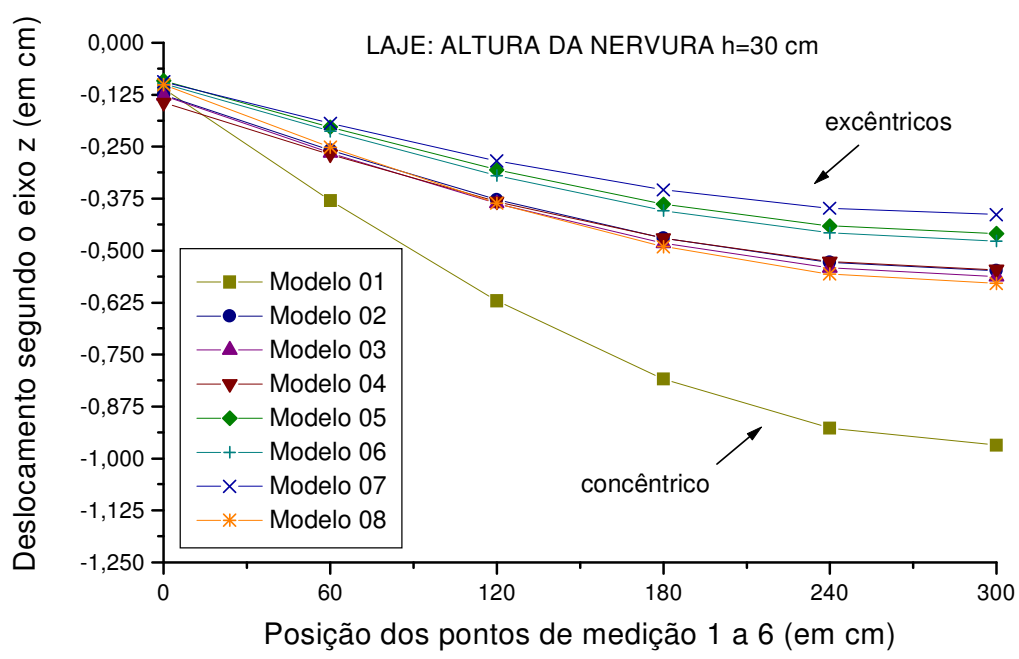

FIGURA 5.24: Deslocamentos em z (cm), na nervura central, na laje com $\mathrm{hf} / \mathrm{h}=0,167$

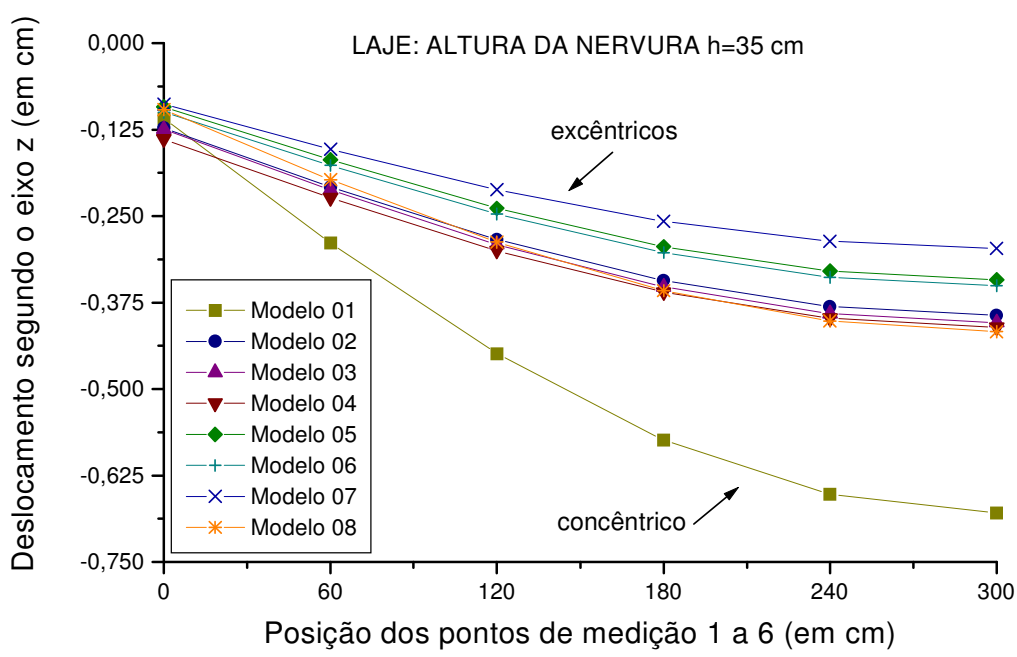

FIGURA 5.25: Deslocamentos em z $(\mathrm{cm})$, na nervura central, na laje com $\mathrm{hf} / \mathrm{h}=0,143$

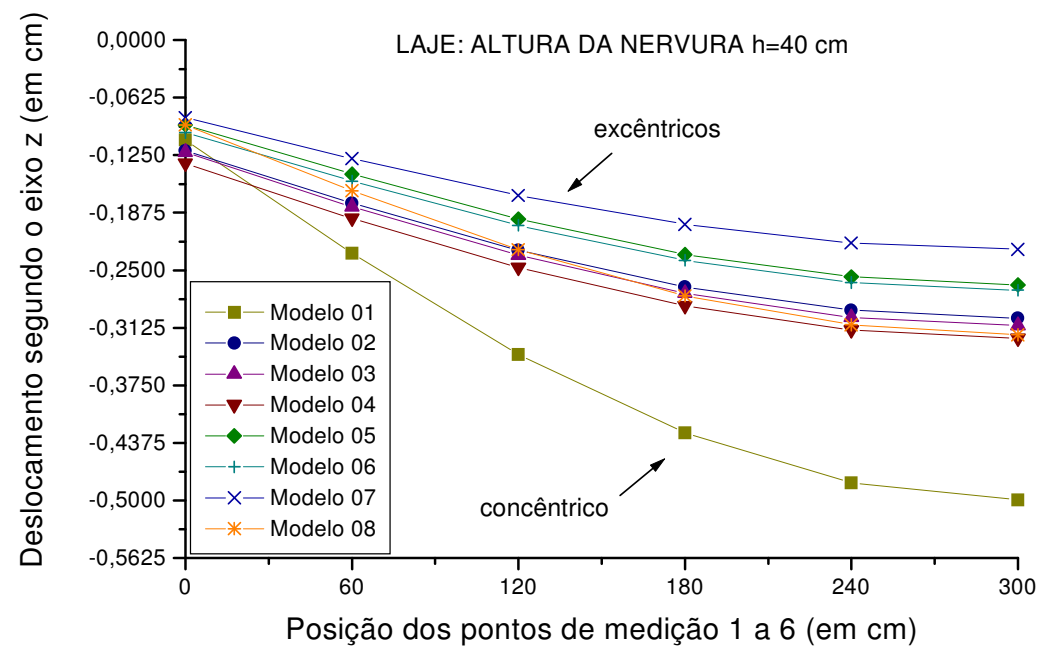

FIGURA 5.26: Deslocamentos em $\mathrm{z}(\mathrm{cm})$, na nervura central, na laje com $\mathrm{hf} / \mathrm{h}=0,125$ 


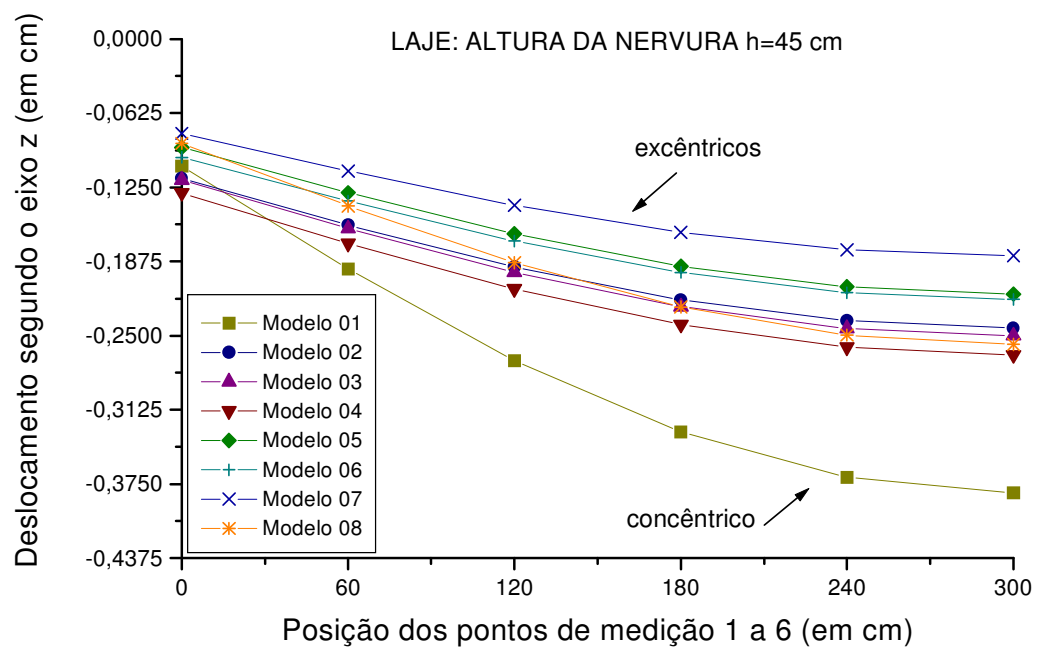

FIGURA 5.27: Deslocamentos em z $(\mathrm{cm})$, na nervura central, na laje com $\mathrm{hf} / \mathrm{h}=0,111$

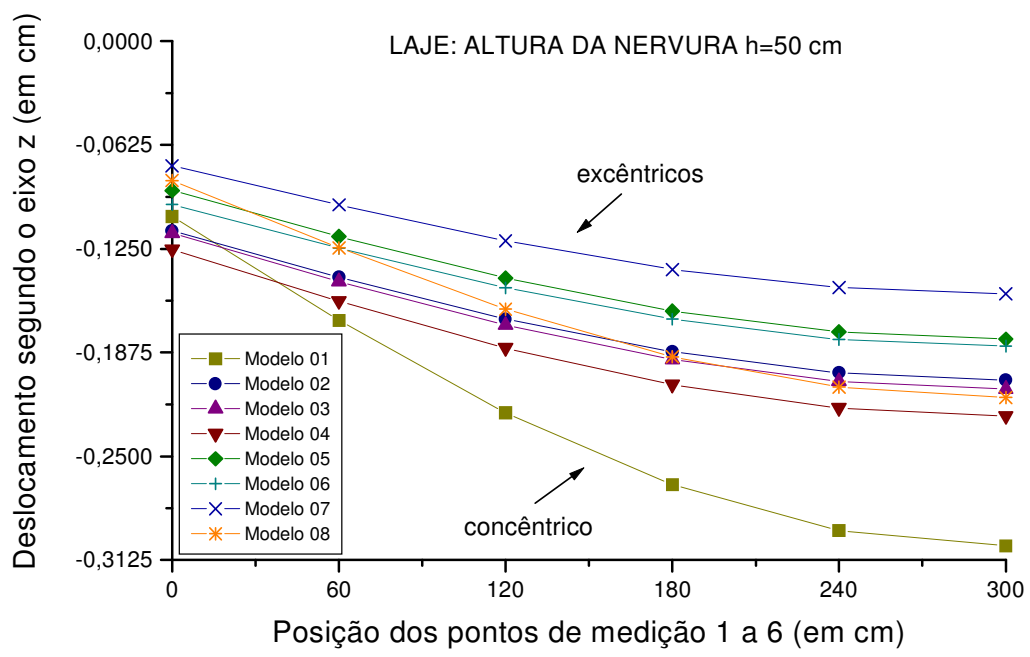

FIGURA 5.28: Deslocamentos em z (cm), na nervura central, na laje com $\mathrm{hf} / \mathrm{h}=0,100$

Analisando as tabelas e gráficos de deslocamentos nas nervuras, segundo os modelos com variação da relação $h_{f} / h$, verificou-se que:

- existe sempre uma grande disparidade entre os resultados de deslocamentos apresentados pelo modelo concêntrico (Modelo 01) frente aos dos modelos excêntricos simplificados e realista. Quanto mais flexível é o sistema, maiores são as diferenças, chegando a apresentar resultado 99\% maior, do deslocamento máximo da nervura central, em relação ao Modelo 04;

- para baixas excentricidades os modelos de viga excêntrica 02 e 03 são mais flexíveis que o modelo realista; à medida que aumenta-se a excentricidade, com a diminuição do fator $h_{f} / h$, tem-se uma aproximação muito melhor dos resultados de deslocamentos (para $h_{f} / h=0,167$ tem-se diferença de apenas $0,37 \%$ entre o deslocamento 
máximo na nervura central do Modelo 02 em comparação com o resultado do Modelo 04); com um aumento ainda maior de excentricidade, ou seja, considerando o pavimento mais rígido, os modelos 02 e 03 começam a ficar mais rígidos que o Modelo 04, com resultados de deslocamentos diferindo no máximo em $10 \%$ na relação $h_{f} / h=0,100$, o que é uma ótima correlação;

- entre os modelos de laje maciça equivalente, percebeu-se que o Modelo 08 (laje maciça com redução da espessura equivalente, conforme ADUL-WAHAB \& KHALIL (2000)) comportou-se exatamente como os modelos de viga excêntrica 02 e 03; o Modelo 07 (laje maciça com redução do $\mathrm{G}_{\mathrm{c}}$, ou módulo de deformação transversal do material) comportou-se, de uma maneira geral, sempre mais rígido que o modelo realista 04 , exceto para baixas excentricidades, como $h_{f} / h=0,25$, onde ofereceu resultados próximos ao realista, com erro de $7,2 \%$ para o máximo deslocamento na nervura central, a menor. Para $\mathrm{h}_{\mathrm{f}} / \mathrm{h}=0,100$, esse erro é de $32,64 \%$;

- os modelos com vigas de seção "T" concêntricas, ou seja, Modelos 05 e 06, apresentaram tendência a serem mais rígidos que o realista e que os modelos de viga excêntrica. Quanto maior a relação $h_{f} / h$, melhores os resultados do Modelo 06: para $h_{f} / h=0,333$, o erro entre o deslocamento máximo na nervura central do Modelo $06 \mathrm{em}$ comparação com o Modelo 04 foi de 3,5\%, a menor; para $h_{f} / h=0,100$, o erro é de 18,65\%. Os resultados do Modelo 05 não apresentaram variação com a mudança de $h_{f} / h$, com um erro praticamente constante em torno de $20 \%$.

Abaixo tem-se os gráficos de deslocamentos ortogonais ao plano da placa para as vigas de contorno externo das lajes processadas nesta série.

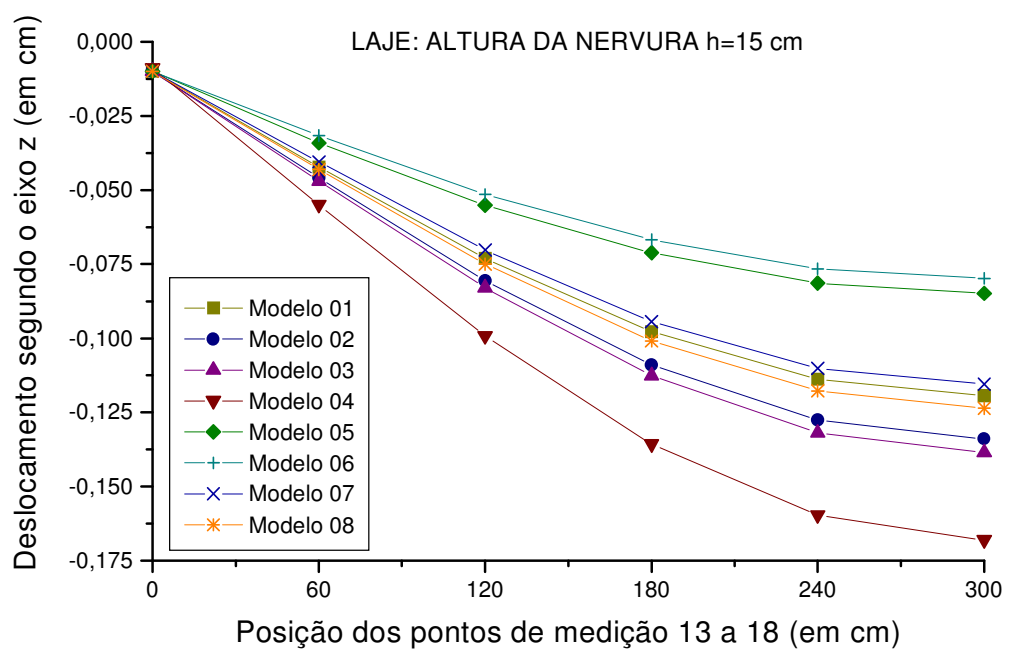

FIGURA 5.29: Deslocamentos em z (cm), nas vigas externas; laje com $\mathrm{hf} / \mathrm{h}=0,333$ 


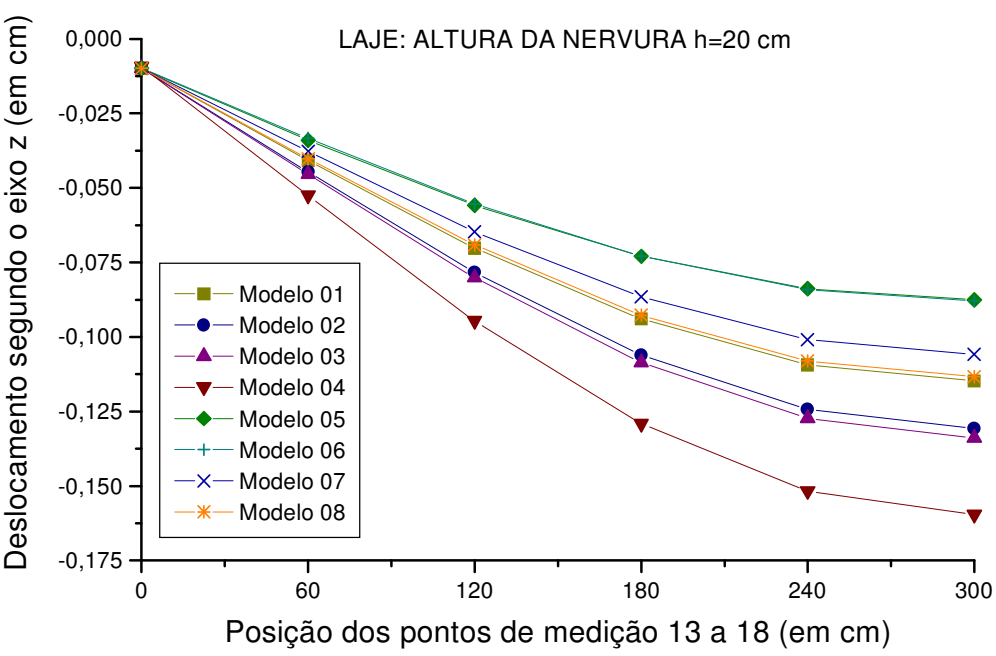

FIGURA 5.30: Deslocamentos em z (cm), nas vigas externas; laje com $\mathrm{hf} / \mathrm{h}=0,250$

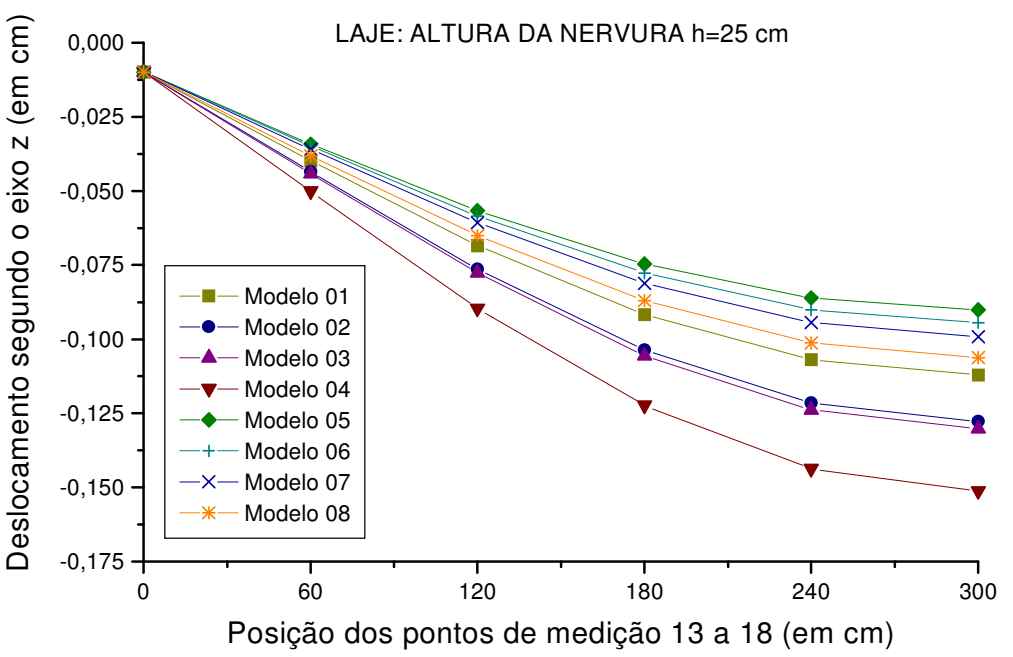

FIGURA 5.31: Deslocamentos em z (cm), nas vigas externas; laje com $\mathrm{hf} / \mathrm{h}=0,200$

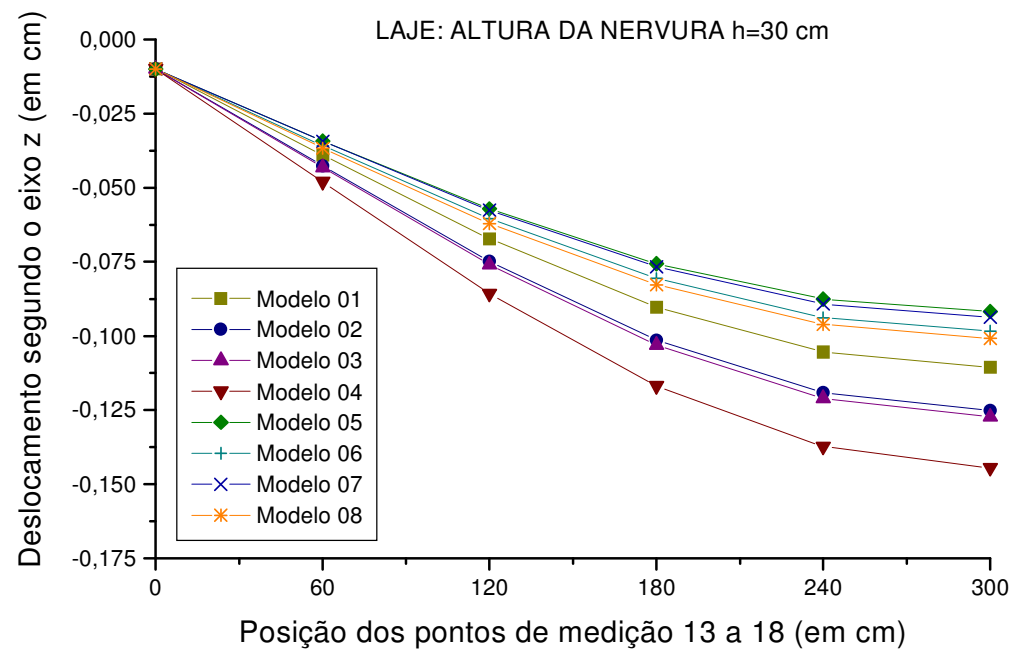

FIGURA 5.32: Deslocamentos em z (cm), nas vigas externas; laje com $\mathrm{hf} / \mathrm{h}=0,167$ 


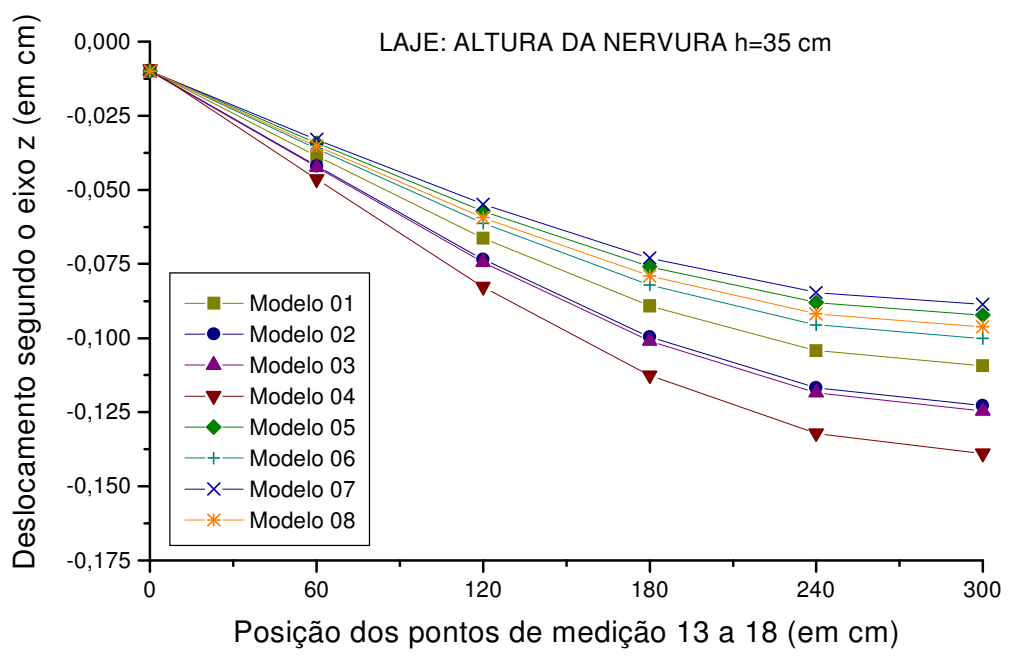

FIGURA 5.33: Deslocamentos em z (cm), nas vigas externas; laje com $\mathrm{hf} / \mathrm{h}=0,143$

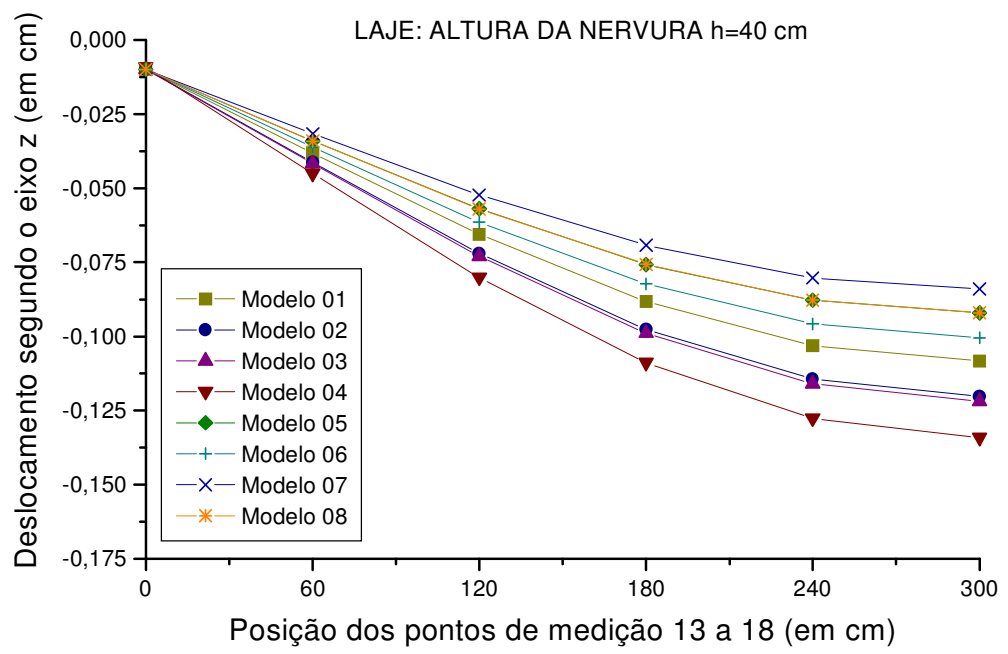

FIGURA 5.34: Deslocamentos em $\mathrm{z}(\mathrm{cm})$, nas vigas externas; laje com $\mathrm{hf} / \mathrm{h}=0,125$

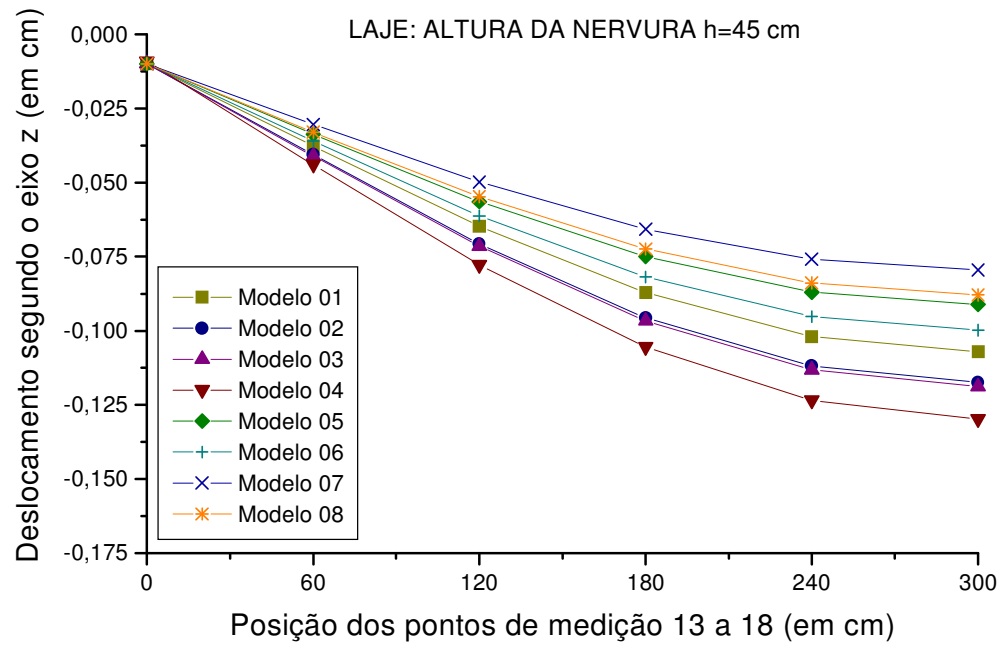

FIGURA 5.35: Deslocamentos em z (cm), nas vigas externas; laje com $\mathrm{hf} / \mathrm{h}=0,111$ 


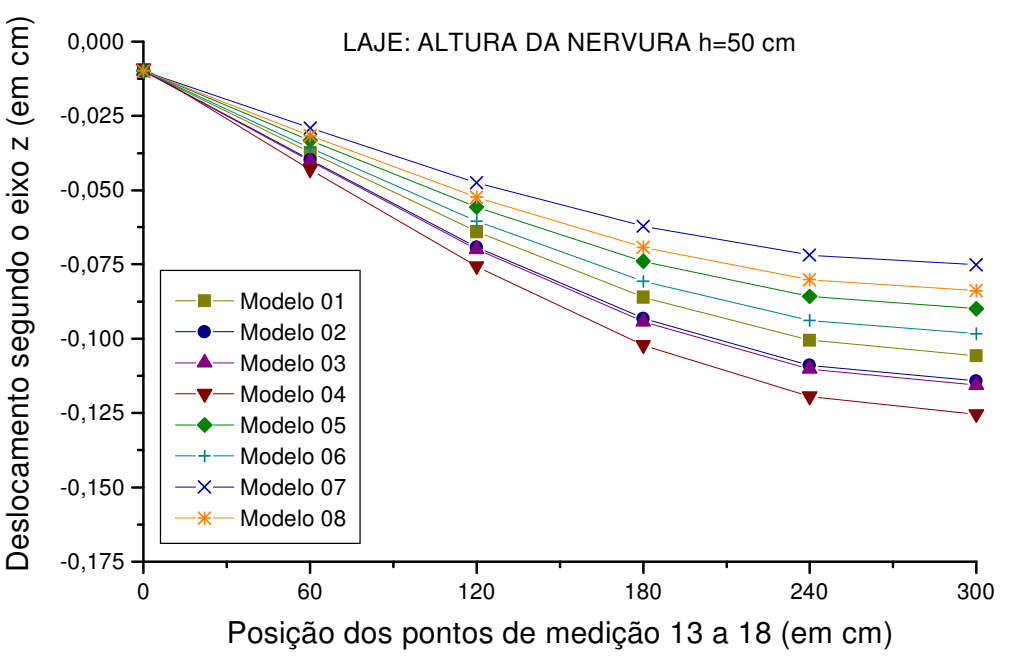

FIGURA 5.36: Deslocamentos em z (cm), nas vigas externas; laje com $\mathrm{hf} / \mathrm{h}=0,100$

Pela análise das tabelas de deslocamentos das vigas de contorno, sempre simuladas pelo elemento BEAM44 excêntrico ou, para o Modelo 04, pelo elemento de casca SHELL63, verificou-se que:

- o modelo realista dá à viga resultados de deslocamentos ortogonais ao plano da placa maiores que os obtidos pelos demais modelos, quanto menor for a excentricidade. Comportou-se sempre mais flexível que os demais modelos, em qualquer relação $h_{f} / h$;

- os modelos 02 e 03 , que simulam a viga e as nervuras utilizando o elemento excêntrico BEAM44, apresentam os melhores resultados de deslocamentos para as vigas em comparação com o Modelo 04, aproximando-se mais dos mesmos para altas excentricidades das nervuras: para $h_{f} / h=0,333$, tem-se um erro de $20,3 \%$ no deslocamento máximo da viga, a menor para o Modelo 02; para $h_{f} / h=0,100$ essa diferença é de 8,85\%;

- simulando a viga de contorno externo de maneira excêntrica, com as nervuras consideradas concêntricas, foram obtidos nos processamentos melhores resultados de deslocamentos para a viga que os fornecidos pelos modelos que simplificam a excentricidade;

- para baixa excentricidade entre as nervuras e a capa ocorreu uma diferença de $52 \%$, a menor para o Modelo 06, quando comparado com o modelo realista, entre os resultados de deslocamento máximo na viga; quanto maior a excentricidade nas nervuras, melhores os resultados para as vigas rígidas do contorno;

- quanto mais excêntricas são as nervuras, ou quanto mais rígido é o sistema, menores são também os deslocamentos da viga pelos modelos 07 e 08 , havendo diferenças 
de $40 \%$ a menor para o Modelo 08, quando comparado ao Modelo 04, na relação $\mathrm{h}_{\mathrm{f}} / \mathrm{h}=0,100$.

Essa diferença é de $26,5 \%$ para $h_{\mathrm{f}} / \mathrm{h}=0,333$.

\subsubsection{Momentos Fletores atuantes nas nervuras e vigas}

TABELA 5.38: Momentos Fletores nas nervuras e vigas, em kN.cm, na laje com altura total $\mathrm{h}=15 \mathrm{~cm}$

\begin{tabular}{|c|c|c|c|c|c|c|c|c|}
\hline \multicolumn{9}{|c|}{$\begin{array}{c}\text { LAJE COM RELAÇÃO hf/h }=0,333 \\
\text { MOMENTOS FLETORES NAS NERVURAS E VIGAS }(\mathrm{kN.cm)}\end{array}$} \\
\hline \multirow{2}{*}{ Ponto } & \multicolumn{8}{|c|}{ Modelos numéricos de análise } \\
\hline & 01 & 02 & 03 & 04 & 05 & 06 & 07 & 08 \\
\hline 1 & $-162,97$ & $-31,88$ & $-62,16$ & $-221,83$ & $-441,52$ & $-503,75$ & $-40,74$ & $-206,28$ \\
\hline 2 & 124,19 & 136,25 & 6,65 & $-50,18$ & $-36,52$ & $-35,92$ & 284,27 & 110,09 \\
\hline 3 & 325,91 & 245,79 & 50,14 & 83,82 & 244,03 & 292,29 & 518,95 & 326,86 \\
\hline 4 & 458,99 & 317,33 & 80,55 & 168,64 & 419,09 & 499,67 & 679,38 & 462,89 \\
\hline 5 & 531,48 & 355,64 & 100,72 & 215,14 & 508,12 & 605,89 & 771,54 & 535,06 \\
\hline 6 & 545,90 & 360,85 & 110,89 & 229,88 & 525,03 & 624,14 & 796,62 & 553,90 \\
\hline 7 & $-253,08$ & -137,34 & $-99,12$ & $\begin{array}{l}-150,21 \\
\end{array}$ & $-242,21$ & $-271,17$ & $-313,31$ & $-307,06$ \\
\hline 8 & $-4,39$ & 30,24 & $-23,89$ & $-40,37$ & 4,92 & 15,34 & 25,75 & $-0,74$ \\
\hline 9 & 167,71 & 135,04 & 17,56 & 43,79 & 150,70 & 181,77 & 252,16 & 162,62 \\
\hline 10 & 279,07 & 201,99 & 46,58 & 92,75 & 232,67 & 275,19 & 399,70 & 257,45 \\
\hline 11 & 337,61 & 235,35 & 64,59 & 118,10 & 272,98 & 321,90 & 479,69 & 307,14 \\
\hline 12 & 348,91 & 239,56 & 73,13 & 125,89 & 280,62 & 330,89 & 500,57 & 320,08 \\
\hline 13 & $-1438,90$ & $-1601,20$ & $-1657,70$ & $-1145,34$ & $-1052,00$ & $-1172,90$ & $-1378,00$ & $-1432,90$ \\
\hline 14 & $-73,22$ & 81,85 & 468,73 & 258,96 & $-116,22$ & 831,81 & 192,47 & 247,42 \\
\hline 15 & 887,98 & 1272,80 & 1784,40 & 1496,58 & 714,32 & 1406,30 & 1248,70 & 1337,80 \\
\hline 16 & 1708,50 & 2212,00 & 2658,20 & 2442,80 & 1806,70 & 1765,80 & 1983,70 & 2120,40 \\
\hline 17 & 2340,80 & 2858,20 & 3159,40 & 3047,20 & 2031,50 & 1922,60 & 2440,70 & 2613,30 \\
\hline 18 & 2730,90 & 3157,70 & 3279,30 & 3254,71 & 1774,90 & 1392,50 & 2616,20 & 2806,70 \\
\hline
\end{tabular}

TABELA 5.39: Momentos Fletores nas nervuras e vigas, em kN.cm, na laje com altura total $\mathrm{h}=20 \mathrm{~cm}$

\begin{tabular}{|c|c|c|c|c|c|c|c|c|}
\hline \multicolumn{9}{|c|}{$\begin{array}{c}\text { LAJE COM RELAÇÃO hf/h }=0,250 \\
\text { MOMENTOS FLETORES NAS NERVURAS E VIGAS (kN.cm) }\end{array}$} \\
\hline \multirow{2}{*}{ Ponto } & \multicolumn{8}{|c|}{ Modelos numéricos de análise } \\
\hline & 01 & $\mathbf{0 2}$ & 03 & 04 & 05 & 06 & 07 & 08 \\
\hline 1 & $-159,79$ & 33,16 & $-56,09$ & $-155,91$ & $-442,03$ & $-453,75$ & 30,71 & $-61,28$ \\
\hline 2 & 194,47 & 200,16 & 39,77 & 20,09 & 7,27 & 29,84 & 368,19 & 219,83 \\
\hline 3 & 444,49 & 310,73 & 101,08 & 151,50 & 330,68 & 377,07 & 604,20 & 416,68 \\
\hline 4 & 614,24 & 382,03 & 143,23 & 235,94 & 541,96 & 605,66 & 762,84 & 544,79 \\
\hline 5 & 716,31 & 420,12 & 170,94 & 283,60 & 659,28 & 732,88 & 853,80 & 614,82 \\
\hline 6 & 750,92 & 424,75 & 184,43 & 299,03 & 696,64 & 773,38 & 878,58 & 633,36 \\
\hline$\overline{77}$ & $-329,44$ & -86,27 & $-104,56$ & $-140,93$ & $-286,17$ & $-291,14$ & $-209,87$ & $-244,22$ \\
\hline 8 & $-29,34$ & 69,29 & $-15,28$ & $-14,79$ & 16,84 & 39,37 & 95,18 & 51,39 \\
\hline 9 & 210,66 & 182,59 & 45,92 & 82,99 & 208,20 & 240,58 & 325,62 & 224,27 \\
\hline 10 & 378,15 & 254,41 & 89,63 & 145,01 & 323,37 & 360,89 & 474,64 & 327,25 \\
\hline 11 & 470,71 & 287,47 & 114,48 & 178,26 & 385,78 & 427,48 & 550,37 & 380,15 \\
\hline 12 & 499,42 & 290,79 & 125,09 & 188,59 & 405,69 & 451,28 & 569,21 & 393,64 \\
\hline 13 & $-1397,60$ & $-1581,10$ & $-1619,70$ & $-1198,26$ & $-1093,40$ & $-1204,20$ & $-1246,60$ & $-1317,70$ \\
\hline 14 & 852,03 & 496,20 & 378,09 & 210,36 & 1379,90 & 800,55 & 186,11 & 232,97 \\
\hline 15 & 1878,20 & 1586,60 & 1617,00 & 1395,20 & 1900,00 & 1687,40 & 1105,30 & 1205,70 \\
\hline 16 & 2433,20 & 2415,80 & 2492,20 & 2298,80 & 2059,90 & 1945,90 & 1775,90 & 1909,40 \\
\hline 17 & 2679,70 & 2927,80 & 3035,80 & 2871,19 & 2062,90 & 2026,90 & 2214,10 & 2363,40 \\
\hline 18 & 2635,10 & 3063,30 & 3199,00 & 3067,06 & 1891,00 & 1929,60 & 2388,30 & 2546,90 \\
\hline
\end{tabular}


TABELA 5.40: Momentos Fletores nas nervuras e vigas, em kN.cm, na laje com altura total $\mathrm{h}=25 \mathrm{~cm}$

\begin{tabular}{c|c|c|c|c|c|c|c|c}
\hline \hline \multicolumn{1}{c}{ LAJE COM RELAÇÃ $\mathbf{~ h f / h ~ = ~ 0 , 2 0 0 ~}$} \\
\hline \multirow{2}{*}{ Ponto } & \multicolumn{7}{c}{ Modelos numéricos de análise } \\
\cline { 2 - 10 } & $\mathbf{0 1}$ & $\mathbf{0 2}$ & $\mathbf{0 3}$ & $\mathbf{0 4}$ & $\mathbf{0 5}$ & $\mathbf{0 6}$ & $\mathbf{0 7}$ & $\mathbf{0 8}$ \\
\hline \hline $\mathbf{1}$ & $-92,18$ & $-52,65$ & $-54,61$ & $\mathbf{- 9 9 , 4 5}$ & $-317,23$ & $-313,06$ & 46,48 & $-2,30$ \\
\hline $\mathbf{2}$ & 294,21 & 153,65 & 64,06 & $\mathbf{8 0 , 1 6}$ & 130,37 & 152,71 & 401,41 & 279,67 \\
\hline $\mathbf{3}$ & 562,83 & 291,03 & 140,97 & $\mathbf{2 0 7 , 6 9}$ & 454,51 & 489,55 & 646,20 & 473,21 \\
\hline $\mathbf{4}$ & 742,87 & 381,27 & 192,48 & $\mathbf{2 9 1 , 5 3}$ & 668,93 & 713,74 & 807,78 & 599,17 \\
\hline $\mathbf{5}$ & 851,53 & 436,26 & 225,33 & $\mathbf{3 3 9 , 6 4}$ & 789,69 & 840,02 & 899,22 & 668,28 \\
\hline $\mathbf{6}$ & 888,74 & 457,99 & 240,74 & $\mathbf{3 5 5 , 3 9}$ & 828,50 & 880,52 & 924,00 & 686,64 \\
\hline \hline $\mathbf{7}$ & $-279,94$ & $-109,25$ & $-82,50$ & $\mathbf{- 1 1 8 , 8 2}$ & $-234,73$ & $-231,63$ & $-117,70$ & $-170,08$ \\
\hline $\mathbf{8}$ & 19,53 & 34,07 & 2,72 & $\mathbf{1 5 , 2 9}$ & 83,57 & 106,80 & 154,21 & 98,21 \\
\hline $\mathbf{9}$ & 284,27 & 167,06 & 76,91 & $\mathbf{1 1 3 , 4 2}$ & 293,49 & 320,98 & 381,29 & 273,79 \\
\hline $\mathbf{1 0}$ & 472,64 & 258,89 & 129,03 & $\mathbf{1 9 4 , 4 9}$ & 425,01 & 454,22 & 526,55 & 378,55 \\
\hline $\mathbf{1 1}$ & 572,68 & 305,04 & 156,55 & $\mathbf{2 3 3 , 0 5}$ & 497,77 & 529,62 & 597,81 & 430,59 \\
\hline $\mathbf{1 2}$ & 602,46 & 320,31 & 167,53 & $\mathbf{2 4 5 , 0 7}$ & 521,12 & 554,25 & 615,24 & 443,55 \\
\hline $\mathbf{1 3}$ & $-1377,10$ & $-1560,60$ & $-1589,30$ & $\mathbf{- 1 2 5 5 , 4 9}$ & $-1132,20$ & $-1273,00$ & $-1148,80$ & $-1231,10$ \\
\hline $\mathbf{1 4}$ & 733,88 & 347,15 & 313,32 & $\mathbf{1 3 7 , 4 2}$ & 1128,40 & 731,78 & 391,22 & 486,00 \\
\hline $\mathbf{1 5}$ & 1692,20 & 1493,80 & 1503,90 & $\mathbf{1 2 9 4 , 4 4}$ & 1713,30 & 1608,20 & 1194,90 & 1346,00 \\
\hline $\mathbf{1 6}$ & 2271,20 & 2349,40 & 2386,10 & $\mathbf{2 1 6 2 , 9 4}$ & 1991,70 & 1997,30 & 1774,90 & 1935,30 \\
\hline $\mathbf{1 7}$ & 2582,00 & 2896,50 & 2950,30 & $\mathbf{2 7 1 0 , 0 0}$ & 2093,60 & 2177,70 & 2130,80 & 2288,00 \\
\hline $\mathbf{1 8}$ & 2599,80 & 3065,70 & 3129,50 & $\mathbf{2 8 9 6 , 8 3}$ & 1994,60 & 2136,00 & 2228,20 & 2379,00 \\
\hline \hline
\end{tabular}

TABELA 5.41: Momentos Fletores nas nervuras e vigas, em kN.cm, na laje com altura total $\mathrm{h}=30 \mathrm{~cm}$

\begin{tabular}{c|c|c|c|c|c|c|c|c}
\hline \hline \multicolumn{7}{c}{ MAJE COM RELAÇÃO hf/h = 0,167 } \\
\hline \multirow{2}{*}{ Ponto } & \multicolumn{7}{c}{$\mathbf{9}$ Modelos numéricos de análise } \\
\cline { 2 - 10 } & $\mathbf{0 1}$ & $\mathbf{0 2}$ & $\mathbf{0 3}$ & $\mathbf{0 4}$ & $\mathbf{0 5}$ & $\mathbf{0 6}$ & $\mathbf{0 7}$ & $\mathbf{0 8}$ \\
\hline \hline $\mathbf{1}$ & $-54,79$ & $-50,18$ & $-55,38$ & $-65,39$ & $-223,53$ & $-221,38$ & 50,68 & 21,21 \\
\hline $\mathbf{2}$ & 353,34 & 159,78 & 79,51 & $\mathbf{1 1 4 , 9 7}$ & 216,07 & 226,92 & 415,33 & 313,37 \\
\hline $\mathbf{3}$ & 636,38 & 303,42 & 169,60 & $\mathbf{2 4 5 , 4 7}$ & 537,17 & 554,78 & 668,46 & 510,86 \\
\hline $\mathbf{4}$ & 823,71 & 397,27 & 229,26 & $\mathbf{3 3 0 , 4 2}$ & 751,92 & 775,42 & 834,60 & 638,46 \\
\hline $\mathbf{5}$ & 936,06 & 453,46 & 266,27 & $\mathbf{3 7 9 , 4 0}$ & 874,09 & 900,96 & 927,78 & 708,24 \\
\hline $\mathbf{6}$ & 974,56 & 475,58 & 283,02 & $\mathbf{3 9 5 , 4 8}$ & 913,60 & 941,46 & 952,98 & 726,78 \\
\hline \hline $\mathbf{7}$ & $-217,12$ & $-68,31$ & $-60,18$ & $\mathbf{- 9 4 , 4 2}$ & $-186,97$ & $-186,77$ & $-52,42$ & $-105,84$ \\
\hline $\mathbf{8}$ & 71,53 & 62,94 & 23,75 & $\mathbf{4 5 , 1 3}$ & 141,36 & 158,25 & 202,32 & 138,17 \\
\hline $\mathbf{9}$ & 345,74 & 196,55 & 107,37 & $\mathbf{1 6 1 , 0 1}$ & 364,80 & 384,13 & 427,36 & 315,11 \\
\hline $\mathbf{1 0}$ & 541,77 & 287,73 & 164,83 & $\mathbf{2 3 8 , 5 9}$ & 508,80 & 529,05 & 571,37 & 420,99 \\
\hline $\mathbf{1 1}$ & 642,21 & 333,52 & 194,77 & $\mathbf{2 8 1 , 1 4}$ & 589,77 & 612,43 & 642,48 & 473,03 \\
\hline $\mathbf{1 2}$ & 671,19 & 349,05 & 206,56 & $\mathbf{2 9 4 , 4 9}$ & 615,93 & 639,80 & 660,12 & 485,98 \\
\hline \hline $\mathbf{1 3}$ & $-1366,30$ & $-1541,10$ & $-1564,20$ & $-\mathbf{1 2 9 8 , 3 1}$ & $-1158,60$ & $-1314,80$ & $-1068,20$ & $-1159,70$ \\
\hline $\mathbf{1 4}$ & 628,99 & 296,62 & 280,96 & $\mathbf{8 6 , 4 2}$ & 942,48 & 689,93 & 388,56 & 483,19 \\
\hline $\mathbf{1 5}$ & 1548,10 & 1423,10 & 1438,20 & $\mathbf{1 2 1 4 , 5 9}$ & 1575,70 & 1554,30 & 1125,70 & 1272,10 \\
\hline $\mathbf{1 6}$ & 2162,20 & 2285,30 & 2319,50 & $\mathbf{2 0 5 3 , 2 6}$ & 1938,60 & 2024,40 & 1672,20 & 1830,20 \\
\hline $\mathbf{1 7}$ & 2525,60 & 2833,50 & 2880,20 & $\mathbf{2 5 7 8 , 2 7}$ & 2108,50 & 2265,20 & 2003,20 & 2165,40 \\
\hline $\mathbf{1 8}$ & 2586,30 & 3005,70 & 3058,90 & $\mathbf{2 7 5 7 , 0 7}$ & 2059,70 & 2258,00 & 2090,00 & 2249,40 \\
\hline \hline
\end{tabular}


TABELA 5.42: Momentos Fletores nas nervuras e vigas, em kN.cm, na laje com altura total $\mathrm{h}=35 \mathrm{~cm}$

\section{LAJE COM RELAÇ̃̃O hf/h $=0,143$}

MOMENTOS FLETORES NAS NERVURAS E VIGAS (kN.cm)

\begin{tabular}{c|c|c|c|c|c|c|c|c}
\hline \multirow{2}{*}{ Ponto } & \multicolumn{7}{|c|}{ Modelos numéricos de análise } \\
\cline { 2 - 9 } & $\mathbf{0 1}$ & $\mathbf{0 2}$ & $\mathbf{0 3}$ & $\mathbf{0 4}$ & $\mathbf{0 5}$ & $\mathbf{0 6}$ & $\mathbf{0 7}$ & $\mathbf{0 8}$ \\
\hline $\mathbf{1}$ & $-35,14$ & $-49,90$ & $-55,85$ & $\mathbf{- 4 7 , 3 8}$ & $-160,37$ & $-164,00$ & 52,41 & 32,40 \\
\hline $\mathbf{2}$ & 383,61 & 158,39 & 88,63 & $\mathbf{1 3 4 , 0 5}$ & 266,31 & 264,57 & 421,25 & 335,07 \\
\hline $\mathbf{3}$ & 676,68 & 306,47 & 189,20 & $\mathbf{2 6 7 , 6 0}$ & 582,24 & 583,13 & 681,36 & 539,42 \\
\hline $\mathbf{4}$ & 869,67 & 404,17 & 256,14 & $\mathbf{3 5 5 , 0 0}$ & 796,18 & 800,45 & 852,78 & 671,10 \\
\hline $\mathbf{5}$ & 984,50 & 462,14 & 296,97 & $\mathbf{4 0 5 , 4 9}$ & 918,95 & 925,35 & 948,66 & 743,04 \\
\hline $\mathbf{6}$ & 1023,70 & 484,76 & 314,86 & $\mathbf{4 2 2 , 0 8}$ & 958,84 & 965,85 & 974,52 & 762,12 \\
\hline \hline $\mathbf{7}$ & $-160,16$ & $-45,97$ & $-46,34$ & $\mathbf{- 7 2 , 2 1}$ & $-149,06$ & $-154,66$ & $-10,22$ & $-57,32$ \\
\hline $\mathbf{8}$ & 119,38 & 88,78 & 45,25 & $\mathbf{7 2 , 7 0}$ & 188,39 & 197,56 & 242,75 & 172,60 \\
\hline $\mathbf{9}$ & 396,52 & 224,46 & 137,02 & $\mathbf{1 9 5 , 8 7}$ & 423,37 & 435,31 & 469,56 & 352,44 \\
\hline $\mathbf{1 0}$ & 594,52 & 316,73 & 199,46 & $\mathbf{2 7 9 , 4 9}$ & 578,37 & 592,10 & 616,50 & 461,40 \\
\hline $\mathbf{1 1}$ & 693,96 & 365,30 & 233,30 & $\mathbf{3 2 6 , 1 8}$ & 667,17 & 683,94 & 691,26 & 515,76 \\
\hline $\mathbf{1 2}$ & 722,31 & 382,56 & 246,87 & $\mathbf{3 4 1 , 0 4}$ & 696,12 & 714,29 & 710,34 & 529,49 \\
\hline \hline $\mathbf{1 3}$ & $-1358,50$ & $-1521,00$ & $-1540,80$ & $-\mathbf{1 3 2 3 , 9 3}$ & $-1172,10$ & $-1334,40$ & $-996,83$ & $-1096,50$ \\
\hline $\mathbf{1 4}$ & 547,90 & 271,48 & 262,09 & $\mathbf{4 0 , 1 2}$ & 817,80 & 670,33 & 385,06 & 476,89 \\
\hline $\mathbf{1 5}$ & 1446,10 & 1387,60 & 1403,03 & $\mathbf{1 1 5 7 , 2 3}$ & 1481,10 & 1518,30 & 1070,90 & 1211,80 \\
\hline $\mathbf{1 6}$ & 2090,30 & 2238,60 & 2270,00 & $\mathbf{1 9 6 6 , 7 6}$ & 1894,80 & 2029,30 & 1581,60 & 1742,40 \\
\hline $\mathbf{1 7}$ & 2486,90 & 2768,60 & 2810,40 & $\mathbf{2 4 6 8 , 6 9}$ & 2104,20 & 2299,50 & 1884,30 & 2058,10 \\
\hline $\mathbf{1 8}$ & 2572,70 & 2933,90 & 2980,70 & $\mathbf{2 6 3 8 , 7 3}$ & 2086,60 & 2310,80 & 1960,60 & 2134,60 \\
\hline \hline
\end{tabular}

TABELA 5.43: Momentos Fletores nas nervuras e vigas, em kN.cm, na laje com altura total $\mathrm{h}=40 \mathrm{~cm}$

LAJE COM RELAÇÃO hf/h = 0,125

MOMENTOS FLETORES NAS NERVURAS E VIGAS $(\mathrm{kN.cm})$

\begin{tabular}{c|c|c|c|c|c|c|c|c}
\hline \multirow{2}{*}{ Ponto } & \multicolumn{7}{|c}{ Modelos numéricos de análise } \\
\cline { 2 - 9 } & $\mathbf{0 1}$ & $\mathbf{0 2}$ & $\mathbf{0 3}$ & $\mathbf{0 4}$ & $\mathbf{0 5}$ & $\mathbf{0 6}$ & $\mathbf{0 7}$ & $\mathbf{0 8}$ \\
\hline \hline $\mathbf{1}$ & $-24,12$ & $-50,02$ & $-55,91$ & $\mathbf{- 3 8 , 4 1}$ & $-118,59$ & $-127,51$ & 53,12 & 38,92 \\
\hline $\mathbf{2}$ & 395,31 & 152,21 & 92,61 & $\mathbf{1 4 1 , 3 3}$ & 290,30 & 277,71 & 423,30 & 351,26 \\
\hline $\mathbf{3}$ & 693,75 & 302,91 & 201,24 & $\mathbf{2 7 8 , 1 6}$ & 598,82 & 585,58 & 689,46 & 563,94 \\
\hline $\mathbf{4}$ & 890,85 & 404,47 & 274,83 & $\mathbf{3 6 8 , 7 9}$ & 811,01 & 799,26 & 866,64 & 701,46 \\
\hline $\mathbf{5}$ & 1007,50 & 464,78 & 319,48 & $\mathbf{4 2 1 , 4 2}$ & 933,96 & 923,49 & 966,00 & 776,88 \\
\hline $\mathbf{6}$ & 1047,10 & 488,06 & 338,47 & $\mathbf{4 3 8 , 7 4}$ & 974,06 & 963,99 & 992,76 & 796,86 \\
\hline \hline $\mathbf{7}$ & $-114,83$ & $-36,30$ & $-40,44$ & $\mathbf{- 5 3 , 5 6}$ & $-120,66$ & $-131,75$ & 16,06 & $-22,98$ \\
\hline $\mathbf{8}$ & 161,10 & 111,96 & 66,09 & $\mathbf{9 7 , 7 6}$ & 226,82 & 229,16 & 278,31 & 203,33 \\
\hline $\mathbf{9}$ & 439,63 & 252,19 & 166,28 & $\mathbf{2 2 9 , 1 5}$ & 473,50 & 480,11 & 511,03 & 388,63 \\
\hline $\mathbf{1 0}$ & 638,46 & 348,48 & 234,97 & $\mathbf{3 1 9 , 8 0}$ & 639,86 & 650,07 & 664,74 & 503,33 \\
\hline $\mathbf{1 1}$ & 738,13 & 402,72 & 274,64 & $\mathbf{3 7 1 , 6 6}$ & 737,29 & 751,65 & 745,92 & 562,19 \\
\hline $\mathbf{1 2}$ & 766,76 & 422,83 & 290,87 & $\mathbf{3 8 8 , 4 9}$ & 769,44 & 785,54 & 767,16 & 577,37 \\
\hline \hline $\mathbf{1 3}$ & $-1350,30$ & $-1498,80$ & $-1516,50$ & $\mathbf{- 1 3 3 4 , 8 8}$ & $-1175,30$ & $-1338,10$ & $-930,55$ & $-1037,70$ \\
\hline $\mathbf{1 4}$ & 489,74 & 264,13 & 257,48 & $\mathbf{3 2 , 5 3}$ & 738,56 & 666,60 & 381,93 & 468,96 \\
\hline $\mathbf{1 5}$ & 1376,10 & 1371,00 & 1386,10 & $\mathbf{1 1 1 7 , 3 4}$ & 1416,40 & 1493,20 & 1022,70 & 1159,50 \\
\hline $\mathbf{1 6}$ & 2039,40 & 2195,30 & 2224,50 & $\mathbf{1 8 9 5 , 1 2}$ & 1854,80 & 2016,90 & 1494,70 & 1661,70 \\
\hline $\mathbf{1 7}$ & 2452,00 & 2695,60 & 2734,10 & $\mathbf{2 3 7 0 , 6 2}$ & 2082,50 & 2294,80 & 1768,80 & 1956,50 \\
\hline $\mathbf{1 8}$ & 2550,60 & 2849,80 & 2892,50 & $\mathbf{2 5 3 0 , 4 4}$ & 2082,70 & 2314,40 & 1835,50 & 2025,70 \\
\hline \hline
\end{tabular}


TABELA 5.44: Momentos Fletores nas nervuras e vigas, em kN.cm, na laje com altura total $\mathrm{h}=45 \mathrm{~cm}$

\begin{tabular}{|c|c|c|c|c|c|c|c|c|}
\hline \multicolumn{9}{|c|}{$\begin{array}{c}\text { LAJE COM RELAÇÃO hf/h }=0,111 \\
\text { MOMENTOS FLETORES NAS NERVURAS E VIGAS (kN.cm) }\end{array}$} \\
\hline \multirow{2}{*}{ Ponto } & \multicolumn{8}{|c|}{ Modelos numéricos de análise } \\
\hline & 01 & 02 & 03 & 04 & 05 & 06 & 07 & 08 \\
\hline 1 & $-17,34$ & $-50,15$ & $-55,69$ & $-34,09$ & $-90,50$ & $-103,41$ & 53,22 & 43,24 \\
\hline 2 & 394,71 & 142,15 & 91,99 & 140,84 & 296,00 & 274,68 & 423,38 & 364,88 \\
\hline 3 & 694,24 & 293,80 & 206,56 & 280,27 & 594,71 & 569,87 & 694,98 & 586,91 \\
\hline 4 & 893,92 & 399,16 & 286,35 & 374,53 & 804,16 & 779,21 & 878,22 & 731,70 \\
\hline 5 & 1011,80 & 462,33 & 335,00 & 429,86 & 926,95 & 902,65 & 981,60 & 811,50 \\
\hline 6 & 1051,70 & 486,46 & 355,17 & 448,16 & 967,19 & 943,15 & 1009,50 & 832,74 \\
\hline$\overline{77}$ & $-80,74$ & $-33,92$ & $-39,70$ & $-38,62$ & $\begin{array}{l}-99,67 \\
\end{array}$ & $\begin{array}{l}-115,07 \\
\end{array}$ & 32,28 & 0,58 \\
\hline 8 & 197,15 & 132,75 & 85,69 & 120,56 & 259,15 & 256,06 & 310,78 & 231,74 \\
\hline 9 & 477,98 & 280,47 & 195,64 & 261,81 & 518,88 & 522,18 & 553,12 & 425,28 \\
\hline 10 & 678,76 & 384,09 & 272,69 & 361,18 & 698,10 & 707,31 & 716,82 & 548,27 \\
\hline 11 & 780,76 & 446,48 & 320,09 & 419,59 & 805,56 & 820,26 & 806,28 & 613,32 \\
\hline 12 & 810,70 & 470,29 & 339,71 & 438,90 & 841,47 & 858,34 & 830,16 & 630,42 \\
\hline 13 & $-1340,30$ & $-1473,03$ & $-1489,50$ & $-1334,42$ & $-1170,70$ & $-1330,80$ & $-867,43$ & $-981,15$ \\
\hline 14 & 450,81 & 270,77 & 265,31 & 27,92 & 690,87 & 674,00 & 379,01 & 460,13 \\
\hline 15 & 1328,10 & 1364,00 & 1378,20 & 1089,29 & 1370,90 & 1474,40 & 976,72 & 1111,00 \\
\hline 16 & 1998,70 & 2149,00 & 2176,40 & 1831,22 & 1814,90 & 1991,00 & 1408,70 & 1583,10 \\
\hline 17 & 2413,90 & 2612,20 & 2648,50 & 2276,43 & 2046,00 & 2262,20 & 1655,10 & 1856,60 \\
\hline 18 & 2517,60 & 2753,00 & 2792,90 & 2424,58 & 2055,50 & 2283,40 & 1713,40 & 1919,00 \\
\hline
\end{tabular}

TABELA 5.45: Momentos Fletores nas nervuras e vigas, em kN.cm, na laje com altura total $\mathrm{h}=50 \mathrm{~cm}$

\begin{tabular}{c|c|c|c|c|c|c|c|c}
\hline \hline \multicolumn{10}{c}{ MAJE COM RELAÇÃO hf/h = 0,100 } \\
\hline \multirow{2}{*}{ Ponto } & \multicolumn{7}{c}{$\mathbf{0}$ Modelos numéricos de análise } \\
\cline { 2 - 10 } & $\mathbf{0 1}$ & $\mathbf{0 2}$ & $\mathbf{0 3}$ & $\mathbf{0 4}$ & $\mathbf{0 5}$ & $\mathbf{0 6}$ & $\mathbf{0 7}$ & $\mathbf{0 8}$ \\
\hline \hline $\mathbf{1}$ & $-12,87$ & $-50,13$ & $-55,23$ & $\mathbf{- 3 2 , 1 1}$ & $-71,06$ & $-86,76$ & 52,93 & 46,34 \\
\hline $\mathbf{2}$ & 385,41 & 163,24 & 87,19 & $\mathbf{1 3 5 , 2 0}$ & 289,08 & 260,86 & 422,35 & 377,32 \\
\hline $\mathbf{3}$ & 682,33 & 307,15 & 205,76 & $\mathbf{2 7 6 , 1 4}$ & 575,53 & 541,15 & 699,18 & 609,54 \\
\hline $\mathbf{4}$ & 883,12 & 407,79 & 291,40 & $\mathbf{3 7 4 , 1 7}$ & 781,13 & 745,20 & 888,72 & 762,60 \\
\hline $\mathbf{5}$ & 1001,90 & 464,91 & 344,31 & $\mathbf{4 3 2 , 6 7}$ & 903,44 & 867,64 & 996,48 & 847,62 \\
\hline $\mathbf{6}$ & 1042,00 & 480,42 & 365,77 & $\mathbf{4 5 2 , 1 9}$ & 943,77 & 908,14 & 1025,58 & 870,36 \\
\hline \hline $\mathbf{7}$ & $-55,58$ & $-35,35$ & $-41,79$ & $\mathbf{- 2 7 , 2 8}$ & $-84,03$ & $-102,54$ & 42,37 & 16,58 \\
\hline $\mathbf{8}$ & 228,67 & 188,24 & 103,68 & $\mathbf{1 4 1 , 2 6}$ & 287,17 & 279,86 & 341,14 & 258,77 \\
\hline $\mathbf{9}$ & 513,82 & 337,53 & 225,37 & $\mathbf{2 9 4 , 3 0}$ & 561,97 & 563,52 & 596,18 & 463,12 \\
\hline $\mathbf{1 0}$ & 718,67 & 442,89 & 313,30 & $\mathbf{4 0 4 , 3 8}$ & 756,13 & 766,19 & 772,26 & 596,53 \\
\hline $\mathbf{1 1}$ & 825,27 & 506,20 & 370,21 & $\mathbf{4 7 0 , 7 5}$ & 875,25 & 892,28 & 871,26 & 669,06 \\
\hline $\mathbf{1 2}$ & 857,44 & 524,67 & 393,83 & $\mathbf{4 9 3 , 0 1}$ & 915,53 & 935,16 & 898,02 & 688,38 \\
\hline \hline $\mathbf{1 3}$ & $-1327,80$ & $-1443,80$ & $-1458,90$ & $-\mathbf{1 3 2 5 , 2 6}$ & $-1160,20$ & $-1315,40$ & $-806,61$ & $-926,07$ \\
\hline $\mathbf{1 4}$ & 427,33 & 288,92 & 284,02 & $\mathbf{3 3 , 8 8}$ & 664,91 & 689,36 & 375,77 & 450,62 \\
\hline $\mathbf{1 5}$ & 1294,70 & 1361,00 & 1374,30 & $\mathbf{1 0 6 8 , 5 7}$ & 1337,30 & 1458,90 & 930,74 & 1063,70 \\
\hline $\mathbf{1 6}$ & 1961,80 & 2096,80 & 2122,80 & $\mathbf{1 7 7 0 , 2 6}$ & 1772,90 & 1954,60 & 1322,80 & 1504,60 \\
\hline $\mathbf{1 7}$ & 2369,40 & 2517,90 & 2552,60 & $\mathbf{2 1 8 1 , 8 2}$ & 1997,30 & 2209,20 & 1543,10 & 1757,00 \\
\hline $\mathbf{1 8}$ & 2473,70 & 2643,70 & 2681,80 & $\mathbf{2 3 1 7 , 1 6}$ & 2010,50 & 2227,90 & 1594,00 & 1813,30 \\
\hline \hline
\end{tabular}

Abaixo tem-se os gráficos de momentos fletores atuantes nas nervuras das lajes processadas nesta série. 


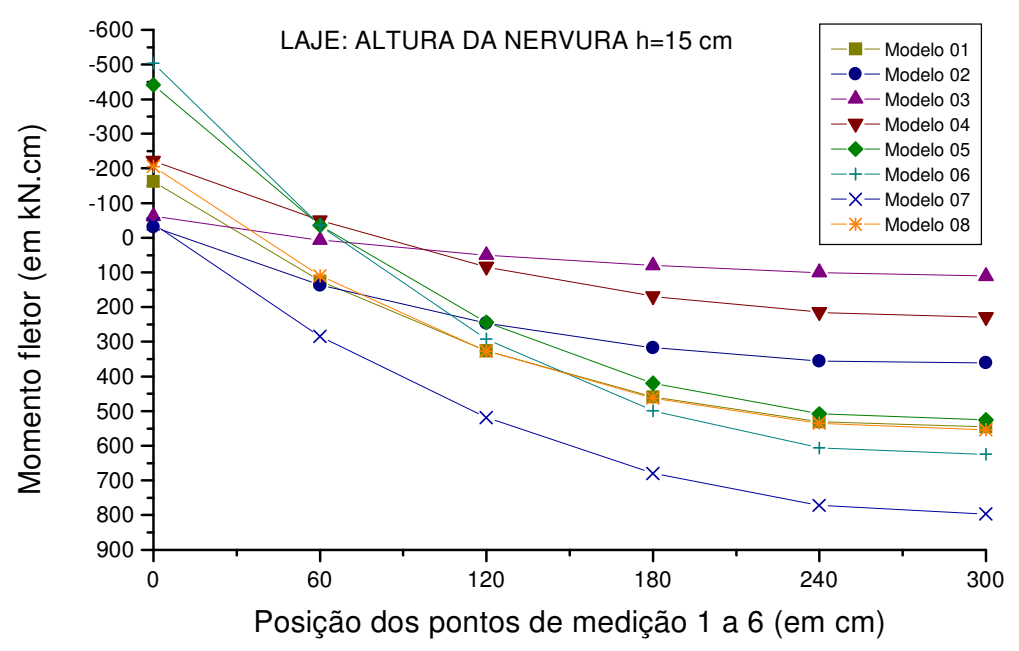

FIGURA 5.37: Momentos fletores ( $\mathrm{kN} . \mathrm{cm}$ ), na nervura central, na laje com $\mathrm{hf} / \mathrm{h}=0,333$

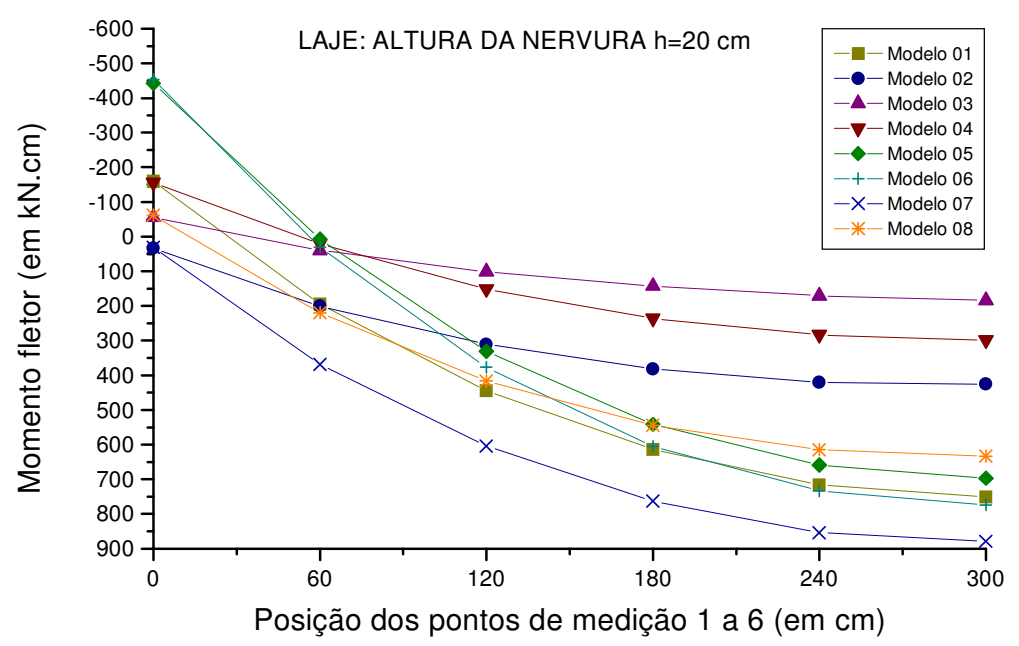

FIGURA 5.38 Momentos fletores (kN.cm), na nervura central, na laje com $\mathrm{hf} / \mathrm{h}=0,250$

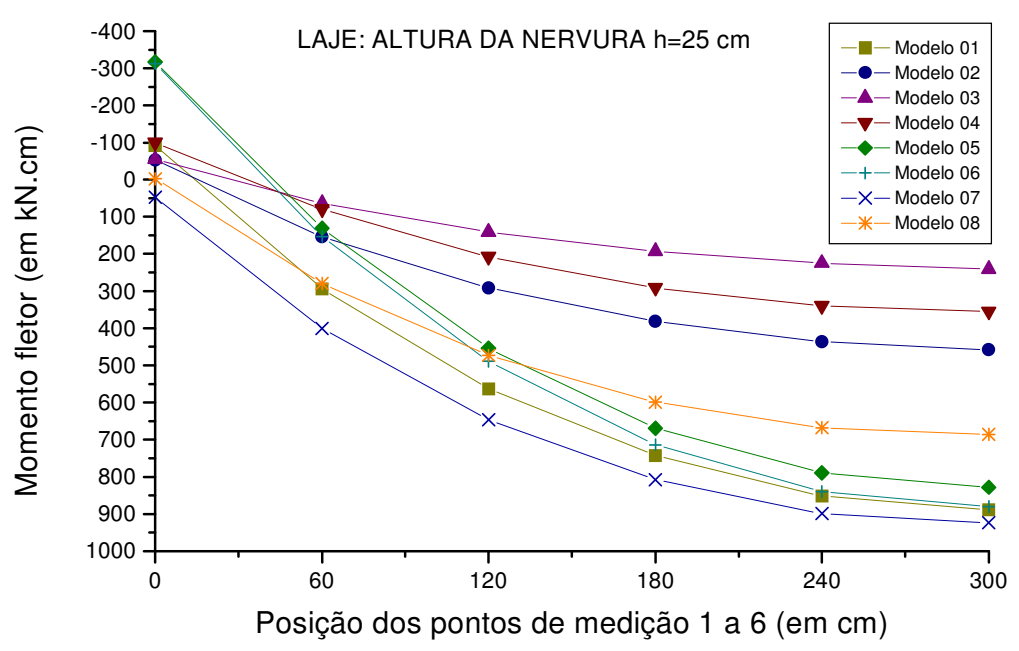

FIGURA 5.39: Momentos fletores ( $\mathrm{kN} . \mathrm{cm}$ ), na nervura central, na laje com $\mathrm{hf} / \mathrm{h}=0,200$ 


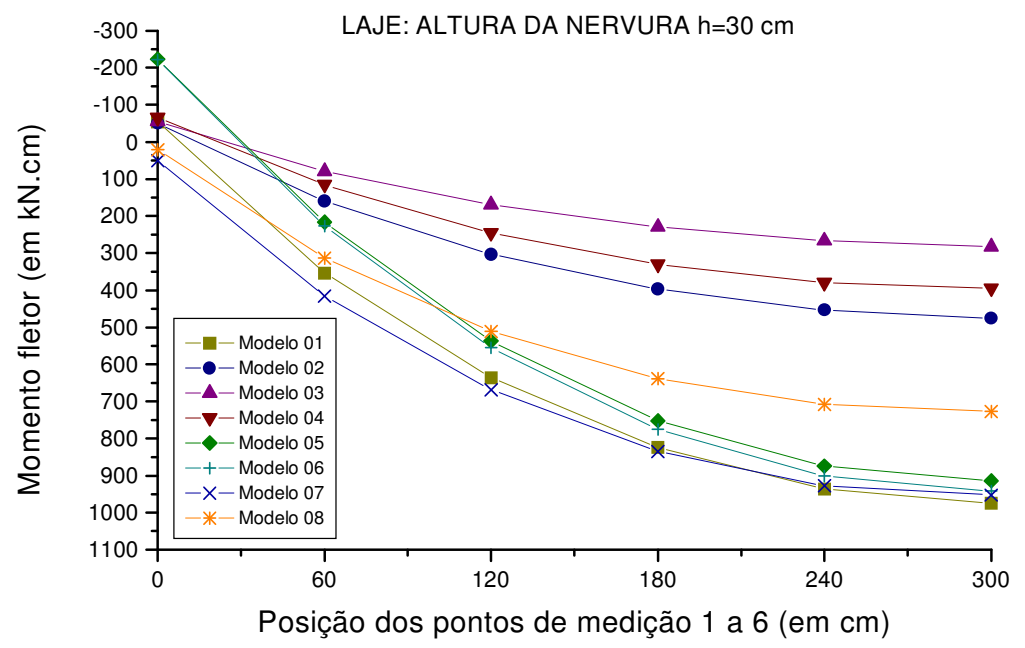

FIGURA 5.40: Momentos fletores (kN.cm), na nervura central, na laje com hf/h=0,167

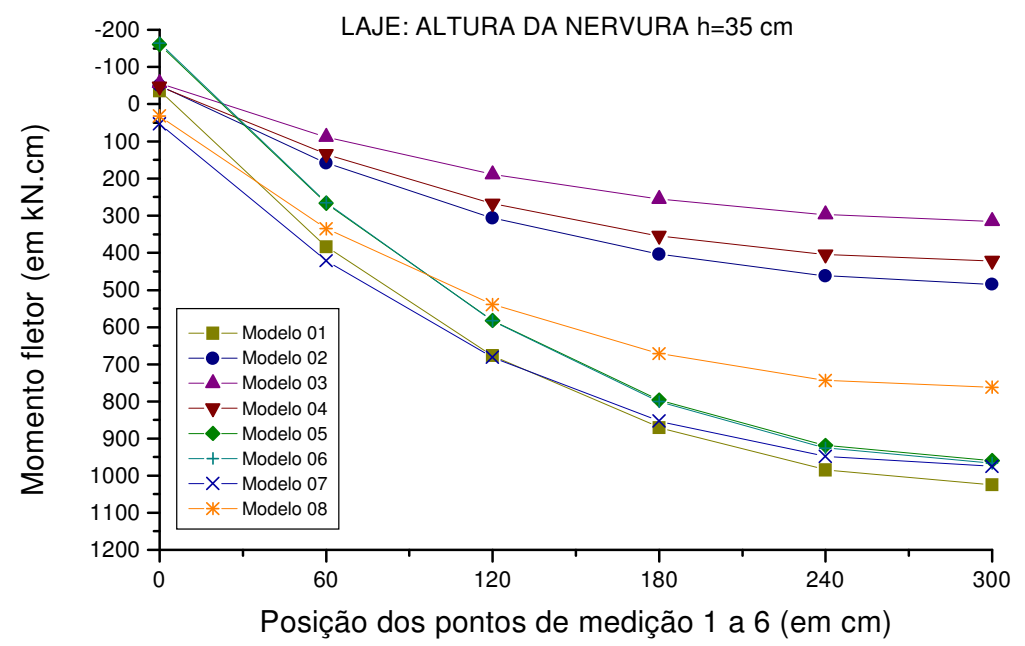

FIGURA 5.41: Momentos fletores (kN.cm), na nervura central, na laje com $\mathrm{hf} / \mathrm{h}=0,143$

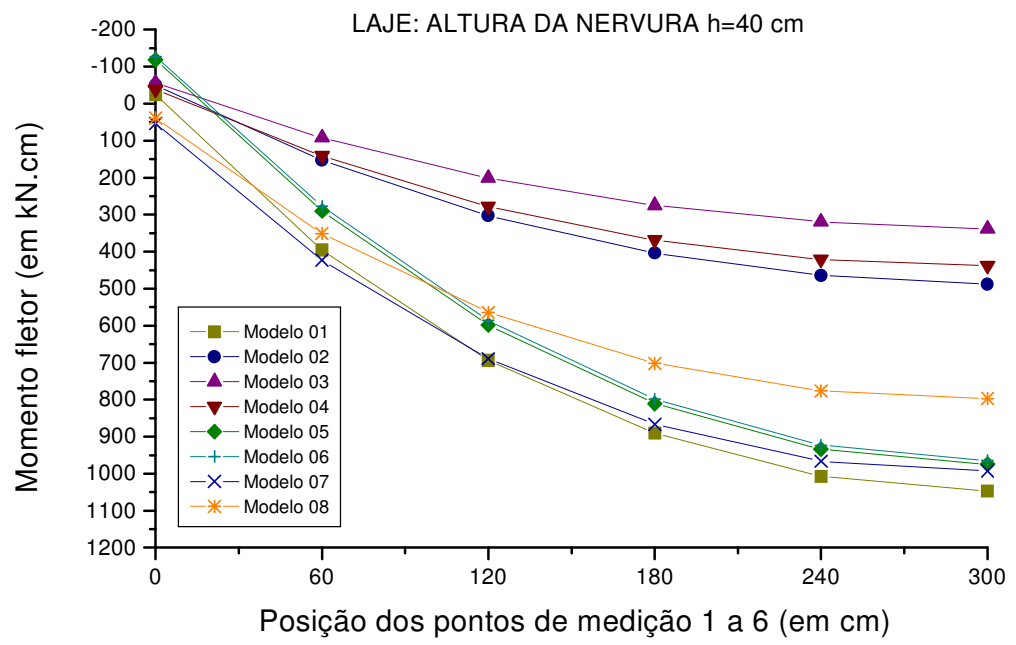

FIGURA 5.42: Momentos fletores ( $\mathrm{kN} . \mathrm{cm})$, na nervura central, na laje com $\mathrm{hf} / \mathrm{h}=0,125$ 


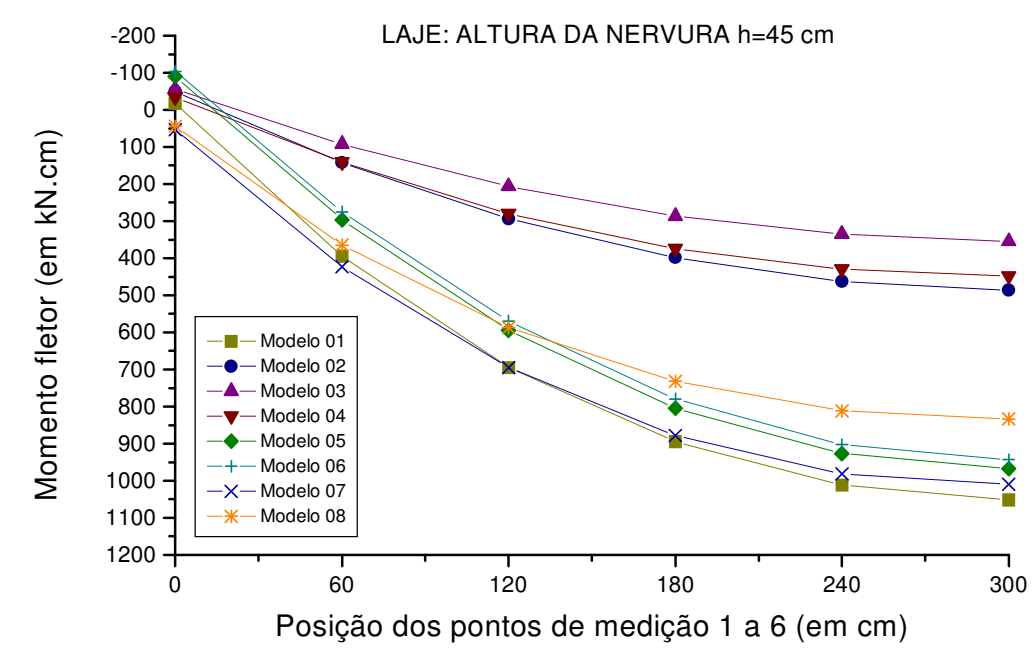

FIGURA 5.43: Momentos fletores $(\mathrm{kN} . \mathrm{cm})$, na nervura central, na laje com $\mathrm{hf} / \mathrm{h}=0,111$

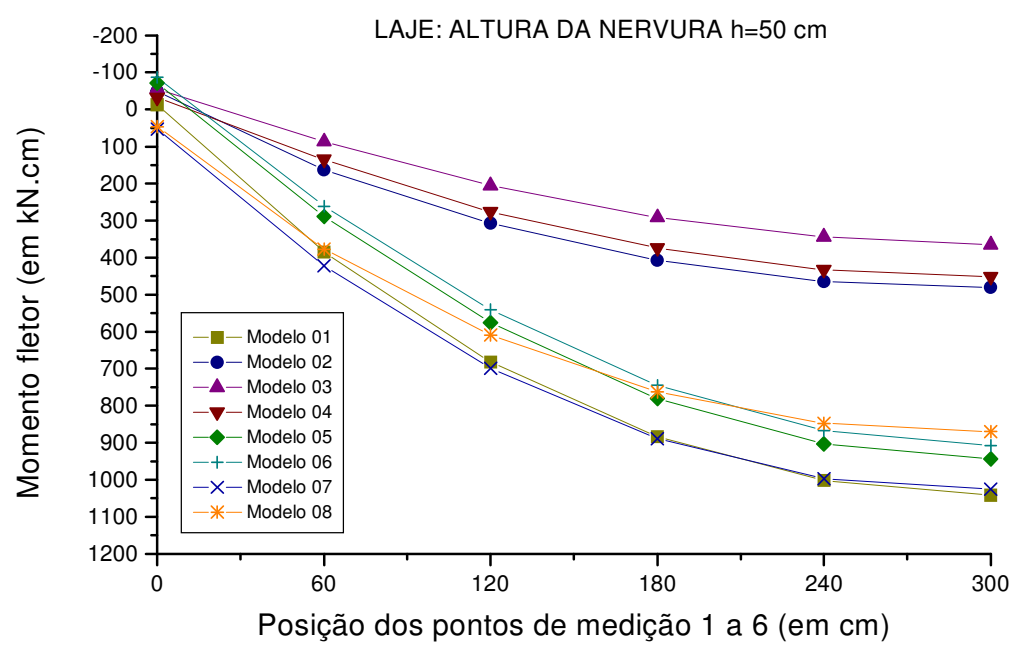

FIGURA 5.44: Momentos fletores ( $\mathrm{kN} . \mathrm{cm}$ ), na nervura central, na laje com $\mathrm{hf} / \mathrm{h}=0,100$

Analisando-se as tabelas e gráficos de momentos fletores nas nervuras, segundo os modelos 01 a 08 , promovendo-se variações na relação $h_{f} / h$, verificou-se que:

- existe uma enorme disparidade entre os resultados de momentos fletores nas nervuras, ligados à condição de flexibilidade dos modelos: maiores momentos fletores nos modelos mais flexíveis (concêntrico, modelos de seção "T" 05 e 06 e modelos de laje maciça equivalente 07 e 08). Quanto mais excêntricas são as nervuras, mais há um agrupamento bem definido dos resultados dos modelos mais simplificados frente ao modelo realista e os de viga excêntrica 02 e 03 . É interessante verificar que o modelo concêntrico fornece resultados de momentos fletores nas nervuras próximos aos fornecidos pelos modelos 05, 06, 07 e 08, mesmo sendo muito mais flexível;

- isso chama a atenção para a necessidade de complementação da análise: não se pode comparar apenas momentos fletores, já que nestes modelos tridimensionais irão 
aparecer esforços normais que irão solicitar as seções transversais com tensões que somarse-ão às tensões advindas da flexão. Da mesma maneira, não se pode imaginar o dimensionamento dessas seções, quando aplicam-se resultados obtidos por essas modelagens com elementos finitos tridimensionais, apenas à flexão. Haverá a necessidade de dimensionamento das seções à flexo-tração e à flexo-compressão.

Abaixo tem-se os gráficos de momentos fletores atuantes nas vigas de contorno externo das lajes processadas nesta série.

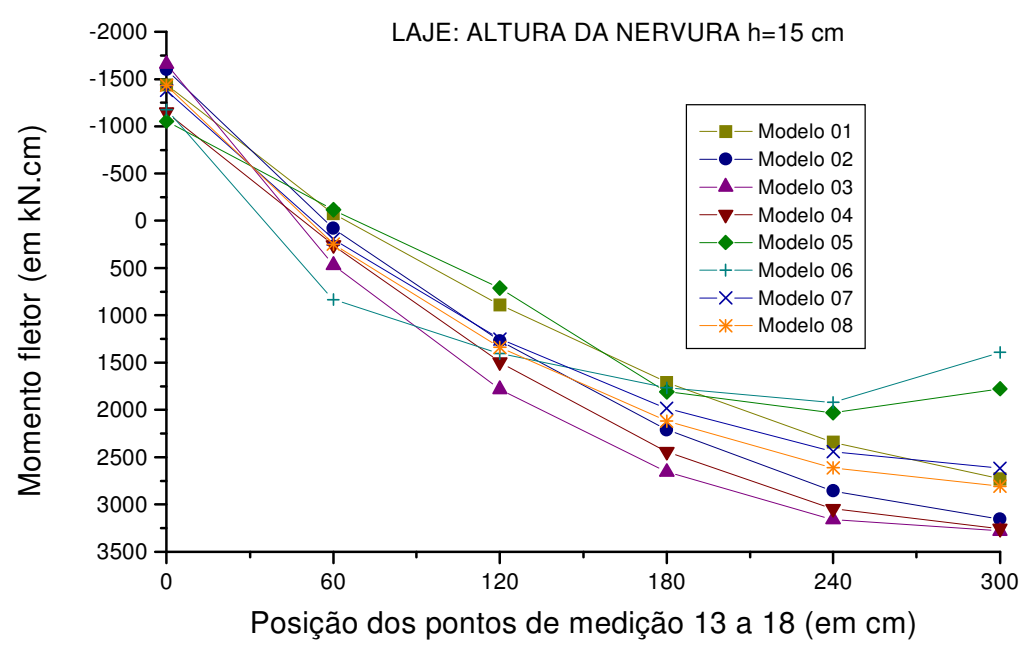

FIGURA 5.45: Momentos fletores (kN.cm), na viga externa; nervuras com altura $\mathrm{h}=15 \mathrm{~cm}$

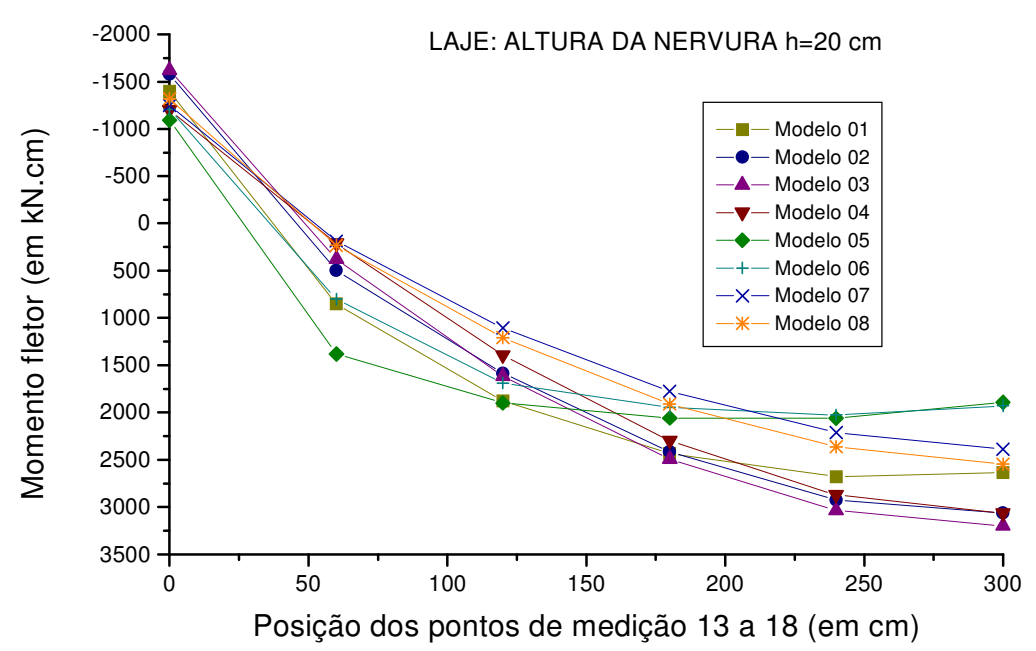

FIGURA 5.46: Momentos fletores (kN.cm), na viga externa; laje com relação $\mathrm{hf} / \mathrm{h}=0,250$ 


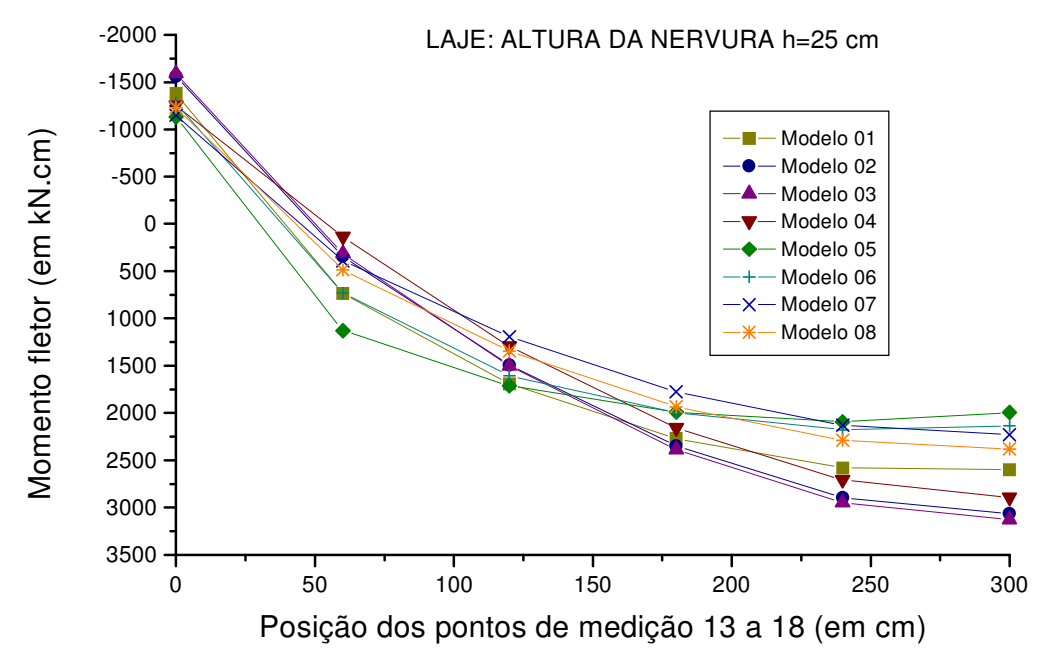

FIGURA 5.47: Momentos fletores (kN.cm), na viga externa; laje com relação $h f / h=0,200$

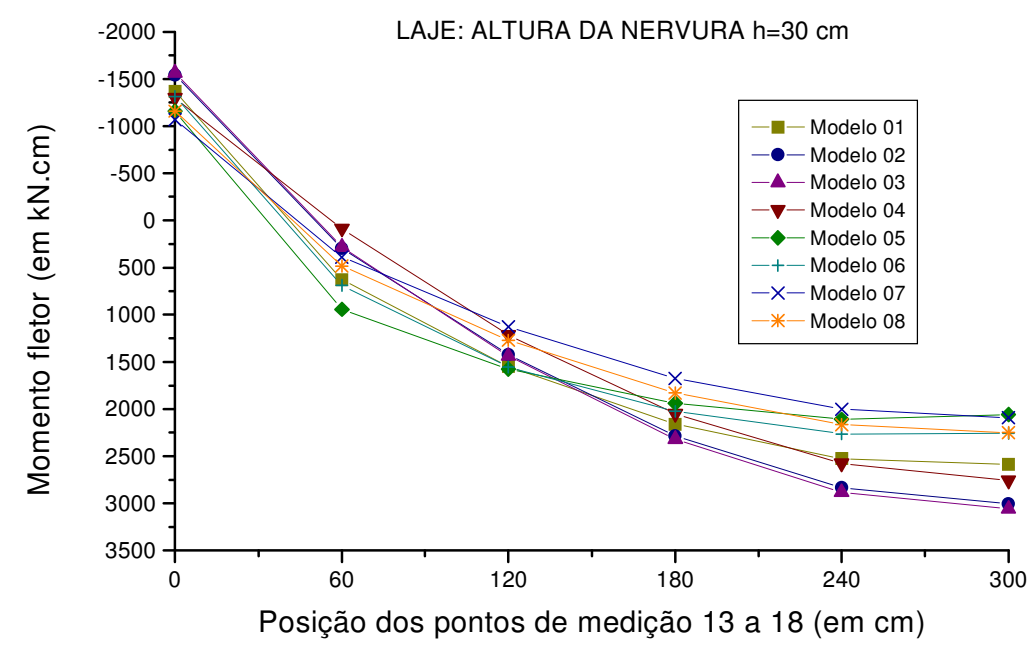

FIGURA 5.48: Momentos fletores (kN.cm), na viga externa; laje com relação hf/h=0,167

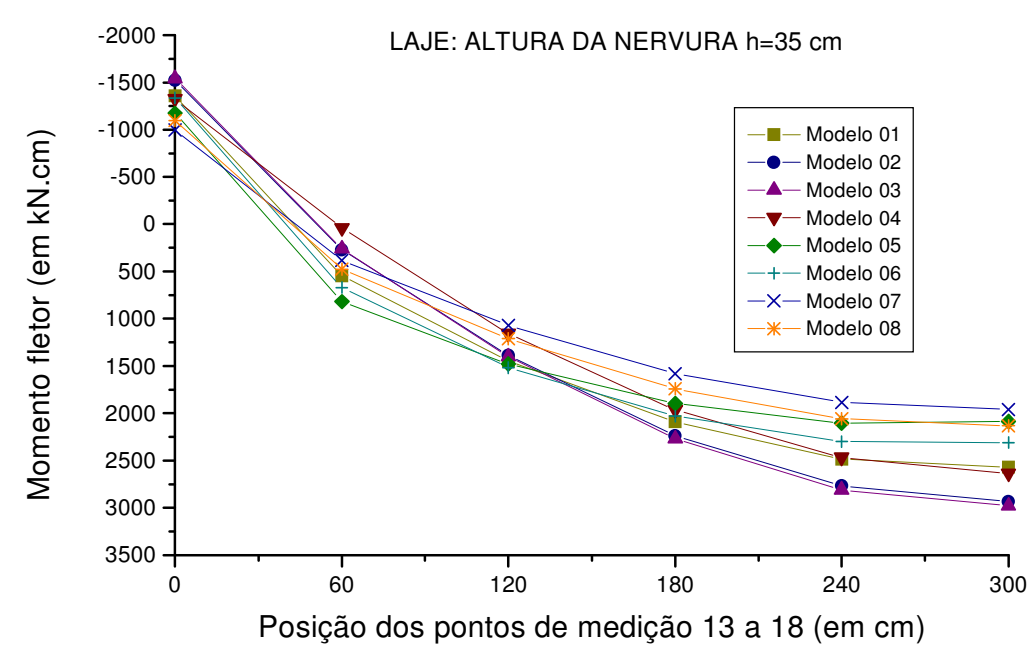

FIGURA 5.49: Momentos fletores (kN.cm), na viga externa; laje com relação hf/h=0,143 


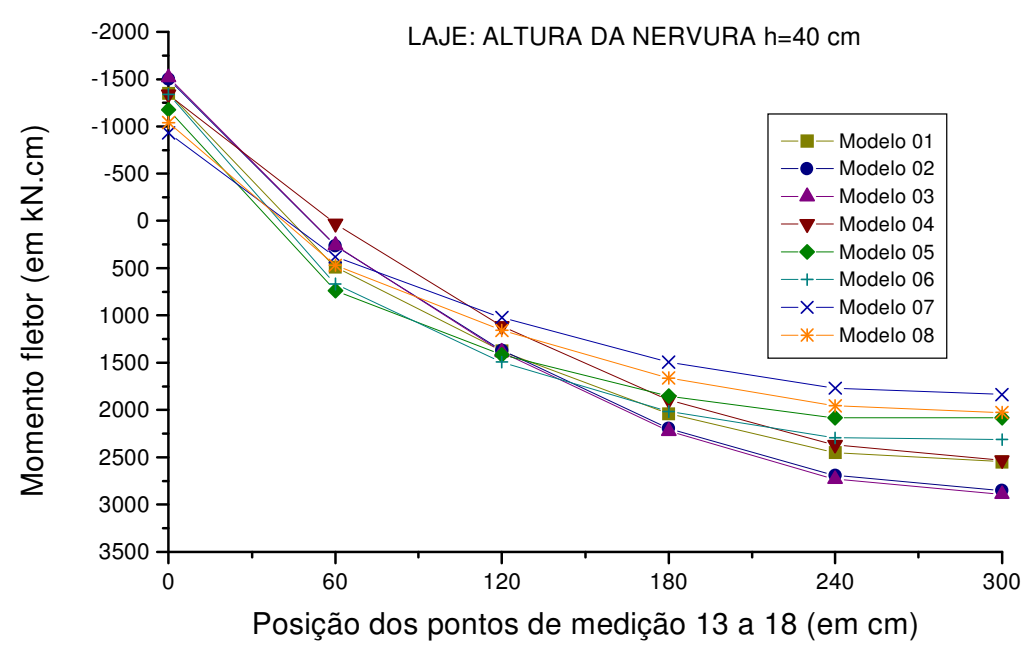

FIGURA 5.50: Momentos fletores (kN.cm), na viga externa; laje com relação $h f / h=0,125$

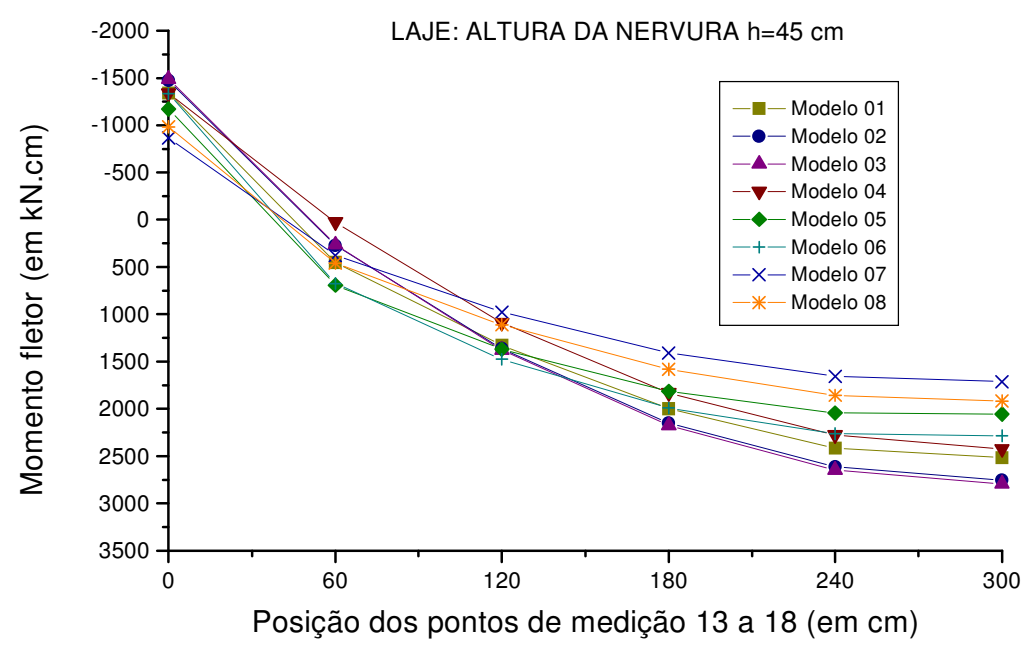

FIGURA 5.51: Momentos fletores ( $k N . c m)$, na viga externa; laje com relação $h f / h=0,111$

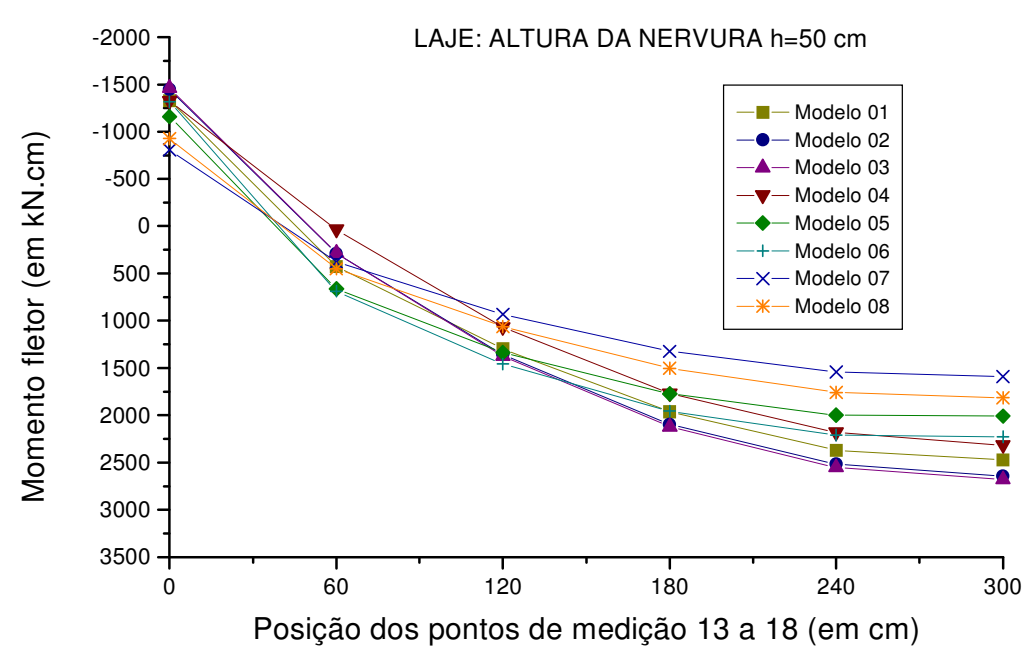

FIGURA 5.52: Momentos fletores (kN.cm), na viga externa; laje com relação $h f / h=0,100$ 
Analisando-se as tabelas e gráficos de momentos fletores atuantes nas vigas do contorno externo, simuladas todas pelo elemento BEAM44 excêntrico ou pelo elemento de casca SHELL63, para o Modelo 04, verificou-se que:

- os diagramas de momentos fletores apresentaram praticamente o mesmo comportamento, independente da simulação das nervuras com ou sem excentricidade; porém, com resultados bastante diferentes, da ordem de até $57,2 \%$ para o máximo momento positivo na viga (quando comparado o Modelo 06 ao Modelo 04, para $\mathrm{h}_{\mathrm{f}} / \mathrm{h}=0,333$ );

- analisando somente os momentos fletores, os modelo excêntricos 02 e 03 são os que mostram resultados que mais aproximam-se daqueles dados pelo Modelo 04;

- como já visto anteriormente, porém, haverá a necessidade de análise das tensões normais nas fibras extremas, já que existirão forças normais nas seções.

\subsubsection{Forças Normais atuantes nas nervuras e vigas}

TABELA 5.46: Esforços Normais nas nervuras e vigas, em $\mathrm{kN}$, na laje com altura total $\mathrm{h}=15$ $\mathrm{cm}$

\begin{tabular}{|c|c|c|c|c|c|c|c|c|}
\hline \multicolumn{9}{|c|}{$\begin{array}{c}\text { LAJE COM RELAÇÃO hf/h }=0,333 \\
\text { ESFORÇOS NORMAIS NAS NERVURAS E VIGAS }(\mathrm{kN})\end{array}$} \\
\hline \multirow{2}{*}{ Ponto } & \multicolumn{8}{|c|}{ Modelos numéricos de análise } \\
\hline & 01 & 02 & 03 & 04 & 05 & 06 & 07 & 08 \\
\hline 1 & $-4,01$ & $-6,85$ & $-8,99$ & $-42,48$ & $-16,72$ & $-22,13$ & $-1,99$ & $-3,41$ \\
\hline 2 & $-1,85$ & 22,54 & 25,63 & $-11,96$ & $-8,83$ & $-22,60$ & $-7,42$ & $-11,84$ \\
\hline 3 & $-2,57$ & 45,39 & 51,47 & 20,54 & $-12,55$ & $-28,70$ & $-9,91$ & $-16,54$ \\
\hline 4 & $-3,04$ & 60,94 & 68,98 & 41,58 & $-14,46$ & $-32,07$ & $-11,30$ & $-19,05$ \\
\hline 5 & $-3,27$ & 69,80 & 78,97 & 53,20 & $-15,17$ & $-33,47$ & $-12,05$ & $-20,28$ \\
\hline 6 & $-3,32$ & 72,04 & 81,57 & 56,90 & $-15,21$ & $-33,47$ & $-12,24$ & $-20,59$ \\
\hline 7 & $-7,33$ & $-23,11$ & $-29,73$ & $-29,69$ & $-9,78$ & $-12,61$ & $-13,37$ & $-13,13$ \\
\hline 8 & $-4,32$ & $-1,34$ & $-0,27$ & $-10,48$ & $-10,09$ & $-22,08$ & $-15,29$ & $-15,41$ \\
\hline 9 & $-4,74$ & 19,10 & 23,44 & 8,44 & $-15,98$ & $-33,80$ & $-17,83$ & $-18,86$ \\
\hline 10 & $-5,37$ & 33,24 & 39,51 & 20,15 & $-20,79$ & $-42,43$ & $-20,21$ & $-23,27$ \\
\hline 11 & $-5,79$ & 40,99 & 48,34 & 26,05 & $-23,41$ & $-46,96$ & $-21,78$ & $-26,39$ \\
\hline 12 & $-5,90$ & 42,80 & 50,54 & 27,86 & $-23,52$ & $-46,96$ & $-22,22$ & $-27,31$ \\
\hline 13 & 48,42 & 38,99 & 38,22 & 20,94 & 58,84 & 64,59 & 32,81 & 36,93 \\
\hline 14 & 72,55 & 53,89 & 49,29 & 33,71 & 98,18 & 96,11 & 51,48 & 55,52 \\
\hline 15 & 99,16 & 71,16 & 63,94 & 55,10 & 145,99 & 142,50 & 76,61 & 87,56 \\
\hline 16 & 114,97 & 80,91 & 72,81 & 70,66 & 177,15 & 175,51 & 96,69 & 113,41 \\
\hline 17 & 120,08 & 84,04 & 76,16 & 85,01 & 190,72 & 192,35 & 108,96 & 129,18 \\
\hline 18 & 115,38 & 81,50 & 74,65 & 83,50 & 186,95 & 192,35 & 112,39 & 133,56 \\
\hline
\end{tabular}


TABELA 5.47: Esforços Normais nas nervuras e vigas, em $\mathrm{kN}$, na laje com altura total $\mathrm{h}=20$ $\mathrm{cm}$

\begin{tabular}{c|c|c|c|c|c|c|c|c}
\hline \hline \multicolumn{10}{c}{ MAJE COM RELAÇÃO hf/h = 0,250 } \\
\hline \multirow{2}{*}{ Ponto } & \multicolumn{7}{c}{ Modelos numéricos de análise } \\
\cline { 2 - 10 } & $\mathbf{0 1}$ & $\mathbf{0 2}$ & $\mathbf{0 3}$ & $\mathbf{0 4}$ & $\mathbf{0 5}$ & $\mathbf{0 6}$ & $\mathbf{0 7}$ & $\mathbf{0 8}$ \\
\hline \hline $\mathbf{1}$ & $-2,38$ & 1,44 & 1,28 & $\mathbf{- 1 7 , 2 8}$ & $-12,75$ & $-15,80$ & $-0,91$ & $-1,69$ \\
\hline $\mathbf{2}$ & $-1,26$ & 27,06 & 30,07 & $\mathbf{4 , 7 3}$ & $-7,59$ & $-18,13$ & $-6,64$ & $-10,63$ \\
\hline $\mathbf{3}$ & $-2,22$ & 45,48 & 50,61 & $\mathbf{2 8 , 4 1}$ & $-10,96$ & $-23,24$ & $-9,13$ & $-15,67$ \\
\hline $\mathbf{4}$ & $-2,83$ & 57,86 & 64,39 & $\mathbf{4 4 , 3 1}$ & $-12,68$ & $-26,00$ & $-10,44$ & $-18,43$ \\
\hline $\mathbf{5}$ & $-3,12$ & 64,93 & 72,29 & $\mathbf{5 3 , 4 3}$ & $-13,34$ & $-27,14$ & $-11,08$ & $-19,79$ \\
\hline $\mathbf{6}$ & $-3,19$ & 66,75 & 74,36 & $\mathbf{5 6 , 4 0}$ & $-13,38$ & $-27,14$ & $-11,23$ & $-20,14$ \\
\hline \hline $\mathbf{7}$ & $-7,77$ & $-13,30$ & $-16,19$ & $\mathbf{- 1 9 , 6 0}$ & $-8,52$ & $-10,27$ & $-9,29$ & $-10,32$ \\
\hline $\mathbf{8}$ & $-4,75$ & 4,23 & 5,51 & $\mathbf{- 3 , 6 0}$ & $-9,28$ & $-18,73$ & $-12,79$ & $-14,02$ \\
\hline $\mathbf{9}$ & $-5,39$ & 20,92 & 24,62 & $\mathbf{1 3 , 0 4}$ & $-14,59$ & $-28,39$ & $-16,48$ & $-18,35$ \\
\hline $\mathbf{1 0}$ & $-6,18$ & 32,70 & 37,86 & $\mathbf{2 3 , 6 9}$ & $-18,78$ & $-35,45$ & $-19,43$ & $-23,29$ \\
\hline $\mathbf{1 1}$ & $-6,67$ & 38,97 & 44,87 & $\mathbf{2 9 , 5 2}$ & $-21,04$ & $-39,15$ & $-21,20$ & $-26,62$ \\
\hline $\mathbf{1 2}$ & $-6,79$ & 40,45 & 46,57 & $\mathbf{3 1 , 3 6}$ & $-21,14$ & $-39,15$ & $-21,68$ & $-27,56$ \\
\hline \hline $\mathbf{1 3}$ & 38,64 & 27,03 & 26,35 & $\mathbf{1 5 , 6 1}$ & 45,36 & 48,30 & 21,49 & 24,94 \\
\hline $\mathbf{1 4}$ & 62,73 & 40,42 & 37,48 & $\mathbf{2 8 , 6 5}$ & 83,17 & 79,57 & 44,91 & 49,85 \\
\hline $\mathbf{1 5}$ & 87,29 & 55,45 & 51,12 & $\mathbf{5 0 , 1 4}$ & 125,08 & 118,71 & 73,45 & 85,76 \\
\hline $\mathbf{1 6}$ & 101,95 & 64,73 & 59,88 & $\mathbf{6 5 , 2 3}$ & 152,52 & 146,07 & 95,71 & 113,81 \\
\hline $\mathbf{1 7}$ & 107,46 & 68,97 & 64,07 & $\mathbf{7 0 , 3 2}$ & 165,00 & 159,91 & 109,25 & 130,69 \\
\hline $\mathbf{1 8}$ & 104,55 & 68,61 & 64,03 & $\mathbf{7 1 , 4 7}$ & 162,73 & 159,91 & 113,03 & 135,37 \\
\hline \hline
\end{tabular}

TABELA 5.48: Esforços Normais nas nervuras e vigas, em $\mathrm{kN}$, na laje com altura total $\mathrm{h}=25$ $\mathrm{cm}$

LAJE COM RELAÇÃO hf/h = 0,200

ESFORÇOS NORMAIS NAS NERVURAS E VIGAS (kN)

\begin{tabular}{c|c|c|c|c|c|c|c|c}
\hline \multirow{2}{*}{ Ponto } & \multicolumn{7}{|c}{ Modelos numéricos de análise } \\
\cline { 2 - 9 } & $\mathbf{0 1}$ & $\mathbf{0 2}$ & $\mathbf{0 3}$ & $\mathbf{0 4}$ & $\mathbf{0 5}$ & $\mathbf{0 6}$ & $\mathbf{0 7}$ & $\mathbf{0 8}$ \\
\hline \hline $\mathbf{1}$ & $-0,97$ & 3,21 & 3,25 & $\mathbf{- 4 , 1 1}$ & $-9,00$ & $-10,96$ & $-1,01$ & $-1,38$ \\
\hline $\mathbf{2}$ & $-0,88$ & 24,43 & 26,95 & $\mathbf{1 2 , 5 8}$ & $-6,53$ & $-14,64$ & $-6,94$ & $-10,51$ \\
\hline $\mathbf{3}$ & $-2,00$ & 39,59 & 43,82 & $\mathbf{2 9 , 2 1}$ & $-9,57$ & $-18,91$ & $-9,35$ & $-15,53$ \\
\hline $\mathbf{4}$ & $-2,65$ & 49,72 & 55,04 & $\mathbf{4 1 , 0 0}$ & $-11,09$ & $-21,15$ & $-10,48$ & $-18,25$ \\
\hline $\mathbf{5}$ & $-2,94$ & 55,47 & 61,41 & $\mathbf{4 7 , 8 8}$ & $-11,68$ & $-22,07$ & $-10,96$ & $-19,57$ \\
\hline $\mathbf{6}$ & $-3,00$ & 56,97 & 63,08 & $\mathbf{5 0 , 1 4}$ & $-11,71$ & $-22,07$ & $-11,08$ & $-19,90$ \\
\hline \hline $\mathbf{7}$ & $-6,87$ & $-6,19$ & $-7,26$ & $\mathbf{- 1 0 , 5 1}$ & $-6,99$ & $-8,20$ & $-5,82$ & $-7,46$ \\
\hline $\mathbf{8}$ & $-4,64$ & 7,46 & 8,73 & $\mathbf{1 , 4 1}$ & $-8,41$ & $-15,86$ & $-10,66$ & $-12,57$ \\
\hline $\mathbf{9}$ & $-5,60$ & 20,25 & 23,37 & $\mathbf{1 4 , 7 1}$ & $-13,19$ & $-23,87$ & $-15,26$ & $-17,78$ \\
\hline $\mathbf{1 0}$ & $-6,53$ & 29,30 & 33,52 & $\mathbf{2 3 , 7 0}$ & $-16,82$ & $-29,67$ & $-18,62$ & $-23,10$ \\
\hline $\mathbf{1 1}$ & $-7,06$ & 34,01 & 38,76 & $\mathbf{2 8 , 7 3}$ & $-18,76$ & $-32,69$ & $-20,56$ & $-26,54$ \\
\hline $\mathbf{1 2}$ & $-7,18$ & 35,12 & 40,01 & $\mathbf{3 0 , 3 2}$ & $-18,85$ & $-32,69$ & $-21,09$ & $-27,50$ \\
\hline \hline $\mathbf{1 3}$ & 30,05 & 18,64 & 18,15 & $\mathbf{1 0 , 3 3}$ & 33,66 & 35,22 & 14,17 & 16,71 \\
\hline $\mathbf{1 4}$ & 53,88 & 32,00 & 30,03 & $\mathbf{2 3 , 7 1}$ & 70,12 & 65,95 & 40,98 & 46,04 \\
\hline $\mathbf{1 5}$ & 76,59 & 46,84 & 44,02 & $\mathbf{4 2 , 6 0}$ & 107,18 & 99,14 & 71,71 & 84,37 \\
\hline $\mathbf{1 6}$ & 90,52 & 56,76 & 53,54 & $\mathbf{5 6 , 0 3}$ & 131,65 & 121,97 & 95,42 & 113,76 \\
\hline $\mathbf{1 7}$ & 96,59 & 62,07 & 58,70 & $\mathbf{6 8 , 0 7}$ & 143,28 & 133,45 & 109,86 & 131,39 \\
\hline $\mathbf{1 8}$ & 95,26 & 62,79 & 59,52 & $\mathbf{6 8 , 2 2}$ & 142,18 & 133,45 & 113,90 & 136,28 \\
\hline \hline
\end{tabular}


TABELA 5.49: Esforços Normais nas nervuras e vigas, em $\mathrm{kN}$, na laje com altura total $\mathrm{h}=30$ $\mathrm{cm}$

LAJE COM RELAÇÃO hf/h $=0,167$

ESFORÇOS NORMAIS NAS NERVURAS E VIGAS (kN)

\begin{tabular}{c|c|c|c|c|c|c|c|c}
\hline \multirow{2}{*}{ Ponto } & \multicolumn{8}{|c}{ Modelos numéricos de análise } \\
\cline { 2 - 9 } & $\mathbf{0 1}$ & $\mathbf{0 2}$ & $\mathbf{0 3}$ & $\mathbf{0 4}$ & $\mathbf{0 5}$ & $\mathbf{0 6}$ & $\mathbf{0 7}$ & $\mathbf{0 8}$ \\
\hline \hline $\mathbf{1}$ & $-0,16$ & 3,36 & 3,37 & $\mathbf{1 , 7 3}$ & $-6,17$ & $-7,81$ & $-1,14$ & $-1,44$ \\
\hline $\mathbf{2}$ &,-- 78 & 20,54 & 22,60 & $\mathbf{1 4 , 8 6}$ & $-5,77$ & $-12,30$ & $-7,23$ & $-10,67$ \\
\hline $\mathbf{3}$ & $-1,98$ & 33,05 & 36,58 & $\mathbf{2 8 , 0 0}$ & $-8,53$ & $-15,96$ & $-9,58$ & $-16,19$ \\
\hline $\mathbf{4}$ & $-2,61$ & 41,50 & 45,91 & $\mathbf{3 7 , 6 3}$ & $-9,87$ & $-17,81$ & $-10,58$ & $-18,18$ \\
\hline $\mathbf{5}$ & $-2,87$ & 46,29 & 51,19 & $\mathbf{4 3 , 3 0}$ & $-10,38$ & $-18,56$ & $-10,97$ & $-19,40$ \\
\hline $\mathbf{6}$ & $-2,92$ & 47,54 & 52,58 & $\mathbf{4 5 , 1 7}$ & $-10,41$ & $-18,56$ & $-11,05$ & $-19,70$ \\
\hline \hline $\mathbf{7}$ & $-5,46$ & $-2,05$ & $-2,37$ & $\mathbf{- 5 , 1 6}$ & $-5,58$ & $-6,65$ & $-3,47$ & $-5,13$ \\
\hline $\mathbf{8}$ & $-4,26$ & 9,02 & 10,26 & $\mathbf{4 , 5 7}$ & $-7,65$ & $-13,78$ & $-9,17$ & $-11,36$ \\
\hline $\mathbf{9}$ & $-5,56$ & 18,97 & 21,65 & $\mathbf{1 5 , 7 8}$ & $-12,02$ & $-20,66$ & $-14,31$ & $-17,24$ \\
\hline $\mathbf{1 0}$ & $-6,61$ & 26,00 & 29,54 & $\mathbf{2 3 , 6 3}$ & $-15,23$ & $-25,59$ & $-17,90$ & $-22,78$ \\
\hline $\mathbf{1 1}$ & $-7,17$ & 29,68 & 33,64 & $\mathbf{2 8 , 0 8}$ & $-16,94$ & $-28,15$ & $-19,96$ & $-26,29$ \\
\hline $\mathbf{1 2}$ & $-7,29$ & 30,56 & 34,64 & $\mathbf{2 9 , 5 0}$ & $-17,02$ & $-28,15$ & $-20,53$ & $-27,27$ \\
\hline \hline $\mathbf{1 3}$ & 23,27 & 12,72 & 12,35 & $\mathbf{6 , 0 6}$ & 24,74 & 26,27 & 9,15 & 11,03 \\
\hline $\mathbf{1 4}$ & 46,98 & 26,63 & 25,14 & $\mathbf{1 9 , 7 3}$ & 60,11 & 56,47 & 38,35 & 43,40 \\
\hline $\mathbf{1 5}$ & 68,46 & 41,88 & 39,80 & $\mathbf{3 7 , 6 0}$ & 93,56 & 85,51 & 70,32 & 83,08 \\
\hline $\mathbf{1 6}$ & 82,06 & 52,51 & 50,12 & $\mathbf{5 2 , 5 2}$ & 115,89 & 105,25 & 94,82 & 113,21 \\
\hline $\mathbf{1 7}$ & 88,67 & 58,59 & 56,02 & $\mathbf{5 9 , 2 4}$ & 126,92 & 115,15 & 109,72 & 131,28 \\
\hline $\mathbf{1 8}$ & 88,42 & 59,86 & 57,31 & $\mathbf{6 2 , 9 1}$ & 126,66 & 115,15 & 113,88 & 136,28 \\
\hline \hline
\end{tabular}

TABELA 5.50: Esforços Normais nas nervuras e vigas, em $\mathrm{kN}$, na laje com altura total $\mathrm{h}=35$ $\mathrm{cm}$

LAJE COM RELAÇÃO hf/h = 0,143

ESFORÇOS NORMAIS NAS NERVURAS E VIGAS (kN)

\begin{tabular}{c|c|c|c|c|c|c|c|c}
\hline \multirow{2}{*}{ Ponto } & \multicolumn{7}{|c}{ Modelos numéricos de análise } \\
\cline { 2 - 9 } & $\mathbf{0 1}$ & $\mathbf{0 2}$ & $\mathbf{0 3}$ & $\mathbf{0 4}$ & $\mathbf{0 5}$ & $\mathbf{0 6}$ & $\mathbf{0 7}$ & $\mathbf{0 8}$ \\
\hline \hline $\mathbf{1}$ & 0,27 & 3,17 & 3,17 & $\mathbf{3 , 9 8}$ & $-4,26$ & $-5,83$ & $-1,18$ & $-1,50$ \\
\hline $\mathbf{2}$ & $-0,84$ & 16,97 & 18,66 & $\mathbf{1 3 , 8 0}$ & $-5,26$ & $-10,77$ & $-7,32$ & $-10,74$ \\
\hline $\mathbf{3}$ & $-2,09$ & 27,27 & 30,22 & $\mathbf{2 3 , 9 9}$ & $-7,82$ & $-13,99$ & $-9,63$ & $-15,57$ \\
\hline $\mathbf{4}$ & $-2,68$ & 34,35 & 38,07 & $\mathbf{3 2 , 5 5}$ & $-9,01$ & $-15,56$ & $-10,55$ & $-18,04$ \\
\hline $\mathbf{5}$ & $-2,89$ & 38,38 & 42,51 & $\mathbf{3 6 , 2 3}$ & $-9,46$ & $-16,18$ & $-10,88$ & $-19,17$ \\
\hline $\mathbf{6}$ & $-2,93$ & 39,44 & 43,69 & $\mathbf{3 7 , 7 4}$ & $-9,49$ & $-16,18$ & $-10,95$ & $-19,44$ \\
\hline $\mathbf{7}$ & $-4,08$ & 0,17 & 0,11 & $\mathbf{- 1 , 5 4}$ & $-4,44$ & $-5,53$ & $-2,05$ & $-3,47$ \\
\hline $\mathbf{8}$ & $-3,84$ & 9,63 & 10,81 & $\mathbf{6 , 4 1}$ & $-7,07$ & $-12,34$ & $-8,18$ & $-10,43$ \\
\hline $\mathbf{9}$ & $-5,43$ & 17,70 & 20,05 & $\mathbf{1 6 , 1 3}$ & $-11,15$ & $-18,48$ & $-13,55$ & $-16,72$ \\
\hline $\mathbf{1 0}$ & $-6,57$ & 23,40 & 26,46 & $\mathbf{2 3 , 0 6}$ & $-14,08$ & $-22,83$ & $-17,24$ & $-22,36$ \\
\hline $\mathbf{1 1}$ & $-7,15$ & 26,46 & 29,88 & $\mathbf{2 7 , 0 5}$ & $-15,62$ & $-25,08$ & $-19,38$ & $-25,90$ \\
\hline $\mathbf{1 2}$ & $-7,27$ & 27,22 & 30,75 & $\mathbf{2 8 , 3 3}$ & $-15,69$ & $-25,08$ & $-19,97$ & $-26,90$ \\
\hline $\mathbf{1 3}$ & 18,13 & 8,40 & 8,07 & $\mathbf{2 , 8 2}$ & 18,43 & 20,43 & 5,52 & 6,95 \\
\hline $\mathbf{1 4}$ & 41,89 & 22,90 & 21,65 & $\mathbf{1 6 , 6 7}$ & 52,97 & 50,15 & 36,36 & 41,40 \\
\hline $\mathbf{1 5}$ & 62,57 & 38,55 & 36,85 & $\mathbf{3 4 , 1 7}$ & 83,86 & 76,37 & 68,85 & 81,65 \\
\hline $\mathbf{1 6}$ & 76,07 & 49,70 & 47,75 & $\mathbf{4 8 , 5 5}$ & 104,68 & 94,05 & 93,55 & 112,01 \\
\hline $\mathbf{1 7}$ & 83,11 & 56,25 & 54,15 & $\mathbf{5 6 , 4 0}$ & 115,27 & 102,91 & 108,51 & 130,20 \\
\hline $\mathbf{1 8}$ & 83,55 & 57,81 & 55,70 & $\mathbf{5 9 , 9 4}$ & 115,55 & 102,91 & 112,68 & 135,24 \\
\hline \hline
\end{tabular}


TABELA 5.51: Esforços Normais nas nervuras e vigas, em $\mathrm{kN}$, na laje com altura total $\mathrm{h}=40$ $\mathrm{cm}$

\begin{tabular}{c|c|c|c|c|c|c|c|c}
\hline \hline \multicolumn{7}{c}{ LAJE COM RELAÇÃO hf/h = 0,125 } \\
\hline \multirow{2}{*}{ Ponto } & \multicolumn{7}{c}{ Modelos numéricos de análise } \\
\cline { 2 - 10 } & $\mathbf{0 1}$ & $\mathbf{0 2}$ & $\mathbf{0 3}$ & $\mathbf{0 4}$ & $\mathbf{0 5}$ & $\mathbf{0 6}$ & $\mathbf{0 7}$ & $\mathbf{0 8}$ \\
\hline \hline $\mathbf{1}$ & 0,51 & 2,93 & 2,92 & $\mathbf{4 , 6 4}$ & $-2,99$ & $-4,57$ & $-1,18$ & $-1,51$ \\
\hline $\mathbf{2}$ & $-0,95$ & 13,96 & 15,35 & $\mathbf{1 2 , 5 3}$ & $-4,93$ & $-9,73$ & $-7,25$ & $-10,67$ \\
\hline $\mathbf{3}$ & $-2,23$ & 22,40 & 24,88 & $\mathbf{2 1 , 0 8}$ & $-7,33$ & $-12,61$ & $-9,51$ & $-15,40$ \\
\hline $\mathbf{4}$ & $-2,78$ & 28,33 & 31,49 & $\mathbf{2 7 , 6 8}$ & $-8,41$ & $-13,98$ & $-10,38$ & $-17,77$ \\
\hline $\mathbf{5}$ & $-2,95$ & 31,74 & 35,62 & $\mathbf{3 1 , 6 2}$ & $-8,81$ & $-14,52$ & $-10,68$ & $-18,83$ \\
\hline $\mathbf{6}$ & $-2,98$ & 32,65 & 36,27 & $\mathbf{3 2 , 9 3}$ & $-8,83$ & $-14,52$ & $-10,74$ & $-19,09$ \\
\hline \hline $\mathbf{7}$ & $-2,92$ & 1,30 & 1,32 & $\mathbf{0 , 6 3}$ & $-3,59$ & $-4,73$ & $-1,27$ & $-2,38$ \\
\hline $\mathbf{8}$ & $-3,46$ & 9,75 & 10,86 & $\mathbf{7 , 5 1}$ & $-6,65$ & $-11,34$ & $-7,54$ & $-9,73$ \\
\hline $\mathbf{9}$ & $-5,27$ & 16,61 & 18,70 & $\mathbf{1 6 , 1 6}$ & $-10,54$ & $-16,96$ & $-12,91$ & $-16,21$ \\
\hline $\mathbf{1 0}$ & $-6,49$ & 21,47 & 24,18 & $\mathbf{2 2 , 4 3}$ & $-13,26$ & $-20,91$ & $-16,60$ & $-21,84$ \\
\hline $\mathbf{1 1}$ & $-7,08$ & 24,17 & 27,21 & $\mathbf{2 6 , 1 0}$ & $-14,68$ & $-22,94$ & $-18,76$ & $-25,38$ \\
\hline $\mathbf{1 2}$ & $-7,20$ & 24,87 & 28,00 & $\mathbf{2 7 , 3 0}$ & $-14,76$ & $-22,94$ & $-19,36$ & $-26,38$ \\
\hline \hline $\mathbf{1 3}$ & 14,30 & 5,14 & 4,80 & $\mathbf{0 , 3 6}$ & 14,07 & 16,61 & 2,83 & 3,92 \\
\hline $\mathbf{1 4}$ & 38,17 & 20,06 & 18,94 & $\mathbf{1 4 , 2 7}$ & 47,95 & 45,90 & 34,71 & 39,73 \\
\hline $\mathbf{1 5}$ & 58,33 & 35,91 & 34,43 & $\mathbf{3 2 , 3 6}$ & 76,97 & 70,13 & 67,14 & 79,95 \\
\hline $\mathbf{1 6}$ & 71,79 & 47,35 & 45,66 & $\mathbf{4 3 , 9 4}$ & 96,65 & 86,36 & 91,56 & 110,11 \\
\hline $\mathbf{1 7}$ & 79,10 & 54,13 & 52,32 & $\mathbf{5 3 , 9 3}$ & 106,85 & 94,49 & 106,24 & 128,14 \\
\hline $\mathbf{1 8}$ & 79,98 & 55,85 & 54,03 & $\mathbf{5 7 , 3 0}$ & 107,46 & 94,49 & 110,31 & 133,13 \\
\hline \hline
\end{tabular}

TABELA 5.52: Esforços Normais nas nervuras e vigas, em kN, na laje com altura total $\mathrm{h}=45$ $\mathrm{cm}$

LAJE COM RELAÇÃO hf/h = 0,111

ESFORÇOS NORMAIS NAS NERVURAS E VIGAS (kN)

\begin{tabular}{c|c|c|c|c|c|c|c|c}
\hline \multirow{2}{*}{ Ponto } & \multicolumn{7}{|c}{ Modelos numéricos de análise } \\
\cline { 2 - 9 } & $\mathbf{0 1}$ & $\mathbf{0 2}$ & $\mathbf{0 3}$ & $\mathbf{0 4}$ & $\mathbf{0 5}$ & $\mathbf{0 6}$ & $\mathbf{0 7}$ & $\mathbf{0 8}$ \\
\hline \hline $\mathbf{1}$ & 0,65 & 2,68 & 2,67 & $\mathbf{4 , 6 5}$ & $-2,14$ & $-3,74$ & $-1,13$ & $-1,49$ \\
\hline $\mathbf{2}$ & $-1,07$ & 11,47 & 12,61 & $\mathbf{1 1 , 0 0}$ & $-4,69$ & $-8,95$ & $-7,05$ & $-10,46$ \\
\hline $\mathbf{3}$ & $-2,37$ & 18,34 & 20,43 & $\mathbf{1 5 , 5 4}$ & $-6,97$ & $-11,59$ & $-9,26$ & $-15,09$ \\
\hline $\mathbf{4}$ & $-2,88$ & 23,28 & 25,99 & $\mathbf{2 2 , 6 5}$ & $-7,96$ & $-12,81$ & $-10,09$ & $-17,36$ \\
\hline $\mathbf{5}$ & $-3,03$ & 26,16 & 29,19 & $\mathbf{2 6 , 9 2}$ & $-8,32$ & $-13,28$ & $-10,37$ & $-18,37$ \\
\hline $\mathbf{6}$ & $-3,04$ & 26,93 & 30,05 & $\mathbf{2 7 , 5 4}$ & $-8,34$ & $-13,28$ & $-10,42$ & $-18,62$ \\
\hline \hline $\mathbf{7}$ & $-2,02$ & 1,85 & 1,89 & $\mathbf{2 , 0 3}$ & $-2,95$ & $-4,15$ & $-0,86$ & $-1,70$ \\
\hline $\mathbf{8}$ & $-3,16$ & 9,62 & 10,64 & $\mathbf{8 , 1 4}$ & $-6,35$ & $-10,61$ & $-7,10$ & $-9,19$ \\
\hline $\mathbf{9}$ & $-5,14$ & 15,71 & 17,60 & $\mathbf{1 5 , 1 6}$ & $-10,09$ & $-15,85$ & $-12,34$ & $-15,68$ \\
\hline $\mathbf{1 0}$ & $-6,40$ & 20,06 & 22,50 & $\mathbf{2 0 , 6 7}$ & $-12,66$ & $-19,50$ & $-15,95$ & $-21,23$ \\
\hline $\mathbf{1 1}$ & $-7,01$ & 22,56 & 25,32 & $\mathbf{2 3 , 9 6}$ & $-14,01$ & $-21,38$ & $-18,08$ & $-24,73$ \\
\hline $\mathbf{1 2}$ & $-7,13$ & 23,22 & 26,07 & $\mathbf{2 3 , 5 8}$ & $-14,07$ & $-21,38$ & $-18,67$ & $-25,72$ \\
\hline \hline $\mathbf{1 3}$ & 11,46 & 2,61 & 2,24 & $\mathbf{0 , 0 0}$ & 11,04 & 14,04 & 0,79 & 1,64 \\
\hline $\mathbf{1 4}$ & 35,47 & 17,72 & 16,66 & $\mathbf{1 2 , 2 8}$ & 44,38 & 42,90 & 33,24 & 38,24 \\
\hline $\mathbf{1 5}$ & 55,22 & 33,56 & 32,20 & $\mathbf{3 0 , 8 9}$ & 71,94 & 65,64 & 65,14 & 77,95 \\
\hline $\mathbf{1 6}$ & 68,60 & 45,04 & 43,52 & $\mathbf{4 2 , 0 8}$ & 90,65 & 80,77 & 88,88 & 107,54 \\
\hline $\mathbf{1 7}$ & 76,07 & 51,87 & 50,27 & $\mathbf{5 1 , 5 7}$ & 100,47 & 88,35 & 103,04 & 125,17 \\
\hline $\mathbf{1 8}$ & 77,22 & 53,65 & 52,04 & $\mathbf{5 4 , 7 4}$ & 101,28 & 88,35 & 106,95 & 130,04 \\
\hline \hline
\end{tabular}


TABELA 5.53: Esforços Normais nas nervuras e vigas, em $\mathrm{kN}$, na laje com altura total $\mathrm{h}=50$ $\mathrm{cm}$

\begin{tabular}{|c|c|c|c|c|c|c|c|c|}
\hline \multicolumn{9}{|c|}{$\begin{array}{c}\text { LAJE COM RELAÇÃO hf } / \mathrm{h}=0,100 \\
\text { ESFORÇOS NORMAIS NAS NERVURAS E VIGAS }(\mathrm{kN})\end{array}$} \\
\hline \multirow{2}{*}{ Ponto } & \multicolumn{8}{|c|}{$\begin{array}{l}\text { Modelos numéricos de análise } \\
\end{array}$} \\
\hline & 01 & 02 & $\mathbf{0 3}$ & 04 & 05 & 06 & 07 & 08 \\
\hline 1 & 0,74 & 2,45 & 2,43 & 4,41 & $-1,56$ & $-3,16$ & $-1,08$ & $-1,44$ \\
\hline 2 & $-1,18$ & 9,41 & 10,35 & 9,48 & $-4,49$ & $-8,34$ & $-6,76$ & $-10,15$ \\
\hline 3 & $-2,49$ & 14,93 & 16,70 & 14,79 & $-6,67$ & $-10,78$ & $-8,90$ & $-14,65$ \\
\hline 4 & $-2,97$ & 19,02 & 21,35 & 19,54 & $-7,60$ & $-11,87$ & $-9,70$ & $-16,84$ \\
\hline 5 & $-3,09$ & 21,44 & 24,07 & 22,45 & $-7,93$ & $-12,29$ & $-9,97$ & $-17,81$ \\
\hline 6 & $-3,10$ & 22,09 & 24,80 & 23,43 & $-7,95$ & $-12,29$ & $-10,03$ & $-18,04$ \\
\hline$\overline{77}$ & $\begin{array}{l}-1,33 \\
\end{array}$ & 2,111 & 2,13 & $\begin{array}{l}2,86 \\
\end{array}$ & $\begin{array}{l}-2,47 \\
\end{array}$ & \begin{tabular}{c|}
$-3,71$ \\
\end{tabular} & $\begin{array}{c}-0,67 \\
\end{array}$ & \begin{tabular}{c|c|}
$-1,30$ \\
\end{tabular} \\
\hline 8 & $-2,93$ & 9,37 & 10,31 & 8,46 & $-6,12$ & $-10,06$ & $-6,76$ & $\begin{array}{l}-8,76 \\
\end{array}$ \\
\hline 9 & $-5,02$ & 14,98 & 16,70 & 15,01 & $-9,74$ & $-15,00$ & $-11,78$ & $-15,13$ \\
\hline 10 & $-6,31$ & 19,02 & 21,26 & 19,87 & $-12,21$ & $-18,40$ & $-15,27$ & $-20,54$ \\
\hline 11 & $-6,94$ & 21,42 & 23,96 & 22,09 & $-13,49$ & $-20,15$ & $-17,34$ & $-23,96$ \\
\hline 12 & $-7,07$ & 22,07 & 24,70 & 23,10 & $-13,55$ & $-20,15$ & $-17,92$ & $-24,93$ \\
\hline 13 & 9,35 & 0,60 & $\begin{array}{l}0,20 \\
\end{array}$ & $-2,73$ & 8,89 & 12,26 & \begin{tabular}{|c|}
$-0,74$ \\
\end{tabular} & $-0,11$ \\
\hline 14 & 33,47 & 15,67 & 14,65 & 10,57 & 41,75 & 40,67 & 31,88 & 36,83 \\
\hline 15 & 52,85 & 31,28 & 30,00 & 29,62 & 68,07 & 62,19 & 62,87 & 75,65 \\
\hline 16 & 66,11 & 42,62 & 41,22 & 40,29 & 85,90 & 76,42 & 85,62 & 104,37 \\
\hline 17 & 73,61 & 49,34 & 47,88 & 49,18 & 95,31 & 83,53 & 99,08 & 121,41 \\
\hline 18 & 74,93 & 51,12 & 49,67 & 52,13 & 96,23 & 83,53 & 102,78 & 126,11 \\
\hline
\end{tabular}

Abaixo tem-se os gráficos de esforços normais na nervura central das lajes processadas nesta série.

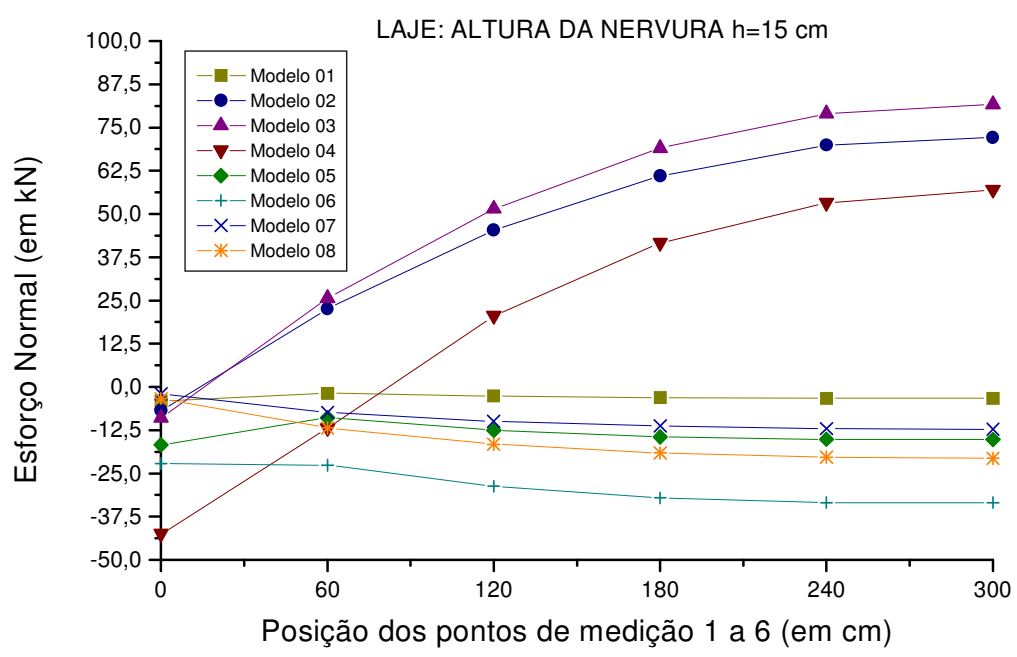

FIGURA 5.53: Esforços Normais $(\mathrm{kN})$, na nervura central, na laje com $\mathrm{hf} / \mathrm{h}=0,333$ 


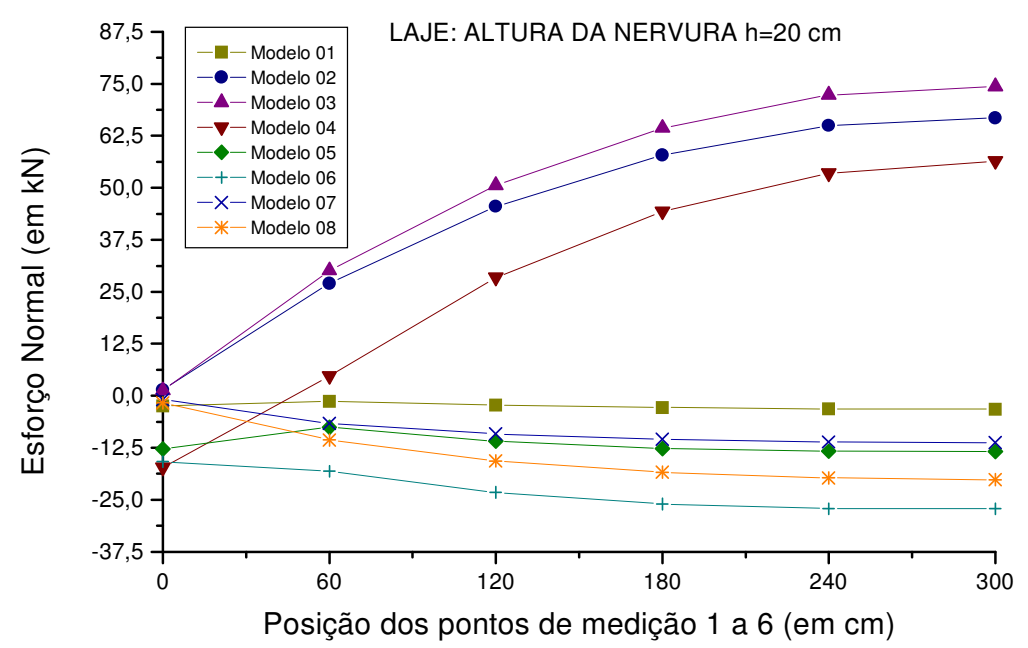

FIGURA 5.54: Esforços Normais $(\mathrm{kN})$, na nervura central, na laje com $\mathrm{hf} / \mathrm{h}=0,250$

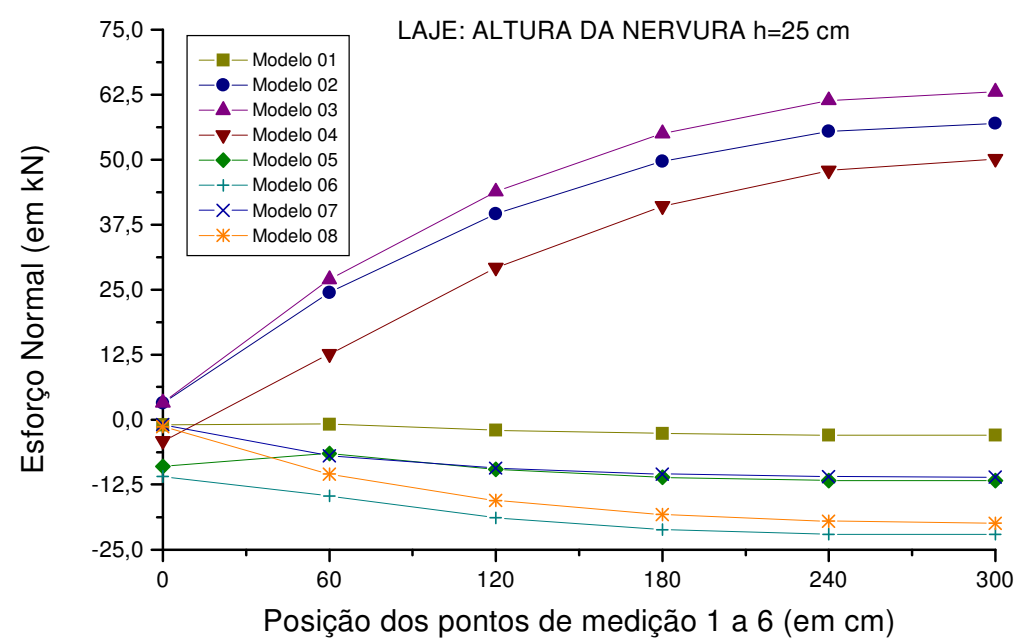

FIGURA 5.55: Esforços Normais $(\mathrm{kN})$, na nervura central, na laje com $\mathrm{hf} / \mathrm{h}=0,200$

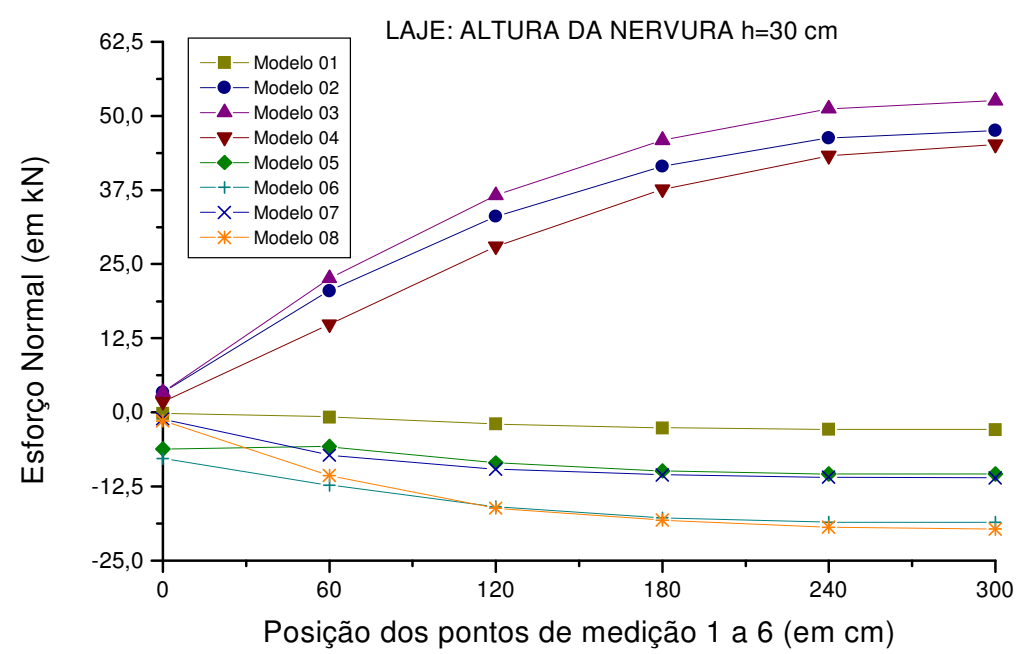

FIGURA 5.56: Esforços Normais $(\mathrm{kN})$, na nervura central, na laje com $\mathrm{hf} / \mathrm{h}=0,167$ 


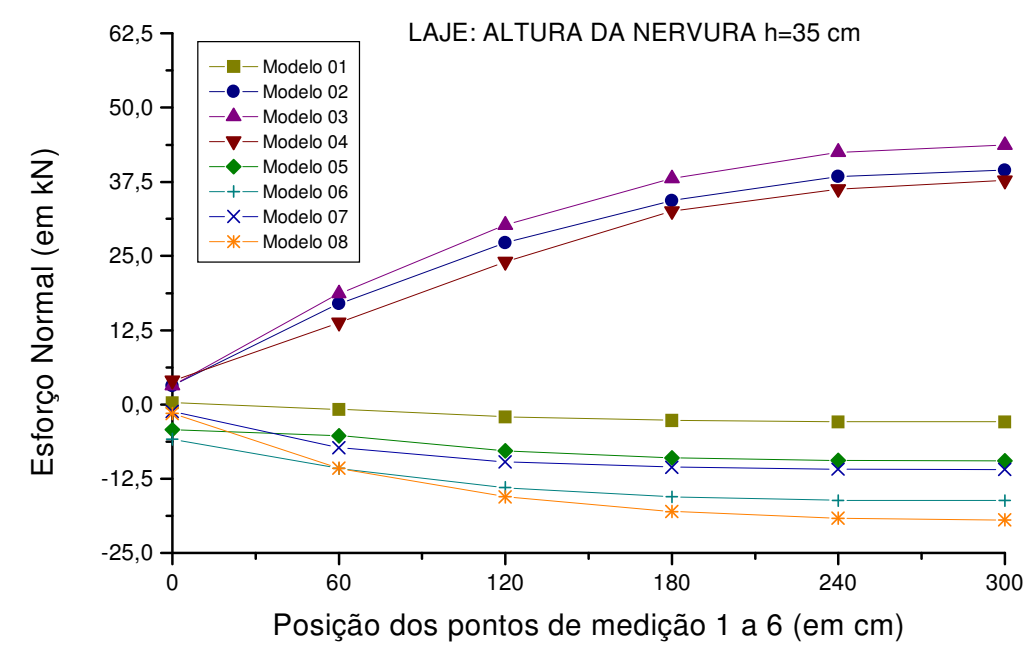

FIGURA 5.57: Esforços Normais $(\mathrm{kN})$, na nervura central, na laje com $\mathrm{hf} / \mathrm{h}=0,143$

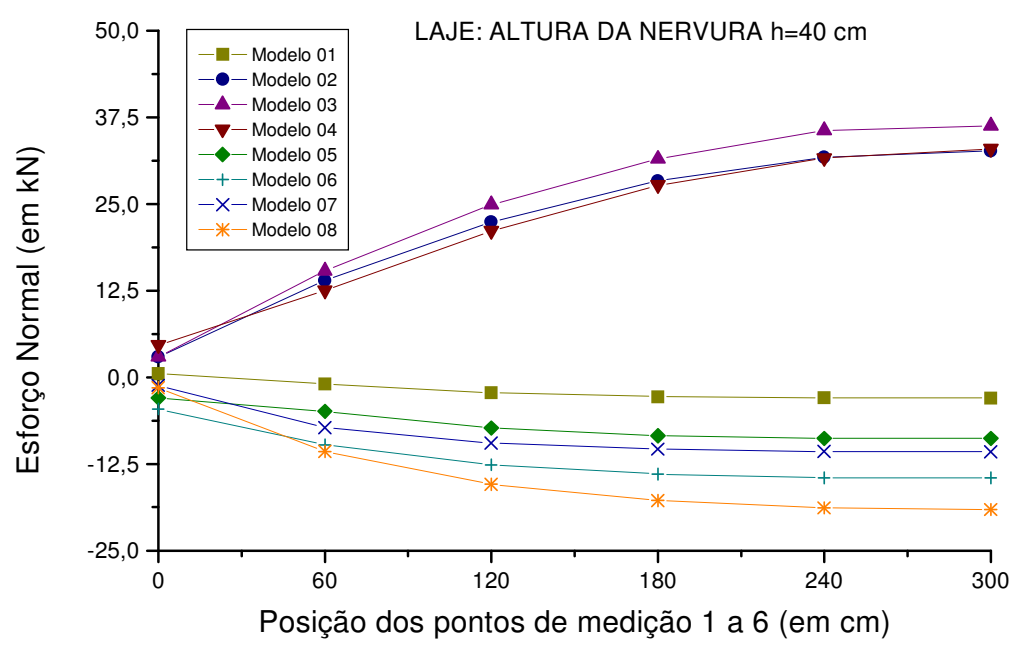

FIGURA 5.58: Esforços Normais $(\mathrm{kN})$, na nervura central, na laje com $\mathrm{hf} / \mathrm{h}=0,125$

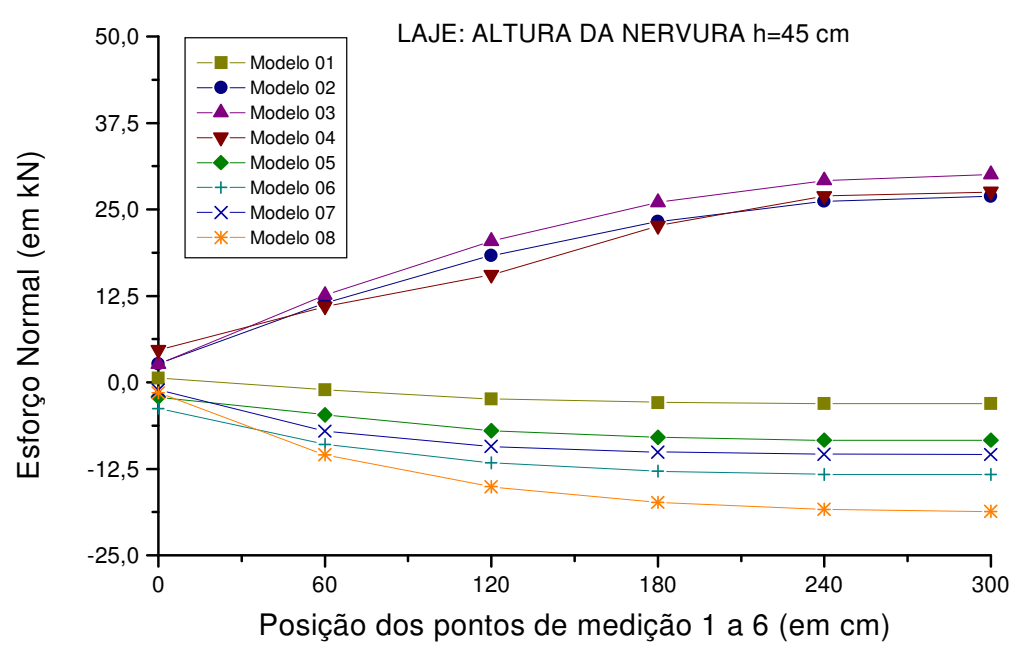

FIGURA 5.59: Esforços Normais ( $\mathrm{kN})$, na nervura central, na laje com $\mathrm{hf} / \mathrm{h}=0,111$ 


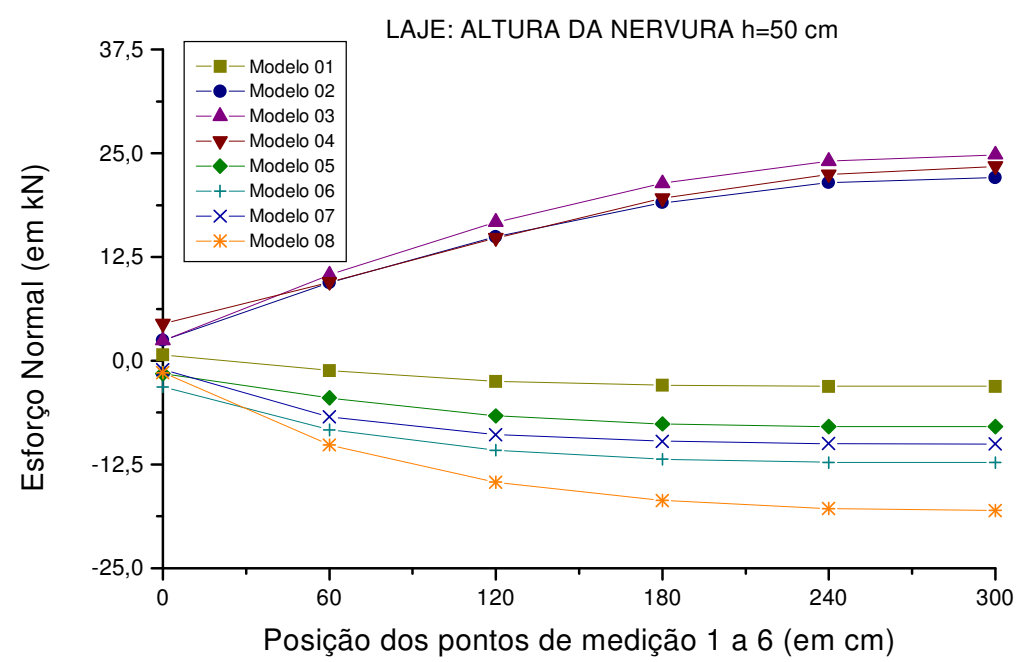

FIGURA 5.60: Esforços Normais $(\mathrm{kN})$, na nervura central, na laje com $\mathrm{hf} / \mathrm{h}=0,100$

Analisando as tabelas e gráficos de esforços normais nas nervuras, segundo os modelos 01 a 08 , promovendo-se variação da relação $h_{f} / h$, tem-se que:

- houve claramente uma separação entre os resultados de modelos simplificados e de viga excêntrica ou realista: os modelos simplificados, de seção "T" concêntrica, chamados de modelos 05, 06, 07 e 08, e o modelo concêntrico, apresentaram esforços normais de compressão. Estes esforços normais de compressão são menores, em módulo, do que os esforços de tração encontrados para os modelos 02, 03 e 04. Estes têm esforços normais de tração porque são lançados de maneira excêntrica (ou pelo "offset rígido" ou pela simulação utilizando o elemento de casca SHELL63), afastados da capa comprimida, porém ligados à mesma, surgindo então a tração pela própria deformação da laje;

- dessa maneira, confirma-se a necessidade de dimensionamento das seções, nestes modelos em MEF, por flexo-tração (nervuras dos modelos 02 a 04) e flexocompressão (nervuras dos modelos 05 a 08);

- espera-se, na análise de tensões normais, que haja um equilíbrio entre os resultados de tensões nas seções entre os modelos de viga excêntrica, realista e simplificados, já que os mesmos divergem na ordem dos valores de momentos fletores, em em sinal nos esforços normais.

Abaixo tem-se os gráficos de esforços normais atuantes nas vigas de contorno externo das lajes processadas nesta série. 


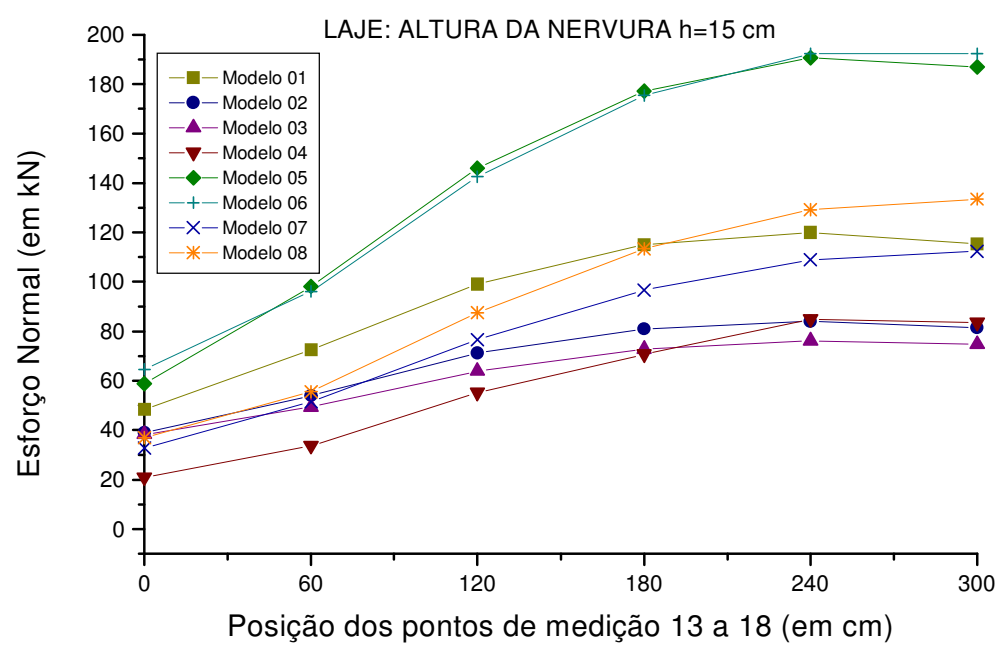

FIGURA 5.61: Esforços Normais ( $\mathrm{kN})$, na viga externa; laje com relação $\mathrm{hf} / \mathrm{h}=0,333$

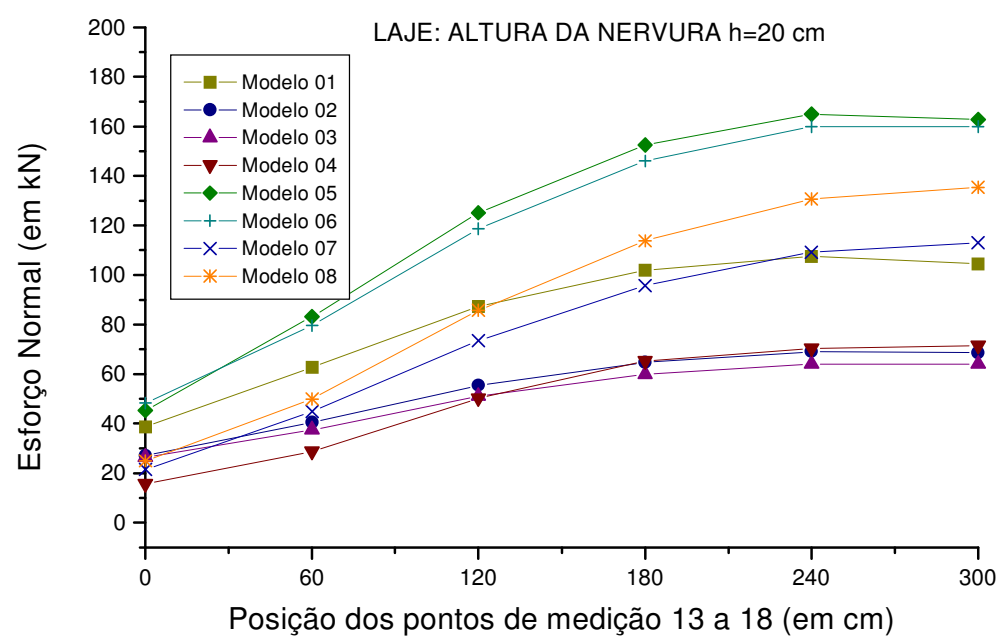

FIGURA 5.62: Esforços Normais $(\mathrm{kN})$, na viga externa; laje com relação $\mathrm{hf} / \mathrm{h}=0,250$

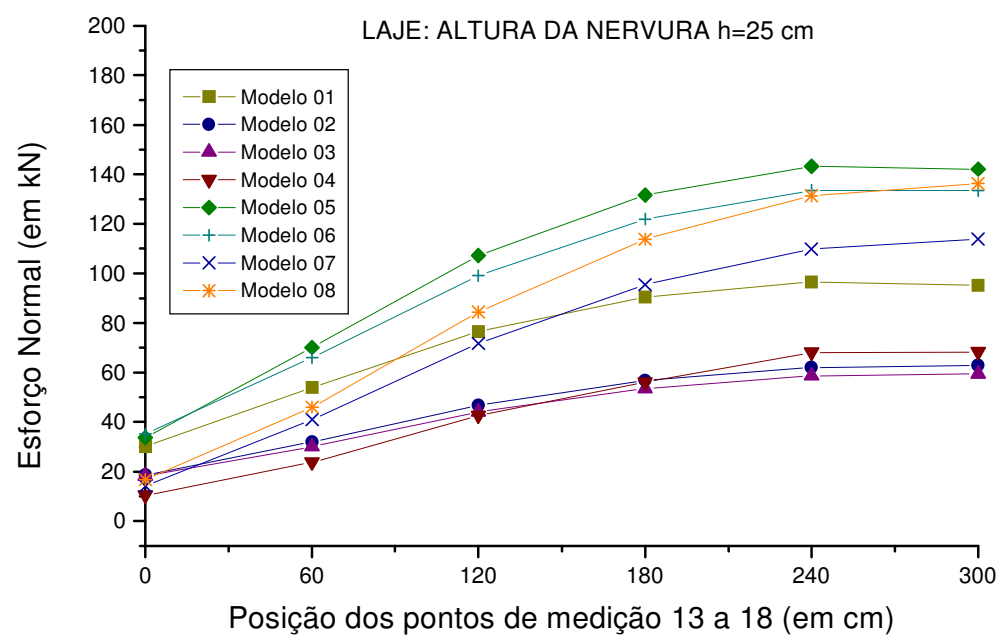

FIGURA 5.63: Esforços Normais ( $\mathrm{kN})$, na viga externa; laje com relação $\mathrm{hf} / \mathrm{h}=0,200$ 


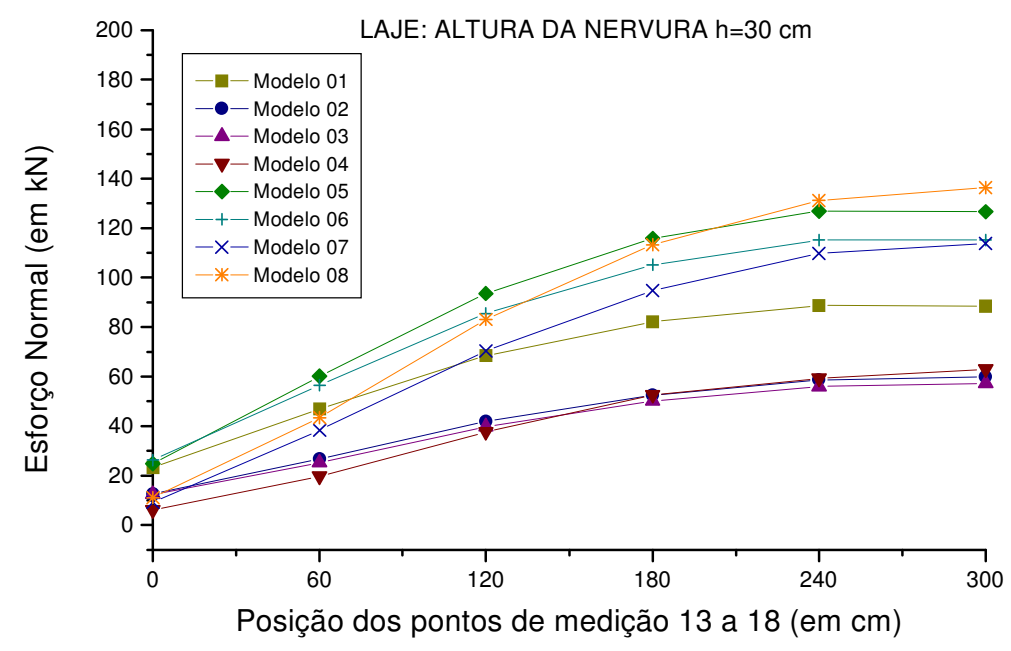

FIGURA 5.64: Esforços Normais $(\mathrm{kN})$, na viga externa; laje com relação $\mathrm{hf} / \mathrm{h}=0,167$

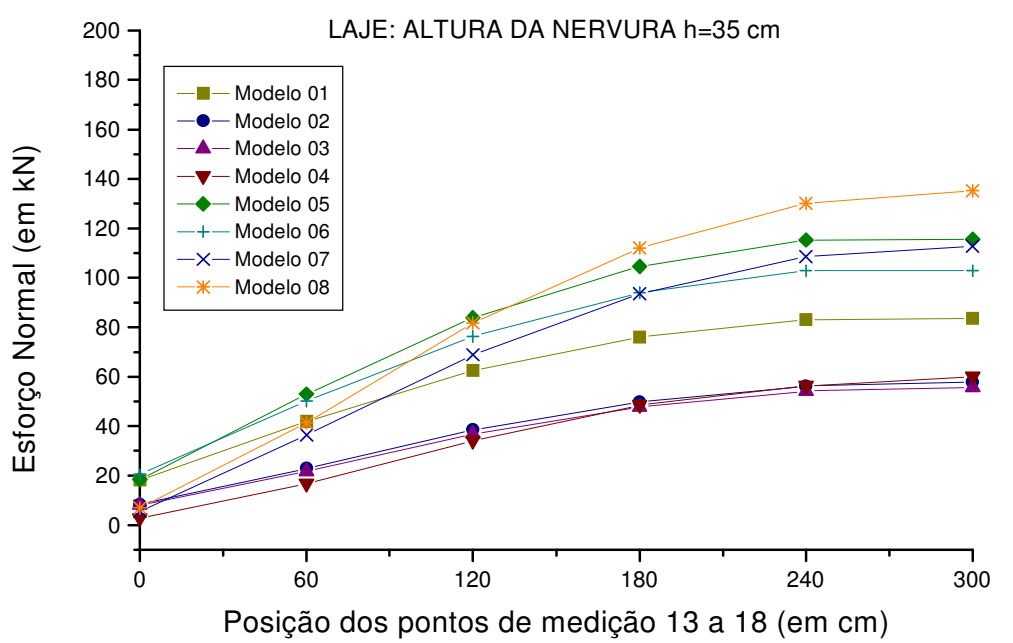

FIGURA 5.65: Esforços Normais $(\mathrm{kN})$, na viga externa; laje com relação $\mathrm{hf} / \mathrm{h}=0,143$

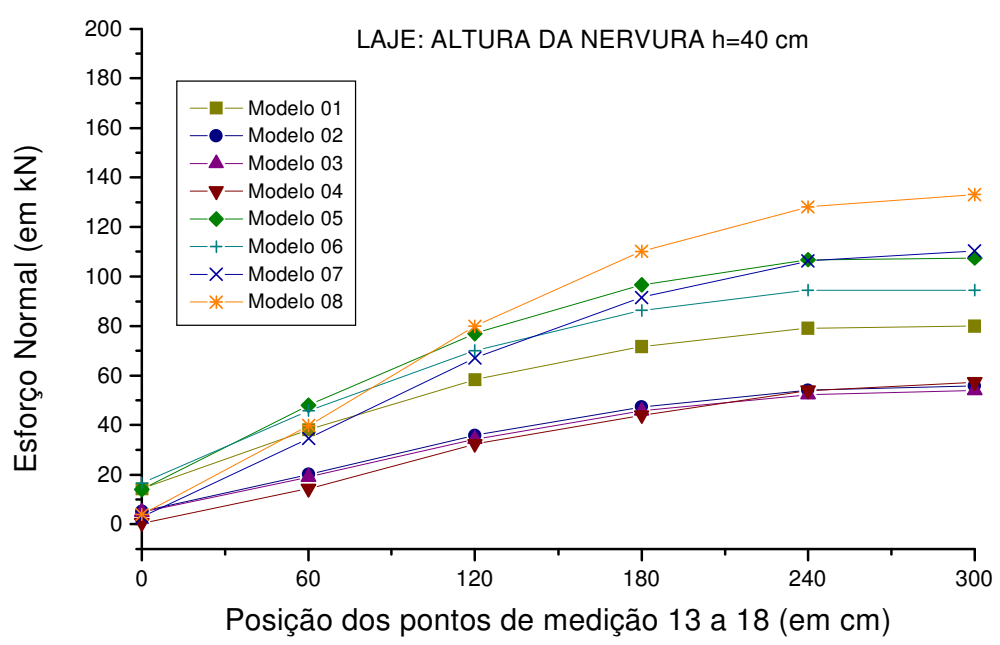

FIGURA 5.66: Esforços Normais ( $\mathrm{kN})$, na viga externa; laje com relação $\mathrm{hf} / \mathrm{h}=0,125$ 


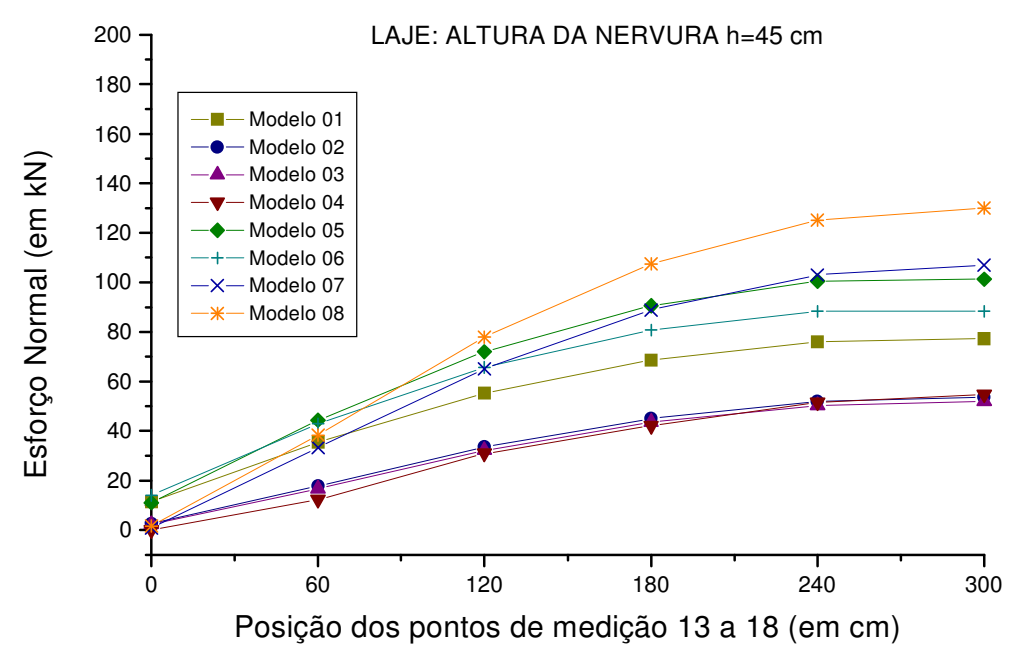

FIGURA 5.67: Esforços Normais ( $\mathrm{kN})$, na viga externa; laje com relação $\mathrm{hf} / \mathrm{h}=0,111$

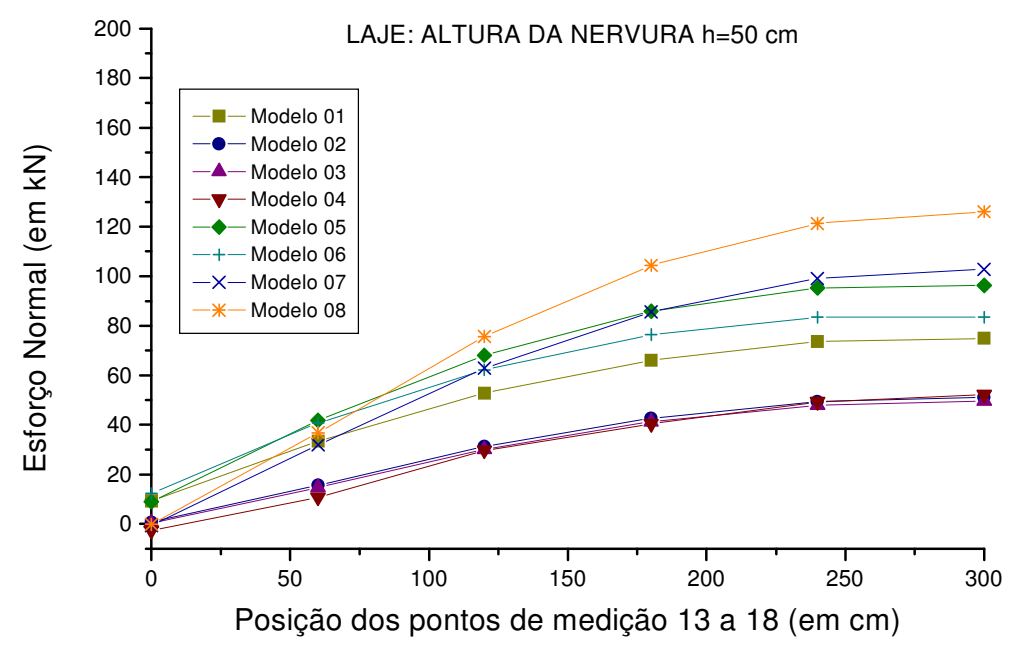

FIGURA 5.68: Esforços Normais ( $\mathrm{kN})$, na viga externa; laje com relação $\mathrm{hf} / \mathrm{h}=0,100$

Pela análise das tabelas e gráficos de esforços normais atuantes nas vigas de contorno, em todos os modelos consideradas excêntricas, verificou-se que:

- todos os elementos apresentaram esforços normais de tração, já que todos consideraram a excentricidade, e estão assim afastados da capa comprimida;

- apresentaram valores diferentes em cada modelagem, com variação ligada à flexibilidade dos sistemas: os modelos que mostram as vigas mais flexíveis, ou seja, os modelos 02 a 04, apresentam os menores valores de força normal. Isso é interessante porque os mesmos foram os que apresentaram os momentos fletores mais elevados. Assim, esperase que na análise de tensões normais haja um equilíbrio de resultados para a viga em todos os modelos. 


\subsubsection{Tensões Normais nas fibras superiores extremas das nervuras e vigas}

TABELA 5.54: Tensões Normais nas fibras superiores extremas das nervuras e vigas, em $\mathrm{kN} / \mathrm{cm}^{2}$, na laje com altura total $\mathrm{h}=15 \mathrm{~cm}$

\begin{tabular}{|c|c|c|c|c|c|c|c|c|}
\hline \multicolumn{9}{|c|}{$\begin{array}{c}\text { LAJE COM RELAÇÃO } \mathrm{hf} / \mathrm{h}=0,333 \\
\text { TENSÕES NORMAIS - FIBRAS SUPERIORES EXTREMAS DAS NERVURAS E VIGAS }\left(\mathrm{kN} / \mathrm{cm}^{2}\right)\end{array}$} \\
\hline \multirow{2}{*}{ Ponto } & \multicolumn{8}{|c|}{ Modelos numéricos de análise } \\
\hline & 01 & 02 & 03 & 04 & 05 & 06 & 07 & 08 \\
\hline 1 & 0,510 & 0,049 & 0,354 & 0,385 & 0,328 & 0,366 & 0,029 & 0,165 \\
\hline 2 & $-0,429$ & $-0,266$ & 0,271 & 0,068 & 0,008 & $-0,029$ & $-0,259$ & $-0,124$ \\
\hline 3 & $-1,108$ & $-0,441$ & 0,267 & $-0,108$ & $-0,238$ & $-0,322$ & $-0,463$ & $-0,319$ \\
\hline 4 & $-1,555$ & $-0,550$ & 0,258 & $-0,216$ & $-0,391$ & $-0,505$ & $-0,602$ & $-0,440$ \\
\hline 5 & $-1,799$ & $-0,604$ & 0,232 & $-0,274$ & $-0,468$ & $-0,598$ & $-0,681$ & $-0,504$ \\
\hline 6 & $-1,847$ & $-0,602$ & 0,188 & $-0,292$ & $-0,482$ & $-0,614$ & $-0,703$ & $-0,521$ \\
\hline 7 & 0,782 & 0,265 & 0,372 & 0,253 & 0,178 & 0,195 & 0,229 & 0,224 \\
\hline 8 & $-0,021$ & $-0,112$ & 0,176 & 0,047 & $-0,031$ & $-0,071$ & $-0,062$ & $-0,040$ \\
\hline 9 & $-0,598$ & $-0,291$ & 0,161 & $-0,076$ & $-0,169$ & $-0,242$ & $-0,259$ & $-0,187$ \\
\hline 10 & $-0,975$ & $-0,396$ & 0,145 & $-0,141$ & $-0,251$ & $-0,343$ & $-0,390$ & $-0,278$ \\
\hline 11 & $-1,174$ & $-0,443$ & 0,120 & $-0,177$ & $-0,291$ & $-0,395$ & $-0,461$ & $-0,328$ \\
\hline 12 & $-1,212$ & $-0,442$ & 0,083 & $-0,187$ & $-0,298$ & $-0,402$ & $-0,480$ & $-0,341$ \\
\hline 13 & 0,160 & 0,165 & 0,169 & 0,113 & 0,136 & 0,151 & 0,142 & 0,150 \\
\hline 14 & 0,066 & 0,037 & 0,001 & 0,006 & 0,090 & 0,009 & 0,026 & 0,025 \\
\hline 15 & 0,007 & $-0,048$ & $-0,096$ & $-0,080$ & 0,060 & 0,000 & $-0,041$ & $-0,040$ \\
\hline 16 & $-0,048$ & $-0,118$ & $-0,162$ & $-0,146$ & $-0,005$ & $-0,003$ & $-0,086$ & $-0,084$ \\
\hline 17 & $-0,097$ & $-0,169$ & $-0,201$ & $-0,184$ & $-0,013$ & $-0,003$ & $-0,114$ & $-0,112$ \\
\hline 18 & $-0,133$ & $-0,196$ & $-0,212$ & $-0,203$ & 0,005 & 0,042 & $-0,126$ & $-0,124$ \\
\hline
\end{tabular}

TABELA 5.55: Tensões Normais nas fibras superiores extremas das nervuras e vigas, em $\mathrm{kN} / \mathrm{cm}^{2}$, na laje com altura total $\mathrm{h}=20 \mathrm{~cm}$

\section{LAJE COM RELAÇÃO hf/h = 0,250}

TENSÕES NORMAIS - FIBRAS SUPERIORES EXTREMAS DAS NERVURAS E VIGAS $\left(\mathrm{kN} / \mathrm{cm}^{2}\right)$

\begin{tabular}{c|c|c|c|c|c|c|c|c}
\hline \multirow{2}{*}{ Ponto } & \multicolumn{7}{|c}{ Modelos numéricos de análise } \\
\cline { 2 - 9 } & $\mathbf{0 1}$ & $\mathbf{0 2}$ & $\mathbf{0 3}$ & $\mathbf{0 4}$ & $\mathbf{0 5}$ & $\mathbf{0 6}$ & $\mathbf{0 7}$ & $\mathbf{0 8}$ \\
\hline \hline $\mathbf{1}$ & 0,285 & $-0,053$ & 0,198 & $\mathbf{0 , 1 8 4}$ & 0,177 & 0,175 & $-0,017$ & 0,025 \\
\hline $\mathbf{2}$ & $-0,373$ & $-0,206$ & 0,118 & $\mathbf{- 0 , 0 0 8}$ & $-0,021$ & $-0,057$ & $-0,188$ & $-0,128$ \\
\hline $\mathbf{3}$ & $-0,847$ & $-0,298$ & 0,085 & $\mathbf{- 0 , 1 0 7}$ & $-0,181$ & $-0,232$ & $-0,305$ & $-0,232$ \\
\hline $\mathbf{4}$ & $-1,169$ & $-0,355$ & 0,059 & $\mathbf{- 0 , 1 6 5}$ & $-0,284$ & $-0,345$ & $-0,382$ & $-0,299$ \\
\hline $\mathbf{5}$ & $-1,363$ & $-0,382$ & 0,033 & $\mathbf{- 0 , 1 9 8}$ & $-0,340$ & $-0,408$ & $-0,426$ & $-0,335$ \\
\hline $\mathbf{6}$ & $-1,428$ & $-0,379$ & 0,005 & $\mathbf{- 0 , 2 0 8}$ & $-0,358$ & $-0,427$ & $-0,438$ & $-0,344$ \\
\hline \hline $\mathbf{7}$ & 0,569 & 0,079 & 0,214 & $\mathbf{0 , 1 4 2}$ & 0,114 & 0,112 & 0,076 & 0,090 \\
\hline $\mathbf{8}$ & 0,025 & $-0,103$ & 0,097 & $\mathbf{0 , 0 0 5}$ & $-0,030$ & $-0,063$ & $-0,075$ & $-0,057$ \\
\hline $\mathbf{9}$ & $-0,429$ & $-0,212$ & 0,052 & $\mathbf{- 0 , 0 7 4}$ & $-0,132$ & $-0,180$ & $-0,192$ & $-0,149$ \\
\hline $\mathbf{1 0}$ & $-0,748$ & $-0,273$ & 0,017 & $\mathbf{- 0 , 1 2 4}$ & $-0,196$ & $-0,253$ & $-0,268$ & $-0,209$ \\
\hline $\mathbf{1 1}$ & $-0,924$ & $-0,295$ & $-0,008$ & $\mathbf{- 0 , 1 5 0}$ & $-0,231$ & $-0,293$ & $-0,308$ & $-0,241$ \\
\hline $\mathbf{1 2}$ & $-0,979$ & $-0,292$ & $-0,029$ & $\mathbf{- 0 , 1 5 8}$ & $-0,240$ & $-0,304$ & $-0,318$ & $-0,250$ \\
\hline \hline $\mathbf{1 3}$ & 0,148 & 0,154 & 0,157 & $\mathbf{0 , 1 1 3}$ & 0,128 & 0,140 & 0,121 & 0,130 \\
\hline $\mathbf{1 4}$ & $-0,020$ & $-0,008$ & $-0,001$ & $\mathbf{0 , 0 0 6}$ & $-0,047$ & $-0,001$ & 0,021 & 0,021 \\
\hline $\mathbf{1 5}$ & $-0,085$ & $-0,087$ & $-0,093$ & $-\mathbf{0 , 0 7 5}$ & $-0,056$ & $-0,043$ & $-0,032$ & $-0,030$ \\
\hline $\mathbf{1 6}$ & $-0,119$ & $-0,148$ & $-0,159$ & $\mathbf{- 0 , 1 3 8}$ & $-0,047$ & $-0,042$ & $-0,070$ & $-0,066$ \\
\hline $\mathbf{1 7}$ & $-0,135$ & $-0,187$ & $-0,200$ & $\mathbf{- 0 , 1 8 2}$ & $-0,037$ & $-0,038$ & $-0,095$ & $-0,090$ \\
\hline $\mathbf{1 8}$ & $-0,134$ & $-0,199$ & $-0,214$ & $\mathbf{- 0 , 1 9 7}$ & $-0,024$ & $-0,030$ & $-0,106$ & $-0,101$ \\
\hline \hline
\end{tabular}


TABELA 5.56: Tensões Normais nas fibras superiores extremas das nervuras e vigas, em $\mathrm{kN} / \mathrm{cm}^{2}$, na laje com altura total $\mathrm{h}=25 \mathrm{~cm}$

LAJE COM RELAÇ̃̃ $\mathrm{hf} / \mathrm{h}=0,200$

TENSÕES NORMAIS - FIBRAS SUPERIORES EXTREMAS DAS NERVURAS E VIGAS $\left(\mathrm{kN} / \mathrm{cm}^{2}\right)$

\begin{tabular}{c|c|c|c|c|c|c|c|c}
\hline \multirow{2}{*}{ Ponto } & \multicolumn{8}{c}{ Modelos numéricos de análise } \\
\cline { 2 - 9 } & $\mathbf{0 1}$ & $\mathbf{0 2}$ & $\mathbf{0 3}$ & $\mathbf{0 4}$ & $\mathbf{0 5}$ & $\mathbf{0 6}$ & $\mathbf{0 7}$ & $\mathbf{0 8}$ \\
\hline \hline $\mathbf{1}$ & 0,106 & 0,079 & 0,123 & $\mathbf{0 , 0 9 9}$ & 0,078 & 0,072 & $-0,016$ & $-0,002$ \\
\hline $\mathbf{2}$ & $-0,357$ & $-0,062$ & 0,048 & $\mathbf{- 0 , 0 3 3}$ & $-0,054$ & $-0,079$ & $-0,139$ & $-0,109$ \\
\hline $\mathbf{3}$ & $-0,685$ & $-0,151$ & 0,010 & $\mathbf{- 0 , 1 0 3}$ & $-0,161$ & $-0,192$ & $-0,219$ & $-0,179$ \\
\hline $\mathbf{4}$ & $-0,905$ & $-0,209$ & $-0,017$ & $\mathbf{- 0 , 1 4 5}$ & $-0,230$ & $-0,266$ & $-0,271$ & $-0,224$ \\
\hline $\mathbf{5}$ & $-1,037$ & $-0,246$ & $-0,039$ & $\mathbf{- 0 , 1 6 8}$ & $-0,268$ & $-0,306$ & $-0,300$ & $-0,248$ \\
\hline $\mathbf{6}$ & $-1,081$ & $-0,265$ & $-0,057$ & $\mathbf{- 0 , 1 7 6}$ & $-0,280$ & $-0,319$ & $-0,308$ & $-0,254$ \\
\hline \hline $\mathbf{7}$ & 0,302 & 0,100 & 0,109 & $\mathbf{0 , 0 9 0}$ & 0,057 & 0,053 & 0,024 & 0,036 \\
\hline $\mathbf{8}$ & $-0,047$ & $-0,004$ & 0,049 & $-\mathbf{- 0 , 0 1 1}$ & $-0,044$ & $-0,067$ & $-0,071$ & $-0,058$ \\
\hline $\mathbf{9}$ & $-0,369$ & $-0,099$ & 0,002 & $\mathbf{- 0 , 0 6 3}$ & $-0,119$ & $-0,151$ & $-0,150$ & $-0,123$ \\
\hline $\mathbf{1 0}$ & $-0,600$ & $-0,164$ & $-0,032$ & $\mathbf{- 0 , 1 1 5}$ & $-0,167$ & $-0,204$ & $-0,202$ & $-0,167$ \\
\hline $\mathbf{1 1}$ & $-0,723$ & $-0,196$ & $-0,051$ & $\mathbf{- 0 , 1 3 6}$ & $-0,194$ & $-0,234$ & $-0,229$ & $-0,190$ \\
\hline $\mathbf{1 2}$ & $-0,759$ & $-0,209$ & $-0,064$ & $\mathbf{- 0 , 1 4 2}$ & $-0,201$ & $-0,242$ & $-0,235$ & $-0,196$ \\
\hline \hline $\mathbf{1 3}$ & $\mathbf{0} 139$ & 0,145 & 0,147 & $\mathbf{0 , 1 1 3}$ & 0,122 & 0,135 & 0,107 & 0,116 \\
\hline $\mathbf{1 4}$ & $-0,017$ & $-0,003$ & $-0,001$ & $\mathbf{0 , 0 0 8}$ & $-0,037$ & $-0,007$ & 0,001 & $-0,003$ \\
\hline $\mathbf{1 5}$ & $-0,078$ & $-0,086$ & $-0,089$ & $-\mathbf{0 , 0 7 3}$ & $-0,055$ & $-0,053$ & $-0,041$ & $-0,043$ \\
\hline $\mathbf{1 6}$ & $-0,115$ & $-0,149$ & $-0,155$ & $\mathbf{- 0 , 1 3 4}$ & $-0,058$ & $-0,066$ & $-0,070$ & $-0,068$ \\
\hline $\mathbf{1 7}$ & $-0,136$ & $-0,190$ & $-0,198$ & $-\mathbf{0 , 1 7 0}$ & $-0,057$ & $-0,072$ & $-0,088$ & $-0,083$ \\
\hline $\mathbf{1 8}$ & $-0,139$ & $-0,204$ & $-0,212$ & $\mathbf{- 0 , 1 8 5}$ & $-0,050$ & $-0,069$ & $-0,092$ & $-0,087$ \\
\hline \hline
\end{tabular}

TABELA 5.57: Tensões Normais nas fibras superiores extremas das nervuras e vigas, em $\mathrm{kN} / \mathrm{cm}^{2}$, na laje com altura total $\mathrm{h}=30 \mathrm{~cm}$

LAJE COM RELAÇ̃̃̃ hf/h $=0,167$

TENSÕES NORMAIS - FIBRAS SUPERIORES EXTREMAS DAS NERVURAS E VIGAS (kN/ $\left.\mathrm{cm}^{2}\right)$

\begin{tabular}{c|c|c|c|c|c|c|c|c}
\hline \multirow{2}{*}{ Ponto } & \multicolumn{7}{|c}{ Modelos numéricos de análise } \\
\cline { 2 - 9 } & $\mathbf{0 1}$ & $\mathbf{0 2}$ & $\mathbf{0 3}$ & $\mathbf{0 4}$ & $\mathbf{0 5}$ & $\mathbf{0 6}$ & $\mathbf{0 7}$ & $\mathbf{0 8}$ \\
\hline \hline $\mathbf{1}$ & 0,045 & 0,056 & 0,083 & $\mathbf{0 , 0 6 2}$ & 0,038 & 0,034 & $-0,014$ & $-0,008$ \\
\hline $\mathbf{2}$ & $-0,298$ & $-0,048$ & 0,018 & $\mathbf{- 0 , 0 3 4}$ & $-0,060$ & $-0,075$ & $-0,107$ & $-0,091$ \\
\hline $\mathbf{3}$ & $-0,539$ & $-0,115$ & $-0,021$ & $\mathbf{- 0 , 0 8 8}$ & $-0,137$ & $-0,156$ & $-0,169$ & $-0,147$ \\
\hline $\mathbf{4}$ & $-0,697$ & $-0,158$ & $-0,046$ & $\mathbf{- 0 , 1 1 9}$ & $-0,188$ & $-0,209$ & $-0,208$ & $-0,179$ \\
\hline $\mathbf{5}$ & $-0,792$ & $-0,185$ & $-0,064$ & $\mathbf{- 0 , 1 3 6}$ & $-0,216$ & $-0,238$ & $-0,229$ & $-0,197$ \\
\hline $\mathbf{6}$ & $-0,824$ & $-0,198$ & $-0,077$ & $\mathbf{- 0 , 1 4 1}$ & $-0,225$ & $-0,247$ & $-0,235$ & $-0,202$ \\
\hline \hline $\mathbf{7}$ & 0,158 & 0,048 & 0,060 & $\mathbf{0 , 0 5 7}$ & 0,031 & 0,028 & 0,005 & 0,013 \\
\hline $\mathbf{8}$ & $-0,077$ & $-0,015$ & 0,023 & $-\mathbf{0 , 0 1 9}$ & $-0,047$ & $-0,063$ & $-0,064$ & $-0,054$ \\
\hline $\mathbf{9}$ & $-0,311$ & $-0,085$ & $-0,021$ & $\mathbf{- 0 , 0 6 8}$ & $-0,106$ & $-0,127$ & $-0,124$ & $-0,105$ \\
\hline $\mathbf{1 0}$ & $-0,479$ & $-0,131$ & $-0,050$ & $\mathbf{- 0 , 1 0 0}$ & $-0,144$ & $-0,169$ & $-0,163$ & $-0,140$ \\
\hline $\mathbf{1 1}$ & $-0,565$ & $-0,154$ & $-0,066$ & $\mathbf{- 0 , 1 1 7}$ & $-0,166$ & $-0,193$ & $-0,183$ & $-0,158$ \\
\hline $\mathbf{1 2}$ & $-0,590$ & $-0,164$ & $-0,075$ & $\mathbf{- 0 , 1 2 2}$ & $-0,172$ & $-0,199$ & $-0,189$ & $-0,163$ \\
\hline \hline $\mathbf{1 3}$ & 0,133 & 0,139 & 0,140 & $\mathbf{0 , 1 1 3}$ & 0,117 & 0,131 & 0,097 & 0,106 \\
\hline $\mathbf{1 4}$ & $-0,014$ & $-0,003$ & $-0,003$ & $\mathbf{0 , 0 0 9}$ & $-0,029$ & $-0,011$ & $-0,001$ & $-0,005$ \\
\hline $\mathbf{1 5}$ & $-0,073$ & $-0,084$ & $-0,087$ & $-\mathbf{0 , 0 7 0}$ & $-0,055$ & $-0,059$ & $-0,036$ & $-0,038$ \\
\hline $\mathbf{1 6}$ & $-0,113$ & $-0,147$ & $-0,152$ & $-\mathbf{0 , 1 2 8}$ & $-0,067$ & $-0,082$ & $-0,062$ & $-0,060$ \\
\hline $\mathbf{1 7}$ & $-0,138$ & $-0,188$ & $-0,194$ & $-\mathbf{0 , 1 6 6}$ & $-0,072$ & $-0,094$ & $-0,077$ & $-0,073$ \\
\hline $\mathbf{1 8}$ & $-0,143$ & $-0,201$ & $-0,208$ & $-\mathbf{0 , 1 7 8}$ & $-0,068$ & $-0,094$ & $-0,081$ & $-0,076$ \\
\hline \hline
\end{tabular}


TABELA 5.58: Tensões Normais nas fibras superiores extremas das nervuras e vigas, em $\mathrm{kN} / \mathrm{cm}^{2}$, na laje com altura total $\mathrm{h}=35 \mathrm{~cm}$

LAJE COM RELAÇÃO hf/h = 0,143

TENSÕES NORMAIS - FIBRAS SUPERIORES EXTREMAS DAS NERVURAS E VIGAS $\left(\mathrm{kN} / \mathrm{cm}^{2}\right)$

\begin{tabular}{c|c|c|c|c|c|c|c|c}
\hline \multirow{2}{*}{ Ponto } & \multicolumn{7}{|c}{ Modelos numéricos de análise } \\
\cline { 2 - 8 } & $\mathbf{0 1}$ & $\mathbf{0 2}$ & $\mathbf{0 3}$ & $\mathbf{0 4}$ & $\mathbf{0 5}$ & $\mathbf{0 6}$ & $\mathbf{0 7}$ & $\mathbf{0 8}$ \\
\hline \hline $\mathbf{1}$ & 0,022 & 0,042 & 0,060 & $\mathbf{0 , 0 4 3}$ & 0,020 & 0,018 & $-0,011$ & $-0,008$ \\
\hline $\mathbf{2}$ & $-0,238$ & $-0,036$ & 0,004 & $\mathbf{- 0 , 0 3 3}$ & $-0,056$ & $-0,066$ & $-0,086$ & $-0,078$ \\
\hline $\mathbf{3}$ & $-0,422$ & $-0,090$ & $-0,032$ & $\mathbf{- 0 , 0 7 8}$ & $-0,115$ & $-0,127$ & $-0,136$ & $-0,122$ \\
\hline $\mathbf{4}$ & $-0,542$ & $-0,125$ & $-0,055$ & $\mathbf{- 0 , 1 0 1}$ & $-0,154$ & $-0,167$ & $-0,167$ & $-0,149$ \\
\hline $\mathbf{5}$ & $-0,613$ & $-0,146$ & $-0,070$ & $\mathbf{- 0 , 1 1 9}$ & $-0,176$ & $-0,190$ & $-0,184$ & $-0,164$ \\
\hline $\mathbf{6}$ & $-0,637$ & $-0,156$ & $-0,080$ & $\mathbf{- 0 , 1 2 4}$ & $-0,183$ & $-0,197$ & $-0,189$ & $-0,168$ \\
\hline \hline $\mathbf{7}$ & 0,083 & 0,029 & 0,039 & $\mathbf{0 , 0 3 9}$ & 0,018 & 0,016 & $-0,002$ & 0,003 \\
\hline $\mathbf{8}$ & $-0,087$ & $-0,020$ & 0,007 & $\mathbf{- 0 , 0 2 2}$ & $-0,046$ & $-0,057$ & $-0,057$ & $-0,049$ \\
\hline $\mathbf{9}$ & $-0,262$ & $-0,074$ & $-0,031$ & $\mathbf{- 0 , 0 6 2}$ & $-0,094$ & $-0,109$ & $-0,106$ & $-0,092$ \\
\hline $\mathbf{1 0}$ & $-0,387$ & $-0,110$ & $-0,056$ & $\mathbf{- 0 , 0 8 9}$ & $-0,126$ & $-0,145$ & $-0,139$ & $-0,121$ \\
\hline $\mathbf{1 1}$ & $-0,450$ & $-0,129$ & $-0,070$ & $\mathbf{- 0 , 1 0 3}$ & $-0,144$ & $-0,165$ & $-0,155$ & $-0,137$ \\
\hline $\mathbf{1 2}$ & $-0,468$ & $-0,137$ & $-0,078$ & $\mathbf{- 0 , 1 0 8}$ & $-0,149$ & $-0,170$ & $-0,160$ & $-0,141$ \\
\hline \hline $\mathbf{1 3}$ & 0,128 & 0,134 & 0,135 & $\mathbf{0 , 1 1 3}$ & 0,113 & 0,128 & 0,088 & 0,097 \\
\hline $\mathbf{1 4}$ & $-0,011$ & $-0,004$ & $-0,004$ & $\mathbf{0 , 0 1 0}$ & $-0,025$ & $-0,015$ & $-0,002$ & $-0,006$ \\
\hline $\mathbf{1 5}$ & $-0,069$ & $-0,084$ & $-0,087$ & $\mathbf{- 0 , 0 6 8}$ & $-0,055$ & $-0,064$ & $-0,033$ & $-0,034$ \\
\hline $\mathbf{1 6}$ & $-0,112$ & $-0,146$ & $-0,150$ & $\mathbf{- 0 , 1 2 4}$ & $-0,072$ & $-0,092$ & $-0,055$ & $-0,053$ \\
\hline $\mathbf{1 7}$ & $-0,139$ & $-0,185$ & $-0,190$ & $\mathbf{- 0 , 1 5 9}$ & $-0,081$ & $-0,107$ & $-0,068$ & $-0,065$ \\
\hline $\mathbf{1 8}$ & $-0,146$ & $-0,197$ & $-0,203$ & $\mathbf{- 0 , 1 7 1}$ & $-0,079$ & $-0,108$ & $-0,071$ & $-0,067$ \\
\hline \hline
\end{tabular}

TABELA 5.59: Tensões Normais nas fibras superiores extremas das nervuras e vigas, em $\mathrm{kN} / \mathrm{cm}^{2}$, na laje com altura total $\mathrm{h}=40 \mathrm{~cm}$

LAJE COM RELAÇÃO hf/h = 0,125

TENSÕES NORMAIS - FIBRAS SUPERIORES EXTREMAS DAS NERVURAS E VIGAS $\left(\mathrm{kN} / \mathrm{cm}^{2}\right)$

\begin{tabular}{c|c|c|c|c|c|c|c|c}
\hline \multirow{2}{*}{ Ponto } & \multicolumn{7}{c}{ Modelos numéricos de análise } \\
\cline { 2 - 8 } & $\mathbf{0 1}$ & $\mathbf{0 2}$ & $\mathbf{0 3}$ & $\mathbf{0 4}$ & $\mathbf{0 5}$ & $\mathbf{0 6}$ & $\mathbf{0 7}$ & $\mathbf{0 8}$ \\
\hline \hline $\mathbf{1}$ & 0,013 & 0,033 & 0,045 & $\mathbf{0 , 0 3 3}$ & 0,011 & 0,010 & $-0,009$ & $-0,008$ \\
\hline $\mathbf{2}$ & $-0,188$ & $-0,028$ & $-0,002$ & $\mathbf{- 0 , 0 2 7}$ & $-0,049$ & $-0,056$ & $-0,072$ & $-0,067$ \\
\hline $\mathbf{3}$ & $-0,332$ & $-0,072$ & $-0,034$ & $\mathbf{- 0 , 0 6 5}$ & $-0,096$ & $-0,103$ & $-0,113$ & $-0,105$ \\
\hline $\mathbf{4}$ & $-0,426$ & $-0,101$ & $-0,056$ & $\mathbf{- 0 , 0 8 6}$ & $-0,128$ & $-0,136$ & $-0,139$ & $-0,128$ \\
\hline $\mathbf{5}$ & $-0,481$ & $-0,119$ & $-0,068$ & $\mathbf{- 0 , 0 9 9}$ & $-0,145$ & $-0,154$ & $-0,153$ & $-0,141$ \\
\hline $\mathbf{6}$ & $-0,500$ & $-0,127$ & $-0,078$ & $\mathbf{- 0 , 1 0 3}$ & $-0,151$ & $-0,160$ & $-0,157$ & $-0,144$ \\
\hline \hline $\mathbf{7}$ & 0,045 & 0,021 & 0,029 & $\mathbf{0 , 0 2 7}$ & 0,011 & 0,010 & $-0,004$ & $-0,001$ \\
\hline $\mathbf{8}$ & $-0,086$ & $-0,022$ & $-0,002$ & $\mathbf{- 0 , 0 2 2}$ & $-0,043$ & $-0,052$ & $-0,052$ & $-0,045$ \\
\hline $\mathbf{9}$ & $-0,223$ & $-0,066$ & $-0,035$ & $\mathbf{- 0 , 0 5 7}$ & $-0,084$ & $-0,096$ & $-0,094$ & $-0,082$ \\
\hline $\mathbf{1 0}$ & $-0,320$ & $-0,096$ & $-0,058$ & $\mathbf{- 0 , 0 8 0}$ & $-0,112$ & $-0,127$ & $-0,121$ & $-0,108$ \\
\hline $\mathbf{1 1}$ & $-0,368$ & $-0,113$ & $-0,071$ & $\mathbf{- 0 , 0 9 3}$ & $-0,128$ & $-0,144$ & $-0,136$ & $-0,122$ \\
\hline $\mathbf{1 2}$ & $-0,382$ & $-0,120$ & $-0,078$ & $\mathbf{- 0 , 0 9 7}$ & $-0,133$ & $-0,149$ & $-0,140$ & $-0,126$ \\
\hline \hline $\mathbf{1 3}$ & 0,124 & 0,129 & 0,130 & $\mathbf{0 , 1 1 2}$ & 0,109 & 0,125 & 0,080 & 0,090 \\
\hline $\mathbf{1 4}$ & $-0,010$ & $-0,006$ & $-0,006$ & $\mathbf{0 , 0 0 9}$ & $-0,022$ & $-0,018$ & $-0,003$ & $-0,007$ \\
\hline $\mathbf{1 5}$ & $-0,067$ & $-0,085$ & $-0,087$ & $-\mathbf{- 0 , 0 6 7}$ & $-0,055$ & $-0,067$ & $-0,030$ & $-0,031$ \\
\hline $\mathbf{1 6}$ & $-0,111$ & $-0,144$ & $-0,148$ & $-\mathbf{0 , 1 2 2}$ & $-0,075$ & $-0,097$ & $-0,050$ & $-0,048$ \\
\hline $\mathbf{1 7}$ & $-0,139$ & $-0,180$ & $-0,185$ & $\mathbf{- 0 , 1 5 3}$ & $-0,086$ & $-0,114$ & $-0,060$ & $-0,058$ \\
\hline $\mathbf{1 8}$ & $-0,147$ & $-0,192$ & $-0,197$ & $\mathbf{- 0 , 1 6 4}$ & $-0,085$ & $-0,115$ & $-0,063$ & $-0,060$ \\
\hline \hline
\end{tabular}


TABELA 5.60: Tensões Normais nas fibras superiores extremas das nervuras e vigas, em $\mathrm{kN} / \mathrm{cm}^{2}$, na laje com altura total $\mathrm{h}=45 \mathrm{~cm}$

LAJE COM RELAÇ̃̃O hf/h $=0,111$

TENSÕES NORMAIS - FIBRAS SUPERIORES EXTREMAS DAS NERVURAS E VIGAS $\left(\mathrm{kN} / \mathrm{cm}^{2}\right)$

\begin{tabular}{|c|c|c|c|c|c|c|c|c|}
\hline \multirow{2}{*}{ Ponto } & \multicolumn{8}{|c|}{ Modelos numéricos de análise } \\
\hline & 01 & 02 & $\mathbf{0 3}$ & 04 & 05 & 06 & 07 & 08 \\
\hline 1 & $\overline{0,008}$ & 0,026 & 0,034 & 0,026 & 0,007 & 0,006 & 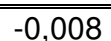 & $\overline{-0,007}$ \\
\hline 2 & $-0,149$ & $-0,021$ & $-0,004$ & $-0,022$ & $-0,042$ & $-0,046$ & $-0,060$ & $-0,059$ \\
\hline 3 & $-0,264$ & $-0,058$ & $-0,033$ & $-0,061$ & $-0,080$ & $-0,085$ & $-0,096$ & $-0,092$ \\
\hline 4 & $-0,339$ & $-0,083$ & $-0,053$ & $-0,076$ & $-0,106$ & $-0,111$ & $-0,118$ & $-0,113$ \\
\hline 5 & $-0,383$ & $-0,099$ & $-0,066$ & $-0,084$ & $-0,121$ & $-0,126$ & $-0,131$ & $-0,124$ \\
\hline 6 & $-0,398$ & $-0,105$ & $-0,073$ & $-0,089$ & $-0,126$ & $-0,131$ & $-0,134$ & $-0,127$ \\
\hline$\overline{7}$ & $\overline{0,024}$ & 0,018 & 0,025 & 0,020 & 0,007 & 0,007 & $-0,005$ & $\begin{array}{c}-0,003 \\
\end{array}$ \\
\hline 8 & $-0,082$ & $-0,022$ & $-0,007$ & $-0,022$ & $-0,040$ & $-0,047$ & $-0,047$ & $-0,042$ \\
\hline 9 & $-0,191$ & $-0,060$ & $-0,037$ & $-0,055$ & $-0,076$ & $-0,086$ & $-0,084$ & $-0,075$ \\
\hline 10 & $-0,269$ & $-0,087$ & $-0,058$ & $-0,076$ & $-0,101$ & $-0,113$ & $-0,109$ & $-0,098$ \\
\hline 11 & $-0,309$ & $-0,103$ & $-0,071$ & $-0,089$ & $-0,116$ & $-0,130$ & $-0,123$ & $-0,111$ \\
\hline 12 & $-0,320$ & $-0,110$ & $-0,078$ & $-0,097$ & $-0,120$ & $-0,134$ & $-0,126$ & $-0,115$ \\
\hline 13 & 0,121 & 0,125 & 0,126 & 0,111 & 0,107 & 0,122 & 0,073 & 0,083 \\
\hline 14 & $-0,008$ & $-0,008$ & $-0,008$ & 0,008 & $-0,021$ & $-0,021$ & $-0,004$ & $-0,007$ \\
\hline 15 & $-0,065$ & $-0,086$ & $-0,088$ & $-0,065$ & $-0,055$ & $-0,069$ & $-0,028$ & $-0,029$ \\
\hline 16 & $-0,110$ & $-0,142$ & $-0,146$ & $-0,118$ & $-0,077$ & $-0,100$ & $-0,045$ & $-0,044$ \\
\hline 17 & $-0,139$ & $-0,175$ & $-0,179$ & $-0,147$ & $-0,088$ & $-0,116$ & $-0,053$ & $-0,052$ \\
\hline 18 & $-0,146$ & $-0,185$ & $-0,190$ & $-0,157$ & $-0,088$ & $-0,118$ & $-0,055$ & $-0,053$ \\
\hline
\end{tabular}

TABELA 5.61: Tensões Normais nas fibras superiores extremas das nervuras e vigas, em $\mathrm{kN} / \mathrm{cm}^{2}$, na laje com altura total $\mathrm{h}=50 \mathrm{~cm}$

LAJE COM RELAÇ̃̃ $\mathrm{hf} / \mathrm{h}=0,100$

TENSÕES NORMAIS - FIBRAS SUPERIORES EXTREMAS DAS NERVURAS E VIGAS (kN/ $\left.\mathrm{cm}^{2}\right)$

\begin{tabular}{c|c|c|c|c|c|c|c|c}
\hline \multirow{2}{*}{ Ponto } & \multicolumn{8}{|c}{ Modelos numéricos de análise } \\
\cline { 2 - 9 } & $\mathbf{0 1}$ & $\mathbf{0 2}$ & $\mathbf{0 3}$ & $\mathbf{0 4}$ & $\mathbf{0 5}$ & $\mathbf{0 6}$ & $\mathbf{0 7}$ & $\mathbf{0 8}$ \\
\hline \hline $\mathbf{1}$ & 0,006 & 0,021 & 0,027 & $\mathbf{0 , 0 2 1}$ & 0,005 & 0,004 & $-0,007$ & $-0,007$ \\
\hline $\mathbf{2}$ & $-0,119$ & $-0,025$ & $-0,004$ & $\mathbf{- 0 , 0 1 7}$ & $-0,035$ & $-0,038$ & $-0,052$ & $-0,053$ \\
\hline $\mathbf{3}$ & $-0,211$ & $-0,055$ & $-0,030$ & $\mathbf{- 0 , 0 4 6}$ & $-0,067$ & $-0,070$ & $-0,082$ & $-0,082$ \\
\hline $\mathbf{4}$ & $-0,272$ & $-0,075$ & $-0,049$ & $\mathbf{- 0 , 0 6 3}$ & $-0,089$ & $-0,091$ & $-0,102$ & $-0,101$ \\
\hline $\mathbf{5}$ & $-0,308$ & $-0,086$ & $-0,061$ & $\mathbf{- 0 , 0 7 4}$ & $-0,101$ & $-0,104$ & $-0,113$ & $-0,111$ \\
\hline $\mathbf{6}$ & $-0,320$ & $-0,089$ & $-0,067$ & $\mathbf{- 0 , 0 7 7}$ & $-0,105$ & $-0,108$ & $-0,116$ & $-0,113$ \\
\hline $\mathbf{7}$ & 0,013 & 0,016 & 0,021 & $\mathbf{0 , 0 1 5}$ & 0,005 & 0,004 & $-0,005$ & $-0,004$ \\
\hline $\mathbf{8}$ & $-0,076$ & $-0,033$ & $-0,010$ & $\mathbf{- 0 , 0 2 1}$ & $-0,038$ & $-0,043$ & $-0,044$ & $-0,039$ \\
\hline $\mathbf{9}$ & $-0,167$ & $-0,064$ & $-0,037$ & $\mathbf{- 0 , 0 5 1}$ & $-0,070$ & $-0,078$ & $-0,077$ & $-0,069$ \\
\hline $\mathbf{1 0}$ & $-0,231$ & $-0,085$ & $-0,057$ & $\mathbf{- 0 , 0 7 2}$ & $-0,093$ & $-0,103$ & $-0,099$ & $-0,090$ \\
\hline $\mathbf{1 1}$ & $-0,265$ & $-0,098$ & $-0,071$ & $\mathbf{- 0 , 0 8 6}$ & $-0,107$ & $-0,119$ & $-0,112$ & $-0,102$ \\
\hline $\mathbf{1 2}$ & $-0,275$ & $-0,102$ & $-0,077$ & $-\mathbf{0 , 0 9 0}$ & $-0,111$ & $-0,123$ & $-0,116$ & $-0,106$ \\
\hline $\mathbf{1 3}$ & 0,118 & 0,121 & 0,122 & $\mathbf{0 , 1 0 8}$ & 0,104 & 0,120 & 0,067 & 0,077 \\
\hline $\mathbf{1 4}$ & $-0,008$ & $-0,011$ & $-0,012$ & $\mathbf{0 , 0 0 6}$ & $-0,021$ & $-0,024$ & $-0,005$ & $-0,007$ \\
\hline $\mathbf{1 5}$ & $-0,065$ & $-0,088$ & $-0,090$ & $\mathbf{- 0 , 0 6 5}$ & $-0,056$ & $-0,071$ & $-0,026$ & $-0,027$ \\
\hline $\mathbf{1 6}$ & $-0,109$ & $-0,140$ & $-0,143$ & $\mathbf{- 0 , 1 1 4}$ & $-0,077$ & $-0,100$ & $-0,040$ & $-0,040$ \\
\hline $\mathbf{1 7}$ & $-0,137$ & $-0,169$ & $-0,173$ & $-\mathbf{0 , 1 4 1}$ & $-0,088$ & $-0,116$ & $-0,047$ & $-0,047$ \\
\hline $\mathbf{1 8}$ & $-0,145$ & $-0,178$ & $-0,183$ & $-\mathbf{0 , 1 5 0}$ & $-0,089$ & $-0,117$ & $-0,049$ & $-0,048$ \\
\hline \hline
\end{tabular}




\subsubsection{Tensões Normais nas fibras inferiores extremas das nervuras e vigas}

TABELA 5.62: Tensões Normais nas fibras inferiores extremas das nervuras e vigas, em $\mathrm{kN} / \mathrm{cm}^{2}$, na laje com altura total $\mathrm{h}=15 \mathrm{~cm}$

\begin{tabular}{|c|c|c|c|c|c|c|c|c|}
\hline \multicolumn{9}{|c|}{$\begin{array}{c}\text { LAJE COM RELAÇÃO } \mathrm{hf} / \mathrm{h}=0,333 \\
\text { TENSÕES NORMAIS - FIBRAS INFERIORES EXTREMAS DAS NERVURAS E VIGAS }\left(\mathrm{kN} / \mathrm{cm}^{2}\right)\end{array}$} \\
\hline \multirow{2}{*}{ Ponto } & \multicolumn{8}{|c|}{ Modelos numéricos de análise } \\
\hline & 01 & 02 & 03 & 04 & $\mathbf{0 5}$ & 06 & 07 & 08 \\
\hline 1 & $-0,577$ & $-0,163$ & $-0,579$ & $-1,093$ & $-1,039$ & $-1,194$ & $-0,097$ & $-0,474$ \\
\hline 2 & 0,399 & 0,642 & 0,370 & $-0,267$ & $-0,106$ & $-0,140$ & 0,621 & 0,217 \\
\hline 3 & 1,065 & 1,197 & 1,019 & 0,451 & 0,517 & 0,583 & 1,144 & 0,693 \\
\hline 4 & 1,504 & 1,565 & 1,466 & 0,909 & 0,907 & 1,042 & 1,502 & 0,993 \\
\hline 5 & 1,744 & 1,767 & 1,743 & 1,160 & 1,106 & 1,278 & 1,708 & 1,153 \\
\hline 6 & 1,792 & 1,803 & 1,851 & 1,240 & 1,144 & 1,319 & 1,764 & 1,195 \\
\hline 7 & $-0,905$ & $-0,650$ & $-1,115$ & $\begin{array}{c}-0,748 \\
\end{array}$ & $-0,572$ & $-0,645$ & $-0,742$ & $-0,727$ \\
\hline 8 & $-0,051$ & 0,090 & $-0,183$ & $-0,222$ & $-0,015$ & $-0,024$ & 0,018 & $-0,042$ \\
\hline 9 & 0,519 & 0,609 & 0,425 & 0,216 & 0,298 & 0,321 & 0,522 & 0,317 \\
\hline 10 & 0,885 & 0,950 & 0,843 & 0,477 & 0,470 & 0,509 & 0,848 & 0,519 \\
\hline 11 & 1,077 & 1,126 & 1,089 & 0,611 & 0,554 & 0,602 & 1,024 & 0,623 \\
\hline 12 & 1,114 & 1,155 & 1,180 & 0,652 & 0,571 & 0,622 & 1,070 & 0,650 \\
\hline 13 & $-0,080$ & $-0,101$ & $-0,107$ & $-0,078$ & $-0,039$ & $-0,045$ & $-0,088$ & $-0,089$ \\
\hline 14 & 0,053 & 0,051 & 0,079 & 0,049 & 0,071 & 0,148 & 0,058 & 0,066 \\
\hline 15 & 0,155 & 0,164 & 0,201 & 0,170 & 0,179 & 0,234 & 0,167 & 0,183 \\
\hline 16 & 0,237 & 0,251 & 0,281 & 0,261 & 0,296 & 0,291 & 0,245 & 0,270 \\
\hline 17 & 0,293 & 0,307 & 0,326 & 0,324 & 0,326 & 0,318 & 0,293 & 0,324 \\
\hline 18 & 0,322 & 0,330 & 0,334 & 0,340 & 0,301 & 0,274 & 0,310 & 0,343 \\
\hline
\end{tabular}

TABELA 5.63: Tensões Normais nas fibras inferiores extremas das nervuras e vigas, em $\mathrm{kN} / \mathrm{cm}^{2}$, na laje com altura total $\mathrm{h}=20 \mathrm{~cm}$

\section{LAJE COM RELAÇÃO hf/h = 0,250}

TENSÕES NORMAIS - FIBRAS INFERIORES EXTREMAS DAS NERVURAS E VIGAS $\left(\mathrm{kN} / \mathrm{cm}^{2}\right)$

\begin{tabular}{c|c|c|c|c|c|c|c|c}
\hline \multirow{2}{*}{ Ponto } & \multicolumn{7}{|c}{ Modelos numéricos de análise } \\
\cline { 2 - 8 } & $\mathbf{0 1}$ & $\mathbf{0 2}$ & $\mathbf{0 3}$ & $\mathbf{0 4}$ & $\mathbf{0 5}$ & $\mathbf{0 6}$ & $\mathbf{0 7}$ & $\mathbf{0 8}$ \\
\hline \hline $\mathbf{1}$ & $-0,314$ & 0,071 & 0,021 & $\mathbf{- 0 , 4 0 0}$ & $-0,596$ & $-0,618$ & 0,037 & $-0,082$ \\
\hline $\mathbf{2}$ & 0,357 & 0,544 & 0,064 & $\mathbf{0 , 0 6 7}$ & $-0,009$ & $-0,005$ & 0,455 & 0,256 \\
\hline $\mathbf{3}$ & 0,820 & 0,867 & 0,554 & $\mathbf{0 , 4 6 2}$ & 0,397 & 0,427 & 0,751 & 0,496 \\
\hline $\mathbf{4}$ & 1,134 & 1,078 & 0,873 & $\mathbf{0 , 7 1 9}$ & 0,663 & 0,713 & 0,951 & 0,653 \\
\hline $\mathbf{5}$ & 1,324 & 1,194 & 1,080 & $\mathbf{0 , 8 6 6}$ & 0,812 & 0,873 & 1,066 & 0,739 \\
\hline $\mathbf{6}$ & 1,388 & 1,214 & 1,189 & $\mathbf{0 , 9 1 3}$ & 0,859 & 0,925 & 1,097 & 0,762 \\
\hline \hline $\mathbf{7}$ & $-0,666$ & $-0,245$ & 0,480 & $\mathbf{- 0 , 3 8 7}$ & $-0,386$ & $-0,397$ & $-0,291$ & $-0,337$ \\
\hline $\mathbf{8}$ & $-0,085$ & 0,156 & $-0,303$ & $\mathbf{- 0 , 0 5 0}$ & $-0,001$ & 0,006 & 0,091 & 0,032 \\
\hline $\mathbf{9}$ & 0,361 & 0,473 & 0,154 & $\mathbf{0 , 2 3 7}$ & 0,232 & 0,240 & 0,377 & 0,243 \\
\hline $\mathbf{1 0}$ & 0,670 & 0,681 & 0,469 & $\mathbf{0 , 4 2 0}$ & 0,369 & 0,377 & 0,561 & 0,363 \\
\hline $\mathbf{1 1}$ & 0,841 & 0,783 & 0,673 & $\mathbf{0 , 5 1 9}$ & 0,443 & 0,454 & 0,654 & 0,423 \\
\hline $\mathbf{1 2}$ & 0,894 & 0,798 & 0,770 & $\mathbf{0 , 5 5 0}$ & 0,469 & 0,484 & 0,677 & 0,438 \\
\hline \hline $\mathbf{1 3}$ & $-0,085$ & $-0,110$ & $-0,113$ & $\mathbf{- 0 , 0 8 7}$ & $-0,054$ & $-0,061$ & $-0,086$ & $-0,089$ \\
\hline $\mathbf{1 4}$ & 0,122 & 0,074 & 0,062 & $\mathbf{0 , 0 4 1}$ & 0,183 & 0,132 & 0,052 & 0,060 \\
\hline $\mathbf{1 5}$ & 0,228 & 0,178 & 0,177 & $\mathbf{0 , 1 5 7}$ & 0,261 & 0,238 & 0,152 & 0,171 \\
\hline $\mathbf{1 6}$ & 0,286 & 0,254 & 0,257 & $\mathbf{0 , 2 4 5}$ & 0,297 & 0,282 & 0,226 & 0,252 \\
\hline $\mathbf{1 7}$ & 0,311 & 0,301 & 0,305 & $\mathbf{0 , 2 9 7}$ & 0,307 & 0,300 & 0,274 & 0,304 \\
\hline $\mathbf{1 8}$ & 0,305 & 0,312 & 0,319 & $\mathbf{0 , 3 1 4}$ & 0,291 & 0,292 & 0,292 & 0,323 \\
\hline \hline
\end{tabular}


TABELA 5.64: Tensões Normais nas fibras inferiores extremas das nervuras e vigas, em $\mathrm{kN} / \mathrm{cm}^{2}$, na laje com altura total $\mathrm{h}=25 \mathrm{~cm}$

\begin{tabular}{|c|c|c|c|c|c|c|c|c|}
\hline \multicolumn{9}{|c|}{$\begin{array}{c}\text { LAJE COM RELAÇÃO } \mathrm{hf} / \mathrm{h}=0,200 \\
\text { TENSÕES NORMAIS - FIBRAS INFERIORES EXTREMAS DAS NERVURAS E VIGAS }\left(\mathrm{kN} / \mathrm{cm}^{2}\right)\end{array}$} \\
\hline \multirow{2}{*}{ Ponto } & \multicolumn{8}{|c|}{ Modelos numéricos de análise } \\
\hline & 01 & $\mathbf{0 2}$ & $\mathbf{0 3}$ & 04 & $\mathbf{0 5}$ & 06 & 07 & 08 \\
\hline 1 & $-0,115$ & $\begin{array}{l}-0,047 \\
\end{array}$ & $0,0,082$ & $-0,140$ & $\begin{array}{l}-0,278 \\
\end{array}$ & $\begin{array}{l}-0,279 \\
\end{array}$ & 0,036 & $\begin{array}{c}-0,005 \\
\end{array}$ \\
\hline 2 & 0,349 & 0,307 & 0,289 & 0,159 & 0,092 & 0,093 & 0,312 & 0,205 \\
\hline 3 & 0,665 & 0,547 & 0,538 & 0,395 & 0,350 & 0,358 & 0,507 & 0,352 \\
\hline 4 & 0,878 & 0,706 & 0,705 & 0,555 & 0,521 & 0,536 & 0,636 & 0,449 \\
\hline 5 & 1,007 & 0,801 & 0,806 & 0,647 & 0,618 & 0,637 & 0,709 & 0,502 \\
\hline 6 & 1,051 & 0,834 & 0,846 & 0,677 & 0,650 & 0,670 & 0,729 & 0,517 \\
\hline$\overline{77}$ & $-0,370$ & $-0,162$ & $-0,200$ & $-0,195$ & $-0,207$ & - $-0,207$ & $-0,109$ & $-0,155$ \\
\hline 8 & 0,000 & 0,078 & 0,060 & 0,025 & 0,050 & 0,053 & 0,103 & 0,053 \\
\hline 9 & 0,313 & 0,302 & 0,290 & 0,210 & 0,211 & 0,210 & 0,278 & 0,185 \\
\hline 10 & 0,535 & 0,457 & 0,451 & 0,352 & 0,310 & 0,306 & 0,389 & 0,258 \\
\hline 11 & 0,652 & 0,536 & 0,536 & 0,423 & 0,365 & 0,361 & 0,443 & 0,293 \\
\hline 12 & 0,687 & 0,560 & 0,564 & 0,446 & 0,384 & 0,381 & 0,456 & 0,302 \\
\hline 13 & $-0,090$ & $-0,115$ & $-0,118$ & $-0,096$ & $-0,067$ & -0,077 & $-0,084$ & $-0,089$ \\
\hline 14 & 0,105 & 0,055 & 0,051 & 0,031 & 0,152 & 0,115 & 0,066 & 0,078 \\
\hline 15 & 0,204 & 0,163 & 0,161 & 0,143 & 0,231 & 0,215 & 0,158 & 0,181 \\
\hline 16 & 0,263 & 0,242 & 0,243 & 0,226 & 0,274 & 0,266 & 0,226 & 0,255 \\
\hline 17 & 0,294 & 0,292 & 0,294 & 0,282 & 0,292 & 0,291 & 0,268 & 0,298 \\
\hline 18 & 0,295 & 0,307 & 0,310 & 0,297 & 0,283 & 0,287 & 0,279 & 0,310 \\
\hline
\end{tabular}

TABELA 5.65: Tensões Normais nas fibras inferiores extremas das nervuras e vigas, em $\mathrm{kN} / \mathrm{cm}^{2}$, na laje com altura total $\mathrm{h}=30 \mathrm{~cm}$

LAJE COM RELAÇ̃̃̃ hf/h $=0,167$

TENSÕES NORMAIS - FIBRAS INFERIORES EXTREMAS DAS NERVURAS E VIGAS $\left(\mathrm{kN} / \mathrm{cm}^{2}\right)$

\begin{tabular}{c|c|c|c|c|c|c|c|c}
\hline \multirow{2}{*}{ Ponto } & \multicolumn{7}{|c}{ Modelos numéricos de análise } \\
\cline { 2 - 9 } & $\mathbf{0 1}$ & $\mathbf{0 2}$ & $\mathbf{0 3}$ & $\mathbf{0 4}$ & $\mathbf{0 5}$ & $\mathbf{0 6}$ & $\mathbf{0 7}$ & $\mathbf{0 8}$ \\
\hline \hline $\mathbf{1}$ & $-0,046$ & $-0,028$ & $-0,050$ & $\mathbf{- 0 , 0 4 7}$ & $-0,139$ & $-0,141$ & 0,026 & 0,009 \\
\hline $\mathbf{2}$ & 0,291 & 0,219 & 0,208 & $\mathbf{0 , 1 5 8}$ & 0,111 & 0,104 & 0,220 & 0,156 \\
\hline $\mathbf{3}$ & 0,522 & 0,391 & 0,386 & $\mathbf{0 , 3 2 1}$ & 0,287 & 0,282 & 0,359 & 0,256 \\
\hline $\mathbf{4}$ & 0,676 & 0,504 & 0,505 & $\mathbf{0 , 4 3 2}$ & 0,405 & 0,403 & 0,451 & 0,324 \\
\hline $\mathbf{5}$ & 0,768 & 0,571 & 0,575 & $\mathbf{0 , 4 9 7}$ & 0,473 & 0,472 & 0,502 & 0,361 \\
\hline $\mathbf{6}$ & 0,800 & 0,594 & 0,603 & $\mathbf{0 , 5 1 8}$ & 0,496 & 0,495 & 0,516 & 0,371 \\
\hline \hline $\mathbf{7}$ & $-0,204$ & $-0,065$ & $-0,084$ & $-\mathbf{0 , 1 0 0}$ & $-0,117$ & $-0,119$ & $-0,037$ & $-0,070$ \\
\hline $\mathbf{8}$ & 0,042 & 0,090 & 0,080 & $\mathbf{0 , 0 5 7}$ & 0,065 & 0,062 & 0,096 & 0,055 \\
\hline $\mathbf{9}$ & 0,265 & 0,243 & 0,237 & $\mathbf{0 , 2 0 0}$ & 0,182 & 0,176 & 0,213 & 0,144 \\
\hline $\mathbf{1 0}$ & 0,424 & 0,348 & 0,345 & $\mathbf{0 , 2 9 7}$ & 0,257 & 0,248 & 0,287 & 0,192 \\
\hline $\mathbf{1 1}$ & 0,505 & 0,402 & 0,402 & $\mathbf{0 , 3 5 1}$ & 0,299 & 0,290 & 0,323 & 0,215 \\
\hline $\mathbf{1 2}$ & 0,529 & 0,418 & 0,421 & $\mathbf{0 , 3 6 8}$ & 0,314 & 0,305 & 0,332 & 0,220 \\
\hline $\mathbf{1 3}$ & $-0,095$ & $-0,118$ & $-0,120$ & $\mathbf{- 0 , 1 0 3}$ & $-0,076$ & $-0,088$ & $-0,082$ & $-0,088$ \\
\hline $\mathbf{1 4}$ & 0,091 & 0,047 & 0,044 & $\mathbf{0 , 0 2 3}$ & 0,128 & 0,104 & 0,064 & 0,076 \\
\hline $\mathbf{1 5}$ & 0,185 & 0,153 & 0,152 & $\mathbf{0 , 1 3 2}$ & 0,208 & 0,200 & 0,151 & 0,174 \\
\hline $\mathbf{1 6}$ & 0,247 & 0,233 & 0,234 & $\mathbf{0 , 2 1 4}$ & 0,257 & 0,255 & 0,217 & 0,245 \\
\hline $\mathbf{1 7}$ & 0,283 & 0,284 & 0,286 & $\mathbf{0 , 2 6 3}$ & 0,280 & 0,283 & 0,257 & 0,288 \\
\hline $\mathbf{1 8}$ & 0,288 & 0,300 & 0,302 & $\mathbf{0 , 2 8 1}$ & 0,275 & 0,283 & 0,268 & 0,299 \\
\hline \hline
\end{tabular}


TABELA 5.66: Tensões Normais nas fibras inferiores extremas das nervuras e vigas, em $\mathrm{kN} / \mathrm{cm}^{2}$, na laje com altura total $\mathrm{h}=35 \mathrm{~cm}$

LAJE COM RELAÇÃO hf/h = 0,143

TENSÕES NORMAIS - FIBRAS INFERIORES EXTREMAS DAS NERVURAS E VIGAS $\left(\mathrm{kN} / \mathrm{cm}^{2}\right)$

\begin{tabular}{c|c|c|c|c|c|c|c|c}
\hline \multirow{2}{*}{ Ponto } & \multicolumn{7}{|c}{ Modelos numéricos de análise } \\
\cline { 2 - 8 } & $\mathbf{0 1}$ & $\mathbf{0 2}$ & $\mathbf{0 3}$ & $\mathbf{0 4}$ & $\mathbf{0 5}$ & $\mathbf{0 6}$ & $\mathbf{0 7}$ & $\mathbf{0 8}$ \\
\hline \hline $\mathbf{1}$ & $-0,021$ & $-0,019$ & $-0,033$ & $\mathbf{- 0 , 0 1 5}$ & $-0,075$ & $-0,079$ & 0,020 & 0,011 \\
\hline $\mathbf{2}$ & 0,232 & 0,158 & 0,152 & $\mathbf{0 , 1 3 1}$ & 0,101 & 0,090 & 0,162 & 0,119 \\
\hline $\mathbf{3}$ & 0,407 & 0,285 & 0,284 & $\mathbf{0 , 2 5 0}$ & 0,228 & 0,217 & 0,265 & 0,195 \\
\hline $\mathbf{4}$ & 0,523 & 0,370 & 0,372 & $\mathbf{0 , 3 3 4}$ & 0,314 & 0,304 & 0,335 & 0,246 \\
\hline $\mathbf{5}$ & 0,592 & 0,420 & 0,425 & $\mathbf{0 , 3 7 8}$ & 0,365 & 0,355 & 0,374 & 0,273 \\
\hline $\mathbf{6}$ & 0,616 & 0,438 & 0,444 & $\mathbf{0 , 3 9 3}$ & 0,381 & 0,372 & 0,385 & 0,281 \\
\hline \hline $\mathbf{7}$ & $-0,113$ & $-0,028$ & $-0,038$ & $\mathbf{- 0 , 0 5 0}$ & $-0,070$ & $-0,075$ & $-0,008$ & $-0,030$ \\
\hline $\mathbf{8}$ & 0,059 & 0,089 & 0,083 & $\mathbf{0 , 0 6 7}$ & 0,065 & 0,059 & 0,086 & 0,052 \\
\hline $\mathbf{9}$ & 0,223 & 0,201 & 0,198 & $\mathbf{0 , 1 7 8}$ & 0,155 & 0,147 & 0,170 & 0,116 \\
\hline $\mathbf{1 0}$ & 0,341 & 0,277 & 0,276 & $\mathbf{0 , 2 5 3}$ & 0,214 & 0,204 & 0,224 & 0,150 \\
\hline $\mathbf{1 1}$ & 0,399 & 0,318 & 0,319 & $\mathbf{0 , 2 9 6}$ & 0,248 & 0,238 & 0,252 & 0,166 \\
\hline $\mathbf{1 2}$ & 0,416 & 0,331 & 0,334 & $\mathbf{0 , 3 1 0}$ & 0,260 & 0,251 & 0,258 & 0,170 \\
\hline $\mathbf{1 3}$ & $-0,098$ & $-0,120$ & $-0,122$ & $\mathbf{- 0 , 1 0 8}$ & $-0,083$ & $-0,094$ & $-0,079$ & $-0,086$ \\
\hline $\mathbf{1 4}$ & 0,080 & 0,041 & 0,040 & $\mathbf{0 , 0 1 7}$ & 0,112 & 0,097 & 0,062 & 0,074 \\
\hline $\mathbf{1 5}$ & 0,172 & 0,147 & 0,147 & $\mathbf{0 , 1 2 4}$ & 0,192 & 0,189 & 0,146 & 0,168 \\
\hline $\mathbf{1 6}$ & 0,237 & 0,227 & 0,228 & $\mathbf{0 , 2 0 4}$ & 0,244 & 0,246 & 0,208 & 0,237 \\
\hline $\mathbf{1 7}$ & 0,275 & 0,277 & 0,279 & $\mathbf{0 , 2 5 2}$ & 0,270 & 0,276 & 0,246 & 0,278 \\
\hline $\mathbf{1 8}$ & 0,283 & 0,292 & 0,294 & $\mathbf{0 , 2 6 9}$ & 0,269 & 0,277 & 0,256 & 0,289 \\
\hline \hline
\end{tabular}

TABELA 5.67: Tensões Normais nas fibras inferiores extremas das nervuras e vigas, em $\mathrm{kN} / \mathrm{cm}^{2}$, na laje com altura total $\mathrm{h}=40 \mathrm{~cm}$

LAJE COM RELAÇÃO hf/h = 0,125

TENSÕES NORMAIS - FIBRAS INFERIORES EXTREMAS DAS NERVURAS E VIGAS $\left(\mathrm{kN} / \mathrm{cm}^{2}\right)$

\begin{tabular}{c|c|c|c|c|c|c|c|c}
\hline \multirow{2}{*}{ Ponto } & \multicolumn{7}{|c}{ Modelos numéricos de análise } \\
\cline { 2 - 9 } & $\mathbf{0 1}$ & $\mathbf{0 2}$ & $\mathbf{0 3}$ & $\mathbf{0 4}$ & $\mathbf{0 5}$ & $\mathbf{0 6}$ & $\mathbf{0 7}$ & $\mathbf{0 8}$ \\
\hline \hline $\mathbf{1}$ & $-0,010$ & $-0,014$ & $-0,024$ & $\mathbf{- 0 , 0 0 4}$ & $-0,043$ & $-0,049$ & 0,015 & 0,010 \\
\hline $\mathbf{2}$ & 0,182 & 0,115 & 0,112 & $\mathbf{0 , 1 0 5}$ & 0,084 & 0,072 & 0,123 & 0,094 \\
\hline $\mathbf{3}$ & 0,318 & 0,212 & 0,212 & $\mathbf{0 , 1 9 6}$ & 0,179 & 0,165 & 0,204 & 0,154 \\
\hline $\mathbf{4}$ & 0,409 & 0,278 & 0,281 & $\mathbf{0 , 2 5 9}$ & 0,245 & 0,231 & 0,259 & 0,194 \\
\hline $\mathbf{5}$ & 0,463 & 0,317 & 0,323 & $\mathbf{0 , 2 9 6}$ & 0,283 & 0,270 & 0,290 & 0,216 \\
\hline $\mathbf{6}$ & 0,482 & 0,331 & 0,337 & $\mathbf{0 , 3 0 9}$ & 0,296 & 0,283 & 0,299 & 0,222 \\
\hline \hline $\mathbf{7}$ & $-0,063$ & $-0,013$ & $-0,020$ & $\mathbf{- 0 , 0 2 3}$ & $-0,045$ & $-0,050$ & 0,003 & $-0,011$ \\
\hline $\mathbf{8}$ & 0,065 & 0,083 & 0,079 & $\mathbf{0 , 0 6 9}$ & 0,061 & 0,054 & 0,076 & 0,048 \\
\hline $\mathbf{9}$ & 0,190 & 0,170 & 0,169 & $\mathbf{0 , 1 5 8}$ & 0,133 & 0,124 & 0,141 & 0,096 \\
\hline $\mathbf{1 0}$ & 0,279 & 0,230 & 0,230 & $\mathbf{0 , 2 2 0}$ & 0,182 & 0,172 & 0,184 & 0,123 \\
\hline $\mathbf{1 1}$ & 0,324 & 0,264 & 0,265 & $\mathbf{0 , 2 5 6}$ & 0,210 & 0,201 & 0,206 & 0,136 \\
\hline $\mathbf{1 2}$ & 0,337 & 0,276 & 0,278 & $\mathbf{0 , 2 6 7}$ & 0,220 & 0,211 & 0,212 & 0,139 \\
\hline \hline $\mathbf{1 3}$ & $-0,101$ & $-0,121$ & $-0,122$ & $\mathbf{- 0 , 1 1 1}$ & $-0,086$ & $-0,098$ & $-0,075$ & $-0,083$ \\
\hline $\mathbf{1 4}$ & 0,072 & 0,038 & 0,037 & $\mathbf{0 , 0 1 4}$ & 0,101 & 0,093 & 0,060 & 0,072 \\
\hline $\mathbf{1 5}$ & 0,162 & 0,144 & 0,144 & $\mathbf{0 , 1 2 0}$ & 0,181 & 0,182 & 0,140 & 0,162 \\
\hline $\mathbf{1 6}$ & 0,229 & 0,222 & 0,223 & $\mathbf{0 , 1 9 4}$ & 0,234 & 0,239 & 0,200 & 0,229 \\
\hline $\mathbf{1 7}$ & 0,269 & 0,269 & 0,271 & $\mathbf{0 , 2 4 2}$ & 0,261 & 0,269 & 0,234 & 0,268 \\
\hline $\mathbf{1 8}$ & 0,278 & 0,283 & 0,285 & $\mathbf{0 , 2 5 8}$ & 0,262 & 0,270 & 0,243 & 0,278 \\
\hline \hline
\end{tabular}


TABELA 5.68: Tensões Normais nas fibras inferiores extremas das nervuras e vigas, em $\mathrm{kN} / \mathrm{cm}^{2}$, na laje com altura total $\mathrm{h}=45 \mathrm{~cm}$

LAJE COM RELAÇ̃̃ $\mathrm{hf} / \mathrm{h}=0,111$

TENSÕES NORMAIS - FIBRAS INFERIORES EXTREMAS DAS NERVURAS E VIGAS $\left(\mathbf{k N} / \mathrm{cm}^{2}\right)$

\begin{tabular}{c|c|c|c|c|c|c|c|c}
\hline \multirow{2}{*}{ Ponto } & \multicolumn{8}{|c|}{ Modelos numéricos de análise } \\
\cline { 2 - 8 } & $\mathbf{0 1}$ & $\mathbf{0 2}$ & $\mathbf{0 3}$ & $\mathbf{0 4}$ & $\mathbf{0 5}$ & $\mathbf{0 6}$ & $\mathbf{0 7}$ & $\mathbf{0 8}$ \\
\hline $\mathbf{1}$ & $-0,005$ & $-0,011$ & $-0,018$ & $\mathbf{0 , 0 0 0}$ & $-0,026$ & $-0,032$ & 0,012 & 0,009 \\
\hline $\mathbf{2}$ & 0,143 & 0,085 & 0,083 & $\mathbf{0 , 0 8 3}$ & 0,068 & 0,055 & 0,096 & 0,076 \\
\hline $\mathbf{3}$ & 0,251 & 0,160 & 0,161 & $\mathbf{0 , 1 4 7}$ & 0,140 & 0,126 & 0,161 & 0,125 \\
\hline $\mathbf{4}$ & 0,323 & 0,213 & 0,215 & $\mathbf{0 , 2 0 2}$ & 0,191 & 0,177 & 0,207 & 0,158 \\
\hline $\mathbf{5}$ & 0,366 & 0,244 & 0,248 & $\mathbf{0 , 2 3 4}$ & 0,222 & 0,208 & 0,232 & 0,176 \\
\hline $\mathbf{6}$ & 0,381 & 0,255 & 0,260 & $\mathbf{0 , 2 4 2}$ & 0,232 & 0,218 & 0,239 & 0,181 \\
\hline \hline $\mathbf{7}$ & $-0,036$ & $-0,007$ & $-0,013$ & $-\mathbf{0 , 0 0 9}$ & $-0,030$ & $-0,036$ & 0,007 & $-0,003$ \\
\hline $\mathbf{8}$ & 0,064 & 0,076 & 0,073 & $\mathbf{0 , 0 6 7}$ & 0,056 & 0,048 & 0,067 & 0,044 \\
\hline $\mathbf{9}$ & 0,163 & 0,148 & 0,147 & $\mathbf{0 , 1 3 9}$ & 0,115 & 0,107 & 0,121 & 0,083 \\
\hline $\mathbf{1 0}$ & 0,234 & 0,198 & 0,198 & $\mathbf{0 , 1 9 1}$ & 0,157 & 0,148 & 0,156 & 0,105 \\
\hline $\mathbf{1 1}$ & 0,270 & 0,228 & 0,229 & $\mathbf{0 , 2 2 2}$ & 0,182 & 0,174 & 0,176 & 0,116 \\
\hline $\mathbf{1 2}$ & 0,280 & 0,239 & 0,241 & $\mathbf{0 , 2 2 8}$ & 0,191 & 0,183 & 0,181 & 0,119 \\
\hline \hline $\mathbf{1 3}$ & $-0,102$ & $-0,121$ & $-0,122$ & $\mathbf{- 0 , 1 1 1}$ & $-0,089$ & $-0,099$ & $-0,072$ & $-0,080$ \\
\hline $\mathbf{1 4}$ & 0,067 & 0,037 & 0,036 & $\mathbf{0 , 0 1 2}$ & 0,094 & 0,091 & 0,059 & 0,070 \\
\hline $\mathbf{1 5}$ & 0,156 & 0,141 & 0,141 & $\mathbf{0 , 1 1 6}$ & 0,173 & 0,177 & 0,135 & 0,156 \\
\hline $\mathbf{1 6}$ & 0,223 & 0,216 & 0,217 & $\mathbf{0 , 1 8 7}$ & 0,226 & 0,232 & 0,190 & 0,220 \\
\hline $\mathbf{1 7}$ & 0,264 & 0,260 & 0,262 & $\mathbf{0 , 2 3 2}$ & 0,253 & 0,261 & 0,222 & 0,257 \\
\hline $\mathbf{1 8}$ & 0,273 & 0,273 & 0,275 & $\mathbf{0 , 2 4 7}$ & 0,254 & 0,263 & 0,230 & 0,267 \\
\hline \hline
\end{tabular}

TABELA 5.69: Tensões Normais nas fibras inferiores extremas das nervuras e vigas, em $\mathrm{kN} / \mathrm{cm}^{2}$, na laje com altura total $\mathrm{h}=50 \mathrm{~cm}$

LAJE COM RELAÇÃO hf $/ \mathrm{h}=0,100$

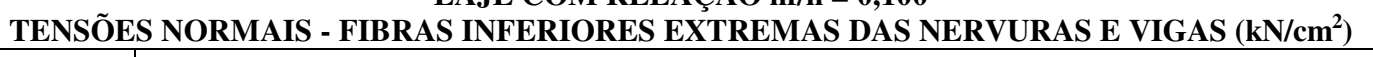

\begin{tabular}{c|c|c|c|c|c|c|c|c}
\hline \multirow{2}{*}{ Ponto } & \multicolumn{8}{c}{ Modelos numéricos de análise } \\
\cline { 2 - 8 } & $\mathbf{0 1}$ & $\mathbf{0 2}$ & $\mathbf{0 3}$ & $\mathbf{0 4}$ & $\mathbf{0 5}$ & $\mathbf{0 6}$ & $\mathbf{0 7}$ & $\mathbf{0 8}$ \\
\hline \hline $\mathbf{1}$ & $-0,002$ & $-0,009$ & $-0,014$ & $\mathbf{0 , 0 0 1}$ & $-0,017$ & $-0,023$ & 0,009 & 0,007 \\
\hline $\mathbf{2}$ & 0,113 & 0,072 & 0,061 & $\mathbf{0 , 0 6 4}$ & 0,053 & 0,041 & 0,077 & 0,063 \\
\hline $\mathbf{3}$ & 0,198 & 0,129 & 0,123 & $\mathbf{0 , 1 2 0}$ & 0,109 & 0,096 & 0,131 & 0,104 \\
\hline $\mathbf{4}$ & 0,258 & 0,170 & 0,167 & $\mathbf{0 , 1 6 1}$ & 0,150 & 0,136 & 0,169 & 0,132 \\
\hline $\mathbf{5}$ & 0,293 & 0,193 & 0,194 & $\mathbf{0 , 1 8 6}$ & 0,175 & 0,161 & 0,191 & 0,148 \\
\hline $\mathbf{6}$ & 0,305 & 0,199 & 0,204 & $\mathbf{0 , 1 9 4}$ & 0,183 & 0,169 & 0,197 & 0,153 \\
\hline \hline $\mathbf{7}$ & $-0,020$ & $-0,005$ & $-0,010$ & $\mathbf{- 0 , 0 0 1}$ & $-0,021$ & $-0,027$ & 0,008 & 0,001 \\
\hline $\mathbf{8}$ & 0,061 & 0,080 & 0,067 & $\mathbf{0 , 0 6 4}$ & 0,050 & 0,043 & 0,060 & 0,040 \\
\hline $\mathbf{9}$ & 0,142 & 0,139 & 0,130 & $\mathbf{0 , 1 2 6}$ & 0,102 & 0,094 & 0,106 & 0,073 \\
\hline $\mathbf{1 0}$ & 0,200 & 0,180 & 0,175 & $\mathbf{0 , 1 7 1}$ & 0,138 & 0,131 & 0,137 & 0,092 \\
\hline $\mathbf{1 1}$ & 0,230 & 0,205 & 0,204 & $\mathbf{0 , 1 9 6}$ & 0,161 & 0,154 & 0,154 & 0,102 \\
\hline $\mathbf{1 2}$ & 0,240 & 0,213 & 0,214 & $\mathbf{0 , 2 0 6}$ & 0,169 & 0,163 & 0,159 & 0,105 \\
\hline $\mathbf{1 3}$ & $-0,103$ & $-0,120$ & $-0,121$ & $\mathbf{- 0 , 1 1 3}$ & $-0,089$ & $-0,100$ & $-0,068$ & $-0,077$ \\
\hline $\mathbf{1 4}$ & 0,063 & 0,037 & 0,036 & $\mathbf{0 , 0 1 1}$ & 0,090 & 0,091 & 0,057 & 0,068 \\
\hline $\mathbf{1 5}$ & 0,151 & 0,139 & 0,139 & $\mathbf{0 , 1 1 3}$ & 0,167 & 0,173 & 0,129 & 0,151 \\
\hline $\mathbf{1 6}$ & 0,218 & 0,210 & 0,211 & $\mathbf{0 , 1 8 1}$ & 0,218 & 0,226 & 0,180 & 0,211 \\
\hline $\mathbf{1 7}$ & 0,258 & 0,250 & 0,252 & $\mathbf{0 , 2 2 2}$ & 0,245 & 0,253 & 0,210 & 0,246 \\
\hline $\mathbf{1 8}$ & 0,268 & 0,262 & 0,264 & $\mathbf{0 , 2 3 6}$ & 0,246 & 0,254 & 0,217 & 0,254 \\
\hline \hline
\end{tabular}

Abaixo apresentam-se os gráficos de tensões normais nas fibras inferiores extremas na nervura central das lajes processadas nesta série. 


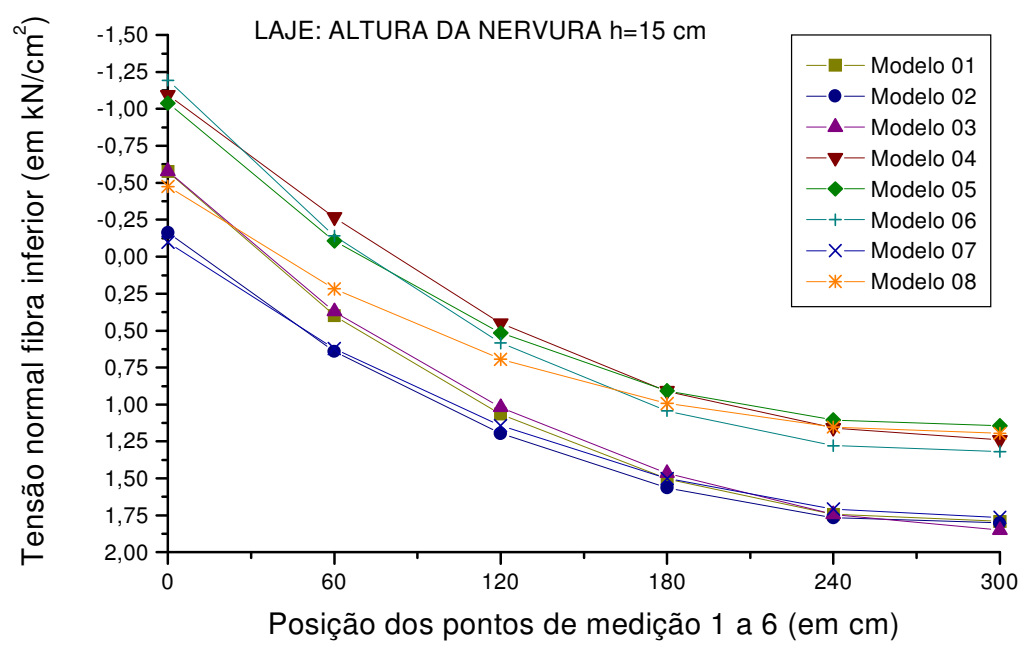

FIGURA 5.69: Tensões Normais fibras inferiores extremas $\left(\mathrm{kN} / \mathrm{cm}^{2}\right)$, na nervura central, na laje com $\mathrm{hf} / \mathrm{h}=0,333$

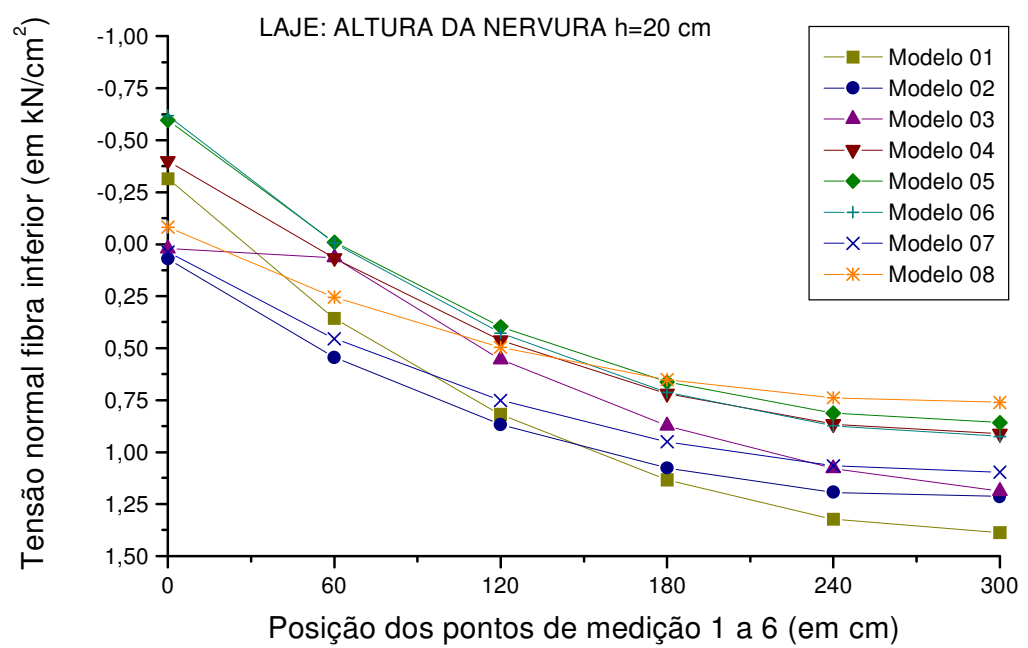

FIGURA 5.70: Tensões Normais fibras inferiores extremas $\left(\mathrm{kN} / \mathrm{cm}^{2}\right)$, na nervura central, na laje com $\mathrm{hf} / \mathrm{h}=0,250$

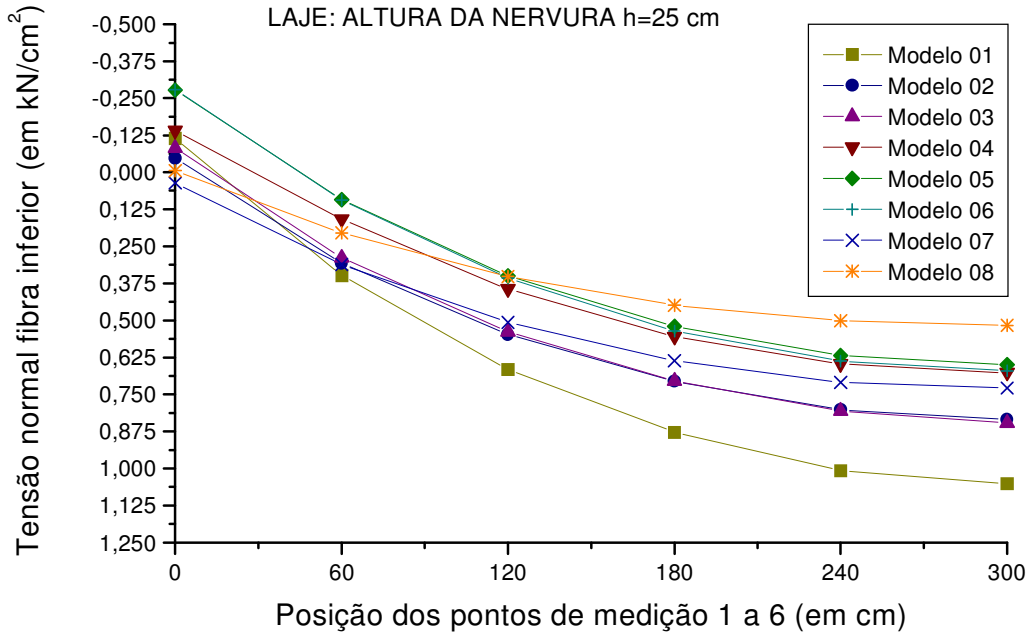

FIGURA 5.71: Tensões Normais fibras inferiores extremas $\left(\mathrm{kN} / \mathrm{cm}^{2}\right)$, na nervura central, na laje com $\mathrm{hf} / \mathrm{h}=0,200$ 


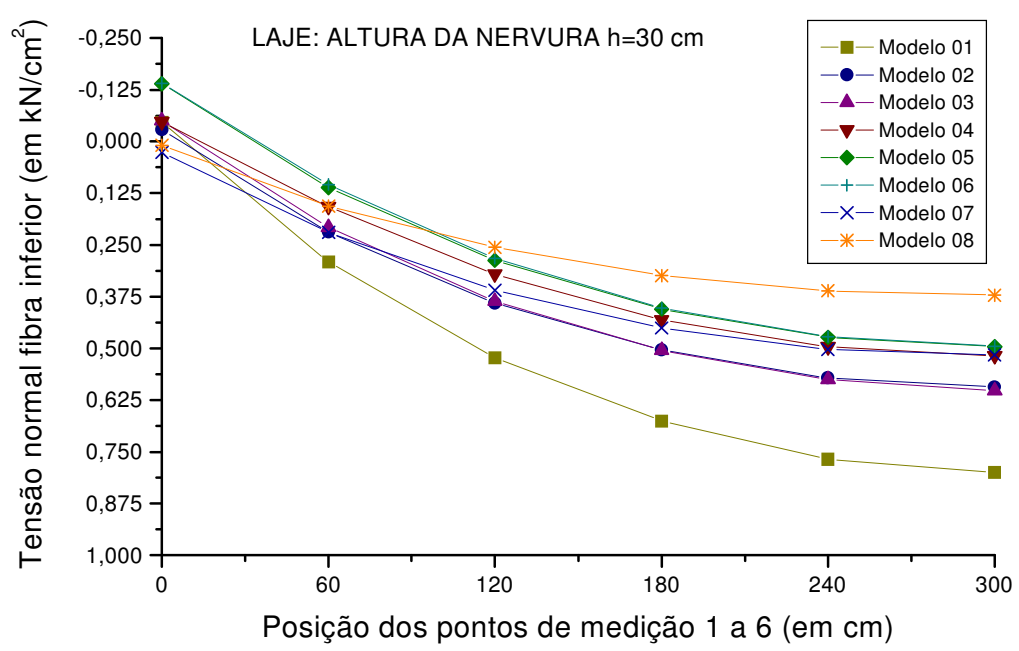

FIGURA 5.72: Tensões Normais fibras inferiores extremas $\left(\mathrm{kN} / \mathrm{cm}^{2}\right)$, na nervura central, na laje com $\mathrm{hf} / \mathrm{h}=0,167$

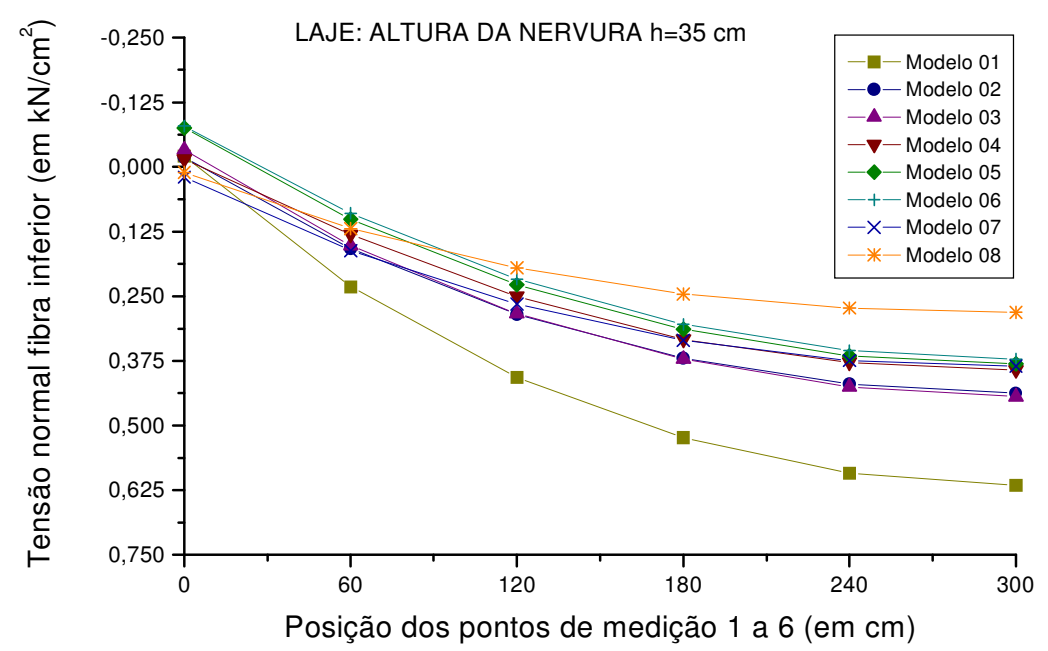

FIGURA 5.73: Tensões Normais fibras inferiores extremas $\left(\mathrm{kN} / \mathrm{cm}^{2}\right)$, na nervura central, na laje com $\mathrm{hf} / \mathrm{h}=0,143$

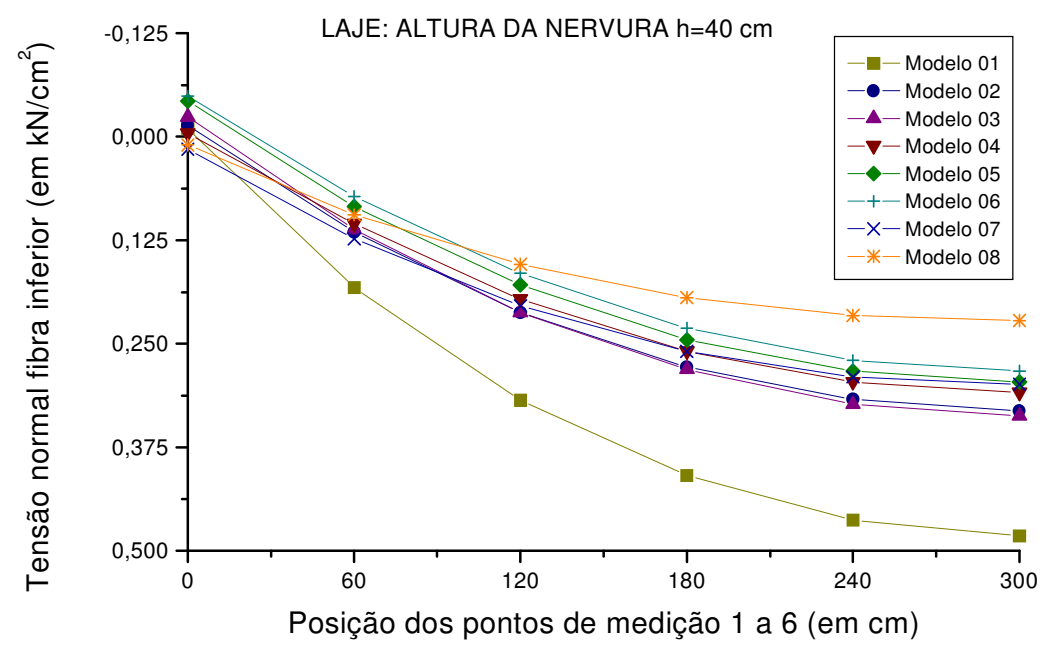

FIGURA 5.74: Tensões Normais fibras inferiores extremas $\left(\mathrm{kN} / \mathrm{cm}^{2}\right)$, na nervura central, na laje com $\mathrm{hf} / \mathrm{h}=0,125$ 


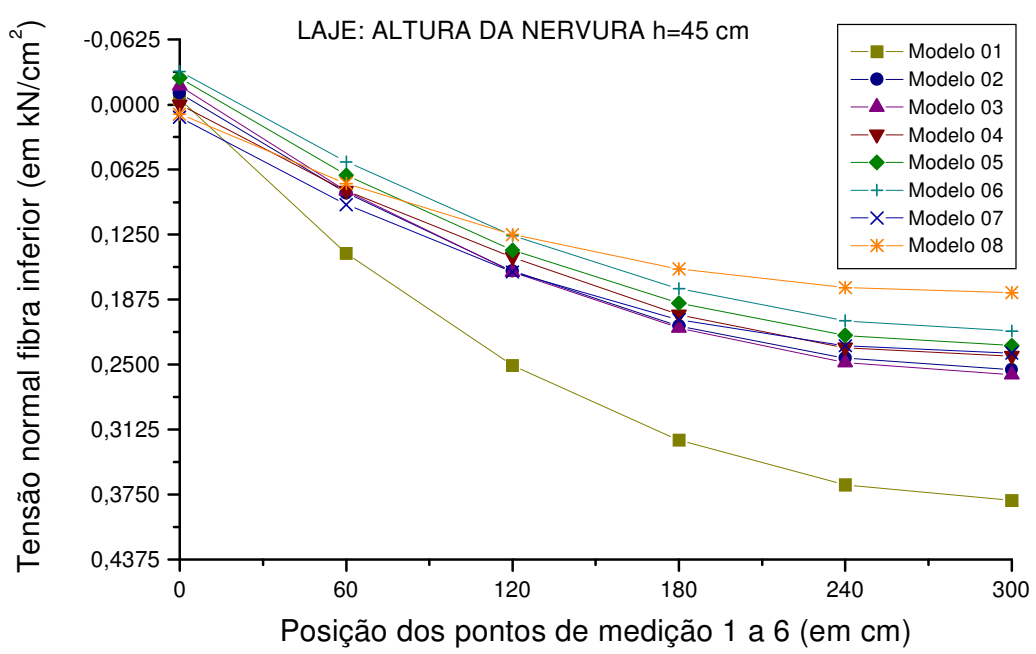

FIGURA 5.75: Tensões Normais fibras inferiores extremas $\left(\mathrm{kN} / \mathrm{cm}^{2}\right)$, na nervura central, na laje com $\mathrm{hf} / \mathrm{h}=0,111$

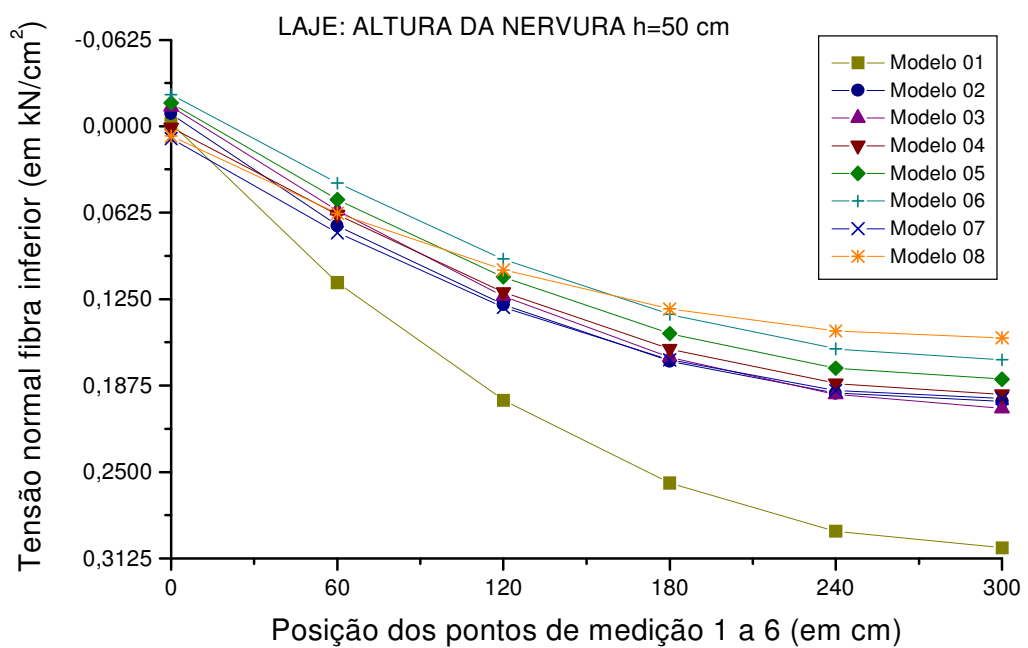

FIGURA 5.76: Tensões Normais fibras inferiores extremas $\left(\mathrm{kN} / \mathrm{cm}^{2}\right)$, na nervura central, na laje com $\mathrm{hf} / \mathrm{h}=0,100$

Analisando-se as tabelas de tensões normais nas fibras superiores e inferiores extremas das nervuras, juntamente com os gráficos, verificou-se que:

- à medida que aumenta-se a excentricidade, ou seja, quanto menor for a relação $h_{f} / h$, maiores são as tensões normais de tração nas seções da nervura considerada concêntrica, ou seja, mais superdimensionada ela será. Isso é confirmado pela grande flexibilidade dada à laje nesse caso, levando a maiores deslocamentos e, consequentemente, a maiores esforços; Para $h_{f} / h=0,100$, a nervura considerada concêntrica apresenta um erro de $57,2 \%$ a mais no valor da tensão máxima de tração na nervura central, em relação ao Modelo 04

- os modelos de viga excêntrica 02 e 03 funcionaram melhores para maiores excentricidades das nervuras; quando $h_{f} / h=0,333$ tem-se uma diferença de $49,3 \%$ entre os 
valores de tensão de tração máxima na viga central do Modelo 03 e do Modelo 04, a maior para o modelo de viga excêntrica; para $\mathrm{h}_{\mathrm{f}} / \mathrm{h}=0,100$ a diferença cai para $5,15 \%$;

- os modelos que simplificam a excentricidade pela consideração de seção "T" em grelha, ou seja, modelos 05 e 06, apresentaram ótimos resultados de tensões de tração nas fibras inferiores extremas, quando comparados ao Modelo 04, em qualquer relação $h_{f} / h$ (máxima diferença de 12,9\% a menor para o Modelo 06 quando comparado ao Modelo 04, para a tensão máxima na nervura central, na laje com relação $h_{f} / h=0,100$ ). Os melhores resultados para o Modelo 05 foram encontrados na relação $h_{f} / h=0,111$, com erro de $4 \%$ a menor no valor da máxima tensão de tração na nervura central frente ao modelo realista; para o Modelo 06 a menor diferença deu-se com $h_{f} / h=0,200$, sendo $1 \%$ menor que a dada pelo Modelo 04. O Modelo 06 é mais sensível às variações da relação $h_{f} / h$ que o Modelo 05;

- o Modelo 07 comportou-se da seguinte maneira: para baixas excentricidades, onde é mais flexível que o modelo realista, tem-se tensões maiores de tração nos enrijecedores, da ordem de 42,3\% quando comparado ao Modelo 04, para $\mathrm{h}_{\mathrm{f}} / \mathrm{h}=0,333$; a partir da relação $h_{f} / h=0,167$, até a menor relação testada, os resultados foram muito bons, chegando a apresentar apenas $0,39 \%$ de erro para $h_{f} / h=0,167$ e $1,55 \%$ para $h_{f} / h=0,100$;

- no Modelo 08, à medida que aumenta-se a excentricidade, distancia-se os resultados de tensões normais de tração na seção da nervura, onde a mesma passa a apresentar valores baixos quando comparada ao Modelo 04, e aos demais modelos; para $\mathrm{h}_{\mathrm{f}} / \mathrm{h}=0,143$ tem-se uma diferença de $28,5 \%$ entre os valores de tensão máxima de tração na nervura central quando comparado ao modelo realista. A partir desta relação as diferenças começam a diminuir, chegando a $21,1 \%$ para $h_{\mathrm{f}} / \mathrm{h}=0,100$, valor ainda elevado;

- as tensões normais de compressão, mais baixas que as de tração, na maioria das posições nas nervuras, nas fibras superiores, foram muito variáveis de modelo a modelo. O modelo 03, ou modelo de viga excêntrica, onde considerou-se como nervura apenas a parte de baixo da capa, apresentou os valores mais baixos de compressão nas fibras superiores extremas, e em muitos casos comportou-se como inteiramente tracionado, como era de se esperar, já que a capa é o elemento comprimido e está destacada da área da nervura no Modelo 03.

Abaixo tem-se os gráficos de tensões normais nas fibras inferiores extremas das vigas de contorno externo das lajes processadas nesta série. 


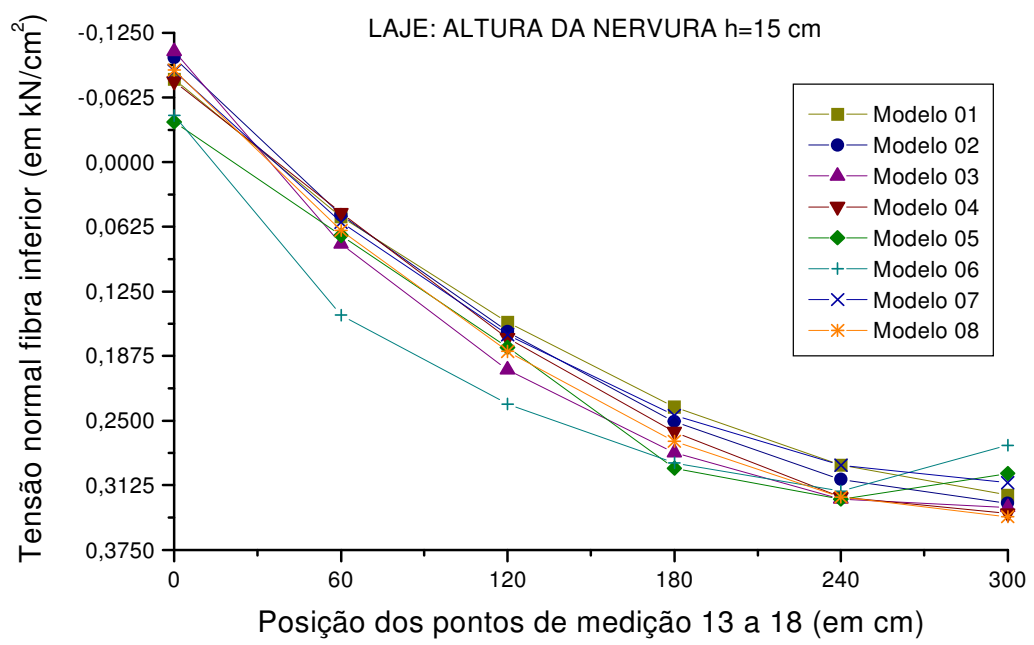

FIGURA 5.77: Tensões Normais fibras inferiores extremas $\left(\mathrm{kN} / \mathrm{cm}^{2}\right)$, na viga externa; laje com relação $\mathrm{hf} / \mathrm{h}=0,333$

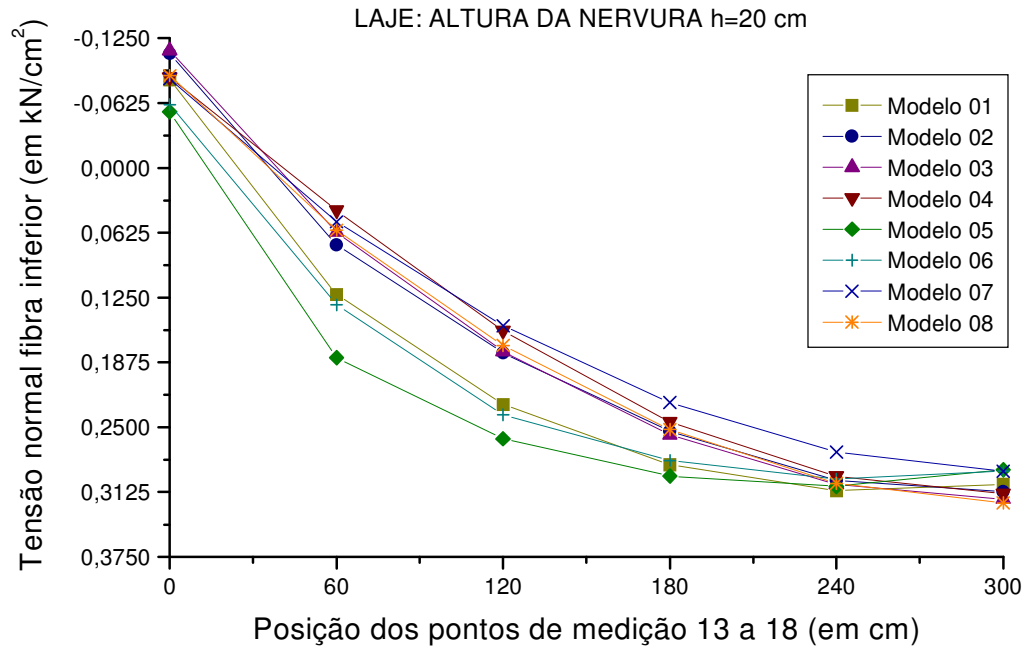

FIGURA 5.78: Tensões Normais fibras inferiores extremas $\left(\mathrm{kN} / \mathrm{cm}^{2}\right)$, na viga externa; laje com relação $\mathrm{hf} / \mathrm{h}=0,250$

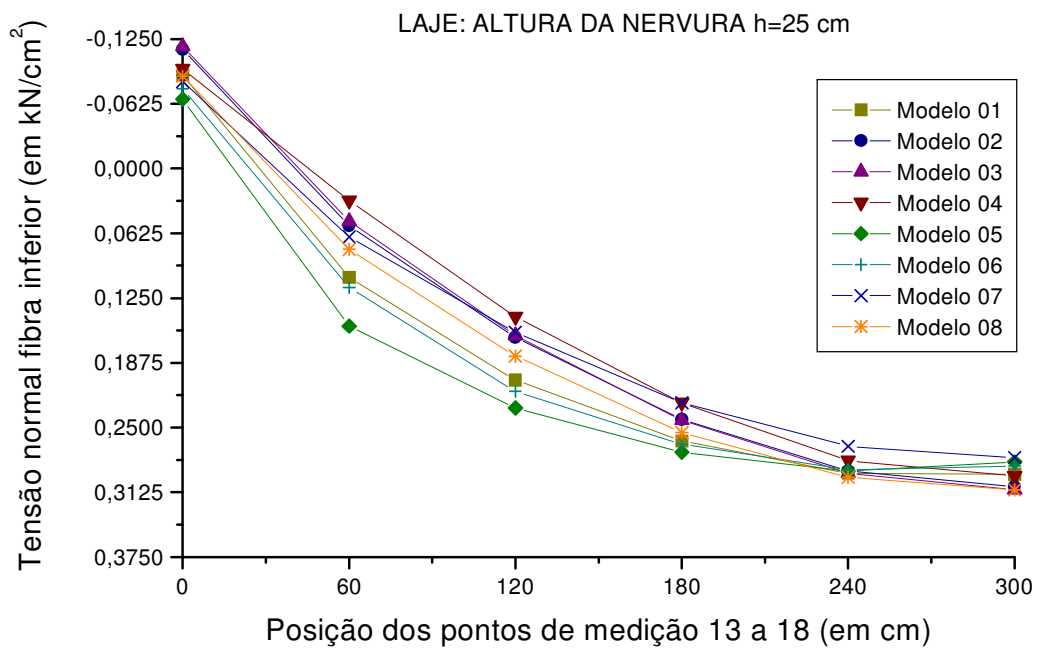

FIGURA 5.79: Tensões Normais fibras inferiores extremas $\left(\mathrm{kN} / \mathrm{cm}^{2}\right)$, na viga externa; laje com relação $\mathrm{hf} / \mathrm{h}=0,200$ 


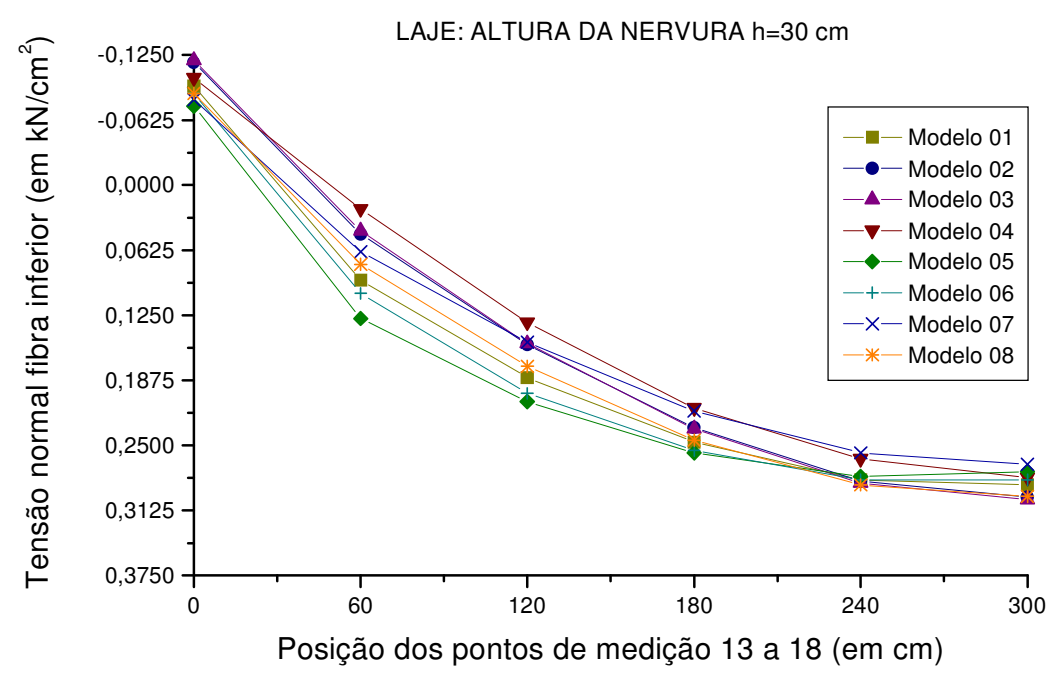

FIGURA 5.80: Tensões Normais fibras inferiores extremas $\left(\mathrm{kN} / \mathrm{cm}^{2}\right)$, na viga externa; laje com relação $\mathrm{hf} / \mathrm{h}=0,167$

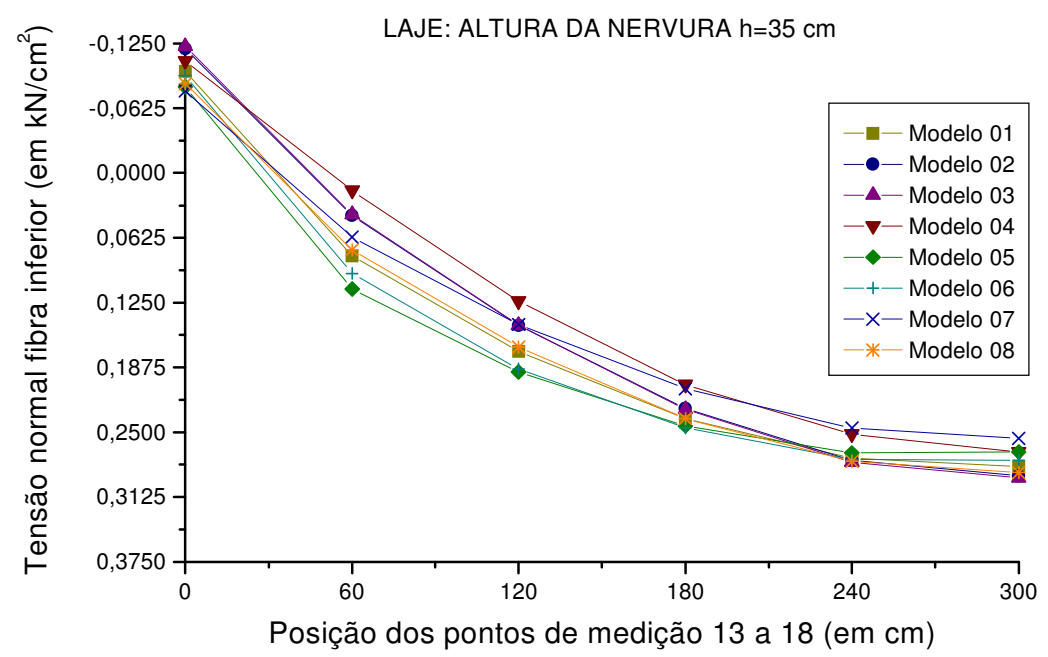

FIGURA 5.81: Tensões Normais fibras inferiores extremas $\left(\mathrm{kN} / \mathrm{cm}^{2}\right)$, na viga externa; laje com relação $h f / h=0,143$

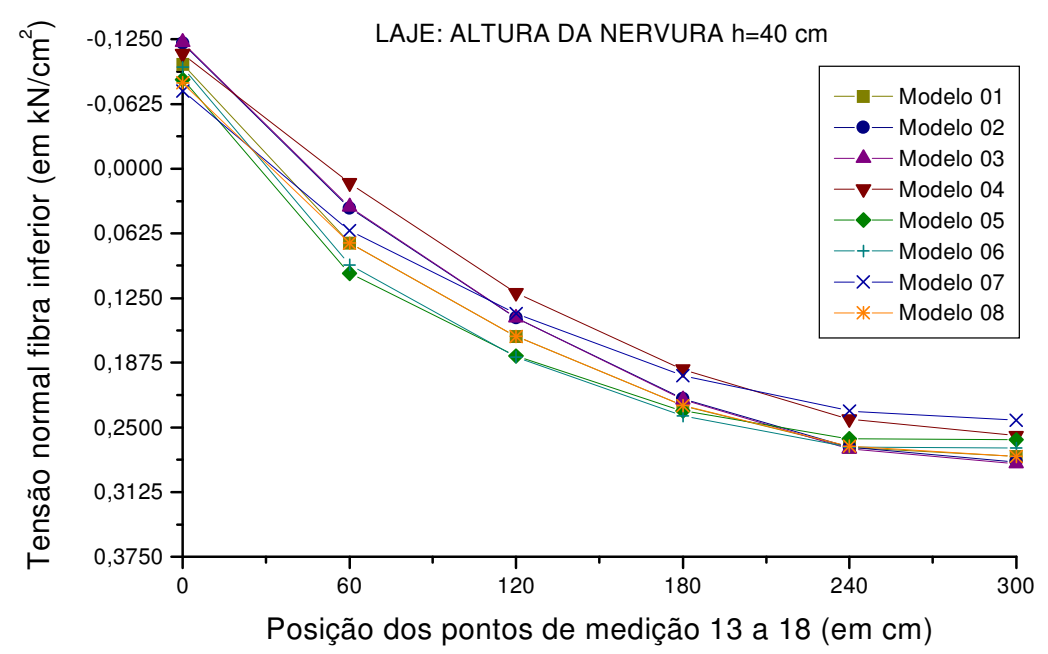

FIGURA 5.82: Tensões Normais fibras inferiores extremas $\left(\mathrm{kN} / \mathrm{cm}^{2}\right)$, na viga externa; laje com relação $\mathrm{hf} / \mathrm{h}=0,125$ 


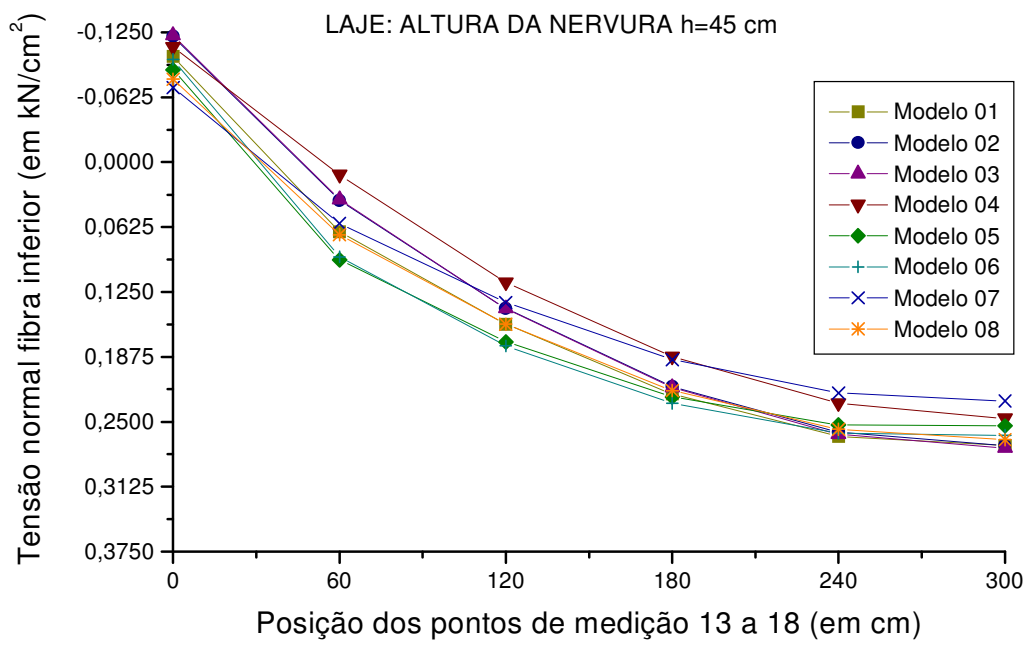

FIGURA 5.83: Tensões Normais fibras inferiores extremas $\left(\mathrm{kN} / \mathrm{cm}^{2}\right)$, na viga externa; laje com relação $\mathrm{hf} / \mathrm{h}=0,111$

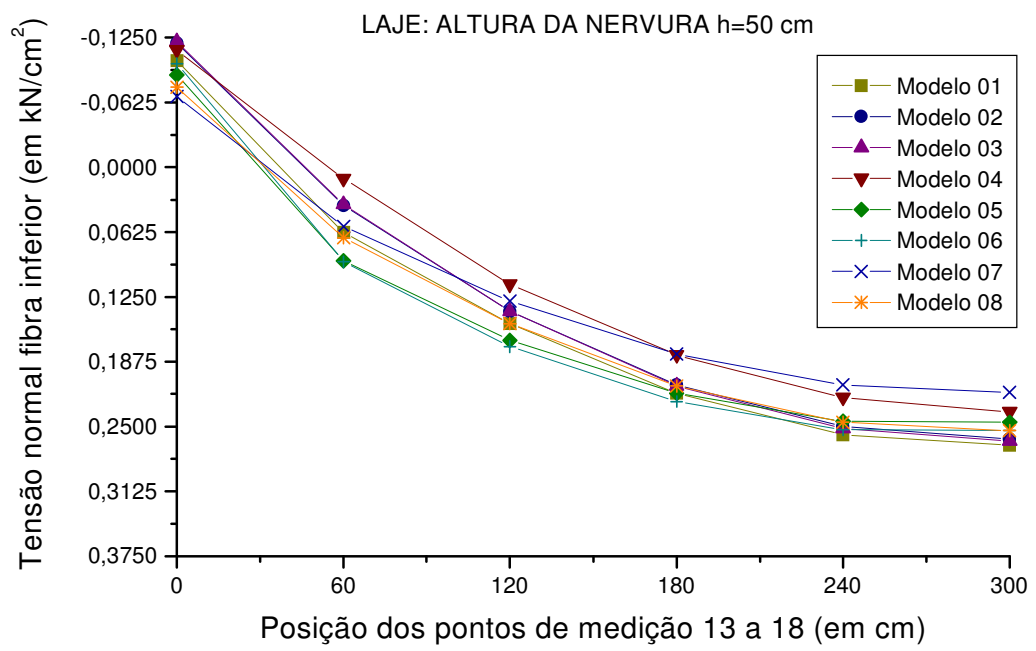

FIGURA 5.84: Tensões Normais fibras inferiores extremas $\left(\mathrm{kN} / \mathrm{cm}^{2}\right)$, na viga externa; laje com relação $\mathrm{hf} / \mathrm{h}=0,100$

Analisando-se as tabelas de tensões normais nas fibras superiores e inferiores extremas, para as vigas de contorno externo, verificou-se que:

- houve ótima correlação entre os resultados de tensões de tração nas vigas em todos os modelos, principalmente nas posições de tensão máxima de tração na viga;

- simulando as nervuras pelo Modelo 07 tem-se, na viga modelada pelo elemento excêntrico BEAM44, em qualquer relação $h_{f} / h$ para a laje, tensões menores de tração que aquelas apresentadas pelo modelo realista 04 . 


\subsubsection{Esforços Cortantes atuantes nas nervuras e vigas}

TABELA 5.70: Esforços Cortantes nas nervuras e vigas, em kN, na laje com altura total $\mathrm{h}=15 \mathrm{~cm}$

\begin{tabular}{|c|c|c|c|c|c|c|c|c|}
\hline \multicolumn{9}{|c|}{$\begin{array}{c}\text { LAJE COM RELAÇÃO hf/h }=0,333 \\
\text { ESFORCOS CORTANTES NAS NERVURAS E VIGAS }(\mathrm{kN})\end{array}$} \\
\hline \multirow{2}{*}{ Ponto } & \multicolumn{8}{|c|}{ Modelos numéricos de análise } \\
\hline & 01 & 02 & 03 & 04 & 05 & 06 & 07 & 08 \\
\hline$\overline{11}$ & 5,53 & 25,87 & $\begin{array}{l}4,95 \\
\end{array}$ & $\overline{5,64}$ & $7,7,68$ & 8,75 & - & - \\
\hline 2 & 4,19 & 4,10 & 3,56 & 4,55 & 5,77 & 6,35 & - & - \\
\hline 3 & 2,96 & 2,91 & 2,53 & 3,06 & 3,88 & 4,25 & - & - \\
\hline 4 & 1,92 & 1,92 & 1,67 & 1,85 & 2,35 & 2,48 & - & - \\
\hline 5 & 0,93 & 0,95 & 0,82 & 0,87 & 1,10 & 1,01 & - & - \\
\hline 6 & 0,03 & 0,04 & 0,04 & 0,00 & 0,04 & 0,34 & - & - \\
\hline 7 & 4,91 & 5,60 & 4,88 & 3,80 & 5,09 & 5,67 & - & - \\
\hline 8 & 3,69 & 3,88 & 3,45 & 2,86 & 3,32 & 3,45 & - & - \\
\hline 9 & 2,58 & 2,77 & 2,39 & 1,79 & 2,10 & 2,10 & - & - \\
\hline 10 & 1,64 & 1,75 & 1,52 & 1,02 & 1,35 & 1,28 & - & - \\
\hline 11 & 0,82 & 0,85 & 0,74 & 0,46 & 0,78 & 0,64 & - & - \\
\hline 12 & 0,06 & 0,04 & 0,02 & 0,00 & 0,27 & 0,04 & - & - \\
\hline 13 & 33,97 & 33,94 & 33,94 & 33,62 & 33,87 & 33,75 & 34,88 & 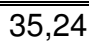 \\
\hline 14 & 28,99 & 24,82 & 25,02 & 30,70 & 30,24 & 33,24 & 31,81 & 35,24 \\
\hline 15 & 21,97 & 17,44 & 17,46 & 25,10 & 23,75 & 29,46 & 24,38 & 28,17 \\
\hline 16 & 14,09 & 10,73 & 10,72 & 17,83 & 15,36 & 22,93 & 16,40 & 19,14 \\
\hline 17 & 5,64 & 3,85 & 3,92 & 9,25 & 5,87 & 14,46 & 7,84 & 9,13 \\
\hline 18 & 3,07 & 3,22 & 3,03 & 0,00 & 4,02 & 4,84 & 1,13 & 1,31 \\
\hline
\end{tabular}

TABELA 5.71: Esforços Cortantes nas nervuras e vigas, em kN, na laje com altura total $\mathrm{h}=20 \mathrm{~cm}$

\section{LAJE COM RELAÇ̃̃O hf/h $=0,250$}

ESFORÇOS CORTANTES NAS NERVURAS E VIGAS (kN)

\begin{tabular}{c|c|c|c|c|c|c|c|c}
\hline \multirow{2}{*}{ Ponto } & \multicolumn{7}{|c}{ Modelos numéricos de análise } \\
\cline { 2 - 9 } & $\mathbf{0 1}$ & $\mathbf{0 2}$ & $\mathbf{0 3}$ & $\mathbf{0 4}$ & $\mathbf{0 5}$ & $\mathbf{0 6}$ & $\mathbf{0 7}$ & $\mathbf{0 8}$ \\
\hline \hline $\mathbf{1}$ & 6,38 & 6,65 & 6,30 & $\mathbf{6 , 4 1}$ & 7,95 & 8,41 & - & - \\
\hline $\mathbf{2}$ & 4,74 & 4,58 & 4,38 & $\mathbf{4 , 8 2}$ & 6,02 & 6,13 & - & - \\
\hline $\mathbf{3}$ & 3,38 & 3,23 & 3,11 & $\mathbf{3 , 3 2}$ & 4,13 & 4,16 & - & - \\
\hline $\mathbf{4}$ & 2,24 & 2,15 & 2,06 & $\mathbf{2 , 0 8}$ & 2,55 & 2,46 & - & - \\
\hline $\mathbf{5}$ & 1,12 & 1,07 & 1,02 & $\mathbf{1 , 0 0}$ & 1,21 & 1,01 & - & - \\
\hline $\mathbf{6}$ & 0,04 & 0,04 & 0,04 & $\mathbf{0 , 0 0}$ & 0,04 & 0,03 & - & - \\
\hline \hline $\mathbf{7}$ & 5,45 & 5,47 & 5,37 & $\mathbf{4 , 4 0}$ & 5,59 & 5,85 & - & - \\
\hline $\mathbf{8}$ & 4,59 & 4,46 & 4,21 & $\mathbf{3 , 4 6}$ & 3,80 & 3,70 & - & - \\
\hline $\mathbf{9}$ & 3,36 & 3,26 & 3,09 & $\mathbf{2 , 3 9}$ & 2,51 & 2,35 & - & - \\
\hline $\mathbf{1 0}$ & 2,09 & 1,97 & 1,89 & $\mathbf{1 , 4 5}$ & 1,63 & 1,45 & - & - \\
\hline $\mathbf{1 1}$ & 1,01 & 0,95 & 0,91 & $\mathbf{0 , 6 7}$ & 0,92 & 0,70 & - & - \\
\hline $\mathbf{1 2}$ & 0,05 & 0,08 & 0,06 & $\mathbf{0 , 0 0}$ & 0,25 & 0,02 & - & - \\
\hline $\mathbf{1 3}$ & 33,90 & 33,86 & 33,86 & $\mathbf{3 3 , 5 9}$ & 33,83 & 33,75 & 35,19 & 35,93 \\
\hline $\mathbf{1 4}$ & 27,73 & 24,39 & 24,63 & $\mathbf{2 9 , 9 1}$ & 29,58 & 33,24 & 30,95 & 35,31 \\
\hline $\mathbf{1 5}$ & 20,73 & 17,83 & 17,92 & $\mathbf{2 3 , 7 6}$ & 22,88 & 28,92 & 24,04 & 27,83 \\
\hline $\mathbf{1 6}$ & 13,22 & 11,44 & 11,48 & $\mathbf{1 6 , 6 7}$ & 14,60 & 22,05 & 16,62 & 18,95 \\
\hline $\mathbf{1 7}$ & 5,07 & 4,20 & 4,26 & $\mathbf{8 , 6 2}$ & 5,41 & 13,70 & 8,07 & 9,08 \\
\hline $\mathbf{1 8}$ & 3,37 & 3,48 & 3,40 & $\mathbf{0 , 0 0}$ & 4,09 & 4,54 & 1,17 & 1,31 \\
\hline \hline
\end{tabular}


TABELA 5.72: Esforços Cortantes nas nervuras e vigas, em $\mathrm{kN}$, na laje com altura total $\mathrm{h}=25 \mathrm{~cm}$

\begin{tabular}{|c|c|c|c|c|c|c|c|c|}
\hline \multicolumn{9}{|c|}{$\begin{array}{c}\text { LAJE COM RELAÇÃO hf/h }=0,200 \\
\text { ESFORÇOS CORTANTES NAS NERVURAS E VIGAS }(\mathrm{kN})\end{array}$} \\
\hline \multirow{2}{*}{ Ponto } & \multicolumn{8}{|c|}{ Modelos numéricos de análise } \\
\hline & 01 & 02 & 03 & 04 & 05 & 06 & 07 & 08 \\
\hline 1 & 6,98 & 7,20 & 7,05 & 6,48 & 7,97 & 8,11 & 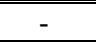 & - \\
\hline 2 & 5,08 & 4,99 & 4,91 & 4,97 & 6,03 & 5,96 & - & - \\
\hline 3 & 3,59 & 3,49 & 3,45 & 3,46 & 4,19 & 4,08 & - & - \\
\hline 4 & 2,39 & 2,29 & 2,26 & 2,21 & 2,63 & 2,44 & - & - \\
\hline 5 & 1,20 & 1,14 & 1,12 & 1,08 & 1,26 & 1,01 & - & - \\
\hline 6 & 0,04 & 0,04 & 0,04 & 0,00 & 0,04 & 0,34 & - & - \\
\hline 7 & 5,46 & 5,07 & 5,10 & 4,77 & 5,86 & 5,98 & - & - \\
\hline 8 & 5,02 & 4,62 & 4,49 & 3,84 & 4,12 & 3,91 & - & - \\
\hline 9 & 3,74 & 3,39 & 3,29 & 2,82 & 2,81 & 2,56 & - & - \\
\hline 10 & 2,26 & 2,00 & 1,97 & 1,77 & 1,82 & 1,60 & - & - \\
\hline 11 & 1,07 & 0,97 & 0,96 & 0,83 & 1,00 & 0,75 & - & - \\
\hline 12 & 0,08 & 0,13 & 0,12 & 0,00 & 0,22 & 0,07 & - & - \\
\hline 13 & 33,85 & "33,81 & "33,81 & 33,56 & 33,80 & 33,75 & 35,32 & 36,46 \\
\hline 14 & 33,11 & 31,65 & 31,75 & 29,45 & 33,15 & 33,24 & 31,90 & 36,56 \\
\hline 15 & 25,84 & 24,03 & 24,20 & 22,93 & 28,19 & 28,51 & 25,52 & 29,58 \\
\hline 16 & 19,03 & 18,22 & 18,25 & 15,98 & 21,24 & 21,51 & 18,74 & 21,26 \\
\hline 17 & 11,74 & 11,54 & 11,51 & 8,25 & 13,01 & 13,29 & 10,42 & 11,67 \\
\hline 18 & 3,61 & 3,71 & 3,66 & 0,00 & 4,06 & 4,39 & 1,18 & 1,31 \\
\hline
\end{tabular}

TABELA 5.73: Esforços Cortantes nas nervuras e vigas, em $\mathrm{kN}$, na laje com altura total $\mathrm{h}=30 \mathrm{~cm}$

LAJE COM RELAÇÃO hf/h = 0,167

ESFORÇOS CORTANTES NAS NERVURAS E VIGAS (kN)

\begin{tabular}{c|c|c|c|c|c|c|c|c}
\hline \multirow{2}{*}{ Ponto } & \multicolumn{7}{|c}{ Modelos numéricos de análise } \\
\cline { 2 - 9 } & $\mathbf{0 1}$ & $\mathbf{0 2}$ & $\mathbf{0 3}$ & $\mathbf{0 4}$ & $\mathbf{0 5}$ & $\mathbf{0 6}$ & $\mathbf{0 7}$ & $\mathbf{0 8}$ \\
\hline \hline $\mathbf{1}$ & 7,37 & 7,39 & 7,33 & $\mathbf{6 , 1 3}$ & 7,87 & 7,82 & - & - \\
\hline $\mathbf{2}$ & 5,33 & 5,28 & 5,25 & $\mathbf{5 , 0 6}$ & 5,98 & 5,81 & - & - \\
\hline $\mathbf{3}$ & 3,73 & 3,70 & 3,69 & $\mathbf{3 , 5 7}$ & 4,20 & 4,02 & - & - \\
\hline $\mathbf{4}$ & 2,48 & 2,40 & 2,39 & $\mathbf{2 , 3 0}$ & 2,66 & 2,43 & - & - \\
\hline $\mathbf{5}$ & 1,25 & 1,18 & 1,18 & $\mathbf{1 , 1 3}$ & 1,28 & 1,01 & - & - \\
\hline $\mathbf{6}$ & 0,04 & 0,04 & 0,04 & $\mathbf{0 , 0 0}$ & 0,04 & 0,34 & - & - \\
\hline \hline $\mathbf{7}$ & 5,32 & 4,94 & 4,97 & $\mathbf{4 , 9 3}$ & 6,04 & 6,09 & - & - \\
\hline $\mathbf{8}$ & 5,19 & 4,66 & 4,58 & $\mathbf{4 , 0 9}$ & 4,35 & 4,10 & - & - \\
\hline $\mathbf{9}$ & 3,88 & 3,41 & 3,34 & $\mathbf{3 , 1 0}$ & 3,02 & 2,75 & - & - \\
\hline $\mathbf{1 0}$ & 2,28 & 2,03 & 2,01 & $\mathbf{1 , 9 8}$ & 1,97 & 1,73 & - & - \\
\hline $\mathbf{1 1}$ & 1,08 & 1,01 & 1,03 & $\mathbf{0 , 9 3}$ & 1,06 & 0,79 & - & - \\
\hline $\mathbf{1 2}$ & 0,12 & 0,15 & 0,14 & $\mathbf{0 , 0 0}$ & 0,18 & 0,12 & - & - \\
\hline $\mathbf{1 3}$ & 33,81 & 33,78 & 33,78 & $\mathbf{3 3 , 5 4}$ & 33,78 & 33,75 & 35,29 & 36,83 \\
\hline $\mathbf{1 4}$ & 33,06 & 32,08 & 32,14 & $\mathbf{2 9 , 1 8}$ & 33,12 & 33,24 & 31,05 & 36,04 \\
\hline $\mathbf{1 5}$ & 25,48 & 24,52 & 24,66 & $\mathbf{2 2 , 4 0}$ & 27,78 & 28,07 & 25,24 & 29,26 \\
\hline $\mathbf{1 6}$ & 19,05 & 18,79 & 18,83 & $\mathbf{1 5 , 5 5}$ & 20,77 & 20,96 & 18,56 & 21,15 \\
\hline $\mathbf{1 7}$ & 11,94 & 11,84 & 11,84 & $\mathbf{8 , 0 2}$ & 12,69 & 12,88 & 10,24 & 11,60 \\
\hline $\mathbf{1 8}$ & 3,77 & 3,78 & 3,76 & $\mathbf{0 , 0 0}$ & 3,99 & 4,24 & 1,15 & 1,31 \\
\hline \hline
\end{tabular}


TABELA 5.74: Esforços Cortantes nas nervuras e vigas, em kN, na laje com altura total $\mathrm{h}=35 \mathrm{~cm}$

\begin{tabular}{|c|c|c|c|c|c|c|c|c|}
\hline \multicolumn{9}{|c|}{$\begin{array}{c}\text { LAJE COM RELAÇÃO hf/h }=0,143 \\
\text { ESFORÇOS CORTANTES NAS NERVURAS E VIGAS }(\mathrm{kN})\end{array}$} \\
\hline \multirow{2}{*}{ Ponto } & \multicolumn{8}{|c|}{ Modelos numéricos de análise } \\
\hline & 01 & $\mathbf{0 2}$ & 03 & 04 & $\mathbf{0 5}$ & 06 & 07 & 08 \\
\hline 1 & 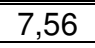 & 7,31 & 7,29 & 6,09 & 7,67 & 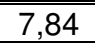 & - & - \\
\hline 2 & 5,51 & 5,41 & 5,41 & 5,07 & 5,90 & 5,65 & - & - \\
\hline 3 & 3,83 & 3,84 & 3,84 & 3,65 & 4,19 & 3,96 & - & - \\
\hline 4 & 2,53 & 2,48 & 2,48 & 2,37 & 2,67 & 2,42 & - & - \\
\hline 5 & 1,27 & 1,22 & 1,21 & 1,17 & 1,29 & 1,01 & - & - \\
\hline 6 & 0,04 & 0,04 & 0,04 & 0,00 & 0,04 & 0,34 & - & - \\
\hline 7 & "5,20 & $5,5,10$ & 5,12 & 5,08 & $\begin{array}{c}6,21 \\
\end{array}$ & $6,2,21$ & - & - \\
\hline 8 & 5,24 & 4,71 & 4,65 & 4,28 & 4,55 & 4,30 & - & - \\
\hline 9 & 3,92 & 3,45 & 3,38 & 3,31 & 3,21 & 2,95 & - & - \\
\hline 10 & 2,28 & 2,11 & 2,09 & 2,14 & 2,11 & 1,87 & - & - \\
\hline 11 & 1,08 & 1,06 & 1,06 & 1,02 & 1,11 & 0,84 & - & - \\
\hline 12 & 0,14 & 0,13 & 0,12 & 0,00 & 0,14 & 0,17 & - & - \\
\hline 13 & 33,78 & 33,76 & 33,76 & 33,53 & 33,76 & 33,75 & 35,09 & 37,03 \\
\hline 14 & 33,03 & 32,35 & 32,39 & 28,98 & 33,10 & 33,24 & 30,18 & 35,31 \\
\hline 15 & 25,28 & 24,87 & 24,99 & 21,98 & 27,36 & 27,58 & 24,73 & 28,79 \\
\hline 16 & 19,11 & 18,94 & 19,00 & 15,16 & 20,26 & 20,36 & 18,02 & 20,80 \\
\hline 17 & 12,05 & 11,76 & 11,79 & 7,79 & 12,33 & 12,43 & 9,85 & 11,37 \\
\hline 18 & 3,85 & 3,72 & 3,72 & 0,00 & 3,89 & 4,08 & 1,11 & 1,28 \\
\hline
\end{tabular}

TABELA 5.75: Esforços Cortantes nas nervuras e vigas, em kN, na laje com altura total $\mathrm{h}=40 \mathrm{~cm}$

LAJE COM RELAÇÃO hf/h = 0,125

ESFORÇOS CORTANTES NAS NERVURAS E VIGAS $(\mathrm{kN})$

\begin{tabular}{c|c|c|c|c|c|c|c|c}
\hline \multirow{2}{*}{ Ponto } & \multicolumn{7}{|c}{ Modelos numéricos de análise } & $\mathbf{0 8}$ \\
\cline { 2 - 9 } & $\mathbf{0 1}$ & $\mathbf{0 2}$ & $\mathbf{0 3}$ & $\mathbf{0 4}$ & $\mathbf{0 5}$ & $\mathbf{0 6}$ & $\mathbf{0 7}$ & $\mathbf{0 8}$ \\
\hline \hline $\mathbf{1}$ & 7,58 & 7,03 & 7,05 & $\mathbf{5 , 9 4}$ & 7,39 & 7,09 & - & - \\
\hline $\mathbf{2}$ & 5,60 & 5,41 & 5,42 & $\mathbf{5 , 0 0}$ & 5,78 & 5,47 & - & - \\
\hline $\mathbf{3}$ & 3,91 & 3,91 & 3,91 & $\mathbf{3 , 6 7}$ & 4,17 & 3,90 & - & - \\
\hline $\mathbf{4}$ & 2,57 & 2,54 & 2,54 & $\mathbf{2 , 4 1}$ & 2,68 & 2,41 & - & - \\
\hline $\mathbf{5}$ & 1,28 & 1,24 & 1,24 & $\mathbf{1 , 2 0}$ & 1,30 & 1,01 & - & - \\
\hline $\mathbf{6}$ & 0,04 & 0,04 & 0,04 & $\mathbf{0 , 0 0}$ & 0,04 & 0,34 & - & - \\
\hline \hline $\mathbf{7}$ & 5,17 & 5,46 & 5,46 & $\mathbf{5 , 2 5}$ & 6,39 & 6,35 & - & - \\
\hline $\mathbf{8}$ & 5,27 & 4,83 & 4,77 & $\mathbf{4 , 4 8}$ & 4,74 & 4,52 & - & - \\
\hline $\mathbf{9}$ & 3,94 & 3,54 & 3,49 & $\mathbf{3 , 5 1}$ & 3,40 & 3,17 & - & - \\
\hline $\mathbf{1 0}$ & 2,29 & 2,25 & 2,23 & $\mathbf{2 , 3 0}$ & 2,25 & 2,03 & - & - \\
\hline $\mathbf{1 1}$ & 1,10 & 1,14 & 1,13 & $\mathbf{1 , 1 2}$ & 1,17 & 0,90 & - & - \\
\hline $\mathbf{1 2}$ & 0,14 & 0,07 & 0,08 & $\mathbf{0 , 0 0}$ & 0,09 & 0,23 & - & - \\
\hline \hline $\mathbf{1 3}$ & 33,77 & 33,75 & 33,75 & $\mathbf{3 3 , 5 2}$ & 33,75 & 33,75 & 34,72 & 37,07 \\
\hline $\mathbf{1 4}$ & 33,02 & 32,53 & 32,56 & $\mathbf{2 8 , 7 9}$ & 33,09 & 33,24 & 29,26 & 34,42 \\
\hline $\mathbf{1 5}$ & 25,14 & 25,01 & 25,13 & $\mathbf{2 1 , 5 3}$ & 26,91 & 27,03 & 23,94 & 28,12 \\
\hline $\mathbf{1 6}$ & 19,08 & 18,71 & 18,79 & $\mathbf{1 4 , 7 1}$ & 19,68 & 19,66 & 17,20 & 20,21 \\
\hline $\mathbf{1 7}$ & 12,01 & 11,41 & 11,56 & $\mathbf{7 , 5 0}$ & 11,89 & 11,90 & 9,32 & 10,99 \\
\hline $\mathbf{1 8}$ & 3,85 & 3,57 & 3,59 & $\mathbf{0 , 0 0}$ & 3,74 & 3,88 & 1,04 & 1,23 \\
\hline \hline
\end{tabular}


TABELA 5.76: Esforços Cortantes nas nervuras e vigas, em kN, na laje com altura total $\mathrm{h}=45 \mathrm{~cm}$

\begin{tabular}{|c|c|c|c|c|c|c|c|c|}
\hline \multicolumn{9}{|c|}{$\begin{array}{c}\text { LAJE COM RELAÇÃO hf/h = 0,111 } \\
\text { ESFORÇOS CORTANTES NAS NERVURAS E VIGAS }(\mathrm{kN})\end{array}$} \\
\hline \multirow{2}{*}{ Ponto } & \multicolumn{8}{|c|}{ Modelos numéricos de análise } \\
\hline & 01 & 02 & 03 & 04 & 05 & 06 & 07 & 08 \\
\hline 1 & 7,46 & 6,62 & 6,66 & 5,68 & 7,03 & 6,64 & 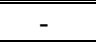 & - \\
\hline 2 & 5,62 & 5,30 & 5,32 & 4,83 & 5,61 & 5,26 & - & - \\
\hline 3 & 3,96 & 3,93 & 3,93 & 3,64 & 4,12 & 3,83 & - & - \\
\hline 4 & 2,59 & 2,58 & 2,57 & 2,43 & 2,68 & 2,40 & - & - \\
\hline 5 & 1,29 & 1,26 & 1,26 & 1,21 & 1,30 & 1,01 & - & - \\
\hline 6 & 0,04 & 0,04 & 0,04 & 0,00 & 0,04 & 0,34 & - & - \\
\hline 7 & 5,22 & 5,91 & 5,91 & 5,45 & 6,58 & 6,52 & - & - \\
\hline 8 & 5,31 & 5,02 & 4,96 & 4,70 & 4,96 & 4,77 & - & - \\
\hline 9 & 3,98 & 3,72 & 3,66 & 3,73 & 3,62 & 3,42 & - & - \\
\hline 10 & 2,33 & 2,45 & 2,42 & 2,48 & 2,42 & 2,22 & - & - \\
\hline 11 & 1,12 & 1,22 & 1,21 & 1,23 & 1,23 & 0,97 & - & - \\
\hline 12 & 0,13 & 0,00 & 0,00 & 0,00 & 0,03 & 0,30 & - & - \\
\hline 13 & 33,75 & "33,74 & "33,74 & 33,51 & 33,74 & 33,75 & 34,19 & 36,97 \\
\hline 14 & 33,02 & 32,65 & 32,67 & 28,58 & 33,09 & 33,24 & 28,25 & 33,40 \\
\hline 15 & 24,98 & 24,91 & 25,04 & 21,01 & 26,39 & 26,40 & 22,89 & 27,24 \\
\hline 16 & 18,92 & 18,15 & 18,27 & 14,16 & 19,00 & 18,86 & 16,20 & 19,43 \\
\hline 17 & 11,84 & 10,85 & 10,93 & 7,15 & 11,36 & 11,29 & 8,71 & 10,51 \\
\hline 18 & 3,78 & 3,54 & 3,38 & 0,00 & 3,56 & 3,66 & 0,97 & 1,18 \\
\hline
\end{tabular}

TABELA 5.77: Esforços Cortantes nas nervuras e vigas, em kN, na laje com altura total $\mathrm{h}=50 \mathrm{~cm}$

LAJE COM RELAÇÃO hf/h = 0,100

ESFORÇOS CORTANTES NAS NERVURAS E VIGAS $(\mathrm{kN})$

\begin{tabular}{c|c|c|c|c|c|c|c|c}
\hline \multirow{2}{*}{ Ponto } & \multicolumn{7}{|c}{ Modelos numéricos de análise } \\
\cline { 2 - 9 } & $\mathbf{0 1}$ & $\mathbf{0 2}$ & $\mathbf{0 3}$ & $\mathbf{0 4}$ & $\mathbf{0 5}$ & $\mathbf{0 6}$ & $\mathbf{0 7}$ & $\mathbf{0 8}$ \\
\hline \hline $\mathbf{1}$ & 7,24 & 6,09 & 6,16 & $\mathbf{5 , 3 4}$ & 6,60 & 6,13 & - & - \\
\hline $\mathbf{2}$ & 5,58 & 4,88 & 5,14 & $\mathbf{4 , 5 9}$ & 5,41 & 5,01 & - & - \\
\hline $\mathbf{3}$ & 3,98 & 3,87 & 3,91 & $\mathbf{3 , 5 6}$ & 4,06 & 3,74 & - & - \\
\hline $\mathbf{4}$ & 2,61 & 2,66 & 2,59 & $\mathbf{2 , 4 2}$ & 2,67 & 2,38 & - & - \\
\hline $\mathbf{5}$ & 1,30 & 1,36 & 1,27 & $\mathbf{1 , 2 3}$ & 1,31 & 1,01 & - & - \\
\hline $\mathbf{6}$ & 0,04 & 0,04 & 0,04 & $\mathbf{0 , 0 0}$ & 0,04 & 0,34 & - & - \\
\hline \hline $\mathbf{7}$ & 5,34 & 6,39 & 6,38 & $\mathbf{5 , 6 9}$ & 6,79 & 6,71 & - & - \\
\hline $\mathbf{8}$ & 5,38 & 5,14 & 5,23 & $\mathbf{4 , 9 6}$ & 5,22 & 5,07 & - & - \\
\hline $\mathbf{9}$ & 4,05 & 4,06 & 3,92 & $\mathbf{3 , 9 9}$ & 3,87 & 3,72 & - & - \\
\hline $\mathbf{1 0}$ & 2,41 & 2,75 & 2,65 & $\mathbf{2 , 7 1}$ & 2,62 & 2,44 & - & - \\
\hline $\mathbf{1 1}$ & 1,17 & 1,46 & 1,31 & $\mathbf{1 , 3 6}$ & 1,31 & 1,05 & - & - \\
\hline $\mathbf{1 2}$ & 0,09 & 0,09 & 0,08 & $\mathbf{0 , 0 0}$ & 0,04 & 0,38 & - & - \\
\hline \hline $\mathbf{1 3}$ & 33,74 & 33,73 & 33,73 & $\mathbf{3 3 , 5 0}$ & 33,73 & 33,75 & 33,51 & 36,70 \\
\hline $\mathbf{1 4}$ & 33,02 & 32,74 & 32,75 & $\mathbf{2 8 , 3 5}$ & 33,08 & 33,24 & 27,15 & 32,26 \\
\hline $\mathbf{1 5}$ & 24,76 & 24,57 & 24,72 & $\mathbf{2 0 , 4 1}$ & 25,79 & 25,68 & 21,64 & 26,16 \\
\hline $\mathbf{1 6}$ & 18,61 & 17,34 & 17,48 & $\mathbf{1 3 , 5 1}$ & 18,21 & 17,96 & 15,07 & 18,50 \\
\hline $\mathbf{1 7}$ & 11,53 & 10,13 & 10,24 & $\mathbf{6 , 7 3}$ & 10,75 & 10,60 & 8,04 & 9,96 \\
\hline $\mathbf{1 8}$ & 3,67 & 3,09 & 3,13 & $\mathbf{0 , 0 0}$ & 3,34 & 3,40 & 0,90 & 1,11 \\
\hline \hline
\end{tabular}

Analisando-se as tabelas de esforços cortantes nas nervuras e vigas, nesta primeira série de processamentos, verificou-se que: 
- as cortantes obtidas pelo Modelo 04, para as nervuras, são sempre menores que as determinadas pelos demais modelos;

- à medida que aumentou-se a excentricidade, mais próximos foram ficando os valores de cortantes máximas nas nervuras entre os vários modelos simplificados; em contrapartida, mais distantes dos resultados encontrados pelo modelo realista;

- para baixos valores de excentricidade, ou seja, $h_{f} / h=0,333$ até $h_{f} / h=0,20$, as nervuras simuladas pelos Modelos 05 e 06 apresentaram valores maiores de cortantes que os demais (com relação ao Modelo 04, o Modelo 06 apresentou diferença de 55,1\% para $\mathrm{h}_{\mathrm{f}} / \mathrm{h}=0,333$ na cortante máxima atuante na nervura central); a partir $\mathrm{de}_{\mathrm{f}} / \mathrm{h}=0,125$ somente as nervuras do Modelo 05 continua apresentando valores maiores;

- as melhores correlações entre cortantes do Modelo 04 em relação ao Modelo 02 e 03 são obtidas nas nervuras mais próximas dos apoios;

- de uma maneira geral as cortantes das vigas de contorno simuladas pelo BEAM44 excêntrico ou pelo SHELL63 apresentaram resultados sempre muito próximos, independente do modelo que se adote para as nervuras (inclusive adotando uma modelagem concêntrica); Nos modelos onde as nervuras são simuladas pelo Modelo 08 tem-se os maiores valores de cortante máximas em relação ao Modelo 04: diferenças da ordem de $10 \%$.

\subsubsection{Momentos Fletores MX atuantes na capa}

TABELA 5.78: Momentos Fletores MX na capa, em kN.cm/cm, na laje com altura total $\mathrm{h}=15 \mathrm{~cm}$

\begin{tabular}{|c|c|c|c|c|c|}
\hline \multicolumn{6}{|c|}{$\begin{array}{c}\text { LAJE COM RELAÇÃO hf/h }=0,333 \\
\text { MOMENTO FLETOR MX NA CAPA }(\mathrm{kN} . \mathrm{cm} / \mathrm{cm})\end{array}$} \\
\hline \multirow{2}{*}{ Ponto } & \multicolumn{5}{|c|}{ Modelos numéricos de análise } \\
\hline & 01 & 02 & $\mathbf{0 3}$ & 04 & 05 \\
\hline$\overline{\mathbf{A}}$ & 3,156 & 2,106 & 2,181 & 1,653 & 1,427 \\
\hline $\mathbf{B}$ & 2,875 & 1,953 & 2,030 & 1,498 & 1,269 \\
\hline D & 2,266 & 1,613 & 1,680 & 1,122 & 0,912 \\
\hline $\mathbf{G}$ & 1,305 & 1,074 & 1,130 & 0,480 & 0,323 \\
\hline $\mathbf{K}$ & $-0,064$ & 0,257 & 0,289 & $-0,536$ & $-0,525$ \\
\hline $\mathbf{C}$ & 2,645 & 1,811 & 1,879 & 1,366 & 1,468 \\
\hline$E$ & 2,049 & 1,465 & 1,527 & 1,022 & 0,835 \\
\hline $\mathrm{H}$ & 1,115 & 0,927 & 0,976 & 0,431 & 0,310 \\
\hline $\mathbf{L}$ & $-0,204$ & 0,136 & 0,156 & $-0,503$ & 0,467 \\
\hline $\bar{F}$ & 1,611 & 1,174 & 1,225 & 0,815 & 0,670 \\
\hline$I$ & 0,743 & 0,647 & 0,685 & 0,334 & 0,276 \\
\hline $\mathbf{M}$ & $-0,471$ & $-0,104$ & 0,102 & $-0,436$ & $-0,346$ \\
\hline $\mathbf{J}$ & 0,284 & 0,299 & 0,321 & 0,188 & 0,202 \\
\hline $\mathbf{N}$ & $-0,736$ & $-0,381$ & 0,392 & $-0,350$ & $-0,181$ \\
\hline 0 & $-0,639$ & $-0,294$ & $-0,320$ & $-0,218$ & $-0,029$ \\
\hline
\end{tabular}


TABELA 5.79: Momentos Fletores MX na capa, em kN.cm/cm, na laje com altura total $\mathrm{h}=20 \mathrm{~cm}$

\begin{tabular}{|c|c|c|c|c|c|}
\hline \multicolumn{6}{|c|}{$\begin{array}{c}\text { LAJE COM RELAÇÃO hf/h = 0,250 } \\
\text { MOMENTO FLETOR MX NA CAPA }(\mathrm{kN} . \mathrm{cm} / \mathrm{cm})\end{array}$} \\
\hline \multirow{2}{*}{ Ponto } & \multicolumn{5}{|c|}{ Modelos numéricos de análise } \\
\hline & 01 & 02 & 03 & 04 & 05 \\
\hline $\mathbf{A}$ & 1,852 & 1,070 & 1,099 & 0,902 & 0,823 \\
\hline B & 1,711 & 1,008 & 1,037 & 0,843 & 0,749 \\
\hline $\mathbf{D}$ & 1,409 & 0,867 & 0,893 & 0,694 & 0,584 \\
\hline $\mathbf{G}$ & 0,937 & 0,640 & 0,663 & 0,441 & 0,316 \\
\hline $\mathbf{K}$ & 0,263 & 0,285 & 0,300 & 0,042 & $-0,065$ \\
\hline $\mathbf{C}$ & 1,587 & 0,945 & 0,973 & 0,787 & 0,688 \\
\hline$E$ & 1,280 & 0,798 & 0,835 & 0,643 & 0,540 \\
\hline $\mathbf{H}$ & 0,812 & 0,569 & 0,589 & 0,401 & 0,297 \\
\hline $\mathbf{L}$ & 0,169 & 0,240 & 0,252 & 0,029 & $-0,056$ \\
\hline $\mathbf{F}$ & 1,025 & 0,663 & 0,685 & 0,539 & 0,448 \\
\hline$I$ & 0,566 & 0,430 & 0,448 & 0,321 & 0,255 \\
\hline $\mathbf{M}$ & $-0,033$ & 0,129 & 0,134 & $-0,001$ & $-0,038$ \\
\hline $\mathbf{J}$ & 0,263 & 0,254 & 0,267 & 0,211 & 0,187 \\
\hline $\mathbf{N}$ & $-0,294$ & $-0,037$ & $-0,037$ & $-0,048$ & $-0,010$ \\
\hline 0 & $-0,353$ & $-0,013$ & $-0,029$ & $-0,048$ & $-0,021$ \\
\hline
\end{tabular}

TABELA 5.80: Momentos Fletores MX na capa, em kN.cm/cm, na laje com altura total $\mathrm{h}=25 \mathrm{~cm}$

\begin{tabular}{|c|c|c|c|c|c|}
\hline \multicolumn{6}{|c|}{$\begin{array}{c}\text { LAJE COM RELAÇ̃̃̃ hf/h }=\mathbf{0 , 2 0 0} \\
\text { MOMENTO FLETOR MX NA CAPA }(\mathbf{k N . c m} / \mathrm{cm})\end{array}$} \\
\hline \multirow{2}{*}{ Ponto } & \multicolumn{5}{|c|}{ Modelos numéricos de análise } \\
\hline & 01 & 02 & $\mathbf{0 3}$ & 04 & 05 \\
\hline A & 1,142 & 0,610 & 0,625 & 0,559 & 0,522 \\
\hline B & 1,064 & 0,581 & 0,597 & 0,533 & 0,483 \\
\hline D & 0,897 & 0,512 & 0,526 & 0,462 & 0,395 \\
\hline $\mathbf{G}$ & 0,637 & 0,397 & 0,408 & 0,342 & 0,255 \\
\hline $\mathrm{K}$ & 0,261 & 0,211 & 0,218 & 0,151 & 0,057 \\
\hline C & 0,992 & 0,551 & 0,566 & 0,507 & 0,449 \\
\hline$E$ & 0,820 & 0,479 & 0,492 & 0,437 & 0,369 \\
\hline $\mathrm{H}$ & 0,563 & 0,363 & 0,373 & 0,318 & 0,240 \\
\hline $\mathrm{L}$ & 0,212 & 0,197 & 0,202 & 0,139 & 0,055 \\
\hline $\mathbf{F}$ & 0,670 & 0,412 & 0,424 & 0,381 & 0,314 \\
\hline$I$ & 0,414 & 0,295 & 0,304 & 0,268 & 0,207 \\
\hline $\mathbf{M}$ & 0,092 & 0,150 & 0,153 & 0,107 & 0,050 \\
\hline $\mathrm{J}$ & 0,225 & 0,205 & 0,212 & 0,197 & 0,158 \\
\hline $\mathbf{N}$ & $-0,092$ & 0,066 & 0,066 & 0,056 & 0,044 \\
\hline 0 & $-0,182$ & 0,079 & 0,066 & 0,035 & 0,041 \\
\hline
\end{tabular}


TABELA 5.81: Momentos Fletores MX na capa, em kN.cm/cm, na laje com altura total $\mathrm{h}=30 \mathrm{~cm}$

\begin{tabular}{c|c|c|c|c|c}
\hline \multicolumn{7}{c}{ LAJE COM RELAÇÃO hf/h = 0,167 } \\
\multicolumn{7}{c}{ MOMENTO FLETOR MX NA CAPA (kN.cm/cm) } \\
\hline \multirow{2}{*}{ Ponto } & \multicolumn{7}{c}{ Modelos numéricos de análise } \\
\cline { 2 - 6 } & $\mathbf{0 1}$ & $\mathbf{0 2}$ & $\mathbf{0 3}$ & $\mathbf{0 4}$ & $\mathbf{0 5}$ \\
\hline \hline $\mathbf{A}$ & 0,741 & 0,385 & 0,395 & $\mathbf{0 , 3 7 4}$ & 0,353 \\
\hline $\mathbf{B}$ & 0,695 & 0,370 & 0,379 & $\mathbf{0 , 3 6 2}$ & 0,330 \\
\hline $\mathbf{D}$ & 0,595 & 0,331 & 0,340 & $\mathbf{0 , 3 2 4}$ & 0,279 \\
\hline $\mathbf{G}$ & 0,437 & 0,265 & 0,272 & $\mathbf{0 , 2 5 8}$ & 0,197 \\
\hline $\mathbf{K}$ & 0,209 & 0,157 & 0,161 & $\mathbf{0 , 1 5 4}$ & 0,083 \\
\hline \hline $\mathbf{C}$ & 0,651 & 0,355 & 0,364 & $\mathbf{0 , 3 5 0}$ & 0,311 \\
\hline $\mathbf{E}$ & 0,548 & 0,315 & 0,322 & $\mathbf{0 , 3 1 2}$ & 0,263 \\
\hline $\mathbf{H}$ & 0,394 & 0,249 & 0,255 & $\mathbf{0 , 2 4 6}$ & 0,187 \\
\hline $\mathbf{L}$ & 0,184 & 0,153 & 0,156 & $\mathbf{0 , 1 4 8}$ & 0,079 \\
\hline \hline $\mathbf{F}$ & 0,457 & 0,281 & 0,288 & $\mathbf{0 , 2 8 2}$ & 0,230 \\
\hline $\mathbf{I}$ & 0,305 & 0,214 & 0,220 & $\mathbf{0 , 2 1 7}$ & 0,165 \\
\hline \hline $\mathbf{M}$ & 0,117 & 0,133 & 0,135 & $\mathbf{0 , 1 2 7}$ & 0,071 \\
\hline $\mathbf{J}$ & 0,188 & 0,166 & 0,170 & $\mathbf{0 , 1 7 5}$ & 0,132 \\
\hline \hline $\mathbf{N}$ & $-0,003$ & 0,090 & 0,090 & $\mathbf{0 , 0 9 2}$ & 0,060 \\
\hline \hline $\mathbf{O}$ & $-0,086$ & 0,099 & 0,090 & $\mathbf{0 , 0 7 2}$ & 0,048 \\
\hline \hline
\end{tabular}

TABELA 5.82: Momentos Fletores MX na capa, em kN.cm/cm, na laje com altura total $\mathrm{h}=35 \mathrm{~cm}$

\begin{tabular}{|c|c|c|c|c|c|}
\hline \multicolumn{6}{|c|}{$\begin{array}{c}\text { LAJE COM RELAÇÃO hf/h }=0,143 \\
\text { MOMENTO FLETOR MX NA CAPA }(\mathrm{kN.cm} / \mathrm{cm})\end{array}$} \\
\hline \multirow{2}{*}{ Ponto } & \multicolumn{5}{|c|}{ Modelos numéricos de análise } \\
\hline & 01 & 02 & $\mathbf{0 3}$ & 04 & 05 \\
\hline$\overline{\mathbf{A}}$ & 0,506 & 0,263 & 0,270 & 0,266 & 0,252 \\
\hline B & 0,476 & 0,255 & 0,262 & 0,260 & 0,238 \\
\hline D & 0,412 & 0,231 & 0,237 & 0,239 & 0,205 \\
\hline $\mathbf{G}$ & 0,310 & 0,190 & 0,195 & 0,199 & 0,154 \\
\hline $\mathbf{K}$ & 0,163 & 0,124 & 0,126 & 0,138 & 0,084 \\
\hline$\overline{\mathbf{C}}$ & 0,449 & 0,248 & 0,254 & 0,255 & 0,226 \\
\hline$E$ & 0,383 & 0,223 & 0,229 & 0,233 & 0,196 \\
\hline $\mathrm{H}$ & 0,285 & 0,182 & 0,187 & 0,194 & 0,148 \\
\hline $\mathbf{L}$ & 0,150 & 0,123 & 0,125 & 0,136 & 0,081 \\
\hline $\bar{F}$ & 0,327 & 0,206 & 0,211 & 0,219 & 0,177 \\
\hline I & 0,231 & 0,165 & 0,169 & 0,179 & 0,134 \\
\hline $\mathbf{M}$ & 0,113 & 0,114 & 0,115 & 0,124 & 0,074 \\
\hline $\bar{J}$ & 0,158 & 0,139 & 0,142 & 0,155 & 0,113 \\
\hline $\mathbf{N}$ & 0,036 & 0,092 & 0,092 & 0,103 & 0,063 \\
\hline 0 & $-0,031$ & 0,098 & 0,093 & 0,086 & 0,051 \\
\hline
\end{tabular}


TABELA 5.83: Momentos Fletores MX na capa, em kN.cm/cm, na laje com altura total $\mathrm{h}=40 \mathrm{~cm}$

\begin{tabular}{|c|c|c|c|c|c|}
\hline \multicolumn{6}{|c|}{$\begin{array}{c}\text { LAJE COM RELAÇÃO hf/h }=0,125 \\
\text { MOMENTO FLETOR MX NA CAPA }(\mathrm{kN} . \mathrm{cm} / \mathrm{cm})\end{array}$} \\
\hline \multirow{2}{*}{ Ponto } & \multicolumn{5}{|c|}{ Modelos numéricos de análise } \\
\hline & 01 & $\mathbf{0 2}$ & 03 & 04 & 05 \\
\hline$\overline{\mathbf{A}}$ & 0,361 & 0,192 & 0,198 & 0,200 & 0,189 \\
\hline B & 0,341 & 0,187 & 0,192 & 0,197 & 0,179 \\
\hline D & 0,298 & 0,171 & 0,176 & 0,184 & 0,158 \\
\hline $\mathbf{G}$ & 0,229 & 0,145 & 0,148 & 0,159 & 0,124 \\
\hline $\mathbf{K}$ & 0,131 & 0,102 & 0,103 & 0,121 & 0,079 \\
\hline$\overline{\mathbf{C}}$ & 0,324 & 0,184 & 0,189 & 0,196 & 0,173 \\
\hline $\mathbf{E}$ & 0,280 & 0,169 & 0,173 & 0,183 & 0,153 \\
\hline $\mathbf{H}$ & 0,214 & 0,142 & 0,145 & 0,158 & 0,120 \\
\hline $\mathbf{L}$ & 0,124 & 0,103 & 0,104 & 0,122 & 0,076 \\
\hline $\bar{F}$ & 0,245 & 0,161 & 0,164 & 0,177 & 0,141 \\
\hline$I$ & 0,181 & 0,134 & 0,137 & 0,152 & 0,112 \\
\hline $\mathbf{M}$ & 0,102 & 0,099 & 0,100 & 0,117 & 0,071 \\
\hline $\bar{J}$ & 0,135 & 0,120 & 0,122 & 0,140 & 0,099 \\
\hline $\mathbf{N}$ & 0,053 & 0,088 & 0,089 & 0,105 & 0,063 \\
\hline 0 & 0,000 & 0,092 & 0,089 & 0,096 & 0,053 \\
\hline
\end{tabular}

TABELA 5.84: Momentos Fletores MX na capa, em kN.cm/cm, na laje com altura total $\mathrm{h}=45 \mathrm{~cm}$

\begin{tabular}{c|c|c|c|c|c}
\hline \hline \multicolumn{6}{c}{ LAJE COM RELAÇ̃̃O hf/h $=\mathbf{0 , 1 1 1}$} \\
\multicolumn{7}{c}{ MOMENTO FLETOR MX NA CAPA (kN.cm/cm) } \\
\hline \multirow{2}{*}{ Ponto } & \multicolumn{6}{c}{ Modelos numéricos de análise } \\
\cline { 2 - 6 } & $\mathbf{0 1}$ & $\mathbf{0 2}$ & $\mathbf{0 3}$ & $\mathbf{0 4}$ & $\mathbf{0 5}$ \\
\hline \hline $\mathbf{A}$ & 0,268 & 0,148 & 0,152 & $\mathbf{0 , 1 5 7}$ & 0,148 \\
\hline $\mathbf{B}$ & 0,254 & 0,145 & 0,149 & $\mathbf{0 , 1 5 6}$ & 0,141 \\
\hline $\mathbf{D}$ & 0,224 & 0,134 & 0,137 & $\mathbf{0 , 1 4 8}$ & 0,126 \\
\hline $\mathbf{G}$ & 0,177 & 0,115 & 0,118 & $\mathbf{0 , 1 3 2}$ & 0,103 \\
\hline $\mathbf{K}$ & 0,110 & 0,088 & 0,089 & $\mathbf{0 , 1 0 8}$ & 0,073 \\
\hline $\mathbf{C}$ & 0,243 & 0,145 & 0,148 & $\mathbf{0 , 1 5 8}$ & 0,138 \\
\hline $\mathbf{E}$ & 0,213 & 0,134 & 0,137 & $\mathbf{0 , 1 4 9}$ & 0,124 \\
\hline $\mathbf{H}$ & 0,168 & 0,115 & 0,118 & $\mathbf{0 , 1 3 3}$ & 0,101 \\
\hline $\mathbf{L}$ & 0,105 & 0,089 & 0,090 & $\mathbf{0 , 1 1 0}$ & 0,072 \\
\hline \hline $\mathbf{F}$ & 0,192 & 0,132 & 0,134 & $\mathbf{0 , 1 4 9}$ & 0,118 \\
\hline $\mathbf{I}$ & 0,147 & 0,113 & 0,115 & $\mathbf{0 , 1 3 2}$ & 0,097 \\
\hline $\mathbf{M}$ & 0,092 & 0,089 & 0,089 & $\mathbf{0 , 1 0 9}$ & 0,068 \\
\hline \hline $\mathbf{J}$ & 0,117 & 0,106 & 0,108 & $\mathbf{0 , 1 2 8}$ & 0,089 \\
\hline $\mathbf{N}$ & 0,059 & 0,083 & 0,083 & $\mathbf{0 , 1 0 4}$ & 0,062 \\
\hline \hline $\mathbf{O}$ & 0,017 & 0,086 & 0,084 & $\mathbf{0 , 0 9 9}$ & 0,053 \\
\hline \hline
\end{tabular}


TABELA 5.85: Momentos Fletores MX na capa, em kN.cm/cm, na laje com altura total $\mathrm{h}=50 \mathrm{~cm}$

\begin{tabular}{|c|c|c|c|c|c|}
\hline \multicolumn{6}{|c|}{$\begin{array}{c}\text { LAJE COM RELAÇÃO hf/h = 0,100 } \\
\text { MOMENTO FLETOR MX NA CAPA }(\mathrm{kN.cm} / \mathrm{cm})\end{array}$} \\
\hline \multirow{2}{*}{ Ponto } & \multicolumn{5}{|c|}{ Modelos numéricos de análise } \\
\hline & 01 & $\mathbf{0 2}$ & $\mathbf{0 3}$ & 04 & 05 \\
\hline 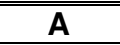 & 0,206 & 0,120 & 0,123 & 0,128 & 0,120 \\
\hline B & 0,196 & 0,117 & 0,120 & 0,128 & 0,115 \\
\hline D & 0,175 & 0,109 & 0,112 & 0,123 & 0,105 \\
\hline $\mathbf{G}$ & 0,141 & 0,096 & 0,098 & 0,112 & 0,089 \\
\hline $\mathbf{K}$ & 0,095 & 0,078 & 0,078 & 0,097 & 0,068 \\
\hline $\mathbf{C}$ & 0,190 & 0,118 & 0,121 & 0,131 & 0,114 \\
\hline$E$ & 0,168 & 0,111 & 0,113 & 0,126 & 0,104 \\
\hline $\mathbf{H}$ & 0,136 & 0,097 & 0,099 & 0,115 & 0,088 \\
\hline $\mathbf{L}$ & 0,092 & 0,080 & 0,080 & 0,100 & 0,067 \\
\hline $\bar{F}$ & 0,155 & 0,112 & 0,114 & 0,129 & 0,101 \\
\hline I & 0,123 & 0,098 & 0,100 & 0,118 & 0,086 \\
\hline $\mathbf{M}$ & 0,083 & 0,081 & 0,081 & 0,102 & 0,065 \\
\hline $\mathbf{J}$ & 0,104 & 0,097 & 0,098 & 0,119 & 0,082 \\
\hline $\mathbf{N}$ & 0,061 & 0,079 & 0,080 & 0,102 & 0,060 \\
\hline 0 & 0,028 & 0,082 & 0,080 & 0,101 & 0,053 \\
\hline
\end{tabular}

Abaixo tem-se os gráficos de momentos fletores MX atuantes na capa das lajes nervuradas processadas nesta série.

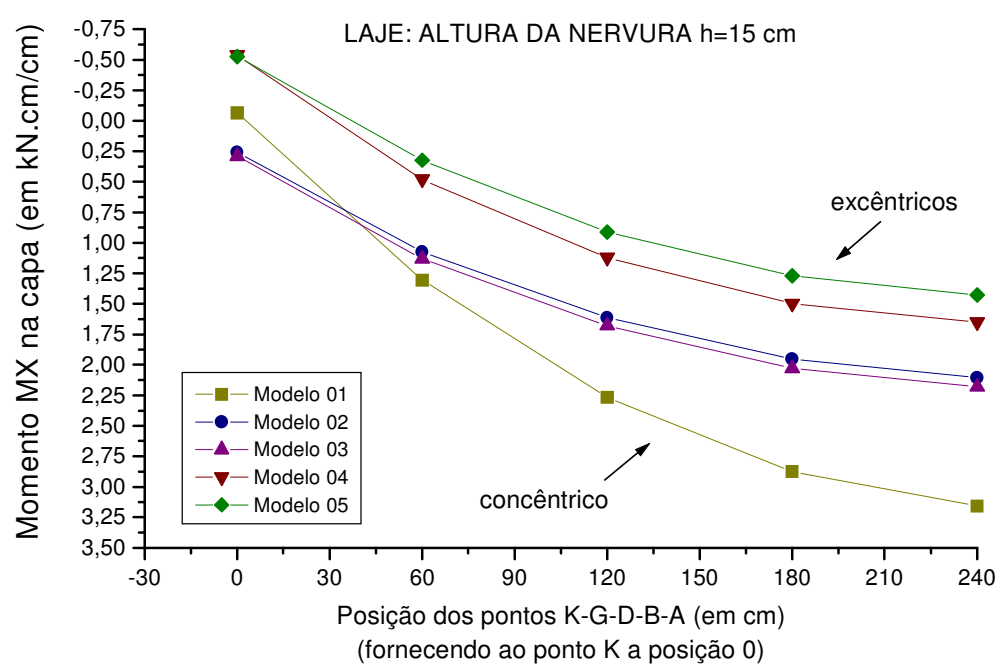

FIGURA 5.85: Momentos MX (kN.cm/cm), na linha K-G-D-B-A da capa; laje com altura $\mathrm{h}=15 \mathrm{~cm}$ 


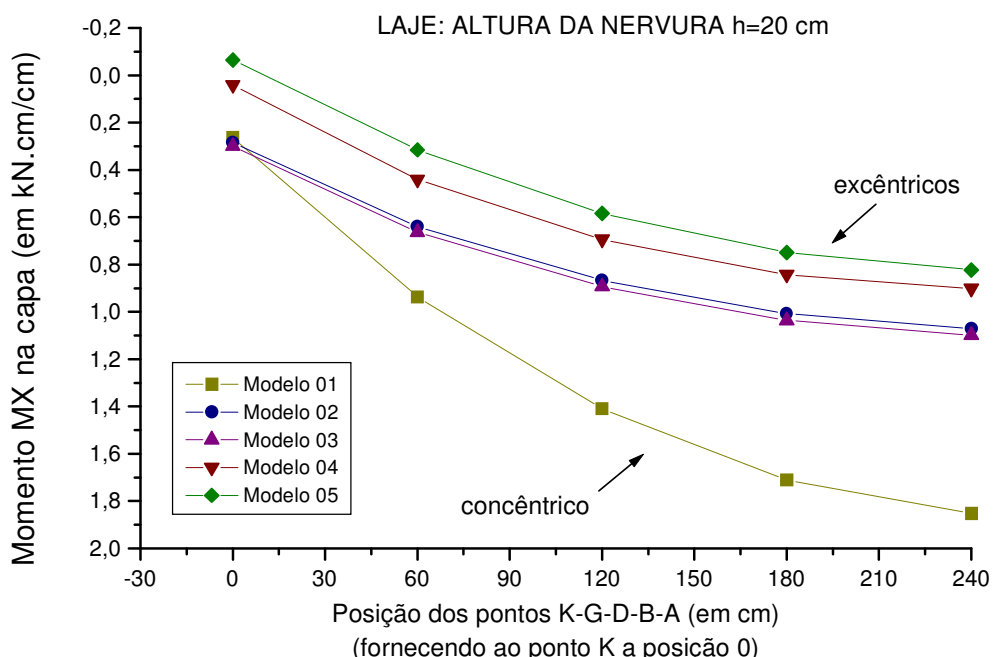

FIGURA 5.86: Momentos MX (kN.cm/cm), na linha K-G-D-B-A da capa; laje com altura h=20 cm

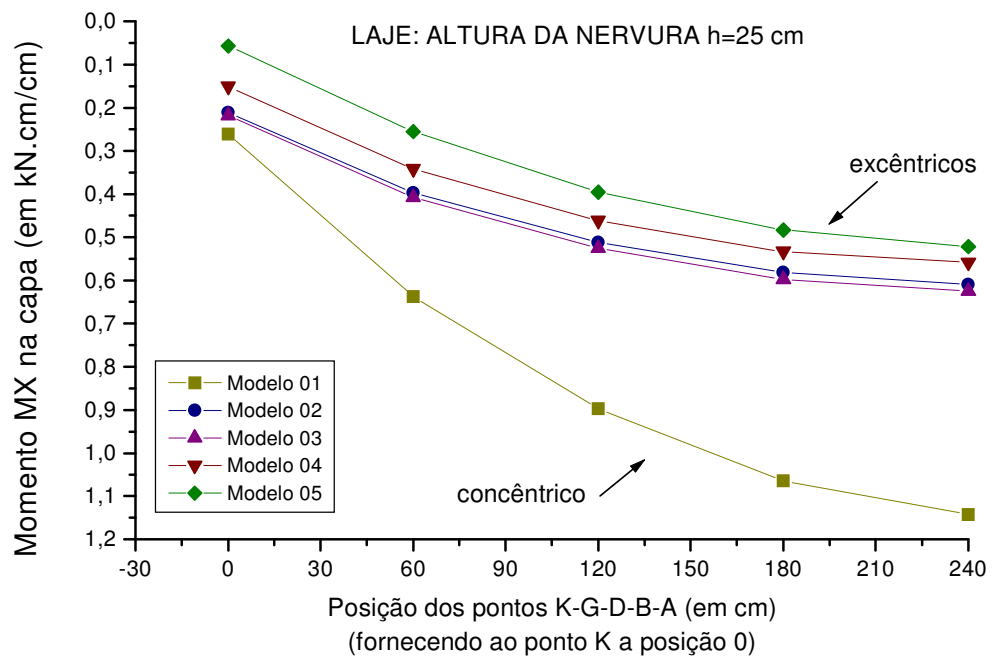

FIGURA 5.87: Momentos MX (kN.cm/cm), na linha K-G-D-B-A da capa; laje com altura $\mathrm{h}=25 \mathrm{~cm}$

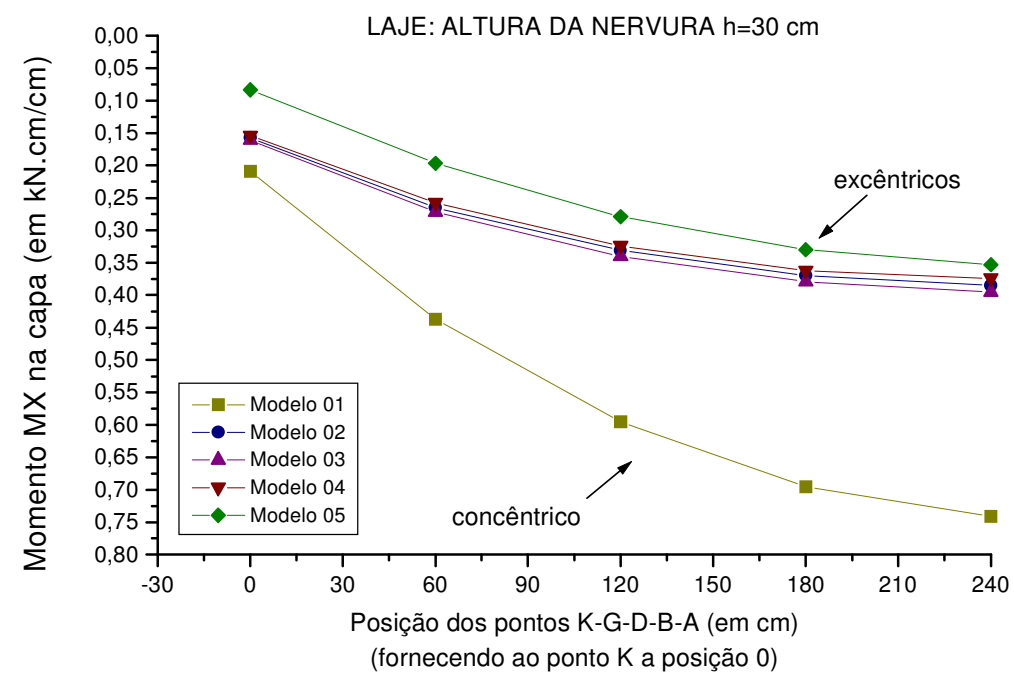

FIGURA 5.88: Momentos MX (kN.cm/cm), na linha K-G-D-B-A da capa; laje com altura $\mathrm{h}=30 \mathrm{~cm}$ 


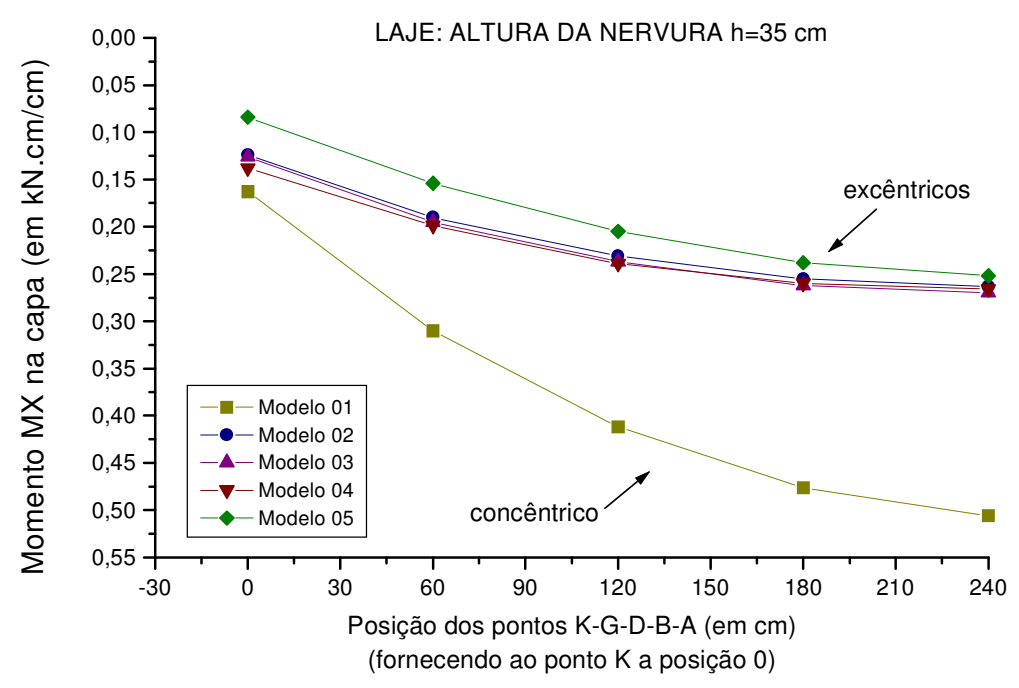

FIGURA 5.89: Momentos MX (kN.cm/cm), na linha K-G-D-B-A da capa; laje com altura h=35 cm

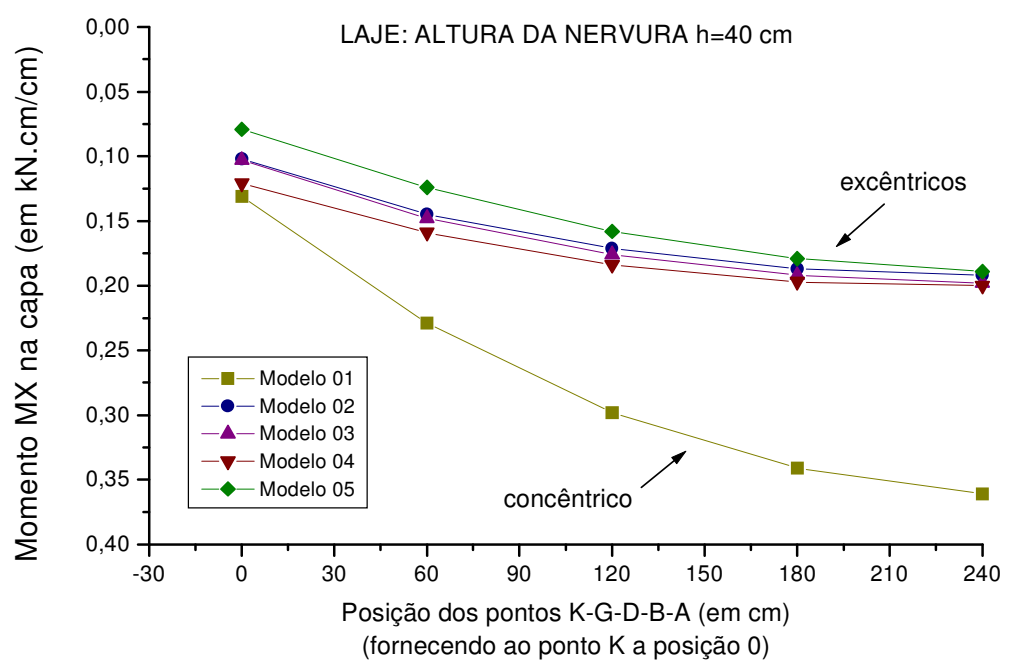

FIGURA 5.90: Momentos MX (kN.cm/cm), na linha K-G-D-B-A da capa; laje com altura $\mathrm{h}=40 \mathrm{~cm}$

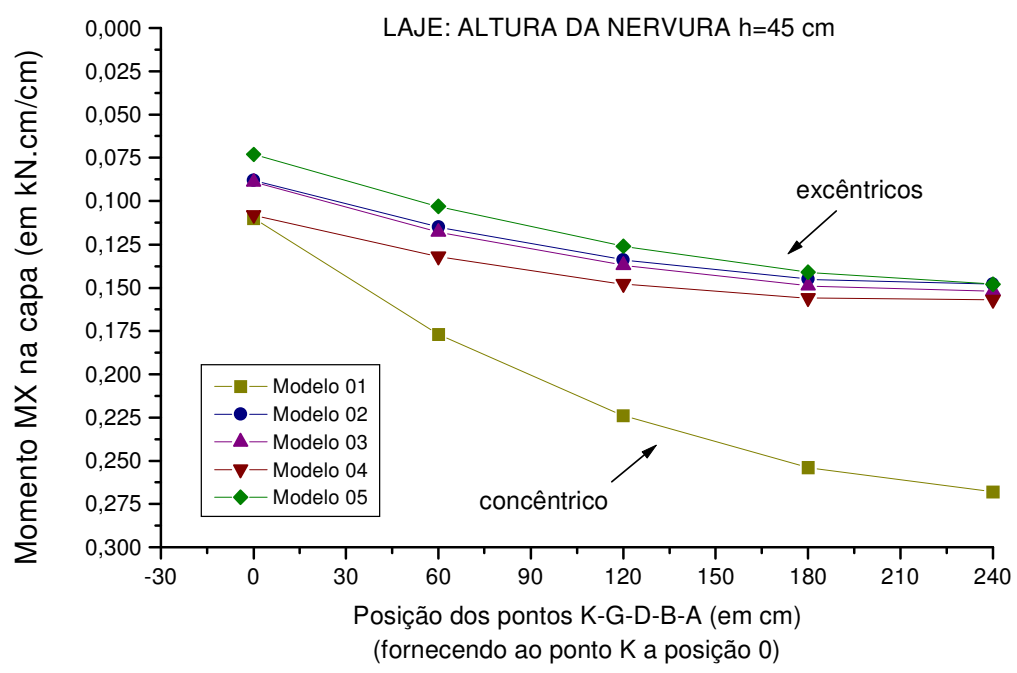

FIGURA 5.91: Momentos MX (kN.cm/cm), na linha K-G-D-B-A da capa; laje com altura h=45 cm 


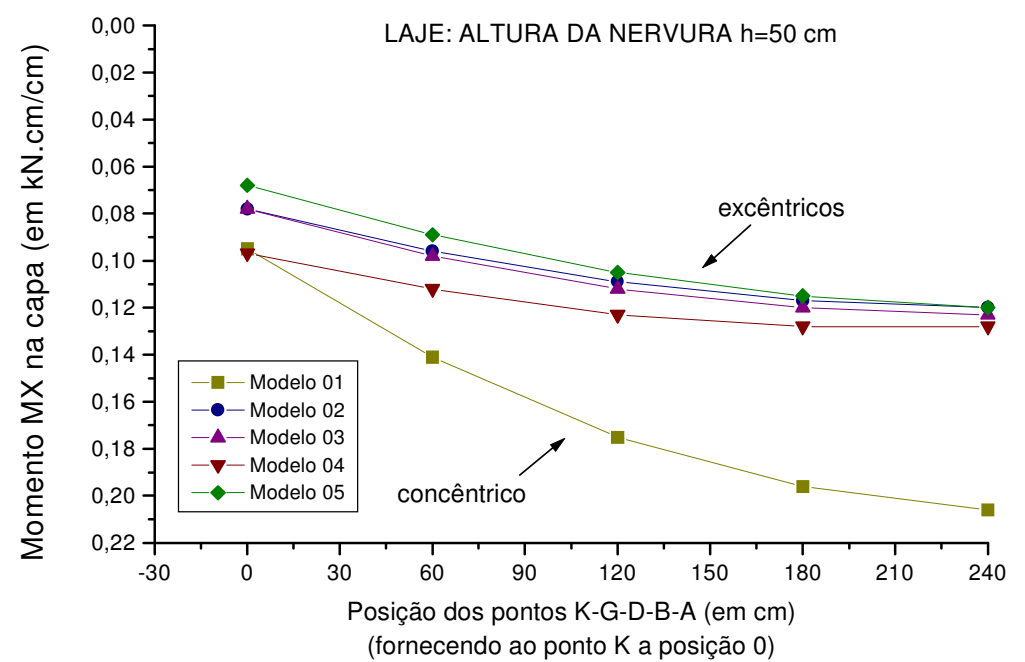

FIGURA 5.92 Momentos MX (kN.cm/cm), na linha K-G-D-B-A da capa; laje com altura $\mathrm{h}=50 \mathrm{~cm}$

Analisando-se os momentos fletores MX na capa, variando-se nos modelos a relação $h_{f} / h$, verificou-se que:

- a modelagem concêntrica apresenta valores muito maiores de momentos fletores na capa, chegando a uma diferença de $105 \%$ comparado ao modelo realista 04, para excentricidades mais baixas; à medida que aumenta-se a excentricidade, os valores de momentos ficam menores nas capas das lajes, e a diferença fica em torno de $38 \%$;

- à medida que a excentricidade entre a nervura e a capa aumenta, ou seja, quando menor for a relação $h_{f} / h$, melhores são os resultados dos momentos MX na capa dos modelos 02 e 03, ou modelos de viga excêntrica, quando comparados ao Modelo 04; para $\mathrm{h}_{\mathrm{f}} / \mathrm{h}=0,333$ tem-se uma discrepância de $32 \%$ entre os resultados de MX máximo dos modelos 03 e 04; para $\mathrm{h}_{\mathrm{f}} / \mathrm{h}=0,100$ essa diferença cai para 6,25\% entre o Modelo 02 e o Modelo 04;

- o modelo 05 apresentou resultados sempre maiores de momentos fletores MX na capa, que os resultados apresentados pelos demais modelos, isso em função da relação $a_{1} / 1=0,100$ utilizada nestas modelagens, conforme poderá ser verificado na análise da série de processamentos a seguir;

- as melhores correlações de momentos na capa, para todos os modelos simplificados, dá-se quanto tem-se maiores excentricidades. 


\subsubsection{Momentos Fletores MY atuantes na capa}

TABELA 5.86: Momentos Fletores MY na capa, em kN.cm/cm, na laje com altura total $\mathrm{h}=15 \mathrm{~cm}$

\begin{tabular}{c|c|c|c|c|c}
\hline \multicolumn{7}{c}{ LAJE COM RELAÇÃO hf/h $=\mathbf{0 , 3 3 3}$} \\
\hline \multirow{2}{*}{ Ponto } & \multicolumn{5}{c}{ MOMENTO FLETOR MY NA CAPA (kN.cm/cm) } \\
\cline { 2 - 6 } & $\mathbf{0 1}$ & $\mathbf{0 2}$ & $\mathbf{0 3}$ & $\mathbf{0 4}$ & $\mathbf{0 5}$ \\
\hline \hline $\mathbf{A}$ & 3,156 & 2,106 & 2,181 & $\mathbf{1 , 6 5 3}$ & 1,427 \\
\hline \hline $\mathbf{B}$ & 2,921 & 1,970 & 2,040 & $\mathbf{1 , 5 1 1}$ & 1,283 \\
\hline $\mathbf{C}$ & 2,645 & 1,811 & 1,879 & $\mathbf{1 , 3 6 6}$ & 1,468 \\
\hline \hline $\mathbf{D}$ & 2,420 & 1,669 & 1,731 & $\mathbf{1 , 2 1 0}$ & 0,990 \\
\hline $\mathbf{E}$ & 2,165 & 1,514 & 1,572 & $\mathbf{1 , 0 9 3}$ & 0,894 \\
\hline $\mathbf{F}$ & 1,611 & 1,174 & 1,225 & $\mathbf{0 , 8 1 5}$ & 0,670 \\
\hline \hline $\mathbf{G}$ & 1,656 & 1,201 & 1,249 & $\mathbf{0 , 7 7 8}$ & 0,587 \\
\hline $\mathbf{H}$ & 1,454 & 1,070 & 1,112 & $\mathbf{0 , 6 9 9}$ & 0,537 \\
\hline $\mathbf{I}$ & 1,004 & 0,776 & 0,809 & $\mathbf{0 , 5 1 6}$ & 0,419 \\
\hline $\mathbf{J}$ & 0,284 & 0,299 & 0,321 & $\mathbf{0 , 1 8 8}$ & 0,202 \\
\hline \hline $\mathbf{K}$ & 0,629 & 0,559 & 0,583 & $\mathbf{0 , 2 3 8}$ & 0,121 \\
\hline $\mathbf{L}$ & 0,525 & 0,530 & 0,547 & $\mathbf{0 , 2 1 0}$ & 0,117 \\
\hline $\mathbf{M}$ & 0,283 & 0,397 & 0,401 & $\mathbf{0 , 1 4 6}$ & 0,103 \\
\hline $\mathbf{N}$ & $-0,116$ & 0,117 & 0,106 & $\mathbf{0 , 0 1 5}$ & 0,070 \\
\hline $\mathbf{O}$ & $-0,639$ & $-0,294$ & $-0,320$ & $\mathbf{- 0 , 2 1 8}$ & $-0,029$ \\
\hline \hline
\end{tabular}

TABELA 5.87: Momentos Fletores MY na capa, em kN.cm/cm, na laje com altura total $\mathrm{h}=20 \mathrm{~cm}$

\begin{tabular}{c|c|c|c|c|c}
\hline \hline \multicolumn{7}{c}{ LAJE COM RELAÇÃO hf/h $=\mathbf{0 , 2 5 0}$} \\
\multicolumn{7}{c}{ MOMENTO FLETOR MY NA CAPA $(\mathbf{k N . c m} / \mathbf{c m})$} \\
\hline \multirow{2}{*}{ Ponto } & \multicolumn{7}{c}{ Modelos numéricos de análise } \\
\cline { 2 - 6 } & $\mathbf{0 1}$ & $\mathbf{0 2}$ & $\mathbf{0 3}$ & $\mathbf{0 4}$ & $\mathbf{0 5}$ \\
\hline \hline $\mathbf{A}$ & 1,852 & 1,070 & 1,099 & $\mathbf{0 , 9 0 2}$ & 0,823 \\
\hline \hline $\mathbf{B}$ & 1,732 & 1,011 & 1,038 & $\mathbf{0 , 8 4 6}$ & 0,754 \\
\hline $\mathbf{C}$ & 1,587 & 0,945 & 0,973 & $\mathbf{0 , 7 8 7}$ & 0,688 \\
\hline $\mathbf{D}$ & 1,470 & 0,876 & 0,900 & $\mathbf{0 , 7 2 0}$ & 0,611 \\
\hline $\mathbf{E}$ & 1,329 & 0,812 & 0,835 & $\mathbf{0 , 6 6 7}$ & 0,561 \\
\hline $\mathbf{F}$ & 1,025 & 0,663 & 0,685 & $\mathbf{0 , 5 3 9}$ & 0,448 \\
\hline $\mathbf{G}$ & 1,055 & 0,661 & 0,681 & $\mathbf{0 , 5 3 1}$ & 0,410 \\
\hline $\mathbf{H}$ & 0,943 & 0,608 & 0,626 & $\mathbf{0 , 4 8 9}$ & 0,379 \\
\hline $\mathbf{I}$ & 0,682 & 0,479 & 0,495 & $\mathbf{0 , 3 8 8}$ & 0,309 \\
\hline $\mathbf{J}$ & 0,263 & 0,254 & 0,267 & $\mathbf{0 , 2 1 1}$ & 0,187 \\
\hline \hline $\mathbf{K}$ & 0,478 & 0,374 & 0,387 & $\mathbf{0 , 2 7 9}$ & 0,165 \\
\hline $\mathbf{L}$ & 0,421 & 0,378 & 0,386 & $\mathbf{0 , 2 6 2}$ & 0,155 \\
\hline $\mathbf{M}$ & 0,275 & 0,333 & 0,337 & $\mathbf{0 , 2 1 2}$ & 0,133 \\
\hline $\mathbf{N}$ & 0,007 & 0,199 & 0,196 & $\mathbf{0 , 1 0 9}$ & 0,095 \\
\hline $\mathbf{O}$ & $-0,353$ & $-0,013$ & $-0,029$ & $\mathbf{- 0 , 0 4 8}$ & 0,021 \\
\hline \hline
\end{tabular}


TABELA 5.88: Momentos Fletores MY na capa, em kN.cm/cm, na laje com altura total $\mathrm{h}=25 \mathrm{~cm}$

\begin{tabular}{c|c|c|c|c|c}
\hline \multicolumn{7}{c}{ LAJE COM RELAÇÃO hf/h = 0,200 } \\
\multicolumn{7}{c}{ MOMENTO FLETOR MY NA CAPA (kN.cm/cm) } \\
\hline \multirow{2}{*}{ Ponto } & \multicolumn{7}{c}{ Modelos numéricos de análise } \\
\cline { 2 - 6 } & $\mathbf{0 1}$ & $\mathbf{0 2}$ & $\mathbf{0 3}$ & $\mathbf{0 4}$ & $\mathbf{0 5}$ \\
\hline \hline A & 1,142 & 0,610 & 0,625 & $\mathbf{0 , 5 5 9}$ & 0,522 \\
\hline \hline B & 1,073 & 0,581 & 0,596 & $\mathbf{0 , 5 3 3}$ & 0,485 \\
\hline $\mathbf{C}$ & 0,992 & 0,551 & 0,566 & $\mathbf{0 , 5 0 7}$ & 0,449 \\
\hline \hline $\mathbf{D}$ & 0,923 & 0,514 & 0,526 & $\mathbf{0 , 4 7 3}$ & 0,408 \\
\hline $\mathbf{E}$ & 0,843 & 0,485 & 0,497 & $\mathbf{0 , 4 4 7}$ & 0,379 \\
\hline $\mathbf{F}$ & 0,670 & 0,412 & 0,424 & $\mathbf{0 , 3 8 1}$ & 0,314 \\
\hline $\mathbf{G}$ & 0,682 & 0,405 & 0,415 & $\mathbf{0 , 3 7 8}$ & 0,298 \\
\hline $\mathbf{H}$ & 0,620 & 0,381 & 0,391 & $\mathbf{0 , 3 5 5}$ & 0,278 \\
\hline $\mathbf{I}$ & 0,472 & 0,320 & 0,328 & $\mathbf{0 , 2 9 8}$ & 0,233 \\
\hline $\mathbf{J}$ & 0,225 & 0,205 & 0,212 & $\mathbf{0 , 1 9 7}$ & 0,158 \\
\hline \hline $\mathbf{K}$ & 0,345 & 0,268 & 0,274 & $\mathbf{0 , 2 4 6}$ & 0,157 \\
\hline $\mathbf{L}$ & 0,315 & 0,273 & 0,276 & $\mathbf{0 , 2 3 8}$ & 0,149 \\
\hline $\mathbf{M}$ & 0,232 & 0,255 & 0,256 & $\mathbf{0 , 2 0 6}$ & 0,128 \\
\hline $\mathbf{N}$ & 0,062 & 0,188 & 0,186 & $\mathbf{0 , 1 3 7}$ & 0,095 \\
\hline $\mathbf{O}$ & $-0,182$ & 0,079 & 0,066 & $\mathbf{0 , 0 3 5}$ & 0,041 \\
\hline \hline
\end{tabular}

TABELA 5.89: Momentos Fletores MY na capa, em kN.cm/cm, na laje com altura total $\mathrm{h}=30 \mathrm{~cm}$

\begin{tabular}{c|c|c|c|c|c}
\hline \hline \multicolumn{6}{c}{ LAJE COM RELAÇÃO hf/h $=\mathbf{0 , 1 6 7}$} \\
\multicolumn{7}{c}{ MOMENTO FLETOR MY NA CAPA (kN.cm/cm) } \\
\hline \multirow{2}{*}{ Ponto } & \multicolumn{5}{c}{ Modelos numéricos de análise } \\
\cline { 2 - 6 } & $\mathbf{0 1}$ & $\mathbf{0 2}$ & $\mathbf{0 3}$ & $\mathbf{0 4}$ & $\mathbf{0 5}$ \\
\hline \hline $\mathbf{A}$ & 0,741 & 0,385 & 0,395 & $\mathbf{0 , 3 7 4}$ & 0,353 \\
\hline \hline B & 0,700 & 0,370 & 0,379 & $\mathbf{0 , 3 6 2}$ & 0,332 \\
\hline $\mathbf{C}$ & 0,651 & 0,355 & 0,364 & $\mathbf{0 , 3 5 0}$ & 0,311 \\
\hline $\mathbf{D}$ & 0,608 & 0,335 & 0,343 & $\mathbf{0 , 3 3 1}$ & 0,288 \\
\hline $\mathbf{E}$ & 0,560 & 0,320 & 0,328 & $\mathbf{0 , 3 1 9}$ & 0,270 \\
\hline $\mathbf{F}$ & 0,457 & 0,281 & 0,288 & $\mathbf{0 , 2 8 2}$ & 0,230 \\
\hline \hline $\mathbf{G}$ & 0,461 & 0,277 & 0,284 & $\mathbf{0 , 2 8 2}$ & 0,225 \\
\hline $\mathbf{H}$ & 0,426 & 0,265 & 0,271 & $\mathbf{0 , 2 7 0}$ & 0,211 \\
\hline $\mathbf{I}$ & 0,339 & 0,231 & 0,236 & $\mathbf{0 , 2 3 6}$ & 0,181 \\
\hline $\mathbf{J}$ & 0,188 & 0,166 & 0,170 & $\mathbf{0 , 1 7 5}$ & 0,132 \\
\hline \hline $\mathbf{K}$ & 0,258 & 0,209 & 0,213 & $\mathbf{0 , 2 0 9}$ & 0,142 \\
\hline $\mathbf{L}$ & 0,241 & 0,211 & 0,213 & $\mathbf{0 , 2 0 6}$ & 0,135 \\
\hline $\mathbf{M}$ & 0,192 & 0,199 & 0,199 & $\mathbf{0 , 1 8 6}$ & 0,117 \\
\hline $\mathbf{N}$ & 0,082 & 0,160 & 0,160 & $\mathbf{0 , 1 4 0}$ & 0,090 \\
\hline $\mathbf{O}$ & $-0,086$ & 0,099 & 0,090 & $\mathbf{0 , 0 7 2}$ & 0,048 \\
\hline \hline
\end{tabular}


TABELA 5.90: Momentos Fletores MY na capa, em kN.cm/cm, na laje com altura total $\mathrm{h}=35 \mathrm{~cm}$

\begin{tabular}{c|c|c|c|c|c}
\hline \multicolumn{7}{c}{ LAJE COM RELAÇÃO hf/h $=\mathbf{0 , 1 4 3}$} \\
\multicolumn{7}{c}{ MOMENTO FLETOR MY NA CAPA (kN.cm/cm) } \\
\hline \multirow{2}{*}{ Ponto } & \multicolumn{7}{c}{ Modelos numéricos de análise } \\
\cline { 2 - 6 } & $\mathbf{0 1}$ & $\mathbf{0 2}$ & $\mathbf{0 3}$ & $\mathbf{0 4}$ & $\mathbf{0 5}$ \\
\hline \hline A & 0,506 & 0,263 & 0,270 & $\mathbf{0 , 2 6 6}$ & 0,252 \\
\hline \hline B & 0,480 & 0,256 & 0,263 & $\mathbf{0 , 2 6 1}$ & 0,240 \\
\hline $\mathbf{C}$ & 0,449 & 0,248 & 0,254 & $\mathbf{0 , 2 5 5}$ & 0,226 \\
\hline \hline $\mathbf{D}$ & 0,422 & 0,238 & 0,244 & $\mathbf{0 , 2 4 7}$ & 0,215 \\
\hline $\mathbf{E}$ & 0,392 & 0,230 & 0,235 & $\mathbf{0 , 2 4 0}$ & 0,203 \\
\hline $\mathbf{F}$ & 0,327 & 0,206 & 0,211 & $\mathbf{0 , 2 1 9}$ & 0,177 \\
\hline $\mathbf{G}$ & 0,330 & 0,208 & 0,213 & $\mathbf{0 , 2 2 1}$ & 0,178 \\
\hline $\mathbf{H}$ & 0,309 & 0,200 & 0,204 & $\mathbf{0 , 2 1 5}$ & 0,168 \\
\hline $\mathbf{I}$ & 0,254 & 0,179 & 0,183 & $\mathbf{0 , 1 9 4}$ & 0,147 \\
\hline $\mathbf{J}$ & 0,158 & 0,139 & 0,142 & $\mathbf{0 , 1 5 5}$ & 0,113 \\
\hline \hline K & 0,205 & 0,175 & 0,177 & $\mathbf{0 , 1 8 2}$ & 0,129 \\
\hline $\mathbf{L}$ & 0,193 & 0,174 & 0,176 & $\mathbf{0 , 1 8 0}$ & 0,122 \\
\hline $\mathbf{M}$ & 0,161 & 0,163 & 0,164 & $\mathbf{0 , 1 6 6}$ & 0,107 \\
\hline $\mathbf{N}$ & 0,087 & 0,136 & 0,135 & $\mathbf{0 , 1 3 5}$ & 0,084 \\
\hline $\mathbf{O}$ & $-0,031$ & 0,098 & 0,093 & $\mathbf{0 , 0 8 6}$ & 0,051 \\
\hline \hline
\end{tabular}

TABELA 5.91: Momentos Fletores MY na capa, em kN.cm/cm, na laje com altura total $\mathrm{h}=40 \mathrm{~cm}$

\begin{tabular}{c|c|c|c|c|c}
\hline \multicolumn{7}{c}{ LAJE COM RELAÇÃO hf/h $=\mathbf{0 , 1 2 5}$} \\
\multicolumn{7}{c}{ MOMENTO FLETOR MY NA CAPA (kN.cm/cm) } \\
\hline \multirow{2}{*}{ Ponto } & \multicolumn{7}{c}{ Modelos numéricos de análise } \\
\cline { 2 - 6 } & $\mathbf{0 1}$ & $\mathbf{0 2}$ & $\mathbf{0 3}$ & $\mathbf{0 4}$ & $\mathbf{0 5}$ \\
\hline \hline $\mathbf{A}$ & 0,361 & 0,192 & 0,198 & $\mathbf{0 , 2 0 0}$ & 0,189 \\
\hline \hline $\mathbf{B}$ & 0,344 & 0,190 & 0,195 & $\mathbf{0 , 1 9 9}$ & 0,182 \\
\hline $\mathbf{C}$ & 0,324 & 0,184 & 0,189 & $\mathbf{0 , 1 9 6}$ & 0,173 \\
\hline \hline $\mathbf{D}$ & 0,308 & 0,181 & 0,186 & $\mathbf{0 , 1 9 3}$ & 0,168 \\
\hline $\mathbf{E}$ & 0,288 & 0,176 & 0,180 & $\mathbf{0 , 1 9 0}$ & 0,159 \\
\hline $\mathbf{F}$ & 0,245 & 0,161 & 0,164 & $\mathbf{0 , 1 7 7}$ & 0,141 \\
\hline \hline $\mathbf{G}$ & 0,250 & 0,167 & 0,171 & $\mathbf{0 , 1 8 2}$ & 0,147 \\
\hline $\mathbf{H}$ & 0,236 & 0,162 & 0,165 & $\mathbf{0 , 1 7 9}$ & 0,140 \\
\hline $\mathbf{I}$ & 0,199 & 0,147 & 0,150 & $\mathbf{0 , 1 6 5}$ & 0,124 \\
\hline $\mathbf{J}$ & 0,135 & 0,120 & 0,122 & $\mathbf{0 , 1 4 0}$ & 0,099 \\
\hline \hline $\mathbf{K}$ & 0,172 & 0,153 & 0,154 & $\mathbf{0 , 1 6 2}$ & 0,118 \\
\hline $\mathbf{L}$ & 0,163 & 0,151 & 0,152 & $\mathbf{0 , 1 6 1}$ & 0,113 \\
\hline $\mathbf{M}$ & 0,139 & 0,141 & 0,141 & $\mathbf{0 , 1 5 1}$ & 0,100 \\
\hline $\mathbf{N}$ & 0,087 & 0,119 & 0,118 & $\mathbf{0 , 1 2 9}$ & 0,079 \\
\hline $\mathbf{O}$ & 0,000 & 0,092 & 0,089 & $\mathbf{0 , 0 9 6}$ & 0,053 \\
\hline \hline
\end{tabular}


TABELA 5.92: Momentos Fletores MY na capa, em kN.cm/cm, na laje com altura total $\mathrm{h}=45 \mathrm{~cm}$

\begin{tabular}{c|c|c|c|c|c}
\hline \hline \multicolumn{6}{c}{ LAJE COM RELAÇÃO hf/h $=\mathbf{0 , 1 1 1}$} \\
\multicolumn{7}{c}{ MOMENTO FLETOR MY NA CAPA (kN.cm/cm) } \\
\hline \multirow{2}{*}{ Ponto } & \multicolumn{7}{c}{ Modelos numéricos de análise } \\
\cline { 2 - 6 } & $\mathbf{0 1}$ & $\mathbf{0 2}$ & $\mathbf{0 3}$ & $\mathbf{0 4}$ & $\mathbf{0 5}$ \\
\hline \hline $\mathbf{A}$ & 0,268 & 0,148 & 0,152 & $\mathbf{0 , 1 5 7}$ & 0,148 \\
\hline \hline $\mathbf{B}$ & 0,258 & 0,148 & 0,152 & $\mathbf{0 , 1 5 8}$ & 0,144 \\
\hline $\mathbf{C}$ & 0,243 & 0,145 & 0,148 & $\mathbf{0 , 1 5 8}$ & 0,138 \\
\hline \hline $\mathbf{D}$ & 0,235 & 0,146 & 0,149 & $\mathbf{0 , 1 5 8}$ & 0,137 \\
\hline $\mathbf{E}$ & 0,221 & 0,142 & 0,146 & $\mathbf{0 , 1 5 7}$ & 0,131 \\
\hline $\mathbf{F}$ & 0,192 & 0,132 & 0,134 & $\mathbf{0 , 1 4 9}$ & 0,118 \\
\hline $\mathbf{G}$ & 0,199 & 0,142 & 0,144 & $\mathbf{0 , 1 5 6}$ & 0,126 \\
\hline $\mathbf{H}$ & 0,188 & 0,137 & 0,140 & $\mathbf{0 , 1 5 5}$ & 0,120 \\
\hline $\mathbf{I}$ & 0,163 & 0,126 & 0,129 & $\mathbf{0 , 1 4 5}$ & 0,108 \\
\hline $\mathbf{J}$ & 0,117 & 0,106 & 0,108 & $\mathbf{0 , 1 2 8}$ & 0,089 \\
\hline \hline $\mathbf{K}$ & 0,150 & 0,137 & 0,139 & $\mathbf{0 , 1 4 7}$ & 0,111 \\
\hline $\mathbf{L}$ & 0,143 & 0,135 & 0,137 & $\mathbf{0 , 1 4 8}$ & 0,106 \\
\hline $\mathbf{M}$ & 0,124 & 0,126 & 0,126 & $\mathbf{0 , 1 4 0}$ & 0,094 \\
\hline $\mathbf{N}$ & 0,084 & 0,107 & 0,107 & $\mathbf{0 , 1 2 4}$ & 0,076 \\
\hline $\mathbf{O}$ & 0,017 & 0,086 & 0,084 & $\mathbf{0 , 0 9 9}$ & 0,053 \\
\hline \hline
\end{tabular}

TABELA 5.93: Momentos Fletores MY na capa, em kN.cm/cm, na laje com altura total $\mathrm{h}=50 \mathrm{~cm}$

\begin{tabular}{c|c|c|c|c|c}
\hline \hline \multicolumn{6}{c}{ LAJE COM RELAÇÃO hf/h $=\mathbf{0 , 1 0 0}$} \\
\multicolumn{7}{c}{ MOMENTO FLETOR MY NA CAPA (kN.cm/cm) } \\
\hline \multirow{2}{*}{ Ponto } & \multicolumn{5}{c}{ Modelos numéricos de análise } \\
\cline { 2 - 6 } & $\mathbf{0 1}$ & $\mathbf{0 2}$ & $\mathbf{0 3}$ & $\mathbf{0 4}$ & $\mathbf{0 5}$ \\
\hline \hline $\mathbf{A}$ & 0,206 & 0,120 & 0,123 & $\mathbf{0 , 1 2 8}$ & 0,120 \\
\hline \hline B & 0,200 & 0,121 & 0,124 & $\mathbf{0 , 1 3 1}$ & 0,118 \\
\hline $\mathbf{C}$ & 0,190 & 0,118 & 0,121 & $\mathbf{0 , 1 3 1}$ & 0,114 \\
\hline $\mathbf{D}$ & 0,186 & 0,123 & 0,125 & $\mathbf{0 , 1 3 4}$ & 0,115 \\
\hline $\mathbf{E}$ & 0,177 & 0,120 & 0,123 & $\mathbf{0 , 1 3 5}$ & 0,111 \\
\hline $\mathbf{F}$ & 0,155 & 0,112 & 0,114 & $\mathbf{0 , 1 2 9}$ & 0,101 \\
\hline \hline $\mathbf{G}$ & 0,165 & 0,124 & 0,126 & $\mathbf{0 , 1 3 7}$ & 0,111 \\
\hline $\mathbf{H}$ & 0,157 & 0,121 & 0,123 & $\mathbf{0 , 1 3 7}$ & 0,107 \\
\hline $\mathbf{I}$ & 0,138 & 0,112 & 0,114 & $\mathbf{0 , 1 3 1}$ & 0,097 \\
\hline $\mathbf{J}$ & 0,104 & 0,097 & 0,098 & $\mathbf{0 , 1 1 9}$ & 0,082 \\
\hline \hline K & 0,136 & 0,126 & 0,128 & $\mathbf{0 , 1 3 5}$ & 0,105 \\
\hline $\mathbf{L}$ & 0,129 & 0,124 & 0,125 & $\mathbf{0 , 1 3 7}$ & 0,100 \\
\hline $\mathbf{M}$ & 0,113 & 0,115 & 0,116 & $\mathbf{0 , 1 3 1}$ & 0,090 \\
\hline $\mathbf{N}$ & 0,081 & 0,099 & 0,099 & $\mathbf{0 , 1 1 9}$ & 0,073 \\
\hline $\mathbf{O}$ & 0,028 & 0,082 & 0,080 & $\mathbf{0 , 1 0 1}$ & 0,053 \\
\hline \hline
\end{tabular}


5.3.1.9 Esforços Normais e Momentos Fletores no topo dos pilares

TABELA 5.94: Esforço Normal, em kN, e Momentos Fletores MX e MY, em kN.cm, nos pilares da laje com altura das nervuras $\mathrm{h}=15 \mathrm{~cm}$

\begin{tabular}{|c|c|c|c|c|c|c|c|c|}
\hline \multicolumn{9}{|c|}{$\begin{array}{c}\text { LAJE COM RELAÇÃO hf/h }=0,333 \\
\text { ESFORÇO NORMAL NOS PILARES }(\mathrm{kN})\end{array}$} \\
\hline \multirow{2}{*}{ Pilares } & \multicolumn{8}{|c|}{ Modelos numéricos de análise } \\
\hline & 01 & $\mathbf{0 2}$ & 03 & 04 & 05 & 06 & 07 & 08 \\
\hline P1 A P4 & $-67,50$ & $-67,50$ & $-67,50$ & $-67,50$ & $-67,50$ & $-67,50$ & $-67,50$ & $-67,50$ \\
\hline \multicolumn{9}{|c|}{$\begin{array}{c}\text { LAJE COM RELAÇÃO hf/h }=0,333 \\
\text { MOMENTOS FLETORES MX E MY NO TOPO DOS PILARES }\end{array}$} \\
\hline \multirow{2}{*}{ Pilares } & \multicolumn{8}{|c|}{ Modelos numéricos de análise } \\
\hline & 01 & $\mathbf{0 2}$ & $\mathbf{0 3}$ & 04 & 05 & 06 & 07 & 08 \\
\hline P1 A P4 & 1821,00 & 1976,00 & 2027,00 & 2509,00 & 1454,00 & 1295,00 & 1706,00 & 1861,00 \\
\hline
\end{tabular}

TABELA 5.95: Esforço Normal, em kN, e Momentos Fletores MX e MY, em kN.cm, nos pilares da laje com altura das nervuras $\mathrm{h}=20 \mathrm{~cm}$

\begin{tabular}{|c|c|c|c|c|c|c|c|c|}
\hline \multicolumn{9}{|c|}{$\begin{array}{c}\text { LAJE COM RELAÇÃO hf/h = 0,250 } \\
\text { ESFORÇO NORMAL NOS PILARES (kN) }\end{array}$} \\
\hline \multirow{2}{*}{ Pilares } & \multicolumn{8}{|c|}{ Modelos numéricos de análise } \\
\hline & 01 & 02 & 03 & 04 & 05 & 06 & 07 & 08 \\
\hline P1 A P4 & $-67,50$ & $-67,50$ & $-67,50$ & $-67,50$ & $-67,50$ & $-67,50$ & $-67,50$ & $-67,50$ \\
\hline \multicolumn{9}{|c|}{$\begin{array}{c}\text { LAJE COM RELAÇÃO } \mathrm{hf} / \mathrm{h}=0,250 \\
\text { MOMENTOS FLETORES MX E MY NO TOPO DOS PILARES }\end{array}$} \\
\hline \multirow{2}{*}{ Pilares } & \multicolumn{8}{|c|}{ Modelos numéricos de análise } \\
\hline & 01 & $\mathbf{0 2}$ & 03 & 04 & 05 & 06 & 07 & 08 \\
\hline P1 A P4 & 1727,00 & 1887,00 & 1926,00 & 2318,00 & 1431,00 & 1360,00 & 1561,00 & 1707,00 \\
\hline
\end{tabular}

TABELA 5.96: Esforço Normal, em kN, e Momentos Fletores MX e MY, em kN.cm, nos pilares da laje com altura das nervuras $\mathrm{h}=25 \mathrm{~cm}$

\begin{tabular}{|c|c|c|c|c|c|c|c|c|}
\hline \multicolumn{9}{|c|}{$\begin{array}{c}\text { LAJE COM RELAÇÃ̃ } \mathrm{hf} / \mathrm{h}=0,200 \\
\text { ESFORÇO NORMAL NOS PILARES }(\mathrm{kN})\end{array}$} \\
\hline \multirow{2}{*}{ Pilares } & \multicolumn{8}{|c|}{ Modelos numéricos de análise } \\
\hline & 01 & 02 & 03 & 04 & 05 & 06 & 07 & 08 \\
\hline P1 A P4 & $-67,50$ & $-67,50$ & $-67,50$ & $-67,50$ & $-67,50$ & $-67,50$ & $-67,50$ & $-67,50$ \\
\hline \multicolumn{9}{|c|}{$\begin{array}{c}\text { LAJE COM RELAÇÃO hf/h }=0,200 \\
\text { MOMENTOS FLETORES MX E MY NO TOPO DOS PILARES }\end{array}$} \\
\hline \multirow{2}{*}{ Pilares } & \multicolumn{8}{|c|}{ Modelos numéricos de análise } \\
\hline & 01 & 02 & 03 & 04 & $\mathbf{0 5}$ & 06 & 07 & 08 \\
\hline P1 A P4 & 1659,00 & 1818,00 & 1850,00 & 2136,00 & 14141,00 & 1412,00 & 141458,00 & 1598,00 \\
\hline
\end{tabular}


TABELA 5.97: Esforço Normal, em kN, e Momentos Fletores MX e MY, em kN.cm, nos pilares da laje com altura das nervuras $\mathrm{h}=30 \mathrm{~cm}$

\begin{tabular}{|c|c|c|c|c|c|c|c|c|}
\hline \multicolumn{9}{|c|}{$\begin{array}{c}\text { LAJE COM RELAÇÃO hf/h }=0,167 \\
\text { ESFORÇO NORMAL NOS PILARES }(\mathrm{kN})\end{array}$} \\
\hline \multirow{2}{*}{ Pilares } & \multicolumn{8}{|c|}{ Modelos numéricos de análise } \\
\hline & 01 & $\mathbf{0 2}$ & 03 & 04 & 05 & 06 & 07 & 08 \\
\hline P1 A P4 & $-67,50$ & $-67,50$ & $-67,50$ & $-67,50$ & $-67,50$ & $-67,50$ & $-67,50$ & $-67,50$ \\
\hline \multicolumn{9}{|c|}{$\begin{array}{c}\text { LAJE COM RELAÇÃO hf/h }=0,167 \\
\text { MOMENTOS FLETORES MX E MY NO TOPO DOS PILARES (kN.cm) }\end{array}$} \\
\hline \multirow{2}{*}{ Pilares } & \multicolumn{8}{|c|}{ Modelos numéricos de análise } \\
\hline & $\mathbf{0 1}$ & 02 & $\mathbf{0 3}$ & 04 & 05 & 06 & 07 & 08 \\
\hline P1 A P4 & 1611,00 & 1767,00 & 1794,00 & 2001,00 & 1393,00 & 1443,00 & 1375,00 & 1515,00 \\
\hline
\end{tabular}

TABELA 5.98: Esforço Normal, em kN, e Momentos Fletores MX e MY, em kN.cm, nos pilares da laje com altura das nervuras $\mathrm{h}=35 \mathrm{~cm}$

\begin{tabular}{|c|c|c|c|c|c|c|c|c|}
\hline \multicolumn{9}{|c|}{$\begin{array}{l}\text { LAJE COM RELAÇÃO hf } / \mathrm{h}=0,143 \\
\text { ESFORÇO NORMAL NOS PILARES }(\mathrm{kN})\end{array}$} \\
\hline \multirow{2}{*}{ Pilares } & \multicolumn{8}{|c|}{ Modelos numéricos de análise } \\
\hline & 01 & 02 & 03 & 04 & 05 & 06 & 07 & 08 \\
\hline P1 A P4 & $-67,50$ & $-67,50$ & $-67,50$ & $-67,50$ & $-67,50$ & $-67,50$ & $-67,50$ & $-67,50$ \\
\hline \multicolumn{9}{|c|}{$\begin{array}{c}\text { LAJE COM RELAÇ̃̃O hf/h }=0,143 \\
\text { MOMENTOS FLETORES MX E MY NO TOPO DOS PILARES }(\mathrm{kN.cm})\end{array}$} \\
\hline \multirow{2}{*}{ Pilares } & \multicolumn{8}{|c|}{ Modelos numéricos de análise } \\
\hline & 01 & 02 & $\mathbf{0 3}$ & 04 & 05 & 06 & 07 & 08 \\
\hline P1 A P4 & 1574,00 & 1725,00 & 1749,00 & 1897,00 & 1375,00 & 1455,00 & 1303,00 & 1444,00 \\
\hline
\end{tabular}

TABELA 5.99: Esforço Normal, em kN, e Momentos Fletores MX e MY, em kN.cm, nos pilares da laje com altura das nervuras $\mathrm{h}=40 \mathrm{~cm}$

\begin{tabular}{|c|c|c|c|c|c|c|c|c|}
\hline \multicolumn{9}{|c|}{$\begin{array}{c}\text { LAJE COM RELAÇÃO hf/h = 0,125 } \\
\text { ESFORÇO NORMAL NOS PILARES }(\mathrm{kN})\end{array}$} \\
\hline \multirow{2}{*}{ Pilares } & \multicolumn{8}{|c|}{ Modelos numéricos de análise } \\
\hline & 01 & $\mathbf{0 2}$ & $\mathbf{0 3}$ & 04 & 05 & 06 & 07 & 08 \\
\hline P1 A P4 & $-67,50$ & $-67,50$ & $-67,50$ & $-67,50$ & $\begin{array}{l}-67,50 \\
\end{array}$ & $\begin{array}{l}-67,50 \\
\end{array}$ & $\begin{array}{l}-67,50 \\
\end{array}$ & $\begin{array}{l}-67,50 \\
\end{array}$ \\
\hline \multicolumn{9}{|c|}{$\begin{array}{c}\text { LAJE COM RELAÇÃO hf/h }=0,125 \\
\text { MOMENTOS FLETORES MX E MY NO TOPO DOS PILARES }(\mathrm{kN} . \mathrm{cm})\end{array}$} \\
\hline \multirow{2}{*}{ Pilares } & \multicolumn{8}{|c|}{ Modelos numéricos de análise } \\
\hline & 01 & $\mathbf{0 2}$ & $\mathbf{0 3}$ & 04 & 05 & 06 & $\mathbf{0 7}$ & 08 \\
\hline P1 A P4 & 1545,00 & 1686,00 & 17708,00 & 1814,00 & 1355,00 & 1452,00 & 1234,00 & 1379,00 \\
\hline
\end{tabular}


TABELA 5.100: Esforço Normal, em kN, e Momentos Fletores MX e MY, em kN.cm, nos pilares da laje com altura das nervuras $\mathrm{h}=45 \mathrm{~cm}$

\begin{tabular}{|c|c|c|c|c|c|c|c|c|}
\hline \multicolumn{9}{|c|}{$\begin{array}{c}\text { LAJE COM RELAÇÃO hf/h = 0,111 } \\
\text { ESFORÇO NORMAL NOS PILARES }(\mathbf{k N})\end{array}$} \\
\hline \multirow{2}{*}{ Pilares } & \multicolumn{8}{|c|}{ Modelos numéricos de análise } \\
\hline & 01 & 02 & 03 & 04 & 05 & 06 & 07 & 08 \\
\hline P1 A P4 & $-67,50$ & $-67,50$ & $-67,50$ & $-67,50$ & $-67,50$ & $-67,50$ & $-67,50$ & $-67,50$ \\
\hline \multicolumn{9}{|c|}{$\begin{array}{l}\text { LAJE COM RELAÇÃO hf/h = 0,111 } \\
\text { MOMENTOS FLETORES MX E MY NO TOPO DOS }\end{array}$} \\
\hline \multirow{2}{*}{ Pilares } & \multicolumn{8}{|c|}{ Modelos numéricos de análise } \\
\hline & 01 & $\mathbf{0 2}$ & 03 & 04 & 05 & 06 & 07 & 08 \\
\hline P1 A P4 & 1518,00 & 1648,00 & 1668,00 & 1743,00 & 1334,00 & 1440,00 & 1167,00 & 1317,00 \\
\hline
\end{tabular}

TABELA 5.101: Esforço Normal, em kN, e Momentos Fletores MX e MY, em kN.cm, nos pilares da laje com altura das nervuras $\mathrm{h}=50 \mathrm{~cm}$

\begin{tabular}{|c|c|c|c|c|c|c|c|c|}
\hline \multicolumn{9}{|c|}{$\begin{array}{c}\text { LAJE COM RELAÇÃO hf/h = 0,100 } \\
\text { ESFORÇO NORMAL NOS PILARES }(\mathrm{kN})\end{array}$} \\
\hline \multirow{2}{*}{ Pilares } & \multicolumn{8}{|c|}{ Modelos numéricos de análise } \\
\hline & 01 & 02 & 03 & 04 & 05 & 06 & 07 & 08 \\
\hline P1 A P4 & $-67,50$ & $-67,50$ & $-67,50$ & $-67,50$ & $-67,50$ & $-67,50$ & $-67,50$ & $-67,50$ \\
\hline \multicolumn{9}{|c|}{$\begin{array}{c}\text { LAJE COM RELAÇÃO hf } / \mathrm{h}=0,100 \\
\text { MOMENTOS FLETORES MX E MY NO TOPO DOS PILARES }\end{array}$} \\
\hline \multirow{2}{*}{ Pilares } & \multicolumn{8}{|c|}{$\begin{array}{l}\text { Modelos numéricos de análise } \\
\end{array}$} \\
\hline & 01 & $\mathbf{0 2}$ & $\mathbf{0 3}$ & 04 & 05 & 06 & 07 & 08 \\
\hline P1 A P4 & 1493,00 & 1608,00 & 161626,00 & 1679,00 & 1310,00 & 141421,00 & 11101,00 & 1255,00 \\
\hline
\end{tabular}




\subsubsection{Resultados apresentados nas modelagens das lajes com variação da relação $a_{1} / l$}

As tabelas de resultados serão apresentadas na seguinte ordem:

a) Tabelas de Deslocamentos Ortogonais ao Plano da Placa, em cm, para as lajes com número de nervuras por lado variando de 5 a 15 nervuras;

b) Tabelas de Momentos Fletores nas Nervuras e Vigas, em kN.cm;

c) Tabelas de Esforços Normais nas Nervuras e Vigas, em kN;

d) Tabelas de Tensões Normais nas Fibras Superiores Extremas das Nervuras e Vigas, em $\mathrm{kN} / \mathrm{cm}^{2}$;

e) Tabelas de Tensões Normais nas Fibras Inferiores Extremas das Nervuras e Vigas, em $\mathrm{kN} / \mathrm{cm}^{2}$;

f) Tabelas de Esforços Cortantes nas Nervuras e Vigas, em kN;

g) Tabelas de Momentos Fletores MY na capa, em kN.cm/cm;

h) Tabelas de Momentos Fletores MX na capa, em kN.cm/cm;

i) Tabelas de Esforços Normais e Momentos Fletores no topo dos Pilares, em $\mathrm{kN}$ e kN.cm, respectivamente.

Gráficos relevantes são também montados, para mostrar com mais clareza o comportamento das lajes, e as respostas de deslocamentos e esforços.

Também apresentam-se comentários sobre os resultados encontrados, nesta série de processamentos, tomando-se sempre como valores de referências os resultados apresentados pelo Modelo 04, considerado aqui como o que apresenta melhores resultados numéricos frente ao comportamento real dos pavimentos em lajes nervuradas, conforme revisão da bibliografia e resultados de ensaios realizados. 


\subsubsection{Deslocamentos ortogonais ao plano da placa}

TABELA 5.102: Deslocamentos ortogonais ao plano da placa, em $\mathrm{cm}$, na laje com 05 nervuras por lado

\begin{tabular}{|c|c|c|c|c|c|c|c|c|}
\hline \multicolumn{9}{|c|}{$\begin{array}{c}\text { LAJE COM RELAÇÃ̃ a1/l=0,1667 } \\
\text { DESLOCAMENTOS ORTOGONAIS AO PLANO DA PLACA }(\mathrm{cm})\end{array}$} \\
\hline \multirow{2}{*}{ Ponto } & \multicolumn{8}{|c|}{ Modelos numéricos de análise } \\
\hline & 01 & 02 & 03 & 04 & 05 & 06 & 07 & 08 \\
\hline 1 & $-0,0328$ & $-0,0350$ & $-0,0356$ & $-0,0452$ & $-0,0286$ & $-0,0306$ & $-0,0299$ & $-0,0326$ \\
\hline 2 & $-0,1800$ & $-0,1216$ & $-0,1251$ & $-0,1113$ & $-0,0955$ & $-0,1020$ & $-0,0946$ & $-0,1229$ \\
\hline 3 & $-0,2880$ & $-0,1836$ & $-0,1891$ & $-0,1627$ & $-0,1467$ & $-0,1568$ & $-0,1411$ & $-0,1894$ \\
\hline 4 & $-0,3272$ & $-0,2059$ & $-0,2121$ & $-0,1816$ & $-0,1655$ & $-0,1769$ & $-0,1578$ & $-0,2135$ \\
\hline 5 & $-0,0283$ & $-0,0301$ & $-0,0305$ & $-0,0388$ & $-0,0248$ & $-0,0264$ & $-0,0259$ & $-0,0282$ \\
\hline 6 & $-0,1560$ & $-0,1071$ & $-0,1101$ & $-0,0984$ & $-0,0845$ & $-0,0901$ & $-0,0835$ & $-0,1078$ \\
\hline 7 & $-0,2525$ & $-0,1632$ & $-0,1681$ & $-0,1453$ & $-0,1300$ & $-0,1389$ & $-0,1257$ & $-0,1677$ \\
\hline 8 & $-0,2880$ & $-0,1836$ & $-0,1891$ & $-0,1627$ & $-0,1467$ & $-0,1568$ & $-0,1411$ & $-0,1894$ \\
\hline 99 & $-0,0166$ & $-0,0174$ & $-0,0176$ & $-0,0223$ & $-0,0149$ & $-0,0155$ & $-0,0154$ & $-0,0167$ \\
\hline 10 & $-0,0923$ & $-0,0676$ & $-0,0694$ & $-0,0639$ & $-0,0543$ & $-0,0578$ & $-0,0533$ & $-0,0670$ \\
\hline 11 & $-0,1560$ & $-0,1071$ & $-0,1101$ & $-0,0984$ & $-0,0845$ & $-0,0901$ & $-0,0835$ & $-0,1078$ \\
\hline 12 & $-0,1800$ & $-0,1216$ & $-0,1251$ & $-0,1113$ & $-0,0955$ & $-0,1020$ & $-0,0946$ & $-0,1229$ \\
\hline 13 & $-0,0036$ & $-0,0036$ & $-0,0036$ & $-0,0034$ & $-0,0036$ & $-0,0036$ & $-0,0036$ & $-0,0036$ \\
\hline 14 & $-0,0166$ & $-0,0174$ & $-0,0176$ & $-0,0222$ & $-0,0149$ & $-0,0155$ & $-0,0154$ & $-0,0167$ \\
\hline 15 & $-0,0283$ & $-0,0301$ & $-0,0305$ & $-0,0387$ & $-0,0248$ & $-0,0264$ & $-0,0259$ & $-0,0282$ \\
\hline 16 & $-0,0328$ & $-0,0350$ & $-0,0356$ & $-0,0450$ & $-0,0286$ & $-0,0306$ & $-0,0299$ & $-0,0326$ \\
\hline
\end{tabular}

TABELA 5.103: Deslocamentos ortogonais ao plano da placa, em cm, na laje com 06 nervuras por lado

\section{LAJE COM RELAÇ̃̃ O a1/l=0,1429}

DESLOCAMENTOS ORTOGONAIS AO PLANO DA PLACA (cm)

\begin{tabular}{|c|c|c|c|c|c|c|c|c|}
\hline \multirow{2}{*}{ Ponto } & \multicolumn{8}{|c|}{ Modelos numéricos de análise } \\
\hline & 01 & 02 & 03 & 04 & 05 & 06 & 07 & 08 \\
\hline 1 & $\begin{array}{c}-0,0481 \\
\end{array}$ & $-0,0522$ & $-0,0531$ & $-0,0657$ & $-0,0405$ & $-0,0427$ & $-0,0442$ & $-0,0479$ \\
\hline 2 & $-0,2804$ & $-0,1894$ & $-0,1947$ & $-0,1689$ & $-0,1407$ & $-0,1512$ & $-0,1481$ & $-0,1913$ \\
\hline 3 & $-0,4681$ & $-0,2974$ & $-0,3060$ & $-0,2571$ & $-0,2262$ & $-0,2439$ & $-0,2300$ & $-0,3073$ \\
\hline 4 & $-0,5716$ & $-0,3562$ & $-0,3667$ & $-0,3065$ & $-0,2742$ & $-0,2959$ & $-0,2747$ & $-0,3709$ \\
\hline 5 & $-0,5855$ & $-0,3642$ & $-0,3748$ & $-0,3135$ & $-0,2810$ & - & $-0,2804$ & $-0,3791$ \\
\hline 6 & $-0,0469$ & $-0,0509$ & $-0,0518$ & $-0,0644$ & $-0,0396$ & $-0,0417$ & $-0,0431$ & $-0,0467$ \\
\hline 7 & $-0,2731$ & $-0,1849$ & $-0,1901$ & $-0,1650$ & $-0,1375$ & $-0,1478$ & $-0,1448$ & $-0,1868$ \\
\hline 8 & $-0,4568$ & $-0,2909$ & $-0,2993$ & $-0,2516$ & $-0,2212$ & $-0,2385$ & $-0,2251$ & $-0,3004$ \\
\hline 9 & $-0,5584$ & $-0,3488$ & $-0,3590$ & $-0,3002$ & $-0,2681$ & $-0,2893$ & $-0,2690$ & $-0,3629$ \\
\hline 10 & $-0,5716$ & $-0,3562$ & $-0,3667$ & $-0,3065$ & $-0,2742$ & $-0,2959$ & $-0,2747$ & $-0,3709$ \\
\hline$\overline{111}$ & $-0,0219$ & $-0,0232$ & $-0,0235$ & $-0,0288$ & $-0,0193$ & $-0,0196$ & $-0,0204$ & $-0,0219$ \\
\hline 12 & $-0,1218$ & $-0,0905$ & $-0,0929$ & $-0,0844$ & $-0,0701$ & $-0,0750$ & $-0,0722$ & $-0,0897$ \\
\hline 13 & $-0,2174$ & $-0,1509$ & $-0,1551$ & $-0,1357$ & $-0,1133$ & $-0,1218$ & $-0,1186$ & $-0,1517$ \\
\hline 14 & $-0,2731$ & $-0,1849$ & $-0,1901$ & $-0,1650$ & $-0,1375$ & $-0,1478$ & $-0,1448$ & $-0,1868$ \\
\hline 15 & $-0,2804$ & $-0,1894$ & $-0,1947$ & $-0,1689$ & $-0,1407$ & $-0,1512$ & $-0,1481$ & $-0,1913$ \\
\hline 16 & $\begin{array}{c}-0,0049 \\
\end{array}$ & $-0,0049$ & $-0,0049$ & $-0,0045$ & $-0,0049$ & $-0,0049$ & $-0,0049$ & -0.0049 \\
\hline 17 & $-0,0219$ & $-0,0232$ & $-0,0235$ & $-0,0288$ & $-0,0193$ & $-0,0196$ & $-0,0204$ & $-0,0219$ \\
\hline 18 & $-0,0377$ & $-0,0406$ & $-0,0413$ & $-0,0511$ & $-0,0322$ & $-0,0336$ & $-0,0347$ & $-0,0376$ \\
\hline 19 & $-0,0469$ & $-0,0509$ & $-0,0518$ & $-0,0641$ & $-0,0396$ & $-0,0417$ & $-0,0431$ & $-0,0467$ \\
\hline 20 & $-0,0481$ & $-0,0522$ & $-0,0531$ & $-0,0658$ & $-0,0405$ & $-0,0428$ & $-0,0442$ & $-0,0479$ \\
\hline
\end{tabular}


TABELA 5.104: Deslocamentos ortogonais ao plano da placa, em cm, na laje com 07 nervuras por lado

\begin{tabular}{|c|c|c|c|c|c|c|c|c|}
\hline \multicolumn{9}{|c|}{$\begin{array}{c}\text { LAJE COM RELAÇÃO a1/l=0,1250 } \\
\text { DESLOCAMENTOS ORTOGONAIS AO PLANO DA PLACA }(\mathrm{cm})\end{array}$} \\
\hline \multirow{2}{*}{ Ponto } & \multicolumn{8}{|c|}{ Modelos numéricos de análise } \\
\hline & 01 & $\mathbf{0 2}$ & 03 & 04 & 05 & 06 & 07 & 08 \\
\hline 1 & $-0,0670$ & $-0,0739$ & $-0,0754$ & $-0,0921$ & $-0,0546$ & $-0,0566$ & $-0,0617$ & $-0,0666$ \\
\hline 2 & $-0,4106$ & $-0,2776$ & $-0,2854$ & $-0,2422$ & $-0,1952$ & $-0,2111$ & $-0,2179$ & $-0,2801$ \\
\hline 3 & $-0,7056$ & $-0,4481$ & $-0,4610$ & $-0,3794$ & $-0,3243$ & $-0,3525$ & $-0,3483$ & $-0,4631$ \\
\hline 4 & $-0,9019$ & $-0,5600$ & $-0,5763$ & $-0,4726$ & $-0,4125$ & $-0,4490$ & $-0,4338$ & $-0,5841$ \\
\hline 5 & $-0,9706$ & $-0,5989$ & $-0,6163$ & $-0,5053$ & $-0,4436$ & $-0,4830$ & $-0,4635$ & $-0,6263$ \\
\hline 6 & $-0,0474$ & $-0,0523$ & $-0,0532$ & $-0,0648$ & $-0,0399$ & $-0,0409$ & $-0,0443$ & $-0,0477$ \\
\hline 7 & $-0,2841$ & $-0,1995$ & $-0,2051$ & $-0,1766$ & $-0,1432$ & $-0,1548$ & $-0,1579$ & $-0,2003$ \\
\hline 8 & $-0,5019$ & $-0,3295$ & $-0,3391$ & $-0,2817$ & $-0,2377$ & $-0,2582$ & $-0,2578$ & $-0,3380$ \\
\hline 9 & $-0,6523$ & $-0,4173$ & $-0,4294$ & $-0,3539$ & $-0,3018$ & $-0,3280$ & $-0,3248$ & $-0,4306$ \\
\hline 10 & $-0,7056$ & $-0,4481$ & $-0,4610$ & $-0,3794$ & $-0,3243$ & $-0,3525$ & $-0,3483$ & $-0,4631$ \\
\hline 11 & $-0,0277$ & $-0,0297$ & $-0,0302$ & $-0,0362$ & $-0,0240$ & $-0,0241$ & $-0,0258$ & $-0,0277$ \\
\hline 12 & $-0,1530$ & $-0,1155$ & $-0,1186$ & $-0,1068$ & $-0,0865$ & $-0,0930$ & $-0,0927$ & $-0,1144$ \\
\hline 13 & $-0,2841$ & $-0,1995$ & $-0,2051$ & $-0,1766$ & $-0,1432$ & $-0,1548$ & $-0,1579$ & $-0,2003$ \\
\hline 14 & $-0,3774$ & $-0,2573$ & $-0,2646$ & $-0,2251$ & $-0,1817$ & $-0,1965$ & $-0,2024$ & $-0,2594$ \\
\hline 15 & $-0,4106$ & $-0,2776$ & $-0,2854$ & $-0,2422$ & $-0,1952$ & $-0,2111$ & $-0,2179$ & $-0,2801$ \\
\hline 16 & $-0,0064$ & $-0,0064$ & $-0,0064$ & $-0,0058$ & $-0,0064$ & $-0,0064$ & $-0,0064$ & $-0,0064$ \\
\hline 17 & $-0,0277$ & $-0,0297$ & $-0,0302$ & $-0,0361$ & $-0,0240$ & $-0,0241$ & $-0,0258$ & $-0,0277$ \\
\hline 18 & $-0,0479$ & $-0,0523$ & $-0,0532$ & $-0,0646$ & $-0,0399$ & $-0,0409$ & $-0,0443$ & $-0,0477$ \\
\hline 19 & $-0,0620$ & $-0,0682$ & $-0,0695$ & $-0,0845$ & $-0,0507$ & $-0,0525$ & $-0,0571$ & $-0,0616$ \\
\hline 20 & $-0,0670$ & $-0,0739$ & $-0,0754$ & $-0,0917$ & $-0,0546$ & $-0,0566$ & $-0,0617$ & $-0,0666$ \\
\hline
\end{tabular}


TABELA 5.105: Deslocamentos ortogonais ao plano da placa, em $\mathrm{cm}$, na laje com 08 nervuras por lado

\begin{tabular}{|c|c|c|c|c|c|c|c|c|}
\hline \multicolumn{9}{|c|}{$\begin{array}{c}\text { LAJE COM RELAÇÃO a1/l=0,1111 } \\
\text { DESLOCAMENTOS ORTOGONAIS AO PLANO DA PLACA }(\mathrm{cm})\end{array}$} \\
\hline \multirow{2}{*}{ Ponto } & \multicolumn{8}{|c|}{ Modelos numéricos de análise } \\
\hline & 01 & 02 & $\mathbf{0 3}$ & 04 & 05 & 06 & 07 & 08 \\
\hline 1 & $-0,0893$ & $-0,1001$ & $-0,1023$ & $-0,1228$ & $-0,0705$ & $-0,0719$ & $-0,0824$ & $-0,0886$ \\
\hline 2 & $-0,5737$ & $-0,3887$ & $-0,3998$ & $-0,3332$ & $-0,2591$ & $-0,2820$ & $-0,3058$ & $-0,3915$ \\
\hline 3 & $-1,0069$ & $-0,6403$ & $-0,6588$ & $-0,5329$ & $-0,4414$ & $-0,4836$ & $-0,4995$ & $-0,6614$ \\
\hline 4 & $-1,3279$ & $-0,8240$ & $-0,8479$ & $-0,6842$ & $-0,5811$ & $-0,6376$ & $-0,6406$ & $-0,8601$ \\
\hline 5 & $-1,4981$ & $-0,9206$ & $-0,9473$ & $-0,7651$ & $-0,6561$ & $-0,7203$ & $-0,7148$ & $-0,9649$ \\
\hline 6 & $-1,5203$ & $-0,9333$ & $-0,9603$ & $-0,7762$ & $-0,6662$ & - & $-0,7242$ & $-0,9782$ \\
\hline 7 & $-0,0880$ & $-0,0986$ & $-0,1007$ & $-0,1214$ & $-0,0695$ & $-0,0709$ & $-0,0812$ & $-0,0873$ \\
\hline 8 & $-0,5642$ & $-0,3829$ & $-0,3938$ & $-0,3283$ & $-0,2555$ & $-0,2780$ & $-0,3013$ & $-0,3856$ \\
\hline 9 & $-0,9912$ & $-0,6312$ & $-0,6495$ & $-0,5254$ & $-0,4351$ & $-0,4767$ & $-0,4926$ & $-0,6519$ \\
\hline 10 & $-1,3083$ & $-0,8128$ & $-0,8364$ & $-0,6749$ & $-0,5727$ & $-0,6285$ & $-0,6321$ & $-0,8482$ \\
\hline 11 & $-1,4766$ & $-0,9084$ & $-0,9348$ & $-0,7549$ & $-0,6466$ & $-0,7098$ & $-0,7055$ & $-0,9517$ \\
\hline 12 & $-1,4981$ & $-0,9206$ & $-0,9473$ & $-0,7651$ & $-0,6561$ & $-0,7203$ & $-0,7148$ & $-0,9649$ \\
\hline 13 & $-0,0589$ & $-0,0649$ & $-0,0663$ & $-0,0793$ & $-0,0479$ & $-0,0482$ & $-0,0544$ & $-0,0584$ \\
\hline 14 & $-0,3547$ & $-0,2523$ & $-0,2594$ & $-0,2207$ & $-0,1737$ & $-0,1888$ & $-0,2006$ & $-0,2527$ \\
\hline 15 & $-0,6444$ & $-0,4274$ & $-0,4400$ & $-0,3603$ & $-0,2945$ & $-0,3223$ & $-0,3363$ & $-0,4379$ \\
\hline 16 & $-0,8695$ & $-0,5603$ & $-0,5766$ & $-0,4677$ & $-0,3862$ & $-0,4230$ & $-0,4384$ & $-0,5777$ \\
\hline 17 & $-0,9912$ & $-0,6312$ & $-0,6495$ & $-0,5254$ & $-0,4351$ & $-0,4767$ & $-0,4926$ & $-0,6519$ \\
\hline 18 & $-1,0069$ & $-0,6403$ & $-0,6588$ & $-0,5329$ & $-0,4414$ & $-0,4836$ & $-0,4995$ & $-0,6614$ \\
\hline 19 & $-0,0341$ & $-0,0369$ & $-0,0375$ & $-0,0442$ & $-0,0290$ & $-0,0287$ & $-0,0317$ & $-0,0339$ \\
\hline 20 & $-0,1857$ & $-0,1422$ & $-0,1460$ & $-0,1308$ & $-0,1032$ & $-0,1116$ & $-0,1147$ & $-0,1404$ \\
\hline 21 & $-0,3547$ & $-0,2523$ & $-0,2594$ & $-0,2207$ & $-0,1737$ & $-0,1888$ & $-0,2006$ & $-0,2527$ \\
\hline 22 & $-0,4905$ & $-0,3375$ & $-0,3471$ & $-0,2907$ & $-0,2270$ & $-0,2470$ & $-0,2664$ & $-0,3394$ \\
\hline 23 & $-0,5642$ & $-0,3829$ & $-0,3938$ & $-0,3283$ & $-0,2555$ & $-0,2780$ & $-0,3013$ & $-0,3856$ \\
\hline 24 & $-0,5737$ & $-0,3887$ & $-0,3998$ & $-0,3332$ & $-0,2591$ & $-0,2820$ & $-0,3058$ & $-0,3915$ \\
\hline 25 & $-0,0080$ & $-0,0080$ & $-0,0080$ & $-0,0073$ & $-0,0080$ & $-0,0080$ & $-0,0080$ & $-0,0080$ \\
\hline 26 & $-0,0341$ & $-0,0369$ & $-0,0375$ & $-0,0440$ & $-0,0290$ & $-0,0287$ & $-0,0317$ & $-0,0339$ \\
\hline 27 & $-0,0589$ & $-0,0649$ & $-0,0663$ & $-0,0790$ & $-0,0479$ & $-0,0482$ & $-0,0544$ & $-0,0584$ \\
\hline 28 & $-0,0778$ & $-0,0867$ & $-0,0886$ & $-0,1062$ & $-0,0620$ & $-0,0630$ & $-0,0718$ & $-0,0771$ \\
\hline 29 & $-0,0880$ & $-0,0986$ & $-0,1007$ & $-0,1210$ & $-0,0695$ & $-0,0709$ & $-0,0812$ & $-0,0873$ \\
\hline 30 & $-0,0893$ & $-0,1001$ & $-0,1023$ & $-0,1228$ & $-0,0705$ & $-0,0719$ & $-0,0824$ & $-0,0886$ \\
\hline
\end{tabular}


TABELA 5.106: Deslocamentos ortogonais ao plano da placa, em $\mathrm{cm}$, na laje com 09 nervuras por lado

\begin{tabular}{|c|c|c|c|c|c|c|c|c|}
\hline \multicolumn{9}{|c|}{$\begin{array}{c}\text { LAJE COM RELAÇÃO a1/l=0,1000 } \\
\text { DESLOCAMENTOS ORTOGONAIS AO PLANO DA PLACA }(\mathrm{cm})\end{array}$} \\
\hline \multirow{2}{*}{ Ponto } & \multicolumn{8}{|c|}{ Modelos numéricos de análise } \\
\hline & 01 & $\mathbf{0 2}$ & 03 & 04 & 05 & 06 & 07 & 08 \\
\hline 1 & $-0,1150$ & $-0,1308$ & $-0,1341$ & $-0,1596$ & $-0,0881$ & $-0,0883$ & $-0,1062$ & $-0,1138$ \\
\hline 2 & $-0,7725$ & $-0,5245$ & $-0,5398$ & $-0,4425$ & $-0,3325$ & $-0,3639$ & $-0,4134$ & $-0,5278$ \\
\hline 3 & $-1,3778$ & $-0,8779$ & $-0,9037$ & $-0,7195$ & $-0,5776$ & $-0,6375$ & $-0,6872$ & $-0,9068$ \\
\hline 4 & $-1,8586$ & $-1,1543$ & $-1,1881$ & $-0,9450$ & $-0,7805$ & $-0,8629$ & $-0,9007$ & $-1,2059$ \\
\hline 5 & $-2,1665$ & $-1,3296$ & $-1,3685$ & $-1,0909$ & $-0,9126$ & $-1,0095$ & $-1,0359$ & $-1,3961$ \\
\hline 6 & $-2,2723$ & $-1,3897$ & $-1,4303$ & $-1,1412$ & $-0,9584$ & $-1,0602$ & $-1,0822$ & $-1,4613$ \\
\hline 7 & $-0,0942$ & $-0,1062$ & $-0,1088$ & $-0,1291$ & $-0,0733$ & $-0,0731$ & $-0,0869$ & $-0,0931$ \\
\hline 8 & $-0,6105$ & $-0,4242$ & $-0,4365$ & $-0,3608$ & $-0,2730$ & $-0,2986$ & $-0,3360$ & $-0,4257$ \\
\hline 9 & $-1,1044$ & $-0,7176$ & $-0,7389$ & $-0,5910$ & $-0,4727$ & $-0,5217$ & $-0,5642$ & $-0,7395$ \\
\hline 10 & $-1,5068$ & $-0,9519$ & $-0,9801$ & $-0,7800$ & $-0,6370$ & $-0,7041$ & $-0,7453$ & $-0,9905$ \\
\hline 11 & $-1,7781$ & $-1,1025$ & $-1,1349$ & $-0,9026$ & $-0,7436$ & $-0,8222$ & $-0,8610$ & $-1,1509$ \\
\hline 12 & $-1,8586$ & $-1,1543$ & $-1,1881$ & $-0,9450$ & $-0,7805$ & $-0,8629$ & $-0,9007$ & $-1,2059$ \\
\hline 13 & $-0,0409$ & $-0,0446$ & $-0,0454$ & $-0,0526$ & $-0,0342$ & $-0,0334$ & $-0,0379$ & $-0,0403$ \\
\hline 14 & $-0,2193$ & $-0,1702$ & $-0,1750$ & $-0,1560$ & $-0,1202$ & $-0,1304$ & $-0,1377$ & $-0,1676$ \\
\hline 15 & $-0,4284$ & $-0,3084$ & $-0,3173$ & $-0,2674$ & $-0,2045$ & $-0,2235$ & $-0,2461$ & $-0,3082$ \\
\hline 16 & $-0,6105$ & $-0,4242$ & $-0,4365$ & $-0,3608$ & $-0,2730$ & $-0,2986$ & $-0,3360$ & $-0,4257$ \\
\hline 17 & $-0,7308$ & $-0,4989$ & $-0,5135$ & $-0,4216$ & $-0,3172$ & $-0,3471$ & $-0,3937$ & $-0,5017$ \\
\hline 18 & $-0,7725$ & $-0,5245$ & $-0,5398$ & $-0,4425$ & $-0,3325$ & $-0,3639$ & $-0,4134$ & $-0,5278$ \\
\hline 19 & $-0,0099$ & $-0,0099$ & $-0,0099$ & $-0,0089$ & $-0,0099$ & $-0,0099$ & $-0,0099$ & $-0,0099$ \\
\hline 20 & $-0,0409$ & $-0,0446$ & $-0,0454$ & $-0,0524$ & $-0,0342$ & $-0,0334$ & $-0,0379$ & $-0,0403$ \\
\hline 21 & $-0,0703$ & $-0,0784$ & $-0,0801$ & $-0,0942$ & $-0,0561$ & $-0,0556$ & $-0,0649$ & $-0,0694$ \\
\hline 22 & $-0,0942$ & $-0,1062$ & $-0,1088$ & $-0,1286$ & $-0,0733$ & $-0,0731$ & $-0,0869$ & $-0,0931$ \\
\hline 23 & $-0,1097$ & $-0,1245$ & $-0,1275$ & $-0,1512$ & $-0,0843$ & $-0,0844$ & $-0,1012$ & $-0,1084$ \\
\hline 24 & $-0,1150$ & $-0,1308$ & $-0,1341$ & $-0,1590$ & $-0,0881$ & $-0,0883$ & $-0,1062$ & $-0,1138$ \\
\hline
\end{tabular}


TABELA 5.107: Deslocamentos ortogonais ao plano da placa, em $\mathrm{cm}$, na laje com 10 nervuras por lado

\begin{tabular}{|c|c|c|c|c|c|c|c|c|}
\hline \multicolumn{9}{|c|}{$\begin{array}{c}\text { LAJE COM RELAÇÃO a1/l=0,0910 } \\
\text { DESLOCAMENTOS ORTOGONAIS AO PLANO DA PLACA }(\mathrm{cm})\end{array}$} \\
\hline \multirow{2}{*}{ Ponto } & \multicolumn{8}{|c|}{ Modelos numéricos de análise } \\
\hline & 01 & 02 & 03 & 04 & 05 & 06 & 07 & 08 \\
\hline 1 & $-0,1440$ & $-0,1661$ & $-0,1706$ & $-0,2003$ & $-0,1072$ & $-0,1055$ & $-0,1330$ & $-0,1421$ \\
\hline 2 & $-1,8240$ & $-1,1651$ & $-1,2000$ & $-0,9422$ & $-0,7333$ & $-0,8149$ & $-0,9150$ & $-1,2039$ \\
\hline 3 & $-2,9878$ & $-1,8344$ & $-1,8887$ & $-1,4883$ & $-1,2141$ & $-1,3524$ & $-1,4341$ & $-1,9294$ \\
\hline 4 & $-3,2399$ & $-1,9778$ & $-2,0362$ & $-1,6080$ & $-1,3207$ & $-1,4712$ & $-1,5450$ & $-2,0851$ \\
\hline 5 & $-3,2724$ & $-1,9963$ & $-2,0552$ & $-1,6242$ & $-1,3348$ & - & $-1,5590$ & $-2,1048$ \\
\hline 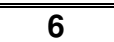 & $-0,1426$ & $-0,1645$ & $-0,1689$ & $-0,1990$ & $-0,1063$ & $-0,1046$ & $-0,1317$ & $-0,1407$ \\
\hline 7 & $-1,8042$ & $-1,1535$ & $-1,1880$ & $-0,9330$ & $-0,7261$ & $-0,8069$ & $-0,9061$ & $-1,1919$ \\
\hline 8 & $-2,9579$ & $-1,8174$ & $-1,8712$ & $-1,4743$ & $-1,2018$ & $-1,3388$ & $-1,4210$ & $-1,9111$ \\
\hline 9 & $-3,2081$ & $-1,9597$ & $-2,0176$ & $-1,5929$ & $-1,3073$ & $-1,4563$ & $-1,5311$ & $-2,0655$ \\
\hline 10 & $-3,2399$ & $-1,9778$ & $-2,0362$ & $-1,6080$ & $-1,3207$ & $-1,4712$ & $-1,5450$ & $-2,0851$ \\
\hline 111 & $-0,1110$ & $-0,1266$ & $-0,1299$ & $-0,1523$ & $-0,0847$ & $-0,0830$ & $-0,1023$ & $\overline{-0,1094}$ \\
\hline 12 & $-1,3537$ & $-0,8874$ & $-0,9143$ & $-0,7225$ & $-0,5605$ & $-0,6229$ & $-0,7010$ & $-0,9145$ \\
\hline 13 & $-2,2735$ & $-1,4251$ & $-1,4677$ & $-1,1525$ & $-0,9216$ & $-1,0262$ & $-1,1179$ & $-1,4885$ \\
\hline 14 & $-2,4770$ & $-1,5423$ & $-1,5882$ & $-1,2472$ & $-1,0010$ & $-1,1147$ & $-1,2080$ & $-1,6127$ \\
\hline 15 & $-2,5029$ & $-1,5572$ & $-1,6035$ & $-1,2593$ & $-1,0111$ & $-1,1259$ & $-1,2194$ & $-1,6284$ \\
\hline 16 & $-0,0480$ & $-0,0528$ & $-0,0538$ & $-0,0614$ & $-0,0396$ & $-0,0382$ & $-0,0444$ & $-0,0471$ \\
\hline 17 & $-0,5044$ & $-0,3673$ & $-0,3783$ & $-0,3162$ & $-0,2355$ & $-0,2586$ & $-0,2940$ & $-0,3664$ \\
\hline 18 & $-0,9079$ & $-0,6243$ & $-0,6429$ & $-0,5210$ & $-0,3797$ & $-0,4177$ & $-0,4940$ & $-0,6271$ \\
\hline 19 & $-0,9983$ & $-0,6801$ & $-0,7005$ & $-0,5661$ & $-0,4113$ & $-0,4525$ & $-0,5371$ & $-0,6841$ \\
\hline 20 & $-1,0098$ & $-0,6872$ & $-0,7079$ & $-0,5719$ & $-0,4153$ & $-0,4569$ & $-0,5426$ & $-0,6913$ \\
\hline 21 & $-0,0120$ & $-0,0120$ & $-0,0120$ & $-0,0107$ & $-0,0120$ & $-0,0120$ & $-0,0120$ & $-0,0120$ \\
\hline 22 & $-0,0822$ & $-0,0925$ & $-0,0948$ & $-0,1100$ & $-0,0645$ & $-0,0628$ & $-0,0757$ & $-0,0808$ \\
\hline 23 & $-0,1318$ & $-0,1514$ & $-0,1554$ & $-0,1822$ & $-0,0989$ & $-0,0972$ & $-0,1216$ & $-0,1299$ \\
\hline 24 & $-0,1426$ & $-0,1645$ & $-0,1689$ & $-0,1983$ & $-0,1063$ & $-0,1046$ & $-0,1317$ & $-0,1407$ \\
\hline 25 & $-0,1440$ & $-0,1661$ & $-0,1706$ & $-0,2003$ & $-0,1072$ & $-0,1055$ & $-0,1330$ & $-0,1421$ \\
\hline
\end{tabular}


TABELA 5.108: Deslocamentos ortogonais ao plano da placa, em cm, na laje com 11 nervuras por lado

\begin{tabular}{|c|c|c|c|c|c|c|c|c|}
\hline \multicolumn{9}{|c|}{$\begin{array}{c}\text { LAJE COM RELAÇÃO a1/l=0,0833 } \\
\text { DESLOCAMENTOS ORTOGONAIS AO PLANO DA PL }\end{array}$} \\
\hline \multirow{2}{*}{ Ponto } & \multicolumn{8}{|c|}{ Modelos numéricos de análise } \\
\hline & 01 & $\mathbf{0 2}$ & 03 & 04 & 05 & 06 & 07 & 08 \\
\hline 1 & $-0,1760$ & $-0,2060$ & $-0,2120$ & $-0,2476$ & $-0,1278$ & $-0,1235$ & $-0,1628$ & $-0,1735$ \\
\hline 2 & $-1,2881$ & $-0,8786$ & $-0,9057$ & $-0,7223$ & $-0,5075$ & $-0,5612$ & $-0,6950$ & $-0,8841$ \\
\hline 3 & $-2,3508$ & $-1,5057$ & $-1,5517$ & $-1,2034$ & $-0,9085$ & $-1,0163$ & $-1,1866$ & $-1,5574$ \\
\hline 4 & $-3,9734$ & $-2,4428$ & $-2,5163$ & $-1,9626$ & $-1,5612$ & $-1,7504$ & $-1,9168$ & $-2,5740$ \\
\hline 5 & $-4,4153$ & $-2,6949$ & $-2,7756$ & $-2,1722$ & $-1,7441$ & $-1,9553$ & $-2,1125$ & $-2,8482$ \\
\hline 6 & $-4,5659$ & $-2,7806$ & $-2,8637$ & $-2,2438$ & $-1,8068$ & $-2,0254$ & $-2,1789$ & $-2,9412$ \\
\hline 7 & $-0,1541$ & $-0,1791$ & $-0,1843$ & $-0,2147$ & $-0,1133$ & $-0,1094$ & $-0,1422$ & $-0,1517$ \\
\hline 8 & $-1,0935$ & $-0,7577$ & $-0,7809$ & $-0,6260$ & $-0,4425$ & $-0,4891$ & $-0,6014$ & $-0,7606$ \\
\hline 9 & $-2,0113$ & $-1,3053$ & $-1,3455$ & $-1,0464$ & $-0,7894$ & $-0,8832$ & $-1,0319$ & $-1,3488$ \\
\hline 10 & $-3,4430$ & $-2,1387$ & $-2,2035$ & $-1,7144$ & $-1,3509$ & $-1,5150$ & $-1,6815$ & $-2,2477$ \\
\hline 11 & $-3,8383$ & $-2,3656$ & $-2,4368$ & $-1,8994$ & $-1,5076$ & $-1,6904$ & $-1,8571$ & $-2,4913$ \\
\hline 12 & $-3,9734$ & $-2,4428$ & $-2,5163$ & $-1,9626$ & $-1,5612$ & $-1,7504$ & $-1,9168$ & $-2,5740$ \\
\hline 13 & $-0,0944$ & $-0,1072$ & $-0,1100$ & $-0,1267$ & $-0,0730$ & $-0,0700$ & $-0,0868$ & $-0,0924$ \\
\hline 14 & $-0,5822$ & $-0,4286$ & $-0,4418$ & $-0,3669$ & $-0,2665$ & $-0,2940$ & $-0,3440$ & $-0,4268$ \\
\hline 15 & $-1,1174$ & $-0,7645$ & $-0,7886$ & $-0,6256$ & $-0,4682$ & $-0,5529$ & $-0,6100$ & $-0,7824$ \\
\hline 16 & $-2,0113$ & $-1,3053$ & $-1,3455$ & $-1,0464$ & $-0,7894$ & $-0,8832$ & $-1,0319$ & $-1,3488$ \\
\hline 17 & $-2,2641$ & $-1,4548$ & $-1,4993$ & $-1,1635$ & $-0,8782$ & $-0,9824$ & $-1,1474$ & $-1,5044$ \\
\hline 18 & $-2,3508$ & $-1,5057$ & $-1,5517$ & $-1,2034$ & $-0,9085$ & $-1,0163$ & $-1,1866$ & $-1,5574$ \\
\hline 19 & $-0,0143$ & $-0,0143$ & $-0,0143$ & $-0,0125$ & $-0,0143$ & $-0,0143$ & $-0,0143$ & $-0,0143$ \\
\hline 20 & $-0,0553$ & $-0,0613$ & $-0,0627$ & $-0,0702$ & $-0,0452$ & $-0,0431$ & $-0,0511$ & $-0,0540$ \\
\hline 21 & $-0,0944$ & $-0,1072$ & $-0,1100$ & $-0,1262$ & $-0,0730$ & $-0,0700$ & $-0,0868$ & $-0,0924$ \\
\hline 22 & $-0,1541$ & $-0,1791$ & $-0,1843$ & $-0,2139$ & $-0,1133$ & $-0,1094$ & $-0,1422$ & $-0,1517$ \\
\hline 23 & $-0,1705$ & $-0,1991$ & $-0,2049$ & $-0,2383$ & $-0,1241$ & $-0,1199$ & $-0,1575$ & $-0,1679$ \\
\hline 24 & $-0,1760$ & $-0,2060$ & $-0,2120$ & $-0,2467$ & $-0,1278$ & $-0,1235$ & $-0,1628$ & $-0,1735$ \\
\hline
\end{tabular}


TABELA 5.109: Deslocamentos ortogonais ao plano da placa, em $\mathrm{cm}$, na laje com 12 nervuras por lado

\begin{tabular}{|c|c|c|c|c|c|c|c|c|}
\hline \multicolumn{9}{|c|}{$\begin{array}{c}\text { LAJE COM RELAÇÃO a1/l=0,0769 } \\
\text { DESLOCAMENTOS ORTOGONAIS AO PLANO DA PLACA }(\mathrm{cm})\end{array}$} \\
\hline \multirow{2}{*}{ Ponto } & \multicolumn{8}{|c|}{ Modelos numéricos de análise } \\
\hline & 01 & 02 & 03 & 04 & 05 & 06 & 07 & 08 \\
\hline 1 & $-0,2110$ & $-0,2503$ & $-0,2582$ & $-0,2976$ & $-0,1496$ & $-0,1418$ & $-0,1954$ & $-0,2079$ \\
\hline 2 & $-2,9636$ & $-1,9036$ & $-1,9632$ & $-1,5060$ & $-1,1033$ & $-1,2420$ & $-1,5055$ & $-1,9717$ \\
\hline 3 & $-5,1344$ & $-3,1630$ & $-3,2598$ & $-2,5194$ & $-1,9544$ & $-2,2046$ & $-2,4912$ & $-3,3395$ \\
\hline 4 & $-6,1617$ & $-3,7501$ & $-3,8639$ & $-3,0066$ & $-2,3723$ & $-2,6746$ & $-2,9485$ & $-3,9789$ \\
\hline 5 & $-6,2062$ & $-3,7756$ & $-3,8901$ & $-3,0289$ & $-2,3909$ & - & $-2,9680$ & $-4,0062$ \\
\hline 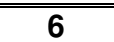 & $-0,2096$ & $-0,2486$ & $-0,2564$ & $-0,2971$ & $-0,1487$ & $-0,1410$ & $-0,1940$ & $-0,2065$ \\
\hline 7 & $-2,9398$ & $-1,8896$ & $-1,9487$ & $-1,4951$ & $-1,0954$ & $-1,2330$ & $-1,4947$ & $-1,9571$ \\
\hline 8 & $-5,0964$ & $-3,1412$ & $-3,2373$ & $-2,5016$ & $-1,9399$ & $-2,1883$ & $-2,4743$ & $-3,3162$ \\
\hline 9 & $-6,1178$ & $-3,7252$ & $-3,8382$ & $-2,9858$ & $-2,3544$ & $-2,6545$ & $-2,9291$ & $-3,9518$ \\
\hline 10 & $-6,1617$ & $-3,7501$ & $-3,8639$ & $-3,0066$ & $-2,3723$ & $-2,6746$ & $-2,9485$ & $-3,9789$ \\
\hline 111 & $-0,1766$ & $-0,2075$ & $-0,2138$ & $-0,2470$ & $-0,1276$ & $-0,1209$ & $-0,1630$ & $-0,1735$ \\
\hline 12 & $-2,3915$ & $-1,5638$ & $-1,6132$ & $-1,2425$ & $-0,9103$ & $-1,0250$ & $-1,2419$ & $-1,6177$ \\
\hline 13 & $-4,2156$ & $-2,6335$ & $-2,7151$ & $-2,0914$ & $-1,6026$ & $-1,8088$ & $-2,0802$ & $-2,7722$ \\
\hline 14 & $-5,0964$ & $-3,1412$ & $-3,2373$ & $-2,5016$ & $-1,9399$ & $-2,1883$ & $-2,4743$ & $-3,3162$ \\
\hline 15 & $-5,1344$ & $-3,1630$ & $-3,2598$ & $-2,5194$ & $-1,9544$ & $-2,2046$ & $-2,4912$ & $-3,3395$ \\
\hline 16 & $-0,1068$ & $-0,1224$ & $-0,1257$ & $-0,1434$ & $-0,0815$ & $-0,0770$ & $-0,0981$ & $-0,1042$ \\
\hline 17 & $-1,2854$ & $-0,8881$ & $-0,9169$ & $-0,7220$ & $-0,5262$ & $-0,5912$ & $-0,7115$ & $-0,9091$ \\
\hline 18 & $-2,3915$ & $-1,5638$ & $-1,6132$ & $-1,2425$ & $-0,9103$ & $-1,0250$ & $-1,2419$ & $-1,6177$ \\
\hline 19 & $-2,9398$ & $-1,8896$ & $-1,9487$ & $-1,4951$ & $-1,0954$ & $-1,2330$ & $-1,4947$ & $-1,9571$ \\
\hline 20 & $-2,9636$ & $-1,9036$ & $-1,9632$ & $-1,5060$ & $-1,1033$ & $-1,2420$ & $-1,5055$ & $-1,9717$ \\
\hline 21 & $-0,0168$ & $-0,0168$ & $-0,0168$ & $-0,0145$ & $-0,0168$ & $-0,0168$ & $-0,0168$ & $-0,0168$ \\
\hline 22 & $-0,1068$ & $-0,1224$ & $-0,1257$ & $-0,1428$ & $-0,0815$ & $-0,0770$ & $-0,0981$ & $-0,1042$ \\
\hline 23 & $-0,1766$ & $-0,2075$ & $-0,2138$ & $-0,2461$ & $-0,1276$ & $-0,1209$ & $-0,1630$ & $-0,1735$ \\
\hline 24 & $-0,2096$ & $-0,2486$ & $-0,2564$ & $-0,2960$ & $-0,1487$ & $-0,1410$ & $-0,1940$ & $-0,2065$ \\
\hline 25 & $-0,2110$ & $-0,2503$ & $-0,2582$ & $-0,2981$ & $-0,1496$ & $-0,1418$ & $-0,1954$ & $-0,2079$ \\
\hline
\end{tabular}


TABELA 5.110: Deslocamentos ortogonais ao plano da placa, em $\mathrm{cm}$, na laje com 13 nervuras por lado

\begin{tabular}{|c|c|c|c|c|c|c|c|c|}
\hline \multicolumn{9}{|c|}{$\begin{array}{c}\text { LAJE COM RELAÇÃO a1/l=0,0714 } \\
\text { DESLOCAMENTOS ORTOGONAIS AO PLANO DA PL }\end{array}$} \\
\hline \multirow{2}{*}{ Ponto } & \multicolumn{8}{|c|}{ Modelos numéricos de análise } \\
\hline & 01 & $\mathbf{0 2}$ & 03 & 04 & 05 & 06 & 07 & 08 \\
\hline 1 & $-0,2489$ & $-0,2992$ & $-0,3092$ & $-0,3561$ & $-0,1726$ & $-0,1605$ & $-0,2309$ & $-0,2477$ \\
\hline 2 & $-3,6671$ & $-2,3625$ & $-2,4382$ & $-1,8525$ & $-1,3180$ & $-1,4924$ & $-1,8753$ & $-3,1422$ \\
\hline 3 & $-6,4812$ & $-4,0025$ & $-4,1273$ & $-3,1638$ & $-2,3944$ & $-2,7163$ & $-3,1646$ & $-5,4535$ \\
\hline 4 & $-8,0440$ & $-4,8983$ & $-5,0493$ & $-3,9050$ & $-3,0184$ & $-3,4209$ & $-3,8651$ & $-6,7210$ \\
\hline 5 & $-8,2463$ & $-5,0138$ & $-5,1682$ & $-4,0014$ & $-3,1003$ & $-3,5131$ & $-3,9552$ & $-6,8847$ \\
\hline 6 & $-0,2264$ & $-0,2706$ & $-0,2795$ & $-0,3214$ & $-0,1587$ & $-0,1476$ & $-0,2095$ & $-0,2248$ \\
\hline 7 & $-3,2652$ & $-2,1238$ & $-2,1921$ & $-1,6686$ & $-1,1877$ & $-1,3451$ & $-1,6897$ & $-2,8090$ \\
\hline 8 & $-5,8218$ & $-3,6219$ & $-3,7357$ & $-2,8583$ & $-2,1500$ & $-2,4404$ & $-2,8688$ & $-4,9182$ \\
\hline 9 & $-7,2586$ & $-4,4493$ & $-4,5873$ & $-3,5328$ & $-2,7054$ & $-3,0678$ & $-3,5147$ & $-6,0858$ \\
\hline 10 & $-7,4456$ & $-4,5564$ & $-4,6975$ & $-3,6206$ & $-2,7780$ & $-3,1498$ & $-3,5981$ & $-6,2370$ \\
\hline 11 & $-0,1194$ & $-0,1380$ & $-0,1419$ & $-0,1604$ & $-0,0901$ & $-0,0839$ & $-0,1096$ & $-0,1169$ \\
\hline 12 & $-1,4569$ & $-1,0161$ & $-1,0500$ & $-0,8218$ & $-0,5841$ & $-0,6598$ & $-0,8172$ & $-1,2844$ \\
\hline 13 & $-2,7865$ & $-1,8362$ & $-1,8957$ & $-1,4480$ & $-1,0314$ & $-1,1683$ & $-1,4650$ & $-2,4100$ \\
\hline 14 & $-3,5651$ & $-2,3022$ & $-2,3760$ & $-1,8059$ & $-1,2850$ & $-1,4551$ & $-1,8284$ & $-3,0578$ \\
\hline 15 & $-3,6671$ & $-2,3625$ & $-2,4382$ & $-1,8525$ & $-1,3180$ & $-1,4924$ & $-1,8753$ & $-3,1422$ \\
\hline 16 & $-0,0195$ & $-0,0195$ & $-0,0195$ & $-0,0166$ & $-0,0195$ & $-0,0195$ & $-0,0195$ & $-0,0195$ \\
\hline 17 & $-0,1194$ & $-0,1380$ & $-0,1419$ & $-0,1598$ & $-0,0901$ & $-0,0839$ & $-0,1096$ & $-0,1169$ \\
\hline 18 & $-0,1992$ & $-0,2364$ & $-0,2440$ & $-0,2788$ & $-0,1417$ & $-0,1318$ & $-0,1839$ & $-0,1972$ \\
\hline 19 & $-0,2432$ & $-0,2919$ & $-0,3017$ & $-0,3460$ & $-0,1690$ & $-0,1572$ & $-0,2254$ & $-0,2419$ \\
\hline 20 & $-0,2489$ & $-0,2992$ & $-0,3092$ & $-0,3548$ & $-0,1726$ & $-0,1605$ & $-0,2309$ & $-0,2477$ \\
\hline
\end{tabular}


TABELA 5.111: Deslocamentos ortogonais ao plano da placa, em $\mathrm{cm}$, na laje com 14 nervuras por lado

\begin{tabular}{|c|c|c|c|c|c|c|c|c|}
\hline \multirow{3}{*}{ Ponto } & \multicolumn{7}{|c|}{$\begin{array}{l}\text { LAJE COM RELAÇÃO a1/l=0,0667 } \\
\text { NTOS ORTOGONAIS AO PLANO DA PLACA }(\mathrm{cm})\end{array}$} & \\
\hline & \multicolumn{8}{|c|}{ Modelos numéricos de análise } \\
\hline & 01 & $\mathbf{0 2}$ & $\mathbf{0 3}$ & 04 & 05 & 06 & 07 & 08 \\
\hline 1 & $-0,2895$ & $-0,3525$ & $-0,3650$ & $-0,4164$ & $-0,1968$ & $-0,1793$ & $-0,2691$ & $-0,2855$ \\
\hline 2 & $-4,4663$ & $-2,8863$ & $-2,9811$ & $-2,2455$ & $-1,5526$ & $-1,7680$ & $-2,2997$ & $-3,0016$ \\
\hline 3 & $-8,0242$ & $-4,9690$ & $-5,1270$ & $-3,9013$ & $-2,8814$ & $-3,2862$ & $-3,9445$ & $-5,2703$ \\
\hline 4 & $-10,2279$ & $-6,2367$ & $-6,4323$ & $-4,9467$ & $-3,7463$ & $-4,2662$ & $-4,9395$ & $-6,6561$ \\
\hline 5 & $-10,6882$ & $-6,4997$ & $-6,7030$ & $-5,1661$ & $-3,9294$ & $-4,4733$ & $-5,1454$ & $-6,9435$ \\
\hline 6 & $-10,7466$ & $-6,5332$ & $-6,7374$ & $-5,1953$ & $-3,9531$ & - & $-5,1713$ & $-6,9796$ \\
\hline 7 & $-0,2881$ & $-0,3506$ & $-0,3631$ & $-0,4156$ & $-0,1959$ & $-0,1786$ & $-0,2677$ & $-0,2840$ \\
\hline 8 & $-4,4389$ & $-2,8700$ & $-2,9642$ & $-2,2330$ & $-1,5440$ & $-1,7582$ & $-2,2870$ & $-2,9846$ \\
\hline 9 & $-7,9783$ & $-4,9425$ & $-5,0998$ & $-3,8801$ & $-2,8650$ & $-3,2676$ & $-3,9239$ & $-5,2420$ \\
\hline 10 & $-10,1721$ & $-6,2047$ & $-6,3994$ & $-4,9203$ & $-3,7244$ & $-4,2416$ & $-4,9146$ & $-6,6215$ \\
\hline 11 & $-10,6304$ & $-6,4667$ & $-6,6691$ & $-5,1385$ & $-3,9064$ & $-4,4473$ & $-5,1196$ & $-6,9075$ \\
\hline 12 & $-10,6882$ & $-6,4997$ & $-6,7030$ & $-5,1661$ & $-3,9294$ & $-4,4733$ & $-5,1454$ & $-6,9435$ \\
\hline 13 & $-0,2543$ & $-0,3071$ & $-0,3178$ & $-0,3629$ & $-0,1755$ & $-0,1603$ & $-0,2355$ & $-0,2500$ \\
\hline 14 & $-3,7983$ & $-2,4873$ & $-2,5692$ & $-1,9405$ & $-1,3433$ & $-1,5301$ & $-1,9879$ & $-2,5840$ \\
\hline 15 & $-6,9065$ & $-4,3208$ & $-4,4598$ & $-3,3851$ & $-2,4803$ & $-2,8313$ & $-3,4387$ & $-4,5777$ \\
\hline 16 & $-8,8639$ & $-5,4539$ & $-5,6265$ & $-4,3014$ & $-3,2152$ & $-3,6653$ & $-4,3269$ & $-5,8045$ \\
\hline 17 & $-9,2751$ & $-5,6904$ & $-5,8698$ & $-4,4939$ & $-3,3704$ & $-3,8409$ & $-4,5114$ & $-6,0594$ \\
\hline 18 & $-9,3270$ & $-5,7202$ & $-5,9005$ & $-4,5182$ & $-3,3900$ & $-3,8630$ & $-4,5346$ & $-6,0915$ \\
\hline 19 & $-0,1322$ & $-0,1539$ & $-0,1586$ & $-0,1777$ & $-0,0988$ & $-0,0908$ & $-0,1212$ & $-0,1283$ \\
\hline 20 & $-1,6312$ & $-1,1480$ & $-1,1874$ & $-0,9244$ & $-0,6416$ & $-0,7287$ & $-0,9268$ & $-1,1766$ \\
\hline 21 & $-3,1939$ & $-2,1210$ & $-2,1915$ & $-1,6620$ & $-1,1523$ & $-1,3128$ & $-1,7002$ & $-2,2008$ \\
\hline 22 & $-4,2216$ & $-2,7408$ & $-2,8308$ & $-2,1340$ & $-1,4761$ & $-1,6810$ & $-2,1862$ & $-2,8493$ \\
\hline 23 & $-4,4389$ & $-2,8700$ & $-2,9642$ & $-2,2330$ & $-1,5440$ & $-1,7582$ & $-2,2870$ & $-2,9846$ \\
\hline 24 & $-4,4663$ & $-2,8863$ & $-2,9811$ & $-2,2455$ & $-1,5526$ & $-1,7680$ & $-2,2997$ & $-3,0016$ \\
\hline 25 & $-0,0223$ & $-0,0223$ & $-0,0223$ & $-0,0189$ & $-0,0223$ & $-0,0223$ & $-0,0223$ & $-0,0223$ \\
\hline 26 & $-0,1322$ & $-0,1539$ & $-0,1586$ & $-0,1769$ & $-0,0988$ & $-0,0908$ & $-0,1212$ & $-0,1283$ \\
\hline 27 & $-0,2219$ & $-0,2658$ & $-0,2748$ & $-0,3117$ & $-0,1557$ & $-0,1424$ & $-0,2048$ & $-0,2174$ \\
\hline 28 & $-0,2767$ & $-0,3359$ & $-0,3478$ & $-0,3963$ & $-0,1891$ & $-0,1724$ & $-0,2568$ & $-0,2725$ \\
\hline 29 & $-0,2881$ & $-0,3506$ & $-0,3631$ & $-0,4141$ & $-0,1959$ & $-0,1786$ & $-0,2677$ & $-0,2840$ \\
\hline 30 & $-0,2895$ & $-0,3525$ & $-0,3650$ & $-0,4164$ & $-0,1968$ & $-0,1793$ & $-0,2691$ & $-0,2855$ \\
\hline
\end{tabular}


TABELA 5.112: Deslocamentos ortogonais ao plano da placa, em $\mathrm{cm}$, na laje com 15 nervuras por lado

\begin{tabular}{|c|c|c|c|c|c|c|c|c|}
\hline \multicolumn{9}{|c|}{$\begin{array}{c}\text { LAJE COM RELAÇÃO a1/l=0,0625 } \\
\text { DESLOCAMENTOS ORTOGONAIS AO PLANO DA PLACA }(\mathrm{cm})\end{array}$} \\
\hline \multirow{2}{*}{ Ponto } & \multicolumn{8}{|c|}{ Modelos numéricos de análise } \\
\hline & 01 & $\mathbf{0 2}$ & $\mathbf{0 3}$ & 04 & $\mathbf{0 5}$ & 06 & 07 & 08 \\
\hline 1 & $-0,3328$ & $-0,4103$ & $-0,4257$ & $-0,4846$ & $-0,2220$ & $-0,1983$ & $-0,3101$ & $-0,3286$ \\
\hline 2 & $-5,3657$ & $-3,4785$ & $-3,5954$ & $-2,6875$ & $-1,8071$ & $-2,0689$ & $-2,7823$ & $-3,6266$ \\
\hline 3 & $-9,7729$ & $-6,0700$ & $-6,2670$ & $-4,7371$ & $-3,4159$ & $-3,9153$ & $-4,8381$ & $-6,4544$ \\
\hline 4 & $-12,7297$ & $-7,7767$ & $-8,0251$ & $-6,1402$ & $-4,5566$ & $-5,2121$ & $-6,1829$ & $-8,3243$ \\
\hline 5 & $-13,5054$ & $-8,2212$ & $-8,4827$ & $-6,5104$ & $-4,8610$ & $-5,5572$ & $-6,5321$ & $-8,8109$ \\
\hline 6 & $-13,7672$ & $-8,3709$ & $-8,6369$ & $-6,6354$ & $-4,9642$ & $-5,6740$ & $-6,6496$ & $-8,9748$ \\
\hline 7 & $-0,3099$ & $-0,3803$ & $-0,3945$ & $-0,4484$ & $-0,2086$ & $-0,1867$ & $-0,2882$ & $-0,3054$ \\
\hline 8 & $-4,9049$ & $-3,2030$ & $-3,3108$ & $-2,4780$ & $-1,6677$ & $-1,9095$ & $-2,5664$ & $-3,3372$ \\
\hline 9 & $-8,9888$ & $-5,6144$ & $-5,7978$ & $-4,3766$ & $-3,1432$ & $-3,6049$ & $-4,4819$ & $-5,9682$ \\
\hline 10 & $-11,7549$ & $-7,2166$ & $-7,4484$ & $-5,6799$ & $-4,1851$ & $-4,7907$ & $-5,7438$ & $-7,7155$ \\
\hline 11 & $-12,4835$ & $-7,6355$ & $-7,8796$ & $-6,0240$ & $-4,4626$ & $-5,1056$ & $-6,0723$ & $-8,1709$ \\
\hline 12 & $-12,7297$ & $-7,7767$ & $-8,0251$ & $-6,1402$ & $-4,5566$ & $-5,2121$ & $-6,1829$ & $-8,3243$ \\
\hline 13 & $-0,2445$ & $-0,2955$ & $-0,3061$ & $-0,3461$ & $-0,1696$ & $-0,1525$ & $-0,2259$ & $-0,2394$ \\
\hline 14 & $-3,6118$ & $-2,4170$ & $-2,4993$ & $-1,8838$ & $-1,2728$ & $-1,4578$ & $-1,9464$ & $-2,5126$ \\
\hline 15 & $-6,7834$ & $-4,3201$ & $-4,4640$ & $-3,3573$ & $-2,3742$ & $-2,7270$ & $-3,4633$ & $-4,5778$ \\
\hline 16 & $-8,9888$ & $-5,6144$ & $-5,7978$ & $-4,3766$ & $-3,1432$ & $-3,6049$ & $-4,4819$ & $-5,9682$ \\
\hline 17 & $-9,5746$ & $-5,9550$ & $-6,1486$ & $-4,6460$ & $-3,3470$ & $-3,8369$ & $-4,7483$ & $-6,3318$ \\
\hline 18 & $-9,7729$ & $-6,0700$ & $-6,2670$ & $-4,7371$ & $-3,4159$ & $-3,9153$ & $-4,8381$ & $-6,4544$ \\
\hline 19 & $-0,1450$ & $-0,1702$ & $-0,1755$ & $-0,1952$ & $-0,1076$ & $-0,0976$ & $-0,1330$ & $-0,1406$ \\
\hline 20 & $-1,8076$ & $-1,2833$ & $-1,3287$ & $-1,0298$ & $-0,6990$ & $-0,7976$ & $-1,0397$ & $-1,3164$ \\
\hline 21 & $-3,6118$ & $-2,4170$ & $-2,4993$ & $-1,8838$ & $-1,2728$ & $-1,4578$ & $-1,9464$ & $-2,5126$ \\
\hline 22 & $-4,9049$ & $-3,2030$ & $-3,3108$ & $-2,4780$ & $-1,6677$ & $-1,9095$ & $-2,5664$ & $-3,3372$ \\
\hline 23 & $-5,2492$ & $-3,4090$ & $-3,5237$ & $-2,6347$ & $-1,7719$ & $-2,0286$ & $-2,7280$ & $-3,5536$ \\
\hline 24 & $-5,3657$ & $-3,4785$ & $-3,5954$ & $-2,6875$ & $-1,8071$ & $-2,0689$ & $-2,7823$ & $-3,6266$ \\
\hline 25 & $-0,0254$ & $-0,0254$ & $-0,0254$ & $-0,0212$ & $-0,0254$ & $-0,0254$ & $-0,0254$ & $-0,0254$ \\
\hline 26 & $-0,1450$ & $-0,1702$ & $-0,1755$ & $-0,1943$ & $-0,1076$ & $-0,0976$ & $-0,1330$ & $-0,1406$ \\
\hline 27 & $-0,2445$ & $-0,2955$ & $-0,3061$ & $-0,3448$ & $-0,1696$ & $-0,1525$ & $-0,2259$ & $-0,2394$ \\
\hline 28 & $-0,3099$ & $-0,3803$ & $-0,3945$ & $-0,4469$ & $-0,2086$ & $-0,1867$ & $-0,2882$ & $-0,3054$ \\
\hline 29 & $-0,3270$ & $-0,4027$ & $-0,4178$ & $-0,4738$ & $-0,2186$ & $-0,1954$ & $-0,3046$ & $-0,3228$ \\
\hline 30 & $-0,3328$ & $-0,4103$ & $-0,4257$ & $-0,4829$ & $-0,2220$ & $-0,1983$ & $-0,3101$ & $-0,3286$ \\
\hline
\end{tabular}

Abaixo tem-se os gráficos de deslocamentos ortogonais ao plano da placa para a nervura central, ou para a linha central, das lajes processadas nesta série. 


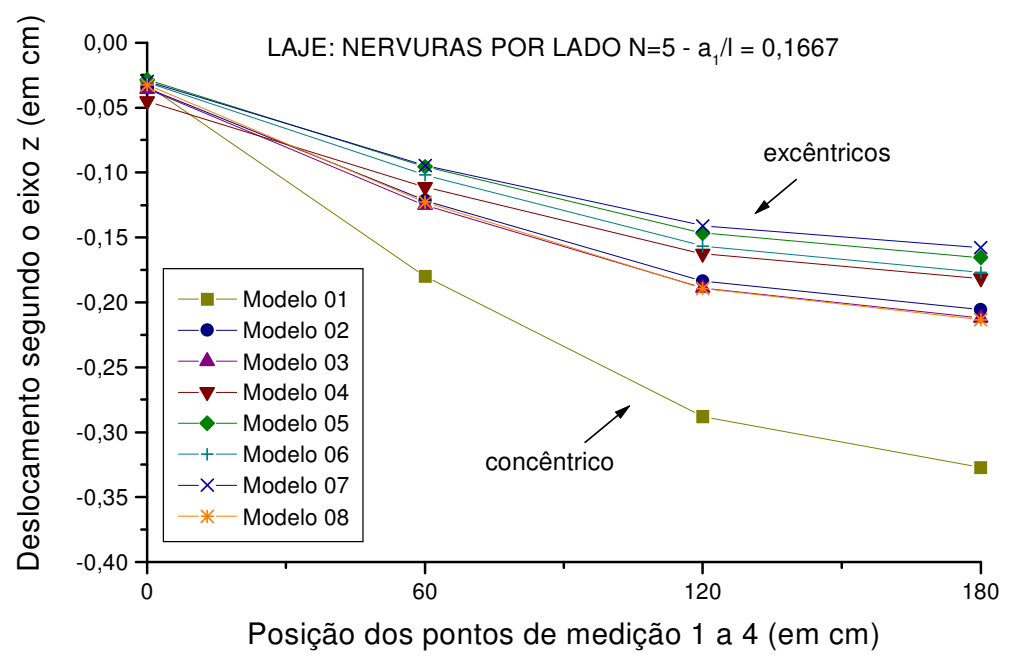

FIGURA 5.93: Deslocamentos em z $(\mathrm{cm})$, na nervura central, na laje com $\mathrm{a}_{1} / \mathrm{l}=0,1667$

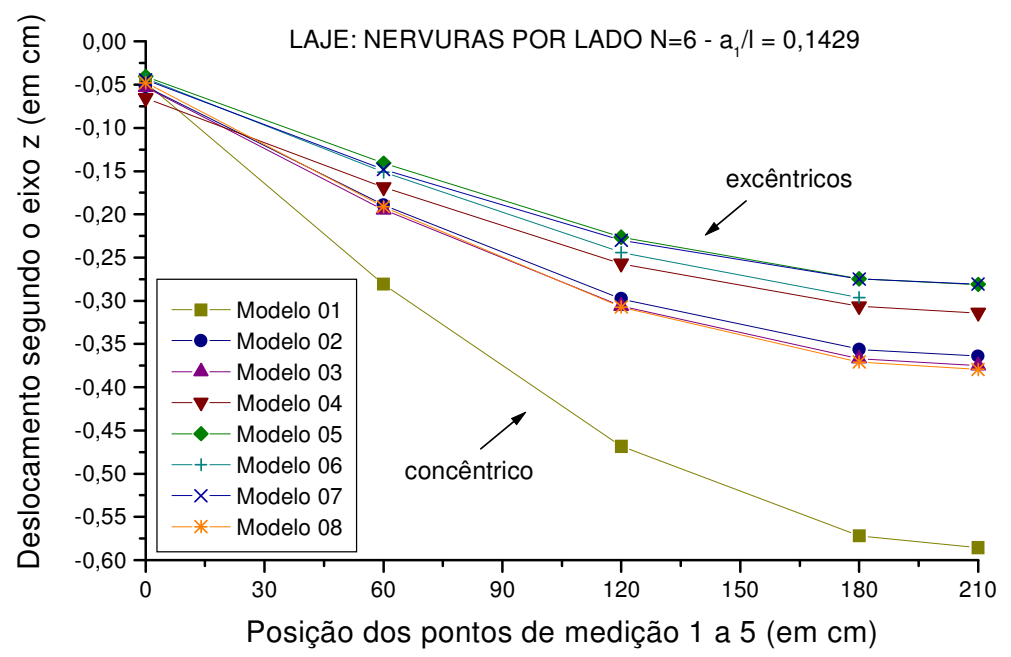

FIGURA 5.94: Deslocamentos em z (cm), no eixo central, na laje com $\mathrm{a}_{1} / \mathrm{l}=0,1429$

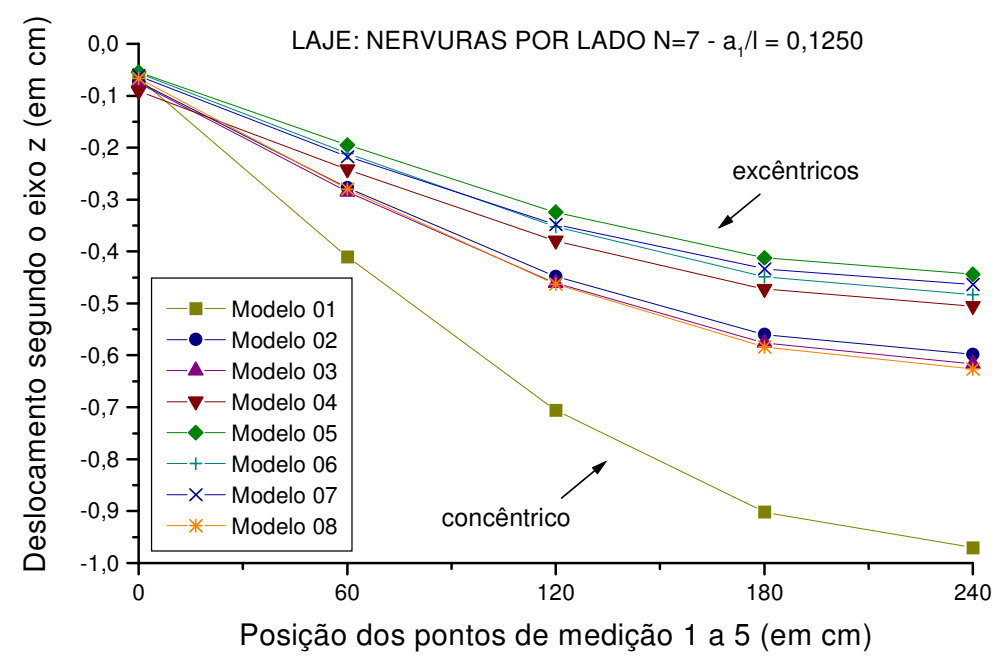

FIGURA 5.95: Deslocamentos em z $(\mathrm{cm})$, na nervura central, na laje com $\mathrm{a}_{1} / \mathrm{l}=0,1250$ 


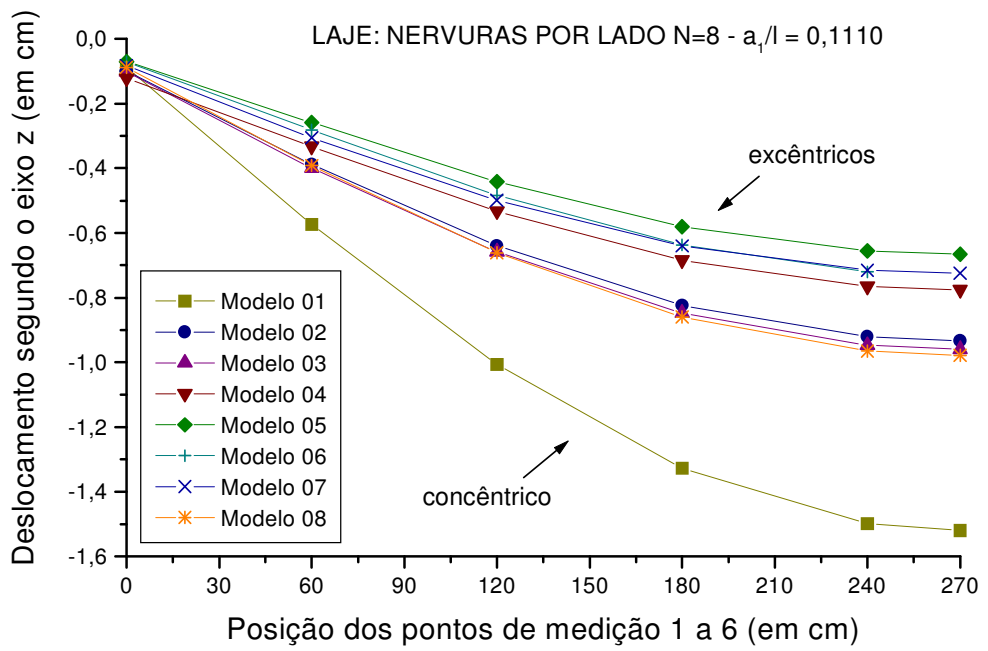

FIGURA 5.96: Deslocamentos em z (cm), no eixo central, na laje com $a_{1} / l=0,1111$

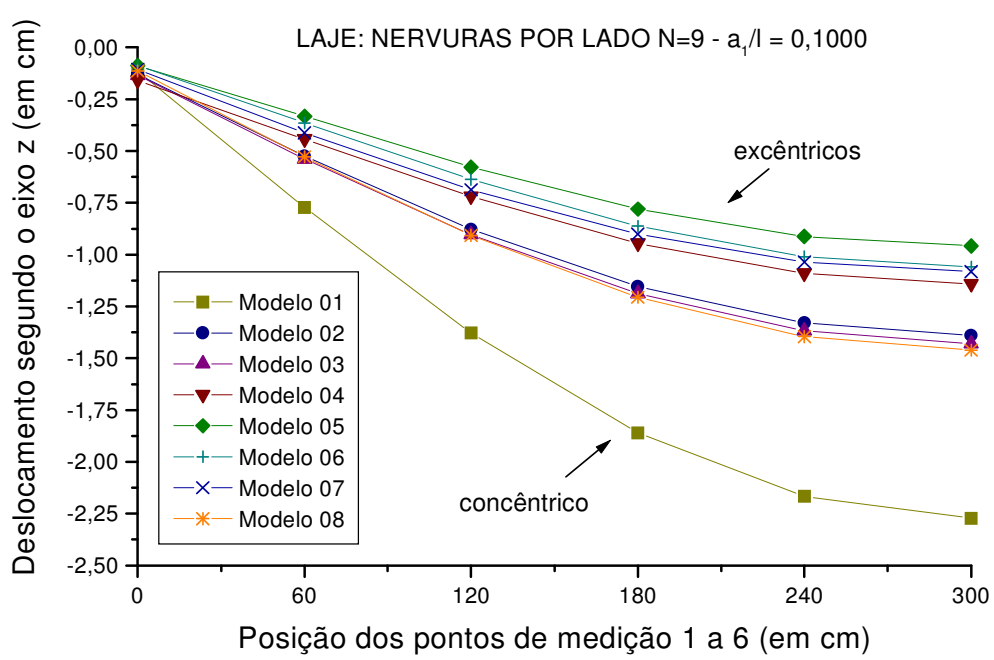

FIGURA 5.97: Deslocamentos em z $(\mathrm{cm})$, na nervura central, na laje com $\mathrm{a}_{1} / \mathrm{l}=0,1000$

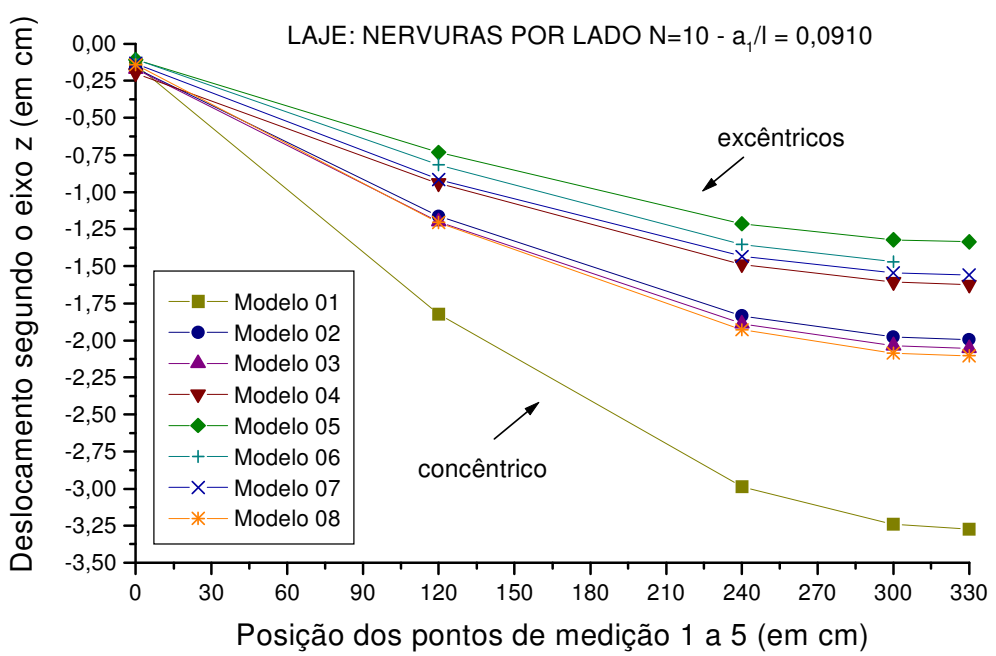

FIGURA 5.98: Deslocamentos em $\mathrm{z}(\mathrm{cm})$, no eixo central, na laje com $\mathrm{a}_{1} / \mathrm{l}=0,0910$ 


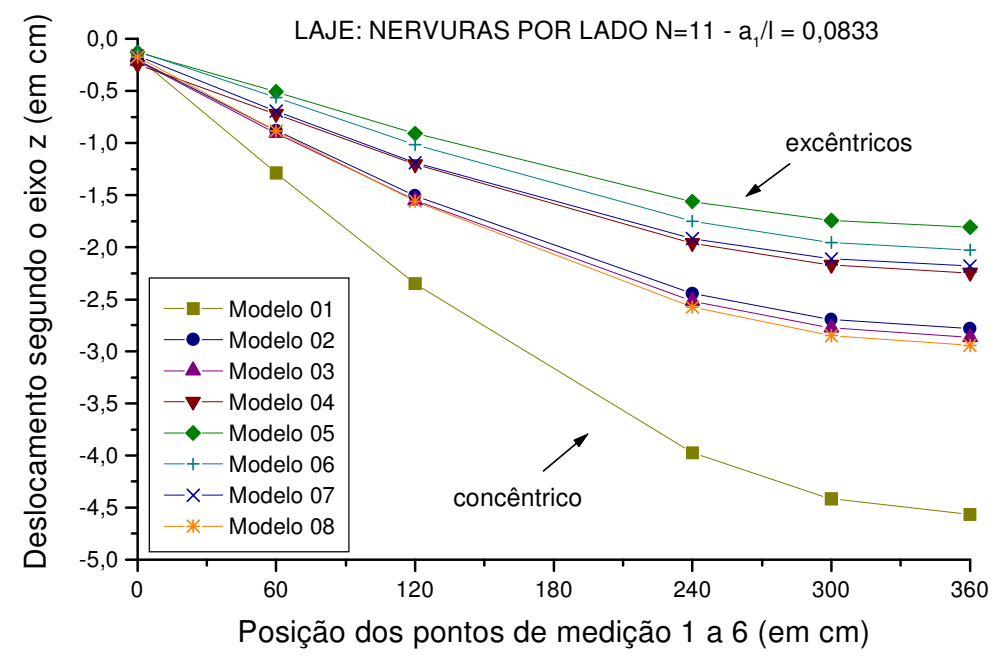

FIGURA 5.99: Deslocamentos em $\mathrm{z}(\mathrm{cm})$, na nervura central, na laje com $\mathrm{a}_{1} / \mathrm{l}=0,0833$

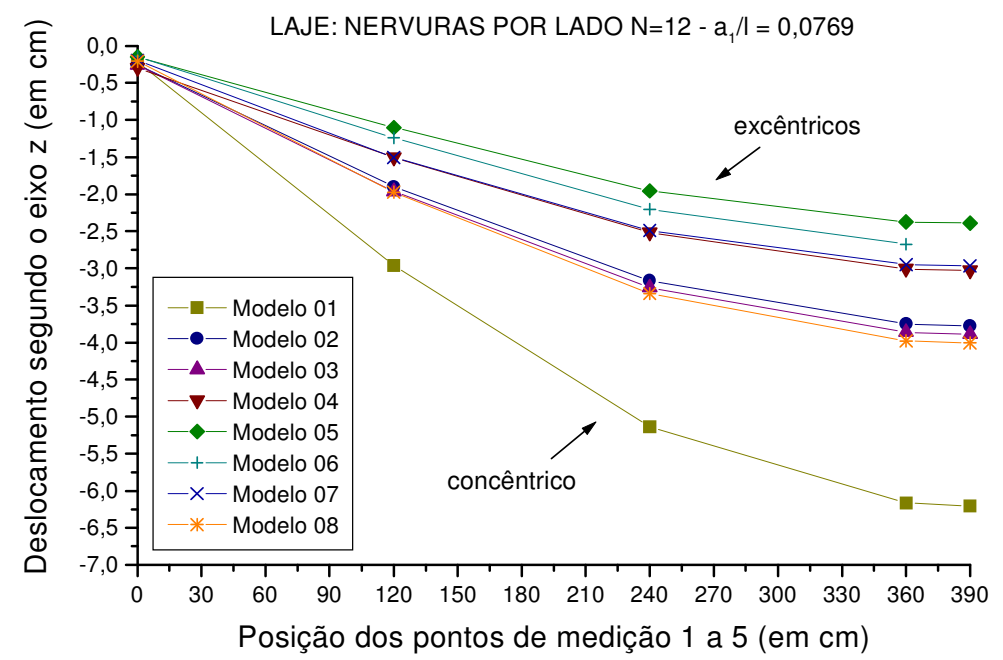

FIGURA 5.100: Deslocamentos em z (cm), no eixo central, na laje com $\mathrm{a}_{1} / \mathrm{l}=0,0769$

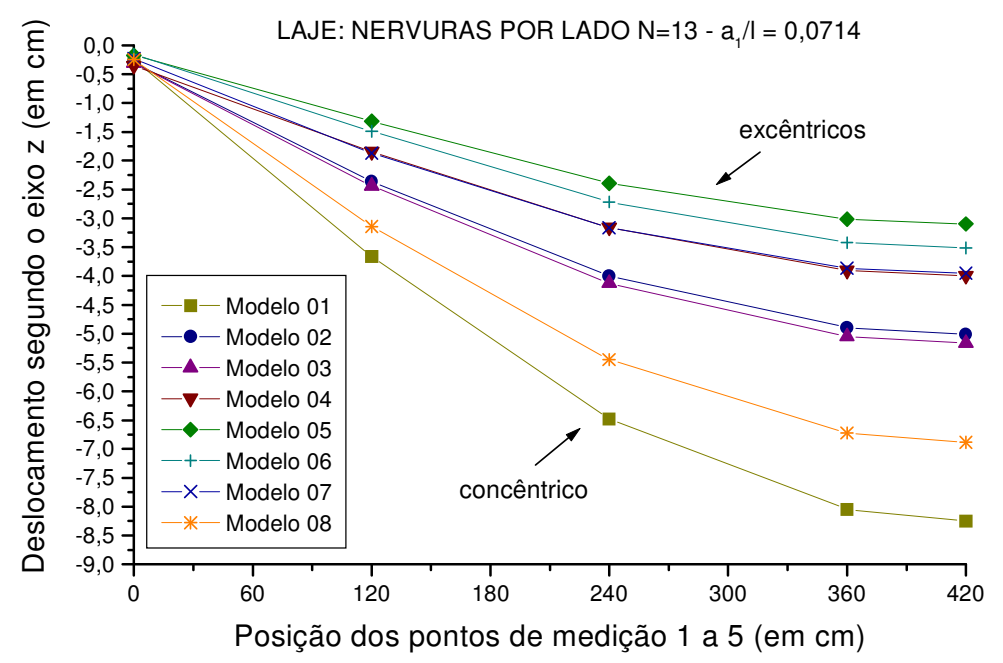

FIGURA 5.101: Deslocamentos em z $(\mathrm{cm})$, na nervura central, na laje com $\mathrm{a}_{1} / \mathrm{l}=0,0714$ 


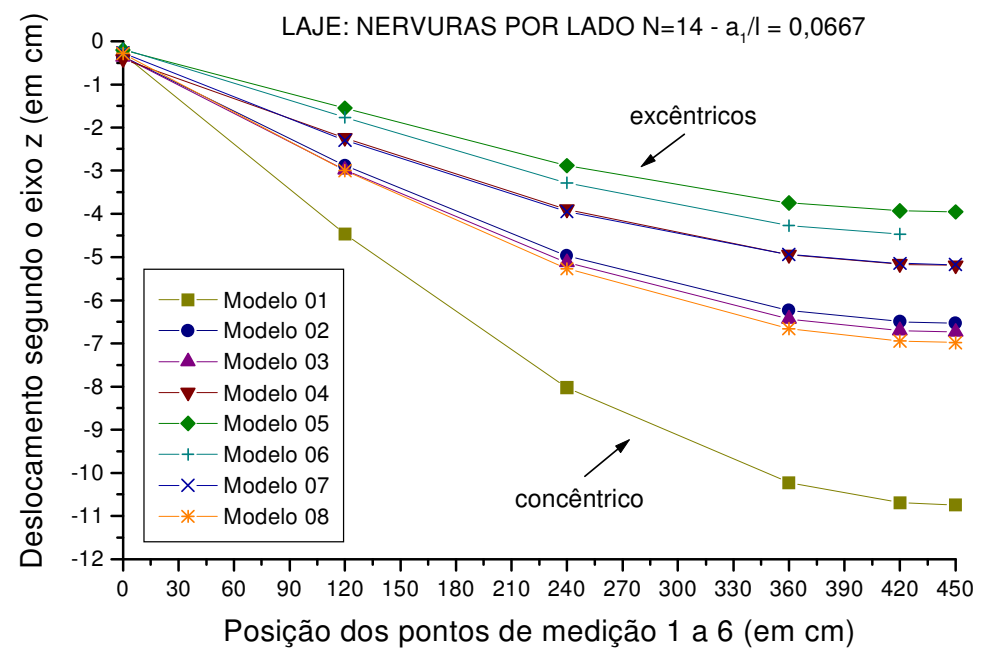

FIGURA 5.102: Deslocamentos em z $(\mathrm{cm})$, na nervura central, na laje com $\mathrm{a}_{1} / \mathrm{l}=0,0667$



FIGURA 5.103: Deslocamentos em $\mathrm{z}(\mathrm{cm})$, no eixo central, na laje com $\mathrm{a}_{1} / \mathrm{l}=0,0625$

Analisando-se as tabelas de deslocamentos nas nervuras, segundo os modelos 01 a 08 , onde variou-se a relação $a_{1} / l$, verificou-se que:

- quanto maior a relação $a_{1} / l$, os deslocamentos dados pelo modelo concêntrico vão tornando-se muito maiores que os apresentados nas modelagens excêntricas; para a relação $a_{1} / l=0,0625$ o deslocamento máximo na nervura central, pelo modelo concêntrico, é $107,5 \%$ maior que o apresentado pelo modelo realista 04 ;

- como foram processados modelos com altura total da laje $\mathrm{h}=20 \mathrm{~cm}$, considerando a altura da capa como sendo $h_{\mathrm{f}}=5 \mathrm{~cm}$, obtendo-se assim uma relação $\mathrm{h}_{\mathrm{f}} / \mathrm{h}=0,25$, os modelos 02 e 03 apresentaram-se muito flexíveis quando comparados ao Modelo 04, conforme pôde ser observado nas análises da série de processamentos anteriores (variação da relação $\left.h_{f} / h\right)$. É claro que, para menores relações $h_{f} / h$, poderiam ser encontrados resultados 
melhores de deslocamentos para estes modelos. Mesmo assim observou-se o seguinte: à medida que diminui-se a relação $a_{1} / l$, ou seja, à medida que tem-se um número maior de nervuras por lado, maiores são as diferenças entre os deslocamentos máximos dados pelos modelos 02 e 03 comparados aos fornecidos pelo Modelo 04; para $a_{1} / l=0,1667$ tem-se uma diferença de $17 \%$, a maior para o deslocamento máximo na nervura central do Modelo 02; para $a_{1} / 1=0,0625$ essa diferença salta para $30 \%$;

- para valores mais altos na relação $\mathrm{a}_{1} / 1$, ou seja, quanto menor for o número de nervuras por lado, piores serão os resultados de deslocamentos do Modelo 07, ou modelo de laje maciça equivalente com redução do $G_{c}$ (módulo de deformação transversal do concreto). É interessante observar que confirmam-se os melhores resultados de deslocamentos nas relações: $a_{1} / l=0,0667$, com uma diferença de apenas $0,462 \%$ entre o deslocamento máximo do Modelo 07 em comparação com o resultado do Modelo 04, conforme havia determinado DEB et al. (1991); $a_{1} / 1=0,0625$, com uma diferença de apenas $0,21 \%$, melhor que a relação anterior; e $a_{1} / l=0,0714$, onde essa diferença foi de $1,15 \%$, o que também pode ser considerada como ótima correlação, confirmando experimentos de HOPPMANN et al. (1956). É importante observar que, nos modelos deste trabalho, chegamos a estes resultados considerando uma redução do módulo de elasticidade transversal para tornar o modelo mais flexível, simulando melhor o comportamento do sistema, haja visto que este é um modelo intrinsicamente mais rígido que os demais excêntricos;

- o Modelo 08, também de laje maciça equivalente, porém com redução de espessura conforme ADBUL-WAHAB \& KHALIL (2000), aplicado a estas lajes com relação $h_{f} / h=0,25$, não comportaram-se bem em termos de deslocamentos, apresentando resultados e comportamento próximos aos dos modelos 02 e 03 . Como verificado na experimentação da série de análise anterior, melhores resultados seriam obtidos com uma maior excentricidade nas nervuras, para este modelo;

- à medida que diminui-se a relação $a_{1} / 1$, ou seja, que aumentou-se o número de nervuras por lado, mais rígidos os modelos 05 e 06 (modelos de seção "T") apresentaramse em relação ao Modelo 04, distanciando dos resultados deste, chegando a apresentarem diferenças de $25,2 \%$ para o máximo deslocamento da nervura (ou eixo) central, na relação $\mathrm{a}_{1} / \mathrm{l}=0,0625$. Para $\mathrm{a}_{1} / \mathrm{l}=0,1667$ o erro foi de apenas $8,87 \%$ para o Modelo 05 , e 2,6\% para o Modelo 06, com deslocamentos menores que os apresentados pelo Modelo 04.

Abaixo tem-se os gráficos de deslocamentos ortogonais ao plano da placa para as vigas de contorno externo das lajes processadas nesta série. 


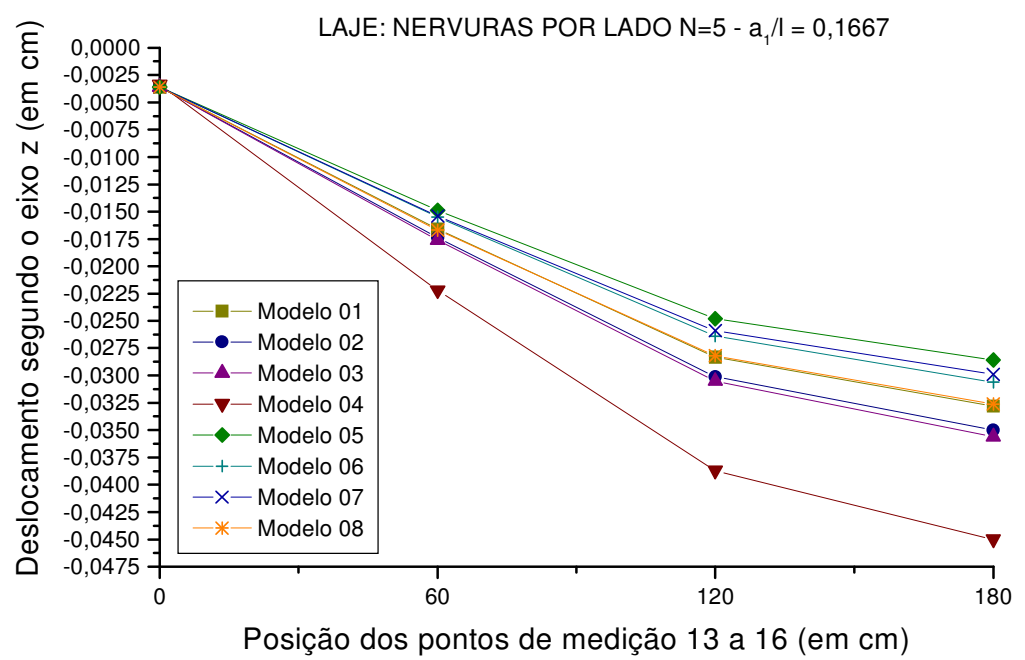

FIGURA 5.104: Deslocamentos em z (cm), na viga externa, na laje com $\mathrm{a}_{1} / \mathrm{l}=0,1667$

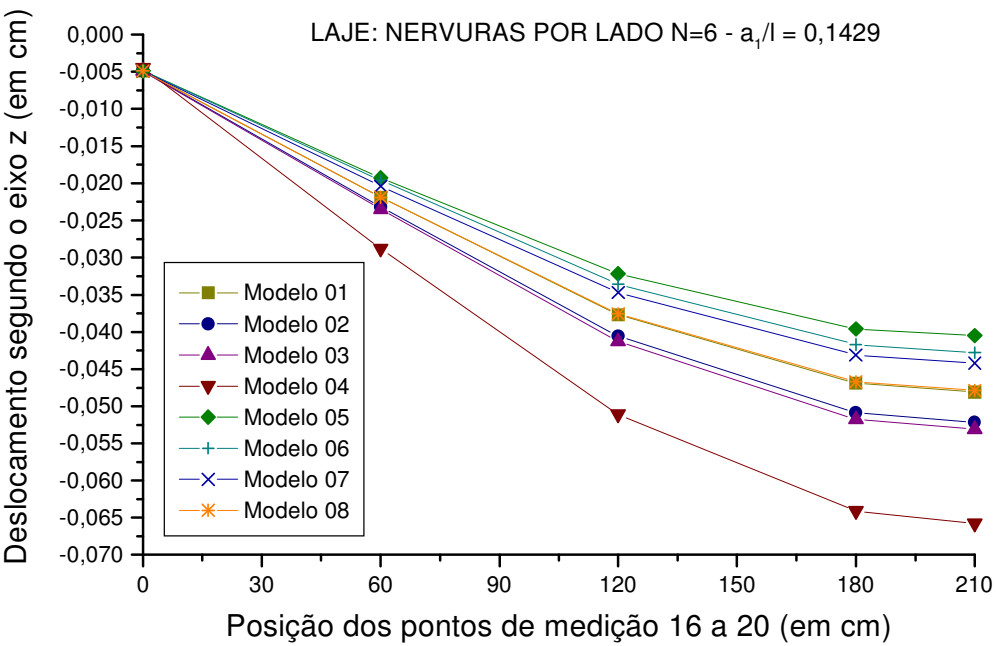

FIGURA 5.105: Deslocamentos em z (cm), na viga externa, na laje com $\mathrm{a}_{1} / \mathrm{l}=0,1420$

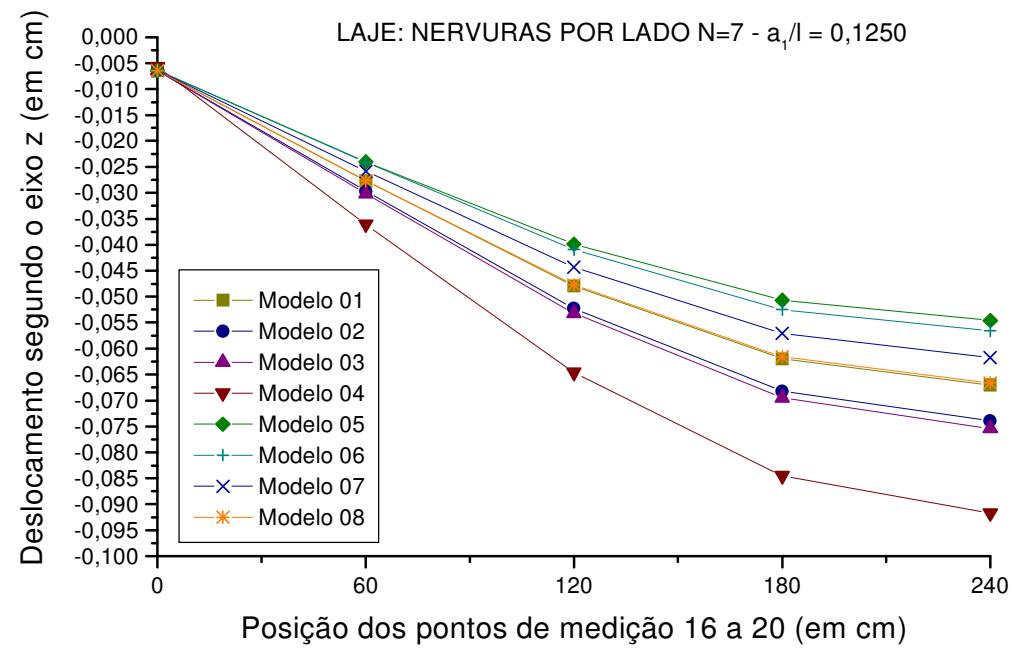

FIGURA 5.106: Deslocamentos em z (cm), na viga externa, na laje com $\mathrm{a}_{1} / \mathrm{l}=0,1250$ 


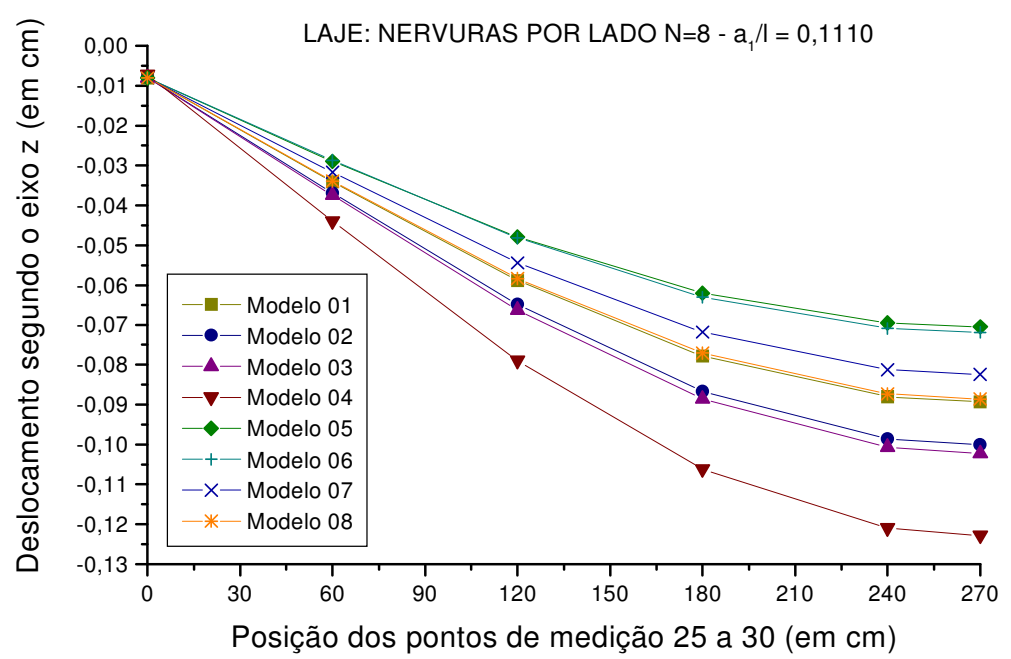

FIGURA 5.107: Deslocamentos em z (cm), na viga externa, na laje com $\mathrm{a}_{1} / \mathrm{l}=0,1111$

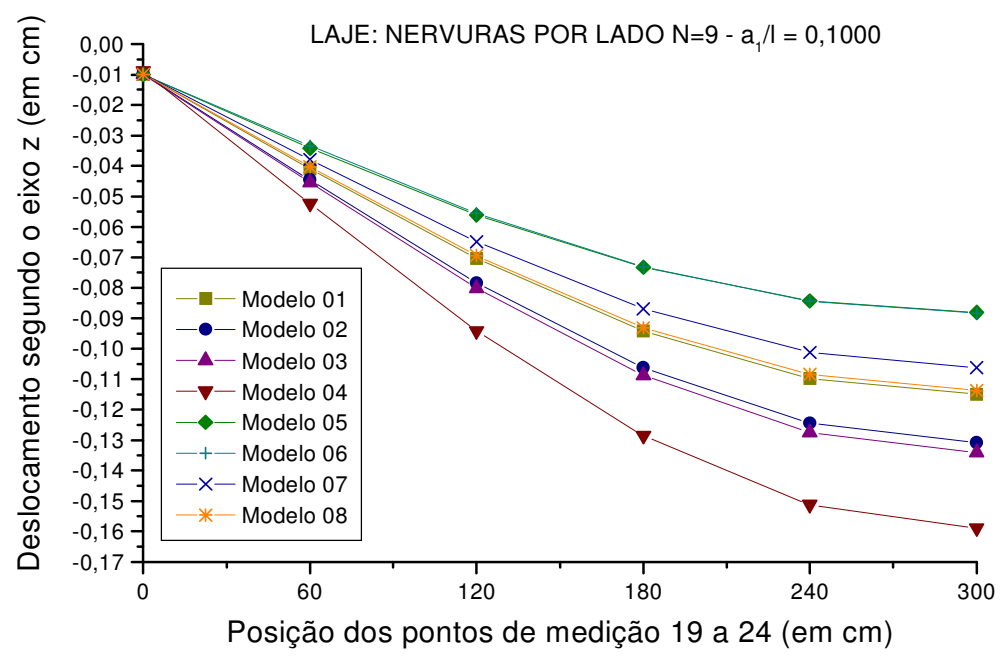

FIGURA 5.108: Deslocamentos em z (cm), na viga externa, na laje com $\mathrm{a}_{1} / \mathrm{l}=0,1000$

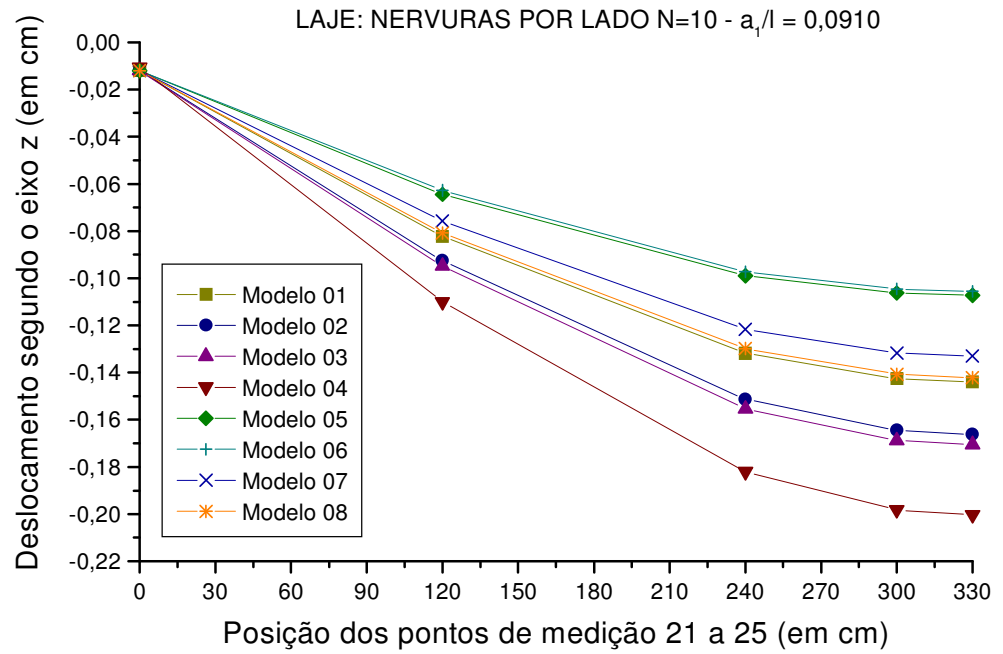

FIGURA 5.109: Deslocamentos em z (cm), na viga externa, na laje com $\mathrm{a}_{1} / \mathrm{l}=0,0910$ 


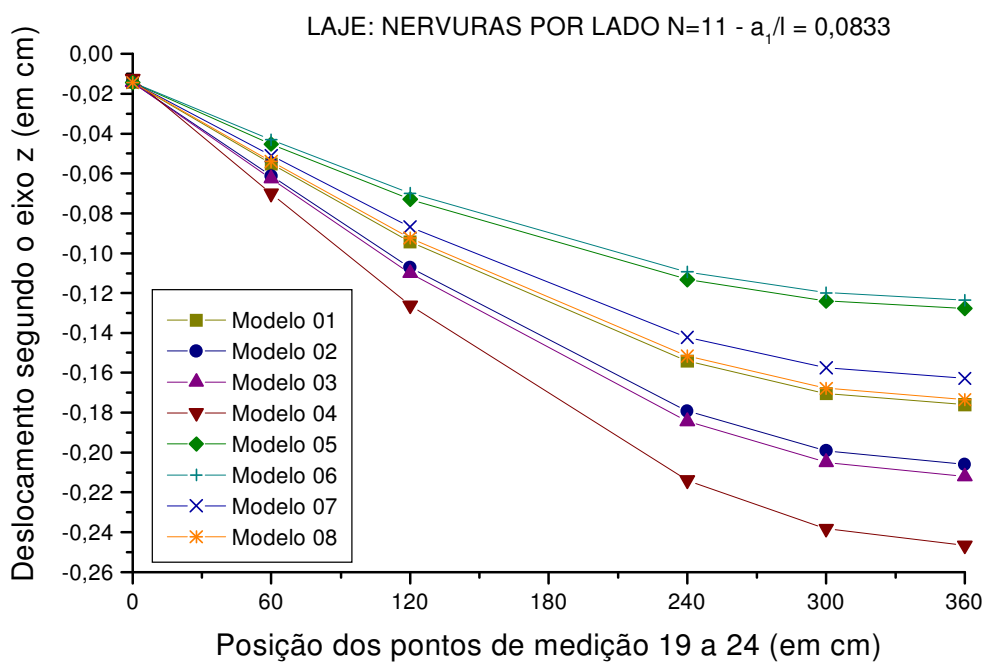

FIGURA 5.110: Deslocamentos em z (cm), na viga externa, na laje com $\mathrm{a}_{1} / \mathrm{l}=0,0833$

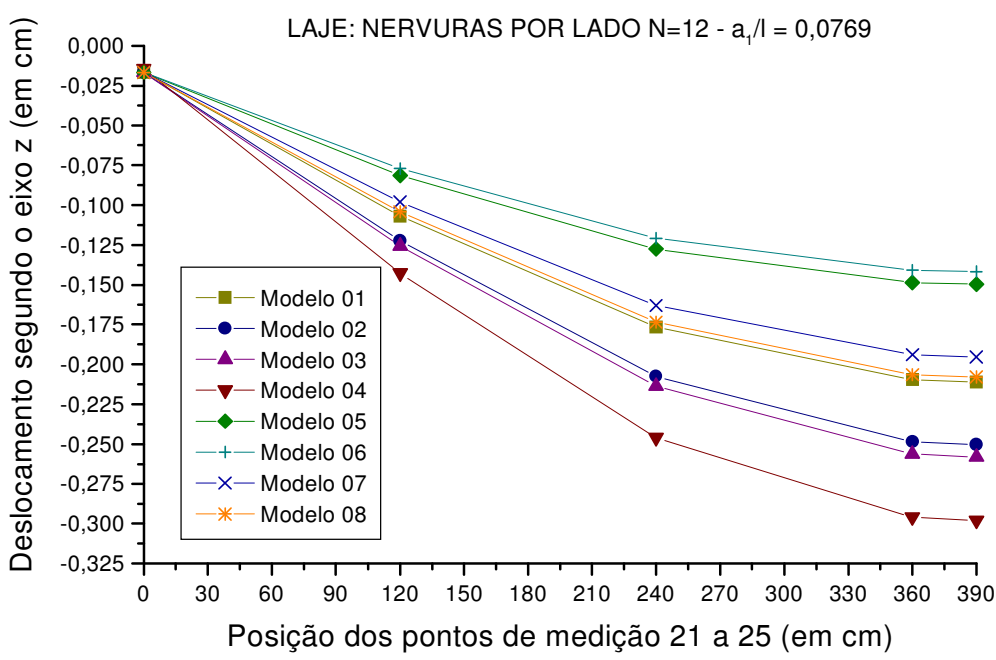

FIGURA 5.111: Deslocamentos em z $(\mathrm{cm})$, na viga externa, na laje com $\mathrm{a}_{1} / \mathrm{l}=0,0769$

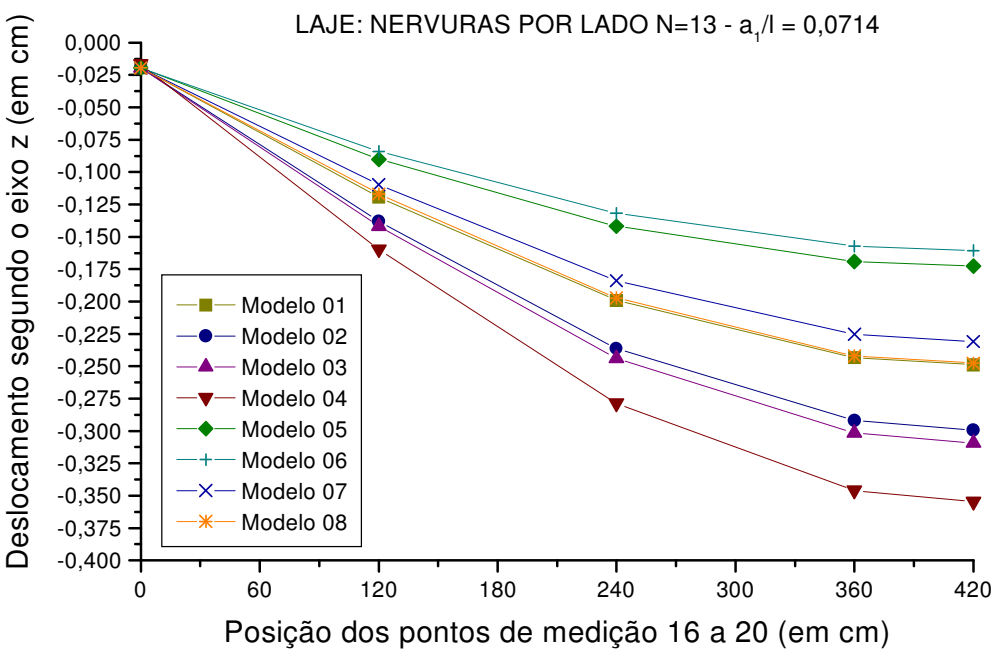

FIGURA 5.112: Deslocamentos em z $(\mathrm{cm})$, na viga externa, na laje com $\mathrm{a}_{1} / \mathrm{l}=0,0714$ 


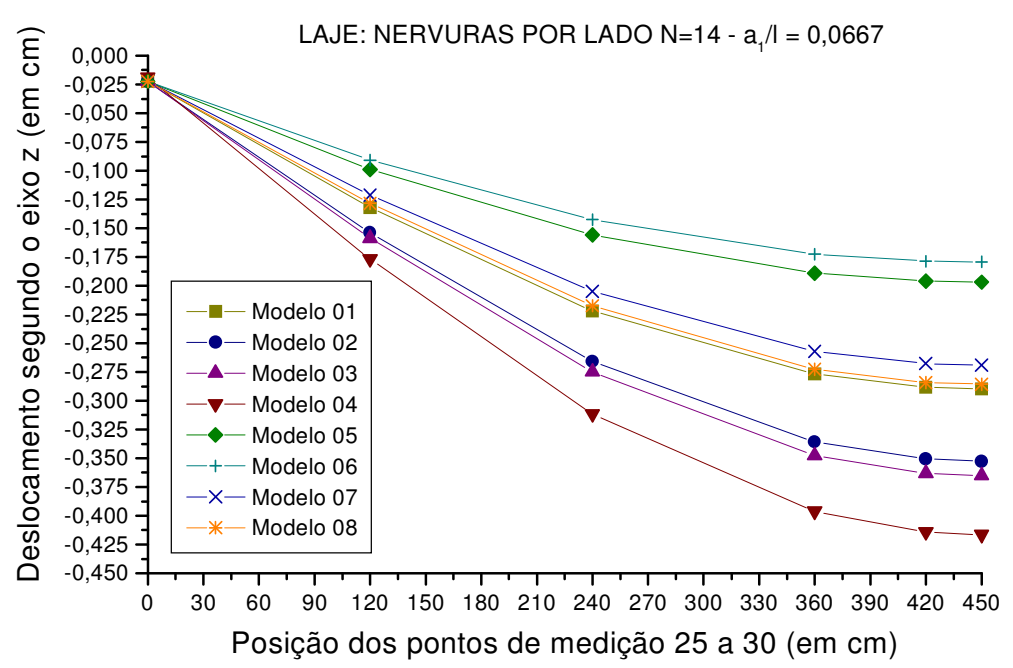

FIGURA 5.113: Deslocamentos em z (cm), na viga externa, na laje com $\mathrm{a}_{1} / \mathrm{l}=0,0667$

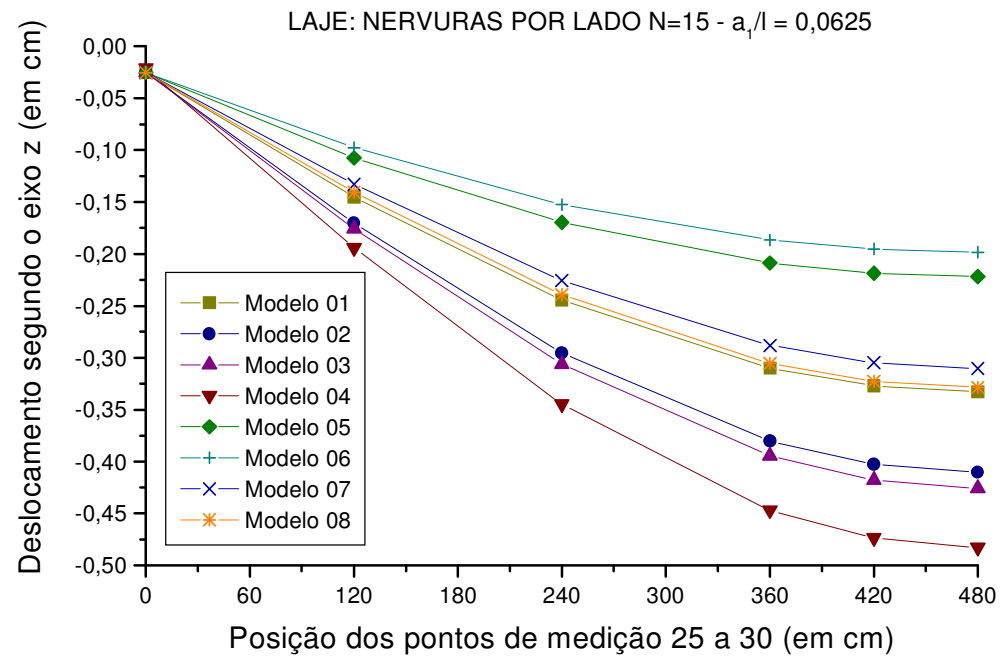

FIGURA 5.114: Deslocamentos em z (cm), na viga externa, na laje com $\mathrm{a}_{1} / \mathrm{l}=0,0625$

Pela análise das tabelas e gráficos de deslocamentos nas vigas de contorno externo, sempre simuladas de maneira excêntrica, nos modelos com variação da relação $a_{1} / l$, verificou-se que:

- o Modelo realista 04 apresentou, em todas as relações $a_{1} / l$, os maiores deslocamentos, seguidos pelos modelos que simulam as nervuras como vigas excêntricas: modelos 02 e 03 ;

- os modelos mais rígidos foram os que simulam as nervuras com seção "T", ou seja, modelos 05 e 06 , que para essas lajes com relação $h_{f} / h=0,25$, como verificado anteriormente, comportam-se realmente com mais rigidez; com relação à variação de $a_{1} / l$, percebe-se que há um afastamento entre os resultados obtidos com a laje simulada nos modelos 05 e 06, em comparação com o modelo realista 04, à medida que diminui-se a 
relação $a_{1} / l$ : para $a_{1} / l=0,1667$ tem-se diferença de $36 \%$ entre os resultados de deslocamentos nas vigas, a menor para os modelos 05 e 06; essa diferença aumenta para 54\% quando $\mathrm{a}_{1} / 1=0,0625$;

- percebe-se também que, há medida que diminui-se a relação $a_{1} / l$, mais próximos são os resultados de deslocamentos entre aqueles apresentados pelos modelos $02 \mathrm{e}$ 03 e os fornecidos pelo Modelo 04. Para $a_{1} / l=0,1667$ há uma diferença de $22,2 \%$ no deslocamento máximo da viga no Modelo 02, a menor, quando comparado com o modelo realista; para $a_{1} / l=0,0625$ esta diferença é de $15 \%$.

\subsubsection{Momentos Fletores atuantes nas nervuras e vigas}

TABELA 5.113: Momentos Fletores nas nervuras e vigas, em $\mathrm{kN} . \mathrm{cm}$, na laje com 05 nervuras por lado

\begin{tabular}{c|c|c|c|c|c|c|c|c}
\hline \multicolumn{7}{c}{ MAJE COM RELAÇÃO a1/I=0,1667 } \\
\hline \multirow{2}{*}{ Ponto } & \multicolumn{7}{c}{ Modelos numéricos de análise } \\
\cline { 2 - 10 } & $\mathbf{0 1}$ & $\mathbf{0 2}$ & $\mathbf{0 3}$ & $\mathbf{0 4}$ & $\mathbf{0 5}$ & $\mathbf{0 6}$ & $\mathbf{0 7}$ & $\mathbf{0 8}$ \\
\hline \hline $\mathbf{1}$ & $-38,25$ & $-20,37$ & $-23,44$ & $\mathbf{- 4 2 , 8 6}$ & $-98,94$ & $-109,72$ & 25,18 & $-8,05$ \\
\hline $\mathbf{2}$ & 144,96 & 82,20 & 27,14 & $\mathbf{4 2 , 9 5}$ & 128,61 & 137,47 & 201,14 & 139,98 \\
\hline $\mathbf{3}$ & 246,54 & 137,71 & 55,57 & $\mathbf{9 4 , 0 0}$ & 251,92 & 270,82 & 295,49 & 216,67 \\
\hline $\mathbf{4}$ & 281,17 & 159,01 & 69,08 & $\mathbf{1 0 9 , 9 4}$ & 289,38 & 311,32 & 321,06 & 236,39 \\
\hline \hline $\mathbf{5}$ & $-58,24$ & $-25,09$ & $-24,79$ & $-\mathbf{4 3 , 9 6}$ & $-92,40$ & $-101,98$ & 4,35 & $-28,01$ \\
\hline $\mathbf{6}$ & 114,38 & 67,13 & 20,73 & $\mathbf{3 6 , 2 8}$ & 115,75 & 125,20 & 165,94 & 115,44 \\
\hline $\mathbf{7}$ & 219,57 & 124,05 & 49,62 & $\mathbf{8 4 , 9 3}$ & 223,45 & 240,49 & 260,63 & 188,83 \\
\hline $\mathbf{8}$ & 255,27 & 145,54 & 63,09 & $\mathbf{1 0 0 , 1 1}$ & 255,73 & 274,96 & 285,95 & 207,32 \\
\hline \hline $\mathbf{9}$ & $-120,59$ & $-63,50$ & $-42,26$ & $\mathbf{- 5 1 , 9 3}$ & $-69,89$ & $-72,24$ & $-90,80$ & $-89,57$ \\
\hline $\mathbf{1 0}$ & 47,05 & 32,41 & 6,05 & $\mathbf{1 7 , 2 4}$ & 74,72 & 82,56 & 86,62 & 57,64 \\
\hline $\mathbf{1 1}$ & 144,32 & 86,89 & 33,88 & $\mathbf{5 8 , 7 4}$ & 144,92 & 156,46 & 173,33 & 118,12 \\
\hline $\mathbf{1 2}$ & 171,65 & 102,58 & 44,03 & $\mathbf{7 1 , 1 6}$ & 166,91 & 180,47 & 192,58 & 132,17 \\
\hline \hline $\mathbf{1 3}$ & $-519,64$ & $-548,53$ & $-555,41$ & $\mathbf{- 3 9 5 , 7 0}$ & $-467,89$ & $-518,75$ & $-445,14$ & $-486,20$ \\
\hline $\mathbf{1 4}$ & 184,29 & 131,42 & 124,60 & $\mathbf{8 1 , 5 4}$ & 248,34 & 190,00 & 122,47 & 147,65 \\
\hline $\mathbf{1 5}$ & 452,05 & 451,46 & 455,07 & $\mathbf{3 9 6 , 2 0}$ & 434,20 & 457,28 & 362,32 & 401,63 \\
\hline $\mathbf{1 6}$ & 505,41 & 551,97 & 560,55 & $\mathbf{5 0 3 , 0 4}$ & 436,64 & 488,20 & 431,80 & 470,33 \\
\hline \hline
\end{tabular}


TABELA 5.114: Momentos Fletores nas nervuras e vigas, em kN.cm, na laje com 06 nervuras por lado

\begin{tabular}{|c|c|c|c|c|c|c|c|c|}
\hline \multicolumn{9}{|c|}{$\begin{array}{c}\text { LAJE COM RELAÇÃO a1/l=0,1429 } \\
\text { MOMENTOS FLETORES NAS NERVURAS E VIGAS }\end{array}$} \\
\hline \multirow{2}{*}{ Ponto } & \multicolumn{8}{|c|}{ Modelos numéricos de análise } \\
\hline & 01 & 02 & 03 & 04 & 05 & 06 & 07 & 08 \\
\hline 6 & $-64,51$ & $-29,55$ & $-30,13$ & $-64,67$ & $-158,55$ & $-170,51$ & 22,85 & $-22,96$ \\
\hline 7 & 156,80 & 92,59 & 29,50 & 41,58 & 118,84 & 130,74 & 232,33 & 255,88 \\
\hline 8 & 293,63 & 165,37 & 65,38 & 110,51 & 285,29 & 310,57 & 360,55 & 260,49 \\
\hline 9 & 362,79 & 203,80 & 86,26 & 142,18 & 360,17 & 391,45 & 419,71 & 305,63 \\
\hline 10 & 374,47 & 213,00 & 93,34 & 146,82 & 372,83 & 401,58 & 423,93 & 308,75 \\
\hline$\overline{11}$ & $-179,98$ & $-104,26$ & $-64,69$ & $-70,61$ & $-94,05$ & $-92,56$ & $-152,20$ & $-137,59$ \\
\hline 12 & 19,61 & 18,06 & $-2,12$ & 7,55 & 62,40 & 72,56 & 68,56 & 43,98 \\
\hline 13 & 146,45 & 91,56 & 34,43 & 58,18 & 144,09 & 156,75 & 185,04 & 122,71 \\
\hline 14 & 197,89 & 118,43 & 49,28 & 79,76 & 181,46 & 197,19 & 226,43 & 152,64 \\
\hline 15 & 209,18 & 127,38 & 56,07 & 83,57 & 194,05 & 207,31 & 228,98 & 154,58 \\
\hline 16 & $-726,11$ & $-779,26$ & $-791,26$ & $-571,73$ & $-633,15$ & $-697,65$ & $-628,00$ & $-679,23$ \\
\hline 17 & 271,45 & 170,99 & 157,32 & 94,09 & 397,20 & 274,35 & 164,76 & 201,72 \\
\hline 18 & 684,28 & 660,49 & 664,51 & 583,16 & 663,58 & 664,87 & 536,72 & 596,10 \\
\hline 19 & 839,00 & 903,59 & 914,50 & 837,04 & 720,96 & 771,48 & 714,20 & 775,59 \\
\hline 20 & 784,33 & 875,97 & 893,57 & 850,04 & 616,95 & 681,15 & 728,69 & 788,00 \\
\hline
\end{tabular}

TABELA 5.115: Momentos Fletores nas nervuras e vigas, em kN.cm, na laje com 07 nervuras por lado

\begin{tabular}{c|c|c|c|c|c|c|c|c}
\hline \hline \multicolumn{7}{c}{ MAJE COM RELAÇÃ a1/l=0,1250 } \\
\hline \multirow{2}{*}{ Ponto } & \multicolumn{7}{c}{ Modelos numéricos de análise } \\
\cline { 2 - 10 } & $\mathbf{0 1}$ & $\mathbf{0 2}$ & $\mathbf{0 3}$ & $\mathbf{0 4}$ & $\mathbf{0 5}$ & $\mathbf{0 6}$ & $\mathbf{0 7}$ & $\mathbf{0 8}$ \\
\hline \hline $\mathbf{1}$ & $-87,48$ & $-39,47$ & $-37,78$ & $\mathbf{- 9 1 , 1 7}$ & $-238,55$ & $-251,28$ & 29,17 & $-29,88$ \\
\hline $\mathbf{2}$ & 180,04 & 109,74 & 34,72 & $\mathbf{3 9 , 9 6}$ & 98,66 & 113,64 & 285,23 & 184,43 \\
\hline $\mathbf{3}$ & 352,70 & 200,73 & 78,57 & $\mathbf{1 2 8 , 9 1}$ & 318,61 & 351,08 & 448,73 & 319,72 \\
\hline $\mathbf{4}$ & 454,19 & 254,97 & 106,30 & $\mathbf{1 7 7 , 6 6}$ & 438,14 & 480,75 & 540,74 & 392,07 \\
\hline $\mathbf{5}$ & 488,80 & 276,25 & 119,81 & $\mathbf{1 9 3 , 2 5}$ & 475,52 & 521,25 & 565,81 & 411,01 \\
\hline \hline $\mathbf{6}$ & $-167,39$ & $-73,64$ & $-52,51$ & $\mathbf{- 8 7 , 6 9}$ & $-187,74$ & $-196,05$ & $-66,93$ & $-109,91$ \\
\hline $\mathbf{7}$ & 67,64 & 49,05 & 8,75 & $\mathbf{1 8 , 3 0}$ & 77,52 & 93,48 & 157,45 & 101,76 \\
\hline $\mathbf{8}$ & 242,59 & 142,88 & 53,69 & $\mathbf{9 3 , 6 5}$ & 234,82 & 260,25 & 318,84 & 224,59 \\
\hline $\mathbf{9}$ & 346,77 & 198,97 & 82,01 & $\mathbf{1 3 4 , 3 9}$ & 316,25 & 346,16 & 406,52 & 286,54 \\
\hline $\mathbf{1 0}$ & 380,14 & 218,63 & 94,50 & $\mathbf{1 4 7 , 1 1}$ & 341,60 & 373,18 & 428,82 & 302,23 \\
\hline \hline $\mathbf{1 1}$ & $-245,52$ & $-153,50$ & $-91,44$ & $\mathbf{- 9 0 , 9 5}$ & $-116,95$ & $-110,81$ & $-224,69$ & $-192,34$ \\
\hline $\mathbf{1 2}$ & $-15,51$ & $-1,51$ & $-12,41$ & $-\mathbf{4 , 7 7}$ & 48,09 & 60,97 & 40,42 & 24,11 \\
\hline $\mathbf{1 3}$ & 139,16 & 91,24 & 38,85 & $\mathbf{5 4 , 5 0}$ & 138,15 & 151,80 & 187,26 & 120,58 \\
\hline $\mathbf{1 4}$ & 213,90 & 130,50 & 53,39 & $\mathbf{8 3 , 5 2}$ & 186,44 & 203,53 & 250,56 & 165,48 \\
\hline $\mathbf{1 5}$ & 234,20 & 141,08 & 60,37 & $\mathbf{9 2 , 0 3}$ & 201,98 & 220,75 & 264,30 & 176,04 \\
\hline \hline $\mathbf{1 6}$ & $-947,83$ & $-1034,50$ & $-1053,40$ & $\mathbf{- 7 6 8 , 9 1}$ & $-799,07$ & $-877,06$ & $-827,14$ & $-887,19$ \\
\hline $\mathbf{1 7}$ & 402,24 & 229,72 & 205,22 & $\mathbf{1 0 3 , 2 4}$ & 622,06 & 398,69 & 220,63 & 272,67 \\
\hline $\mathbf{1 8}$ & 988,78 & 920,10 & 922,91 & $\mathbf{8 0 8 , 4 6}$ & 970,85 & 929,16 & 747,44 & 832,11 \\
\hline $\mathbf{1 9}$ & 1261,30 & 1333,80 & 1354,20 & $\mathbf{1 2 4 6 , 2 3}$ & 1077,00 & 1103,40 & 1054,00 & 1144,40 \\
\hline $\mathbf{2 0}$ & 1284,00 & 1460,10 & 1491,00 & $\mathbf{1 3 9 7 , 1 4}$ & 1008,70 & 1077,70 & 1142,50 & 1228,80 \\
\hline \hline
\end{tabular}


TABELA 5.116: Momentos Fletores nas nervuras e vigas, em kN.cm, na laje com 08 nervuras por lado

\begin{tabular}{c|c|c|c|c|c|c|c|c}
\hline \hline \multicolumn{7}{c}{ MAJE COM RELAÇÃO a1/l=0,1111 } \\
\hline \multirow{2}{*}{ Ponto } & \multicolumn{7}{c}{ Modelos numéricos de análise } \\
\cline { 2 - 10 } & $\mathbf{0 1}$ & $\mathbf{0 2}$ & $\mathbf{0 3}$ & $\mathbf{0 4}$ & $\mathbf{0 5}$ & $\mathbf{0 6}$ & $\mathbf{0 7}$ & $\mathbf{0 8}$ \\
\hline \hline $\mathbf{7}$ & $-124,55$ & $-52,72$ & $-46,57$ & $\mathbf{- 1 2 0 , 7 8}$ & $-328,42$ & $-340,99$ & 25,90 & $-49,46$ \\
\hline $\mathbf{8}$ & 182,66 & 117,80 & 36,08 & $\mathbf{3 1 , 9 6}$ & 60,53 & 79,05 & 316,28 & 196,07 \\
\hline $\mathbf{9}$ & 392,70 & 227,47 & 88,08 & $\mathbf{1 3 9 , 7 0}$ & 327,68 & 366,78 & 514,37 & 361,07 \\
\hline $\mathbf{1 0}$ & 528,70 & 298,64 & 123,09 & $\mathbf{2 0 5 , 3 5}$ & 489,07 & 541,53 & 639,78 & 460,16 \\
\hline $\mathbf{1 1}$ & 597,84 & 336,95 & 143,93 & $\mathbf{2 3 6 , 4 7}$ & 563,83 & 622,41 & 698,04 & 503,95 \\
\hline $\mathbf{1 2}$ & 609,51 & 346,12 & 150,99 & $\mathbf{2 4 1 , 0 3}$ & 576,48 & 632,53 & 702,18 & 507,01 \\
\hline \hline $\mathbf{1 3}$ & $-242,67$ & $-115,15$ & $-75,47$ & $\mathbf{- 1 1 3 , 0 8}$ & $-237,15$ & $-243,86$ & $-129,27$ & $-170,75$ \\
\hline $\mathbf{1 4}$ & 24,59 & 29,03 & $-1,89$ & $\mathbf{3 , 3 4}$ & 48,94 & 68,25 & 132,92 & 80,96 \\
\hline $\mathbf{1 5}$ & 232,63 & 141,50 & 51,17 & $\mathbf{9 0 , 3 3}$ & 224,85 & 253,94 & 328,41 & 228,67 \\
\hline $\mathbf{1 6}$ & 369,06 & 215,07 & 87,14 & $\mathbf{1 4 2 , 0 8}$ & 324,71 & 358,74 & 446,52 & 311,23 \\
\hline $\mathbf{1 7}$ & 432,92 & 249,17 & 105,73 & $\mathbf{1 6 5 , 6 9}$ & 370,46 & 407,54 & 496,08 & 346,01 \\
\hline $\mathbf{1 8}$ & 444,41 & 158,40 & 112,84 & $\mathbf{1 6 9 , 9 1}$ & 383,10 & 417,66 & 499,44 & 348,40 \\
\hline \hline $\mathbf{1 9}$ & $-315,16$ & $-209,00$ & $-121,27$ & $\mathbf{- 1 1 2 , 9 9}$ & $-138,45$ & $-127,18$ & $-306,37$ & $-252,55$ \\
\hline $\mathbf{2 0}$ & $-56,70$ & $-25,35$ & $-24,32$ & $\mathbf{- 1 9 , 9 4}$ & 32,93 & 48,82 & 2,90 & $-1,47$ \\
\hline $\mathbf{2 1}$ & 123,77 & 86,05 & 29,16 & $\mathbf{4 8 , 4 0}$ & 129,23 & 143,87 & 180,19 & 112,15 \\
\hline $\mathbf{2 2}$ & 221,43 & 138,96 & 56,12 & $\mathbf{8 4 , 0 2}$ & 185,41 & 203,42 & 266,73 & 171,98 \\
\hline $\mathbf{2 3}$ & 259,62 & 157,15 & 66,27 & $\mathbf{9 8 , 9 4}$ & 212,16 & 233,03 & 296,77 & 195,08 \\
\hline $\mathbf{2 4}$ & 270,78 & 166,07 & 72,95 & $\mathbf{1 0 2 , 3 3}$ & 224,74 & 243,16 & 298,66 & 196,61 \\
\hline \hline $\mathbf{2 5}$ & $-1175,30$ & $-1305,00$ & $-1332,70$ & $\mathbf{- 9 7 8 , 8 4}$ & $-956,73$ & $-1049,30$ & $-1036,20$ & $-1103,30$ \\
\hline $\mathbf{2 6}$ & 591,03 & 316,48 & 276,24 & $\mathbf{1 4 8 , 2 1}$ & 942,50 & 570,73 & 294,15 & 364,83 \\
\hline $\mathbf{2 7}$ & 1382,10 & 1239,70 & 1238,40 & $\mathbf{1 0 7 7 , 7 1}$ & 1376,90 & 1265,40 & 998,45 & 1113,60 \\
\hline $\mathbf{2 8}$ & 1788,30 & 1850,10 & 1877,60 & $\mathbf{1 7 3 2 , 7 6}$ & 1520,20 & 1493,00 & 1453,20 & 1579,50 \\
\hline $\mathbf{2 9}$ & 1918,00 & 2156,40 & 2202,30 & $\mathbf{2 0 7 5 , 5 7}$ & 1493,80 & 1529,30 & 1675,50 & 1798,90 \\
\hline $\mathbf{3 0}$ & 1800,70 & 2098,50 & 2152,00 & $\mathbf{2 0 8 9 , 9 7}$ & 1301,10 & 1377,60 & 1692,50 & 1812,60 \\
\hline \hline
\end{tabular}


TABELA 5.117: Momentos Fletores nas nervuras e vigas, em kN.cm, na laje com 09 nervuras por lado

\begin{tabular}{|c|c|c|c|c|c|c|c|c|}
\hline \multicolumn{9}{|c|}{$\begin{array}{c}\text { LAJE COM RELAÇÃO a1/l=0,1000 } \\
\text { MOMENTOS FLETORES NAS NERVURAS E VIGAS }(\mathrm{kN.cm})\end{array}$} \\
\hline \multirow{2}{*}{ Ponto } & \multicolumn{8}{|c|}{$\begin{array}{l}\text { Modelos numéricos de análise } \\
\end{array}$} \\
\hline & 01 & 02 & 03 & 04 & 05 & 06 & 07 & 08 \\
\hline 1 & $-159,77$ & $-66,59$ & $-56,08$ & $-155,91$ & $-441,54$ & $-453,19$ & 30,71 & $-61,25$ \\
\hline 2 & 194,51 & 131,53 & 39,77 & 20,09 & 7,72 & 30,39 & 368,22 & 219,89 \\
\hline 3 & 444,55 & 262,25 & 101,07 & 151,50 & 331,10 & 377,61 & 604,26 & 416,76 \\
\hline 4 & 614,32 & 349,85 & 143,23 & 235,94 & 542,37 & 606,21 & 762,96 & 544,88 \\
\hline 5 & 716,38 & 404,10 & 170,94 & 283,60 & 659,70 & 733,43 & 853,86 & 614,88 \\
\hline 6 & 750,99 & 425,34 & 184,43 & 299,03 & 697,06 & 773,93 & 878,70 & 633,42 \\
\hline 7 & $-229,95$ & $-93,82$ & $-67,50$ & $-145,19$ & $-373,85$ & $-385,46$ & $-49,28$ & $-135,97$ \\
\hline 8 & 84,48 & 72,98 & 14,98 & 5,11 & 12,66 & 34,12 & 239,24 & 136,20 \\
\hline 9 & 326,05 & 196,90 & 72,99 & 119,64 & 276,63 & 318,13 & 466,23 & 324,61 \\
\hline 10 & 501,66 & 289,29 & 117,02 & 194,03 & 441,38 & 494,08 & 624,78 & 442,87 \\
\hline 11 & 607,47 & 345,99 & 145,62 & 235,70 & 530,68 & 589,19 & 713,70 & 505,91 \\
\hline 12 & 642,52 & 367,23 & 159,02 & 249,04 & 558,93 & 619,40 & 737,34 & 522,40 \\
\hline 13 & $-387,49$ & $-269,02$ & $-153,25$ & $-136,49$ & $-158,67$ & $-142,03$ & $-395,57$ & $-317,17$ \\
\hline 14 & $-102,72$ & $-52,68$ & $-37,53$ & $-33,67$ & 17,51 & 36,58 & $-43,25$ & $-32,24$ \\
\hline 15 & 101,48 & 76,31 & 23,50 & 40,28 & 118,61 & 134,22 & 163,98 & 97,75 \\
\hline 16 & 221,45 & 143,70 & 57,26 & 82,09 & 180,60 & 199,27 & 275,30 & 172,59 \\
\hline 17 & 276,99 & 170,35 & 71,34 & 102,32 & 215,59 & 237,93 & 321,79 & 207,86 \\
\hline 18 & 292,53 & 177,69 & 76,10 & 108,30 & 226,98 & 250,74 & 332,18 & 216,36 \\
\hline 19 & $-1400,60$ & $-1583,10$ & $-1621,50$ & $-1198,26$ & $-1099,40$ & $-1209,80$ & $-1250,30$ & $-1322,50$ \\
\hline 20 & 851,71 & 439,92 & 378,15 & 210,36 & 1376,60 & 794,99 & 388,58 & 481,66 \\
\hline 21 & 1880,70 & 1628,30 & 1618,70 & 1395,20 & 1903,40 & 1688,90 & 1293,00 & 1443,90 \\
\hline 22 & 2437,60 & 2461,10 & 2495,00 & 2298,80 & 2067,90 & 1951,70 & 1914,30 & 2083,80 \\
\hline 23 & 2685,30 & 2975,50 & 3039,20 & 2871,19 & 2073,90 & 2035,40 & 2290,70 & 2459,20 \\
\hline 24 & 2641,20 & 3119,50 & 3202,60 & 3067,06 & 1903,40 & 1939,50 & 2397,00 & 2558,20 \\
\hline
\end{tabular}

TABELA 5.118: Momentos Fletores nas nervuras e vigas, em kN.cm, na laje com 10 nervuras por lado

\begin{tabular}{|c|c|c|c|c|c|c|c|c|}
\hline \multicolumn{9}{|c|}{$\begin{array}{c}\text { LAJE COM RELAÇÃO a1/l=0,0910 } \\
\text { MOMENTOS FLETORES NAS NERVURAS E VIGAS } \\
\end{array}$} \\
\hline \multirow{2}{*}{ Ponto } & \multicolumn{8}{|c|}{$\begin{array}{ll}\text { Modelos numéricos de análise } \\
\end{array}$} \\
\hline & 01 & 02 & 03 & 04 & 05 & 06 & 07 & 08 \\
\hline 6 & $-209,02$ & $-84,15$ & $-66,92$ & \begin{tabular}{l|l|}
$-193,36$ \\
\end{tabular} & $-562,52$ & $-572,80$ & 26,42 & $-85,51$ \\
\hline 7 & 475,43 & 287,22 & 109,89 & 155,74 & 312,82 & 366,42 & 670,32 & 454,70 \\
\hline 8 & 817,57 & 463,48 & 194,59 & 322,42 & 727,91 & 814,92 & 986,94 & 707,16 \\
\hline 9 & 886,70 & 501,68 & 215,38 & 353,25 & 802,62 & 895,79 & 1044,72 & 750,30 \\
\hline 10 & 898,37 & 510,84 & 222,44 & 357,77 & 815,26 & 905,92 & 1048,80 & 753,30 \\
\hline$\overline{111}$ & $-313,67$ & $-134,05$ & $\begin{array}{c}-89,68 \\
\end{array}$ & $\begin{array}{l}-176,49 \\
\end{array}$ & $-449,26$ & $-460,38$ & 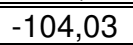 & $-200,21$ \\
\hline 12 & 304,88 & 191,52 & 68,80 & 111,81 & 251,13 & 297,20 & 473,05 & 325,56 \\
\hline 13 & 653,68 & 375,64 & 156,53 & 252,33 & 550,22 & 615,64 & 784,56 & 552,44 \\
\hline 14 & 721,92 & 412,94 & 176,73 & 277,67 & 602,40 & 671,49 & 838,08 & 589,63 \\
\hline 15 & 733,49 & 422,06 & 183,77 & 281,96 & 615,02 & 681,62 & 841,80 & 592,22 \\
\hline 16 & $-461,53$ & $-332,35$ & $-186,77$ & $-161,39$ & $-177,82$ & $-155,71$ & $-490,94$ & $-385,32$ \\
\hline 17 & 73,36 & 62,44 & 16,10 & 30,42 & 107,06 & 123,59 & 138,85 & 77,69 \\
\hline 18 & 287,57 & 180,78 & 75,35 & 103,24 & 214,56 & 237,93 & 340,46 & 215,18 \\
\hline 19 & 316,92 & 193,66 & 82,43 & 113,84 & 234,47 & 260,36 & 363,49 & 234,09 \\
\hline 20 & 328,03 & 202,34 & 88,85 & 116,93 & 247,07 & 270,48 & 364,97 & 235,36 \\
\hline 21 & $-1617,50$ & $-1862,50$ & $-1913,60$ & $-1421,82$ & $-1222,20$ & $-1356,40$ & $-1466,00$ & $-1541,20$ \\
\hline 22 & 2501,20 & 2094,20 & 2070,50 & 1765,90 & 2572,50 & 2215,10 & 1633,60 & 1825,40 \\
\hline 23 & 3603,00 & 3924,00 & 4007,40 & 3784,70 & 2763,80 & 2603,50 & 2988,80 & 3211,00 \\
\hline 24 & 3666,30 & 4285,10 & 4400,00 & 4218,05 & 2621,40 & 2556,20 & 3254,70 & 3469,40 \\
\hline 25 & 3454,20 & 4185,60 & 4314,70 & 4233,09 & 2314,50 & 2337,50 & 3273,90 & 3484,20 \\
\hline
\end{tabular}


TABELA 5.119: Momentos Fletores nas nervuras e vigas, em kN.cm, na laje com 11 nervuras por lado

\begin{tabular}{c|c|c|c|c|c|c|c|c}
\hline \hline \multicolumn{7}{c}{ LAJE COM RELAÇÃO a1/l=0,0833 } \\
\hline \multirow{2}{*}{ Ponto } & \multicolumn{7}{c}{$\mathbf{0}$ Modelos numéricos de análise } \\
\cline { 2 - 10 } & $\mathbf{0 1}$ & $\mathbf{0 2}$ & $\mathbf{0 3}$ & $\mathbf{0 4}$ & $\mathbf{0 5}$ & $\mathbf{0 6}$ & $\mathbf{0 7}$ & $\mathbf{0 8}$ \\
\hline \hline $\mathbf{1}$ & $-257,77$ & $-102,29$ & $-78,30$ & $\mathbf{- 2 3 6 , 6 8}$ & $-709,10$ & $-717,12$ & 29,94 & $-102,03$ \\
\hline $\mathbf{2}$ & 184,91 & 146,23 & 41,77 & $\mathbf{- 1 4 , 7 6}$ & $-146,53$ & $-114,43$ & 449,47 & 246,10 \\
\hline $\mathbf{3}$ & 516,88 & 319,68 & 121,94 & $\mathbf{1 6 0 , 4 5}$ & 284,35 & 345,92 & 760,68 & 506,27 \\
\hline $\mathbf{4}$ & 929,14 & 530,14 & 221,49 & $\mathbf{3 6 4 , 8 0}$ & 799,79 & 901,85 & 1114,74 & 816,90 \\
\hline $\mathbf{5}$ & 1031,70 & 584,48 & 249,23 & $\mathbf{4 1 1 , 8 0}$ & 915,74 & 1027,50 & 1235,10 & 885,54 \\
\hline $\mathbf{6}$ & 1066,30 & 605,67 & 262,69 & $\mathbf{4 2 7 , 2 1}$ & 953,09 & 1068,00 & 1259,76 & 903,90 \\
\hline \hline $\mathbf{7}$ & $-319,61$ & $-126,15$ & $-88,40$ & $\mathbf{- 2 2 2 , 0 4}$ & $-627,24$ & $-638,14$ & $-40,39$ & $-173,11$ \\
\hline $\mathbf{8}$ & 83,61 & 93,48 & 19,71 & $\mathbf{- 2 4 , 3 0}$ & $-120,44$ & $-92,12$ & 325,22 & 162,19 \\
\hline $\mathbf{9}$ & 398,05 & 252,89 & 93,31 & $\mathbf{1 3 2 , 6 8}$ & 256,08 & 312,47 & 619,08 & 415,88 \\
\hline $\mathbf{1 0}$ & 816,27 & 468,66 & 194,79 & $\mathbf{3 1 8 , 5 4}$ & 688,47 & 777,11 & 1002,18 & 710,94 \\
\hline $\mathbf{1 1}$ & 922,10 & 525,32 & 223,42 & $\mathbf{3 6 1 , 0 8}$ & 783,02 & 878,49 & 1091,70 & 774,66 \\
\hline $\mathbf{1 2}$ & 957,46 & 546,99 & 237,09 & $\mathbf{3 7 4 , 8 8}$ & 813,33 & 911,06 & 1115,82 & 791,58 \\
\hline \hline $\mathbf{1 3}$ & $-529,52$ & $-305,45$ & $-178,80$ & $\mathbf{- 2 0 3 , 9 5}$ & $-379,09$ & $-380,39$ & $-421,45$ & $-424,52$ \\
\hline $\mathbf{1 4}$ & $-163,37$ & $-67,69$ & $-49,19$ & $\mathbf{- 6 2 , 4 0}$ & $-50,74$ & $-21,79$ & $-17,15$ & $-31,75$ \\
\hline $\mathbf{1 5}$ & 137,00 & 100,99 & 28,24 & $\mathbf{5 8 , 5 2}$ & 164,54 & 202,88 & 285,45 & 192,29 \\
\hline $\mathbf{1 6}$ & 509,82 & 305,10 & 125,29 & $\mathbf{1 9 0 , 0 8}$ & 391,19 & 440,05 & 627,30 & 424,57 \\
\hline $\mathbf{1 7}$ & 588,19 & 344,56 & 145,87 & $\mathbf{2 1 6 , 9 4}$ & 440,31 & 493,75 & 691,20 & 470,50 \\
\hline $\mathbf{1 8}$ & 612,38 & 357,85 & 154,62 & $\mathbf{2 2 5 , 3 1}$ & 459,19 & 511,35 & 707,10 & 482,29 \\
\hline \hline $\mathbf{1 9}$ & $-1821,30$ & $-2138,60$ & $-2204,10$ & $\mathbf{- 1 6 4 6 , 2 6}$ & $-1321,50$ & $-1488,80$ & $-1680,90$ & $-1757,10$ \\
\hline $\mathbf{2 0}$ & 1640,80 & 828,70 & 702,92 & $\mathbf{3 9 4 , 3 3}$ & 2651,10 & 1406,90 & 649,44 & 799,36 \\
\hline $\mathbf{2 1}$ & 3259,90 & 2645,30 & 2600,40 & $\mathbf{2 1 9 3 , 7 5}$ & 3407,00 & 2859,60 & 2022,10 & 2259,80 \\
\hline $\mathbf{2 2}$ & 4689,30 & 5009,30 & 5113,10 & $\mathbf{4 8 1 7 , 2 6}$ & 3579,50 & 3243,10 & 3771,10 & 4056,20 \\
\hline $\mathbf{2 3}$ & 4867,70 & 5616,90 & 5768,20 & $\mathbf{5 5 2 6 , 9 9}$ & 3454,70 & 3227,00 & 4216,90 & 4494,80 \\
\hline $\mathbf{2 4}$ & 4714,20 & 5767,40 & 5951,30 & $\mathbf{5 7 6 8 , 1 9}$ & 3153,50 & 3052,30 & 4340,50 & 4608,20 \\
\hline \hline
\end{tabular}


TABELA 5.120: Momentos Fletores nas nervuras e vigas, em kN.cm, na laje com 12 nervuras por lado

\begin{tabular}{|c|c|c|c|c|c|c|c|c|}
\hline \multicolumn{9}{|c|}{$\begin{array}{l}\text { LAJE COM RELAÇÃO a1/l=0,0769 } \\
\text { MOMENTOS FLETORES NAS NERVURAS E VIGAS }\end{array}$} \\
\hline \multirow{2}{*}{ Ponto } & \multicolumn{8}{|c|}{ Modelos numéricos de análise } \\
\hline & 01 & 02 & 03 & 04 & 05 & 06 & 07 & 08 \\
\hline 6 & $-320,50$ & $-124,52$ & $-91,26$ & $-281,87$ & $-861,96$ & $-867,77$ & 24,61 & $-130,97$ \\
\hline 7 & 536,82 & 342,06 & 129,71 & 158,31 & 236,75 & 305,81 & 826,98 & 540,32 \\
\hline 8 & 1022,10 & 588,33 & 244,77 & 398,69 & 844,76 & 960,12 & 1279,14 & 907,92 \\
\hline 9 & 1228,00 & 697,37 & 300,37 & 492,86 & 1075,60 & 1210,00 & 1459,74 & 1044,78 \\
\hline 10 & 1239,60 & 706,52 & 307,43 & $\begin{array}{l}497,26 \\
\end{array}$ & 1088,20 & 1220,00 & 1463,88 & 1047,78 \\
\hline 11 & $-412,27$ & $-167,04$ & $-110,70$ & $-259,72$ & $-729,74$ & $-740,56$ & $-89,22$ & $-239,77$ \\
\hline 12 & 366,60 & 244,87 & 88,06 & 119,80 & 211,14 & 272,07 & 624,72 & 412,66 \\
\hline 13 & 853,39 & 495,64 & 204,62 & 332,09 & 695,36 & 791,88 & 1073,94 & 758,10 \\
\hline 14 & 1062,90 & 607,96 & 261,42 & 413,88 & 871,95 & 981,32 & 1250,22 & 882,48 \\
\hline 15 & 1074,60 & 617,04 & 268,44 & 418,20 & 884,58 & 991,45 & 1254,18 & 885,24 \\
\hline 16 & $-639,91$ & $-387,36$ & $-222,81$ & $-239,03$ & $-423,33$ & $-423,22$ & $-550,31$ & $-529,40$ \\
\hline 17 & 87,52 & 76,91 & 16,16 & 42,14 & 139,16 & 179,95 & 248,48 & 165,28 \\
\hline 18 & 513,80 & 313,45 & 127,48 & 190,82 & 384,81 & 436,30 & 651,00 & 435,68 \\
\hline 19 & 661,04 & 387,39 & 166,12 & 240,37 & 473,68 & 534,18 & 772,62 & 523,71 \\
\hline 20 & 672,32 & 397,00 & 173,46 & 244,18 & 486,33 & 544,30 & 775,02 & 525,53 \\
\hline 21 & $-2008,10$ & $-2407,50$ & $-2489,50$ & $-1869,31$ & $-1394,50$ & $-1607,50$ & $-1893,20$ & $-1968,40$ \\
\hline 22 & 4173,00 & 3289,20 & 3214,40 & 2681,90 & 4429,90 & 3638,60 & 2459,60 & 2748,70 \\
\hline 23 & 5963,90 & 6239,50 & 6363,00 & 5970,36 & 4538,60 & 3965,80 & 4639,30 & 4996,70 \\
\hline 24 & 6213,20 & 7525,30 & 7766,20 & 7518,26 & 4129,70 & 3818,30 & 5592,30 & 5932,30 \\
\hline 25 & 5869,00 & 7372,60 & 7637,30 & 7533,29 & 3683,40 & 3528,80 & 5613,70 & 5948,10 \\
\hline
\end{tabular}

TABELA 5.121: Momentos Fletores nas nervuras e vigas, em kN.cm, na laje com 13 nervuras por lado

\begin{tabular}{c|c|c|c|c|c|c|c|c}
\hline \hline \multicolumn{8}{c}{ MAJE COM RELAÇÃO a1/l=0,0714 } \\
\hline \multirow{2}{*}{ Ponto } & $\mathbf{0}$ Modelos numéricos de análise \\
\cline { 2 - 10 } & $\mathbf{0 1}$ & $\mathbf{0 2}$ & $\mathbf{0 3}$ & $\mathbf{0 4}$ & $\mathbf{0 5}$ & $\mathbf{0 6}$ & $\mathbf{0 7}$ & $\mathbf{0 8}$ \\
\hline \hline $\mathbf{1}$ & $-384,00$ & $-147,39$ & $-104,65$ & $\mathbf{- 3 3 3 , 1 2}$ & $-1042,40$ & $-1045,00$ & 26,94 & $-70,39$ \\
\hline $\mathbf{2}$ & 565,50 & 371,14 & 140,39 & $\mathbf{1 5 5 , 7 9}$ & 175,30 & 252,79 & 917,10 & 791,10 \\
\hline $\mathbf{3}$ & 1125,60 & 654,21 & 271,44 & $\mathbf{4 3 6 , 0 1}$ & 889,07 & 1019,10 & 1438,92 & 1314,96 \\
\hline $\mathbf{4}$ & 1398,70 & 795,51 & 340,94 & $\mathbf{5 6 3 , 3 7}$ & 1205,60 & 1361,60 & 1684,56 & 1564,20 \\
\hline $\mathbf{5}$ & 1433,30 & 816,66 & 354,38 & $\mathbf{5 7 8 , 7 6}$ & 1242,90 & 1402,10 & 1709,16 & 1589,10 \\
\hline \hline $\mathbf{6}$ & $-438,55$ & $-169,32$ & $-114,27$ & $\mathbf{- 3 1 6 , 2 5}$ & $-948,55$ & $-956,10$ & $-37,38$ & $-184,43$ \\
\hline $\mathbf{7}$ & 451,83 & 306,67 & 112,82 & $\mathbf{1 3 2 , 1 6}$ & 169,31 & 240,57 & 775,86 & 650,16 \\
\hline $\mathbf{8}$ & 1008,50 & 588,73 & 243,08 & $\mathbf{3 9 1 , 9 8}$ & 799,29 & 917,94 & 1293,24 & 1176,00 \\
\hline $\mathbf{9}$ & 1288,60 & 735,76 & 314,87 & $\mathbf{5 0 9 , 8 0}$ & 1070,80 & 1210,20 & 1539,18 & 1425,42 \\
\hline $\mathbf{1 0}$ & 1323,90 & 757,47 & 328,60 & $\mathbf{5 2 3 , 9 2}$ & 1102,60 & 1244,50 & 1563,54 & 1450,14 \\
\hline \hline $\mathbf{1 1}$ & $-755,46$ & $-476,69$ & $-270,63$ & $\mathbf{- 2 7 6 , 4 0}$ & $-466,01$ & $-464,86$ & $-692,76$ & $-779,28$ \\
\hline $\mathbf{1 2}$ & 30,99 & 48,20 & 2,13 & $\mathbf{2 3 , 3 3}$ & 112,56 & 155,44 & 200,78 & 111,64 \\
\hline $\mathbf{1 3}$ & 508,81 & 317,04 & 127,59 & $\mathbf{1 8 8 , 7 6}$ & 374,50 & 428,08 & 665,10 & 564,79 \\
\hline $\mathbf{1 4}$ & 698,72 & 412,55 & 175,98 & $\mathbf{2 5 1 , 5 3}$ & 483,25 & 548,21 & 828,84 & 748,26 \\
\hline $\mathbf{1 5}$ & 719,20 & 423,39 & 183,17 & $\mathbf{2 5 8 , 3 9}$ & 496,14 & 562,74 & 842,40 & 764,70 \\
\hline \hline $\mathbf{1 6}$ & $-2175,10$ & $-2666,70$ & $-2767,00$ & $\mathbf{- 2 0 8 6 , 1 7}$ & $-1439,10$ & $-1713,50$ & $-2102,00$ & $-2263,00$ \\
\hline $\mathbf{1 7}$ & 5256,90 & 4033,50 & 3918,30 & $\mathbf{3 2 3 5 , 1 8}$ & 5664,80 & 4569,00 & 2947,20 & 3161,20 \\
\hline $\mathbf{1 8}$ & 7446,80 & 7623,00 & 7763,70 & $\mathbf{7 2 4 7 , 3 8}$ & 5660,00 & 4784,80 & 5595,20 & 6064,80 \\
\hline $\mathbf{1 9}$ & 7931,40 & 9493,30 & 9797,90 & $\mathbf{9 4 6 7 , 9 1}$ & 5240,90 & 4635,60 & 6969,60 & 7485,90 \\
\hline $\mathbf{2 0}$ & 7620,30 & 9637,30 & 9992,00 & $\mathbf{9 7 5 5 , 0 4}$ & 4780,90 & 4376,00 & 7110,20 & 7631,80 \\
\hline \hline
\end{tabular}


TABELA 5.122: Momentos Fletores nas nervuras e vigas, em kN.cm, na laje com 14 nervuras por lado

\begin{tabular}{c|c|c|c|c|c|c|c|c}
\hline \hline \multicolumn{7}{c}{ LAJE COM RELAÇÃ O a1/l=0,0667 } \\
\hline \multirow{2}{*}{ Ponto } & \multicolumn{7}{c}{ Modelos numéricos de análise } \\
\cline { 2 - 10 } & $\mathbf{0 1}$ & $\mathbf{0 2}$ & $\mathbf{0 3}$ & $\mathbf{0 4}$ & $\mathbf{0 5}$ & $\mathbf{0 6}$ & $\mathbf{0 7}$ & $\mathbf{0 8}$ \\
\hline \hline $\mathbf{7}$ & $-461,39$ & $-174,68$ & $-119,85$ & $\mathbf{- 3 8 6 , 0 0}$ & $-1227,70$ & $-1227,70$ & 20,55 & $-185,76$ \\
\hline $\mathbf{8}$ & 572,86 & 390,32 & 146,89 & $\mathbf{1 4 6 , 7 0}$ & 97,04 & 182,21 & 983,40 & 617,52 \\
\hline $\mathbf{9}$ & 1209,10 & 710,78 & 294,15 & $\mathbf{4 6 4 , 7 4}$ & 908,02 & 1051,20 & 1574,64 & 1104,30 \\
\hline $\mathbf{1 0}$ & 1551,20 & 885,42 & 377,98 & $\mathbf{6 2 4 , 9 4}$ & 1307,40 & 1482,70 & 1885,98 & 1345,08 \\
\hline $\mathbf{1 1}$ & 1620,30 & 923,45 & 398,69 & $\mathbf{6 5 5 , 6 9}$ & 1382,10 & 1563,60 & 1943,22 & 1387,50 \\
\hline $\mathbf{1 2}$ & 1632,00 & 932,60 & 405,74 & $\mathbf{6 6 0 , 0 8}$ & 1394,70 & 1573,70 & 1947,30 & 1390,56 \\
\hline \hline $\mathbf{1 3}$ & $-541,71$ & $-212,53$ & $-137,50$ & $\mathbf{- 3 6 0 , 7 3}$ & $-1079,20$ & $-1087,10$ & $-82,30$ & $-290,29$ \\
\hline $\mathbf{1 4}$ & 410,23 & 296,59 & 106,78 & $\mathbf{1 1 4 , 2 9}$ & 102,15 & 177,66 & 781,50 & 490,50 \\
\hline $\mathbf{1 5}$ & 1035,70 & 612,85 & 251,79 & $\mathbf{4 0 1 , 6 0}$ & 790,16 & 917,05 & 1365,00 & 959,10 \\
\hline $\mathbf{1 6}$ & 1384,90 & 794,71 & 338,51 & $\mathbf{5 4 6 , 1 2}$ & 1116,50 & 1268,00 & 1675,68 & 1184,88 \\
\hline $\mathbf{1 7}$ & 1454,80 & 833,54 & 359,54 & $\mathbf{5 7 3 , 5 4}$ & 1176,70 & 1333,00 & 1731,84 & 1224,24 \\
\hline $\mathbf{1 8}$ & 1466,40 & 842,62 & 366,55 & $\mathbf{5 7 7 , 8 9}$ & 1189,30 & 1343,10 & 1735,80 & 1227,06 \\
\hline \hline $\mathbf{1 9}$ & $-875,16$ & $-572,51$ & $-321,79$ & $\mathbf{- 3 1 5 , 9 2}$ & $-507,25$ & $-505,48$ & $-847,38$ & $-763,44$ \\
\hline $\mathbf{2 0}$ & $-31,74$ & 15,23 & $-13,68$ & $\mathbf{2 , 3 2}$ & 85,23 & 129,82 & 142,75 & 91,06 \\
\hline $\mathbf{2 1}$ & 495,69 & 316,08 & 125,71 & $\mathbf{1 8 4 , 2 0}$ & 361,30 & 416,48 & 669,78 & 437,17 \\
\hline $\mathbf{2 2}$ & 727,03 & 433,84 & 184,29 & $\mathbf{2 5 9 , 5 4}$ & 486,77 & 555,40 & 877,02 & 584,95 \\
\hline $\mathbf{2 3}$ & 765,80 & 452,38 & 194,75 & $\mathbf{2 7 2 , 3 0}$ & 510,31 & 582,07 & 907,20 & 608,52 \\
\hline $\mathbf{2 4}$ & 777,04 & 462,19 & 202,22 & $\mathbf{2 7 5 , 9 6}$ & 522,99 & 592,20 & 909,24 & 610,14 \\
\hline $\mathbf{2 5}$ & $-2319,80$ & $-2914,00$ & $-3034,70$ & $\mathbf{- 2 3 0 0 , 6 4}$ & $-1453,30$ & $-1808,10$ & $-2306,50$ & $-2373,80$ \\
\hline $\mathbf{2 6}$ & 6527,90 & 4885,60 & 4717,90 & $\mathbf{3 8 5 1 , 8 7}$ & 7135,80 & 5668,30 & 3485,40 & 3893,90 \\
\hline $\mathbf{2 7}$ & 9158,90 & 9168,60 & 9321,80 & $\mathbf{8 6 4 7 , 1 5}$ & 6963,20 & 5715,00 & 6640,40 & 7170,50 \\
\hline $\mathbf{2 8}$ & 9888,20 & 11677,00 & 12051,00 & $\mathbf{1 1 6 1 3 , 5 2}$ & 6501,40 & 5511,50 & 8471,80 & 8992,00 \\
\hline $\mathbf{2 9}$ & 9671,90 & 12112,00 & 12559,00 & $\mathbf{1 2 2 3 1 , 4 7}$ & 6038,80 & 5269,90 & 8823,20 & 9327,80 \\
\hline $\mathbf{3 0}$ & 9153,10 & 11894,00 & 12378,00 & $\mathbf{1 2 2 4 5 , 9 1}$ & 5427,70 & 4906,90 & 8846,80 & 9344,60 \\
\hline \hline & & & & & & & & \\
\hline
\end{tabular}


TABELA 5.123: Momentos Fletores nas nervuras e vigas, em kN.cm, na laje com 15 nervuras por lado

\begin{tabular}{|c|c|c|c|c|c|c|c|c|}
\hline \multicolumn{9}{|c|}{$\begin{array}{c}\text { LAJE COM RELAÇÃO a1/l=0,0625 } \\
\text { MOMENTOS FLETORES NAS NERVURAS E VIGAS }\end{array}$} \\
\hline \multirow{2}{*}{ Ponto } & \multicolumn{8}{|c|}{ Modelos numéricos de análise } \\
\hline & 01 & 02 & 03 & 04 & 05 & 06 & 07 & 08 \\
\hline 1 & $-540,80$ & $-204,74$ & $-135,43$ & $-445,08$ & $-1442,20$ & $-1438,70$ & 21,73 & $-211,58$ \\
\hline 2 & 587,11 & 415,40 & 155,97 & 136,59 & 1,97 & 95,74 & 1072,74 & 660,30 \\
\hline 3 & 1302,50 & 775,07 & 320,26 & 495,96 & 922,37 & 1079,80 & 1736,04 & 1208,82 \\
\hline 4 & 1713,10 & 982,23 & 418,12 & 691,06 & 1414,10 & 1610,40 & 2112,66 & 1504,08 \\
\hline 5 & 1816,20 & 1036,70 & 445,88 & 737,65 & 1528,50 & 1734,30 & 2202,42 & 1571,40 \\
\hline 6 & 1850,80 & 1057,80 & 459,31 & 753,00 & 1565,90 & 1774,80 & 2226,96 & 1589,58 \\
\hline 7 & $-588,71$ & $-223,29$ & $-144,83$ & $-426,85$ & $-1338,20$ & $-1341,00$ & $-38,64$ & $-278,76$ \\
\hline 8 & 481,05 & 354,74 & 130,06 & 117,26 & 14,86 & 101,46 & 934,26 & 571,72 \\
\hline 9 & 1183,80 & 706,97 & 290,83 & 454,31 & 854,04 & 1001,30 & 1587,60 & 1109,10 \\
\hline 10 & 1600,70 & 920,44 & 391,22 & 638,16 & 1291,90 & 1473,10 & 1966,14 & 1394,10 \\
\hline 11 & 1705,60 & 976,55 & 419,67 & 681,99 & 1392,70 & 1581,90 & 2055,84 & 1458,66 \\
\hline 12 & 1740,80 & 998,20 & 433,37 & 696,41 & 1425,50 & 1617,40 & 2080,20 & 1476,00 \\
\hline 13 & $-764,43$ & $-350,74$ & $-209,79$ & $-386,00$ & $-1030,40$ & $-1044,10$ & $-339,67$ & $-524,08$ \\
\hline 14 & 193,00 & 178,16 & 54,08 & 57,20 & 44,38 & 114,42 & 558,24 & 343,47 \\
\hline 15 & 873,64 & 531,49 & 215,04 & 341,02 & 652,69 & 767,13 & 1207,56 & 841,32 \\
\hline 16 & 1274,20 & 742,09 & 314,27 & 491,13 & 952,71 & 1089,70 & 1567,14 & 1092,42 \\
\hline 17 & 1370,20 & 792,97 & 340,27 & 525,58 & 1020,80 & 1163,90 & 1647,30 & 1147,86 \\
\hline 18 & 1401,70 & 811,98 & 352,46 & 536,75 & 1043,00 & 1188,10 & 1668,66 & 1162,62 \\
\hline 19 & $-998,19$ & $-673,98$ & $-375,84$ & $-357,48$ & $-547,15$ & $-545,23$ & $-1013,04$ & $-890,88$ \\
\hline 20 & $-99,91$ & $-21,68$ & $-31,13$ & $-21,20$ & 57,51 & 103,43 & 74,76 & 44,50 \\
\hline 21 & 475,21 & 310,75 & 121,91 & 177,37 & 345,98 & 402,30 & 664,92 & 427,94 \\
\hline 22 & 747,04 & 451,52 & 191,08 & 264,90 & 485,63 & 557,23 & 917,58 & 605,94 \\
\hline 23 & 802,92 & 477,68 & 204,95 & 282,99 & 518,09 & 594,16 & 963,96 & 642,12 \\
\hline 24 & 820,44 & 486,63 & 210,89 & 288,70 & 528,74 & 606,33 & 975,66 & 651,54 \\
\hline 25 & $-2440,40$ & $-3147,70$ & $-3290,80$ & $-2510,34$ & $-1435,40$ & $-1892,60$ & $-2506,40$ & $-2566,90$ \\
\hline 26 & 8002,60 & 5853,10 & 5619,00 & 4534,85 & 8867,40 & 6955,00 & 4074,80 & 4551,70 \\
\hline 27 & 11122,00 & 10885,00 & 11044,00 & 10172,28 & 8469,00 & 6772,50 & 7776,70 & 8406,90 \\
\hline 28 & 12105,00 & 14085,00 & 14532,00 & 13955,73 & 7926,80 & 6455,60 & 10099,00 & 10729,00 \\
\hline 29 & 11986,00 & 14842,00 & 15390,00 & 14946,55 & 7451,00 & 6211,10 & 10682,00 & 11294,00 \\
\hline 30 & 11464,00 & 14965,00 & 15585,00 & 15280,56 & 6804,60 & 5862,20 & 10840,00 & 11436,00 \\
\hline
\end{tabular}

Analisando as tabelas de momentos fletores nas nervuras e vigas, em modelos com variação da relação $a_{1} / l$, verificou-se que:

- existe novamente uma separação entre dois grupos, onde os componentes de cada grupo têm momentos fletores da mesma ordem de grandeza, para as nervuras: modelos 02 a 04, com valores próximos e mais baixos que os dados pelos modelos 05 a 08 . Novamente verifica-se que é necessário a análise das tensões normais nas seções, haja visto que as nervuras dos modelos 02 a 04 apresentarão esforços normais de tração. As nervuras dos demais modelos apresentarão esforços normais de compressão. A consideração da flexotração e da flexo-compressão possibilitará a comparação dos resultados entre os modelos;

- para as vigas vê-se que, à medida que diminui-se a relação $a_{1} / l$ da laje, os momentos fletores apresentados pelos modelos 05 e 06 tornam-se mais distantes daqueles do Modelo 04, e dos demais, sempre com valores muito menores. Isso está de acordo com o 
comportamento descrito para o deslocamento segundo o eixo z para estes modelos, ou seja, quanto menor for a relação $a_{1} / l$, mais rígida é a laje simulada. Será necessário analisar também as tensões normais.

\subsubsection{Forças Normais atuantes nas nervuras e vigas}

TABELA 5.124: Esforços Normais nas nervuras e vigas, em kN, na laje com 05 nervuras por lado

\begin{tabular}{c|c|c|c|c|c|c|c|c}
\hline \hline \multicolumn{7}{c}{ LAJE COM RELAÇ̃̃O a1/l=0,1667 } \\
\multicolumn{8}{c}{ ESFORÇOS NORMAIS NAS NERVURAS E VIGAS (kN) } \\
\hline \multirow{2}{*}{ Ponto } & \multicolumn{7}{c}{ Modelos numéricos de análise } \\
\cline { 2 - 10 } & $\mathbf{0 1}$ & $\mathbf{0 2}$ & $\mathbf{0 3}$ & $\mathbf{0 4}$ & $\mathbf{0 5}$ & $\mathbf{0 6}$ & $\mathbf{0 7}$ & $\mathbf{0 8}$ \\
\hline \hline $\mathbf{1}$ & $-0,93$ & 2,41 & 2,52 & $\mathbf{- 3 , 2 1}$ & $-4,83$ & $-6,62$ & $-0,64$ & $-1,27$ \\
\hline $\mathbf{2}$ & $-0,98$ & 15,28 & 17,08 & $\mathbf{7 , 5 5}$ & $-4,73$ & $-9,80$ & $-3,89$ & $-7,25$ \\
\hline $\mathbf{3}$ & $-1,35$ & 22,41 & 25,10 & $\mathbf{1 6 , 3 5}$ & $-5,67$ & $-11,38$ & $-4,90$ & $-8,78$ \\
\hline $\mathbf{4}$ & $-1,45$ & 24,22 & 27,17 & $\mathbf{1 9 , 2 1}$ & $-5,72$ & $-11,38$ & $-5,08$ & $-9,02$ \\
\hline \hline $\mathbf{5}$ & $-1,95$ & 0,96 & 0,93 & $\mathbf{- 3 , 7 8}$ & $-4,61$ & $-6,16$ & $-1,48$ & $-2,41$ \\
\hline $\mathbf{6}$ & $-1,50$ & 12,75 & 14,35 & $\mathbf{6 , 2 5}$ & $-4,98$ & $-10,15$ & $-4,64$ & $-7,30$ \\
\hline $\mathbf{7}$ & $-1,83$ & 19,75 & 22,25 & $\mathbf{1 4 , 5 7}$ & $-6,27$ & $-12,47$ & $-5,89$ & $-9,10$ \\
\hline $\mathbf{8}$ & $-1,93$ & 21,55 & 24,31 & $\mathbf{1 7 , 2 6}$ & $-6,34$ & $-12,47$ & $-6,18$ & $-9,64$ \\
\hline \hline $\mathbf{9}$ & $-5,22$ & $-6,33$ & $-6,63$ & $\mathbf{- 7 , 1 8}$ & $-3,64$ & $-4,32$ & $-7,63$ & $-7,67$ \\
\hline $\mathbf{1 0}$ & $-3,16$ & 5,09 & 6,42 & $\mathbf{1 , 7 6}$ & $-6,54$ & $-12,04$ & $-7,66$ & $-5,87$ \\
\hline $\mathbf{1 1}$ & $-3,49$ & 11,52 & 13,73 & $\mathbf{8 , 6 1}$ & $-9,90$ & $-17,56$ & $-10,46$ & $-11,80$ \\
\hline $\mathbf{1 2}$ & $-3,65$ & 12,94 & 15,38 & $\mathbf{1 0 , 6 4}$ & $-9,95$ & $-17,56$ & $-11,46$ & $-13,82$ \\
\hline \hline $\mathbf{1 3}$ & 9,53 & 5,00 & 4,87 & $\mathbf{0 , 0 0}$ & 9,79 & 12,30 & 3,29 & 3,97 \\
\hline $\mathbf{1 4}$ & 19,43 & 11,10 & 10,15 & $\mathbf{7 , 3 8}$ & 26,69 & 25,60 & 15,17 & 17,42 \\
\hline $\mathbf{1 5}$ & 26,68 & 16,81 & 15,71 & $\mathbf{1 7 , 0 5}$ & 37,96 & 34,22 & 26,67 & 32,20 \\
\hline $\mathbf{1 6}$ & 27,06 & 17,79 & 16,80 & $\mathbf{1 9 , 5 8}$ & 38,31 & 34,22 & 30,07 & 36,51 \\
\hline \hline
\end{tabular}

TABELA 5.125: Esforços Normais nas nervuras e vigas, em kN, na laje com 06 nervuras por lado

\begin{tabular}{c|c|c|c|c|c|c|c|c}
\hline \hline \multicolumn{7}{c}{ LAJE COM RELAÇãO a1/l=0,1429 } \\
\multicolumn{10}{c}{ ESFORÇOS NORMAIS NAS NERVURAS E VIGAS $(\mathbf{k N})$} \\
\hline \multirow{2}{*}{ Ponto } & $\mathbf{0}$ Modelos numéricos de análise \\
\cline { 2 - 10 } & $\mathbf{0 1}$ & $\mathbf{0 2}$ & $\mathbf{0 3}$ & $\mathbf{0 4}$ & $\mathbf{0 5}$ & $\mathbf{0 6}$ & $\mathbf{0 7}$ & $\mathbf{0 8}$ \\
\hline \hline $\mathbf{6}$ & $-1,46$ & 2,07 & 2,13 & $\mathbf{- 5 , 6 4}$ & $-6,62$ & $-8,70$ & $-0,86$ & $-1,63$ \\
\hline $\mathbf{7}$ & $-1,22$ & 17,76 & 19,80 & $\mathbf{7 , 4 4}$ & $-5,73$ & $-12,16$ & $-4,92$ & $-8,42$ \\
\hline $\mathbf{8}$ & $-1,72$ & 27,53 & 30,77 & $\mathbf{1 9 , 3 3}$ & $-7,30$ & $-14,75$ & $-6,28$ & $-10,91$ \\
\hline $\mathbf{9}$ & $-1,95$ & 32,00 & 35,79 & $\mathbf{2 5 , 0 1}$ & $-7,72$ & $-15,48$ & $-6,77$ & $-11,74$ \\
\hline $\mathbf{1 0}$ & $-1,96$ & 32,28 & 36,17 & $\mathbf{2 5 , 8 2}$ & $-7,72$ & $-15,48$ & $-6,80$ & $-11,79$ \\
\hline \hline $\mathbf{1 1}$ & $-6,73$ & $-10,66$ & $-11,59$ & $\mathbf{- 1 0 , 7 1}$ & $-4,11$ & $-4,71$ & $-10,28$ & $-10,10$ \\
\hline $\mathbf{1 2}$ & $-4,09$ & 2,64 & 3,98 & $-\mathbf{- 0 , 5 8}$ & $-7,84$ & $-14,36$ & $-9,81$ & $-6,76$ \\
\hline $\mathbf{1 3}$ & $-4,68$ & 11,28 & 13,87 & $\mathbf{8 , 0 3}$ & $-13,06$ & $-22,64$ & $-13,91$ & $-14,29$ \\
\hline $\mathbf{1 4}$ & $-5,22$ & 14,49 & 17,58 & $\mathbf{1 1 , 5 0}$ & $-15,00$ & $-25,72$ & $-16,55$ & $-18,80$ \\
\hline $\mathbf{1 5}$ & $-5,28$ & 14,71 & 17,92 & $\mathbf{1 2 , 0 6}$ & $-15,06$ & $-25,72$ & $-16,76$ & $-19,13$ \\
\hline \hline $\mathbf{1 6}$ & 15,03 & 9,03 & 8,82 & $\mathbf{1 , 4 5}$ & 16,29 & 18,97 & 6,44 & 7,63 \\
\hline $\mathbf{1 7}$ & 27,81 & 16,38 & 15,03 & $\mathbf{1 1 , 2 2}$ & 38,27 & 37,14 & 20,84 & 23,63 \\
\hline $\mathbf{1 8}$ & 38,55 & 24,11 & 22,40 & $\mathbf{2 3 , 7 7}$ & 56,01 & 52,10 & 36,61 & 43,81 \\
\hline $\mathbf{1 9}$ & 41,91 & 27,15 & 25,47 & $\mathbf{2 8 , 0 2}$ & 61,89 & 57,27 & 44,72 & 54,04 \\
\hline $\mathbf{2 0}$ & 41,81 & 28,04 & 26,50 & $\mathbf{2 8 , 7 3}$ & 61,95 & 57,57 & 45,32 & 54,79 \\
\hline \hline
\end{tabular}


TABELA 5.126: Esforços Normais nas nervuras e vigas, em kN, na laje com 07 nervuras por lado

LAJE COM RELAÇÃO a1/l=0,1250

ESFORÇOS NORMAIS NAS NERVURAS E VIGAS (kN)

\begin{tabular}{c|c|c|c|c|c|c|c|c}
\hline \multirow{2}{*}{ Ponto } & \multicolumn{7}{|c}{ Modelos numéricos de análise } \\
\cline { 2 - 9 } & $\mathbf{0 1}$ & $\mathbf{0 2}$ & $\mathbf{0 3}$ & $\mathbf{0 4}$ & $\mathbf{0 5}$ & $\mathbf{0 6}$ & $\mathbf{0 7}$ & $\mathbf{0 8}$ \\
\hline \hline $\mathbf{1}$ & $-1,62$ & 2,15 & 2,20 & $\mathbf{- 9 , 4 8}$ & $-8,66$ & $-11,09$ & $-0,81$ & $-1,51$ \\
\hline $\mathbf{2}$ & $-1,20$ & 21,41 & 23,82 & $\mathbf{7 , 6 5}$ & $-6,48$ & $-14,31$ & $-5,51$ & $-9,25$ \\
\hline $\mathbf{3}$ & $-1,85$ & 34,02 & 37,91 & $\mathbf{2 2 , 7 2}$ & $-8,62$ & $-17,64$ & $-7,17$ & $-12,67$ \\
\hline $\mathbf{4}$ & $-2,20$ & 41,08 & 45,82 & $\mathbf{3 1 , 4 9}$ & $-9,40$ & $-18,97$ & $-7,88$ & $-14,05$ \\
\hline $\mathbf{5}$ & $-2,28$ & 42,90 & 47,89 & $\mathbf{3 4 , 3 2}$ & $-9,44$ & $-18,97$ & $-8,05$ & $-14,38$ \\
\hline $\mathbf{6}$ & $-4,73$ & $-4,24$ & $-5,14$ & $\mathbf{- 9 , 9 9}$ & $-7,03$ & $-8,72$ & $-4,60$ & $-5,74$ \\
\hline $\mathbf{7}$ & $-2,97$ & 10,96 & 12,57 & $\mathbf{2 , 7 9}$ & $-7,33$ & $-14,91$ & $-8,18$ & $-10,42$ \\
\hline $\mathbf{8}$ & $-3,46$ & 22,92 & 26,17 & $\mathbf{1 5 , 6 8}$ & $-10,64$ & $-20,89$ & $-10,76$ & $-13,87$ \\
\hline $\mathbf{9}$ & $-3,86$ & 29,88 & 33,95 & $\mathbf{2 2 , 8 3}$ & $-12,47$ & $-24,01$ & $-12,23$ & $-16,70$ \\
\hline $\mathbf{1 0}$ & $-3,96$ & 31,60 & 35,91 & $\mathbf{2 5 , 1 0}$ & $-12,56$ & $-24,01$ & $-12,61$ & $-17,56$ \\
\hline \hline $\mathbf{1 1}$ & $-8,09$ & $-15,40$ & $-17,17$ & $\mathbf{- 1 5 , 3 6}$ & $-4,35$ & $-4,92$ & $-12,85$ & $-12,50$ \\
\hline $\mathbf{1 2}$ & $-4,98$ & $-0,64$ & 0,65 & $\mathbf{- 3 , 4 1}$ & $-8,86$ & $-16,29$ & $-11,93$ & $-7,72$ \\
\hline $\mathbf{1 3}$ & $-5,86$ & 10,11 & 13,02 & $\mathbf{6 , 1 4}$ & $-15,85$ & $-27,06$ & $-17,18$ & $-16,39$ \\
\hline $\mathbf{1 4}$ & $-6,89$ & 14,91 & 18,62 & $\mathbf{1 0 , 8 1}$ & $-19,73$ & $-33,19$ & $-21,55$ & $-23,00$ \\
\hline $\mathbf{1 5}$ & $-7,16$ & 15,87 & 19,79 & $\mathbf{1 2 , 7 9}$ & $-19,66$ & $-33,19$ & $-22,87$ & $-24,86$ \\
\hline $\mathbf{1 6}$ & 21,73 & 14,07 & 13,73 & $\mathbf{5 , 0 1}$ & 24,38 & 27,15 & 10,53 & 12,36 \\
\hline $\mathbf{1 7}$ & 37,85 & 23,04 & 21,21 & $\mathbf{1 5 , 7 4}$ & 51,65 & 50,11 & 27,66 & 31,07 \\
\hline $\mathbf{1 8}$ & 52,61 & 32,93 & 30,48 & $\mathbf{2 9 , 7 4}$ & 76,69 & 72,38 & 47,67 & 56,55 \\
\hline $\mathbf{1 9}$ & 59,27 & 37,97 & 35,42 & $\mathbf{3 6 , 8 4}$ & 88,98 & 83,98 & 60,50 & 72,72 \\
\hline $\mathbf{2 0}$ & 58,23 & 38,32 & 35,97 & $\mathbf{4 0 , 7 6}$ & 88,16 & 83,98 & 64,14 & 77,26 \\
\hline \hline
\end{tabular}

TABELA 5.127: Esforços Normais nas nervuras e vigas, em kN, na laje com 08 nervuras por lado

LAJE COM RELAÇ̃̃O a1/l=0,1111

ESFORÇOS NORMAIS NAS NERVURAS E VIGAS $(\mathrm{kN})$

\begin{tabular}{c|c|c|c|c|c|c|c|c}
\hline \multirow{2}{*}{ Ponto } & \multicolumn{7}{|c|}{ Modelos numéricos de análise } \\
\cline { 2 - 9 } & $\mathbf{0 1}$ & $\mathbf{0 2}$ & $\mathbf{0 3}$ & $\mathbf{0 4}$ & $\mathbf{0 5}$ & $\mathbf{0 6}$ & $\mathbf{0 7}$ & $\mathbf{0 8}$ \\
\hline \hline $\mathbf{7}$ & $-2,13$ & 1,63 & 1,54 & $\mathbf{- 1 3 , 0 5}$ & $-10,57$ & $-13,28$ & $-0,97$ & $-1,79$ \\
\hline $\mathbf{8}$ & $-1,34$ & 23,70 & 26,35 & $\mathbf{6 , 2 9}$ & $-7,13$ & $-16,27$ & $-6,17$ & $-10,09$ \\
\hline $\mathbf{9}$ & $-2,13$ & 39,06 & 43,51 & $\mathbf{2 4 , 7 3}$ & $-9,92$ & $-20,59$ & $-8,33$ & $-14,34$ \\
\hline $\mathbf{1 0}$ & $-2,61$ & 48,78 & 54,35 & $\mathbf{3 6 , 4 9}$ & $-11,18$ & $-22,70$ & $-9,40$ & $-16,45$ \\
\hline $\mathbf{1 1}$ & $-2,80$ & 53,26 & 59,37 & $\mathbf{4 2 , 1 4}$ & $-11,53$ & $-23,31$ & $-9,83$ & $-17,30$ \\
\hline $\mathbf{1 2}$ & $-2,81$ & 53,55 & 59,76 & $\mathbf{4 2 , 9 4}$ & $-11,53$ & $-23,31$ & $-9,86$ & $-17,36$ \\
\hline \hline $\mathbf{1 3}$ & $-6,25$ & $-8,34$ & $-10,09$ & $\mathbf{- 1 4 , 7 6}$ & $-7,87$ & $-9,59$ & $-6,80$ & $-7,92$ \\
\hline $\mathbf{1 4}$ & $-3,83$ & 8,15 & 9,64 & $\mathbf{0 , 0 0}$ & $-8,34$ & $-16,91$ & $-10,36$ & $-12,14$ \\
\hline $\mathbf{1 5}$ & $-4,39$ & 22,51 & 26,02 & $\mathbf{1 3 , 9 7}$ & $-12,68$ & $-24,77$ & $-13,53$ & $-16,10$ \\
\hline $\mathbf{1 6}$ & $-4,98$ & 31,92 & 36,56 & $\mathbf{2 3 , 7 3}$ & $-15,66$ & $-29,82$ & $-15,72$ & $-20,05$ \\
\hline $\mathbf{1 7}$ & $-5,26$ & 36,00 & 41,12 & $\mathbf{2 7 , 9 2}$ & $-16,75$ & $-31,56$ & $-16,75$ & $-22,16$ \\
\hline $\mathbf{1 8}$ & $-5,27$ & 36,26 & 41,49 & $\mathbf{2 8 , 5 7}$ & $-16,76$ & $-31,56$ & $-16,82$ & $-22,31$ \\
\hline $\mathbf{1 9}$ & $-9,28$ & $-20,36$ & $-23,14$ & $\mathbf{- 1 9 , 6 3}$ & $-4,44$ & $-5,00$ & $-15,27$ & $-14,83$ \\
\hline $\mathbf{2 0}$ & $-5,80$ & $-4,57$ & $-3,40$ & $\mathbf{- 6 , 6 9}$ & $-9,61$ & $-17,87$ & $-14,00$ & $-8,77$ \\
\hline $\mathbf{2 1}$ & $-6,97$ & 8,15 & 11,30 & $\mathbf{4 , 0 2}$ & $-18,24$ & $-30,81$ & $-20,21$ & $-18,22$ \\
\hline $\mathbf{2 2}$ & $-8,54$ & 14,47 & 18,75 & $\mathbf{9 , 6 2}$ & $-23,98$ & $-39,77$ & $-26,20$ & $-26,53$ \\
\hline $\mathbf{2 3}$ & $-9,37$ & 16,55 & 21,30 & $\mathbf{1 2 , 3 7}$ & $-25,84$ & $-42,91$ & $-29,37$ & $-30,56$ \\
\hline $\mathbf{2 4}$ & $-9,46$ & 16,72 & 21,60 & $\mathbf{1 2 , 7 9}$ & $-25,94$ & $-42,91$ & $-29,60$ & $-30,85$ \\
\hline \hline $\mathbf{2 5}$ & 29,57 & 20,06 & 19,56 & $\mathbf{9 , 7 0}$ & 34,03 & 36,89 & 15,52 & 18,10 \\
\hline $\mathbf{2 6}$ & 49,45 & 31,02 & 28,67 & $\mathbf{2 1 , 6 1}$ & 66,55 & 64,22 & 35,60 & 39,71 \\
\hline $\mathbf{2 7}$ & 68,78 & 43,31 & 39,99 & $\mathbf{3 9 , 0 6}$ & 99,62 & 94,56 & 59,82 & 70,37 \\
\hline $\mathbf{2 8}$ & 79,19 & 50,41 & 46,80 & $\mathbf{4 3 , 5 8}$ & 119,09 & 113,58 & 77,35 & 92,46 \\
\hline $\mathbf{2 9}$ & 81,23 & 52,71 & 49,20 & $\mathbf{5 8 , 4 4}$ & 124,52 & 119,99 & 85,91 & 103,13 \\
\hline $\mathbf{3 0}$ & 80,92 & 53,82 & 50,48 & $\mathbf{5 9 , 1 8}$ & 124,55 & 119,99 & 86,53 & 103,90 \\
\hline \hline
\end{tabular}


TABELA 5.128: Esforços Normais nas nervuras e vigas, em kN, na laje com 09 nervuras por lado

\begin{tabular}{c|c|c|c|c|c|c|c|c}
\hline \hline \multicolumn{7}{c}{ LAJE COM RELAÇÃO a1/I=0,1000 } \\
\hline \multirow{2}{*}{ Ponto } & \multicolumn{7}{c}{ Modelos numéricos de análise } \\
\cline { 2 - 10 } & $\mathbf{0 1}$ & $\mathbf{0 2}$ & $\mathbf{0 3}$ & $\mathbf{0 4}$ & $\mathbf{0 5}$ & $\mathbf{0 6}$ & $\mathbf{0 7}$ & $\mathbf{0 8}$ \\
\hline \hline $\mathbf{1}$ & $-2,38$ & 1,43 & 1,28 & $\mathbf{- 1 7 , 2 8}$ & $-12,75$ & $-15,78$ & $-0,91$ & $-1,69$ \\
\hline $\mathbf{2}$ & $-1,26$ & 27,06 & 30,07 & $\mathbf{4 , 7 3}$ & $-7,56$ & $-18,07$ & $-6,61$ & $-10,58$ \\
\hline $\mathbf{3}$ & $-2,22$ & 45,48 & 50,61 & $\mathbf{2 7 , 4 6}$ & $-10,92$ & $-23,16$ & $-9,09$ & $-15,60$ \\
\hline $\mathbf{4}$ & $-2,82$ & 57,87 & 64,39 & $\mathbf{4 2 , 1 1}$ & $-12,63$ & $-25,91$ & $-10,39$ & $-18,34$ \\
\hline $\mathbf{5}$ & $-3,11$ & 64,94 & 72,29 & $\mathbf{5 0 , 7 6}$ & $-13,28$ & $-27,04$ & $-11,02$ & $-19,69$ \\
\hline $\mathbf{6}$ & $-3,18$ & 66,76 & 74,36 & $\mathbf{5 3 , 5 8}$ & $-13,36$ & $-27,04$ & $-11,18$ & $-20,04$ \\
\hline \hline $\mathbf{7}$ & $-4,59$ & $-3,48$ & $-4,70$ & $\mathbf{- 1 7 , 7 2}$ & $-10,93$ & $-13,49$ & $-3,29$ & $-4,67$ \\
\hline $\mathbf{8}$ & $-2,69$ & 17,15 & 19,16 & $\mathbf{1 , 4 9}$ & $-8,28$ & $-18,07$ & $-8,48$ & $-12,32$ \\
\hline $\mathbf{9}$ & $-3,47$ & 34,09 & 38,40 & $\mathbf{2 0 , 7 8}$ & $-12,06$ & $-24,67$ & $-11,61$ & $-16,91$ \\
\hline $\mathbf{1 0}$ & $-4,11$ & 46,50 & 52,28 & $\mathbf{3 3 , 8 7}$ & $-14,46$ & $-28,94$ & $-13,61$ & $-20,17$ \\
\hline $\mathbf{1 1}$ & $-4,46$ & 53,72 & 60,30 & $\mathbf{4 1 , 3 2}$ & $-15,63$ & $-31,02$ & $-14,68$ & $-22,18$ \\
\hline $\mathbf{1 2}$ & $-4,54$ & 55,56 & 62,38 & $\mathbf{4 3 , 7 2}$ & $-15,69$ & $-31,02$ & $-14,95$ & $-22,73$ \\
\hline \hline $\mathbf{1 3}$ & $-10,34$ & $-25,42$ & $-29,36$ & $\mathbf{- 2 4 , 2 2}$ & $-4,41$ & $-5,02$ & $-17,52$ & $-17,08$ \\
\hline $\mathbf{1 4}$ & $-6,53$ & $-9,03$ & $-8,03$ & $\mathbf{- 1 0 , 3 3}$ & $-10,13$ & $-19,11$ & $-16,00$ & $-9,89$ \\
\hline $\mathbf{1 5}$ & $-7,98$ & 5,51 & 8,81 & $\mathbf{1 , 4 5}$ & $-20,27$ & $-33,94$ & $-23,02$ & $-19,85$ \\
\hline $\mathbf{1 6}$ & $-10,11$ & 13,34 & 18,12 & $\mathbf{8 , 1 9}$ & $-27,72$ & $-45,43$ & $-30,44$ & $-29,52$ \\
\hline $\mathbf{1 7}$ & $-11,56$ & 16,37 & 21,91 & $\mathbf{1 1 , 3 8}$ & $-31,42$ & $-51,56$ & $-35,38$ & $-35,39$ \\
\hline $\mathbf{1 8}$ & $-11,90$ & 16,96 & 22,70 & $\mathbf{1 2 , 1 6}$ & $-31,18$ & $-51,56$ & $-36,79$ & $-37,01$ \\
\hline $\mathbf{1 9}$ & 38,56 & 26,97 & 26,29 & $\mathbf{1 5 , 6 1}$ & 45,21 & 48,20 & 21,37 & 24,81 \\
\hline $\mathbf{2 0}$ & 62,50 & 40,25 & 37,33 & $\mathbf{2 8 , 6 5}$ & 82,71 & 79,22 & 44,60 & 49,48 \\
\hline $\mathbf{2 1}$ & 86,97 & 55,22 & 50,92 & $\mathbf{5 0 , 1 4}$ & 124,44 & 118,20 & 73,03 & 85,23 \\
\hline $\mathbf{2 2}$ & 101,58 & 64,48 & 59,64 & $\mathbf{6 5 , 2 3}$ & 151,75 & 145,46 & 95,20 & 113,16 \\
\hline $\mathbf{2 3}$ & 107,06 & 68,70 & 63,81 & $\mathbf{7 1 , 2 6}$ & 164,17 & 159,25 & 108,69 & 129,99 \\
\hline $\mathbf{2 4}$ & 104,14 & 68,33 & 63,77 & $\mathbf{7 5 , 4 4}$ & 161,90 & 159,25 & 112,45 & 134,64 \\
\hline \hline & & & & & & & & \\
\hline \hline
\end{tabular}

TABELA 5.129: Esforços Normais nas nervuras e vigas, em kN, na laje com 10 nervuras por lado

\begin{tabular}{c|c|c|c|c|c|c|c|c}
\hline \hline \multicolumn{7}{c}{ LAJE COM RELAÇ̃̃O a1/l=0,0910 } \\
\begin{tabular}{c}
\hline \multirow{2}{*}{ Ponto } \\
\cline { 2 - 9 }
\end{tabular} & $\mathbf{0 1}$ & $\mathbf{0 2}$ & $\mathbf{0 3}$ & $\mathbf{0 4}$ & $\mathbf{0 5}$ & $\mathbf{0 6}$ & $\mathbf{0 7}$ & $\mathbf{0 8}$ \\
\hline \hline $\mathbf{6}$ & $-2,89$ & 0,67 & 0,31 & $\mathbf{- 2 3 , 3 1}$ & $-14,74$ & $-18,05$ & $-1,03$ & $-1,92$ \\
\hline $\mathbf{7}$ & $-2,41$ & 50,36 & 56,05 & $\mathbf{2 7 , 8 9}$ & $-11,85$ & $-25,63$ & $-10,03$ & $-16,86$ \\
\hline $\mathbf{8}$ & $-3,54$ & 75,20 & 83,68 & $\mathbf{5 7 , 8 1}$ & $-15,11$ & $-30,94$ & $-12,59$ & $-22,19$ \\
\hline $\mathbf{9}$ & $-3,70$ & 79,69 & 88,70 & $\mathbf{6 3 , 4 3}$ & $-15,42$ & $-31,47$ & $-12,98$ & $-23,03$ \\
\hline $\mathbf{1 0}$ & $-3,71$ & 79,98 & 89,09 & $\mathbf{6 4 , 2 3}$ & $-15,42$ & $-31,47$ & $-13,01$ & $-23,09$ \\
\hline \hline $\mathbf{1 1}$ & $-5,91$ & $-7,10$ & $-9,25$ & $\mathbf{- 2 3 , 5 0}$ & $-11,92$ & $-14,59$ & $-4,88$ & $-6,33$ \\
\hline $\mathbf{1 2}$ & $-4,20$ & 33,51 & 37,99 & $\mathbf{1 9 , 2 4}$ & $-13,50$ & $-27,58$ & $-13,76$ & $-18,88$ \\
\hline $\mathbf{1 3}$ & $-5,48$ & 58,23 & 65,60 & $\mathbf{4 3 , 9 2}$ & $-18,60$ & $-36,68$ & $-17,88$ & $-25,66$ \\
\hline $\mathbf{1 4}$ & $-5,69$ & 62,66 & 70,52 & $\mathbf{4 8 , 4 6}$ & $-19,28$ & $-37,82$ & $-18,58$ & $-27,04$ \\
\hline $\mathbf{1 5}$ & $-5,69$ & 62,94 & 70,90 & $\mathbf{4 9 , 1 6}$ & $-19,28$ & $-37,82$ & $-18,62$ & $-27,14$ \\
\hline \hline $\mathbf{1 6}$ & $-11,27$ & $-30,54$ & $-35,74$ & $\mathbf{- 2 9 , 1 0}$ & $-4,29$ & $-4,99$ & $-19,61$ & $-19,24$ \\
\hline $\mathbf{1 7}$ & $-8,88$ & 2,28 & 5,65 & $\mathbf{- 1 , 4 0}$ & $-21,96$ & $-36,48$ & $-25,60$ & $-21,34$ \\
\hline $\mathbf{1 8}$ & $-13,66$ & 15,57 & 21,84 & $\mathbf{9 , 4 4}$ & $-36,39$ & $-59,12$ & $-40,82$ & $-39,49$ \\
\hline $\mathbf{1 9}$ & $-14,64$ & 16,79 & 23,51 & $\mathbf{1 1 , 3 5}$ & $-37,98$ & $-62,15$ & $-44,08$ & $-43,00$ \\
\hline $\mathbf{2 0}$ & $-14,77$ & 16,91 & 23,77 & $\mathbf{1 1 , 6 6}$ & $-38,12$ & $-62,15$ & $-44,32$ & $-43,25$ \\
\hline \hline $\mathbf{2 1}$ & 48,68 & 34,78 & 33,89 & $\mathbf{2 2 , 6 8}$ & 57,91 & 61,12 & 28,02 & 32,42 \\
\hline $\mathbf{2 2}$ & 107,01 & 68,59 & 63,21 & $\mathbf{5 9 , 4 8}$ & 150,85 & 142,97 & 87,20 & 101,04 \\
\hline $\mathbf{2 3}$ & 135,62 & 86,33 & 79,85 & $\mathbf{8 6 , 0 0}$ & 206,60 & 201,06 & 132,37 & 157,70 \\
\hline $\mathbf{2 4}$ & 135,89 & 87,81 & 81,53 & $\mathbf{9 4 , 3 4}$ & 21,14 & 208,41 & 141,19 & 168,62 \\
\hline $\mathbf{2 5}$ & 135,27 & 89,06 & 83,01 & $\mathbf{9 5 , 0 4}$ & 211,12 & 208,41 & 141,83 & 169,40 \\
\hline \hline
\end{tabular}


TABELA 5.130: Esforços Normais nas nervuras e vigas, em kN, na laje com 11 nervuras por lado

\begin{tabular}{|c|c|c|c|c|c|c|c|c|}
\hline \multicolumn{9}{|c|}{$\begin{array}{c}\text { LAJE COM RELAÇÃ̃ a1/l=0,0833 } \\
\text { ESFORÇOS NORMAIS NAS NERVURAS E VIGAS }(\mathrm{kN})\end{array}$} \\
\hline \multirow{2}{*}{ Ponto } & \multicolumn{8}{|c|}{ Modelos numéricos de análise } \\
\hline & 01 & 02 & 03 & 04 & 05 & 06 & 07 & 08 \\
\hline 1 & $-3,21$ & 0,16 & $-0,32$ & $-27,32$ & $-16,99$ & $-20,62$ & $-0,97$ & $-1,83$ \\
\hline 2 & $-1,15$ & 32,02 & 35,60 & $-0,73$ & $-8,13$ & $-21,17$ & $-7,42$ & $-11,51$ \\
\hline 3 & $-2,44$ & 56,53 & 62,93 & 28,90 & $-12,53$ & $-27,82$ & $-10,65$ & $-17,74$ \\
\hline 4 & $-3,80$ & 86,82 & 96,54 & 65,61 & $-16,62$ & $-34,32$ & $-13,64$ & $-24,14$ \\
\hline 5 & $-4,05$ & 93,92 & 104,46 & 74,17 & $-17,19$ & $-35,32$ & $-14,21$ & $-25,43$ \\
\hline 6 & $-4,11$ & 95,74 & 106,53 & 76,97 & $-17,23$ & $-35,32$ & $-14,35$ & $-25,78$ \\
\hline 7 & $-4,86$ & $-3,91$ & $\begin{array}{l}-5,47 \\
\end{array}$ & $-27,71$ & $-15,11$ & $-18,40$ & $-2,67$ & $-4,13$ \\
\hline 8 & $-2,37$ & 22,91 & 25,40 & $-2,83$ & $-8,76$ & $-21,02$ & $-8,82$ & $-13,20$ \\
\hline 9 & $-3,46$ & 45,27 & 50,69 & 23,62 & $-13,38$ & $-28,54$ & $-12,50$ & $-19,16$ \\
\hline 10 & $-4,89$ & 75,42 & 84,34 & 56,57 & $-18,28$ & $-37,04$ & $-16,54$ & $-26,11$ \\
\hline 11 & $-5,17$ & 82,74 & 92,45 & 64,24 & $-19,14$ & $-38,59$ & $-17,38$ & $-27,75$ \\
\hline 12 & $-5,24$ & 84,61 & 94,56 & 66,75 & $-19,19$ & $-38,59$ & $-17,60$ & $-28,20$ \\
\hline 13 & \begin{tabular}{c|}
$-10,70$ \\
\end{tabular} & $-25,25$ & $-31,17$ & $-29,81$ & $\begin{array}{c}-9,33 \\
\end{array}$ & $-111,12$ & \begin{tabular}{c|}
$-14,69$ \\
\end{tabular} & $-15,43$ \\
\hline 14 & $-6,61$ & $-6,42$ & $-5,78$ & $-12,57$ & $-10,74$ & $-21,41$ & $-17,81$ & $-17,75$ \\
\hline 15 & $-7,36$ & 14,75 & 18,62 & 6,64 & $-17,57$ & $-34,10$ & $-22,22$ & $-22,26$ \\
\hline 16 & $-9,59$ & 41,49 & 48,76 & 28,53 & $-28,68$ & $-52,62$ & $-29,87$ & $-34,07$ \\
\hline 17 & $-10,19$ & 46,71 & 54,67 & 34,78 & $-31,13$ & $-56,61$ & $-31,90$ & $-37,40$ \\
\hline 18 & $-10,33$ & 47,92 & 56,08 & 36,25 & $-31,24$ & $-56,61$ & $-32,47$ & $-38,33$ \\
\hline 19 & 59,90 & 43,49 & 42,36 & 30,83 & 72,11 & 75,68 & 35,45 & 40,91 \\
\hline 20 & 92,44 & 62,10 & 57,98 & 46,06 & 117,99 & 111,01 & 65,45 & 72,06 \\
\hline 21 & 128,77 & 83,33 & 76,79 & 69,67 & 178,61 & 168,56 & 102,29 & 117,74 \\
\hline 22 & 166,83 & 105,57 & 97,31 & 103,80 & 251,41 & 244,90 & 156,88 & 186,18 \\
\hline 23 & 170,60 & 108,87 & 100,62 & 116,55 & 263,35 & 260,35 & 170,75 & 203,36 \\
\hline 24 & 165,36 & 107,66 & 99,91 & 111,58 & 259,46 & 260,35 & 174,59 & 208,09 \\
\hline
\end{tabular}

TABELA 5.131: Esforços Normais nas nervuras e vigas, em kN, na laje com 12 nervuras por lado

LAJE COM RELAÇ̃̃̃ a1/l=0,0769

ESFORÇOS NORMAIS NAS NERVURAS E VIGAS (kN)

\begin{tabular}{c|c|c|c|c|c|c|c|c}
\hline \multirow{2}{*}{ Ponto } & \multicolumn{8}{c}{ Modelos numéricos de análise } \\
\cline { 2 - 9 } & $\mathbf{0 1}$ & $\mathbf{0 2}$ & $\mathbf{0 3}$ & $\mathbf{0 4}$ & $\mathbf{0 5}$ & $\mathbf{0 6}$ & $\mathbf{0 7}$ & $\mathbf{0 8}$ \\
\hline \hline $\mathbf{6}$ & $-3,74$ & $-0,90$ & $-1,64$ & $\mathbf{- 3 4 , 4 5}$ & $-19,04$ & $-22,96$ & $-1,07$ & $-2,03$ \\
\hline $\mathbf{7}$ & $-2,56$ & 61,13 & 68,10 & $\mathbf{2 9 , 3 9}$ & $-13,16$ & $-29,89$ & $-11,41$ & $-18,70$ \\
\hline $\mathbf{8}$ & $-4,16$ & 96,94 & 107,82 & $\mathbf{7 3 , 0 7}$ & $-18,16$ & $-37,78$ & $-14,99$ & $-26,18$ \\
\hline $\mathbf{9}$ & $-4,63$ & 111,21 & 123,68 & $\mathbf{9 0 , 4 4}$ & $-19,31$ & $-39,77$ & $-16,13$ & $-28,76$ \\
\hline $\mathbf{1 0}$ & $-4,64$ & 111,49 & 124,07 & $\mathbf{9 1 , 2 5}$ & $-19,32$ & $-39,77$ & $-16,16$ & $-28,81$ \\
\hline \hline $\mathbf{1 1}$ & $-6,03$ & $-7,30$ & $-9,84$ & $\mathbf{- 3 2 , 4 3}$ & $-16,22$ & $-19,66$ & $-3,77$ & $-5,43$ \\
\hline $\mathbf{1 2}$ & $-4,04$ & 44,57 & 50,09 & $\mathbf{2 1 , 7 0}$ & $-14,41$ & $-30,83$ & $-14,18$ & $-20,82$ \\
\hline $\mathbf{1 3}$ & $-5,72$ & 79,80 & 89,48 & $\mathbf{5 9 , 7 7}$ & $-20,54$ & $-41,54$ & $-19,13$ & $-28,90$ \\
\hline $\mathbf{1 4}$ & $-6,29$ & 94,35 & 105,58 & $\mathbf{7 4 , 7 5}$ & $-22,42$ & $-44,88$ & $-20,88$ & $-35,27$ \\
\hline $\mathbf{1 5}$ & $-6,29$ & 94,63 & 105,96 & $\mathbf{7 5 , 4 8}$ & $-22,42$ & $-44,88$ & $-20,92$ & $-32,35$ \\
\hline \hline $\mathbf{1 6}$ & $-12,06$ & $-32,03$ & $-39,81$ & $\mathbf{- 3 6 , 5 6}$ & $-9,57$ & $-11,40$ & $-17,48$ & $-18,06$ \\
\hline $\mathbf{1 7}$ & $-8,33$ & 10,33 & 14,18 & $\mathbf{2 , 9 8}$ & $-18,76$ & $-36,39$ & $-25,08$ & $-24,16$ \\
\hline $\mathbf{1 8}$ & $-11,07$ & 41,28 & 49,14 & $\mathbf{2 7 , 8 7}$ & $-32,09$ & $-58,60$ & $-34,12$ & $-37,37$ \\
\hline $\mathbf{1 9}$ & $-12,37$ & 50,97 & 60,20 & $\mathbf{3 5 , 9 5}$ & $-37,06$ & $-66,69$ & $-38,35$ & $-43,85$ \\
\hline $\mathbf{2 0}$ & $-12,39$ & 51,19 & 60,54 & $\mathbf{3 6 , 4 5}$ & $-37,07$ & $-66,69$ & $-38,45$ & $-44,00$ \\
\hline \hline $\mathbf{2 1}$ & 72,24 & 53,08 & 51,70 & $\mathbf{4 0 , 0 4}$ & 87,82 & 91,89 & 43,61 & 50,25 \\
\hline $\mathbf{2 2}$ & 152,10 & 99,35 & 91,58 & $\mathbf{8 0 , 6 8}$ & 207,51 & 194,74 & 118,21 & 135,28 \\
\hline $\mathbf{2 3}$ & 200,57 & 126,41 & 116,15 & $\mathbf{1 1 9 , 7 6}$ & 298,29 & 290,34 & 182,17 & 215,35 \\
\hline $\mathbf{2 4}$ & 206,19 & 132,05 & 121,93 & $\mathbf{1 3 4 , 0 6}$ & 321,44 & 322,61 & 210,03 & 249,83 \\
\hline $\mathbf{2 5}$ & 205,21 & 133,35 & 123,50 & $\mathbf{1 3 4 , 7 4}$ & 321,34 & 322,61 & 210,67 & 250,63 \\
\hline \hline
\end{tabular}


TABELA 5.132: Esforços Normais nas nervuras e vigas, em kN, na laje com 13 nervuras por lado

\begin{tabular}{|c|c|c|c|c|c|c|c|c|}
\hline \multicolumn{9}{|c|}{$\begin{array}{c}\text { LAJE COM RELAÇÃO a1/l=0,0714 } \\
\text { ESFORÇOS NORMAIS NAS NERVURAS E VIGAS }(\mathrm{kN})\end{array}$} \\
\hline \multirow{2}{*}{ Ponto } & \multicolumn{8}{|c|}{ Modelos numéricos de análise } \\
\hline & $\mathbf{0 1}$ & $\mathbf{0 2}$ & $\mathbf{0 3}$ & 04 & 05 & 06 & 07 & 08 \\
\hline 1 & $-4,12$ & $-1,74$ & $-2,68$ & $-42,06$ & $-21,36$ & $-25,60$ & $-1,01$ & $-2,01$ \\
\hline 2 & $-2,53$ & 66,92 & 74,61 & 29,83 & $-13,58$ & $-31,76$ & $-11,90$ & $-12,56$ \\
\hline 3 & $-4,38$ & 108,45 & 120,60 & 82,78 & $-19,42$ & $-40,83$ & $-15,88$ & $-16,66$ \\
\hline 4 & $-5,01$ & 127,95 & 142,24 & 107,07 & $-21,09$ & $-43,68$ & $-17,38$ & $-18,33$ \\
\hline 5 & $-5,05$ & 129,77 & 144,31 & 110,02 & $-21,12$ & $-43,68$ & $-17,51$ & $-18,49$ \\
\hline 6 & $-5,41$ & $-5,26$ & $\begin{array}{l}-7,28 \\
\end{array}$ & $-40,31$ & $-19,48$ & $-23,46$ & $-2,33$ & $-4,94$ \\
\hline 7 & $-3,40$ & 56,11 & 62,71 & 25,20 & $-14,28$ & $-32,11$ & $-13,33$ & $-15,04$ \\
\hline 8 & $-5,27$ & 96,79 & 108,09 & 73,90 & $-20,63$ & $-42,65$ & $-18,22$ & $-19,52$ \\
\hline 9 & $-5,97$ & 116,82 & 130,24 & 96,30 & $-22,77$ & $-46,47$ & $-20,18$ & $-21,46$ \\
\hline 10 & $-6,02$ & 118,70 & 132,36 & 99,01 & $-22,81$ & $-46,47$ & $-20,37$ & $-21,65$ \\
\hline 11 & $-13,35$ & $-39,23$ & $-49,07$ & $-44,07$ & $-9,74$ & $\begin{array}{c}-11,62 \\
\end{array}$ & $\begin{array}{c}-20,26 \\
\end{array}$ & -23,35 \\
\hline 12 & $-9,27$ & 5,14 & 8,90 & $-1,32$ & $-19,74$ & $-38,28$ & $-27,88$ & $-28,91$ \\
\hline 13 & $-12,52$ & 40,23 & 48,61 & 26,73 & $-35,17$ & $-63,98$ & $-38,20$ & $-38,09$ \\
\hline 14 & $-14,44$ & 52,98 & 63,23 & 36,86 & $-42,54$ & $-76,16$ & $-44,10$ & $-43,66$ \\
\hline 15 & $-14,61$ & 53,95 & 64,39 & 37,96 & $-42,63$ & $-76,16$ & $-44,72$ & $-44,24$ \\
\hline 16 & 85,69 & 63,57 & 61,91 & 50,17 & 105,02 & 109,76 & 52,51 & 688,77 \\
\hline 17 & 176,88 & 116,58 & 107,52 & 92,56 & 237,35 & 221,30 & 134,94 & 142,03 \\
\hline 18 & 236,71 & 148,79 & 136,34 & 146,64 & 346,97 & 337,06 & 208,18 & 209,82 \\
\hline 19 & 250,08 & 157,95 & 145,17 & 156,81 & 386,13 & 387,27 & 246,13 & 245,06 \\
\hline 20 & 242,11 & 155,76 & 143,69 & 160,82 & 380,48 & 387,27 & 250,02 & 248,66 \\
\hline
\end{tabular}

TABELA 5.133: Esforços Normais nas nervuras e vigas, em kN, na laje com 14 nervuras por lado

\begin{tabular}{|c|c|c|c|c|c|c|c|c|}
\hline \multicolumn{9}{|c|}{$\begin{array}{l}\text { LAJE COM RELAÇÃO a1/l=0,0667 } \\
\text { ORÇOS NORMAIS NAS NERVURAS E VIGAS }(k N)\end{array}$} \\
\hline \multirow{2}{*}{ Ponto } & \multicolumn{8}{|c|}{ Modelos numéricos de análise } \\
\hline & 01 & $\mathbf{0 2}$ & $\mathbf{0 3}$ & 04 & 05 & 06 & 07 & 08 \\
\hline 7 & $-4,68$ & $-3,12$ & $-4,39$ & $-49,31$ & $-23,46$ & $-28,01$ & $-1,10$ & $-2,14$ \\
\hline 8 & $-2,57$ & 71,15 & 79,43 & 28,28 & $-13,97$ & $-33,51$ & $-12,52$ & $-20,08$ \\
\hline 9 & $-4,67$ & 118,38 & 131,70 & 88,31 & $-20,68$ & $-43,90$ & $-17,03$ & $-29,38$ \\
\hline 10 & $-5,46$ & 143,22 & 159,22 & 118,84 & $-22,92$ & $-47,71$ & $-18,94$ & $-33,68$ \\
\hline 11 & $-5,58$ & 147,73 & 164,25 & 124,73 & $-23,18$ & $-48,13$ & $-19,26$ & $-34,43$ \\
\hline 12 & $-5,58$ & 148,02 & 164,63 & 125,56 & $-23,18$ & $-48,13$ & $-19,28$ & $-34,48$ \\
\hline 13 & $-6,46$ & $-8,61$ & $-11,65$ & $-49,40$ & $-20,68$ & $-24,84$ & $-3,17$ & $-4,90$ \\
\hline 14 & $-3,84$ & 55,30 & 61,95 & 21,89 & $-15,01$ & $-33,99$ & $-14,66$ & $-22,12$ \\
\hline 15 & $-5,96$ & 100,96 & 112,99 & 75,57 & $-22,41$ & $-46,36$ & $-20,33$ & $-31,70$ \\
\hline 16 & $-6,85$ & 126,38 & 141,10 & 102,95 & $-25,43$ & $-51,78$ & $-22,96$ & $-36,67$ \\
\hline 17 & $-6,99$ & 131,00 & 146,21 & 108,19 & $-25,82$ & $-52,43$ & $-23,39$ & $-37,58$ \\
\hline 18 & $-7,00$ & 131,29 & 146,60 & 108,96 & $-25,82$ & $-52,43$ & $-23,43$ & $-37,65$ \\
\hline 19 & $-14,58$ & $-46,77$ & $-58,87$ & $-48,31$ & $-9,84$ & $\begin{array}{l}-11,79 \\
\end{array}$ & $-23,00$ & $-23,30$ \\
\hline 20 & $-10,18$ & $-0,75$ & 2,84 & $-6,05$ & $-20,52$ & $-39,78$ & $-30,59$ & $-27,78$ \\
\hline 21 & $-13,93$ & 38,39 & 47,22 & 25,18 & $-37,93$ & $-68,78$ & $-42,10$ & $-43,12$ \\
\hline 22 & $-16,50$ & 54,12 & 65,35 & 37,20 & $-47,63$ & $-84,94$ & $-49,64$ & $-53,48$ \\
\hline 23 & $-16,98$ & 56,33 & 67,96 & 39,23 & $-48,92$ & $-87,02$ & $-51,11$ & $-55,45$ \\
\hline 24 & $-17,00$ & 56,53 & 68,29 & 39,70 & $-48,94$ & $-87,02$ & $-51,22$ & $-55,58$ \\
\hline 25 & 100,25 & 74,95 & 72,99 & 61,32 & 123,72 & 129,32 & 62,10 & 71,36 \\
\hline 26 & 202,99 & 134,93 & 124,54 & 111,72 & 268,00 & 248,07 & 152,41 & 172,67 \\
\hline 27 & 275,12 & 172,67 & 157,86 & 164,68 & 397,24 & 384,79 & 234,90 & 275,60 \\
\hline 28 & 296,96 & 185,37 & 169,65 & 179,72 & 453,20 & 453,91 & 282,85 & 335,07 \\
\hline 29 & 292,28 & 184,82 & 169,61 & 187,73 & 455,11 & 462,58 & 291,93 & 346,23 \\
\hline 30 & 290,87 & 186,07 & 171,19 & 188,42 & 454,92 & 462,58 & 292,58 & 347,03 \\
\hline
\end{tabular}


TABELA 5.134: Esforços Normais nas nervuras e vigas, em kN, na laje com 15 nervuras por lado

\begin{tabular}{|c|c|c|c|c|c|c|c|c|}
\hline \multicolumn{9}{|c|}{$\begin{array}{c}\text { LAJE COM RELAÇÃO a1/l=0,0625 } \\
\text { ESFORÇOS NORMAIS NAS NERVURAS E VIGAS }(\mathrm{kN})\end{array}$} \\
\hline \multirow{2}{*}{ Ponto } & \multicolumn{8}{|c|}{ Modelos numéricos de análise } \\
\hline & 01 & 02 & 03 & 04 & 05 & 06 & 07 & 08 \\
\hline$\overline{c 1}$ & $-5,12$ & $-4,34$ & $-5,86$ & $-60,79$ & $-25,81$ & $-30,70$ & $-1,04$ & $-2,08$ \\
\hline 2 & $-2,49$ & 76,44 & 85,46 & 26,58 & $-14,20$ & $-35,11$ & $-12,92$ & $-20,55$ \\
\hline 3 & $-4,85$ & 129,67 & 144,31 & 94,37 & $-21,71$ & $-46,64$ & $-17,81$ & $-30,62$ \\
\hline 4 & $-5,78$ & 159,78 & 177,62 & 131,53 & $-24,48$ & $-51,29$ & $-20,04$ & $-35,69$ \\
\hline 5 & $-5,97$ & 166,94 & 185,56 & 140,44 & $-24,95$ & $-52,09$ & $-20,51$ & $-36,82$ \\
\hline 6 & $-6,01$ & 168,77 & 187,64 & 143,38 & $-24,98$ & $-52,09$ & $-20,63$ & $-37,12$ \\
\hline$\overline{77}$ & $-6,14$ & $\begin{array}{l}-7,46 \\
\end{array}$ & $\begin{array}{l}-10,07 \\
\end{array}$ & $-58,65$ & $\begin{array}{l}-23,98 \\
\end{array}$ & $-28,64$ & $-2,12$ & $-3,67$ \\
\hline 8 & $-3,26$ & 66,23 & 74,09 & 22,78 & $-14,80$ & $-35,29$ & $-14,07$ & $-21,85$ \\
\hline 9 & $-5,60$ & 117,88 & 131,59 & 86,19 & $-22,63$ & $-47,85$ & $-19,70$ & $-32,10$ \\
\hline 10 & $-6,60$ & 148,52 & 165,47 & 121,11 & $-25,86$ & $-53,49$ & $-22,44$ & $-37,54$ \\
\hline 11 & $-6,80$ & 155,87 & 173,59 & 129,47 & $-26,45$ & $-54,53$ & $-23,03$ & $-38,80$ \\
\hline 12 & $-6,85$ & 157,74 & 175,71 & 132,23 & $-26,49$ & $-54,53$ & $-23,19$ & $-39,14$ \\
\hline 13 & $-9,84$ & $-22,34$ & $-29,55$ & $-54,58$ & $-18,54$ & $-22,40$ & $-8,62$ & $-10,62$ \\
\hline 14 & $-6,03$ & 35,20 & 40,36 & 10,48 & $-17,28$ & $-36,75$ & $-20,09$ & $-26,07$ \\
\hline 15 & $-8,47$ & 84,87 & 96,30 & 62,35 & $-26,93$ & $-53,94$ & $-27,48$ & $-36,68$ \\
\hline 16 & $-9,78$ & 114,48 & 129,13 & 90,37 & $-32,30$ & $-63,64$ & $-31,58$ & $-43,73$ \\
\hline 17 & $-10,06$ & 121,24 & 136,62 & 96,88 & $-33,41$ & $-65,61$ & $-32,52$ & $-45,48$ \\
\hline 18 & $-10,13$ & 122,93 & 138,54 & 99,01 & $-33,47$ & $-65,61$ & $-32,77$ & $-45,96$ \\
\hline 19 & $-15,74$ & $-54,61$ & $-69,13$ & $-58,31$ & $-9,90$ & $-11,93$ & $-25,68$ & $-25,87$ \\
\hline 20 & $-11,03$ & $-7,29$ & $-3,94$ & $-11,20$ & $-21,10$ & $-40,88$ & $-33,22$ & $-29,50$ \\
\hline 21 & $-15,27$ & 35,83 & 45,03 & 21,98 & $-40,38$ & $-73,00$ & $-45,80$ & $-45,64$ \\
\hline 22 & $-18,52$ & 54,53 & 66,68 & 37,08 & $-52,32$ & $-93,02$ & $-54,94$ & $-57,67$ \\
\hline 23 & $-19,34$ & 57,84 & 70,61 & 39,93 & $-54,79$ & $-97,16$ & $-57,28$ & $-60,64$ \\
\hline 24 & $-19,54$ & 58,61 & 71,55 & 40,83 & $-54,87$ & $-97,16$ & $-57,92$ & $-61,45$ \\
\hline 25 & 115,93 & 87,22 & 84,94 & 73,37 & 143,91 & 150,56 & 72,39 & 83,11 \\
\hline 26 & 230,35 & 154,34 & 142,59 & 125,88 & 299,33 & 274,89 & 170,67 & 192,46 \\
\hline 27 & 315,70 & 198,01 & 180,67 & 183,12 & 448,93 & 433,30 & 262,27 & 306,60 \\
\hline 28 & 346,75 & 214,30 & 195,37 & 219,72 & 522,37 & 522,19 & 320,14 & 378,44 \\
\hline 29 & 345,63 & 215,32 & 196,68 & 226,70 & 532,24 & 540,03 & 334,40 & 395,98 \\
\hline 30 & 334,54 & 212,02 & 194,33 & 227,91 & 524,73 & 540,03 & 338,32 & 400,79 \\
\hline
\end{tabular}

Analisando-se as tabelas de esforços normais nas nervuras e vigas, nos modelos com variação de $\mathrm{a}_{1} / \mathrm{l}$, verificou-se que:

- as nervuras simuladas nos modelos 02,03 e 04 apresentam esforços normais de tração, enquanto as dos modelos 05 a 08 apresentam compressão;

- as vigas, simuladas pelo elemento BEAM44 excêntrico e pelo elemento de casca SHELL63 apresentam, em todos os modelos, esforços normais de tração, muito maiores para os modelos 05 a 08 , justamente os que apresentaram-se mais rígidos e, consequentemente, com menores valores de momentos fletores. 


\subsubsection{Tensões Normais nas fibras superiores extremas das nervuras e vigas}

TABELA 5.135: Tensões Normais nas fibras superiores extremas das nervuras e vigas, em $\mathrm{kN} / \mathrm{cm}^{2}$, na laje com 05 nervuras por lado

\begin{tabular}{|c|c|c|c|c|c|c|c|c|}
\hline \multicolumn{9}{|c|}{$\begin{array}{c}\text { LAJE COM RELAÇÃO a1/l=0,1667 } \\
\text { TENSÕES NORMAIS - FIBRAS SUPERIORES EXTREMAS - NERVURAS E VIGAS }\left(\mathrm{kN} / \mathrm{cm}^{2}\right)\end{array}$} \\
\hline \multirow{2}{*}{ Ponto } & \multicolumn{8}{|c|}{ Modelos numéricos de análise } \\
\hline & 01 & 02 & 03 & 04 & 05 & 06 & 07 & 08 \\
\hline 1 & 0,066 & 0,053 & 0,099 & 0,060 & 0,035 & 0,036 & $-0,013$ & 0,001 \\
\hline 2 & $-0,278$ & $-0,059$ & 0,052 & $-0,033$ & $-0,071$ & $-0,088$ & $-0,103$ & $-0,083$ \\
\hline 3 & $-0,471$ & $-0,118$ & 0,024 & $-0,074$ & $-0,131$ & $-0,154$ & $-0,150$ & $-0,122$ \\
\hline 4 & $-0,536$ & $-0,147$ & $-0,004$ & $-0,086$ & $-0,149$ & $-0,173$ & $-0,162$ & $-0,132$ \\
\hline 5 & 0,097 & 0,053 & 0,090 & 0,059 & 0,032 & 0,033 & $-0,006$ & 0,007 \\
\hline 6 & $-0,224$ & $-0,046$ & 0,050 & $-0,029$ & $-0,066$ & $-0,083$ & $-0,089$ & $-0,071$ \\
\hline 7 & $-0,423$ & $-0,109$ & 0,020 & $-0,068$ & $-0,120$ & $-0,142$ & $-0,136$ & $-0,110$ \\
\hline 8 & $-0,491$ & $-0,138$ & $-0,008$ & $-0,080$ & $-0,135$ & $-0,158$ & $-0,149$ & $-0,120$ \\
\hline 9 & 0,193 & 0,080 & 0,086 & 0,052 & 0,024 & 0,024 & 0,024 & 0,024 \\
\hline 10 & $-0,108$ & $-0,029$ & 0,033 & $-0,021$ & $-0,051$ & $-0,067$ & $-0,059$ & $-0,041$ \\
\hline 11 & $-0,292$ & $-0,091$ & 0,001 & $-0,056$ & $-0,091$ & $-0,115$ & $-0,106$ & $-0,083$ \\
\hline 12 & $-0,345$ & $-0,111$ & $-0,019$ & $-0,067$ & $-0,102$ & $-0,126$ & $-0,117$ & $-0,095$ \\
\hline$\overline{13}$ & 0,134 & 0,134 & 0,135 & 0,092 & 0,122 & 0,137 & 0,108 & 0,118 \\
\hline 14 & $-0,016$ & $-0,015$ & $-0,015$ & $-0,009$ & $-0,020$ & $-0,008$ & $-0,007$ & $-0,010$ \\
\hline 15 & $-0,068$ & $-0,081$ & $-0,084$ & $-0,068$ & $-0,048$ & $-0,058$ & $-0,047$ & $-0,048$ \\
\hline 16 & $-0,079$ & $-0,103$ & $-0,106$ & $-0,089$ & $-0,048$ & $-0,065$ & $-0,058$ & $-0,058$ \\
\hline
\end{tabular}

TABELA 5.136: Tensões Normais nas fibras superiores extremas das nervuras e vigas, em $\mathrm{kN} / \mathrm{cm}^{2}$, na laje com 06 nervuras por lado

\section{LAJE COM RELAÇ̃̃O a1/l=0,1429}

TENSÕES NORMAIS - FIBRAS SUPERIORES EXTREMAS - NERVURAS E VIGAS $\left(\mathrm{kN} / \mathrm{cm}^{2}\right)$

\begin{tabular}{c|c|c|c|c|c|c|c|c}
\hline \multirow{2}{*}{ Ponto } & \multicolumn{7}{|c}{ Modelos numéricos de análise } \\
\cline { 2 - 9 } & $\mathbf{0 1}$ & $\mathbf{0 2}$ & $\mathbf{0 3}$ & $\mathbf{0 4}$ & $\mathbf{0 5}$ & $\mathbf{0 6}$ & $\mathbf{0 7}$ & $\mathbf{0 8}$ \\
\hline \hline $\mathbf{6}$ & 0,112 & 0,068 & 0,118 & $\mathbf{0 , 0 8 6}$ & 0,058 & 0,059 & $-0,013$ & 0,007 \\
\hline $\mathbf{7}$ & $-0,302$ & $-0,063$ & 0,067 & $\mathbf{- 0 , 0 3 1}$ & $-0,069$ & $-0,090$ & $-0,120$ & $-0,140$ \\
\hline $\mathbf{8}$ & $-0,561$ & $-0,138$ & 0,038 & $\mathbf{- 0 , 0 8 6}$ & $-0,151$ & $-0,180$ & $-0,184$ & $-0,148$ \\
\hline $\mathbf{9}$ & $-0,692$ & $-0,182$ & 0,011 & $\mathbf{- 0 , 1 1 0}$ & $-0,187$ & $-0,220$ & $-0,213$ & $-0,171$ \\
\hline $\mathbf{1 0}$ & $-0,714$ & $-0,198$ & $-0,010$ & $\mathbf{- 0 , 1 1 4}$ & $-0,193$ & $-0,225$ & $-0,215$ & $-0,173$ \\
\hline \hline $\mathbf{1 1}$ & 0,295 & 0,129 & 0,119 & $\mathbf{0 , 0 6 5}$ & 0,034 & 0,032 & 0,047 & 0,040 \\
\hline $\mathbf{1 2}$ & $-0,062$ & $-0,017$ & 0,040 & $\mathbf{- 0 , 0 1 8}$ & $-0,048$ & $-0,068$ & $-0,055$ & $-0,037$ \\
\hline $\mathbf{1 3}$ & $-0,304$ & $-0,101$ & 0,001 & $\mathbf{- 0 , 0 5 9}$ & $-0,099$ & $-0,127$ & $-0,120$ & $-0,091$ \\
\hline $\mathbf{1 4}$ & $-0,404$ & $-0,131$ & $-0,018$ & $\mathbf{- 0 , 0 7 8}$ & $-0,121$ & $-0,154$ & $-0,145$ & $-0,116$ \\
\hline $\mathbf{1 5}$ & $-0,425$ & $-0,147$ & $-0,038$ & $\mathbf{- 0 , 0 8 1}$ & $-0,127$ & $-0,158$ & $-0,147$ & $-0,118$ \\
\hline \hline $\mathbf{1 6}$ & 0,14 & 0,14 & 0,15 & $\mathbf{0 , 1 0}$ & 0,13 & 0,14 & 0,11 & 0,12 \\
\hline $\mathbf{1 7}$ & $-0,01$ & $-0,01$ & $-0,01$ & $\mathbf{0 , 0 0}$ & $-0,02$ & 0,00 & 0,00 & $-0,01$ \\
\hline $\mathbf{1 8}$ & $-0,07$ & $-0,08$ & $-0,09$ & $-\mathbf{0 , 0 7}$ & $-0,05$ & $-0,05$ & $-0,05$ & $-0,05$ \\
\hline $\mathbf{1 9}$ & $-0,09$ & $-0,12$ & $-0,13$ & $-\mathbf{0 , 1 1}$ & $-0,05$ & $-0,06$ & $-0,07$ & $-0,07$ \\
\hline $\mathbf{2 0}$ & $-0,08$ & $-0,12$ & $-0,12$ & $-\mathbf{0 , 1 1}$ & $-0,03$ & $-0,05$ & $-0,07$ & $-0,07$ \\
\hline \hline
\end{tabular}


TABELA 5.137: Tensões Normais nas fibras superiores extremas das nervuras e vigas, em $\mathrm{kN} / \mathrm{cm}^{2}$, na laje com 07 nervuras por lado

LAJE COM RELAÇÃO a1/l=0,1250

TENSÕES NORMAIS - FIBRAS SUPERIORES EXTREMAS - NERVURAS E VIGAS (kN/ $\left.\mathrm{cm}^{2}\right)$

\begin{tabular}{c|c|c|c|c|c|c|c|c}
\hline \multirow{2}{*}{ Ponto } & \multicolumn{7}{c}{ Modelos numéricos de análise } \\
\cline { 2 - 9 } & $\mathbf{0 1}$ & $\mathbf{0 2}$ & $\mathbf{0 3}$ & $\mathbf{0 4}$ & $\mathbf{0 5}$ & $\mathbf{0 6}$ & $\mathbf{0 7}$ & $\mathbf{0 8}$ \\
\hline \hline $\mathbf{1}$ & 0,154 & 0,087 & 0,144 & $\mathbf{0 , 1 1 2}$ & 0,091 & 0,091 & $-0,016$ & 0,010 \\
\hline $\mathbf{2}$ & $-0,345$ & $-0,072$ & 0,083 & $\mathbf{- 0 , 0 2 7}$ & $-0,062$ & $-0,087$ & $-0,147$ & $-0,108$ \\
\hline $\mathbf{3}$ & $-0,673$ & $-0,164$ & 0,054 & $\mathbf{- 0 , 1 0 0}$ & $-0,170$ & $-0,206$ & $-0,227$ & $-0,180$ \\
\hline $\mathbf{4}$ & $-0,865$ & $-0,221$ & 0,028 & $\mathbf{- 0 , 1 3 6}$ & $-0,227$ & $-0,270$ & $-0,272$ & $-0,217$ \\
\hline $\mathbf{5}$ & $-0,931$ & $-0,250$ & 0,000 & $\mathbf{- 0 , 1 4 8}$ & $-0,245$ & $-0,289$ & $-0,284$ & $-0,227$ \\
\hline \hline $\mathbf{6}$ & 0,284 & 0,112 & 0,132 & $\mathbf{0 , 1 0 2}$ & 0,071 & 0,071 & 0,020 & 0,038 \\
\hline $\mathbf{7}$ & $-0,145$ & $-0,023$ & 0,076 & $\mathbf{- 0 , 0 1 7}$ & $-0,054$ & $-0,079$ & $-0,093$ & $-0,072$ \\
\hline $\mathbf{8}$ & $-0,476$ & $-0,125$ & 0,039 & $\mathbf{- 0 , 0 7 8}$ & $-0,135$ & $-0,172$ & $-0,175$ & $-0,138$ \\
\hline $\mathbf{9}$ & $-0,674$ & $-0,186$ & 0,010 & $\mathbf{- 0 , 1 0 9}$ & $-0,178$ & $-0,219$ & $-0,219$ & $-0,174$ \\
\hline $\mathbf{1 0}$ & $-0,738$ & $-0,212$ & $-0,016$ & $\mathbf{- 0 , 1 1 9}$ & $-0,190$ & $-0,232$ & $-0,231$ & $-0,183$ \\
\hline \hline $\mathbf{1 1}$ & 0,410 & 0,192 & 0,162 & $\mathbf{0 , 0 7 5}$ & 0,044 & 0,040 & 0,075 & 0,060 \\
\hline $\mathbf{1 2}$ & $-0,002$ & $-0,001$ & 0,047 & $\mathbf{- 0 , 0 1 2}$ & $-0,044$ & $-0,067$ & $-0,047$ & $-0,030$ \\
\hline $\mathbf{1 3}$ & $-0,298$ & $-0,108$ & $-0,021$ & $\mathbf{- 0 , 0 6 4}$ & $-0,102$ & $-0,135$ & $-0,129$ & $-0,095$ \\
\hline $\mathbf{1 4}$ & $-0,444$ & $-0,152$ & $-0,023$ & $\mathbf{- 0 , 0 8 9}$ & $-0,134$ & $-0,174$ & $-0,169$ & $-0,132$ \\
\hline $\mathbf{1 5}$ & $-0,484$ & $-0,165$ & $-0,036$ & $\mathbf{- 0 , 0 9 3}$ & $-0,141$ & $-0,182$ & $-0,178$ & $-0,142$ \\
\hline \hline $\mathbf{1 6}$ & 0,15 & 0,15 & 0,15 & $\mathbf{0 , 1 1}$ & 0,13 & 0,14 & 0,12 & 0,13 \\
\hline $\mathbf{1 7}$ & $-0,01$ & $-0,01$ & 0,00 & $\mathbf{0 , 0 0}$ & $-0,03$ & 0,00 & 0,00 & 0,00 \\
\hline $\mathbf{1 8}$ & $-0,07$ & $-0,09$ & $-0,09$ & $\mathbf{- 0 , 0 7}$ & $-0,05$ & $-0,05$ & $-0,05$ & $-0,05$ \\
\hline $\mathbf{1 9}$ & $-0,10$ & $-0,13$ & $-0,14$ & $\mathbf{- 0 , 1 2}$ & $-0,05$ & $-0,06$ & $-0,07$ & $-0,07$ \\
\hline $\mathbf{2 0}$ & $-0,11$ & $-0,15$ & $-0,16$ & $\mathbf{- 0 , 1 4}$ & $-0,04$ & $-0,05$ & $-0,08$ & $-0,08$ \\
\hline \hline
\end{tabular}

TABELA 5.138: Tensões Normais nas fibras superiores extremas das nervuras e vigas, em $\mathrm{kN} / \mathrm{cm}^{2}$, na laje com 08 nervuras por lado

LAJE COM RELAÇÃO a1/l=0,1111

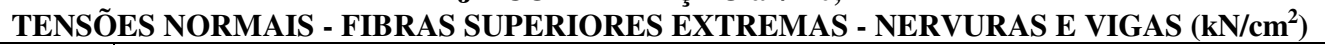

\begin{tabular}{c|c|c|c|c|c|c|c|c}
\hline \multirow{2}{*}{ Ponto } & \multicolumn{8}{|c|}{ Modelos numéricos de análise } \\
\cline { 2 - 9 } & $\mathbf{0 1}$ & $\mathbf{0 2}$ & $\mathbf{0 3}$ & $\mathbf{0 4}$ & $\mathbf{0 5}$ & $\mathbf{0 6}$ & $\mathbf{0 7}$ & $\mathbf{0 8}$ \\
\hline \hline $\mathbf{7}$ & 0,220 & 0,109 & 0,168 & $\mathbf{0 , 1 4 5}$ & 0,129 & 0,128 & $-0,014$ & 0,019 \\
\hline $\mathbf{8}$ & $-0,351$ & $-0,073$ & 0,099 & $\mathbf{- 0 , 0 2 1}$ & $-0,045$ & $-0,076$ & $-0,163$ & $-0,116$ \\
\hline $\mathbf{9}$ & $-0,750$ & $-0,182$ & 0,069 & $\mathbf{- 0 , 1 0 7}$ & $-0,177$ & $-0,221$ & $-0,261$ & $-0,203$ \\
\hline $\mathbf{1 0}$ & $-1,008$ & $-0,255$ & 0,043 & $\mathbf{- 0 , 1 5 7}$ & $-0,256$ & $-0,308$ & $-0,322$ & $-0,255$ \\
\hline $\mathbf{1 1}$ & $-1,138$ & $-0,299$ & 0,015 & $\mathbf{- 0 , 1 8 0}$ & $-0,291$ & $-0,347$ & $-0,350$ & $-0,277$ \\
\hline $\mathbf{1 2}$ & $-1,160$ & $-0,314$ & $-0,005$ & $\mathbf{- 0 , 1 8 4}$ & $-0,297$ & $-0,352$ & $-0,352$ & $-0,279$ \\
\hline \hline $\mathbf{1 3}$ & 0,416 & 0,164 & 0,167 & $\mathbf{0 , 1 2 0}$ & 0,092 & 0,091 & 0,044 & 0,061 \\
\hline $\mathbf{1 4}$ & $-0,070$ & $-0,003$ & 0,087 & $\mathbf{- 0 , 0 0 6}$ & $-0,043$ & $-0,072$ & $-0,087$ & $-0,067$ \\
\hline $\mathbf{1 5}$ & $-0,464$ & $-0,125$ & 0,046 & $\mathbf{- 0 , 0 8 2}$ & $-0,135$ & $-0,178$ & $-0,186$ & $-0,145$ \\
\hline $\mathbf{1 6}$ & $-0,723$ & $-0,204$ & 0,014 & $\mathbf{- 0 , 1 1 8}$ & $-0,189$ & $-0,239$ & $-0,246$ & $-0,193$ \\
\hline $\mathbf{1 7}$ & $-0,845$ & $-0,242$ & $-0,010$ & $\mathbf{- 0 , 1 3 6}$ & $-0,213$ & $-0,266$ & $-0,272$ & $-0,215$ \\
\hline $\mathbf{1 8}$ & $-0,866$ & $-0,070$ & $-0,030$ & $\mathbf{- 0 , 1 4 0}$ & $-0,219$ & $-0,271$ & $-0,274$ & $-0,216$ \\
\hline $\mathbf{1 9}$ & 0,533 & 0,265 & 0,211 & $\mathbf{0 , 0 8 9}$ & 0,054 & 0,048 & 0,107 & 0,083 \\
\hline $\mathbf{2 0}$ & 0,070 & 0,019 & 0,053 & $\mathbf{- 0 , 0 0 4}$ & $-0,038$ & $-0,065$ & $-0,035$ & $-0,020$ \\
\hline $\mathbf{2 1}$ & $-0,276$ & $-0,110$ & $-0,003$ & $\mathbf{- 0 , 0 6 6}$ & $-0,104$ & $-0,141$ & $-0,132$ & $-0,096$ \\
\hline $\mathbf{2 2}$ & $-0,469$ & $-0,170$ & $-0,031$ & $\mathbf{- 0 , 0 9 7}$ & $-0,144$ & $-0,190$ & $-0,187$ & $-0,144$ \\
\hline $\mathbf{2 3}$ & $-0,545$ & $-0,191$ & $-0,043$ & $-\mathbf{0 , 1 0 8}$ & $-0,161$ & $-0,211$ & $-0,209$ & $-0,164$ \\
\hline $\mathbf{2 4}$ & $-0,567$ & $-0,207$ & $-0,063$ & $-\mathbf{0 , 1 1 2}$ & $-0,167$ & $-0,216$ & $-0,210$ & $-0,165$ \\
\hline \hline $\mathbf{2 5}$ & 0,15 & 0,15 & 0,16 & $\mathbf{0 , 1 1}$ & 0,13 & 0,14 & 0,12 & 0,13 \\
\hline $\mathbf{2 6}$ & $-0,02$ & 0,00 & 0,00 & $\mathbf{0 , 0 0}$ & $-0,04$ & 0,00 & 0,00 & 0,00 \\
\hline $\mathbf{2 7}$ & $-0,08$ & $-0,09$ & $-0,09$ & $\mathbf{- 0 , 0 7}$ & $-0,05$ & $-0,04$ & $-0,05$ & $-0,05$ \\
\hline $\mathbf{2 8}$ & $-0,11$ & $-0,14$ & $-0,15$ & $\mathbf{- 0 , 1 4}$ & $-0,05$ & $-0,05$ & $-0,08$ & $-0,08$ \\
\hline $\mathbf{2 9}$ & $-0,12$ & $-0,17$ & $-0,18$ & $\mathbf{- 0 , 1 6}$ & $-0,04$ & $-0,05$ & $-0,09$ & $-0,09$ \\
\hline $\mathbf{3 0}$ & $-0,11$ & $-0,17$ & $-0,17$ & $\mathbf{- 0 , 1 6}$ & $-0,02$ & $-0,03$ & $-0,09$ & $-0,09$ \\
\hline \hline
\end{tabular}


TABELA 5.139: Tensões Normais nas fibras superiores extremas das nervuras e vigas, em $\mathrm{kN} / \mathrm{cm}^{2}$, na laje com 09 nervuras por lado

LAJE COM RELAÇãO a1/l=0,1000

TENSÕES NORMAIS - FIBRAS SUPERIORES EXTREMAS - NERVURAS E VIGAS $\left(\mathrm{kN} / \mathrm{cm}^{2}\right)$

\begin{tabular}{c|c|c|c|c|c|c|c|c}
\hline \multirow{2}{*}{ Ponto } & \multicolumn{7}{|c}{ Modelos numéricos de análise } \\
\cline { 2 - 9 } & $\mathbf{0 1}$ & $\mathbf{0 2}$ & $\mathbf{0 3}$ & $\mathbf{0 4}$ & $\mathbf{0 5}$ & $\mathbf{0 6}$ & $\mathbf{0 7}$ & $\mathbf{0 8}$ \\
\hline \hline $\mathbf{1}$ & 0,285 & 0,134 & 0,198 & $\mathbf{0 , 1 8 4}$ & 0,176 & 0,175 & $-0,017$ & 0,025 \\
\hline $\mathbf{2}$ & $-0,373$ & $-0,077$ & 0,118 & $\mathbf{- 0 , 0 0 8}$ & $-0,022$ & $-0,057$ & $-0,188$ & $-0,128$ \\
\hline $\mathbf{3}$ & $-0,847$ & $-0,207$ & 0,085 & $\mathbf{- 0 , 1 1 2}$ & $-0,181$ & $-0,232$ & $-0,304$ & $-0,232$ \\
\hline $\mathbf{4}$ & $-1,169$ & $-0,294$ & 0,059 & $\mathbf{- 0 , 1 7 9}$ & $-0,284$ & $-0,345$ & $-0,382$ & $-0,299$ \\
\hline $\mathbf{5}$ & $-1,363$ & $-0,352$ & 0,033 & $\mathbf{- 0 , 2 1 5}$ & $-0,340$ & $-0,408$ & $-0,426$ & $-0,335$ \\
\hline $\mathbf{6}$ & $-1,428$ & $-0,380$ & 0,005 & $\mathbf{- 0 , 2 2 6}$ & $-0,358$ & $-0,427$ & $-0,438$ & $-0,344$ \\
\hline \hline $\mathbf{7}$ & 0,402 & 0,154 & 0,186 & $\mathbf{0 , 1 6 1}$ & 0,149 & 0,148 & 0,015 & 0,053 \\
\hline $\mathbf{8}$ & $-0,175$ & $-0,030$ & 0,110 & $\mathbf{0 , 0 0 0}$ & $-0,026$ & $-0,059$ & $-0,132$ & $-0,093$ \\
\hline $\mathbf{9}$ & $-0,633$ & $-0,156$ & 0,077 & $\mathbf{- 0 , 0 9 4}$ & $-0,158$ & $-0,208$ & $-0,246$ & $-0,192$ \\
\hline $\mathbf{1 0}$ & $-0,966$ & $-0,252$ & 0,046 & $\mathbf{- 0 , 1 5 2}$ & $-0,241$ & $-0,300$ & $-0,325$ & $-0,255$ \\
\hline $\mathbf{1 1}$ & $-1,167$ & $-0,313$ & 0,017 & $\mathbf{- 0 , 1 8 4}$ & $-0,286$ & $-0,350$ & $-0,369$ & $-0,290$ \\
\hline $\mathbf{1 2}$ & $-1,233$ & $-0,341$ & $-0,010$ & $\mathbf{- 0 , 1 9 4}$ & $-0,299$ & $-0,364$ & $-0,381$ & $-0,299$ \\
\hline \hline $\mathbf{1 3}$ & 0,662 & 0,346 & 0,266 & $\mathbf{0 , 1 0 5}$ & 0,064 & 0,055 & 0,143 & 0,108 \\
\hline $\mathbf{1 4}$ & 0,152 & 0,042 & 0,058 & $\mathbf{- 0 , 0 0 1}$ & $-0,032$ & $-0,063$ & $-0,018$ & $-0,008$ \\
\hline $\mathbf{1 5}$ & $-0,240$ & $-0,109$ & $-0,005$ & $\mathbf{- 0 , 0 6 6}$ & $-0,104$ & $-0,144$ & $-0,132$ & $-0,093$ \\
\hline $\mathbf{1 6}$ & $-0,478$ & $-0,186$ & $-0,040$ & $\mathbf{- 0 , 1 0 3}$ & $-0,151$ & $-0,201$ & $-0,201$ & $-0,151$ \\
\hline $\mathbf{1 7}$ & $-0,592$ & $-0,217$ & $-0,055$ & $\mathbf{- 0 , 1 2 1}$ & $-0,176$ & $-0,234$ & $-0,235$ & $-0,182$ \\
\hline $\mathbf{1 8}$ & $-0,623$ & $-0,227$ & $-0,064$ & $\mathbf{- 0 , 1 2 7}$ & $-0,180$ & $-0,240$ & $-0,243$ & $-0,189$ \\
\hline \hline $\mathbf{1 9}$ & 0,15 & 0,15 & 0,16 & $\mathbf{0 , 1 1}$ & 0,13 & 0,14 & 0,12 & 0,13 \\
\hline $\mathbf{2 0}$ & $-0,02$ & 0,00 & 0,00 & $\mathbf{0 , 0 1}$ & $-0,05$ & 0,00 & 0,00 & 0,00 \\
\hline $\mathbf{2 1}$ & $-0,08$ & $-0,09$ & $-0,09$ & $\mathbf{- 0 , 0 7}$ & $-0,05$ & $-0,04$ & $-0,05$ & $-0,05$ \\
\hline $\mathbf{2 2}$ & $-0,12$ & $-0,15$ & $-0,16$ & $\mathbf{- 0 , 1 4}$ & $-0,05$ & $-0,04$ & $-0,08$ & $-0,08$ \\
\hline $\mathbf{2 3}$ & $-0,13$ & $-0,19$ & $-0,20$ & $\mathbf{- 0 , 1 8}$ & $-0,04$ & $-0,04$ & $-0,10$ & $-0,10$ \\
\hline $\mathbf{2 4}$ & $-0,13$ & $-0,20$ & $-0,21$ & $\mathbf{- 0 , 1 9}$ & $-0,02$ & $-0,03$ & $-0,11$ & $-0,10$ \\
\hline
\end{tabular}

TABELA 5.140: Tensões Normais nas fibras superiores extremas das nervuras e vigas, em $\mathrm{kN} / \mathrm{cm}^{2}$, na laje com 10 nervuras por lado

LAJE COM RELAÇãO a1/l=0,0910

TENSÕES NORMAIS - FIBRAS SUPERIORES EXTREMAS - NERVURAS E VIGAS $\left(\mathrm{kN} / \mathrm{cm}^{2}\right)$

\begin{tabular}{c|c|c|c|c|c|c|c|c}
\hline \multirow{2}{*}{ Ponto } & \multicolumn{7}{|c}{ Modelos numéricos de análise } \\
\cline { 2 - 9 } & $\mathbf{0 1}$ & $\mathbf{0 2}$ & $\mathbf{0 3}$ & $\mathbf{0 4}$ & $\mathbf{0 5}$ & $\mathbf{0 6}$ & $\mathbf{0 7}$ & $\mathbf{0 8}$ \\
\hline \hline $\mathbf{6}$ & 0,374 & 0,162 & 0,226 & $\mathbf{0 , 2 1 7}$ & 0,228 & 0,225 & $-0,015$ & 0,035 \\
\hline $\mathbf{7}$ & $-0,906$ & $-0,224$ & 0,101 & $\mathbf{- 0 , 1 1 8}$ & $-0,175$ & $-0,233$ & $-0,338$ & $-0,253$ \\
\hline $\mathbf{8}$ & $-1,555$ & $-0,399$ & 0,049 & $\mathbf{- 0 , 2 4 3}$ & $-0,377$ & $-0,455$ & $-0,492$ & $-0,384$ \\
\hline $\mathbf{9}$ & $-1,686$ & $-0,443$ & 0,021 & $\mathbf{- 0 , 2 6 6}$ & $-0,412$ & $-0,494$ & $-0,520$ & $-0,406$ \\
\hline $\mathbf{1 0}$ & $-1,708$ & $-0,458$ & 0,001 & $\mathbf{- 0 , 2 6 9}$ & $-0,418$ & $-0,499$ & $-0,522$ & $-0,408$ \\
\hline \hline $\mathbf{1 1}$ & 0,551 & 0,207 & 0,222 & $\mathbf{0 , 1 8 4}$ & 0,182 & 0,181 & 0,037 & 0,079 \\
\hline $\mathbf{1 2}$ & $-0,598$ & $-0,150$ & 0,087 & $\mathbf{- 0 , 0 8 9}$ & $-0,150$ & $-0,205$ & $-0,254$ & $-0,197$ \\
\hline $\mathbf{1 3}$ & $-1,260$ & $-0,340$ & 0,025 & $\mathbf{- 0 , 1 9 9}$ & $-0,302$ & $-0,375$ & $-0,410$ & $-0,320$ \\
\hline $\mathbf{1 4}$ & $-1,389$ & $-0,383$ & $-0,001$ & $\mathbf{- 0 , 2 1 8}$ & $-0,328$ & $-0,404$ & $-0,436$ & $-0,340$ \\
\hline $\mathbf{1 5}$ & $-1,411$ & $-0,398$ & $-0,022$ & $\mathbf{- 0 , 2 2 1}$ & $-0,334$ & $-0,409$ & $-0,438$ & $-0,342$ \\
\hline \hline $\mathbf{1 6}$ & 0,795 & 0,432 & 0,325 & $\mathbf{0 , 1 2 1}$ & 0,073 & 0,061 & 0,183 & 0,135 \\
\hline $\mathbf{1 7}$ & $-0,193$ & $-0,103$ & $-0,007$ & $\mathbf{- 0 , 0 6 6}$ & $-0,102$ & $-0,145$ & $-0,126$ & $-0,087$ \\
\hline $\mathbf{1 8}$ & $-0,625$ & $-0,242$ & $-0,069$ & $\mathbf{- 0 , 1 3 5}$ & $-0,187$ & $-0,252$ & $-0,257$ & $-0,195$ \\
\hline $\mathbf{1 9}$ & $-0,686$ & $-0,258$ & $-0,079$ & $\mathbf{- 0 , 1 4 3}$ & $-0,200$ & $-0,270$ & $-0,275$ & $-0,212$ \\
\hline $\mathbf{2 0}$ & $-0,707$ & $-0,274$ & $-0,098$ & $\mathbf{- 0 , 1 4 6}$ & $-0,206$ & $-0,275$ & $-0,276$ & $-0,213$ \\
\hline \hline $\mathbf{2 1}$ & 0,15 & 0,15 & 0,16 & $\mathbf{0 , 1 2}$ & 0,13 & 0,14 & 0,12 & 0,13 \\
\hline $\mathbf{2 2}$ & $-0,09$ & $-0,09$ & $-0,09$ & $\mathbf{- 0 , 0 8}$ & $-0,06$ & $-0,04$ & $-0,05$ & $-0,05$ \\
\hline $\mathbf{2 3}$ & $-0,15$ & $-0,20$ & $-0,22$ & $\mathbf{- 0 , 2 0}$ & $-0,03$ & $-0,03$ & $-0,11$ & $-0,10$ \\
\hline $\mathbf{2 4}$ & $-0,15$ & $-0,23$ & $-0,24$ & $\mathbf{- 0 , 2 2}$ & $-0,02$ & $-0,02$ & $-0,12$ & $-0,11$ \\
\hline $\mathbf{2 5}$ & $-0,14$ & $-0,22$ & $-0,23$ & $\mathbf{- 0 , 2 2}$ & 0,00 & 0,00 & $-0,12$ & $-0,11$ \\
\hline \hline
\end{tabular}


TABELA 5.141: Tensões Normais nas fibras superiores extremas das nervuras e vigas, em $\mathrm{kN} / \mathrm{cm}^{2}$, na laje com 11 nervuras por lado

LAJE COM RELAÇ̃̃O a1/l=0,0833

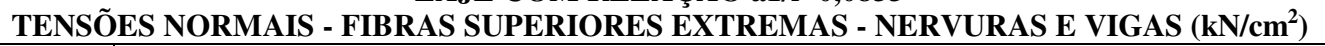

\begin{tabular}{c|c|c|c|c|c|c|c|c}
\hline \multirow{2}{*}{ Ponto } & \multicolumn{7}{|c}{ Modelos numéricos de análise } \\
\cline { 2 - 9 } & $\mathbf{0 1}$ & $\mathbf{0 2}$ & $\mathbf{0 3}$ & $\mathbf{0 4}$ & $\mathbf{0 5}$ & $\mathbf{0 6}$ & $\mathbf{0 7}$ & $\mathbf{0 8}$ \\
\hline $\mathbf{1}$ & 0,463 & 0,193 & 0,258 & $\mathbf{0 , 2 7 3}$ & 0,291 & 0,287 & $-0,016$ & 0,043 \\
\hline $\mathbf{2}$ & $-0,354$ & $-0,074$ & 0,157 & $\mathbf{0 , 0 2 3}$ & 0,049 & 0,003 & $-0,228$ & $-0,143$ \\
\hline $\mathbf{3}$ & $-0,984$ & $-0,246$ & 0,118 & $\mathbf{- 0 , 1 2 0}$ & $-0,163$ & $-0,228$ & $-0,381$ & $-0,279$ \\
\hline $\mathbf{4}$ & $-1,766$ & $-0,451$ & 0,066 & $\mathbf{- 0 , 2 7 4}$ & $-0,414$ & $-0,504$ & $-0,554$ & $-0,440$ \\
\hline $\mathbf{5}$ & $-1,960$ & $-0,509$ & 0,040 & $\mathbf{- 0 , 3 0 9}$ & $-0,470$ & $-0,565$ & $-0,612$ & $-0,475$ \\
\hline $\mathbf{6}$ & $-2,025$ & $-0,537$ & 0,012 & $\mathbf{- 0 , 3 2 0}$ & $-0,487$ & $-0,584$ & $-0,624$ & $-0,484$ \\
\hline \hline $\mathbf{7}$ & 0,569 & 0,212 & 0,249 & $\mathbf{0 , 2 4 3}$ & 0,258 & 0,255 & 0,013 & 0,071 \\
\hline $\mathbf{8}$ & $-0,172$ & $-0,032$ & 0,146 & $\mathbf{0 , 0 2 8}$ & 0,036 & $-0,007$ & $-0,173$ & $-0,107$ \\
\hline $\mathbf{9}$ & $-0,768$ & $-0,191$ & 0,111 & $\mathbf{- 0 , 1 0 1}$ & $-0,152$ & $-0,214$ & $-0,320$ & $-0,240$ \\
\hline $\mathbf{1 0}$ & $-1,561$ & $-0,407$ & 0,054 & $\mathbf{- 0 , 2 4 4}$ & $-0,366$ & $-0,452$ & $-0,508$ & $-0,395$ \\
\hline $\mathbf{1 1}$ & $-1,761$ & $-0,468$ & 0,026 & $\mathbf{- 0 , 2 7 6}$ & $-0,412$ & $-0,503$ & $-0,552$ & $-0,429$ \\
\hline $\mathbf{1 2}$ & $-1,828$ & $-0,497$ & $-0,002$ & $\mathbf{- 0 , 2 8 6}$ & $-0,426$ & $-0,518$ & $-0,564$ & $-0,438$ \\
\hline $\mathbf{1 3}$ & 0,926 & 0,415 & 0,336 & $\mathbf{0 , 1 9 6}$ & 0,155 & 0,152 & 0,162 & 0,162 \\
\hline $\mathbf{1 4}$ & 0,265 & 0,087 & 0,116 & $\mathbf{0 , 0 3 8}$ & $-0,002$ & $-0,041$ & $-0,034$ & $-0,027$ \\
\hline $\mathbf{1 5}$ & $-0,303$ & $-0,097$ & 0,061 & $\mathbf{- 0 , 0 6 8}$ & $-0,119$ & $-0,176$ & $-0,187$ & $-0,143$ \\
\hline $\mathbf{1 6}$ & $-1,016$ & $-0,313$ & $-0,011$ & $\mathbf{- 0 , 1 7 8}$ & $-0,251$ & $-0,331$ & $-0,365$ & $-0,280$ \\
\hline $\mathbf{1 7}$ & $-1,167$ & $-0,354$ & $-0,031$ & $\mathbf{- 0 , 1 8 9}$ & $-0,280$ & $-0,366$ & $-0,399$ & $-0,309$ \\
\hline $\mathbf{1 8}$ & $-1,213$ & $-0,371$ & $-0,048$ & $-\mathbf{0 , 1 9 6}$ & $-0,289$ & $-0,374$ & $-0,408$ & $-0,317$ \\
\hline $\mathbf{1 9}$ & 0,15 & 0,15 & 0,16 & $\mathbf{0 , 1 2}$ & 0,13 & 0,14 & 0,12 & 0,13 \\
\hline $\mathbf{2 0}$ & $-0,03$ & 0,00 & 0,00 & $\mathbf{0 , 0 1}$ & $-0,07$ & 0,00 & 0,01 & 0,00 \\
\hline $\mathbf{2 1}$ & $-0,10$ & $-0,10$ & $-0,10$ & $\mathbf{- 0 , 0 8}$ & $-0,07$ & $-0,05$ & $-0,05$ & $-0,05$ \\
\hline $\mathbf{2 2}$ & $-0,16$ & $-0,22$ & $-0,23$ & $\mathbf{- 0 , 2 1}$ & $-0,03$ & $-0,02$ & $-0,11$ & $-0,11$ \\
\hline $\mathbf{2 3}$ & $-0,16$ & $-0,25$ & $-0,26$ & $\mathbf{- 0 , 2 4}$ & $-0,02$ & $-0,01$ & $-0,13$ & $-0,12$ \\
\hline $\mathbf{2 4}$ & $-0,16$ & $-0,26$ & $-0,28$ & $\mathbf{- 0 , 2 6}$ & 0,00 & 0,00 & $-0,13$ & $-0,12$ \\
\hline \hline
\end{tabular}

TABELA 5.142: Tensões Normais nas fibras superiores extremas das nervuras e vigas, em $\mathrm{kN} / \mathrm{cm}^{2}$, na laje com 12 nervuras por lado

LAJE COM RELAÇÃO a1/l=0,0769

TENSÕES NORMAIS - FIBRAS SUPERIORES EXTREMAS - NERVURAS E VIGAS (kN/cm²)

\begin{tabular}{c|c|c|c|c|c|c|c|c}
\hline \multirow{2}{*}{ Ponto } & \multicolumn{7}{|c}{ Modelos numéricos de análise } \\
\cline { 2 - 9 } & $\mathbf{0 1}$ & $\mathbf{0 2}$ & $\mathbf{0 3}$ & $\mathbf{0 4}$ & $\mathbf{0 5}$ & $\mathbf{0 6}$ & $\mathbf{0 7}$ & $\mathbf{0 8}$ \\
\hline \hline $\mathbf{6}$ & 0,578 & 0,228 & 0,291 & $\mathbf{0 , 3 1 3}$ & 0,358 & 0,351 & $-0,014$ & 0,056 \\
\hline $\mathbf{7}$ & $-1,023$ & $-0,259$ & 0,135 & $\mathbf{- 0 , 1 1 3}$ & $-0,142$ & $-0,214$ & $-0,414$ & $-0,297$ \\
\hline $\mathbf{8}$ & $-1,942$ & $-0,497$ & 0,083 & $\mathbf{- 0 , 2 9 1}$ & $-0,439$ & $-0,539$ & $-0,634$ & $-0,487$ \\
\hline $\mathbf{9}$ & $-2,331$ & $-0,613$ & 0,029 & $\mathbf{- 0 , 3 5 9}$ & $-0,549$ & $-0,661$ & $-0,722$ & $-0,557$ \\
\hline $\mathbf{1 0}$ & $-2,353$ & $-0,628$ & 0,009 & $\mathbf{- 0 , 3 6 2}$ & $-0,555$ & $-0,666$ & $-0,724$ & $-0,559$ \\
\hline \hline $\mathbf{1 1}$ & 0,735 & 0,268 & 0,287 & $\mathbf{0 , 2 8 4}$ & 0,303 & 0,300 & 0,033 & 0,099 \\
\hline $\mathbf{1 2}$ & $-0,713$ & $-0,181$ & 0,124 & $\mathbf{- 0 , 0 8 9}$ & $-0,133$ & $-0,201$ & $-0,326$ & $-0,243$ \\
\hline $\mathbf{1 3}$ & $-1,636$ & $-0,431$ & 0,064 & $\mathbf{- 0 , 2 4 9}$ & $-0,374$ & $-0,470$ & $-0,548$ & $-0,424$ \\
\hline $\mathbf{1 4}$ & $-2,032$ & $-0,550$ & 0,008 & $\mathbf{- 0 , 3 0 9}$ & $-0,461$ & $-0,566$ & $-0,635$ & $-0,497$ \\
\hline $\mathbf{1 5}$ & $-2,054$ & $-0,566$ & $-0,012$ & $\mathbf{- 0 , 3 1 2}$ & $-0,467$ & $-0,571$ & $-0,637$ & $-0,491$ \\
\hline \hline $\mathbf{1 6}$ & 1,124 & 0,526 & 0,411 & $\mathbf{0 , 2 2 0}$ & 0,175 & 0,171 & 0,216 & 0,205 \\
\hline $\mathbf{1 7}$ & $-0,216$ & $-0,080$ & 0,064 & $\mathbf{- 0 , 0 6 0}$ & $-0,110$ & $-0,171$ & $-0,176$ & $-0,135$ \\
\hline $\mathbf{1 8}$ & $-1,033$ & $-0,330$ & $-0,015$ & $\mathbf{- 0 , 1 8 4}$ & $-0,257$ & $-0,344$ & $-0,386$ & $-0,293$ \\
\hline $\mathbf{1 9}$ & $-1,317$ & $-0,408$ & $-0,052$ & $\mathbf{- 0 , 2 2 6}$ & $-0,310$ & $-0,409$ & $-0,453$ & $-0,350$ \\
\hline $\mathbf{2 0}$ & $-1,338$ & $-0,424$ & $-0,074$ & $\mathbf{- 0 , 2 3 0}$ & $-0,316$ & $-0,414$ & $-0,454$ & $-0,351$ \\
\hline \hline $\mathbf{2 1}$ & 0,15 & 0,15 & 0,16 & $\mathbf{0 , 1 2}$ & 0,13 & 0,14 & 0,12 & 0,13 \\
\hline $\mathbf{2 2}$ & $-0,11$ & $-0,10$ & $-0,10$ & $-\mathbf{0 , 0 8}$ & $-0,09$ & $-0,05$ & $-0,05$ & $-0,05$ \\
\hline $\mathbf{2 3}$ & $-0,17$ & $-0,23$ & $-0,24$ & $\mathbf{- 0 , 2 2}$ & $-0,03$ & $-0,01$ & $-0,11$ & $-0,11$ \\
\hline $\mathbf{2 4}$ & $-0,17$ & $-0,29$ & $-0,30$ & $-\mathbf{0 , 2 8}$ & 0,00 & 0,02 & $-0,14$ & $-0,13$ \\
\hline $\mathbf{2 5}$ & $-0,16$ & $-0,28$ & $-0,30$ & $\mathbf{- 0 , 2 9}$ & 0,02 & 0,03 & $-0,14$ & $-0,13$ \\
\hline \hline
\end{tabular}


TABELA 5.143: Tensões Normais nas fibras superiores extremas das nervuras e vigas, em $\mathrm{kN} / \mathrm{cm}^{2}$, na laje com 13 nervuras por lado

LAJE COM RELAÇãO a1/l=0,0714

TENSÕES NORMAIS - FIBRAS SUPERIORES EXTREMAS - NERVURAS E VIGAS $\left(\mathrm{kN} / \mathrm{cm}^{2}\right)$

\begin{tabular}{c|c|c|c|c|c|c|c|c}
\hline \multirow{2}{*}{ Ponto } & \multicolumn{7}{|c}{ Modelos numéricos de análise } \\
\cline { 2 - 9 } & $\mathbf{0 1}$ & $\mathbf{0 2}$ & $\mathbf{0 3}$ & $\mathbf{0 4}$ & $\mathbf{0 5}$ & $\mathbf{0 6}$ & $\mathbf{0 7}$ & $\mathbf{0 8}$ \\
\hline \hline $\mathbf{1}$ & 0,694 & 0,265 & 0,326 & $\mathbf{0 , 3 6 2}$ & 0,437 & 0,428 & $-0,015$ & 0,028 \\
\hline $\mathbf{2}$ & $-1,076$ & $-0,278$ & 0,154 & $\mathbf{- 0 , 1 0 6}$ & $-0,114$ & $-0,194$ & $-0,458$ & $-0,400$ \\
\hline $\mathbf{3}$ & $-2,138$ & $-0,549$ & 0,100 & $\mathbf{- 0 , 3 0 0}$ & $-0,462$ & $-0,574$ & $-0,711$ & $-0,655$ \\
\hline $\mathbf{4}$ & $-2,654$ & $-0,692$ & 0,049 & $\mathbf{- 0 , 3 8 7}$ & $-0,614$ & $-0,741$ & $-0,830$ & $-0,776$ \\
\hline $\mathbf{5}$ & $-2,719$ & $-0,720$ & 0,021 & $\mathbf{- 0 , 3 9 8}$ & $-0,632$ & $-0,760$ & $-0,842$ & $-0,788$ \\
\hline \hline $\mathbf{6}$ & 0,788 & 0,285 & 0,320 & $\mathbf{0 , 3 4 1}$ & 0,398 & 0,392 & 0,012 & 0,075 \\
\hline $\mathbf{7}$ & $-0,868$ & $-0,224$ & 0,147 & $\mathbf{- 0 , 0 9 0}$ & $-0,113$ & $-0,189$ & $-0,395$ & $-0,340$ \\
\hline $\mathbf{8}$ & $-1,924$ & $-0,499$ & 0,090 & $\mathbf{- 0 , 2 7 3}$ & $-0,423$ & $-0,531$ & $-0,649$ & $-0,597$ \\
\hline $\mathbf{9}$ & $-2,453$ & $-0,649$ & 0,036 & $\mathbf{- 0 , 3 5 4}$ & $-0,555$ & $-0,677$ & $-0,768$ & $-0,718$ \\
\hline $\mathbf{1 0}$ & $-2,520$ & $-0,678$ & 0,008 & $\mathbf{- 0 , 3 6 4}$ & $-0,570$ & $-0,693$ & $-0,780$ & $-0,730$ \\
\hline \hline $\mathbf{1 1}$ & 1,333 & 0,649 & 0,493 & $\mathbf{0 , 2 4 3}$ & 0,195 & 0,190 & 0,276 & 0,309 \\
\hline $\mathbf{1 2}$ & $-0,116$ & $-0,058$ & 0,067 & $\mathbf{- 0 , 0 5 2}$ & $-0,100$ & $-0,164$ & $-0,160$ & $-0,121$ \\
\hline $\mathbf{1 3}$ & $-1,032$ & $-0,343$ & $-0,020$ & $\mathbf{- 0 , 1 8 7}$ & $-0,259$ & $-0,353$ & $-0,402$ & $-0,355$ \\
\hline $\mathbf{1 4}$ & $-1,400$ & $-0,442$ & $-0,060$ & $\mathbf{- 0 , 2 4 1}$ & $-0,327$ & $-0,438$ & $-0,493$ & $-0,454$ \\
\hline $\mathbf{1 5}$ & $-1,440$ & $-0,457$ & $-0,074$ & $\mathbf{- 0 , 2 4 7}$ & $-0,334$ & $-0,445$ & $-0,501$ & $-0,463$ \\
\hline \hline $\mathbf{1 6}$ & 0,14 & 0,15 & 0,15 & $\mathbf{0 , 1 2}$ & 0,12 & 0,14 & 0,12 & 0,14 \\
\hline $\mathbf{1 7}$ & $-0,12$ & $-0,10$ & $-0,10$ & $\mathbf{- 0 , 0 8}$ & $-0,10$ & $-0,06$ & $-0,04$ & $-0,05$ \\
\hline $\mathbf{1 8}$ & $-0,18$ & $-0,24$ & $-0,25$ & $\mathbf{- 0 , 2 2}$ & $-0,03$ & 0,00 & $-0,11$ & $-0,13$ \\
\hline $\mathbf{1 9}$ & $-0,19$ & $-0,31$ & $-0,33$ & $\mathbf{- 0 , 3 1}$ & 0,01 & 0,03 & $-0,15$ & $-0,17$ \\
\hline $\mathbf{2 0}$ & $-0,18$ & $-0,32$ & $-0,34$ & $-\mathbf{0 , 3 2}$ & 0,02 & 0,04 & $-0,15$ & $-0,18$ \\
\hline \hline
\end{tabular}

TABELA 5.144: Tensões Normais nas fibras superiores extremas das nervuras e vigas, em $\mathrm{kN} / \mathrm{cm}^{2}$, na laje com 14 nervuras por lado

\section{LAJE COM RELAÇÃO a1/l=0,0667}

TENSÕES NORMAIS - FIBRAS SUPERIORES EXTREMAS - NERVURAS E VIGAS $\left(\mathrm{kN} / \mathrm{cm}^{2}\right)$

\begin{tabular}{c|c|c|c|c|c|c|c|c}
\hline \multirow{2}{*}{ Ponto } & \multicolumn{7}{|c}{ Modelos numéricos de análise } \\
\cline { 2 - 9 } & $\mathbf{0 1}$ & $\mathbf{0 2}$ & $\mathbf{0 3}$ & $\mathbf{0 4}$ & $\mathbf{0 5}$ & $\mathbf{0 6}$ & $\mathbf{0 7}$ & $\mathbf{0 8}$ \\
\hline \hline $\mathbf{7}$ & 0,836 & 0,308 & 0,363 & $\mathbf{0 , 4 1 6}$ & 0,519 & 0,508 & $-0,012$ & 0,082 \\
\hline $\mathbf{8}$ & $-1,090$ & $-0,287$ & 0,172 & $\mathbf{- 0 , 0 9 8}$ & $-0,079$ & $-0,165$ & $-0,490$ & $-0,337$ \\
\hline $\mathbf{9}$ & $-2,296$ & $-0,593$ & 0,117 & $\mathbf{- 0 , 3 1 9}$ & $-0,474$ & $-0,597$ & $-0,778$ & $-0,587$ \\
\hline $\mathbf{1 0}$ & $-2,943$ & $-0,765$ & 0,067 & $\mathbf{- 0 , 4 2 9}$ & $-0,666$ & $-0,808$ & $-0,928$ & $-0,710$ \\
\hline $\mathbf{1 1}$ & $-3,073$ & $-0,808$ & 0,040 & $\mathbf{- 0 , 4 5 0}$ & $-0,702$ & $-0,846$ & $-0,955$ & $-0,731$ \\
\hline $\mathbf{1 2}$ & $-3,095$ & $-0,824$ & 0,019 & $\mathbf{- 0 , 4 5 3}$ & $-0,708$ & $-0,851$ & $-0,957$ & $-0,733$ \\
\hline \hline $\mathbf{1 3}$ & 0,975 & 0,345 & 0,361 & $\mathbf{0 , 3 6 8}$ & 0,456 & 0,450 & 0,031 & 0,124 \\
\hline $\mathbf{1 4}$ & $-0,793$ & $-0,210$ & 0,160 & $\mathbf{- 0 , 0 7 7}$ & $-0,084$ & $-0,164$ & $-0,401$ & $-0,282$ \\
\hline $\mathbf{1 5}$ & $-1,979$ & $-0,518$ & 0,102 & $\mathbf{- 0 , 2 8 1}$ & $-0,423$ & $-0,540$ & $-0,687$ & $-0,524$ \\
\hline $\mathbf{1 6}$ & $-2,640$ & $-0,700$ & 0,047 & $\mathbf{- 0 , 3 8 1}$ & $-0,583$ & $-0,717$ & $-0,839$ & $-0,642$ \\
\hline $\mathbf{1 7}$ & $-2,771$ & $-0,744$ & 0,020 & $\mathbf{- 0 , 3 9 9}$ & $-0,612$ & $-0,749$ & $-0,866$ & $-0,662$ \\
\hline $\mathbf{1 8}$ & $-2,793$ & $-0,759$ & 0,000 & $\mathbf{- 0 , 4 0 3}$ & $-0,618$ & $-0,753$ & $-0,868$ & $-0,664$ \\
\hline \hline $\mathbf{1 9}$ & 1,550 & 0,781 & 0,582 & $\mathbf{0 , 2 9 0}$ & 0,214 & 0,209 & 0,342 & 0,302 \\
\hline $\mathbf{2 0}$ & $-0,004$ & $-0,033$ & 0,069 & $\mathbf{- 0 , 0 4 2}$ & $-0,089$ & $-0,155$ & $-0,140$ & $-0,109$ \\
\hline $\mathbf{2 1}$ & $-1,016$ & $-0,353$ & $-0,026$ & $\mathbf{- 0 , 1 8 8}$ & $-0,259$ & $-0,359$ & $-0,414$ & $-0,307$ \\
\hline $\mathbf{2 2}$ & $-1,466$ & $-0,475$ & $-0,070$ & $\mathbf{- 0 , 2 5 4}$ & $-0,341$ & $-0,462$ & $-0,529$ & $-0,401$ \\
\hline $\mathbf{2 3}$ & $-1,542$ & $-0,496$ & $-0,083$ & $\mathbf{- 0 , 2 6 5}$ & $-0,355$ & $-0,480$ & $-0,546$ & $-0,417$ \\
\hline $\mathbf{2 4}$ & $-1,563$ & $-0,513$ & $-0,105$ & $\mathbf{- 0 , 2 6 9}$ & $-0,361$ & $-0,484$ & $-0,548$ & $-0,418$ \\
\hline \hline $\mathbf{2 5}$ & 0,14 & 0,15 & 0,15 & $\mathbf{0 , 1 2}$ & 0,12 & 0,14 & 0,12 & 0,13 \\
\hline $\mathbf{2 6}$ & $-0,13$ & $-0,11$ & $-0,11$ & $\mathbf{- 0 , 0 8}$ & $-0,12$ & $-0,07$ & $-0,04$ & $-0,05$ \\
\hline $\mathbf{2 7}$ & $-0,19$ & $-0,24$ & $-0,26$ & $\mathbf{- 0 , 2 3}$ & $-0,04$ & 0,00 & $-0,12$ & $-0,11$ \\
\hline $\mathbf{2 8}$ & $-0,20$ & $-0,33$ & $-0,35$ & $\mathbf{- 0 , 3 3}$ & 0,01 & 0,05 & $-0,16$ & $-0,15$ \\
\hline $\mathbf{2 9}$ & $-0,20$ & $-0,35$ & $-0,37$ & $\mathbf{- 0 , 3 5}$ & 0,03 & 0,06 & $-0,16$ & $-0,15$ \\
\hline $\mathbf{3 0}$ & $-0,18$ & $-0,34$ & $-0,36$ & $\mathbf{- 0 , 3 5}$ & 0,05 & 0,08 & $-0,17$ & $-0,15$ \\
\hline \hline
\end{tabular}


TABELA 5.145: Tensões Normais nas fibras superiores extremas das nervuras e vigas, em $\mathrm{kN} / \mathrm{cm}^{2}$, na laje com 15 nervuras por lado

\section{LAJE COM RELAÇÃO a1/l=0,0625}

TENSÕES NORMAIS - FIBRAS SUPERIORES EXTREMAS - NERVURAS E VIGAS $\left(\mathrm{kN} / \mathrm{cm}^{2}\right)$

\begin{tabular}{|c|c|c|c|c|c|c|c|c|}
\hline \multirow{2}{*}{ Ponto } & \multicolumn{8}{|c|}{ Modelos numéricos de análise } \\
\hline & 01 & $\mathbf{0 2}$ & 03 & 04 & 05 & 06 & 07 & 08 \\
\hline 1 & 0,982 & 0,357 & 0,403 & 0,455 & 0,614 & 0,600 & $-0,013$ & 0,094 \\
\hline 2 & $-1,116$ & $-0,301$ & 0,192 & $-0,090$ & $-0,035$ & $-0,128$ & $-0,533$ & $-0,358$ \\
\hline 3 & $-2,473$ & $-0,643$ & 0,135 & $-0,340$ & $-0,483$ & $-0,616$ & $-0,855$ & $-0,639$ \\
\hline 4 & $-3,248$ & $-0,843$ & 0,086 & $-0,474$ & $-0,720$ & $-0,876$ & $-1,037$ & $-0,789$ \\
\hline 5 & $-3,443$ & $-0,900$ & 0,060 & $-0,505$ & $-0,775$ & $-0,936$ & $-1,080$ & $-0,823$ \\
\hline 6 & $-3,508$ & $-0,929$ & 0,033 & $-0,516$ & $-0,792$ & $-0,955$ & $-1,091$ & $-0,832$ \\
\hline 7 & 1,065 & 0,372 & $0,0,399$ & 0,434 & 0,569 & 0,559 & 0,013 & 0,122 \\
\hline 8 & $-0,922$ & $-0,251$ & 0,184 & $-0,077$ & $-0,042$ & $-0,132$ & $-0,471$ & $-0,320$ \\
\hline 9 & $-2,255$ & $-0,589$ & 0,127 & $-0,313$ & $-0,454$ & $-0,583$ & $-0,790$ & $-0,596$ \\
\hline 10 & $-3,043$ & $-0,798$ & 0,075 & $-0,440$ & $-0,666$ & $-0,817$ & $-0,974$ & $-0,742$ \\
\hline 11 & $-3,241$ & $-0,857$ & 0,048 & $-0,470$ & $-0,715$ & $-0,870$ & $-1,017$ & $-0,775$ \\
\hline 12 & $-3,307$ & $-0,886$ & 0,020 & $-0,479$ & $-0,730$ & $-0,887$ & $-1,029$ & $-0,784$ \\
\hline 13 & 1,372 & 0,518 & 0,453 & 0,383 & 0,438 & 0,435 & 0,138 & 0,220 \\
\hline 14 & $-0,400$ & $-0,114$ & 0,156 & $-0,042$ & $-0,062$ & $-0,141$ & $-0,309$ & $-0,223$ \\
\hline 15 & $-1,691$ & $-0,466$ & 0,086 & $-0,250$ & $-0,370$ & $-0,487$ & $-0,631$ & $-0,481$ \\
\hline 16 & $-2,450$ & $-0,676$ & 0,029 & $-0,356$ & $-0,523$ & $-0,662$ & $-0,809$ & $-0,615$ \\
\hline 17 & $-2,632$ & $-0,729$ & 0,004 & $-0,380$ & $-0,557$ & $-0,701$ & $-0,848$ & $-0,646$ \\
\hline 18 & $-2,692$ & $-0,754$ & $-0,020$ & $-0,388$ & $-0,568$ & $-0,712$ & $-0,859$ & $-0,654$ \\
\hline 19 & 1,773 & 0,922 & 0,677 & 0,306 & 0,233 & 0,227 & 0,413 & 0,355 \\
\hline 20 & 0,118 & $-0,005$ & 0,071 & $-0,030$ & $-0,077$ & $-0,146$ & $-0,114$ & $-0,091$ \\
\hline 21 & $-0,986$ & $-0,359$ & $-0,031$ & $-0,195$ & $-0,258$ & $-0,362$ & $-0,420$ & $-0,309$ \\
\hline 22 & $-1,516$ & $-0,506$ & $-0,081$ & $-0,265$ & $-0,352$ & $-0,482$ & $-0,560$ & $-0,421$ \\
\hline 23 & $-1,626$ & $-0,534$ & $-0,095$ & $-0,281$ & $-0,373$ & $-0,509$ & $-0,588$ & $-0,445$ \\
\hline 24 & $-1,660$ & $-0,546$ & $-0,107$ & $-0,286$ & $-0,378$ & $-0,515$ & $-0,595$ & $-0,451$ \\
\hline 25 & 0,14 & 0,15 & 0,15 & 0,12 & 0,12 & 0,14 & 0,12 & 0,13 \\
\hline 26 & $-0,14$ & $-0,11$ & $-0,11$ & $-0,08$ & $-0,13$ & $-0,08$ & $-0,04$ & $-0,05$ \\
\hline 27 & $-0,20$ & $-0,25$ & $-0,27$ & $-0,24$ & $-0,04$ & 0,01 & $-0,12$ & $-0,11$ \\
\hline 28 & $-0,21$ & $-0,35$ & $-0,37$ & $-0,34$ & 0,01 & 0,06 & $-0,16$ & $-0,15$ \\
\hline 29 & $-0,21$ & $-0,37$ & $-0,40$ & $-0,37$ & 0,03 & 0,08 & $-0,17$ & $-0,16$ \\
\hline 30 & $-0,20$ & $-0,38$ & $-0,41$ & $-0,38$ & 0,05 & 0,09 & $-0,18$ & $-0,16$ \\
\hline
\end{tabular}




\subsubsection{Tensões Normais nas fibras inferiores extremas das nervuras e vigas}

TABELA 5.146: Tensões Normais nas fibras inferiores extremas das nervuras e vigas, em $\mathrm{kN} / \mathrm{cm}^{2}$, na laje com 05 nervuras por lado

\begin{tabular}{|c|c|c|c|c|c|c|c|c|}
\hline \multicolumn{9}{|c|}{$\begin{array}{c}\text { LAJE COM RELAÇÃO a1/l=0,1667 } \\
\text { TENSÕES NORMAIS - FIBRAS INFERIORES EXTREMAS - NERVURAS E VIGAS }\left(\mathrm{kN} / \mathrm{cm}^{2}\right)\end{array}$} \\
\hline \multirow{2}{*}{ Ponto } & \multicolumn{8}{|c|}{ Modelos numéricos de análise } \\
\hline & 01 & 02 & 03 & 04 & 05 & 06 & 07 & 08 \\
\hline 1 & $-0,078$ & $-0,023$ & $-0,057$ & $-0,100$ & $-0,138$ & $-0,156$ & 0,031 & $-0,013$ \\
\hline 2 & 0,266 & 0,250 & 0,233 & 0,128 & 0,153 & 0,153 & 0,248 & 0,162 \\
\hline 3 & 0,454 & 0,398 & 0,394 & 0,278 & 0,309 & 0,319 & 0,366 & 0,256 \\
\hline 4 & 0,518 & 0,450 & 0,457 & 0,326 & 0,357 & 0,371 & 0,399 & 0,281 \\
\hline$\overline{5}$ & $-0,121$ & $-0,041$ & $-0,075$ & $-0,106$ & $-0,129$ & $-0,145$ & 0,002 & $-0,042$ \\
\hline 6 & 0,205 & 0,206 & 0,189 & 0,107 & 0,136 & 0,136 & 0,201 & 0,130 \\
\hline 7 & 0,400 & 0,356 & 0,351 & 0,250 & 0,271 & 0,278 & 0,319 & 0,220 \\
\hline 8 & 0,467 & 0,408 & 0,413 & 0,296 & 0,312 & 0,322 & 0,351 & 0,242 \\
\hline 9 & $-0,259$ & $-0,159$ & $-0,196$ & $-0,142$ & $-0,098$ & $-0,103$ & $-0,134$ & $-0,133$ \\
\hline 10 & 0,068 & 0,093 & 0,074 & 0,043 & 0,080 & 0,077 & 0,093 & 0,060 \\
\hline 11 & 0,249 & 0,235 & 0,227 & 0,164 & 0,162 & 0,158 & 0,197 & 0,123 \\
\hline 12 & 0,299 & 0,273 & 0,275 & 0,200 & 0,190 & 0,189 & 0,219 & 0,136 \\
\hline 13 & $-0,107$ & $-0,120$ & $-0,122$ & $-0,092$ & $-0,095$ & $-0,103$ & $-0,098$ & $-0,107$ \\
\hline 14 & 0,070 & 0,046 & 0,043 & 0,029 & 0,095 & 0,080 & 0,049 & 0,058 \\
\hline 15 & 0,142 & 0,128 & 0,127 & 0,115 & 0,153 & 0,153 & 0,121 & 0,138 \\
\hline 16 & 0,155 & 0,152 & 0,153 & 0,144 & 0,154 & 0,161 & 0,142 & 0,160 \\
\hline
\end{tabular}

TABELA 5.147: Tensões Normais nas fibras inferiores extremas das nervuras e vigas, em $\mathrm{kN} / \mathrm{cm}^{2}$, na laje com 06 nervuras por lado

\section{LAJE COM RELAÇ̃̃O a1/l=0,1429}

TENSÕES NORMAIS - FIBRAS INFERIORES EXTREMAS - NERVURAS E VIGAS (kN/cm²)

\begin{tabular}{c|c|c|c|c|c|c|c|c}
\hline \multirow{2}{*}{ Ponto } & \multicolumn{7}{|c}{ Modelos numéricos de análise } \\
\cline { 2 - 9 } & $\mathbf{0 1}$ & $\mathbf{0 2}$ & $\mathbf{0 3}$ & $\mathbf{0 4}$ & $\mathbf{0 5}$ & $\mathbf{0 6}$ & $\mathbf{0 7}$ & $\mathbf{0 8}$ \\
\hline \hline $\mathbf{6}$ & $-0,130$ & $-0,042$ & $-0,083$ & $\mathbf{- 0 , 1 5 7}$ & $-0,219$ & $-0,239$ & 0,027 & $-0,033$ \\
\hline $\mathbf{7}$ & 0,286 & 0,285 & 0,263 & $\mathbf{0 , 1 2 4}$ & 0,138 & 0,138 & 0,286 & 0,307 \\
\hline $\mathbf{8}$ & 0,540 & 0,482 & 0,474 & $\mathbf{0 , 3 2 8}$ & 0,348 & 0,362 & 0,446 & 0,307 \\
\hline $\mathbf{9}$ & 0,668 & 0,582 & 0,586 & $\mathbf{0 , 4 2 3}$ & 0,442 & 0,464 & 0,521 & 0,363 \\
\hline $\mathbf{1 0}$ & 0,690 & 0,601 & 0,613 & $\mathbf{0 , 4 3 7}$ & 0,459 & 0,477 & 0,526 & 0,367 \\
\hline \hline $\mathbf{1 1}$ & $-0,380$ & $-0,262$ & $-0,312$ & $\mathbf{- 0 , 1 9 9}$ & $-0,130$ & $-0,130$ & $-0,219$ & $-0,200$ \\
\hline $\mathbf{1 2}$ & 0,011 & 0,050 & 0,026 & $\mathbf{0 , 0 1 1}$ & 0,061 & 0,059 & 0,064 & 0,040 \\
\hline $\mathbf{1 3}$ & 0,245 & 0,242 & 0,230 & $\mathbf{0 , 1 5 9}$ & 0,153 & 0,147 & 0,204 & 0,123 \\
\hline $\mathbf{1 4}$ & 0,338 & 0,313 & 0,311 & $\mathbf{0 , 2 2 1}$ & 0,196 & 0,191 & 0,250 & 0,151 \\
\hline $\mathbf{1 5}$ & 0,359 & 0,331 & 0,336 & $\mathbf{0 , 2 3 2}$ & 0,212 & 0,204 & 0,253 & 0,152 \\
\hline \hline $\mathbf{1 6}$ & $-0,11$ & $-0,12$ & $-0,12$ & $\mathbf{- 0 , 1 0}$ & $-0,09$ & $-0,10$ & $-0,10$ & $-0,11$ \\
\hline $\mathbf{1 7}$ & 0,08 & 0,05 & 0,04 & $\mathbf{0 , 0 3}$ & 0,11 & 0,09 & 0,05 & 0,06 \\
\hline $\mathbf{1 8}$ & 0,16 & 0,14 & 0,14 & $\mathbf{0 , 1 3}$ & 0,18 & 0,18 & 0,13 & 0,15 \\
\hline $\mathbf{1 9}$ & 0,19 & 0,19 & 0,19 & $\mathbf{0 , 1 8}$ & 0,20 & 0,20 & 0,17 & 0,20 \\
\hline $\mathbf{2 0}$ & 0,18 & 0,18 & 0,18 & $\mathbf{0 , 1 8}$ & 0,18 & 0,18 & 0,18 & 0,20 \\
\hline \hline
\end{tabular}


TABELA 5.148: Tensões Normais nas fibras inferiores extremas das nervuras e vigas, em $\mathrm{kN} / \mathrm{cm}^{2}$, na laje com 07 nervuras por lado

LAJE COM RELAÇãO a1/l=0,1250

TENSÕES NORMAIS - FIBRAS INFERIORES EXTREMAS - NERVURAS E VIGAS $\left(\mathbf{k N} / \mathrm{cm}^{2}\right)$

\begin{tabular}{c|c|c|c|c|c|c|c|c}
\hline \multirow{2}{*}{ Ponto } & \multicolumn{8}{c}{ Modelos numéricos de análise } \\
\cline { 2 - 9 } & $\mathbf{0 1}$ & $\mathbf{0 2}$ & $\mathbf{0 3}$ & $\mathbf{0 4}$ & $\mathbf{0 5}$ & $\mathbf{0 6}$ & $\mathbf{0 7}$ & $\mathbf{0 8}$ \\
\hline \hline $\mathbf{1}$ & $-0,174$ & $-0,061$ & $-0,108$ & $\mathbf{- 0 , 2 3 0}$ & $-0,326$ & $-0,348$ & 0,035 & $-0,042$ \\
\hline $\mathbf{2}$ & 0,330 & 0,340 & 0,314 & $\mathbf{0 , 1 2 3}$ & 0,111 & 0,111 & 0,352 & 0,214 \\
\hline $\mathbf{3}$ & 0,650 & 0,589 & 0,578 & $\mathbf{0 , 3 8 4}$ & 0,387 & 0,407 & 0,557 & 0,379 \\
\hline $\mathbf{4}$ & 0,838 & 0,735 & 0,736 & $\mathbf{0 , 5 3 0}$ & 0,538 & 0,570 & 0,673 & 0,468 \\
\hline $\mathbf{5}$ & 0,902 & 0,786 & 0,798 & $\mathbf{0 , 5 7 7}$ & 0,586 & 0,622 & 0,705 & 0,492 \\
\hline $\mathbf{6}$ & $-0,343$ & $-0,165$ & $-0,218$ & $\mathbf{- 0 , 2 2 7}$ & $-0,257$ & $-0,272$ & $-0,097$ & $-0,154$ \\
\hline $\mathbf{7}$ & 0,108 & 0,160 & 0,134 & $\mathbf{0 , 0 5 2}$ & 0,082 & 0,084 & 0,182 & 0,105 \\
\hline $\mathbf{8}$ & 0,433 & 0,411 & 0,397 & $\mathbf{0 , 2 7 4}$ & 0,275 & 0,283 & 0,382 & 0,254 \\
\hline $\mathbf{9}$ & 0,626 & 0,560 & 0,556 & $\mathbf{0 , 3 9 5}$ & 0,375 & 0,386 & 0,491 & 0,327 \\
\hline $\mathbf{1 0}$ & 0,688 & 0,607 & 0,614 & $\mathbf{0 , 4 3 3}$ & 0,407 & 0,420 & 0,519 & 0,345 \\
\hline \hline $\mathbf{1 1}$ & $-0,511$ & $-0,384$ & $-0,448$ & $\mathbf{- 0 , 2 6 7}$ & $-0,160$ & $-0,153$ & $-0,318$ & $-0,276$ \\
\hline $\mathbf{1 2}$ & $-0,060$ & $-0,007$ & $-0,036$ & $\mathbf{- 0 , 0 3 0}$ & 0,040 & 0,039 & 0,023 & 0,012 \\
\hline $\mathbf{1 3}$ & 0,224 & 0,234 & 0,238 & $\mathbf{0 , 1 4 1}$ & 0,139 & 0,130 & 0,199 & 0,115 \\
\hline $\mathbf{1 4}$ & 0,358 & 0,338 & 0,333 & $\mathbf{0 , 2 2 4}$ & 0,192 & 0,181 & 0,269 & 0,157 \\
\hline $\mathbf{1 5}$ & 0,394 & 0,364 & 0,366 & $\mathbf{0 , 2 5 2}$ & 0,212 & 0,203 & 0,284 & 0,166 \\
\hline \hline $\mathbf{1 6}$ & $-0,10$ & $-0,12$ & $-0,12$ & $\mathbf{- 0 , 0 9}$ & $-0,08$ & $-0,09$ & $-0,10$ & $-0,10$ \\
\hline $\mathbf{1 7}$ & 0,09 & 0,05 & 0,05 & $\mathbf{0 , 0 3}$ & 0,13 & 0,10 & 0,06 & 0,07 \\
\hline $\mathbf{1 8}$ & 0,18 & 0,15 & 0,15 & $\mathbf{0 , 1 4}$ & 0,21 & 0,20 & 0,15 & 0,17 \\
\hline $\mathbf{1 9}$ & 0,23 & 0,21 & 0,21 & $\mathbf{0 , 2 0}$ & 0,23 & 0,23 & 0,20 & 0,22 \\
\hline $\mathbf{2 0}$ & 0,23 & 0,23 & 0,23 & $\mathbf{0 , 2 2}$ & 0,22 & 0,23 & 0,22 & 0,24 \\
\hline \hline
\end{tabular}

TABELA 5.149: Tensões Normais nas fibras inferiores extremas das nervuras e vigas, em $\mathrm{kN} / \mathrm{cm}^{2}$, na laje com 08 nervuras por lado

\section{LAJE COM RELAÇ̃̃O a1/l=0,1111}

TENSÕES NORMAIS - FIBRAS INFERIORES EXTREMAS - NERVURAS E VIGAS $\left(\mathbf{k N} / \mathrm{cm}^{2}\right)$

\begin{tabular}{c|c|c|c|c|c|c|c|c}
\hline \multirow{2}{*}{ Ponto } & \multicolumn{8}{c}{ Modelos numéricos de análise } \\
\cline { 2 - 9 } & $\mathbf{0 1}$ & $\mathbf{0 2}$ & $\mathbf{0 3}$ & $\mathbf{0 4}$ & $\mathbf{0 5}$ & $\mathbf{0 6}$ & $\mathbf{0 7}$ & $\mathbf{0 8}$ \\
\hline \hline $\mathbf{7}$ & $-0,247$ & $-0,089$ & $-0,142$ & $\mathbf{- 0 , 3 0 8}$ & $-0,445$ & $-0,468$ & 0,031 & $-0,068$ \\
\hline $\mathbf{8}$ & 0,334 & 0,369 & 0,340 & $\mathbf{0 , 0 9 9}$ & 0,060 & 0,062 & 0,390 & 0,227 \\
\hline $\mathbf{9}$ & 0,723 & 0,671 & 0,656 & $\mathbf{0 , 4 1 7}$ & 0,396 & 0,420 & 0,638 & 0,428 \\
\hline $\mathbf{1 0}$ & 0,975 & 0,865 & 0,863 & $\mathbf{0 , 6 1 3}$ & 0,599 & 0,639 & 0,796 & 0,550 \\
\hline $\mathbf{1 1}$ & 1,103 & 0,965 & 0,975 & $\mathbf{0 , 7 0 7}$ & 0,694 & 0,741 & 0,870 & 0,604 \\
\hline $\mathbf{1 2}$ & 1,125 & 0,984 & 1,001 & $\mathbf{0 , 7 2 0}$ & 0,710 & 0,754 & 0,875 & 0,607 \\
\hline \hline $\mathbf{1 3}$ & $-0,494$ & $-0,268$ & $-0,336$ & $\mathbf{- 0 , 3 0 4}$ & $-0,322$ & $-0,335$ & $-0,182$ & $-0,237$ \\
\hline $\mathbf{1 4}$ & 0,022 & 0,105 & 0,074 & $\mathbf{0 , 0 0 6}$ & 0,043 & 0,047 & 0,145 & 0,075 \\
\hline $\mathbf{1 5}$ & 0,409 & 0,406 & 0,387 & $\mathbf{0 , 2 5 7}$ & 0,257 & 0,266 & 0,388 & 0,254 \\
\hline $\mathbf{1 6}$ & 0,661 & 0,603 & 0,595 & $\mathbf{0 , 4 1 5}$ & 0,378 & 0,388 & 0,534 & 0,350 \\
\hline $\mathbf{1 7}$ & 0,779 & 0,692 & 0,695 & $\mathbf{0 , 4 8 5}$ & 0,434 & 0,446 & 0,595 & 0,390 \\
\hline $\mathbf{1 8}$ & 0,800 & 0,524 & 0,722 & $\mathbf{0 , 4 9 7}$ & 0,450 & 0,459 & 0,599 & 0,393 \\
\hline $\mathbf{1 9}$ & $-0,649$ & $-0,519$ & $-0,597$ & $\mathbf{- 0 , 3 3 5}$ & $-0,188$ & $-0,175$ & $-0,428$ & $-0,358$ \\
\hline $\mathbf{2 0}$ & $-0,143$ & $-0,076$ & $-0,109$ & $\mathbf{- 0 , 0 7 9}$ & 0,019 & 0,020 & $-0,030$ & $-0,023$ \\
\hline $\mathbf{2 1}$ & 0,189 & 0,212 & 0,191 & $\mathbf{0 , 1 1 6}$ & 0,122 & 0,111 & 0,182 & 0,100 \\
\hline $\mathbf{2 2}$ & 0,362 & 0,351 & 0,343 & $\mathbf{0 , 2 1 8}$ & 0,180 & 0,166 & 0,279 & 0,157 \\
\hline $\mathbf{2 3}$ & 0,428 & 0,398 & 0,398 & $\mathbf{0 , 2 6 3}$ & 0,210 & 0,196 & 0,310 & 0,177 \\
\hline $\mathbf{2 4}$ & 0,449 & 0,416 & 0,423 & $\mathbf{0 , 2 7 2}$ & 0,226 & 0,209 & 0,312 & 0,178 \\
\hline \hline $\mathbf{2 5}$ & $-0,09$ & $-0,12$ & $-0,12$ & $\mathbf{- 0 , 0 9}$ & $-0,07$ & $-0,07$ & $-0,09$ & $-0,10$ \\
\hline $\mathbf{2 6}$ & 0,11 & 0,06 & 0,05 & $\mathbf{0 , 0 4}$ & 0,16 & 0,12 & 0,06 & 0,07 \\
\hline $\mathbf{2 7}$ & 0,21 & 0,17 & 0,16 & $\mathbf{0 , 1 5}$ & 0,23 & 0,22 & 0,16 & 0,18 \\
\hline $\mathbf{2 8}$ & 0,26 & 0,24 & 0,24 & $\mathbf{0 , 2 2}$ & 0,27 & 0,26 & 0,22 & 0,25 \\
\hline $\mathbf{2 9}$ & 0,27 & 0,27 & 0,27 & $\mathbf{0 , 2 7}$ & 0,27 & 0,27 & 0,25 & 0,28 \\
\hline $\mathbf{3 0}$ & 0,26 & 0,27 & 0,27 & $\mathbf{0 , 2 7}$ & 0,25 & 0,25 & 0,25 & 0,28 \\
\hline \hline
\end{tabular}


TABELA 5.150: Tensões Normais nas fibras inferiores extremas das nervuras e vigas, em $\mathrm{kN} / \mathrm{cm}^{2}$, na laje com 09 nervuras por lado

\begin{tabular}{c|c|c|c|c|c|c|c|c}
\hline \hline \multirow{2}{*}{ TENSÕES NORMAIS - FIBRAS INFERIORES EXTREMAS - NERVURAS E VIGAS $\left(\mathbf{k N} / \mathbf{c m}^{\mathbf{2}}\right)$} \\
\hline \multirow{2}{*}{ Ponto } & \multicolumn{7}{c}{ Modelos numéricos de análise } \\
\cline { 2 - 10 } & $\mathbf{0 1}$ & $\mathbf{0 2}$ & $\mathbf{0 3}$ & $\mathbf{0 4}$ & $\mathbf{0 5}$ & $\mathbf{0 6}$ & $\mathbf{0 7}$ & $\mathbf{0 8}$ \\
\hline \hline $\mathbf{1}$ & $-0,314$ & $-0,116$ & $-0,176$ & $\mathbf{- 0 , 4 0 0}$ & $-0,595$ & $-0,617$ & 0,037 & $-0,082$ \\
\hline $\mathbf{2}$ & 0,357 & 0,416 & 0,383 & $\mathbf{0 , 0 6 7}$ & $-0,008$ & $-0,004$ & 0,455 & 0,256 \\
\hline $\mathbf{3}$ & 0,820 & 0,776 & 0,759 & $\mathbf{0 , 4 5 6}$ & 0,398 & 0,428 & 0,751 & 0,496 \\
\hline $\mathbf{4}$ & 1,134 & 1,018 & 1,014 & $\mathbf{0 , 7 0 6}$ & 0,664 & 0,714 & 0,951 & 0,653 \\
\hline $\mathbf{5}$ & 1,324 & 1,164 & 1,172 & $\mathbf{0 , 8 4 9}$ & 0,812 & 0,874 & 1,066 & 0,740 \\
\hline $\mathbf{6}$ & 1,388 & 1,215 & 1,234 & $\mathbf{0 , 8 9 6}$ & 0,860 & 0,926 & 1,097 & 0,763 \\
\hline \hline $\mathbf{7}$ & $-0,460$ & $-0,198$ & $-0,264$ & $\mathbf{- 0 , 3 8 3}$ & $-0,504$ & $-0,525$ & $-0,071$ & $-0,185$ \\
\hline $\mathbf{8}$ & 0,142 & 0,244 & 0,210 & $\mathbf{0 , 0 1 9}$ & $-0,004$ & 0,001 & 0,286 & 0,145 \\
\hline $\mathbf{9}$ & 0,590 & 0,582 & 0,563 & $\mathbf{0 , 3 5 4}$ & 0,325 & 0,348 & 0,569 & 0,375 \\
\hline $\mathbf{1 0}$ & 0,915 & 0,833 & 0,826 & $\mathbf{0 , 5 7 5}$ & 0,530 & 0,563 & 0,767 & 0,519 \\
\hline $\mathbf{1 1}$ & 1,111 & 0,984 & 0,988 & $\mathbf{0 , 7 0 0}$ & 0,642 & 0,680 & 0,878 & 0,594 \\
\hline $\mathbf{1 2}$ & 1,176 & 1,036 & 1,050 & $\mathbf{0 , 7 4 0}$ & 0,678 & 0,719 & 0,908 & 0,614 \\
\hline \hline $\mathbf{1 3}$ & $-0,791$ & $-0,663$ & $-0,755$ & $\mathbf{- 0 , 4 0 7}$ & $-0,213$ & $-0,194$ & $-0,548$ & $-0,446$ \\
\hline $\mathbf{1 4}$ & $-0,233$ & $-0,155$ & $-0,192$ & $-\mathbf{0 , 1 2 8}$ & $-0,002$ & 0,001 & $-0,093$ & $-0,065$ \\
\hline $\mathbf{1 5}$ & 0,140 & 0,178 & 0,152 & $\mathbf{0 , 0 8 5}$ & 0,103 & 0,091 & 0,155 & 0,078 \\
\hline $\mathbf{1 6}$ & 0,352 & 0,353 & 0,342 & $\mathbf{0 , 2 0 5}$ & 0,165 & 0,147 & 0,280 & 0,151 \\
\hline $\mathbf{1 7}$ & 0,447 & 0,422 & 0,420 & $\mathbf{0 , 2 6 3}$ & 0,201 & 0,182 & 0,327 & 0,182 \\
\hline $\mathbf{1 8}$ & 0,474 & 0,439 & 0,443 & $\mathbf{0 , 2 7 9}$ & 0,216 & 0,198 & 0,337 & 0,189 \\
\hline \hline $\mathbf{1 9}$ & $-0,08$ & $-0,11$ & $-0,11$ & $-\mathbf{0 , 0 9}$ & $-0,05$ & $-0,06$ & $-0,09$ & $-0,09$ \\
\hline $\mathbf{2 0}$ & 0,12 & 0,07 & 0,06 & $\mathbf{0 , 0 4}$ & 0,18 & 0,13 & 0,07 & 0,08 \\
\hline $\mathbf{2 1}$ & 0,23 & 0,18 & 0,18 & $\mathbf{0 , 1 6}$ & 0,26 & 0,24 & 0,17 & 0,19 \\
\hline $\mathbf{2 2}$ & 0,29 & 0,26 & 0,26 & $\mathbf{0 , 2 5}$ & 0,30 & 0,28 & 0,24 & 0,27 \\
\hline $\mathbf{2 3}$ & 0,31 & 0,31 & 0,31 & $\mathbf{0 , 3 0}$ & 0,31 & 0,30 & 0,28 & 0,31 \\
\hline $\mathbf{2 4}$ & 0,31 & 0,32 & 0,32 & $\mathbf{0 , 3 2}$ & 0,29 & 0,29 & 0,29 & 0,33 \\
\hline \hline
\end{tabular}

TABELA 5.151: Tensões Normais nas fibras inferiores extremas das nervuras e vigas, em $\mathrm{kN} / \mathrm{cm}^{2}$, na laje com 10 nervuras por lado

LAJE COM RELAÇãO a1/l=0,0910

TENSÕES NORMAIS - FIBRAS INFERIORES EXTREMAS - NERVURAS E VIGAS $\left(\mathrm{kN} / \mathrm{cm}^{2}\right)$

\begin{tabular}{c|c|c|c|c|c|c|c|c}
\hline \multirow{2}{*}{ Ponto } & \multicolumn{7}{|c}{ Modelos numéricos de análise } \\
\cline { 2 - 9 } & $\mathbf{0 1}$ & $\mathbf{0 2}$ & $\mathbf{0 3}$ & $\mathbf{0 4}$ & $\mathbf{0 5}$ & $\mathbf{0 6}$ & $\mathbf{0 7}$ & $\mathbf{0 8}$ \\
\hline \hline $\mathbf{6}$ & $-0,410$ & $-0,154$ & $-0,220$ & $\mathbf{- 0 , 5 0 8}$ & $-0,755$ & $-0,776$ & 0,031 & $-0,114$ \\
\hline $\mathbf{7}$ & 0,876 & 0,853 & 0,833 & $\mathbf{0 , 4 6 6}$ & 0,372 & 0,408 & 0,834 & 0,542 \\
\hline $\mathbf{8}$ & 1,511 & 1,339 & 1,346 & $\mathbf{0 , 9 6 6}$ & 0,895 & 0,969 & 1,233 & 0,852 \\
\hline $\mathbf{9}$ & 1,639 & 1,439 & 1,457 & $\mathbf{1 , 0 5 9}$ & 0,990 & 1,071 & 1,306 & 0,905 \\
\hline $\mathbf{1 0}$ & 1,661 & 1,458 & 1,484 & $\mathbf{1 , 0 7 2}$ & 1,006 & 1,084 & 1,311 & 0,909 \\
\hline \hline $\mathbf{1 1}$ & $-0,625$ & $-0,296$ & $-0,376$ & $\mathbf{- 0 , 4 7 8}$ & $-0,603$ & $-0,624$ & $-0,145$ & $-0,271$ \\
\hline $\mathbf{1 2}$ & 0,545 & 0,569 & 0,546 & $\mathbf{0 , 3 3 0}$ & 0,289 & 0,315 & 0,572 & 0,372 \\
\hline $\mathbf{1 3}$ & 1,191 & 1,068 & 1,068 & $\mathbf{0 , 7 4 8}$ & 0,660 & 0,700 & 0,961 & 0,646 \\
\hline $\mathbf{1 4}$ & 1,318 & 1,166 & 1,177 & $\mathbf{0 , 8 2 4}$ & 0,725 & 0,769 & 1,028 & 0,690 \\
\hline $\mathbf{1 5}$ & 1,340 & 1,185 & 1,203 & $\mathbf{0 , 8 3 6}$ & 0,741 & 0,782 & 1,033 & 0,693 \\
\hline \hline $\mathbf{1 6}$ & $-0,936$ & $-0,814$ & $-0,920$ & $\mathbf{- 0 , 4 8 4}$ & $-0,238$ & $-0,211$ & $-0,675$ & $-0,539$ \\
\hline $\mathbf{1 7}$ & 0,082 & 0,131 & 0,101 & $\mathbf{0 , 0 4 8}$ & 0,085 & 0,071 & 0,117 & 0,049 \\
\hline $\mathbf{1 8}$ & 0,454 & 0,436 & 0,433 & $\mathbf{0 , 2 5 3}$ & 0,188 & 0,164 & 0,338 & 0,181 \\
\hline $\mathbf{1 9}$ & 0,503 & 0,468 & 0,471 & $\mathbf{0 , 2 8 4}$ & 0,210 & 0,185 & 0,360 & 0,197 \\
\hline $\mathbf{2 0}$ & 0,523 & 0,485 & 0,494 & $\mathbf{0 , 2 9 2}$ & 0,225 & 0,198 & 0,361 & 0,198 \\
\hline $\mathbf{2 1}$ & $-0,07$ & $-0,10$ & $-0,11$ & $\mathbf{- 0 , 0 8}$ & $-0,04$ & $-0,05$ & $-0,08$ & $-0,08$ \\
\hline $\mathbf{2 2}$ & 0,25 & 0,20 & 0,19 & $\mathbf{0 , 1 7}$ & 0,29 & 0,26 & 0,18 & 0,20 \\
\hline $\mathbf{2 3}$ & 0,35 & 0,34 & 0,34 & $\mathbf{0 , 3 3}$ & 0,35 & 0,33 & 0,31 & 0,34 \\
\hline $\mathbf{2 4}$ & 0,36 & 0,36 & 0,36 & $\mathbf{0 , 3 6}$ & 0,34 & 0,33 & 0,33 & 0,37 \\
\hline $\mathbf{2 5}$ & 0,34 & 0,36 & 0,36 & $\mathbf{0 , 3 6}$ & 0,32 & 0,32 & 0,33 & 0,37 \\
\hline \hline
\end{tabular}


TABELA 5.152: Tensões Normais nas fibras inferiores extremas das nervuras e vigas, em $\mathrm{kN} / \mathrm{cm}^{2}$, na laje com 11 nervuras por lado

LAJE COM RELAÇ̃̃O a1/l=0,0833

TENSÕES NORMAIS - FIBRAS INFERIORES EXTREMAS - NERVURAS E VIGAS $\left(\mathrm{kN} / \mathrm{cm}^{2}\right)$

\begin{tabular}{c|c|c|c|c|c|c|c|c}
\hline \multirow{2}{*}{ Ponto } & \multicolumn{7}{|c|}{ Modelos numéricos de análise } \\
\cline { 2 - 9 } & $\mathbf{0 1}$ & $\mathbf{0 2}$ & $\mathbf{0 3}$ & $\mathbf{0 4}$ & $\mathbf{0 5}$ & $\mathbf{0 6}$ & $\mathbf{0 7}$ & $\mathbf{0 8}$ \\
\hline $\mathbf{1}$ & $-0,503$ & $-0,191$ & $-0,264$ & $\mathbf{- 0 , 6 1 5}$ & $-0,948$ & $-0,967$ & 0,036 & $-0,135$ \\
\hline $\mathbf{2}$ & 0,340 & 0,474 & 0,436 & $\mathbf{- 0 , 0 3 2}$ & $-0,207$ & $-0,197$ & 0,557 & 0,287 \\
\hline $\mathbf{3}$ & 0,954 & 0,953 & 0,931 & $\mathbf{0 , 4 8 1}$ & 0,334 & 0,376 & 0,948 & 0,605 \\
\hline $\mathbf{4}$ & 1,718 & 1,537 & 1,543 & $\mathbf{1 , 0 9 4}$ & 0,984 & 1,072 & 1,394 & 0,988 \\
\hline $\mathbf{5}$ & 1,909 & 1,683 & 1,701 & $\mathbf{1 , 2 3 6}$ & 1,131 & 1,230 & 1,546 & 1,072 \\
\hline $\mathbf{6}$ & 1,974 & 1,734 & 1,763 & $\mathbf{1 , 2 8 2}$ & 1,178 & 1,282 & 1,577 & 1,095 \\
\hline \hline $\mathbf{7}$ & $-0,630$ & $-0,261$ & $-0,340$ & $\mathbf{- 0 , 5 9 0}$ & $-0,838$ & $-0,860$ & $-0,058$ & $-0,231$ \\
\hline $\mathbf{8}$ & 0,142 & 0,318 & 0,277 & $-\mathbf{0 , 0 6 3}$ & $-0,175$ & $-0,168$ & 0,395 & 0,176 \\
\hline $\mathbf{9}$ & 0,725 & 0,757 & 0,733 & $\mathbf{0 , 3 9 6}$ & 0,296 & 0,332 & 0,762 & 0,486 \\
\hline $\mathbf{1 0}$ & 1,500 & 1,350 & 1,352 & $\mathbf{0 , 9 5 1}$ & 0,837 & 0,906 & 1,243 & 0,847 \\
\hline $\mathbf{1 1}$ & 1,697 & 1,502 & 1,515 & $\mathbf{1 , 0 7 9}$ & 0,956 & 1,032 & 1,355 & 0,925 \\
\hline $\mathbf{1 2}$ & 1,762 & 1,554 & 1,578 & $\mathbf{1 , 1 2 0}$ & 0,995 & 1,074 & 1,386 & 0,946 \\
\hline $\mathbf{1 3}$ & $-1,060$ & $-0,731$ & $-0,856$ & $\mathbf{- 0 , 5 6 9}$ & $-0,507$ & $-0,513$ & $-0,574$ & $-0,580$ \\
\hline $\mathbf{1 4}$ & $-0,348$ & $-0,167$ & $-0,212$ & $\mathbf{- 0 , 1 9 6}$ & $-0,090$ & $-0,079$ & $-0,064$ & $-0,083$ \\
\hline $\mathbf{1 5}$ & 0,211 & 0,282 & 0,249 & $\mathbf{0 , 1 5 1}$ & 0,169 & 0,178 & 0,312 & 0,193 \\
\hline $\mathbf{1 6}$ & 0,896 & 0,831 & 0,824 & $\mathbf{0 , 5 3 5}$ & 0,432 & 0,438 & 0,731 & 0,462 \\
\hline $\mathbf{1 7}$ & 1,039 & 0,938 & 0,942 & $\mathbf{0 , 6 2 4}$ & 0,489 & 0,497 & 0,808 & 0,513 \\
\hline $\mathbf{1 8}$ & 1,084 & 0,970 & 0,983 & $\mathbf{0 , 6 4 9}$ & 0,513 & 0,519 & 0,827 & 0,526 \\
\hline $\mathbf{1 9}$ & $-0,06$ & $-0,09$ & $-0,10$ & $\mathbf{- 0 , 0 7}$ & $-0,03$ & $-0,03$ & $-0,07$ & $-0,07$ \\
\hline $\mathbf{2 0}$ & 0,16 & 0,09 & 0,08 & $\mathbf{0 , 0 5}$ & 0,24 & 0,16 & 0,08 & 0,10 \\
\hline $\mathbf{2 1}$ & 0,28 & 0,21 & 0,20 & $\mathbf{0 , 1 8}$ & 0,32 & 0,28 & 0,19 & 0,21 \\
\hline $\mathbf{2 2}$ & 0,39 & 0,36 & 0,36 & $\mathbf{0 , 3 5}$ & 0,38 & 0,36 & 0,33 & 0,36 \\
\hline $\mathbf{2 3}$ & 0,40 & 0,40 & 0,40 & $\mathbf{0 , 4 0}$ & 0,38 & 0,37 & 0,36 & 0,40 \\
\hline $\mathbf{2 4}$ & 0,39 & 0,41 & 0,41 & $\mathbf{0 , 4 1}$ & 0,36 & 0,36 & 0,37 & 0,41 \\
\hline \hline
\end{tabular}

TABELA 5.153: Tensões Normais nas fibras inferiores extremas das nervuras e vigas, em $\mathrm{kN} / \mathrm{cm}^{2}$, na laje com 12 nervuras por lado

LAJE COM RELAÇÃO a1/l=0,0769

TENSÕES NORMAIS - FIBRAS INFERIORES EXTREMAS - NERVURAS E VIGAS $\left(\mathrm{kN} / \mathrm{cm}^{2}\right)$

\begin{tabular}{c|c|c|c|c|c|c|c|c}
\hline \multirow{2}{*}{ Ponto } & \multicolumn{7}{c}{ Modelos numéricos de análise } \\
\cline { 2 - 9 } & $\mathbf{0 1}$ & $\mathbf{0 2}$ & $\mathbf{0 3}$ & $\mathbf{0 4}$ & $\mathbf{0 5}$ & $\mathbf{0 6}$ & $\mathbf{0 7}$ & $\mathbf{0 8}$ \\
\hline \hline $\mathbf{6}$ & $-0,624$ & $-0,239$ & $-0,318$ & $\mathbf{- 0 , 7 4 4}$ & $-1,148$ & $-1,165$ & 0,029 & $-0,172$ \\
\hline $\mathbf{7}$ & 0,991 & 1,023 & 1,000 & $\mathbf{0 , 4 8 1}$ & 0,272 & 0,320 & 1,031 & 0,647 \\
\hline $\mathbf{8}$ & 1,890 & 1,709 & 1,714 & $\mathbf{1 , 2 0 4}$ & 1,037 & 1,138 & 1,601 & 1,099 \\
\hline $\mathbf{9}$ & 2,274 & 2,003 & 2,032 & $\mathbf{1 , 4 8 9}$ & 1,330 & 1,453 & 1,829 & 1,268 \\
\hline $\mathbf{1 0}$ & 2,295 & 2,022 & 2,059 & $\mathbf{1 , 5 0 3}$ & 1,346 & 1,466 & 1,834 & 1,272 \\
\hline \hline $\mathbf{1 1}$ & $-0,811$ & $-0,359$ & $-0,451$ & $\mathbf{- 0 , 6 9 0}$ & $-0,972$ & $-0,994$ & $-0,123$ & $-0,320$ \\
\hline $\mathbf{1 2}$ & 0,662 & 0,738 & 0,711 & $\mathbf{0 , 3 6 0}$ & 0,236 & 0,275 & 0,765 & 0,478 \\
\hline $\mathbf{1 3}$ & 1,564 & 1,428 & 1,428 & $\mathbf{0 , 9 9 6}$ & 0,841 & 0,914 & 1,328 & 0,901 \\
\hline $\mathbf{1 4}$ & 1,954 & 1,730 & 1,751 & $\mathbf{1 , 2 4 3}$ & 1,062 & 1,149 & 1,550 & 1,045 \\
\hline $\mathbf{1 5}$ & 1,976 & 1,748 & 1,778 & $\mathbf{1 , 2 5 6}$ & 1,078 & 1,162 & 1,555 & 1,055 \\
\hline \hline $\mathbf{1 6}$ & $-1,275$ & $-0,926$ & $-1,074$ & $-\mathbf{0 , 6 7 7}$ & $-0,564$ & $-0,569$ & $-0,746$ & $-0,720$ \\
\hline $\mathbf{1 7}$ & 0,112 & 0,209 & 0,172 & $\mathbf{0 , 0 9 8}$ & 0,133 & 0,144 & 0,258 & 0,154 \\
\hline $\mathbf{1 8}$ & 0,894 & 0,846 & 0,834 & $\mathbf{0 , 5 3 2}$ & 0,416 & 0,419 & 0,752 & 0,468 \\
\hline $\mathbf{1 9}$ & 1,162 & 1,045 & 1,055 & $\mathbf{0 , 6 7 5}$ & 0,518 & 0,525 & 0,897 & 0,566 \\
\hline $\mathbf{2 0}$ & 1,183 & 1,064 & 1,083 & $\mathbf{0 , 6 8 6}$ & 0,534 & 0,538 & 0,900 & 0,568 \\
\hline \hline $\mathbf{2 1}$ & $-0,05$ & $-0,08$ & $-0,09$ & $-\mathbf{0 , 0 7}$ & $-0,01$ & $-0,02$ & $-0,07$ & $-0,06$ \\
\hline $\mathbf{2 2}$ & 0,30 & 0,23 & 0,22 & $\mathbf{0 , 1 8}$ & 0,35 & 0,30 & 0,20 & 0,22 \\
\hline $\mathbf{2 3}$ & 0,42 & 0,39 & 0,39 & $\mathbf{0 , 3 7}$ & 0,42 & 0,38 & 0,35 & 0,38 \\
\hline $\mathbf{2 4}$ & 0,44 & 0,46 & 0,46 & $\mathbf{0 , 4 6}$ & 0,41 & 0,40 & 0,41 & 0,45 \\
\hline $\mathbf{2 5}$ & 0,42 & 0,45 & 0,46 & $\mathbf{0 , 4 6}$ & 0,39 & 0,38 & 0,41 & 0,45 \\
\hline \hline
\end{tabular}


TABELA 5.154: Tensões Normais nas fibras inferiores extremas das nervuras e vigas, em $\mathrm{kN} / \mathrm{cm}^{2}$, na laje com 13 nervuras por lado

LAJE COM RELAÇãO a1/l=0,0714

TENSÕES NORMAIS - FIBRAS INFERIORES EXTREMAS - NERVURAS E VIGAS $\left(\mathrm{kN} / \mathrm{cm}^{2}\right)$

\begin{tabular}{c|c|c|c|c|c|c|c|c}
\hline \multirow{2}{*}{ Ponto } & \multicolumn{7}{|c}{ Modelos numéricos de análise } \\
\cline { 2 - 9 } & $\mathbf{0 1}$ & $\mathbf{0 2}$ & $\mathbf{0 3}$ & $\mathbf{0 4}$ & $\mathbf{0 5}$ & $\mathbf{0 6}$ & $\mathbf{0 7}$ & $\mathbf{0 8}$ \\
\hline \hline $\mathbf{1}$ & $-0,746$ & $-0,287$ & $-0,371$ & $\mathbf{- 0 , 8 8 7}$ & $-1,384$ & $-1,398$ & 0,032 & $-0,095$ \\
\hline $\mathbf{2}$ & 1,045 & 1,114 & 1,090 & $\mathbf{0 , 4 7 9}$ & 0,192 & 0,248 & 1,145 & 0,982 \\
\hline $\mathbf{3}$ & 2,083 & 1,904 & 1,910 & $\mathbf{1 , 3 3 5}$ & 1,091 & 1,207 & 1,803 & 1,643 \\
\hline $\mathbf{4}$ & 2,591 & 2,291 & 2,322 & $\mathbf{1 , 7 2 6}$ & 1,492 & 1,638 & 2,114 & 1,957 \\
\hline $\mathbf{5}$ & 2,656 & 2,342 & 2,384 & $\mathbf{1 , 7 7 3}$ & 1,540 & 1,690 & 2,145 & 1,989 \\
\hline \hline $\mathbf{6}$ & $-0,856$ & $-0,350$ & $-0,442$ & $\mathbf{- 0 , 8 4 5}$ & $-1,260$ & $-1,279$ & $-0,053$ & $-0,248$ \\
\hline $\mathbf{7}$ & 0,826 & 0,926 & 0,899 & $\mathbf{0 , 4 0 5}$ & 0,183 & 0,231 & 0,961 & 0,796 \\
\hline $\mathbf{8}$ & 1,858 & 1,709 & 1,711 & $\mathbf{1 , 1 9 7}$ & 0,973 & 1,073 & 1,611 & 1,458 \\
\hline $\mathbf{9}$ & 2,379 & 2,110 & 2,135 & $\mathbf{1 , 5 5 8}$ & 1,316 & 1,438 & 1,921 & 1,772 \\
\hline $\mathbf{1 0}$ & 2,445 & 2,162 & 2,198 & $\mathbf{1 , 6 0 1}$ & 1,356 & 1,481 & 1,952 & 1,804 \\
\hline \hline $\mathbf{1 1}$ & $-1,500$ & $-1,139$ & $-1,311$ & $-\mathbf{0 , 7 9 4}$ & $-0,619$ & $-0,622$ & $-0,934$ & $-1,053$ \\
\hline $\mathbf{1 2}$ & 0,000 & 0,123 & 0,081 & $\mathbf{0 , 0 3 5}$ & 0,097 & 0,108 & 0,190 & 0,074 \\
\hline $\mathbf{1 3}$ & 0,876 & 0,846 & 0,830 & $\mathbf{0 , 5 2 1}$ & 0,395 & 0,395 & 0,760 & 0,632 \\
\hline $\mathbf{1 4}$ & 1,220 & 1,105 & 1,114 & $\mathbf{0 , 7 0 2}$ & 0,517 & 0,520 & 0,955 & 0,853 \\
\hline $\mathbf{1 5}$ & 1,257 & 1,131 & 1,147 & $\mathbf{0 , 7 2 2}$ & 0,533 & 0,539 & 0,971 & 0,873 \\
\hline \hline $\mathbf{1 6}$ & $-0,04$ & $-0,08$ & $-0,08$ & $-\mathbf{0 , 0 6}$ & 0,00 & $-0,01$ & $-0,06$ & $-0,06$ \\
\hline $\mathbf{1 7}$ & 0,33 & 0,24 & 0,23 & $\mathbf{0 , 1 9}$ & 0,38 & 0,33 & 0,21 & 0,22 \\
\hline $\mathbf{1 8}$ & 0,46 & 0,41 & 0,41 & $\mathbf{0 , 4 0}$ & 0,45 & 0,40 & 0,36 & 0,38 \\
\hline $\mathbf{1 9}$ & 0,49 & 0,50 & 0,50 & $\mathbf{0 , 5 0}$ & 0,45 & 0,43 & 0,44 & 0,46 \\
\hline $\mathbf{2 0}$ & 0,47 & 0,50 & 0,51 & $\mathbf{0 , 5 1}$ & 0,43 & 0,42 & 0,45 & 0,47 \\
\hline \hline
\end{tabular}

TABELA 5.155: Tensões Normais nas fibras inferiores extremas das nervuras e vigas, em $\mathrm{kN} / \mathrm{cm}^{2}$, na laje com 14 nervuras por lado

LAJE COM RELAÇÃO a1/l=0,0667

TENSÕES NORMAIS - FIBRAS INFERIORES EXTREMAS - NERVURAS E VIGAS $\left(\mathrm{kN} / \mathrm{cm}^{2}\right)$

\begin{tabular}{c|c|c|c|c|c|c|c|c}
\hline \multirow{2}{*}{ Ponto } & \multicolumn{7}{|c|}{ Modelos numéricos de análise } \\
\cline { 2 - 9 } & $\mathbf{0 1}$ & $\mathbf{0 2}$ & $\mathbf{0 3}$ & $\mathbf{0 4}$ & $\mathbf{0 5}$ & $\mathbf{0 6}$ & $\mathbf{0 7}$ & $\mathbf{0 8}$ \\
\hline $\mathbf{7}$ & $-0,894$ & $-0,347$ & $-0,436$ & $\mathbf{- 1 , 0 3 2}$ & $-1,626$ & $-1,637$ & 0,024 & $-0,243$ \\
\hline $\mathbf{8}$ & 1,058 & 1,177 & 1,152 & $\mathbf{0 , 4 5 2}$ & 0,091 & 0,153 & 1,228 & 0,742 \\
\hline $\mathbf{9}$ & 2,238 & 2,073 & 2,078 & $\mathbf{1 , 4 2 3}$ & 1,112 & 1,240 & 1,974 & 1,343 \\
\hline $\mathbf{1 0}$ & 2,874 & 2,555 & 2,587 & $\mathbf{1 , 9 1 5}$ & 1,618 & 1,783 & 2,368 & 1,641 \\
\hline $\mathbf{1 1}$ & 3,003 & 2,655 & 2,698 & $\mathbf{2 , 0 0 9}$ & 1,713 & 1,886 & 2,440 & 1,693 \\
\hline $\mathbf{1 2}$ & 3,025 & 2,674 & 2,724 & $\mathbf{2 , 0 2 2}$ & 1,729 & 1,899 & 2,445 & 1,697 \\
\hline $\mathbf{1 3}$ & $-1,056$ & $-0,452$ & $-0,555$ & $\mathbf{- 0 , 9 8 5}$ & $-1,430$ & $-1,450$ & $-0,113$ & $-0,383$ \\
\hline $\mathbf{1 4}$ & 0,745 & 0,902 & 0,872 & $\mathbf{0 , 3 5 1}$ & 0,095 & 0,146 & 0,965 & 0,575 \\
\hline $\mathbf{1 5}$ & 1,905 & 1,780 & 1,781 & $\mathbf{1 , 2 2 5}$ & 0,957 & 1,063 & 1,698 & 1,151 \\
\hline $\mathbf{1 6}$ & 2,554 & 2,280 & 2,304 & $\mathbf{1 , 6 6 7}$ & 1,368 & 1,499 & 2,089 & 1,429 \\
\hline $\mathbf{1 7}$ & 2,684 & 2,382 & 2,417 & $\mathbf{1 , 7 5 2}$ & 1,444 & 1,580 & 2,160 & 1,477 \\
\hline $\mathbf{1 8}$ & 2,706 & 2,400 & 2,443 & $\mathbf{1 , 7 6 5}$ & 1,460 & 1,593 & 2,165 & 1,480 \\
\hline $\mathbf{1 9}$ & $-1,732$ & $-1,366$ & $-1,563$ & $\mathbf{- 0 , 8 9 4}$ & $-0,672$ & $-0,675$ & $-1,139$ & $-1,032$ \\
\hline $\mathbf{2 0}$ & $-0,123$ & 0,024 & $-0,022$ & $\mathbf{- 0 , 0 3 3}$ & 0,060 & 0,071 & 0,110 & 0,050 \\
\hline $\mathbf{2 1}$ & 0,842 & 0,833 & 0,813 & $\mathbf{0 , 5 0 3}$ & 0,372 & 0,369 & 0,757 & 0,457 \\
\hline $\mathbf{2 2}$ & 1,260 & 1,152 & 1,159 & $\mathbf{0 , 7 1 9}$ & 0,509 & 0,508 & 1,004 & 0,621 \\
\hline $\mathbf{2 3}$ & 1,330 & 1,200 & 1,215 & $\mathbf{0 , 7 5 6}$ & 0,536 & 0,537 & 1,039 & 0,646 \\
\hline $\mathbf{2 4}$ & 1,351 & 1,220 & 1,243 & $\mathbf{0 , 7 6 6}$ & 0,553 & 0,550 & 1,041 & 0,648 \\
\hline \hline $\mathbf{2 5}$ & $-0,03$ & $-0,07$ & $-0,07$ & $-\mathbf{0 , 0 5}$ & 0,01 & 0,00 & $-0,05$ & $-0,05$ \\
\hline $\mathbf{2 6}$ & 0,35 & 0,26 & 0,24 & $\mathbf{0 , 2 0}$ & 0,41 & 0,35 & 0,21 & 0,24 \\
\hline $\mathbf{2 7}$ & 0,49 & 0,44 & 0,43 & $\mathbf{0 , 4 1}$ & 0,48 & 0,43 & 0,38 & 0,42 \\
\hline $\mathbf{2 8}$ & 0,53 & 0,54 & 0,54 & $\mathbf{0 , 5 3}$ & 0,49 & 0,46 & 0,47 & 0,52 \\
\hline $\mathbf{2 9}$ & 0,52 & 0,55 & 0,56 & $\mathbf{0 , 5 6}$ & 0,48 & 0,45 & 0,49 & 0,54 \\
\hline $\mathbf{3 0}$ & 0,50 & 0,54 & 0,55 & $\mathbf{0 , 5 6}$ & 0,45 & 0,44 & 0,49 & 0,54 \\
\hline \hline
\end{tabular}


TABELA 5.156: Tensões Normais nas fibras inferiores extremas das nervuras e vigas, em $\mathrm{kN} / \mathrm{cm}^{2}$, na laje com 15 nervuras por lado

\section{LAJE COM RELAÇ̃̃O a1/l=0,0625}

TENSÕES NORMAIS - FIBRAS INFERIORES EXTREMAS - NERVURAS E VIGAS $\left(\mathbf{k N} / \mathrm{cm}^{2}\right)$

\begin{tabular}{c|c|c|c|c|c|c|c|c}
\hline \multirow{2}{*}{ Ponto } & \multicolumn{7}{|c|}{ Modelos numéricos de análise } \\
\cline { 2 - 9 } & $\mathbf{0 1}$ & $\mathbf{0 2}$ & $\mathbf{0 3}$ & $\mathbf{0 4}$ & $\mathbf{0 5}$ & $\mathbf{0 6}$ & $\mathbf{0 7}$ & $\mathbf{0 8}$ \\
\hline $\mathbf{1}$ & $-1,046$ & $-0,411$ & $-0,500$ & $\mathbf{- 1 , 2 1 4}$ & $-1,906$ & $-1,914$ & 0,025 & $-0,276$ \\
\hline $\mathbf{2}$ & 1,085 & 1,257 & 1,232 & $\mathbf{0 , 4 2 2}$ & $-0,031$ & 0,039 & 1,342 & 0,796 \\
\hline $\mathbf{3}$ & 2,412 & 2,264 & 2,270 & $\mathbf{1 , 5 2 0}$ & 1,128 & 1,270 & 2,178 & 1,474 \\
\hline $\mathbf{4}$ & 3,176 & 2,840 & 2,874 & $\mathbf{2 , 1 1 8}$ & 1,751 & 1,938 & 2,655 & 1,839 \\
\hline $\mathbf{5}$ & 3,368 & 2,987 & 3,033 & $\mathbf{2 , 2 6 1}$ & 1,896 & 2,095 & 2,769 & 1,923 \\
\hline $\mathbf{6}$ & 3,433 & 3,038 & 3,095 & $\mathbf{2 , 3 0 8}$ & 1,944 & 2,146 & 2,800 & 1,945 \\
\hline \hline $\mathbf{7}$ & $-1,142$ & $-0,465$ & $-0,567$ & $\mathbf{- 1 , 1 6 7}$ & $-1,769$ & $-1,784$ & $-0,054$ & $-0,365$ \\
\hline $\mathbf{8}$ & 0,882 & 1,079 & 1,051 & $\mathbf{0 , 3 6 2}$ & $-0,016$ & 0,046 & 1,162 & 0,679 \\
\hline $\mathbf{9}$ & 2,185 & 2,062 & 2,066 & $\mathbf{1 , 3 9 1}$ & 1,039 & 1,167 & 1,984 & 1,342 \\
\hline $\mathbf{1 0}$ & 2,960 & 2,654 & 2,683 & $\mathbf{1 , 9 5 3}$ & 1,591 & 1,757 & 2,462 & 1,694 \\
\hline $\mathbf{1 1}$ & 3,156 & 2,805 & 2,845 & $\mathbf{2 , 0 8 8}$ & 1,719 & 1,894 & 2,575 & 1,774 \\
\hline $\mathbf{1 2}$ & 3,221 & 2,858 & 2,909 & $\mathbf{2 , 1 3 2}$ & 1,761 & 1,939 & 2,606 & 1,795 \\
\hline \hline $\mathbf{1 3}$ & $-1,495$ & $-0,797$ & $-0,946$ & $\mathbf{- 1 , 0 6 5}$ & $-1,362$ & $-1,389$ & $-0,455$ & $-0,696$ \\
\hline $\mathbf{1 4}$ & 0,324 & 0,554 & 0,517 & $\mathbf{0 , 1 7 3}$ & 0,016 & 0,059 & 0,666 & 0,377 \\
\hline $\mathbf{1 5}$ & 1,585 & 1,527 & 1,519 & $\mathbf{1 , 0 2 9}$ & 0,771 & 0,853 & 1,479 & 0,989 \\
\hline $\mathbf{1 6}$ & 2,328 & 2,107 & 2,124 & $\mathbf{1 , 4 8 6}$ & 1,142 & 1,243 & 1,930 & 1,293 \\
\hline $\mathbf{1 7}$ & 2,506 & 2,245 & 2,273 & $\mathbf{1 , 5 9 1}$ & 1,226 & 1,333 & 2,030 & 1,360 \\
\hline $\mathbf{1 8}$ & 2,565 & 2,291 & 2,329 & $\mathbf{1 , 6 2 5}$ & 1,255 & 1,364 & 2,057 & 1,378 \\
\hline \hline $\mathbf{1 9}$ & $-1,970$ & $-1,605$ & $-1,829$ & $\mathbf{- 1 , 0 3 5}$ & $-0,724$ & $-0,726$ & $-1,357$ & $-1,201$ \\
\hline $\mathbf{2 0}$ & $-0,256$ & $-0,086$ & $-0,137$ & $\mathbf{- 0 , 1 1 0}$ & 0,023 & 0,035 & 0,017 & $-0,013$ \\
\hline $\mathbf{2 1}$ & 0,796 & 0,807 & 0,782 & $\mathbf{0 , 4 7 0}$ & 0,346 & 0,341 & 0,742 & 0,439 \\
\hline $\mathbf{2 2}$ & 1,285 & 1,187 & 1,193 & $\mathbf{0 , 7 2 8}$ & 0,497 & 0,491 & 1,043 & 0,638 \\
\hline $\mathbf{2 3}$ & 1,385 & 1,257 & 1,272 & $\mathbf{0 , 7 8 0}$ & 0,532 & 0,529 & 1,097 & 0,677 \\
\hline $\mathbf{2 4}$ & 1,416 & 1,279 & 1,299 & $\mathbf{0 , 7 9 7}$ & 0,546 & 0,544 & 1,110 & 0,687 \\
\hline $\mathbf{2 5}$ & $-0,02$ & $-0,06$ & $-0,06$ & $\mathbf{- 0 , 0 4}$ & 0,03 & 0,02 & $-0,04$ & $-0,04$ \\
\hline $\mathbf{2 6}$ & 0,38 & 0,27 & 0,26 & $\mathbf{0 , 2 1}$ & 0,44 & 0,37 & 0,22 & 0,25 \\
\hline $\mathbf{2 7}$ & 0,53 & 0,46 & 0,45 & $\mathbf{0 , 4 3}$ & 0,51 & 0,45 & 0,39 & 0,43 \\
\hline $\mathbf{2 8}$ & 0,57 & 0,57 & 0,57 & $\mathbf{0 , 5 7}$ & 0,53 & 0,48 & 0,50 & 0,55 \\
\hline $\mathbf{2 9}$ & 0,57 & 0,60 & 0,60 & $\mathbf{0 , 6 0}$ & 0,52 & 0,48 & 0,52 & 0,57 \\
\hline $\mathbf{3 0}$ & 0,55 & 0,60 & 0,61 & $\mathbf{0 , 6 2}$ & 0,49 & 0,47 & 0,53 & 0,58 \\
\hline \hline
\end{tabular}

Abaixo tem-se os gráficos de tensões normais nas fibras inferiores da nervura central das lajes processadas nesta série. 


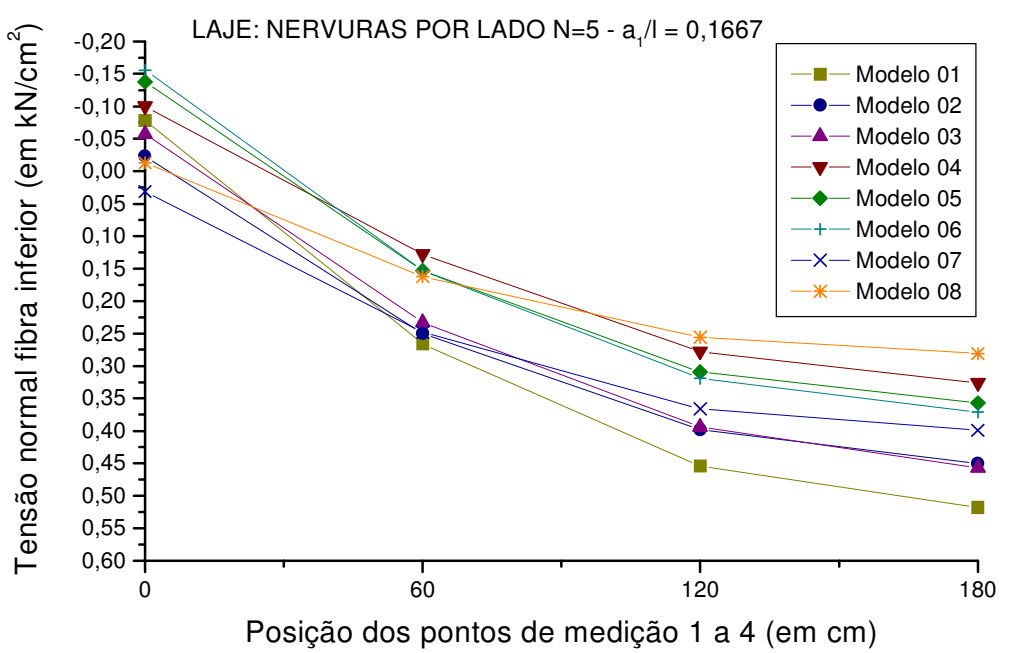

FIGURA 5.115: Tensões Normais fibras inferiores extremas $\left(\mathrm{kN} / \mathrm{cm}^{2}\right)$, na nervura central, na laje com $a_{1} / l=0,1667$

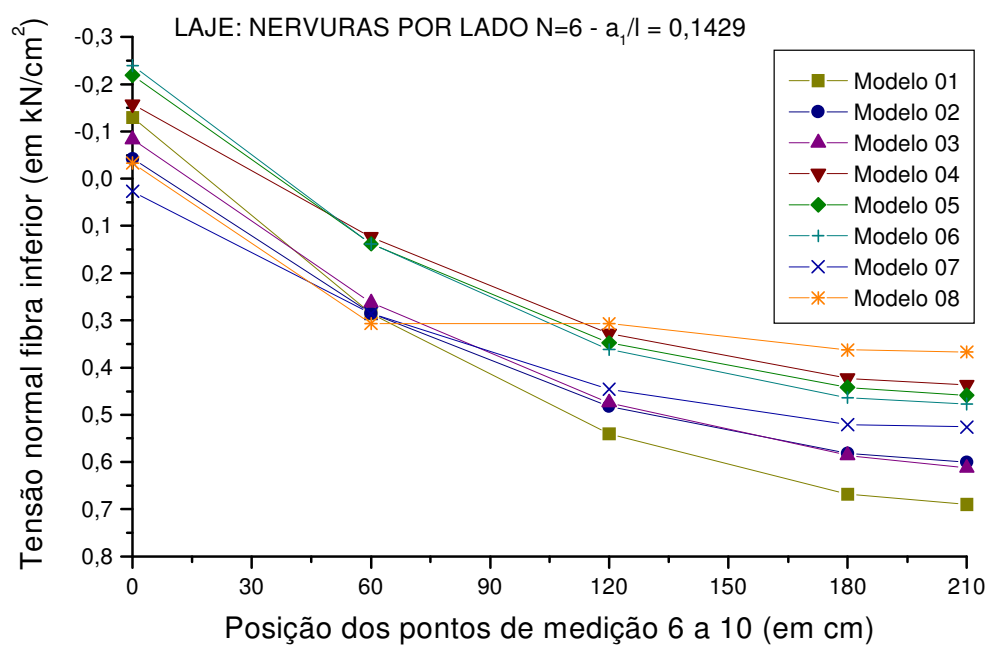

FIGURA 5.116: Tensões Normais fibras inferiores extremas $\left(\mathrm{kN} / \mathrm{cm}^{2}\right)$, na nervura central, na laje com $a_{1} / l=0,1429$

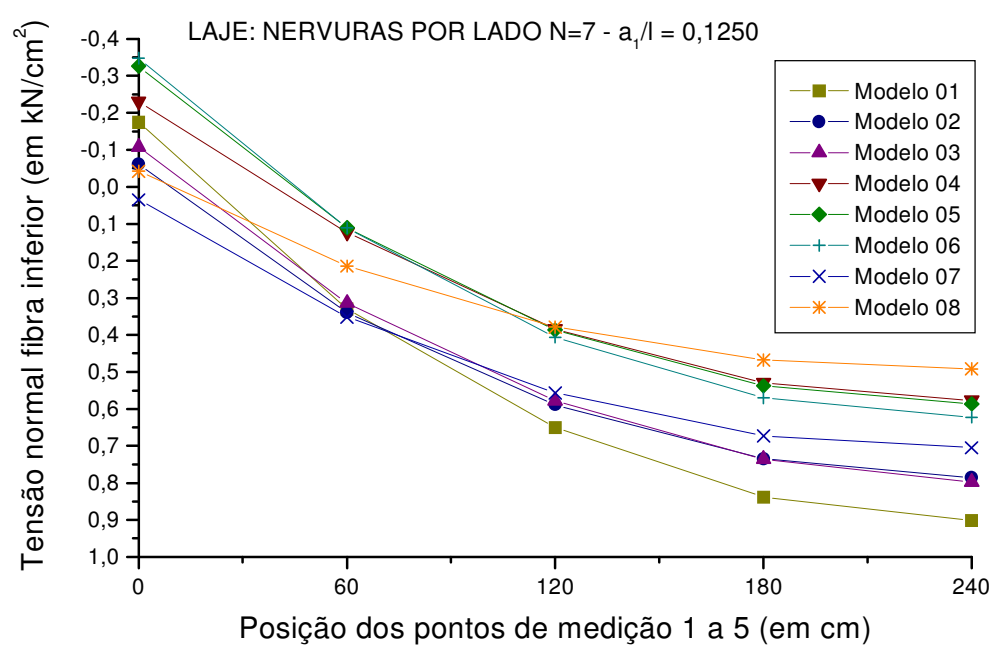

FIGURA 5.117: Tensões Normais fibras inferiores extremas $\left(\mathrm{kN} / \mathrm{cm}^{2}\right)$, na nervura central, na laje com $a_{1} / l=0,1250$ 


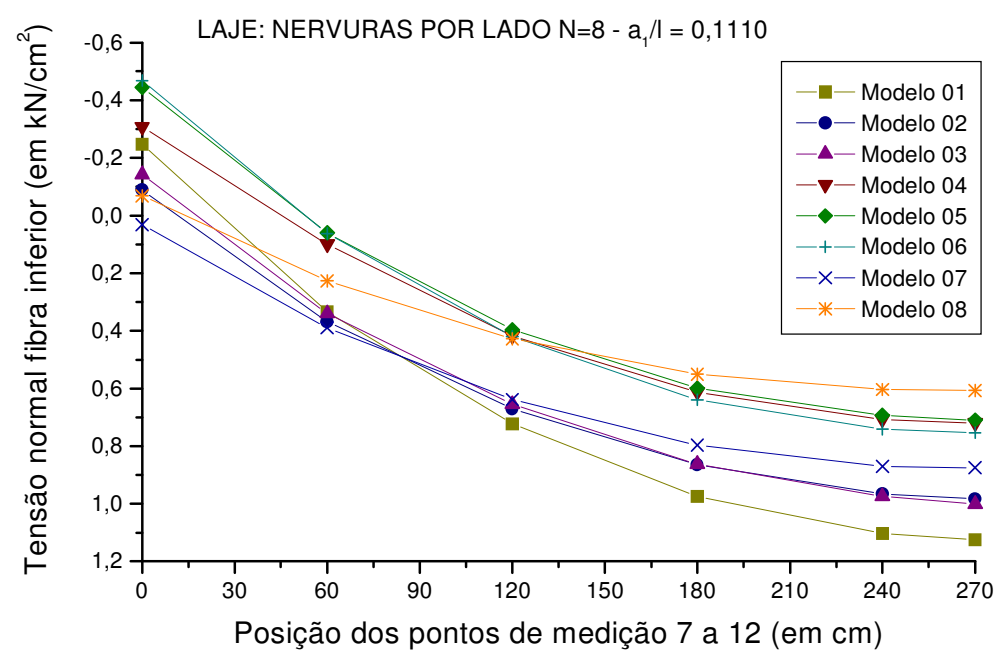

FIGURA 5.118: Tensões Normais fibras inferiores extremas $\left(\mathrm{kN} / \mathrm{cm}^{2}\right)$, na nervura central, na laje com $a_{1} / l=0,1111$

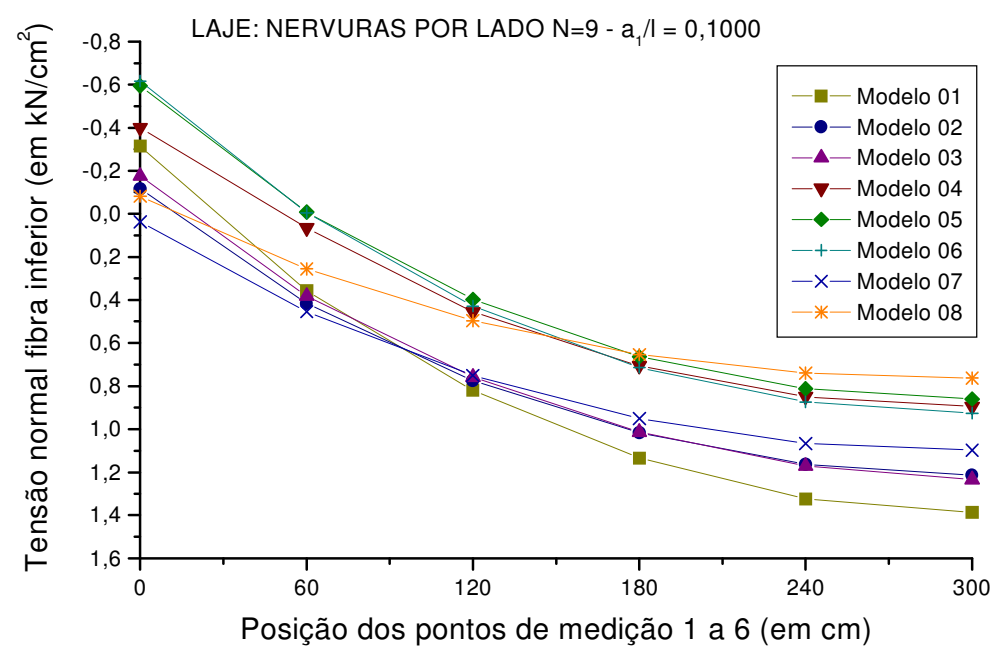

FIGURA 5.119: Tensões Normais fibras inferiores extremas $\left(\mathrm{kN} / \mathrm{cm}^{2}\right)$, na nervura central, na laje com $a_{1} / l=0,1000$

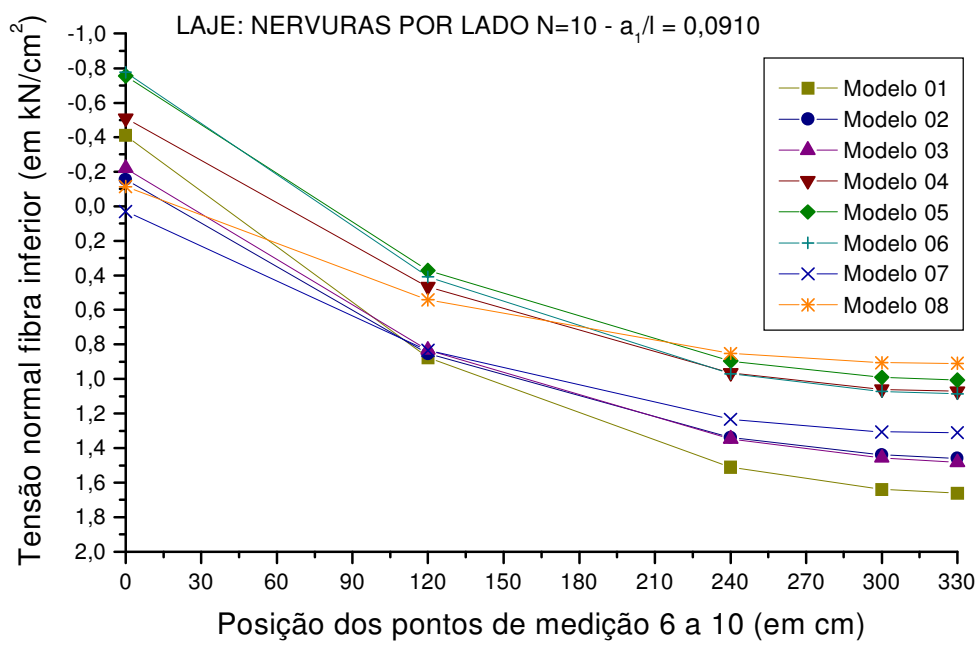

FIGURA 5.120: Tensões Normais fibras inferiores extremas $\left(\mathrm{kN} / \mathrm{cm}^{2}\right)$, na nervura central, na laje com $a_{1} / l=0,0910$ 


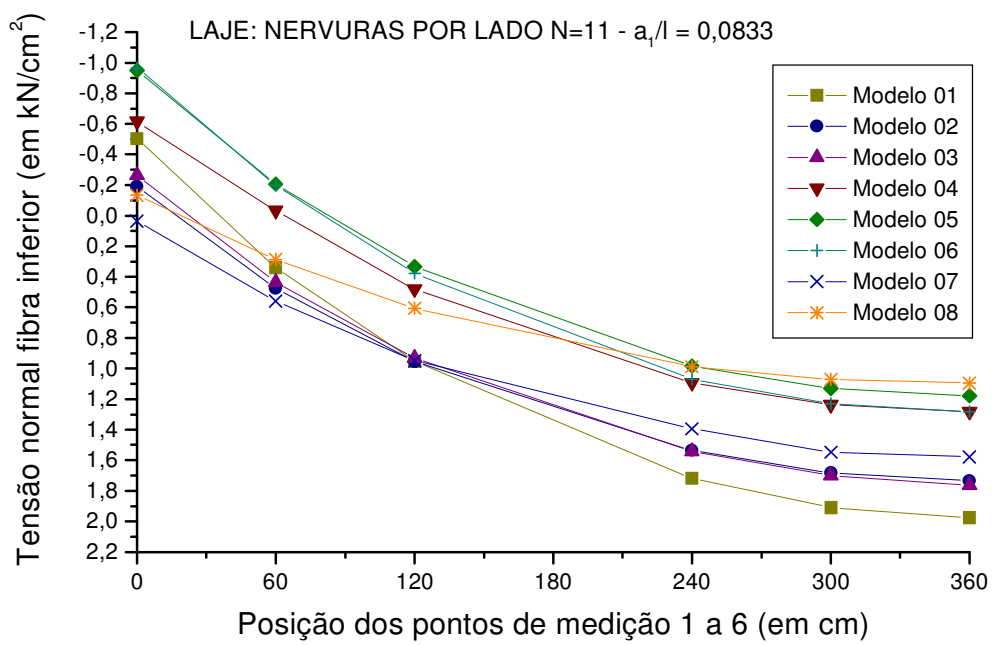

FIGURA 5.121: Tensões Normais fibras inferiores extremas $\left(\mathrm{kN} / \mathrm{cm}^{2}\right)$, na nervura central, na laje com $a_{1} / l=0,0833$

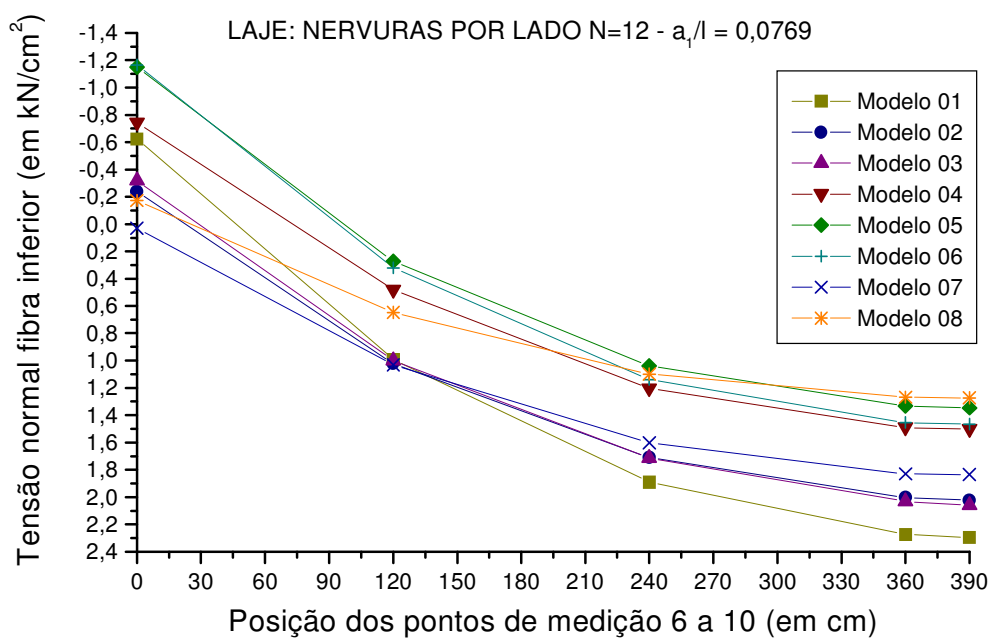

FIGURA 5.122: Tensões Normais fibras inferiores extremas $\left(\mathrm{kN} / \mathrm{cm}^{2}\right)$, na nervura central, na laje com $a_{1} / l=0,0769$

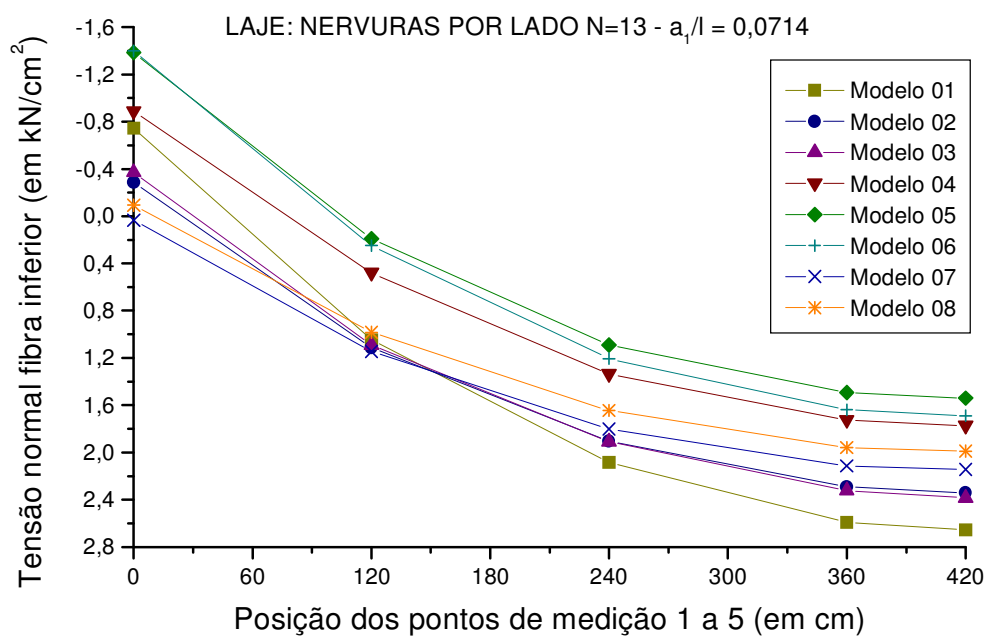

FIGURA 5.123: Tensões Normais fibras inferiores extremas $\left(\mathrm{kN} / \mathrm{cm}^{2}\right)$, na nervura central, na laje com $a_{1} / l=0,0714$ 


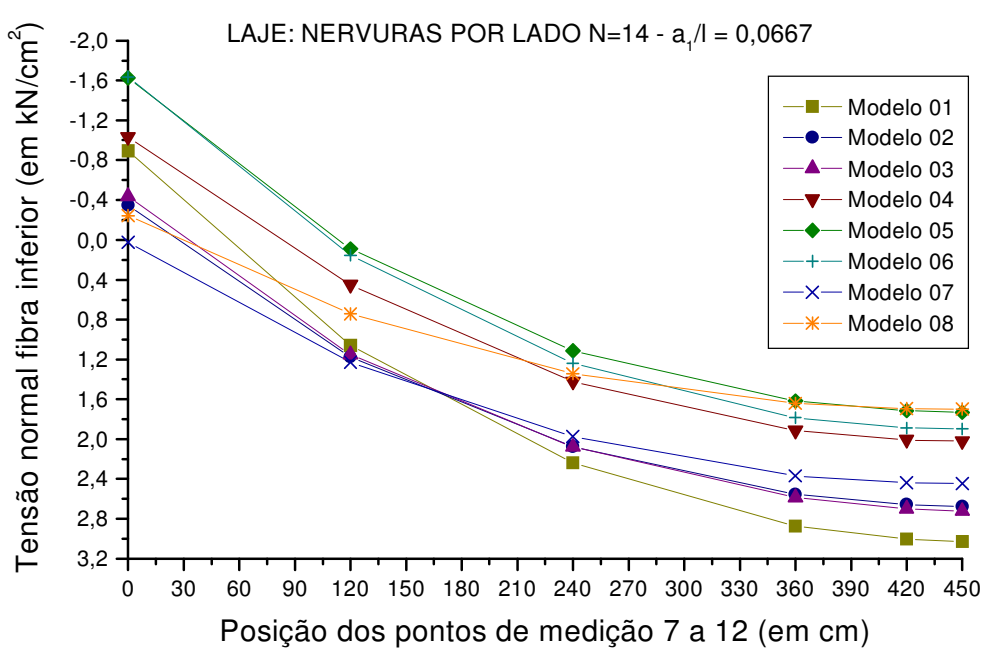

FIGURA 5.124: Tensões Normais fibras inferiores extremas $\left(\mathrm{kN} / \mathrm{cm}^{2}\right)$, na nervura central, na laje com $\mathrm{a}_{1} / \mathrm{l}=0,0667$

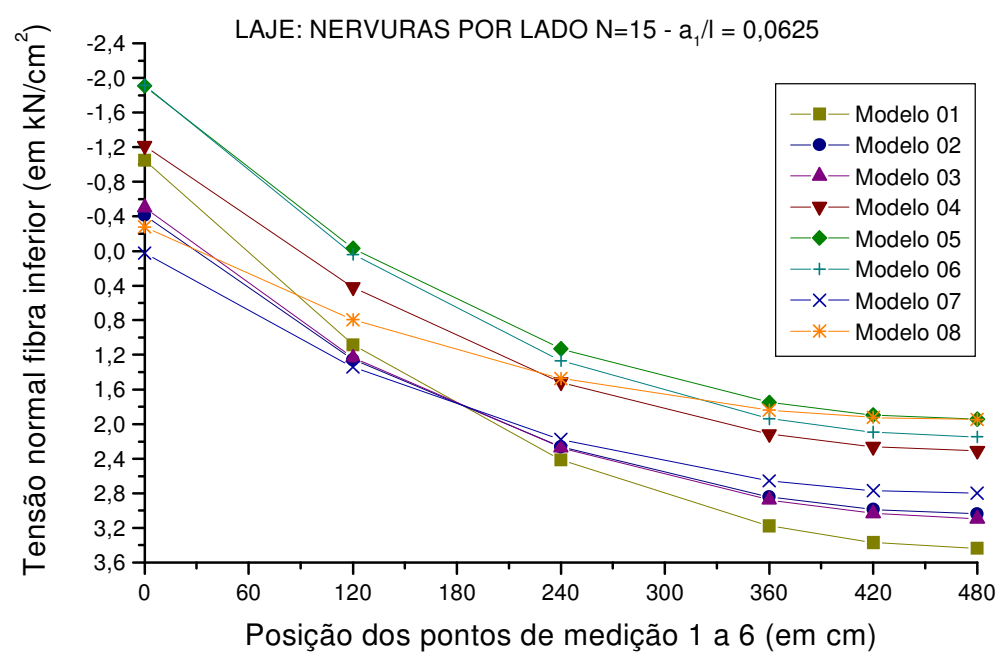

FIGURA 5.125: Tensões Normais fibras inferiores extremas $\left(\mathrm{kN} / \mathrm{cm}^{2}\right)$, na nervura central, na laje com $a_{1} / l=0,0625$

De acordo com as tabelas e gráficos de tensões normais extremas inferiores e superiores nas seções das nervuras, nos modelos com variação da relação $a_{1} / l$, viu-se que:

- a modelagem concêntrica apresenta às nervuras valores maiores de tensão de tração, como esperado, da ordem de $50 \%$ a mais quando comparado com os resultados apresentados pela modelagem realista 04 ;

- as tensões de tração máximas obtidas para as nervuras nos modelos 02 e 03 são bem maiores que aquelas encontradas com o modelo realista, haja visto que nas lajes com relação $\mathrm{hf} / \mathrm{h}=0,25$, como demonstrado na análise da série anterior processada, estes modelos comportam-se com demasiada flexibilidade. Verificou-se, porém, que parecem não variar com a variação da relação $a_{1} / l$, apresentado erros quase constantes da ordem de $38 \%$ nesse estudo, em função da relação $h_{f} / h$ adotada; 
- as tensões de tração apresentadas pelo Modelo 08 (ou modelo de laje maciça equivalente com redução da espessura conforme ABDUL-WAHAB \& KHALIL (2000)), nestas lajes com relação $h_{f} / h=0,25$, estão sempre mais próximas daquelas obtidas pelo Modelo 04 do que as encontradas pelo Modelo 07 (ou modelo de laje maciça com redução do $\mathrm{G}_{\mathrm{c}}$ ), porém sempre menores. Contudo, estes resultados estão diretamente ligados à excentricidade destas lajes. Verifica-se, por outro lado, que parece não haver alteração do comportamento das tensões de tração destes modelos (Modelos 07 e 08), frente ao Modelo 04, conforme promovem-se variações na relação $\mathrm{a}_{1} / \mathrm{l}$;

- os modelos 05 e 06 apresentaram o seguinte comportamento: forneceram tensões de tração maiores nas nervuras para altas relações de $a_{1} / l$, comparadas com as tensões obtidas no modelo realista (para $a_{1} / l=0,1667$ tem-se uma diferença de $13,80 \%$ a maior para o Modelo 06, na tensão máxima de tração da nervura mais central); à medida que a relação $a_{1} / l$ diminui, os valores vão ficando mais próximos entre os dois modelos (para $a_{1} / l=0,0833$ essa diferença é nula); porém, para valores ainda mais baixos de $a_{1} / l$, a tensão de tração máxima apresentada pelos modelos 05 e 06 tornam-se menores que aquela dada pelo Modelo 04 (para $a_{1} / l=0,0625$ tem-se uma diferença de 7,0\%, a menor para o Modelo 06, na tensão máxima de tração da nervura mais central).

- as tensões normais de compressão máximas nas nervuras, para o Modelo 04, são sempre muito menores do que nos demais modelos, de $50 \%$ a $60 \%$ das tensões que mais se aproximam, que são as do Modelo 08. As nervuras do Modelo 03 têm as menores tensões de compressão.

Abaixo tem-se os gráficos de tensões normais nas fibras inferiores das vigas de contorno externo das lajes processadas nesta série.

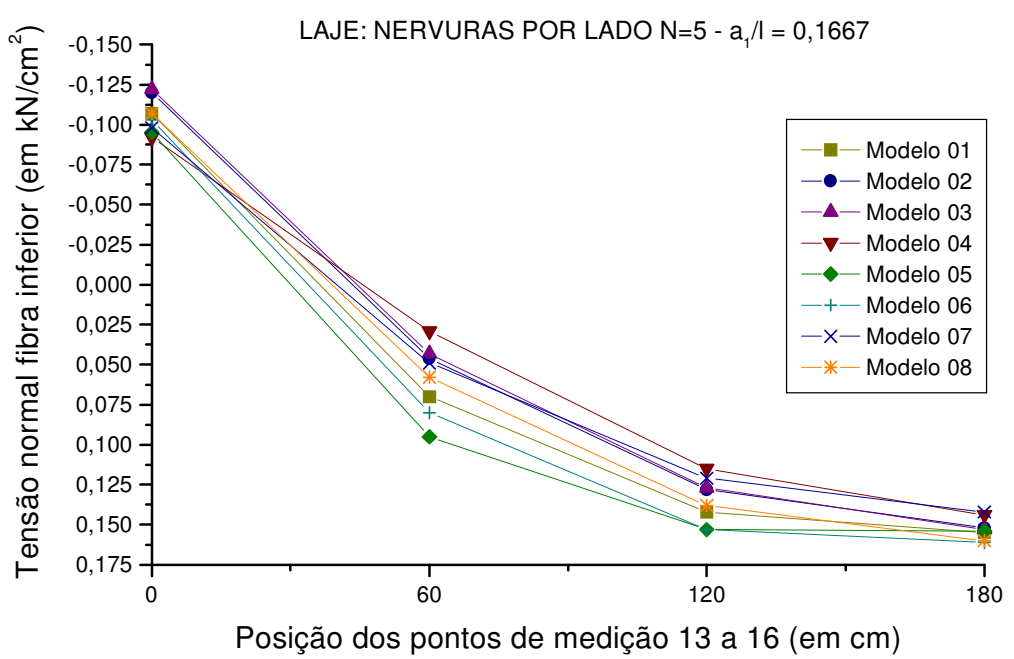

FIGURA 5.126: Tensões Normais fibras inferiores extremas $\left(\mathrm{kN} / \mathrm{cm}^{2}\right)$, na viga externa, na laje com $a_{1} / l=0,1667$ 


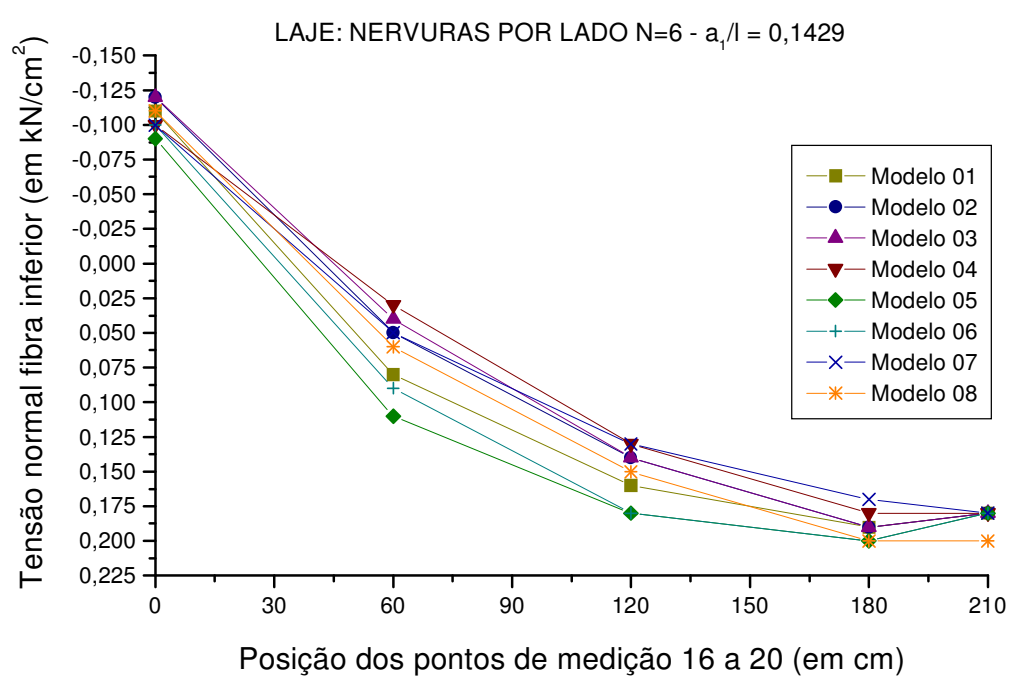

FIGURA 5.127: Tensões Normais fibras inferiores extremas $\left(\mathrm{kN} / \mathrm{cm}^{2}\right)$, na viga externa, na laje com $a_{1} / l=0,1429$

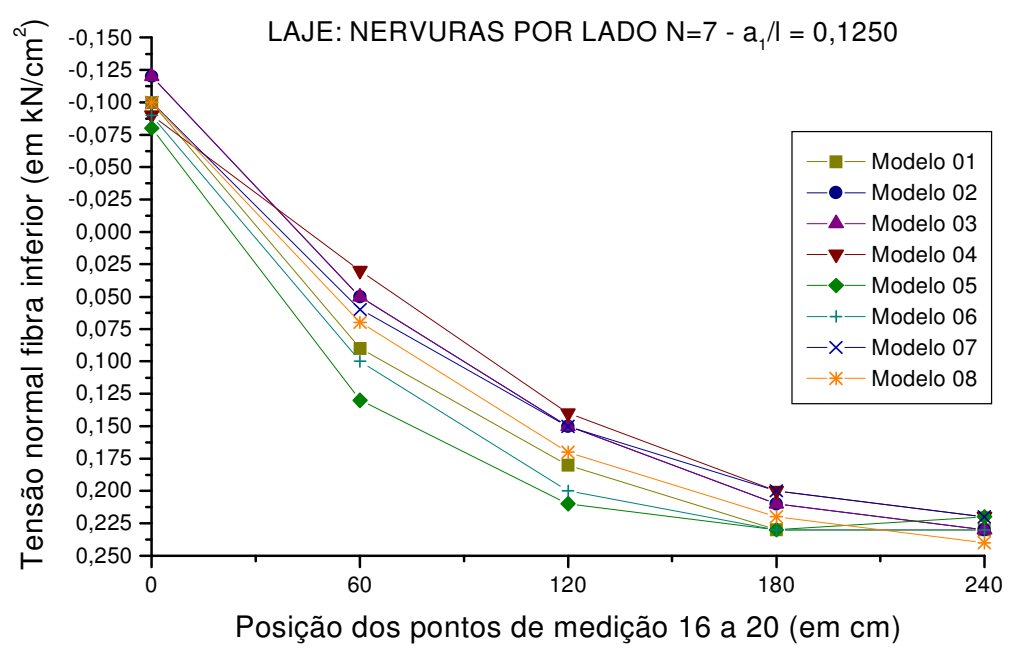

FIGURA 5.128: Tensões Normais fibras inferiores extremas $\left(\mathrm{kN} / \mathrm{cm}^{2}\right)$, na viga externa, na laje com $a_{1} / l=0,1250$

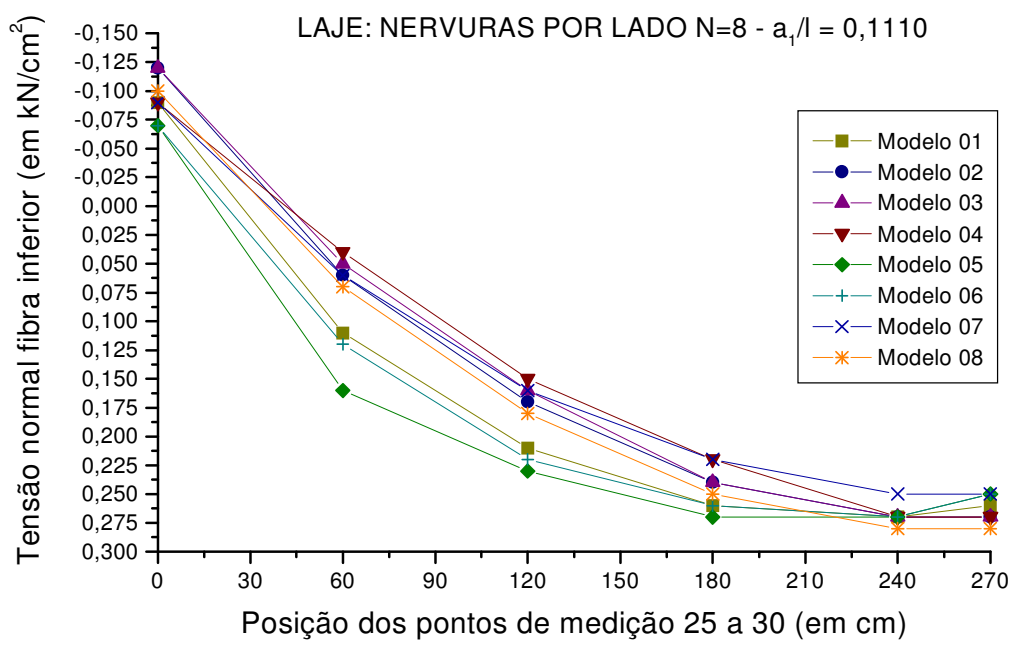

FIGURA 5.129: Tensões Normais fibras inferiores extremas $\left(\mathrm{kN} / \mathrm{cm}^{2}\right)$, na viga externa, na laje com $\mathrm{a}_{1} / \mathrm{l}=0,1111$ 


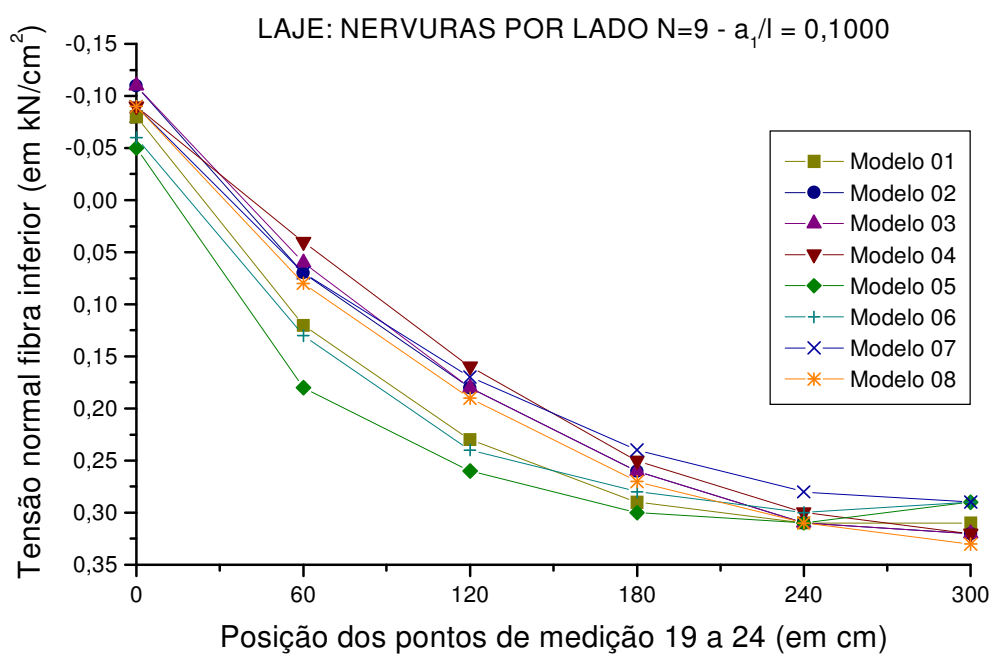

FIGURA 5.130: Tensões Normais fibras inferiores extremas $\left(\mathrm{kN} / \mathrm{cm}^{2}\right)$, na viga externa, na laje com $a_{1} / l=0,1000$

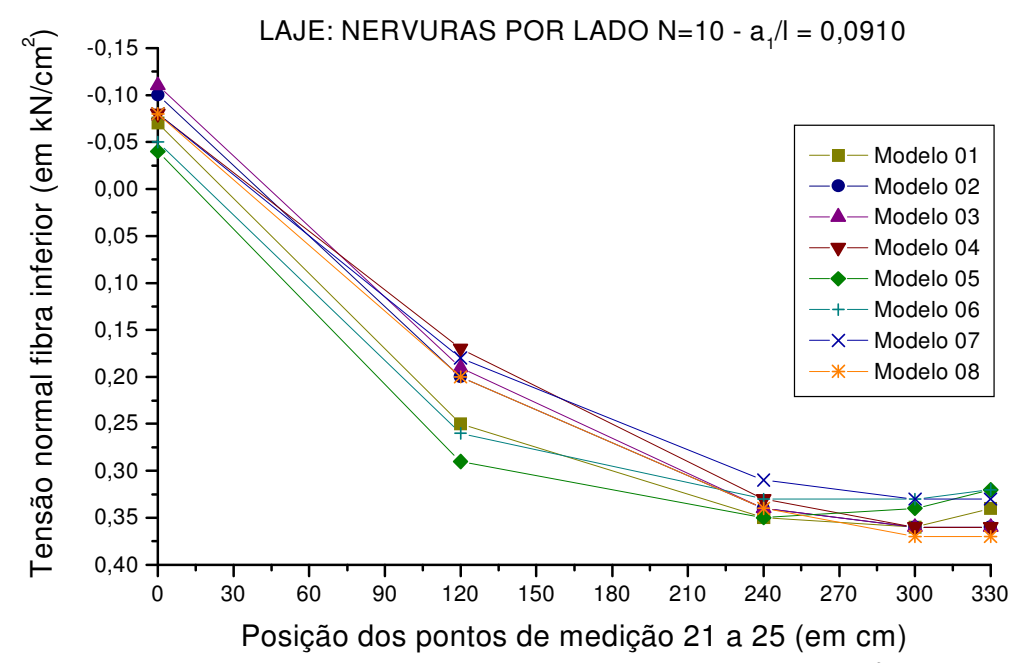

FIGURA 5.131: Tensões Normais fibras inferiores extremas $\left(\mathrm{kN} / \mathrm{cm}^{2}\right)$, na viga externa, na laje com $\mathrm{a}_{1} / \mathrm{l}=0,0910$

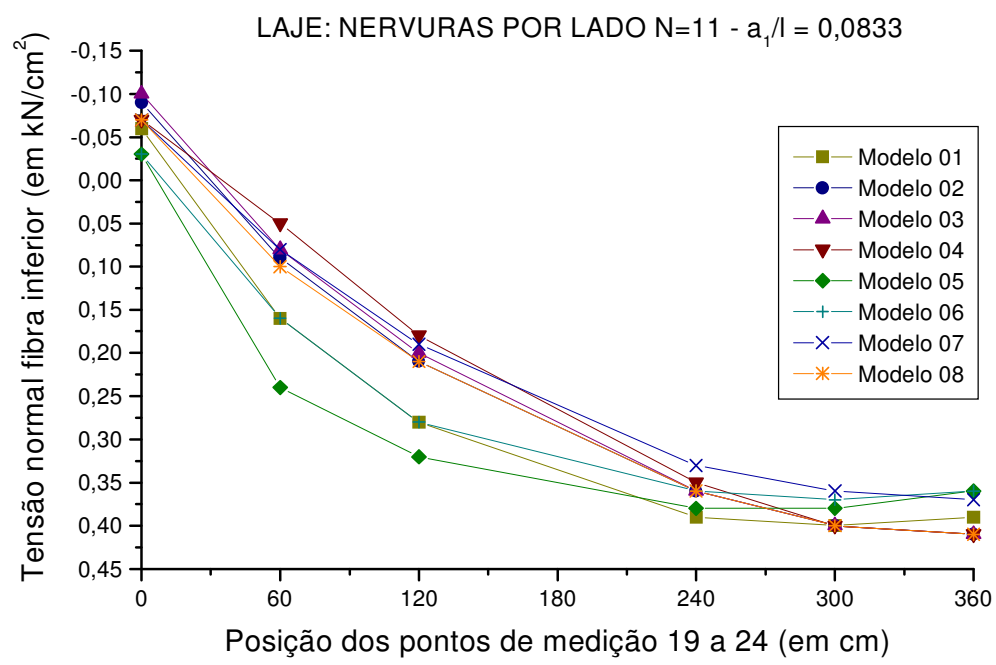

FIGURA 5.132: Tensões Normais fibras inferiores extremas $\left(\mathrm{kN} / \mathrm{cm}^{2}\right)$, na viga externa, na laje com $a_{1} / l=0,0833$ 


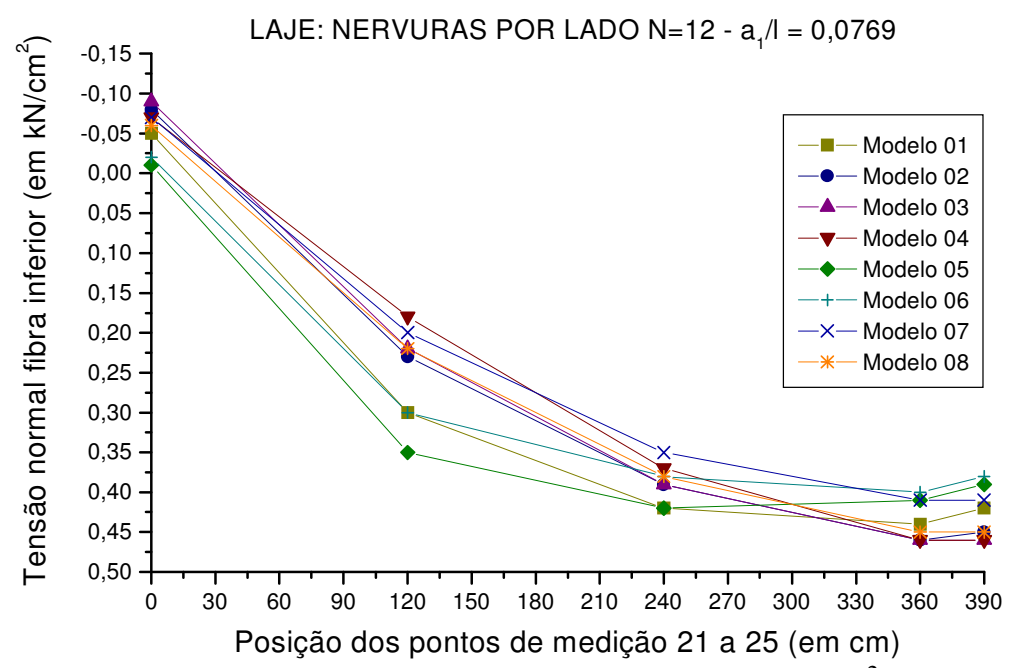

FIGURA 5.133: Tensões Normais fibras inferiores extremas $\left(\mathrm{kN} / \mathrm{cm}^{2}\right)$, na viga externa, na laje com $a_{1} / l=0,0769$

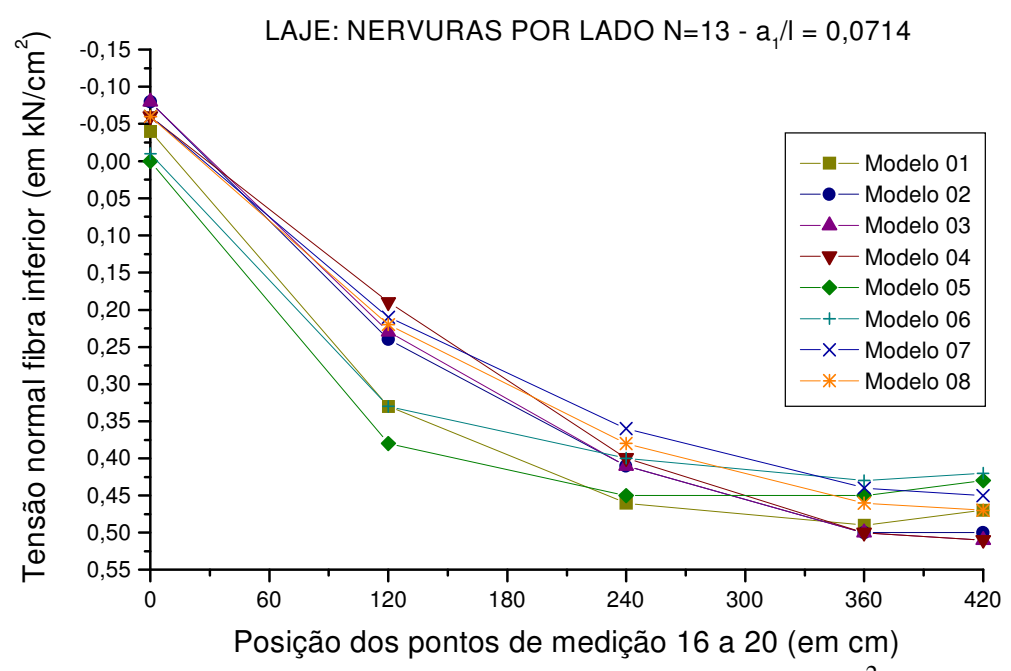

FIGURA 5.134: Tensões Normais fibras inferiores extremas $\left(\mathrm{kN} / \mathrm{cm}^{2}\right)$, na viga externa, na laje com $a_{1} / l=0,0714$

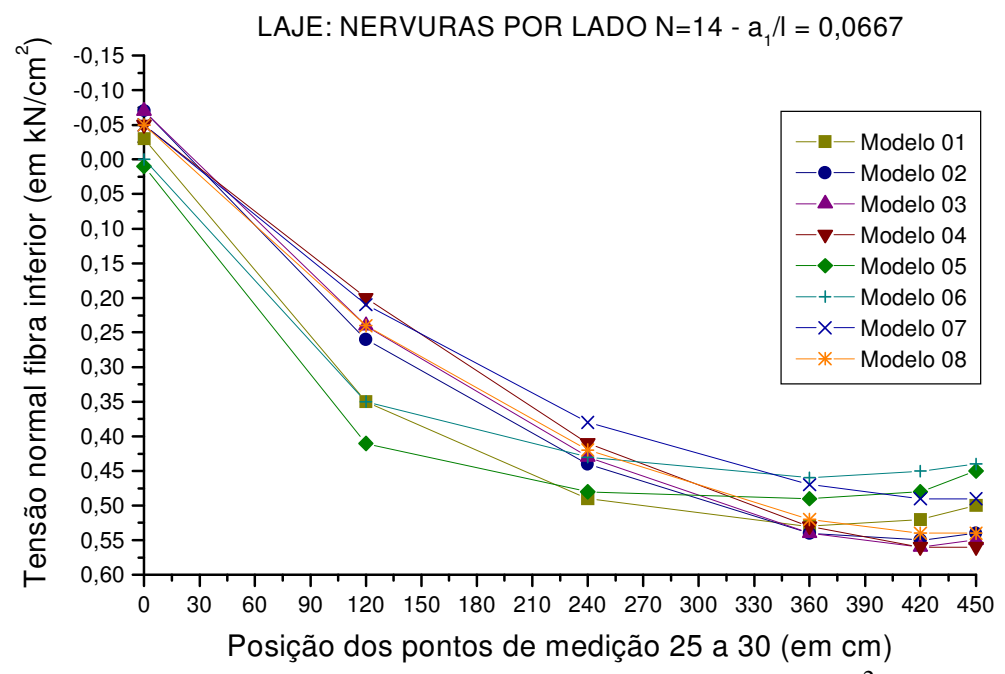

FIGURA 5.135: Tensões Normais fibras inferiores extremas $\left(\mathrm{kN} / \mathrm{cm}^{2}\right)$, na viga externa, na laje com $\mathrm{a}_{1} / \mathrm{l}=0,0667$ 


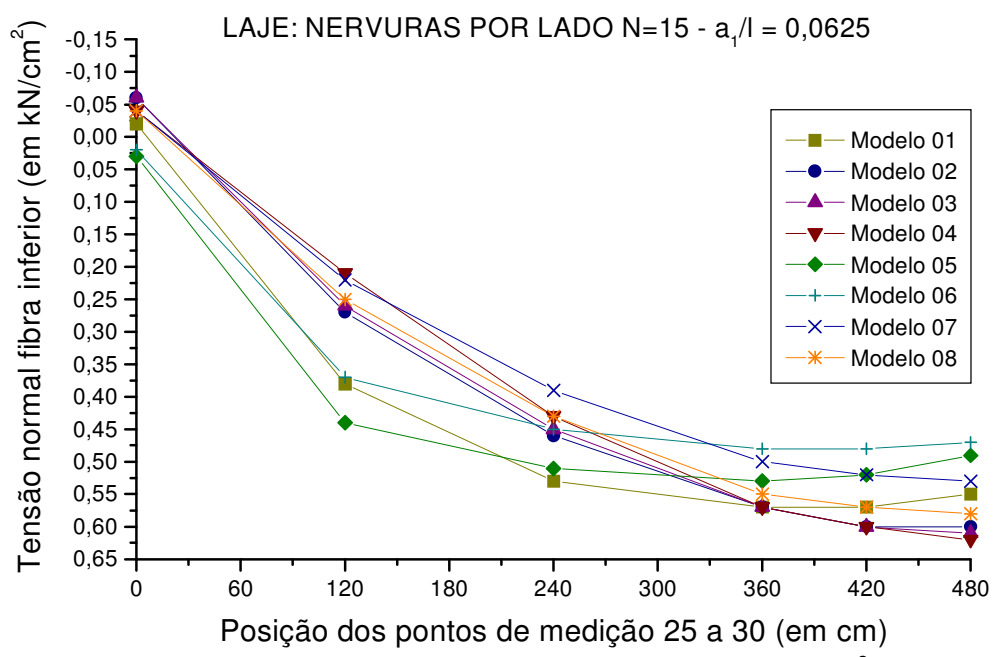

FIGURA 5.136: Tensões Normais fibras inferiores extremas $\left(\mathrm{kN} / \mathrm{cm}^{2}\right)$, na viga externa, na laje com $a_{1} / l=0,0625$

De acordo com as tabelas e gráficos de tensões normais extremas inferiores e superiores, nas vigas de contorno externo, nos modelos com variação da relação $a_{1} / l$, verificou-se que:

- as tensões máximas de tração, de maneira geral, convergem para resultados próximos entre os modelos, para todas as relações $a_{1} / l$; em pontos intermediários das nervuras, fora da posição de tensão máxima, vê-se que o Modelo 04 apresenta menores tensões que as fornecidas pelos demais modelos, na maioria das relações $a_{1} / 1$ testadas;

- verificou-se, porém, que à medida em que a relação $a_{1} / l$ é diminuída, as tensões de tração máximas fornecidas principalmente nos modelos 05, 06 e 07, pela viga simulada com o elemento excêntrico BEAM44, começam a ficar bem menores que aquelas dadas pelo Modelo 04, onde a viga é simulada pelo elemento SHELL63. Para a relação $a_{1} / l=0,0625$ tem-se uma diferença, entre o resultado de tensão máxima da viga dada pelo Modelo 06 em comparação com o modelo realista, de 24,2\%, menor para o Modelo 06. 
5.3.2.6 Esforços Cortantes atuantes nas nervuras e vigas

TABELA 5.157: Esforços Cortantes nas nervuras e vigas, em kN, na laje com 05 nervuras por lado

\begin{tabular}{|c|c|c|c|c|c|c|c|c|}
\hline \multicolumn{9}{|c|}{$\begin{array}{c}\text { LAJE COM RELAÇÃO a1/l=0,1667 } \\
\text { ESFORÇOS CORTANTES NAS NERVURAS E VIGAS }(\mathrm{kN})\end{array}$} \\
\hline \multirow{2}{*}{ Ponto } & \multicolumn{8}{|c|}{ Modelos numéricos de análise } \\
\hline & 01 & 02 & 03 & 04 & 05 & 06 & 07 & 08 \\
\hline 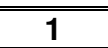 & 3,54 & 3,57 & 3,38 & $3, \mathbf{3 , 1 1}$ & 4,28 & 4,46 & 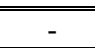 & 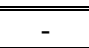 \\
\hline 2 & 2,40 & 2,18 & 2,09 & 2,16 & 2,66 & 2,56 & - & - \\
\hline 3 & 1,12 & 1,07 & 1,02 & 1,02 & 1,21 & 1,01 & - & - \\
\hline 4 & 0,04 & 0,04 & 0,04 & 0,00 & 0,04 & 0,34 & - & - \\
\hline 5 & 3,34 & 3,29 & 3,14 & 2,95 & 3,98 & 4,13 & - & - \\
\hline 6 & 2,31 & 2,20 & 2,09 & 2,03 & 2,40 & 2,26 & - & - \\
\hline 7 & 1,14 & 1,07 & 1,02 & 0,97 & 1,12 & 0,91 & - & - \\
\hline 8 & 0,05 & 0,04 & 0,04 & 0,00 & 0,05 & 0,24 & - & - \\
\hline 9 & 3,26 & 3,41 & 3,24 & 2,69 & 2,96 & 2,92 & - & - \\
\hline 10 & 2,19 & 2,07 & 1,97 & 1,74 & 1,76 & 1,57 & - & - \\
\hline 11 & 0,99 & 0,90 & 0,87 & 0,80 & 0,95 & 0,74 & - & - \\
\hline 12 & 0,08 & 0,08 & 0,06 & 0,00 & 0,22 & 0,06 & - & - \\
\hline 13 & 12,22 & 12,19 & 12,19 & 12,00 & 12,18 & 12,15 & 12,79 & 13,37 \\
\hline 14 & 11,31 & 10,68 & 10,67 & 9,22 & 11,47 & 11,64 & 9,94 & 11,56 \\
\hline 15 & 6,69 & 6,28 & 6,26 & 4,77 & 7,41 & 7,71 & 5,68 & 6,58 \\
\hline 16 & 1,89 & 1,89 & 1,84 & 0,00 & 2,22 & 2,57 & 0,66 & 0,75 \\
\hline
\end{tabular}

TABELA 5.158: Esforços Cortantes nas nervuras e vigas, em kN, na laje com 06 nervuras por lado

\section{LAJE COM RELAÇÃO a1/l=0,1429}

ESFORÇOS CORTANTES NAS NERVURAS E VIGAS (kN)

\begin{tabular}{c|c|c|c|c|c|c|c|c}
\hline \multirow{2}{*}{ Ponto } & \multicolumn{8}{|c|}{ Modelos numéricos de análise } \\
\cline { 2 - 9 } & $\mathbf{0 1}$ & $\mathbf{0 2}$ & $\mathbf{0 3}$ & $\mathbf{0 4}$ & $\mathbf{0 5}$ & $\mathbf{0 6}$ & $\mathbf{0 7}$ & $\mathbf{0 8}$ \\
\hline \hline $\mathbf{6}$ & 4,17 & 4,22 & 4,00 & $\mathbf{3 , 7 5}$ & 5,11 & 5,70 & - & - \\
\hline $\mathbf{7}$ & 2,83 & 2,73 & 2,63 & $\mathbf{2 , 7 6}$ & 3,39 & 3,68 & - & - \\
\hline $\mathbf{8}$ & 1,70 & 1,62 & 1,55 & $\mathbf{1 , 5 4}$ & 1,84 & 2,03 & - & - \\
\hline $\mathbf{9}$ & 0,54 & 0,51 & 0,49 & $\mathbf{0 , 4 9}$ & 0,58 & 0,68 & - & - \\
\hline $\mathbf{1 0}$ & 0,23 & 0,22 & 0,21 & $\mathbf{0 , 0 0}$ & 0,25 & 0,00 & - & - \\
\hline $\mathbf{1 1}$ & 3,83 & 4,18 & 3,99 & $\mathbf{3 , 0 0}$ & 3,16 & 3,43 & - & - \\
\hline $\mathbf{1 2}$ & 2,69 & 2,61 & 2,47 & $\mathbf{2 , 0 0}$ & 1,95 & 2,08 & - & - \\
\hline $\mathbf{1 3}$ & 1,40 & 1,25 & 1,22 & $\mathbf{1 , 0 6}$ & 1,21 & 1,35 & - & - \\
\hline $\mathbf{1 4}$ & 0,52 & 0,48 & 0,45 & $\mathbf{0 , 3 2}$ & 0,58 & 0,68 & - & - \\
\hline $\mathbf{1 5}$ & 0,22 & 0,21 & 0,20 & $\mathbf{0 , 0 0}$ & 0,24 & 0,00 & - & - \\
\hline \hline $\mathbf{1 6}$ & 16,63 & 16,60 & 16,60 & $\mathbf{1 6 , 4 0}$ & 16,58 & 16,54 & 17,39 & 18,00 \\
\hline $\mathbf{1 7}$ & 15,76 & 14,84 & 14,85 & $\mathbf{1 3 , 4 1}$ & 15,89 & 16,03 & 14,46 & 16,65 \\
\hline $\mathbf{1 8}$ & 10,52 & 9,71 & 9,71 & $\mathbf{8 , 4 4}$ & 11,63 & 11,93 & 9,56 & 11,07 \\
\hline $\mathbf{1 9}$ & 5,12 & 4,91 & 4,86 & $\mathbf{2 , 9 0}$ & 5,85 & 6,21 & 3,90 & 4,44 \\
\hline $\mathbf{2 0}$ & 0,24 & 0,20 & 0,21 & $\mathbf{0 , 0 0}$ & 0,21 & 0,17 & 0,79 & 0,89 \\
\hline \hline
\end{tabular}


TABELA 5.159: Esforços Cortantes nas nervuras e vigas, em kN, na laje com 07 nervuras por lado

\begin{tabular}{|c|c|c|c|c|c|c|c|c|}
\hline \multicolumn{9}{|c|}{$\begin{array}{c}\text { LAJE COM RELAÇÃO a1/l=0,1250 } \\
\text { ESFORÇOS CORTANTES NAS NERVURAS E VIGAS (kN) }\end{array}$} \\
\hline \multirow{2}{*}{ Ponto } & \multicolumn{8}{|c|}{ Modelos numéricos de análise } \\
\hline & 01 & 02 & 03 & 04 & 05 & 06 & 07 & 08 \\
\hline 1 & $\overline{4,94}$ & 5,08 & 4,81 & $\overline{4,51}$ & 6,09 & 6,43 & - & - \\
\hline 2 & 3,44 & 3,32 & 3,19 & 3,46 & 4,28 & 4,30 & - & - \\
\hline 3 & 2,23 & 2,14 & 2,06 & 2,12 & 2,59 & 2,50 & - & - \\
\hline 4 & 1,12 & 1,07 & 1,02 & 1,01 & 1,21 & 1,01 & - & - \\
\hline 5 & 0,04 & 0,04 & 0,04 & 0,00 & 0,04 & 0,34 & - & - \\
\hline 6 & 4,36 & 4,26 & 4,13 & 3,77 & 4,94 & 5,17 & - & - \\
\hline 7 & 3,49 & 3,33 & 3,16 & 2,83 & 3,23 & 3,46 & - & - \\
\hline 8 & 2,29 & 2,18 & 2,06 & 1,75 & 1,95 & 1,77 & - & - \\
\hline 9 & 1,09 & 1,03 & 0,98 & 0,82 & 1,01 & 1,13 & - & - \\
\hline 10 & 0,02 & 0,00 & 0,00 & 0,00 & 0,16 & 0,22 & - & - \\
\hline$\overline{111}$ & $4,4,37$ & $4,4,98$ & 4,75 & 3,28 & 3,30 & 3,20 & - & - \\
\hline 12 & 3,17 & 3,14 & 2,96 & 2,25 & 2,10 & 1,85 & - & - \\
\hline 13 & 1,80 & 1,59 & 1,55 & 1,28 & 1,39 & 1,20 & - & - \\
\hline 14 & 0,86 & 0,74 & 0,72 & 0,55 & 0,84 & 0,62 & - & - \\
\hline 15 & 0,18 & 0,20 & 0,17 & 0,00 & 0,32 & 0,05 & - & - \\
\hline 16 & 21,72 & 21,68 & 21,68 & 21,48 & 21,66 & 21,60 & 22,65 & 23,31 \\
\hline 17 & 20,90 & 19,63 & 19,67 & 18,32 & 20,99 & 21,09 & 19,77 & 22,55 \\
\hline 18 & 15,09 & 13,72 & 13,76 & 12,89 & 16,58 & 16,88 & 14,19 & 16,46 \\
\hline 19 & 9,08 & 8,52 & 8,47 & 6,72 & 10,35 & 10,70 & 8,02 & 9,13 \\
\hline 20 & 2,62 & 2,67 & 2,61 & 0,00 & 3,14 & 3,55 & 0,92 & 1,03 \\
\hline
\end{tabular}

TABELA 5.160: Esforços Cortantes nas nervuras e vigas, em kN, na laje com 08 nervuras por lado

\begin{tabular}{|c|c|c|c|c|c|c|c|c|}
\hline \multicolumn{9}{|c|}{$\begin{array}{l}\text { LAJE COM RELAÇÃO a1/l=0,1111 } \\
\text { ESFORÇOS CORTANTES NAS NERVURAS E VIGAS }(\mathrm{kN})\end{array}$} \\
\hline \multirow{2}{*}{ Ponto } & \multicolumn{8}{|c|}{ Modelos numéricos de análise } \\
\hline & 01 & $\mathbf{0 2}$ & $\mathbf{0 3}$ & 04 & 05 & 06 & 07 & 08 \\
\hline 7 & 5,60 & 5,78 & 5,47 & 5,17 & 6,95 & 7,69 & - & 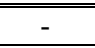 \\
\hline 8 & 4,06 & 3,91 & 3,75 & 4,09 & 5,07 & 5,48 & - & - \\
\hline 9 & 2,81 & 2,69 & 2,59 & 2,68 & 3,29 & 3,59 & - & - \\
\hline 10 & 1,69 & 1,62 & 1,55 & 1,52 & 1,84 & 2,03 & - & - \\
\hline 11 & 0,54 & 0,51 & 0,49 & 0,49 & 0,58 & 0,68 & - & - \\
\hline 12 & 0,23 & 0,22 & 0,21 & 0,00 & 0,25 & 0,00 & - & - \\
\hline 13 & $\begin{array}{l}4,89 \\
\end{array}$ & $4,8,83$ & $4 \overline{4,72}$ & 4,10 & $5,5,30$ & 25,55 & - & - \\
\hline 14 & 4,05 & 3,89 & 3,69 & 3,16 & 3,54 & 3,44 & - & - \\
\hline 15 & 2,84 & 2,72 & 2,58 & 2,08 & 2,26 & 2,09 & - & - \\
\hline 16 & 1,61 & 1,51 & 1,45 & 1,15 & 1,35 & 1,15 & - & - \\
\hline 17 & 0,53 & 0,51 & 0,49 & 0,36 & 0,58 & 0,34 & - & - \\
\hline 18 & 0,22 & 0,22 & 0,21 & 0,00 & 0,25 & 0,34 & - & - \\
\hline 19 & $4,8,88$ & 5,77 & 5,50 & 3,55 & 3,41 & 3,61 & - & - \\
\hline 20 & 3,61 & 3,65 & 3,42 & 2,48 & 2,20 & 2,26 & - & - \\
\hline 21 & 2,19 & 1,95 & 1,90 & 1,48 & 1,52 & 1,67 & - & - \\
\hline 22 & 1,16 & 0,95 & 0,93 & 0,73 & 1,03 & 1,17 & - & - \\
\hline 23 & 0,52 & 0,46 & 0,43 & 0,21 & 0,58 & 0,68 & - & - \\
\hline 24 & 0,22 & 0,20 & 0,19 & 0,00 & 0,24 & 0,00 & - & - \\
\hline 25 & 27,47 & 27,43 & 27,43 & 27,12 & 27,41 & 27,34 & 28,58 & 29,28 \\
\hline 26 & 26,72 & 25,04 & 25,10 & 23,64 & 26,76 & 26,83 & 25,87 & 29,25 \\
\hline 27 & 20,40 & 18,33 & 18,42 & 17,88 & 22,25 & 22,55 & 19,59 & 22,72 \\
\hline 28 & 13,79 & 12,67 & 12,63 & 11,25 & 15,65 & 15,99 & 12,93 & 14,75 \\
\hline 29 & 6,72 & 6,47 & 6,39 & 3,85 & 7,79 & 8,19 & 5,17 & 5,82 \\
\hline 30 & 0,28 & 0,20 & 0,22 & 0,00 & 0,23 & 0,17 & 1,04 & 1,17 \\
\hline
\end{tabular}


TABELA 5.161: Esforços Cortantes nas nervuras e vigas, em kN, na laje com 09 nervuras por lado

LAJE COM RELAÇÃ $O$ a1/l=0,1000

ESFORÇOS CORTANTES NAS NERVURAS E VIGAS (kN)

\begin{tabular}{c|c|c|c|c|c|c|c|c}
\hline \multirow{2}{*}{ Ponto } & \multicolumn{7}{|c}{ Modelos numéricos de análise } & $\mathbf{0 8}$ \\
\cline { 2 - 9 } & $\mathbf{0 1}$ & $\mathbf{0 2}$ & $\mathbf{0 3}$ & $\mathbf{0 4}$ & $\mathbf{0 5}$ & $\mathbf{0 6}$ & $\mathbf{0 7}$ & $\mathbf{0 8}$ \\
\hline \hline $\mathbf{1}$ & 6,38 & 6,65 & 6,30 & $\mathbf{5 , 9 3}$ & 7,95 & 8,75 & - & - \\
\hline $\mathbf{2}$ & 4,74 & 4,58 & 4,38 & $\mathbf{4 , 8 2}$ & 6,02 & 6,47 & - & - \\
\hline $\mathbf{3}$ & 3,38 & 3,23 & 3,11 & $\mathbf{3 , 3 2}$ & 4,13 & 4,16 & - & - \\
\hline $\mathbf{4}$ & 2,24 & 2,15 & 2,06 & $\mathbf{2 , 0 8}$ & 2,55 & 2,80 & - & - \\
\hline $\mathbf{5}$ & 1,12 & 1,07 & 1,02 & $\mathbf{1 , 0 0}$ & 1,21 & 1,35 & - & - \\
\hline $\mathbf{6}$ & 0,04 & 0,04 & 0,04 & $\mathbf{0 , 0 0}$ & 0,04 & 0,00 & - & - \\
\hline $\mathbf{7}$ & 5,69 & 5,62 & 5,42 & $\mathbf{5 , 1 5}$ & 6,94 & 7,34 & - & - \\
\hline $\mathbf{8}$ & 4,59 & 4,32 & 4,15 & $\mathbf{4 , 1 3}$ & 5,02 & 5,08 & - & - \\
\hline $\mathbf{9}$ & 3,48 & 3,33 & 3,17 & $\mathbf{2 , 8 7}$ & 3,35 & 3,28 & - & - \\
\hline $\mathbf{1 0}$ & 2,31 & 2,21 & 2,10 & $\mathbf{1 , 8 0}$ & 2,08 & 2,26 & - & - \\
\hline $\mathbf{1 1}$ & 1,12 & 1,07 & 1,02 & $\mathbf{0 , 8 6}$ & 1,05 & 0,84 & - & - \\
\hline $\mathbf{1 2}$ & 0,05 & 0,04 & 0,04 & $\mathbf{0 , 0 0}$ & 0,11 & 0,17 & - & - \\
\hline \hline $\mathbf{1 3}$ & 5,36 & 6,53 & 6,21 & $\mathbf{3 , 8 2}$ & 3,49 & 3,31 & - & - \\
\hline $\mathbf{1 4}$ & 4,02 & 4,13 & 3,85 & $\mathbf{2 , 7 0}$ & 2,28 & 1,96 & - & - \\
\hline $\mathbf{1 5}$ & 2,57 & 2,31 & 2,24 & $\mathbf{1 , 6 7}$ & 1,62 & 1,42 & - & - \\
\hline $\mathbf{1 6}$ & 1,46 & 1,15 & 1,14 & $\mathbf{0 , 8 9}$ & 1,17 & 0,98 & - & - \\
\hline $\mathbf{1 7}$ & 0,78 & 0,62 & 0,59 & $\mathbf{0 , 3 7}$ & 0,77 & 0,55 & - & - \\
\hline $\mathbf{1 8}$ & 0,26 & 0,28 & 0,24 & $\mathbf{0 , 0 0}$ & 0,39 & 0,12 & - & - \\
\hline $\mathbf{1 9}$ & 33,90 & 33,86 & 33,86 & $\mathbf{3 3 , 5 9}$ & 33,83 & 33,75 & 35,19 & 35,93 \\
\hline $\mathbf{2 0}$ & 33,23 & 31,07 & 31,17 & $\mathbf{2 9 , 9 1}$ & 33,20 & 33,24 & 32,74 & 36,74 \\
\hline $\mathbf{2 1}$ & 26,44 & 23,54 & 23,69 & $\mathbf{2 3 , 7 6}$ & 28,63 & 28,92 & 25,76 & 29,85 \\
\hline $\mathbf{2 2}$ & 19,23 & 17,34 & 17,33 & $\mathbf{1 6 , 6 7}$ & 21,73 & 22,05 & 18,58 & 21,27 \\
\hline $\mathbf{2 3}$ & 11,59 & 10,84 & 10,75 & $\mathbf{8 , 6 2}$ & 13,33 & 13,70 & 10,30 & 11,62 \\
\hline $\mathbf{2 4}$ & 3,37 & 3,48 & 3,40 & $\mathbf{0 , 0 0}$ & 4,09 & 4,54 & 1,17 & 1,31 \\
\hline \hline
\end{tabular}

TABELA 5.162: Esforços Cortantes nas nervuras e vigas, em kN, na laje com 10 nervuras por lado

LAJE COM RELAÇÃO a1/l=0,0910

ESFORÇOS CORTANTES NAS NERVURAS E VIGAS (kN)

\begin{tabular}{c|c|c|c|c|c|c|c|c}
\hline \multirow{2}{*}{ Ponto } & \multicolumn{7}{c}{ Modelos numéricos de análise } \\
\cline { 2 - 9 } & $\mathbf{0 1}$ & $\mathbf{0 2}$ & $\mathbf{0 3}$ & $\mathbf{0 4}$ & $\mathbf{0 5}$ & $\mathbf{0 6}$ & $\mathbf{0 7}$ & $\mathbf{0 8}$ \\
\hline \hline $\mathbf{6}$ & 7,06 & 7,36 & 6,98 & $\mathbf{6 , 6 0}$ & 8,84 & 9,68 & - & - \\
\hline $\mathbf{7}$ & 3,98 & 3,80 & 3,65 & $\mathbf{3 , 9 1}$ & 4,89 & 4,97 & - & - \\
\hline $\mathbf{8}$ & 1,69 & 1,62 & 1,55 & $\mathbf{1 , 5 0}$ & 1,83 & 2,03 & - & - \\
\hline $\mathbf{9}$ & 0,54 & 0,51 & 0,49 & $\mathbf{0 , 4 9}$ & 0,58 & 0,68 & - & - \\
\hline $\mathbf{1 0}$ & 0,27 & 0,22 & 0,21 & $\mathbf{0 , 0 0}$ & 0,25 & 0,00 & - & - \\
\hline \hline $\mathbf{1 1}$ & 6,18 & 6,08 & 5,89 & $\mathbf{5 , 5 0}$ & 7,38 & 7,81 & - & - \\
\hline $\mathbf{1 2}$ & 4,06 & 3,89 & 3,69 & $\mathbf{3 , 2 4}$ & 3,73 & 3,67 & - & - \\
\hline $\mathbf{1 3}$ & 1,68 & 1,60 & 1,52 & $\mathbf{1 , 2 3}$ & 1,46 & 1,27 & - & - \\
\hline $\mathbf{1 4}$ & 0,54 & 0,51 & 0,49 & $\mathbf{0 , 4 0}$ & 0,58 & 0,34 & - & - \\
\hline $\mathbf{1 5}$ & 0,22 & 0,22 & 0,21 & $\mathbf{0 , 0 0}$ & 0,25 & 0,34 & - & - \\
\hline \hline $\mathbf{1 6}$ & 5,80 & 7,26 & 6,88 & $\mathbf{4 , 0 7}$ & 3,55 & 3,34 & - & - \\
\hline $\mathbf{1 7}$ & 2,94 & 2,68 & 2,59 & $\mathbf{1 , 8 5}$ & 1,69 & 1,49 & - & - \\
\hline $\mathbf{1 8}$ & 1,01 & 0,73 & 0,71 & $\mathbf{0 , 4 9}$ & 0,92 & 0,71 & - & - \\
\hline $\mathbf{1 9}$ & 0,51 & 0,44 & 0,40 & $\mathbf{0 , 1 4}$ & 0,58 & 0,34 & - & - \\
\hline $\mathbf{2 0}$ & 0,22 & 0,19 & 0,18 & $\mathbf{0 , 0 0}$ & 0,25 & 0,34 & - & - \\
\hline \hline $\mathbf{2 1}$ & 41,00 & 40,96 & 40,96 & $\mathbf{4 0 , 7 4}$ & 40,93 & 40,84 & 42,47 & 43,26 \\
\hline $\mathbf{2 2}$ & 33,21 & 29,35 & 29,57 & $\mathbf{3 0 , 3 5}$ & 35,70 & 35,98 & 32,71 & 37,84 \\
\hline $\mathbf{2 3}$ & 17,20 & 15,73 & 15,65 & $\mathbf{1 4 , 2 4}$ & 19,70 & 20,04 & 16,23 & 18,35 \\
\hline $\mathbf{2 4}$ & 8,36 & 8,02 & 7,92 & $\mathbf{4 , 8 4}$ & 9,76 & 10,18 & 6,41 & 7,19 \\
\hline $\mathbf{2 5}$ & 0,32 & 0,19 & 0,21 & $\mathbf{0 , 0 0}$ & 0,25 & 0,17 & 1,29 & 1,44 \\
\hline \hline
\end{tabular}


TABELA 5.163: Esforços Cortantes nas nervuras e vigas, em kN, na laje com 11 nervuras por lado

\begin{tabular}{|c|c|c|c|c|c|c|c|c|}
\hline \multicolumn{9}{|c|}{$\begin{array}{c}\text { LAJE COM RELAÇÃO a1/l=0,0833 } \\
\text { ESFORÇOS CORTANTES NAS NERVURAS E VIGAS (kN) }\end{array}$} \\
\hline \multirow{2}{*}{ Ponto } & \multicolumn{8}{|c|}{ Modelos numéricos de análise } \\
\hline & 01 & 02 & 03 & 04 & 05 & 06 & 07 & 08 \\
\hline 1 & 7,86 & 8,24 & $7,8,81$ & 7,36 & 9,84 & 10,40 & - & - \\
\hline 2 & 6,12 & 5,91 & 5,64 & 6,21 & 7,82 & 8,02 & - & - \\
\hline 3 & 4,60 & 4,39 & 4,22 & 4,58 & 5,78 & 5,91 & - & - \\
\hline 4 & 2,25 & 2,15 & 2,06 & 2,04 & 2,52 & 2,44 & - & - \\
\hline 5 & 1,12 & 1,07 & 1,02 & 0,99 & 1,21 & 1,01 & - & - \\
\hline 6 & 0,04 & 0,04 & 0,04 & 0,00 & 0,04 & 0,00 & - & - \\
\hline$\overline{77}$ & 7,18 & 7,23 & $6,9,92$ & 6,63 & 8,93 & 9,79 & - & - \\
\hline 8 & 5,84 & 5,46 & 5,25 & 5,53 & 6,91 & 7,43 & - & - \\
\hline 9 & 4,61 & 4,38 & 4,19 & 4,10 & 4,99 & 5,40 & - & - \\
\hline 10 & 2,31 & 2,21 & 2,11 & 1,84 & 2,16 & 2,37 & - & - \\
\hline 11 & 1,13 & 1,08 & 1,03 & 0,89 & 1,09 & 1,22 & - & - \\
\hline 12 & 0,05 & 0,05 & 0,05 & 0,00 & 0,08 & 0,21 & - & - \\
\hline 13 & 6,58 & 6,92 & 6,82 & 4,98 & 6,03 & 6,32 & - & - \\
\hline 14 & 5,62 & 5,57 & 5,25 & 4,01 & 4,20 & 4,09 & - & - \\
\hline 15 & 4,35 & 4,32 & 4,07 & 2,94 & 2,91 & 2,74 & - & - \\
\hline 16 & 1,85 & 1,71 & 1,66 & 1,17 & 1,41 & 1,23 & - & - \\
\hline 17 & 0,93 & 0,87 & 0,84 & 0,54 & 0,85 & 0,63 & - & - \\
\hline 18 & 0,12 & 0,16 & 0,13 & 0,00 & 0,32 & 0,04 & - & - \\
\hline 19 & 48,79 & 48,74 & 48,74 & 48,55 & 48,71 & 48,60 & 50,43 & $\overline{51,26}$ \\
\hline 20 & 48,28 & 44,99 & 45,17 & 44,55 & 48,10 & 48,09 & 48,78 & 54,03 \\
\hline 21 & 40,71 & 35,75 & 36,06 & 37,64 & 43,45 & 43,73 & 40,44 & 46,68 \\
\hline 22 & 23,56 & 21,11 & 21,05 & 20,66 & 26,87 & 27,17 & 22,92 & 26,00 \\
\hline 23 & 14,14 & 13,12 & 13,01 & 10,59 & 16,33 & 16,71 & 12,54 & 14,07 \\
\hline 24 & 4,14 & 4,30 & 4,20 & 0,00 & 5,04 & 5,36 & 1,41 & 1,58 \\
\hline
\end{tabular}

TABELA 5.164: Esforços Cortantes nas nervuras e vigas, em kN, na laje com 12 nervuras por lado

\begin{tabular}{c|c|c|c|c|c|c|c|c}
\hline \hline \multicolumn{7}{c}{ LAJE COM RELAÇÃO a1/l=0,0769 } \\
\multicolumn{2}{c}{ Ponto } & \multicolumn{7}{c}{ Modelos numéricos de análise } \\
\cline { 2 - 10 } & $\mathbf{0 1}$ & $\mathbf{0 2}$ & $\mathbf{0 3}$ & $\mathbf{0 4}$ & $\mathbf{0 5}$ & $\mathbf{0 6}$ & $\mathbf{0 7}$ & $\mathbf{0 8}$ \\
\hline \hline $\mathbf{6}$ & 8,55 & 8,96 & 8,50 & $\mathbf{8 , 0 4}$ & 10,74 & 11,34 & - & - \\
\hline $\mathbf{7}$ & 5,24 & 4,99 & 4,78 & $\mathbf{5 , 2 0}$ & 6,59 & 6,76 & - & - \\
\hline $\mathbf{8}$ & 2,82 & 2,69 & 2,58 & $\mathbf{2 , 5 7}$ & 3,20 & 3,16 & - & - \\
\hline $\mathbf{9}$ & 0,54 & 0,51 & 0,49 & $\mathbf{0 , 4 9}$ & 0,58 & 0,34 & - & - \\
\hline $\mathbf{1 0}$ & 0,23 & 0,22 & 0,21 & $\mathbf{0 , 0 0}$ & 0,25 & 0,34 & - & - \\
\hline \hline $\mathbf{1 1}$ & 7,66 & 7,64 & 7,34 & $\mathbf{7 , 0 0}$ & 9,44 & 9,98 & - & - \\
\hline $\mathbf{1 2}$ & 5,18 & 4,92 & 4,71 & $\mathbf{4 , 4 9}$ & 5,43 & 5,52 & - & - \\
\hline $\mathbf{1 3}$ & 2,88 & 2,77 & 2,64 & $\mathbf{2 , 2 4}$ & 2,59 & 2,48 & - & - \\
\hline $\mathbf{1 4}$ & 0,54 & 0,51 & 0,49 & $\mathbf{0 , 4 2}$ & 0,58 & 0,68 & - & - \\
\hline $\mathbf{1 5}$ & 0,23 & 0,22 & 0,21 & $\mathbf{0 , 0 0}$ & 0,25 & 0,00 & - & - \\
\hline \hline $\mathbf{1 6}$ & 7,14 & 7,69 & 7,58 & $\mathbf{5 , 2 6}$ & 6,19 & 6,84 & - & - \\
\hline $\mathbf{1 7}$ & 4,82 & 4,83 & 4,55 & $\mathbf{3 , 2 0}$ & 3,07 & 3,22 & - & - \\
\hline $\mathbf{1 8}$ & 2,24 & 2,08 & 2,02 & $\mathbf{1 , 4 0}$ & 1,59 & 1,77 & - & - \\
\hline $\mathbf{1 9}$ & 0,52 & 0,51 & 0,48 & $\mathbf{0 , 2 4}$ & 0,58 & 0,68 & - & - \\
\hline $\mathbf{2 0}$ & 0,22 & 0,22 & 0,21 & $\mathbf{0 , 0 0}$ & 0,25 & 0,00 & - & - \\
\hline \hline $\mathbf{2 1}$ & 57,25 & 57,20 & 57,20 & $\mathbf{5 7 , 0 3}$ & 57,16 & 57,04 & 59,07 & 59,94 \\
\hline $\mathbf{2 2}$ & 48,93 & 42,76 & 43,15 & $\mathbf{4 5 , 6 4}$ & 51,89 & 52,16 & 48,97 & 56,37 \\
\hline $\mathbf{2 3}$ & 30,65 & 26,97 & 26,93 & $\mathbf{2 7 , 8 6}$ & 34,83 & 35,07 & 30,35 & 34,55 \\
\hline $\mathbf{2 4}$ & 10,02 & 9,55 & 9,43 & $\mathbf{5 , 8 2}$ & 11,74 & 12,18 & 7,64 & 8,54 \\
\hline $\mathbf{2 5}$ & 0,35 & 0,18 & 0,20 & $\mathbf{0 , 0 0}$ & 0,26 & 0,17 & 1,53 & 1,71 \\
\hline \hline
\end{tabular}


TABELA 5.165: Esforços Cortantes nas nervuras e vigas, em kN, na laje com 13 nervuras por lado

\begin{tabular}{|c|c|c|c|c|c|c|c|c|}
\hline \multicolumn{9}{|c|}{$\begin{array}{c}\text { LAJE COM RELAÇÃO a1/l=0,0714 } \\
\text { ESFORÇOS CORTANTES NAS NERVURAS E VIGAS }(\mathrm{kN})\end{array}$} \\
\hline \multirow{2}{*}{ Ponto } & \multicolumn{8}{|c|}{ Modelos numéricos de análise } \\
\hline & 01 & 02 & 03 & 04 & 05 & 06 & 07 & 08 \\
\hline 1 & 9,35 & 9,82 & 9,31 & 8,80 & 11,74 & 12,73 & - & - \\
\hline 2 & 5,90 & 5,62 & 5,38 & 5,88 & 7,51 & 8,07 & - & - \\
\hline 3 & 3,38 & 3,22 & 3,09 & 3,14 & 3,96 & 4,31 & - & - \\
\hline 4 & 1,12 & 1,07 & 1,02 & 0,99 & 1,21 & 1,35 & - & - \\
\hline 5 & 0,04 & 0,04 & 0,04 & 0,00 & 0,04 & 0,34 & - & - \\
\hline 6 & 8,72 & 8,90 & 8,48 & 8,13 & 10,92 & 1011,54 & - & - \\
\hline 7 & 5,79 & 5,47 & 5,25 & 5,40 & 6,75 & 6,94 & - & - \\
\hline 8 & 3,46 & 3,32 & 3,17 & 2,91 & 3,49 & 3,45 & - & - \\
\hline 9 & 1,13 & 1,08 & 1,03 & 0,91 & 1,11 & 0,91 & - & - \\
\hline 10 & 0,05 & 0,06 & 0,05 & 0,00 & 0,05 & 0,23 & - & - \\
\hline 11 & 7,69 & 8,49 & 8,35 & 5,55 & 6,33 & 6,66 & - & - \\
\hline 12 & 5,27 & 5,34 & 5,02 & 3,45 & 3,20 & 3,01 & - & - \\
\hline 13 & 2,62 & 2,45 & 2,38 & 1,61 & 1,74 & 1,94 & - & - \\
\hline 14 & 0,86 & 0,80 & 0,77 & 0,43 & 0,80 & 0,92 & - & - \\
\hline 15 & 0,18 & 0,23 & 0,20 & 0,00 & 0,37 & 0,43 & - & - \\
\hline 16 & $\bar{~} 66,38$ & 266,33 & 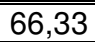 & 65,96 & 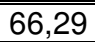 & 266,15 & 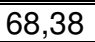 & 67,95 \\
\hline 17 & 57,86 & 50,36 & 50,84 & 54,04 & 61,01 & 61,28 & 58,30 & 59,38 \\
\hline 18 & 38,48 & 33,29 & 33,29 & 35,61 & 43,54 & 43,73 & 38,52 & 38,06 \\
\hline 19 & 16,71 & 15,35 & 15,22 & 12,49 & 19,34 & 19,72 & 14,76 & 14,28 \\
\hline 20 & 4,92 & 5,12 & 5,00 & 0,00 & 6,07 & 6,53 & 1,66 & 1,60 \\
\hline
\end{tabular}

TABELA 5.166: Esforços Cortantes nas nervuras e vigas, em kN, na laje com 14 nervuras por lado

\begin{tabular}{|c|c|c|c|c|c|c|c|c|}
\hline \multicolumn{9}{|c|}{$\begin{array}{l}\text { LAJE COM RELAÇÃ̃ a1/l=0,0667 } \\
\text { ESFORÇOS CORTANTES NAS NERVURAS E VIGAS }(\mathrm{kN})\end{array}$} \\
\hline \multirow{2}{*}{ Ponto } & \multicolumn{8}{|c|}{ Modelos numéricos de análise } \\
\hline & 01 & 02 & 03 & 04 & 05 & 06 & 07 & 08 \\
\hline 7 & 10,07 & 10,56 & 10,01 & 9,48 & 12,65 & 13,34 & 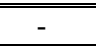 & - \\
\hline 8 & 6,56 & 6,24 & 5,97 & 6,52 & 8,35 & 8,61 & - & - \\
\hline 9 & 3,97 & 3,77 & 3,62 & 3,70 & 4,68 & 4,75 & - & - \\
\hline 10 & 1,69 & 1,62 & 1,55 & 1,49 & 1,83 & 1,69 & - & - \\
\hline 11 & 0,54 & 0,51 & 0,49 & 0,49 & 0,58 & 0,68 & - & - \\
\hline 12 & 0,23 & 0,22 & 0,21 & 0,00 & 0,25 & 0,00 & - & - \\
\hline 13 & 9,21 & 9,31 & 8,89 & 8,53 & 11,47 & 12,45 & - & 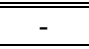 \\
\hline 14 & 6,36 & 5,99 & 5,75 & 5,81 & 7,25 & 7,80 & - & - \\
\hline 15 & 4,04 & 3,89 & 3,71 & 3,33 & 3,95 & 4,28 & - & - \\
\hline 16 & 1,71 & 1,64 & 1,56 & 1,33 & 1,59 & 1,76 & - & - \\
\hline 17 & 0,54 & 0,51 & 0,49 & 0,44 & 0,58 & 0,68 & - & - \\
\hline 18 & 0,23 & 0,22 & 0,21 & 0,00 & 0,25 & 0,00 & - & - \\
\hline 19 & 8,23 & 9,29 & 9,11 & 5,83 & 6,45 & 7,14 & - & 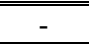 \\
\hline 20 & 5,70 & 5,83 & 5,48 & 3,70 & 3,32 & 3,46 & - & - \\
\hline 21 & 2,99 & 2,83 & 2,75 & 1,81 & 1,87 & 1,75 & - & - \\
\hline 22 & 1,17 & 1,05 & 1,03 & 0,61 & 0,98 & 0,78 & - & - \\
\hline 23 & 0,52 & 0,52 & 0,48 & 0,19 & 0,58 & 0,34 & - & - \\
\hline 24 & 0,22 & 0,22 & 0,21 & 0,00 & 0,25 & 0,34 & - & - \\
\hline 25 & 76,19 & 76,13 & 76,13 & 75,87 & 76,09 & 75,94 & 78,37 & 79,33 \\
\hline 26 & 67,51 & 58,54 & 59,12 & 63,38 & 70,80 & 71,07 & 68,43 & 78,24 \\
\hline 27 & 47,05 & 40,08 & 40,14 & 44,24 & 52,99 & 53,13 & 47,41 & 54,28 \\
\hline 28 & 24,17 & 21,65 & 21,50 & 20,05 & 27,83 & 28,12 & 22,70 & 25,44 \\
\hline 29 & 11,70 & 11,05 & 10,91 & 6,76 & 13,73 & 14,18 & 8,86 & 9,88 \\
\hline 30 & 0,38 & 0,16 & 0,19 & 0,00 & 0,28 & 0,17 & 1,78 & 1,98 \\
\hline
\end{tabular}


TABELA 5.167: Esforços Cortantes nas nervuras e vigas, em kN, na laje com 15 nervuras por lado

\begin{tabular}{|c|c|c|c|c|c|c|c|c|}
\hline \multicolumn{9}{|c|}{$\begin{array}{c}\text { LAJE COM RELAÇÃO a1/l=0,0625 } \\
\text { ESFORÇOS CORTANTES NAS NERVURAS E VIGAS }(\mathrm{kN})\end{array}$} \\
\hline \multirow{2}{*}{ Ponto } & \multicolumn{8}{|c|}{ Modelos numéricos de análise } \\
\hline & 01 & 02 & 03 & 04 & 05 & 06 & 07 & 08 \\
\hline$\overline{c 1}$ & 10,87 & 11,41 & 10,81 & 10,24 & 13,66 & 14,39 & - & - \\
\hline 2 & 7,26 & 6,91 & 6,60 & 7,22 & 9,30 & 9,60 & - & - \\
\hline 3 & 4,55 & 4,31 & 4,14 & 4,30 & 5,49 & 5,61 & - & - \\
\hline 4 & 2,26 & 2,16 & 2,07 & 2,01 & 2,50 & 2,41 & - & - \\
\hline 5 & 1,12 & 1,07 & 1,02 & 0,99 & 1,21 & 1,01 & - & - \\
\hline 6 & 0,04 & 0,04 & 0,04 & 0,00 & 0,04 & 0,34 & - & - \\
\hline 7 & 10,29 & 10,57 & 10,05 & $9,9,64$ & 12,91 & 13,95 & - & - \\
\hline 8 & 7,07 & 6,66 & 6,38 & 6,74 & 8,58 & 9,20 & - & - \\
\hline 9 & 4,60 & 4,40 & 4,21 & 4,04 & 4,97 & 5,39 & - & - \\
\hline 10 & 2,30 & 2,21 & 2,10 & 1,89 & 2,27 & 2,49 & - & - \\
\hline 11 & 1,13 & 1,08 & 1,03 & 0,93 & 1,13 & 1,27 & - & - \\
\hline 12 & 0,05 & 0,06 & 0,05 & 0,00 & 0,04 & 0,08 & - & - \\
\hline 13 & 9,09 & 8,97 & 8,71 & 7,95 & 10,60 & 11,56 & - & 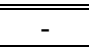 \\
\hline 14 & 6,81 & 6,48 & 6,20 & 5,51 & 6,48 & 6,99 & - & - \\
\hline 15 & 4,50 & 4,38 & 4,17 & 3,30 & 3,61 & 3,91 & - & - \\
\hline 16 & 2,14 & 2,06 & 1,97 & 1,49 & 1,72 & 1,91 & - & - \\
\hline 17 & 1,06 & 1,01 & 0,97 & 0,72 & 0,95 & 1,08 & - & - \\
\hline 18 & 0,01 & 0,01 & 0,00 & 0,00 & 0,21 & 0,27 & - & - \\
\hline 19 & 8,75 & 10,09 & 9,88 & 6,13 & 6,56 & 6,92 & - & - \\
\hline 20 & 6,11 & 6,31 & 5,92 & 3,94 & 3,42 & 3,21 & - & - \\
\hline 21 & 3,36 & 3,22 & 3,12 & 2,02 & 1,98 & 2,21 & - & - \\
\hline 22 & 1,46 & 1,29 & 1,27 & 0,77 & 1,13 & 1,29 & - & - \\
\hline 23 & 0,81 & 0,75 & 0,72 & 0,35 & 0,76 & 0,88 & - & - \\
\hline 24 & 0,23 & 0,29 & 0,25 & 0,00 & 0,41 & 0,14 & - & - \\
\hline 25 & 86,67 & 86,62 & 86,62 & 86,44 & 86,56 & 86,40 & 89,04 & 90,04 \\
\hline 26 & 77,85 & 67,31 & 67,99 & 73,41 & 81,27 & 81,54 & 79,34 & 90,41 \\
\hline 27 & 56,35 & 47,33 & 47,45 & 53,58 & 63,17 & 63,25 & 57,05 & 65,46 \\
\hline 28 & 32,41 & 28,39 & 28,25 & 28,44 & 37,15 & 37,62 & 31,42 & 35,30 \\
\hline 29 & 19,30 & 17,51 & 17,36 & 14,43 & 22,36 & 22,74 & 16,96 & 18,93 \\
\hline 30 & 5,71 & 5,94 & 5,80 & 0,00 & 6,98 & 7,53 & 1,90 & 2,11 \\
\hline
\end{tabular}

Pela análise das tabelas de esforços cortantes nas nervuras e vigas, nos modelos com variação da relação $\mathrm{a}_{1} / 1$, verificou-se que:

- os modelos 05 e 06 apresentaram, para as nervuras, sempre os maiores valores de força cortantes, chegando a uma diferença de 48,74\% a maior para o Modelo 06, em comparação com os resultados do Modelo 04, na nervura mais central da laje com relação $\mathrm{a}_{1} / \mathrm{l}=0,1111$;

- as cortantes obtidas para as nervuras segundo os modelos 02 e 03, para as nervuras centrais, estiveram sempre muito próximas daquelas dadas pelo modelo realista; à medida que diminui-se a relação $a_{1} / l$ as cortantes dadas pelos modelos 02 e 03 , para as nervuras mais próximas, em planta, dos apoios fixos, vão ficando cada vez maiores em comparação com aquelas dadas pelos modelos 04, 05 e 06, chegando a uma diferença de 
64,6\% a mais, quando comparamos a força cortante do Modelo 02 para o ponto 19 da laje $a_{1} / l=0,0625$, com a fornecida pelo Modelo 04 .

\subsubsection{Momentos Fletores $M X$ atuantes na capa}

TABELA 5.168: Momentos Fletores MX na capa, em kN.cm/cm, na laje com 05 nervuras por lado

\begin{tabular}{c|c|c|c|c|c}
\hline \hline \multicolumn{6}{c}{ LAJE COM RELAÇÃO a1/l=0,1667 } \\
\multicolumn{7}{c}{ MOMENTO FLETOR MX NA CAPA $(\mathbf{k N . c m} / \mathbf{c m})$} \\
\hline \multirow{2}{*}{ Ponto } & \multicolumn{7}{c}{ Modelos numéricos de análise } \\
\cline { 2 - 6 } & $\mathbf{0 1}$ & $\mathbf{0 2}$ & $\mathbf{0 3}$ & $\mathbf{0 4}$ & $\mathbf{0 5}$ \\
\hline \hline A & 0,668 & 0,385 & 0,394 & $\mathbf{0 , 3 2 4}$ & 0,341 \\
\hline B & 0,485 & 0,282 & 0,287 & $\mathbf{0 , 2 1 2}$ & 0,248 \\
\hline D & 0,128 & 0,074 & 0,072 & $\mathbf{- 0 , 0 2 3}$ & 0,045 \\
\hline \hline C & 0,337 & 0,201 & 0,203 & $\mathbf{0 , 1 5 4}$ & 0,197 \\
\hline E & 0,000 & $-0,003$ & $-0,006$ & $\mathbf{- 0 , 0 5 5}$ & 0,039 \\
\hline \hline F & $-0,106$ & $-0,039$ & $-0,046$ & $\mathbf{- 0 , 0 7 7}$ & 0,022 \\
\hline \hline
\end{tabular}

TABELA 5.169: Momentos Fletores MX na capa, em kN.cm/cm, na laje com 06 nervuras por lado

\begin{tabular}{|c|c|c|c|c|c|}
\hline \multicolumn{6}{|c|}{$\begin{array}{c}\text { LAJE COM RELAÇÃO a1/l=0,1429 } \\
\text { MOMENTO FLETOR MX NA CAPA }(\mathrm{kN} . \mathrm{cm} / \mathrm{cm})\end{array}$} \\
\hline \multirow{2}{*}{ Ponto } & \multicolumn{5}{|c|}{ Modelos numéricos de análise } \\
\hline & 01 & $\mathbf{0 2}$ & 03 & 04 & 05 \\
\hline$\overline{\mathbf{A}}$ & 0,961 & 0,555 & 0,569 & 0,472 & 0,471 \\
\hline B & 0,860 & 0,494 & 0,505 & 0,403 & 0,418 \\
\hline $\mathbf{D}$ & 0,598 & 0,351 & 0,358 & 0,242 & 0,272 \\
\hline $\mathbf{G}$ & 0,141 & 0,095 & 0,093 & $-0,059$ & 0,078 \\
\hline$\overline{\mathbf{C}}$ & 0,771 & 0,441 & 0,450 & 0,359 & 0,376 \\
\hline $\mathbf{E}$ & 0,506 & 0,297 & 0,301 & 0,207 & 0,249 \\
\hline $\mathbf{H}$ & 0,073 & 0,038 & 0,034 & $-0,078$ & 0,009 \\
\hline $\bar{F}$ & 0,305 & 0,184 & 0,185 & 0,134 & 0,188 \\
\hline I & $-0,101$ & $-0,071$ & $-0,076$ & $-0,106$ & 0,014 \\
\hline J & $-0,161$ & $-0,067$ & $-0,076$ & $-0,100$ & 0,015 \\
\hline
\end{tabular}

TABELA 5.170: Momentos Fletores MX na capa, em kN.cm/cm, na laje com 07 nervuras por lado

LAJE COM RELAÇ̃̃̃ a1/l=0,1250

MOMENTO FLETOR MX NA CAPA $(\mathrm{kN} . \mathrm{cm} / \mathrm{cm})$

\begin{tabular}{c|c|c|c|c|c}
\hline \multirow{2}{*}{ Ponto } & \multicolumn{5}{|c}{ Modelos numéricos de análise } \\
\cline { 2 - 6 } & $\mathbf{0 1}$ & $\mathbf{0 2}$ & $\mathbf{0 3}$ & $\mathbf{0 4}$ & $\mathbf{0 5}$ \\
\hline \hline $\mathbf{A}$ & 1,175 & 0,671 & 0,687 & $\mathbf{0 , 5 5 9}$ & 0,551 \\
\hline $\mathbf{B}$ & 0,992 & 0,567 & 0,580 & $\mathbf{0 , 4 4 7}$ & 0,457 \\
\hline $\mathbf{D}$ & 0,646 & 0,382 & 0,389 & $\mathbf{0 , 2 3 9}$ & 0,268 \\
\hline $\mathbf{G}$ & 0,103 & 0,066 & 0,063 & $\mathbf{- 0 , 1 2 3}$ & $-0,045$ \\
\hline \hline $\mathbf{C}$ & 0,833 & 0,476 & 0,486 & $\mathbf{0 , 3 7 6}$ & 0,391 \\
\hline $\mathbf{E}$ & 0,489 & 0,291 & 0,295 & $\mathbf{0 , 1 8 8}$ & 0,235 \\
\hline $\mathbf{H}$ & $-0,020$ & $-0,023$ & $-0,028$ & $\mathbf{- 0 , 1 4 1}$ & $-0,035$ \\
\hline \hline $\mathbf{F}$ & 0,246 & 0,152 & 0,151 & $\mathbf{0 , 1 0 5}$ & 0,173 \\
\hline $\mathbf{I}$ & $-0,222$ & $-0,158$ & $-0,167$ & $\mathbf{- 0 , 1 6 2}$ & $-0,012$ \\
\hline \hline $\mathbf{J}$ & $-0,220$ & $-0,098$ & $-0,109$ & $\mathbf{- 0 , 1 2 3}$ & 0,008 \\
\hline \hline
\end{tabular}


TABELA 5.171: Momentos Fletores MX na capa, em kN.cm/cm, na laje com 08 nervuras por lado

\begin{tabular}{|c|c|c|c|c|c|}
\hline \multicolumn{6}{|c|}{$\begin{array}{c}\text { LAJE COM RELAÇÃO a1/l=0,1111 } \\
\text { MOMENTO FLETOR MX NA CAPA }(\mathrm{kN} . \mathrm{cm} / \mathrm{cm})\end{array}$} \\
\hline \multirow{2}{*}{ Ponto } & \multicolumn{5}{|c|}{ Modelos numéricos de análise } \\
\hline & 01 & $\mathbf{0 2}$ & $\mathbf{0 3}$ & 04 & 05 \\
\hline $\bar{A}$ & 1,535 & 0,880 & 0,903 & 0,742 & 0,703 \\
\hline B & 1,433 & 0,819 & 0,839 & 0,673 & 0,650 \\
\hline D & 1,172 & 0,678 & 0,693 & 0,514 & 0,506 \\
\hline $\mathbf{G}$ & 0,741 & 0,449 & 0,458 & 0,249 & 0,260 \\
\hline $\mathbf{K}$ & 0,092 & 0,085 & 0,082 & $-0,182$ & $-0,114$ \\
\hline $\mathbf{C}$ & 1,345 & 0,765 & 0,783 & 0,623 & 0,604 \\
\hline$E$ & 1,079 & 0,619 & 0,632 & 0,470 & 0,474 \\
\hline $\mathrm{H}$ & 0,651 & 0,393 & 0,399 & 0,219 & 0,247 \\
\hline $\mathbf{L}$ & 0,031 & 0,014 & 0,010 & $-0,196$ & $-0,106$ \\
\hline $\bar{F}$ & 0,855 & 0,492 & 0,502 & $\begin{array}{c}0,377 \\
\end{array}$ & 0,391 \\
\hline I & 0,436 & 0,268 & 0,271 & 0,156 & 0,212 \\
\hline $\mathbf{M}$ & $-0,134$ & $-0,109$ & $-0,118$ & $-0,210$ & $-0,081$ \\
\hline $\mathbf{J}$ & 0,165 & 0,106 & 0,104 & 0,069 & 0,154 \\
\hline $\mathbf{N}$ & $-0,360$ & $-0,262$ & $-0,276$ & $-0,222$ & $-0,038$ \\
\hline 0 & $-0,281$ & $-0,131$ & $-0,145$ & $-0,147$ & 0,000 \\
\hline
\end{tabular}

TABELA 5.172: Momentos Fletores MX na capa, em kN.cm/cm, na laje com 09 nervuras por lado

\begin{tabular}{c|c|c|c|c|c}
\hline \multicolumn{6}{c}{ LAJE COM RELAÇÃO a1/l=0,1000 } \\
\multicolumn{2}{c}{ MoMENTO FLETOR MX NA CAPA (kN.cm/cm) } \\
\hline \multirow{2}{*}{ Ponto } & \multicolumn{5}{c}{ Modelos numéricos de análise } \\
\cline { 2 - 6 } & $\mathbf{0 1}$ & $\mathbf{0 2}$ & $\mathbf{0 3}$ & $\mathbf{0 4}$ & $\mathbf{0 5}$ \\
\hline \hline B & 1,815 & 1,034 & 1,061 & $\mathbf{0 , 8 6 0}$ & 0,803 \\
\hline $\mathbf{D}$ & 1,631 & 0,931 & 0,954 & $\mathbf{0 , 7 4 7}$ & 0,708 \\
\hline $\mathbf{G}$ & 1,288 & 0,747 & 0,764 & $\mathbf{0 , 5 4 2}$ & 0,521 \\
\hline $\mathbf{K}$ & 0,770 & 0,475 & 0,484 & $\mathbf{0 , 2 2 8}$ & 0,229 \\
\hline \hline $\mathbf{C}$ & 0,032 & 0,039 & 0,036 & $\mathbf{- 0 , 2 6 5}$ & $-0,194$ \\
\hline $\mathbf{E}$ & 1,471 & 0,837 & 0,857 & $\mathbf{0 , 6 6 7}$ & 0,635 \\
\hline $\mathbf{H}$ & 1,122 & 0,649 & 0,663 & $\mathbf{0 , 4 7 6}$ & 0,472 \\
\hline $\mathbf{L}$ & 0,617 & 0,384 & 0,389 & $\mathbf{0 , 1 8 6}$ & 0,214 \\
\hline \hline $\mathbf{F}$ & $-0,073$ & $-0,063$ & $-0,069$ & $\mathbf{- 0 , 2 7 5}$ & $-0,173$ \\
\hline $\mathbf{I}$ & 0,843 & 0,490 & 0,499 & $\mathbf{0 , 3 6 4}$ & 0,380 \\
\hline $\mathbf{M}$ & 0,354 & 0,228 & 0,229 & $\mathbf{0 , 1 1 4}$ & 0,183 \\
\hline \hline $\mathbf{J}$ & $-0,280$ & $-0,221$ & $-0,236$ & $\mathbf{- 0 , 2 8 4}$ & $-0,129$ \\
\hline $\mathbf{N}$ & 0,065 & 0,048 & 0,045 & $\mathbf{0 , 0 2 6}$ & 0,133 \\
\hline \hline $\mathbf{O}$ & $-0,511$ & $-0,383$ & $-0,401$ & $\mathbf{- 0 , 2 8 7}$ & $-0,640$ \\
\hline \hline
\end{tabular}


TABELA 5.173: Momentos Fletores MX na capa, em kN.cm/cm, na laje com 10 nervuras por lado

\begin{tabular}{|c|c|c|c|c|c|}
\hline \multicolumn{6}{|c|}{$\begin{array}{c}\text { LAJE COM RELAÇÃ̃ a1/l=0,0910 } \\
\text { MOMENTO FLETOR MX NA CAPA }(\mathbf{k N . c m} / \mathrm{cm})\end{array}$} \\
\hline \multirow{2}{*}{ Ponto } & \multicolumn{5}{|c|}{ Modelos numéricos de análise } \\
\hline & 01 & 02 & 03 & 04 & 05 \\
\hline 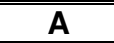 & 2,240 & 1,282 & 1,317 & 1,076 & 0,975 \\
\hline B & 2,138 & 1,221 & 1,253 & 1,006 & 0,921 \\
\hline $\mathbf{D}$ & 1,877 & 1,080 & 1,107 & 0,848 & 0,779 \\
\hline $\mathbf{G}$ & 1,451 & 0,856 & 0,877 & 0,591 & 0,538 \\
\hline $\mathbf{K}$ & 0,840 & 0,536 & 0,548 & 0,218 & 0,188 \\
\hline $\mathbf{P}$ & $-0,006$ & 0,058 & 0,055 & $-0,344$ & $-0,296$ \\
\hline C & 2,050 & 1,167 & 1,196 & $0,0,954$ & 0,874 \\
\hline$E$ & 1,784 & 1,021 & 1,045 & 0,800 & 0,742 \\
\hline $\mathrm{H}$ & 1,357 & 0,794 & 0,812 & 0,551 & 0,516 \\
\hline $\mathbf{L}$ & 0,757 & 0,481 & 0,489 & 0,192 & 0,184 \\
\hline $\mathbf{Q}$ & $-0,060$ & $-0,032$ & $-0,036$ & $-0,356$ & $-0,282$ \\
\hline $\bar{F}$ & 1,554 & 0,889 & 0,909 & 0,692 & 0,646 \\
\hline I & 1,127 & 0,659 & 0,673 & 0,466 & 0,457 \\
\hline $\mathbf{M}$ & 0,548 & 0,357 & 0,361 & 0,141 & 0,171 \\
\hline $\mathbf{R}$ & $-0,208$ & $-0,167$ & $-0,177$ & $-0,360$ & $-0,243$ \\
\hline J & 0,801 & 0,471 & 0,479 & 0,341 & 0,361 \\
\hline $\mathbf{N}$ & 0,245 & 0,172 & 0,172 & 0,063 & 0,149 \\
\hline $\mathrm{S}$ & $-0,450$ & $-0,359$ & $-0,381$ & $-0,366$ & $-0,178$ \\
\hline 0 & $-0,051$ & $-0,020$ & $-0,026$ & $-0,023$ & 0,110 \\
\hline $\mathbf{T}$ & $-0,673$ & $-0,516$ & $-0,541$ & $-0,356$ & $-0,089$ \\
\hline $\bar{U}$ & $-0,407$ & $-0,203$ & $-0,224$ & $-0,199$ & $-0,015$ \\
\hline
\end{tabular}

TABELA 5.174: Momentos Fletores MX na capa, em kN.cm/cm, na laje com 11 nervuras por lado

\section{LAJE COM RELAÇ̃̃O a1/l=0,0833}

MOMENTO FLETOR MX NA CAPA $(\mathrm{kN} . \mathrm{cm} / \mathrm{cm})$

\begin{tabular}{c|c|c|c|c|c}
\hline \multirow{2}{*}{ Ponto } & \multicolumn{5}{|c}{ Modelos numéricos de análise } \\
\cline { 2 - 6 } & $\mathbf{0 1}$ & $\mathbf{0 2}$ & $\mathbf{0 3}$ & $\mathbf{0 4}$ & $\mathbf{0 5}$ \\
\hline \hline $\mathbf{A}$ & 2,584 & 1,474 & $\mathbf{1 , 5 1 3}$ & $\mathbf{1 , 2 2 4}$ & 1,094 \\
\hline $\mathbf{B}$ & 2,400 & 1,371 & 1,407 & $\mathbf{1 , 1 1 2}$ & 0,999 \\
\hline $\mathbf{D}$ & 2,057 & 1,188 & 1,218 & $\mathbf{0 , 9 0 8}$ & 0,814 \\
\hline $\mathbf{G}$ & 1,547 & 0,921 & 0,943 & $\mathbf{0 , 6 0 3}$ & 0,527 \\
\hline $\mathbf{K}$ & 0,847 & 0,555 & 0,568 & $\mathbf{0 , 1 7 8}$ & 0,130 \\
\hline $\mathbf{P}$ & $-0,090$ & $-0,009$ & $-0,012$ & $\mathbf{- 0 , 4 4 8}$ & $-0,405$ \\
\hline $\mathbf{C}$ & 2,403 & 1,277 & 1,308 & $\mathbf{1 , 0 2 5}$ & 0,921 \\
\hline $\mathbf{E}$ & 1,891 & 1,088 & 1,114 & $\mathbf{0 , 8 3 2}$ & 0,755 \\
\hline $\mathbf{H}$ & 1,383 & 0,820 & 0,838 & $\mathbf{0 , 5 4 3}$ & 0,495 \\
\hline $\mathbf{L}$ & 0,706 & 0,468 & 0,476 & $\mathbf{0 , 1 4 4}$ & 0,128 \\
\hline $\mathbf{Q}$ & $-0,183$ & $-0,128$ & $-0,134$ & $\mathbf{- 0 , 4 5 3}$ & $-0,374$ \\
\hline \hline $\mathbf{F}$ & 1,598 & 0,920 & 0,941 & $\mathbf{0 , 7 0 1}$ & 0,644 \\
\hline $\mathbf{I}$ & 1,095 & 0,650 & 0,664 & $\mathbf{0 , 4 4 2}$ & 0,432 \\
\hline $\mathbf{M}$ & 0,447 & 0,312 & 0,315 & $\mathbf{0 , 0 8 5}$ & 0,123 \\
\hline $\mathbf{R}$ & $-0,371$ & $-0,299$ & $-0,315$ & $\mathbf{- 0 , 4 5 1}$ & $-0,314$ \\
\hline \hline $\mathbf{J}$ & 0,731 & 0,436 & 0,443 & $\mathbf{0 , 3 0 7}$ & 0,336 \\
\hline $\mathbf{N}$ & 0,112 & 0,101 & 0,099 & $\mathbf{0 , 0 0 4}$ & 0,112 \\
\hline $\mathbf{S}$ & $-0,641$ & $-0,521$ & $-0,551$ & $\mathbf{- 0 , 4 5 3}$ & $-0,227$ \\
\hline \hline $\mathbf{O}$ & $-0,181$ & $-0,099$ & $-0,105$ & $\mathbf{- 0 , 0 7 6}$ & 0,087 \\
\hline $\mathbf{T}$ & $-0,843$ & $-0,662$ & $-0,694$ & $\mathbf{- 0 , 4 2 9}$ & $-0,114$ \\
\hline \hline $\mathbf{U}$ & $-0,471$ & $-0,241$ & $-0,265$ & $\mathbf{- 0 , 2 2 6}$ & $-0,022$ \\
\hline \hline
\end{tabular}


TABELA 5.175: Momentos Fletores MX na capa, em kN.cm/cm, na laje com 12 nervuras por lado

\begin{tabular}{|c|c|c|c|c|c|}
\hline \multicolumn{6}{|c|}{$\begin{array}{c}\text { LAJE COM RELAÇÃO a1/l=0,0769 } \\
\text { MOMENTO FLETOR MX NA CAPA }(\mathrm{kN.cm} / \mathrm{cm})\end{array}$} \\
\hline \multirow{2}{*}{ Ponto } & \multicolumn{5}{|c|}{ Modelos numéricos de análise } \\
\hline & 01 & 02 & 03 & 04 & 05 \\
\hline $\bar{A}$ & 3,073 & 1,760 & 1,809 & 1,473 & 1,285 \\
\hline B & 2,972 & 1,699 & 1,745 & 1,403 & 1,232 \\
\hline D & 2,709 & 1,558 & 1,599 & 1,246 & 1,091 \\
\hline $\mathbf{G}$ & 2,284 & 1,336 & 1,371 & 0,994 & 0,854 \\
\hline $\mathbf{K}$ & 1,687 & 1,026 & 1,052 & 0,634 & 0,512 \\
\hline $\mathbf{P}$ & 0,888 & 0,609 & 0,626 & 0,147 & 0,056 \\
\hline $\mathbf{V}$ & $-0,158$ & 0,010 & 0,008 & $-0,546$ & $-0,540$ \\
\hline C & 2,883 & 1,644 & 1,687 & 1,348 & $1,1,184$ \\
\hline$E$ & 2,617 & 1,499 & 1,537 & 1,194 & 1,050 \\
\hline $\mathbf{H}$ & 2,190 & 1,273 & 1,305 & 0,947 & 0,825 \\
\hline $\mathbf{L}$ & 1,596 & 0,963 & 0,986 & 0,597 & 0,498 \\
\hline $\mathbf{Q}$ & 0,813 & 0,556 & 0,568 & 0,125 & 0,058 \\
\hline W & $-0,206$ & $-0,101$ & $-0,104$ & $-0,557$ & $-0,521$ \\
\hline $\bar{F}$ & 2,386 & 1,364 & 1,399 & 1,077 & 0,947 \\
\hline I & 1,956 & 1,134 & 1,161 & 0,846 & 0,751 \\
\hline $\mathbf{M}$ & 1,369 & 0,825 & 0,843 & 0,520 & 0,461 \\
\hline $\mathbf{R}$ & 0,619 & 0,438 & 0,444 & 0,084 & 0,064 \\
\hline$X$ & $-0,337$ & $-0,252$ & $-0,262$ & $-0,555$ & $-0,469$ \\
\hline J & $1,1,606$ & 0,933 & 0,954 & 0,697 & 0,630 \\
\hline $\mathbf{N}$ & 1,032 & 0,623 & 0,636 & 0,406 & 0,398 \\
\hline $\mathbf{S}$ & 0,317 & 0,251 & 0,252 & 0,021 & 0,070 \\
\hline $\mathbf{Y}$ & $-0,561$ & $-0,460$ & $-0,484$ & $-0,549$ & $-0,386$ \\
\hline 0 & 0,637 & 0,387 & 0,392 & 0,264 & $0,0,308$ \\
\hline $\mathbf{T}$ & $-0,040$ & 0,017 & 0,013 & $-0,062$ & 0,073 \\
\hline $\mathbf{Z}$ & $-0,849$ & $-0,708$ & $-0,747$ & $-0,546$ & $-0,274$ \\
\hline $\mathbf{U}$ & $-0,321$ & $-0,185$ & $-0,193$ & $-0,134$ & 0,064 \\
\hline AA & $-1,020$ & $-0,818$ & $-0,858$ & $-0,506$ & $-0,137$ \\
\hline BA & $-0,535$ & $-0,280$ & $-0,309$ & $-0,254$ & $-0,030$ \\
\hline
\end{tabular}


TABELA 5.176: Momentos Fletores MX na capa, em kN.cm/cm, na laje com 13 nervuras por lado

\begin{tabular}{|c|c|c|c|c|c|}
\hline \multicolumn{6}{|c|}{$\begin{array}{c}\text { LAJE COM RELAÇÃO a1/l=0,0714 } \\
\text { MOMENTO FLETOR MX NA CAPA }(\mathrm{kN.cm} / \mathrm{cm})\end{array}$} \\
\hline \multirow{2}{*}{ Ponto } & \multicolumn{5}{|c|}{ Modelos numéricos de análise } \\
\hline & 01 & $\mathbf{0 2}$ & $\mathbf{0 3}$ & 04 & $\mathbf{0 5}$ \\
\hline $\mathbf{A}$ & 3,480 & 1,989 & 2,044 & 1,652 & 1,424 \\
\hline B & 3,297 & 1,887 & 1,937 & 1,540 & 1,329 \\
\hline D & 2,952 & 1,704 & 1,749 & 1,338 & 1,145 \\
\hline $\mathbf{G}$ & 2,444 & 1,439 & 1,477 & 1,038 & 0,863 \\
\hline $\mathbf{K}$ & 1,759 & 1,084 & 1,113 & 0,628 & 0,474 \\
\hline $\mathbf{P}$ & 0,870 & 0,621 & 0,639 & 0,089 & $-0,032$ \\
\hline $\mathbf{V}$ & $-0,270$ & $-0,079$ & $-0,081$ & $-0,669$ & $-0,679$ \\
\hline C & 3,136 & 1,792 & 1,839 & 1,449 & 1,248 \\
\hline$E$ & 2,788 & 1,603 & 1,645 & 1,254 & 1,079 \\
\hline $\mathrm{H}$ & 2,278 & 1,335 & 1,369 & 0,967 & 0,818 \\
\hline $\mathbf{L}$ & 1,602 & 0,983 & 1,007 & 0,574 & 0,455 \\
\hline $\mathbf{Q}$ & 0,741 & 0,538 & 0,550 & 0,061 & $-0,023$ \\
\hline $\mathbf{W}$ & $-0,352$ & $-0,220$ & $-0,225$ & $-0,672$ & $-0,640$ \\
\hline $\bar{F}$ & 2,489 & 1,431 & 1,467 & 1,111 & 0,955 \\
\hline$I$ & 1,981 & 1,159 & 1,187 & 0,845 & 0,773 \\
\hline $\mathbf{M}$ & 1,319 & 0,811 & 0,829 & 0,484 & 0,418 \\
\hline $\mathbf{R}$ & 0,499 & 0,390 & 0,395 & 0,015 & $-0,060$ \\
\hline$X$ & $-0,519$ & $-0,406$ & $-0,422$ & $-0,664$ & $-0,506$ \\
\hline J & 1,582 & 0,928 & 0,949 & 0,679 & 0,608 \\
\hline $\mathbf{N}$ & 0,939 & 0,580 & 0,592 & 0,360 & 0,359 \\
\hline $\mathbf{S}$ & 0,161 & 0,175 & 0,172 & $-0,052$ & 0,015 \\
\hline $\mathbf{Y}$ & $-0,775$ & $-0,651$ & $-0,683$ & $-0,653$ & $-0,458$ \\
\hline 0 & 0,522 & 0,324 & 0,328 & 0,213 & 0,276 \\
\hline $\mathbf{T}$ & $-0,211$ & $-0,079$ & $-0,086$ & $-0,135$ & 0,034 \\
\hline $\mathbf{Z}$ & $-1,073$ & $-0,915$ & $-0,965$ & $-0,645$ & $-0,321$ \\
\hline $\mathbf{U}$ & $\begin{array}{c}-0,472 \\
\end{array}$ & $-0,279$ & $-0,289$ & $-0,197$ & 0,041 \\
\hline AA & $-1,201$ & $-0,983$ & $-1,032$ & $-0,586$ & $-0,161$ \\
\hline BA & $-0,599$ & $-0,320$ & $-0,353$ & $-0,283$ & $-0,037$ \\
\hline
\end{tabular}


TABELA 5.177: Momentos Fletores MX na capa, em kN.cm/cm, na laje com 14 nervuras por lado

\begin{tabular}{|c|c|c|c|c|c|}
\hline \multicolumn{6}{|c|}{$\begin{array}{c}\text { LAJE COM RELAÇÃO a1/l=0,0667 } \\
\text { MOMENTO FLETOR MX NA CAPA }(\mathbf{k N . c m} / \mathrm{cm})\end{array}$} \\
\hline \multirow{2}{*}{ Ponto } & \multicolumn{5}{|c|}{ Modelos numéricos de análise } \\
\hline & $\mathbf{0 1}$ & $\mathbf{0 2}$ & $\mathbf{0 3}$ & 04 & 05 \\
\hline $\mathbf{A}$ & 4,031 & 2,312 & 2,378 & 1,933 & 1,634 \\
\hline B & 3,929 & 2,251 & 2,314 & 1,863 & 1,581 \\
\hline $\mathbf{D}$ & 3,666 & 2,110 & 2,168 & 1,707 & 1,440 \\
\hline $\mathbf{G}$ & 3,241 & 1,889 & 1,941 & 1,458 & 1,207 \\
\hline $\mathbf{K}$ & 2,649 & 1,584 & 1,628 & 1,107 & 0,872 \\
\hline $\mathbf{P}$ & 1,871 & 1,183 & 1,217 & 0,640 & 0,426 \\
\hline $\mathbf{V}$ & 0,880 & 0,667 & 0,690 & 0,038 & $-0,139$ \\
\hline CA & $-0,370$ & $-0,058$ & $-0,059$ & $-0,785$ & $-0,846$ \\
\hline C & 3,841 & 2,196 & 2,256 & 1,807 & $1,1,532$ \\
\hline$E$ & 3,575 & 2,051 & 2,106 & 1,652 & 1,398 \\
\hline $\mathbf{H}$ & 3,148 & 1,826 & 1,874 & 1,407 & 1,174 \\
\hline $\mathbf{L}$ & 2,556 & 1,518 & 1,558 & 1,062 & 0,851 \\
\hline $\mathbf{Q}$ & 1,786 & 1,120 & 1,150 & 0,606 & 0,419 \\
\hline $\mathbf{W}$ & 0,812 & 0,615 & 0,633 & 0,019 & $-0,131$ \\
\hline DA & $-0,412$ & $-0,196$ & $-0,197$ & $-0,797$ & $-0,823$ \\
\hline $\bar{F}$ & 3,343 & 1,916 & 1,967 & 1,529 & 1,289 \\
\hline I & 2,913 & 1,685 & 1,729 & 1,296 & 1,088 \\
\hline $\mathbf{M}$ & 2,323 & 1,375 & 1,410 & 0,969 & 0,795 \\
\hline $\mathbf{R}$ & 1,569 & 0,984 & 1,008 & 0,538 & 0,400 \\
\hline $\mathbf{X}$ & 0,635 & 0,504 & 0,515 & $-0,014$ & $-0,111$ \\
\hline EA & $-0,528$ & $-0,368$ & $-0,377$ & $-0,793$ & $-0,761$ \\
\hline $\mathbf{J}$ & 2,552 & 1,477 & 1,515 & 1,128 & 0,950 \\
\hline $\mathbf{N}$ & 1,969 & 1,165 & 1,194 & 0,829 & 0,705 \\
\hline $\mathbf{S}$ & 1,236 & 0,779 & 0,796 & 0,436 & 0,367 \\
\hline $\mathbf{Y}$ & 0,350 & 0,326 & 0,328 & $-0,064$ & $-0,080$ \\
\hline FA & $-0,727$ & $-0,591$ & $-0,614$ & $-0,778$ & $-0,663$ \\
\hline 0 & 1,528 & 0,906 & 0,927 & 0,651 & 0,578 \\
\hline $\mathbf{T}$ & 0,821 & 0,522 & 0,532 & 0,304 & 0,316 \\
\hline $\mathbf{Z}$ & $-0,019$ & 0,083 & 0,077 & $-0,133$ & $-0,042$ \\
\hline GA & $-1,010$ & $-0,869$ & $-0,913$ & $-0,763$ & $-0,529$ \\
\hline $\mathbf{U}$ & 0,387 & 0,249 & 0,250 & 0,155 & 0,243 \\
\hline AA & $-0,398$ & $-0,187$ & $-0,196$ & $-0,214$ & $-0,006$ \\
\hline HA & $-1,310$ & $-1,143$ & $-1,206$ & $-0,750$ & $-0,367$ \\
\hline BA & $-0,630$ & $-0,380$ & $-0,391$ & $-0,263$ & 0,018 \\
\hline IA & $-1,387$ & $-1,156$ & $-1,215$ & $-0,670$ & $-0,183$ \\
\hline JA & $-0,664$ & $-0,360$ & $-0,397$ & $-0,313$ & $-0,045$ \\
\hline
\end{tabular}


TABELA 5.178: Momentos Fletores MX na capa, em kN.cm/cm, na laje com 15 nervuras por lado

\begin{tabular}{|c|c|c|c|c|c|}
\hline \multicolumn{6}{|c|}{$\begin{array}{c}\text { LAJE COM RELAÇÃO a1/l=0,0625 } \\
\text { MOMENTO FLETOR MX NA CAPA }(\mathrm{kN.cm} / \mathrm{cm})\end{array}$} \\
\hline \multirow{2}{*}{ Ponto } & \multicolumn{5}{|c|}{ Modelos numéricos de análise } \\
\hline & 01 & 02 & 03 & 04 & 05 \\
\hline 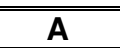 & 4,499 & 2,578 & 2,651 & 2,144 & 1,791 \\
\hline B & 4,316 & 2,475 & 2,544 & 2,031 & 1,696 \\
\hline D & 3,971 & 2,293 & 2,356 & 1,830 & 1,513 \\
\hline $\mathbf{G}$ & 3,463 & 2,029 & 2,085 & 1,535 & 1,235 \\
\hline $\mathbf{K}$ & 2,784 & 1,681 & 1,728 & 1,135 & 0,853 \\
\hline $\mathbf{P}$ & 1,917 & 1,234 & 1,271 & 0,617 & 0,358 \\
\hline V & 0,833 & 0,671 & 0,696 & $-0,039$ & $-0,257$ \\
\hline CA & $-0,511$ & $-0,173$ & $-0,173$ & $-0,928$ & $-1,016$ \\
\hline C & 4,155 & 2,380 & 2,446 & 1,938 & 1,613 \\
\hline$E$ & 3,807 & 2,192 & 2,252 & 1,742 & 1,442 \\
\hline $\mathbf{H}$ & 3,297 & 1,924 & 1,977 & 1,455 & 1,181 \\
\hline $\mathbf{L}$ & 2,622 & 1,575 & 1,617 & 1,068 & 0,821 \\
\hline $\mathbf{Q}$ & 1,770 & 1,135 & 1,166 & 0,568 & 0,351 \\
\hline $\mathbf{W}$ & 0,717 & 0,592 & 0,610 & $-0,062$ & $-0,239$ \\
\hline DA & $-0,584$ & $-0,340$ & $-0,343$ & $-0,931$ & $-0,970$ \\
\hline $\bar{F}$ & 3,506 & 2,018 & 2,072 & 1,589 & 1,310 \\
\hline I & 2,996 & 1,745 & 1,792 & 1,319 & 1,081 \\
\hline $\mathbf{M}$ & 2,328 & 1,394 & 1,431 & 0,956 & 0,760 \\
\hline $\mathbf{R}$ & 1,500 & 0,965 & 0,989 & 0,488 & 0,336 \\
\hline $\mathbf{X}$ & 0,496 & 0,453 & 0,462 & $-0,098$ & $-0,204$ \\
\hline EA & $-0,731$ & $-0,547$ & $-0,560$ & $-0,919$ & $-0,884$ \\
\hline $\mathbf{J}$ & 2,579 & 1,504 & 1,543 & $\overline{1,131}$ & 0,933 \\
\hline $\mathbf{N}$ & 1,924 & 1,152 & 1,182 & 0,801 & 0,668 \\
\hline S & 1,122 & 0,729 & 0,746 & 0,377 & 0,310 \\
\hline $\mathbf{Y}$ & 0,174 & 0,246 & 0,244 & $-0,150$ & $-0,156$ \\
\hline FA & $-0,961$ & $-0,807$ & $-0,839$ & $-0,898$ & $-0,759$ \\
\hline 0 & 1,448 & 0,869 & 0,889 & 0,612 & 0,544 \\
\hline$T$ & 0,678 & 0,448 & 0,457 & 0,240 & 0,270 \\
\hline $\mathbf{Z}$ & $-0,219$ & $-0,023$ & $-0,032$ & $-0,222$ & $-0,101$ \\
\hline GA & $-1,264$ & $-1,116$ & $-1,172$ & $-0,880$ & $-0,599$ \\
\hline $\mathbf{U}$ & 0,236 & 0,161 & 0,160 & 0,090 & 0,208 \\
\hline$\overline{\text { AA }}$ & $-0,599$ & $-0,306$ & $-0,318$ & $-0,299$ & $-0,046$ \\
\hline HA & $-1,557$ & $-1,390$ & $-1,466$ & $-0,860$ & $-0,411$ \\
\hline BA & $-0,795$ & $-0,486$ & $-0,499$ & $-0,334$ & $-0,005$ \\
\hline IA & $-1,575$ & $-1,337$ & $-1,406$ & $-0,757$ & $-0,206$ \\
\hline JA & $-0,728$ & $-0,400$ & $-0,443$ & $-0,345$ & $-0,053$ \\
\hline
\end{tabular}

Abaixo tem-se os gráficos de momentos fletores MX atuantes na capa das lajes nervuradas processadas nesta série. 


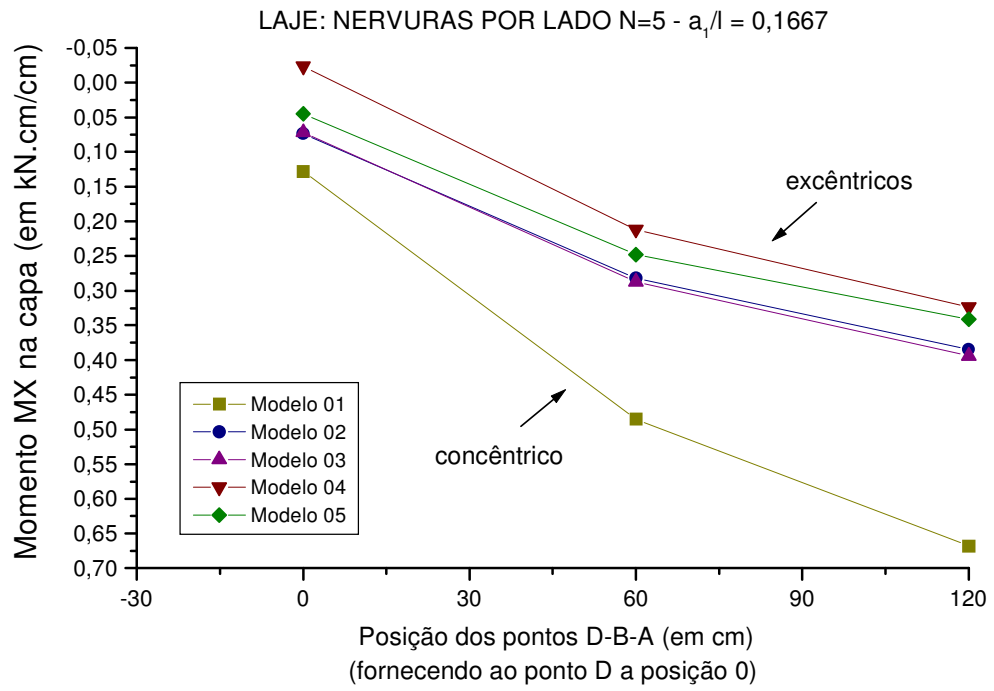

FIGURA 5.137: Momentos fletores MX (kN.cm/cm), na linha D-B-A da capa; laje $\mathrm{a}_{1} / \mathrm{l}=0,1667$

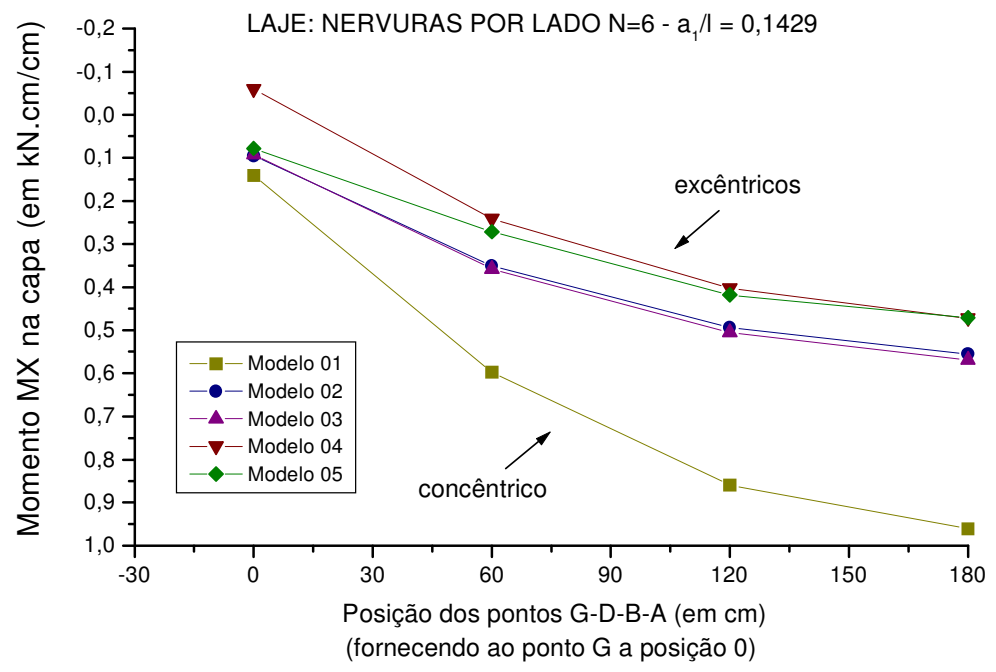

FIGURA 5.138: Momentos fletores MX (kN.cm/cm), na linha G-D-B-A da capa; laje $\mathrm{a}_{1} / \mathrm{l}=0,1429$

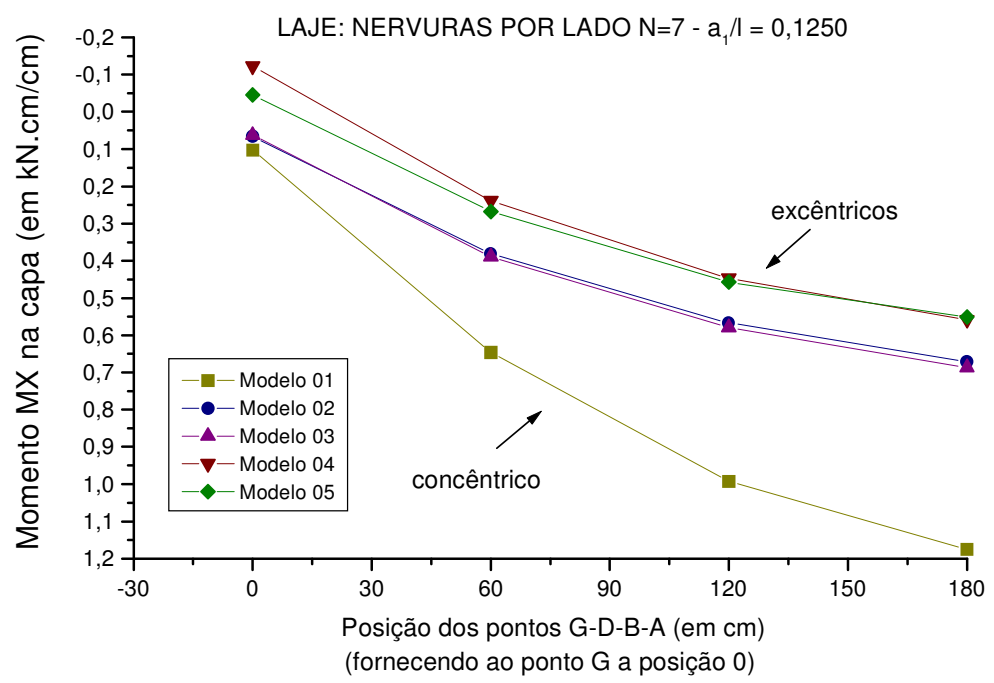

FIGURA 5.139: Momentos fletores MX (kN.cm/cm), na linha D-B-A da capa; laje $\mathrm{a}_{1} / \mathrm{l}=0,1250$ 


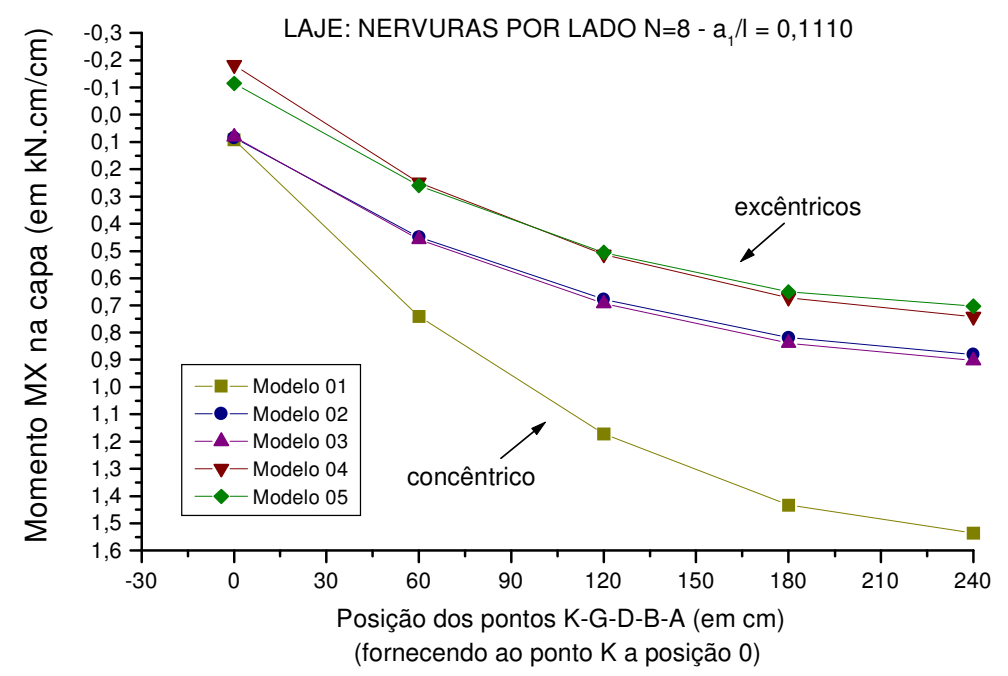

FIGURA 5.140: Momentos fletores MX (kN.cm/cm), na linha K-G-D-B-A da capa; laje $a_{1} / \mathrm{l}=0,1111$

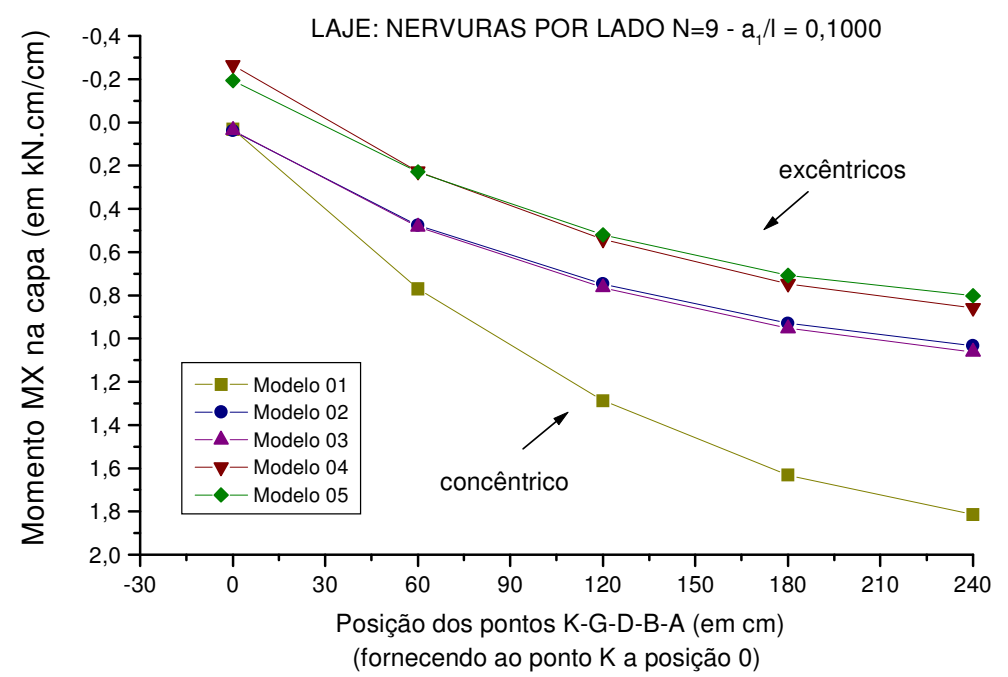

FIGURA 5.141: Momentos fletores MX (kN.cm/cm), na linha K-G-D-B-A da capa; laje $\mathrm{a}_{1} / \mathrm{l}=0,1000$

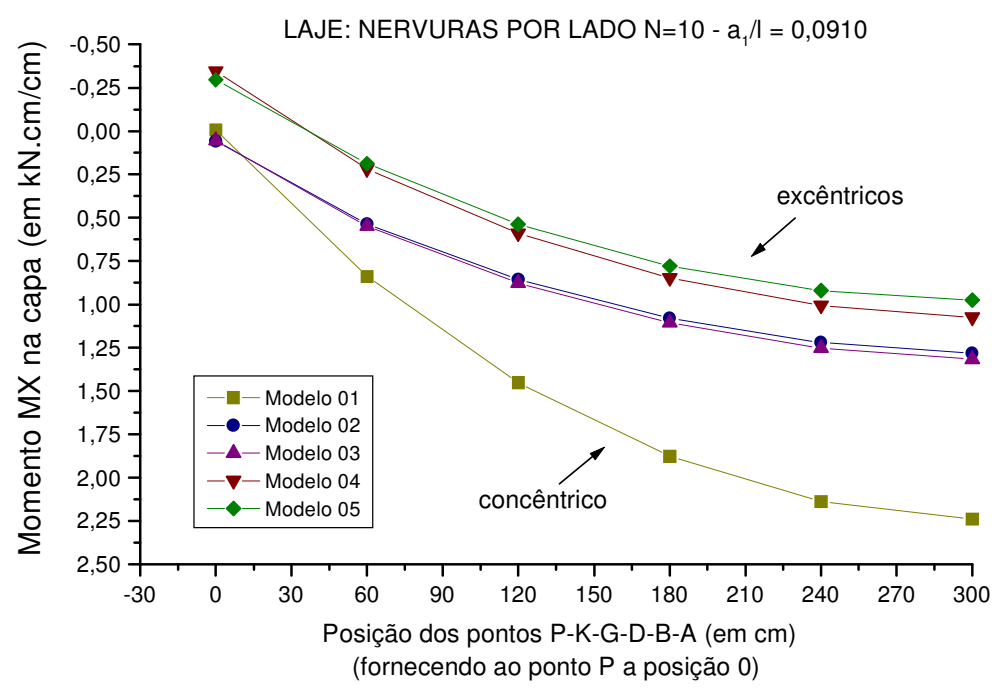

FIGURA 5.142: Momentos fletores MX (kN.cm/cm), na linha P-K-G-D-B-A da capa; laje $\mathrm{a}_{1} / \mathrm{l}=0,0910$ 


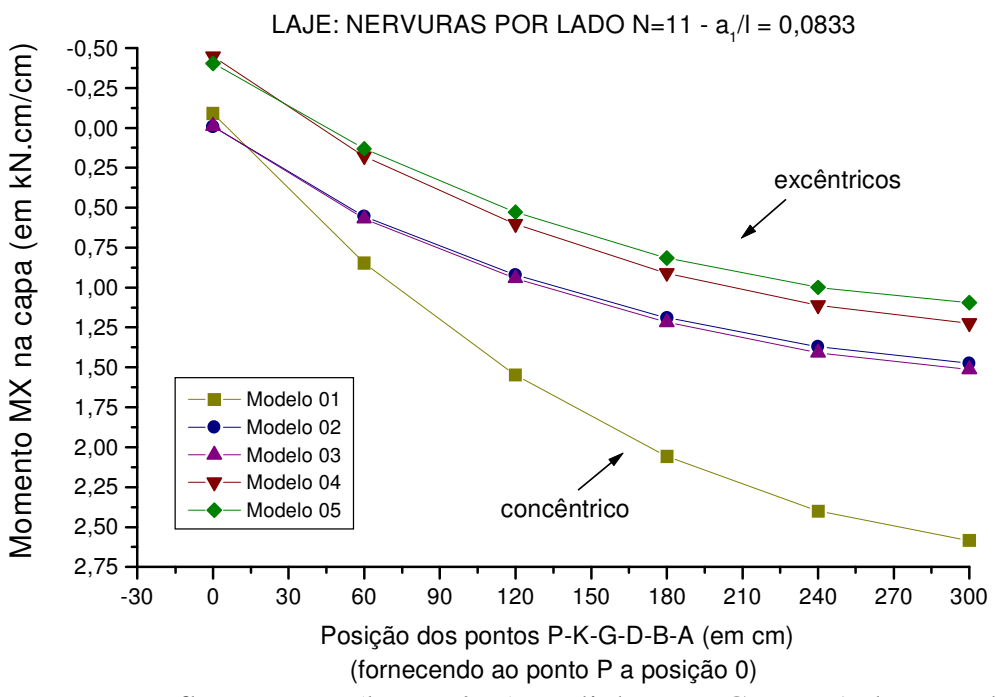

FIGURA 5.143: Momentos fletores MX (kN.cm/cm), na linha P-K-G-D-B-A da capa; laje $\mathrm{a}_{1} / \mathrm{l}=0,0833$

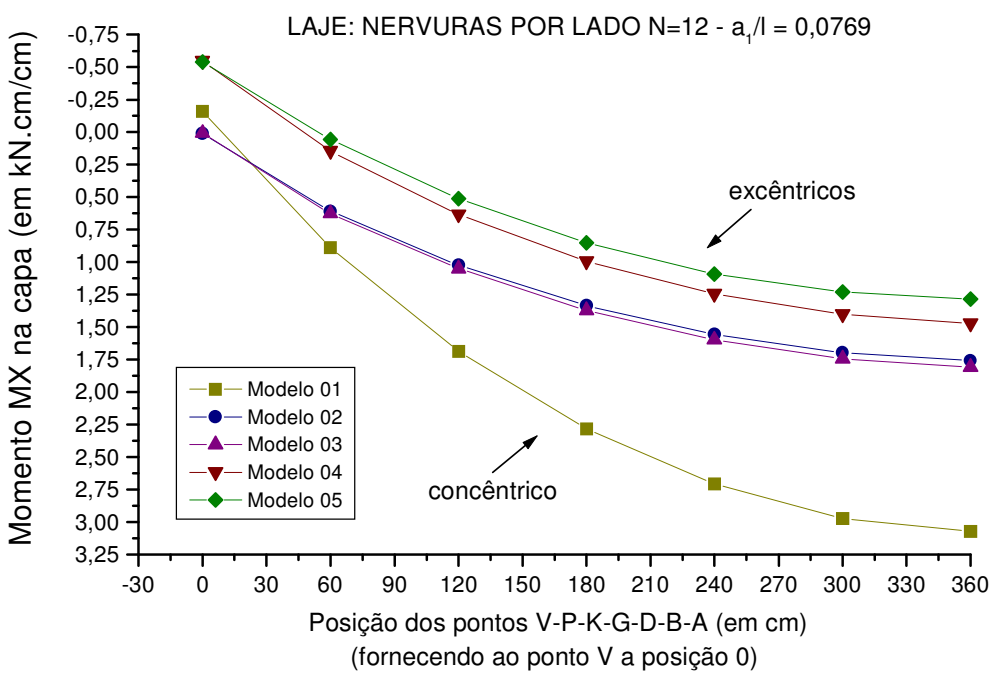

FIGURA 5.144: Momentos fletores MX (kN.cm/cm), na linha V-P-K-G-D-B-A da capa; laje $a_{1} / l=0,0760$

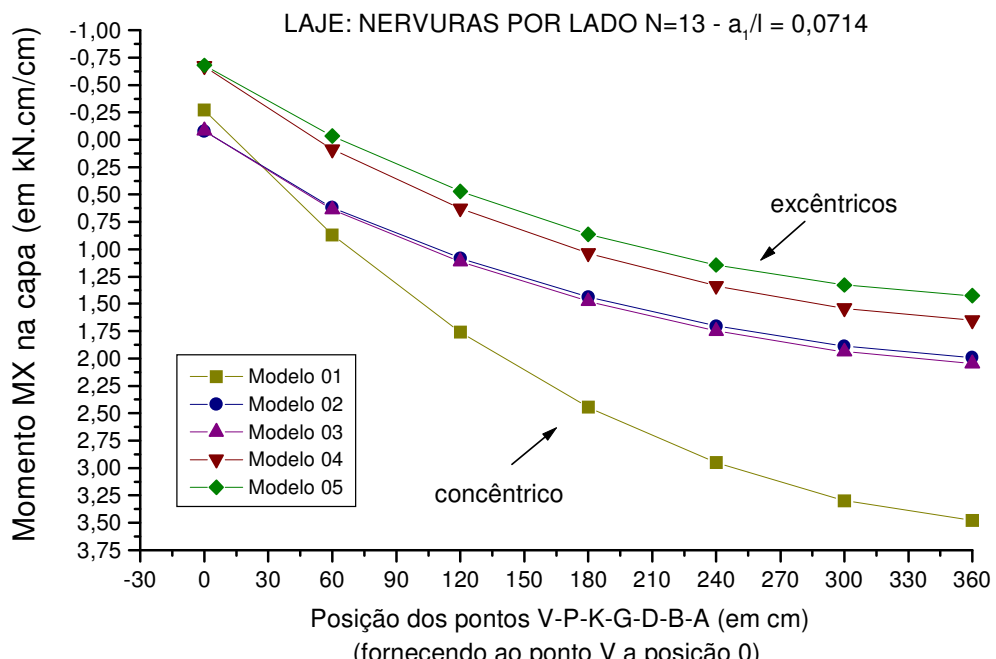

FIGURA 5.145: Momentos fletores MX (kN.cm/cm), na linha V-P-K-G-D-B-A da capa; laje $\mathrm{a}_{1} / \mathrm{l}=0,0714$ 


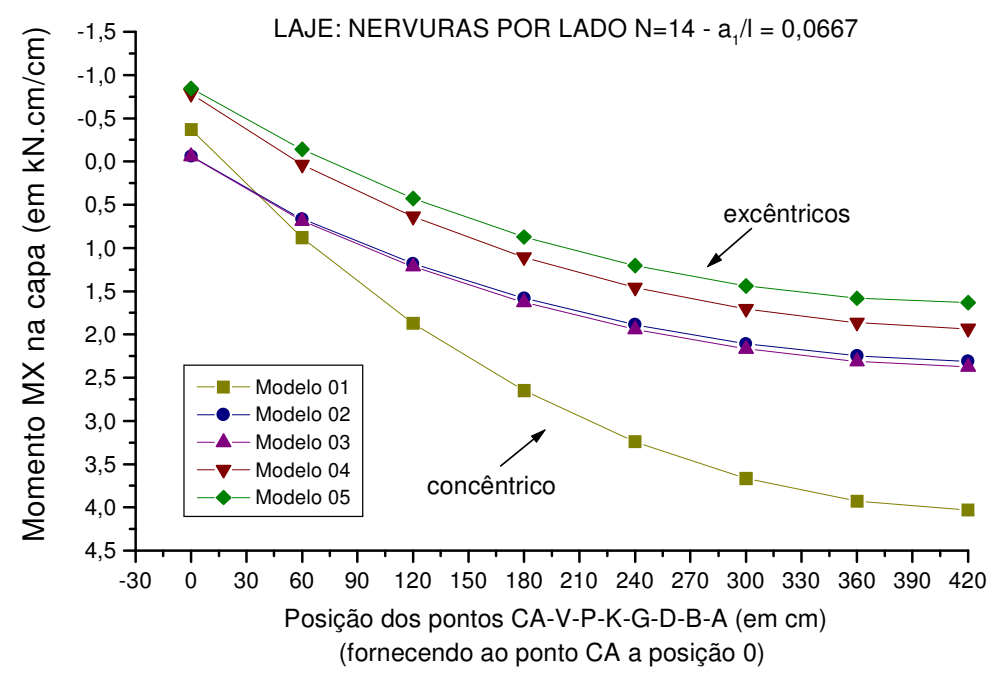

FIGURA 5.146: Momentos fletores MX (kN.cm/cm), na linha CA-V-P-K-G-D-B-A da capa; laje $\mathrm{a}_{1} / 1=0,0667$

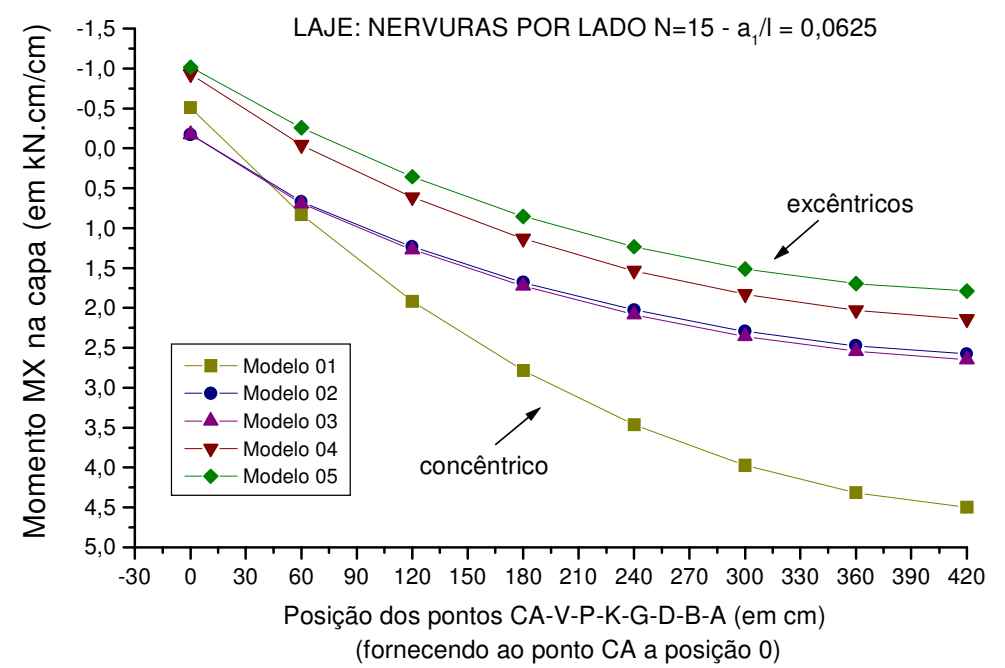

FIGURA 5.147: Momentos fletores MX (kN.cm/cm), na linha CA-V-P-K-G-D-B-A da capa; laje $\mathrm{a}_{1} / \mathrm{l}=0,0625$

Pela análise das tabelas e gráficos de momentos fletores MX atuantes na capa, nas lajes com variação da relação $a_{1} / 1$, tem-se que:

- o momento fletor MX na capa é sempre maior no modelo concêntrico, em geral $50 \%$, em todas as relações $a_{1} / 1$ testadas;

- à medida que aumenta-se o número de nervuras por lado, ou seja, que diminui-se a relação $a_{1} / l$, o momento fletor MX máximo na capa dado pelo Modelo 05 , inicialmente maior que o dado pelo Modelo 04 (para $a_{1} / l=0,1667$ tem-se uma diferença de $5,24 \%$ a maior para o Modelo 05), vai tornando-se menor (para $a_{1} / 1=0,0625$ a diferença é de 16,5\%, agora a menor para o Modelo 05). Nas posições intermediárias alguns valores 
chegam a ser bem próximos: para $\mathrm{a}_{1} / \mathrm{l}=0,1429$ a diferença entre os momentos máximos é de 0,21\%, a menor para o Modelo 05, quando comparado ao resultado do Modelo 04;

- os modelos 02 e 03 apresentam momentos fletores MX na capa sempre maiores que aqueles dados pelo Modelo 04, não variando em relação aos apresentados pelo modelo realista com a variação de $\mathrm{a}_{1} / \mathrm{l}$. Os valores sempre maiores estão diretamente ligados à relação $h_{f} / h=0,25$, como visto nas análises da série anterior processada. Ou seja, melhores resultados seriam obtidos para relações $h_{f} / h$ menores (maiores excentricidades).

\subsubsection{Momentos Fletores MY atuantes na capa}

TABELA 5.179: Momentos Fletores MY na capa, em kN.cm/cm, na laje com 05 nervuras por lado

\begin{tabular}{c|c|c|c|c|c}
\hline \hline \multicolumn{6}{c}{ LAJE COM RELAÇÃO a1/l=0,1667 } \\
\multicolumn{7}{c}{ MOMENTO FLETOR MY NA CAPA (kN.cm/cm) } \\
\hline \multirow{2}{*}{ Ponto } & \multicolumn{7}{c}{ Modelos numéricos de análise } \\
\cline { 2 - 6 } & $\mathbf{0 1}$ & $\mathbf{0 2}$ & $\mathbf{0 3}$ & $\mathbf{0 4}$ & $\mathbf{0 5}$ \\
\hline \hline A & 0,668 & 0,385 & 0,394 & $\mathbf{0 , 3 2 4}$ & 0,341 \\
\hline B & 0,516 & 0,302 & 0,307 & $\mathbf{0 , 2 5 4}$ & 0,264 \\
\hline C & 0,337 & 0,201 & 0,203 & $\mathbf{0 , 1 5 4}$ & 0,197 \\
\hline \hline D & 0,216 & 0,143 & 0,143 & $\mathbf{0 , 1 1 7}$ & 0,115 \\
\hline E & 0,105 & 0,065 & 0,065 & $\mathbf{0 , 0 4 8}$ & 0,080 \\
\hline \hline F & $-0,106$ & $-0,039$ & $-0,046$ & $\mathbf{- 0 , 0 7 7}$ & 0,022 \\
\hline \hline
\end{tabular}

TABELA 5.180: Momentos Fletores MY na capa, em kN.cm/cm, na laje com 06 nervuras por lado

\begin{tabular}{c|c|c|c|c|c}
\hline \multicolumn{6}{c}{ LAJE COM RELAÇÃO a1/l=0,1429 } \\
\multicolumn{7}{c}{ MOMENTO FLETOR MY NA CAPA $(\mathbf{k N . c m} / \mathbf{c m})$} \\
\hline \multirow{2}{*}{ Ponto } & \multicolumn{5}{c}{ Modelos numéricos de análise } \\
\cline { 2 - 6 } & $\mathbf{0 1}$ & $\mathbf{0 2}$ & $\mathbf{0 3}$ & $\mathbf{0 4}$ & $\mathbf{0 5}$ \\
\hline \hline A & 0,961 & 0,555 & 0,569 & $\mathbf{0 , 4 7 2}$ & 0,471 \\
\hline \hline B & 0,876 & 0,505 & 0,517 & $\mathbf{0 , 4 2 5}$ & 0,422 \\
\hline $\mathbf{C}$ & 0,771 & 0,441 & 0,450 & $\mathbf{0 , 3 5 9}$ & 0,376 \\
\hline \hline D & 0,649 & 0,382 & 0,390 & $\mathbf{0 , 3 1 7}$ & 0,304 \\
\hline E & 0,556 & 0,324 & 0,329 & $\mathbf{0 , 2 6 2}$ & 0,274 \\
\hline F & 0,305 & 0,184 & 0,185 & $\mathbf{0 , 1 3 4}$ & 0,188 \\
\hline $\mathbf{G}$ & 0,255 & 0,182 & 0,182 & $\mathbf{0 , 1 3 5}$ & 0,121 \\
\hline $\mathbf{H}$ & 0,208 & 0,131 & 0,132 & $\mathbf{0 , 0 9 9}$ & 0,104 \\
\hline $\mathbf{I}$ & 0,062 & 0,030 & 0,031 & $\mathbf{0 , 0 2 3}$ & 0,069 \\
\hline $\mathbf{J}$ & $-0,161$ & $-0,067$ & $-0,076$ & $\mathbf{- 0 , 1 0 0}$ & 0,015 \\
\hline \hline
\end{tabular}


TABELA 5.181: Momentos Fletores MY na capa, em kN.cm/cm, na laje com 07 nervuras por lado

\begin{tabular}{|c|c|c|c|c|c|}
\hline \multicolumn{6}{|c|}{$\begin{array}{c}\text { LAJE COM RELAÇÃO a1/l=0,1250 } \\
\text { MOMENTO FLETOR MY NA CAPA }(\mathrm{kN} . \mathrm{cm} / \mathrm{cm})\end{array}$} \\
\hline \multirow{2}{*}{ Ponto } & \multicolumn{5}{|c|}{ Modelos numéricos de análise } \\
\hline & $\mathbf{0 1}$ & $\mathbf{0 2}$ & $\mathbf{0 3}$ & 04 & $\mathbf{0 5}$ \\
\hline $\mathbf{A}$ & 1,175 & 0,671 & 0,687 & 0,559 & 0,551 \\
\hline B B & 1,019 & 0,583 & 0,596 & 0,478 & 0,467 \\
\hline $\mathbf{C}$ & 0,833 & 0,476 & 0,486 & 0,376 & 0,391 \\
\hline$\overline{\mathbf{D}}$ & 0,723 & 0,422 & 0,430 & 0,337 & 0,320 \\
\hline $\mathbf{E}$ & 0,564 & 0,330 & 0,334 & 0,257 & 0,272 \\
\hline $\mathbf{F}$ & 0,246 & 0,152 & 0,151 & 0,105 & 0,173 \\
\hline $\mathbf{G}$ & 0,263 & 0,177 & 0,179 & 0,122 & 0,109 \\
\hline $\mathbf{H}$ & 0,185 & 0,105 & 0,107 & 0,077 & 0,090 \\
\hline I & 0,008 & $-0,016$ & $-0,015$ & $-0,003$ & 0,059 \\
\hline $\mathrm{J}$ & $-0,220$ & $-0,098$ & $-0,109$ & $-0,123$ & 0,008 \\
\hline
\end{tabular}

TABELA 5.182: Momentos Fletores MY na capa, em $\mathrm{kN} . \mathrm{cm} / \mathrm{cm}$, na laje com 08 nervuras por lado

\section{LAJE COM RELAÇÃO a1/l=0,1111}

MOMENTO FLETOR MY NA CAPA $(\mathrm{kN} . \mathrm{cm} / \mathrm{cm})$

\begin{tabular}{c|c|c|c|c|c}
\hline \multirow{2}{*}{ Ponto } & \multicolumn{5}{|c}{ Modelos numéricos de análise } \\
\cline { 2 - 6 } & $\mathbf{0 1}$ & $\mathbf{0 2}$ & $\mathbf{0 3}$ & $\mathbf{0 4}$ & $\mathbf{0 5}$ \\
\hline \hline $\mathbf{A}$ & 1,535 & 0,880 & 0,903 & $\mathbf{0 , 7 4 2}$ & 0,703 \\
\hline \hline $\mathbf{B}$ & 1,449 & 0,830 & 0,850 & $\mathbf{0 , 6 9 1}$ & 0,653 \\
\hline $\mathbf{C}$ & 1,345 & 0,765 & 0,783 & $\mathbf{0 , 6 2 3}$ & 0,604 \\
\hline \hline $\mathbf{D}$ & 1,222 & 0,705 & 0,721 & $\mathbf{0 , 5 7 1}$ & 0,528 \\
\hline $\mathbf{E}$ & 1,120 & 0,640 & 0,653 & $\mathbf{0 , 5 1 2}$ & 0,491 \\
\hline $\mathbf{F}$ & 0,855 & 0,492 & 0,502 & $\mathbf{0 , 3 7 7}$ & 0,391 \\
\hline \hline $\mathbf{G}$ & 0,843 & 0,499 & 0,510 & $\mathbf{0 , 3 8 9}$ & 0,344 \\
\hline $\mathbf{H}$ & 0,765 & 0,447 & 0,454 & $\mathbf{0 , 3 4 4}$ & 0,322 \\
\hline $\mathbf{I}$ & 0,544 & 0,322 & 0,324 & $\mathbf{0 , 2 4 3}$ & 0,262 \\
\hline $\mathbf{J}$ & 0,165 & 0,106 & 0,104 & $\mathbf{0 , 0 6 9}$ & 0,154 \\
\hline \hline $\mathbf{K}$ & 0,292 & 0,218 & 0,220 & $\mathbf{0 , 1 3 1}$ & 0,104 \\
\hline $\mathbf{L}$ & 0,256 & 0,159 & 0,161 & $\mathbf{0 , 1 0 4}$ & 0,094 \\
\hline $\mathbf{M}$ & 0,150 & 0,065 & 0,067 & $\mathbf{0 , 0 5 3}$ & 0,075 \\
\hline $\mathbf{N}$ & $-0,052$ & $-0,073$ & $-0,072$ & $\mathbf{- 0 , 0 3 2}$ & 0,049 \\
\hline $\mathbf{O}$ & $-0,281$ & $-0,131$ & $-0,145$ & $\mathbf{- 0 , 1 4 7}$ & 0,000 \\
\hline \hline
\end{tabular}


TABELA 5.183: Momentos Fletores MY na capa, em kN.cm/cm, na laje com 09 nervuras por lado

\begin{tabular}{|c|c|c|c|c|c|}
\hline \multicolumn{6}{|c|}{$\begin{array}{c}\text { LAJE COM RELAÇÃO a1/l=0,1000 } \\
\text { MOMENTO FLETOR MY NA CAPA }(\mathrm{kN.cm} / \mathrm{cm})\end{array}$} \\
\hline \multirow{2}{*}{ Ponto } & \multicolumn{5}{|c|}{ Modelos numéricos de análise } \\
\hline & 01 & $\mathbf{0 2}$ & $\mathbf{0 3}$ & 04 & 05 \\
\hline$\overline{\mathbf{A}}$ & 1,815 & 1,034 & 1,061 & 0,860 & 0,803 \\
\hline B B & 1,659 & 0,945 & 0,968 & 0,772 & 0,716 \\
\hline $\mathbf{C}$ & 1,471 & 0,837 & 0,857 & 0,667 & 0,635 \\
\hline 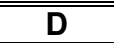 & 1,360 & 0,780 & 0,798 & 0,619 & 0,559 \\
\hline $\mathbf{E}$ & 1,183 & 0,677 & 0,691 & 0,529 & 0,500 \\
\hline $\mathbf{F}$ & 0,843 & 0,490 & 0,499 & 0,364 & 0,380 \\
\hline$\overline{\mathbf{G}}$ & 0,912 & 0,536 & 0,547 & 0,405 & 0,350 \\
\hline $\mathbf{H}$ & 0,779 & 0,458 & 0,464 & 0,341 & 0,316 \\
\hline I & 0,501 & 0,300 & 0,300 & 0,220 & 0,248 \\
\hline $\mathbf{J}$ & 0,065 & 0,048 & 0,045 & 0,026 & 0,133 \\
\hline $\bar{K}$ & 0,295 & 0,204 & 0,207 & 0,115 & 0,087 \\
\hline $\mathbf{L}$ & 0,236 & 0,125 & 0,128 & 0,082 & 0,076 \\
\hline $\mathbf{M}$ & 0,105 & 0,010 & 0,012 & 0,026 & 0,061 \\
\hline $\mathbf{N}$ & $-0,118$ & $-0,141$ & $-0,139$ & $-0,062$ & 0,040 \\
\hline 0 & $-0,343$ & $-0,166$ & $-0,183$ & $-0,173$ & $-0,007$ \\
\hline
\end{tabular}

TABELA 5.184: Momentos Fletores MY na capa, em kN.cm/cm, na laje com 10 nervuras por lado

\begin{tabular}{|c|c|c|c|c|c|}
\hline \multicolumn{6}{|c|}{$\begin{array}{c}\text { LAJE COM RELAÇÃO a1/l=0,0910 } \\
\text { MOMENTO FLETOR MY NA CAPA }(\mathbf{k N . c m} / \mathrm{cm})\end{array}$} \\
\hline \multirow{2}{*}{ Ponto } & \multicolumn{5}{|c|}{ Modelos numéricos de análise } \\
\hline & 01 & $\mathbf{0 2}$ & 03 & 04 & 05 \\
\hline$\overline{\mathbf{A}}$ & 2,240 & 1,282 & 1,317 & 1,076 & 0,975 \\
\hline$\overline{\mathbf{B}}$ & 2,154 & 1,231 & 1,263 & 1,022 & 0,924 \\
\hline $\mathbf{C}$ & 2,050 & 1,167 & 1,196 & 0,954 & 0,874 \\
\hline$\overline{\mathbf{D}}$ & 1,927 & 1,106 & 1,133 & 0,896 & 0,796 \\
\hline $\mathbf{E}$ & 1,823 & 1,038 & 1,063 & 0,833 & 0,756 \\
\hline $\mathbf{F}$ & 1,554 & 0,889 & 0,909 & 0,692 & 0,646 \\
\hline$\overline{\mathbf{G}}$ & 1,552 & 0,899 & 0,921 & 0,702 & 0,602 \\
\hline $\mathrm{H}$ & 1,459 & 0,837 & 0,855 & 0,649 & 0,574 \\
\hline I & 1,210 & 0,697 & 0,711 & 0,533 & 0,497 \\
\hline $\mathbf{J}$ & 0,801 & 0,471 & 0,479 & 0,341 & 0,361 \\
\hline $\mathrm{K}$ & 1,018 & 0,608 & 0,623 & 0,447 & 0,361 \\
\hline $\mathbf{L}$ & 0,953 & 0,561 & 0,572 & 0,410 & 0,345 \\
\hline $\mathbf{M}$ & 0,769 & 0,456 & 0,460 & 0,329 & 0,303 \\
\hline $\mathbf{N}$ & 0,436 & 0,264 & 0,262 & 0,190 & 0,230 \\
\hline 0 & $-0,051$ & $-0,020$ & $-0,026$ & $-0,023$ & 0,110 \\
\hline $\mathbf{P}$ & 0,314 & 0,249 & 0,251 & 0,116 & 0,072 \\
\hline $\mathbf{Q}$ & 0,285 & 0,174 & 0,178 & 0,094 & 0,066 \\
\hline $\mathbf{R}$ & 0,205 & 0,074 & 0,078 & 0,056 & 0,057 \\
\hline $\mathbf{S}$ & 0,050 & $-0,061$ & $-0,058$ & $-0,003$ & 0,046 \\
\hline $\mathbf{T}$ & $-0,190$ & $-0,219$ & $-0,215$ & $-0,094$ & 0,032 \\
\hline $\mathbf{U}$ & $-0,407$ & $-0,203$ & $-0,224$ & $-0,199$ & $-0,015$ \\
\hline
\end{tabular}


TABELA 5.185: Momentos Fletores MY na capa, em kN.cm/cm, na laje com 11 nervuras por lado

\begin{tabular}{|c|c|c|c|c|c|}
\hline \multicolumn{6}{|c|}{$\begin{array}{c}\text { LAJE COM RELAÇÃO a1/l=0,0833 } \\
\text { MOMENTO FLETOR MY NA CAPA }(\mathrm{kN} . \mathrm{cm} / \mathrm{cm})\end{array}$} \\
\hline \multirow{2}{*}{ Ponto } & \multicolumn{5}{|c|}{ Modelos numéricos de análise } \\
\hline & 01 & 02 & 03 & 04 & 05 \\
\hline$\overline{\mathbf{A}}$ & 2,584 & 1,474 & 1,513 & 1,224 & 1,094 \\
\hline B & 2,427 & 1,384 & 1,420 & 1,133 & 1,005 \\
\hline $\mathbf{C}$ & 2,240 & 1,278 & 1,308 & 1,025 & 0,921 \\
\hline$\overline{\mathbf{D}}$ & 2,129 & 1,219 & 1,248 & 0,972 & 0,844 \\
\hline $\mathbf{E}$ & 1,945 & 1,111 & 1,137 & 0,875 & 0,777 \\
\hline $\mathbf{F}$ & 1,598 & 0,920 & 0,941 & 0,701 & 0,644 \\
\hline$\overline{\mathbf{G}}$ & 1,682 & 0,972 & 0,996 & 0,744 & 0,622 \\
\hline $\mathbf{H}$ & 1,522 & 0,877 & 0,895 & 0,666 & 0,576 \\
\hline I & 1,206 & 0,701 & 0,714 & 0,524 & 0,485 \\
\hline $\mathrm{J}$ & 0,731 & 0,436 & 0,443 & 0,307 & 0,336 \\
\hline $\bar{K}$ & 1,080 & 0,643 & 0,658 & 0,458 & 0,358 \\
\hline $\mathbf{L}$ & 0,970 & 0,575 & 0,584 & 0,406 & 0,334 \\
\hline $\mathbf{M}$ & 0,738 & 0,442 & 0,444 & 0,310 & 0,287 \\
\hline $\mathbf{N}$ & 0,353 & 0,217 & 0,213 & 0,154 & 0,209 \\
\hline 0 & $-0,181$ & $-0,099$ & $-0,105$ & $-0,076$ & 0,087 \\
\hline $\bar{P}$ & 0,312 & 0,221 & 0,226 & 0,096 & 0,049 \\
\hline $\mathbf{Q}$ & 0,265 & 0,127 & 0,133 & 0,069 & 0,044 \\
\hline $\mathbf{R}$ & 0,163 & 0,006 & 0,011 & 0,029 & 0,038 \\
\hline $\mathrm{S}$ & $-0,013$ & $-0,148$ & $-0,144$ & $-0,035$ & 0,032 \\
\hline $\mathbf{T}$ & $-0,264$ & $-0,306$ & $-0,302$ & $-0,127$ & 0,024 \\
\hline $\mathbf{U}$ & $-0,471$ & $-0,241$ & $-0,265$ & $-0,226$ & $-0,022$ \\
\hline
\end{tabular}


TABELA 5.186: Momentos Fletores MY na capa, em kN.cm/cm, na laje com 12 nervuras por lado

\begin{tabular}{|c|c|c|c|c|c|}
\hline \multicolumn{6}{|c|}{$\begin{array}{c}\text { LAJE COM RELAÇÃO a1/l=0,0769 } \\
\text { MOMENTO FLETOR MY NA CAPA }(\mathrm{kN} . \mathrm{cm} / \mathrm{cm})\end{array}$} \\
\hline \multirow{2}{*}{ Ponto } & \multicolumn{5}{|c|}{ Modelos numéricos de análise } \\
\hline & 01 & 02 & 03 & 04 & 05 \\
\hline$\overline{\mathbf{A}}$ & 3,073 & 1,760 & 1,809 & 1,473 & 1,285 \\
\hline$\overline{\mathbf{B}}$ & 2,987 & 1,709 & 1,755 & 1,418 & 1,234 \\
\hline $\mathbf{C}$ & 2,883 & 1,644 & 1,687 & 1,348 & 1,184 \\
\hline $\bar{D}$ & 2,759 & 1,582 & 1,624 & 1,288 & 1,105 \\
\hline $\mathbf{E}$ & 2,655 & 1,515 & 1,553 & 1,222 & 1,062 \\
\hline $\mathbf{F}$ & 2,386 & 1,364 & 1,399 & 1,077 & 0,947 \\
\hline$\overline{\mathbf{G}}$ & 2,386 & 1,377 & 1,413 & 1,087 & 0,906 \\
\hline $\mathrm{H}$ & 2,287 & 1,310 & 1,342 & 1,028 & 0,873 \\
\hline I & 2,027 & 1,163 & 1,190 & 0,901 & 0,784 \\
\hline $\mathbf{J}$ & 1,606 & 0,933 & 0,954 & 0,697 & 0,630 \\
\hline $\mathrm{K}$ & 1,859 & 1,087 & 1,115 & 0,819 & 0,651 \\
\hline $\mathbf{L}$ & 1,776 & 1,028 & 1,052 & 0,771 & 0,629 \\
\hline $\mathbf{M}$ & 1,553 & 0,900 & 0,919 & 0,671 & 0,569 \\
\hline $\mathbf{N}$ & 1,175 & 0,689 & 0,701 & 0,506 & 0,466 \\
\hline 0 & 0,637 & 0,387 & 0,392 & 0,264 & 0,308 \\
\hline $\mathbf{P}$ & 1,173 & 0,711 & 0,729 & 0,492 & 0,359 \\
\hline $\mathbf{Q}$ & 1,119 & 0,667 & 0,681 & 0,460 & 0,348 \\
\hline $\mathbf{R}$ & 0,966 & 0,577 & 0,584 & 0,395 & 0,318 \\
\hline $\mathrm{S}$ & 0,687 & 0,416 & 0,415 & 0,284 & 0,267 \\
\hline$T$ & 0,255 & 0,160 & 0,152 & 0,112 & 0,188 \\
\hline $\mathbf{U}$ & $-0,321$ & $-0,185$ & $-0,193$ & $-0,134$ & 0,064 \\
\hline$\overline{\mathrm{V}}$ & 0,323 & 0,273 & 0,277 & 0,092 & 0,027 \\
\hline W & 0,298 & 0,177 & 0,183 & 0,071 & 0,023 \\
\hline $\mathbf{X}$ & 0,233 & 0,062 & 0,069 & 0,042 & 0,021 \\
\hline $\mathbf{Y}$ & 0,112 & $-0,080$ & $-0,074$ & $-0,001$ & 0,020 \\
\hline $\mathbf{Z}$ & $-0,083$ & $-0,249$ & $-0,245$ & $-0,069$ & 0,019 \\
\hline$\overline{\text { AA }}$ & $-0,342$ & $-0,402$ & $-0,396$ & $-0,163$ & 0,016 \\
\hline BA & $-0,535$ & $-0,280$ & $-0,309$ & $-0,254$ & $-0,030$ \\
\hline
\end{tabular}


TABELA 5.187: Momentos Fletores MY na capa, em kN.cm/cm, na laje com 13 nervuras por lado

\begin{tabular}{|c|c|c|c|c|c|}
\hline \multicolumn{6}{|c|}{$\begin{array}{c}\text { LAJE COM RELAÇÃO a1/l=0,0714 } \\
\text { MOMENTO FLETOR MY NA CAPA }(\mathrm{kN} . \mathrm{cm} / \mathrm{cm})\end{array}$} \\
\hline \multirow{2}{*}{ Ponto } & \multicolumn{5}{|c|}{ Modelos numéricos de análise } \\
\hline & 01 & $\mathbf{0 2}$ & $\mathbf{0 3}$ & 04 & 05 \\
\hline $\mathbf{A}$ & 3,480 & 1,989 & 2,044 & 2,044 & 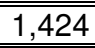 \\
\hline B & 3,323 & 1,899 & 1,950 & 1,950 & 1,334 \\
\hline $\mathbf{C}$ & 3,136 & 1,792 & 1,839 & 1,839 & 1,248 \\
\hline$\overline{\mathbf{D}}$ & 3,024 & 1,732 & 1,778 & 1,778 & 1,170 \\
\hline $\mathbf{E}$ & 2,838 & 1,623 & 1,664 & 1,664 & 1,098 \\
\hline $\mathbf{F}$ & 2,489 & 1,431 & 1,467 & 1,467 & 0,955 \\
\hline $\mathbf{G}$ & 2,578 & 1,487 & 1,525 & 1,525 & 0,941 \\
\hline $\mathbf{H}$ & 2,405 & 1,382 & 1,416 & 1,416 & 0,887 \\
\hline$I$ & 2,074 & 1,197 & 1,225 & 1,225 & 0,778 \\
\hline $\mathrm{J}$ & 1,582 & 0,928 & 0,949 & 0,949 & 0,608 \\
\hline$\overline{\mathrm{K}}$ & 1,980 & 1,156 & 1,186 & 1,186 & 0,661 \\
\hline $\mathbf{L}$ & 1,839 & 1,069 & 1,093 & 1,093 & 0,625 \\
\hline $\mathbf{M}$ & 1,557 & 0,909 & 0,927 & 0,927 & 0,555 \\
\hline $\mathbf{N}$ & 1,119 & 0,662 & 0,673 & 0,673 & 0,443 \\
\hline 0 & 0,522 & 0,324 & 0,328 & 0,328 & 0,276 \\
\hline$\overline{\mathbf{P}}$ & $1,1,228$ & 0,743 & 0,761 & 0,761 & 0,348 \\
\hline $\mathbf{Q}$ & 1,136 & 0,681 & 0,694 & 0,694 & 0,331 \\
\hline $\mathbf{R}$ & 0,943 & 0,569 & 0,574 & 0,574 & 0,298 \\
\hline $\mathrm{S}$ & 0,619 & 0,380 & 0,376 & 0,376 & 0,245 \\
\hline$T$ & 0,142 & 0,092 & 0,082 & 0,082 & 0,165 \\
\hline $\mathbf{U}$ & $-0,472$ & $-0,279$ & $-0,289$ & $-0,289$ & 0,041 \\
\hline V V & 0,314 & 0,230 & 0,237 & $0,0,237$ & $\overline{-2-0,002}$ \\
\hline $\mathbf{W}$ & 0,274 & 0,114 & 0,123 & 0,123 & $-0,004$ \\
\hline $\mathbf{X}$ & 0,193 & $-0,022$ & $-0,013$ & $-0,013$ & $-0,002$ \\
\hline $\mathbf{Y}$ & 0,053 & $-0,184$ & $-0,178$ & $-0,178$ & 0,001 \\
\hline $\mathbf{Z}$ & $-0,158$ & $-0,365$ & $-0,361$ & $-0,361$ & 0,006 \\
\hline$\overline{\mathbf{A A}}$ & $-0,422$ & $-0,507$ & $-0,500$ & $-0,500$ & 0,008 \\
\hline BA & $-0,599$ & $-0,320$ & $-0,353$ & $-0,353$ & $-0,037$ \\
\hline
\end{tabular}


TABELA 5.188: Momentos Fletores MY na capa, em kN.cm/cm, na laje com 14 nervuras por lado

\begin{tabular}{|c|c|c|c|c|c|}
\hline \multicolumn{6}{|c|}{$\begin{array}{c}\text { LAJE COM RELAÇÃO a1/l=0,0667 } \\
\text { MOMENTO FLETOR MY NA CAPA }(\mathbf{k N . c m} / \mathrm{cm})\end{array}$} \\
\hline \multirow{2}{*}{ Ponto } & \multicolumn{5}{|c|}{ Modelos numéricos de análise } \\
\hline & 01 & 02 & 03 & 04 & 05 \\
\hline$\overline{\mathbf{A}}$ & 4,031 & 2,312 & 2,378 & 1,933 & 1,634 \\
\hline B & 3,944 & 2,260 & 2,324 & 1,877 & 1,583 \\
\hline $\mathbf{C}$ & 3,841 & 2,196 & 2,256 & 1,807 & 1,532 \\
\hline D & 3,716 & 2,133 & 2,192 & 1,745 & 1,453 \\
\hline $\mathbf{E}$ & 3,612 & 2,066 & 2,121 & 1,677 & 1,408 \\
\hline $\bar{F}$ & 3,343 & 1,916 & 1,967 & 1,529 & 1,289 \\
\hline$\overline{\mathbf{G}}$ & 3,344 & 1,929 & 1,981 & 1,539 & 1,251 \\
\hline $\mathbf{H}$ & 3,242 & 1,860 & 1,909 & 1,476 & 1,214 \\
\hline I & 2,978 & 1,710 & 1,754 & 1,341 & 1,116 \\
\hline $\mathbf{J}$ & 2,552 & 1,477 & 1,515 & 1,128 & 0,950 \\
\hline $\bar{K}$ & 2,821 & 1,641 & 1,686 & 1,263 & 0,988 \\
\hline $\mathbf{L}$ & 2,729 & 1,576 & 1,617 & 1,209 & 0,961 \\
\hline $\mathbf{M}$ & 2,487 & 1,436 & 1,471 & 1,094 & 0,888 \\
\hline $\mathbf{N}$ & 2,087 & 1,214 & 1,242 & 0,911 & 0,764 \\
\hline 0 & 1,528 & 0,906 & 0,927 & 0,651 & 0,578 \\
\hline $\bar{P}$ & 2,142 & 1,266 & $1,1,302$ & 0,922 & 0,678 \\
\hline $\mathbf{Q}$ & 2,070 & 1,211 & 1,242 & 0,880 & 0,660 \\
\hline $\mathbf{R}$ & 1,873 & 1,095 & 1,120 & 0,792 & 0,614 \\
\hline $\mathrm{S}$ & 1,536 & 0,904 & 0,920 & 0,651 & 0,535 \\
\hline$T$ & 1,040 & 0,622 & 0,631 & 0,442 & 0,416 \\
\hline $\mathbf{U}$ & 0,387 & 0,249 & 0,250 & 0,155 & 0,243 \\
\hline $\mathbf{V}$ & $1,1,308$ & 0,807 & 0,830 & 0,527 & 0,339 \\
\hline $\mathbf{W}$ & 1,262 & 0,765 & 0,783 & 0,498 & 0,331 \\
\hline$X$ & 1,134 & 0,686 & 0,697 & 0,443 & 0,311 \\
\hline $\mathbf{Y}$ & 0,901 & 0,550 & 0,552 & 0,354 & 0,276 \\
\hline $\mathbf{Z}$ & 0,535 & 0,333 & 0,326 & 0,216 & 0,223 \\
\hline$\overline{\mathbf{A A}}$ & 0,018 & 0,016 & 0,002 & 0,012 & 0,143 \\
\hline BA & $-0,630$ & $-0,380$ & $-0,391$ & $-0,263$ & 0,018 \\
\hline CA & 0,316 & 0,291 & 0,297 & 0,058 & $-0,032$ \\
\hline DA & 0,295 & 0,169 & 0,178 & 0,038 & $-0,033$ \\
\hline EA & 0,241 & 0,032 & 0,043 & 0,014 & $-0,032$ \\
\hline FA & 0,143 & $-0,125$ & $-0,115$ & $-0,020$ & $-0,026$ \\
\hline GA & $-0,013$ & $-0,307$ & $-0,300$ & $-0,069$ & $-0,017$ \\
\hline HA & $-0,238$ & $-0,496$ & $-0,491$ & $-0,143$ & $-0,007$ \\
\hline IA & $-0,503$ & $-0,619$ & $-0,611$ & $-0,238$ & 0,000 \\
\hline JA & $-0,664$ & $-0,360$ & $-0,397$ & $-0,313$ & $-0,045$ \\
\hline
\end{tabular}


TABELA 5.189: Momentos Fletores MY na capa, em kN.cm/cm, na laje com 15 nervuras por lado

\begin{tabular}{|c|c|c|c|c|c|}
\hline \multicolumn{6}{|c|}{$\begin{array}{c}\text { LAJE COM RELAÇÃO a1/l=0,0625 } \\
\text { MOMENTO FLETOR MY NA CAPA }(\mathrm{kN.cm} / \mathrm{cm})\end{array}$} \\
\hline \multirow{2}{*}{ Ponto } & \multicolumn{5}{|c|}{ Modelos numéricos de análise } \\
\hline & 01 & 02 & 03 & 04 & 05 \\
\hline$\overline{\mathbf{A}}$ & 4,499 & 2,578 & 2,651 & 2,144 & 1,791 \\
\hline B & 4,341 & 2,487 & 2,557 & 2,049 & 1,701 \\
\hline $\mathbf{C}$ & 4,155 & 2,380 & 2,446 & 1,938 & 1,613 \\
\hline D & 4,041 & 2,320 & 2,384 & 1,879 & 1,536 \\
\hline $\mathbf{E}$ & 3,856 & 2,210 & 2,270 & 1,774 & 1,459 \\
\hline $\mathbf{F}$ & 3,506 & 2,018 & 2,072 & 1,589 & 1,310 \\
\hline $\mathbf{G}$ & 3,597 & 2,075 & 2,132 & $\begin{array}{l}1,637 \\
\end{array}$ & 1,302 \\
\hline $\mathbf{H}$ & 3,418 & 1,967 & 2,019 & 1,542 & 1,241 \\
\hline I & 3,079 & 1,776 & 1,823 & 1,376 & 1,120 \\
\hline $\mathbf{J}$ & 2,579 & 1,504 & 1,543 & 1,131 & 0,933 \\
\hline $\bar{K}$ & 3,002 & 1,747 & 1,795 & $1,1,327$ & 1,012 \\
\hline $\mathbf{L}$ & 2,844 & 1,648 & 1,690 & 1,247 & 0,967 \\
\hline $\mathbf{M}$ & 2,536 & 1,473 & 1,509 & 1,107 & 0,879 \\
\hline $\mathbf{N}$ & 2,071 & 1,214 & 1,243 & 0,898 & 0,742 \\
\hline 0 & 1,448 & 0,869 & 0,889 & 0,612 & 0,544 \\
\hline $\bar{P}$ & 2,255 & 1,332 & 1,370 & 0,954 & 0,679 \\
\hline $\mathbf{Q}$ & 2,130 & 1,251 & 1,283 & 0,893 & 0,651 \\
\hline $\mathbf{R}$ & 1,882 & 1,108 & 1,132 & 0,788 & 0,596 \\
\hline $\mathrm{S}$ & 1,491 & 0,885 & 0,900 & 0,628 & 0,511 \\
\hline$T$ & 0,941 & 0,569 & 0,575 & 0,399 & 0,386 \\
\hline $\mathbf{U}$ & 0,236 & 0,161 & 0,160 & 0,090 & 0,208 \\
\hline V & 1,356 & 0,835 & 0,859 & 0,529 & 0,321 \\
\hline $\mathbf{W}$ & 1,277 & 0,779 & 0,796 & 0,490 & 0,309 \\
\hline $\mathbf{X}$ & 1,114 & 0,681 & 0,690 & 0,425 & 0,287 \\
\hline $\mathbf{Y}$ & 0,844 & 0,522 & 0,521 & 0,325 & 0,252 \\
\hline $\mathbf{Z}$ & 0,438 & 0,277 & 0,265 & 0,173 & 0,199 \\
\hline AA & $-0,118$ & $-0,069$ & $-0,086$ & $-0,045$ & 0,120 \\
\hline BA & $-0,795$ & $-0,486$ & $-0,499$ & $-0,334$ & $-0,005$ \\
\hline CA & 0,301 & 0,231 & 0,240 & 0,029 & $-0,067$ \\
\hline DA & 0,267 & 0,088 & 0,100 & 0,008 & $-0,066$ \\
\hline EA & 0,199 & $-0,070$ & $-0,058$ & $-0,019$ & $-0,060$ \\
\hline FA & 0,086 & $-0,249$ & $-0,238$ & $-0,054$ & $-0,049$ \\
\hline GA & $-0,087$ & $-0,448$ & $-0,440$ & $-0,106$ & $-0,035$ \\
\hline HA & $-0,323$ & $-0,640$ & $-0,635$ & $-0,183$ & $-0,019$ \\
\hline IA & $-0,586$ & $-0,739$ & $-0,730$ & $-0,278$ & $-0,007$ \\
\hline JA & $-0,728$ & $-0,400$ & $-0,443$ & $-0,345$ & $-0,053$ \\
\hline
\end{tabular}


5.3.2.9 Esforços Normais e Momentos Fletores no topo dos pilares

TABELA 5.190: Esforço Normal, em kN, e Momentos Fletores MX e MY, em kN.cm, nos pilares da laje com 05 nervuras por lado

LAJE COM RELAÇ̃̃O a1/l=0,1667

ESFORÇO NORMAL NOS PILARES (kN)

\begin{tabular}{c|c|c|c|c|c|c|c|c}
\hline \multirow{2}{*}{ Pilares } & \multicolumn{8}{c}{ Modelos numéricos de análise } \\
\cline { 2 - 8 } & $\mathbf{0 1}$ & $\mathbf{0 2}$ & $\mathbf{0 3}$ & $\mathbf{0 4}$ & $\mathbf{0 5}$ & $\mathbf{0 6}$ & $\mathbf{0 7}$ & $\mathbf{0 8}$ \\
\hline \hline P1 A P4 & $-24,30$ & $-24,30$ & $-24,30$ & $\mathbf{- 2 4 , 3 0}$ & $-24,30$ & $-24,30$ & $-24,30$ & $-24,30$ \\
\hline \hline
\end{tabular}

LAJE COM RELAÇ̃̃O a1/l=0,1667

MOMENTOS FLETORES MX E MY NO TOPO DOS PILARES (kN.cm)

\begin{tabular}{l|c|c|c|c|c|c|c|c}
\hline \multirow{2}{*}{ Pilares } & \multicolumn{7}{|c}{ Modelos numéricos de análise } \\
\cline { 2 - 9 } & $\mathbf{0 1}$ & $\mathbf{0 2}$ & $\mathbf{0 3}$ & $\mathbf{0 4}$ & $\mathbf{0 5}$ & $\mathbf{0 6}$ & $\mathbf{0 7}$ & $\mathbf{0 8}$ \\
\hline \hline P1 A P4 & 618,98 & 640,84 & 648,49 & $\mathbf{7 6 9 , 1 3}$ & 560,15 & 557,25 & 578,91 & 646,73 \\
\hline \hline
\end{tabular}

TABELA 5.191: Esforço Normal, em kN, e Momentos Fletores MX e MY, em kN.cm, nos pilares da laje com 06 nervuras por lado

LAJE COM RELAÇ̃̃O a1/l=0,1429

ESFORÇO NORMAL NOS PILARES (kN)

\begin{tabular}{c|c|c|c|c|c|c|c|c}
\hline \multirow{2}{*}{ Pilares } & \multicolumn{8}{|c}{ Modelos numéricos de análise } \\
\cline { 2 - 9 } & $\mathbf{0 1}$ & $\mathbf{0 2}$ & $\mathbf{0 3}$ & $\mathbf{0 4}$ & $\mathbf{0 5}$ & $\mathbf{0 6}$ & $\mathbf{0 7}$ & $\mathbf{0 8}$ \\
\hline \hline P1 A P4 & $-33,08$ & $-33,08$ & $-33,08$ & $\mathbf{- 3 3 , 0 8}$ & $-33,08$ & $-33,08$ & $-33,08$ & $-33,08$ \\
\hline \hline
\end{tabular}

LAJE COM RELAÇÃO a1/l=0,1429

MOMENTOS FLETORES MX E MY NO TOPO DOS PILARES (kN.cm)

\begin{tabular}{l|c|c|c|c|c|c|c|c}
\hline \multirow{2}{*}{ Pilares } & \multicolumn{8}{|c}{ Modelos numéricos de análise } \\
\cline { 2 - 9 } & $\mathbf{0 1}$ & $\mathbf{0 2}$ & $\mathbf{0 3}$ & $\mathbf{0 4}$ & $\mathbf{0 5}$ & $\mathbf{0 6}$ & $\mathbf{0 7}$ & $\mathbf{0 8}$ \\
\hline \hline P1 A P4 & 870,17 & 914,47 & 927,51 & $\mathbf{1 1 0 2 , 0 0}$ & 769,50 & 757,96 & 806,29 & 894,84 \\
\hline \hline
\end{tabular}

TABELA 5.192: Esforço Normal, em kN, e Momentos Fletores MX e MY, em kN.cm, nos pilares da laje com 07 nervuras por lado

LAJE COM RELAÇÃO a1/l=0,1250

ESFORÇO NORMAL NOS PILARES (kN)

\begin{tabular}{c|c|c|c|c|c|c|c|c}
\hline \multirow{2}{*}{ Pilares } & \multicolumn{8}{c}{ Modelos numéricos de análise } \\
\cline { 2 - 9 } & $\mathbf{0 1}$ & $\mathbf{0 2}$ & $\mathbf{0 3}$ & $\mathbf{0 4}$ & $\mathbf{0 5}$ & $\mathbf{0 6}$ & $\mathbf{0 7}$ & $\mathbf{0 8}$ \\
\hline P1 A P4 & $-43,20$ & $-43,20$ & $-43,20$ & $\mathbf{- 4 3 , 2 0}$ & $-43,20$ & $-43,20$ & $-43,20$ & $-43,20$ \\
\hline \hline
\end{tabular}

LAJE COM RELAÇÃO a1/l=0,1250

MOMENTOS FLETORES MX E MY NO TOPO DOS PILARES (kN.cm)

\begin{tabular}{c|c|c|c|c|c|c|c|c}
\hline \multirow{2}{*}{ Pilares } & \multicolumn{8}{c}{ Modelos numéricos de análise } \\
\cline { 2 - 9 } & $\mathbf{0 1}$ & $\mathbf{0 2}$ & $\mathbf{0 3}$ & $\mathbf{0 4}$ & $\mathbf{0 5}$ & $\mathbf{0 6}$ & $\mathbf{0 7}$ & $\mathbf{0 8}$ \\
\hline \hline P1 A P4 & 1145,00 & 1220,00 & 1240,00 & $\mathbf{1 4 7 9 , 0 0}$ & 990,18 & 964,40 & 1051,00 & 1160,00 \\
\hline \hline
\end{tabular}


TABELA 5.193: Esforço Normal, em kN, e Momentos Fletores MX e MY, em kN.cm, nos pilares da laje com 08 nervuras por lado

\begin{tabular}{|c|c|c|c|c|c|c|c|c|}
\hline \multicolumn{9}{|c|}{$\begin{array}{c}\text { LAJE COM RELAÇÃ̃ a1/l=0,1111 } \\
\text { ESFORÇO NORMAL NOS PILARES }(\mathbf{k N})\end{array}$} \\
\hline \multirow{2}{*}{ Pilares } & \multicolumn{8}{|c|}{ Modelos numéricos de análise } \\
\hline & 01 & 02 & 03 & 04 & 05 & 06 & 07 & 08 \\
\hline P1 A P4 & $-54,68$ & $-54,68$ & $-54,68$ & $-54,68$ & $-54,68$ & $-54,68$ & $-54,68$ & $-54,68$ \\
\hline \multicolumn{9}{|c|}{$\begin{array}{r}\text { LAJE COM RELAÇÃO a1/l=0,1111 } \\
\text { MOMENTOS FLETORES MX E MY NO TOPO DOS P }\end{array}$} \\
\hline \multirow{2}{*}{ Pilares } & \multicolumn{8}{|c|}{ Modelos numéricos de análise } \\
\hline & 01 & 02 & 03 & 04 & 05 & 06 & 07 & 08 \\
\hline P1 A P4 & 1435,00 & 1548,00 & 1576,00 & 1878,00 & 1215,00 & 11169,00 & 1307,00 & 1436,00 \\
\hline
\end{tabular}

TABELA 5.194: Esforço Normal, em kN, e Momentos Fletores MX e MY, em kN.cm, nos pilares da laje com 09 nervuras por lado

\begin{tabular}{|c|c|c|c|c|c|c|c|c|}
\hline \multicolumn{9}{|c|}{$\begin{array}{c}\text { LAJE COM RELAÇÃO a1/l=0,1000 } \\
\text { ESFORÇO NORMAL NOS PILARES }(\mathbf{k N})\end{array}$} \\
\hline \multirow{2}{*}{ Pilares } & \multicolumn{8}{|c|}{ Modelos numéricos de análise } \\
\hline & 01 & $\mathbf{0 2}$ & $\mathbf{0 3}$ & 04 & 05 & 06 & 07 & 08 \\
\hline P1 A P4 & $-67,50$ & $-67,50$ & $-67,50$ & $-67,50$ & $-67,50$ & $-67,50$ & $-67,50$ & $-67,50$ \\
\hline \multicolumn{9}{|c|}{$\begin{array}{c}\text { LAJE COM RELAÇÃO a1/l=0,1000 } \\
\text { MOMENTOS FLETORES MX E MY NO TOPO DOS PILARES }\end{array}$} \\
\hline \multirow{2}{*}{ Pilares } & \multicolumn{8}{|c|}{ Modelos numéricos de análise } \\
\hline & 01 & 02 & 03 & 04 & 05 & 06 & 07 & 08 \\
\hline P1 A P4 & 1732,00 & 1890,00 & 1929,00 & 2318,00 & 1439,00 & 1366,00 & 1567,00 & 1715,00 \\
\hline
\end{tabular}

TABELA 5.195: Esforço Normal, em kN, e Momentos Fletores MX e MY, em kN.cm, nos pilares da laje com 10 nervuras por lado

\begin{tabular}{|c|c|c|c|c|c|c|c|c|}
\hline \multicolumn{9}{|c|}{$\begin{array}{c}\text { LAJE COM RELAÇÃO a1/l=0,0910 } \\
\text { ESFORÇO NORMAL NOS PILARES }(\mathrm{kN}) \\
\end{array}$} \\
\hline \multirow{2}{*}{ Pilares } & \multicolumn{8}{|c|}{ Modelos numéricos de análise } \\
\hline & 01 & 02 & 03 & 04 & 05 & 06 & 07 & 08 \\
\hline P1 A P4 & $-81,68$ & $-81,68$ & $-81,68$ & $-81,68$ & $-81,68$ & $-81,68$ & $-81,68$ & $-81,68$ \\
\hline \multicolumn{9}{|c|}{$\begin{array}{r}\text { LAJE COM RELAÇÃO a1/l=0,0910 } \\
\text { SS FLETORES MX E MY NO TOPO DOS I }\end{array}$} \\
\hline \multirow{2}{*}{ Pilares } & \multicolumn{8}{|c|}{ Modelos numéricos de análise } \\
\hline & 01 & 02 & $\mathbf{0 3}$ & 04 & 05 & 06 & 07 & 08 \\
\hline P1 A P4 & 2032,00 & 2241,00 & 2292,00 & 2783,00 & 1660,00 & 1554,00 & 1829,00 & 1995,00 \\
\hline
\end{tabular}


TABELA 5.196: Esforço Normal, em kN, e Momentos Fletores MX e MY, em kN.cm, nos pilares da laje com 11 nervuras por lado

\begin{tabular}{|c|c|c|c|c|c|c|c|c|}
\hline \multicolumn{9}{|c|}{$\begin{array}{c}\text { LAJE COM RELAÇÃ̃O a1/l=0,0833 } \\
\text { ESFORÇO NORMAL NOS PILARES }(\mathbf{k N})\end{array}$} \\
\hline \multirow{2}{*}{ Pilares } & \multicolumn{8}{|c|}{ Modelos numéricos de análise } \\
\hline & 01 & 02 & 03 & 04 & 05 & 06 & 07 & 08 \\
\hline P1 A P4 & $-97,20$ & $-97,20$ & $-97,20$ & $-97,20$ & $-97,20$ & $-97,20$ & $-97,20$ & $-97,20$ \\
\hline \multicolumn{9}{|c|}{$\begin{array}{c}\text { LAJE COM RELAÇÃO } \mathbf{a} 1 / \mathrm{l}=0,0833 \\
\text { MOMENTOS FLETORES MX E MY NO TOPO DOS PILARES }\end{array}$} \\
\hline \multirow{2}{*}{ Pilares } & \multicolumn{8}{|c|}{ Modelos numéricos de análise } \\
\hline & 01 & 02 & 03 & 04 & 05 & 06 & 07 & 08 \\
\hline P1 A P4 & 2331,00 & 2597,00 & 2660,00 & 3270,00 & 1877,00 & 1732,00 & 2089,00 & 2273,00 \\
\hline
\end{tabular}

TABELA 5.197: Esforço Normal, em kN, e Momentos Fletores MX e MY, em kN.cm, nos pilares da laje com 12 nervuras por lado

\begin{tabular}{|c|c|c|c|c|c|c|c|c|}
\hline \multicolumn{9}{|c|}{$\begin{array}{c}\text { LAJE COM RELAÇÃO a1/l=0,0769 } \\
\text { ESFORÇO NORMAL NOS PILARES }(\mathrm{kN})\end{array}$} \\
\hline \multirow{2}{*}{ Pilares } & \multicolumn{8}{|c|}{ Modelos numéricos de análise } \\
\hline & 01 & 02 & 03 & 04 & 05 & 06 & 07 & 08 \\
\hline P1 A P4 & $-114,08$ & $-114,08$ & $-114,08$ & $-114,08$ & $-114,08$ & $-114,08$ & $-114,08$ & $-114,08$ \\
\hline \multicolumn{9}{|c|}{$\begin{array}{r}\text { LAJE COM RELAÇÃO a1/l=0,0769 } \\
\text { MOMENTOS FLETORES MX E MY NO TOPO DOS }\end{array}$} \\
\hline \multirow{2}{*}{ Pilares } & \multicolumn{8}{|c|}{ Modelos numéricos de análise } \\
\hline & 01 & $\mathbf{0 2}$ & 03 & 04 & 05 & 06 & 07 & 08 \\
\hline P1 A P4 & 2627,00 & 2954,00 & 3031,00 & 3778,00 & 2088,00 & 1900,00 & 2347,00 & 2548,00 \\
\hline
\end{tabular}

TABELA 5.198: Esforço Normal, em kN, e Momentos Fletores MX e MY, em kN.cm, nos pilares da laje com 13 nervuras por lado

\begin{tabular}{|c|c|c|c|c|c|c|c|c|}
\hline \multicolumn{9}{|c|}{$\begin{array}{c}\text { LAJE COM RELAÇÃO a1/l=0,0714 } \\
\text { ESFORÇO NORMAL NOS PILARES (kN) }\end{array}$} \\
\hline \multirow{2}{*}{ Pilares } & \multicolumn{8}{|c|}{ Modelos numéricos de análise } \\
\hline & 01 & 02 & 03 & 04 & 05 & 06 & 07 & 08 \\
\hline P1 A P4 & $-132,30$ & $-132,30$ & $-132,30$ & $-132,30$ & $-132,30$ & $-132,30$ & $-132,30$ & $-132,30$ \\
\hline \multicolumn{9}{|c|}{$\begin{array}{c}\text { LAJE COM RELAÇÃO a1/l=0,0714 } \\
\text { MOMENTOS FLETORES MX E MY NO TOPO DOS PILARES }(\mathrm{kN} . \mathrm{cm})\end{array}$} \\
\hline \multirow{2}{*}{ Pilares } & \multicolumn{8}{|c|}{ Modelos numéricos de análise } \\
\hline & 01 & $\mathbf{0 2}$ & $\mathbf{0 3}$ & 04 & 05 & 06 & 07 & 08 \\
\hline P1 A P4 & 2919,00 & 3311,00 & 3402,00 & 4284,00 & 2294,00 & 2060,00 & 2602,00 & 2799,00 \\
\hline
\end{tabular}


TABELA 5.199: Esforço Normal, em kN, e Momentos Fletores MX e MY, em kN.cm, nos pilares da laje com 14 nervuras por lado

\begin{tabular}{|c|c|c|c|c|c|c|c|c|}
\hline \multicolumn{9}{|c|}{$\begin{array}{c}\text { LAJE COM RELAÇÃO a1/l=0,0667 } \\
\text { ESFORÇO NORMAL NOS PILARES }(k N)\end{array}$} \\
\hline \multirow{2}{*}{ Pilares } & \multicolumn{8}{|c|}{ Modelos numéricos de análise } \\
\hline & 01 & 02 & 03 & 04 & 05 & 06 & 07 & 08 \\
\hline P1 A P4 & $-151,88$ & $-151,88$ & $-151,88$ & $-151,88$ & $-151,88$ & $-151,88$ & $-151,88$ & $-151,88$ \\
\hline \multicolumn{9}{|c|}{$\begin{array}{c}\text { LAJE COM RELAÇÃO a1/l=0,0667 } \\
\text { MOMENTOS FLETORES MX E MY NO TOPO DOS PILARES }\end{array}$} \\
\hline \multirow{2}{*}{ Pilares } & \multicolumn{8}{|c|}{ Modelos numéricos de análise } \\
\hline & 01 & 02 & 03 & 04 & 05 & 06 & 07 & 08 \\
\hline P1 A P4 & 3205,00 & 3666,00 & 3772,00 & 4829,00 & 2497,00 & 2212,00 & 2852,00 & 3087,00 \\
\hline
\end{tabular}

TABELA 5.200: Esforço Normal, em kN, e Momentos Fletores MX e MY, em kN.cm, nos pilares da laje com 15 nervuras por lado

\begin{tabular}{|c|c|c|c|c|c|c|c|c|}
\hline \multicolumn{9}{|c|}{$\begin{array}{l}\text { LAJE COM RELAÇÃO a1/l=0,0625 } \\
\text { ESFORÇO NORMAL NOS PILARES }(\mathrm{kN})\end{array}$} \\
\hline \multirow{2}{*}{ Pilares } & \multicolumn{8}{|c|}{ Modelos numéricos de análise } \\
\hline & 01 & $\mathbf{0 2}$ & $\mathbf{0 3}$ & 04 & 05 & 06 & 07 & 08 \\
\hline P1 A P4 & $-172,80$ & $\begin{array}{l}-172,80 \\
\end{array}$ & $-172,80$ & $-172,80$ & $\begin{array}{l}-172,80 \\
\end{array}$ & $\begin{array}{l}-172,80 \\
\end{array}$ & $-172,80$ & $-172,80$ \\
\hline \multicolumn{9}{|c|}{$\begin{array}{l}\text { LAJE COM RELAÇÃO a1/l=0,0625 } \\
\text { MOMENTOS FLETORES MX E MY NO TOPO DOS PILARES (kN.cm) }\end{array}$} \\
\hline \multirow{2}{*}{ Pilares } & \multicolumn{8}{|c|}{ Modelos numéricos de análise } \\
\hline & 01 & $\mathbf{0 2}$ & $\mathbf{0 3}$ & 04 & 05 & 06 & 07 & 08 \\
\hline P1 A P4 & 3485,00 & 4018,00 & 4140,00 & 5396,00 & 2695,00 & 2358,00 & 3099,00 & 3349,00 \\
\hline
\end{tabular}




\subsubsection{Resultados apresentados nas modelagens das lajes com variação do espaçamento entre os eixos das nervuras}

As tabelas de resultados serão apresentadas na seguinte ordem:

a) Tabelas de Deslocamentos Ortogonais ao Plano da Placa, em cm, para as lajes com espaçamento entre os eixos das nervuras variando de 40 a $90 \mathrm{~cm}$;

b) Tabelas de Momentos Fletores nas Nervuras e Vigas, em kN.cm;

c) Tabelas de Esforços Normais nas Nervuras e Vigas, em kN;

d) Tabelas de Tensões Normais nas Fibras Superiores Extremas das Nervuras e Vigas, em $\mathrm{kN} / \mathrm{cm}^{2}$;

e) Tabelas de Tensões Normais nas Fibras Inferiores Extremas das Nervuras e Vigas, em $\mathrm{kN} / \mathrm{cm}^{2}$;

f) Tabelas de Esforços Cortantes nas Nervuras e Vigas, em kN;

g) Tabelas de Momentos Fletores MY na capa, em kN.cm/cm;

h) Tabelas de Momentos Fletores MX na capa, em kN.cm/cm;

i) Tabelas de Esforços Normais e Momentos Fletores no topo dos Pilares, em $\mathrm{kN}$ e $\mathrm{kN} . \mathrm{cm}$, respectivamente.

Gráficos relevantes são também montados, para mostrar com mais clareza o comportamento das lajes, e as respostas de deslocamentos e esforços.

Também apresentam-se comentários sobre os resultados encontrados, nesta série de processamentos, tomando-se sempre como valores de referências os resultados apresentados pelo Modelo 04, considerado aqui como o que apresenta melhores resultados numéricos frente ao comportamento real dos pavimentos em lajes nervuradas, conforme revisão da bibliografia. 


\subsubsection{Deslocamentos ortogonais ao plano da placa}

TABELA 5.201: Deslocamentos ortogonais ao plano da placa, em $\mathrm{cm}$, na laje com espaçamento entre os eixos das nervuras $\mathrm{E}=40 \mathrm{~cm}$

\begin{tabular}{|c|c|c|c|c|c|c|c|c|}
\hline \multicolumn{9}{|c|}{$\begin{array}{l}\text { VARIAÇÃO DO ESPAÇAMENTO ENTRE NERVURAS: E }=40 \mathrm{~cm} \\
\text { DESLOCAMENTOS ORTOGONAIS AO PLANO DA PLACA }(\mathrm{cm})\end{array}$} \\
\hline \multirow{2}{*}{ Ponto } & \multicolumn{8}{|c|}{ Modelos numéricos de análise } \\
\hline & 01 & 02 & 03 & 04 & 05 & 06 & 07 & 08 \\
\hline 11 & $-0,0606$ & $-0,0676$ & $-0,0694$ & $-0,0798$ & $-0,0515$ & $-0,0540$ & $-0,0568$ & $-0,0618$ \\
\hline 2 & $-0,2010$ & $-0,1480$ & $-0,1532$ & $-0,1434$ & $-0,1203$ & $-0,1287$ & $-0,1206$ & $-0,1534$ \\
\hline 3 & $-0,3300$ & $-0,2214$ & $-0,2296$ & $-0,2041$ & $-0,1855$ & $-0,1992$ & $-0,1788$ & $-0,2379$ \\
\hline 4 & $-0,4363$ & $-0,2814$ & $-0,2921$ & $-0,2551$ & $-0,2402$ & $-0,2582$ & $-0,2264$ & $-0,3074$ \\
\hline 5 & $-0,5116$ & $-0,3237$ & $-0,3361$ & $-0,2917$ & $-0,2792$ & $-0,3003$ & $-0,2600$ & $-0,3564$ \\
\hline 6 & $-0,5505$ & $-0,3456$ & $-0,3589$ & $-0,3107$ & $-0,2995$ & $-0,3222$ & $-0,2774$ & $-0,3818$ \\
\hline 7 & $-0,5556$ & $-0,3484$ & $-0,3618$ & $-0,3233$ & $-0,3021$ & - & $-0,2795$ & $-0,3850$ \\
\hline 8 & $-0,0600$ & $-0,0669$ & $-0,0686$ & $-0,0828$ & $-0,0510$ & $-0,0535$ & $-0,0562$ & $-0,0611$ \\
\hline 9 & $-0,1989$ & $-0,1467$ & $-0,1518$ & $-0,1475$ & $-0,1192$ & $-0,1275$ & $-0,1195$ & $-0,1520$ \\
\hline 10 & $-0,3268$ & $-0,2195$ & $-0,2276$ & $-0,2095$ & $-0,1839$ & $-0,1975$ & $-0,1773$ & $-0,2358$ \\
\hline 11 & $-0,4322$ & $-0,2791$ & $-0,2896$ & $-0,2615$ & $-0,2381$ & $-0,2560$ & $-0,2245$ & $-0,3047$ \\
\hline 12 & $-0,5069$ & $-0,3211$ & $-0,3334$ & $-0,2987$ & $-0,2768$ & $-0,2978$ & $-0,2579$ & $-0,3534$ \\
\hline 13 & $-0,5456$ & $-0,3428$ & $-0,3560$ & $-0,3181$ & $-0,2969$ & $-0,3195$ & $-0,2752$ & $-0,3786$ \\
\hline 14 & $-0,5505$ & $-0,3456$ & $-0,3589$ & $-0,3205$ & $-0,2995$ & $-0,3222$ & $-0,2773$ & $-0,3818$ \\
\hline 15 & $-0,0453$ & $-0,0501$ & $-0,0514$ & $-0,0621$ & -0,0391 & $-0,0406$ & $-0,0427$ & $-0,0465$ \\
\hline 16 & $-0,1518$ & $-0,1149$ & $-0,1188$ & $-0,1156$ & $-0,0941$ & $-0,1001$ & $-0,0941$ & $-0,1183$ \\
\hline 17 & $-0,2530$ & $-0,1750$ & $-0,1814$ & $-0,1679$ & $-0,1466$ & $-0,1574$ & $-0,1419$ & $-0,1864$ \\
\hline 18 & $-0,3385$ & $-0,2250$ & $-0,2334$ & $-0,2125$ & $-0,1905$ & $-0,2048$ & $-0,1816$ & $-0,2433$ \\
\hline 19 & $-0,4000$ & $-0,2606$ & $-0,2705$ & $-0,2447$ & $-0,2218$ & $-0,2385$ & $-0,2099$ & $-0,2837$ \\
\hline 20 & $-0,4322$ & $-0,2791$ & $-0,2896$ & $-0,2615$ & $-0,2381$ & $-0,2560$ & $-0,2245$ & $-0,3047$ \\
\hline 21 & $-0,4363$ & $-0,2814$ & $-0,2921$ & $-0,2636$ & $-0,2402$ & $-0,2582$ & $-0,2264$ & $-0,3074$ \\
\hline 22 & $-0,0184$ & $-0,0197$ & $-0,0201$ & $-0,0239$ & $-0,0166$ & $-0,0167$ & $-0,0177$ & $-0,0190$ \\
\hline 23 & $-0,0616$ & $-0,0522$ & $-0,0537$ & $-0,0544$ & $-0,0443$ & $-0,0471$ & $-0,0435$ & $-0,0520$ \\
\hline 24 & $-0,1093$ & $-0,0858$ & $-0,0887$ & $-0,0869$ & $-0,0713$ & $-0,0760$ & $-0,0707$ & $-0,0875$ \\
\hline 25 & $-0,1518$ & $-0,1149$ & $-0,1188$ & $-0,1156$ & $-0,0941$ & $-0,1006$ & $-0,0941$ & $-0,1183$ \\
\hline 26 & $-0,1828$ & $-0,1358$ & $-0,1405$ & $-0,1365$ & $-0,1106$ & $-0,1183$ & $-0,1108$ & $-0,1405$ \\
\hline 27 & $-0,1989$ & $-0,1467$ & $-0,1518$ & $-0,1475$ & $-0,1192$ & $-0,1275$ & $-0,1195$ & $-0,1520$ \\
\hline 28 & $-0,2010$ & $-0,1480$ & $-0,1532$ & $-0,1489$ & $-0,1203$ & $-0,1287$ & $-0,1206$ & $-0,1534$ \\
\hline 29 & $-0,0053$ & $-0,0053$ & $-0,0053$ & $-0,0050$ & $-0,0053$ & $-0,0053$ & $-0,0053$ & $-0,0053$ \\
\hline 30 & $-0,0184$ & $-0,0197$ & $-0,0201$ & $-0,0239$ & $-0,0166$ & $-0,0167$ & $-0,0177$ & $-0,0190$ \\
\hline 31 & $-0,0326$ & $-0,0357$ & $-0,0365$ & $-0,0439$ & $-0,0286$ & $-0,0293$ & $-0,0309$ & $-0,0336$ \\
\hline 32 & $-0,0453$ & $-0,0501$ & $-0,0514$ & $-0,0619$ & $-0,0391$ & $-0,0406$ & $-0,0427$ & $-0,0465$ \\
\hline 33 & $-0,0549$ & $-0,0611$ & $-0,0626$ & $-0,0753$ & $-0,0469$ & $-0,0490$ & $-0,0515$ & $-0,0560$ \\
\hline 34 & $-0,0600$ & $-0,0669$ & $-0,0687$ & $-0,0825$ & $-0,0510$ & $-0,0535$ & $-0,0562$ & $-0,0611$ \\
\hline 35 & $-0,0606$ & $-0,0676$ & $-0,0694$ & $-0,0834$ & $-0,0515$ & $-0,0540$ & $-0,0568$ & $-0,0618$ \\
\hline
\end{tabular}


TABELA 5.202: Deslocamentos ortogonais ao plano da placa, em $\mathrm{cm}$, na laje com espaçamento entre os eixos das nervuras $\mathrm{E}=50 \mathrm{~cm}$

\begin{tabular}{|c|c|c|c|c|c|c|c|c|}
\hline \multicolumn{9}{|c|}{$\begin{array}{l}\text { VARIAÇÃO DO ESPAÇAMENTO ENTRE NERVURAS: E }=50 \mathrm{~cm} \\
\text { DESLOCAMENTOS ORTOGONAIS AO PLANO DA PLACA }(\mathrm{cm})\end{array}$} \\
\hline \multirow{2}{*}{ Ponto } & \multicolumn{8}{|c|}{ Modelos numéricos de análise } \\
\hline & 01 & 02 & 03 & 04 & 05 & 06 & 07 & 08 \\
\hline 1 & $-0,1083$ & $-0,1225$ & $-0,1256$ & $-0,1485$ & $-0,0872$ & $-0,0894$ & $-0,1013$ & $-0,1093$ \\
\hline 2 & $-0,5070$ & $-0,3530$ & $-0,3640$ & $-0,3252$ & $-0,2567$ & $-0,2779$ & $-0,2815$ & $-0,3604$ \\
\hline 3 & $-0,8759$ & $-0,5634$ & $-0,5814$ & $-0,4963$ & $-0,4219$ & $-0,4603$ & $-0,4453$ & $-0,5922$ \\
\hline 4 & $-1,1806$ & $-0,7355$ & $-0,7591$ & $-0,6408$ & $-0,5621$ & $-0,6147$ & $-0,5790$ & $-0,7830$ \\
\hline 5 & $-1,3970$ & $-0,8568$ & $-0,8844$ & $-0,7445$ & $-0,6631$ & $-0,7257$ & $-0,6732$ & $-0,9178$ \\
\hline 6 & $-1,5090$ & $-0,9195$ & $-0,9491$ & $-0,7985$ & $-0,7158$ & $-0,7835$ & $-0,7218$ & $-0,9874$ \\
\hline 7 & $-1,5230$ & $-0,9276$ & $-0,9574$ & $-0,8060$ & $-0,7227$ & - & $-0,7280$ & $-0,9962$ \\
\hline 8 & $-0,1072$ & $-0,1212$ & $-0,1243$ & $-0,1475$ & $-0,0864$ & $-0,0886$ & $-0,1002$ & $-0,1082$ \\
\hline 9 & $-0,5016$ & $-0,3496$ & $-0,3605$ & $-0,3221$ & $-0,2543$ & $-0,2753$ & $-0,2788$ & $-0,3568$ \\
\hline 10 & $-0,8669$ & $-0,5582$ & $-0,5760$ & $-0,4918$ & $-0,4180$ & $-0,4561$ & $-0,4412$ & $-0,5867$ \\
\hline 11 & $-1,1690$ & $-0,7289$ & $-0,7523$ & $-0,6351$ & $-0,5570$ & $-0,6091$ & $-0,5739$ & $-0,7759$ \\
\hline 12 & $-1,3836$ & $-0,8494$ & $-0,8767$ & $-0,7381$ & $-0,6570$ & $-0,7190$ & $-0,6674$ & $-0,9096$ \\
\hline 13 & $-1,4949$ & $-0,9116$ & $-0,9409$ & $-0,7917$ & $-0,7092$ & $-0,7763$ & $-0,7157$ & $-0,9787$ \\
\hline 14 & $-1,5090$ & $-0,9195$ & $-0,9491$ & $-0,7985$ & $-0,7158$ & $-0,7835$ & $-0,7218$ & $-0,9874$ \\
\hline 15 & $-0,0820$ & $-0,0918$ & $-0,0940$ & $-0,1114$ & $-0,0672$ & $-0,0683$ & $-0,0767$ & $-0,0829$ \\
\hline 16 & $-0,3771$ & $-0,2705$ & $-0,2788$ & $-0,2503$ & $-0,1993$ & $-0,2156$ & $-0,2170$ & $-0,2748$ \\
\hline 17 & $-0,6613$ & $-0,4376$ & $-0,4516$ & $-0,3879$ & $-0,3283$ & $-0,3582$ & $-0,3477$ & $-0,4577$ \\
\hline 18 & $-0,9029$ & $-0,5773$ & $-0,5959$ & $-0,5056$ & $-0,4376$ & $-0,4783$ & $-0,4564$ & $-0,6107$ \\
\hline 19 & $-1,0776$ & $-0,6771$ & $-0,6988$ & $-0,5907$ & $-0,5161$ & $-0,5644$ & $-0,5338$ & $-0,7195$ \\
\hline 20 & $-1,1690$ & $-0,7289$ & $-0,7523$ & $-0,6351$ & $-0,5570$ & $-0,6091$ & $-0,5739$ & $-0,7759$ \\
\hline 21 & $-1,1806$ & $-0,7355$ & $-0,7591$ & $-0,6408$ & $-0,5621$ & $-0,6147$ & $-0,5790$ & $-0,7830$ \\
\hline 22 & $-0,0337$ & $-0,0366$ & $-0,0373$ & $-0,0433$ & $-0,0293$ & $-0,0290$ & $-0,0319$ & $-0,0342$ \\
\hline 23 & $-0,1413$ & $-0,1140$ & $-0,1171$ & $-0,1117$ & $-0,0898$ & $-0,0964$ & $-0,0934$ & $-0,1129$ \\
\hline 24 & $-0,2653$ & $-0,1977$ & $-0,2036$ & $-0,1854$ & $-0,1491$ & $-0,1610$ & $-0,1597$ & $-0,1995$ \\
\hline 25 & $-0,3771$ & $-0,2705$ & $-0,2788$ & $-0,2503$ & $-0,1993$ & $-0,2156$ & $-0,2170$ & $-0,2748$ \\
\hline 26 & $-0,4589$ & $-0,3227$ & $-0,3326$ & $-0,2974$ & $-0,2355$ & $-0,2548$ & $-0,2578$ & $-0,3288$ \\
\hline 27 & $-0,5016$ & $-0,3496$ & $-0,3605$ & $-0,3221$ & $-0,2543$ & $-0,2753$ & $-0,2788$ & $-0,3568$ \\
\hline 28 & $-0,5070$ & $-0,3530$ & $-0,3640$ & $-0,3252$ & $-0,2567$ & $-0,2779$ & $-0,2815$ & $-0,3604$ \\
\hline 29 & $-0,0083$ & $-0,0083$ & $-0,0083$ & $-0,0076$ & $-0,0083$ & $-0,0083$ & $-0,0083$ & $-0,0083$ \\
\hline 30 & $-0,0337$ & $-0,0366$ & $-0,0373$ & $-0,0432$ & $-0,0293$ & $-0,0290$ & $-0,0319$ & $-0,0342$ \\
\hline 31 & $-0,0595$ & $-0,0658$ & $-0,0674$ & $-0,0793$ & $-0,0498$ & $-0,0501$ & $-0,0558$ & $-0,0603$ \\
\hline 32 & $-0,0820$ & $-0,0918$ & $-0,0940$ & $-0,1110$ & $-0,0672$ & $-0,0683$ & $-0,0767$ & $-0,0829$ \\
\hline 33 & $-0,0985$ & $-0,1110$ & $-0,1138$ & $-0,1345$ & $-0,0798$ & $-0,0816$ & $-0,0921$ & $-0,0995$ \\
\hline 34 & $-0,1072$ & $-0,1212$ & $-0,1243$ & $-0,1470$ & $-0,0864$ & $-0,0886$ & $-0,1002$ & $-0,1082$ \\
\hline 35 & $-0,1083$ & $-0,1225$ & $-0,1256$ & $-0,1486$ & $-0,0872$ & $-0,0894$ & $-0,1013$ & $-0,1093$ \\
\hline
\end{tabular}


TABELA 5.203: Deslocamentos ortogonais ao plano da placa, em $\mathrm{cm}$, na laje com espaçamento entre os eixos das nervuras $\mathrm{E}=60 \mathrm{~cm}$

\begin{tabular}{|c|c|c|c|c|c|c|c|c|}
\hline \multicolumn{9}{|c|}{$\begin{array}{l}\text { VARIAÇÃO DO ESPAÇAMENTO ENTRE NERVURAS: E }=60 \mathrm{~cm} \\
\text { DESLOCAMENTOS ORTOGONAIS AO PLANO DA PLACA }(\mathrm{cm})\end{array}$} \\
\hline \multirow{2}{*}{ Ponto } & \multicolumn{8}{|c|}{ Modelos numéricos de análise } \\
\hline & 01 & 02 & 03 & 04 & 05 & 06 & 07 & 08 \\
\hline 1 & $-0,1728$ & $-0,1978$ & $-0,2027$ & $-0,2364$ & $-0,1327$ & $-0,1322$ & $-0,1601$ & $-0,1720$ \\
\hline 2 & $-1,1000$ & $-0,7391$ & $-0,7601$ & $-0,6298$ & $-0,4761$ & $-0,5209$ & $-0,5809$ & $-0,7455$ \\
\hline 3 & $-1,9600$ & $-1,2340$ & $-1,2690$ & $-1,0171$ & $-0,8218$ & $-0,9082$ & $-0,9630$ & $-1,2771$ \\
\hline 4 & $-2,6800$ & $-1,6386$ & $-1,6853$ & $-1,3466$ & $-1,1202$ & $-1,2410$ & $-1,2747$ & $-1,7153$ \\
\hline 5 & $-3,1870$ & $-1,9244$ & $-1,9790$ & $-1,5840$ & $-1,3367$ & $-1,4820$ & $-1,4943$ & $-2,0253$ \\
\hline 6 & $-3,4510$ & $-2,0720$ & $-2,1308$ & $-1,7078$ & $-1,4501$ & $-1,6080$ & $-1,6076$ & $-2,1853$ \\
\hline 7 & $-3,4850$ & $-2,0911$ & $-2,1503$ & $-1,7245$ & $-1,4650$ & - & $-1,6219$ & $-2,2056$ \\
\hline 8 & $-0,1711$ & $-0,1958$ & $-0,2006$ & $-0,2348$ & $-0,1315$ & $-0,1310$ & $-0,1585$ & $\overline{-0,1703}$ \\
\hline 9 & $-1,0876$ & $-0,7316$ & $-0,7525$ & $-0,6235$ & $-0,4716$ & $-0,5159$ & $-0,5752$ & $-0,7379$ \\
\hline 10 & $-1,9419$ & $-1,2218$ & $-1,2567$ & $-1,0073$ & $-0,8139$ & $-0,8994$ & $-0,9539$ & $-1,2647$ \\
\hline 11 & $-2,6508$ & $-1,6233$ & $-1,6696$ & $-1,3340$ & $-1,1093$ & $-1,2289$ & $-1,2630$ & $-1,6991$ \\
\hline 12 & $-3,1556$ & $-1,9069$ & $-1,9611$ & $-1,5694$ & $-1,3236$ & $-1,4674$ & $-1,4809$ & $-2,0060$ \\
\hline 13 & $-3,4178$ & $-2,0534$ & $-2,1117$ & $-1,6922$ & $-1,4358$ & $-1,5920$ & $-1,5933$ & $-2,1653$ \\
\hline 14 & $-3,4510$ & $-2,0720$ & $-2,1308$ & $-1,7078$ & $-1,4501$ & $-1,6079$ & $-1,6076$ & $-2,1853$ \\
\hline 15 & $-0,1318$ & $-0,1492$ & $-0,1527$ & $-0,1783$ & $-0,1032$ & $-0,1022$ & $-0,1219$ & $-0,1311$ \\
\hline 16 & $-0,8082$ & $-0,5596$ & $-0,5754$ & $-0,4805$ & $-0,3672$ & $-0,4014$ & $-0,4429$ & $-0,5624$ \\
\hline 17 & $-1,4662$ & $-0,9461$ & $-0,9735$ & $-0,7843$ & $-0,6321$ & $-0,6984$ & $-0,7429$ & $-0,9765$ \\
\hline 18 & $-2,0290$ & $-1,2703$ & $-1,3069$ & $-1,0457$ & $-0,8594$ & $-0,9517$ & $-0,9928$ & $-1,3237$ \\
\hline 19 & $-2,4370$ & $-1,5025$ & $-1,5456$ & $-1,2350$ & $-1,0236$ & $-1,1339$ & $-1,1708$ & $-1,5710$ \\
\hline 20 & $-2,6510$ & $-1,6233$ & $-1,6696$ & $-1,3340$ & $-1,1093$ & $-1,2289$ & $-1,2630$ & $-1,6991$ \\
\hline 21 & $-2,6780$ & $-1,6386$ & $-1,6853$ & $-1,3466$ & $-1,1202$ & $-1,2409$ & $-1,2747$ & $-1,7153$ \\
\hline 22 & $-0,0546$ & $-0,0599$ & $-0,0611$ & $-0,0697$ & $-0,0459$ & $-0,0445$ & $-0,0508$ & 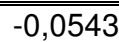 \\
\hline 23 & $-0,2847$ & $-0,2213$ & $-0,2273$ & $-0,2040$ & $-0,1594$ & $-0,1728$ & $-0,1790$ & $-0,2180$ \\
\hline 24 & $-0,5585$ & $-0,4015$ & $-0,4127$ & $-0,3511$ & $-0,2718$ & $-0,2968$ & $-0,3202$ & $-0,4016$ \\
\hline 25 & $-0,8082$ & $-0,5596$ & $-0,5754$ & $-0,4805$ & $-0,3672$ & $-0,4014$ & $-0,4429$ & $-0,5624$ \\
\hline 26 & $-0,9916$ & $-0,6731$ & $-0,6922$ & $-0,5745$ & $-0,4358$ & $-0,4766$ & $-0,5302$ & $-0,6780$ \\
\hline 27 & $-1,0876$ & $-0,7316$ & $-0,7525$ & $-0,6235$ & $-0,4716$ & $-0,5159$ & $-0,5752$ & $-0,7379$ \\
\hline 28 & $-1,0998$ & $-0,7391$ & $-0,7601$ & $-0,6298$ & $-0,4761$ & $-0,5209$ & $-0,5809$ & $-0,7455$ \\
\hline 29 & $-0,0120$ & $-0,0120$ & $-0,0120$ & $-0,0108$ & $-0,0120$ & $-0,0120$ & $-0,0120$ & $-0,0120$ \\
\hline 30 & $-0,0546$ & $-0,0599$ & $-0,0611$ & $-0,0695$ & $-0,0459$ & $-0,0445$ & $-0,0508$ & $-0,0543$ \\
\hline 31 & $-0,0963$ & $-0,1077$ & $-0,1101$ & $-0,1275$ & $-0,0773$ & $-0,0759$ & $-0,0891$ & $-0,0957$ \\
\hline 32 & $-0,1318$ & $-0,1492$ & $-0,1527$ & $-0,1776$ & $-0,1032$ & $-0,1022$ & $-0,1219$ & $-0,1311$ \\
\hline 33 & $-0,1575$ & $-0,1796$ & $-0,1841$ & $-0,2146$ & $-0,1218$ & $-0,1211$ & $-0,1459$ & $-0,1568$ \\
\hline 34 & $-0,1711$ & $-0,1958$ & $-0,2006$ & $-0,2340$ & $-0,1315$ & $-0,1310$ & $-0,1585$ & $-0,1703$ \\
\hline 35 & $-0,1728$ & $-0,1978$ & $-0,2027$ & $-0,2364$ & $-0,1327$ & $-0,1322$ & $-0,1601$ & $-0,1720$ \\
\hline
\end{tabular}


TABELA 5.204: Deslocamentos ortogonais ao plano da placa, em $\mathrm{cm}$, na laje com espaçamento entre os eixos das nervuras $\mathrm{E}=70 \mathrm{~cm}$

\begin{tabular}{|c|c|c|c|c|c|c|c|c|}
\hline \multicolumn{9}{|c|}{$\begin{array}{l}\text { VARIAÇÃO DO ESPAÇAMENTO ENTRE NERVURAS: E }=70 \mathrm{~cm} \\
\text { DESLOCAMENTOS ORTOGONAIS AO PLANO DA PLACA }(\mathrm{cm})\end{array}$} \\
\hline \multirow{2}{*}{ Ponto } & \multicolumn{8}{|c|}{ Modelos numéricos de análise } \\
\hline & 01 & 02 & 03 & 04 & 05 & 06 & 07 & 08 \\
\hline 1 & $-0,2542$ & $-0,2942$ & $-0,3014$ & $-0,3475$ & $-0,1875$ & $-0,1814$ & $-0,2333$ & $-0,2496$ \\
\hline 2 & $-2,1370$ & $-1,4040$ & $-1,4415$ & $-1,1178$ & $-0,8027$ & $-0,8847$ & $-1,0950$ & $-1,4044$ \\
\hline 3 & $-3,8990$ & $-2,4201$ & $-2,4841$ & $-1,8879$ & $-1,4434$ & $-1,6083$ & $-1,8776$ & $-2,4794$ \\
\hline 4 & $-5,3650$ & $-3,2529$ & $-3,3378$ & $-2,5479$ & $-2,0053$ & $-2,2399$ & $-2,5162$ & $-3,3677$ \\
\hline 5 & $-6,4099$ & $-3,8410$ & $-3,9407$ & $-3,0250$ & $-2,4166$ & $-2,7009$ & $-2,9661$ & $-3,9966$ \\
\hline 6 & $-6,9528$ & $-4,1451$ & $-4,2522$ & $-3,2743$ & $-2,6328$ & $-2,9430$ & $-3,1982$ & $-4,3217$ \\
\hline 7 & $-7,0225$ & $-4,1843$ & $-4,2923$ & $-3,3077$ & $-2,6613$ & - & $-3,2276$ & $-4,3628$ \\
\hline 8 & $-0,2518$ & $-0,2913$ & $-0,2984$ & $-0,3451$ & $-0,1858$ & $-0,1798$ & $-0,2310$ & $-0,2471$ \\
\hline 9 & $-2,1121$ & $-1,3894$ & $-1,4265$ & $-1,1063$ & $-0,7948$ & $-0,8760$ & $-1,0840$ & $-1,3897$ \\
\hline 10 & $-3,8566$ & $-2,3959$ & $-2,4592$ & $-1,8690$ & $-1,4290$ & $-1,5923$ & $-1,8593$ & $-2,4546$ \\
\hline 11 & $-5,3092$ & $-3,2215$ & $-3,3057$ & $-2,5230$ & $-1,9850$ & $-2,2172$ & $-2,4925$ & $-3,3350$ \\
\hline 12 & $-6,3457$ & $-3,8051$ & $-3,9038$ & $-2,9958$ & $-2,3918$ & $-2,6732$ & $-2,9388$ & $-3,9586$ \\
\hline 13 & $-6,8844$ & $-4,1068$ & $-4,2130$ & $-3,2429$ & $-2,6056$ & $-2,9125$ & $-3,1691$ & $-4,2809$ \\
\hline 14 & $-6,9528$ & $-4,1451$ & $-4,2522$ & $-3,2743$ & $-2,6328$ & $-2,9430$ & $-3,1982$ & $-4,3217$ \\
\hline 15 & $-0,1948$ & $-0,2229$ & $-0,2282$ & $-0,2631$ & $-0,1470$ & $-0,1416$ & $-0,1783$ & $-0,1909$ \\
\hline 16 & $-1,5550$ & $-1,0525$ & $-1,0804$ & $-0,8460$ & $-0,6152$ & $-0,6777$ & $-0,8267$ & $-1,0497$ \\
\hline 17 & $-2,8906$ & $-1,8384$ & $-1,8877$ & $-1,4402$ & $-1,0992$ & $-1,2248$ & $-1,4351$ & $-1,8804$ \\
\hline 18 & $-4,0378$ & $-2,4996$ & $-2,5661$ & $-1,9543$ & $-1,5197$ & $-1,6970$ & $-1,9429$ & $-2,5787$ \\
\hline 19 & $-4,8717$ & $-2,9743$ & $-3,0525$ & $-2,3276$ & $-1,8252$ & $-2,0387$ & $-2,3048$ & $-3,0768$ \\
\hline 20 & $-5,3092$ & $-3,2215$ & $-3,3057$ & $-2,5230$ & $-1,9850$ & $-2,2172$ & $-2,4925$ & $-3,3350$ \\
\hline 21 & $-5,3649$ & $-3,2529$ & $-3,3378$ & $-2,5479$ & $-2,0053$ & $-2,2399$ & $-2,5162$ & $-3,3677$ \\
\hline 22 & $-0,0812$ & $-0,0899$ & $-0,0917$ & $-0,1034$ & $-0,0662$ & $-0,0628$ & $-0,0745$ & $-0,0793$ \\
\hline 23 & $-0,5224$ & $-0,3948$ & $-0,4053$ & $-0,3432$ & $-0,2586$ & $-0,2822$ & $-0,3165$ & $-0,3874$ \\
\hline 24 & $-1,0601$ & $-0,7437$ & $-0,7636$ & $-0,6103$ & $-0,4512$ & $-0,4966$ & $-0,5888$ & $-0,7395$ \\
\hline 25 & $-1,5550$ & $-1,0525$ & $-1,0804$ & $-0,8460$ & $-0,6152$ & $-0,6777$ & $-0,8267$ & $-1,0497$ \\
\hline 26 & $-1,9205$ & $-1,2747$ & $-1,3086$ & $-1,0171$ & $-0,7332$ & $-0,8080$ & $-0,9966$ & $-1,2736$ \\
\hline 27 & $-2,1121$ & $-1,3894$ & $-1,4265$ & $-1,1063$ & $-0,7948$ & $-0,8760$ & $-1,0840$ & $-1,3897$ \\
\hline 28 & $-2,1366$ & $-1,4040$ & $-1,4415$ & $-1,1178$ & $-0,8027$ & $-0,8847$ & $-1,0950$ & $-1,4044$ \\
\hline 29 & $-0,0163$ & $-0,0163$ & $-0,0163$ & $-0,0144$ & $-0,0163$ & $-0,0163$ & $-0,0163$ & $-0,0163$ \\
\hline 30 & $-0,0812$ & $-0,0899$ & $-0,0917$ & $-0,1030$ & $-0,0662$ & $-0,0628$ & $-0,0745$ & $-0,0793$ \\
\hline 31 & $-0,1429$ & $-0,1616$ & $-0,1652$ & $-0,1887$ & $-0,1108$ & $-0,1062$ & $-0,1306$ & $-0,1398$ \\
\hline 32 & $-0,1948$ & $-0,2229$ & $-0,2282$ & $-0,2622$ & $-0,1470$ & $-0,1416$ & $-0,1783$ & $-0,1909$ \\
\hline 33 & $-0,2322$ & $-0,2677$ & $-0,2742$ & $-0,3158$ & $-0,1726$ & $-0,1668$ & $-0,2129$ & $-0,2278$ \\
\hline 34 & $-0,2518$ & $-0,2913$ & $-0,2984$ & $-0,3440$ & $-0,1858$ & $-0,1798$ & $-0,2310$ & $-0,2471$ \\
\hline 35 & $-0,2542$ & $-0,2942$ & $-0,3014$ & $-0,3475$ & $-0,1875$ & $-0,1814$ & $-0,2333$ & $-0,2496$ \\
\hline
\end{tabular}


TABELA 5.205: Deslocamentos ortogonais ao plano da placa, em $\mathrm{cm}$, na laje com espaçamento entre os eixos das nervuras $\mathrm{E}=80 \mathrm{~cm}$

\begin{tabular}{|c|c|c|c|c|c|c|c|c|}
\hline \multicolumn{9}{|c|}{$\begin{array}{l}\text { VARIAÇÃO DO ESPAÇAMENTO ENTRE NERVURAS: E = } 80 \mathrm{~cm} \\
\text { DESLOCAMENTOS ORTOGONAIS AO PLANO DA PLACA }(\mathrm{cm})\end{array}$} \\
\hline \multirow{2}{*}{ Ponto } & \multicolumn{8}{|c|}{ Modelos numéricos de análise } \\
\hline & 01 & 02 & 03 & 04 & 05 & 06 & 07 & 08 \\
\hline 1 & $-0,3525$ & $-0,4121$ & $-0,4221$ & $-0,4818$ & $-0,2514$ & $-0,2366$ & $-0,3206$ & $-0,3420$ \\
\hline 2 & $-3,8182$ & $-2,4747$ & $-2,5375$ & $-1,8573$ & $-1,2657$ & $-1,4012$ & $-1,9242$ & $-2,4607$ \\
\hline 3 & $-7,0808$ & $-4,3672$ & $-4,4756$ & $-3,2523$ & $-2,3587$ & $-2,6403$ & $-3,3815$ & $-4,4424$ \\
\hline 4 & $-9,8030$ & $-5,9201$ & $-6,0646$ & $-4,4559$ & $-3,3324$ & $-3,7385$ & $-4,5715$ & $-6,0838$ \\
\hline 5 & $-11,7473$ & $-7,0179$ & $-7,1876$ & $-5,3289$ & $-4,0506$ & $-4,5467$ & $-5,4100$ & $-7,2474$ \\
\hline 6 & $-12,7584$ & $-7,5856$ & $-7,7682$ & $-5,7858$ & $-4,4294$ & $-4,9726$ & $-5,8428$ & $-7,8491$ \\
\hline 7 & $-12,8881$ & $-7,6588$ & $-7,8430$ & $-5,8465$ & $-4,4793$ & - & $-5,8976$ & $-7,9253$ \\
\hline 8 & $-0,3492$ & $-0,4080$ & $-0,4178$ & $-0,4786$ & $-0,2493$ & $-0,2345$ & $-0,3175$ & $-0,3386$ \\
\hline 9 & $-3,7735$ & $-2,4483$ & $-2,5103$ & $-1,8377$ & $-1,2531$ & $-1,3872$ & $-1,9044$ & $-2,4344$ \\
\hline 10 & $-7,0024$ & $-4,3223$ & $-4,4297$ & $-3,2189$ & $-2,3445$ & $-2,6132$ & $-3,3478$ & $-4,3970$ \\
\hline 11 & $-9,6996$ & $-5,8617$ & $-6,0049$ & $-4,4108$ & $-3,2974$ & $-3,6993$ & $-4,5273$ & $-6,0236$ \\
\hline 12 & $-11,6278$ & $-6,9507$ & $-7,1189$ & $-5,2755$ & $-4,0073$ & $-4,4982$ & $-5,3591$ & $-7,1771$ \\
\hline 13 & $-12,6311$ & $-7,5142$ & $-7,6952$ & $-5,7281$ & $-4,3817$ & $-4,9190$ & $-5,7885$ & $-7,7737$ \\
\hline 14 & $-12,7584$ & $-7,5856$ & $-7,7682$ & $-5,7858$ & $-4,4294$ & $-4,9726$ & $-5,8428$ & $-7,8491$ \\
\hline 15 & $-0,2711$ & $-0,3132$ & $-0,3205$ & $-0,3658$ & $-0,1983$ & $-0,1861$ & $-0,2456$ & $-0,2623$ \\
\hline 16 & $-2,7578$ & $-1,8394$ & $-1,8860$ & $-1,3953$ & $-0,9645$ & $-1,0674$ & $-1,4408$ & $-1,8253$ \\
\hline 17 & $-5,2194$ & $-3,2932$ & $-3,3766$ & $-2,4590$ & $-1,7805$ & $-1,9932$ & $-2,5663$ & $-3,3476$ \\
\hline 18 & $-7,3419$ & $-4,5198$ & $-4,6326$ & $-3,3844$ & $-2,4982$ & $-2,8020$ & $-3,5074$ & $-4,6311$ \\
\hline 19 & $-8,8879$ & $-5,4019$ & $-5,5348$ & $-4,0580$ & $-3,0225$ & $-3,3910$ & $-4,1790$ & $-5,5480$ \\
\hline 20 & $-9,6996$ & $-5,8617$ & $-6,0049$ & $-4,4108$ & $-3,2974$ & $-3,6993$ & $-4,5273$ & $-6,0236$ \\
\hline 21 & $-9,8030$ & $-5,9201$ & $-6,0646$ & $-4,4559$ & $-3,3324$ & $-3,7385$ & $-4,5715$ & $-6,0838$ \\
\hline 22 & $-0,1133$ & $-0,1268$ & $-0,1292$ & $-0,1442$ & $-0,0901$ & -0,0837 & $-0,1027$ & $-0,1092$ \\
\hline 23 & $-0,8925$ & $-0,6608$ & $-0,6782$ & $-0,5433$ & $-0,3938$ & $-0,4316$ & $-0,5274$ & $-0,6469$ \\
\hline 24 & $-1,8604$ & $-1,2839$ & $-1,3169$ & $-0,9952$ & $-0,7016$ & $-0,7757$ & $-1,0134$ & $-1,2716$ \\
\hline 25 & $-2,7578$ & $-1,8394$ & $-1,8860$ & $-1,3953$ & $-0,9645$ & $-1,0674$ & $-1,4408$ & $-1,8253$ \\
\hline 26 & $-3,4236$ & $-2,2407$ & $-2,2974$ & $-1,6860$ & $-1,1541$ & $-1,2775$ & $-1,7468$ & $-2,2262$ \\
\hline 27 & $-3,7735$ & $-2,4483$ & $-2,5103$ & $-1,8376$ & $-1,2531$ & $-1,3872$ & $-1,9044$ & $-2,4344$ \\
\hline 28 & $-3,8182$ & $-2,4747$ & $-2,5375$ & $-1,8573$ & $-1,2657$ & $-1,4012$ & $-1,9242$ & $-2,4607$ \\
\hline 29 & $-0,0214$ & $-0,0214$ & $-0,0214$ & $-0,0184$ & $-0,0214$ & $-0,0214$ & $-0,0214$ & $-0,0214$ \\
\hline 30 & $-0,1133$ & $-0,1268$ & $-0,1292$ & $-0,1436$ & $-0,0901$ & $-0,0837$ & $-0,1027$ & $-0,1092$ \\
\hline 31 & $-0,1994$ & $-0,2276$ & $-0,2326$ & $-0,2630$ & $-0,1503$ & $-0,1405$ & $-0,1803$ & $-0,1924$ \\
\hline 32 & $-0,2711$ & $-0,3132$ & $-0,3205$ & $-0,3646$ & $-0,1983$ & $-0,1861$ & $-0,2456$ & $-0,2623$ \\
\hline 33 & $-0,3224$ & $-0,3753$ & $-0,3843$ & $-0,4383$ & $-0,2319$ & $-0,2180$ & $-0,2928$ & $-0,3124$ \\
\hline 34 & $-0,3492$ & $-0,4080$ & $-0,4178$ & $-0,4770$ & $-0,2493$ & $-0,2345$ & $-0,3175$ & $-0,3386$ \\
\hline 35 & $-0,3525$ & $-0,4121$ & $-0,4221$ & $-0,4818$ & $-0,2514$ & $-0,2366$ & $-0,3206$ & $-0,3420$ \\
\hline
\end{tabular}


TABELA 5.206: Deslocamentos ortogonais ao plano da placa, em $\mathrm{cm}$, na laje com espaçamento entre os eixos das nervuras $\mathrm{E}=90 \mathrm{~cm}$

\begin{tabular}{|c|c|c|c|c|c|c|c|c|}
\hline \multicolumn{9}{|c|}{$\begin{array}{l}\text { VARIAÇÃO DO ESPAÇAMENTO ENTRE NERVURAS: E }=90 \mathrm{~cm} \\
\text { DESLOCAMENTOS ORTOGONAIS AO PLANO DA PLACA }(\mathrm{cm})\end{array}$} \\
\hline \multirow{2}{*}{ Ponto } & \multicolumn{8}{|c|}{ Modelos numéricos de análise } \\
\hline & 01 & 02 & 03 & 04 & 05 & 06 & 07 & 08 \\
\hline 1 & $-0,4674$ & $-0,5517$ & $-0,5648$ & $-0,6392$ & $-0,3244$ & $-0,2976$ & $-0,4219$ & $-0,4489$ \\
\hline 2 & $-6,3917$ & $-4,1100$ & $-4,2099$ & $-2,9300$ & $-1,9012$ & $-2,1090$ & $-3,1960$ & $-4,0697$ \\
\hline 3 & $-11,9971$ & $-7,3816$ & $-7,5558$ & $-5,2850$ & $-3,6573$ & $-4,1017$ & $-5,7193$ & $-7,4723$ \\
\hline 4 & $-16,6879$ & $-10,0697$ & $-10,3026$ & $-7,3294$ & $-5,2442$ & $-5,8945$ & $-7,7813$ & $-10,2976$ \\
\hline 5 & $-20,0438$ & $-11,9718$ & $-12,2454$ & $-8,8170$ & $-6,4226$ & $-7,2234$ & $-9,2352$ & $-12,3032$ \\
\hline 6 & $-21,7906$ & $-12,9560$ & $-13,2504$ & $-9,5966$ & $-7,0462$ & $-7,9261$ & $-9,9859$ & $-13,3409$ \\
\hline 7 & $-22,0145$ & $-13,0828$ & $-13,3798$ & $-9,6998$ & $-7,1283$ & - & $-10,0808$ & $-13,4722$ \\
\hline 8 & $-0,4630$ & $-0,5462$ & $-0,5592$ & $-0,6349$ & $-0,3217$ & $-0,2951$ & $-0,4178$ & $-0,4446$ \\
\hline 9 & $-6,3156$ & $-4,0652$ & $-4,1638$ & $-2,8985$ & $-1,8818$ & $-2,0875$ & $-3,1623$ & $-4,0252$ \\
\hline 10 & $-11,8624$ & $-7,3044$ & $-7,4768$ & $-5,2293$ & $-3,6187$ & $-4,0586$ & $-5,6612$ & $-7,3946$ \\
\hline 11 & $-16,5098$ & $-9,9687$ & $-10,1994$ & $-7,2533$ & $-5,1873$ & $-5,8307$ & $-7,7050$ & $-10,1941$ \\
\hline 12 & $-19,8376$ & $-11,8554$ & $-12,1266$ & $-8,7262$ & $-6,3517$ & $-7,1436$ & $-9,1470$ & $-12,1820$ \\
\hline 13 & $-21,5706$ & $-12,8322$ & $-13,1240$ & $-9,4982$ & $-6,9676$ & $-7,8376$ & $-9,8917$ & $-13,2108$ \\
\hline 14 & $-21,7906$ & $-12,9560$ & $-13,2504$ & $-9,5966$ & $-7,0462$ & $-7,9261$ & $-9,9859$ & $-13,3409$ \\
\hline 15 & $-0,3603$ & $-0,4202$ & $-0,4298$ & $-0,4862$ & $-0,2569$ & $-0,2354$ & $-0,3238$ & $-0,3449$ \\
\hline 16 & $-4,5886$ & $-3,0332$ & $-3,1069$ & $-2,1870$ & $-1,4410$ & $-1,5982$ & $-2,3763$ & $-2,9997$ \\
\hline 17 & $-8,8043$ & $-5,5344$ & $-5,6682$ & $-3,9663$ & $-2,7391$ & $-3,0722$ & $-4,3163$ & $-5,6024$ \\
\hline 18 & $-12,4510$ & $-7,6501$ & $-7,8315$ & $-5,5224$ & $-3,8939$ & $-4,3757$ & $-5,9413$ & $-7,8028$ \\
\hline 19 & $-15,1116$ & $-9,1738$ & $-9,3878$ & $-6,6578$ & $-4,7417$ & $-5,3298$ & $-7,1023$ & $-9,3770$ \\
\hline 20 & $-16,5098$ & $-9,9687$ & $-10,1994$ & $-7,2533$ & $-5,1873$ & $-5,8307$ & $-7,7050$ & $-10,1941$ \\
\hline 21 & $-16,6879$ & $-10,0697$ & $-10,3026$ & $-7,3294$ & $-5,2442$ & $-5,8945$ & $-7,7813$ & $-10,2976$ \\
\hline 22 & $-0,1508$ & $-0,1704$ & $-0,1736$ & $-0,1920$ & $-0,1176$ & $-0,1072$ & $-0,1356$ & $-0,1438$ \\
\hline 23 & $-1,4420$ & $-1,0517$ & $-1,0791$ & $-0,8212$ & $-0,5727$ & $-0,6291$ & $-0,8383$ & $-1,0286$ \\
\hline 24 & $-3,0699$ & $-2,0959$ & $-2,1482$ & $-1,5442$ & $-1,0401$ & $-1,1527$ & $-1,6543$ & $-2,0709$ \\
\hline 25 & $-4,5886$ & $-3,0332$ & $-3,1069$ & $-2,1870$ & $-1,4410$ & $-1,5982$ & $-2,3763$ & $-2,9997$ \\
\hline 26 & $-5,7197$ & $-3,7128$ & $-3,8028$ & $-2,6545$ & $-1,7305$ & $-1,9196$ & $-2,8949$ & $-3,6743$ \\
\hline 27 & $-6,3156$ & $-4,0652$ & $-4,1638$ & $-2,8985$ & $-1,8818$ & $-2,0875$ & $-3,1623$ & $-4,0252$ \\
\hline 28 & $-6,3917$ & $-4,1100$ & $-4,2099$ & $-2,9300$ & $-1,9012$ & $-2,1090$ & $-3,1960$ & $-4,0697$ \\
\hline 29 & $-0,0270$ & $-0,0270$ & $-0,0270$ & $-0,0228$ & $-0,0270$ & $-0,0270$ & $-0,0270$ & $-0,0270$ \\
\hline 30 & $-0,1508$ & $-0,1704$ & $-0,1736$ & $-0,1912$ & $-0,1176$ & $-0,1072$ & $-0,1356$ & $-0,1438$ \\
\hline 31 & $-0,2654$ & $-0,3059$ & $-0,3125$ & $-0,3502$ & $-0,1954$ & $-0,1787$ & $-0,2380$ & $-0,2534$ \\
\hline 32 & $-0,3603$ & $-0,4202$ & $-0,4298$ & $-0,4846$ & $-0,2569$ & $-0,2354$ & $-0,3238$ & $-0,3449$ \\
\hline 33 & $-0,4279$ & $-0,5029$ & $-0,5147$ & $-0,5818$ & $-0,2997$ & $-0,2748$ & $-0,3855$ & $-0,4104$ \\
\hline 34 & $-0,4630$ & $-0,5462$ & $-0,5592$ & $-0,6328$ & $-0,3217$ & $-0,2951$ & $-0,4178$ & $-0,4446$ \\
\hline 35 & $-0,4674$ & $-0,5517$ & $-0,5648$ & $-0,6392$ & $-0,3244$ & $-0,2976$ & $-0,4219$ & $-0,4489$ \\
\hline
\end{tabular}

Abaixo tem-se os gráficos de deslocamentos ortogonais ao plano da placa para a linha central das lajes processadas nesta série. 


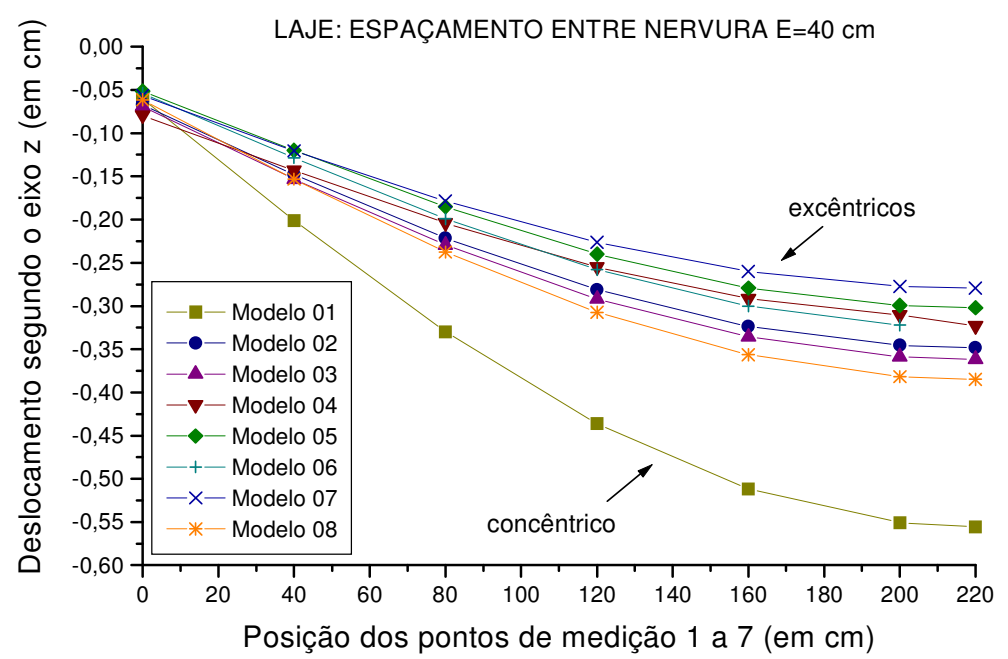

FIGURA 5.148: Deslocamentos em z (cm), no eixo central; laje com espaçamento $\mathrm{E}=40 \mathrm{~cm}$

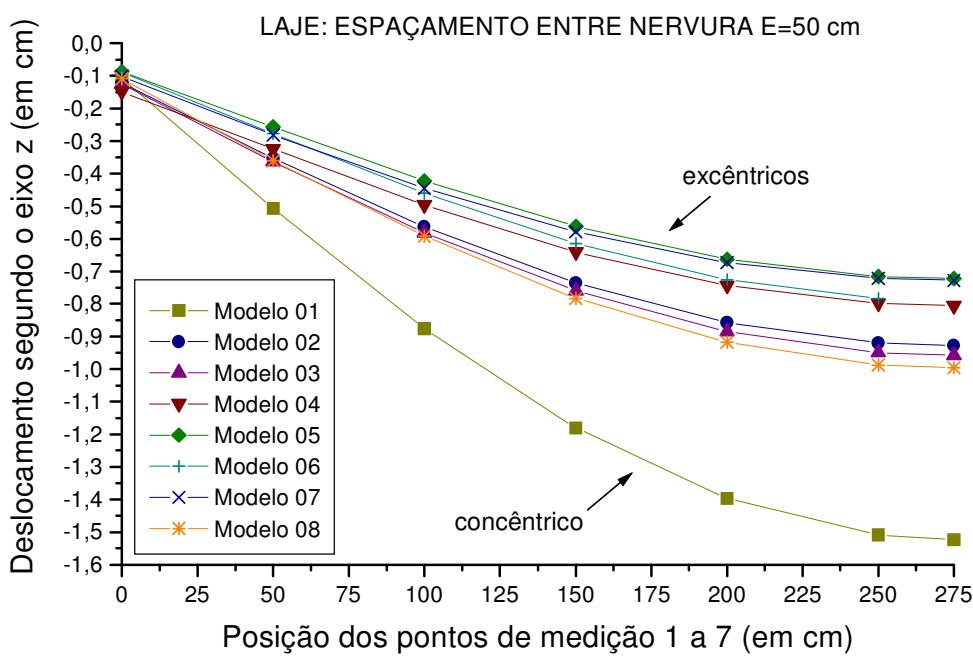

FIGURA 5.149: Deslocamentos em z $(\mathrm{cm})$, no eixo central; laje com espaçamento $\mathrm{E}=50 \mathrm{~cm}$

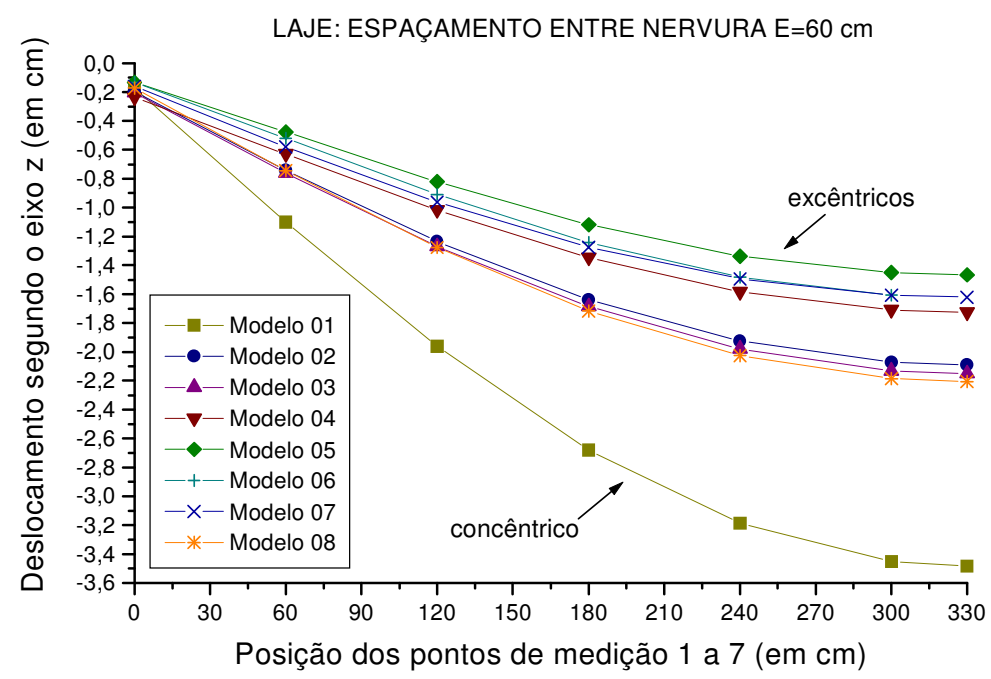

FIGURA 5.150: Deslocamentos em z $(\mathrm{cm})$, no eixo central; laje com espaçamento $\mathrm{E}=60 \mathrm{~cm}$ 


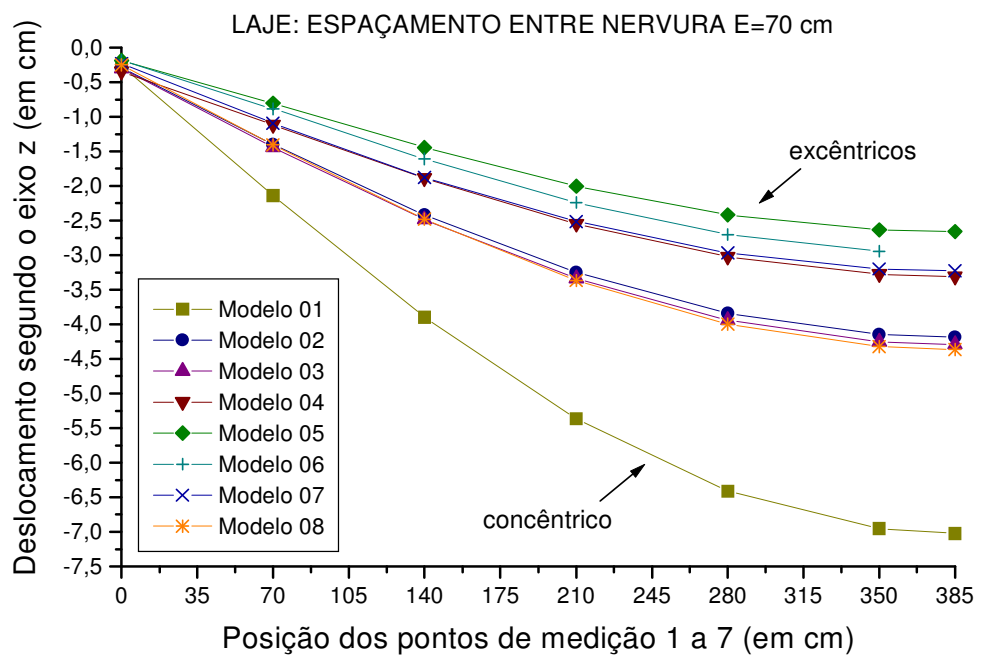

FIGURA 5.151: Deslocamentos em z (cm), no eixo central; laje com espaçamento $E=70 \mathrm{~cm}$

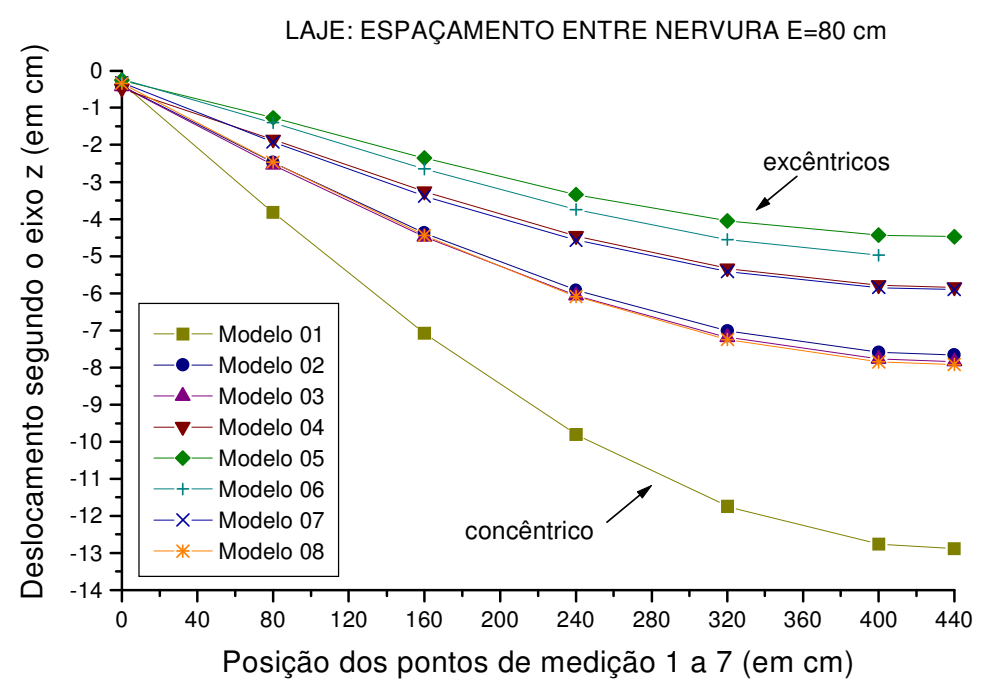

FIGURA 5.152: Deslocamentos em z (cm), no eixo central; laje com espaçamento $E=80 \mathrm{~cm}$

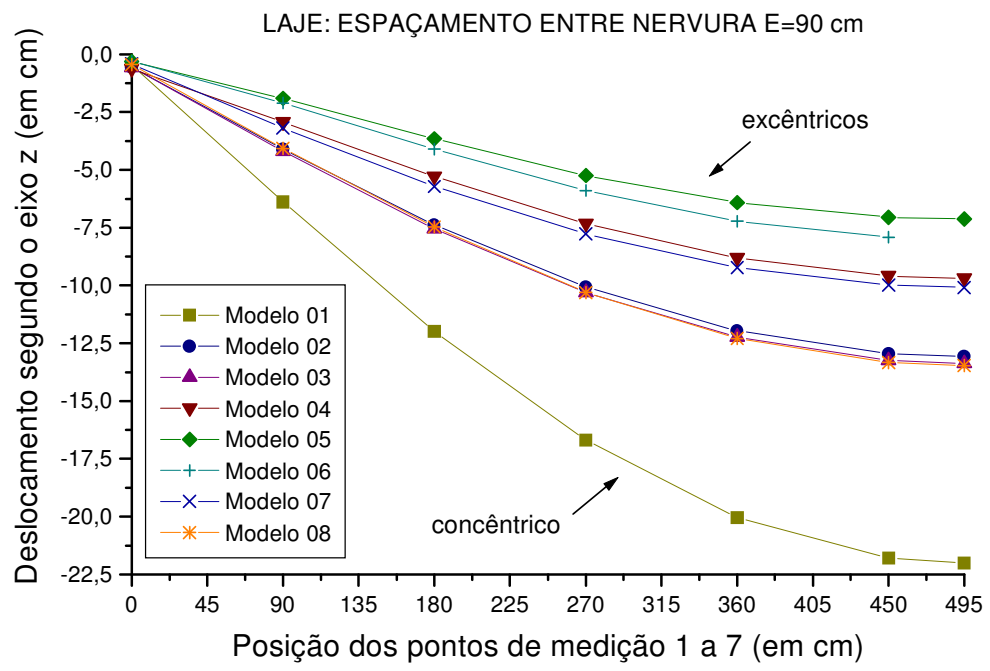

FIGURA 5.153: Deslocamentos em z (cm), no eixo central; laje com espaçamento $\mathrm{E}=90 \mathrm{~cm}$ 
Conforme análise das tabelas e gráficos de deslocamentos nas nervuras, em lajes com variação do espaçamento entre os eixos das nervuras, verificou-se que:

- o modelo concêntrico novamente apresentou deslocamentos ortogonais ao plano da placa muito maiores que os fornecidos pelos modelos excêntricos; à medida que aumenta-se o espaçamento entre os eixos das nervuras, ou seja, que a laje vai tornando-se mais flexível, aumenta-se a diferença entre os valores. Comparando o deslocamento máximo dado pelo modelo concêntrico com aquele obtido pelo modelo realista, para espaçamento entre os eixos das nervuras $\mathrm{E}=90 \mathrm{~cm}$, tem-se uma diferença de $127 \%$ a maior no modelo concêntrico;

- em todas as relações de espaçamento os deslocamentos dados pelos modelos 02, 03 e 08 foram maiores que os do Modelo 04. Como já visto, isso está diretamente ligado à alta relação $h_{f} / h=0,25$ destas lajes testadas. Vê-se, contudo, que à medida que aumenta-se o espaçamento entre os eixos das nervuras, mais distantes os deslocamentos das lajes destes modelos vão ficando dos resultados realistas (para $\mathrm{E}=40 \mathrm{~cm}$ tem-se uma diferença de $19 \%$ a maior entre o resultado de deslocamento máximo pelo Modelo 08 em comparação como o Modelo 04; para E=90 cm essa diferença salta para $39 \%)$;

- à medida que aumenta-se o espaçamento entre os eixos das nervuras, melhores resultados de deslocamentos são dados pelo Modelo 07 (laje maciça equivalente com redução de $\mathrm{G}_{\mathrm{c}}$ ). Para $\mathrm{E}=80 \mathrm{~cm}$ a diferença é de $0,87 \%$ a maior para a o deslocamento máximo, em comparação com o resultado do Modelo 04; para espaçamentos mais baixos a laje maciça equivalente comporta-se com mais rigidez e, com isso, vê-se que quanto maior for o espaçamento entre os eixos das nervuras, mais o sistema aproxima-se do comportamento da estrutura real, haja visto que o modelo 07 torna-se mais flexível. Para $\mathrm{E}=40 \mathrm{~cm}$ a diferença é de $13,6 \%$ a menor para o deslocamento máximo, em relação ao resultado do Modelo 04;

- à medida que aumenta-se o espaçamento entre os eixos das nervuras, mais rígida é a modelagem 05 e 06 frente aos resultados realistas. Verifica-se, novamente, que os modelos de grelha de vigas apresentam melhores resultados para as lajes com nervuras menos espaçadas, onde há a predominância do comportamento das vigas. Para $\mathrm{E}=40 \mathrm{~cm}$ o deslocamento máximo na nervura central, pelo Modelo 05, difere apenas 6,56\%, a menor, em relação ao valor dado pelo Modelo 04. Essa diferença aumenta para 26,51\%, a menor para o Modelo 05, quando a laje tem espaçamento $E=90 \mathrm{~cm}$ entre as nervuras.

Abaixo tem-se os gráficos de deslocamentos ortogonais ao plano da placa para as vigas de contorno externo processadas nesta série. 


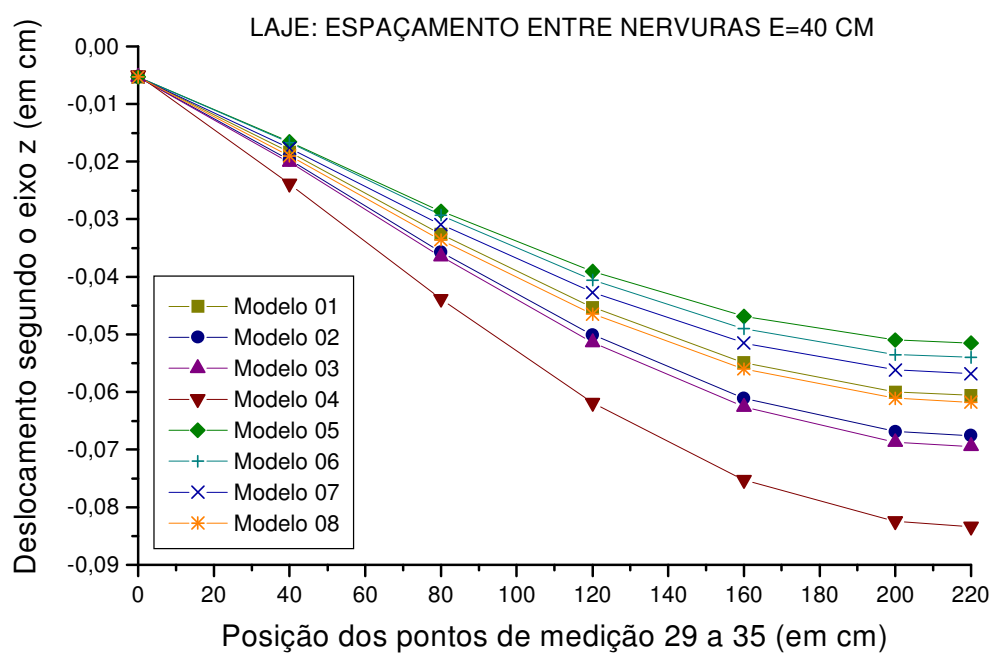

FIGURA 5.154: Deslocamentos em z (cm), na viga externa; laje com espaçamento $\mathrm{E}=40 \mathrm{~cm}$

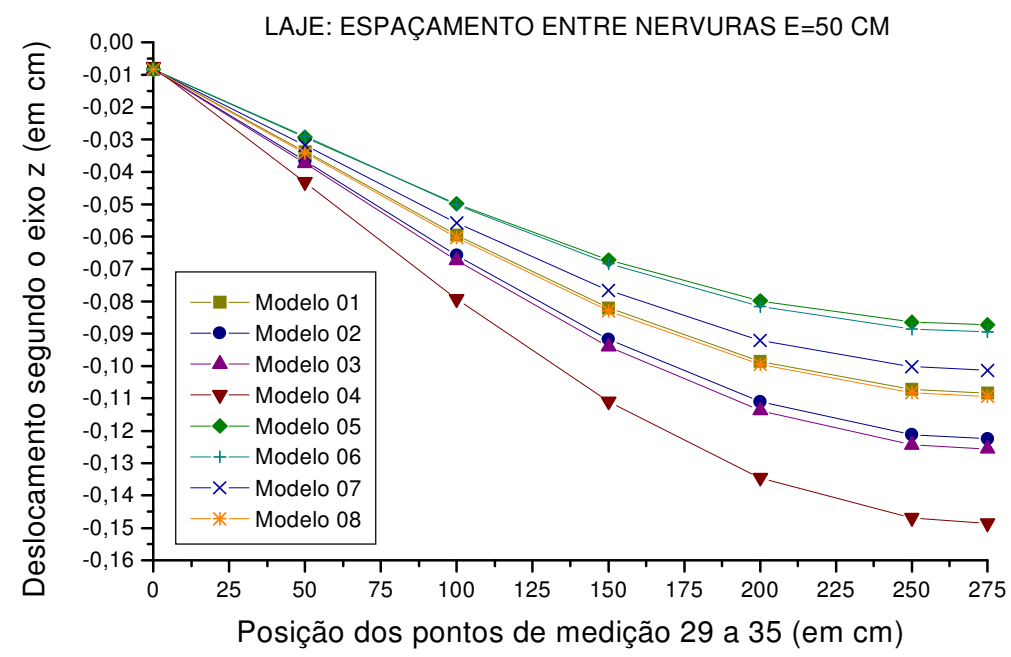

FIGURA 5.155: Deslocamentos em z (cm), na viga externa; laje com espaçamento $E=50 \mathrm{~cm}$

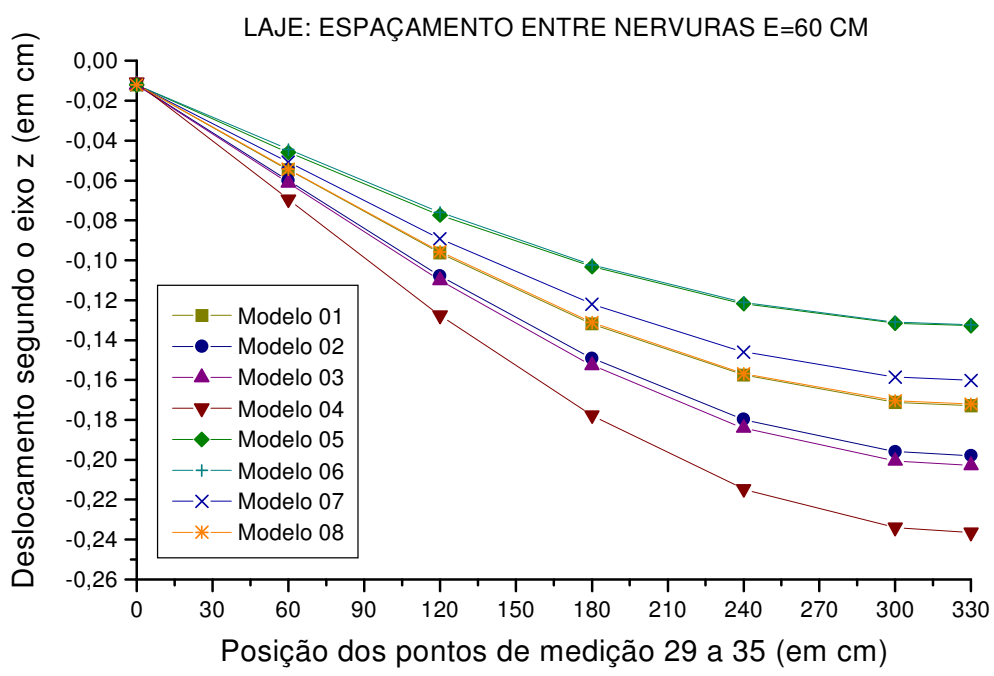

FIGURA 5.156: Deslocamentos em z (cm), na viga externa; laje com espaçamento $E=60 \mathrm{~cm}$ 


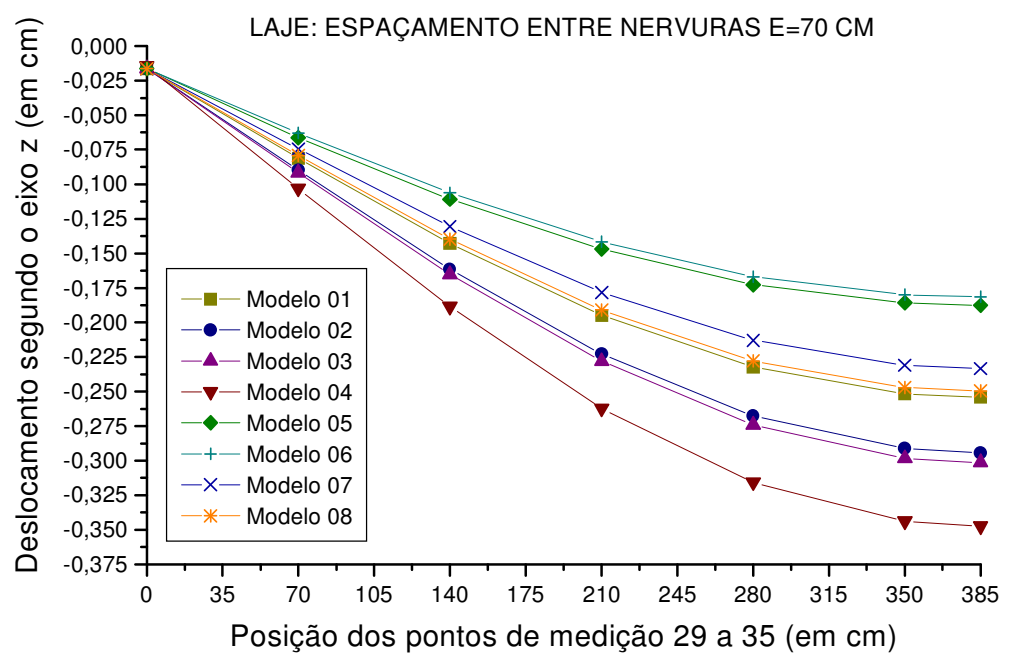

FIGURA 5.157: Deslocamentos em z (cm), na viga externa; laje com espaçamento $\mathrm{E}=70 \mathrm{~cm}$

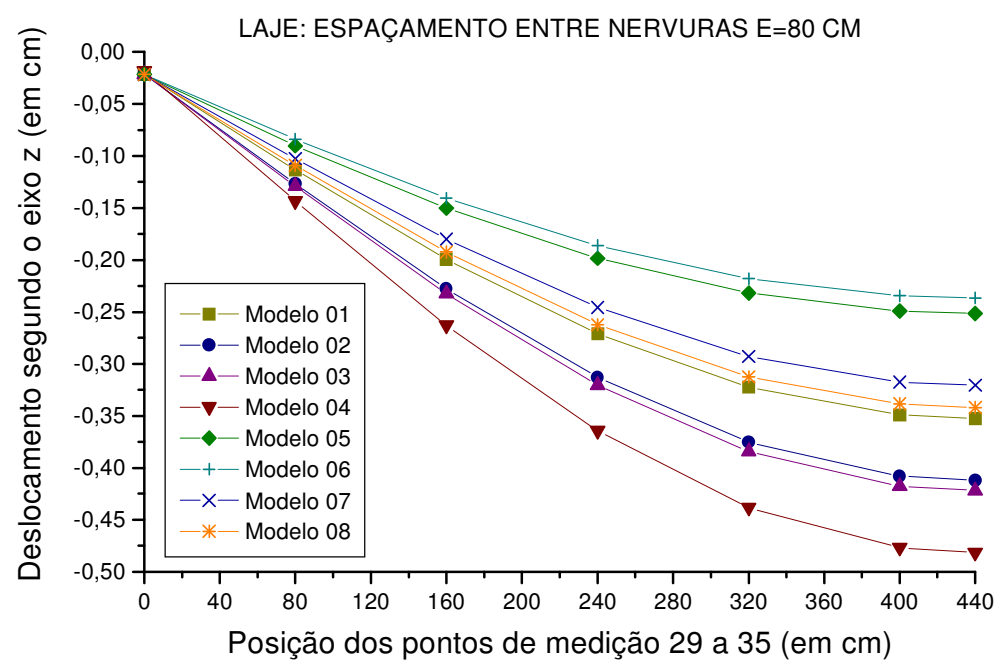

FIGURA 5.158: Deslocamentos em z (cm), na viga externa; laje com espaçamento $\mathrm{E}=80 \mathrm{~cm}$

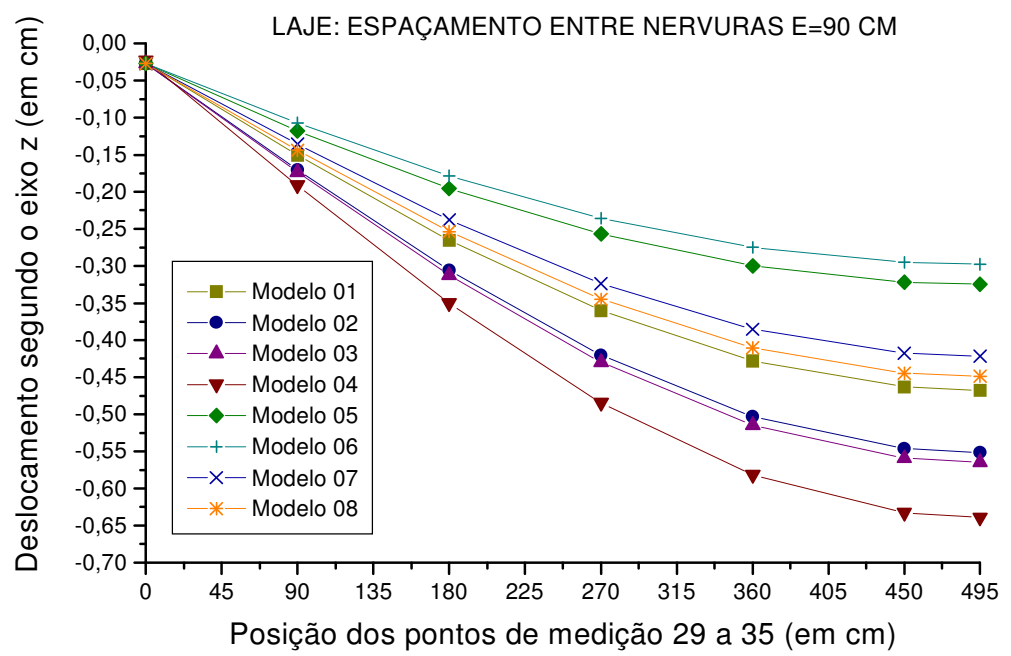

FIGURA 5.159: Deslocamentos em z (cm), na viga externa; laje com espaçamento $E=90 \mathrm{~cm}$ 
Analisando-se as tabelas e gráficos de deslocamentos nas vigas de borda, promovendo-se a variação do espaçamento entre os eixos das nervuras, verificou-se que:

- os maiores deslocamentos são encontrados pela simulação das nervuras e vigas utilizando-se elementos de casca;

- os modelos 02 e 03, de viga excêntrica simulando as nervuras, fazem com que os deslocamentos apresentados pela viga excêntrica BEAM44 sejam, frente aos demais modelos, os que mais se aproximam do modelo realista; para $\mathrm{E}=40 \mathrm{~cm}$ estes apresentam diferença de $18,94 \%$, a menor, para o deslocamento máximo da nervura central pelo Modelo 02 em relação ao Modelo 04; para E=90 cm essa diferença cai para 13,69\%, ainda a menor para o Modelo 02. Melhores resultados seriam obtidos para uma menor relação de $\mathrm{h}_{\mathrm{f}} / \mathrm{h}$;

- os modelos 05 e 06 são os mais rígidos: para $\mathrm{E}=40 \mathrm{~cm}$ tem-se uma diferença de $38,25 \%$, a menor, para o deslocamento máximo da nervura central do Modelo 05 em comparação ao Modelo 04; para E=90 cm essa diferença chega a 49,2\%, ou seja, quanto maior o espaçamento entre os eixos das nervuras, mais flexível é a estrutura real, e os modelos 05 e 06 não conseguem acompanhar satisfatoriamente essa redução de rigidez do sistema;

- os modelos de laje maciça equivalente 07 e 08 fazem a viga apresentar resultados intermediários entre aqueles mais rígidos (modelos 05 e 06) e os mais flexíveis (modelo 02 e 03). 


\subsubsection{Momentos Fletores atuantes nas nervuras e vigas}

TABELA 5.207: Momentos Fletores nas nervuras e vigas, em kN.cm, na laje com espaçamento entre os eixos das nervuras $\mathrm{E}=40 \mathrm{~cm}$

\begin{tabular}{|c|c|c|c|c|c|c|c|c|}
\hline \multicolumn{9}{|c|}{$\begin{array}{l}\text { VARIAÇÃO DO ESPAÇAMENTO ENTRE NERVURAS: E }=40 \mathrm{~cm} \\
\text { MOMENTOS FLETORES NAS NERVURAS E VIGAS }(\mathrm{kN.cm})\end{array}$} \\
\hline \multirow{2}{*}{ Ponto } & \multicolumn{8}{|c|}{ Modelos numéricos de análise } \\
\hline & 01 & 02 & 03 & 04 & 05 & 06 & 07 & 08 \\
\hline 8 & $-31,39$ & $-17,94$ & $\begin{array}{l}-17,83 \\
\end{array}$ & $-37,81$ & $-81,71$ & $-82,03$ & 14,70 & $-6,31$ \\
\hline 9 & 90,76 & 51,79 & 16,70 & 18,75 & 56,73 & 65,40 & 129,07 & 87,13 \\
\hline 10 & 180,82 & 101,95 & 40,28 & 62,68 & 161,95 & 176,85 & 212,71 & 154,90 \\
\hline 11 & 244,68 & 137,09 & 57,00 & 93,79 & 236,13 & 255,97 & 271,89 & 202,06 \\
\hline 12 & 286,97 & 160,22 & 68,40 & 113,90 & 283,02 & 305,98 & 309,76 & 231,38 \\
\hline 13 & 308,47 & 172,34 & 74,96 & 123,82 & 305,60 & 329,94 & 327,34 & 244,66 \\
\hline 14 & 312,11 & 175,13 & 77,14 & 125,12 & 309,43 & 332,94 & 327,34 & 245,60 \\
\hline 15 & $-58,29$ & $-21,19$ & $-17,76$ & $-40,74$ & $-76,70$ & $-77,76$ & $-5,57$ & $-31,05$ \\
\hline 16 & 42,01 & 32,21 & 8,50 & 7,41 & 42,74 & 51,46 & 84,46 & 51,88 \\
\hline 17 & 125,83 & 77,06 & 29,58 & 47,74 & 131,11 & 145,63 & 161,50 & 116,35 \\
\hline 18 & 191,26 & 112,02 & 46,15 & 77,49 & 191,35 & 208,29 & 219,32 & 160,61 \\
\hline 19 & 234,94 & 134,98 & 57,36 & 96,71 & 228,86 & 246,99 & 255,56 & 187,26 \\
\hline 20 & 256,24 & 146,36 & 63,46 & 106,03 & 246,93 & 265,81 & 271,68 & 198,98 \\
\hline 21 & 259,85 & 172,34 & 65,66 & 107,29 & 250,76 & 268,81 & 271,68 & 199,80 \\
\hline 22 & $-135,78$ & $-82,43$ & $-48,42$ & $-65,12$ & $-55,95$ & $-43,98$ & $-138,05$ & $-118,46$ \\
\hline 23 & $-34,47$ & $-14,07$ & $-12,11$ & $-20,02$ & 13,50 & 22,88 & $-13,03$ & $-13,22$ \\
\hline 24 & 43,76 & 32,21 & 8,50 & 18,00 & 60,80 & 65,77 & 67,70 & 41,28 \\
\hline 25 & 93,44 & 64,36 & 25,95 & 42,09 & 96,47 & 103,34 & 114,09 & 73,78 \\
\hline 26 & 117,92 & 78,89 & 33,24 & 55,76 & 118,85 & 127,99 & 136,85 & 90,62 \\
\hline 27 & 127,52 & 85,25 & 36,64 & 61,92 & 129,60 & 139,97 & 145,86 & 97,38 \\
\hline 28 & 131,04 & 88,08 & 38,82 & 62,80 & 133,41 & 142,97 & 145,86 & 97,84 \\
\hline 29 & $-854,36$ & $-937,18$ & $-959,62$ & $-727,40$ & $-752,33$ & $-810,98$ & $-759,01$ & $-831,66$ \\
\hline 30 & $-260,25$ & $-240,10$ & $-240,91$ & $-206,29$ & $-237,52$ & $-263,27$ & $-145,97$ & $-145,48$ \\
\hline 31 & 373,19 & 281,51 & 276,63 & 224,37 & 422,79 & 365,80 & 264,72 & 311,01 \\
\hline 32 & 627,99 & 613,66 & 623,13 & 547,40 & 590,65 & 584,21 & 510,42 & 569,29 \\
\hline 33 & 787,93 & 844,10 & 863,41 & 769,64 & 687,52 & 713,36 & 676,45 & 740,05 \\
\hline 34 & 851,70 & 958,68 & 984,35 & 883,09 & 710,79 & 758,94 & 756,34 & 820,79 \\
\hline 35 & 818,48 & 943,87 & 971,58 & 889,04 & 658,83 & 718,27 & 762,41 & 826,05 \\
\hline
\end{tabular}


TABELA 5.208: Momentos Fletores nas nervuras e vigas, em kN.cm, na laje com espaçamento entre os eixos das nervuras $\mathrm{E}=50 \mathrm{~cm}$

\begin{tabular}{|c|c|c|c|c|c|c|c|c|}
\hline \multicolumn{9}{|c|}{$\begin{array}{l}\text { VARIAÇÃO DO ESPAÇAMENTO ENTRE NERVURAS: } \mathrm{E}=50 \mathrm{~cm} \\
\text { MOMENTOS FLETORES NAS NERVURAS E VIGAS }(\mathrm{kN} . \mathrm{cm})\end{array}$} \\
\hline \multirow{2}{*}{ Ponto } & \multicolumn{8}{|c|}{ Modelos numéricos de análise } \\
\hline & 01 & 02 & 03 & 04 & 05 & 06 & 07 & 08 \\
\hline 8 & $-80,85$ & $-39,15$ & $-35,53$ & $-91,94$ & $-228,86$ & $-230,12$ & 24,20 & $-24,99$ \\
\hline 9 & 153,89 & 93,81 & 29,32 & 20,63 & 51,34 & 70,33 & 246,90 & 157,09 \\
\hline 10 & 325,32 & 186,39 & 75,53 & 108,98 & 261,62 & 294,65 & 407,99 & 288,31 \\
\hline 11 & 446,56 & 250,64 & 102,97 & 168,97 & 407,94 & 451,84 & 521,35 & 378,69 \\
\hline 12 & 526,91 & 293,28 & 123,94 & 206,96 & 449,35 & 550,12 & 593,75 & 434,35 \\
\hline 13 & 567,84 & 315,97 & 136,25 & 225,48 & 542,98 & 596,62 & 627,35 & 459,41 \\
\hline 14 & 574,76 & 321,32 & 140,39 & 228,12 & 550,37 & 602,78 & 629,75 & 461,17 \\
\hline$\overline{15}$ & -136,33 & $-51,88$ & $-39,16$ & $-88,77$ & $-196,65$ & $-194,40$ & $-24,54$ & $\begin{array}{l}-78,04 \\
\end{array}$ \\
\hline 16 & 57,60 & 49,45 & 10,76 & 4,55 & 39,44 & 56,95 & 151,44 & 88,16 \\
\hline 17 & 217,47 & 132,32 & 49,38 & 80,71 & 208,79 & 237,37 & 300,00 & 212,34 \\
\hline 18 & 342,48 & 198,01 & 80,31 & 134,33 & 322,06 & 357,68 & 410,59 & 295,62 \\
\hline 19 & 425,94 & 241,44 & 101,47 & 168,12 & 391,27 & 430,19 & 479,46 & 345,15 \\
\hline 20 & 466,56 & 262,94 & 113,05 & 184,30 & 424,14 & 464,88 & 509,90 & 366,81 \\
\hline 21 & 473,42 & 268,31 & 117,21 & 186,82 & 431,52 & 470,74 & 512,05 & 368,32 \\
\hline 22 & $-274,40$ & $-181,42$ & $-104,54$ & $-106,75$ & $-104,30$ & $-85,04$ & $-276,26$ & $-227,75$ \\
\hline 23 & 80,31 & $-38,91$ & $-27,49$ & $-30,39$ & 15,90 & 32,43 & $-36,27$ & $-29,38$ \\
\hline 24 & 66,79 & 53,92 & 16,73 & 26,46 & 92,63 & 103,05 & 111,01 & 65,91 \\
\hline 25 & 155,98 & 104,56 & 41,94 & 62,08 & 145,00 & 157,69 & 192,30 & 122,00 \\
\hline 26 & 198,93 & 126,49 & 53,12 & 81,28 & 177,63 & 193,55 & 229,53 & 150,35 \\
\hline 27 & 215,38 & 134,85 & 57,58 & 89,64 & 193,36 & 211,13 & 243,25 & 161,36 \\
\hline 28 & 222,01 & 140,21 & 61,62 & 91,46 & 200,71 & 216,98 & 244,15 & 162,10 \\
\hline 29 & $-1369,40$ & $-1525,60$ & $-1561,80$ & $-1206,03$ & $-1147,30$ & $-1242,20$ & $-1216,30$ & $-1312,00$ \\
\hline 30 & $-312,42$ & $-241,06$ & $-234,28$ & $-200,00$ & $-289,33$ & $-290,04$ & $-111,03$ & $-89,07$ \\
\hline 31 & 1009,20 & 797,64 & 787,71 & 646,38 & 1099,40 & 951,80 & 686,57 & 790,45 \\
\hline 32 & 1469,10 & 1432,70 & 1451,80 & 1302,44 & 1332,60 & 1271,60 & 1161,10 & 1282,80 \\
\hline 33 & 1744,10 & 1878,50 & 1917,70 & 1761,49 & 1451,80 & 1451,20 & 1485,00 & 1609,80 \\
\hline 34 & 1836,70 & 2099,50 & 2152,30 & 1998,18 & 1446,00 & 1495,10 & 1641,40 & 1764,10 \\
\hline 35 & 1751,00 & 2059,00 & 2117,00 & 2008,93 & 1314,80 & 1396,40 & 1652,90 & 1773,50 \\
\hline
\end{tabular}


TABELA 5.209: Momentos Fletores nas nervuras e vigas, em kN.cm, na laje com espaçamento entre os eixos das nervuras $\mathrm{E}=60 \mathrm{~cm}$

\begin{tabular}{|c|c|c|c|c|c|c|c|c|}
\hline \multicolumn{9}{|c|}{$\begin{array}{l}\text { VARIAÇÃO DO ESPAÇAMENTO ENTRE NERVURAS: } \mathrm{E}=60 \mathrm{~cm} \\
\text { MOMENTOS FLETORES NAS NERVURAS E VIGAS }(\mathrm{kN} . \mathrm{cm})\end{array}$} \\
\hline \multirow{2}{*}{ Ponto } & \multicolumn{8}{|c|}{ Modelos numéricos de análise } \\
\hline & 01 & 02 & $\mathbf{0 3}$ & 04 & 05 & 06 & 07 & 08 \\
\hline 8 & $-167,20$ & $-74,47$ & $-62,95$ & $-177,67$ & $-498,47$ & $-508,00$ & 34,75 & $-62,84$ \\
\hline 9 & 230,11 & 148,66 & 44,68 & 19,01 & $-3,03$ & 25,98 & 416,66 & 251,74 \\
\hline 10 & 519,40 & 301,64 & 115,91 & 168,85 & 366,40 & 422,65 & 692,16 & 478,24 \\
\hline 11 & 724,10 & 407,68 & 166,08 & 270,87 & 621,42 & 698,43 & 885,90 & 633,48 \\
\hline 12 & 859,71 & 478,51 & 200,92 & 334,75 & 779,10 & 869,35 & 1009,74 & 728,70 \\
\hline 13 & 928,74 & 516,54 & 221,62 & 365,57 & 853,77 & 950,22 & 1067,22 & 771,36 \\
\hline 14 & 940,39 & 525,69 & 228,67 & 370,09 & 866,41 & 960,34 & 1071,30 & 774,36 \\
\hline 15 & $-265,10$ & $-106,32$ & $-74,95$ & $-162,78$ & $-405,15$ & $-415,04$ & $-64,16$ & $-160,78$ \\
\hline 16 & 68,13 & 68,17 & 11,05 & $-3,55$ & 5,20 & 32,06 & 242,17 & 133,24 \\
\hline 17 & 339,08 & 148,66 & 75,13 & 123,09 & 293,50 & 342,51 & 498,17 & 347,21 \\
\hline 18 & 549,62 & 316,01 & 126,66 & 210,58 & 482,67 & 543,82 & 687,78 & 488,78 \\
\hline 19 & 689,90 & 389,00 & 162,26 & 264,87 & 596,26 & 664,29 & 805,68 & 572,56 \\
\hline 20 & 758,22 & 425,40 & 181,98 & 290,54 & 649,56 & 721,16 & 857,76 & 609,12 \\
\hline 21 & $\begin{array}{l}769,76 \\
\end{array}$ & 434,54 & 189,03 & $\begin{array}{l}294,83 \\
\end{array}$ & 662,18 & 731,29 & 861,42 & 611,70 \\
\hline 22 & $-473,58$ & $-325,46$ & $-183,59$ & $-164,65$ & $-173,47$ & $-147,78$ & $-486,13$ & $-390,52$ \\
\hline 23 & $-148,66$ & $-76,49$ & $-50,10$ & $-47,56$ & 14,29 & 39,08 & $-79,01$ & $-58,27$ \\
\hline 24 & 93,26 & 75,83 & 21,83 & 36,97 & 127,20 & 144,99 & 165,28 & 95,51 \\
\hline 25 & 238,49 & 157,20 & 62,44 & 87,63 & 199,62 & 220,01 & 299,48 & 186,32 \\
\hline 26 & 308,99 & 190,95 & 79,84 & 113,95 & 244,84 & 269,71 & 359,35 & 232,15 \\
\hline 27 & 336,12 & 202,79 & 86,20 & 125,13 & 266,81 & 294,36 & 380,48 & 249,79 \\
\hline 28 & 347,20 & 211,77 & 92,85 & 128,24 & 279,39 & 304,48 & 381,84 & 250,96 \\
\hline 29 & $-1922,00$ & $-2175,90$ & $-2228,40$ & $-1704,46$ & $-1525,20$ & $-1666,00$ & $-1716,50$ & $-1825,40$ \\
\hline 30 & 869,78 & 300,17 & 216,19 & 0,00 & 1573,70 & 764,01 & 311,09 & 425,67 \\
\hline 31 & 2154,50 & 1761,60 & 1739,80 & 1463,52 & 2285,50 & 1964,20 & 1428,10 & 1619,60 \\
\hline 32 & 2899,60 & 2841,30 & 2872,80 & 2617,01 & 2550,30 & 2353,30 & 2233,60 & 2450,10 \\
\hline 33 & 3320,00 & 3600,20 & 3669,60 & 3431,32 & 2650,80 & 2548,00 & 2786,30 & 3003,00 \\
\hline 34 & 3430,80 & 3972,30 & 4068,40 & 3851,87 & 2562,10 & 2551,10 & 3054,00 & 3263,50 \\
\hline 35 & 3251,40 & 3884,00 & 3991,50 & 3866,73 & 2286,80 & 2351,00 & 3073,10 & 3278,40 \\
\hline
\end{tabular}


TABELA 5.210: Momentos Fletores nas nervuras e vigas, em kN.cm, na laje com espaçamento entre os eixos das nervuras $\mathrm{E}=70 \mathrm{~cm}$

\begin{tabular}{|c|c|c|c|c|c|c|c|c|}
\hline \multicolumn{9}{|c|}{$\begin{array}{l}\text { VARIAÇÃO DO ESPAÇAMENTO ENTRE NERVURAS: E }=70 \mathrm{~cm} \\
\text { MOMENTOS FLETORES NAS NERVURAS E VIGAS }(\mathrm{kN} . \mathrm{cm})\end{array}$} \\
\hline \multirow{2}{*}{ Ponto } & \multicolumn{8}{|c|}{ Modelos numéricos de análise } \\
\hline & 01 & 02 & 03 & 04 & 05 & 06 & 07 & 08 \\
\hline 8 & $-300,67$ & $-128,06$ & $-102,31$ & $-306,39$ & $-922,12$ & $-955,43$ & 44,47 & $-128,75$ \\
\hline 9 & 316,98 & 222,75 & $-62,18$ & 2,82 & $-123,13$ & $-90,13$ & 645,81 & 372,06 \\
\hline 10 & 766,44 & 450,43 & 171,16 & 242,41 & 470,19 & 551,01 & 1079,82 & 732,83 \\
\hline 11 & 1084,90 & 613,04 & 248,09 & 403,72 & 877,36 & 994,32 & 1385,65 & 979,37 \\
\hline 12 & 1295,60 & 722,17 & 301,81 & 504,72 & 1127,20 & 1267,20 & 1581,30 & 1130,08 \\
\hline 13 & 1402,70 & 781,13 & 334,01 & 553,46 & 1244,70 & 1395,60 & 1672,23 & 1197,56 \\
\hline 14 & 1420,70 & 795,55 & 345,10 & 560,58 & 1264,60 & 1411,70 & 1678,74 & 1202,25 \\
\hline 15 & $-456,14$ & $-191,01$ & $\begin{array}{c}-7,52 \\
\end{array}$ & $-271,76$ & $-723,03$ & $-750,92$ & $-133,54$ & $-290,98$ \\
\hline 16 & 70,18 & 86,87 & 8,17 & $-22,41$ & $-70,45$ & $-37,48$ & 358,19 & 186,09 \\
\hline 17 & 492,74 & 300,48 & 107,01 & 173,25 & 381,60 & 451,85 & 765,31 & 526,37 \\
\hline 18 & 818,26 & 469,51 & 186,37 & 306,73 & 673,48 & 765,24 & 1065,68 & 748,42 \\
\hline 19 & 1034,50 & 582,55 & 241,64 & 388,82 & 846,17 & 950,24 & 1252,58 & 881,16 \\
\hline 20 & 1140,00 & 639,42 & 272,63 & 427,47 & 926,39 & 1036,70 & 1335,32 & 938,70 \\
\hline 21 & 1157,90 & 653,78 & 283,67 & 434,34 & 946,22 & 1052,70 & 1341,06 & 942,69 \\
\hline 22 & $-739,60$ & $-517,15$ & $-287,02$ & $-243,00$ & $-267,49$ & $-238,09$ & $-780,99$ & $-615,37$ \\
\hline 23 & $-241,73$ & $-128,95$ & $-81,52$ & $-79,77$ & 7,05 & 40,14 & $-146,19$ & $-102,68$ \\
\hline 24 & 122,83 & 99,63 & 25,79 & 48,61 & 163,52 & 189,84 & 230,69 & 129,86 \\
\hline 25 & 342,35 & 222,75 & 87,26 & 118,69 & 259,82 & 289,14 & 439,89 & 268,45 \\
\hline 26 & 450,81 & 273,96 & 113,89 & 154,39 & 320,02 & 355,31 & 533,09 & 339,09 \\
\hline 27 & 493,17 & 291,46 & 123,46 & 169,38 & 349,41 & 388,41 & 565,38 & 366,32 \\
\hline 28 & 510,21 & 305,40 & 133,67 & 174,31 & 369,22 & 404,48 & 567,44 & 368,14 \\
\hline 29 & $-2475,90$ & $-2847,90$ & $-2919,00$ & $-2203,26$ & $-1851,50$ & $-2059,50$ & $-2238,30$ & $-2347,60$ \\
\hline 30 & 1941,60 & 1025,10 & 883,27 & 474,79 & 3248,60 & 1799,20 & 842,99 & 1047,80 \\
\hline 31 & 3942,80 & 3319,10 & 3274,60 & 2786,11 & 4105,00 & 3489,00 & 2574,60 & 2887,60 \\
\hline 32 & 5072,80 & 5017,50 & 5062,60 & 4640,24 & 4352,60 & 3896,70 & 3832,80 & 4180,90 \\
\hline 33 & 5674,60 & 6206,70 & 6318,00 & 5959,48 & 4377,80 & 4054,10 & 4698,10 & 5043,00 \\
\hline 34 & 5788,90 & 6781,40 & 6940,50 & 6644,42 & 4135,00 & 3962,20 & 5117,50 & 5448,20 \\
\hline 35 & 5465,50 & 6614,40 & 6796,00 & 6665,93 & 3634,90 & 3605,50 & 5146,90 & 5470,30 \\
\hline
\end{tabular}


TABELA 5.211: Momentos Fletores nas nervuras e vigas, em kN.cm, na laje com espaçamento entre os eixos das nervuras $\mathrm{E}=80 \mathrm{~cm}$

\begin{tabular}{|c|c|c|c|c|c|c|c|c|}
\hline \multicolumn{9}{|c|}{$\begin{array}{l}\text { VARIAÇÃO DO ESPAÇAMENTO ENTRE NERVURAS: } \mathrm{E}=80 \mathrm{~cm} \\
\text { MOMENTOS FLETORES NAS NERVURAS E VIGAS }(\mathrm{kN} . \mathrm{cm})\end{array}$} \\
\hline \multirow{2}{*}{ Ponto } & \multicolumn{8}{|c|}{ Modelos numéricos de análise } \\
\hline & 01 & $\mathbf{0 2}$ & $\mathbf{0 3}$ & 04 & 05 & 06 & 07 & 08 \\
\hline 8 & $-491,06$ & $-204,06$ & $-155,76$ & $-481,12$ & $-1526,30$ & $-1607,00$ & 50,60 & $-232,90$ \\
\hline 9 & 411,98 & 296,42 & 81,31 & $-25,05$ & $-321,46$ & $-295,90$ & 941,04 & 518,27 \\
\hline 10 & 1069,30 & 635,26 & 238,99 & 331,35 & 570,49 & 674,05 & 1585,12 & 1059,60 \\
\hline 11 & 1535,60 & 871,23 & 350,65 & 571,00 & 1179,90 & 1342,00 & 2039,92 & 1428,72 \\
\hline 12 & 1843,80 & 1030,20 & 428,96 & 720,27 & 1551,60 & 1751,10 & 2331,44 & 1653,76 \\
\hline 13 & 2000,00 & 1116,40 & 476,22 & 791,88 & 1725,50 & 1942,80 & 2466,96 & 1754,40 \\
\hline 14 & 2026,30 & 1137,70 & 492,60 & 802,34 & 1754,80 & 1966,80 & 2476,64 & 1761,52 \\
\hline 15 & $-720,18$ & $-311,87$ & $-201,93$ & $-417,52$ & $-1168,40$ & $-1230,70$ & $-242,62$ & $-480,84$ \\
\hline 16 & 60,59 & 104,08 & 1,01 & $-51,30$ & $-195,51$ & $-163,32$ & 500,54 & 245,30 \\
\hline 17 & 680,27 & 416,06 & 145,15 & 233,95 & 471,85 & 562,92 & 1110,32 & 754,85 \\
\hline 18 & 1153,40 & 661,74 & 260,55 & 427,71 & 897,30 & 1023,40 & 1558,64 & 1086,56 \\
\hline 19 & 1466,80 & 826,69 & 341,40 & 546,86 & 1146,00 & 1292,20 & 1837,92 & 1282,24 \\
\hline 20 & 1619,80 & 910,39 & 387,21 & 602,90 & 1260,60 & 1416,70 & 1961,84 & 1367,76 \\
\hline 21 & 1645,70 & 931,62 & 403,51 & 612,33 & 1289,90 & 1440,70 & 1970,56 & 1373,76 \\
\hline 22 & $-1078,20$ & $-760,81$ & $-416,69$ & $-340,26$ & $-390,63$ & $-361,90$ & $-1173,20$ & $-910,16$ \\
\hline 23 & $-361,46$ & $-198,52$ & $-123,31$ & $-111,65$ & $-7,17$ & 33,32 & $-242,37$ & $-165,12$ \\
\hline 24 & 155,32 & 124,62 & 27,86 & 62,79 & 201,41 & 236,72 & 307,36 & 168,83 \\
\hline 25 & 468,87 & 301,82 & 116,31 & 156,52 & 326,12 & 365,17 & 617,44 & 369,92 \\
\hline 26 & 626,81 & 377,14 & 155,75 & 203,71 & 403,91 & 450,67 & 757,10 & 473,82 \\
\hline 27 & 689,56 & 403,13 & 170,25 & 223,40 & 441,95 & 493,57 & 805,44 & 514,22 \\
\hline 28 & 714,24 & 423,58 & 185,14 & 230,56 & 471,30 & 517,57 & 808,48 & 516,90 \\
\hline 29 & $-3008,90$ & $-3514,70$ & $-3606,40$ & $-2617,61$ & $-2105,20$ & $-2417,60$ & $-2771,00$ & $-2865,20$ \\
\hline 30 & 3534,30 & 2200,10 & 1977,80 & 1299,10 & 5723,70 & 3342,40 & 1669,00 & 1996,60 \\
\hline 31 & 6488,90 & 5610,20 & 5528,60 & 4766,46 & 6669,20 & 5599,70 & 4207,50 & 4679,30 \\
\hline 32 & 8127,10 & 8137,50 & 8195,80 & 7553,84 & 6841,10 & 5965,30 & 6060,80 & 6581,70 \\
\hline 33 & 8957,50 & 9896,50 & 10062,00 & 9546,46 & 6722,50 & 6021,50 & 7335,50 & 7850,30 \\
\hline 34 & 9061,20 & 10733,00 & 10978,00 & 10581,64 & 6240,70 & 5769,00 & 7953,40 & 8445,40 \\
\hline 35 & 8536,60 & 10449,00 & 10733,00 & 10608,93 & 5420,10 & 5190,20 & 7996,00 & 8476,70 \\
\hline
\end{tabular}


TABELA 5.212: Momentos Fletores nas nervuras e vigas, em kN.cm, na laje com espaçamento entre os eixos das nervuras $\mathrm{E}=90 \mathrm{~cm}$

\begin{tabular}{|c|c|c|c|c|c|c|c|c|}
\hline \multicolumn{9}{|c|}{$\begin{array}{l}\text { VARIAÇÃO DO ESPAÇAMENTO ENTRE NERVURAS: E }=90 \mathrm{~cm} \\
\text { MOMENTOS FLETORES NAS NERVURAS E VIGAS }(\mathrm{kN.cm})\end{array}$} \\
\hline \multirow{2}{*}{ Ponto } & \multicolumn{8}{|c|}{ Modelos numéricos de análise } \\
\hline & 01 & 02 & 03 & 04 & 05 & 06 & 07 & 08 \\
\hline 8 & $-747,90$ & $-306,62$ & $-225,41$ & $-716,37$ & $-2334,70$ & $-2494,00$ & 49,50 & $-386,85$ \\
\hline 9 & 512,43 & 388,88 & 101,56 & $-73,34$ & $-608,28$ & $-606,10$ & 1308,33 & 689,69 \\
\hline 10 & 1430,50 & 858,43 & 320,09 & 431,94 & 666,62 & 788,97 & 2221,38 & 1465,65 \\
\hline 11 & 2082,30 & 1186,50 & 475,35 & 772,02 & 1534,60 & 1746,90 & 2867,67 & 1993,50 \\
\hline 12 & 2512,50 & 1408,10 & 584,60 & 983,14 & 2061,60 & 2331,30 & 3282,48 & 2314,62 \\
\hline 13 & 2729,90 & 1528,70 & 650,84 & 1084,26 & 2307,20 & 2604,20 & 3475,53 & 2457,99 \\
\hline 14 & 2766,50 & 1558,80 & 673,92 & 1099,16 & 2348,60 & 2638,40 & 3489,30 & 2468,07 \\
\hline 15 & $-1067,30$ & $-474,45$ & $-298,51$ & $-611,22$ & $-1758,00$ & $-1876,20$ & $-402,08$ & $-743,18$ \\
\hline 16 & 36,26 & 118,35 & $-11,47$ & $-96,45$ & $-376,63$ & $-355,18$ & 669,79 & 309,04 \\
\hline 17 & 903,20 & 554,19 & 189,74 & 303,76 & 564,21 & 674,30 & 1541,61 & 1037,34 \\
\hline 18 & 1559,40 & 895,76 & 350,27 & 574,47 & 1158,10 & 1322,00 & 2180,43 & 1508,76 \\
\hline 19 & 1992,80 & 1125,80 & 463,27 & 740,02 & 1501,90 & 1696,80 & 2578,95 & 1786,50 \\
\hline 20 & 2204,40 & 1243,40 & 527,86 & 817,69 & 1659,30 & 1869,20 & 2756,43 & 1908,09 \\
\hline 21 & 2240,50 & 1273,30 & 550,79 & 831,06 & 1700,60 & 1903,30 & 2768,85 & 1916,55 \\
\hline 22 & $-1494,70$ & $-1060,50$ & $-574,50$ & $-461,64$ & $-547,11$ & $-524,85$ & $-1674,63$ & $-1282,14$ \\
\hline 23 & $-509,54$ & $-282,70$ & $-176,77$ & $-151,65$ & $-29,53$ & 16,79 & $-371,93$ & $-247,95$ \\
\hline 24 & 190,63 & 150,40 & 27,54 & 78,20 & 241,07 & 285,38 & 395,26 & 212,12 \\
\hline 25 & 619,20 & 395,19 & 149,70 & 200,85 & 399,50 & 448,85 & 835,70 & 491,95 \\
\hline 26 & 839,13 & 502,16 & 205,97 & 262,28 & 497,85 & 556,97 & 1037,43 & 638,62 \\
\hline 27 & 927,93 & 539,97 & 227,45 & 287,92 & 545,87 & 611,14 & 1107,72 & 696,22 \\
\hline 28 & 962,07 & 568,64 & 248,28 & 297,89 & 587,35 & 645,32 & 1112,13 & 700,07 \\
\hline 29 & $-3508,80$ & "-4159,30 & $-4273,50$ & "2972,04 & "-2272,60 & $-2742,10$ & $-3309,80$ & "-3370,90 \\
\hline 30 & 5711,30 & 3908,80 & 3580,40 & 2619,21 & 9117,90 & 5459,10 & 2838,00 & 3325,30 \\
\hline 31 & 9894,00 & 8770,00 & 8633,90 & 7485,42 & 10084,00 & 8367,30 & 6405,80 & 7077,80 \\
\hline 32 & 12191,00 & 12376,00 & 12446,00 & 11483,36 & 10114,00 & 8624,10 & 9018,50 & 9758,20 \\
\hline 33 & 13311,00 & 14870,00 & 15103,00 & 14356,10 & 9773,40 & 8506,50 & 10813,00 & 11546,00 \\
\hline 34 & 13394,00 & 16036,00 & 16392,00 & 15854,23 & 8955,20 & 8018,60 & 11683,00 & 12382,00 \\
\hline 35 & 12607,00 & 15589,00 & 16009,00 & 15895,65 & 7704,80 & 7142,90 & 11742,00 & 12425,00 \\
\hline
\end{tabular}




\subsubsection{Forças Normais atuantes nas nervuras e vigas}

TABELA 5.213: Esforços normais nas nervuras e vigas, em $\mathrm{kN}$, na laje com espaçamento entre os eixos das nervuras $\mathrm{E}=40 \mathrm{~cm}$

\begin{tabular}{c|c|c|c|c|c|c|c|c}
\hline \multicolumn{7}{c}{ VARIAÇÃO DO ESPAÇAMENTO ENTRE NERVURAS: E = 40 cm } \\
\multicolumn{7}{c}{ ESFORÇOS NORMAIS NAS NERVURAS E VIGAS $(\mathbf{k N})$} \\
\hline \multirow{2}{*}{ Ponto } & \multicolumn{7}{c}{ Modelos numéricos de análise } \\
\cline { 2 - 10 } & $\mathbf{0 1}$ & $\mathbf{0 2}$ & $\mathbf{0 3}$ & $\mathbf{0 4}$ & $\mathbf{0 5}$ & $\mathbf{0 6}$ & $\mathbf{0 7}$ & $\mathbf{0 8}$ \\
\hline \hline $\mathbf{8}$ & $-0,54$ & 1,32 & 1,29 & $\mathbf{- 2 , 2 7}$ & $-3,48$ & $-4,36$ & $-0,36$ & $-0,60$ \\
\hline $\mathbf{9}$ & $-0,49$ & 9,22 & 10,54 & $\mathbf{3 , 6 7}$ & $-2,77$ & $-6,09$ & $-2,99$ & $-4,71$ \\
\hline $\mathbf{1 0}$ & $-1,06$ & 15,17 & 17,56 & $\mathbf{1 0 , 4 2}$ & $-4,09$ & $-7,89$ & $-4,00$ & $-6,81$ \\
\hline $\mathbf{1 1}$ & $-1,38$ & 19,44 & 22,55 & $\mathbf{1 5 , 5 3}$ & $-4,76$ & $-8,85$ & $-4,48$ & $-7,82$ \\
\hline $\mathbf{1 2}$ & $-1,55$ & 22,18 & 25,74 & $\mathbf{1 8 , 5 4}$ & $-5,04$ & $-9,30$ & $-4,71$ & $-8,28$ \\
\hline $\mathbf{1 3}$ & $-1,61$ & 23,43 & 27,20 & $\mathbf{2 0 , 1 7}$ & $-5,12$ & $-9,42$ & $-4,79$ & $-8,46$ \\
\hline $\mathbf{1 4}$ & $-1,61$ & 23,50 & 27,30 & $\mathbf{2 0 , 4 2}$ & $-5,12$ & $-9,42$ & $-4,80$ & $-8,47$ \\
\hline \hline $\mathbf{1 5}$ & $-1,97$ & $-0,20$ & $-0,37$ & $\mathbf{- 3 , 8 2}$ & $-3,44$ & $-4,18$ & $-1,06$ & $-1,77$ \\
\hline $\mathbf{1 6}$ & $-1,36$ & 6,08 & 6,99 & $\mathbf{1 , 4 7}$ & $-3,14$ & $-6,19$ & $-3,16$ & $-4,88$ \\
\hline $\mathbf{1 7}$ & $-1,84$ & 11,21 & 13,15 & $\mathbf{7 , 5 6}$ & $-4,53$ & $-8,40$ & $-4,56$ & $-6,59$ \\
\hline $\mathbf{1 8}$ & $-2,23$ & 15,16 & 17,83 & $\mathbf{1 2 , 2 4}$ & $-5,50$ & $-10,01$ & $-5,54$ & $-8,01$ \\
\hline $\mathbf{1 9}$ & $-2,45$ & 17,74 & 20,85 & $\mathbf{1 4 , 7 7}$ & $-6,09$ & $-10,99$ & $-6,12$ & $-9,10$ \\
\hline $\mathbf{2 0}$ & $-2,54$ & 18,89 & 22,20 & $\mathbf{1 6 , 6 7}$ & $-6,30$ & $-11,33$ & $-6,37$ & $-9,64$ \\
\hline $\mathbf{2 1}$ & $-2,54$ & 18,95 & 22,30 & $\mathbf{1 6 , 9 1}$ & $-6,30$ & $-11,33$ & $-6,38$ & $-9,68$ \\
\hline \hline $\mathbf{2 2}$ & $-6,13$ & $-9,86$ & $-10,72$ & $\mathbf{- 1 1 , 0 6}$ & $-2,62$ & $-2,23$ & $-8,72$ & $-8,27$ \\
\hline $\mathbf{2 3}$ & $-3,35$ & $-3,39$ & $-2,91$ & $\mathbf{- 4 , 9 8}$ & $-2,56$ & $-4,45$ & $-4,54$ & 0,54 \\
\hline $\mathbf{2 4}$ & $-4,17$ & 1,33 & 2,94 & $\mathbf{0 , 5 3}$ & $-6,81$ & $-10,87$ & $-7,57$ & $-4,92$ \\
\hline $\mathbf{2 5}$ & $-5,63$ & 3,90 & 6,34 & $\mathbf{3 , 7 3}$ & $-10,44$ & $-16,24$ & $-11,76$ & $-10,98$ \\
\hline $\mathbf{2 6}$ & $-6,76$ & 5,02 & 7,94 & $\mathbf{5 , 1 1}$ & $-12,67$ & $-19,59$ & $-15,11$ & $-15,14$ \\
\hline $\mathbf{2 7}$ & $-7,29$ & 5,41 & 8,54 & $\mathbf{6 , 1 2}$ & $-13,39$ & $-20,72$ & $-16,81$ & $-17,12$ \\
\hline $\mathbf{2 8}$ & $-7,33$ & 5,44 & 8,62 & $\mathbf{6 , 2 2}$ & $-13,42$ & $-20,72$ & $-16,93$ & $-17,26$ \\
\hline \hline $\mathbf{2 9}$ & 14,74 & 8,96 & 8,67 & $\mathbf{0 , 0 0}$ & 14,47 & 16,73 & 4,53 & 5,56 \\
\hline $\mathbf{3 0}$ & 22,21 & 12,13 & 10,79 & $\mathbf{4 , 8 6}$ & 26,34 & 26,63 & 11,97 & 12,49 \\
\hline $\mathbf{3 1}$ & 33,84 & 20,02 & 18,00 & $\mathbf{1 5 , 9 3}$ & 44,59 & 42,20 & 26,64 & 31,18 \\
\hline $\mathbf{3 2}$ & 42,12 & 26,19 & 23,85 & $\mathbf{2 4 , 2 3}$ & 57,89 & 54,10 & 39,19 & 47,11 \\
\hline $\mathbf{3 3}$ & 46,87 & 30,14 & 27,64 & $\mathbf{3 1 , 0 3}$ & 65,76 & 61,33 & 47,94 & 58,03 \\
\hline $\mathbf{3 4}$ & 48,13 & 31,70 & 29,20 & $\mathbf{3 4 , 2 3}$ & 68,15 & 63,74 & 52,17 & 63,26 \\
\hline $\mathbf{3 5}$ & 48,07 & 32,16 & 29,72 & $\mathbf{3 4 , 6 2}$ & 68,18 & 63,74 & 52,47 & 63,63 \\
\hline \hline
\end{tabular}


TABELA 5.214: Esforços normais nas nervuras e vigas, em $\mathrm{kN}$, na laje com espaçamento entre os eixos das nervuras $\mathrm{E}=50 \mathrm{~cm}$

\begin{tabular}{|c|c|c|c|c|c|c|c|c|}
\hline \multicolumn{9}{|c|}{$\begin{array}{c}\text { VARIAÇÃO DO ESPAÇAMENTO ENTRE NERVURAS: E }=50 \mathrm{~cm} \\
\text { ESFORÇOS NORMAIS NAS NERVURAS E VIGAS }(\mathrm{kN})\end{array}$} \\
\hline \multirow{2}{*}{ Ponto } & \multicolumn{8}{|c|}{ Modelos numéricos de análise } \\
\hline & 01 & $\mathbf{0 2}$ & 03 & 04 & 05 & 06 & 07 & 08 \\
\hline 8 & $-1,26$ & $1,1,75$ & $1,1,68$ & $-8,12$ & $-7,89$ & $-9,67$ & $-0,67$ & $-1,11$ \\
\hline 9 & $-0,75$ & 18,21 & 20,44 & 4,74 & $-5,04$ & $-11,81$ & $-5,07$ & $-7,88$ \\
\hline 10 & $-1,62$ & 30,40 & 34,34 & 18,92 & $-7,50$ & $-15,37$ & $-6,94$ & $-11,65$ \\
\hline 11 & $-2,15$ & 39,04 & 44,14 & 29,27 & $-8,82$ & $-17,39$ & $-7,89$ & $-13,68$ \\
\hline 12 & $-2,43$ & 44,58 & 50,41 & 35,91 & $-9,41$ & $-18,36$ & $-8,38$ & $-14,74$ \\
\hline 13 & $-2,54$ & 47,12 & 53,30 & 39,18 & $-9,59$ & $-18,65$ & $-8,56$ & $-15,17$ \\
\hline 14 & $-2,54$ & 47,27 & 53,51 & 39,66 & $-9,59$ & $-18,65$ & $-8,58$ & $-15,20$ \\
\hline 15 & $-3,49$ & $-1,60$ & "-2,22 & $-9,66$ & $-6,97$ & $-8,44$ & $-2,19$ & $-3,34$ \\
\hline 16 & $-2,18$ & 10,87 & 12,25 & 1,34 & $-5,72$ & $-11,90$ & $-5,93$ & $-8,75$ \\
\hline 17 & $-2,89$ & 21,40 & 24,53 & 13,57 & $-8,43$ & $-16,47$ & $-8,47$ & $-12,04$ \\
\hline 18 & $-3,51$ & 29,62 & 33,96 & 22,59 & $-10,35$ & $-19,77$ & $-10,23$ & $-14,68$ \\
\hline 19 & $-3,84$ & 35,00 & 40,05 & 28,37 & $-11,50$ & $-21,76$ & $-11,28$ & $-16,62$ \\
\hline 20 & $-4,02$ & 37,40 & 42,78 & 31,17 & $-11,91$ & $-22,43$ & $-11,73$ & $-17,57$ \\
\hline 21 & $-4,02$ & 37,55 & 42,99 & 31,60 & $-11,91$ & $-22,43$ & $-11,77$ & $-17,64$ \\
\hline 22 & $-9,34$ & $-18,81$ & $-21,22$ & $-18,91$ & $-3,64$ & $-3,55$ & $-14,18$ & $-13,71$ \\
\hline 23 & $-5,41$ & $-7,34$ & $-6,67$ & $-8,86$ & $-5,76$ & $-10,61$ & $-9,88$ & $-3,24$ \\
\hline 24 & $-6,60$ & 2,31 & 4,83 & 0,12 & $-13,29$ & $-21,67$ & $-15,23$ & $-11,48$ \\
\hline 25 & $-8,67$ & 7,44 & 11,26 & 5,45 & $-19,40$ & $-30,86$ & $-21,94$ & $-20,51$ \\
\hline 26 & $-10,29$ & 9,46 & 14,01 & 8,03 & $-23,11$ & $-36,67$ & $-27,18$ & $-26,73$ \\
\hline 27 & $-11,05$ & 10,07 & 14,91 & 8,95 & $-24,25$ & $-38,64$ & $-29,84$ & $-29,69$ \\
\hline 28 & $-11,13$ & 10,12 & 15,06 & 9,13 & $-24,33$ & $-38,64$ & $-30,03$ & $-29,91$ \\
\hline 29 & 28,09 & 18,42 & 177,86 & 5,24 & 31,31 & 34,22 & 1212,13 & 14,53 \\
\hline 30 & 44,08 & 26,41 & 24,11 & 15,61 & 55,89 & 54,47 & 27,81 & 30,29 \\
\hline 31 & 64,28 & 39,49 & 36,04 & 32,21 & 88,86 & 84,06 & 52,07 & 60,87 \\
\hline 32 & 77,94 & 48,95 & 45,00 & 46,00 & 112,41 & 106,38 & 72,47 & 86,53 \\
\hline 33 & 85,26 & 54,70 & 50,54 & 56,62 & 126,00 & 119,92 & 86,62 & 104,07 \\
\hline 34 & 86,60 & 56,76 & 52,65 & 61,66 & 129,65 & 124,44 & 93,44 & 112,44 \\
\hline 35 & 86,37 & 57,62 & 53,65 & 62,24 & 129,67 & 124,44 & 93,94 & 113,04 \\
\hline
\end{tabular}


TABELA 5.215: Esforços normais nas nervuras e vigas, em $\mathrm{kN}$, na laje com espaçamento entre os eixos das nervuras $\mathrm{E}=60 \mathrm{~cm}$

\begin{tabular}{|c|c|c|c|c|c|c|c|c|}
\hline \multicolumn{9}{|c|}{$\begin{array}{c}\text { VARIAÇÃO DO ESPAÇAMENTO ENTRE NERVURAS: E }=60 \mathrm{~cm} \\
\text { ESFORÇOS NORMAIS NAS NERVURAS E VIGAS }(\mathrm{kN})\end{array}$} \\
\hline \multirow{2}{*}{ Ponto } & \multicolumn{8}{|c|}{ Modelos numéricos de análise } \\
\hline & 01 & 02 & $\mathbf{0 3}$ & 04 & 05 & 06 & 07 & 08 \\
\hline 8 & $-2,24$ & 1,89 & 1,68 & $-19,68$ & $-14,35$ & $-17,66$ & $-1,06$ & $-1,76$ \\
\hline 9 & $-1,06$ & 30,96 & 34,36 & 4,77 & $-8,04$ & $-19,83$ & $-7,67$ & $-11,89$ \\
\hline 10 & $-2,28$ & 52,54 & 58,44 & 30,74 & $-12,03$ & $-25,88$ & $-10,67$ & $-17,83$ \\
\hline 11 & $-3,05$ & 67,78 & 75,37 & 48,44 & $-14,29$ & $-29,48$ & $-12,29$ & $-21,26$ \\
\hline 12 & $-3,47$ & 77,56 & 86,23 & 60,00 & $-15,31$ & $-31,26$ & $-13,15$ & $-23,16$ \\
\hline 13 & $-3,64$ & 82,06 & 91,25 & 65,63 & $-15,63$ & $-31,80$ & $-13,49$ & $-23,96$ \\
\hline 14 & $-3,64$ & 82,35 & 91,64 & 66,42 & $-15,63$ & $-31,80$ & $-13,51$ & $-24,02$ \\
\hline 15 & $-5,36$ & $-4,49$ & $-6,01$ & $-20,09$ & $-11,86$ & $-14,52$ & $-3,85$ & $-5,49$ \\
\hline 16 & $-3,12$ & 17,18 & 19,13 & 0,10 & $-9,11$ & $-19,80$ & $-9,71$ & $-13,87$ \\
\hline 17 & $-4,09$ & 36,02 & 40,64 & 21,32 & $-13,66$ & $-27,87$ & $-13,72$ & $-19,27$ \\
\hline 18 & $-4,96$ & 50,78 & 57,22 & 36,57 & $-16,89$ & $-33,65$ & $-16,51$ & $-23,53$ \\
\hline 19 & $-5,49$ & 60,45 & 67,96 & 46,21 & $-18,82$ & $-37,09$ & $-18,17$ & $-26,56$ \\
\hline 20 & $-5,71$ & 64,80 & 72,78 & 50,82 & $-19,51$ & $-38,23$ & $-18,90$ & $-28,03$ \\
\hline 21 & $-5,72$ & 65,08 & 73,16 & 51,52 & $-19,51$ & $-38,23$ & $-18,95$ & $-28,13$ \\
\hline 22 & $-12,73$ & $-31,37$ & $-36,20$ & $-29,71$ & $-4,72$ & $-5,18$ & $-21,08$ & $-20,69$ \\
\hline 23 & $-7,65$ & $-12,97$ & $-12,09$ & $-13,98$ & $-10,41$ & $-20,22$ & $-17,48$ & $-9,08$ \\
\hline 24 & $-9,31$ & 3,99 & 7,61 & $-0,19$ & $-22,16$ & $-36,99$ & $-25,79$ & $-20,84$ \\
\hline 25 & $-12,08$ & 13,17 & 18,64 & 7,78 & $-31,42$ & $-51,07$ & $-35,53$ & $-33,23$ \\
\hline 26 & $-14,24$ & 16,78 & 23,28 & 11,47 & $-37,01$ & $-60,15$ & $-43,00$ & $-41,77$ \\
\hline 27 & $-15,25$ & 17,80 & 24,72 & 13,60 & $-38,69$ & $-63,27$ & $-46,76$ & $-45,85$ \\
\hline 28 & $-15,38$ & 17,92 & 24,98 & 13,94 & $-38,82$ & $-63,27$ & $-47,03$ & $-46,15$ \\
\hline 29 & 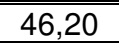 & 31,42 & 30,53 & 16,75 & 155,62 & 59,83 & 23,69 & 27,96 \\
\hline 30 & 74,57 & 47,19 & 43,60 & 32,27 & 98,52 & 94,90 & 50,87 & 56,17 \\
\hline 31 & 106,14 & 66,88 & 61,56 & 56,06 & 151,01 & 143,80 & 87,07 & 101,46 \\
\hline 32 & 126,73 & 80,18 & 74,11 & 76,60 & 188,13 & 180,53 & 117,02 & 139,01 \\
\hline 33 & 137,16 & 87,77 & 81,47 & 89,29 & 209,18 & 202,84 & 137,68 & 164,58 \\
\hline 34 & 138,31 & 90,12 & 83,99 & 91,07 & 214,29 & 210,32 & 147,63 & 176,76 \\
\hline 35 & 137,79 & 91,53 & 85,62 & 91,81 & 214,28 & 210,32 & 148,35 & 177,64 \\
\hline
\end{tabular}


TABELA 5.216: Esforços normais nas nervuras e vigas, em $\mathrm{kN}$, na laje com espaçamento entre os eixos das nervuras $\mathrm{E}=70 \mathrm{~cm}$

\begin{tabular}{|c|c|c|c|c|c|c|c|c|}
\hline \multicolumn{9}{|c|}{$\begin{array}{c}\text { VARIAÇÃO DO ESPAÇAMENTO ENTRE NERVURAS: } \mathrm{E}=70 \mathrm{~cm} \\
\text { ESFORÇOS NORMAIS NAS NERVURAS E VIGAS }(\mathrm{kN})\end{array}$} \\
\hline \multirow{2}{*}{ Ponto } & \multicolumn{8}{|c|}{ Modelos numéricos de análise } \\
\hline & 01 & 02 & $\mathbf{0 3}$ & 04 & 05 & 06 & 07 & 08 \\
\hline 8 & $-3,44$ & 1,42 & 0,92 & $-38,41$ & $-22,69$ & $-28,34$ & $-1,54$ & $-2,63$ \\
\hline 9 & $-1,41$ & 47,77 & 52,59 & 2,60 & $-11,72$ & $-30,07$ & $-10,82$ & $-16,74$ \\
\hline 10 & $-3,00$ & 82,47 & 90,72 & 46,37 & $-17,62$ & $-39,36$ & $-15,23$ & $-25,35$ \\
\hline 11 & $-4,05$ & 106,96 & 117,53 & 77,25 & $-21,07$ & $-45,06$ & $-17,68$ & $-30,55$ \\
\hline 12 & $-4,62$ & 122,70 & 134,78 & 96,71 & $-22,66$ & $-47,95$ & $-19,01$ & $-33,51$ \\
\hline 13 & $-4,85$ & 130,00 & 142,79 & 102,60 & $-23,15$ & $-48,82$ & $-19,56$ & $-34,80$ \\
\hline 14 & $-4,86$ & 130,49 & 143,43 & 104,77 & $-23,15$ & $-48,82$ & $-19,59$ & $-34,88$ \\
\hline 15 & $-7,53$ & $-9,50$ & $-12,45$ & $-37,26$ & $-17,99$ & $-22,37$ & $-60,96$ & $-8,27$ \\
\hline 16 & $-4,14$ & 24,97 & 27,59 & $-3,00$ & $-13,24$ & $-29,81$ & $-14,54$ & $-20,24$ \\
\hline 17 & $-5,39$ & 55,64 & 62,07 & 30,76 & $-20,13$ & $-42,53$ & $-20,31$ & $-28,25$ \\
\hline 18 & $-6,55$ & 79,66 & 88,62 & 54,67 & $-25,04$ & $-51,60$ & $-24,34$ & $-34,48$ \\
\hline 19 & $-7,26$ & 95,41 & 105,86 & 69,62 & $-27,96$ & $-56,91$ & $-26,76$ & $-38,84$ \\
\hline 20 & $-7,56$ & 102,51 & 113,63 & 78,08 & $-28,99$ & $-58,67$ & $-27,83$ & $-40,94$ \\
\hline 21 & $-7,57$ & 102,99 & 114,25 & 79,18 & $-28,99$ & $-58,67$ & $-27,90$ & $-41,10$ \\
\hline 22 & $-16,23$ & $-48,31$ & $-56,51$ & $-44,10$ & $-5,90$ & $-7,13$ & $-29,40$ & $-29,15$ \\
\hline 23 & $-9,88$ & $-20,60$ & $-19,50$ & $-20,64$ & $-16,49$ & $-33,50$ & $-27,21$ & $-17,15$ \\
\hline 24 & $-12,07$ & 6,41 & 11,30 & $-0,39$ & $-33,27$ & $-56,77$ & $-39,12$ & $-32,82$ \\
\hline 25 & $-15,61$ & 21,44 & 28,84 & 10,79 & $-46,29$ & $-76,66$ & $-52,38$ & $-49,00$ \\
\hline 26 & $-18,37$ & 27,54 & 36,33 & 17,03 & $-54,15$ & $-89,79$ & $-62,42$ & $-60,16$ \\
\hline 27 & $-19,68$ & 29,31 & 38,66 & 18,94 & $-56,44$ & $-94,33$ & $-67,44$ & $-65,49$ \\
\hline 28 & $-19,88$ & 29,55 & 39,09 & 19,48 & $-56,65$ & $-94,33$ & $-67,80$ & $-65,87$ \\
\hline 29 & 699,23 & 48,24 & 446,98 & 32,76 & 87,15 & 93,66 & 39,22 & 445,85 \\
\hline 30 & 113,50 & 74,69 & 69,56 & 54,57 & 153,85 & 147,98 & 81,00 & 89,85 \\
\hline 31 & 159,09 & 102,39 & 94,75 & 89,25 & 230,39 & 221,19 & 131,38 & 152,62 \\
\hline 32 & 188,18 & 119,95 & 111,27 & 115,83 & 284,25 & 276,13 & 172,57 & 204,18 \\
\hline 33 & 202,35 & 129,34 & 120,42 & 132,46 & 314,45 & 309,63 & 200,85 & 239,19 \\
\hline 34 & 203,12 & 131,68 & 123,13 & 134,18 & 321,22 & 320,87 & 214,43 & 255,84 \\
\hline 35 & 202,21 & 133,76 & 125,55 & 146,46 & 321,16 & 320,87 & 215,41 & 257,04 \\
\hline
\end{tabular}


TABELA 5.217: Esforços normais nas nervuras e vigas, em $\mathrm{kN}$, na laje com espaçamento entre os eixos das nervuras $\mathrm{E}=80 \mathrm{~cm}$

\begin{tabular}{|c|c|c|c|c|c|c|c|c|}
\hline \multicolumn{9}{|c|}{$\begin{array}{c}\text { VARIAÇÃO DO ESPAÇAMENTO ENTRE NERVURAS: E }=80 \mathrm{~cm} \\
\text { ESFORÇOS NORMAIS NAS NERVURAS E VIGAS }(\mathrm{kN})\end{array}$} \\
\hline \multirow{2}{*}{ Ponto } & \multicolumn{8}{|c|}{ Modelos numéricos de análise } \\
\hline & 01 & 02 & 03 & 04 & 05 & 06 & 07 & 08 \\
\hline 8 & $-4,85$ & $-0,05$ & $-1,02$ & $-66,97$ & $-32,75$ & $-41,54$ & $-2,14$ & $-3,74$ \\
\hline 9 & $-1,80$ & 68,91 & 75,37 & $-2,04$ & $-16,03$ & $-42,39$ & $-14,50$ & $-22,46$ \\
\hline 10 & $-3,78$ & 121,02 & 132,00 & 60,81 & $-24,19$ & $-55,62$ & $-20,59$ & $-34,19$ \\
\hline 11 & $-5,11$ & 157,82 & 171,85 & 104,85 & $-29,07$ & $-63,96$ & $-24,06$ & $-41,49$ \\
\hline 12 & $-5,85$ & 181,52 & 197,54 & 132,47 & $-31,34$ & $-68,24$ & $-25,96$ & $-45,73$ \\
\hline 13 & $-6,15$ & 192,55 & 209,52 & 148,32 & $-32,04$ & $-69,54$ & 26,75 & $-47,59$ \\
\hline 14 & $-6,17$ & 193,32 & 210,50 & 150,18 & $-32,05$ & $-69,54$ & $-26,81$ & $-47,72$ \\
\hline 15 & $-9,95$ & $-17,29$ & $-22,32$ & $-59,48$ & $-25,26$ & $-31,91$ & $-8,98$ & $-11,70$ \\
\hline 16 & $-5,23$ & 32,20 & 37,56 & $-8,35$ & $-18,06$ & $-41,81$ & $-20,42$ & $-27,84$ \\
\hline 17 & $-6,76$ & 80,80 & 89,32 & 42,21 & $-27,74$ & $-60,29$ & $-28,23$ & $-38,90$ \\
\hline 18 & $-8,21$ & 117,20 & 129,09 & 77,44 & $-34,67$ & $-73,42$ & $-33,70$ & $-47,45$ \\
\hline 19 & $-9,12$ & 141,08 & 154,94 & 99,78 & $-38,77$ & $-81,02$ & $-37,01$ & $-53,38$ \\
\hline 20 & $-9,51$ & 151,89 & 166,63 & 111,54 & $-40,22$ & $-83,52$ & $-38,46$ & $-56,22$ \\
\hline 21 & $-9,52$ & 152,64 & 167,60 & 113,12 & $-40,22$ & $-83,52$ & $-38,57$ & $-56,42$ \\
\hline 22 & $-19,80$ & $-70,42$ & $-83,01$ & $-62,07$ & $-7,18$ & $-9,44$ & $-39,06$ & $-39,07$ \\
\hline 23 & $-12,01$ & $-30,55$ & $-29,22$ & $-28,63$ & $-23,90$ & $-50,41$ & $-38,92$ & $-27,14$ \\
\hline 24 & $-14,75$ & 9,64 & 15,94 & $-0,22$ & $-46,47$ & $-80,80$ & $-55,03$ & $-47,24$ \\
\hline 25 & $-19,11$ & 32,61 & 42,19 & 15,37 & $-63,78$ & $-107,31$ & $-72,33$ & $-67,69$ \\
\hline 26 & $-22,53$ & 42,31 & 53,70 & 23,17 & $-74,26$ & $-125,18$ & $-85,28$ & $-81,77$ \\
\hline 27 & $-24,20$ & 45,26 & 57,36 & 25,76 & $-77,26$ & $-131,42$ & $-91,72$ & $-88,50$ \\
\hline 28 & $-24,49$ & 45,68 & 58,05 & 26,56 & $-77,56$ & $-131,42$ & $-92,18$ & $-88,98$ \\
\hline 29 & 997,24 & "69,03 & 6767,40 & 53,27 & 125,49 & 13135,37 & 258,71 & "68,15 \\
\hline 30 & 160,49 & 108,92 & 101,98 & 84,74 & 221,23 & 213,25 & 117,94 & 131,03 \\
\hline 31 & 222,58 & 145,90 & 135,53 & 130,96 & 326,06 & 315,37 & 184,71 & 213,96 \\
\hline 32 & 261,74 & 168,03 & 156,30 & 164,00 & 399,68 & 392,10 & 238,79 & 281,62 \\
\hline 33 & 280,33 & 179,06 & 167,10 & 184,89 & 440,65 & 439,02 & 275,76 & 327,46 \\
\hline 34 & 280,64 & 181,04 & 169,70 & 186,24 & 449,27 & 454,80 & 293,48 & 349,25 \\
\hline 35 & 279,26 & 183,89 & 173,04 & 187,52 & 449,14 & 454,80 & 294,76 & 350,81 \\
\hline
\end{tabular}


TABELA 5.218: Esforços normais nas nervuras e vigas, em $\mathrm{kN}$, na laje com espaçamento entre os eixos das nervuras $\mathrm{E}=90 \mathrm{~cm}$

\begin{tabular}{|c|c|c|c|c|c|c|c|c|}
\hline \multicolumn{9}{|c|}{$\begin{array}{c}\text { VARIAÇÃO DO ESPAÇAMENTO ENTRE NERVURAS: } \mathrm{E}=90 \mathrm{~cm} \\
\text { ESFORÇOS NORMAIS NAS NERVURAS E VIGAS }(\mathrm{kN})\end{array}$} \\
\hline \multirow{2}{*}{ Ponto } & \multicolumn{8}{|c|}{ Modelos numéricos de análise } \\
\hline & 01 & 02 & 03 & 04 & 05 & 06 & 07 & 08 \\
\hline 8 & $-6,43$ & $-2,93$ & $-4,60$ & $-103,23$ & $-44,36$ & $-57,12$ & $-2,90$ & $-5,10$ \\
\hline 9 & $-2,23$ & 94,57 & 102,91 & $-10,65$ & $-20,92$ & $-56,68$ & $-18,76$ & $-29,05$ \\
\hline 10 & $-4,61$ & 168,92 & 183,00 & 84,18 & $-31,68$ & $-74,51$ & $-26,77$ & $-44,37$ \\
\hline 11 & $-6,23$ & 221,50 & 239,46 & 150,50 & $-38,21$ & $-85,98$ & $-31,40$ & $-54,07$ \\
\hline 12 & $-7,14$ & 255,41 & 275,91 & 185,54 & $-41,28$ & $-91,94$ & $-33,98$ & $-59,79$ \\
\hline 13 & $-7,52$ & 271,24 & 292,95 & 204,79 & $-42,24$ & $-93,77$ & $-35,07$ & $-62,32$ \\
\hline 14 & $-7,53$ & 272,37 & 294,37 & 214,58 & $-42,24$ & $-93,77$ & $-35,15$ & $-62,50$ \\
\hline 15 & $\begin{array}{l}-12,57 \\
\end{array}$ & $-28,58$ & $\begin{array}{l}-36,38 \\
\end{array}$ & $-89,58$ & $-33,59$ & $\begin{array}{l}-43,07 \\
\end{array}$ & -12,55 & $-15,80$ \\
\hline 16 & $-6,37$ & 44,79 & 48,95 & $-16,72$ & $-23,52$ & $-55,69$ & $-27,35$ & $-36,67$ \\
\hline 17 & $-8,18$ & 111,96 & 122,84 & 56,27 & $-36,45$ & $-81,00$ & $-37,47$ & $-51,20$ \\
\hline 18 & $-9,93$ & 164,28 & 179,48 & 106,82 & $-45,71$ & $-98,91$ & $-44,55$ & $-62,40$ \\
\hline 19 & $-11,03$ & 198,59 & 216,32 & 137,97 & $-51,16$ & $-109,18$ & $-48,87$ & $-70,11$ \\
\hline 20 & $-11,52$ & 214,18 & 233,05 & 152,66 & $-53,09$ & $-112,54$ & $-50,78$ & $-73,79$ \\
\hline 21 & $-11,53$ & 215,30 & 234,45 & 154,89 & $-53,09$ & $-112,54$ & $-50,91$ & $-74,05$ \\
\hline 22 & $-23,43$ & $-98,50$ & $-116,51$ & $-84,39$ & $-8,58$ & $-12,11$ & $-50,04$ & $-50,43$ \\
\hline 23 & $-14,02$ & $-43,08$ & $-41,58$ & $-38,40$ & $-32,57$ & $-70,81$ & $-52,50$ & $-38,93$ \\
\hline 24 & $-17,30$ & 13,77 & 21,61 & 0,00 & $-61,61$ & $-108,85$ & $-73,40$ & $-63,99$ \\
\hline 25 & $-22,51$ & 47,05 & 59,01 & 21,28 & $-83,75$ & $-142,74$ & $-95,26$ & $-89,15$ \\
\hline 26 & $-26,64$ & 61,62 & 75,87 & 32,05 & $-97,18$ & $-165,99$ & $-111,46$ & $-106,51$ \\
\hline 27 & $-28,72$ & 66,24 & 81,39 & 36,38 & $-100,96$ & $-174,17$ & $-119,48$ & $-114,79$ \\
\hline 28 & $-29,15$ & 66,93 & 82,43 & 37,60 & $-101,36$ & $-174,17$ & $-120,06$ & $-115,38$ \\
\hline 29 & 130,26 & 93,93 & 91,93 & 77,85 & 170,26 & 184,57 & 82,16 & 94,87 \\
\hline 30 & 215,18 & 149,75 & 140,80 & 116,97 & 300,03 & 290,10 & 161,52 & 179,46 \\
\hline 31 & 296,05 & 197,15 & 183,70 & 168,96 & 437,22 & 425,44 & 246,80 & 285,16 \\
\hline 32 & 346,81 & 224,06 & 208,84 & 220,43 & 533,49 & 527,31 & 315,38 & 370,98 \\
\hline 33 & 370,59 & 236,48 & 221,06 & 227,19 & 586,78 & 589,77 & 362,11 & 429,05 \\
\hline 34 & 370,49 & 237,67 & 223,21 & 247,01 & 597,46 & 610,80 & 384,48 & 456,61 \\
\hline 35 & 368,60 & 241,40 & 227,59 & 248,66 & 597,25 & 610,80 & 386,09 & 458,59 \\
\hline
\end{tabular}

Analisando-se as tabelas de momentos fletores e esforços normais, para as nervuras e vigas, nos modelos com variação do espaçamento entre os eixos das nervuras, vêse que:

- para as nervuras, momentos fletores positivos menores são apresentados pelos modelos 05, 06, 07 e 08. As nervuras destes sofrem forças normais de compressão, de pequena ordem quando comparadas, em módulo, com as normais de tração encontradas nos modelos 02, 03 e 04 para as nervuras. Como já apontado anteriormente, nos modelos 05, 06, 07 e 08 os elementos finitos são lançados de forma concêntrica à capa, explicando daí a compressão nas peças;

- para as vigas os maiores momentos fletores são obtidos quando modela-se o pavimento segundo os modelos 02,03 e 04 ; em contrapartida, os maiores esforços normais aparecem nas modelagens 05 a 08, e são de tração em todos os modelos, haja visto que a viga sempre foi considerada excêntrica à capa. 


\subsubsection{Tensões Normais nas fibras superiores extremas das nervuras e vigas}

TABELA 5.219: Tensões normais nas fibras superiores extremas das nervuras e vigas, em $\mathrm{kN} / \mathrm{cm}^{2}$, na laje com espaçamento entre os eixos das nervuras $\mathrm{E}=40 \mathrm{~cm}$

\begin{tabular}{|c|c|c|c|c|c|c|c|c|}
\hline \multicolumn{9}{|c|}{$\begin{array}{l}\text { VARIAÇÃO DO ESPAÇAMENTO ENTRE NERVURAS: E = } 40 \mathrm{~cm} \\
\text { TENSÕES NORMAIS - FIBRAS SUPERIORES EXTREMAS - NERVURAS E VIGAS }\left(\mathrm{kN} / \mathrm{cm}^{2}\right)\end{array}$} \\
\hline \multirow{2}{*}{ Ponto } & \multicolumn{8}{|c|}{ Modelos numéricos de análise } \\
\hline & 01 & $\mathbf{0 2}$ & 03 & 04 & 05 & 06 & 07 & 08 \\
\hline 8 & 0,055 & 0,042 & 0,070 & 0,057 & 0,039 & 0,037 & $-0,010$ & 0,002 \\
\hline 9 & $-0,173$ & $-0,039$ & 0,032 & $-0,012$ & $-0,044$ & $-0,059$ & $-0,089$ & $-0,068$ \\
\hline 10 & $-0,346$ & $-0,096$ & 0,012 & $-0,052$ & $-0,112$ & $-0,133$ & $-0,143$ & $-0,116$ \\
\hline 11 & $-0,467$ & $-0,136$ & $-0,002$ & $-0,079$ & $-0,160$ & $-0,185$ & $-0,181$ & $-0,149$ \\
\hline 12 & $-0,548$ & $-0,162$ & $-0,013$ & $-0,098$ & $-0,190$ & $-0,217$ & $-0,205$ & $-0,168$ \\
\hline 13 & $-0,588$ & $-0,177$ & $-0,023$ & $-0,106$ & $-0,204$ & $-0,232$ & $-0,216$ & $-0,177$ \\
\hline 14 & $-0,595$ & $-0,181$ & $-0,030$ & $-0,107$ & $-0,206$ & $-0,234$ & $-0,216$ & $-0,177$ \\
\hline 15 & 0,097 & 0,038 & 0,056 & 0,053 & 0,036 & 0,035 & 0,000 & 0,014 \\
\hline 16 & $-0,087$ & $-0,022$ & 0,030 & $-0,005$ & $-0,036$ & $-0,051$ & $-0,062$ & $-0,047$ \\
\hline 17 & $-0,247$ & $-0,074$ & 0,011 & $-0,042$ & $-0,095$ & $-0,116$ & $-0,114$ & $-0,092$ \\
\hline 18 & $-0,373$ & $-0,115$ & $-0,005$ & $-0,069$ & $-0,135$ & $-0,159$ & $-0,152$ & $-0,124$ \\
\hline 19 & $-0,456$ & $-0,142$ & $-0,017$ & $-0,089$ & $-0,160$ & $-0,186$ & $-0,176$ & $-0,144$ \\
\hline 20 & $-0,496$ & $-0,156$ & $-0,027$ & $-0,095$ & $-0,171$ & $-0,199$ & $-0,187$ & $-0,152$ \\
\hline 21 & $-0,503$ & $-0,205$ & $-0,033$ & $-0,095$ & $-0,174$ & $-0,201$ & $-0,187$ & $-0,153$ \\
\hline 22 & 0,216 & 0,093 & 0,072 & 0,053 & 0,026 & 0,020 & 0,058 & 0,047 \\
\hline 23 & 0,044 & 0,005 & 0,016 & 0,006 & $-0,016$ & $-0,028$ & $-0,006$ & 0,010 \\
\hline 24 & $-0,108$ & $-0,052$ & $-0,004$ & $-0,030$ & $-0,059$ & $-0,074$ & $-0,065$ & $-0,041$ \\
\hline 25 & $-0,210$ & $-0,096$ & $-0,034$ & $-0,056$ & $-0,092$ & $-0,114$ & $-0,107$ & $-0,080$ \\
\hline 26 & $-0,263$ & $-0,117$ & $-0,045$ & $-0,073$ & $-0,113$ & $-0,140$ & $-0,131$ & $-0,103$ \\
\hline 27 & $-0,285$ & $-0,126$ & $-0,051$ & $-0,078$ & $-0,122$ & $-0,151$ & $-0,142$ & $-0,113$ \\
\hline 28 & $-0,292$ & $-0,131$ & $-0,058$ & $-0,079$ & $-0,124$ & $-0,153$ & $-0,143$ & $-0,114$ \\
\hline 29 & 0,179 & 0,187 & 0,191 & 0,136 & 0,159 & 0,173 & 0,148 & 0,163 \\
\hline 30 & 0,077 & 0,060 & 0,059 & 0,045 & 0,077 & 0,083 & 0,042 & 0,043 \\
\hline 31 & $-0,028$ & $-0,028$ & $-0,029$ & $-0,022$ & $-0,024$ & $-0,016$ & $-0,016$ & $-0,019$ \\
\hline 32 & $-0,065$ & $-0,082$ & $-0,087$ & $-0,072$ & $-0,038$ & $-0,042$ & $-0,047$ & $-0,048$ \\
\hline 33 & $-0,089$ & $-0,121$ & $-0,127$ & $-0,106$ & $-0,047$ & $-0,057$ & $-0,067$ & $-0,066$ \\
\hline 34 & $-0,100$ & $-0,140$ & $-0,148$ & $-0,123$ & $-0,048$ & $-0,063$ & $-0,077$ & $-0,075$ \\
\hline 35 & $-0,093$ & $-0,137$ & $-0,145$ & $-0,123$ & $-0,038$ & $-0,055$ & $-0,077$ & $-0,075$ \\
\hline
\end{tabular}


TABELA 5.220: Tensões normais nas fibras superiores extremas das nervuras e vigas, em $\mathrm{kN} / \mathrm{cm}^{2}$, na laje com espaçamento entre os eixos das nervuras $\mathrm{E}=50 \mathrm{~cm}$

\begin{tabular}{|c|c|c|c|c|c|c|c|c|}
\hline \multicolumn{9}{|c|}{$\begin{array}{l}\text { VARIAÇÃO DO ESPAÇAMENTO ENTRE NERVURAS: E = } 50 \mathrm{~cm} \\
\text { TENSÕES NORMAIS - FIBRAS SUPERIORES EXTREMAS - NERVURAS E VIGAS }\left(\mathrm{kN} / \mathrm{cm}^{2}\right)\end{array}$} \\
\hline \multirow{2}{*}{ Ponto } & \multicolumn{8}{|c|}{ Modelos numéricos de análise } \\
\hline & 01 & 02 & 03 & 04 & 05 & 06 & 07 & 08 \\
\hline 8 & 0,144 & 0,084 & 0,132 & 0,122 & 0,099 & 0,095 & $-0,015$ & 0,010 \\
\hline 9 & $-0,293$ & $-0,062$ & 0,073 & $-0,009$ & $-0,041$ & $-0,069$ & $-0,144$ & $-0,104$ \\
\hline 10 & $-0,620$ & $-0,159$ & 0,034 & $-0,086$ & $-0,158$ & $-0,197$ & $-0,234$ & $-0,184$ \\
\hline 11 & $-0,851$ & $-0,226$ & 0,025 & $-0,134$ & $-0,239$ & $-0,286$ & $-0,297$ & $-0,237$ \\
\hline 12 & $-1,003$ & $-0,271$ & 0,007 & $-0,164$ & $-0,263$ & $-0,340$ & $-0,336$ & $-0,269$ \\
\hline 13 & $-1,081$ & $-0,298$ & $-0,010$ & $-0,178$ & $-0,313$ & $-0,365$ & $-0,354$ & $-0,284$ \\
\hline 14 & $-1,094$ & $-0,307$ & $-0,022$ & $-0,180$ & $-0,316$ & $-0,369$ & $-0,356$ & $-0,285$ \\
\hline 15 & 0,234 & 0,087 & 0,112 & 0,106 & 0,085 & 0,080 & 0,007 & 0,032 \\
\hline 16 & $-0,122$ & $-0,025$ & 0,066 & 0,000 & $-0,036$ & $-0,062$ & $-0,096$ & $-0,070$ \\
\hline 17 & $-0,426$ & $-0,114$ & 0,040 & $-0,067$ & $-0,133$ & $-0,170$ & $-0,181$ & $-0,145$ \\
\hline 18 & $-0,664$ & $-0,186$ & 0,015 & $-0,111$ & $-0,198$ & $-0,242$ & $-0,244$ & $-0,196$ \\
\hline 19 & $-0,823$ & $-0,234$ & $-0,004$ & $-0,138$ & $-0,238$ & $-0,286$ & $-0,284$ & $-0,227$ \\
\hline 20 & $-0,900$ & $-0,259$ & $-0,020$ & $-0,151$ & $-0,256$ & $-0,306$ & $-0,301$ & $-0,241$ \\
\hline 21 & $-0,913$ & $-0,268$ & $-0,032$ & $-0,153$ & $-0,260$ & $-0,309$ & $-0,302$ & $-0,242$ \\
\hline 22 & 0,456 & 0,223 & 0,172 & 0,082 & 0,045 & 0,035 & 0,108 & 0,083 \\
\hline 23 & $-0,184$ & 0,027 & 0,036 & 0,002 & $-0,024$ & $-0,046$ & $-0,008$ & 0,007 \\
\hline 24 & $-0,166$ & $-0,087$ & $-0,016$ & $-0,049$ & $-0,085$ & $-0,113$ & $-0,100$ & $-0,066$ \\
\hline 25 & $-0,347$ & $-0,150$ & $-0,046$ & $-0,082$ & $-0,129$ & $-0,167$ & $-0,161$ & $-0,120$ \\
\hline 26 & $-0,437$ & $-0,178$ & $-0,060$ & $-0,102$ & $-0,156$ & $-0,201$ & $-0,195$ & $-0,152$ \\
\hline 27 & $-0,473$ & $-0,190$ & $-0,068$ & $-0,112$ & $-0,168$ & $-0,216$ & $-0,209$ & $-0,165$ \\
\hline 28 & $-0,486$ & $-0,200$ & $-0,080$ & $-0,114$ & $-0,172$ & $-0,219$ & $-0,210$ & $-0,166$ \\
\hline 29 & 0,192 & 0,201 & 0,205 & 0,150 & 0,169 & 0,183 & 0,158 & 0,172 \\
\hline 30 & 0,082 & 0,055 & 0,052 & 0,040 & 0,091 & 0,089 & 0,041 & 0,041 \\
\hline 31 & $-0,057$ & $-0,056$ & $-0,058$ & $-0,045$ & $-0,043$ & $-0,030$ & $-0,030$ & $-0,034$ \\
\hline 32 & $-0,098$ & $-0,123$ & $-0,129$ & $-0,110$ & $-0,048$ & $-0,046$ & $-0,067$ & $-0,067$ \\
\hline 33 & $-0,124$ & $-0,171$ & $-0,180$ & $-0,155$ & $-0,048$ & $-0,054$ & $-0,092$ & $-0,089$ \\
\hline 34 & $-0,134$ & $-0,195$ & $-0,206$ & $-0,178$ & $-0,044$ & $-0,055$ & $-0,104$ & $-0,099$ \\
\hline 35 & $-0,124$ & $-0,189$ & $-0,200$ & $-0,179$ & $-0,028$ & $-0,043$ & $-0,104$ & $-0,100$ \\
\hline
\end{tabular}


TABELA 5.221: Tensões normais nas fibras superiores extremas das nervuras e vigas, em $\mathrm{kN} / \mathrm{cm}^{2}$, na laje com espaçamento entre os eixos das nervuras $\mathrm{E}=60 \mathrm{~cm}$

VARIAÇÃO DO ESPAÇAMENTO ENTRE NERVURAS: E $=60 \mathrm{~cm}$

TENSÕES NORMAIS - FIBRAS SUPERIORES EXTREMAS - NERVURAS E VIGAS (kN/cm²)

\begin{tabular}{c|c|c|c|c|c|c|c|c}
\hline \multirow{2}{*}{ Ponto } & \multicolumn{7}{|c|}{ Modelos numéricos de análise } \\
\cline { 2 - 9 } & $\mathbf{0 1}$ & $\mathbf{0 2}$ & $\mathbf{0 3}$ & $\mathbf{0 4}$ & $\mathbf{0 5}$ & $\mathbf{0 6}$ & $\mathbf{0 7}$ & $\mathbf{0 8}$ \\
\hline \hline $\mathbf{8}$ & 0,300 & 0,151 & 0,224 & $\mathbf{0 , 2 1 0}$ & 0,199 & 0,196 & $-0,019$ & 0,025 \\
\hline $\mathbf{9}$ & $-0,438$ & $-0,085$ & 0,137 & $\mathbf{- 0 , 0 0 6}$ & $-0,018$ & $-0,059$ & $-0,213$ & $-0,146$ \\
\hline $\mathbf{1 0}$ & $-0,988$ & $-0,237$ & 0,101 & $\mathbf{- 0 , 1 2 4}$ & $-0,200$ & $-0,259$ & $-0,349$ & $-0,266$ \\
\hline $\mathbf{1 1}$ & $-1,377$ & $-0,341$ & 0,074 & $\mathbf{- 0 , 2 0 5}$ & $-0,325$ & $-0,397$ & $-0,444$ & $-0,347$ \\
\hline $\mathbf{1 2}$ & $-1,634$ & $-0,412$ & 0,049 & $\mathbf{- 0 , 2 5 3}$ & $-0,401$ & $-0,481$ & $-0,504$ & $-0,396$ \\
\hline $\mathbf{1 3}$ & $-1,764$ & $-0,456$ & 0,022 & $\mathbf{- 0 , 2 7 5}$ & $-0,437$ & $-0,520$ & $-0,532$ & $-0,418$ \\
\hline $\mathbf{1 4}$ & $-1,786$ & $-0,471$ & 0,001 & $\mathbf{- 0 , 2 7 9}$ & $-0,443$ & $-0,525$ & $-0,534$ & $-0,420$ \\
\hline \hline $\mathbf{1 5}$ & 0,464 & 0,171 & 0,200 & $\mathbf{0 , 1 8 0}$ & 0,161 & 0,160 & 0,021 & 0,062 \\
\hline $\mathbf{1 6}$ & $-0,147$ & $-0,020$ & 0,123 & $\mathbf{0 , 0 0 7}$ & $-0,024$ & $-0,062$ & $-0,136$ & $-0,095$ \\
\hline $\mathbf{1 7}$ & $-0,661$ & $-0,054$ & 0,088 & $\mathbf{- 0 , 0 9 8}$ & $-0,170$ & $-0,227$ & $-0,266$ & $-0,208$ \\
\hline $\mathbf{1 8}$ & $-1,062$ & $-0,275$ & 0,055 & $\mathbf{- 0 , 1 6 6}$ & $-0,266$ & $-0,335$ & $-0,361$ & $-0,285$ \\
\hline $\mathbf{1 9}$ & $-1,328$ & $-0,352$ & 0,025 & $\mathbf{- 0 , 2 0 8}$ & $-0,324$ & $-0,399$ & $-0,420$ & $-0,331$ \\
\hline $\mathbf{2 0}$ & $-1,457$ & $-0,393$ & 0,000 & $\mathbf{- 0 , 2 2 7}$ & $-0,350$ & $-0,429$ & $-0,446$ & $-0,352$ \\
\hline $\mathbf{2 1}$ & $-1,479$ & $-0,408$ & $-0,020$ & $\mathbf{- 0 , 2 3 1}$ & $-0,356$ & $-0,433$ & $-0,448$ & $-0,353$ \\
\hline $\mathbf{2 2}$ & 0,808 & 0,414 & 0,310 & $\mathbf{0 , 1 2 3}$ & 0,070 & 0,057 & 0,177 & 0,134 \\
\hline $\mathbf{2 3}$ & 0,231 & 0,062 & 0,066 & $\mathbf{0 , 0 0 2}$ & $-0,031$ & $-0,066$ & $-0,005$ & 0,006 \\
\hline $\mathbf{2 4}$ & $-0,233$ & $-0,117$ & $-0,009$ & $\mathbf{- 0 , 0 7 1}$ & $-0,112$ & $-0,156$ & $-0,139$ & $-0,094$ \\
\hline $\mathbf{2 5}$ & $-0,523$ & $-0,212$ & $-0,053$ & $\mathbf{- 0 , 1 1 6}$ & $-0,168$ & $-0,225$ & $-0,225$ & $-0,166$ \\
\hline $\mathbf{2 6}$ & $-0,668$ & $-0,253$ & $-0,072$ & $\mathbf{- 0 , 1 4 2}$ & $-0,203$ & $-0,269$ & $-0,271$ & $-0,208$ \\
\hline $\mathbf{2 7}$ & $-0,726$ & $-0,269$ & $-0,081$ & $-\mathbf{0 , 1 5 0}$ & $-0,217$ & $-0,288$ & $-0,289$ & $-0,226$ \\
\hline $\mathbf{2 8}$ & $-0,747$ & $-0,285$ & $-0,101$ & $\mathbf{- 0 , 1 5 3}$ & $-0,223$ & $-0,293$ & $-0,291$ & $-0,227$ \\
\hline \hline $\mathbf{2 9}$ & 0,199 & 0,208 & 0,211 & $\mathbf{0 , 1 5 6}$ & 0,173 & 0,189 & 0,163 & 0,175 \\
\hline $\mathbf{3 0}$ & $-0,010$ & 0,014 & 0,018 & $\mathbf{0 , 0 2 7}$ & $-0,049$ & 0,015 & 0,016 & 0,011 \\
\hline $\mathbf{3 1}$ & $-0,091$ & $-0,091$ & $-0,094$ & $\mathbf{- 0 , 0 7 5}$ & $-0,065$ & $-0,044$ & $-0,046$ & $-0,050$ \\
\hline $\mathbf{3 2}$ & $-0,136$ & $-0,170$ & $-0,178$ & $\mathbf{- 0 , 1 5 4}$ & $-0,056$ & $-0,046$ & $-0,089$ & $-0,088$ \\
\hline $\mathbf{3 3}$ & $-0,162$ & $-0,227$ & $-0,238$ & $\mathbf{- 0 , 2 1 2}$ & $-0,047$ & $-0,043$ & $-0,117$ & $-0,113$ \\
\hline $\mathbf{3 4}$ & $-0,171$ & $-0,256$ & $-0,269$ & $\mathbf{- 0 , 2 4 5}$ & $-0,035$ & $-0,037$ & $-0,131$ & $-0,125$ \\
\hline $\mathbf{3 5}$ & $-0,156$ & $-0,247$ & $-0,261$ & $\mathbf{- 0 , 2 4 6}$ & $-0,012$ & $-0,021$ & $-0,132$ & $-0,125$ \\
\hline \hline
\end{tabular}


TABELA 5.222: Tensões normais nas fibras superiores extremas das nervuras e vigas, em $\mathrm{kN} / \mathrm{cm}^{2}$, na laje com espaçamento entre os eixos das nervuras $\mathrm{E}=70 \mathrm{~cm}$

\begin{tabular}{|c|c|c|c|c|c|c|c|c|}
\hline \multicolumn{9}{|c|}{$\begin{array}{l}\text { VARIAÇÃO DO ESPAÇAMENTO ENTRE NERVURAS: E = } 70 \mathrm{~cm} \\
\text { TENSÕES NORMAIS - FIBRAS SUPERIORES EXTREMAS - NERVURAS E VIGAS }\left(\mathrm{kN} / \mathrm{cm}^{2}\right)\end{array}$} \\
\hline \multirow{2}{*}{ Ponto } & \multicolumn{8}{|c|}{ Modelos numéricos de análise } \\
\hline & 01 & 02 & 03 & 04 & 05 & 06 & 07 & 08 \\
\hline 8 & 0,542 & 0,249 & 0,349 & 0,334 & 0,343 & 0,345 & $-0,022$ & 0,049 \\
\hline 9 & $-0,603$ & $-0,119$ & 0,646 & 0,011 & 0,027 & $-0,026$ & $-0,297$ & $-0,193$ \\
\hline 10 & $-1,456$ & $-0,329$ & 0,185 & $-0,165$ & $-0,237$ & $-0,317$ & $-0,490$ & $-0,365$ \\
\hline 11 & $-2,060$ & $-0,481$ & 0,152 & $-0,274$ & $-0,417$ & $-0,518$ & $-0,625$ & $-0,480$ \\
\hline 12 & $-2,458$ & $-0,587$ & 0,117 & $-0,342$ & $-0,526$ & $-0,639$ & $-0,711$ & $-0,551$ \\
\hline 13 & $-2,660$ & $-0,652$ & 0,077 & $-0,396$ & $-0,577$ & $-0,696$ & $-0,751$ & $-0,582$ \\
\hline 14 & $-2,694$ & $-0,676$ & 0,045 & $-0,396$ & $-0,586$ & $-0,703$ & $-0,754$ & $-0,584$ \\
\hline 15 & 0,808 & 0,299 & $-0,079$ & 0,277 & 0,268 & 0,271 & $-0,073$ & 0,106 \\
\hline 16 & $-0,157$ & $-0,007$ & 0,203 & 0,023 & 0,002 & $-0,048$ & $-0,183$ & $-0,122$ \\
\hline 17 & $-0,958$ & $-0,216$ & 0,161 & $-0,133$ & $-0,205$ & $-0,282$ & $-0,368$ & $-0,283$ \\
\hline 18 & $-1,575$ & $-0,382$ & 0,117 & $-0,233$ & $-0,339$ & $-0,434$ & $-0,504$ & $-0,391$ \\
\hline 19 & $-1,985$ & $-0,496$ & 0,077 & $-0,294$ & $-0,418$ & $-0,524$ & $-0,588$ & $-0,456$ \\
\hline 20 & $-2,185$ & $-0,558$ & 0,038 & $-0,314$ & $-0,455$ & $-0,564$ & $-0,626$ & $-0,485$ \\
\hline 21 & $-2,218$ & $-0,582$ & 0,007 & $-0,320$ & $-0,463$ & $-0,571$ & $-0,628$ & $-0,487$ \\
\hline 22 & 1 & 0,668 & 0,486 & 0,180 & 0,101 & 0,086 & 0,269 & 0,199 \\
\hline 23 & 0,391 & 0,113 & 0,109 & 0,021 & $-0,038$ & $-0,088$ & 0,004 & 0,007 \\
\hline 24 & $-0,306$ & $-0,147$ & 0,008 & $-0,094$ & $-0,140$ & $-0,201$ & $-0,181$ & $-0,125$ \\
\hline 25 & $-0,739$ & $-0,284$ & $-0,051$ & $-0,155$ & $-0,209$ & $-0,286$ & $-0,298$ & $-0,218$ \\
\hline 26 & $-0,960$ & $-0,342$ & $-0,077$ & $-0,183$ & $-0,251$ & $-0,342$ & $-0,359$ & $-0,272$ \\
\hline 27 & $-1,048$ & $-0,363$ & $-0,089$ & $-0,199$ & $-0,268$ & $-0,365$ & $-0,383$ & $-0,295$ \\
\hline 28 & $-1,081$ & $-0,388$ & $-0,120$ & $-0,205$ & $-0,277$ & $-0,372$ & $-0,385$ & $-0,296$ \\
\hline 29 & 0,201 & 0,209 & 0,212 & 0,158 & 0,176 & 0,193 & 0,165 & 0,176 \\
\hline 30 & $-0,038$ & $-0,009$ & $-0,004$ & 0,010 & $-0,089$ & $-0,004$ & 0,006 & 0,000 \\
\hline 31 & $-0,128$ & $-0,130$ & $-0,133$ & $-0,107$ & $-0,087$ & $-0,056$ & $-0,064$ & $-0,068$ \\
\hline 32 & $-0,176$ & $-0,222$ & $-0,230$ & $-0,201$ & $-0,063$ & $-0,041$ & $-0,111$ & $-0,110$ \\
\hline 33 & $-0,203$ & $-0,288$ & $-0,301$ & $-0,270$ & $-0,043$ & $-0,027$ & $-0,144$ & $-0,138$ \\
\hline 34 & $-0,209$ & $-0,321$ & $-0,337$ & $-0,311$ & $-0,024$ & $-0,013$ & $-0,160$ & $-0,151$ \\
\hline 35 & $-0,190$ & $-0,309$ & $-0,326$ & $-0,304$ & 0,007 & 0,008 & $-0,161$ & $-0,151$ \\
\hline
\end{tabular}


TABELA 5.223: Tensões normais nas fibras superiores extremas das nervuras e vigas, em $\mathrm{kN} / \mathrm{cm}^{2}$, na laje com espaçamento entre os eixos das nervuras $\mathrm{E}=80 \mathrm{~cm}$

VARIAÇÃO DO ESPAÇAMENTO ENTRE NERVURAS: $\mathrm{E}=80 \mathrm{~cm}$

TENSÕES NORMAIS - FIBRAS SUPERIORES EXTREMAS - NERVURAS E VIGAS (kN/cm²)

\begin{tabular}{c|c|c|c|c|c|c|c|c}
\hline \multirow{2}{*}{ Ponto } & \multicolumn{7}{|c}{ Modelos numéricos de análise } \\
\cline { 2 - 9 } & $\mathbf{0 1}$ & $\mathbf{0 2}$ & $\mathbf{0 3}$ & $\mathbf{0 4}$ & $\mathbf{0 5}$ & $\mathbf{0 6}$ & $\mathbf{0 7}$ & $\mathbf{0 8}$ \\
\hline $\mathbf{8}$ & 0,890 & 0,382 & 0,511 & $\mathbf{0 , 4 8 4}$ & 0,533 & 0,548 & $-0,024$ & 0,084 \\
\hline $\mathbf{9}$ & $-0,784$ & $-0,125$ & 0,357 & $\mathbf{0 , 0 3 4}$ & 0,095 & 0,034 & $-0,395$ & $-0,246$ \\
\hline $\mathbf{1 0}$ & $-2,029$ & $-0,435$ & 0,303 & $\mathbf{- 0 , 2 4 1}$ & $-0,269$ & $-0,370$ & $-0,658$ & $-0,479$ \\
\hline $\mathbf{1 1}$ & $-2,911$ & $-0,647$ & 0,263 & $\mathbf{- 0 , 4 1 5}$ & $-0,517$ & $-0,647$ & $-0,843$ & $-0,638$ \\
\hline $\mathbf{1 2}$ & $-3,494$ & $-0,797$ & 0,216 & $\mathbf{- 0 , 5 2 3}$ & $-0,666$ & $-0,815$ & $-0,960$ & $-0,734$ \\
\hline $\mathbf{1 3}$ & $-3,788$ & $-0,890$ & 0,159 & $\mathbf{- 0 , 5 5 8}$ & $-0,735$ & $-0,892$ & $-0,912$ & $-0,776$ \\
\hline $\mathbf{1 4}$ & $-3,838$ & $-0,925$ & 0,112 & $\mathbf{- 0 , 5 6 6}$ & $-0,747$ & $-0,902$ & $-1,018$ & $-0,780$ \\
\hline \hline $\mathbf{1 5}$ & 1,288 & 0,477 & 0,487 & $\mathbf{0 , 4 1 1}$ & 0,408 & 0,419 & 0,077 & 0,165 \\
\hline $\mathbf{1 6}$ & $-0,146$ & 0,006 & 0,310 & $\mathbf{0 , 0 4 4}$ & 0,042 & $-0,017$ & $-0,235$ & $-0,149$ \\
\hline $\mathbf{1 7}$ & $-1,318$ & $-0,275$ & 0,261 & $\mathbf{- 0 , 1 7 5}$ & $-0,238$ & $-0,336$ & $-0,488$ & $-0,370$ \\
\hline $\mathbf{1 8}$ & $-2,214$ & $-0,508$ & 0,207 & $\mathbf{- 0 , 3 1 8}$ & $-0,417$ & $-0,541$ & $-0,673$ & $-0,515$ \\
\hline $\mathbf{1 9}$ & $-2,807$ & $-0,668$ & 0,153 & $\mathbf{- 0 , 4 0 2}$ & $-0,522$ & $-0,660$ & $-0,789$ & $-0,603$ \\
\hline $\mathbf{2 0}$ & $-3,097$ & $-0,758$ & 0,098 & $\mathbf{- 0 , 4 3 3}$ & $-0,570$ & $-0,714$ & $-0,840$ & $-0,642$ \\
\hline $\mathbf{2 1}$ & $-3,145$ & $-0,793$ & 0,052 & $\mathbf{- 0 , 4 4 1}$ & $-0,581$ & $-0,723$ & $-0,844$ & $-0,645$ \\
\hline $\mathbf{2 2}$ & 1,898 & 0,986 & 0,697 & $\mathbf{0 , 2 5 0}$ & 0,139 & 0,123 & 0,383 & 0,280 \\
\hline $\mathbf{2 3}$ & 0,603 & 0,181 & 0,168 & $\mathbf{0 , 0 3 0}$ & $-0,043$ & $-0,110$ & 0,020 & 0,012 \\
\hline $\mathbf{2 4}$ & $-0,383$ & $-0,173$ & 0,040 & $\mathbf{- 0 , 1 1 9}$ & $-0,168$ & $-0,248$ & $-0,226$ & $-0,157$ \\
\hline $\mathbf{2 5}$ & $-0,999$ & $-0,362$ & $-0,036$ & $\mathbf{- 0 , 1 9 7}$ & $-0,250$ & $-0,349$ & $-0,380$ & $-0,275$ \\
\hline $\mathbf{2 6}$ & $-1,316$ & $-0,443$ & $-0,072$ & $\mathbf{- 0 , 2 3 7}$ & $-0,301$ & $-0,417$ & $-0,460$ & $-0,342$ \\
\hline $\mathbf{2 7}$ & $-1,444$ & $-0,473$ & $-0,089$ & $-\mathbf{0 , 2 5 8}$ & $-0,321$ & $-0,445$ & $-0,491$ & $-0,371$ \\
\hline $\mathbf{2 8}$ & $-1,492$ & $-0,509$ & $-0,133$ & $\mathbf{- 0 , 2 6 6}$ & $-0,333$ & $-0,455$ & $-0,493$ & $-0,373$ \\
\hline \hline $\mathbf{2 9}$ & 0,202 & 0,208 & 0,211 & $\mathbf{0 , 1 5 6}$ & 0,177 & 0,198 & 0,167 & 0,177 \\
\hline $\mathbf{3 0}$ & $-0,065$ & $-0,035$ & $-0,029$ & $-\mathbf{0 , 0 0 8}$ & $-0,130$ & $-0,023$ & $-0,005$ & $-0,012$ \\
\hline $\mathbf{3 1}$ & $-0,165$ & $-0,172$ & $-0,174$ & $\mathbf{- 0 , 1 4 2}$ & $-0,109$ & $-0,065$ & $-0,082$ & $-0,086$ \\
\hline $\mathbf{3 2}$ & $-0,217$ & $-0,276$ & $-0,286$ & $\mathbf{- 0 , 2 5 2}$ & $-0,071$ & $-0,035$ & $-0,135$ & $-0,133$ \\
\hline $\mathbf{3 3}$ & $-0,245$ & $-0,352$ & $-0,367$ & $\mathbf{- 0 , 3 3 2}$ & $-0,040$ & $-0,008$ & $-0,172$ & $-0,163$ \\
\hline $\mathbf{3 4}$ & $-0,249$ & $-0,390$ & $-0,409$ & $\mathbf{- 0 , 3 8 0}$ & $-0,012$ & 0,014 & $-0,189$ & $-0,178$ \\
\hline $\mathbf{3 5}$ & $-0,226$ & $-0,375$ & $-0,395$ & $\mathbf{- 0 , 3 8 0}$ & 0,027 & 0,041 & $-0,191$ & $-0,178$ \\
\hline \hline
\end{tabular}


TABELA 5.224: Tensões normais nas fibras superiores extremas das nervuras e vigas, em $\mathrm{kN} / \mathrm{cm}^{2}$, na laje com espaçamento entre os eixos das nervuras $\mathrm{E}=90 \mathrm{~cm}$

\begin{tabular}{|c|c|c|c|c|c|c|c|c|}
\hline \multicolumn{9}{|c|}{$\begin{array}{l}\text { VARIAÇÃO DO ESPAÇAMENTO ENTRE NERVURAS: } \mathrm{E}=90 \mathrm{~cm} \\
\text { TENSÕES NORMAIS - FIBRAS SUPERIORES EXTREMAS - NERVURAS E VIGAS }\left(\mathrm{kN} / \mathrm{cm}^{2}\right)\end{array}$} \\
\hline \multirow{2}{*}{ Ponto } & \multicolumn{8}{|c|}{ Modelos numéricos de análise } \\
\hline & 01 & $\mathbf{0 2}$ & 03 & 04 & $\mathbf{0 5}$ & 06 & 07 & 08 \\
\hline 8 & 1,362 & 0,557 & 0,713 & 0,698 & 0,771 & 0,807 & $-0,023$ & 0,132 \\
\hline 9 & $-0,975$ & $-0,138$ & 0,519 & 0,071 & 0,185 & 0,121 & $-0,509$ & $-0,302$ \\
\hline 10 & $-2,711$ & $-0,554$ & 0,458 & $-0,284$ & $-0,298$ & $-0,418$ & $-0,855$ & $-0,611$ \\
\hline 11 & $-3,943$ & $-0,840$ & 0,411 & $-0,507$ & $-0,625$ & $-0,786$ & $-1,098$ & $-0,820$ \\
\hline 12 & $-4,756$ & $-1,044$ & 0,351 & $-0,684$ & $-0,822$ & $-1,009$ & $-1,254$ & $-0,947$ \\
\hline 13 & $-5,166$ & $-1,171$ & 0,272 & $-0,753$ & $-0,913$ & $-1,112$ & $-1,326$ & $-1,003$ \\
\hline 14 & $-5,234$ & $-1,220$ & 0,207 & $-0,720$ & $-0,928$ & $-1,124$ & $-1,331$ & $-1,007$ \\
\hline 15 & 1,923 & 0,711 & 0,692 & 0,586 & 0,581 & 0,607 & 0,124 & 0,243 \\
\hline 16 & $-0,108$ & 0,058 & 0,446 & 0,076 & 0,096 & 0,031 & $-0,292$ & $-0,177$ \\
\hline 17 & $-1,745$ & $-0,339$ & 0,391 & $-0,218$ & $-0,269$ & $-0,387$ & $-0,626$ & $-0,467$ \\
\hline 18 & $-2,986$ & $-0,653$ & 0,328 & $-0,410$ & $-0,501$ & $-0,654$ & $-0,871$ & $-0,658$ \\
\hline 19 & $-3,805$ & $-0,870$ & 0,258 & $-0,525$ & $-0,636$ & $-0,809$ & $-1,024$ & $-0,773$ \\
\hline 20 & $-4,205$ & $-0,993$ & 0,183 & $-0,579$ & $-0,697$ & $-0,877$ & $-1,092$ & $-0,823$ \\
\hline 21 & $-4,273$ & $-1,042$ & 0,118 & $-0,590$ & $-0,712$ & $-0,890$ & $-1,096$ & $-0,827$ \\
\hline 22 & 2,656 & 1,373 & 0,944 & 0,338 & 0,184 & 0,170 & 0,521 & 0,378 \\
\hline 23 & 0,868 & 0,261 & 0,243 & 0,044 & $-0,046$ & $-0,130$ & 0,043 & 0,022 \\
\hline 24 & $-0,466$ & $-0,196$ & 0,088 & $-0,147$ & $-0,196$ & $-0,295$ & $-0,273$ & $-0,189$ \\
\hline 25 & $-1,302$ & $-0,447$ & $-0,007$ & $-0,244$ & $-0,292$ & $-0,414$ & $-0,471$ & $-0,335$ \\
\hline 26 & $-1,740$ & $-0,556$ & $-0,054$ & $-0,291$ & $-0,352$ & $-0,494$ & $-0,573$ & $-0,419$ \\
\hline 27 & $-1,919$ & $-0,598$ & $-0,080$ & $-0,312$ & $-0,376$ & $-0,528$ & $-0,613$ & $-0,455$ \\
\hline 28 & $-1,986$ & $-0,648$ & $-0,141$ & $-0,324$ & $-0,391$ & $-0,540$ & $-0,615$ & $-0,457$ \\
\hline 29 & 0,202 & 0,206 & 0,209 & 0,153 & 0,179 & 0,204 & 0,168 & 0,178 \\
\hline 30 & $-0,092$ & $-0,062$ & $-0,054$ & $-0,032$ & $-0,171$ & $-0,041$ & $-0,015$ & $-0,023$ \\
\hline 31 & $-0,202$ & $-0,215$ & $-0,218$ & $-0,183$ & $-0,131$ & $-0,074$ & $-0,100$ & $-0,104$ \\
\hline 32 & $-0,259$ & $-0,334$ & $-0,345$ & $-0,303$ & $-0,078$ & $-0,026$ & $-0,159$ & $-0,155$ \\
\hline 33 & $-0,287$ & $-0,419$ & $-0,437$ & $-0,405$ & $-0,036$ & 0,013 & $-0,199$ & $-0,189$ \\
\hline 34 & $-0,290$ & $-0,462$ & $-0,483$ & $-0,450$ & 0,000 & 0,042 & $-0,219$ & $-0,205$ \\
\hline 35 & $-0,262$ & $-0,443$ & $-0,466$ & $-0,451$ & 0,046 & 0,075 & $-0,220$ & $-0,205$ \\
\hline
\end{tabular}




\subsubsection{Tensões Normais nas fibras inferiores extremas das nervuras e vigas}

TABELA 5.225: Tensões normais nas fibras inferiores extremas das nervuras e vigas, em $\mathrm{kN} / \mathrm{cm}^{2}$, na laje com espaçamento entre os eixos das nervuras $\mathrm{E}=40 \mathrm{~cm}$

\begin{tabular}{c|c|c|c|c|c|c|c|c}
\hline \hline \multirow{2}{*}{ TENSÕES NORMAIS - FIBRAS INFERIORES EXTREMAS - NERVURAS E VIGAS (kN/cm $)^{2}$} \\
\hline \multirow{2}{*}{ Ponto } & \multicolumn{7}{c}{ Modelos numéricos de análise } \\
\cline { 2 - 10 } & $\mathbf{0 1}$ & $\mathbf{0 2}$ & $\mathbf{0 3}$ & $\mathbf{0 4}$ & $\mathbf{0 5}$ & $\mathbf{0 6}$ & $\mathbf{0 7}$ & $\mathbf{0 8}$ \\
\hline \hline $\mathbf{8}$ & $-0,062$ & $-0,025$ & $-0,049$ & $\mathbf{- 0 , 0 8 5}$ & $-0,121$ & $-0,125$ & 0,019 & $-0,010$ \\
\hline $\mathbf{9}$ & 0,167 & 0,155 & 0,143 & $\mathbf{0 , 0 5 8}$ & 0,068 & 0,069 & 0,165 & 0,103 \\
\hline $\mathbf{1 0}$ & 0,332 & 0,286 & 0,281 & $\mathbf{0 , 1 8 3}$ & 0,206 & 0,215 & 0,275 & 0,188 \\
\hline $\mathbf{1 1}$ & 0,450 & 0,379 & 0,378 & $\mathbf{0 , 2 7 3}$ & 0,304 & 0,319 & 0,354 & 0,249 \\
\hline $\mathbf{1 2}$ & 0,528 & 0,439 & 0,442 & $\mathbf{0 , 3 2 9}$ & 0,367 & 0,385 & 0,404 & 0,287 \\
\hline $\mathbf{1 3}$ & 0,568 & 0,470 & 0,477 & $\mathbf{0 , 3 5 8}$ & 0,397 & 0,417 & 0,428 & 0,304 \\
\hline $\mathbf{1 4}$ & 0,575 & 0,475 & 0,485 & $\mathbf{0 , 3 6 2}$ & 0,402 & 0,421 & 0,428 & 0,306 \\
\hline \hline $\mathbf{1 5}$ & $-0,122$ & $-0,041$ & $-0,062$ & $\mathbf{- 0 , 1 0 0}$ & $-0,114$ & $-0,118$ & $-0,011$ & $-0,048$ \\
\hline $\mathbf{1 6}$ & 0,070 & 0,098 & 0,087 & $\mathbf{0 , 0 2 3}$ & 0,048 & 0,050 & 0,104 & 0,055 \\
\hline $\mathbf{1 7}$ & 0,224 & 0,215 & 0,208 & $\mathbf{0 , 1 3 7}$ & 0,163 & 0,171 & 0,204 & 0,137 \\
\hline $\mathbf{1 8}$ & 0,345 & 0,305 & 0,302 & $\mathbf{0 , 2 2 2}$ & 0,242 & 0,250 & 0,279 & 0,192 \\
\hline $\mathbf{1 9}$ & 0,425 & 0,364 & 0,365 & $\mathbf{0 , 2 7 4}$ & 0,290 & 0,300 & 0,326 & 0,225 \\
\hline $\mathbf{2 0}$ & 0,465 & 0,392 & 0,397 & $\mathbf{0 , 3 0 3}$ & 0,314 & 0,324 & 0,348 & 0,239 \\
\hline $\mathbf{2 1}$ & 0,471 & 0,442 & 0,405 & $\mathbf{0 , 3 0 7}$ & 0,319 & 0,328 & 0,347 & 0,240 \\
\hline \hline $\mathbf{2 2}$ & $-0,293$ & $-0,216$ & $-0,251$ & $\mathbf{- 0 , 1 9 1}$ & $-0,084$ & $-0,066$ & $-0,214$ & $-0,186$ \\
\hline $\mathbf{2 3}$ & $-0,086$ & $-0,048$ & $-0,065$ & $\mathbf{- 0 , 0 6 9}$ & 0,010 & 0,017 & $-0,032$ & $-0,016$ \\
\hline $\mathbf{2 4}$ & 0,056 & 0,069 & 0,053 & $\mathbf{0 , 0 3 7}$ & 0,061 & 0,055 & 0,068 & 0,040 \\
\hline $\mathbf{2 5}$ & 0,140 & 0,145 & 0,139 & $\mathbf{0 , 1 0 2}$ & 0,098 & 0,089 & 0,118 & 0,065 \\
\hline $\mathbf{2 6}$ & 0,179 & 0,179 & 0,177 & $\mathbf{0 , 1 3 6}$ & 0,121 & 0,112 & 0,138 & 0,075 \\
\hline $\mathbf{2 7}$ & 0,194 & 0,194 & 0,193 & $\mathbf{0 , 1 5 4}$ & 0,133 & 0,125 & 0,145 & 0,078 \\
\hline $\mathbf{2 8}$ & 0,200 & 0,199 & 0,201 & $\mathbf{0 , 1 5 7}$ & 0,138 & 0,129 & 0,144 & 0,078 \\
\hline \hline $\mathbf{2 9}$ & $-0,142$ & $-0,165$ & $-0,169$ & $\mathbf{- 0 , 1 3 6}$ & $-0,123$ & $-0,131$ & $-0,137$ & $-0,149$ \\
\hline $\mathbf{3 0}$ & $-0,021$ & $-0,030$ & $-0,032$ & $\mathbf{- 0 , 0 3 3}$ & $-0,012$ & $-0,016$ & $-0,012$ & $-0,012$ \\
\hline $\mathbf{3 1}$ & 0,112 & 0,078 & 0,074 & $\mathbf{0 , 0 6 2}$ & 0,135 & 0,121 & 0,083 & 0,097 \\
\hline $\mathbf{3 2}$ & 0,170 & 0,148 & 0,147 & $\mathbf{0 , 1 3 3}$ & 0,183 & 0,177 & 0,145 & 0,166 \\
\hline $\mathbf{3 3}$ & 0,206 & 0,196 & 0,196 & $\mathbf{0 , 1 8 3}$ & 0,211 & 0,210 & 0,187 & 0,211 \\
\hline $\mathbf{3 4}$ & 0,220 & 0,219 & 0,221 & $\mathbf{0 , 2 0 8}$ & 0,218 & 0,222 & 0,207 & 0,233 \\
\hline $\mathbf{3 5}$ & 0,214 & 0,217 & 0,219 & $\mathbf{0 , 2 1 0}$ & 0,209 & 0,214 & 0,209 & 0,234 \\
\hline \hline
\end{tabular}


TABELA 5.226: Tensões normais nas fibras inferiores extremas das nervuras e vigas, em $\mathrm{kN} / \mathrm{cm}^{2}$, na laje com espaçamento entre os eixos das nervuras $\mathrm{E}=50 \mathrm{~cm}$

VARIAÇÃO DO ESPAÇAMENTO ENTRE NERVURAS: E $=50 \mathrm{~cm}$

TENSÕES NORMAIS - FIBRAS INFERIORES EXTREMAS - NERVURAS E VIGAS $\left(\mathrm{kN} / \mathrm{cm}^{2}\right)$

\begin{tabular}{c|c|c|c|c|c|c|c|c}
\hline \multirow{2}{*}{ Ponto } & \multicolumn{7}{|c|}{ Modelos numéricos de análise } \\
\cline { 2 - 9 } & $\mathbf{0 1}$ & $\mathbf{0 2}$ & $\mathbf{0 3}$ & $\mathbf{0 4}$ & $\mathbf{0 5}$ & $\mathbf{0 6}$ & $\mathbf{0 7}$ & $\mathbf{0 8}$ \\
\hline \hline $\mathbf{8}$ & $-0,159$ & $-0,062$ & $-0,104$ & $\mathbf{- 0 , 2 2 3}$ & $-0,321$ & $-0,328$ & 0,030 & $-0,036$ \\
\hline $\mathbf{9}$ & 0,284 & 0,290 & 0,268 & $\mathbf{0 , 0 6 8}$ & 0,054 & 0,060 & 0,310 & 0,185 \\
\hline $\mathbf{1 0}$ & 0,600 & 0,539 & 0,538 & $\mathbf{0 , 3 2 3}$ & 0,323 & 0,345 & 0,516 & 0,346 \\
\hline $\mathbf{1 1}$ & 0,824 & 0,714 & 0,711 & $\mathbf{0 , 5 0 0}$ & 0,511 & 0,545 & 0,662 & 0,459 \\
\hline $\mathbf{1 2}$ & 0,973 & 0,829 & 0,833 & $\mathbf{0 , 6 1 2}$ & 0,563 & 0,671 & 0,755 & 0,529 \\
\hline $\mathbf{1 3}$ & 1,049 & 0,887 & 0,898 & $\mathbf{0 , 6 6 8}$ & 0,686 & 0,731 & 0,799 & 0,561 \\
\hline $\mathbf{1 4}$ & 1,062 & 0,898 & 0,914 & $\mathbf{0 , 6 7 6}$ & 0,695 & 0,740 & 0,802 & 0,563 \\
\hline $\mathbf{1 5}$ & $-0,277$ & $-0,107$ & $-0,149$ & $\mathbf{- 0 , 2 2 7}$ & $-0,277$ & $-0,278$ & $-0,038$ & $-0,111$ \\
\hline $\mathbf{1 6}$ & 0,094 & 0,161 & 0,138 & $\mathbf{0 , 0 1 7}$ & 0,036 & 0,042 & 0,182 & 0,092 \\
\hline $\mathbf{1 7}$ & 0,390 & 0,382 & 0,369 & $\mathbf{0 , 2 3 6}$ & 0,251 & 0,267 & 0,370 & 0,246 \\
\hline $\mathbf{1 8}$ & 0,620 & 0,556 & 0,551 & $\mathbf{0 , 3 9 3}$ & 0,394 & 0,415 & 0,510 & 0,348 \\
\hline $\mathbf{1 9}$ & 0,775 & 0,671 & 0,672 & $\mathbf{0 , 4 9 3}$ & 0,482 & 0,505 & 0,598 & 0,407 \\
\hline $\mathbf{2 0}$ & 0,850 & 0,727 & 0,733 & $\mathbf{0 , 5 4 0}$ & 0,524 & 0,549 & 0,637 & 0,433 \\
\hline $\mathbf{2 1}$ & 0,863 & 0,738 & 0,749 & $\mathbf{0 , 5 4 8}$ & 0,533 & 0,556 & 0,639 & 0,435 \\
\hline \hline $\mathbf{2 2}$ & $-0,573$ & $-0,458$ & $-0,525$ & $-\mathbf{0 , 3 1 8}$ & $-0,147$ & $-0,121$ & $-0,400$ & $-0,336$ \\
\hline $\mathbf{2 3}$ & 0,117 & $-0,119$ & $-0,147$ & $\mathbf{0 , 1 1 2}$ & 0,005 & 0,014 & $-0,074$ & $-0,047$ \\
\hline $\mathbf{2 4}$ & 0,084 & 0,116 & 0,096 & $\mathbf{0 , 0 5 0}$ & 0,085 & 0,076 & 0,104 & 0,055 \\
\hline $\mathbf{2 5}$ & 0,238 & 0,243 & 0,234 & $\mathbf{0 , 1 5 0}$ & 0,138 & 0,123 & 0,193 & 0,104 \\
\hline $\mathbf{2 6}$ & 0,309 & 0,296 & 0,294 & $\mathbf{0 , 2 0 3}$ & 0,170 & 0,155 & 0,227 & 0,125 \\
\hline $\mathbf{2 7}$ & 0,335 & 0,316 & 0,316 & $\mathbf{0 , 2 2 4}$ & 0,188 & 0,172 & 0,238 & 0,131 \\
\hline $\mathbf{2 8}$ & 0,347 & 0,326 & 0,331 & $\mathbf{0 , 2 2 9}$ & 0,197 & 0,180 & 0,239 & 0,132 \\
\hline \hline $\mathbf{2 9}$ & $-0,136$ & $-0,165$ & $-0,170$ & $\mathbf{- 0 , 1 3 9}$ & $-0,106$ & $-0,115$ & $-0,134$ & $-0,143$ \\
\hline $\mathbf{3 0}$ & 0,007 & $-0,003$ & $-0,004$ & $\mathbf{- 0 , 0 0 8}$ & 0,021 & 0,020 & 0,014 & 0,020 \\
\hline $\mathbf{3 1}$ & 0,185 & 0,135 & 0,131 & $\mathbf{0 , 1 1 0}$ & 0,221 & 0,198 & 0,134 & 0,156 \\
\hline $\mathbf{3 2}$ & 0,254 & 0,221 & 0,219 & $\mathbf{0 , 2 0 2}$ & 0,272 & 0,259 & 0,212 & 0,240 \\
\hline $\mathbf{3 3}$ & 0,295 & 0,280 & 0,281 & $\mathbf{0 , 2 6 8}$ & 0,300 & 0,294 & 0,265 & 0,297 \\
\hline $\mathbf{3 4}$ & 0,307 & 0,309 & 0,311 & $\mathbf{0 , 3 0 1}$ & 0,303 & 0,304 & 0,290 & 0,324 \\
\hline $\mathbf{3 5}$ & 0,296 & 0,305 & 0,308 & $\mathbf{0 , 3 0 3}$ & 0,287 & 0,292 & 0,292 & 0,326 \\
\hline \hline
\end{tabular}


TABELA 5.227: Tensões normais nas fibras inferiores extremas das nervuras e vigas, em $\mathrm{kN} / \mathrm{cm}^{2}$, na laje com espaçamento entre os eixos das nervuras $\mathrm{E}=60 \mathrm{~cm}$

VARIAÇÃO DO ESPAÇAMENTO ENTRE NERVURAS: E $=60 \mathrm{~cm}$

TENSÕES NORMAIS - FIBRAS INFERIORES EXTREMAS - NERVURAS E VIGAS (kN/cm²)

\begin{tabular}{c|c|c|c|c|c|c|c|c}
\hline \multirow{2}{*}{ Ponto } & \multicolumn{7}{|c|}{ Modelos numéricos de análise } \\
\cline { 2 - 9 } & $\mathbf{0 1}$ & $\mathbf{0 2}$ & $\mathbf{0 3}$ & $\mathbf{0 4}$ & $\mathbf{0 5}$ & $\mathbf{0 6}$ & $\mathbf{0 7}$ & $\mathbf{0 8}$ \\
\hline $\mathbf{8}$ & $-0,328$ & $-0,128$ & $-0,196$ & $\mathbf{- 0 , 4 5 6}$ & $-0,672$ & $-0,692$ & 0,042 & $-0,085$ \\
\hline $\mathbf{9}$ & 0,425 & 0,472 & 0,435 & $\mathbf{0 , 0 6 5}$ & $-0,023$ & $-0,014$ & 0,515 & 0,294 \\
\hline $\mathbf{1 0}$ & 0,960 & 0,894 & 0,873 & $\mathbf{0 , 5 0 9}$ & 0,440 & 0,479 & 0,860 & 0,569 \\
\hline $\mathbf{1 1}$ & 1,339 & 1,188 & 1,182 & $\mathbf{0 , 8 1 1}$ & 0,761 & 0,823 & 1,104 & 0,760 \\
\hline $\mathbf{1 2}$ & 1,590 & 1,382 & 1,388 & $\mathbf{1 , 0 0 3}$ & 0,960 & 1,038 & 1,260 & 0,877 \\
\hline $\mathbf{1 3}$ & 1,719 & 1,481 & 1,499 & $\mathbf{1 , 0 9 6}$ & 1,055 & 1,140 & 1,333 & 0,930 \\
\hline $\mathbf{1 4}$ & 1,740 & 1,500 & 1,526 & $\mathbf{1 , 1 0 9}$ & 1,071 & 1,153 & 1,338 & 0,933 \\
\hline $\mathbf{1 5}$ & $-0,531$ & $-0,227$ & $-0,300$ & $\mathbf{- 0 , 4 3 1}$ & $-0,547$ & $-0,566$ & $-0,091$ & $-0,219$ \\
\hline $\mathbf{1 6}$ & 0,108 & 0,235 & 0,196 & $\mathbf{- 0 , 0 0 6}$ & $-0,015$ & $-0,006$ & 0,287 & 0,137 \\
\hline $\mathbf{1 7}$ & 0,610 & 0,504 & 0,589 & $\mathbf{0 , 3 6 4}$ & 0,343 & 0,372 & 0,605 & 0,398 \\
\hline $\mathbf{1 8}$ & 1,000 & 0,910 & 0,899 & $\mathbf{0 , 6 2 3}$ & 0,577 & 0,616 & 0,841 & 0,569 \\
\hline $\mathbf{1 9}$ & 1,259 & 1,107 & 1,107 & $\mathbf{0 , 7 8 5}$ & 0,718 & 0,762 & 0,987 & 0,669 \\
\hline $\mathbf{2 0}$ & 1,386 & 1,203 & 1,213 & $\mathbf{0 , 8 6 2}$ & 0,785 & 0,832 & 1,052 & 0,713 \\
\hline $\mathbf{2 1}$ & 1,408 & 1,222 & 1,240 & $\mathbf{0 , 8 7 5}$ & 0,801 & 0,845 & 1,057 & 0,716 \\
\hline $\mathbf{2 2}$ & $-0,968$ & $-0,806$ & $-0,914$ & $\mathbf{- 0 , 4 9 4}$ & $-0,233$ & $-0,201$ & $-0,672$ & $-0,549$ \\
\hline $\mathbf{2 3}$ & $-0,327$ & $-0,224$ & $-0,268$ & $\mathbf{- 0 , 1 7 7}$ & $-0,007$ & 0,002 & $-0,143$ & $-0,096$ \\
\hline $\mathbf{2 4}$ & 0,117 & 0,167 & 0,136 & $\mathbf{0 , 0 6 8}$ & 0,110 & 0,097 & 0,150 & 0,073 \\
\hline $\mathbf{2 5}$ & 0,372 & 0,377 & 0,363 & $\mathbf{0 , 2 1 3}$ & 0,181 & 0,160 & 0,299 & 0,159 \\
\hline $\mathbf{2 6}$ & 0,490 & 0,463 & 0,460 & $\mathbf{0 , 2 8 5}$ & 0,225 & 0,202 & 0,357 & 0,198 \\
\hline $\mathbf{2 7}$ & 0,535 & 0,491 & 0,493 & $\mathbf{0 , 3 2 0}$ & 0,249 & 0,226 & 0,375 & 0,210 \\
\hline $\mathbf{2 8}$ & 0,555 & 0,509 & 0,518 & $\mathbf{0 , 3 2 8}$ & 0,265 & 0,239 & 0,377 & 0,211 \\
\hline \hline $\mathbf{2 9}$ & $-0,122$ & $-0,155$ & $-0,160$ & $-\mathbf{0 , 1 2 8}$ & $-0,081$ & $-0,089$ & $-0,123$ & $-0,129$ \\
\hline $\mathbf{3 0}$ & 0,135 & 0,064 & 0,054 & $\mathbf{0 , 0 2 7}$ & 0,213 & 0,143 & 0,068 & 0,082 \\
\hline $\mathbf{3 1}$ & 0,268 & 0,203 & 0,196 & $\mathbf{0 , 1 6 9}$ & 0,316 & 0,284 & 0,192 & 0,220 \\
\hline $\mathbf{3 2}$ & 0,347 & 0,304 & 0,301 & $\mathbf{0 , 2 8 2}$ & 0,369 & 0,347 & 0,284 & 0,320 \\
\hline $\mathbf{3 3}$ & 0,391 & 0,373 & 0,374 & $\mathbf{0 , 3 6 0}$ & 0,395 & 0,381 & 0,347 & 0,387 \\
\hline $\mathbf{3 4}$ & 0,401 & 0,406 & 0,409 & $\mathbf{0 , 3 9 7}$ & 0,392 & 0,388 & 0,378 & 0,419 \\
\hline $\mathbf{3 5}$ & 0,386 & 0,400 & 0,404 & $\mathbf{0 , 3 9 9}$ & 0,369 & 0,371 & 0,380 & 0,421 \\
\hline \hline
\end{tabular}


TABELA 5.228: Tensões normais nas fibras inferiores extremas das nervuras e vigas, em $\mathrm{kN} / \mathrm{cm}^{2}$, na laje com espaçamento entre os eixos das nervuras $\mathrm{E}=70 \mathrm{~cm}$

VARIAÇÃO DO ESPAÇAMENTO ENTRE NERVURAS: $\mathrm{E}=70 \mathrm{~cm}$

TENSÕES NORMAIS - FIBRAS INFERIORES EXTREMAS - NERVURAS E VIGAS $\left(\mathrm{kN} / \mathrm{cm}^{2}\right)$

\begin{tabular}{c|c|c|c|c|c|c|c|c}
\hline \multirow{2}{*}{ Ponto } & \multicolumn{7}{|c}{ Modelos numéricos de análise } \\
\cline { 2 - 8 } & $\mathbf{0 1}$ & $\mathbf{0 2}$ & $\mathbf{0 3}$ & $\mathbf{0 4}$ & $\mathbf{0 5}$ & $\mathbf{0 6}$ & $\mathbf{0 7}$ & $\mathbf{0 8}$ \\
\hline $\mathbf{8}$ & $-0,585$ & $-0,231$ & $-0,333$ & $\mathbf{- 0 , 8 1 5}$ & $-1,205$ & $-1,259$ & 0,053 & $-0,167$ \\
\hline $\mathbf{9}$ & 0,586 & 0,716 & 0,231 & $\mathbf{0 , 0 2 2}$ & $-0,179$ & $-0,177$ & 0,787 & 0,431 \\
\hline $\mathbf{1 0}$ & 1,418 & 1,360 & 1,327 & $\mathbf{0 , 7 4 4}$ & 0,552 & 0,607 & 1,322 & 0,865 \\
\hline $\mathbf{1 1}$ & 2,009 & 1,818 & 1,806 & $\mathbf{1 , 2 4 0}$ & 1,056 & 1,151 & 1,701 & 1,164 \\
\hline $\mathbf{1 2}$ & 2,400 & 2,121 & 2,129 & $\mathbf{1 , 5 5 1}$ & 1,366 & 1,488 & 1,943 & 1,346 \\
\hline $\mathbf{1 3}$ & 2,600 & 2,277 & 2,303 & $\mathbf{1 , 6 7 9}$ & 1,512 & 1,647 & 2,056 & 1,428 \\
\hline $\mathbf{1 4}$ & 2,633 & 2,307 & 2,346 & $\mathbf{1 , 7 0 6}$ & 1,537 & 1,667 & 2,064 & 1,434 \\
\hline $\mathbf{1 5}$ & $-0,902$ & $-0,418$ & $-0,129$ & $\mathbf{- 0 , 7 4 2}$ & $-0,945$ & $-0,990$ & $-0,297$ & $-0,383$ \\
\hline $\mathbf{1 6}$ & 0,106 & 0,319 & 0,257 & $\mathbf{- 0 , 0 6 1}$ & $-0,117$ & $-0,110$ & 0,418 & 0,190 \\
\hline $\mathbf{1 7}$ & 0,890 & 0,911 & 0,874 & $\mathbf{0 , 5 1 7}$ & 0,436 & 0,476 & 0,917 & 0,600 \\
\hline $\mathbf{1 8}$ & 1,493 & 1,378 & 1,360 & $\mathbf{0 , 9 1 7}$ & 0,792 & 0,850 & 1,285 & 0,866 \\
\hline $\mathbf{1 9}$ & 1,894 & 1,689 & 1,688 & $\mathbf{1 , 1 6 4}$ & 1,002 & 1,071 & 1,514 & 1,023 \\
\hline $\mathbf{2 0}$ & 2,090 & 1,840 & 1,856 & $\mathbf{1 , 2 9 0}$ & 1,100 & 1,176 & 1,616 & 1,090 \\
\hline $\mathbf{2 1}$ & 2,124 & 1,870 & 1,898 & $\mathbf{1 , 3 0 9}$ & 1,125 & 1,196 & 1,623 & 1,095 \\
\hline $\mathbf{2 2}$ & $-1,488$ & $-1,272$ & $-1,428$ & $\mathbf{- 0 , 7 3 1}$ & $-0,348$ & $-0,314$ & $-1,042$ & $-0,834$ \\
\hline $\mathbf{2 3}$ & $-0,515$ & $-0,371$ & $-0,434$ & $-\mathbf{0 , 2 7 9}$ & $-0,026$ & $-0,021$ & $-0,241$ & $-0,165$ \\
\hline $\mathbf{2 4}$ & 0,155 & 0,227 & 0,180 & $\mathbf{0 , 0 8 9}$ & 0,134 & 0,117 & 0,206 & 0,093 \\
\hline $\mathbf{2 5}$ & 0,544 & 0,552 & 0,531 & $\mathbf{0 , 2 9 0}$ & 0,227 & 0,200 & 0,440 & 0,233 \\
\hline $\mathbf{2 6}$ & 0,730 & 0,686 & 0,682 & $\mathbf{0 , 3 9 6}$ & 0,286 & 0,255 & 0,536 & 0,297 \\
\hline $\mathbf{2 7}$ & 0,802 & 0,730 & 0,734 & $\mathbf{0 , 4 3 6}$ & 0,318 & 0,287 & 0,566 & 0,320 \\
\hline $\mathbf{2 8}$ & 0,832 & 0,757 & 0,771 & $\mathbf{0 , 4 4 9}$ & 0,343 & 0,307 & 0,568 & 0,322 \\
\hline \hline $\mathbf{2 9}$ & $-0,102$ & $-0,140$ & $-0,145$ & $-\mathbf{0 , 1 1 1}$ & $-0,051$ & $-0,059$ & $-0,109$ & $-0,111$ \\
\hline $\mathbf{3 0}$ & 0,200 & 0,116 & 0,104 & $\mathbf{0 , 0 6 8}$ & 0,309 & 0,216 & 0,109 & 0,128 \\
\hline $\mathbf{3 1}$ & 0,355 & 0,276 & 0,268 & $\mathbf{0 , 2 3 4}$ & 0,416 & 0,372 & 0,251 & 0,286 \\
\hline $\mathbf{3 2}$ & 0,445 & 0,393 & 0,389 & $\mathbf{0 , 3 6 7}$ & 0,470 & 0,436 & 0,358 & 0,402 \\
\hline $\mathbf{3 3}$ & 0,492 & 0,472 & 0,473 & $\mathbf{0 , 4 5 9}$ & 0,493 & 0,469 & 0,431 & 0,480 \\
\hline $\mathbf{3 4}$ & 0,500 & 0,509 & 0,513 & $\mathbf{0 , 5 0 3}$ & 0,483 & 0,472 & 0,466 & 0,516 \\
\hline $\mathbf{3 5}$ & 0,479 & 0,501 & 0,506 & $\mathbf{0 , 5 1 3}$ & 0,452 & 0,450 & 0,469 & 0,519 \\
\hline \hline
\end{tabular}


TABELA 5.229: Tensões normais nas fibras inferiores extremas das nervuras e vigas, em $\mathrm{kN} / \mathrm{cm}^{2}$, na laje com espaçamento entre os eixos das nervuras $\mathrm{E}=80 \mathrm{~cm}$

\begin{tabular}{c|c|c|c|c|c|c|c|c}
\hline \hline \multirow{2}{*}{ TENSÕES NORMAIS - FIBRAS INFERIORES EXTREMAS - NERVURAS E VIGAS $\left(\mathbf{k N} / \mathbf{c m}^{\mathbf{2}}\right)$} \\
\hline \multirow{2}{*}{ Ponto } & \multicolumn{7}{c}{ Modelos numéricos de análise } \\
\cline { 2 - 10 } & $\mathbf{0 1}$ & $\mathbf{0 2}$ & $\mathbf{0 3}$ & $\mathbf{0 4}$ & $\mathbf{0 5}$ & $\mathbf{0 6}$ & $\mathbf{0 7}$ & $\mathbf{0 8}$ \\
\hline \hline $\mathbf{8}$ & $-0,951$ & $-0,383$ & $-0,528$ & $\mathbf{- 1 , 3 2 1}$ & $-1,946$ & $-2,063$ & 0,058 & $-0,295$ \\
\hline $\mathbf{9}$ & 0,761 & 0,986 & 0,899 & $\mathbf{- 0 , 0 6 0}$ & $-0,427$ & $-0,447$ & 1,133 & 0,596 \\
\hline $\mathbf{1 0}$ & 1,981 & 1,947 & 1,897 & $\mathbf{1 , 0 0 1}$ & 0,657 & 0,725 & 1,916 & 1,242 \\
\hline $\mathbf{1 1}$ & 2,847 & 2,620 & 2,601 & $\mathbf{1 , 7 2 6}$ & 1,400 & 1,533 & 2,470 & 1,683 \\
\hline $\mathbf{1 2}$ & 3,421 & 3,066 & 3,076 & $\mathbf{2 , 1 7 8}$ & 1,854 & 2,029 & 2,826 & 1,952 \\
\hline $\mathbf{1 3}$ & 3,712 & 3,297 & 3,333 & $\mathbf{2 , 4 1 2}$ & 2,067 & 2,263 & 3,095 & 2,073 \\
\hline $\mathbf{1 4}$ & 3,761 & 3,341 & 3,396 & $\mathbf{2 , 4 4 3}$ & 2,103 & 2,293 & 3,004 & 2,081 \\
\hline \hline $\mathbf{1 5}$ & $-1,413$ & $-0,693$ & $-0,859$ & $\mathbf{- 1 , 1 5 5}$ & $-1,490$ & $-1,580$ & $-0,317$ & $-0,616$ \\
\hline $\mathbf{1 6}$ & 0,081 & 0,396 & 0,316 & $\mathbf{- 0 , 1 4 8}$ & $-0,276$ & $-0,282$ & 0,578 & 0,249 \\
\hline $\mathbf{1 7}$ & 1,233 & 1,285 & 1,228 & $\mathbf{0 , 7 0 2}$ & 0,529 & 0,579 & 1,316 & 0,856 \\
\hline $\mathbf{1 8}$ & 2,111 & 1,973 & 1,944 & $\mathbf{1 , 2 8 6}$ & 1,040 & 1,121 & 1,858 & 1,249 \\
\hline $\mathbf{1 9}$ & 2,693 & 2,432 & 2,429 & $\mathbf{1 , 6 4 9}$ & 1,339 & 1,438 & 2,196 & 1,479 \\
\hline $\mathbf{2 0}$ & 2,978 & 2,656 & 2,679 & $\mathbf{1 , 8 2 8}$ & 1,478 & 1,587 & 2,346 & 1,579 \\
\hline $\mathbf{2 1}$ & 3,026 & 2,701 & 2,742 & $\mathbf{1 , 8 5 5}$ & 1,514 & 1,617 & 2,357 & 1,586 \\
\hline \hline $\mathbf{2 2}$ & $-2,145$ & $-1,867$ & $-2,081$ & $\mathbf{- 1 , 0 2 6}$ & $-0,496$ & $-0,465$ & $-1,523$ & $-1,198$ \\
\hline $\mathbf{2 3}$ & $-0,753$ & $-0,563$ & $-0,655$ & $\mathbf{- 0 , 3 8 8}$ & $-0,055$ & $-0,056$ & $-0,374$ & $-0,256$ \\
\hline $\mathbf{2 4}$ & 0,199 & 0,294 & 0,226 & $\mathbf{0 , 1 1 6}$ & 0,159 & 0,137 & 0,273 & 0,117 \\
\hline $\mathbf{2 5}$ & 0,760 & 0,770 & 0,739 & $\mathbf{0 , 3 9 0}$ & 0,280 & 0,244 & 0,623 & 0,326 \\
\hline $\mathbf{2 6}$ & 1,034 & 0,972 & 0,967 & $\mathbf{0 , 5 2 7}$ & 0,356 & 0,315 & 0,770 & 0,427 \\
\hline $\mathbf{2 7}$ & 1,142 & 1,039 & 1,045 & $\mathbf{0 , 5 8 0}$ & 0,397 & 0,356 & 0,817 & 0,464 \\
\hline $\mathbf{2 8}$ & 1,186 & 1,080 & 1,101 & $\mathbf{0 , 5 9 8}$ & 0,432 & 0,386 & 0,820 & 0,467 \\
\hline \hline $\mathbf{2 9}$ & $-0,080$ & $-0,122$ & $-0,127$ & $\mathbf{- 0 , 0 8 9}$ & $-0,020$ & $-0,029$ & $-0,093$ & $-0,092$ \\
\hline $\mathbf{3 0}$ & 0,266 & 0,171 & 0,156 & $\mathbf{0 , 1 1 4}$ & 0,407 & 0,290 & 0,152 & 0,175 \\
\hline $\mathbf{3 1}$ & 0,443 & 0,354 & 0,344 & $\mathbf{0 , 3 0 5}$ & 0,516 & 0,460 & 0,313 & 0,353 \\
\hline $\mathbf{3 2}$ & 0,545 & 0,486 & 0,482 & $\mathbf{0 , 4 5 7}$ & 0,570 & 0,525 & 0,433 & 0,485 \\
\hline $\mathbf{3 3}$ & 0,595 & 0,576 & 0,576 & $\mathbf{0 , 5 6 3}$ & 0,591 & 0,557 & 0,516 & 0,573 \\
\hline $\mathbf{3 4}$ & 0,600 & 0,616 & 0,621 & $\mathbf{0 , 6 1 2}$ & 0,573 & 0,555 & 0,556 & 0,614 \\
\hline $\mathbf{3 5}$ & 0,575 & 0,605 & 0,611 & $\mathbf{0 , 6 1 4}$ & 0,535 & 0,528 & 0,559 & 0,617 \\
\hline \hline
\end{tabular}


TABELA 5.230: Tensões normais nas fibras inferiores extremas das nervuras e vigas, em $\mathrm{kN} / \mathrm{cm}^{2}$, na laje com espaçamento entre os eixos das nervuras $\mathrm{E}=90 \mathrm{~cm}$

\begin{tabular}{c|c|c|c|c|c|c|c|c}
\hline \hline \multirow{2}{*}{ TENSÕES NORMAIS - FIBRAS INFERIORES EXTREMAS - NERVURAS E VIGAS $\left(\mathbf{k N / \mathbf { c m } ^ { 2 }}\right)$} \\
\hline \multirow{2}{*}{ Ponto } & \multicolumn{7}{c}{ Modelos numéricos de análise } \\
\cline { 2 - 10 } & $\mathbf{0 1}$ & $\mathbf{0 2}$ & $\mathbf{0 3}$ & $\mathbf{0 4}$ & $\mathbf{0 5}$ & $\mathbf{0 6}$ & $\mathbf{0 7}$ & $\mathbf{0 8}$ \\
\hline \hline $\mathbf{8}$ & $-1,443$ & $-0,593$ & $-0,790$ & $\mathbf{- 1 , 9 8 8}$ & $-2,917$ & $-3,133$ & 0,055 & $-0,479$ \\
\hline $\mathbf{9}$ & 0,947 & 1,320 & 1,196 & $\mathbf{- 0 , 2 0 4}$ & $-0,776$ & $-0,836$ & 1,558 & 0,788 \\
\hline $\mathbf{1 0}$ & 2,653 & 2,665 & 2,592 & $\mathbf{1 , 3 3 6}$ & 0,755 & 0,829 & 2,654 & 1,704 \\
\hline $\mathbf{1 1}$ & 3,865 & 3,609 & 3,580 & $\mathbf{2 , 3 8 8}$ & 1,799 & 1,973 & 3,432 & 2,329 \\
\hline $\mathbf{1 2}$ & 4,666 & 4,237 & 4,248 & $\mathbf{3 , 0 0 3}$ & 2,434 & 2,673 & 3,932 & 2,709 \\
\hline $\mathbf{1 3}$ & 5,072 & 4,562 & 4,611 & $\mathbf{3 , 3 1 3}$ & 2,731 & 3,002 & 4,164 & 2,879 \\
\hline $\mathbf{1 4}$ & 5,140 & 4,625 & 4,699 & $\mathbf{3 , 4 0 2}$ & 2,782 & 3,044 & 4,181 & 2,891 \\
\hline \hline $\mathbf{1 5}$ & $-2,080$ & $-1,068$ & $-1,298$ & $\mathbf{- 1 , 7 0 6}$ & $-2,197$ & $-2,357$ & $-0,511$ & $-0,931$ \\
\hline $\mathbf{1 6}$ & 0,028 & 0,502 & 0,370 & $\mathbf{- 0 , 2 8 5}$ & $-0,499$ & $-0,530$ & 0,766 & 0,311 \\
\hline $\mathbf{1 7}$ & 1,642 & 1,739 & 1,656 & $\mathbf{0 , 9 2 1}$ & 0,622 & 0,678 & 1,809 & 1,171 \\
\hline $\mathbf{1 8}$ & 2,862 & 2,706 & 2,663 & $\mathbf{1 , 7 4 5}$ & 1,328 & 1,434 & 2,573 & 1,725 \\
\hline $\mathbf{1 9}$ & 3,668 & 3,352 & 3,347 & $\mathbf{2 , 2 5 0}$ & 1,736 & 1,872 & 3,050 & 2,049 \\
\hline $\mathbf{2 0}$ & 4,061 & 3,670 & 3,702 & $\mathbf{2 , 4 8 7}$ & 1,924 & 2,075 & 3,263 & 2,191 \\
\hline $\mathbf{2 1}$ & 4,129 & 3,733 & 3,790 & $\mathbf{2 , 5 2 6}$ & 1,975 & 2,117 & 3,277 & 2,200 \\
\hline \hline $\mathbf{2 2}$ & $-2,949$ & $-2,604$ & $-2,886$ & $\mathbf{- 1 , 3 9 3}$ & $-0,680$ & $-0,659$ & $-2,124$ & $-1,647$ \\
\hline $\mathbf{2 3}$ & $-1,043$ & $-0,799$ & $-0,936$ & $\mathbf{- 0 , 5 2 4}$ & $-0,093$ & $-0,104$ & $-0,544$ & $-0,370$ \\
\hline $\mathbf{2 4}$ & 0,249 & 0,368 & 0,272 & $\mathbf{0 , 1 4 7}$ & 0,185 & 0,156 & 0,352 & 0,146 \\
\hline $\mathbf{2 5}$ & 1,020 & 1,035 & 0,991 & $\mathbf{0 , 5 1 0}$ & 0,339 & 0,295 & 0,849 & 0,442 \\
\hline $\mathbf{2 6}$ & 1,407 & 1,327 & 1,319 & $\mathbf{0 , 6 9 2}$ & 0,435 & 0,386 & 1,066 & 0,590 \\
\hline $\mathbf{2 7}$ & 1,560 & 1,426 & 1,436 & $\mathbf{0 , 7 6 7}$ & 0,487 & 0,438 & 1,137 & 0,645 \\
\hline $\mathbf{2 8}$ & 1,622 & 1,485 & 1,515 & $\mathbf{0 , 7 9 4}$ & 0,536 & 0,479 & 1,142 & 0,649 \\
\hline $\mathbf{2 9}$ & $-0,058$ & $-0,102$ & $-0,107$ & $\mathbf{- 0 , 0 6 7}$ & 0,010 & 0,001 & $-0,077$ & $-0,072$ \\
\hline $\mathbf{3 0}$ & 0,331 & 0,228 & 0,211 & $\mathbf{0 , 1 6 2}$ & 0,504 & 0,363 & 0,195 & 0,223 \\
\hline $\mathbf{3 1}$ & 0,531 & 0,434 & 0,422 & $\mathbf{0 , 3 7 1}$ & 0,616 & 0,546 & 0,374 & 0,421 \\
\hline $\mathbf{3 2}$ & 0,644 & 0,583 & 0,577 & $\mathbf{0 , 5 4 8}$ & 0,671 & 0,612 & 0,509 & 0,568 \\
\hline $\mathbf{3 3}$ & 0,699 & 0,682 & 0,682 & $\mathbf{0 , 6 5 8}$ & 0,688 & 0,643 & 0,602 & 0,666 \\
\hline $\mathbf{3 4}$ & 0,702 & 0,726 & 0,731 & $\mathbf{0 , 7 2 4}$ & 0,664 & 0,636 & 0,646 & 0,712 \\
\hline $\mathbf{3 5}$ & 0,672 & 0,711 & 0,719 & $\mathbf{0 , 7 2 7}$ & 0,617 & 0,604 & 0,649 & 0,715 \\
\hline \hline
\end{tabular}

Abaixo tem-se os gráficos de tensões normais atuantes nas fibras inferiores extremas para a nervura central das lajes processadas nesta série. 


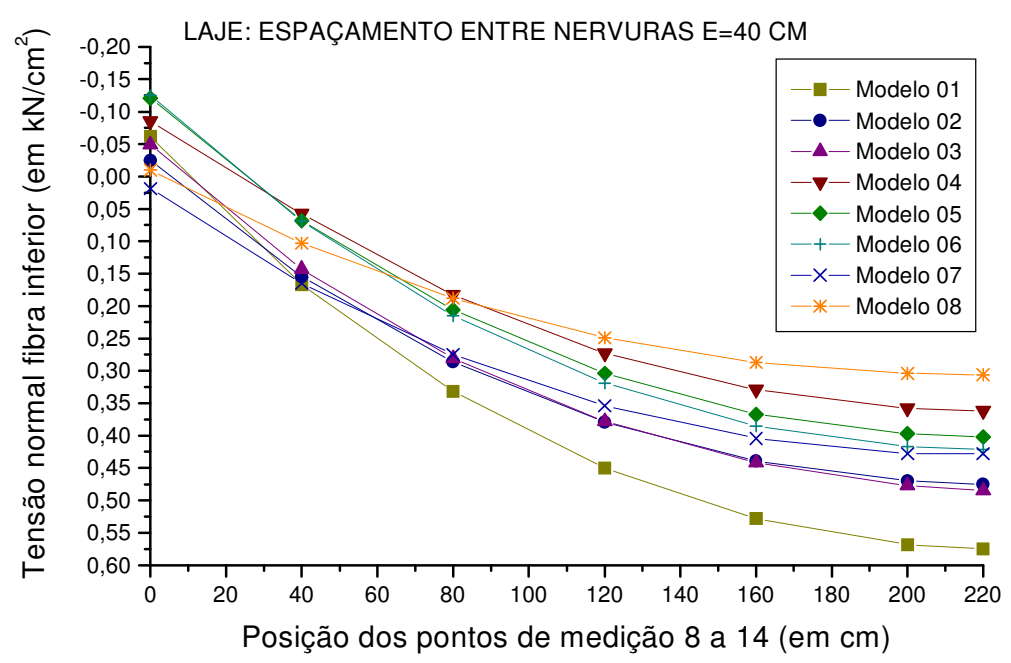

FIGURA 5.160: Tensões Normais fibras inferiores extremas $\left(\mathrm{kN} / \mathrm{cm}^{2}\right)$, nervura central, laje $\mathrm{E}=40 \mathrm{~cm}$

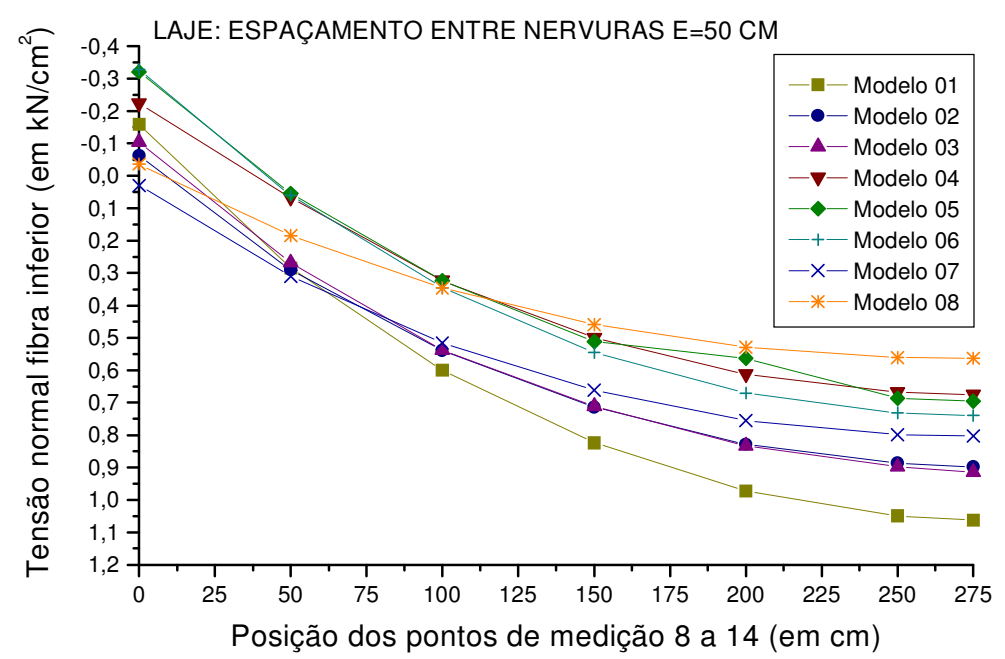

FIGURA 5.161: Tensões Normais fibras inferiores extremas $\left(\mathrm{kN} / \mathrm{cm}^{2}\right)$, nervura central, laje $\mathrm{E}=50 \mathrm{~cm}$

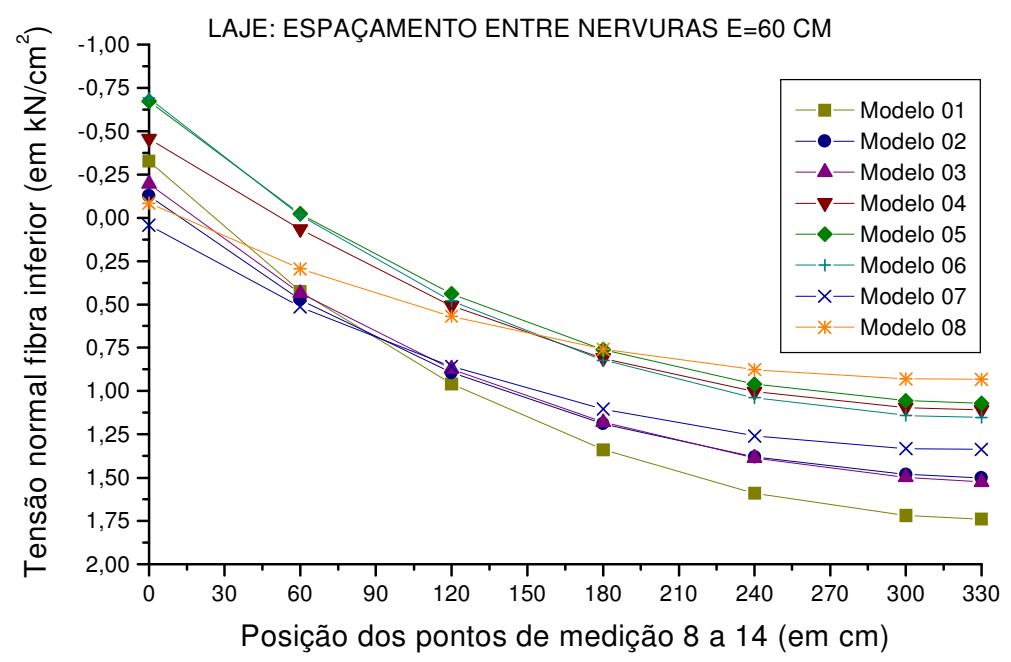

FIGURA 5.162: Tensões Normais fibras inferiores extremas $\left(\mathrm{kN} / \mathrm{cm}^{2}\right)$, nervura central, laje E=60 cm 


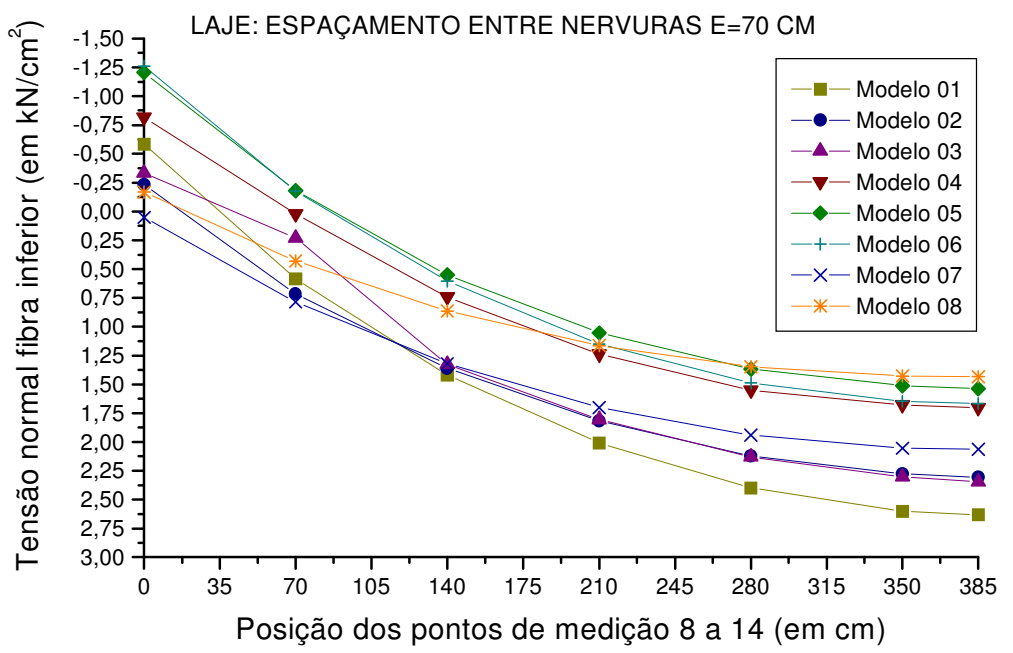

FIGURA 5.163: Tensões Normais fibras inferiores extremas $\left(\mathrm{kN} / \mathrm{cm}^{2}\right)$, nervura central, laje E=70 cm

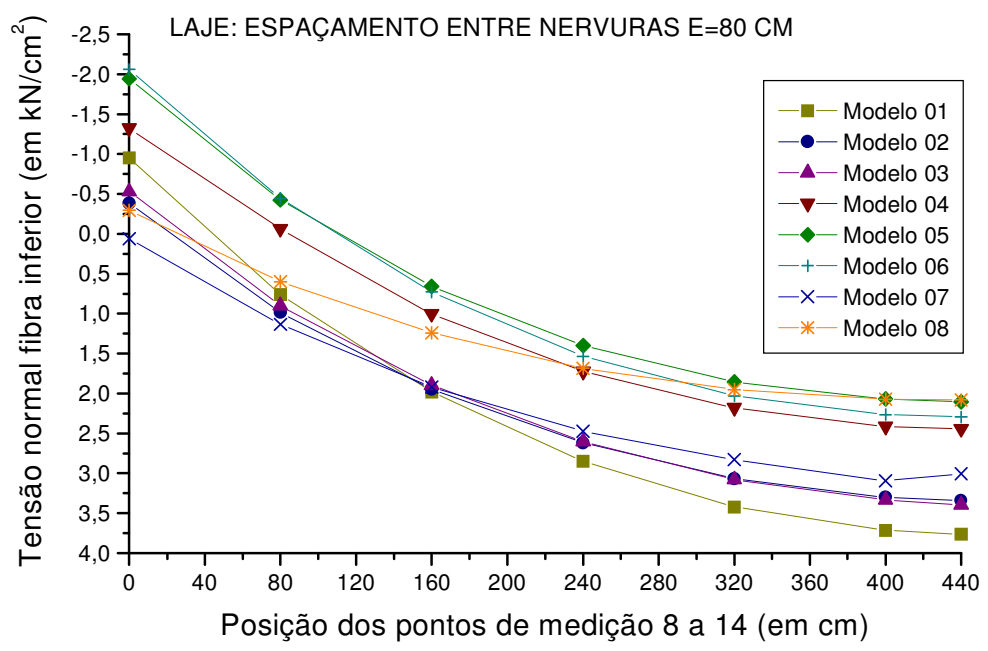

FIGURA 5.164: Tensões Normais fibras inferiores extremas $\left(\mathrm{kN} / \mathrm{cm}^{2}\right)$, nervura central, laje $\mathrm{E}=80 \mathrm{~cm}$

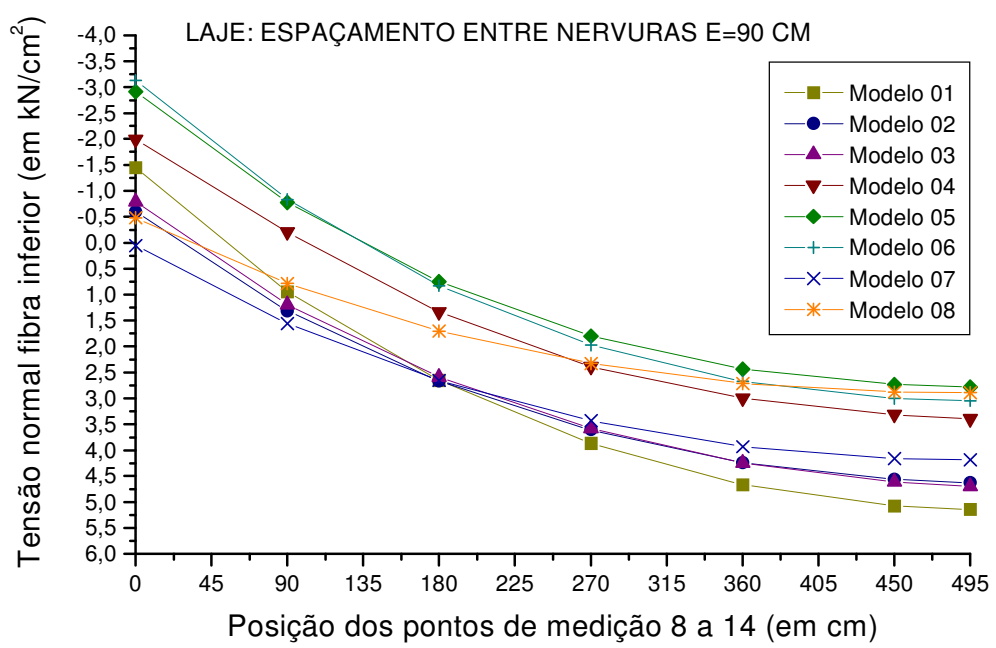

FIGURA 5.165: Tensões Normais fibras inferiores extremas $\left(\mathrm{kN} / \mathrm{cm}^{2}\right)$, nervura central, laje E=90 cm 
De acordo com as tabelas e gráficos de tensões normais nas fibras extremas superiores e inferiores, para as nervuras, nos modelos com variação do espaçamento entre os eixos das nervuras, tem-se:

- o modelo concêntrico apresenta as maiores tensões de tração, errando em $59 \%$ quando $\mathrm{E}=40 \mathrm{~cm}$, para a tensão máxima de tração na nervura central, quando comparada à tensão dada pelo modelo realista; os erros diminuem um pouco à medida que aumenta-se o espaçamento, ou seja, à medida que o sistema fica mais flexível, já que neste trabalho aumentou-se o espaçamento mantendo-se as nervuras com as mesmas propriedades geométricas; neste caso, para $\mathrm{E}=90 \mathrm{~cm}$ tem-se uma diferença de $51 \%$, ainda demasiadamente elevada;

- os modelos 02 e 03 , devido a alta relação $h_{f} / h=0,25$, tornam-se modelos mais flexíveis que o realista, apresentando para todas as relações de espaçamento testadas tensões maiores de tração dentre os modelos excêntricos; tem-se uma diferença de $34 \%$ entre a tensão máxima de tração na nervura central, a maior para o Modelo 03, quando comparada ao Modelo 04, para $\mathrm{E}=40 \mathrm{~cm}$; para espaçamento maiores que $\mathrm{E}=50 \mathrm{~cm}$, essa diferença fica em torno de $39 \%$, ou seja, variando muito pouco com relação à variação do espaçamento entre os eixos das nervuras;

- os modelos 05 e 06, ou modelos de vigas de seção "T" concêntricas, apresentam tensões de tração maiores nas nervuras para lajes com distâncias menores entre os eixos das mesmas; os melhores resultados foram encontrados com $\mathrm{E}=50 \mathrm{~cm}$ para o Modelo 05, com erro na tensão máxima da nervura central de apenas $2,81 \%$ em relação ao Modelo 04, e com E=70 cm para o Modelo 06, com erro de 2,29\% em relação ao modelo realista, na tensão máxima de tração; Para os espaçamento E=80 cm e E=90 cm o Modelo 06 passa a apresentar tensões menores que aquelas dadas pelo Modelo 04, com erro de 10,5\%, a menor, na tensão máxima de tração da nervura central, para E=90 cm;

- o Modelo 08 não conseguiu fornecer uma solução satisfatória em nenhum dos espaçamentos, sempre mostrando tensões de tração menores que as apresentadas pelo Modelo 04; como já visto anteriormente, a alta relação $h_{f} / h$ é favorável aos resultados de tensões de tração neste modelo. As mesmas foram aqui processadas com $\mathrm{h}_{\mathrm{f}} / \mathrm{h}=0,25$, e melhores resultados seriam obtidos com relações maiores que esta, a partir de $h_{f} / h=0,333$;

- as tensões de tração dadas pelo Modelo 07 apresentam-se sempre maiores que as dadas pelos modelo realista, isso em função da relação $h_{f} / h$ utilizada, com valores mais próximos para os menores espaçamentos entre as nervuras (diferença de $18 \%$ entre a tensão de tração máxima da nervura central do Modelo 07 em comparação com a dada pelo Modelo 04, para $E=40 \mathrm{~cm}$; essa diferença foi de $23 \%$ para $E=90 \mathrm{~cm}$ ); 
- como verificado anteriormente, houve muita variação dos resultados de tensões de compressão entre os modelos, sendo as do Modelo 04 menores que a dos demais.

Abaixo tem-se os gráficos de tensões normais atuantes nas fibras inferiores extremas para as vigas do contorno externo das lajes processadas nesta série.

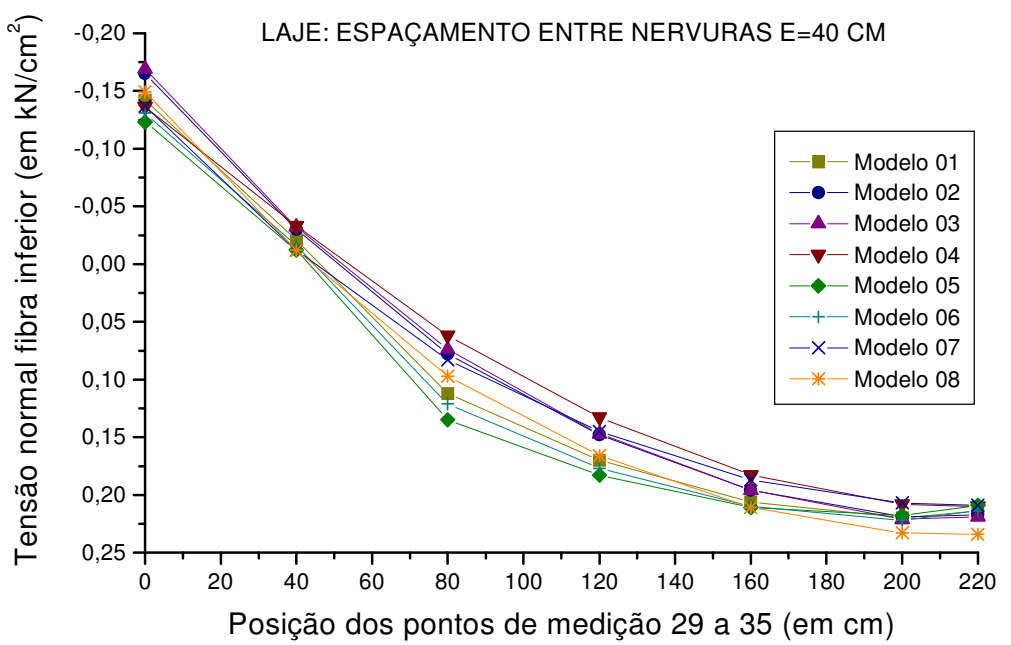

FIGURA 5.166: Tensões Normais fibras inferiores extremas $\left(\mathrm{kN} / \mathrm{cm}^{2}\right)$, viga externa, laje $\mathrm{E}=40 \mathrm{~cm}$

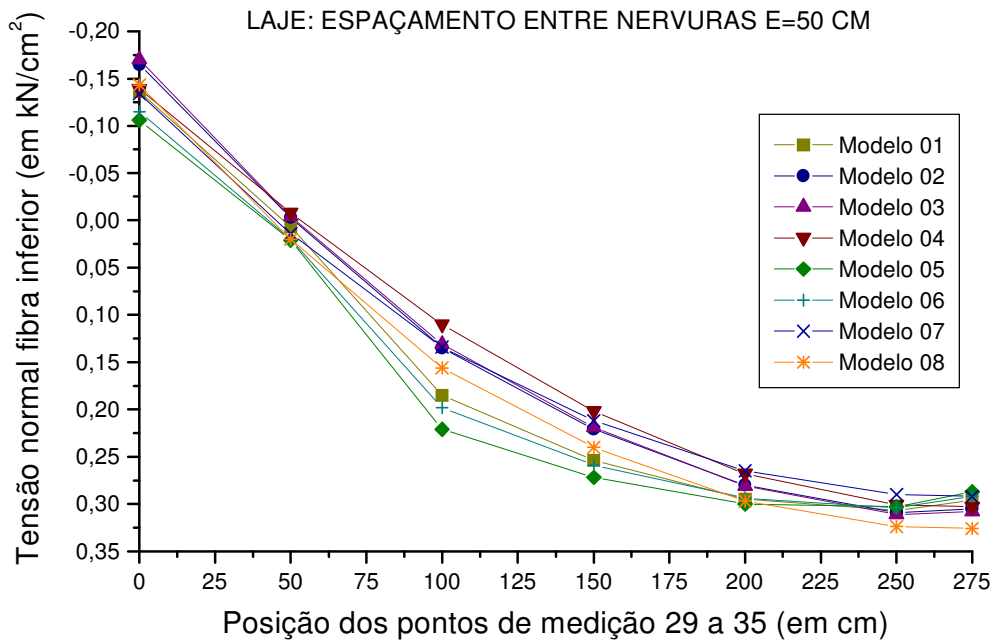

FIGURA 5.167: Tensões Normais fibras inferiores extremas $\left(\mathrm{kN} / \mathrm{cm}^{2}\right)$, viga externa, laje $\mathrm{E}=50 \mathrm{~cm}$ 


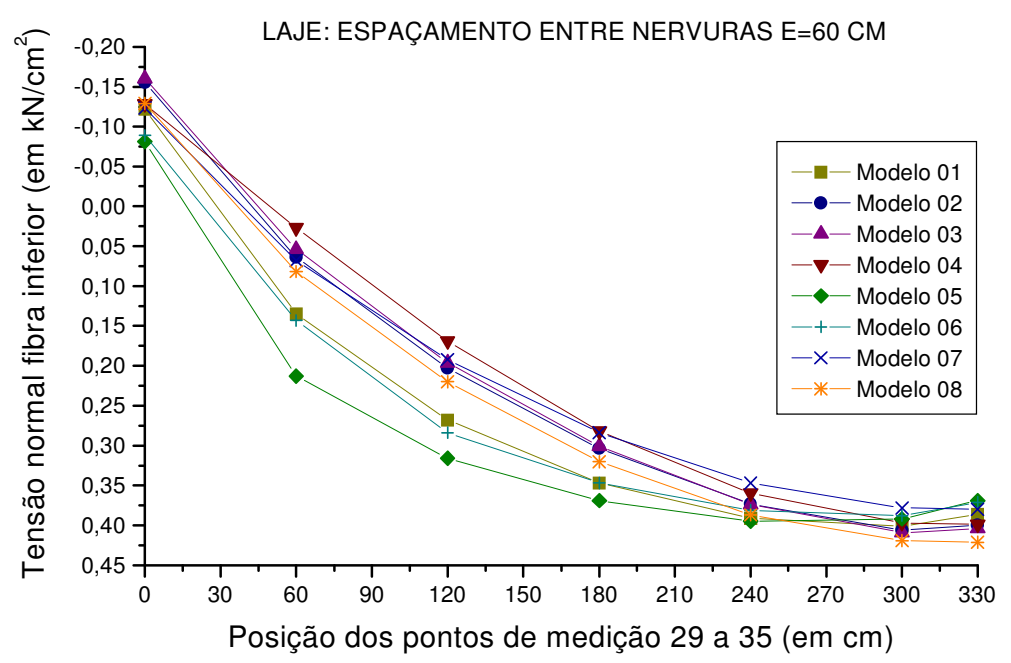

FIGURA 5.168: Tensões Normais fibras inferiores extremas $\left(\mathrm{kN} / \mathrm{cm}^{2}\right)$, viga externa, laje $\mathrm{E}=60 \mathrm{~cm}$

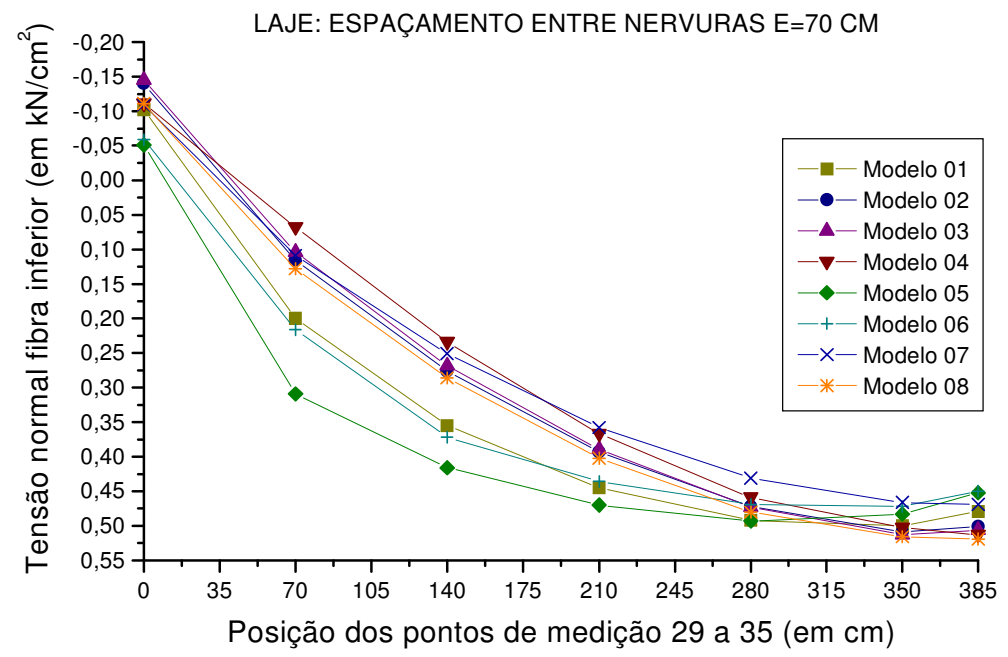

FIGURA 5.169: Tensões Normais fibras inferiores extremas $\left(\mathrm{kN} / \mathrm{cm}^{2}\right)$, viga externa, laje $\mathrm{E}=70 \mathrm{~cm}$

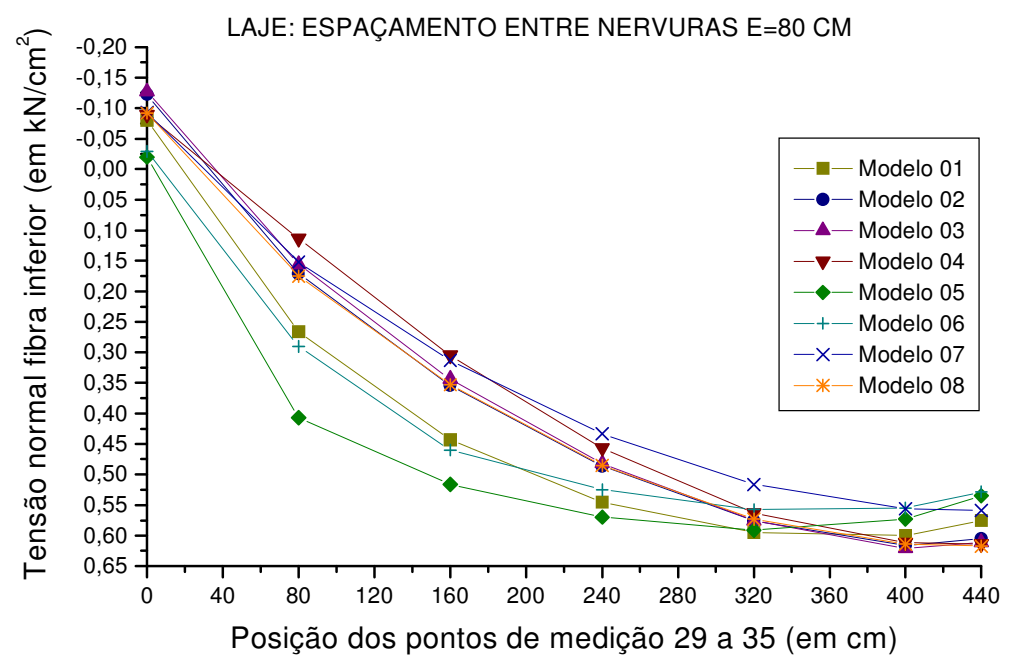

FIGURA 5.170: Tensões Normais fibras inferiores extremas $\left(\mathrm{kN} / \mathrm{cm}^{2}\right)$, viga externa, laje $\mathrm{E}=80 \mathrm{~cm}$ 


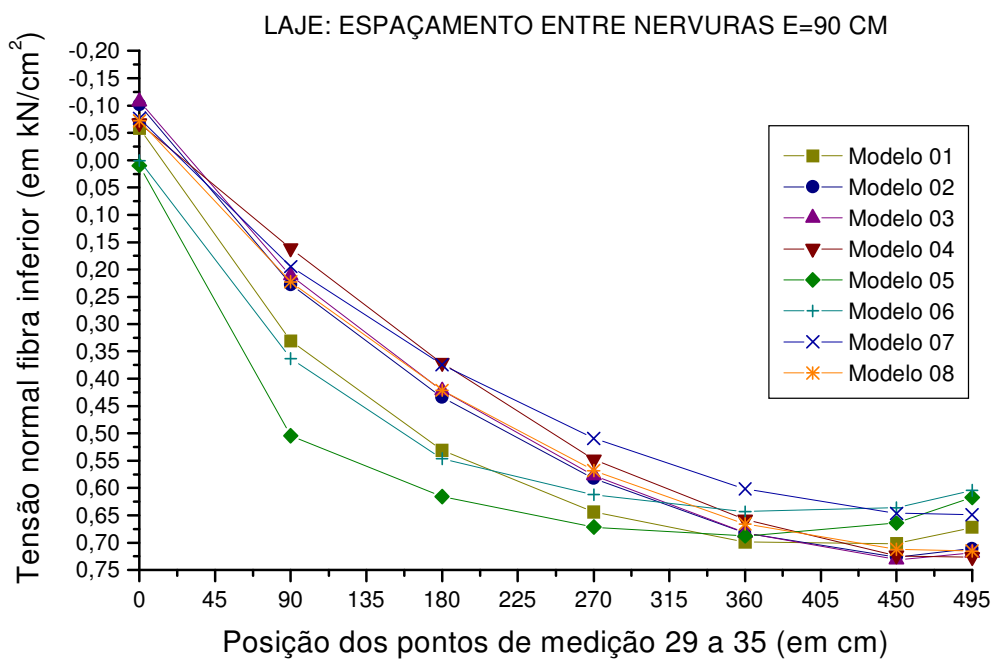

FIGURA 5.171: Tensões Normais fibras inferiores extremas $\left(\mathrm{kN} / \mathrm{cm}^{2}\right)$, viga externa, laje $\mathrm{E}=90 \mathrm{~cm}$

Analisando-se as tabelas e gráficos das tensões normais atuantes nas vigas do contorno externo, verificou-se que:

- quanto menor o espaçamento entre os eixos das nervuras que compõem o sistema, melhor é a convergência, para um mesmo ponto, das tensões máximas em todos os modelos analisados;

- à medida que aumenta-se o espaçamento, os modelos 05, 06 e 07 começam a apresentar tensões de tração máximas menores que as dadas pelo Modelo 04; para E=90 cm, o Modelo 06 apresenta tensão máxima de tração menor que a dada pelo modelo realista em $16,9 \%$. Isso ocorre porque o pavimento apresenta-se mais rígido nessas modelagens. 


\subsubsection{Esforços Cortantes atuantes nas nervuras e vigas}

TABELA 5.231: Esforços Cortantes nas nervuras e vigas, em $\mathrm{kN}$, na laje com espaçamento entre os eixos das nervuras $\mathrm{E}=40 \mathrm{~cm}$

\begin{tabular}{|c|c|c|c|c|c|c|c|c|}
\hline \multicolumn{9}{|c|}{$\begin{array}{c}\text { VARIAÇÃO DO ESPAÇAMENTO ENTRE NERVURAS: E }=40 \mathrm{~cm} \\
\text { ESFORÇOS CORTANTES NAS NERVURAS E VIGAS }(\mathrm{kN})\end{array}$} \\
\hline \multirow{2}{*}{ Ponto } & \multicolumn{8}{|c|}{ Modelos numéricos de análise } \\
\hline & 01 & 02 & 03 & 04 & 05 & 06 & 07 & 08 \\
\hline 8 & 3,24 & 3,21 & 3,09 & 2,83 & 3,64 & 3,84 & - & - \\
\hline 9 & 2,52 & 2,32 & 2,23 & 2,10 & 2,91 & 3,09 & - & - \\
\hline 10 & 1,85 & 1,71 & 1,65 & 1,56 & 2,13 & 2,28 & - & - \\
\hline 11 & 1,31 & 1,19 & 1,15 & 1,08 & 1,44 & 1,55 & - & - \\
\hline 12 & 0,79 & 0,71 & 0,68 & 0,64 & 0,83 & 0,90 & - & - \\
\hline 13 & 0,25 & 0,22 & 0,22 & 0,21 & 0,27 & 0,30 & - & - \\
\hline 14 & 0,11 & 0,10 & 0,10 & 0,00 & 0,11 & 0,00 & - & - \\
\hline 15 & 2,67 & 2,57 & 2,50 & 2,11 & 3,18 & 3,39 & - & 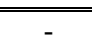 \\
\hline 16 & 2,36 & 2,08 & 2,00 & 1,85 & 2,49 & 2,66 & - & - \\
\hline 17 & 1,89 & 1,67 & 1,59 & 1,44 & 1,78 & 1,87 & - & - \\
\hline 18 & 1,35 & 1,71 & 1,12 & 1,02 & 1,21 & 1,27 & - & - \\
\hline 19 & 0,79 & 0,68 & 0,65 & 0,60 & 0,72 & 0,77 & - & - \\
\hline 20 & 0,25 & 0,23 & 0,22 & 0,20 & 0,27 & 0,30 & - & - \\
\hline 21 & 0,11 & 0,10 & 0,10 & 0,00 & 0,11 & 0,00 & - & - \\
\hline 22 & 2,75 & 3,30 & 3,20 & 2,34 & 1,96 & 1,82 & - & - \\
\hline 23 & 2,23 & 2,19 & 2,11 & 1,82 & 1,45 & 1,37 & - & - \\
\hline 24 & 1,51 & 1,32 & 1,30 & 1,29 & 1,16 & 1,24 & - & - \\
\hline 25 & 0,86 & 0,72 & 0,72 & 0,79 & 0,83 & 0,92 & - & - \\
\hline 26 & 0,49 & 0,41 & 0,41 & 0,42 & 0,53 & 0,60 & - & - \\
\hline 27 & 0,24 & 0,21 & 0,20 & 0,13 & 0,26 & 0,30 & - & - \\
\hline 28 & 0,10 & 0,09 & 0,09 & 0,00 & 0,11 & 0,00 & - & - \\
\hline 29 & 18,24 & $\overline{18,22}$ & $\overline{18,22}$ & 177,84 & 18,22 & 18,15 & 19,21 & 19,95 \\
\hline 30 & 15,08 & 13,61 & 13,69 & 15,56 & 15,86 & 15,88 & 16,32 & 18,85 \\
\hline 31 & 14,45 & 13,15 & 13,20 & 12,29 & 15,40 & 15,65 & 13,88 & 16,25 \\
\hline 32 & 11,04 & 10,21 & 10,22 & 9,08 & 12,00 & 12,18 & 10,70 & 12,35 \\
\hline 33 & 7,57 & 7,13 & 7,11 & 5,61 & 8,18 & 8,35 & 6,95 & 7,92 \\
\hline 34 & 3,73 & 3,58 & 3,55 & 1,90 & 4,02 & 4,22 & 2,74 & 3,11 \\
\hline 35 & 0,12 & 0,11 & 0,11 & 0,00 & 0,10 & 0,08 & 0,55 & 0,62 \\
\hline
\end{tabular}


TABELA 5.232: Esforços Cortantes nas nervuras e vigas, em $\mathrm{kN}$, na laje com espaçamento entre os eixos das nervuras $\mathrm{E}=50 \mathrm{~cm}$

\begin{tabular}{|c|c|c|c|c|c|c|c|c|}
\hline \multicolumn{9}{|c|}{$\begin{array}{l}\text { VARIAÇÃO DO ESPAÇAMENTO ENTRE NERVURAS: E }=50 \mathrm{~cm} \\
\text { ESFORÇOS CORTANTES NAS NERVURAS E VIGAS }(\mathrm{kN})\end{array}$} \\
\hline \multirow{2}{*}{ Ponto } & \multicolumn{8}{|c|}{ Modelos numéricos de análise } \\
\hline & 01 & $\mathbf{0 2}$ & 03 & 04 & 05 & 06 & 07 & 08 \\
\hline 8 & 5,01 & 5,14 & 4,91 & 4,17 & 5,89 & 6,25 & - & 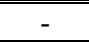 \\
\hline 9 & 3,84 & 3,63 & 3,49 & 3,57 & 4,64 & 4,96 & - & - \\
\hline 10 & 2,82 & 2,65 & 2,56 & 2,59 & 3,35 & 3,62 & - & - \\
\hline 11 & 1,99 & 1,86 & 1,79 & 1,76 & 2,24 & 2,44 & - & - \\
\hline 12 & 1,20 & 1,11 & 1,07 & 1,02 & 1,28 & 1,41 & - & - \\
\hline 13 & 0,38 & 0,35 & 0,34 & 0,34 & 0,41 & 0,47 & - & - \\
\hline 14 & 0,16 & 0,16 & 0,15 & 0,00 & 0,17 & 0,00 & - & - \\
\hline 15 & 4,15 & 4,03 & 3,91 & 3,55 & $\bar{~} 5,04$ & $\bar{~} 5,37$ & - & - \\
\hline 16 & 3,60 & 3,26 & 3,13 & 3,00 & 3,82 & 4,10 & - & - \\
\hline 17 & 2,90 & 2,64 & 2,52 & 2,24 & 2,69 & 2,86 & - & - \\
\hline 18 & 2,06 & 1,86 & 1,77 & 1,54 & 1,80 & 1,92 & - & - \\
\hline 19 & 1,20 & 1,07 & 1,03 & 0,89 & 1,07 & 1,16 & - & - \\
\hline 20 & 0,38 & 0,35 & 0,34 & 0,29 & 0,41 & 0,47 & - & - \\
\hline 21 & 0,16 & 0,15 & 0,15 & 0,00 & 0,17 & 0,00 & - & - \\
\hline 22 & 4,28 & 5,24 & 5,03 & 3,20 & 2,77 & 2,59 & 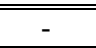 & - \\
\hline 23 & 3,38 & 3,37 & 3,18 & 2,37 & 1,95 & 1,88 & - & - \\
\hline 24 & 2,19 & 1,88 & 1,85 & 1,58 & 1,46 & 1,56 & - & - \\
\hline 25 & 1,24 & 0,94 & 0,94 & 0,91 & 1,06 & 1,19 & - & - \\
\hline 26 & 0,70 & 0,52 & 0,51 & 0,45 & 0,72 & 0,82 & - & - \\
\hline 27 & 0,37 & 0,31 & 0,29 & 0,14 & 0,41 & 0,47 & - & - \\
\hline 28 & 0,16 & 0,14 & 0,13 & 0,00 & 0,17 & 0,00 & - & - \\
\hline 29 & 28,50 & 28,46 & 28,46 & 28,10 & 28,45 & 28,36 & 29,73 & 30,56 \\
\hline 30 & 23,64 & 21,00 & 21,17 & 24,99 & 25,12 & 25,07 & 26,11 & 29,96 \\
\hline 31 & 22,70 & 20,37 & 20,50 & 20,22 & 24,43 & 24,72 & 22,32 & 25,95 \\
\hline 32 & 17,41 & 15,89 & 15,90 & 15,34 & 19,32 & 19,57 & 17,25 & 19,76 \\
\hline 33 & 11,92 & 11,19 & 11,14 & 9,42 & 13,24 & 13,50 & 11,25 & 12,69 \\
\hline 34 & 5,85 & 5,68 & 5,62 & 3,21 & 6,53 & 6,84 & 4,45 & 4,98 \\
\hline 35 & 0,21 & 0,15 & 0,17 & 0,00 & 0,17 & 0,12 & 0,89 & 1,00 \\
\hline
\end{tabular}


TABELA 5.233: Esforços Cortantes nas nervuras e vigas, em kN, na laje com espaçamento entre os eixos das nervuras $\mathrm{E}=60 \mathrm{~cm}$

\begin{tabular}{c|c|c|c|c|c|c|c|c}
\hline \hline \multicolumn{7}{c}{ VARIAÇÃO DO ESPAÇAMENTO ENTRE NERVURAS: E = 60 cm } \\
\hline \multirow{2}{*}{ Ponto } & \multicolumn{7}{c}{ ESFORÇOS CORTATES NAS NERVURAS E VIGAS (kN) } \\
\cline { 2 - 11 } & $\mathbf{0 1}$ & $\mathbf{0 2}$ & $\mathbf{0 3}$ & $\mathbf{0 4}$ & $\mathbf{0 5}$ & $\mathbf{0 6}$ & $\mathbf{0 7}$ & $\mathbf{0 8}$ \\
\hline \hline $\mathbf{8}$ & 7,09 & 7,44 & 7,06 & $\mathbf{6 , 5 2}$ & 8,70 & 9,25 & - & - \\
\hline $\mathbf{9}$ & 5,40 & 5,27 & 5,04 & $\mathbf{5 , 4 2}$ & 6,79 & 7,30 & - & - \\
\hline $\mathbf{1 0}$ & 3,96 & 3,83 & 3,68 & $\mathbf{3 , 8 9}$ & 4,86 & 5,28 & - & - \\
\hline $\mathbf{1 1}$ & 2,80 & 2,69 & 2,59 & $\mathbf{2 , 6 1}$ & 3,22 & 3,53 & - & - \\
\hline $\mathbf{1 2}$ & 1,69 & 1,62 & 1,55 & $\mathbf{1 , 5 0}$ & 1,83 & 2,03 & - & - \\
\hline $\mathbf{1 3}$ & 0,54 & 0,51 & 0,49 & $\mathbf{0 , 4 9}$ & 0,58 & 0,68 & - & - \\
\hline $\mathbf{1 4}$ & 0,23 & 0,22 & 0,21 & $\mathbf{0 , 0 0}$ & 0,25 & 0,00 & - & - \\
\hline \hline $\mathbf{1 5}$ & 5,98 & 5,87 & 5,67 & $\mathbf{5 , 4 1}$ & 7,33 & 7,80 & - & - \\
\hline $\mathbf{1 6}$ & 5,08 & 4,76 & 4,56 & $\mathbf{4 , 4 5}$ & 5,43 & 5,86 & - & - \\
\hline $\mathbf{1 7}$ & 4,07 & 3,86 & 3,67 & $\mathbf{3 , 2 5}$ & 3,76 & 4,04 & - & - \\
\hline $\mathbf{1 8}$ & 2,89 & 2,73 & 2,59 & $\mathbf{2 , 1 9}$ & 2,48 & 2,69 & - & - \\
\hline $\mathbf{1 9}$ & 1,68 & 1,57 & 1,50 & $\mathbf{1 , 2 5}$ & 1,47 & 1,62 & - & - \\
\hline $\mathbf{2 0}$ & 0,54 & 0,51 & 0,49 & $\mathbf{0 , 4 0}$ & 0,58 & 0,68 & - & - \\
\hline $\mathbf{2 1}$ & 0,22 & 0,22 & 0,21 & $\mathbf{0 , 0 0}$ & 0,25 & 0,00 & - & - \\
\hline \hline $\mathbf{2 2}$ & 6,04 & 7,43 & 7,06 & $\mathbf{4 , 2 7}$ & 3,67 & 3,45 & - & - \\
\hline $\mathbf{2 3}$ & 4,67 & 4,77 & 4,43 & $\mathbf{3 , 0 8}$ & 2,48 & 2,44 & - & - \\
\hline $\mathbf{2 4}$ & 3,00 & 2,65 & 2,57 & $\mathbf{1 , 9 7}$ & 1,79 & 1,93 & - & - \\
\hline $\mathbf{2 5}$ & 1,71 & 1,29 & 1,28 & $\mathbf{1 , 0 9}$ & 1,34 & 1,50 & - & - \\
\hline $\mathbf{2 6}$ & 0,97 & 0,71 & 0,68 & $\mathbf{0 , 5 1}$ & 0,95 & 1,09 & - & - \\
\hline $\mathbf{2 7}$ & 0,51 & 0,45 & 0,41 & $\mathbf{0 , 1 5}$ & 0,58 & 0,68 & - & - \\
\hline $\mathbf{2 8}$ & 0,22 & 0,19 & 0,18 & $\mathbf{0 , 0 0}$ & 0,25 & 0,00 & - & - \\
\hline \hline $\mathbf{2 9}$ & 41,04 & 40,98 & 40,98 & $\mathbf{4 0 , 6 6}$ & 40,95 & 40,84 & 42,66 & 43,61 \\
\hline $\mathbf{3 0}$ & 40,39 & 30,12 & 37,82 & $\mathbf{3 6 , 5 5}$ & 40,32 & 40,33 & 40,05 & 45,00 \\
\hline $\mathbf{3 1}$ & 32,89 & 29,23 & 29,43 & $\mathbf{2 9 , 9 7}$ & 35,56 & 35,87 & 32,58 & 37,75 \\
\hline $\mathbf{3 2}$ & 25,24 & 22,75 & 22,77 & $\mathbf{2 2 , 5 7}$ & 28,36 & 28,69 & 25,15 & 28,73 \\
\hline $\mathbf{3 3}$ & 17,22 & 16,03 & 15,95 & $\mathbf{1 4 , 0 8}$ & 19,52 & 19,88 & 16,41 & 18,45 \\
\hline $\mathbf{3 4}$ & 8,41 & 8,17 & 8,08 & $\mathbf{4 , 7 8}$ & 9,65 & 10,09 & 6,49 & 7,24 \\
\hline $\mathbf{3 5}$ & 0,32 & 0,21 & 0,23 & $\mathbf{0 , 0 0}$ & 0,25 & 0,17 & 1,30 & 1,45 \\
\hline \hline & & & & & & & & - \\
\hline
\end{tabular}


TABELA 5.234: Esforços Cortantes nas nervuras e vigas, em kN, na laje com espaçamento entre os eixos das nervuras $\mathrm{E}=70 \mathrm{~cm}$

\begin{tabular}{|c|c|c|c|c|c|c|c|c|}
\hline \multicolumn{9}{|c|}{$\begin{array}{l}\text { VARIAÇÃO DO ESPAÇAMENTO ENTRE NERVURAS: } \mathrm{E}=70 \mathrm{~cm} \\
\text { ESFORÇOS CORTANTES NAS NERVURAS E VIGAS }(\mathrm{kN})\end{array}$} \\
\hline \multirow{2}{*}{ Ponto } & \multicolumn{8}{|c|}{ Modelos numéricos de análise } \\
\hline & 01 & $\mathbf{0 2}$ & 03 & 04 & 05 & 06 & 07 & 08 \\
\hline 8 & 9,49 & 10,08 & 9,51 & 9 & 12,05 & 12,84 & - & $\begin{array}{l}- \\
\end{array}$ \\
\hline 9 & 7,19 & 7,21 & 6,87 & 7,68 & 9,34 & 10,09 & - & - \\
\hline 10 & 5,29 & 5,24 & 5,02 & 5,47 & 6,64 & 7,26 & - & - \\
\hline 11 & 3,73 & 3,69 & 3,53 & 3,64 & 4,38 & 4,83 & - & - \\
\hline 12 & 2,25 & 2,22 & 2,12 & 2,09 & 2,47 & 2,76 & - & - \\
\hline 13 & 0,72 & 0,71 & 0,67 & 0,68 & 0,79 & 0,92 & - & - \\
\hline 14 & 0,30 & 0,30 & 0,29 & 0,00 & 0,33 & 0,00 & - & - \\
\hline 15 & 8,13 & 8,08 & $7,7,76$ & $7,6,61$ & 10,01 & 10,66 & - & - \\
\hline 16 & 6,80 & 6,56 & 6,28 & 6,20 & 7,31 & 7,92 & - & - \\
\hline 17 & 5,40 & 5,31 & 5,04 & 4,46 & 4,99 & 5,40 & - & - \\
\hline 18 & 3,83 & 3,76 & 3,57 & 2,97 & 3,27 & 3,57 & - & - \\
\hline 19 & 2,23 & 2,17 & 2,07 & 1,68 & 1,94 & 2,16 & - & - \\
\hline 20 & 0,71 & 0,70 & 0,67 & 0,54 & 0,79 & 0,92 & - & - \\
\hline 21 & 0,30 & 0,30 & 0,29 & 0,00 & 0,33 & 0,00 & - & - \\
\hline 22 & 8,02 & 9,84 & 9,26 & 5,51 & 4,67 & 4,43 & - & - \\
\hline 23 & 6,08 & 6,39 & 5,90 & 3,93 & 3,04 & 3,06 & - & - \\
\hline 24 & 3,92 & 3,66 & 3,51 & 2,45 & 2,17 & 2,34 & - & - \\
\hline 25 & 2,27 & 1,82 & 1,77 & 1,31 & 1,65 & 1,86 & - & - \\
\hline 26 & 1,29 & 0,99 & 0,94 & 0,61 & 1,21 & 1,39 & - & - \\
\hline 27 & 0,68 & 0,62 & 0,56 & 0,17 & 0,79 & 0,92 & - & - \\
\hline 28 & 0,29 & 0,26 & 0,24 & 0,00 & 0,33 & 0,00 & - & - \\
\hline 29 & $\bar{~} 55,86$ & $\bar{~} 55,78$ & $\bar{~} 55,78$ & $\bar{~} 55,49$ & $\bar{~} 55,73$ & "55,58 & "57,95 & 59,04 \\
\hline 30 & 55,04 & 51,13 & 51,27 & 50,24 & 54,91 & 54,90 & 54,91 & 61,40 \\
\hline 31 & 45,03 & 39,78 & 40,03 & 41,54 & 48,76 & 49,08 & 44,68 & 51,66 \\
\hline 32 & 34,55 & 30,83 & 30,84 & 31,41 & 39,13 & 39,54 & 34,39 & 39,30 \\
\hline 33 & 23,48 & 21,66 & 21,54 & 19,63 & 27,01 & 27,50 & 22,42 & 25,21 \\
\hline 34 & 11,41 & 11,07 & 10,93 & 6,69 & 13,37 & 13,99 & 8,87 & 9,88 \\
\hline 35 & 0,46 & 0,28 & 0,31 & 0,00 & 0,35 & 0,23 & 1,78 & 1,98 \\
\hline
\end{tabular}


TABELA 5.235: Esforços Cortantes nas nervuras e vigas, em $\mathrm{kN}$, na laje com espaçamento entre os eixos das nervuras $\mathrm{E}=80 \mathrm{~cm}$

\begin{tabular}{c|c|c|c|c|c|c|c|c}
\hline \hline \multicolumn{7}{c}{ VARIAÇÃO DO ESPAÇAMENTO ENTRE NERVURAS: E = 80 cm } \\
\hline \multirow{2}{*}{ Ponto } & \multicolumn{7}{c}{ ESFORÇOS CORTATES NAS NERVURAS E VIGAS (kN) } \\
\cline { 2 - 11 } & $\mathbf{0 1}$ & $\mathbf{0 2}$ & $\mathbf{0 3}$ & $\mathbf{0 4}$ & $\mathbf{0 5}$ & $\mathbf{0 6}$ & $\mathbf{0 7}$ & $\mathbf{0 8}$ \\
\hline \hline $\mathbf{8}$ & 12,19 & 13,07 & 12,24 & $\mathbf{1 2 , 5 5}$ & 15,93 & 17,01 & - & - \\
\hline $\mathbf{9}$ & 9,21 & 9,44 & 8,98 & $\mathbf{1 0 , 3 2}$ & 12,28 & 13,45 & - & - \\
\hline $\mathbf{1 0}$ & 6,77 & 6,86 & 6,55 & $\mathbf{7 , 3 3}$ & 8,70 & 9,57 & - & - \\
\hline $\mathbf{1 1}$ & 4,78 & 4,84 & 4,62 & $\mathbf{4 , 8 6}$ & 5,70 & 6,33 & - & - \\
\hline $\mathbf{1 2}$ & 2,87 & 2,92 & 2,77 & $\mathbf{2 , 7 7}$ & 3,20 & 3,60 & - & - \\
\hline $\mathbf{1 3}$ & 0,92 & 0,93 & 0,88 & $\mathbf{0 , 9 0}$ & 1,02 & 1,20 & - & - \\
\hline $\mathbf{1 4}$ & 0,38 & 0,40 & 0,38 & $\mathbf{0 , 0 0}$ & 0,43 & 0,00 & - & - \\
\hline \hline $\mathbf{1 5}$ & 10,59 & 10,64 & 10,15 & $\mathbf{1 0 , 2 4}$ & 13,10 & 13,96 & - & - \\
\hline $\mathbf{1 6}$ & 8,73 & 8,66 & 8,27 & $\mathbf{8 , 2 7}$ & 9,45 & 10,29 & - & - \\
\hline $\mathbf{1 7}$ & 6,88 & 6,98 & 6,61 & $\mathbf{5 , 8 9}$ & 6,38 & 6,97 & - & - \\
\hline $\mathbf{1 8}$ & 4,87 & 4,95 & 4,69 & $\mathbf{3 , 8 9}$ & 4,14 & 4,57 & - & - \\
\hline $\mathbf{1 9}$ & 2,83 & 2,86 & 2,72 & $\mathbf{2 , 1 8}$ & 2,45 & 2,76 & - & - \\
\hline $\mathbf{2 0}$ & 0,91 & 0,92 & 0,87 & $\mathbf{0 , 7 0}$ & 1,02 & 1,20 & - & - \\
\hline $\mathbf{2 1}$ & 0,38 & 0,39 & 0,37 & $\mathbf{0 , 0 0}$ & 0,43 & 0,00 & - & - \\
\hline \hline $\mathbf{2 2}$ & 10,19 & 12,48 & 11,65 & $\mathbf{6 , 9 4}$ & 5,77 & 5,54 & - & - \\
\hline $\mathbf{2 3}$ & 7,59 & 8,25 & 7,59 & $\mathbf{4 , 9 3}$ & 3,65 & 3,74 & - & - \\
\hline $\mathbf{2 4}$ & 4,92 & 4,89 & 4,65 & $\mathbf{3 , 0 2}$ & 2,58 & 2,80 & - & - \\
\hline $\mathbf{2 5}$ & 2,89 & 2,50 & 2,42 & $\mathbf{1 , 6 0}$ & 1,99 & 2,67 & - & - \\
\hline $\mathbf{2 6}$ & 1,66 & 1,36 & 1,29 & $\mathbf{0 , 7 3}$ & 1,50 & 1,74 & - & - \\
\hline $\mathbf{2 7}$ & 0,86 & 0,82 & 0,74 & $\mathbf{0 , 2 1}$ & 1,02 & 1,20 & - & - \\
\hline $\mathbf{2 8}$ & 0,36 & 0,34 & 0,31 & $\mathbf{0 , 0 0}$ & 0,43 & 0,00 & - & - \\
\hline \hline $\mathbf{2 9}$ & 72,98 & 72,87 & 72,87 & $\mathbf{7 2 , 5 9}$ & 72,78 & 72,60 & 75,60 & 76,85 \\
\hline $\mathbf{3 0}$ & 71,96 & 66,70 & 66,84 & $\mathbf{6 6 , 1 2}$ & 71,75 & 71,70 & 72,08 & 80,25 \\
\hline $\mathbf{3 1}$ & 59,12 & 52,07 & 52,35 & $\mathbf{5 5 , 0 0}$ & 64,04 & 64,36 & 58,64 & 67,69 \\
\hline $\mathbf{3 2}$ & 45,34 & 40,19 & 40,16 & $\mathbf{4 1 , 6 7}$ & 51,60 & 52,08 & 44,98 & 51,46 \\
\hline $\mathbf{3 3}$ & 30,71 & 28,12 & 27,94 & $\mathbf{2 6 , 0 5}$ & 35,71 & 36,33 & 29,29 & 32,98 \\
\hline $\mathbf{3 4}$ & 14,84 & 14,36 & 14,16 & $\mathbf{8 , 8 6}$ & 17,70 & 18,51 & 11,59 & 12,93 \\
\hline $\mathbf{3 5}$ & 0,63 & 0,37 & 0,40 & $\mathbf{0 , 0 0}$ & 0,47 & 0,30 & 2,33 & 2,59 \\
\hline \hline & & & & & & & & - \\
\hline
\end{tabular}


TABELA 5.236: Esforços Cortantes nas nervuras e vigas, em $\mathrm{kN}$, na laje com espaçamento entre os eixos das nervuras $\mathrm{E}=90 \mathrm{~cm}$

\begin{tabular}{|c|c|c|c|c|c|c|c|c|}
\hline \multicolumn{9}{|c|}{$\begin{array}{c}\text { VARIAÇÃO DO ESPAÇAMENTO ENTRE NERVURAS: } \mathrm{E}=90 \mathrm{~cm} \\
\text { ESFORÇOS CORTANTES NAS NERVURAS E VIGAS }(\mathrm{kN})\end{array}$} \\
\hline \multirow{2}{*}{ Ponto } & \multicolumn{8}{|c|}{ Modelos numéricos de análise } \\
\hline & 01 & 02 & 03 & 04 & 05 & 06 & 07 & 08 \\
\hline 8 & 15,16 & 16,37 & 15,24 & 16,20 & 20,33 & 21,76 & - & - \\
\hline 9 & 11,44 & 8,85 & 11,33 & 13,35 & 15,59 & 17,05 & - & - \\
\hline 10 & 8,42 & 8,70 & 8,28 & 9,47 & 11,01 & 12,18 & - & - \\
\hline 11 & 5,93 & 6,14 & 5,84 & 6,25 & 7,18 & 8,03 & - & - \\
\hline 12 & 3,56 & 3,70 & 3,51 & 3,55 & 4,02 & 4,56 & - & - \\
\hline 13 & 1,13 & 1,18 & 1,11 & 1,16 & 1,28 & 1,52 & - & - \\
\hline 14 & 0,47 & 0,50 & 0,47 & 0,00 & 0,54 & 0,00 & - & - \\
\hline$\overline{15}$ & 13,35 & 13,54 & 12,82 & 13,18 & 16,56 & 17,68 & - & - \\
\hline 16 & 10,86 & 11,02 & 10,50 & 10,62 & 11,85 & 12,98 & - & - \\
\hline 17 & 8,50 & 8,85 & 8,37 & 7,50 & 7,94 & 8,73 & - & - \\
\hline 18 & 5,99 & 6,29 & 5,94 & 4,92 & 5,12 & 5,69 & - & - \\
\hline 19 & 3,49 & 3,65 & 3,46 & 2,75 & 3,03 & 3,44 & - & - \\
\hline 20 & 1,12 & 1,17 & 1,10 & 0,88 & 1,27 & 1,52 & - & - \\
\hline 21 & 0,47 & 0,50 & 0,47 & 0,00 & 0,54 & 0,00 & - & - \\
\hline 22 & 12,56 & 15,33 & 14,21 & 8,53 & 6,99 & 6,77 & - & - \\
\hline 23 & 9,20 & 10,32 & 9,48 & 6,02 & 4,31 & 4,49 & - & - \\
\hline 24 & 6,01 & 6,31 & 5,98 & 3,64 & 3,04 & 3,33 & - & - \\
\hline 25 & 3,58 & 3,33 & 3,20 & 1,90 & 2,38 & 2,72 & - & - \\
\hline 26 & 2,06 & 1,81 & 1,71 & 0,87 & 1,82 & 2,12 & - & - \\
\hline 27 & 1,06 & 1,05 & 0,95 & 0,25 & 1,28 & 1,52 & - & - \\
\hline 28 & 0,44 & 0,43 & 0,39 & 0,00 & 0,54 & 0,00 & - & - \\
\hline 29 & 92,38 & 92,24 & 92,24 & 91,96 & 92,10 & 91,88 & 95,59 & 97,00 \\
\hline 30 & 91,16 & 84,45 & 84,57 & 84,14 & 90,84 & 90,75 & 91,56 & 101,56 \\
\hline 31 & 75,18 & 66,16 & 66,43 & 70,29 & 81,38 & 81,70 & 74,47 & 85,85 \\
\hline 32 & 57,62 & 50,86 & 50,78 & 53,36 & 65,75 & 66,32 & 56,94 & 65,22 \\
\hline 33 & 38,91 & 35,44 & 35,18 & 33,38 & 45,59 & 46,37 & 37,00 & 41,77 \\
\hline 34 & 18,72 & 18,07 & 17,80 & 11,38 & 22,62 & 23,66 & 14,63 & 16,36 \\
\hline 35 & 0,84 & 0,47 & 0,51 & 0,02 & 0,61 & 0,38 & 2,94 & 3,28 \\
\hline
\end{tabular}

Pela análise das tabelas de esforços cortantes nas nevuras, para lajes com variação do espaçamento entre os eixos das nervuras, verificou-se que:

- o Modelo 04 apresenta cortante máxima na nervura central menor que a de todos os outros modelos, com diferença de 36\% em relação à cortante do Modelo 06 para um espaçamento $\mathrm{E}=40 \mathrm{~cm}$; à medida que aumenta-se o espaçamento entre as nervuras mais os resultados máximos de cortante do Modelos 02 e 03 aproximan-se dos resultados do Modelo 04

- as maiores cortantes são obtidas nas nervuras simuladas pelos modelos de vigas de seção "T", modelos 05 e 06; para E=90 cm tem-se uma diferença de $26 \%$ a maior para a cortante do máxima do Modelo 06 em relação a cortante máxima do Modelo 04; essa diferença também é encontrada para $\mathrm{E}=40 \mathrm{~cm}$, o que mostra que esses valores maiores de cortantes independem do espaçamento entre os eixos das nervuras para os modelos 05 e 06. 


\subsubsection{Momentos Fletores MX atuantes na capa}

TABELA 5.237: Momentos Fletores MX na capa, em kN.cm/cm, na laje com espaçamento entre os eixos das nervuras $\mathrm{E}=40 \mathrm{~cm}$

\begin{tabular}{|c|c|c|c|c|c|}
\hline \multicolumn{6}{|c|}{$\begin{array}{c}\text { VARIAÇÃO DO ESPAÇAMENTO ENTRE AS NERVURAS: E }=40 \mathrm{~cm} \\
\text { MOMENTO FLETOR MX NA CAPA }(\mathrm{kN} . \mathrm{cm} / \mathrm{cm})\end{array}$} \\
\hline \multirow{2}{*}{ Ponto } & \multicolumn{5}{|c|}{ Modelos numéricos de análise } \\
\hline & 01 & $\mathbf{0 2}$ & $\mathbf{0 3}$ & 04 & 05 \\
\hline$\overline{\mathrm{A}}$ & 0,783 & 0,442 & 0,459 & 0,395 & 0,417 \\
\hline B & 0,751 & 0,420 & 0,436 & 0,369 & 0,399 \\
\hline D & 0,669 & 0,372 & 0,385 & 0,315 & 0,351 \\
\hline $\mathbf{G}$ & 0,537 & 0,297 & 0,306 & 0,231 & 0,272 \\
\hline $\mathrm{K}$ & 0,346 & 0,188 & 0,194 & 0,113 & 0,159 \\
\hline $\mathbf{P}$ & 0,079 & 0,040 & 0,037 & $-0,060$ & 0,002 \\
\hline C & 0,734 & 0,402 & 0,417 & 0,353 & 0,383 \\
\hline$E$ & 0,652 & 0,353 & 0,366 & 0,299 & 0,338 \\
\hline $\mathbf{H}$ & 0,519 & 0,278 & 0,287 & 0,216 & 0,262 \\
\hline $\mathbf{L}$ & 0,331 & 0,173 & 0,177 & 0,101 & 0,153 \\
\hline $\mathbf{Q}$ & 0,071 & 0,018 & 0,016 & $-0,072$ & 0,000 \\
\hline $\mathbf{F}$ & 0,589 & 0,314 & 0,324 & 0,266 & 0,303 \\
\hline I & 0,456 & 0,239 & 0,246 & 0,184 & 0,236 \\
\hline $\mathbf{M}$ & 0,275 & 0,140 & 0,142 & 0,075 & 0,137 \\
\hline $\mathbf{R}$ & 0,037 & $-0,015$ & $-0,017$ & $-0,091$ & $-0,003$ \\
\hline $\mathbf{J}$ & 0,356 & 0,183 & 0,187 & 0,139 & 0,193 \\
\hline $\mathbf{N}$ & 0,181 & 0,085 & 0,085 & 0,033 & 0,111 \\
\hline S & $-0,039$ & $-0,070$ & $-0,073$ & $-0,122$ & $-0,010$ \\
\hline 0 & 0,068 & 0,019 & 0,016 & $-0,017$ & 0,076 \\
\hline $\mathbf{T}$ & $-0,150$ & $-0,129$ & $-0,135$ & $-0,161$ & $-0,014$ \\
\hline $\mathbf{U}$ & $-0,165$ & $-0,070$ & $-0,079$ & $-0,168$ & $-0,018$ \\
\hline
\end{tabular}

TABELA 5.238: Momentos Fletores MX na capa, em kN.cm/cm, na laje com espaçamento entre os eixos das nervuras $\mathrm{E}=50 \mathrm{~cm}$

\begin{tabular}{|c|c|c|c|c|c|}
\hline \multicolumn{6}{|c|}{$\begin{array}{c}\text { VARIAÇÃO DO ESPAÇAMENTO ENTRE AS NERVURAS: } \mathrm{E}=50 \mathrm{~cm} \\
\text { MOMENTO FLETOR MX NA CAPA }(\mathrm{kN} . \mathrm{cm} / \mathrm{cm})\end{array}$} \\
\hline \multirow{2}{*}{ Ponto } & \multicolumn{5}{|c|}{ Modelos numéricos de análise } \\
\hline & 01 & $\mathbf{0 2}$ & $\mathbf{0 3}$ & 04 & 05 \\
\hline $\mathbf{A}$ & 1,436 & 0,808 & 0,832 & 0,697 & 0,691 \\
\hline B & 1,375 & 0,769 & 0,792 & 0,652 & 0,659 \\
\hline D & 1,220 & 0,682 & 0,701 & 0,554 & 0,572 \\
\hline $\mathbf{G}$ & 0,967 & 0,544 & 0,558 & 0,398 & 0,426 \\
\hline $\mathrm{K}$ & 0,603 & 0,345 & 0,353 & 0,174 & 0,216 \\
\hline $\mathbf{P}$ & 0,095 & 0,061 & 0,057 & $-0,160$ & $-0,077$ \\
\hline C & 1,321 & 0,735 & 0,756 & 0,620 & 0,629 \\
\hline$E$ & 1,163 & 0,646 & 0,664 & 0,524 & 0,547 \\
\hline $\mathrm{H}$ & 0,909 & 0,507 & 0,520 & 0,371 & 0,409 \\
\hline $\mathbf{L}$ & 0,554 & 0,315 & 0,321 & 0,155 & 0,208 \\
\hline $\mathbf{Q}$ & 0,067 & 0,015 & 0,012 & $-0,174$ & $-0,075$ \\
\hline $\mathbf{F}$ & 1,021 & 0,567 & 0,582 & 0,459 & 0,484 \\
\hline$I$ & 0,765 & 0,428 & 0,438 & 0,315 & 0,364 \\
\hline $\mathbf{M}$ & 0,424 & 0,246 & 0,249 & 0,115 & 0,186 \\
\hline $\mathbf{R}$ & $-0,019$ & $-0,053$ & $-0,057$ & $-0,190$ & $-0,069$ \\
\hline J & 0,562 & 0,317 & 0,323 & 0,234 & 0,292 \\
\hline $\mathbf{N}$ & 0,228 & 0,137 & 0,136 & 0,053 & 0,152 \\
\hline $\mathbf{S}$ & $-0,181$ & $-0,163$ & $-0,171$ & $-0,218$ & $-0,058$ \\
\hline 0 & 0,025 & 0,014 & 0,091 & $-0,019$ & 0,105 \\
\hline $\mathbf{T}$ & $-0,370$ & $-0,277$ & $-0,290$ & $-0,248$ & $-0,037$ \\
\hline $\mathbf{U}$ & $-0,263$ & $-0,127$ & $-0,141$ & $-0,191$ & $-0,018$ \\
\hline
\end{tabular}


TABELA 5.239: Momentos Fletores MX na capa, em kN.cm/cm, na laje com espaçamento entre os eixos das nervuras $\mathrm{E}=60 \mathrm{~cm}$

\begin{tabular}{|c|c|c|c|c|c|}
\hline \multicolumn{6}{|c|}{$\begin{array}{c}\text { VARIAÇÃO DO ESPAÇAMENTO ENTRE AS NERVURAS: E }=60 \mathrm{~cm} \\
\text { MOMENTO FLETOR MX NA CAPA }(\mathrm{kN} . \mathrm{cm} / \mathrm{cm})\end{array}$} \\
\hline \multirow{2}{*}{ Ponto } & \multicolumn{5}{|c|}{ Modelos numéricos de análise } \\
\hline & 01 & 02 & 03 & 04 & 05 \\
\hline$\overline{\mathbf{A}}$ & 2,343 & 1,319 & 1,353 & 1,111 & 1,033 \\
\hline B & 2,241 & 1,258 & 1,289 & 1,042 & 0,980 \\
\hline $\mathbf{D}$ & 1,979 & 1,116 & 1,143 & 0,884 & 0,837 \\
\hline $\mathbf{G}$ & 1,553 & 0,891 & 0,911 & 0,629 & 0,597 \\
\hline $\mathrm{K}$ & 0,939 & 0,565 & 0,577 & 0,257 & 0,249 \\
\hline $\mathbf{P}$ & 0,085 & 0,084 & 0,080 & $-0,304$ & $-0,235$ \\
\hline C & 2,150 & $\begin{array}{l}1,202 \\
\end{array}$ & $\begin{array}{l}1,231 \\
\end{array}$ & $\begin{array}{c}0,989 \\
\end{array}$ & 0,932 \\
\hline $\mathbf{E}$ & 1,883 & 1,056 & 1,080 & 0,835 & 0,799 \\
\hline $\mathbf{H}$ & 1,455 & 0,829 & 0,846 & 0,588 & 0,572 \\
\hline $\mathbf{L}$ & 0,855 & 0,513 & 0,522 & 0,230 & 0,241 \\
\hline $\mathbf{Q}$ & 0,035 & 0,005 & 0,002 & $-0,318$ & $-0,225$ \\
\hline $\mathbf{F}$ & 1,645 & 0,923 & 0,943 & 0,727 & 0,700 \\
\hline I & 1,215 & 0,694 & 0,708 & 0,499 & 0,508 \\
\hline $\mathbf{M}$ & 0,638 & 0,393 & 0,397 & 0,174 & 0,221 \\
\hline $\mathbf{R}$ & $-0,110$ & $-0,114$ & $-0,122$ & $-0,327$ & $-0,195$ \\
\hline $\mathbf{J}$ & 0,875 & 0,505 & 0,513 & 0,369 & 0,404 \\
\hline $\mathbf{N}$ & 0,314 & 0,207 & 0,206 & 0,087 & 0,186 \\
\hline $\mathrm{S}$ & $-0,373$ & $-0,302$ & $-0,319$ & $-0,344$ & $-0,146$ \\
\hline 0 & $-0,014$ & 0,004 & $-0,002$ & $-0,013$ & 0,134 \\
\hline $\mathrm{T}$ & $-0,660$ & $-0,491$ & $-0,514$ & $-0,358$ & $-0,076$ \\
\hline $\mathbf{U}$ & $-0,447$ & $-0,219$ & $-0,240$ & $-0,227$ & $-0,020$ \\
\hline
\end{tabular}

TABELA 5.240: Momentos Fletores MX na capa, em kN.cm/cm, na laje com espaçamento entre os eixos das nervuras $\mathrm{E}=70 \mathrm{~cm}$

\begin{tabular}{|c|c|c|c|c|c|}
\hline \multicolumn{6}{|c|}{$\begin{array}{c}\text { VARIAÇÃO DO ESPAÇAMENTO ENTRE AS NERVURAS: E }=70 \mathrm{~cm} \\
\text { MOMENTO FLETOR MX NA CAPA }(\mathrm{kN} . \mathrm{cm} / \mathrm{cm})\end{array}$} \\
\hline \multirow{2}{*}{ Ponto } & \multicolumn{5}{|c|}{ Modelos numéricos de análise } \\
\hline & 01 & $\mathbf{0 2}$ & $\mathbf{0 3}$ & 04 & 05 \\
\hline $\mathbf{A}$ & 3,533 & 1,992 & 2,039 & 1,640 & 1,447 \\
\hline B & 3,375 & 1,902 & 1,945 & 1,538 & 1,366 \\
\hline D & 2,969 & 1,689 & 1,725 & 1,299 & 1,150 \\
\hline $\mathbf{G}$ & 2,307 & 1,347 & 1,375 & 0,907 & 0,784 \\
\hline $\mathrm{K}$ & 1,355 & 0,854 & 0,872 & 0,335 & 0,250 \\
\hline $\mathbf{P}$ & 0,035 & 0,108 & 0,105 & $-0,533$ & $-0,488$ \\
\hline $\bar{C}$ & 3,235 & 1,819 & 1,858 & 1,457 & 1,294 \\
\hline$E$ & 2,821 & 1,598 & 1,631 & 1,225 & 1,094 \\
\hline $\mathrm{H}$ & 2,158 & 1,253 & 1,277 & 0,847 & 0,752 \\
\hline $\mathbf{L}$ & 1,226 & 0,772 & 0,785 & 0,298 & 0,246 \\
\hline $\mathbf{Q}$ & $-0,044$ & $-0,013$ & $-0,018$ & $-0,545$ & $-0,462$ \\
\hline $\mathbf{F}$ & 2,457 & 1,393 & 1,421 & 1,059 & 0,951 \\
\hline I & 1,792 & 1,044 & 1,063 & 0,717 & 0,666 \\
\hline $\mathbf{M}$ & 0,895 & 0,584 & 0,590 & 0,224 & 0,235 \\
\hline $\mathbf{R}$ & $-0,269$ & $-0,201$ & $-0,214$ & $-0,539$ & $-0,393$ \\
\hline $\mathbf{J}$ & 1,273 & 0,753 & 0,764 & 0,526 & 0,526 \\
\hline $\mathbf{N}$ & 0,408 & 0,296 & 0,296 & 0,109 & 0,210 \\
\hline $\mathbf{S}$ & $-0,659$ & $-0,489$ & $-0,519$ & $-0,534$ & $-0,282$ \\
\hline 0 & $-0,078$ & $-0,010$ & $-0,018$ & $-0,023$ & 0,159 \\
\hline $\mathbf{T}$ & $-1,058$ & $-0,771$ & $-0,808$ & $-0,521$ & $-0,135$ \\
\hline$\overline{u U}$ & $-0,692$ & $-0,353$ & "-0,381 & "-0,294 & "-0,024 \\
\hline
\end{tabular}


TABELA 5.241: Momentos Fletores MX na capa, em kN.cm/cm, na laje com espaçamento entre os eixos das nervuras $\mathrm{E}=80 \mathrm{~cm}$

\begin{tabular}{|c|c|c|c|c|c|}
\hline \multicolumn{6}{|c|}{$\begin{array}{c}\text { VARIAÇÃO DO ESPAÇAMENTO ENTRE AS NERVURAS: E }=80 \mathrm{~cm} \\
\text { MOMENTO FLETOR MX NA CAPA }(\mathrm{kN} . \mathrm{cm} / \mathrm{cm})\end{array}$} \\
\hline \multirow{2}{*}{ Ponto } & \multicolumn{5}{|c|}{ Modelos numéricos de análise } \\
\hline & 01 & $\mathbf{0 2}$ & 03 & 04 & 05 \\
\hline A & 5,032 & 2,845 & 2,906 & 2,304 & 1,940 \\
\hline B & 4,802 & 2,718 & 2,775 & 2,162 & 1,825 \\
\hline D & 4,208 & 2,413 & 2,462 & 1,822 & 1,515 \\
\hline $\mathbf{G}$ & 3,242 & 1,922 & 1,960 & 1,259 & 0,988 \\
\hline $\mathrm{K}$ & 1,853 & 1,214 & 1,240 & 0,430 & 0,217 \\
\hline $\mathbf{P}$ & $-0,067$ & 0,132 & 0,130 & $-0,830$ & $-0,847$ \\
\hline $\bar{C}$ & 4,599 & 2,600 & 2,652 & 2,047 & 1,724 \\
\hline$E$ & 3,996 & 2,834 & 2,328 & 1,718 & 1,438 \\
\hline $\mathbf{H}$ & 3,028 & 1,787 & 1,821 & 1,177 & 0,947 \\
\hline $\mathbf{L}$ & 1,667 & 1,095 & 1,115 & 0,384 & 0,220 \\
\hline $\mathbf{Q}$ & $-0,184$ & $-0,039$ & $-0,046$ & $-0,834$ & $-0,799$ \\
\hline $\bar{F}$ & 3,471 & 1,989 & 2,026 & 1,481 & 1,241 \\
\hline I & 2,505 & 1,486 & 1,513 & 0,997 & 0,840 \\
\hline $\mathbf{M}$ & 1,195 & 0,821 & 0,830 & 0,290 & 0,225 \\
\hline $\mathbf{R}$ & $-0,511$ & $-0,313$ & $-0,345$ & $-0,803$ & $-0,672$ \\
\hline $\mathbf{J}$ & 1,762 & 1,065 & 1,081 & 0,731 & 0,660 \\
\hline $\mathbf{N}$ & 0,506 & 0,406 & 0,407 & 0,145 & 0,220 \\
\hline S & $-1,054$ & $-0,727$ & $-0,772$ & $-0,763$ & $-0,471$ \\
\hline 0 & $-0,171$ & $-0,031$ & $-0,038$ & $-0,022$ & 0,181 \\
\hline $\mathbf{T}$ & $-1,574$ & $-1,120$ & $-1,174$ & $-0,709$ & $-0,218$ \\
\hline$\overline{\mathbf{U}}$ & $-1,002$ & $-0,531$ & $-0,568$ & $-0,377$ & $-0,031$ \\
\hline
\end{tabular}

TABELA 5.242: Momentos Fletores MX na capa, em kN.cm/cm, na laje com espaçamento entre os eixos das nervuras $\mathrm{E}=90 \mathrm{~cm}$

\begin{tabular}{|c|c|c|c|c|c|}
\hline \multicolumn{6}{|c|}{$\begin{array}{c}\text { VARIAÇÃO DO ESPAÇAMENTO ENTRE AS NERVURAS: E }=90 \mathrm{~cm} \\
\text { MOMENTO FLETOR MX NA CAPA }(\mathrm{kN} . \mathrm{cm} / \mathrm{cm})\end{array}$} \\
\hline \multirow{2}{*}{ Ponto } & \multicolumn{5}{|c|}{ Modelos numéricos de análise } \\
\hline & 01 & 02 & 03 & 04 & 05 \\
\hline A & 6,861 & 3,893 & 3,971 & 3,102 & 2,523 \\
\hline B & 6,542 & 3,721 & 3,794 & 2,910 & 2,365 \\
\hline D & 5,715 & 3,301 & 3,365 & 2,441 & 1,938 \\
\hline $\mathbf{G}$ & 4,368 & 2,625 & 2,675 & 1,660 & 1,211 \\
\hline $\mathrm{K}$ & 2,432 & 1,649 & 1,686 & 0,508 & 0,145 \\
\hline $\mathbf{P}$ & $-0,235$ & 0,154 & 0,153 & $-1,247$ & $-1,323$ \\
\hline C & 6,262 & 3,560 & 3,627 & 2,751 & 2,228 \\
\hline$E$ & 5,424 & 3,126 & 3,184 & 2,299 & 1,837 \\
\hline $\mathbf{H}$ & 4,076 & 2,442 & 2,486 & 1,552 & 1,162 \\
\hline $\mathbf{L}$ & 2,178 & 1,486 & 1,514 & 0,452 & 0,159 \\
\hline $\mathbf{Q}$ & $-0,399$ & $-0,076$ & $-0,085$ & $-1,238$ & $-1,244$ \\
\hline $\bar{F}$ & $4,7,702$ & 2,720 & 2,768 & $1,1,974$ & $1,1,576$ \\
\hline I & 3,362 & 2,027 & 2,062 & 1,311 & 1,031 \\
\hline $\mathbf{M}$ & 1,536 & 1,105 & 1,120 & 0,338 & 0,190 \\
\hline $\mathbf{R}$ & $-0,849$ & $-0,453$ & $-0,485$ & $-1,171$ & $-1,039$ \\
\hline J & 2,347 & 1,446 & $1,1,467$ & 0,955 & 0,806 \\
\hline $\mathbf{N}$ & 0,608 & 0,535 & 0,539 & 0,162 & 0,218 \\
\hline S & $-1,572$ & $-1,018$ & $-1,082$ & $-1,077$ & $-0,719$ \\
\hline 0 & $-0,296$ & $-0,059$ & $-0,066$ & $-0,042$ & 0,199 \\
\hline $\mathbf{T}$ & $-2,220$ & $-1,540$ & $-1,615$ & $-0,960$ & $-0,326$ \\
\hline$\overline{\mathbf{U}}$ & $\begin{array}{l}-1,378 \\
\end{array}$ & $-0,756$ & $-0,803$ & $-0,491$ & $-0,039$ \\
\hline
\end{tabular}


Abaixo tem-se os gráficos de momentos fletores MX atuantes na capa das lajes nervuradas processadas nesta série.

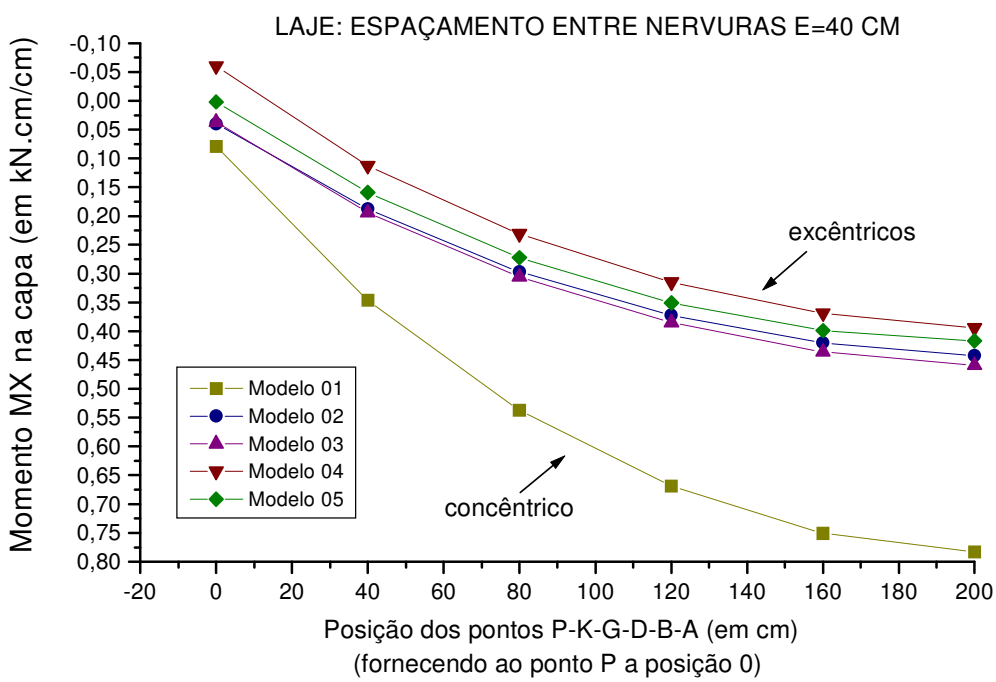

FIGURA 5.172: Momentos fletores MX (kN.cm/ $\mathrm{cm})$, na linha P-K-G-D-B-A da capa; laje com espaçamento entre os eixos das nervuras $\mathrm{E}=40 \mathrm{~cm}$

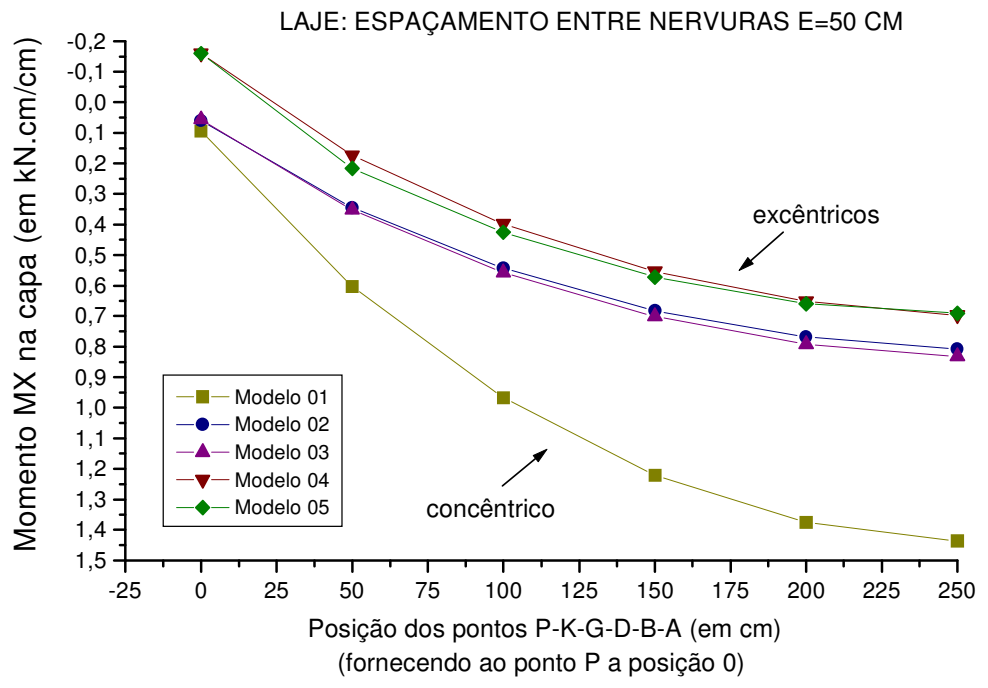

FIGURA 5.173: Momentos fletores MX (kN.cm/cm), na linha P-K-G-D-B-A da capa; laje com espaçamento entre os eixos das nervuras $\mathrm{E}=50 \mathrm{~cm}$ 


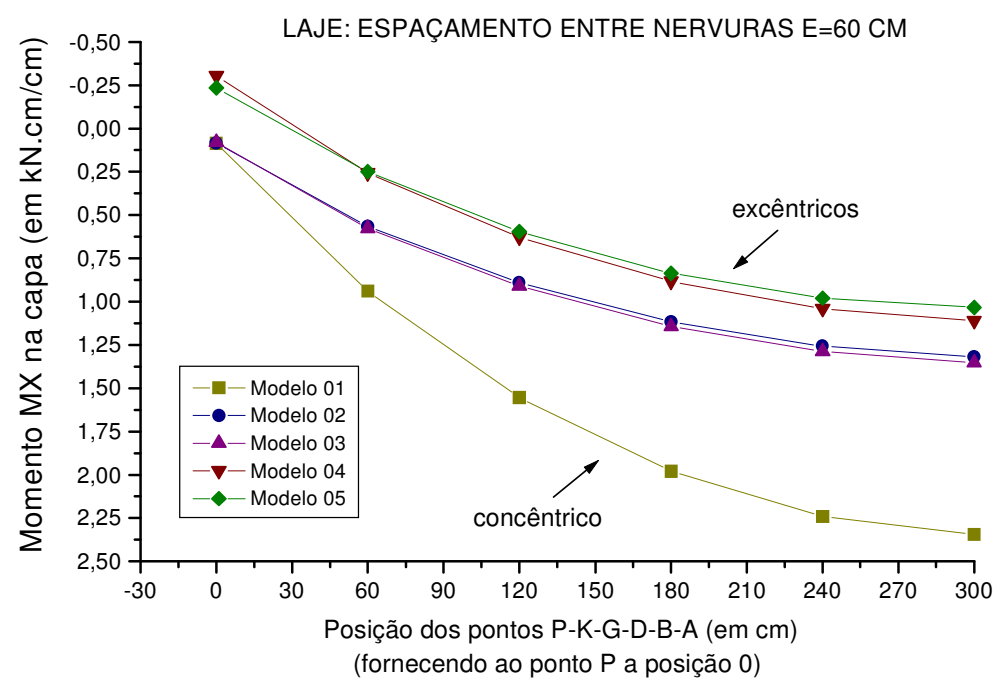

FIGURA 5.174: Momentos fletores MX $(\mathrm{kN} . \mathrm{cm} / \mathrm{cm})$, na linha P-K-G-D-B-A da capa; laje com espaçamento entre os eixos das nervuras $\mathrm{E}=60 \mathrm{~cm}$

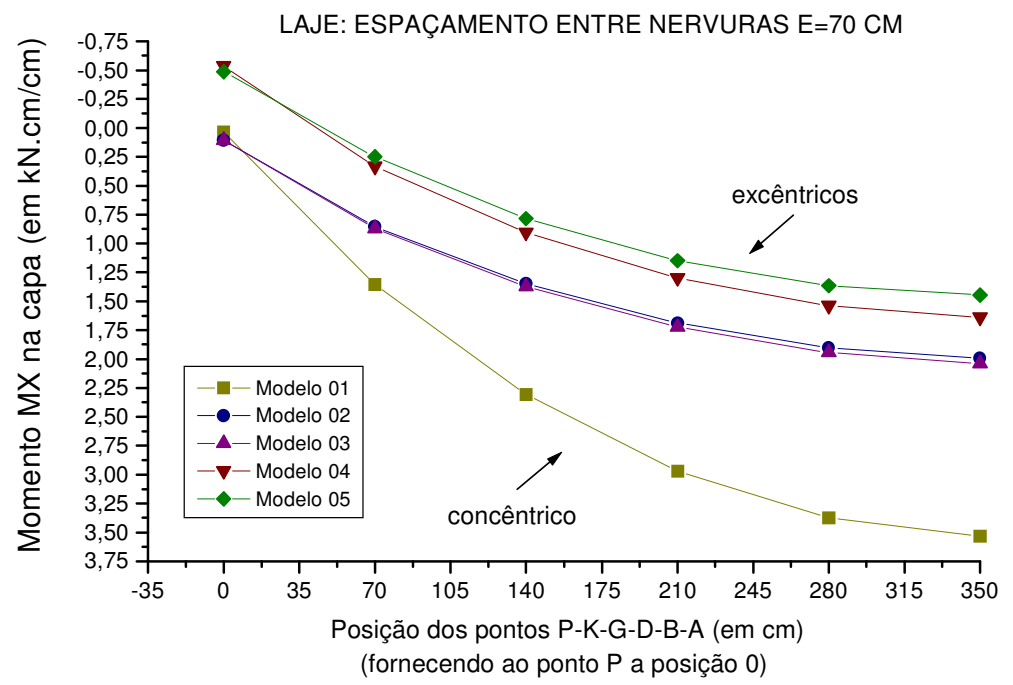

FIGURA 5.175: Momentos fletores MX $(\mathrm{kN} . \mathrm{cm} / \mathrm{cm})$, na linha P-K-G-D-B-A da capa; laje com espaçamento entre os eixos das nervuras $\mathrm{E}=70 \mathrm{~cm}$ 


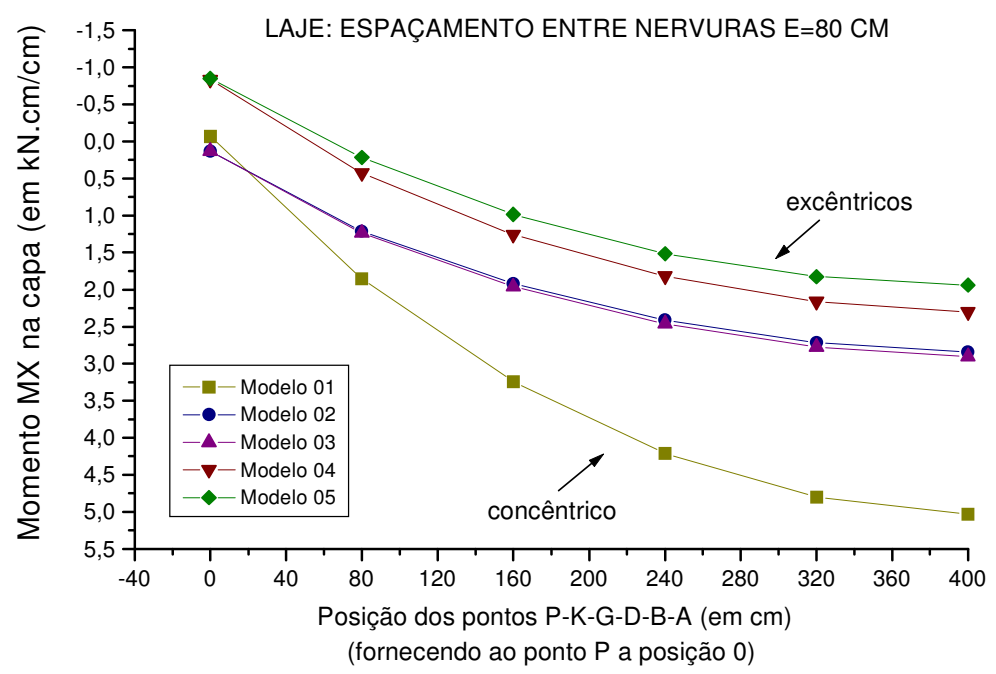

FIGURA 5.176: Momentos fletores MX (kN.cm/cm), na linha P-K-G-D-B-A da capa; laje com espaçamento entre os eixos das nervuras $\mathrm{E}=80 \mathrm{~cm}$

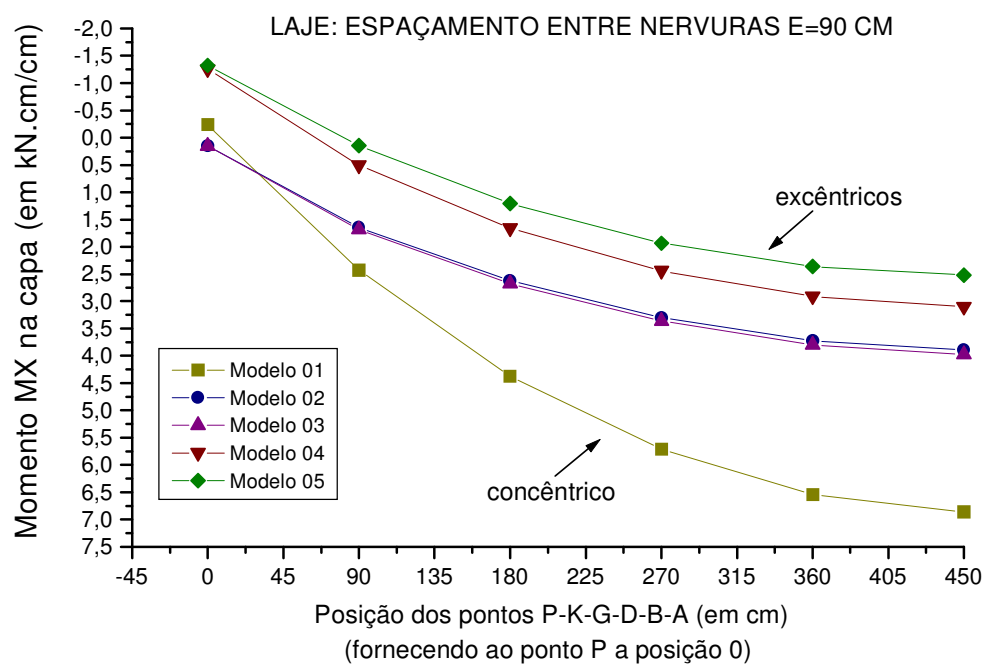

FIGURA 5.177: Momentos fletores MX (kN.cm/cm), na linha P-K-G-D-B-A da capa; laje com espaçamento entre os eixos das nervuras $\mathrm{E}=90 \mathrm{~cm}$

Analisando-se as tabelas e gráficos de momentos fletores MX na capa, nas lajes com variação do espaçamento entre os eixos das nervuras, pode-se afirmar que:

- o modelo concêntrico fornece momentos fletores muito maiores na capa que os modelos excêntricos;

- resultados mais próximos dados pelos modelos 02 e 03 , em comparação com os fornecidos pelo Modelo 04, aconteceram quando houve menor espaçamento entre os eixos das nervuras. Para $\mathrm{E}=40 \mathrm{~cm}$, o valor de MX máximo dado pelo Modelo 03 foi maior que o dado pelo modelo realista em $16,2 \%$; para $\mathrm{E}=90 \mathrm{~cm}$ essa diferença subiu para $28 \%$; 
- o Modelo 05, à medida que aumenta-se o espaçamento entre os eixos das nervuras, passa a apresentar momentos fletores menores na capa que os obtidos com o Modelo 04. Para E=50 cm a diferença entre ambos é de apenas $0,86 \%$, a menor para o Modelo 05; quando E=90 cm, essa diferença aumenta para 18,7\%, ainda a menor para o Modelo 05.

\subsubsection{Momentos Fletores MY atuantes na capa}

TABELA 5.243: Momentos Fletores MY na capa, em kN.cm/cm, na laje com espaçamento entre os eixos das nervuras $\mathrm{E}=40 \mathrm{~cm}$

\begin{tabular}{|c|c|c|c|c|c|}
\hline \multicolumn{6}{|c|}{$\begin{array}{c}\text { VARIAÇÃO DO ESPAÇAMENTO ENTRE AS NERVURAS: E }=40 \mathrm{~cm} \\
\text { MOMENTO FLETOR MY NA CAPA }(\mathrm{kN} . \mathrm{cm} / \mathrm{cm})\end{array}$} \\
\hline \multirow{2}{*}{ Ponto } & \multicolumn{5}{|c|}{ Modelos numéricos de análise } \\
\hline & 01 & $\mathbf{0 2}$ & $\mathbf{0 3}$ & 04 & 05 \\
\hline 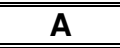 & 0,783 & 0,442 & 0,459 & 0,395 & 0,417 \\
\hline B & 0,755 & 0,425 & 0,441 & 0,379 & 0,400 \\
\hline $\mathbf{C}$ & 0,736 & 0,402 & 0,417 & 0,353 & 0,383 \\
\hline - D & 0,684 & 0,385 & 0,399 & 0,345 & 0,358 \\
\hline$E$ & 0,664 & 0,363 & 0,375 & 0,319 & 0,343 \\
\hline $\mathbf{F}$ & 0,593 & 0,314 & 0,324 & 0,266 & 0,303 \\
\hline$\overline{\mathbf{G}}$ & 0,565 & 0,323 & 0,334 & 0,292 & 0,293 \\
\hline $\mathbf{H}$ & 0,548 & 0,302 & 0,311 & 0,267 & 0,280 \\
\hline I & 0,482 & 0,256 & 0,264 & 0,217 & 0,248 \\
\hline $\mathbf{J}$ & 0,365 & 0,183 & 0,187 & 0,139 & 0,193 \\
\hline$\overline{\bar{K}}$ & 0,396 & 0,235 & 0,243 & 0,219 & 0,208 \\
\hline $\mathbf{L}$ & 0,384 & 0,218 & 0,224 & 0,198 & 0,199 \\
\hline $\mathbf{M}$ & 0,336 & 0,181 & 0,185 & 0,154 & 0,175 \\
\hline $\mathbf{N}$ & 0,240 & 0,115 & 0,116 & 0,083 & 0,134 \\
\hline 0 & 0,087 & 0,019 & 0,016 & $-0,017$ & 0,076 \\
\hline $\bar{P}$ & 0,171 & 0,140 & 0,142 & 0,116 & 0,099 \\
\hline $\mathbf{Q}$ & 0,166 & 0,113 & 0,116 & 0,095 & 0,091 \\
\hline $\mathbf{R}$ & 0,142 & 0,072 & 0,075 & 0,059 & 0,076 \\
\hline $\mathbf{S}$ & 0,088 & 0,012 & 0,015 & 0,005 & 0,051 \\
\hline $\mathbf{T}$ & $-0,009$ & $-0,063$ & $-0,060$ & $-0,071$ & 0,018 \\
\hline $\mathbf{U}$ & $-0,115$ & $-0,070$ & $-0,079$ & $-0,168$ & $-0,018$ \\
\hline
\end{tabular}


TABELA 5.244: Momentos Fletores MY na capa, em kN.cm/cm, na laje com espaçamento entre os eixos das nervuras $\mathrm{E}=50 \mathrm{~cm}$

\begin{tabular}{|c|c|c|c|c|c|}
\hline \multicolumn{6}{|c|}{$\begin{array}{c}\text { VARIAÇÃO DO ESPAÇAMENTO ENTRE AS NERVURAS: E }=50 \mathrm{~cm} \\
\text { MOMENTO FLETOR MY NA CAPA }(\mathrm{kN} . \mathrm{cm} / \mathrm{cm})\end{array}$} \\
\hline \multirow{2}{*}{ Ponto } & \multicolumn{5}{|c|}{ Modelos numéricos de análise } \\
\hline & 01 & 02 & $\mathbf{0 3}$ & 04 & 05 \\
\hline $\mathbf{A}$ & 1,436 & 0,808 & 0,832 & 0,697 & 0,691 \\
\hline B & 1,383 & 0,776 & 0,799 & 0,666 & 0,660 \\
\hline $\mathbf{C}$ & 1,321 & 0,735 & 0,756 & 0,620 & 0,629 \\
\hline$\overline{\mathbf{D}}$ & 1,245 & 0,699 & 0,719 & 0,593 & 0,581 \\
\hline$E$ & 1,183 & 0,658 & 0,675 & 0,550 & 0,554 \\
\hline$F$ & 1,021 & 0,567 & 0,582 & 0,459 & 0,484 \\
\hline$\overline{\mathbf{G}}$ & 1,015 & 0,575 & 0,590 & 0,481 & 0,459 \\
\hline $\mathrm{H}$ & 0,960 & 0,537 & 0,551 & 0,443 & 0,439 \\
\hline$I$ & 0,810 & 0,454 & 0,464 & 0,363 & 0,385 \\
\hline $\mathbf{J}$ & 0,562 & 0,317 & 0,323 & 0,234 & 0,292 \\
\hline $\bar{K}$ & 0,687 & 0,401 & 0,411 & $0, \mathbf{3 3 1}$ & 0,303 \\
\hline $\mathbf{L}$ & 0,649 & 0,372 & 0,380 & 0,302 & 0,290 \\
\hline $\mathbf{M}$ & 0,541 & 0,309 & 0,313 & 0,240 & 0,255 \\
\hline $\mathbf{N}$ & 0,334 & 0,191 & 0,191 & 0,135 & 0,196 \\
\hline 0 & 0,025 & 0,014 & 0,091 & $-0,019$ & 0,105 \\
\hline $\mathbf{P}$ & 0,253 & 0,197 & 0,199 & 0,132 & 0,108 \\
\hline $\mathbf{Q}$ & 0,235 & 0,152 & 0,156 & 0,107 & 0,100 \\
\hline $\mathbf{R}$ & 0,183 & 0,088 & 0,093 & 0,066 & 0,084 \\
\hline S & 0,077 & $-0,039$ & 0,000 & 0,003 & 0,060 \\
\hline$T$ & $-0,101$ & $-0,121$ & $-0,117$ & $-0,086$ & 0,030 \\
\hline $\mathbf{U}$ & $-0,263$ & $-0,127$ & $-0,141$ & $-0,191$ & $-0,018$ \\
\hline
\end{tabular}

TABELA 5.245: Momentos Fletores MY na capa, em kN.cm/cm, na laje com espaçamento entre os eixos das nervuras $\mathrm{E}=60 \mathrm{~cm}$

\begin{tabular}{|c|c|c|c|c|c|}
\hline \multicolumn{6}{|c|}{$\begin{array}{c}\text { VARIAÇÃO DO ESPAÇAMENTO ENTRE AS NERVURAS: E }=60 \mathrm{~cm} \\
\text { MOMENTO FLETOR MY NA CAPA }(\mathrm{kN} . \mathrm{cm} / \mathrm{cm})\end{array}$} \\
\hline \multirow{2}{*}{ Ponto } & \multicolumn{5}{|c|}{ Modelos numéricos de análise } \\
\hline & 01 & $\mathbf{0 2}$ & 03 & 04 & 05 \\
\hline 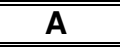 & 2,343 & 1,319 & 1,353 & 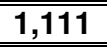 & 1,033 \\
\hline B B & 2,255 & 1,267 & 1,299 & 1,058 & 0,981 \\
\hline $\mathbf{C}$ & 2,150 & 1,202 & 1,231 & 0,989 & 0,932 \\
\hline 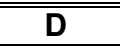 & 2,022 & 1,138 & 1,166 & 0,933 & 0,852 \\
\hline $\mathbf{E}$ & 1,917 & 1,072 & 1,096 & 0,869 & 0,810 \\
\hline $\mathbf{F}$ & 1,645 & 0,923 & 0,943 & 0,727 & 0,700 \\
\hline$\overline{\mathbf{G}}$ & 1,635 & 0,928 & 0,950 & 0,739 & 0,654 \\
\hline $\mathrm{H}$ & 1,542 & 0,867 & 0,886 & 0,685 & 0,624 \\
\hline I & 1,291 & 0,730 & 0,744 & 0,566 & 0,544 \\
\hline $\mathrm{J}$ & 0,875 & 0,505 & 0,513 & 0,369 & 0,404 \\
\hline $\bar{K}$ & 1,082 & 0,632 & 0,647 & 0,483 & 0,406 \\
\hline $\mathbf{L}$ & 1,020 & 0,588 & 0,598 & 0,444 & 0,389 \\
\hline $\mathbf{M}$ & 0,839 & 0,486 & 0,491 & 0,360 & 0,342 \\
\hline $\mathbf{N}$ & 0,497 & 0,296 & 0,294 & 0,213 & 0,262 \\
\hline 0 & $-0,014$ & 0,004 & $-0,002$ & $-0,013$ & 0,134 \\
\hline $\bar{P}$ & 0,357 & 0,270 & 0,273 & 0,149 & 0,104 \\
\hline $\mathbf{Q}$ & 0,330 & 0,201 & 0,206 & 0,123 & 0,095 \\
\hline $\mathbf{R}$ & 0,250 & 0,108 & 0,112 & 0,080 & 0,081 \\
\hline $\mathbf{S}$ & 0,087 & $-0,028$ & $-0,024$ & 0,010 & 0,061 \\
\hline $\mathrm{T}$ & $-0,184$ & $-0,204$ & $-0,200$ & $-0,098$ & 0,037 \\
\hline $\mathbf{U}$ & $-0,447$ & $-0,219$ & $-0,240$ & $-0,227$ & $-0,020$ \\
\hline
\end{tabular}


TABELA 5.246: Momentos Fletores MY na capa, em kN.cm/cm, na laje com espaçamento entre os eixos das nervuras $\mathrm{E}=70 \mathrm{~cm}$

\begin{tabular}{|c|c|c|c|c|c|}
\hline \multicolumn{6}{|c|}{$\begin{array}{c}\text { VARIAÇÃO DO ESPAÇAMENTO ENTRE AS NERVURAS: E = 70 cm } \\
\text { MOMENTO FLETOR MY NA CAPA }(\mathrm{kN} . \mathrm{cm} / \mathrm{cm})\end{array}$} \\
\hline \multirow{2}{*}{ Ponto } & \multicolumn{5}{|c|}{ Modelos numéricos de análise } \\
\hline & 01 & 02 & 03 & 04 & 05 \\
\hline $\mathbf{A}$ & 3,533 & 1,992 & 2,039 & 1,640 & 1,447 \\
\hline $\mathbf{B}$ & 3,397 & 1,914 & 1,957 & 1,558 & 1,369 \\
\hline $\mathbf{C}$ & 3,235 & 1,819 & 1,858 & 1,457 & 1,294 \\
\hline 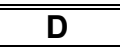 & 3,038 & 1,717 & 1,755 & 1,362 & 1,174 \\
\hline$E$ & 2,876 & 1,619 & 1,652 & 1,269 & 1,114 \\
\hline $\mathbf{F}$ & 2,457 & 1,393 & 1,421 & 1,059 & 0,951 \\
\hline$\overline{\mathbf{G}}$ & 2,441 & $1,1,394$ & 1,424 & 1,059 & 0,880 \\
\hline $\mathrm{H}$ & 2,298 & 1,304 & 1,329 & 0,983 & 0,838 \\
\hline$I$ & 1,913 & 1,095 & 1,114 & 0,811 & 0,726 \\
\hline $\mathbf{J}$ & 1,273 & 0,753 & 0,764 & 0,526 & 0,526 \\
\hline $\bar{K}$ & 1,593 & 0,938 & 0,959 & 0,662 & 0,515 \\
\hline $\mathbf{L}$ & 1,496 & 0,872 & 0,887 & 0,610 & 0,493 \\
\hline $\mathbf{M}$ & 1,217 & 0,720 & 0,726 & 0,496 & 0,434 \\
\hline $\mathbf{N}$ & 0,697 & 0,432 & 0,429 & 0,294 & 0,331 \\
\hline 0 & $-0,078$ & $-0,010$ & $-0,018$ & $-0,023$ & 0,159 \\
\hline $\mathbf{P}$ & 0,483 & 0,361 & 0,363 & 0,152 & 0,084 \\
\hline $\mathbf{Q}$ & 0,442 & 0,265 & 0,269 & 0,125 & 0,075 \\
\hline $\mathbf{R}$ & 0,325 & 0,134 & 0,138 & 0,079 & 0,065 \\
\hline S & 0,087 & $-0,055$ & $-0,055$ & 0,002 & 0,054 \\
\hline$T$ & $-0,302$ & $-0,308$ & $-0,309$ & $-0,128$ & 0,038 \\
\hline $\mathbf{U}$ & $-0,692$ & $-0,353$ & $-0,381$ & $-0,294$ & $-0,024$ \\
\hline
\end{tabular}

TABELA 5.247: Momentos Fletores MY na capa, em kN.cm/cm, na laje com espaçamento entre os eixos das nervuras $\mathrm{E}=80 \mathrm{~cm}$

\begin{tabular}{|c|c|c|c|c|c|}
\hline \multicolumn{6}{|c|}{$\begin{array}{c}\text { VARIAÇÃO DO ESPAÇAMENTO ENTRE AS NERVURAS: E }=80 \mathrm{~cm} \\
\text { MOMENTO FLETOR MY NA CAPA }(\mathrm{kN} . \mathrm{cm} / \mathrm{cm})\end{array}$} \\
\hline \multirow{2}{*}{ Ponto } & \multicolumn{5}{|c|}{ Modelos numéricos de análise } \\
\hline & $\mathbf{0 1}$ & $\mathbf{0 2}$ & $\mathbf{0 3}$ & 04 & 05 \\
\hline$\overline{\mathbf{A}}$ & 5,032 & 2,845 & 2,906 & 2,304 & 1,940 \\
\hline B & 4,834 & 2,734 & 2,791 & 2,186 & 1,830 \\
\hline $\mathbf{C}$ & 4,599 & 2,600 & 2,652 & 2,047 & 1,724 \\
\hline 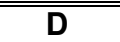 & 4,313 & 2,451 & 2,501 & $1,1,902$ & 1,554 \\
\hline$E$ & 4,078 & 2,312 & 2,356 & 1,775 & 1,470 \\
\hline $\mathbf{F}$ & 3,471 & 1,989 & 2,026 & 1,481 & 1,241 \\
\hline$\overline{\mathbf{G}}$ & 3,450 & 1,984 & 2,024 & 1,461 & 1,139 \\
\hline $\mathbf{H}$ & 3,243 & 1,857 & 1,891 & 1,360 & 1,083 \\
\hline I & 2,686 & 1,557 & 1,582 & 1,126 & 0,932 \\
\hline $\mathrm{J}$ & 1,762 & 1,065 & 1,081 & 0,731 & 0,660 \\
\hline $\bar{K}$ & 2,227 & 1,324 & 1,353 & 0,887 & 0,631 \\
\hline $\mathbf{L}$ & 2,085 & 1,232 & 1,253 & 0,821 & 0,604 \\
\hline $\mathbf{M}$ & 1,680 & 1,013 & 1,021 & 0,673 & 0,532 \\
\hline $\mathbf{N}$ & 0,935 & 0,601 & 0,598 & 0,406 & 0,403 \\
\hline 0 & $-0,171$ & $-0,031$ & $-0,038$ & $-0,022$ & 0,181 \\
\hline $\bar{P}$ & 0,631 & 0,471 & 0,473 & 0,156 & 0,046 \\
\hline $\mathbf{Q}$ & 0,573 & 0,346 & 0,348 & 0,129 & 0,038 \\
\hline $\mathbf{R}$ & 0,405 & 0,172 & 0,172 & 0,084 & 0,035 \\
\hline S & 0,073 & $-0,085$ & $-0,090$ & 0,000 & 0,036 \\
\hline$T$ & $-0,459$ & $-0,432$ & $-0,439$ & $-0,154$ & 0,035 \\
\hline $\mathbf{U}$ & $-1,002$ & $-0,531$ & $-0,568$ & $-0,377$ & $-0,031$ \\
\hline
\end{tabular}


TABELA 5.248: Momentos Fletores MY na capa, em kN.cm/cm, na laje com espaçamento entre os eixos das nervuras $\mathrm{E}=90 \mathrm{~cm}$

\begin{tabular}{|c|c|c|c|c|c|}
\hline \multicolumn{6}{|c|}{$\begin{array}{c}\text { VARIAÇÃO DO ESPAÇAMENTO ENTRE AS NERVURAS: E }=90 \mathrm{~cm} \\
\text { MOMENTO FLETOR MY NA CAPA }(\mathrm{kN} . \mathrm{cm} / \mathrm{cm})\end{array}$} \\
\hline \multirow{2}{*}{ Ponto } & \multicolumn{5}{|c|}{ Modelos numéricos de análise } \\
\hline & 01 & 02 & $\mathbf{0 3}$ & 04 & 05 \\
\hline 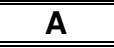 & 6,861 & 3,893 & 3,971 & 3,102 & 2,523 \\
\hline B B & 6,587 & 3,741 & 3,815 & 2,939 & 2,373 \\
\hline $\mathbf{C}$ & 6,262 & 3,560 & 3,627 & 2,751 & 2,228 \\
\hline D D & 5,866 & 3,352 & 3,416 & 2,543 & 1,996 \\
\hline$E$ & 5,542 & 3,164 & 3,222 & 2,374 & 1,884 \\
\hline $\mathbf{F}$ & 4,702 & 2,720 & 2,768 & 1,974 & 1,576 \\
\hline $\mathbf{G}$ & 4,675 & 2,708 & 2,761 & 1,931 & 1,435 \\
\hline $\mathrm{H}$ & 4,388 & 2,536 & 2,580 & 1,798 & 1,363 \\
\hline$I$ & 3,620 & 2,124 & 2,156 & 1,486 & 1,166 \\
\hline $\mathrm{J}$ & 2,347 & 1,446 & 1,467 & 0,955 & 0,806 \\
\hline $\bar{K}$ & 2,991 & 1,797 & 1,835 & 1,138 & 0,754 \\
\hline $\mathbf{L}$ & 2,793 & 1,672 & 1,700 & 1,055 & 0,723 \\
\hline $\mathbf{M}$ & 2,232 & 1,369 & 1,381 & 0,864 & 0,637 \\
\hline $\mathbf{N}$ & 1,213 & 0,804 & 0,802 & 0,519 & 0,480 \\
\hline 0 & $-0,296$ & $-0,059$ & $-0,066$ & $-0,042$ & 0,199 \\
\hline $\mathbf{P}$ & 0,800 & 0,603 & $-0,603$ & 0,138 & $-0,012$ \\
\hline $\mathbf{Q}$ & 0,720 & 0,445 & 0,445 & 0,112 & $-0,018$ \\
\hline $\mathbf{R}$ & 0,490 & 0,221 & 0,217 & 0,067 & $-0,011$ \\
\hline $\mathrm{S}$ & 0,044 & $-0,115$ & $-0,128$ & $-0,022$ & 0,008 \\
\hline $\mathbf{T}$ & $-0,657$ & $-0,576$ & $-0,592$ & $-0,202$ & 0,026 \\
\hline $\mathbf{U}$ & $-1,378$ & $-0,756$ & $-0,803$ & $-0,491$ & $-0,039$ \\
\hline
\end{tabular}

\subsubsection{Esforços Normais e Momentos Fletores no topo dos pilares}

TABELA 5.249: Esforço Normal, em kN, e Momentos Fletores MX e MY, em kN.cm, nos pilares da laje com espaçamento entre os eixos das nervuras $\mathrm{E}=40 \mathrm{~cm}$

\begin{tabular}{|c|c|c|c|c|c|c|c|c|}
\hline \multicolumn{9}{|c|}{$\begin{array}{c}\text { VARIAÇÃO DO ESPAÇAMENTO ENTRE NERVURAS: E }=40 \mathrm{~cm} \\
\text { ESFORÇO NORMAL NOS PILARES (kN) }\end{array}$} \\
\hline \multirow{2}{*}{ Pilares } & \multicolumn{8}{|c|}{ Modelos numéricos de análise } \\
\hline & 01 & 02 & $\mathbf{0 3}$ & 04 & 05 & 06 & 07 & 08 \\
\hline P1 A P4 & $-36,30$ & $-36,30$ & $-36,30$ & $-36,30$ & $-36,30$ & $-36,30$ & $-36,30$ & $-36,30$ \\
\hline \multicolumn{9}{|c|}{$\begin{array}{l}\text { VARIAÇÃO DO ESPAÇAMENTO ENTRE NERVURAS: E }=40 \mathrm{~cm} \\
\text { MOMENTOS FLETORES MX E MY NO TOPO DOS PILARES }(\mathrm{kN.cm})\end{array}$} \\
\hline \multirow{2}{*}{ Pilares } & \multicolumn{8}{|c|}{ Modelos numéricos de análise } \\
\hline & 01 & 02 & 03 & 04 & 05 & 06 & 07 & 08 \\
\hline P1 A P4 & 1009,00 & 1085,00 & 11110,00 & 1278,00 & 896,40 & 876,10 & 963,90 & 1076,00 \\
\hline
\end{tabular}


TABELA 5.250: Esforço Normal, em kN, e Momentos Fletores MX e MY, em kN.cm, nos pilares da laje com espaçamento entre os eixos das nervuras $\mathrm{E}=50 \mathrm{~cm}$

\begin{tabular}{|c|c|c|c|c|c|c|c|c|}
\hline \multicolumn{9}{|c|}{$\begin{array}{c}\text { VARIAÇÃO DO ESPAÇAMENTO ENTRE NERVURAS: E }=50 \mathrm{~cm} \\
\text { ESFORCO NORMAL NOS PILARES (kN) }\end{array}$} \\
\hline \multirow{2}{*}{ Pilares } & \multicolumn{8}{|c|}{ Modelos numéricos de análise } \\
\hline & 01 & 02 & 03 & 04 & 05 & 06 & 07 & 08 \\
\hline P1 A P4 & $-56,72$ & $-56,72$ & $-56,72$ & $-56,72$ & $-56,72$ & $-56,72$ & $-56,72$ & $-56,72$ \\
\hline \multicolumn{9}{|c|}{$\begin{array}{c}\text { VARIAÇÃO DO ESPAÇAMENTO ENTRE NERVURAS: E }=50 \mathrm{~cm} \\
\text { MOMENTOS FLETORES MX E MY NO TOPO DOS PILARES }(\mathrm{kN} . \mathrm{cm})\end{array}$} \\
\hline \multirow{2}{*}{ Pilares } & \multicolumn{8}{|c|}{ Modelos numéricos de análise } \\
\hline & 01 & 02 & $\mathbf{0 3}$ & 04 & 05 & 06 & 07 & 08 \\
\hline P1 A P4 & 1654,00 & 1793,00 & 1832,00 & 2140,00 & 1425,00 & 1369,00 & 1540,00 & 1703,00 \\
\hline
\end{tabular}

TABELA 5.251: Esforço Normal, em kN, e Momentos Fletores MX e MY, em kN.cm, nos pilares da laje com espaçamento entre os eixos das nervuras $E=60 \mathrm{~cm}$

\begin{tabular}{|c|c|c|c|c|c|c|c|c|}
\hline \multicolumn{9}{|c|}{$\begin{array}{c}\text { VARIAÇÃO DO ESPAÇAMENTO ENTRE NERVURAS: E }=60 \mathrm{~cm} \\
\text { ESFORÇO NORMAL NOS PILARES }(\mathrm{kN})\end{array}$} \\
\hline \multirow{2}{*}{ Pilares } & \multicolumn{8}{|c|}{ Modelos numéricos de análise } \\
\hline & 01 & 02 & 03 & 04 & 05 & 06 & 07 & 08 \\
\hline P1 A P4 & $-81,68$ & $-81,68$ & $-81,68$ & $-81,68$ & $-81,68$ & $-81,68$ & $-81,68$ & $-81,68$ \\
\hline \multicolumn{9}{|c|}{$\begin{array}{l}\text { VARIAÇÃO DO ESPAÇAMENTO ENTRE NERVURAS: E }=60 \mathrm{~cm} \\
\text { MOMENTOS FLETORES MX E MY NO TOPO DOS PILARES }(\mathrm{kN} . \mathrm{cm})\end{array}$} \\
\hline \multirow{2}{*}{ Pilares } & \multicolumn{8}{|c|}{ Modelos numéricos de análise } \\
\hline & 01 & $\mathbf{0 2}$ & 03 & 04 & 05 & 06 & 07 & 08 \\
\hline P1 A P4 & 2378,00 & 2600,00 & 2653,00 & 3157,00 & 1995,00 & 1878,00 & 2168,00 & 2380,00 \\
\hline
\end{tabular}

TABELA 5.252: Esforço Normal, em kN, e Momentos Fletores MX e MY, em kN.cm, nos pilares da laje com espaçamento entre os eixos das nervuras $\mathrm{E}=70 \mathrm{~cm}$

\begin{tabular}{|c|c|c|c|c|c|c|c|c|}
\hline \multicolumn{9}{|c|}{$\begin{array}{c}\text { VARIAÇÃO DO ESPAÇAMENTO ENTRE NERVURAS: E }=70 \mathrm{~cm} \\
\text { ESFORÇO NORMAL NOS PILARES }(\mathrm{kN})\end{array}$} \\
\hline \multirow{2}{*}{ Pilares } & \multicolumn{8}{|c|}{ Modelos numéricos de análise } \\
\hline & 01 & 02 & 03 & 04 & 05 & 06 & 07 & 08 \\
\hline P1 A P4 & $-111,17$ & $-111,17$ & $\begin{array}{ll}-111,17 \\
\end{array}$ & $-111,17$ & $-111,17$ & $\begin{array}{l}-111,17 \\
\end{array}$ & $\begin{array}{ll}-111,17 \\
\end{array}$ & $\begin{array}{ll}-111,17 \\
\end{array}$ \\
\hline \multicolumn{9}{|c|}{$\begin{array}{l}\text { VARIAÇÃO DO ESPAÇAMENTO ENTRE NERVURAS: } \mathrm{E}=70 \mathrm{~cm} \\
\text { MOMENTOS FLETORES MX E MY NO TOPO DOS PILARES }(\mathrm{kN} . \mathrm{cm})\end{array}$} \\
\hline \multirow{2}{*}{ Pilares } & \multicolumn{8}{|c|}{ Modelos numéricos de análise } \\
\hline & 01 & $\mathbf{0 2}$ & $\mathbf{0 3}$ & 04 & 05 & 06 & $\mathbf{0 7}$ & $\mathbf{0 8}$ \\
\hline P1 A P4 & 3141,00 & 3462,00 & 3530,00 & 4301,00 & 2582,00 & 2379,00 & 2818,00 & 3078,00 \\
\hline
\end{tabular}


TABELA 5.253: Esforço Normal, em kN, e Momentos Fletores MX e MY, em kN.cm, nos pilares da laje com espaçamento entre os eixos das nervuras $\mathrm{E}=80 \mathrm{~cm}$

\begin{tabular}{|c|c|c|c|c|c|c|c|c|}
\hline \multicolumn{9}{|c|}{$\begin{array}{c}\text { VARIAÇÃO DO ESPAÇAMENTO ENTRE NERVURAS: } \mathrm{E}=80 \mathrm{~cm} \\
\text { ESFORÇO NORMAL NOS PILARES }(\mathrm{kN})\end{array}$} \\
\hline \multirow{2}{*}{ Pilares } & \multicolumn{8}{|c|}{ Modelos numéricos de análise } \\
\hline & 01 & 02 & 03 & 04 & 05 & 06 & 07 & 08 \\
\hline P1 A P4 & $-145,20$ & $-145,20$ & $-145,20$ & $-145,20$ & $-145,20$ & $-145,20$ & $-145,20$ & $-145,20$ \\
\hline \multicolumn{9}{|c|}{$\begin{array}{c}\text { VARIAÇÃO DO ESPAÇAMENTO ENTRE NERVURAS: } \mathrm{E}=80 \mathrm{~cm} \\
\text { MOMENTOS FLETORES MX E MY NO TOPO DOS PILARES }(\mathrm{kN.cm})\end{array}$} \\
\hline \multirow{2}{*}{ Pilares } & \multicolumn{8}{|c|}{ Modelos numéricos de análise } \\
\hline & 01 & 02 & 03 & 04 & 05 & 06 & 07 & 08 \\
\hline P1 A P4 & 3917,00 & 4353,00 & 4435,00 & 5549,00 & 3171,00 & 2864,00 & 3473,00 & 3779,00 \\
\hline
\end{tabular}

TABELA 5.254: Esforço Normal, em kN, e Momentos Fletores MX e MY, em kN.cm, nos pilares da laje com espaçamento entre os eixos das nervuras $\mathrm{E}=90 \mathrm{~cm}$

\begin{tabular}{|c|c|c|c|c|c|c|c|c|}
\hline \multicolumn{9}{|c|}{$\begin{array}{c}\text { VARIAÇÃO DO ESPAÇAMENTO ENTRE NERVURAS: E }=90 \mathrm{~cm} \\
\text { ESFORÇO NORMAL NOS PILARES }(\mathrm{kN})\end{array}$} \\
\hline \multirow{2}{*}{ Pilares } & \multicolumn{8}{|c|}{ Modelos numéricos de análise } \\
\hline & 01 & 02 & 03 & 04 & 05 & 06 & 07 & 08 \\
\hline P1 A P4 & $-183,77$ & $-183,77$ & $-183,77$ & $-183,77$ & $-183,77$ & $-183,77$ & $-183,77$ & $-183,77$ \\
\hline \multicolumn{9}{|c|}{$\begin{array}{l}\text { VARIAÇÃO DO ESPAÇAMENTO ENTRE NERVURAS: E }=90 \mathrm{~cm} \\
\text { MOMENTOS FLETORES MX E MY NO TOPO DOS PILARES }(\mathrm{kN.cm})\end{array}$} \\
\hline \multirow{2}{*}{ Pilares } & \multicolumn{8}{|c|}{ Modelos numéricos de análise } \\
\hline & 01 & $\mathbf{0 2}$ & 03 & 04 & 05 & 06 & 07 & 08 \\
\hline P1 A P4 & 4693,00 & 5254,00 & 5351,00 & 6898,00 & 3756,00 & 3337,00 & 4126,00 & 4477,00 \\
\hline
\end{tabular}





\section{CAPÍTULO 6 - CONSIDERAÇÕES FINAIS E CONCLUSÕES}

Neste trabalho foram apresentadas as considerações teóricas necessárias para a análise de lajes nervuradas utilizando modelos em Método dos Elementos Finitos, indicando-se modelos mecânicos de cálculo possíveis, dos mais simplificados aos realistas, na consideração da excentricidade existente entre os eixos das nervuras e do plano médio da capa.

A modelagem de lajes nervuradas desconsiderando a excentricidade nervuracapa forneceu resultados muito distantes do comportamento real das lajes, em análises elásticas. Os deslocamentos obtidos foram sempre muito maiores, chegando a mais de $100 \%$, assim como os esforços finais nas seções, o que leva a um superdimensionamento das peças.

$\mathrm{O}$ modelo que apresentou os melhores resultados nos testes efetuados foi o Modelo 04, onde a capa e as nervuras foram simuladas pelo elemento finito de casca SHELL63, do software ANSYS 5.5.

Quando a análise é efetuada por modelos tridimensionais, em MEF, as peças devem sempre serem verificadas e dimensionadas a esforços combinados: flexo-tração ou flexo-compressão; os modelos que simulam a excentricidade das vigas por "offsets rígidos", Modelos 02 e 03, e o modelo realista apresentaram, frente aos outros modelos mais simplificados, momentos fletores com valores mais baixos nas nervuras, mesmo havendo deslocamentos da laje na mesma ordem entre todos os modelos que consideraram a excentricidade neste trabalho. Porém, mostraram elevados esforços de tração nas nervuras, haja visto que as mesmas, lançadas de maneira excêntrica à capa comprimida, recebem toda a parcela de tração do momento fletor gerado pelos deslocamentos ortogonais ao plano da placa, em função do carregamento aplicado. Os modelos simplificados, que simulam a excentricidade por meio de seções " $\mathrm{T}$ " atribuídas a elementos finitos concêntricos de viga 
BEAM4 (Modelos 05 e 06) ou de casca com equivalência em inércia destas seções (Modelos 07 e 08), em contrapartida, apresentaram elevados valores de momentos fletores para as as nervuras, porém as mesmas sofreram esforços normais de compressão, de ordem mais baixa que a tração obtida nos modelos anteriores, já que estão concêntricos à capa comprimida. Dessa forma, a composição flexão-esforço normal levou a um equilíbrio dos resultados de esforços nas nervuras entre todos os sistemas.

Para os modelos 02 e 03 apresentados, que simulam as nervuras pelo elemento de viga excêntrica BEAM44, ora considerando como nervura a seção até a face superior da capa, ora até a face inferior, podem ser feitas as seguintes observações:

- estes modelos mostraram-se extremamente dependentes da relação entre a altura da capa pela altura total da laje $\left(h_{f} / h\right)$, já que este é o fator para geração automática do "offset rígido" no elemento finito; melhores resultados para as nervuras, em termos de deslocamentos e tensões normais, foram obtidos para baixos valores da relação, ou seja, para maiores excentricidades ensaiadas numericamente. Conforme DEB et al (1990) os parâmetros de excentricidade das formulações de elementos que a consideram são determinantes nos resultados destes modelos. Assim, nas excentricidades baixas comportaram-se com mais flexibilidade que a estrutura real, conforme comparado com o Modelo 04; da mesma maneira, para estes modelos, quanto menor foi a relação $h_{f} / h$, melhores foram os resultados de momentos fletores na capa, quando comparados ao modelo realista;

- quando simulando as nervuras, ofereceram às vigas rígidas, modeladas também pelo elemento excêntrico BEAM44, os melhores resultados de deslocamentos em todas as variações dos parâmetros geométricos feitas nas lajes, frente aos obtidos pelo Modelo 04. Quanto menor foi a relação $a_{1} / 1$, sendo $a_{1}=$ distância entre os eixos das nervuras e 1 = distância entre os apoios da laje, verificou-se também que melhores foram os resultados de deslocamentos para as vigas rígidas nestes modelos, haja visto que em todos a viga simulada pelo Modelo 04 foi a mais flexível e, à medida que diminui-se a relação $\mathrm{a}_{1} / \mathrm{l}$, mais flexíveis são os modelos 02 e 03 frente ao modelo realista o que, em contrapartida, leva a grandes diferenças quanto ao deslocamento das nervuras; essa demasiada flexibilidade é também incrementada à medida que aumenta-se o espaçamento entre as nervuras;

- apresentaram para as cortantes nas nervuras os valores mais próximos daqueles fornecidos pelo Modelo 04, sendo sensíveis à variação da relação $h_{f} / h$ : para $\mathrm{h}_{\mathrm{f}} / \mathrm{h}=0,333$, a cortante máxima da nervura central do Modelo 02 diferenciou-se em $4 \%$, a maior, daquela dada pelo modelo realista; para $\mathrm{h}_{\mathrm{f}} / \mathrm{h}=0,143$ esse erro foi de $20 \%$; 
- os momentos fletores na capa das lajes nervuradas também mostraram-se dependentes da excentricidade nestes modelos, precisamente da variação da relação $h_{f} / h$ : quanto maior a excentricidade nervuras-capa, mais próximos são os resultados destes quando comparados as resultados do Modelo $04\left(\right.$ para $h_{f} / h=0,333$, o máximo momento fletor positivo na capa apresentou um erro de $32 \%$, a maior para o valor encontrado Modelo 02; para $h_{f} / h=0,100$ a diferença foi de apenas $6,25 \%$, agora a maior para o modelo realista);

- os momentos fletores no topo dos pilares obtidos pelos modelos 02 e 03 , em todas as lajes testadas, foram os mais próximos daqueles apresentados pelo Modelo 04, sendo estes sempre maiores. Para $h_{f} / h=0,333$ verificou-se um erro de $21 \%$, a menor para o Modelo 02; para $h_{f} / h=0,100$ o erro foi de apenas $4 \%$, ou seja, quanto maior a excentricidade, melhor o comportamento dos modelos 02 e 03 frente ao modelo realista; quanto maior a relação $a_{1} / l$, menores são os erros dos resultados de momentos nos pilares dos modelos simplificados em relação àquele dado pelo Modelo 04: erro de $17 \%$, para $\mathrm{a}_{1} / \mathrm{l}=0,1667$, a menor para o Modelo 02, e de 25,5\% quando tem-se $a_{1} / l=0,0625$.

Para os modelos 05 e 06 apresentados, que simulam as nervuras pelo elemento concêntrico BEAM4, considerando as características geométricas das seções "T", com a capa sendo simulada pelo elemento de casca SHELL63 no Modelo 05 e sem a capa no Modelo 06, podem ser feitas as seguintes anotações:

- em termos de deslocamentos nas nervuras os modelos apresentaram comportamentos diferentes: o Modelo 06 mostrou-se dependente da relação $h_{f} / h$, com melhores resultados para baixas excentricidades frente ao modelo realista ( para $_{\mathrm{f}} / \mathrm{h}=0,333 \mathrm{o}$ erro foi de apenas $3,54 \%$, subindo para $18,7 \%$ quando $h_{f} / h=0,100$, a menor para o Modelo 06, no deslocamento máximo da nervura central); o Modelo 05 não apresentou variação das diferenças em comparação ao Modelo 04 com a variação da relação $h_{f} / h$, apresentado erros de 15 a $20 \%$ no deslocamento máximo (lembra-se que neste modelo a capa é simulada). À medida que diminuiu-se a relação $a_{1} / l$, ou seja, quando fez-se um número maior de nervuras por lado, mais rígidos ainda estes modelos se apresentaram frente aos resultados do modelo realista, gerando também um afastamento entre os resultados apresentados pelo Modelo 05 em comparação àqueles do Modelo 06, onde o Modelo 05 foi ficando cada vez mais rígido frente ao Modelo 04, em comparação com o Modelo 06. O mesmo ocorreu com o aumento do espaçamento entre as nervuras, pois aí a estrutura real estava mais flexível, já que foram mantidas as mesmas características geométricas das seções das nervuras nas análises efetuadas, em qualquer espaçamento;

- apresentaram ótimos resultados de tensões normais de tração nas seções mais solicitadas das nervuras quando comparadas às oferecidas pelo Modelo 04, em todos os 
modelos analisados com variação de $\mathrm{h}_{\mathrm{f}} / \mathrm{h}$, com erros de no máximo $13 \%$, apresentado pela máxima tensão nas nervuras do Modelo 06 para $h_{f} / h=0,100$. Os melhores resultados para 0 Modelo 05 foram achados na relação $h_{f} / h=0,111$, onde a tensão máxima apresentou erro de $4 \%$, a menor, para o Modelo 05, e $\mathrm{h}_{\mathrm{f}} / \mathrm{h}=0,200$ para o Modelo 06, onde o mesmo demonstrou erro de apenas $1 \%$, com tensão menor que a dada pelo modelo realista; melhores também forma os resultados destes modelos à medida que diminuiu-se a relação $a_{1} / l$, ou quando aumentou-se o espaçamento entre as nervuras. Para $a_{1} / l=0,1667$ o erro da tensão máxima de tração nas nervuras pelo Modelo 06 foi de $13,8 \%$, a maior; para $a_{1} / 1=0,0833$ esta diferença foi nula;

- os modelos 05 e 06 foram os que apresentaram os maiores valores de cortantes nas nervuras: à medida que diminuiu-se a relação $h_{f} / h$, mais próximos os esforços cortantes destes ficaram em relação àqueles apresentados pelos modelos 02 e 03;

- no modelo 05, onde foi possível medir os momentos fletores na capa da laje nervurada, verificou-se que os resultados independem da relação $h_{f} / h$; ao diminuírmos a relação $a_{1} / 1$, ou aumentarmos o espaçamento entre as nervuras, porém, os momentos fletores apresentaram-se menores do que os momentos obtidos pelo Modelo 04: encontrou-se erros de no máximo $16,5 \%$, entre os resultados de momentos na capa apresentados pelo Modelo 05, em comparação com o modelo realista, para $a_{1} / 1=0,0625$, a menor para o modelo simplificado.

Para os modelos 07 e 08 ensaiados numericamente, modelos de laje maciça com equivalência em inércia à flexão, com redução do módulo de elasticidade transversal do concreto $\left(\mathrm{G}_{\mathrm{c}}\right)$ para o Modelo 07 , e com redução da espessura equivalente, conforme ABDUL-WAHAB \& KHALIL (2000), para o Modelo 08, lajes estas simuladas pelo elemento de casca SHELL63, podem ser feitos os seguintes comentários:

- não foram aplicados neste trabalho lajes maciças equivalentes sem reduções, haja visto que pela bibliografia consultada, e por testes realizados [DIAS et al. (2001)], verificou-se que este sistema é intrinsicamente mais rígido que a estrutura real (a laje maciça é mais rígida que a laje nervurada, sob as mesmas condições de inércia); as reduções, então, aparecem como artifícios minimizadores dessa rigidez;

- com relação aos deslocamentos, o Modelo 08 comportou-se melhor para baixas relações de $h_{f} / h$, ou seja, para altas excentricidades, tornando-se assim menos flexível que a estrutura real, sendo então extremamente dependente da relação $h_{f} / h$, num comportamento muito similar ao apresentado pelos modelos 02 e 03 com relação aos deslocamentos, e oposto ao comportamento do Modelo 07. Para $\mathrm{h}_{\mathrm{f}} / \mathrm{h}=0,333$, apresentou erro de $48 \%$ a maior no deslocamento máximo da nervura central; para $\mathrm{h}_{\mathrm{f}} / \mathrm{h}=0,125$ esse erro foi 
de $1,3 \%$ a menor, chegando a um erro máximo de $5 \%$ a menor para $\mathrm{h}_{\mathrm{f}} / \mathrm{h}=0,100$ testado. Melhores são também os resultados para altas relações de $a_{1} / l$;

- o Modelo 07 comportou-se com mais rigidez para baixas relações de $h_{f} / h$, sendo sempre mais rígido que o Modelo 08 em todas as lajes processadas: para $h_{f} / h=0,333$ apresentou o deslocamento máximo na nervura central 15,8\% maior que aquele dado pelo Modelo 04; para $h_{f} / h=0,100$ o erro foi de $32,6 \%$, a menor, mostrando um comportamento mais rígido frente ao Modelo 04. Ambos os erros foram altos, devido principalmente à relação $a_{1} / l=0,1000$ utilizada nesta primeira série de processamento. Neste trabalho puderam ser também testados, e confirmados, parâmetros que indicam o uso desse modelo, conforme a bibliografia consultada, em função da relação $a_{1} / l$ : melhores resultados de deslocamentos das nervuras foram obtidos a partir da relação $a_{1} / l=0,0667$ (erro de $0,462 \%$ em comparação com resultados do Modelo 04), e para a relação imediatamente menor testada $\mathrm{a}_{1} / \mathrm{l}=0,0625$ (erro de 0,21\% em comparação com resultados do Modelo 04), conforme anteriormente verificado por DEB et al. (1991). Para $a_{1} / l=0,0714$ a correlação também foi excelente, com erro de apenas $1,15 \%$, o que também confirma os resultados encontrados por HOPPMANN et al. (1956). Como comparação a estes ótimos resultados verificou-se que, para $a_{1} / l=0,1667$ esse erro foi de $13 \%$, a menor para o Modelo 07. Assim, pode-se afirmar que os melhores resultados do Modelo 07 são dados com $\mathrm{a}_{1} / \mathrm{l}$ em torno de 0,07 . Também viu-se que, quanto maior o espaçamento entre as nervuras, mais os resultados do Modelo 07 aproximam-se dos resultados do modelo realista, ou seja, mais o Modelo 07 vai tornando-se flexível, perdendo a rigidez intrínsica;

- ao serem analisados os deslocamentos das vigas, sempre simuladas pelo elemento excêntrico BEAM44, quando simulam-se as nervuras pelos Modelos 07 e 08, verificou-se que quanto mais excêntricas forem as nervuras, menores serão os deslocamentos das vigas, comparados aos resultados obtidos pelo Modelo 04;

- o Modelo 07, em termos de tensões normais de tração nas seções das nervuras, é dependente da relação $h_{f} / h$; quanto mais flexível é a estrutura real, ou seja, para altas relações $h_{f} / h$, o modelo apresenta valores muito elevados de tensões normais quando comparadas às apresentadas pelo Modelo 04 , com erros de até $42 \%$. Chegou a apresentar ótimas correlações a partir da relação $h_{f} / h=0,167$, até a relação $h_{f} / h=0,100$ testada, com erros em torno de apenas 1,6\% nestes casos. As tensões de tração apresentadas pelo Modelo 07 não sofreram variações, em relação às tensões apresentadas pelo modelo realista, de acordo com a variação de $a_{1} / l$, apresentando erros da ordem de $20 \%$ nos modelos testados, em função de $h_{f} / h=0,250$ dos modelos testados. À medida que aumentou-se o espaçamento entre 
as nervuras, piores foram os resultados de tensão de tração frente aos resultados do modelo realista;

- no Modelo 08, à medida que aumentou-se a excentricidade, menores foram as tensões normais nas seções: para $h_{f} / h=0,333$ tem-se um erro de $3,62 \%$, e para $h_{f} / h=0,143$ esse erro é de $28,5 \%$, sempre a menor, quando comparadas as tensões deste com as do Modelo 04. Não sofreram variações de acordo com a variação da relação $a_{1} / 1$;

- os modelos 07 e 08 não são capazes de fornecer momentos fletores na capa das lajes nervuradas, e esforços cortantes de maneira automática pelo software, nas posições das nervuras.

Por tudo isso ora apresentado, vê-se a necessidade de modelar as lajes nervuradas sempre considerando a excentricidade, seja por modelos realistas ou por modelos simplificados, devendo serem verificadas as relações geométricas dos pavimentos, buscando nos parâmetros $h_{f} / h, a_{1} / l$ e espaçamento entre nervuras subsídios que indiquem o modelo que melhor simula a laje, nas análises: modelo de grelha de nervuras, de placa maciça com espessura equivalente em inércia e artifícios redutores de rigidez, e de nervuras simuladas por elementos que considerem "offsets rígidos". Os melhores modelos, que podem ser aplicados em qualquer situação, como verificado, são os Modelos 04 e 05; porém o Modelo 04 é de construção e leitura de resultados extremamente trabalhosas para a aplicação no diaa-dia dos escritórios de cálculo. O Modelo 05 exige um software em elementos finitos, já que é necessário o funcionamento conjunto de elementos de viga simulando as nervuras seção "T" e elementos finitos de casca (ou placa, em modelos planos) simulando a capa da laje nervurada.

Trabalhando com o modelos tridimensionais a verificação e o dimensionamento das peças devem sempre serem feitos para os esforços combinados: flexotração ou flexo-compressão.

Apresentam-se a seguir, nas Fig. 6.1 e 6.2, quadros resumos de indicações de aplicação dos modelos mecânicos para análise de lajes nervuradas, a partir dos comportamentos dos modelos de pavimento com pano único de laje ensaiados numericamente, conforme as relações geométricas deste trabalho. 


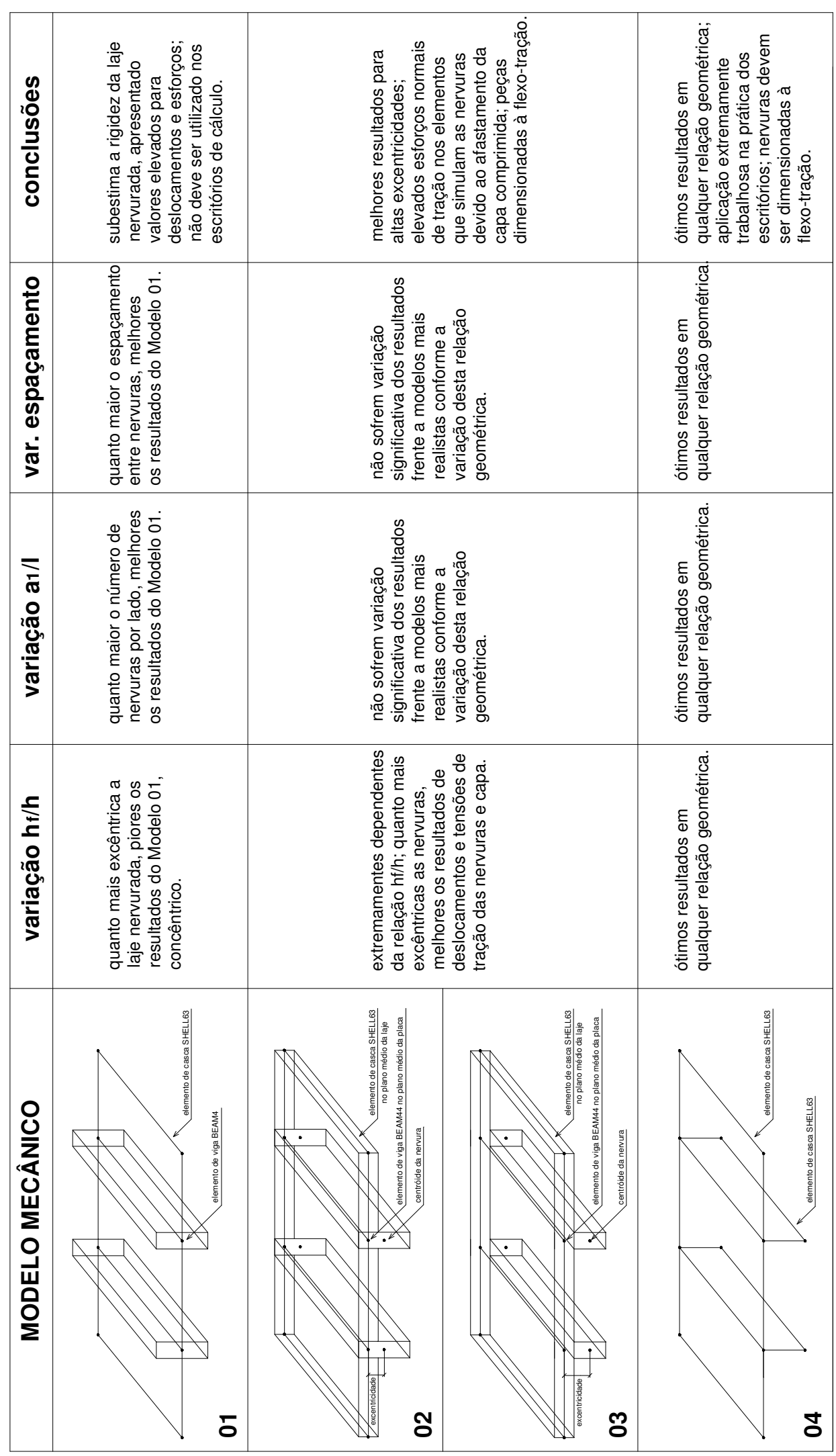

FIGURA 6.1: Quadro resumo de indicações para a modelagem de lajes nervuradas Modelos 01 a 04 


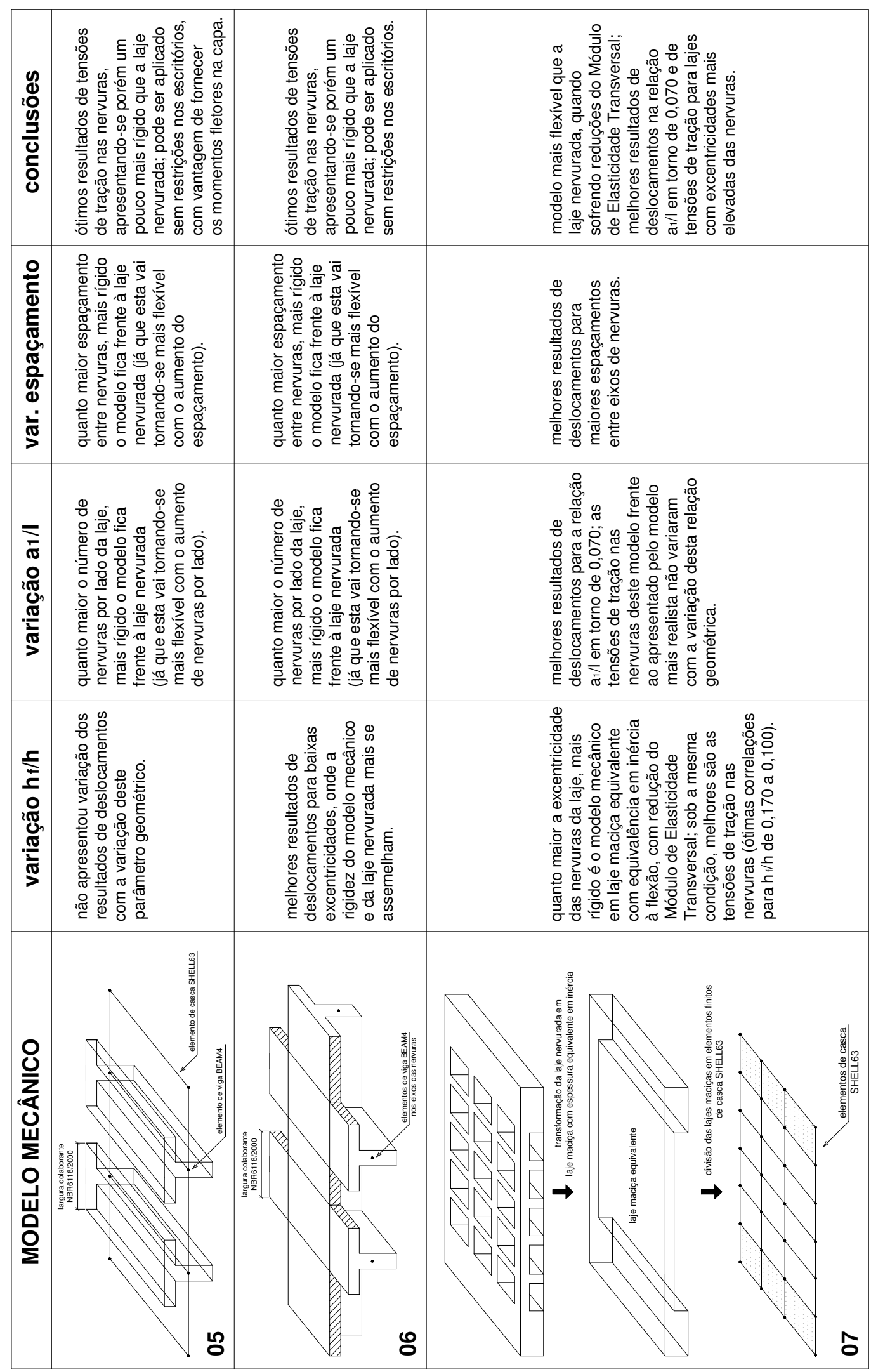

FIGURA 6.2: Quadro resumo de indicações para a modelagem de lajes nervuradas Modelos 05 a 07

Para o prosseguimento da pesquisa alguns tópicos são indicados: 
- análise das lajes nervuradas considerando a não-linearidade física do material concreto armado, podendo haver ensaios de modelos em pequena escala;

- promover novas análises numéricas, agora criando diversas lajes com uma variação maior da relação $h_{f} / h$, e em cada uma delas fazer variar as relações $a_{1} / l$ e espaçamento entre as nervuras, preenchendo desta forma uma lacuna deste trabalho;

- analisar pavimentos em lajes nervuradas com diversas tipologias: laje apoiada nas vigas rígidas (como as aqui analisadas), lajes apoiadas diretamente sobre pilares, lajes com faixas rígidas maciças embutidas na espessura da laje, lajes com efeitos de protensão, modelos com mais panos de laje por pavimento;

- analisar resultados oferecidos por modelos de Pórticos Mútliplos e de Pórticos Equivalentes, para pavimentos em lajes nervuradas sem vigas. 



\section{REFERÊNCIAS BIBLIOGRÁFICAS}

ABDUL-WAHAB, H. M. S.; KHALIL, M. H. (2000). Rigidity and strength of orthotropic reinforced concrete waffle slabs. Journal of Structural Engineering, v. 126, n. 2, Feb., p. 219227.

AJDUKIEWICZ, A. B.; KLISZCZEWICZ, A. T. (1986). Experimental analysis of limit states in a six planel waffle flat-plate structure. ACI Journal, v. 83, n. 6, Nov.-Dec., p. 909915.

ALBUQUERQUE, A.T. (1998). Análise de Alternativas Estruturais para edifícios em concreto armado. 100p. Dissertação (Mestrado) - Escola de Engenharia de São Carlos, Universidade de São Paulo, São Carlos. 1998.

ALLEN, D. N. G.; SEVERN, R. T. (1961). Composite action of beams and slabs under transverse loading. The Structural Engineer, v. 39, July, p. 235-239.

AMERICAN CONCRETE INSTITUTE (1989). ACI-318: Building code requirements for reinforced concrete. Detroit.

AMERICAN CONCRETE INSTITUTE (1989). ACI-435: Deflection of two-way reinforced concrete floor systems: state-of-the-art report. Detroit. 
ANSYS 5.5: REFERENCE MANUAL (1994). Swanson Analysis Systems, Inc.

ASSAN, A. E. (1999). Método dos elementos finitos: primeiros passos. Campinas: Editora da Unicamp. p.83-86.

ASSOCIAÇÃO BRASILEIRA DE NORMAS TÉCNICAS (1978). NB1: Projeto e execução de obras de concreto armado. Rio de Janeiro.

ASSOCIAÇÃO BRASILEIRA DE NORMAS TÉCNICAS (2000). Texto base para revisão da NB1/78- NBR61118: Projeto de revisão e comentários. Rio de Janeiro.

BARBIRATO, C.B.C. (1997). Contribuições à análise de pavimento de edifício em laje nervurada. 138p. Dissertação (Mestrado) - Escola de Engenharia de São Carlos, Universidade de São Paulo, São Carlos. 1997.

BARBOZA, A.S.R. (1992). Contribuição à análise estrutural de sistemas lajes-vigas de concreto armado mediante analogia de grelha. 130p. Dissertação (Mestrado) - Escola de Engenharia de São Carlos, Universidade de São Paulo, São Carlos. 1992.

BARES, R.; MASSONNET, C. (1968). Analysis of beam grids and orthotropic plates. New York: Frerick Ungar.

BEDAIR, O. K. (1997). Analysis of stiffened plates under lateral loading using sequential quadratic programming (SQP). Computers and Structures, v. 62, n. 1, p. 63-80.

BOCCHI JÚNIOR, C. F. (1995). Lajes nervuradas de concreto armado.183p. Dissertação (Mestrado) - Escola de Engenharia de São Carlos, Universidade de São Paulo, São Carlos. 1995.

CANO, M. T.; KLINGNER, R. E. (1988). Comparison of analysis procedures for two-way slabs. ACI Structural Journal, Nov.-Dec, p. 597-608. 
CARRIJO, E. C.; PAIVA, J. B. (1997). Estudo numérico e experimental da interação placaviga. In: Anais do V Encontro Nacional de Mecânica Computacional, Universidade do Minho - Guimarães, Portugal, v. 1, p. 759-764.

CORLEY, W. G.; JIRSA, J. O. (1970). Equivalent frame analysis for slab design. ACI Journal, Proceedings, v.67, n. 11, Nov., p. 875-884.

CORLEY, W. G.; MAGURA, D. D. (1971). Testes to destruction of multipanel waffle slab structure - 1964-1965 New York World's Fair. ACI Journal, Proceedings v. 68, n. 9, Sept., p. 699-703.

CORRÊA. M. R. S. (1991). Aperfeiçoamento de modelos usualmente empregados no projeto de sistemas estruturais de edifícios. São Carlos, 331p. Tese (Doutorado) - Escola de Engenharia de São Carlos, Universidade de São Paulo, São Carlos. 1991.

CORRÊA, M. R. S.; RAMALHO, M. A. (1987). Sistema LASER de análise estrutural. In: Simpósio Nacional de Tecnologia da Construção, 5., "Software para o projeto do edifício", São Paulo, 15-16 out. Anais. São Paulo: EPUSP.

DEB, A.; BOOTON, M. (1987). Finite element models for stiffened plates under transverse loading. Computers and Structures, v. 28, n. 3, p. 361-372.

DEB, A.; DEB, M. K.; BOOTON, M. (1991). Analysis of orthotropically modeled stiffened plates. International Journal of Solids Structures, v. 27, n. 5, p. 647-664.

DIAS, R. H; GIONGO, J. S.; PAIVA, J. B. (2001). Análises numéricas de lajes nervuradas sem vigas considerando diferentes modelos mecânicos. In: Anais do $43^{\circ}$ Congresso Brasileiro do Concreto - 2001, Foz do Iguaçu, Brasil.

EUROCODE 2 (1992). Design of concrete structures - Part 1: General rules and rules for buildings. Brussels, CEN. 253 p. (ENV 1992-1-1). 
FRANCA, A. B. M.; FUSCO, P. B. (1997). As lajes nervuradas na moderna construção de edifícios. São Paulo: AFALA \& ABRAPEX.

FIORIN, E. (1998). Arranjos de armaduras em estruturas de concreto armado. 248p. Dissertação (Mestrado) - Escola de Engenharia de São Carlos, Universidade de São Paulo, São Carlos. 1998.

GUARDA, M. C. C. (1995). Cálculo de lajes-cogumelo pela teoria das charneiras plásticas. 164p. São Carlos. Dissertação (Mestrado) - EESC - USP.

HARIK, E. I.; SALAMOUN, G. L. (1988). The analytical strip method of solution for stiffened rectangular plates. Computers and Structures, v. 29, p. 283-291.

HOPPMANN, W. H.; HUFFINGTON JR., N. J.; MAGNESS, L. S. (1956). A study of orthogonally stiffened plates. Journal of Applied Mechanics, v. 23, n. 3, September, p. 343350.

IKEDA, N. A.; GUIMARÃES, G. N.; PRADO, A. A. (2000). Análise computacional de lajes cogumelo pelo método do pórtico equivalente. In: Anais do Congresso Brasileiro do concreto - IBRACON.

KANOK-NUKULCHAI, W.; GILANI, A. K. (1982). A macroelement for waffle slab analysis. Computers and Structures, v. 15, n. 2, p. 117-122.

KENNEDY, J. B.; EL-SEBAKHY, I. S. (1982). Waffle slab concrete bridges: ultimate behavior. Journal of the Structural Division, Proceedings of the Americam Society of Civil Engineers, ASCE, v. 108, n. ST6, June, p. 1285-1301.

KLEIN, D.L.; SELISTRE, S.L.C. (1997). Análise numérico-experimental de lajes nervuradas submetidas a cargas uniformemente distribuídas. In: Jornadas Sul-Americanas de engenharia estrutural, 28, São Carlos, 1997. Estruturas e Fundações. São Carlos, EESCUSP/ASAEE, v. 1, p. 249-258. 
LEONHARDT, F.; MÖNNIG, E. (1978). Construções de concreto. v. 1. Rio de Janeiro: Interciência.

LEONHARDT, F.; MÖNNIG, E. (1978). Construções de concreto. v. 3. Rio de Janeiro: Interciência.

LIMA, E. L.; BALAT, V. H.; BISSIO, J. F. [200?]. Hormigón Armado: Notas sobre su evolución $y$ la de su teoría. Disponível em: $<$ http://www.ing.unlp.edu.ar/construcciones/hormigon/ejercicios/sem-ha.pdf >

MACGREGOR, J. G. (1992). Reinforced concrete - mechanics and design. 2.ed. New Jersey: Pretince Hall.

MILLER, R. E. (1980). Reduction of the error in eccentric beam modelling. International Journal for Numerical Methods in Engineering, v. 15, p. 575-582.

MUKHOPADHYAY, M. (1994). Stiffened plates in bending. Computers and Structures, v. 50, n. 4 , p. 541-548.

NAVARRA, E. O. I. (1995). Cálculo de estructuras por el método de elementos finitos: análisis estático lineal. 2.ed. Barcelona: Centro Internacional de Métodos Numéticos en Ingeneria.

NAWY, E.G. (1995). Reinforced concrete: a fundamental approach. New Jersey: PretinceHall.

OLIVEIRA, R. S.; ARAÚJO, D. L.; CORRÊA, M. R. S.; RAMALHO, M. A. (1999). Avaliação da deformação de lajes nervuradas considerando a não-linearidade física: comparação entre valores teóricos e experimentais. In: Simpósio EPUSP.

PALANI, G. S.; IYER, N. R.; APPA RAO, T. V. S. R. (1992). An efficient finite element model for static and vibration analysis of eccentrically stiffened plates/shells. Computers and Structures, v.43, n. 4, p. 651-661. 
PENG-CHENG, S.; DADE, H.; ZONGMU, W. (1987). Static, vibration and stability analysis of stiffened plates using B spline functions. Computers and Structures, v. 27, n. 1, p. 73-78.

PINHEIRO, L. M. (1993). Concreto Armado: tabelas e ábacos. São Carlos, Escola de Engenharia de São Carlos, Universidade de São Paulo.

ROSSOW, M. P.; IBRAHIMKHALIL, A. K., (1978). Constraint method analysis of stiffened plates. Computers \& Structures, v. 8, p. 51-60.

SAPOUNTZAKIS, E. J.; KATSIKADELIS, J. T. (2000). Analysis of plates reinforced with beams. Computational Mechanics, v. 26, p. 66-74.

SAVASSI, W. (2000). Introdução ao Método dos Elementos Finitos - em análise linear de estruturas. São Carlos: EESC-USP.

SHEIKH, A. H.; MUKHOPADHYAY, M. (1992). Analysis of stiffened plate with arbitray planform by the general spline finite strip method. Computers and Structures, v. 42, n. 1, p. 53-67.

SIDDIQI, Z. A.; KUKRETI, A. R. (1998). Analysis of eccentrically stiffened plates with mixed boundary conditions using differential quadrature method. Apllied Mathematical Modelling, v. 22, p. 251-275.

SILVANY, T.T. (1996). Deslocamentos transversais em lajes-cogumelo. 144p. São Carlos. Dissertação (Mestrado) - EESC - USP.

SUSSEKIND, J.C. (1978). Curso de análise estrutural. v. 3. Porto Alegre: Editora Globo.

SUSSEKIND, J.C. (1985). Curso de concreto. v. 1. Porto Alegre: Editora Globo. 
TANAKA, M.; BERCIN, A. N. (1998). Static bending analysis of stiffened plates using the boundary element method. Engineering Analysis with Boundary Elements, v. 21, p. 147-154.

TANAKA, M.; MATSUMOTO, T.; OIDA, S. (2000). A boundary element method apllied to the elastostatic bending problem of beam-stiffened plates. Engineering Analysis with Boundary Elements, v. 24, p. 751-758.

TAKEYA, T. et al. (1985). Recomendações para o projeto e execução da estrutura em lajes cogumelo pertencentes às unidades básicas de saúde do plano metropolitano de saúde. São Carlos, EESC-USP. Relatório Técnico.

TENCHEV, R. T. (1996). Shear lag in orthotropic beam flanges and plates with stiffeners. International Journal of Solids Structures, v. 33, n. 9, p. 1317-1334.

TESORO, F. R. (1991). Los forjados reticulados: manual practico. Espanha: Editora Cype Ingenieros.

TIMOSHENKO, S. P.; WOINOWSKI-KRIEGER, S. (1959). Theory of plates and shells. 2.ed. New York: McGraw-Hill.

WANG, X.; RAMMERSTORFER, F. G. (1996). Determination of effective breadth and effective width of stiffened plates by finite strip analysis. Thin-Walled Structures, v. 26, n. 4 , p. 261-286. 